\title{
LOS MOZARABES DE TOLEDO \\ EN LOS SIGLOS XII Y XIII
}

VOLUMEN PRELIMINAR

ESTUDIO EINDICES 
Fjemplar núm. $\quad 58$ 


\section{LOS MOZÁRABES DE TOLEDO \\ EN LOS SIGLOS XII Y XIII \\ lok}

\section{ANGEL GONZÁLEZ PALENCIA

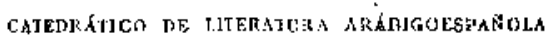

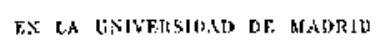

VOLUMEN PRELIMINAR

ESTUDIO E ÍNDICES

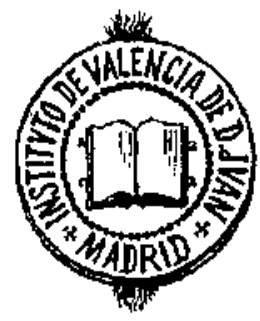

MADRID: MCMXXX 
ES PROPIFDAD

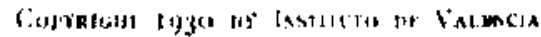

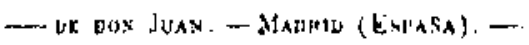


A MIS QUElRIDOS MAESlROS

D. II I I R RTBRA Y TARRAG

$r$

D. IIGLEL, ASIN PAIACIOS 



\section{UADRO DE MATERIAS}

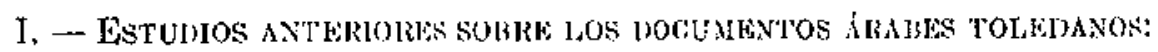
1. El jesuita expulso Juan Andrés . ................ 1

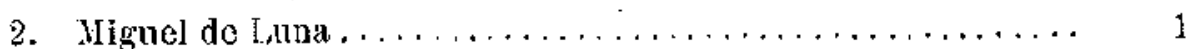
3. Traductor anónimo del siglo XYII...............
4. Juan Andrés Paredes . ....................... 4

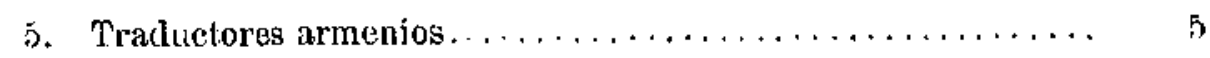
b. Invostigadores del siglo XIX.................

II. - LA COI,ECCIÓN:

7. Procedencias que eomprende $\ldots \ldots \ldots \ldots \ldots \ldots \ldots \ldots \ldots$ n

8. Iista de los documentos por el orden en que van publicados., 11

9. Lista por orden cronológico de los documentos publiendos.... 27

11). Nuestra edieión ........................... 42

11. Notas paleográficas......................... 44

12. Cifras numéricas.......................... 47

IIT. - EL LUGAR:

13-14. Topografia de Toledo....................... $\$ 1$

15. Barrio de la Catedral ........................ "51

16. Nlcudia ......................... is

17. Adarve de Aben Mohariz ...............

18. Natadero.......................... 58

19. Alberguería........................ 
[ Parrio de la ratetlral. ;

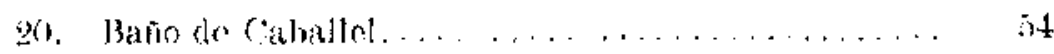

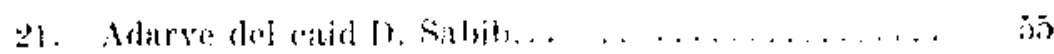

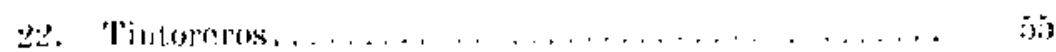

23.

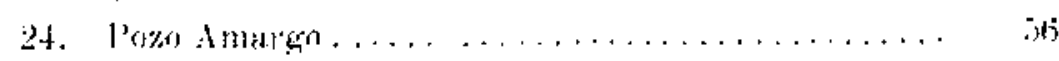

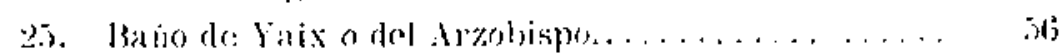

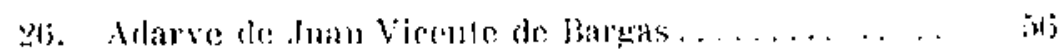

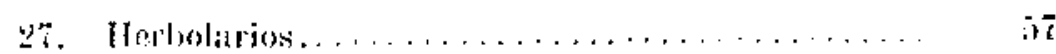

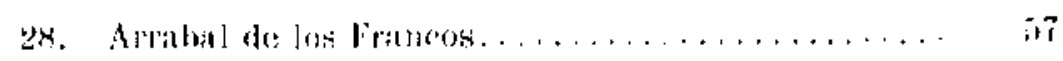

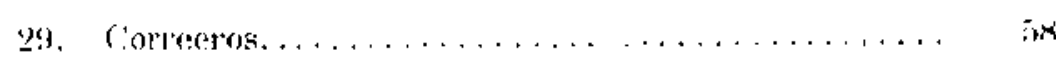

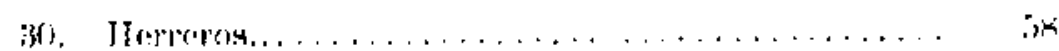

35. Mhondign del Rey.................. 38

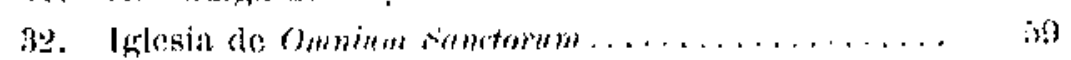

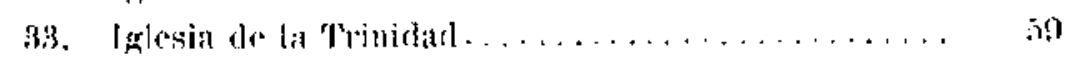

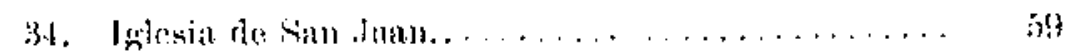

3i) Nlomit....................... 60

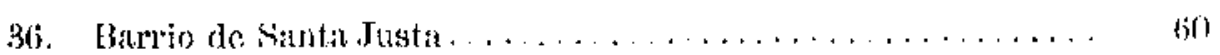

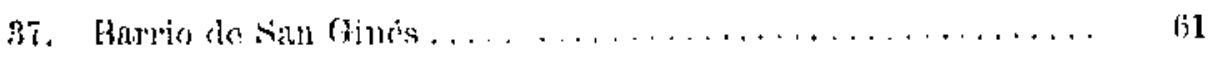

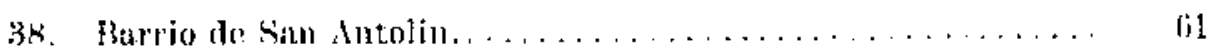

3!). Barrio de sam lorenzo................... tiz

40. Barrio de Sam Hajeos..................... tiz

+1. Barrio de sian Andres. . . . . . . . . . . . . . . . ris

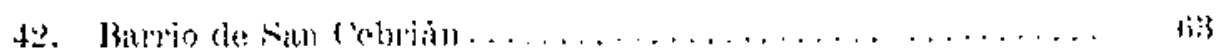

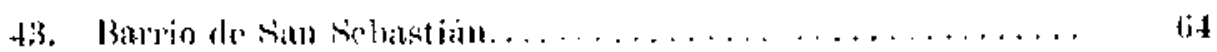

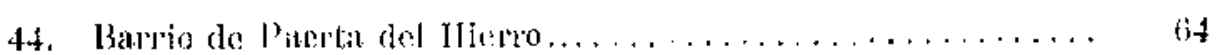

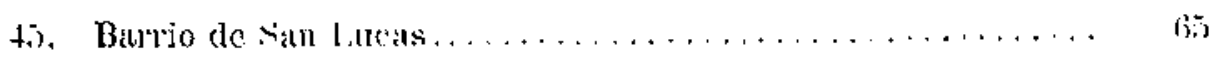

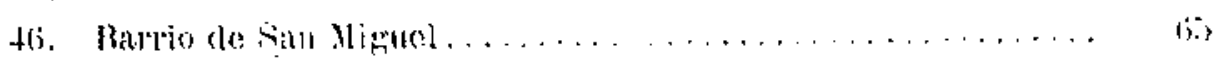

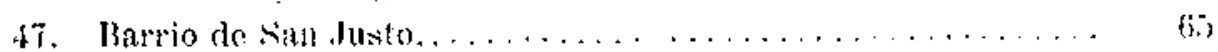

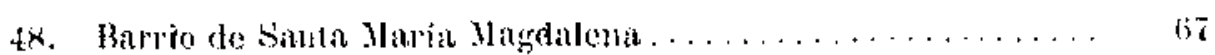

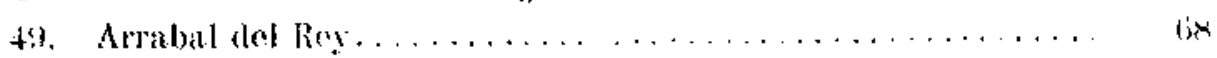

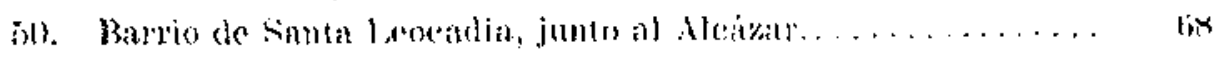

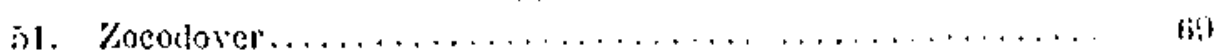

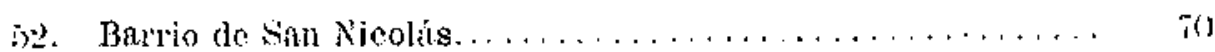

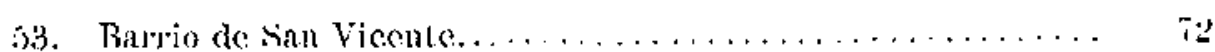

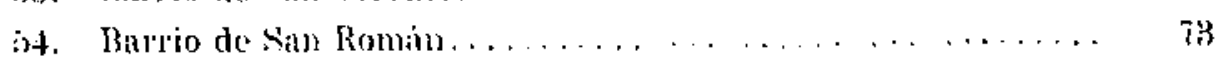

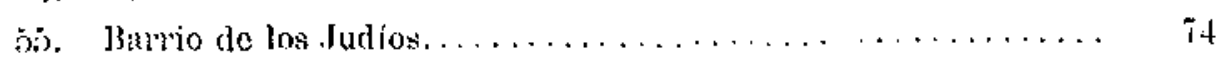

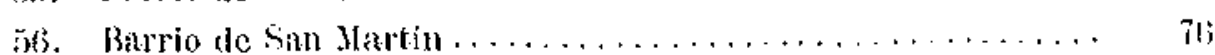

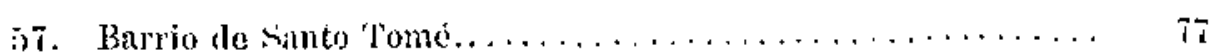

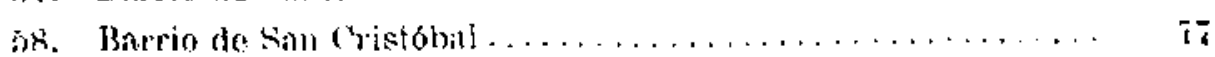


59. Arrabal: Barrio do Santiago $\ldots \ldots \ldots \ldots \ldots \ldots \ldots \ldots \ldots, \quad 77$

60. Arrabal: Barrio de la Torre Nueva.............. 78

61. Arrabal: Barrio de San Isidro.................. 78

62. Arrahal: Barrio de San Pedro . . . . . . . . . . . . . . . 79

63. Arrabal: Barrio rle la Puerta de Pedro Benién........... 79

64. Sinta leoendia de Afuera.................... 79

65. Pluertas................................. 80

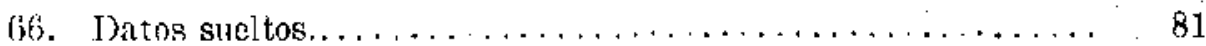

67. Alrededores de Toledo $\ldots \ldots \ldots \ldots \ldots \ldots \ldots \ldots \ldots \ldots \ldots, 81$

68-31 \%. Lughes de la provincia de Toledo.................. 85

IV. - RAZAS:

A) los mozimotes.

318. Su situación antes de la reconquista de Toledo... . . 117

319. Privilegio de 1101 y confirmaciones............ 118

320. I os mozárabes toledanos $\ldots \ldots \ldots \ldots \ldots \ldots \ldots \ldots \ldots \ldots \ldots$

321. Nombres de persona ...................... 128

322. Duplieidad de nombre: árabe y romance........... 123

323. Apclidos.............................. 124

324. Ilijos de clérigos....................... 124

325. Filiación por hembras.................... 124

326. Títulos honorificos: «mair» y «don”............. 125

827. Apodos $y$ motes........................... 125

328. Lengua.............................. 129

\$29. El árabe......................... 130

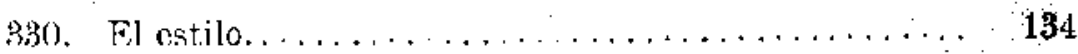

331. El aljamiado....................... 136

B) Los froness.

332. Funilias de francos................... 140

C) Los judios.

333. Ta juderia toledana....................... 142

334. Familias judias toledanas.....

D) Los noros.

33̄̃. J os musulmanes toledanos.... . . . . . . . . . . . 151 


\section{Y. - INSTITUCloNES:}

A) I. Coledoul.

Parte

3315. Cauta de dotación $\ldots \ldots \ldots \ldots \ldots \ldots \ldots \ldots \ldots \ldots \ldots$ 15.

337. Privilegion de la ('atedral . ............... 15i

33k. Aumento do los hiemes rle la (atedral........... f(i)

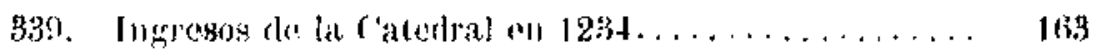

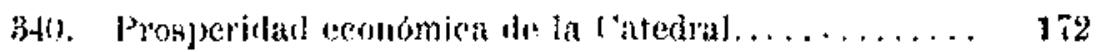

341, El templo de la catedral............... 17t

13) El Cabildo.

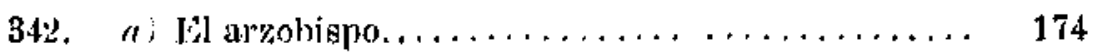

343. b) Fil deán..................... 175

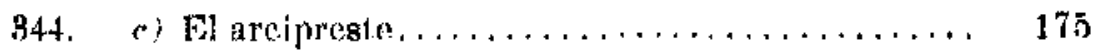

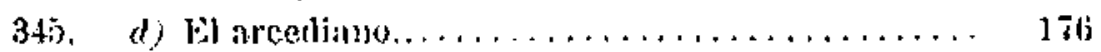

34ti. e; Citmastresenda................. 177

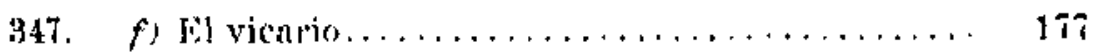

34. gi fil cupiscol..................... 178

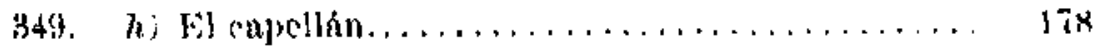

3ino, i) fil tesoremo.....................

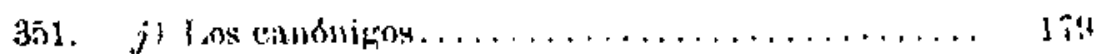

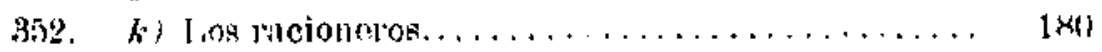

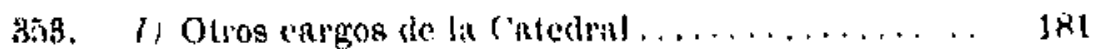

354. m) Clero de fuen de Toledo............... 181

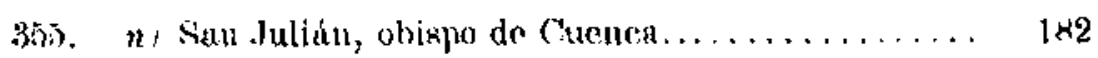

(a) lytesins y comentos do 'Joledo.

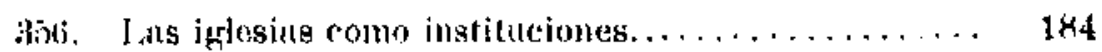

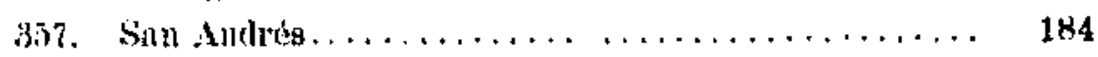

$35 \%$. San Antolln.................... 184

30\%. Calatrava (Frailes do $\ldots \ldots \ldots \ldots \ldots \ldots \ldots \ldots \ldots$ 18.

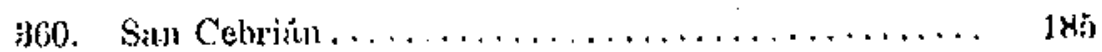

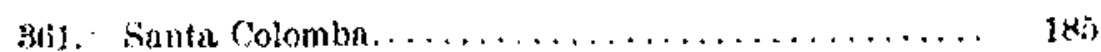

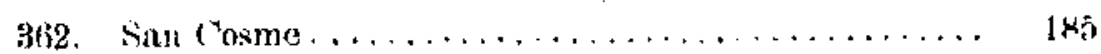

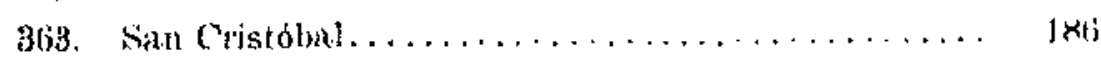

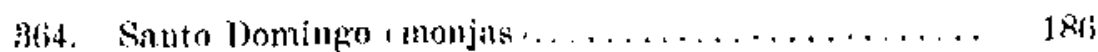


[Iglesias y conventos de Toledo.]

365. Santo Domingo (Irailes)................. 187

3tit. Santo Domingo (Talavera) ............... 187

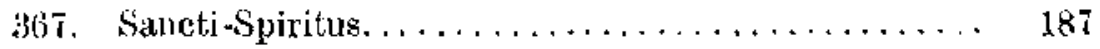

368 . San Esteban...................... 187

369. San Eugenio...................... 187

37). Santa Eulnlia........................... 187

371. San Feliz........................... 188

372. $\operatorname{san}$ Ginćs......................... 188

373. San Ildefonso ......................... 188

374. San $J_{1}$ an ............................ 188

37). San Juan del Fospital (railes) .............. 188

3i6. San Justo. . . . . . . . . . . . . . . . . . . 189

$37 \pi$. Santa Justa..., . . . . . . . . . . . . . . . . 189

378. San Jazaro . . . . . . . . ................... 189

379. Santa Teocadia de Afuera................. 189

380. Santa Leocadia de junto al Alcázar............. 190

381. San Lorenzo. . . . . . . . . . . . . . . . . . . . . . . . . . . . . 191

382. San Lucas......................... 191

383. Santa Maria en Alhicem........................ 191

3\$4. Santa Maria de Burguillos....................... . 192

385. Santa Maria Nagdalena . . . . . . . . . . . . . . . . 192

386. Santa Maria de la Sisla ......... ........... 192

387. San Marcos.......................... 192

388. San Martín. . . . . . . . . . . . . . . . . . . . 192

389. San Hateo............................., 192

390. San Higuel........................ 192

391. San Nicolás . . . . . . . . . . . . . . . . . . . . 198

392. San Pablo . . . . . . . . . . . . . . . . . . . . . . . 198

393. San Pedro en Alhicem..................... 194

394. San Pedro (convento)..... . .............. 195

395. San Román (convento)................... 195

396. San Román............................... 195

397. San Salvador . . . . . . . . . . . . . . . . . ... 196

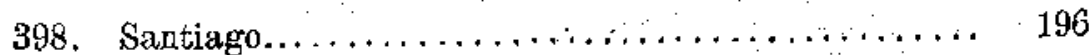

399. Santiago (Orden de j.... . ................. 198

400. San Sebastián........................... 198

401. San Servando .............................. 199

402. Santo Tomé... ............................. 199

403. San Torcuato.......................... 199 
[Iglesias $y$ conventos de Toledo.]

404. Santa Cruz . . . . . . . . . . . . . . . . . . . 199

405. Santisima Trinidad ....................... 199

406. Santisima Trinjelad (Orden de la i. . . . . . . . . . 199

407. San Vicente... . . . . . . . . . . . . . . . . . . . . 199

408. Sim Vicente del Monte. . . . . . . . . . . . . . 20.0

409. San Zocl o San Zoilo.. ................. .

410. El convento de $\operatorname{San}$ Clemente............... 201

411. Bienes de San Clemente. . . . . . . . . . . . . . . 203

D! Cofradias.

412. Cofradias en las iglesias................ 205

413. I a cofradia do presbiteros de Toledo . . . . . . . . . 206

E) 414. Anivessarios, misas, capellanias y fundaciones piadosas.

415. Entierros y funcrales................... 213

416. I imosna a los pobres ................ 215

417. Alberguerías y hospitales................ 216

F) 418. Cargos puiblicos.

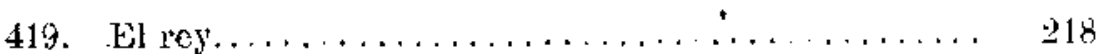

420. El conde... . . . . . . . . . . . . . . . 218

421. Alguacil ilcalde................... 219

422. Alguacil alhaquim................... 222

423. Alguacil sahibaxorta . . . . . . . . . . . . . . . 223

424. Escribanos, notarios y seeretarios.......... 223

425. Pregonero....................... 224

426. Abogados, apoderados y procuradores........... 224

427. Alguacil almojarife................. 225

4. 2 . Almotacén. . . . . . . . . . . . . . . . . . 225

439. Nadir o comendador, mayordomo, "ray"........ 225

430. Repostero...................... 226

431. Caid o alcaide ..................... 227

432. Adalid ......................... 227

433. Arráez.......................... 228

434. Maestros y ensenanza................... 228 
PI. - CONDTCIÓX UE TuS PERSONAS

435, Los nobles............................. 831

43t. Señorios, solariegos y fueros especiales ............. 232

437. Religiosos ........................ 232

138. Padrinos y ahijados...................... 233

439). Oficios manuales . . . . . . . . . . . $\ldots \ldots \ldots \ldots \ldots$

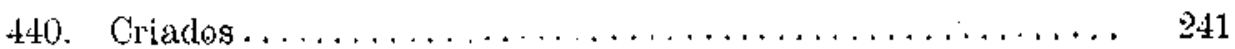

4+ Esclavos . . . . . . . . . . . . . . . . . . . . 242

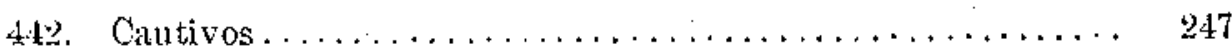

VII. - ADquISICLÓN DE LA PROPLEDAD:

a) Complaventa.

443-444. Fórmulas generales $\ldots \ldots \ldots \ldots \ldots \ldots \ldots \ldots \ldots \ldots$

445. Fvicción y sancamiento.............. 251

446. Titulo de propiedad. . . . . . . . . . . . 252

447. Compraventa por medio do apoderado ......... 254

448. Precio....................... 255

44!. Testigos ....................... 257

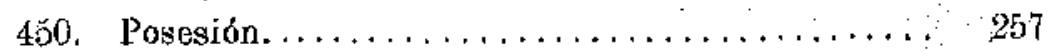

4b1. Venta forzosa.................... 258

452. Servidumbres .................. 258

453. Medianerias...................... 259

454. Limitaciones....................... 260

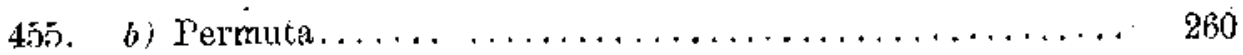

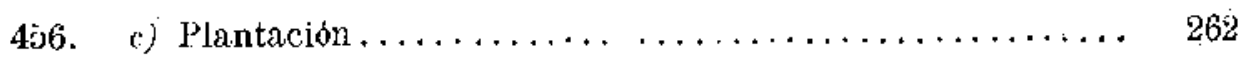

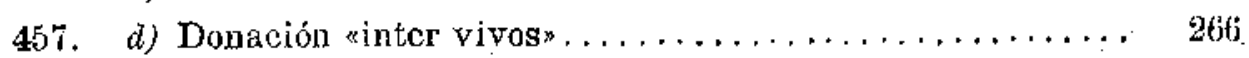

458. e) Dote y aruas....................... 270

459 . f) Testamentos, mayorazgos y mejoras . . . . . . . . . . . 273

461. gi Particiones de bienes................... 279

462. h) Renuncia de derechos $\ldots \ldots \ldots \ldots \ldots \ldots \ldots \ldots \ldots \ldots \ldots 283$

463. i) Avenencias y concordias en pleitos ................ 284

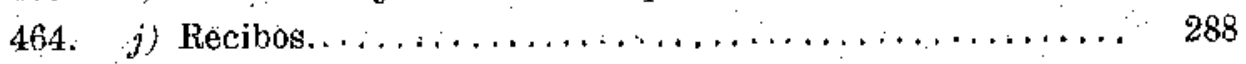

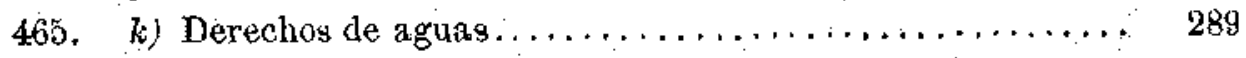

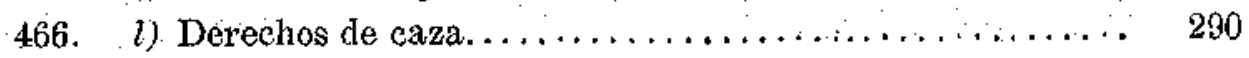

$467 . \ldots$ m) Derechos de pastos y ganadería............... 291

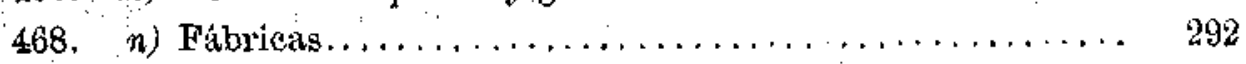




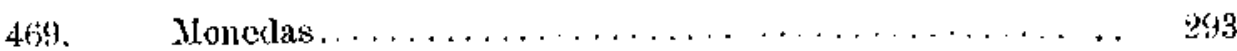

470. Jedidas.......................

4i1. Ropas, alhajas y utensilios. . . . . . . . . . . . . 206

4 il bis. J'rocios de ropas, vestidos, etc............

471 ter. IPrecios de casas y fineas vendidas. . . . . . . . . . . . 301으.

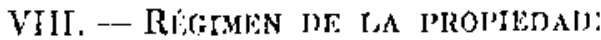

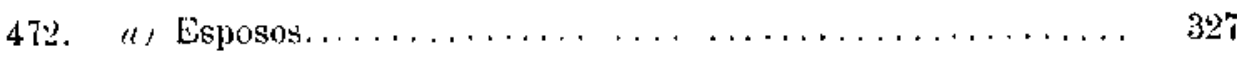

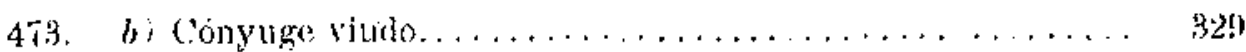

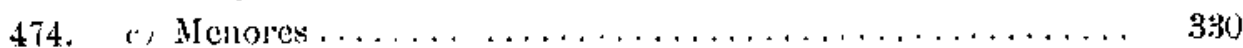

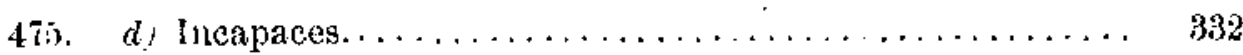

476, e) Coparticipes: personas que aprueban compras y ventus . . \$32

477. f; pro indiviso....................... 334

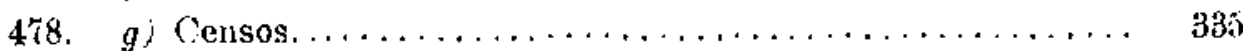

479. h) Arriendos...................... 384

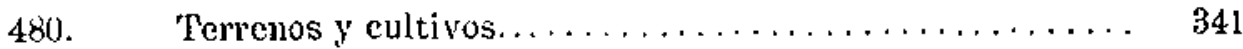

481. Árboles cultivados ................... 343

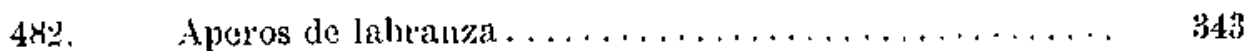

48:3. $\quad i$ Contratos de sonjedad . . . . . . . .

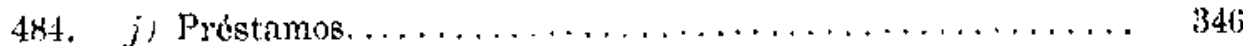

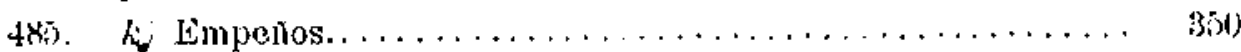

4.

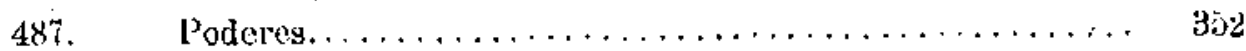

488. Pleitos sobre propiedad de casns y ticreas. . . . . . . . . . 352

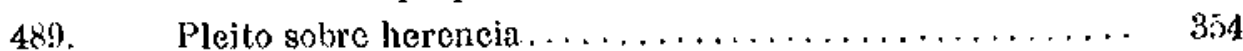

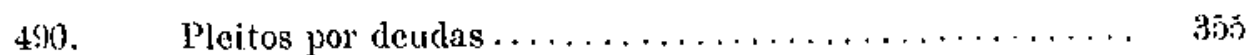

491. Pleitos por derecho de plantación . . . . . . . . . . 358

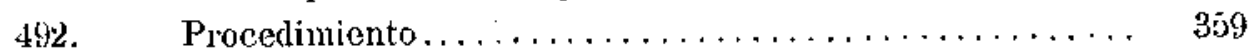

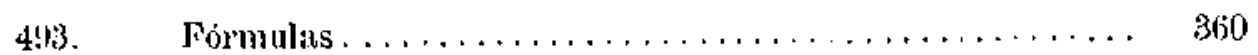

APrindCE III. - Documentos números $1.152-1.175 \ldots \ldots \ldots \ldots \ldots \ldots \ldots$

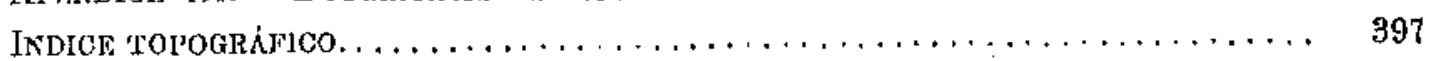

INDTCE DE NOMBRES DE PELSONA $\ldots \ldots \ldots \ldots \ldots \ldots \ldots \ldots \ldots \ldots \ldots \ldots$ 


\section{ESTUDIOS ANTERIORES SOBRE LOS DOCUMENTOS ARABES TOLEDANOS}

1. El jesufta expulso don Juan Andrés, en su curiosa historia de la Literatura comparada, publicada con el título de Origen, progresos y estado actual de toda la Literalura (edición italiana, 1782-98; traducción castellana, 1784-1806), al tratar de la inlluencia que las musulmanes de España debieron de ejercer literariamente sobre los cristianos, señala, entre otros hechos, la circunstancia de existir en la Catedral de 'Toledo muchos centenares de documentos árabes escritos por los cristianos. Seguramente conocería la existencia de tales documentos por noticia del P. Andrés Burriel, que organizó el Archivo de la Catedral primada y cuyo inventario, todavía en uso, anota el número de escrituras arábigas relalivas a cada puebla, finca o derecho de la Catedral a que primitivamente correspondfan. El P. Burriel, en su Paleografía, página $307 \mathrm{y}$ sigs., alude también a estos documentos.

No tuvieren fortuna en el erudito siglo XVIII los docnmentos árabes de Toledo, y nadie los estudió. A ello contribuirían dos causas príncipales: una, la falta de interés por parte de la Catedral en conocer el contenido de aquellos pergaminos, lítulos de propiedad de otras épocas; otra, la dificultad en encontrar personas que pudieran leerlos y traducirlos.

2. Alguna vez la Catedral había necesitado conocer el contenido de algán documento, seguramente por causa de litigio, y lo habia hecho traducir. Así la escritura de compra de una parte de la alquería llamada Alameda, en la Sagra de To- 
ledo, quc el año 1193 adquiría el arccdiano Don Gareía. La Catedral, a 25 de junio de 1607 , pide la traducción oficial de un documento (que es el número 250 de nuestra coleccion); el alcalde de Casa y Corle, licenciado Cristóbal de Villarroel, provee un auto, mandando que Miguel de L.una, intérprete de lengua arábiga en el Consejo de Castilia, lo traduzca. Líl célebre morisco granardino, autor de la Verdadera Historia del Rey Don Rodrigo y de la pírdida de España (1592), que aparecio como obra de Abulcásim Taric Abentariquue, presentó si traducción el día 13 de julio siguiente. La version, conservada en unión del documento, no es muy exacta, sobre todo en la transcripción de nombres propios; es nalural que a $\mathrm{nn}$ morisco no le fueran fáciles ciertos nombres cristianos. Compárese la versión de Lana con la de nuestro documento número 250 (1):

"En el nombre de Dios piadoso y miscricordioso. Compró el areediano don Ciarcía, ensalce Dios su honor, de don luan Mronso [Domingucz] y de su hermano Michacl Alfonso [Dominguez], hijos do don Ferrán [17omingro] P'edro, que tiene por apelliclo el de Domingo Garcia [Crespo], y de su madre doña Sancha Barl,ola | lijiola ], toda la sucrte de tierras que poseen por suya propia en el lugar de la Amada, que por atro nombre ee llama Ela Jameda, que esta $\mathrm{m}$ la Sagra de T'oledo, la cual Jios guarde; y esta suerte de lierres es lahor de una yunta, igual cantidad a las demás suertes de tierra que bay en el, que alinda con otra suerto de tierras lque es partieión de otra tierral que ellos poseen y con otra suerte de tierras que tiene doña Leocadia [Auria], mujer que fué de don Villaseca [Velasco j, y también le verten todo el de recho do señorio que tienen y posicn de prisente de todo el clicho lugar, ya nombrado, assí en sus campos como dencro del, con sus perienencias, eras, ubrevaderos y pastos de grandos, pozos y fuentes, riegos y secanos, sierras, valles y lanos, bueno y malo de toclo el dicho derecho y señorio que les pertenecc de hecho y de derecho, comprondido dentro de los limites, terminos y mojones del dielo lugar de suso referido y lo a él anijo y concerniente de balllos y sierras por todos los cuatro ángulos, con todas sus cntradas y sulislas, sin reservar en si cosa.alguna de usos y costumbres. Y tambjén entran en osta venta las tres viñas que poseen en el dicho lugar, que la una de ellas alinda por la parte oriental con tierras de Juan Cadas, y por la parto de Oceidente con viñas del arcediano don Garela, comprador do suso roferido, y por el Mediodia son viña de los hercleros de don Villascea 'Yelgsco! (marida de doña Leocadia), de suso relerido, y por el Septentrión con tierras de los vendciores; y la segunda viñ ansi mismo alinda por la parte Oriental con el arcediano de suso referido, y por la parto de crecidente enn el carnino de la Nabatolia [Pantojal, y por el Mediodit con viña de los herederos de don Villaseca [Velasco], ya nombrado, y por el Septentrión eun tierras du los venledores; y los linderos de in tereera vinia son, por la parte de] Oriente, viña de Jum Cadas, y por ol Oecidente, viña de los herederos de don Villaseca, ya nombrados, y por el Hedicula cou vina de Juan Cadas, ya nombrado, y ansi mismo entra en esta venta todo el pulazo de majuelo que lo pertenece del majuelo que plantó on sus tierras Juan Pedio [Pérez], que cae junto al camino de las chozas [

(1) Añado entro paréntesís [ ] las correcciones al texto. 
el corral que tienen y poseen por suyo propio en el dicho ligar eon sus tinados y dos palomeres que bay en ell...., lo cual vention en su justo jrecio y valor, el cual precio es 74 pessantes de la moneda de oro usual [alfonsí , sin liga de buena moneda, de justo y buen pesso, como es costumbre.... Todo lo cual se hizo y efecturi en los diez días postreros del mes de Septiembre, año de 1231 do la hera.

Y lo otorgaron en el tirmino del dicho Jugar referido de suso, en presencin de los testi-

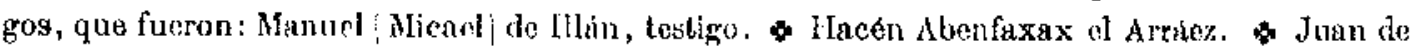
Illán de Sicla, testigo. \& I ]atnoh Pedro] $A$ bennommr $A$ betgaleb el Jalez [Callas|, eserivano.

Concuerda la data desta (scritura de venta con ol principio del mes de Septicombre dol año del nacimiento the nuestro salsudor Jesucrioto de 1193 atus, la cual dicha traduccín e interpre-

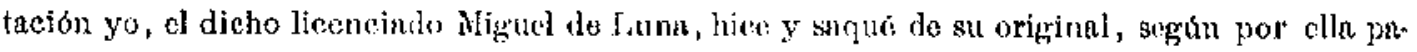
rece, esti sana, no rota ji ennceliula, ni en jarte alguoa sospechisa, ni viciosa, y legralmenle escrita y orderada en la villa de Madrid, a 13 díns flol mos de dulio de 1607 nños, y lo firmó. Jil licenciado Aliguel de I,uma.

3. Otra versión anónima, de fines del siglo XVIl o principios del XVIII, acompaña al documento número 183 . También vacila en la lectura de nombres propios, y no ha entendido el sentido de algunas cláusulas:

an el nombre de Jios miserieordioso, que lifeo miscricorclias, y la alnbanza a 1)ios sólo.

Compró don Pedro Alajame, jara el areediano excelento don Domíngo de Malagr, que Dios los ensalee a entrambos, a doña Placencir, que fue mujer cle l'elayo de Garganda, todo al unesón corcano conocido por suyo, que esta junto a la Caledral honoranda de Banta Maria, que está dentro de la ciudad de T'oledo, que Dios la guarde; juntamente compró al dicho mesón con una açutea que esta encima del dicho mesón y del arco quo se junta con el y con la torre mayor, donde se juuta con la solredicha iglesia y el término de todo el sobredicho; por parto del Oriente alinda con unas tiendas que son de doria Marfa, que fue mujer de don Gareia Camarón. y por parte del (Jecidente aliofla con la plaçuela quo estr delante de la puerta de la iglesia; donde corresponde la pucrta del mesin, y por parte del Mediodia alinda con la calle que pasa por debajo del arco solsredicho, que se junta con la torre mayor, y por parte del Norte alinda con el mesón de don Salvator.....; por frecio coneortalo de 21 escudos alfonsinos de aro de peso cabales..... IEstuvioron presentes a este contrato doña Marla y doña Urraca, hijas de la vendedora sobredicha, y cada una dellas consintio en la dicha vonta, y renunció cada una dellas, juntamonte con su madre doña Plasencia, y declaraion cómo teriari vendido el dicho mesón por una necesidad que tenian, y por esto han declarado y renunciado sus derechas, $\mathrm{y}$ que ninguna dellas, ni sus allegados puedon pretender en poco ni en mueho, ni en manera tinguna, por ninguna causa ni razón, y asf hubo cuatro testigos, a los cuales ellas mismas llamaron y consintieron que fuesen presentes; $y$ todo esto se hizo estando ellas en su juicio y con su consentimiento $y$ con el consentimiento del dicho comprador jor parte del arcediano sobredicho, por la autoridad y poder que tenia para sas negocios. Y esto se hizo en el postrero tercio del mea de Agosto del año 1224, que es cuando se escribió este contrato. Lo cual fué la verdad, $y$ on Dios está la concordia, $\mathrm{y}$ no firmaron los testigos hasta el postrero tercio del maes de sep. tiembre del mismo año." 
4. A medida que avanzaba el siglo XVIII se acentuaba el desconocimiento del árabe, aunque no fallara algún que olro pedante que se atreviera a dar como traducciones sartas de disparates ininteligibles. Modelo del género es el parto de un Juan Andrés Paredes, que Iranscribe (a su modo, claro está) al árabe, traduce al latín y al castellamo el documento número 449 de nuestra colección. La portada puesta a su obra por el tal Paredes ya muestra que estaba poseído de lo valioso y difícil de su labor:

"Transeriptio arabica, cum latina, et hizpana versionibus cuiusdam folii coriacei, quod sul titulo Villa antiqua do Maskarale a 'Toletanac ceclesino illmo canonicorum capitulo iuter alia etiam arabice conscripta asservatur. Quaceunque igitur lectioni, et quidem difficilimac, pafuere integre transcrij,ta, ef verse sunt, aliquot tamon voces practermissue, utpote abritissinace, et absque ulteriori auxilio inpracsentiarm omnino imperviae nedum corporis aculis, sed etiam mentis, et intelligentiae vertentis. s

Su transcripción árabe demuestra que desconocía hasta las palabras más usuales. Pase que se equivoque en transcribir un nombre propio; pero que lea المكران المعكه الفكسب, en lugar de leer المكران المعةه القديس, es imperdonable, por tratarse de adjetivos corrientes. Hacemos gracia al lector de esta transcripción, y de la versión latina que la acompana; notaremos, no obstante, el error de techa: el documento va fechado en la primera decena de $\Lambda$ bril del año 1257 de la era de Asafar, o cristiana; Paredes dice que "probatum est initio mensis Saphar ami millesimi ducentesimi quinquagesimi septimi *, y se cree en el caso de poner una nota *erudilísima* que lo deja en ridículo:

*Mortuo Domino Roderico Ximenez anno 1247, impossilile vicletur, venditionem, de qua hic sit mentio eidem Roderico factam esse, nisi adversus historiographos onnes ejus vitam velimus usque ad annum 1247 protralieles; verumtamen vel ininimo negotio ab lac difficultate expediemur, annum mortis Roderici juxta vulgarem aeram mumerantes, annum autem huiusmodi contractus non itidem a volgari acra, sed ab Hispanica, Hisjaniac \& usque ad 14 saeculum usitata, computantes; atque ila, veritatte patefacta, coneludemus, imgrapham hanc anno 1213 fuisse consignatam, omnisçue aequivocatio relegabitur. *

Pero sí nerece conocerse la versión castellana como muestra de las aberraciones de un mal traductor:

* En nombre de Dios miscricordioso. La alabanza para Dios sólo, justa es su alabanza.

Vendió el Marrach don Esteban Beythars, hijo de don Beytharah, que fué hijo de Morahhamin, el vasto fundamento de. Santa Mrria, a su señorfa el melropolitano, el liberal, cl zanto, el honrado don Rodrigo Jiméncz, ayúdele Dios perpetuamente, por parte de las riquezas del metropolitano dicho, en virtud de su palabra con dona Geti, hija de don Beytbarah Ennelchaniense, mujer que fué de don Fernando Bilabyr, hijo de don Pelayo, Dios tenga misericordia de 
ellos; pactando el darla toda tercern parte de las poreiones mensuales do ln Villa Villaje, antigruo do las villas de la ciudad de 'loledo, que Dios conserve, y la terema poreión de las asignaclas fae de la proximiclad do la vill a antigan y en sus inmediaciones, y se la concedió una parte do estas por venta de chon Bilipan, hijo de Beytharal, pues el y el Karatir pusieron los límites a las dos partes, enire las euales el más nolfe, era don lbeytharah Nelchaniense, ya menciona. do, y la segunda parte del tio della Jirrachaclba, hijo do don Damenehah Nolchaniense, Jios temga misericorilia de ollos.

A este tenor lo vendió la mejos parte de la hacienda en la vilia de Magskarak, que es una do las viilas de la eiudad meneionada, y en las inmediaciones de la villa de Magskarak mencionada, la compró una parte de todia cuarta parte contada en lodo aquêllo que cra occesario para la venta referida en cacla villa de las dos villas referidas, en los barbechos de cllas, y on la tierra cultivada, y en la planieic de ellas, y en lo aspero y col lo dividido de ellas, y en lo no dividido, $\mathrm{y}$ en los prados du ellas, y en sus jastos, y en los úrboles re clas y on sus arroyos, $y$ on ans lagramas, $y$ en los pozis do cllas, $y$ on las fuentes de sus agtias, $y$ en sus amenas hierlas, $y$ en lo desolado de ellas, y en lo estable o permanente, y on las eras do ellas, y en todo derecho y po. sesion que so hubiero hecho 1 cecsario para la venta referida en cada villa de las dos villas referidas hasin el término en donde sp mide eadla villa de estas dos por sus ruatro eostados; y la en. tratla en todo esti $y$ la salida de ello no será prevenida o pervertida por la vendedora moncionada, por si misma ni por otro; por tanto, el bios suppremo cris hombres sanos para lo vendido cxpensto; y no en algo de ello vertlad, y no posesión poca, y us mucha utilidad, y no cosa per. manente por ninguno de sus lailos, y en ninguno do sus oaminos si no se saliere de ella para vender lo mencionado en venta sana, a la cual no se ha de juntar condición perníciosa. El comprador dicho se disminuyó en sll mansión, por cadr parte de todo fruto contado, sois cargas, las que entregó a la vendedora mencionada, la cual to recibió de él y agregó a sí. Y vino a habitar en lo vendido expuesto y cl fin y término de su peligro, sin ignorar algo de ello. Y cntregó la vendedora dichn al comprador mencionado la heredad de su venta en la parte o suerte sola de don Bi. liân, hijo de don Beytharah, y de una suorte en la villa antigua y heredad sogunda por venta del tio de ella, Errachadba, de la mencionada porción segunda de doña Sansl, que fué mujer de Laminah Teldaniense, y la parte también de ollos que se vendió en la villa de Magskarak. Y en lo restante de lo vendiclo soure todas las riguczas de ella y sobre todos los estados do sus frutos, en favor del comprador meencionato; en todo aquello que se hace mención, hubo para todo suficientes testigos de cllo. Y conocido que fué crn estado perfecto, se aprobó a primeros del mes Safar del año 1257. - Yo, Christohsal, canónigo, testigo. Yo, Domigo Micret Nielo, testigo. Y Juan Ben Mcrljin Chalcf Benjacen Saadin. \$ Y Juantuh Elfali. \$ Jlabeh Benchas Ben Ayl-Elars. \& Yroytharah, Dios tenga misericordia de ellos.

5. No es de extrañar, después de conocer este monumento de la historia de las traducciones, que el Cabildo perdiera to esperanza de saber nunca lo que aquellos pergaminos de enrevesadas escrituras contenían.

Ni tuvo más fortuna el Monasterio de San Clemente, que también posela un buen número de documentos árabes. Con ocasión del paso por Toledo de algán armenio, de los que en el siglo XVIII venfan por España pidiendo limosna, las mon- 
jas quisieron aprovechar el conocimiento del árabe que aquéllos manifestarían tener, y les presentaron para su lectura el documento número 911 de nuestra coleccion. Es curiosa la nota que se conserva cosida con el documento:

a solo el Dios 'Todopoderoso sca atribuida la gloria, - Prosiguen unas pralah'as supersticiosas to que usan los moros piliendo, o experando, ser librakes de torlo mal.

Se sigue una eseritura de ven la de mas casas y otros biencs raices, cuyo lerritorio no es fácil exprestr por no saher el equivalente que tiene en nuestro ittioma: hizose la venta en esta ciudad de Toledo, ante aseribano pulb]ico, en que pareco habes sido hecha on ol tiempo que estaba poseida de los moros, por serlo el signo y nombe del escrilsuo, que rs la firma que está a la derecha; y la que se mira encima es del que vende la tal lucienda. No ponc dia ni ano en que se ejecuto la venta; parenc ser acorca do hacienda que ha tenikio, o tieme, ol Atomastorio en Portillo, segrín se saca del contoxto y por la inseripción antigua que se halla ('It la vuela del pergamino.

So hallan en la dercha del papel, e izquierda del que lo loyere, tres firmas do mujerce, escritas on latín, en letra antigua; y presumo estar en idioma latino, por ser costumbre en Espana, hasta Ios timmos del rey I)on Alonso el decimo, escribir todos los instrumentos pu. blicos en esta lengua, en gue so prucha so mueha antiguiedad. - Ins nombres son: Vrraca Miquel. Jueia Miger Suároz. Narla (sarcía. I luego se sigue stra firma ruás baja, que dice: Sgo M., Decanus Tolotanus.

Ias firmas primeras pareco significar, segin al contexto, sureligiosas, por las ahreviaturas de priera rue on ellos se mira, y en la otra parece que dieo cantora.

Esto os lo qur: se ha podido stcar, por estar cl dicho instrumento escrito en lengua arabiga anticuada y habur alguna diversidad on la fornacion do las letras, y ser su tenor más conformo a el de los moros argelines que a al de los tureos ni asiáticos, do donde son los que han explicarlo su temor; por lo que no he sido fucil trulucirle a el pie de la letra, y va asi por mayor la noticia de su conturido.

6. Cuando, por los años de 1870 , se form6 el Archivo Histórico de Toledo, fucron a integrar sus fondos la mayoría de los pergaminos írabes de la Caledral; $y$ al deshacerse este Archivo, pasaron sus documentos al Archivo Histórico Nacional de Madrid. En este mismo Archivo vinicron a reunirse los documentos de las iglesias, conventos y monasterios, recogidos, en virtud de las leyes desamortizadoras (1841), por una disposición de 28 de Marzo de 1866: entre los de San Clemente de Toledo había varios centenares de escrituras árabes.

Ya en el Archivo Histórico Nacional, y habiendo, en la segunda mitad del siglo XIX, renacido el estudio de la lengua árabe en España, gracias a los esfuerzos de Gayangos y Codera principalmente, pareća más fácil leer y estudiar los documentos arábigos toledanos.

Aprovechando la circunstancia de prestar sus servicios en el Archivo el arabista D. Francisco Pons Boigues, dedico su atención al fondo procedente de la Catedral de Toledo. Antes que él, b. Francisco Simonel habia revisado algunos, para utilizar 
sus datos lexicográficos en la conocida obra Glosario de uoces lalinas e ibéricas usadas por los mozirabes españoles. Madrid, 1888 . Pero fué l’ons quien inició el calálogo de aquellos documentos. Ordenó los de la Catedtal eronológicamente, denlro del grupo de Particulares, que les correspondía en la clasificación adoplada por don Vicente Vignau para el arreglo de los papeles de origen eclesiástico, y redació las papeletas del catúlogo. Algdinas de estas papeletas, hasta 130 , un poco mós extensas, las publicó en el Boletín de la Sociedad española de Excursiones, y son las recogidas en el libro Apuntes sobre las escrituras moztimbes toledanas que se conservan en el Archivo Itistórico Nacional, Madrid, Imprenta de Tello, 1897. A modo de apendice reprodujo tolalmente, pero sin las firmas, y tradujo hasta ocho documentos de dislinta clase, para dar idea de las formulas usadas: escrituras de compraventa, de donación, testamento, partición de lierras, pago de deuta y convenio matrimonial. Desgraciadamente, difienltades de orden economieo hicieron suspender la publicación cmpezada por P’ons"1).

Después de P’ons siguió ocupándose en la calalogación de los documentos árabes del convento de San Clemente de Toledo otro arabisti, D. Luis Conzalvo y París. Pero los tiempos en que Gonzalvo trabajaba en el Archivo Ilislórico eran ilos de formación y acrecentamiento de la sección de Clero, y no pulo dedicar a estos pergaminos árabes el tiempo que sus aficiones le pedían, sino el escaso que le dejaban libre las perentorias ocupaciones de clasificar y fechar miles y miles de pergaminos, procedenles ue las delegaciones de Hacienda de casi toda Lispafia. Fechó los de San Clemente, y empezó a redactar papeletas, siguiendo cl modelo de Pons. Muy pocas lermino, y sin seguir ningún orden, sino eligiendo los documentos que más le gustaban.

Por Mayo del año 1913, fui yo destinado a prestar mis servicios en el Archiva Histórico Nacional, y dedicado por su entonces director, D. Juan Menéndez Pidal, al estudio de esta colección de documentos: su proposilo era, no sólo la terminacion del calálogo, siguiendo las huellas de Pons, sino la publicación de los documentos mismos. Poco más de u!ı año continué con aquel encarno; a principios de 1915 , las necesidades del Archivo exigieron que yo pasase a ocuparme en In sección del Consejo de Castilla, cuyos papeles eran muy solicilados del público estudioso. Lin el traslado, arreglo y catalogación de más de 52,000 legajos; en la publicación de algunos catálogos, como el de Titulos de Castilla (1919), el de papeles de Indias (1920), el de Hidalgulas (1920), el de la Sala de Alcaldes de Casa y Corte (1925) (colaborando con mi buen amigo y compañero D. Éudosio Varón), y el de Pleitos sobre mayorazgos, estados y seĥortos (1927), hube de emplear la mayor parte del tiempo.

(1) Don Rodrigo Amador do los Rios, utilizando las papolotas de Pone, publices on la Revista de Archivos algunos artículos, quo wás adelante lendremos ocssión de cíar. 
bios se digno darme la tenacidad suficiente para dedicar lodos los dlas algunos minulos a los documentos áralues, que eran mi mayor afición e'ntre las muchas male-

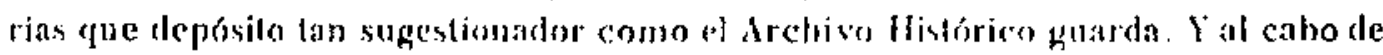
mucho diempo luve la salixfaccion de ver repiados lodos los documentos.

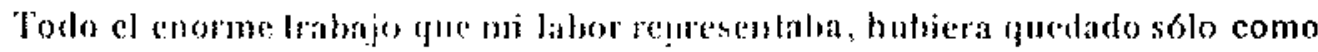

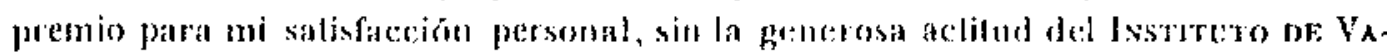

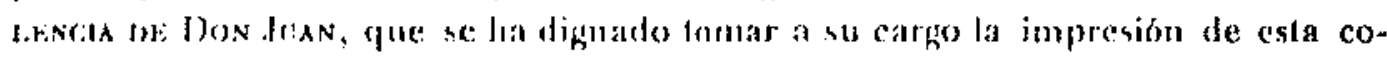
leceion de documentos. Si anuna atilidad concuentran los eroditos y los historiado-

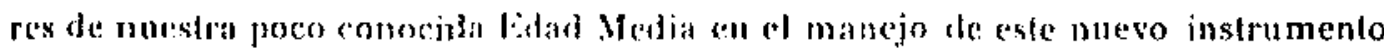
de trabiajo que lan rica y copiosa coleceion les brinda, agradécanlo al Instituto, digno sucesor en las ideas y an las whas do su ilustre fundador. Ior mi parte, les expreso el testimonio de la más profunda gratiturd: sin su kenerosa intervención esta obra habria quedado, segneamente, inedila. 


\section{II}

\section{LA COLECCION}

7. Comprende nuestra colección 1.175 documentos árabes, recogidos en archivos toledanos.

El fondo más numeroso lo proporciona la Catedral de Toledo: de este Archivo se conservan en el Histórico Nacional 6002 documentos en la Sección de Clero secular y regular, Toledo, Catedral, con las siguientes signaturas:

Caja 1963. Documentos cuyo catílogo publicó Pons, números
1.J.XV
$\Rightarrow 1964$.

Además, en el Archivo de la Catedral primada se conservan todavia buen número de documentos árabes, para cuya rebusca me ha auxiliado eficacísimamente el culto y erudito canónigo archivero don Eduardo Estella. En la primera vuelta encontramos 98 documentos, que son los que en la lista de nuestra colección llevan el número con la letra $T$ añadida (su signatura topográfica se indica en cada documento). Después, todavía halla el Sr. Estella otros 35 documentos, más uno rabínico, 
en el cajón \%-8; éslos son los que conslituyen nuestro Apéndice I, y en la lista gene. ral figuran con la signalura Cal. Tol. \%.8. Son, pues, 133 documenlos que añadir a los 652 del Archivo lfistorico Nacional, o sea un tolal de 785 documentos, sólo de la catedral.

Wi nácleo que sigue en interes en el de los documentos procedentes del Monasterio de monjas Bernardas de Sun Clemente, y que guarda el Archivo Lislórico Na. cionul, Seccion de Gilro secular y regular, con eslas signaluras:

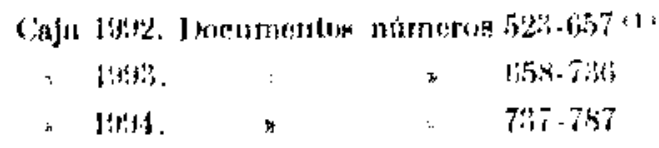

A eslos 201 documentos hay que aflarlir tho, interesantisimo, que conservan todavia en el Monnatcrio, y cuya fotografín me ha facilitado mi buen amigo y colega don Antonio Sierra, crudilo invesligador en los Archivos Toledanos: es el que figura en nuestro Apéndice III con el número 1.175.

lil mismo Sr. Sierra me ha indicado la existencia de olros 1.1 documentos, que conserva el Archivo del Cabildo de púrrocos de Toledo ("), en la Iglesia de San Nicolás, donde yo había encontrado ya dos, que figuran con los números 167 y 623 de nuestra coleccion,

Finalmente, en el Archivo del Ayunlamiento de la Imperial Ciudad se guardan hasta nueve documentos más, ch el Archivo sectelo, cayo conocimiento me ha facililado st culto nrchivero don Adotfo fionzílez Vegue, y para cuya lotografía y estudio me la dado toda clase de facilidates cl señor Alcalde, don Gregorio Ledesma, enamorado fervienle de las glorias de Toledo.

Estos documentos municipales, con los 11 de San Nicolás, se reproducen en el Apéndice IlI (al final de este mismo lomo).

A estos 1.075 documentos, nlgunos de los cuales contienen dos o tres o más instrumenlos distintos, hny que ahudir 21 documentos escritos en árabe con caracteres rabínicos, que integran el Apéntice $I I$, y que han sido lefdos por mi buen amigo y compnnero, el doctísimo caledratico de lengua hebrea en esta Universidad, don José Marín Miljás Vallicrosa. De ellos, 20 se conservan en el Archivo Histórico Nacional, Sección de Clero secular y reguhr, Toledo, Catedral, caja 1972; el ofro se guarda en el Arelivo de la Catedral Primada, Z-8, múmero 6.

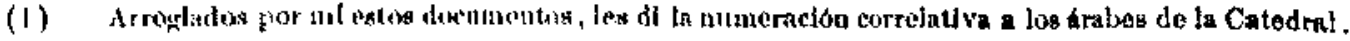

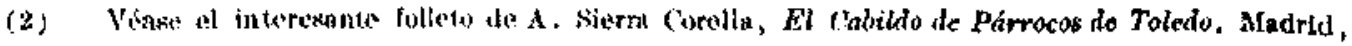
1925, pig. 17. 
8. I.LSTA DE LOS DOCUMENTOS

POR EL ORDEN EN QUL VAN PUBLICADOS

Los indicados en numeración romana son los publicados por Pons.

Los seguidos de T se guardan ahora en el Archivo de la Catedral toledana.

Los demás se conservan en el Archivo Histórico Nacional, si no se indica otra signatura .

Los números encerrados entre paréntesis indican varios instrumentos de un mis. mo documento, colocados en el lugar que su asunto exige, cuya referencia se tiene así junta.

COMPRAVEYJA

\begin{tabular}{|c|c|c|c|c|c|}
\hline N. ${ }^{\circ}$ & Signalura. & A ถั०. & N. ${ }^{\circ}$ & Signatura. & Año. \\
\hline 1. & I & 1083, Ramadán. & 23. & 527 & 1135, Agosto. \\
\hline 2. & 48 T $(9,17,36,143)$ & ) 1092, Noviembre. & 24. & $\mathrm{IX}$ & 1135, Diciembre. \\
\hline 8. & $\mathrm{I} X \mathrm{XV}(20,118,728)$ & 1098, Abril & 25. & 768 & 1137, Mayo. \\
\hline 4. & II & 1095, Abril. & 26. & 528 & 1139 , Enero. \\
\hline 5. & 1 & 1107?, Marzo & 27. & XI & 1139, Octubre. \\
\hline 6. & 2 & 1110, Marzo. & 28. & XII & 1140, Diciembre. \\
\hline 7. & IIT & 1111, Febrero. & 29 & 529 & 1141, Agosto, \\
\hline 8. & $46 \mathrm{~T}$ & 1112 , Septiembre. & 30. & $1 \times X V(3,118,738)$ & 1142, Junis. \\
\hline 9. & $48 \mathrm{~T}(2,17,36,143)$ & 1113, Noviembre. & 81. & XIV & 1144, Abril. \\
\hline 10. & 3 & 1117, Junio. & 32. & $x y$ & 1116, Enero. \\
\hline 11. & $W$ & 119.20, Diciembre. & 33 & 530 & 1146, Marzo. \\
\hline 12. & 4 & 1119, Diciembre. & 34 & XVT & 1146, Octubre. \\
\hline 13. & $\mathrm{~V}$ & 1121, Fnero. & 35. & XVII & 1147, Marzo. \\
\hline 14. & 528 & 1124, Abril. & 36. & $48 \mathrm{~T}(2,9,17,143)$ & 1149, Mayo. \\
\hline 15. & 5 & 1125, Enero. & 37. & $576(213)$ & 1149 , Noviembro. \\
\hline 16. & 6 & 1127, Marzo. & 38 . & 581 & 1149, Diciembre. \\
\hline 17. & $48 \mathrm{~T}(2,9,36,143)$ & 1129, Marzo. & 39. & 532 & 1150, Abril. \\
\hline 18. & 524 & 1132, Septiembre. & 40. & 538 & 1150, Diclembra. \\
\hline 19. & 7 & 1183, Julio. & 41. & $11 \mathrm{~T}$ & 1150, Abril. \\
\hline 20. & 8 & 1134, Julio. & 42. & 9 & 1152, Octubre. \\
\hline 21. & 525 & 1134, Septiembre. & 43. & 10 & 1158, Enero. \\
\hline 22. & 526 & 1134, Septiembro. & 44. & $\mathrm{XIX}$ & 1153 , Noviembre. \\
\hline
\end{tabular}




\begin{tabular}{|c|c|c|c|c|c|}
\hline$N .0$ & SIgnatura. & Año, & N. ${ }^{\circ}$ & Signatura. & Аัก๊o. \\
\hline 4.5. & 534 & 1154, Agosto. & 86. & $2 \vec{i}$ & 1168, Agosto. \\
\hline 46. & 11 & 1154, Diciembre. & 87. & $76 \mathrm{~T}$ & 1168, Septiembre. \\
\hline 47. & $\mathrm{xx}$ & 1156, Abril. & 88. & 28 & 1168, Octubre. \\
\hline 48. & 535 & 1156, Mayo. & 89. & Xxvil & 1168, Noviembre. \\
\hline 49. & 12 & 1156, Julio. & 90. & XXVIII & 1169, Noviembre. \\
\hline 50. & 13 & 1156, Septiembre. & 91. & 29 & 1170, Enero. \\
\hline 51. & 14 & 1156, Octubre. & 92 & 30 & 1170 , Felbrero. \\
\hline 52. & 15 & 1157, Febrero. & 98. & $\mathrm{xxx}$ & 1170, Junio. \\
\hline 58 & $10 \mathrm{~T}$ & 1157, Febrero. & 94. & 81 & 1170 , Septiembre. \\
\hline 54. & 16 & 1157, Marzo. & 95. & 549 & 1170 , Oetubre. \\
\hline 55. & $96 \mathrm{~T}$ & 1157, Septiembre. & 96. & 32 & 1170, Diciembre. \\
\hline $56:$ & 536 & 1157, Septiembre. & 97. & $90 \mathrm{~T}$ & 1171, Agosto. \\
\hline 57. & 17 & 1158, Enero. & 98. & 33 & 1171, Septiembre. \\
\hline 58. & 538 & 1158, Marzo. & 99. & 34 & 1171, Soptiembre. \\
\hline 59. & 537 & 1158 , Octubre. & 100 . & $65 \mathrm{~T}$ & 1171 , Octubre. \\
\hline 60. & 18 & 1158. & 101. & 550 & 1172 , Marzo. \\
\hline 61. & 539 & 1160, Marzo, & 102. & XXXII & 1172, Junio. \\
\hline 62. & 540 & 1160, Marzo. & 108 & 35 & 1173, Febrero. \\
\hline 63. & 19 & 1180 , Septiembre. & $10 x$. & 282 & $1173 ?$, Marco. \\
\hline 64. & 541. & 1160, Octubre. & 105 & 36 & 1173, Mayo. \\
\hline 65 . & 20 & 1161, Abril. & 106 & $15 \mathrm{~T}$ & 1176, Mayo. \\
\hline 66 & 542 & 1161, Diciemilure. & 107. & XXXIII & 1173 , Junio. \\
\hline 67. & 21 & 1162, Enero. & 308. & $\operatorname{cxxX}(100,081)$ & 1173 , Septiembre \\
\hline 68. & 22 & 1162, Octubre. & $j 09$. & $\operatorname{CXXIX}(108,981)$ & 1174, Febrero. \\
\hline 68. & 23 & 1162, Octubre. & 110. & XXXIV $(181,1.072)$ & 1174, Febrero: \\
\hline 70. & 548 & 1162, Dieiembre. & 111. & xxxv & 1174, Marzo. \\
\hline 71 . & $22 \mathrm{~T}$ & 1163, Fnero. & 112 & 37 & 1174, Marzo. \\
\hline 72. & 24 & 1163, Febrero. & 113. & 38 & $1174, \Lambda$ gosto: \\
\hline 73 & XXґI & 1164, Marzo. & 114. & 551 & 1174, Noviembre. \\
\hline 74. & 544 & 1165, Abril, . & 115. & $77 \mathrm{~T}$ & 1175, Febrero. \\
\hline 75. & 25 & 1165, Maya. & 116. & $49 \mathrm{~T}$ & 1175, Febrero. \\
\hline 76. & 545 & 1165, Junio. & 117. & 39 & 1175, Marzo. \\
\hline 77. & LXXXIV & 1165, Diciembre. & 118. & $\operatorname{LXV}(3,30,728)$ & 1175, Marzo. \\
\hline 78. & 546 & 1166, Enero. & 119. & $552(732)$ & 1175 , Abril. \\
\hline 79 . & $49(156)$ & 1166, Marzo. & 120 , & $41 \mathrm{~T}$ & 1175, Agosto. \\
\hline 80 . & $x X V$ & L166, Septiembre. & 121. & XXXVII & 1175 , Septiembre. \\
\hline 81. & $12 \mathrm{~T}$ & ¿11669\% Oelubro. & 122 & 558 & 1175 , Noviembre. \\
\hline 82 . & XXVI & 1167, Mayo. & 123. & 555 & 1176, Mayo. \\
\hline 83. & 547 & 1167, Julio. & 124 & 554 & 1176, Junio. \\
\hline 84. & 26 & 1168, Marzo. & 125. & $\mathrm{XI},(164)$ & 1176, Junio. \\
\hline 85 . & 548 & 1.168, Abril. & 126. & 40 & 1176, Julio \\
\hline
\end{tabular}




\begin{tabular}{ll} 
N. & \multicolumn{1}{c}{ Signatura. } \\
- & \\
127. & XIJI \\
128. & 41 \\
129. & 558 \\
130. & 42 \\
131. & 556 \\
132. & 557 \\
133. & 43 \\
134. & $21 \mathrm{~T}$ \\
135. & XI,Il \\
136. & XXXI
\end{tabular}

137. C $(221,264,268,270,278,286,296,321$, $324,951,361) \quad 1178$, Febrevo.

138. 44

139. XLIL

140. $45(150)$

14:1. XLIV

142. $26 \mathrm{~T}$

143. $48 \mathrm{~T}(2,9,17,36)$

144: $562(737)$

145. 559

146. $66 \mathrm{~T}$ ?

147. 46

148. 560

149. 501

150. $45(140)$

151. 565

152. 563

153. 564

154. 47

155. 48

156. $49(79)$

157. $36 \mathrm{~T}$

158. XLVI

159. 50

160. 51

161. $94 \mathrm{~T}$

162. 52

163. 53

164. XL (125)

165. $95 \mathrm{~T}$

166. 54
1176, Noviembre.

1176 , Dieiembre.

1177 , Enero.

1177 , liebrero.

117, Febrero.

1177, Marzo.

1177, Mayo.

1177, Junio.

1177, Jicienlifre.

1178, Enero.

1178, Febrero.

1178, Abril.

1178, Mayo.

1178, Junio.

1179, Mayo.

1179, Agosto.

1180, Enero.

1180 , Julio.

1180, Agosto.

1180, Agosto.

1180, Septiembre.

1180, Septiembre.

1180 , Diciembre.

1181, Enero.

1181, Febrero.

1181, Febrero.

1181, Harzo.

1181, Mayo.

1181, Oetubre.

1181 , Octubre.

1181 , Diciembre.

1182, Febrero.

1182, ¿Marzo?

1182, Abril.

1182, Agosto.

1182, Septiembre.

1182, Septiembre.

1183 , Febrero.

1183, Febrero.
N. - Signalura.

167. S. Nicolas, Toledo 1188, Marzo.

168. 55 1183, Mayo.

169. 56

1183 , Septiembre.

170. 566

171. $57(1.086)$

1.84, Abril.

172. 58

1184, Mayo.

1185, Enero.

173. 59

1185, Enero.

174. $40 \mathrm{~T}(736,1.017) \quad$ 1185, Julio.

17.5. 86 ' 1185. Julio.

176. $16 \mathrm{~T} \quad 1185$, Septiembre.

17i. 567

1.7. XLIX

179. 60

1185, Oetubre.

118\%, Noviembre.

1185, Diciembre.

180. 61

1185, Diciembre.

181. XXXIV (181, 1.072) 1186, Enero.

182. 496

1186, Febrero,

188. L

184. . LI

i.85. LII

186. 572

187. 568

188. 570

189. 63

1.90. 571

191. 64

192. LIII ,

193. 569

194. 578

195, 574

196. 65

197. LIV

1186, Agosto.

1186, Septfembre.

1186, Octubro.

1187, Marzo.

1187; Abril.

1187, Mayo.

1187, Mayo.

1187, Junio.

1187, Julio.

1187, Agosto.

1187, Octubre.

1187, Noviembre.

1188, Enero.

1188, Abril.

1188, Abril .

1188, Mayo.

198. 574 bis

199. 66

200. $43 \mathrm{~T}$

1188, Agosto.

1188, Agosto.

201. 67

202. 575

203. $44 \mathrm{~T}$

204. 69

205. 68

206. 70

207. 230
1188, Septiembre.

1188, Septiembre.

1188, Noviembre.

1189, Julio.

1189, Febrero.

1189, Diclembre.

$118 \ldots$ 


\begin{tabular}{|c|c|c|c|c|c|}
\hline N. ${ }^{\circ}$ & Slgnaiura. & Ano. & N." & Slanatuta. & Año. \\
\hline 20. & 577 & $11 \% 0$, Marzo. & 248. & $8 i j$ & 11!3, Noviembro. \\
\hline 269. & 71 & 1190, Mayo. & 240. & $x 7$ & $115 \%$, Diciembre. \\
\hline 210. & 72 & $1.3,0, \pm$ ulio. & 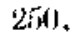 & $\mathrm{I} X \mathrm{X}$ & 11.1, Jiciembres. \\
\hline 211. & 78 & $11(\pi), A$ gosto. & 251. & $8 x$ & I1!1, Enero. \\
\hline 212. & LXIII $(227)$ & 1Ifk, Soptiemlire. & 252 & TXXI & 11!k, Eneto. \\
\hline 213. & $576(37)$ & 1180, octubre. & $25 \%$ & ! T & 11 1, Fuero. \\
\hline 214. & 578 & I101, Eners. & $2 \pi 4$ & $x: 1$ & I1!A, Feorrero. \\
\hline 215. & LVI & 1191, Marto. & 2nis. & $7 \times 12$ & 11!4, , Iu]jo. \\
\hline 216. & 74 & J191, Marzo. & 254 & $\mathrm{x} 2 \mathrm{~T}$ & Ilow, Igosto. \\
\hline 217. & $7 ら$ & 1:31, Septimmlore. & 257. & (N) & 114, octubro. \\
\hline 218. & LVIII & 1191, Seplicnbre. & 258. & !! & 114, Noviemiles. \\
\hline 215. & 76 & 1191, Octubre. & $250:$ & $35 \mathrm{~T}$ & 1195, Febrero. \\
\hline 220 . & 77 & 1101 , Octubre. & 2601. & 92 & 1195, Jullo. \\
\hline 21. & $C(137,264,26)$ & $, 27 \%, 280,296,321$ & 261. & IXXII & 1145, Agosto. \\
\hline & $824,351,361)$ & 1191, Dieiemlire. & $26 ; 2$. & 93 & 1146, Enero. \\
\hline 222 & LLLX & 1302 , Folurero. & 2633 & is & 11:H, Srptiemire. \\
\hline 223. & 78 & 1192, listorero. & 24.4. & $\mathrm{C}(13 \overline{7}, 221,2 \mathrm{i}, 2 \pi$ & , 278, 246, 294, 321 , \\
\hline 224. & $\mathrm{I} . \mathrm{X}$ & 11 ind, Narzo. & & $324,351,261)$ & $119 i$, Oetubre. \\
\hline 225. & I,XII & $11 \% 2$, Mayo. & $26 i 5$ & 562 & 1196, Octulure. \\
\hline 226. & $8 \mathrm{~T}$ & 1192, lunio. & 2430. & $24 \mathrm{~T}$ & 1196, Jiciembre. \\
\hline 227 . & LXUI (2]2) & J192, Agos(1). & $2 t i i$. & 95 & 11!4, Jiciembre. \\
\hline 228. & I,XIV & 1192 , Scplienbre. & 2 (in. & $G(137,221,24,4,2 ;)$ & $1,27 h, 246,290 ;, 321$, \\
\hline 229 & 579 & 1192, Octubre. & & $32.1,351,3(61)$ & 11:n;, Ineiembre. \\
\hline 230. & 79 & 1 $1: 2$, Octubre. & 264 & $1 . x \times y(1 .+12(1)$ & $11 \%$, , lebrero. \\
\hline 231. & LXVI $(942)$ & 1102, licdemhre. & 270 & $(1,37,221,2 i 4,268$ & $3,278,280,291 ;, 321$, \\
\hline 232 . & JXXII & 1192, Diciembre. & & $324,351,3(31)$ & 11!7, Abril. \\
\hline $2 ; 33$ & 581 & 1193 , lnero. & $27 !$ & BT $\mathbf{T}$ & $11: 17$, Abril. \\
\hline 234. & 8) & 1193, Febrero. & 272. & 96 & 1tst, Abril. \\
\hline 235 & $7 \mathrm{~J}$ & 11m, Mfarzo. & 273. & LXXYYI & 197, Aluril. \\
\hline 230. & 81 & 1198, Marzo. & 274. & 87 ' & Iist, Julio. \\
\hline $2: 37$ & $23 \mathrm{I}^{3}$ & 11)3, Marzo. & 275. & $m$ & 1147 , Septiombro. \\
\hline 238. & ISVIII & 11:1:3, Abril. & $27(j$, & JXXV山 & 1197, Noviembre. \\
\hline 289. & $14 T$ & 1.9k, Mayo. & 277. & 188 & 1197, Noviembre. \\
\hline 240. & LXIX & l19:3, Mayo. & $2 \pi 8$. & $C^{\prime}(137,221,26$ & $4,268,270,286$, \\
\hline 241. & 82 & 119k, Julio. & & $290,321,324$ & , 351,361$)$ \\
\hline 212. & $91 \mathrm{I}$ & 110 , Agosto. & & & 1167, Diciembre. \\
\hline B. & $104(294)$ & 11\%i, Agosto. & $27 \%$ & JXXVIII & J16r, Diciembro. \\
\hline 244. & $580(731)$ & 1198, Scptionare. & 280. & LXXI & 1198, Febrero. \\
\hline 45 & 83 & $11) 3$, Septiembre. & 281. & IXXX & 1148, Bebrero. \\
\hline 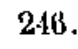 & 84 & 159is, Octubre. & 282. & $\mathrm{~L} \dot{\mathrm{X} X \mathrm{XI}}$ & $11 ! k$, Abril. \\
\hline 247. & 85 & 1193, Noviombre. & 283. & 99 & 1198, Abril. \\
\hline
\end{tabular}




\begin{tabular}{|c|c|c|}
\hline N." & Signatura. & $\operatorname{Año}$. \\
\hline 284 & LXXXII & 1198, Mayo. \\
\hline 285. & 100 & 1198, Jukio. \\
\hline 286 & $\mathrm{C}(137,221,284,26$ & $8,270,296,821,824$, \\
\hline & $351,361)$ & 1198, Octubre. \\
\hline 287. & 101 & 119s, Noviembre. \\
\hline 288. & 102 & 1198, Noviembre. \\
\hline 289. & $38 \mathrm{~T}$ & 1198, Diciembre. \\
\hline 290. & LXXXIII & 1198, Diciembre. \\
\hline 291. & 103 & 11 ty, Fobrero. \\
\hline 292. & $32 \mathrm{~T}$ & 1199, Mazo. \\
\hline 293. & 584 & 1199, Marzo. \\
\hline 294. & $104(24 i)$ & 1199, Marzo. \\
\hline 295. & LXXXY & 1199, Mayo. \\
\hline 296. & $\begin{array}{c}\mathrm{C}(137,221,264, \\
\quad 324,351,361)\end{array}$ & $\begin{array}{c}268,270,286,321 \\
1199 \text {, Noviembre. }\end{array}$ \\
\hline 297. & $80 \mathrm{~T}(335)$ & 1199, Djciembre. \\
\hline 298. & 105 & 11.99. \\
\hline 299 . & $28 t$ & 1..8 (Fin XII.) \\
\hline 300. & 657 & Siglo Xll. \\
\hline 301. & LXXXVI & 1200, Enero. \\
\hline 302. & 106 & 1200, Agosto. \\
\hline 303. & 107 & 1201, Enero. \\
\hline 304. & $75 \mathrm{~T}$ & 1201, Enero. \\
\hline 305. & LXXXYII & 1201, Mayo. \\
\hline 306. & 585 & 1201, Junio. \\
\hline 307. & 586 & 1201, Diciembre. \\
\hline 308. & LXXXYIL & 1201, Diciembre. \\
\hline 309 . & 108 & 1202, Enero. \\
\hline 310. & 109 & 1202 , wnero. \\
\hline 311. & 110 & 1202, Abril. \\
\hline 312. & 111 & 1202, Mayo. \\
\hline 313. & 112 & 1202, Mayo. \\
\hline 314. & 120 & 1202, Junio. \\
\hline 315. & $65 \mathrm{~T}$ & 1202, Agosto. \\
\hline 316. & 113 & 1202, Agosto. \\
\hline 317 & 501 & 1202, Agosto. \\
\hline 318. & 114 & 1202, Octubre. \\
\hline 319. & $56 \mathrm{~T}$ & 1202, Octubre. \\
\hline 320. & 115 & 1202, Diciembre. \\
\hline 321. & $\begin{array}{c}\mathrm{C}(137,221,264, \\
324,351,361)\end{array}$ & $\begin{array}{c}268,270,286,298 \\
1202 \text {, Diciembre, }\end{array}$ \\
\hline
\end{tabular}

\begin{tabular}{|c|c|c|}
\hline$N,{ }^{n}$ & SIgnatura. & A ถ́o. \\
\hline 342. & LXXXLX & 1202, Diciembre. \\
\hline 323. & 116 & 1203, Enero. \\
\hline 324. & $\begin{array}{c}C(187,221,264 \\
321,851,361)\end{array}$ & $\begin{array}{l}268,270,286,296, \\
1206, \text { Nar?o. }\end{array}$ \\
\hline 325. & 117 & 1203, Mayo. \\
\hline 326. & 588 & 1203, Mayo. \\
\hline $32 \bar{t}$ & 587 & 1203, Septiembre. \\
\hline 328. & $74 \mathrm{r}$ & 1203, Octubre. \\
\hline $32 \%$ & $\mathrm{XCI}$ & 120s, Diciembre. \\
\hline 830. & $589^{\circ}$ & 1204, Noviembre. \\
\hline 381. & 118 & 1204, Febrero. \\
\hline 332 & 777 & 1204, F'cbrero. \\
\hline 893. & XCII & 1204, Malzo. \\
\hline 334. & 119 & 1204, Mayo. \\
\hline 330. & $80 \Gamma(297)$ & 1204, Mayo. \\
\hline 336. & $30 \mathrm{~T}$ & 1204, Junio. \\
\hline 337. & XCIII & 1204, Junio. \\
\hline 338. & 590 & 1204, Julio. \\
\hline 399. & 591 & 1204, Septiembre. \\
\hline 840. & $50 \mathrm{~T}$ & 1205, Mazzo. \\
\hline 341. & 141 & 1205, Marzo. \\
\hline 342. & 122 & 1205, Mayo. \\
\hline 343. & 123 & 1205, Mayo. \\
\hline 344. & 124 & 1205, Diciembre. \\
\hline 345 & 125 & 1206 , Enero. \\
\hline 346. & XCVI & 1206, Marzo. \\
\hline 347. & 126 & 1206, Julio. \\
\hline 318. & 127 & 1206, Agosto. \\
\hline 349 . & X(VII & 1206, Octubre. \\
\hline 350. & 592 & 1206, Diciembre. \\
\hline 351 . & $\begin{array}{c}\mathrm{C}(137,221,264, \\
321,324,361)\end{array}$ & $\begin{array}{l}\text { 268, 270, 286, } 296, \\
\text { 1207, Enero. }\end{array}$ \\
\hline 352. & 593 & 1207, Enero. \\
\hline 358. & 595 & 1207, Магzо. \\
\hline 354. & 128 & 1207, Marzo. \\
\hline 355. & 129 & 1207, Mayo. \\
\hline 356. & $57 \mathrm{~T}$ & $120 \%$, Junio. \\
\hline 357. & 130 & 1207, Agosto. \\
\hline 358. & 594 & 1207, Octubre. \\
\hline 359. & XCVШ & 1207; Diciembre. \\
\hline 360. & 596 & 1207. \\
\hline
\end{tabular}




\begin{tabular}{|c|c|c|}
\hline N." & Slanatura. & $A+0$ \\
\hline ist. & 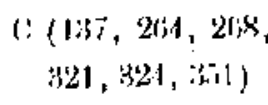 & $\begin{array}{l}2 \pi 0,2 \pi s, 2 k t i, 2 t w i, \\
120 \text {, lielorers. }\end{array}$ \\
\hline $8+i 2$. & 131 & jusk, ckeluhere. \\
\hline 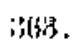 & (2) $\mathrm{I}$ & 120k, singtionstris. \\
\hline 344. & xist & 120 Kr, Novicmbre. \\
\hline 365. & 132 & 1200, Fetbram. \\
\hline sists. & 1333 & 1204, watsero. \\
\hline$\ddot{B i z}$. & $1: 4$ & 12xis, [eetrom. \\
\hline $3(9-4$. & 135 & $124 ! 1$, Fohrors. \\
\hline Btist. & Jisi & 12001, folitroro. \\
\hline 370. & $5: 47$ & Izali, Mlril. \\
\hline 371. & 187 & $120) 4, A g o s k o$ \\
\hline 372 & 138 & $1 \%()$, Agosto. \\
\hline 378 & 134 & 1200, Octuthrs. \\
\hline 374. & 1.40 & 12(y), Oefoutser. \\
\hline 375. & 1.11 & 120", (jelulire. \\
\hline Bits. & 112 & 12001, toduhto. \\
\hline 877. & cl & 1210, Enorn. \\
\hline 878. & 1.45 & 1210, Pulirero. \\
\hline 379. & CII & 1210, Mayo. \\
\hline 380. & GIII & 1210), Jutzio. \\
\hline $380 \mathrm{~b}$ & 18. $Q\left(1 / f_{r}, 3+i\right)$ & 12111, Agosto. \\
\hline $8 \times 1$ & 143 & f2H, octulbre. \\
\hline $3 \times 2$. & 14.1 & 12t1, Sovinlulere. \\
\hline 3584 & $(000$ & 1211, linoro. \\
\hline 384. & $5 \div 4)$ & 1211, Febrors. \\
\hline 385. & $\sin 8$ & 1211, Mtrro. \\
\hline 3856. & CIV & 1211, Abril. \\
\hline 387. & CW & 1211 , Alril. \\
\hline 368. & $1.11 i$ & 1211, Muyo. \\
\hline $38 ! 9$. & U'I & 1211, Nayo. \\
\hline 360. & (VH & {$[21]$, Minyo. } \\
\hline $8 ! 41$. & $14 \pi$ & 1211, Julio. \\
\hline 392. & $98 \mathrm{~T}$ & 1211, Noviomlire. \\
\hline BSt8. & 148 & 1212, fubrero. \\
\hline 804. & $\cos$ & 1212, liebroro: \\
\hline 895. & 602 & 1212, Mayo. \\
\hline 890 & $1-19$ & 1212, Julio. \\
\hline
\end{tabular}

(1) Tumo II.

\begin{tabular}{|c|c|c|}
\hline N." & sianators & $A$ ก。. \\
\hline $3 ! 1 \%$ & lifol & 1212, Soptieubro. \\
\hline $39 k$ & (i) & 121\%, Septiemlyro. \\
\hline 894. & $\operatorname{lix}(7 \mathrm{I})$ & 1212,0 ctulse. \\
\hline$f(x)$ & $(' X 1$ & 1213, Enero. \\
\hline (1)1. & $71 \mathrm{~T}$ & IYl3, Julio. \\
\hline 102 & (:XIJ & 1213. Agosto. \\
\hline 103. & $\operatorname{lin} 1$ & $121:$, Noviembro. \\
\hline 101.4. & $\mathrm{COS}^{\circ}$ & 1214 , Enero. \\
\hline 105. & $(i n)$ & 121.t, Whrero. \\
\hline $\mathrm{HOH}$ & 15 & 1211 , Febrero. \\
\hline 1017 & CXYH & $121\}$, Febrero. \\
\hline 108. & 151 & 1214, Marzo. \\
\hline $4 t)\}$ & 1.52 & 1214, Marzo. \\
\hline 410. & 153 & 121.4, Jiaro. \\
\hline 411. & $70^{\circ} \mathrm{r}$ & 1214, Abril. \\
\hline$\$ 12$ & 154 & 1214, Abril. \\
\hline 413. & d1: & 1211 , Abril. \\
\hline$\$ 14$ & 51. 'T & 1214, Mayo. \\
\hline 415 & $6(17$ & 1214, Mayo. \\
\hline slit. & $156 \sqrt{3}$ & I21. I, Iunio. \\
\hline 117 & (XYl) & 1214, Julio. \\
\hline 41s. & (ithis & 1214 , septimbre. \\
\hline H11. & liji; & 1214, Jicimulre. \\
\hline .201 & $13 \pi$ & Izls, Abril. \\
\hline 121 & \{ilns & 1215, Mayo. \\
\hline 1222 & $70 \mathrm{l}$ & 1215, Agosto. \\
\hline $12:$ & (i11) & 1215, ( )etubre. \\
\hline 421 & 89 & 1215. Novieubre. \\
\hline t25. & $\operatorname{cxix}$ & 1215, Noviemine. \\
\hline 126 & ti(1) $3(3: k)$ & 1215, Novicmbre. \\
\hline $42 \pi$ & 559 bis & S. Xll, 1,er tercjo. \\
\hline $42 S$. & $15 k$ & l21ti, Ėuero. \\
\hline d2త. & li11 & 1216, Enero. \\
\hline 130 & 58 & 1216, Febreto. \\
\hline 131. & $61+4$ & 1216, Eebrero. \\
\hline 132. & $61: 3$ & 1216, Marzo. \\
\hline 133. & lit2 & 121\}, Mayo. \\
\hline 134 & $15 !$ & 121i;, Julio. \\
\hline 435. & $1(3)$ & 12li, Febrero. \\
\hline $43<0$. & (i15 & 1217, Marzo. \\
\hline 437. & (i11i & $121 \vec{i}$, Alsril. \\
\hline
\end{tabular}




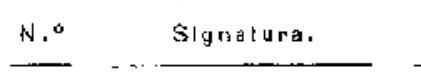

438. 161

434. CXXI

110. 162

441. 163

442. 618

413. 83 ' '

444. $1 \mathrm{~T}$

445. 617

446. 164

447. $618 \mathrm{bis}$

418. 619

449. 165

450. OXXIV

451. CXXIII

459. CXXV

453 . CXXVI

454. 160

455. 47 '

456. 167

457. 168

458. 169

459. CXXVIJI

460. 170

461. 171

462. 172

463. 178

464. 620

465. 174

466, 175

467. 621

468. CXXX

4.69. 176

470. 177.

471. $52 \mathrm{~T}$.

472, 622

473. 178

474. 179

475.623

476, 180

477. 181

478. 624

\section{.}

1217, Abril.

1217, Mayo.

1217, Junio.

1217, Julio.

1.218, Mayo.

1218, Agosto.

1218 , Agrosto.

1218, Dieicmbrc.

1219, Febrero.

1219, Pebrero.

1219, Marzo.

1219, Abril.

1219, Abrit.

1219, Mayo.

1220, Pebrero.

1220, Marzo.

1220, Mbril.

1220, Mayo.

1220, Mayo.

1220 , Julio.

1220 , Oclubre.

1221 , Julio.

1221, Septiembre.

1221, Octubre.

1221 , Octubre.

1221, Noviembre.

1221, Noviembre.

1222 , Junio.

1222, Junio.

1222, Julio.

1222, Agosto.

1222, Noviembre.

1222, Dieiembre.

1223, Abril.

1228 , Noviemlure.

1223, Dielembre.

1224, Enero.

1.224, Mazo.

1224, Mayo.

1224, Junio.

1224, Diciembre.

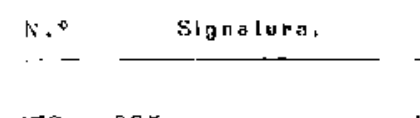

479. 625

430. 182

181. 183

482. 184

483.626

484. 185

185. $60 \mathrm{x}$

486. 186

487. 627

488. 187

489. 188

490. 189

191. 628

492. 629

493. 190

494. 1.91

495. 192

496. 630

497. 631

498. 198

499. 632

500. 194

501. 195

502. 196

503. 197

504. 198

$505, \quad 683$

506. 199

507. 634

508. 200

509. 201

510. 202

511, 686

512. 635

513. $72 \mathrm{~T}$

514, $61 \mathrm{~T}$

515. 208

516. $81 \mathrm{~T}$

517. 204

518. 205

519. $92 \mathrm{~T}$ \begin{tabular}{l} 
A í . \\
\hline 1225, Agosto. \\
1225, Agosto. \\
1225, Agrosto. \\
1226, Febrero. \\
1226, Marzo. \\
1226, Octubre. \\
1226, Septiembre. \\
1226, Novicmobre.
\end{tabular}

1227 , Octubre.

1227, Octubre.

1228 , Febrero.

1228, Alril.

1228, Abril.

1228, Mayo.

1228, Dieiembre.

1229, Febrero.

1229, Marzo.

1229, Marzo.

1229, Mayo.

1229, Octubre.

1280, Enero.

1230, Abril.

1280 , septiembre.

1.230, Septiembre.

1231, Mayo.

1231, Mayo.

1.231, Septiembre.

1231, Diciembre.

123\%, Febrero.

1233, Mayo.

1238, Junio.

1233, Julio.

1234, Marzo.

1284, Abril.

1234, Mayo.

1234, Agosto.

1235, Febrero.

1235, Abril.

1235, Mayo.

1285, Septiembre.

1236, Junio, 


\begin{tabular}{|c|c|c|}
\hline$N .^{\circ}$ & Slgnatura. & Aถู०. \\
\hline 520. & $206^{\circ}$ & 1236, igosto. \\
\hline 521 & 637 & 1237, Мarzo. \\
\hline 522 & 207 & 12:7, Mayo. \\
\hline 523 & 208 & 1237, Noviembre, \\
\hline 524 & 209 & 1237 , Dieiemisre. \\
\hline 525 & 210 & 123s, Mnero. \\
\hline 526. & 211 & $12 \% 8$, Marzo. \\
\hline 527. & 639 bis & 1238, Abril. \\
\hline 528 & 639 & 1238, Junio. \\
\hline 523 & 212 & 1238, Julio. \\
\hline 580. & 213 & 1258, Lgosto. \\
\hline 531. & $68 \mathrm{\prime}$ & 1238, Agosto. \\
\hline 532 & 688 & 1288, septiembre. \\
\hline 533. & 214 & 1239, Enero. \\
\hline 534. & 215 & 1239, Julio. \\
\hline $595:$ & 216 & 1289. \\
\hline 536. & 217 & 1240, Marzo. \\
\hline 537. & 218 & 1240, Mayo. \\
\hline 538. & 219 & 1240, Septiemlore. \\
\hline $539 \%$ & 640 & 1240 , Octubre. \\
\hline 540 & 220 & 1240 , Dieiembre. \\
\hline 541 & 221 & 1241, liebrero. \\
\hline 542 & 222 & 1241 , Junio. \\
\hline 548 & 223 & 1241, Junio. \\
\hline 544. & 224 & 1.241, Junio. \\
\hline 545 & 225 & 1.241, Julio. \\
\hline 546. & $67 \mathrm{~T}$ & 1241, Julio. \\
\hline 547. & $29 \mathrm{~T}$ & 1241, Julio. \\
\hline $548:$ & 226 & 1241, Agosto. \\
\hline 549 & 227 & 1241 , Octubre. \\
\hline 550 & 228 & 1242, Febrero, \\
\hline 551 & $69 \mathrm{Y}$ & 1242, Marzo. \\
\hline 552 & 229 & 1242, Abril. \\
\hline 553 & $230^{\circ}$ & 1242, Abril. \\
\hline 554 & 281 & 1242, Abril. \\
\hline 555. & 232 & 1242, Abril. \\
\hline 556 & 233 & 1242, Julio. \\
\hline 557. & 234 & 1242 , Agosto. \\
\hline 558. & 235 & 1242, Oetubre. \\
\hline 559. & $84 \mathrm{~T}$ & 1242, Noviembre. \\
\hline 560. & $640 \mathrm{biB}$ & 1243 , Febrero. \\
\hline
\end{tabular}

\begin{tabular}{|c|c|c|}
\hline$N \cdot a$ & Signatura, & Ano. \\
\hline 561 & $(841(1.081)$ & 1244, Febrero, \\
\hline 562. & $2 * 0$ & 1214, Marzo. \\
\hline 503 & 237 & 1244, Abril. \\
\hline 564. & 288 & 1244, Julio. \\
\hline 565. & 239 & 1244, Septiembre. \\
\hline 566 & 240 & 1245, Enero. \\
\hline 567 & 241 & 12.15, Abril. \\
\hline 568. & 242 & 1245 , Abril. \\
\hline 569. & 243 & 1245, Noviembre. \\
\hline 570. & 244 & 1246, Enero. \\
\hline 571 & 245 & 1246 , Abril. \\
\hline 572. & .509 & 1246, Mayo. \\
\hline 573. & 246 & 1247, Mayo. \\
\hline 574. & 247 & 1248, Enero. \\
\hline 575. & 248 & 1248, Julio. \\
\hline 576. & 249 & 1248, Noviembre. \\
\hline 577. & 250 & 1250, Julio. \\
\hline 578. & 251 & 1250, Septiembre. \\
\hline 579. & 252 & 1251, Suptiembre. \\
\hline 580. & 253 & 1251 , Octubre. \\
\hline 581. & 254 & $125 .$. Noviembre. \\
\hline 582 & 255 & 1252 , Julio. \\
\hline 583 & 250 & 1252, Noviembre. \\
\hline 584 & 257 & 1253, Marzo. \\
\hline 585. & 258 & 1253, Abril. \\
\hline 586. & 259 & 1253, Mayo. \\
\hline 587. & 260 & 1253, Septiembre. \\
\hline 588. & 261 & 1253, Oetubre. \\
\hline 589 & 262 & 1254, Agosto. \\
\hline 590 & $85 \mathrm{~T}$ & $12 \check{6} 4$, Oetubre. \\
\hline 591. & 263 & 1254, Noviembre. \\
\hline 592 & 264 & $125 \check{0}$, Enero. \\
\hline 593. & 265 & 1255, Abril. \\
\hline 594. & $63 \mathrm{~T}$ & 1255, Mayo. \\
\hline 595. & 266 & 1255, Julio. \\
\hline 596. & 642 & 1255, Agosto. \\
\hline 597. & 267 & 1256, Fnerv. \\
\hline 598. & 268 & 1256, Enero. : \\
\hline 599. & 269 & 1257, Enero. \\
\hline 600 . & 270 & 1257, Enero. \\
\hline 601. & 271 & 1257, Febrero. \\
\hline
\end{tabular}




\begin{tabular}{|c|c|c|c|c|c|}
\hline N.: & Signatura. & Año. & $N \cdot{ }^{\circ}$ & Slgnatura. & Ano. \\
\hline 602 & 272 & 1257 , Abril. & 643. & 806 & 1274, Dieiemure. \\
\hline 603 & 273 & $125 \bar{i}$, Septiombre. & 644 & $\sin 1$ & 1275, ¿Marzo? \\
\hline 604 & 274 & 1257, Septiembre. & bitis. & $30 \bar{i}$ & 1275, Julio. \\
\hline 605 & 643 & 1258, Mlarzo. & (i.16. & :30s & 1275, Agosto. \\
\hline 606 & 275 & 1258, Oetubre. & 647. & 305 & 127\%, Agosto. \\
\hline $60 \bar{i}$ & 644 & 1258, Jiciembre. & $7+8$. & 310 & 1275, Septicmbre. \\
\hline 608 & 276 & $12: 9$, Мгвуо. & 749 & 311 & 1275, Noviembre. \\
\hline 609 & $27 i$ & 1260. Mnyo. & 650 & 812 & 1275, Diciembre. \\
\hline 610. & 278 & t260, Julio. & (is) & 313 & 1275, Diciembre. \\
\hline 611. & 279 & 1201, Mayo. & 652. & $31+$ & 1276, Diciembrc. \\
\hline 612 & 280 & 1261, Jiciembre. & 653. & 316 & 1277 , Mayo. \\
\hline 613. & 283 & 1262, Febrero. & 654 & $315(062)$ & 1277, Diciombro. \\
\hline 614 & 284 & $1202, \Lambda$ bril. & (65). & 317 & 1278, Enero. \\
\hline 615. & 285 & 1262, Julio. & 656 & 318 & 1278, $A$ bril. \\
\hline 616. & 286 & 1262, Octubre. & 657 & 819 & 1278, Octubre. \\
\hline 617. & 287 & 1263, Octubre. & 658 & 320 & 1278, Noviembre. \\
\hline 618. & $25 \mathrm{~T}$ & 1264, Mayo. & 659. & 321 & 1278, Diciembre. \\
\hline 619. & $290(626,629,633)$ & 1264, Mayo. & 860. & 322 & 1279, Febrero. \\
\hline 620 & $\mathbf{B T}$ & 1264, Junio. & 601. & 323 & 1279, Abril. \\
\hline 621 & 288 & 1264, Junio. & 662. & 324 & 1270, Agosto. \\
\hline 622. & 289 & 1264, Agosto. & 663. & 325 & 1280, Febrero. \\
\hline 628. & Ban Nicolás & 1265, Agosto: & 364. & 646 & 1280, Marzo. \\
\hline 624. & 645 & 1265, Septiembre. & 665. & 326 & 1280, Abril. \\
\hline $62 \dot{5}$ & 291 & 1265 , Octubre. & 666 & 827 & 1280, Abril \\
\hline 626. & $290(619,629,633)$ & 1265, Dieiembre. & 667. & 328 & 1280, Junio. \\
\hline 627. & 292 & 1266, Abrill. & 368. & 329 & 1280, Octubre. \\
\hline 628. & 293 & 1266, Agosto. & 669 & $647(683)$ & 1280 , Noviembre. \\
\hline 629. & $290(619,626,683)$ & 1266, Septionbre. & 670. & 330 & 1281, Junio. \\
\hline 630 & 294 & 1266, Oetubre. & 671. & 331 & 1281, Agusto. \\
\hline 631. & 295 & 1267, Marzo. & 672. & 382 & 1282, Noviembre. \\
\hline 632. & 296 & 1267, Abril. & 673. & 383 & 1288 , Juiio. \\
\hline 633 & $290(610,626,62 \theta)$ & 1271, Noviembre. & 674. & 648 bis & 1283, Agosto. \\
\hline 634. & 297 & 1273, Enero. & 675. & 648 & 1283, Agosto. \\
\hline 635 & 298 & 1273, Marzo. & 676. & 334 & 1283, Bepticmbre. \\
\hline 636 & 300 & 1273, Marzo. & B77. & $385(983,1.035)$ & 1283, Diciemlire. \\
\hline 637 & 301 & 1273, Junio. & 678. & 336 & 1284, Abril. \\
\hline 638 & 302 & 1273, Julío. & 679. & 387 & 1284, Mayo. \\
\hline 639. & 304 & 1273, Diciembre. & 680. & g38 & 1284, Septlembre. \\
\hline 640. & 299 & 1274, Marzo. & 681. & 339 & 1284, Soptiembre. \\
\hline 641. & 805 & 1274, Abril. & 682. & $340(687)$ & 1285, Febrero. \\
\hline 642 & 303 & 1274, Septiembre. & 683. & $647(669)$ & 1285, Marzo. \\
\hline
\end{tabular}




\begin{tabular}{|c|c|c|c|c|c|}
\hline$N \cdot 0^{\circ}$ & Signatura. & Añ. & N." & Slgnalura. & Año. \\
\hline 684. & $\begin{array}{c}28-6 . T(709,871,87 \\
1.031 \text { y } 1.092)\end{array}$ & $\begin{array}{l}2,874 \text { al sk5, 1.(5)! } \\
1285, \text { Agoslo. }\end{array}$ & $\begin{array}{l}724 . \\
725 .\end{array}$ & $\begin{array}{l}6.54 \\
65.5\end{array}$ & $\begin{array}{l}\text { 1299, Enero. } \\
1300, \text { Alisil. }\end{array}$ \\
\hline 685. & (34:) & 1285, Sieptitmbre. & $\vec{i} 2 i$ & $(0.36$ & 1308, Agosto. \\
\hline 686. & 341 & 1.28: , ontuldes. & & & \\
\hline 687. & $340(1382)$ & 3286, Entoro. & & & \\
\hline 688. & $3: 2$ & 1286, Jinero. & \multirow{3}{*}{\multicolumn{3}{|c|}{ JONAOCONA }} \\
\hline 689 & 343 & $12 \times 6$, Agosto. & & & \\
\hline 600 & 650 & 1286; Noviembre. & & & \\
\hline 601. & 344 & 1286, Dicismlyte. & $727(1)$ & 370 & 1.137, Julio. \\
\hline 602 & 345 & 1287, linero. & 728. & $2(3,30,118)$ & $1152, \Delta 1, r i]$ \\
\hline $6 \$ 3$. & 346 & 1287, Mayo. & 728 & 658 & 1157 , Noviembre. \\
\hline 694 & 347 & 1287 , Oetubre. & 750 & 659 & 1.157, Noviemure. \\
\hline 645. & 348 & 1287, Diciombre. & 731 & $580(244)$ & 1159, Mayo. \\
\hline 696 & $34 ! 3$ & 1288 , lipbrero. & 732 & $552(11 \unlhd)$ & 1160, Enero. \\
\hline 697 & 350 & 1288, Futsoro. & 7333 & 600 & $11 \mathrm{ti}$, Oetubre. \\
\hline 698. & 851 & 1288, MfRzo. & 734 & XXIX & 1370, Febrero. \\
\hline 699. & $4 \mathrm{~T}$ & 1288, Sepliembre. & 735. & 774 & 117\%, Mayo. \\
\hline 700 & $17 \mathrm{~T}$ & 1289, Junio. & 734 & $40 \mathrm{~T}(1 \mathrm{i} 4,1.017)$ & 1179, Diciemlire. \\
\hline 701. & 352 & 1200, Marzo. & 737 & $737(1.44)$ & 1180, Marzo. \\
\hline 702. & $353(991)$ & 1290, Abril. & 7 ths. & 449 & $118 \bar{T}$, Aloril. \\
\hline 708. & 651 & 1290, Julio. & 789 & 371 & 1189, linero. \\
\hline 704 & 354 & 1200 , Julio. & 740 & LXXIY & 1196, Junio. \\
\hline 705. & 355 & 1290, Septiembre. & 741 & $7 \pi$ & 1196, Dieiembre. \\
\hline 706 & 356 & 1200, Septionbre. & 742 & XCIV & 1204 \\
\hline 707. & 357 & 1240, Noviomire. & 743 & 661 & 1206, Oclubre. \\
\hline 708. & 858 & 1290, Diciombre. & 744 & B(i2 & 1207, Febrero. \\
\hline 709 & 28-11. 'l' & 1291, Novlembre. & 745 & 502 & 1207, Julio. \\
\hline 710 & 652 & 1292, Mayo. & 746 & 779 & 1210, Junio. \\
\hline 711 & 350 & 1292, Septiemloro. & 747 & $\mathrm{CX}(399)$ & 1212, Septicmbre. \\
\hline 7.12 & 300 & 1293, Abril. & 748. & 372 & 1213, Abrit. \\
\hline 713. & 301 & 1293, Agrosto. & 749 & 373 & 1213, Abril. \\
\hline 711. & 653 & 1293, Noviembre. & 750 & CXIY & I213, Julio. \\
\hline 71.5 & 362 & 126il, Mnrzo. & 751 . & CXII & 1213. Sepliembre. \\
\hline $7 \mathrm{its}$ & 363 & 12ilt, Octulser. & 752. & $6 i 63$ & 1213, Noviembre. \\
\hline 717 & 364 & 124.4, Novitmbre. & 758 & 374 & 121, Febrero. \\
\hline 718. & 865 & 1245, Febrero. & 754 & 665 & 1210, Sepliembre. \\
\hline 719. & 366 & 1295, Junio. & 735. & 634 & 1216, Noviembre. \\
\hline 720. & 307 & 1295, Junio. & 756. & 660 & 1217, Febrero. \\
\hline 721. & 368 & 1296, Agosto. & & & \\
\hline 722. & $54 \mathrm{~T}$ & 1296, Septiomlse. & & & \\
\hline 723. & 369 & 1297, Febrero. & (1) & Tomo IIl. & \\
\hline
\end{tabular}




\begin{tabular}{|c|c|c|}
\hline $\mathrm{N},{ }^{\circ}$ & Slgnalup. & Ano \\
\hline 757. & 680 & $122 \ldots$ \\
\hline 758. & 375 & 1221, Agosto. \\
\hline 759. & 667 & 1224, Abril. \\
\hline 760 & 668 & 1225, Abril. \\
\hline 761 & 669 & 1225, Abril. \\
\hline 762. & ${ }^{3} 70$ & 1226, Julio. \\
\hline 763. & 671 & 1226, Julio. \\
\hline 764 & 672 & $122 \%$, Aturil. \\
\hline 765. & $93 \mathbf{T}$ & 1227, Julio. \\
\hline 766 . & CXXII & 1228, Julto. \\
\hline 767. & 673 & 1228, Noviemlıre. \\
\hline 768. & 376 & 1230, Felurero. \\
\hline 769. & 674 & 1280, Mayo. \\
\hline 770. & 675 & 1233 , Oetabro. \\
\hline 771. & 676 & 1233, loiciembre. \\
\hline 772 & 677 & 1234, Mayo. \\
\hline 773 & $33 \mathrm{~T}$ & 1235, Agosto. \\
\hline 774. & 678 & 1289, Julio. \\
\hline 775. & 785 & 1243 , Enero. \\
\hline 776. & 377 & 1245, Dicicmbre. \\
\hline 777. & 378 & 1246, Enero. \\
\hline 778. & 380 & 1252, Oetubre. \\
\hline 779. & 381 & 1254, Abril. \\
\hline 780 & 679 & 1256, Diciembre. \\
\hline 781. & 382 & 1265, Marzo. \\
\hline 782. & 383 & 1266, Septiembre. \\
\hline 783 & 681 & 1283, Febrero. \\
\hline 784. & 682 & 1295, Agosto. \\
\hline
\end{tabular}

EMANOIPACIÓN DE ESCLAVOS

$\begin{array}{lll}\text { 785. XXII } & \text { 1163, Jumio. } \\ 786 . & \text { XXIX } & 1176, \text { Julio. } \\ 787 . & 762 & 1235, \text { Mayo. } \\ 788 . & 487 & 1241, \text { Diciembre. } \\ 789 . & 763 & 1247, \text { Noviembre. } \\ 790 . & 766 & 1248, \text { Diciembro. } \\ 791 . & 791 & 1251, \text { Octubro. } \\ 792 . & 488 & 1252, \text { Enero. }\end{array}$

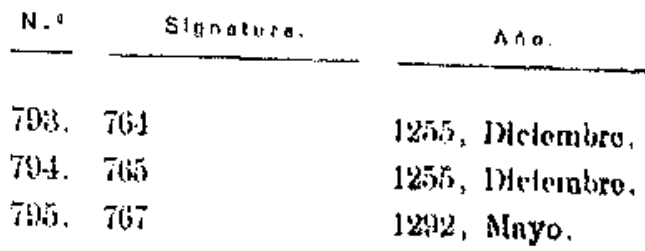

793. $7(5.1$

$704 . \quad 7(6)$

$78 \% .767$

12his, DHciembro. 125\%, linternore. 1242, Mayo.

\section{OAMBION}

796. $50^{\circ} \mathrm{T}$

$707,70 \%$

798.706

799. 421

800. I,VII

801. 122

80x. $70 \%$

803. 708

804.423

805. 709

806. 710

807. 711

808. 712

809. 713

810. 714

811. 715

812. 716

813. 717

811. 718

815. 719

816. $97 \mathrm{~T}$

817. 720

81.8. $73 \mathrm{~T}$

819. 65

820. 424

821. 425

822. 720 bis

823. 426

824. 427

825. 721

826,722

827. 723

\author{
1150, Hinnsu. \\ 1169. soptlembrn. \\ 1179, Alril. \\ 1]88, septlentre. \\ 1191, Junios.

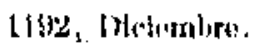 \\ 1193, Junda. \\ 115), Novtembro. \\ 11 ita. Fethera. \\ 1108, Mlarzo. \\ 1202, Oetuture. \\ 1200, sppllombra. \\ 1210, Agosto. \\ 1211, Junlo. \\ 1213, Abrtl. \\ I214, Holirero. \\ 1214 , libiruro. \\ 1225, Al, rj\}. \\ 12tis, Mayo. \\ 1286, Mareo. \\ 1230, Diclembro. \\ 12d, Marzo. \\ 1254, Novinmbro. \\ 1250, Marzo. \\ 1250, Marzo. \\ 125y, Abrll. \\ 1250, Atru. \\ 1260, Bapttembro. \\ 1281, Mayo. \\ 1280, Julio. \\ 1282, Julo. \\ 1284, Novitmbro.
}




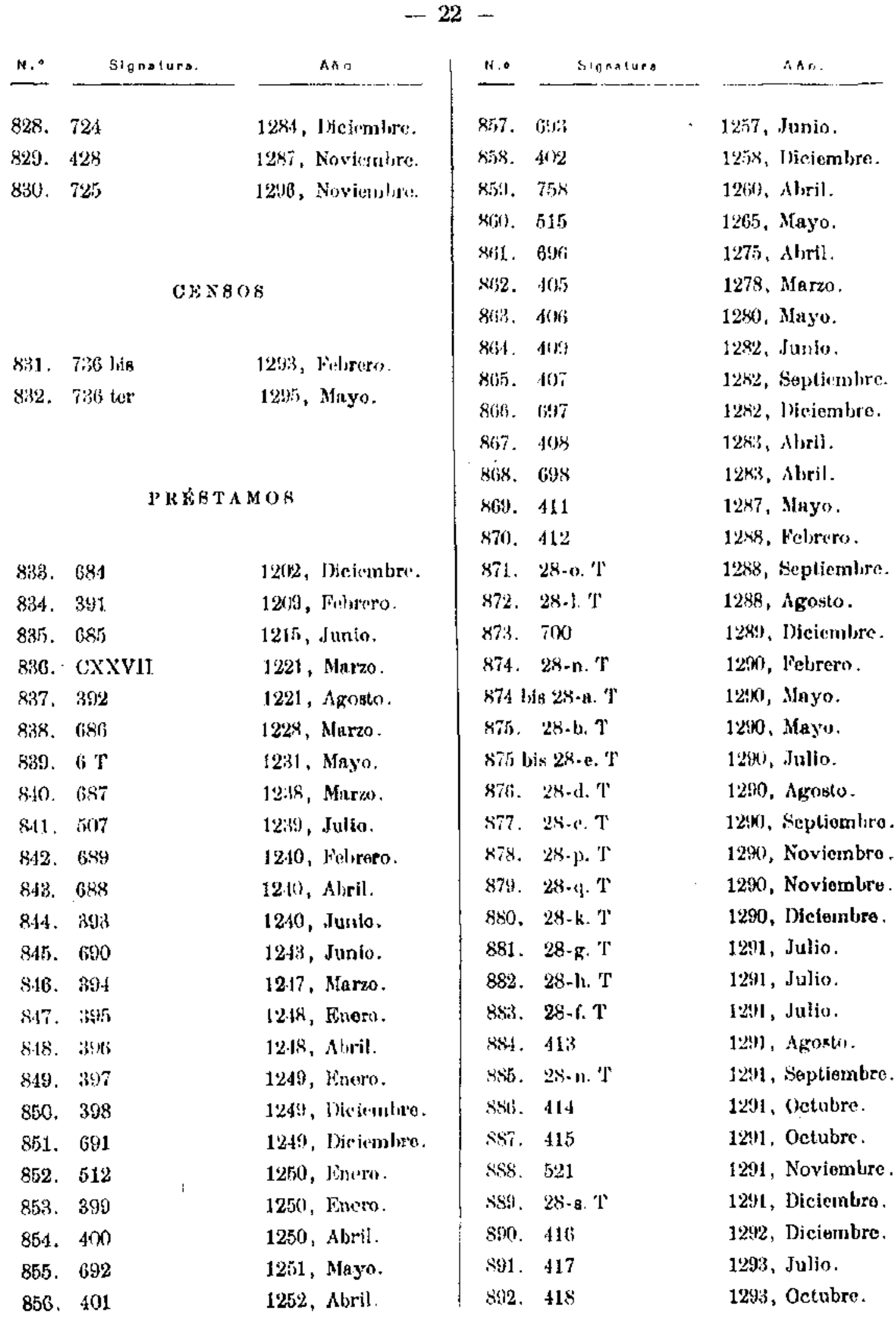




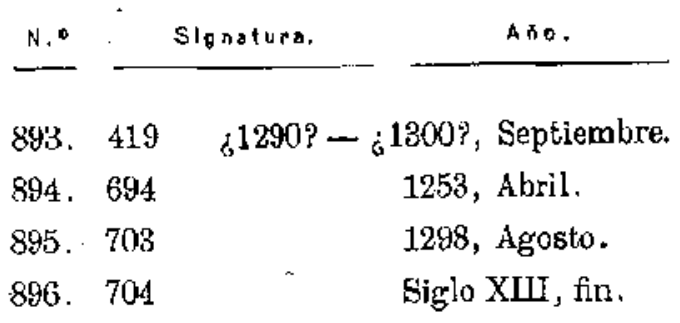

EMPENO

$\begin{array}{ll}\text { 897. } & 384 \\ 898 . & 385 \\ 899 . & \text { XXXVI } \\ 900 . & 386 \\ 901 . & 387 \\ 902 . & 388 \\ 903 . & 389 \\ 904 . & 390 \\ 905 . & \text { ГXXII } \\ 906 . & 683 \\ 907 . & \text { XCV } \\ 908 . & 403\end{array}$

A RRIENDOS

909. $45 \mathrm{~T}$

910. 429

911. 726

912. 430

913. 62 小

914. 431

915. 727

915 bis.

916. 728

917. 729

918. 492

919. 730
1167, Hebrero.

1175, Mayo.

1176, Febrero.

1180, Enero.

1182, Octubre.

1188, Febrero.

1190, Junio.

1196, Abril.

1197, Dicistabre.

1208, Enero.

1259, Noviembre.
1163, Febrero.

1232, Abril.

1241, Agosto.

1246, Julio.

1250, Marzo.

1258, Ociubre.

1260, Enera.

1261, Enero.

1265 , Sep tiembre.

1272, Oetubre.

$$
\text { N. }
$$

920. 732

921. 731

922. 749

Signatura.

Año.

1293 , Septiembre.

1.293 , Octubre.

\& Siglo XII, fin?

T UTEIA

923. 767 bis

1179, Julio.

PI, $\Lambda$ T T ClÓN

924. 483

925. 434

$926 . \quad 435$

927. XVII

928. 733

929. $13 \mathrm{~T}$

930. 784

931. 734 bis

932, 735

933. 786

1144, Febrero.

1144, Febrezo.

1148, Diciembre.

1153, Abril.

1159 , Marzo.

1165, Abril.

1257, Mayo.

1257, Mayo.

1258, Enero.

\&12609...

DEPOSITO

934. 508

1240, Octulbre.

FIANZAS I'ERSONALES

985, 605

936. 699

1260, Diciembre.

937. 701

1287, Junio.

938. 702

1296, Septiembre.

939. 420

1297, Junio.

1315, Abril.

\section{PLITO8}

940. 474

941. 760
1114, Oetubre.

1186, Enera. 


\begin{tabular}{|c|c|c|}
\hline $\mathbf{N} .^{\circ}$ & Signatura. & Ano. \\
\hline 942 . & $\mathrm{I}, \mathrm{XVI}(2 \mathrm{2} 1)$ & 1192, Jiciembre. \\
\hline (34). & $42 \mathrm{I}$ & J 397, Alsil. \\
\hline 94.4 & 476 & 11 ניו! Julio. \\
\hline 945. & 439 & Lex), funio. \\
\hline 946. & $7 \cdot 42$ & 1204, . Mtarzo. \\
\hline 947. & 742 biss & 1266, dunio. \\
\hline 948. & $18 \mathrm{~T}$ & 1207 , Julio. \\
\hline 949 & 477 & 1209, Julio. \\
\hline 950 & 478 & 120\%, oclubre. \\
\hline 951. & 479) & 1213, hyosto. \\
\hline 952. & 440 & 121.1, Wuero. \\
\hline 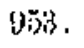 & .180 & 1214, agonto. \\
\hline 954. & CXX & 1216, Jiciombre. \\
\hline $9 ; 5$ & 761 & 1218, Mayo. \\
\hline 956. & 441 & 1226, Marzo. \\
\hline 957. & 448 & 1201, Abril. \\
\hline 958 & 404 & 126*2, l'ebrero. \\
\hline 950 . & 481 & 1262 , Junio. \\
\hline 960. & 482 & 1269, , Marzo. \\
\hline 961. & 488 & 1271, Septionlyre. \\
\hline 462 & $315(6.51)$ & loti, Albril. \\
\hline 968. & $285(677,1.055)$ & 128il, (letulne'. \\
\hline 944. & 484 & 1ย89, Mayo. \\
\hline 965. & $48 i$ & 1294, Junio. \\
\hline
\end{tabular}

OUNVENIOS

\begin{tabular}{|c|c|}
\hline $966 . \quad V 1$ & 1121, Agosto. \\
\hline 967,436 & IJ 24 , Agosto. \\
\hline $968 . x^{x}$ & 1138, Agosto. \\
\hline 969. XIll & 1143, Meinmbre. \\
\hline 970.737 & 1147, Febroro. \\
\hline 9๋1. 73s & 1150, Abril. \\
\hline 972.739 & 1158, linnero. \\
\hline 973.740 & 1160, Noviejnbre \\
\hline 974. XXIV & 1164, Abril. \\
\hline 975. XXXYIII & $117 \mathrm{k}$, lebrero. \\
\hline $976 . \quad 437$ & 1177 , Septienbre. \\
\hline 977. XLVII & 1185 , Julio. \\
\hline
\end{tabular}

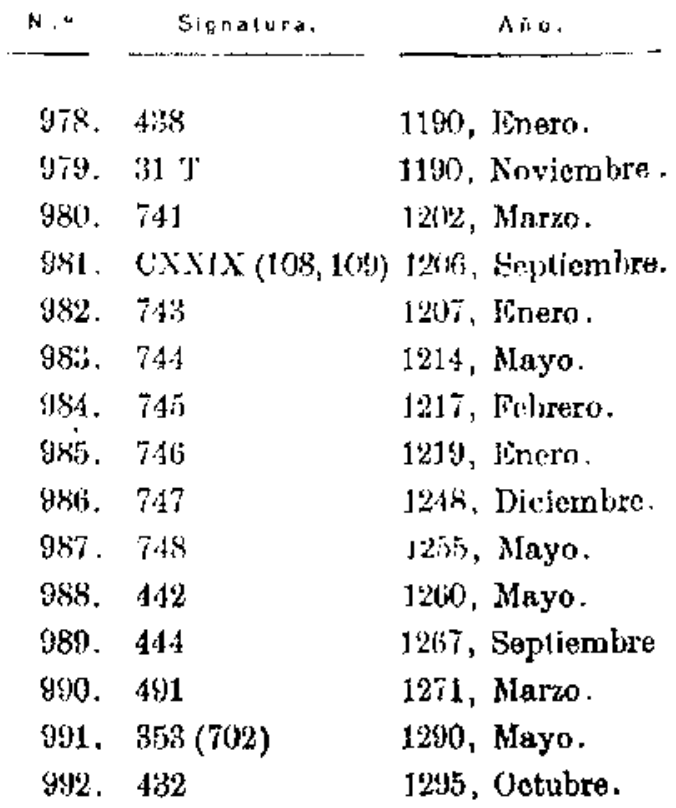




\begin{tabular}{lll} 
N.9 & Signalura. & \multicolumn{1}{c}{ Ano. } \\
1.007 .772 & 1178, Nayo. \\
1.008 .475 & 1184, Jonio. \\
1.009 .493 & 1251, Diciembre.
\end{tabular}

CARTAG MATHIMONIALTS
1.010. 486
1185, Marzo.
1.011. 186
1185, Marzo.

\section{TESTAMENTOS}

$\begin{array}{ll}1.012 . & \text { VIIJ } \\ 1.013 . & 445 \\ 1.014 . & \text { XXI } \\ 1.015 . & 446 \\ 1.016 . & \text { LV } \\ 1.017 . & 40 \mathrm{~T}(174.736) \\ 1.018 . & 448 \\ 1.019 . & 447 \\ 1.020 . & 150 \\ 1.021 . & \text { LXXY }(269) \\ 1.022 . & 45 \mathrm{~T} \\ 1.023 . & \mathrm{CVIII} \\ 1.024 . & 750 \\ 1.025 . & 751 \\ 1.026 . & 452 \\ 1.027 . & 782 . \\ 1.028 . & 453 \\ 1.029 . & 454 \\ 1.030 . & 455 \\ 1.031 . & 490 \\ 1.032 . & 786 \\ 1.033 . & 456 \\ 1.034 . & 753 \\ 1.035 . & 335(677,963)\end{array}$

1125, Diciembre. 1156, Mayo.

1161, Diciembre.

1177, Junio.

1185, Abril.

1185, Julio.

1180, Mayo.

1185, Noviembie.

1192, Enero.

1195, Marzo.

1209, Julio:

1211, Febrero.

1211, Junio.

1212, Noviembre.

1216, Marzo.

1232, Agosto.

1233, Septiembre.

1253, Julio.

1266, Mayo.

1267, Septiembre.

1275, Felirero.

1280, Noviembre.

1281, Mayo.

1282, Diciembre.

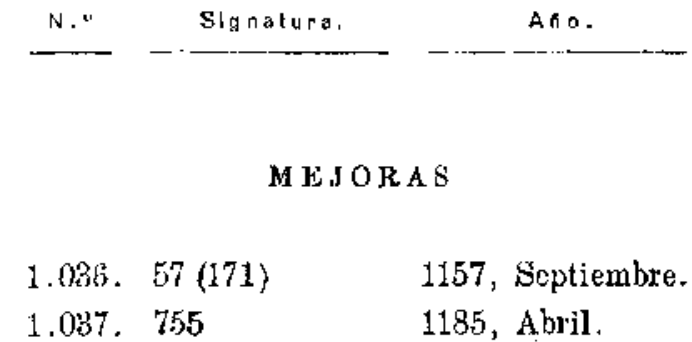

PARTICIONES DE BIENES

1.038. 756

1172, Diciembre.

1.039. XLV

1178, Agosto.

1.040. $39 \mathrm{~T}$

1195, Agosto.

1.041. $\mathrm{XC}$

1.042. 754

1. 018.457

1.044. 752

1.045. 458

1.046. 459

1203, Dicientre.

Siglo XII, fin.

1260, Mayo.

1272, Noviembre.

1281, Mayo.

1.047. 2 '

1288, Septiembre.

1291, Mayo.

\section{TESTLMONIOS DE POBESIÓN}

1.048. 769

1146, Septiembre.

1.049. 494

11 วั, Octubre.

1.050 .485

1161, Junie.

1.051, 773

1179 , Julio.

1.052. 775

1179, Julio.

1.053. 497

1187, Septiembre.

1.054. 498

1189, Octubre.

1.055. I.XI

1192, Abril.

$1.056 . .500$

1201, Mayo.

1.057. 778

1207 , Abril.

1. 058,780

1211, Febrero.

$1.059,503$

1224, Enero.

1. 060.504

1227, Octuł)re.

1.061. 505 1229, Noviembre.

1.062. 506

1. 063.510
1239, Noviembre.

1248 , Junio. 


\begin{tabular}{ll} 
N. & \multicolumn{1}{c}{ Signatura. } \\
\hline 1.064 .518 & 1276, Margo. \\
1.065 .520 & 1289, Mbril. \\
1.066 .522 & 1291, Alıril.
\end{tabular}

K LCIBOS

\begin{tabular}{|c|c|}
\hline 1.067 & 460 \\
\hline 1.068 & 757 \\
\hline 1.065 & 461 \\
\hline 1.070 & $34 \mathrm{~T}$ \\
\hline 1.071 & 462 \\
\hline 1.072 & XXXIV (181) \\
\hline 1.073 & XIL VIII \\
\hline 1.074 & 463 \\
\hline 1.075 & 464 \\
\hline 1.076. & 465 \\
\hline 1.077 & 466 \\
\hline 1.078 & 467 \\
\hline $1.07 \%$. & $55 \mathrm{~T}$ \\
\hline 1.080 & 468 \\
\hline 1.081. & $641(561)$ \\
\hline 1.082 & 469 \\
\hline 1.083 & 470 \\
\hline 1.084 & 750 \\
\hline 1.085. & 410 \\
\hline 1.086 & 471 \\
\hline 1.087. & 472 \\
\hline 1.088 & 473 \\
\hline 1.089 & 757 \\
\hline 1.000 & 2S-r. 'l' \\
\hline 1.091 & 28 -j. T \\
\hline 1.092 & 28-i. T \\
\hline
\end{tabular}

1134, Diciemble. 1158, Lirero. 11.61 , Marzo. 1172 , Oetulro. 1174, Agosh. 1174, bepliomilr. 1) 35, Noviemilre. 1191, septionbro. 1207, Novientire. 1210, Agosto. 1210 , Novicmbre. 1211 , Mayo. 1212, Novientrac. $12: 10$. 1241;, Dicienlare. 1254, fobrero. [2(0), Felurcro. 1284, Diciembre. 1286, Nelmero. 1287, Julia. 1290, Julio. 1290, Noviembre. 1291 , Fulurero. 1291, Noviembre. 12!1, Jicientore. 1291, Diciembre.

\section{REVISIÓN DE ESCRITURA}

1.093. VII

\section{APENDICE I}

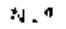

Sigrtaturat

AกO.

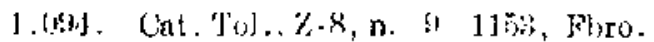

1.tes. lat. 'ol., Z, x, n, 2 110\%, dinero.

1.tm;. S. Clemente, n. 2 1167, Ftro.

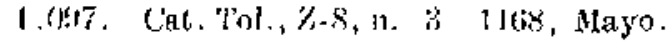

1. ris. Cat. Lol, $7, x, n .12$ [j69, Dlure.

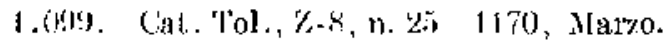

1.f(k). Cat. Iol, Z.8, 17, 7 l19l', Mayo.

1.101. cal. Tol., \%.s, n. l!) 11!4, Nhre.

1.102. $8 \mathrm{~s}$ '

S. XII, IF]ro.

1.10)3. Cad. 'Tol., \%-8, n. 17 12(n, Mayo.

1.194. Cat. Tol., 7-8, n. \& 1216, Junio.

I.105. Cht. Tol., \%.8, n. 22 1232, Agto.

1.14r, (at. Jol., \%-8, 1. 15 1232, Dbre.

1.107. (at. I'ol., 7.-8, 11. 2\% 1285, Agto.

I.|c.s. Cut. Tol., 7.8, 11, 27 1235, $A$ gto.

1.105, Cat. Jol., $/-8$, n. 5 1240, Abril.

1.116. Gnt. Tol., $7-8$, n. 14 1242, Enero,

1.111. Cat. 'Tol., Z.-8, n. 32 124t), Hho.

1.112. Cnt. Tol, $7,8, \mathrm{n}, 41249$, Marzo.

1.31\%, Gut. Tol, \% \%, n. 38 1253, Julio.

1.114. Cnt. lat, \%-8, n. 26 1266, Enero.

1.115. Cat. Tol., \%-8, n. 28 1278, spbre.

1.J16. Cul, Tol., \%.4, n. 11 12r9, Fbro.

1.117. Cal. Tol., \%.8, n. 13 1280, Aturil.

1.113. Cal. T'ol., Z-8, n. 1 1283, Enero.

1.119. Cat. Tol., \%.8, n. 31 1288, spbro.

1.120. Cat. Tol., $\% \cdot 8, n, 3131295$, Enero.

1.121. Cat. 'l'ol., \%-8, n. 18 1181, Linero.

1.122. (at. Tol, \%.8, n. 35 1207, splore.

1.12: CXVI 1210, Oetbre.

1.12zt. Lat. Tol., Z+\&, 1, 18 1283, Eneso.

1.125. Cat. Tol. Z-s, n. 3.1166 , Dbre.

1.120. Cat. Tol, Z-i, n. 淮 1 197, Agosto.

1.127. Cat. Tol., Z-8, n. 201201 , Nise.

1.129. Cat. Tol., $\%$. , n. 23 1264, Junio.

1.194. Cat. Tol., Z-S, n. 16 1189, Abril.

1. 130. Cat. Tol., Z.8, n. 10 1211, Spbre.

1.181. Cal. Tol, Z-S, n, 24 11190, Agosto. 


\section{A PENDlCE II}

\section{DOCUMENTOS HEBREOS}

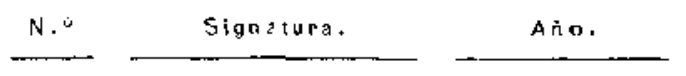

1.132, Catedral, n. 8 a

1248, Octubre.

1.133. Caiedral, n. 8 b

$1248, N$, Nro.

1.134. Catedral, n. $8 \mathrm{c}$

1248, N,-Dbre

1.185. Caletral, n. 5

1270 , Nbre.

1.136. Catredral, n. 4

1277 , Marzo.

1.137, Catedral, n. 6

1294, Nbro.

1.138. Catedral, n. 3 a 1382 , Julio.

1.139. Catedral, n. 3 b 1382, Julio.

1.140, Catedral, n. 1

1391, Abri].

1.141. S. Clemente, n. 11

1.141 bis. C. Tol, Z8, 1. 6

1.142. S. Clemente, n. 8

1.143. S. Clemente, n. 10

1.1. S. Clemente, n. 9

1.145. S. Clemente, n. 2

1.146. S. Clemente, n. 7

1.147. S. Clementi, n. 1

1.tils. S. Clemente, n. 4

1.149. B. Glemente, n. 6

1.150. S. Clemente, n. 3

1.1ว1. S. Clemente, n. 5
1283, Junio.

1239, Abril.

1248, Abril.

$1254, \mathrm{Muy} \cdot \mathrm{J}$.

1271, Dbre.

1280, Marzo.

1281, N1ure.

1252, Dbre:

1282, Dbre.

1282, Dbre.

1282, Dure.

1284, Dbre.
A PENDICE III (1)

N. ${ }^{\circ}-$ Signatura. ---1 Año.

1.152. San Nicolas, n. 12 1164, Enero.

1.153. Aguntamiento, n. 8 1204, Agosto.

1.154. Ayuntamiento, n. 2 1210, Marzo.

1.155. Ayuntamiento, 1.. 3 1220, Enero.

1.156. Ayuntamiento, n. 6 1220, Encro.

1.157. San Nicolás, n. 5 1220, Junio.

1.158. Ayuntaruiento, n. 1 1221, Junio.

1.159. Ayuntamiento, 0. 4 1221, Dbre.

1.160. San Nicolás, n. 8 1222, Jullo.

1.161. San Nicolás, n. 4 1227, Mayo.

1.162. San Nicolás, n. 14 1243, Enero.

1.163. San Nicolás, n. 11 1245, lebrero

1.164. San Nicolás, n. 13 1267, Spbre.

1.165. San Nicolás, n. 10 1279, Mayo.

1.166. San Nicolás, n.z 1282, Nbre.

1.167. Ayuntamiento, n. 5 1214, Mayo.

1.168. San Nicolás, n. 9 1288, Jullo.

1.169. San Nicolảs, n. 1 1279, Marzo.

1.170. San Nicolés, n. 6 1237, Fehrero

1.171. San Nicolás, n. 7 1238, Otbrc.

1.172. San Nicolás, n. 3 1285, Mayo.

1.173. Ayuntamiento, n. 7 1278, Otbre.

1.174. Ayuntamiento, n. 9 1226, Marzo.

1.175. Convento S. Clemente: Toledo, $128 j$.

(1) Impreso al fin de egte mismo volumen.

\section{9.}

\section{LISTA POR ORDEN LRONOLOGICO}

\section{DE LOS DOCUMENTOS PUBLICADOS}

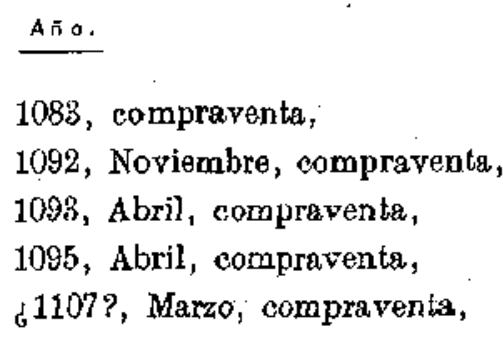

A กั

1083, compraventa, 1092, Noviembre, compraventa, 1093, Abril, compraventa, ¿1107?, Marzo; compraventa,
N."

1110, Marzo, compraventa, 6 1111, Febrero, compraventa; 7 1112, Septiembre, compraventa, 8 1113, Noviembre, 3." doc., cormpraventa, 9 1114, Oetubre, pleito,

940 
1125, Encro, compravunta.

1128 , Soptiembre, rovisión do escri-

$$
\text { tura, }
$$

1129, Narzo, compraponta,

1132 , Septiembre, compraventa, 113\%, Juljo, compraventa,

1184, Julio, compraventa,

1134, Soptiombre, conpraventa,

1134, Sepliembre, (n) oluventa,

1.134, ¿lojeiembra?, recibo,

1135, Agosto, 1." dec, compraventa, $2 \%$

1135, Diciombre, compraventa, 24

1137, Mayo, compraxonta, 25

1137, Julio, donnción, $\quad 727$

1138, Agosto, convenio, stes

1.180, Encro, compraventa, 26

1139, Octubre, compraventa, 27

1140, Dicicmbre, 1." dee., compraventa, 28

1141, Agosto, complaventa, 29

1142, Junio, compraventa, 30

1142, Noviombre, compraventa, 1.099 (13)

1143, Djeiombre, comvonio, 960

114, Fobrero, plauklacion, $\quad \%$

1144, Jebrero, plaracion,

1144, Amril, comprnyenta, $\quad 31$

$1] 46$, linero, compraventat, 32

1146, Marzo, compraventa,

1146, Scptiembre, $2{ }^{a}$ dec., posesión, 1.0.48

1146, Oetubre, compravonta,

1147, Febrero, convenio,

1147, Marzo, compraventa,
Il52, $A$ tril, domacion, $\quad 728$

1152, (octubre, "3." dec., compraventa, 42

1153, Fnero, compraventa; 43

1153, Febrero, compravonta, $\quad 1.094$

1163, Abril, 3. ${ }^{n}$ dec., plantación, $\quad 927$

1153, Novicmbro, compraventa, 44

1154, Agosto, corropraventa, 45

1154, Diciembre, compraventa, 46

1155, Oetubre, posesión, $\quad 1.049$

1156, Enero, exmbio, $\quad 796$

1lint, Aluril, compraventa, $\quad 47$

1 löji, Mayo, 2." dec., compraventa, 48

Ilin, Mayo, tesitamento, $\quad 1.013$

115i, Julio, compraventa, 49

1156, septienbre, compraventa, $\quad 50$

11:xi, Oclubre, compraventa, 51

1157, Fejreco, compraventa, - 52

1157, Nebrero, compraventa, $\quad 53$

1107, Marzo, compraventa, $\quad 54$

1157, Septiembre, compraventa, $\quad 55$

1157, Soptionbre, compraventa, $\quad 56$

115\%, Septiembre, mojora, $\quad 1.030$

1157, Noviembre, $3{ }^{\wedge}$ dec., donación, 729-730

1158, Jisero, recito, $\quad 1.068$

1158, Enero, compraytmia, 57

1158, linero, convenio, $\quad 972$

1158. Marzo, compravenla, 58

1158, Octubre, 1." dec., compraventa, 59

115s, compraventa, $\quad 60$

1159, Marzo, plantación, $\quad 928$

1159, Nayo, 3." dec., donación, 731

1160, bincro, 2 " dec., donación, $\quad 732$ 
Ax̆

1160, Marzo, compravente , 1160, Marzo, 3." dec, compruventa, 116), Septienubre, compraventa, 1160, Oetulure, compraventa, 1160, Noviembre, convenio,

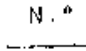

62

63

64

973

1161, Marzo, recibo,

1161, Abril, 1. 'i dec., compraventa,

1161, Tunio, posesión,

1161, Diciembre, testamento,

1161, Diciembre, eomplaverta,

1162, Enero, compraventa,

1162, Octubre, $1 .^{\text {it }}$ dec, compraventa,

1162, Octubre, couppraventa,

1162, Diciembrc, compraventa,

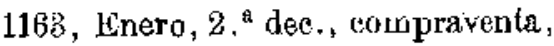

1163, Enero, compraventa,

1163, Febrero, 2. " dec., enupeño,

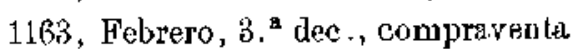

1163, funio, esclavo (emancipación do), 785

1161, Enero, compraventa,

1.152

1161, Marzo, compraventa,

1.164, Abril, convenio,

1165, Abril, compraventa,

1165, Abril, plantacion,

1165, Mayo, eompraventa,

1165, .Junio, 1," dec., compraventa,

1165, Dioiembre, compraventa,

1166, Enero, compraventa,

1166, Marzo, empraventa,

1166, Septiembre, 3 , $^{\text {n }}$ dec., compraventa, 80

\&1166?, Octubre, $2 .^{n}$ dee., compraventa, $\$ 1$

1167, Febrero, 2.' dee., compraventa, 1.096

1167, Febrero, 3." dec., cmpeño,

898

1167, Mayo, 3. ${ }^{\mathrm{a}}$ dec., compraventa,

1167, Juliu, compraventa,

1168. Marzo, compraventa,

1168, Abril, compraventa,

1168, Mayo, compraventa,

1168, Agosto, compraventa,

1168, Septiembre, compraventa,

1168, Octubre, compraventa,
1,049

65

1.050

1.014

0

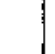

(1)

$$
\begin{aligned}
& 11 \\
& 11 \\
& 11
\end{aligned}
$$

1168, Octubre, donación, $\quad 738$

1.168, Noviembre, compraventa, $\quad 89$

1169, Septicmbre, cambio, $\quad 797$

1169, Noviombre, compraventa, 90

1169, Diciembre, compraventa, 1.098

1170, Fnero, compraventa, $\quad 91$

1170, Febrero, donación, 734

1170, kebrero, $3 .^{n}$ dec., compraventa, 92

1170, Marzo, compraventa, $\quad 1.099$

1170, Junio, compraventa, 93

1170, Scotienbre, comprayenta, $\quad 94$

1170, Octubre, compraventa, 95

1170, Diciembre, $3 .{ }^{\circ}$ clec., compraventa, 96

1171, Agosto, compraventa, $\quad 97$

1171, Septiembre, compraventa, 98

11i1, Soptiembre, compraventa, $\quad 99$

1171, Octubre, compraventa, $\quad 100$

1172, Marzo, compruvenka, 101

1172, Junio, $2,{ }^{n}$ dec., compraventa, 102

1172, Oetubre, recibo, $\quad 1.070$

1172 , Diciembre, partición de bienes, 1.038

1173 , Fobrcro, compraventa, $\quad 103$

¿1173?, Marzo, $24^{a}$ dec., compraventa, 104

1173, Mayo, renuncia de derechos; 993

1178 , Mayo, compraventa, $\quad 105$

1173, Mayo, compraventa, $\quad 106$

1173, Junio, compraventa, $\quad 107$

1173, Julio, tutcla, $\quad 928$

1178, Septicmbre, compraventa, 108

1174, Hebrero, compraventa, $\quad 110$

1174, Febrero, compraventa, $\quad 109$

11.74, Marzo, compraventa, $\quad 111$

1174, Marzo, compraventa, $\quad 112$

1174, Agosto, recibo, $\quad 3.071$

$\begin{array}{llr}83 & 1174, \text { Agosto, compraventa, } & 113 \\ 84 & 1174, \text { Scptiembre, recibo, } & 1.072\end{array}$

851174, Noviembre, compraventa, 114

1.097 1175, Febrero, compraventa, 115

861175, Febrcro, compraventa, 116

87 1175, Marzo, compraventa, 117

88 1175, Marzo, compraventa, 118 
$N \cdot \cdot$
-11

1)75, Abril, $3 .{ }^{\mathrm{a}}$ die., compravents

1175, Mayo, ampono,

1175, Agosto, compravonta,

1175, Sopticonbre, comprasontat,

1175 , Novienbue, compraventa,

1176, Fetrero, ennyenio,

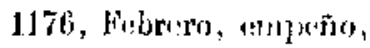

1176, Mayo, 1." dece, compraventa,

1176, Junio, compraventa,

1176, Jubo, coungraventu,

1170, Julio, dislinde,

1176, Julio, esclavo,

1.17t, Julio, 2." dec., compraventa,

1176, Noviembre, compraventa,

1176,1 heiembre, compraventa,

1177 , Jitucro, fin, compraventa,

1177 , Felsrero, cotopraventa,

1177, Febrero, compliventa,

1177, Marzo, compravinth,

1177, Mayo, comprousenta,

1177, Junio, 1, "doce, conepraventn,

1177, Junios, trstumlento,

1.77, sipliembre, estvenis,

1177, Diciembre, coinpraventu,

1178, Enero, compraventa,

1178, frebreto, eompraventa,

1.178, licbrero, compraventa,

1178, Abril, compraventa,

117', Mayo, deslindo,

1178, Mayo, tompraventa,

1178, Junio, compraventa,

1178, dgosto, fines, partición,

1179, Abril, cumbio,

1170 , Mayo, compraventa,

1179, Mayo, dontución,

1179, Julio, posesión.

1170, Julio, prosesion,

1179, Agosto, compravonia,

1179, Noviembre, donación,

1180, Enero, $10^{n}$ dec., compraventa,

1180, Lncro, Gu, emueño,

\section{ค เ อ}

118!!, Marzo, :2." dee... Inomación,

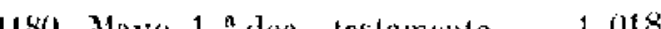
llso, Julio, 2." dec., compravento, $\quad 1.15$ 1180, $\Lambda_{\text {gosion, compraventa, }} \quad 116$ 11so, Agosio, complaventa, $\quad 147$

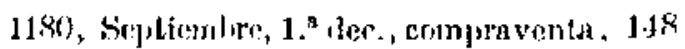
1180, Sejtiembre, 3." rlec., comprnvents, 149) 1180, Jieicmbre, complywents, 150 1|s|, Eijero, compraventit, |5] 1181 , Enero, ronacion. $\quad 1.121$ 1181, liebrese, compravonta, 152 1181, Fulurero, 2. ${ }^{\mathrm{a}}$ dec., compruventa, 15\% 1181, Marzo, compraventa, 154 1181, Mayo, compraventa, 155 1181, Octubre, 1." dec., compraventa, 156; 1181, ()ciubre, 2." dec., compraventa, 157 1181, Diciombre, 3. ${ }^{\mathrm{B}}$ dec., compravents, 158 1182, linero, 2." dec., testamento, 1.020 1182, loilurero, 2." dec., comjuraventa, 159 1182, AJarzo?, comprnvinla, 160 11k\%, Abril, rompravouth, $\quad 161$

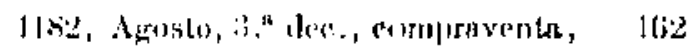

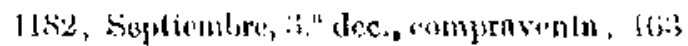
1182, Uelubse, 2." dee, etupene, $\quad 902$ 115:i, l'ebrero, compraventa, $\quad 165$ 1183, liblero, compraventa, $\quad 166$ 118:?, Marzo, $3 .^{n}$ dec., compraventr, 167 1188, Soptiembre, compravinta, 164 118:, Mayo, 3." dec., comproventa, las 1188, Soptiembre, 2." doc., compraventa, 16! 1184, Abril, compravenia, $\quad 170$ 1184, Minyo, 3." dee., compraventa, 17! 1184, Junio, deslinde, 1.1008 1185, Enero, compraventa, $\quad 172$ 1185, Eniro, $3 . "$ dec., compraventa, 173 1185, Malzo, carta matrimonial, 1.010-1.011 118i, Abril, testamento, 1.016 1185, Almil, mojora, $\quad 1.087$ 1185, Julio, 1." dec., compraventa, 174 1185, Julio, 2." dec., compraventa, 175 1185, Julio, convenio, 
1185, Septicmbre, 1. dec., compraventa, 176

1185, Octubre, 2." dex., compraventa, 17

1185, Noviombre, 2. dec., tistanuento, 1.01 !

1185, Noviemulure, 2, dec., recilo, 1.07

1185, Noviembre, 3. dec., eompraventa, 778

1185, Dicienure, I." dec., compraxenta, 179

1185, Dicienbre, tompraventa,

1.18i, Enero, 2." Aec., compraventa, 181

1180, Enero, $3 . "$ dec., pleitó, y.1

1186, Tebrero, 1." dec., compraventa, 182

1186, Agosto, 3. dee., compraventa, 183

1186, Septiembre, compraventa, 184

1186, Octubre, 1. 2 dee, compraventa, 185

1187, Mar\%o, fin, compraventa, $\quad 186$

1187, Abril, compraventa, $\quad 187$

1187. Abril, donacion, 738

1187, Mayo, 2. dec., compraventa, 188

1187, Mayo, compraventa, $\quad 189$

1187, Junio, 2." dec., compraventa, 190

1187, Juljo, 3." dee., compraventa, 191

1187, dgosto, compraventa, 192

1187, septitumbre, pososión, $\quad 1.05 \%$

1187, Octubre, 3. ${ }^{2}$ dec., compraventa, 193

1187. Noviembre, compraventa, 194

1188. Enero, 3. a dee., compraventa, 195

1188, Febrero, entpeño, 913:

118s, Abril, 2. ${ }^{\mathrm{a}}$ dec., compraventa, 196

1188, Abril, compraventa, $\quad 197$

1188, Mayo, 1." dee., compraventa, 198

1188, Agrosto, 3." dec., compraventa, 199

1188, Agosto, 3." dec , compraventa, 200

118s, Septiembre, 1." dec., compraventa, 201

1188, Septiembre, $1 .^{2}$ dec., cambio, 799

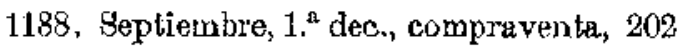

1188, Noviombre, compraventa, 203

1189, Enero, 1. ${ }^{n}$ dec., douación, 739

1189, Febrero, 8. ${ }^{\mathbf{n}}$ dee., complaventa, 205

1189, Abril, $3 .^{\mathrm{A}}$ dec., partición, $\quad \mathbf{1 . 1 2 9}$

1189, Julio, 3." dec., compraventa, 204

1189, Dicicmbre, compraventa, 206

118... compraventa, $\quad 207$

1190, Lncro, convenio, $\quad 978$

11011, Marzo, 1." Aec., cormpraventa, 208

1190 , Hayo, $3 . "$ dec, , compravent, 209

1190, Junio, 1." dec, empeño, $\quad 804$

1190, Julio, I. ${ }^{\pi}$ dec , compraventa, $\quad 210$

1190 , Agosto, 2.2 (lec., compraventa, 211

1190 , Septiembre, $1 .^{a}$ dec, compraventa, 212

1190, Octubre, 3." dec., compraventa, . 213

1190, Noxiembre, $3 .^{n}$ dec., convenio, .979

1191, Enero, 1." dec., compraventa, 214

1101, Marzo, 1." dec., compraventa, 215

1191, Marzo, 2." dec., compraventa, 216

11)1, Junio, 1." dec., cambio, 800

1191, Septiombre, 1. ${ }^{\text {n }}$ dec, compraventa, 217

1101, Septienbre, 1. dec., compraventa, 218

1191, Septiembrc, recibo, $\quad 1.074$

1191, Octubre, 1. ${ }^{\text {n }}$ dec., comprarenta, 219

1191, Octuhre, 2. ${ }^{\mathrm{A}}$ dec., compraventa, 220

1191, Diciembre, 2. ${ }^{a}$ dec., compruventa, 221

1. 92 , Febrero, 1. Aec, compraventa, 222 (A)

1192, Marzo, 1. ${ }^{\Omega}$ dec., compraventa, 222 (B)

1192, Febrero, 2." dec., compraventa, 223

1192, Marzo, 1. "dec, compraventa, . 224

1192, Abril, 3." dec., posesion, $\quad 1.055$

1192, Mayo, 2." dec., compraventa, 225

1192, Junio, compraventa, ' 226

1192, Agosto, compraventa, 227

1192, Septiembre, 1, dec, compraventu, 228

1192, Octubre, compraventa, . 229

1192, Octubre, 3. dec., compraventa, 230

1192, Diciembre, 2. a dec., cambio, . . 801

1192, Diciembre, $3 .{ }^{a}$ dec, compraventa, 231

1192, Diciem brc, 3. dce, compraventa, 232

1192, Diciembre, pleito, . 942

1198, Enero, 2. ${ }^{2}$ dec., compraventa; . 233

1198, Febrero, compraventa, 234

1193, Marzo, compraventa, . 235

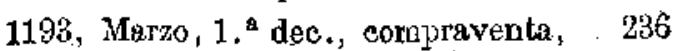

1189, Octubre, posesión,

1.054

1193, Marzo, 3. a dec.., compraventa, . 237 
Ano.

1193, Abril, comjuraventa, N. : 1193, Mayo, 2." de., compraventa,

1193, Mayo, $3{ }^{a}$ dec., compraventa,

119\%, Mayo, compravinta,

240

119\%, Junio, 1." dec, cambio.

$1.1(k)$

$8+2$

1143, Julio, 1." dec., compraventa, 241

1193, Agosto, 1." dec., compraventa, 242

1198, Agosto, 3." dec., compraventa, 24:

118*, Septiembre, $1 .^{\text {a }}$ tec., compraventa, $24 d$

119:, Septienlure, $3 . "$ doc., compraventa, 245

1198, Octubre, comprivenla, $\quad 246$

1198, Noviarubre, 1." dec., cambio, 808

1199, Nuviembre, 2. ${ }^{n}$ Jec, compravenla, 247

1193, Noviomire, 33." Jec., compraventa, 248

1198, Diciemalre, 1." dec, comjraventa, 249

1193, Iteiombre, 3." dec., compraventa, 250

1194, Enoro, compraventa, 251

1194, Jincro, 1." dec., compraventa, 252

1194, linero, 3 . $^{*}$ dec., compravonta, $25 \%$

1194, kelsrero, is." dec., compravonta, 25i

1194, Juljo, 3." dec., compraventu, 255

1194, Agrosto, 3." tec., compraventat, 256 ;

1194, Oetulore, compravenla, $\quad 257$

1194, Noviombre, 1." dec., compraventa, 258

11y1, Noviembre, 1." dec., compraventa 1.101

1195, Febrero, 1." dec., compraventa, 259

1195, Fobero, cambio, \$01

1195, Marzo, 1." dee., teatamento, 1,021

1195, Julio, compraventa, 260

1195, Agroato, partición, $\quad 1.040$

1195, Agosto, B." dec., compraventa, 241

1196, buero, L." dec., eomjoraventa, 2102

1.15k, Abril, 1." dee., cmpeño, th5

1196, Junio, $1 .^{\Omega}$ dec., donación, 7.40

1196, Septiombre, i." dec, compraventu, $2(i)$

$11 \% 6$, Oetubre, 1." doc., compraveuta, 264

1196, Oebubro, $2 .{ }^{\mathrm{A}}$ dec.. compraventr, 2156

1196, Diciemlsre, 2." dec., poder, 1.125

1196, Dicionlore, 3. n dec., donación, 741

1196, Diciembre, 2." dec., compraventa, 267

1196, Diciembre, 3. ${ }^{n}$ dec., compraven la, 268
$A B D^{2}$

N.'

119;, Diciombre, conopraventa,

266

1157 , Hero, poder, $\quad 1125(\mathrm{~B})$

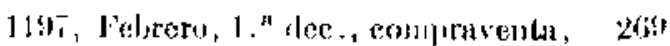

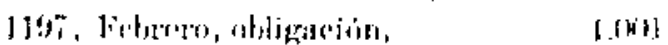

1197 , Abril, comprawata.

1197. Ahril, romvanio, $1125(0)$

1197, Alril, :." alec., pleito, 9.13

1137, Al,ril, comprasenta, $\quad 271$

11:4, Abril, cempreventa, 272

1197, Alril, $3 . "$ dec, compraventa, 2i:

1197. Julio, 3." dee., compravenia, 274

1197, Agosto, 3. ${ }^{n}$ dee., convenio, 1.1\%;

1187, Sejutiomlore, compraventa, 275

1197, Novfembro, compraventa, 276

1197, Noviembre, 2." dec, compravanta, 277

1197, Dicieunbro, 1. dec., comprapenta, 278

119 , Dicimbro, 1." dec., empeño, $\quad 906$

1197 , Diciemure, $8{ }^{n}$ dec., compravdata, 279

11:4, fobrow, $3{ }^{n}$ dec., compravonta, 280

1198 , Fetrero, $3 . "$ dec., compraventa, $281(\mathrm{~A})$

1198, Agrosto, 3."dec., complusenta, 2sis (B)

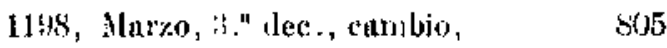

1195, Alstil, comptraventits, 282

1198, Abril, $3 . "$ dec , compraventa, $28 ;$

1198, Mayo, compraventa, 284

1198, Julio, compraventa, 285

1198, Octubre, 2." dec., comprayonta, 286

1198, Novienbre, 1. dec., compraventa, 287

1198, Novienbro, 2." dec., compraventu, $284^{\circ}$

1198, Diciembre, compraventa, 280

1108, Dicimbro, compraventa, 200

1199, Febroro, 1." dec., compraventa, 2y1

1199, Matzo, 1." dec., coupraventa, 292

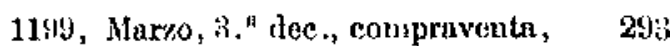

1195, Marzo, i.." dece., compraventa, 294

1194, Mayo, comuraventa, $\quad 395$

1199, Julio, 1." dec., plaito, 944

1199, Agosto, recilo, $\quad 1.131$

1199, Noviembre, comproventa, 296

1196, Diciembro, 2. " dec., compraventa, 297

1199, compraventa, 298 
 \\ A กิo.}

Siglo xU, fin, compraventa,

Siglo XII, compraventa,

Siglo XIJ, fin, partición,

Siglo XII, fin, compraventa,

1200, Encro, 1." dec., compraventa,

1200, Julio, 3. "dec., convenio,

1200, Agosto, 3." dec., comprayenta,

1201, Enero, 3. dec., compraventr,

1201, Enero, 3." dec., compraventa,

1201, Mayo, 2, dec., compraventa,

1201, Mayo, $3 .^{n}$ dec., posesión,

1201, Junio, 1. ${ }^{\text {R dec., compraventa, }}$

1201, Noviembre, convenio,

1201, Diciembre, 2., dec, compraventa, 807

1201, Diciembre, compraventa, 308

1202, Enero, 1. dec., compraventa, 309

1202, Enero, 2." dec., compraventa, $\quad 310$

1202, Marzo, convenio,

980

1202, Abril, 2. ${ }^{\text {}}$ dec., compraventa,

1202, Mayo, 1. ${ }^{\text {dec., compraventa, }}$

1202, Mayo, 3." dec., compraventa,

311

312

318

1202, Junio, 2." dec, compraventa,

314

1202, Agosto, 1." dec., compraventa,

315

1202, Agosto, 1, dec, compraventa,

316

1202, Agosto, 2. dec., compravenla,

317

1202, Octubre, 2." dec., compravonta.

319

$\begin{array}{ll}\text { 1202, Octubre, } 3 .^{\mathrm{a}} \text { dee, compraventa, } & 318 \\ 1202, \text { Octubre, } 3 .^{\mathrm{a}} \text { dec., cambio, } & 806\end{array}$

1202, Diciembre, 1. dec., compraventa, 320

1202, Diciembre, $1 .^{n}$ dec., préstamo, 833

1202, Diciembre, 2." dec., compraventa, 321

1202, Diciembre, compraventa, $\quad 322$

1203, Enero, compraventa, 323

1208, Marzo, 1." dee., compraventa, 324

1208, Mayo, compraventa, 325

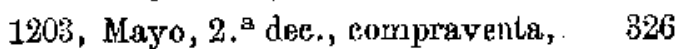

1203, Septiembre, 2." dec., compraventa, 327

1203, Octubre, 2." dec., compraventa, 328

1208, Diciembre, 2. dec., particion, 1.041

1203, Diciembre, compraventa,

329

1204, Febrero, 2." dec, compraventa, 331

\section{Ans.}

N. ${ }^{\circ}$

1204, Febrero, compraventa,

332

1204, Marzo, 2." dec., ploito,

946

1204, Marzo, 3. ${ }^{a}$ dec., compraventa, 333

1204, Mayo, 1. 1' dec., compraventa, 331

1204, Mayo, compraventa, 335

1204, Junio, 2. ${ }^{\mathrm{a}}$ dec., compraventa, 336

1204, Junio, 3. dec, compraventa, $\quad 337$

1204, Julio, 3. a dec.. compraventa, 338

1204, Agosto, 3." dec., compraventa, 1.163

1204, Septiembre, compraventa, $\quad 399$

1204, Noviombre, 2. dec., compraventa, 330

1204, donacion, 742

1205, Marzo, 2." dec., compraventa, 340

1205, Marco, 2." dec., compraventa, 341

1205, Marzo, 3." dec., posesión, 1.057 (B)

1205, Mayo, 1.." dec., compraventa, $\quad 342$

1205, Mayo, compraventa, 343

12015, Septiembre, 2. "dec, arriendo, 909

1205 , Diciembre, compraventa, $\quad 344$

1.206, Enero, 3. ${ }^{\Omega}$ dec., eompraventa, 345

1206, Marzo, 1." dec., compraventa, $\quad 316^{\circ}$

1206, Junio, pleito, ' 947

1206, Julio, 3. A dec, compraventa, 347

1206, Agesto, 3." dec., compraventa, $34 \mathrm{~S}$

1206, Septiembre, 2." dcc., cambio, 807

1206, Septiembre, 2." dec., converio, 981

1206, Octubre, 2. dec., conuraventa, 349

1206, Octubre, 3." dec, donación, 743

1206, Diciembre, compraventa, $\quad 350$

1207, Enero, 1." dec., compraventa, 351

1207, Enero, 1. "dec., convenio, 982

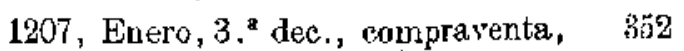

1207, Febreco, donación, 744

1207, Marzo, $3 .{ }^{n}$ dec., compraventa, $\quad 358$

1207, Marzo, 3." dee., conpraventa, 354

1207, Abril, posesión, $\quad 1.057$

1207, Mayo, 3. dec., compraventa, 355

1207 , Junio, 2. ${ }^{a}$ dec., cornpraventa, 356

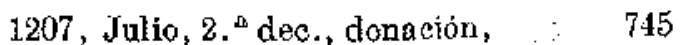

1207, Julio, 3. ${ }^{\circledR}$ dec., pleito, 948

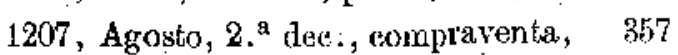


1267, Septiembro, $8 .^{\mathrm{A}}$ dec., donación, 1.122

1211, Enero, $2 .^{5}$ dee., compravenla, 283

1207, Octubre, 3." dec, compraventa, jis

1211, Fehrer", 2." dec., 384

1207, Noviembre, 1." dec., recilo, 1.075

1207 , Dicienalire, compraventa, 3is

1211, Fel,rero, 3." doc., testamento, 1.023

1207, compraventa,

1208, Enero, empeño, $\quad$ \$x/7

1208, Felrero, 3." dec., compruventa, \$1

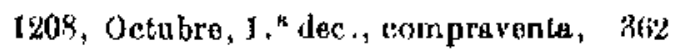

1208, Soptiembro, 3." dec., compraventa, 364s

1208, Noviembre, 3." dec., comjruventa, gti4

i2us, Fobrero, 1." dec., compraventa, 365

12(r), IPebrero, 2." dec., compraventa, 896

1269, Febrero, 2." dec., compraventa, 367

120\%, Eebrero, 2. ${ }^{A}$ dec., compraventa, 368

12(4), febrol'o, B. dec., compruvonta, 301)

1200, Pebrero, 8." dee., préstamo, $\$ 34$

1209, Aluril, 1." dec., compraventa, 370

1200, Miyo, 1." dec., compl'aventa, 1.103

1209, Julio, testamento, $\quad 1,022$

120), Julio, 1." dec., pleito, fo.t?

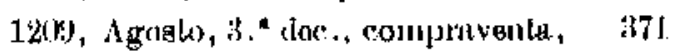

1206), Agosto, 3." dec, compravonlat, 372

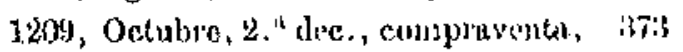

1204, Octubles, $2 . "$ dec. pleito,

120y, Octalure, 2." dec., comprnvents, 374

124), Oetubre, 3." doc., compraventa, 375

1201), Oclubro, 8." dec, enjupraventu, $371 \%$

1210, Fincro, 3." dec., compraventa, 377

1210, Felyrero, 1." dec., compraventa, 378

3210, Mnyo, 1." dec., compraventa, Bis

1210, Junio, 2." dec., compravenla, zio

1211. Mar\%, $\because{ }^{\mathrm{B}}$ dec., eompraventa, $\quad 385$

1211, Alirit, 1." dec., compraventa, 386

1211, Afril, 2." dec., compraventa, $\quad 387$

1211, Mayo, 1. ${ }^{\mathrm{a}}$ dec., empraventa, 386

1211, Mayo, 2." dec., reciho, 1.078

121\}, Mayo, 3." dec., compraventa, 389

1211, Mayo, i3." dec., compraventa, 390

1211, Junto, 1." dec., cembio, 809

1.211, Junio, 1." dec., testamento, 1.024

1211 , Julio, 3." dec., compruventa, 391

1211, Septlembre, 1.* dec., posesión, 1.130

1211, Nov, , b. dec., compraventa, 392

1212, Febrcro, 1." doc., compraventa, 398

1212, Febrero, 8." dec., compraventa, 894

1212, Naryo, 2. dec., remuncia,

1212, Mayo, 3." dec., compraventa, bu!)

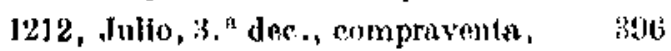

1212, soptienbre, t." der., compraventa, 397

[212, Sc]tianbre, 2." dece, compraventa, 398

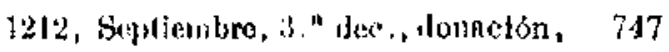

1212, ()cLaltr, compraverta, \$9g

1212, Novismilure, $1 . "$ dec., recibo, $1.07 \mathrm{~s}$

1212, Noviembre, 2." dec., tostamento, 1.025

1213 , Fnero, compravesta, $\quad 400$

1213, Abril, 1." dec., donnción, $\quad 748$

1218, Abril, 2." dec., donación, $\quad 749$

1213, Abril, 2." dec., cambio, 810

121: Jatio, $2 .{ }^{n}$ dec., compraventa, $\quad 401$

1210, Junio, B." dec., donación, 741

121;, Julio, 2." dec., domnción, 750

1210, Agosto, 1." dec., recibm, 1.07 i

1213, Agosio, 1." dec.., pleito, 951

1210, Agusto, 2." dec., cambio, $80 \mathrm{~s}$

1210, Agosto, 3." dec., Septiemure y

Octubre, compraventa, $\quad 380$ bis

1213, Agosto, 2." dec.. compraventa, 402

1213, Septiombre, donación, $\quad 750(\mathrm{~B})$

1213, Septiembre, donación, $\quad 751$

1210, Octubre, 1." dec., donación, $1.123(\mathrm{Ay} B) \quad$ 1213, Noviemlite, 2. Aec., tonación, 752

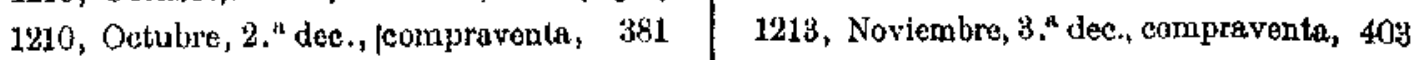

1210, Noviombre, 3. ${ }^{\mathrm{a}}$ dec., compravento, 382 1214, Enero, 2." dec.. pleito, 952

1210, Noviembre, reciluo, $\quad 1.077$

1214, Enero, 3." dec., compraventa, 404

1210, Diciembre, $3 .^{a}$ dec., donacisin, 1.123 (C)

1214 , Euero, 3." dec., donación, 1.123 (D) 
N.*

1211, Febrero, 1. ${ }^{2}$ dec., compraventa,

405

12:14, Febrero, 2a dec, donarión,

753

1214, Febrero, 2." dec., compraventa,

$40 \overline{7}$

1214, Febrero, $3:^{n}$ dec., compraventa,

1214, Febrero, 3." dec., cambio,

106

811

1214, Febrero, $8{ }^{2}$ dec., camtio,

812

1214, Marzo, 1. ${ }^{\mathrm{a}}$ dec., compraventa,

408

1214, Marzo, 2, dce., compraventa,

409

1214, Marzo, compraventa,

410

1214, Abril, 1. 'iec., compraventa,

411

1214, Abrī, 8ิ." dec., compraventa,

1214, Abril, fines, compraventa,

1214, Mayo, 2, dec., compraventa,

1214, Mayo, 2. ${ }^{\mathrm{a}} \mathrm{dec}$, , convenio,

1214, Mayo, compraventa,

1214, Mayo, donación,

1214, Junio, 3. "Aec., compraventa,

1214, Julio, 2. " dec., compraventa,

1214, Agosto, 2." doc., ploito,

1214, Septiembre, compraventa,

1214, Diciembre, compraventa,

1215, Abril, 3." dec., compraventa,

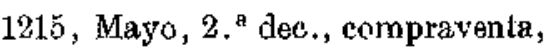

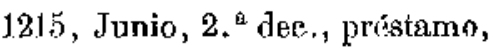

1215, Agosto, compraventa,

1215, Oetubre, compraventa,

1215, Nmiembre, 1. dec., compraventa, 424

1215, Noviembre, 1. dec, compraventa, 425

1215, Novienabre, 3. dec., compraventa, 426

1216, Enero, 2. ${ }^{\text {a }}$ dec., compraventa, 428

1216, Encro, 3." dee, compraventa, 429

1216, Febrero, $1 .^{*}$ dec., compraventa, 430

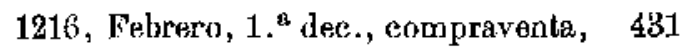

1216, Marzo, 2." dec., compraventa, 432

1216, Marzo, 2..$^{n}$ dec., testamento, 1.026

1216, Mayo, $2 .^{a}$ dec., comprayenta, 433

1216, Junio, compraventa, $\quad 1.104$

1816, Julio, $1{ }^{A}$ dec., compraventa, 434

1216, Sepliembre, 2. ${ }^{a}$ dec., donación, 754

1216, Noviembre, donación, $\quad 750$

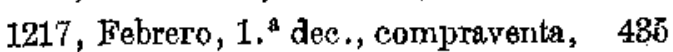

Año. $\quad$ N.

1217, Febrero, 1." dec., donación, $\quad 756$ 1217, Hebrero y Mayo, convenjo, 984

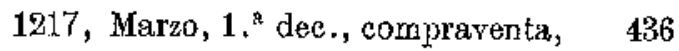

1217, Abril, 2." dee., compraventa, 437

1217, Abril, 3." dec., compraventa, 438

1217, Mayo, compraventa, 439

1217, Junio, 1. "dec., arriendo, 910

1217, Junio, 3. ${ }^{\text {A }}$ dec., compraventa, 440

1217, Julio, 3." dec., compraventa, 441

1218, Mayo, 1. "dec., compraventa, 442

1218, Mayo, 3. dec., pleito, 955

1218, Agosto, 1." dec., compraventa, 443

1218, Agosto, 3. ${ }^{a}$ dec., compraventa, . 444

1218, Diciembre, 1. dec., compraventa, 145

1219, Knero, convenio, 985

1219, Febrero, 2. ${ }^{\mathrm{a}}$ dec., compraventa, 446

1219, Febrero, 3. ${ }^{2}$ dec., compraventa, 447

1219, Marzo, 2," dec., compraventa, 1.154

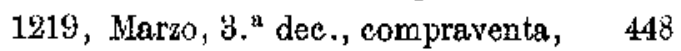

1219, Abril, 1. ${ }^{\mathrm{a}}$ dec., compraventa, . 440

1219, Abril, compraventa, $\quad 450$

1219, Mayo, 3." dec., compraventa, 451.

1220, Enero, 3. ${ }^{\text {n }}$ dec., compraventa, 1.155

1220, Enero, 3." dec., compraventa, 1.156

1220, Fehrero, compraventa, $\quad 452$

1220, Marzo, compraventa, $\quad 453$

1220, Abril, 1. dec., compraventa, 454

1220, Nayo, compraventa, 455

1220, Mayo, 1. dec., compraventa, 456

1220, Junio, 1. a dec, compraventa, 1.157

1220, Julio, 2* dec., compraventa, 457

1220, Octubre, compraventa, 458

1221, Marzo, préstamo; $\quad 836$

1221, Junio, compraventa, $\quad 1.158$

1221, Julio, compraventa, 450

1221, Agosto, préstamo, $\quad: \quad 837$

1221, Agosto, donación, 758

1221, Septiembre, 3." dec., compraventa, 460

1221, Octubre, 8. dec., comprarenta, 461

1221, Octubre, $3 .^{\text {* }}$ dec., compraventa, 462

1221, Noviembre, 1.a dec, compraventa, 463 
1221, Novismbre, 1," dec., compraventa, if 1221, Diciembre,3." dec., compraventa, 1.159) 1222, Junio, 3." Ale , comprav'nta, $4(65$,

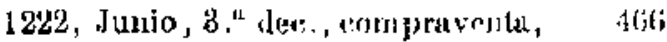
1222, Julio, i," dee., compraventa, 467 1222 , Julo, 2." ree., emurraventa, 1.16 , 1222, Agusto, 2." dec., compraventa, 468 1222, Novitmbre, compraventa, 4ise 122', Dicicmbre, s." dece, eompraventa, 470 1223, Abril, compleaventa,

1223, Noviembre, 2." dee., compraventa, 472 1283, Diciombro, is." doc., eoml raventa, 473 1224, Enero, compraventa,
122\%, Narzo, préstimo, $\quad 838$

$122 \%$, Abril, compravents, $\quad 490$

122s, Abril, 1." dec., compravonta, $\$ 91$

122s, Nayo, compravinta, $\quad 492$

122\%, Julio, donacirin, $\quad$ if6

122x, Novjembre, tonactin, $\quad \mathbf{7 6 7}$

122\%, Dicienbre, compraventa, $\quad 493$

122:3, Fidirero, compravista, $\quad \mathbf{4 9 4}$

122\%, Narso, I." rles., eompreventa, 495

1244, Marzo, 3." doc., sumpmventa, 446

1229, Mayo, compravonta, 497

122\%, Oetulsre, compraventa, 498

1229, Noviombre, 2." tive., pouksion, 1.061

122... Al,ril, donncitin, $\quad 757$

Biglo Xll, , jrimo t.rcio, compraventa, 427

12H(I, Liners, 2. ${ }^{\mathrm{A}}$ dec. compraventa, 498

123 , tinl,rero, 1. dec., donación, 768

12b), Aluril, $22^{n}$ dec., compravuntu, $\quad 500$

J2u, Mayo, donación, $7(34$

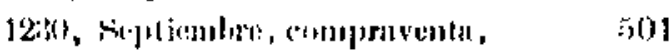

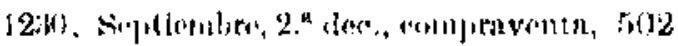

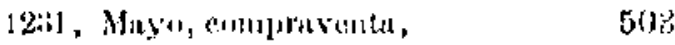

12:31, Mayor, 1." dec, twinlso, 814

1231, Mayo, $2 . "$ dee., compreventa, $\quad 504$

12is, Mityo, próstano, $\quad 839$

12:31, Septicmbre, compraventa, $\quad 505$

1231. Diefembre, compraventa, $\quad 506$

123\%, Felbrero, $1 .^{n}$ dec., compraventa, 507

1232, Abril, 1. dec., arriendo, 911

12:2, Agosto, 1. a dec., iestrmento, 1.027

12:32, Agosto, compraventa, 1.105

12:32, Diciembre, rompravents, $\quad 1.100$

123:, Aluyo, 3." dec., compraventa, 508

12isi, Junio, compravenia, 1.141

1233, Junio, compraventa, $\quad 509$

1233, Julio, 3." dec., comprnventa, 510

123s, Sepptiombrd, testwments, $\quad 1.028$

123\%, Octubre, 3." dec., donacion, 770

1233, Dicieubre, 1. Aec., Jonación, 771

1234, Marzo, 1. dec., compravenla, 511

1334, Abril, 3." dec., compriventa, $\quad 512$ 


\begin{tabular}{|c|c|c|c|}
\hline \multicolumn{4}{|c|}{$-37-$} \\
\hline An & N. ${ }^{\circ}$ & Año. & $N \cdot{ }^{\circ}$ \\
\hline 1234, Mayo, 1." dec., donación, & 772 & 1240, Febrero, prestamo, & 812 \\
\hline 1234, Mayo, 3. "dec, compraventa, & 513 & 1240, Marzo, compraventa, & 586 \\
\hline 1235, Mayo, 2.a dec., esclavo, & 787 & 1240, Abril, courjpraventa, & 1.109 \\
\hline 1285, Agosto, 1. a dec., compraventa, & 1.107 & 1240, Abril, préstamo, & $84 i 3$ \\
\hline 1235, Agosto, $2 .^{n}$ dec., compraventa, & 1.108 & 1240, Mayo, ' 2 dec., compraventid, & 587 \\
\hline 1235, Agosto, $2{ }^{a}$ dec., donación & 773 & 1240, Junio, préstano, & 844 \\
\hline 1234, Agosto, compraventa, & 514 & 1240, Septiembre, compraventa, & 588 \\
\hline 1235, Febrero, compraventa, & 515 & 1240, Octubre, compraventa, & 539 \\
\hline 1235, Abril, compraventa, & 516 & 1240, Octubre, depósits, & 34 \\
\hline 1235, Mayo, 3," dec., compraventa, & 517 & 1240, Diciembre, compraventa, & 540 \\
\hline 1235, Septiembre, compraventa, & 518 & 1240, rectibo & 1.080 \\
\hline 1235, Noviembre, 3," dee., donación, 1.1 & $107(B)$ & 1241, Febreso, compraventa, & 541 \\
\hline 1236, Marzo, 1." dec., cambio, & 815 & 1241, Febrero, 2." dec., posesion, & 1.058 \\
\hline 1236, Marzo, 2. dec., renuncia, & 995 & 1241, Junio, compraventa, & 542 \\
\hline 1236, Junjo, compraventa, & 518 & 1241, Junlo, compraventa, & 543 \\
\hline 1236, Agosto, compraventa, & 520 & 1241, Jumio, compraventa, & 544 \\
\hline 1237, Febrero, préstamo, & 1.170 & 1241, Julio, comprav onta, & 545 \\
\hline 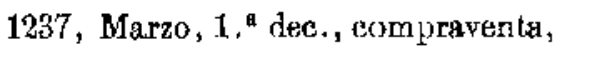 & 521 & 1241, Julio, eomplaventa, & 546 \\
\hline 1237, Mayo, compraventa, & 522 & 1241, Julio, $3 .^{2}$ dec., compraventa, & 547 \\
\hline 1237, Julio, compraventa, & $519(B)$ & 1241, Agosto, arriendo, & 012 \\
\hline $1<37$, Noviembre, compraventa, & 528 & 1241, Agosto, compraventa, & 548 \\
\hline 1237, Diciembre, $1 .^{a}$ dec., complaventa & $\mathrm{ta}, 524$ & 1241. Octubre, compraventa, & 549 \\
\hline 1238, Enero, compraventa, & 525 & 1241. Dicíemlure, $2 .^{\mathrm{a}}$ dec., eselavo, & 788 \\
\hline 1238, Marzo, préstamo, & 840 & 1241, Dieiembre, $3 .^{\text {a }}$ dec., renuncia, & 946 \\
\hline 1238, Marzo, compraventa, & 526 & 1242, Enero, compraventa, & 1.110 \\
\hline 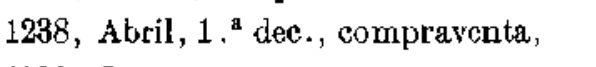 & 527 & 1242, Febrero, compraventa, & 550 \\
\hline 1238, Junio, compraventa, & 528 & 1242, Marzo, compraventa, & 551 \\
\hline 1238, Julio, compraventa, & 529 & 1242, Abril, compraventa, & 552 \\
\hline 1238, Julio, 2." dec, donación, & 1.168 & 1242, Abril, 1" dec., compraventu, & 558 \\
\hline 1298, Agosto, compravenia & 530 & 1242, Abril, compraventa, & 554 \\
\hline 1238, Agosto, compraventa, & 531 & 1242, Abril, compraventa, & 555 \\
\hline 1238, Septiombre, compraventa, & 532 & 1242 , Julio, compraventa, & 556 \\
\hline 1238, Octubre, 1." dec., préstamo, & 1.171 & 1242, Agosto, compraventa, & 5057 \\
\hline 1289, Fnero, 1. "dec., compraventa, & 533 & $1242 ;$ Octubre, $3 .^{\text {at }}$ dec., compraventa & 508 \\
\hline 1289, Abril, compraventa, & 141. bis & 1242 , Noviembre, compraventa, & 559 \\
\hline 12:39, Julio, 1." dec., donación, & 774 & 1243, Enero, compraventa, & 1.162 \\
\hline 1239 , Julio, compraventa, & 534 & 1243, Enero, donación, & 775 \\
\hline 1239, Julio, préstamo, & 841 & 1243, Fobrero, compraventa, & 560 \\
\hline 1239, Noviembie, 1. dec., posesión, 1 & 1.062 & 1243, Junio, préstamo, & 845 \\
\hline 1239, Diciembre, cambio, & 816 & 1244, Febrero, compraventa, & 561 \\
\hline 1239, compraventa, & 535 & 1244, Marzo, compraventa, & 5162 \\
\hline
\end{tabular}


AND.

1244, Marzo, 2. 'ilec, cambio, 1244, Alsil, compraventa, 1244, Julio, compraventa, 1244, Soptiembre, compraventa, 1245, Jinro, compravinta, 1245, Febrero, compraventa, 1245, Abril, conopraventa, 1245, Abril, comjuraventu, 1245, Novinmber, compuraventa, 1245, Diciembre, donacion, 1246, Enera, donacicin, 1246 , Enero, 3." dec., compraventa, 124f, Abril, compraventa, 1246, Mayo, compraventa, 1246, Julio, arriendo, 1246, Dicienzre, $2 . "$ dec., pleito, 1246, Dieiembre, recibo, 1247, Marzo, preatamo, 1247, Mayo, $1 .^{n}$ dec., compreventa 579 1247, Noviembre, esclayo, $78 \%$ 1248, Enero, préstamo, $\quad 847$ 1248, linero, compraventa, bi. 1248, Abril, préstamo, 8.18 1248, Abril, ecompraventa, 1248, Junio, posesion, 1248, Julio, compraventa, 575 1248, Octubre, compraventa, 124R, Noviembro, compraventa, 576 1248, Noviembre, compraventa 1248, Noviembro-Diciembre, ronuncia, 1.134 124s, Diciembre, esclavo, 1248, Diciembre, convenio, 790 1249, Enero, préslazno, 081 1249, Fubrero, compraventa, 845 1249, Marzo, compraventa,

1.111 1249, Abril, renuncia,

1249. Septiembre, convenio, $586(\mathrm{~B})$ 1240, Diciembre, préstamo, 850 1249, Ditembre, préstano, 852 1250, Enero, préstamo, 1250, Enero, préstamo,

\section{Ano.}

1250, Marto, arriendo, 1250), Ahril, prestamo, 854 1250, Julio, compraventa, $\quad 577$ 1250, Septiembre, compraventa, $\quad 578$ 125l, Mayo, prestamo, $\quad 855$ J251, Septiombre, compraventa, . 5179 1251, (Melubre, (selavo, 751 1251, Octubro, compraventa, $\quad 580$ 1251, ilieientre, deslinule, $\quad 1.005$ 12f2, linero, chelavo, $\quad 792$ 1252, Abril, yéstamo, 1252, Julio, 8." dec., compraventa, $\quad 582$ 1252, Octubre, 1. ${ }^{\text {a }}$ dec., donación, 778 1252, Noviembre, conpraventa, 588 1253, Marzo, compraventa, $\quad 584$ 1253, Abril, préstarnn, 894 1253, Abril, 1, dec., compraventa, 5855 1253, Mayo, 3." dec., compraventa, $\quad 686$ 1253, Junio, testamento, 1.029 1253, Julio, combraventa, $\quad 1.113$ 1258, Sejuliombre, compravents, $56 \pi$ 1253. Oetubre, comproventa, $58 \mathrm{~s}$ 1.54, fabrere, reibo, 1.082

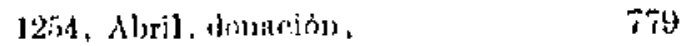
1254, Mnyo-dunio, compraventa, 1.145 125.t, Julio, zemuncia, $\quad 948$ 1.254, \& Agosto\%, compraventa, $\quad \$ \$ 9$ 1254, Oetubri, 2." dec., compraventa, $5+10$ 1254, Noviculre, cambio, 818 1254, Novionulire, compravonta, $\quad 591$ 1254, Noviambre, obligación, $\quad 1.002$ 1255, Enero, compraventa, $\quad 592$ 1255, Abril, compravent,$\quad 593$ 1255, Mlayo, compraventa, $\quad 594$ 1255, Nayo, convenio, 987 [255, Julio, compraventa, $\quad 595$ 1255, Agosto, compraventa, $\quad 596$ 1255, Diciembre, esclnvo, $\quad 793-794$ I2i6, Enero, compravenla, $\quad 597$ 1256, Enero, compraventa, 598 1256, Diciembre, donación, 780 
1257 , Kinero, compraventa, 
1273, MTarzo, comprevonta 1280, Marzo, empeño, 1.145

1273, Junio, compraventa, 1280, Aluril, compraventa, $\quad 665$

1273, Julio, compraventa, 12xit, Alril, compraventa, $\quad 666$

1273 , Dicienture, 2." doc, comfreventa, 639 127., Marzo, compraventa,

1274, Abril compraventa,

1274, Sopicmbre, compraventa,

1274, Dicicmubro, compraventa,

$127 \%$, Febrero, testrmento,

127i, \& Max\%o \%, compravonta,

644

1275, Abril, préstamo,

861

1275, Julio, compraventa,

(i,15

1275, Agosko, compruventa,

0.16

1275, Agosto, compraventa,

647

1275, Sepliembre, compraventa,

648

1275, Noviembre, compraventa,

64)

1275, Diclombre, compraventa,

650

1275, Diciembre, compraventa,

(551

1.276, Marzo, posesión,

1.064

1276, Abril, pleito,

432

1276 , Diciembre, compravonta,

1277, Marzo, compraventi,

1277, Mayo, compraventa,

(5):3

1277, Diciemluro, compravonia,

[5i5.

1278, Enero, compravonta,

655

1278, Marzo, préstamo,

862

1278, Abril, cumpraventa,

1278. Septioubre, compraventa,

1.115

1278, Octulure, compraventa,

1280, Abril, 2." dec., compraventa, 1.117

1250 , Mayo, presstamo, 863

1.280, Junio, complaventa, $\quad 667$

12 \& 1 , Julio, $3{ }^{n}$ dec., carnbio, 825

12\$0), (Jcubre, compraventa, 668

1280, Noviembre, $1 .^{n}$ dec., compraventa, 669

1280, Nowiembre, testamento, $\quad 1.03 \%$

1281, Mayo, testamento, $\quad 1.034$

1281, Mayo, particlón, $\quad 1.045$

1281, Junto, compraventa, 670

1281, Agosto, compraventa, $\quad 671$

1281, Octubre, obligación, $\quad 1.004$

1281, Noviembro, compraventa, $\quad 1.146$

1282, Junio, préstamo, $\quad 864$

1282, Jullo, cambio, $\quad 826$

1282, Septiembre, prostamo, 865

12\%2, Noviembre, compraventa, $\quad 562$

1282, Dicionbre, wstamento, 1.035

1:th', Iniciambre, préstamo, 866

1282, Dicicmbre, donación, $\quad 1.147$

1282 , Diciembre, comprayonta, $\quad 1.148$

12s2, Diciombre, renuncia, $\quad 1.149$

12\$2, Diciembre, donación, $\quad 1.150$

1282, Octubre, domación, $\quad 1.151$

1282, Noviembro, compravents, $\quad 1.166$

1278 , Octubre, convenio, $\quad 1.173$

1278, Novierabre, compriventa, $\quad$ \$558

1278, Diciembre, comprnventa,

1279, Enero, oblignción, $1,0 \mathrm{mi}$

1279 , Folurero, tompraventa, $\quad 660$

1270 , Febrero, compraventa, $\quad 1.116$

1279, Marzo, $2 .^{n}$ dec., donación, 1.16

1279, Abril, compraventa,

661

1279 , Mayo, comprayenta,

1. 165

1279, Agosto, compraventa,

(ivi2

1280, liebrero, 3." dec., comprayenta, 663

1283, Enero, compraventa,

1.118

1.283, Enero, prestamo,

1.124

128:, Febrero, donación,

788

1283, Abril, préstamo, $\quad 867$

12\$is, Alrril, 1." dec., préstamo, 868

1283, Octulire, pleito, $\quad 963$

1283, Juliu, compraventa, 673

1283, Agosto, compraventa, $\quad 674$

1283, Agosto, compraventa, $\quad 675$

1253, Septienbre, compraventa, $\quad 676$

1283, Diciembre, compraventa, $\quad 677$

1284, Abril, compraventa, 678

1280 , Marzo, compraventa,

664

1284, Abril, prétamo,

864 (B) 
Año.

1284, Mayo, compravente, 1284, Septiembre, compraventa, 1284, Septiembre, compraventa, 1284, Novierabre, cambio, 1284, Diciembre, cambio, 1284, Diciembre, recibo, 1285, Febrero, compraventa, 1285, Febrero, renuncia, 1285, Marzo, compraventa, 1285, Mayo, arriendo, 1285, Julio, caria matrimonial, 1285, Agosto, compraventa, 1285, Septiembre, compraventa, 1285, Octubre, compraventa, 1286, Enero, vompraventa, 1286, Fnero, compraventa, 1286, Febrero, recibo, 1286, Agosto, compraventa, 1286, Noviembre, compraventa, 1286, Diciembre, compraventa, 1287, Enero, compraventa, 1287. Mayo, compraventa, 1287, Mayo, prestamo, 1287, Junio, fanza, 1287, Julio, recibo, 1287, Octubre, compraventa, 1287, Noviembre, cambio, 1287, Diciembre, compraventa, 1288, Febrero, préstamo, 1288, Febrero, compraventa, 1288, Febrero, compraventa, 1288, Marzo, compraventa, 1288, Junio, compraventa, 1288, Agosto, préstamo, 1288, Soptiembre, compraventa, 1288, Septiembre, partición, 1288, Septiembre, préstamo. 1288, Septismbre, compraventa, 1289, Abril, posesión, 1289, Mayo, 1.2 dec., pleito, 1289 , Junio, compraventa.

\begin{tabular}{|c|c|c|}
\hline N.* & A กัo. & $N \cdot 0^{\circ}$ \\
\hline 679 & 1289, Diciembre, préstamo, & 873 \\
\hline 680 & 1290, Febrero, préstamo, & 874 \\
\hline 681 & 1290, Marzo, compraventa, & 701 \\
\hline $82 \vec{i}$ & 1290, Abril, compraventa, & 702 \\
\hline 828 & 1290, Mayo, préstamo, & 874 bis \\
\hline 1.084 & 1290, Mayo, préstamo, & 875 \\
\hline 682 & 1290 , Mayo-Jnnio, convonio, & 991 \\
\hline 1.000 & 1290, Julio, recibo, & 1.087 \\
\hline$B 83$ & 1290 , Julio, compraventa, & 703 \\
\hline 1.172 & 120), Inlio, prestamo, & $87 \mathrm{~b}$ bis \\
\hline 1.175 & 1290, Julio, fin, compraventa, & 704 \\
\hline 684 & 1290, Agogto, préstamo, & 876 \\
\hline 685 & 1290, Septiembre, prestamo, & 877 \\
\hline 686 & 1290, Scpticmire, compraventa, & 705 \\
\hline 687 & 1290, Septiembre, compraventa, & 706 \\
\hline 688 & 1290, Noviembre, pućstamo, & 878 \\
\hline 1.085 & 1290 , Noviembre, prestamo, & 879 \\
\hline 689 & 1290, Noviembre, recjbo, & 1.088 \\
\hline 690 & 1290, Noviembre, compraventa, & 707 \\
\hline 691 & 1290, Diciembre, compraventa, & 708 \\
\hline 892 & 1290, Diciembre, prestamo, & 880 \\
\hline 693 & ¿1290?, \&1300?, Septiembrc, préstar & 10,898 \\
\hline 869 & 1291, Febrero, recibo, & 1.089 \\
\hline 936 & 1291, Abril, posesion, & 1.066 \\
\hline 1.086 & 1291, Mayo, partición, & 1.047 \\
\hline 694 & 1291, Julio, préstamo, & 881 \\
\hline 829 & 1291, Julio, préstamo, & 882 \\
\hline 695 & 1291, Julio, préstamo, & 889 \\
\hline 870 & 1291, Agosto, préstamo, & 884 \\
\hline 696 & 1.291, Septiembre, préstamo, & 885 \\
\hline 697 & 1291, Octubre, préstamo, & 886 \\
\hline 698 & 1291, Getuhre, préstamo, & 887 \\
\hline $685(\mathrm{~B})$ & 1291, Noviembre, compraventa, & 709 \\
\hline 872 & 1291, Noviembre, recibo, & 1.090 \\
\hline 1.119 & 1291, Noviembre, fin, préstamo, & 888 \\
\hline 1.016 & 1291, Diciembre, préstamo, & 889 \\
\hline 871 & 1291, Diclembre, zecibo, & 1.091 \\
\hline 699 & 1291, Dieiembre, recibo, & 1.092 \\
\hline 1.065 & 1292, Mayo, compraventa, & 710 \\
\hline 964 & 1292, MLayo, asclaro, & 795 \\
\hline 700 & 1292, Septiembre, compraventa, & 711 \\
\hline
\end{tabular}




\title{
Ana.
}

1252, Diciembre, préstamo,

126) , Febrero, cenbo,

12!8, Abril, compraventa,

1293, Jalio, prestamo,

129;, Agosto, compruventix,

1203, Septiembre, arriendo,

$129 \%$, Octubre, prestar no.

12ys, Oetubre, arriendo.

1208, Noviembre, 2." dee, compraventa, 71

1294, Mar\%o, compraventa,

1294, Octubro, compraventa,

1294, Noviombre, compraventa,

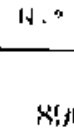

s!a

521

\begin{tabular}{|c|c|}
\hline 4ก. & is." \\
\hline 12!5, octul,re, convenio, & 992 \\
\hline 1295, eosupraventa, & 720 \\
\hline 12:16, Agristo, complaventa. & 721 \\
\hline 12th, Steptientre, fianza, & $\$ 87$ \\
\hline 12un, soptionlore, compraventa, & 722 \\
\hline 12!n;, Noviemlre, ckmbin, & 830 \\
\hline legs, l'elorero, cumpravents, & $72: 3$ \\
\hline 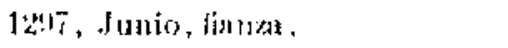 & 938 \\
\hline Jym, Igrasta, pristamer, & $x ! 15$ \\
\hline Iz!t!, linero, comprastula, & 724 \\
\hline Bighlo XIll fin, linero, jurstumo, & 890 \\
\hline Siglo XIII lin, Felsero, al'riende, & 922 \\
\hline 1:Ho, Ahril, compraventa, & 725 \\
\hline 130, Agosto, compraventa, & $72 x$ \\
\hline I 315, Abril, fiarza, & $9+39$ \\
\hline 1:3א2, Julio, denteion, & 1.138 \\
\hline 1Bk2, ,ulio, mouncis, & 1.139 \\
\hline 1,301, Al,ril, complzaventh, & 1.1 .40 \\
\hline
\end{tabular}

\author{
NUESTIBA LIII:IÓN \\ 10.
}

Considerando el elevado número de documentos a reproducir, y a fin de no dar una exlensión desmesurada a este trabajo, adopté el procedimiento de reproducir literalmente el texta árabe, en la parle que no es formularia, y suplir esta parte formularia por un signo que la representase. Esto llevó de la mano a la agrupación de los documentos por asuntos, para que el leclor pudiera suplir cómoda y fácilmente la fórmula respectiva.

Hasta veinticuatro grupos diversos han resultado de tal clasificacion. Los documentos de cada grupo van ordenados cronológicamente. A la cabeza de cada grupo (cscrituras de compraventa, carlas de donación, de emancipación de esclavos, etc.) (1) se reproducen las fórmulas más corrientes en acuella clase de documentos, sustituyendo cada formula, en el texto del documento, con un número en.

(1) Véaso el findice al fin del tomo III de Documentos. 
ccrrado entre paréntesis cuadrados [1] [2] [3]. Lil texto, pues, impreso de cada documen lo reproduce su contenido esencial, más la relación de los testigos, que se ha copiado siempre que ha sido posible.

He liecho la traducción castellana, libre, no literal, del texto reproducido, pero en forma que el lector no arabista pueda disponer de todos los datos esenciales y aun accidentales que el documeoto conliene. Las listas de testigos que firman, no se han traducido, cuando las firmas estaban en árabe.

Las palabras romances, que no son nombres propios, empleadas en el texto, Jas he subrayado, salvo aquellas tan corrientes y tan imposibles de suponer en la lengua árabe, como s eanónigos, "arcediano", etc., que no ocarrirá pensar en que el árabe las ha podido traducir. En cambio, aquelias que ticnen en árabe su voz propia, porque el documento pone las romances correspondientes, son las que van en Jetra cursiva,. gr., casa de la rodela, con el sotano y la caballeriza (núm. 63), sendero (núm. 222), sobrinas (nóm. 310), els., ete.

He prescindido siempre de las fórmulas de invocación. Todos los documentos principian por cl بسم الله الرحمث الرحيه, "En el nombre de Dios clemente y mí. sericordiuso", a usanza musulmana; muchos llevan sólo esla fórmula; otros añaden

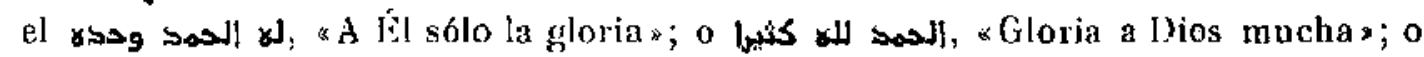

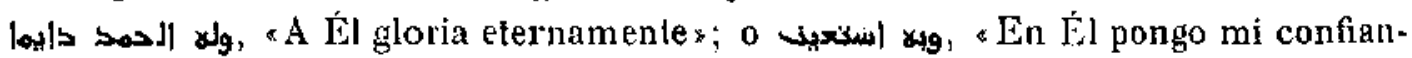

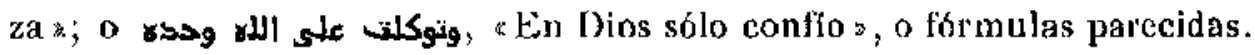

Hay otras formulas que he reproducido en el texto árabe, pero que de ordinario no he traducido. Una de ellas es ta que sigue ordinariamente a la cita de la ciu-

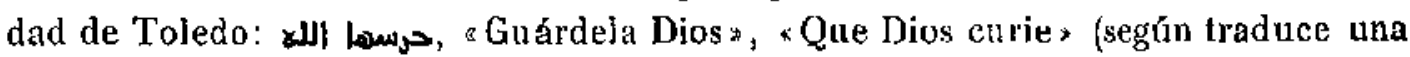

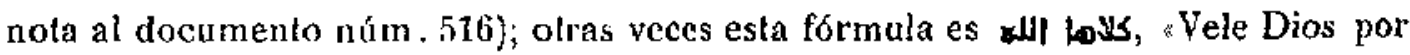

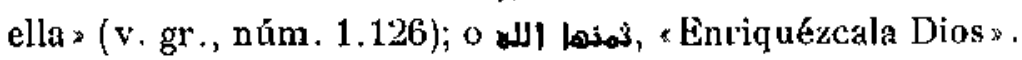

Es tamnién corriente, despućs de nombrar personas de viso, añadir alguna fór-

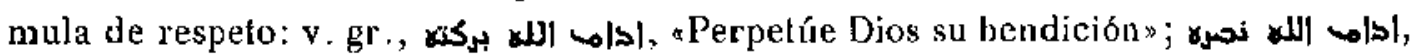

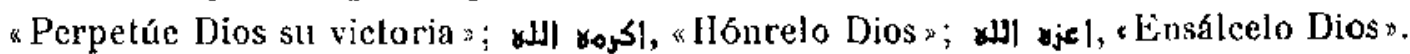
Si se nombra a un difun to suple añadirse el

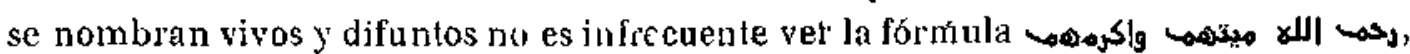

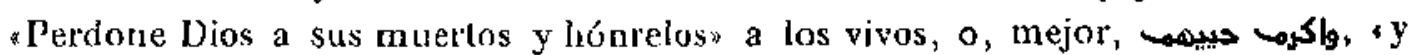

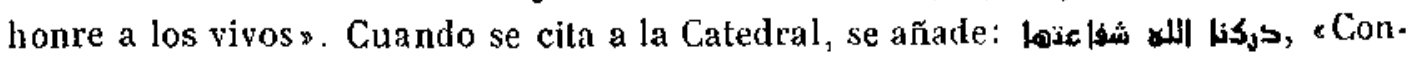
cédanos Dios su intercesión por ellas. Todas estas fórmulas, como los adjetivos de encomio que acompañan a ciertos nombres de persnnas iłıstres: reyes, arzobíspos, alcaldes, scñores de gran viso, etc., las he dejado de traducir.

He transcrito, cuantas veces ha sido posible, las notas puestas al dorso de los documentos, porque son del más alto interés, sobre todo en la identificación de lu. gares. Me he limitarto a transcribir las indicaciones antiguas, de letra coetánea de los documentos o poco posterior, prescindiendo de las notas modernas, del siglo XVIII generalmente, puestas al catalogar los pergaminos. 
11.

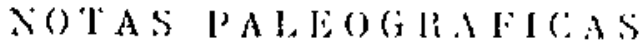

Casi todos los documentos están escritos en perganino, cuyo lamaño se anota en cada caso. Todos van escritos por una sola cara; pero alguna vez cn el dorso de una escritura de venta se ceseribe la venta posterior fóm 21), Hay, no obstante, algunos en papel, v. gr., el númcro 80, fechado en la ujtima decena de Septiembre del año 116ti; el úumero 87, fechado en Septiembre de 1168; el número 1 0!fi, que es copia liecha en Noviembre de 1186 de olro documenlo anterior; y el mimero 167 , de Julio de 1222, que conserva una loja en blanco.

Para la hisloria del papel en lispana son inluresantes estos halos, pues scrán quiź́ los ejemplares fechatos nás antiguos que se conservan en nuestros archivos. lil Breviarium gothicum sive mozarabicum, de Silos, ser̂alado por Fetrotin Glistoire de l'abbaye de Silos) como el primer códice nuestro en papel, es del siglo XI; para

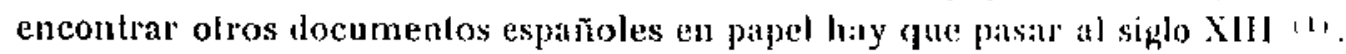

No tienen los documentos que esludiamos ningún aspecelo ormatnental: ni miniaturus, ni letras capilales, ni dilujos o iluminaciones de nínguta clase: solo ana excepción puede sefaalarse con al docnmento múmero 1.175 . cata matrimomial en latín y en árabe, cuya parte latina está ornanentada cou bedous capuales iluminadas. I a letra es la cursiva corrienle y usual, cuyos carateres, hastante fruesos en los documenlos antghos, van athándose a medida que avanza d licmpo. hejrod! cimos docnmentos de distintas manos y de diversas fechas, procurando escoger enIre los bien conservados y de tamaño no desproporcionado.

Inicamente toman cierto aspecto ornamenlal algrumas lirmas árabes. Alguma re. presenta una curiosa tradición familiar: así, la de Salomon ben Ail ben Cinaid, es contiuuada por su hijo listeban y por su nielo Salomon. Y' a imilación de los de ésta, que intervienen en la redacción de muchos documentos, vemos otras varias.

Pocos sellos se conservan en estos documentos. El número 27.1 Heva pendiente el sello del abad de Husillos en 1197; el número 1.023 liene el sello de 1). García, tercer obispo de Ciuenca, en su testamento de Febreco de 1211; el número 628 conserva el sello de Garei Martinez, alcalde de Madrid en 1260 , y tiene huellas de haber. llevado el de Ciil pérez, otro alcalde de Madrid del mismo aro; y al describir una es. critura, que se entregalya como titulo de propiednd con el número 639, se indica

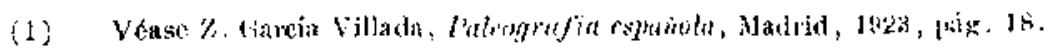




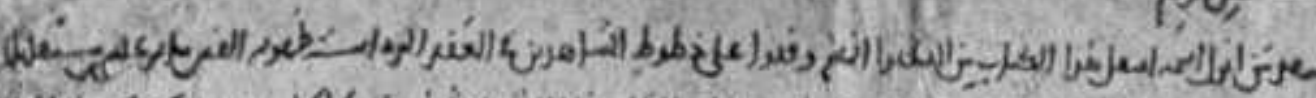

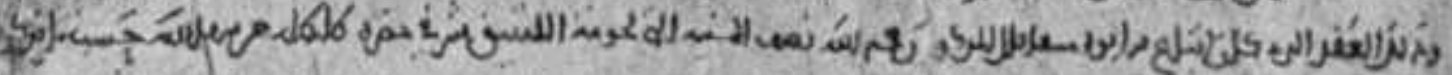

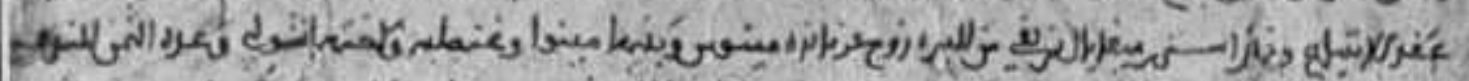
c.

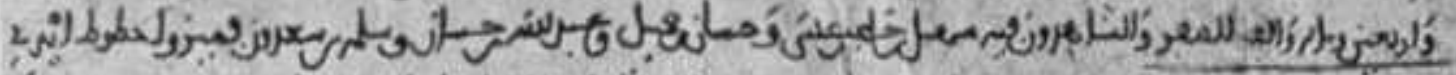

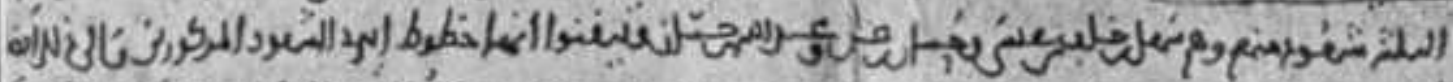
(-

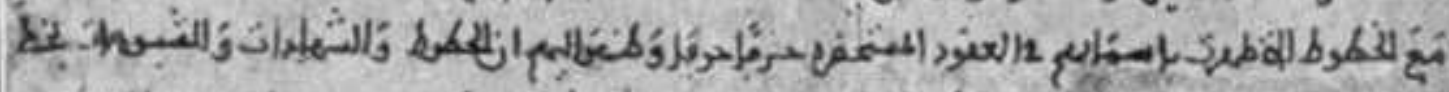

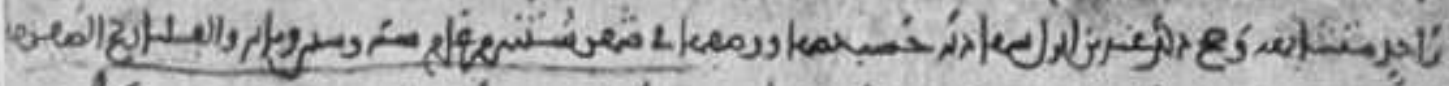

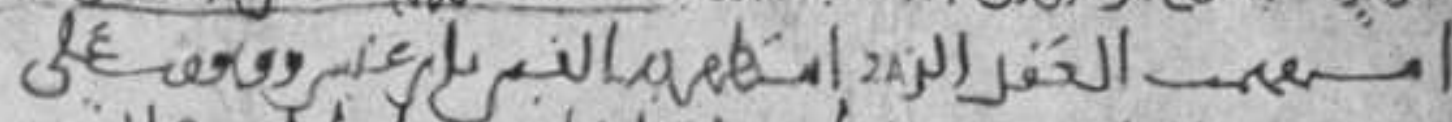

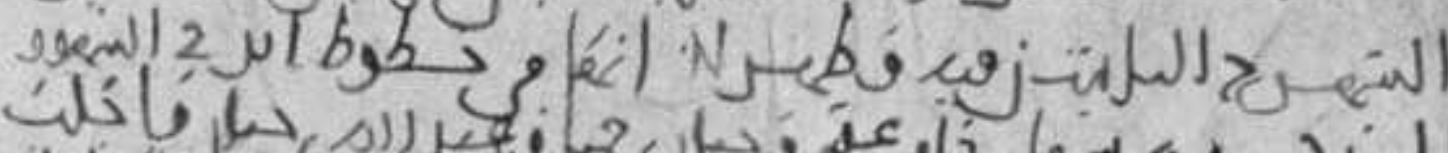

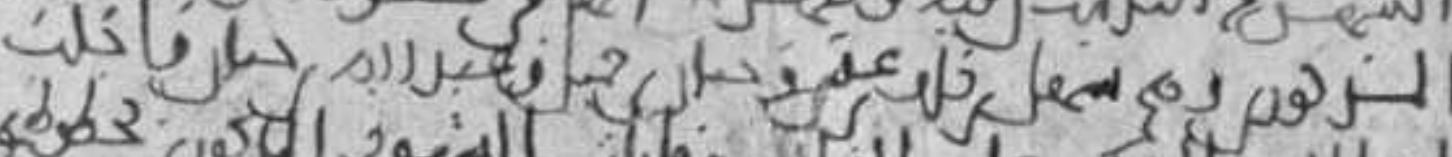

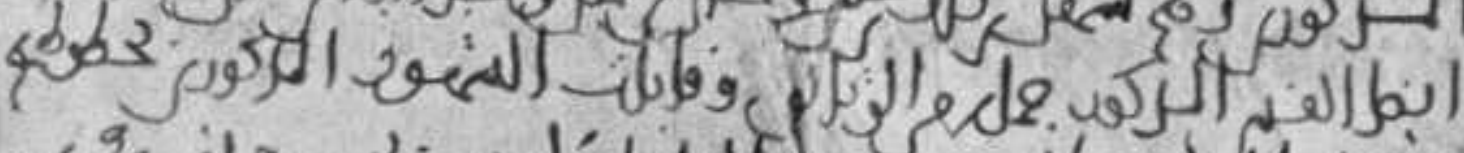

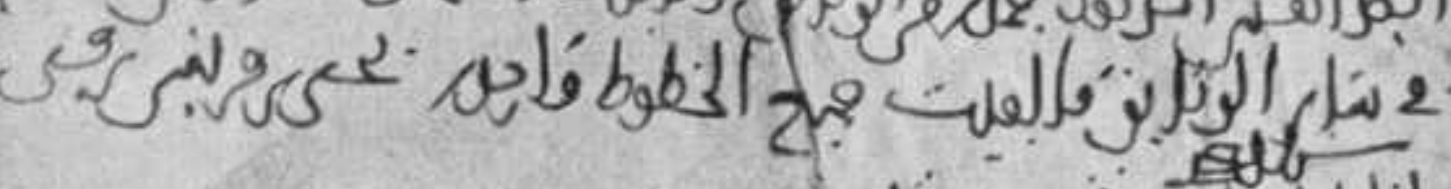

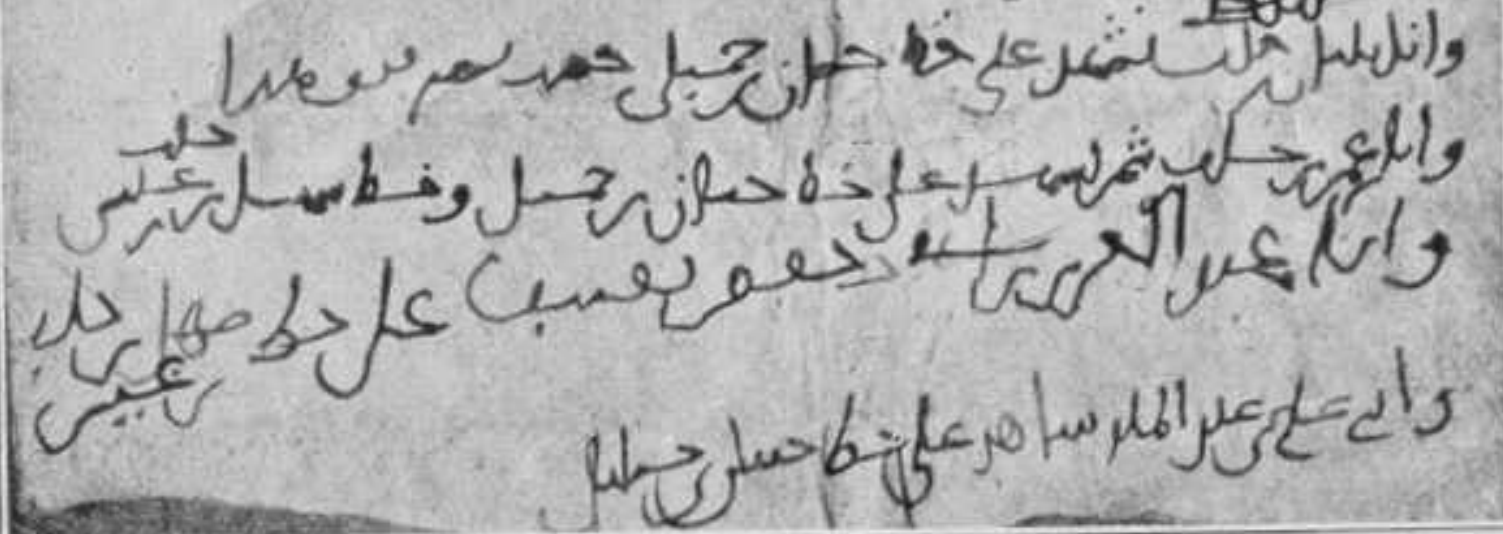


que lievaba la firma y el sello peudiente del obispo de Cuenca, D. Gonzalbo Juanes, por Diciembre de 1242 .

Las fechas extremas de la culección son 1083 (núm. 1) y 1315 (núm. 939) (1); y salvo el documento número 1, fechado a la musulmana, todos los demás llevan la fecha de la era de Asular (الصفر), del latón, que es la era española. El documento número $206 \mathrm{da}$, por excepción, la equivalencia: * Fecha en el día 2 de Diciembre del año 1189 de la cra de nuestro Señor Jesús el Mesias, correspondiente a 1227 de la era del latón o española *: los demás documentos sólo indican la era de Asofar. Los me-

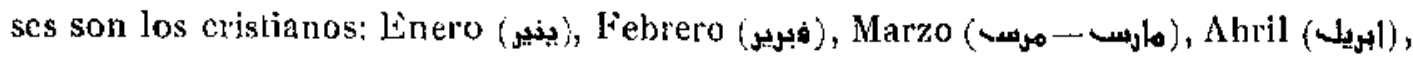

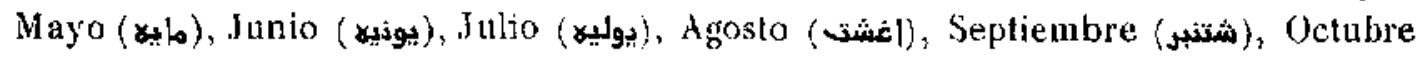

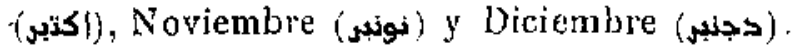

Más que la fecha del día del mes, que se ve algnnas veces, suelen emplear la decena: "Fecha en la primera decena, o en la decena de en medio, o en la decena última del mes tal *, y en pocas ocasiones dicen la decena y el día, v. gr., primera decena de Julio, dá 9 (núm. 1.022).

Alguna vez se fecha en arabe por el orden cristiano (núm. 7953; alguna en la fiesta de San Nicolás, 6 de Diciembre íním. 708), y otra se da como fecha un acontecimiento domésico: "Fecha en Moratalfaz, día de lunes, otro día de San Cebrián, cuando cantó Pedro lllán misa nuevas (núm. 559).

Fieslas. - Muchas veces se indica como fecha, especialmente para plazo de arriendos, pagos, etc., el dia de una festividad religiosa; por ejemplo:

- Ficsta de las Candelas, 1250 (nims. 853 y 915).

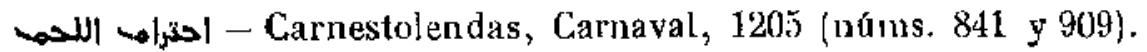

- Semana Santa: se pone como plazo en Febrero y consta haberse pagado este piazo en la primera decena de Abril; otro plazo es San Juan, y otro San Miguel, 21195 (núm. 259),

- Penítecostés (a los cincuenta días), 1205 (núms. 838 y 909).

- - San Vicente, 9 de Junio (27 de ¿Septiembre?), 1214 (uúm. 952).

- San Juan (24 de Junio), 1174 (núms. 110, 907, 958 y 960 ).

- Santa María, a mediados de Agosto, 1207 (núms. 921 y 982).

- San Cebrián o Cipriano (26 de Septiemure), 1207 (núms. 843, 915 bis y 982 ).

- San Miguel (29 de Septiembre), 1205 (núms. 848, 909 y 915). - - San Martín (11 de Noviembre), 1205 (núms. 909, 921, 961 y 989). ع - Fiesla de Natividad, 1290 (núms. 831, 832 y 893).

(1) No euento dos o tres documentos hebreos de fines del siglo XIV. 
Había tres fiestas al año en que era costumbre hacer regalos a los señores: un liberto se obligaba a dar regalo a su dueña en cada una de sus tres fiestas, loslate (ntím. 793).

Casi nunca indican el lugar donde se otorga el documento, que siempre es la cíudad de Tuieda. Algunos documentos judios esián fechados en Uclés, 1248; Talavera, 1248, y Sevilla, 1254 (núms. 1.142 y 1.143 ).

Las firmas de los documentos son unas autógrafas, otras puesłas a ruego: estas

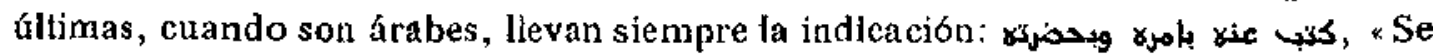
firmó por él en virtud de su mandado y en su presencia.* Se firma indislinlamente en árabe y en romance, sin que falten algunas en rabínico. Los documentos del siglo XII tienen mayor número de testigos, y éstos más variados que los del siglo XIII, y a medida que avanza este siglo, los testigos son menos y firman casi siempre los mismos (véanse los doeunentos núms, 630 a 725).

Las firmas árabes suelen ser más comprensivas que las romances, que muchas veces sólo dan el nombre de pila, mientras que aquéllas dan noticia de tres o cuatro generaciones. Véanse, por ejempla, las del documento nímero 141: mbentras que las firmas laiinas sólo tian la inicial del nomìre propio: $D$. (Dominicus), W. (Guillelmus), F. (Fernandus), o lo más el nombre completo: "Petrus, Gondisalbus, etc., las árabes tienen tres generaciones: ‘Pedro ben Abderráh men ben Yahyas, 0 *.Salomón ben Alf ben Guaid.. Son muy frecuentes las firmas árabes de cuatro filiaciones o más ( $v$. gr., documento núu. 146 y otros muchos).

Suele indicarse el cargo a continuación de la firma (diácono, presbiftero, zapatero, etc.); alguna vez se añade una fórmula poco frecuente: علميك عبيد المسيح, Siervo de los siervos de Cristo afios de 1206, 1207 y 1208 (documentos núms. 981, 3533 y 907 ).

Algunos documentos tienen sólo firmas árabes; ofros sólo firmas romances (núms. 47,448, 729,741,960 y 1.934), aunque lo corriente es que no falte alguna firma árabe en cada documento. Otros quedaron sin Hrmar (v. gr., núms. 749 y 833), sin duda por no haber llegado al otorgamiento de la escrilura. Y tampoco faltan algunos cuya firma por los tesligos se retrasó, bien sea cosa de un mes (núm. 183), bien sea más de medio ano: redactado el número 414 en Mayo de 1252 , no se firm 6 hasta Enero de 1253.

Muchos documentos sau copia ( «fija de carta id del romance) de otros más antiguos: siempre se indica esta condición de copia, y se nombran las personas que han cotejado la copia con su original, aunque en muchos casos no se declara si los que han cotejado ( $)$ ( $)$ obran en virtad de artoridad judicial o notarial. Alguna vez los que cotejan la copia son escribas de otros documentos: como Yahya ben Gualid hen Cásim (núm. 72), o Salomón ben Domingo ben Almursí ben Gálib ben Abdelmélic (núm. 199).

Otros documentos son autorizados por un alcalde. Lin esta clase de documen- 
tos lleva cada firma superpuesta la frase puño y letra del alcalde, que a continuación de las firmas declara: "Se han escrito los testimonios de este documento en mi presencia, y conozco a los testigos y yo Jair ben Salomón ben Alí ben Guaid» (núms. 333, 349 y 1.130). De esta clase son los doeumentos números 25 y 33 , autorizados por Abderráhmen ben Yabya ben Harits; núrneros 68 y 69 , por Julián ben Abilhasán ben Albazo; múmero 78 , por Juanes ben .... ben Ataf ben Lampader; el número 216, por Salomón ben Alí ben Guaid; el número 1.121, por Feliz ben Abdelaziz ben Lampader; número 1.197, por Julián ben Ésteban Julianis.

Cuando se hace la copia de un decumento autorizado (v. gr., el ním. 9), des-

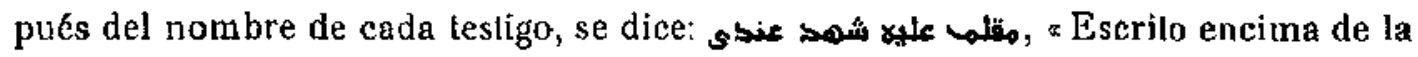
firma, atestignó ante mi. * Alguna vez el documento sospechoso de autenticidad, al copiarlo, no es ratificado ( $\mathrm{n} u ́ m .1 .150$ ).

También se citan a veces documentos que no son copiados, v.gr, la carta de donación de Arcicolla y de Camarena Alta por el emperador Alfonso VIl (número 292), el Reparlimiento de Sevilla por Alfonso X (núm. 990), algunas escrituras romances (núms. 605 y 594 ).

Cuando es preciso, se subsanan las erralas deslizadas en el texto del documento; yo las he tenido en cuenta, pero no he reproducido su lista en la copia de los documenlos, por parecerme innecesario.

12.

\section{CIFRAS NUMERICAS}

En muchos documentos, después de indicar una cantidad numérica (precio de una venta, de un objeto), se añade la misma cantidad, consignada en cifra. He podido, por tanto, reconstruir el sistema de numeración sin más que calcar cada cífra y hacer después la selección de los diversos tipos con que aparecen.

El sistema de numeración que se ve desde los principios del siglo XIII y rara vez en el állimo tercio del siglo XII, es el que reproduce el siguiente cuadro: 
$-18-$

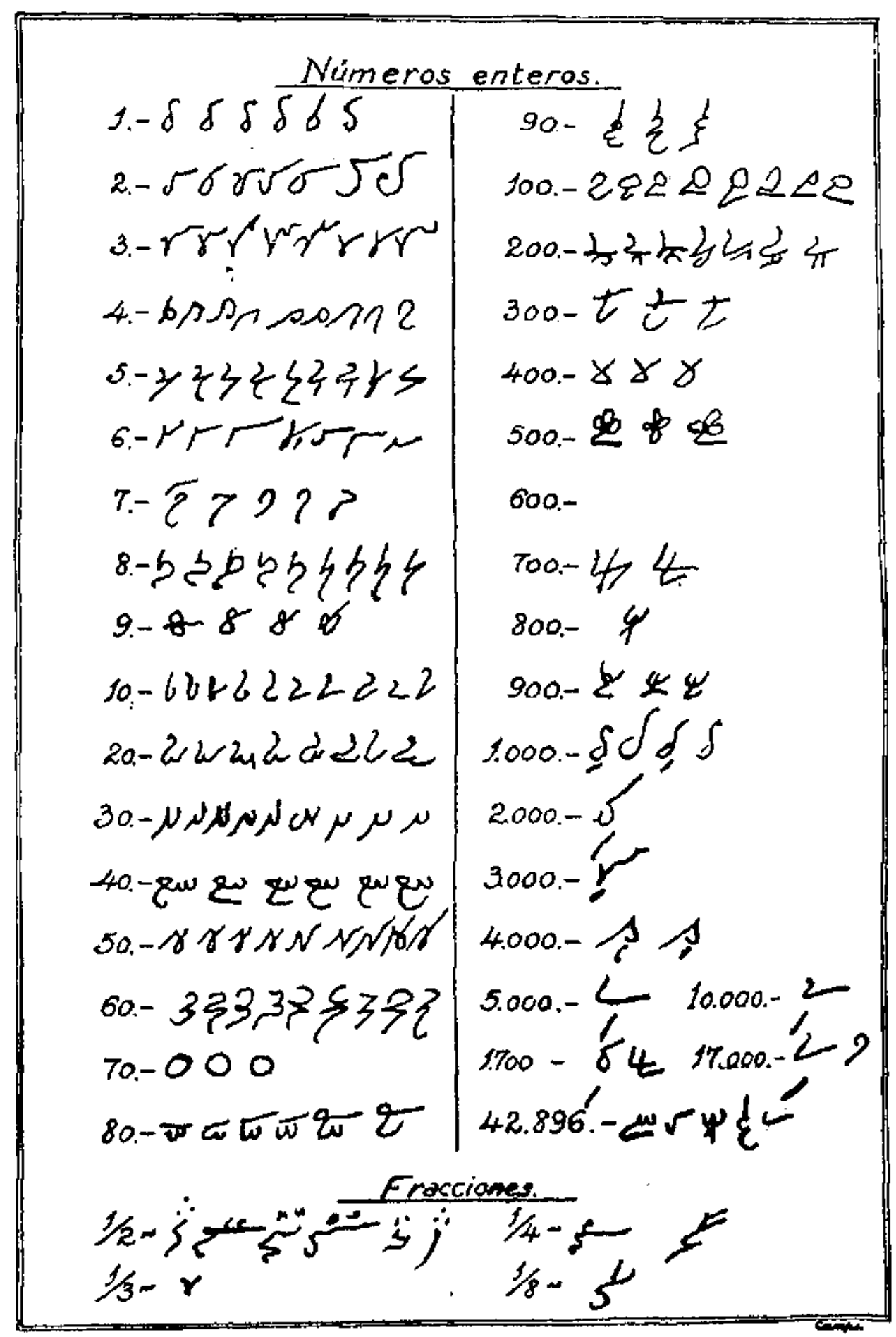

Sistema de numeración. 
Del interés que el estudio de la hisloria de numeración ha despertado entre los sabios, dan clara idea las obras de Smith y Karpinski (The Hindu-arabic numerals, Boston, 1911), y otras anteriores de Sedillot, Rodef, Martín, Humboldt, Wocpcke, Vincent, Tamnery y Pihan.

Es de la mayor importancia, por los cuadros y dibujos de números que trae, desde el siglo X al XVI, el trabajo de G. F. Hill, On the Farly Ise of Arabic Namerals in Europe. (Art. en Archaeologia or Miscelaneous tracts relating to Antiquity, published by The Socjety of Anliquaries of London, vol. LXII, pág. 137, 0x. ford, 1910.) 



\section{I 1}

\section{E L L U GA R}

13. Los lugares a que estos documentos se contraen son Toledo y otros

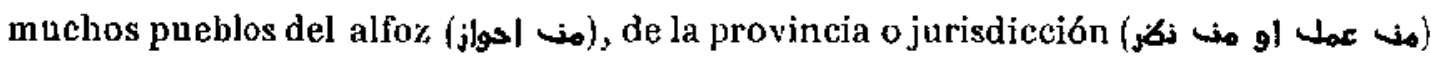
de Toledo y de Talavera. De gran interés son los datos topográficos que la colección arroja. Procuraré agruparlos (1).

14.

TOPOGRAFIA DE TOLEDO

La cita de casas, calles, plazas, etc., suele hacerse con referencia al harrio (حو) , o colación, o parroquia (艹) en que están enclavadas, y era base para la agrupación la iglesia, llamada muchas veces aljama (enolatl). Otras veces se refieren a arrabales (de Santiago, de San Isidro, de los Judíos, de los Francos, etc.), que queria decir simplemente barrio aparte, no siempre extramuros.

15. Barrio de la Catedral. - Principiaremos por la Catedral (القأعدة العهos), la Sede) de Santa María Ja Mayor, «madre de las luces* (اله (اله ), ya que esto nos fa.

(1) R. Amador de los Ríos publicó un artículo titulado «Toledo en los siglos XII y XIL, según los documentos muzarábigosy (Revista de Archivos, 1904, $\mathrm{X}$, pág. 45), utilizando los datos gue la proporcionaron las papeletas que Pons había becho en el Archivo Histórico, y con un poco de barullo y coufusión. 
cilita la localizacion, puesto que el lugar que ocupaba en el siglo XII era ya el mismo de hoy, aunque va ampliándose con la adquisición de casas para el edificio aclual, inaugurado, como se sabe, el ano $1226^{(1)}$, El arcipreste D. Nicolás adquiere en Mayo de 1167 la mitad de una mezquita que habia en la colación de Santa Maria, compránduia de Douninga, hija de Salvador, que con su bermana Sol la posefa (nú. mero 82), y la otra milad por compra a ésta, en Febrero de 1170 (ndim. 92). Estas casas formaron el adarve llamado en 1199 adarve del arcipreste D. Nicolás, que contaba en sus aledafios el establo que fué mezquita, propiedad entonces del arcipresle 1). Pedro de Talavera ( $\mathbf{n}$ (́m. 295). Los albaceas del arcipresle D. Nicolás, uno de los cuales era el famoso arcediano Domingo Gronzález (Dominicus Gundisalbi), vendían una casa y un establo frente a ella (que antes había sido me\%quita) al arcipreste don Pedro ben Micael en Junio de 1178 (núm. 141). En Agosto de 1186 el arcediano don Domingo el Polichent campraba a dofu Piacencia, esposa que fué de Pelayo Garganta, un mesón derruído, sito cerca de la Catedral, con la algorfa que habia encima de el y del arco, conliguo al mesón y a la lorre mayor, en el lado que se junta con la iglesia (núm. 183).

Otra casa carca de ha Catedral, cuya puerla estaba frenle a la puerla de la Catedral, separada de ella por la via páblica, es la donada, en 1230, por 0 . Juan de Hrihuega, prior de la Caledral, a dos sobrinos; entre las casas colindantes estaba una del obispo de Cuenca [D. Gonzalo Juanes], donde vivía el vicario D. Nicolás (1); olra del arcediano [D. Bellín; otra dal racionero I). Bernaldo Astur, y otra del propio prior donante. Esta misma casa, sita cen el barrio de la Caledral, ell el arrabal de los Barberos ", es vendida en 1232 por los sobrinos donalarios al arcipreste don Martín Chofíc (núm. 1.106); la calle, a la cual daba la puerta, iba por detrás de la Caledral. También ald eslailan las tlendas de los barberos, liendas que eran del rey (núm. 768 ).

16. Dentro del barrio de la Catedral estaba la Alcudia, en direccion hacia la iglesia de San $J u s t o(n u ́ m .156)$; se llamó primeso Alcudia althatab, "Cerro de la lefia *

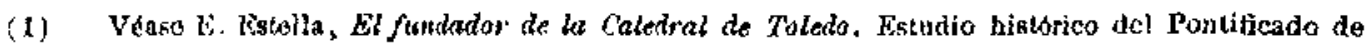

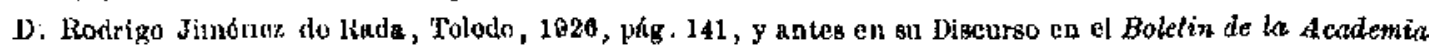
de Bellins Artes de Toielo, Julio-J)iciembro, 1029.

(2) Testimonio que da Ferrand Juanes do que él dío al Cabildo una tierra en Zaiencas (2. th Agosto 1221 ):

I10n 4 mor. que a lavie de inmar cadruno del loguer do las tiendas do los farineros en el Alewdia, las aabudas a D. Jomingo (sic), obispo do Cuenca, por rund el obispo derribo las quatro tjenuras que oran en AC,

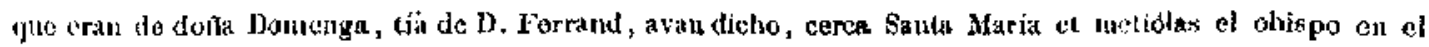
hospital que comenzó do fazer cabo Simeta Marias, (A, H. N., Cart, 1, fol, ij v.) - Advierlo que the rethero stompre que digo Cart. a los Carlularios primero y segindo de la Caveilal de Tuledn, hoy oji el Arclitwo tfistórico Nacional, Codices números $98 \mathrm{i}$ y 000 . 
(año 1163), y después simplemente Alcudia (núm. 1.095): se vende un mesón en la calle que bajaba de la Alcudia al baño de Caballel; otra casa, en el barrio de la Al. cudia (núm. 484), lindaba con la calle que dividía enlre la Catedral y la casa; otra casa de la Alcudia (núm. 611)

Se citan varios mesones en la Alcudia (núm. 899): uno que Juan Pedro el Kizzdaqui, su anadre Mayorí y su nujer Leocadia venden a Cristóbal hen Said el Ribatarí. Este Cristóbal lo vende a Domingo Juanes y María Domínguez, la cual, casada de segundas con Juan ¿Faloso?, lo vende al canónigo D. Jordán en Marzo de 1174 (núm. 111). También había tiendas en la Alcudia, entre ellas unas que fueron del ohispo de Cuenca, D. García (núm. 488).

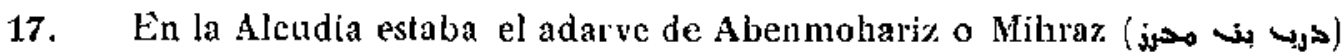
(núm. 738), que luego se llam6 adarve de Almoguac y de Abentahir, y que en 1200 se llamaba adarve del amín Abuljáir (núm. 302), y en época algo posterior, en el dorso del documento número 302 , se nomlra *Alcudia de los canónigos ». Algunas casas de este adarve lindaban con la alberquerta de la Catedral y con la calle que baja cerca del baño de Caballel (núm. 1.105). No sê si será este nismo adarve el que a mediados del siglo XIII se le llama adarve hundido (uúm. 581), aunque me inclino por la afirmativa, comparando las lindes de las casas vendidas en los docu. mentos números 302 y 581 .

Cerca de la $\Lambda$ lcudia, y en el mismo barrio de la Catedral, estaba el adarve de Ferrand García (núm, 617).

18. En la Alcuoia, y cerca del laño de Caballel, estaba ya por el año 1166 el fondaque donde degollaban los carniceros ( $\mathrm{n}$ úm. 79), que en 1181 se le llama rincón donde desuellan los carniceros sus reses, y se le sitúa en la Alcudia (barrio de San Justo) (núm. 156). La Catedral tenía una casa cerca de la que servía de matadero (núm. 801) (1), y en 1205 se vende la nropia casa, donde degüellan los carneros, en el barrio de la Catedral y cerca de ella (núm. 341). En 1240 era ya corral donde deguellan las racas, según el documento número 1.109; este corral, donde degüellan las vacas y los carneros, en la Alcudia, cerca de la Catedral, se vendía en 1253 (núm. 58ô) y en 1260 (nám. 610); entre sus lindes se cita en este último documento - la calle que va desde el limite de las tiendas de los Carniceros y de los Tintoreros hasta la iglesia de San Justo.

19. Destle 1163 habia en este barrio de la Catedral, y por la Alcudia, una alberguería (البرغلية - البرعية) de la Caiedral (núm. 1.095); en 1190 (núm. 979): duran-

(1) Año 1192, Diciemure, 10: "Cambio entro el Cabildo y los Adolantados de Barrio de Francos. Fi Cabilio da las casas que tenía junto a las en que degátellan el ganado, y los «contrades dieron la «casuga que hahía en Santa María Magdalena, y lo que tenían én San Ginés (olleros).» (A. II. X., Cart. I, fol. 77 r.) 
te el siglo XIII continuó allí la alberguería (núm. 1.105), citándose en 1283 una lienda cerca de la Caledral, junlo a la alberguería ( $n u ́ m$. 963).

20. En este barrio, y subiendo en dirección a San Justo (núms. 256 y 684), es-

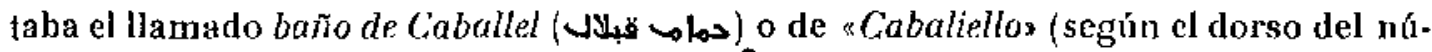
mero 236 ; , citado en los números 346,498 y 1.10 . Ya existja el baño en 1163 , pues una casa vendida lindaba con la calle que desde el Cerro de la leña, Alcudia, bajaba al haño ( $n$ úm. 1.095). En 1166 se vendía la habitación del Norte de una casa cerca de los baños de Caballel, uno de cuyos lindes era el fondac donde matan los carniceros (núm. 79).

Cerca del baño habia una casa que por los años de 1194 * ae le habían caf́o algunas paredes y tapado algunas saljdas, y temían que se hundiera del todo»; era propia de menores, $y$ con autorización del alcalde, D. Salomón ben Als ben Guaid, se vendió al presbitero D. Marlín, del clero de San Justo; lindaba con casa de los berederos del Gasco, con otra de Salvador Guter, y daba su puerta a un caliejón sín salida (núm. 256).

En este mismo barrio del baño de Caballel adquieren los canónigos un pozo de agua que tenía la casa de D. Juan de Espania, agua que llevaron luego al baño del Arzobispo, o de Yaix, sito por el barrio del Pozo Amargo (núm. 455)(1).

Otra casa, que debla estar muy cerca del baño de Caballel, era la de Pedro Martinez el Gallego, colindante con casas de Micael Juanes ben Abiljáir, de Julián el Droguero ben Catruf, de dona Gastona y otra de Cebrián el Hortelano, que habia comprado el camónigo D. Fernando García, complador de la que se describe en 1229 (núm. 498).

Cerca del haño habla un horno (núm. 34(i), que debe ser el horno de Mair Yahya ben Gálib, en 1150 (núm. 81), cuyo solar contiguo, ruinoso, compró este Yahya, y que después se le llamó «Furous Petri Abhatis * y „Forno de María Yahya (número 41), y supongo es el mismo que, juntamente con un meson, se silúa en la Alcudia (núm. 957) a mediados del siglo XIII.

A otra Alcudia, de las afueras, debe referirse la cita del documento número 514:

(1) Afo 1243: «Conosecuda cosa sea a todos los que esta certa uieren, como yo, dona Mayor Arias, do ot otorgo con ueluntad ct otorganiento de todos los fiios de D. fiarci Ferrandez, mio merido, que parayso ayk, a Deán el a Cabildo de Sancta Maria de Toludo, por muchas de amores que fizieron a $D$. García en su vida et experamos yo et suts fios aner de ellos, el otrossi por el alma de D. Garciat el por remisión de nuestros pecrados, una casa que yo cl ellos aucwos en Toledo, que es dicha el Mesoncicllo, cerca do los banzos del Caualielio, eon el pozo que as hy.... Las affrontaciones deste Mesonciello sou, de la una parte, la fuente del Cabillo sobredicho et las casas de Pedro Doningo el Pedrero, et cle la oura parte las casas de Sant Justo ct el corral del Rey, et do la otra parto las casas de dona Pola la Vercera et las casas de Bancta Justa et las casas de Sani Justo, ot de la otra parte la eitrera que pasa ante la pnerta del nfesonetello et ua pora Sant Jugto. $x_{\text {( }}$ A. H. X, Cart. 1, fol. 61 v.). 
un molino, enfrente de la huerta de la Alcudia, en el barrio de la Paerta del IJierro.

21. Un adarve había en la Alcudia, muy cilado eñ estos documentos: el ada!ve del caid don Sabib, que alguna vez se llama simplemente ael adarve» (núm. 63), al dorso del documento; olras veces se le nombra "la darve del $\Lambda$ lcadia» (1177) (número 130), " adarve de Vicent Sebil " (núm. 311), a adarve del arcediano de Talavera. (núm. 476), y termina llanándosele adarve de Santa María, el cual fué dicho antiguamente el adarve de D. Sabib» (núm. 351).

Por este adarve tenían alģnna casa los herederos de Zafadola (por 1177), el últi. mo Abenhud, aliado con Alfonso VII (núm. 130). De algunas casas puede seguirse el hilo de su transmisión: v. gr., la que lindaba con otra de Almoguac el Musulmán (núms. 160, 314, 417 y 751); otra que lindaba con las del vicario D. Gil García y el canónigo D. Quillén de Segovia (núms. $538,518,1.063$ y 1.111). Dos hijas del caíd D. Sabib siguieron teniendo casa en este adarve: doña Loba (núms. 354 y 542) y dona Lla (núm. 269). La de doña Loba fué a parar a manos del arzobispo, y estaba junto a las llamadas e casas del Canto (nútu. 542). También se cita una tintorería (número 476).

22. En este mismo barrio de la Catedral, cerca de la iglesia de San Antolín (núms. 591 y 627), y encima del barrio del Pozo A margo (núms. 217 y 220) se hallaban las tiendas de los Tintoreros (الحباغين) (núms. $411,451,486,558,627$ y 823), que ya a principios del siglo XIII se les llamó *Tíntes viejos * (num. 411) o × Tintores viejos* (núms. 451 y 513). Alguna casa de este barrio, que fué de D. Nicolás y su esposa doña María Mozola, y que lindaba por un lado con el arco de piedra de los herederos de Domingo ben Charrah, se va transmitiendo sucesivamente en 1213, 1214, 1219,1227 (núms. 401, 411, 513 y 765).

23. Cerca de la Catedral, en este mismo zaco de los Tintoreros (núms. 819 y

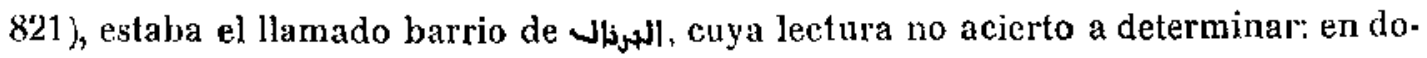
cumento de 1190 he leido GPorronal? (núm. 978), mientras que cn otro de 1222 be leído Bornel (núm. 470); me inclinadsa por la lectura el Porronal, porque un documento de 1242, en el dorso, teñfa la equivalencia «asas del Redomero (núm. 558), pero otro documento posterior, de 1259, también en el dorso, lo cita llamándolas «casas del Porniello (núm. 821): estaba este lugar cerca de una calle que bajaba a la que va a las tiendas de los Tintoreros, al lado de la casa del arzobispo, por donde se iba a ln Caledral, y uno de sus lindes era el adarve cerrado de Guillermo Pitevín; consta todo en las escrituras referentes a una casa que lindaba con casa hundida de la Catedral, detrás de la cual poseía otra la iglesia mayor, en la que vivía el arcipres. te de Illescas, D. Pedro, por los años de 1259 (núms. 186, 819 y 821). El arzobispo D. Martín López compraba en 1203 a Gonzalbo y Maria Juanes dos casas grandes y otra pequeña en el barrio del Pornel, cerca de la iglesia de Santa Trinidad, uno de cuyos lindes era calle del fondac (núm. 329). 
En los Tintoreros había una llamada c casa del vino * (año 1234, núm. 513) y un mesón para vender la sal (año 1226 , núm. 486), citándose también un fondaque hundido (núm. 558).

24. Pozo Amargo. - Siguiendo en el mismo barrio de Ja Catedral, cerca del barrio de San Antolín (núm. 1.113) y de las tiendas de los Tintoreros (627) por un lado, y del baño de Caballel (núns. 698 y 731), y extendjéndose basta tocar al barrio

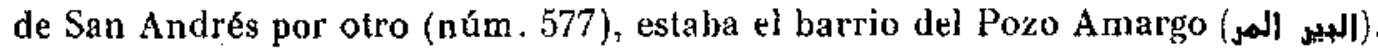

En el siglo XI, año 1093, se le llamaba plaza del Caxalí (رحبة النشالى) (núm. 3), y a mediados del XII, en 1142, seguía síendo el pozo del Caxalí (núm. 30); pero la misma firca citada en estos docnmentos se vende en 1175 y se dice ya sita en el barrio del Pozo Amargo (ním. 118), encontrando ya el nombre de Pozo Amargo ell 1162 (núms. 67 y 68), nombre que sigue dándosele durante todo el siglo XIl y el XIII.

Debajo de las tiendas de los Tintores habia un adarve, llamado "el Adarvejo. en 1191, ya en el barrio del Pozo Amergo; en una de sus casas habitaban los here. deros de una Marfa *Collo Alba , y en otra Julián ben Abichádal; uno de los lindes era el vertedero, detrás del cual estaha la casa de Abencosuch (núms. 217, $220 \mathrm{y}$ 228). En este barrio se cita la * casa del maestrescuela s don Juan, que la habilaba por 1257 el maestro Yunien, arcediano de Guadalajara (númıs. 574, 604 y 1.112); la casa de doña Luna de Yamero (1.260), juato a la de Micael ben García y a otra de la Catedral (núm. 1.043); la casa que el vicario don Fernando, canónigo de la Catedral, compraba en 1267 , que ya tenía otra contigua a aquélla (núm. 631), que acaso pudiera identificarse con el actual callejon del Vicarib. En 1288 se vendía una casa cerea del mismo Pozo Amargo, lindante con el horno que habia bajo el pozo y cer. ca de él, en la calle que va al río y con el baño de Caballel (núms. 698 y 701). Un horno de pan cocer había junto a una casa de la citada dofa Luna de Yamero, según la partición de sus bienes en 1260 (núm. 1.043).

25. En el Pozo Amargo Inabía un baño de Yaix (حسميثن), que debe ser el citado ya en 1197 ( núm . 1.001), y que en 1202 se le llama ya en el dorso del documento 319 « banno del Arzobispo». En el barrio de San Lorenzo, y cerca del baño de Yaix, flgura nna casa vendida en 1242 (nîtm. 559). Como larrio aparie, y cerca del Pozo Amargo, se nombra en 1216, y también en el dorso se le llama «baño del Arzobispo "; sin embargo, en 1226, y en la escritura de compra de la mísma finca, precisamente del documento 1.001 , se dice al dorso el banno del Fierro. (núor. 485); y en otra escritura dos años posterinr, en qike intervienen los mismos otorgantes, se cita el barrio del baño de Yaix, sin identificarlo al dorso, que dice: "Casas que son al Cenizal, en el adarve que end passa ( so pudiera explicarse la dualidad de nombres, suponiendo que se llamaba abaño del Arzobispo » por ser de propiedai de éste, y «del Hierro» por el ingar, cerca de la Puerta del Hierro.

26. Otro adarve del barrio de la Catedral era el en que vivía D. Juan de Vi- 


\section{CROQUIS DE TOLEDO}

\section{SEGÚN LAS ESCRITURAS MOZARABES}

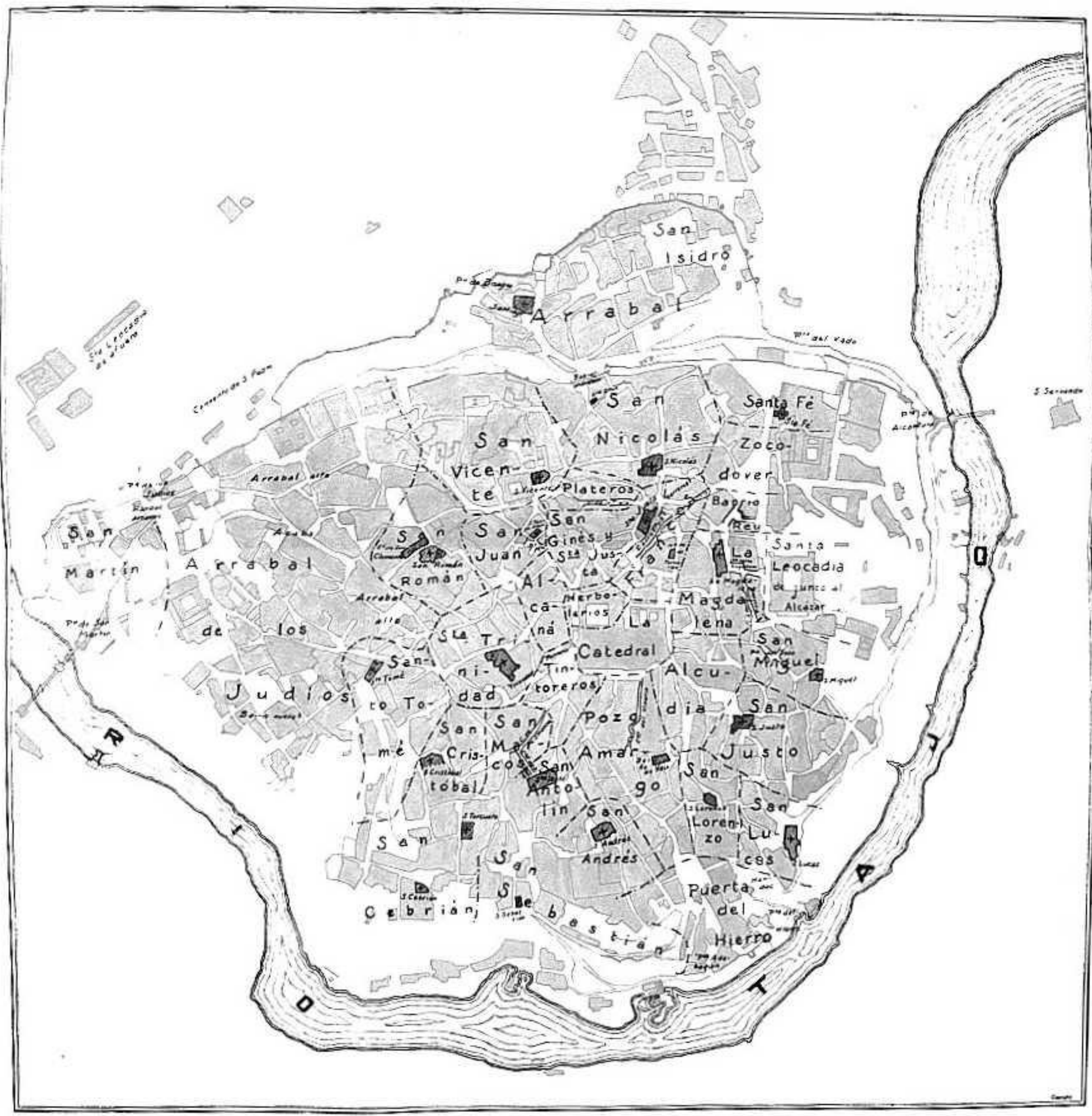

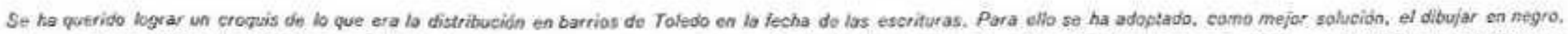
sabre un pheno actual de la cïudad, en sepia, lodos fos datos que con mayor o menor verosimilitud podian localizarse. partiendo de dos bases; la primera. qué dada la especialisima topogrefia de Toledo, el trazado de calles, sajvo ensanches accidentales, ha dobido ser siompro el mismo, correspondiente a las accidentes naturaies; la segunda. la peraistencia de las

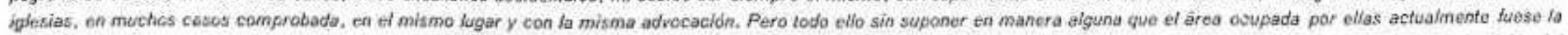
misme, en cuanto a emplitud $y$ formo, que ocupation entonces, Las lineas de cuntos y rayas con que se han separado los barrios son sollo meras indicaciones para claridad de visibin del croquis, sin valor afguno definitivo. Los fetreros an versalitas pequeñas a quo no acompavia localizacián tienen of mismo valor de refertencias. 
cente de Vargas y el arcediano D. Bartolomé (núm, 603): se le suele nombrar por el nombre âl primero (núms. 997 y 653 ), y en el número 659 , Adarve de los can6-

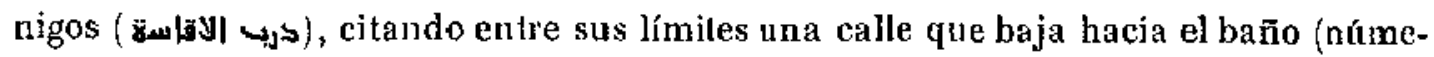
ros 659 y 660). Quizá la casa del arcediano, que se menciona en 1269 (núm. 960), sea la del arcediano $\mathbf{D}$. Bartolomé, siła en este adarve (núms. 653 y 659):

Sólo una vez se nombra el adarve de D. Bernardo, en el barrlo de la Catedral (núm. 608).

27. Cerca de la Catedral estaba también el barrio de los Herbolarios (عشابيف) - Herberos, citado pocas veces, y sólo en documentos muy antiguos $(1170,1178$ y 1191): había en su alrededor tiendas, una del rey y olra de los canónigos (números 96,139 y 215 ). El hecho de no citarse este barrio después de 1200 , me hace sospechar si estaría tan cerca de la Catedral que fuera ocupado en el perímetro de la consfrucción aclual (1).

28. Arrabal de los Francos. - Desde la Catedral se subía al arrabal de los

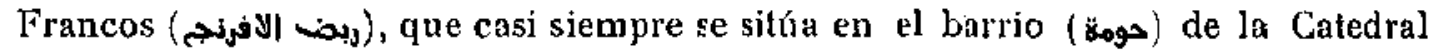
(núm. (6522): ، Barrio de Francos > (núm. 434) o « Ca] de Francos» (aúm. 625), según las notas al dorso de los documentos, se le cila desde 1134 (núm. 20) y menudean las citas de este arrabal, por ser barrio de comercio y de movimiento. Cerca de la Catedral (núm . 20), debla empezar junto al barrio de los Herbolarios (número 291). Poseian casas en este arrabal el Cabildo de la Caledral (núm. 1.071), Pedro Chasolín (núms. 291 y 323); el alcalde de los Francos, D. James (núm. 628); el alcalde D. Fernando Mateos y los frailes de la Trinidad (númu. 655, 670 y 829), por no citar sino las casas que más suenan.

En este arrabal había muchas tiendas del rey (núm. 201), en las que vendian los alfareros (núm. 473), los drogueros (العكارين) (núms. 473 y 829) (3), los carniceros

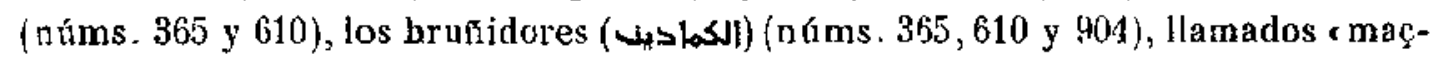
liçadores* (3) al dorso del documento número 944, los cambiadores (الصرافيف) (nú.

(1) Julián, preboste de los canónigos, compra (afo 1191, warzo), con dinero del Cabildo, al areediano D. Domingo Alpoliehen, una tienda en un solar contiguo a los herveros, cerca de los Orcbzes y cerca de Santa Maria, por 20 morab. (A. H. N., Cart. 1, fol. 76 v.)

2) El arzobispo D. Pedro Tenorio cedió el silio de unas tiendas del Alcaná (que se habían quemado, para edificio del claustro de la Catedral: algunas de esas tiendas se llamaban de los alatares, o sea, drogueros. Vid. Cervantes, Quijote, edición de Rodríguez Marín, 1027-28, I, págs. 288-289, que cita a J. Narbona, Historia de I) I'edbo Tenorio, arzobispa de Toledo, Toledo, 1624, fol, 205 r.

(3) “Compri Martín (opero (año 1186, Julio) un mesón de dos puertas, en Barrio de Francos, de dona Maria, fija de Pelai P'érez de Frómesta, la muger que fué dol alcalde D. Melendo, con IUt poyos que se tienen con la ona pueria caho lós mozcladores et con dos poyos que so tienen con el mesón o cosen las pielles et tićnese con mesón del comprador et con mesón de berederos del alcalde D. Mejendo et con la carrera et con otra carrera que descendo a ln Camia por deece el dos morabetinos doro..... (A. H. N., Cart. 1, fol. 76.) 
meros $317,365,904$ y 914 ) o cambiantes, los estereros (الحصارين) o esparteros (números $29,367,550$ y 829), los belluteros o pelcleros (بلكيرين) (núm. 1.035), los guarnicioneros (لجاهين) (núms. 1.02 .1 y $1.10 \%$ ), casi todos en su zoco o mercado aparte.

Al lado del zoco de los bruñidores, que estaba encima de los cambiadores, se hallaba la mezcuita de los musulmanes por los años de 1190 a 1202 (núms. 904, 911 y 317). Todavia se mencionan en este arrabal el "mesón grande, donde se vende la pe\% (nám. (225), los mesones del grano para el zoco de la hacina (núm. 77) (estaba allf por (1) ano 1165); se les llana lambien stondarum en los Fanaetes ( nim 7h8): y sospecho rgue a este amabal hay que roferir el c corral que fué fondac de] rey y en el que ahora (ano 1170) degitelian los lirancos las vacas * (núm, 3.0939), sito cerca del zoco de los l'escadores. Tres mesones se venden cerca de este \%oco en 1170: uno que daba a la calle en que estaba el corral que fué fondac del rey y luego matadero de los francos, contigno al mesón nuevo en una de las liendas ricl rey; los otros dos, contiguos y frente al primero, del lado del mesón del (iasco, del de Domingo Montero y del de Pedro ben Charrah (ním. 1.099).

por este barrio pasaba una calzada, a la que salian otras calles menos importantes, por los antos de 1260 (núm. (j28).

Hasta nuestros días conserva este barrio au caracteríslica, y la calle del Comercio está recordando los zocos y liendas del amabal de los Francos.

29. Correeros ( المشكازي). Vo puedo delerminar lacia gué lado calo esle barrio, dentro de Toleln; el capiscol D). laimundo compraba en 1169 a (iiraldo Cor. vino una casa, lindante con olras de Pedro Cobisa, de D). Paris y del cald D. Pelayo Petrez (núm. 1.(698): al dorso del documento se idlentilica el lugar son con ein corrigioris, ch los correcos. Por los personajes que intervienen me parece que debín eslar este burrio en ol arrabal de los francos, y no sé si por la actual calle de las Cordonerias (1).

30. Brrio de los Herreros (s) - No lo encuentro citado más que una vez en 1178: el capellán 1). Raimundo, de la Caledral, compró, para aniversario de su hermano Guillermo, un mesón con algorfa nueva encima, lindamle con corral hundido de la Caledral, con casa de habahí el Musulmán; debajo había un sótano de Rodrigo Moro (uńm. 138). Estaba por Santa Justa, cerca de lo que ahora es Hotel de Lino (núm. 1l6.)

31. Ahóndiga del Rry. - lin al barrio mismo de la Catedral y corca de los

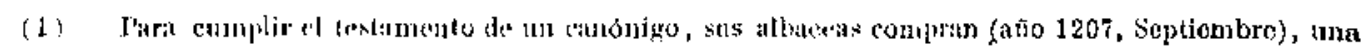

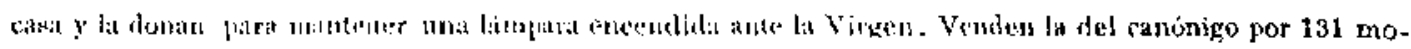

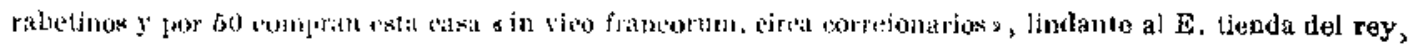

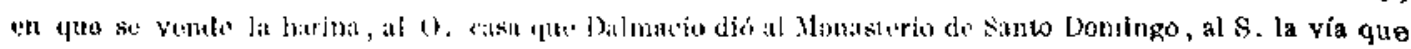

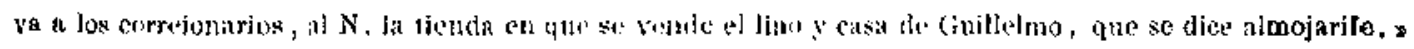
(A. Tl. N., Cart. 1, ind, iB. 
Tintoreros (núms. 337 y 396) estaba el barrio de la Alhóndiga del Rey (الفندت البلكان), ya en 1117 (núm. 10), llamado * Alfondica , "Alfóndega * al dorso del documento. En 1201 se vende en este sitio ua alhochra que el canónigo D. Juan Martín habia heredado de su tío el arcediano D. Domingo el Policheu\{ (núm. 337): con el mismo fondac lindaba la casa que Lope López y su mujer Soli vendían en 1217 al canónigo D. Cristobal, hijo de D. Torouato, que ampliaba así su propia casa (núm. 441); al lado de esta casa de I). I.ope tenía otra su hermano D. Fernando (las dos eran efec. to de la partición de las de șus padres IJ. Lope Fernández y doña Maŕa): esta parte, constiluida por una sala y una algorfa, donde trabaja el vidriero, la compraba también en 1221 el mismo canónigo D. Cristóbal.

52. Barrio de la iglesia de Omnium Sanclorum.-.- Lindando con el barrio de la Alhóndiga del Rey estaba este barrio: con la calle que iba a la Alhóndiga lindaba la casa que Golialmut el Franco vendía en 1187 al presijtero de Omnium Sanctortum, D. Nicoiás, representante del canónigo D. Feliz, hijo de Micae]; alli tenía otra casa D. Didaco, capellán del arzobispo D. Cerebruno (núm. 1.053). Cerca de la misma iglesia de Omnium Sanctorum se vendía por el preshítero 13. Guillén, el 1153, a un musulmán, otra casita ( $n$ ḿm. 1.094), casa que en 1183 es vendida otra vez a Dominga Micael, viuda de Domingo Junnes (núm. 168).

Una de las calles de este barrio pasaba contigua a la casa del Arzobispo, y había otro adarvillo (الدريش) sin salida: el capiscol de la Catedral, D. Domingo, adquirió en 1223 unà casa grande, otra pequefra y un corral contiguo, que eran de D. Rodrigo de Funes y de su esplesa dona Loba, hija del adalid Domingo Chico, casas que lindaban por un lado con la propia casa del arzobispo (núm. 471). Otra casa de esta colación lindaba, por 1167, con la casa del Alcarrac (el Alpargatero), y con unas tiendas de los herederos del alguacil D. Illán Petrez (núm. 83).

Después del primer tercio del siglo XIII no se cita este barrio en los documentos.

33. Barrio de la Trinidad. - Lindando con el barrio del Porronal o Porniello (uúm. 329) y con los Tintoreros (núm. 823) cstaba el de la iglesia de la Santa Trinidad. El arzobispo D. Mart́́n López posela et 1203 una casa que fué de Pedro Raimundo, otra que había sido del deán D. Juan, y adquiría otras dos casas grandes con una pequeña (núm. 329), que lindaban con la calle del fondac, a la cual daba la puerta del adarve en que estas tres casas estaban emplazadas.

El Cabildo adquiria, por cambio, en 1260 otra casa, lindante con fincas suyas, en este mismo barrio y cerca de las tiendas de. los Tintoreros, junto a las casas de Sancha Guteriz (núm. 823); y el arzobispo D. Gonzalbo Petrez, en 1294, compraba una casa derruida, linuante con la capilla de San Juan del Arzobispo, junto a casas de la Catediral y con la calle que iba a la iglesia de la Santa Trinidad. Estaba esta casa pegando con el Alcaná (núm. 716).

34. Barrio de San Juan,-No encuentro datos suficientes para identificar esta 
iglesia con la actual de San Ildefonso, o sea lo que fué residencia de los Padres Jesútas. Mejor pudiera ser la actual de San Felipe Neri. Se cila ya el barrio en do. cumentos de 1173; pero los lindes de las pocas casas vendidas de él suelen ser nombres de los propietarios, más que de lugares (núms. 109, 155, 382 y 544).

Cerca de este barrio estaban los Plateros, OOrebzes* 11 *Orfebres* (الحاغة) (nú. meros 504 y 951 ), citándoke la plaza de los Platerns en 1289 (núm. 1.605). Amador de los Rios la identifica con la plaza de los P'ostes, y la iglesia loy de San Felipe Neri. - La calle de la Plata actual está recordando al harrio de los Plateros.

35. El Alcaná. Al lado de la Trinidad estaba, pues, el Alcaná (القلاة o 0

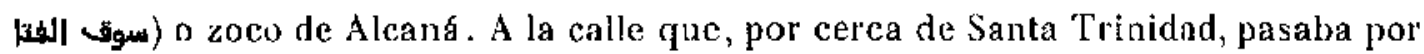
el Alcaná, daba la puerta de la casa gmediuna? que fué del canónigo D. Marlín Chofré, que poséa su sobrina doña Edeba, en 1269, junto a otra que era de D. Marı́n Fernández, hijo de D. Fernando Petrez el Portugalés, y lindando con la iglesia de San Juan del Arzobispo, con casa del arcediano y con aira de la Catediral (núm. 960).

En un callejón sin salida, cerca del Alcaná, y lindante con la misma calle, que iba cerca de la iglesia de Santa Trinidad, se sitúa la casa de D. Gonzalbo \& Rechico?, en que habilaba el racionero Mertín Micael (núm. 67\%), casa que se adjudica a doña Matea, esposa seguada de D. Ganzalbo, en la partición de los bienes de éste en Ootubre de 1283 (núm. 963), y es vendida a Rodrigo de Santa Eulalia por los herederos de doña Matea en Diciembre del mismo año (núm. 677) (1).

Estas fiendas del Alcaná se quemaron, y su solar lo cedió el arzobispo D. Pedro Tenorio para edificio del claustro de la Catedral (2).

36. Barrio de Santa Jasia. - Por el lado de los Drogueros (arrahal de los Francos) empezaba ya el barrio de Santa Justa (ním. 945): por Febrero de 1175 se vendfa una habilación (الحجرة) en el barrio de la iglesia de Santa Justa, cerca de las tiendas de los Herraros, sita sobre un mesón propiedad del camprador (Lázaro Sancho el Tabernero); este mesón era arrendado, en 1493, por el Cabildo Catedral y durante su vida a Sancho de Toledo, mércader, y antes lo tenía Diego de Toledo, limonero, y estaba sen linde del Mesón del lino»: clara está su identificación con el actual "Hotel de Lino", hasta hace poco *Posada de Lino* (núm. 116).

Por los alrededores de este mesón estaban las tiendas de los Herreros y el corral del Albeitar, propiedad de la Catedral (núm. 116) (3).

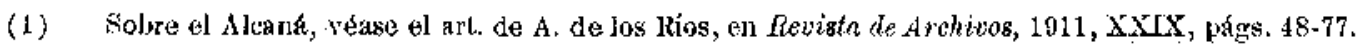

(2) Sobre ol Alcaná que sustituyó a éste, véase Eugeuio Narbona, Histuria de D. Pedro Tenorio, arabjispo de Toledo, 1624, fol. $105 \mathrm{v}$-Cir. Cervantes, Quzjote, edición de Kodríguez Marín, Madrid 1927 , tomo I, yáge. $288-9$.

(3) A ßo 1162: El Cabildo da in prestimonium a D. Juan un solur sin nostro alfonduca, quod a nobis habetur in barrio Sancte Justes, con la condición do que lo que en él se edifique, a la muorte de don Juan quede propiedad de la iglesia. (A. H. N., Cart. 1, fol. 62 v.) 
Este barrio es citada a veces junto con el de San Ginés: casa en el barrio de Sany ta Justa y San Ginés ( centre San Ginés y Santa Justa», al dorso), se vende en el número 318 .

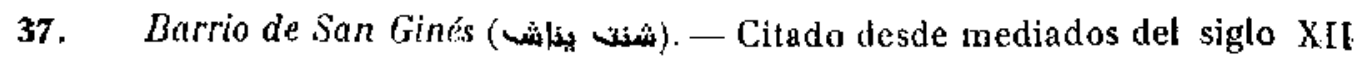
(año 1158), el barrio entre la iglesia de Santa María y la de San Gines debía ocupar lo que ahora es calle de San Ginés (núm. 60); la calle que iba de San Ginés a Santa María podría ser la calle de la Granada, y la plaza donde cstaba la casa ven: dida podría ser el espacio donde confluyen la calle y el callejón de San (Ginés y la calle de la Sal y de la Lechuga (ahora de Bécquer) (núm. 60).

Una casita, donde luego estuvo el horno que había pegado a la iglesia, era do.

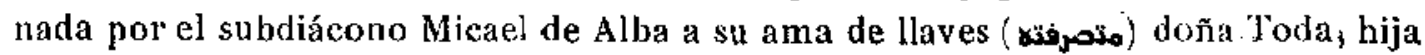
de Lope de Cotarel, en 1207 (núm. 1.122), casita que ella vendió en 1208 (núm. 362. )

Lindando con la casa de este Micael de Alba estaban las liendas de los Alfare, ros, Alfahares, o venden los terrazos ; un mesón en los Alfareros, cerca de la iglesia de San Ginés, se vende _en el número 347; otro, en el zoco de los Alfareros, lindaba con lienda del rey Alfonso y con mesón del arcipreste. D. Donningo (númen ro 902). Los canónigos tenían un mesón para vender loza y d desde 1192 (núm. 801 ).

La noble famiina mozárabe de los Polichení poseja fincas en este barrio, v. gr.; un mesón sito cerca de la iglesia misma de San Ginés, que fué de Domingo ben Abdala el Polichení (nú m. 298); dos mesones y tres tieudas que cran de dona Lazarena ben Abdala el Polichení y anles habían sido de su hermano el areediano D. Dc mingo, vendidos al almojarife, quien los cede al arzobispo D. Martín L6pez (1204) (núm. 335). Al lado de estos mesones había tiendas del rey, así como el Arzobispado (الهكرانية poseía otras tiendas contiguas a ellos y a la casa de D. Pedro Abad, de la iglesia de San (rinés, y a la de Pedro Conejero (1207): en este mesón de los canóni. gos se vendía loza por 1192 , y a su lado babía por aquella fecha un corral hundido, propiedad del Cabildo y de la Cofradía de los Francos (núm. 801).

38. Barrio de San Antolín. - Desde 1121 se cita ya esta iglesia, En el bario de la plaza de $A$ benaziz, del arrabal de la iglesia de San Antonín, se vendia este año una casa exterior, con callejó de entrada a la casa interior por unos muros de Domingo Sidis y su esposa; tenía casa en el mismo sitio Suleimán Arraxah (número 13). Otra casa compraba Lázaro ben Ali a Domingo ben Suleimán en el mismo barrio en 1157 (núm. 52). También temían casas en este sitio Servando, hijn de Pedro García (núm. 68), y Pedro ben Amir, que las compra el presbitero D. Gesión, de San Antolín: ésta lindaba con la calle mayor del barrio (núm. 69).

A la calle detrás de la cual estaba la iglesia de San Antolín daba la casa que fué primero del presbitero 1 . Domingo, del clero de esta misma parroquia, y luego del convento de Santo Domingo, colindante con casas de Pedro, hịjo de Lázaro ben Alí, de Alí ben María y de Domingo Martín ben Alquitar: con esta casa se vendía (1193) un corral contiguo al corral de la iglesia de San Marcos (núm. 249); esta mis. 
ma casa, que el convento de Santo Domingo vendió, apremiado por la necesidad en aquel fatal año estéril, se vuelve a vender en 1211 por Micael Cebrián a Pedro Lázaro, del clero de San Antolín, y se indica lindar al Norte con la iglesia de San Mar. cos (núm. 388).

Identifleado San Antolin con lo que hoy es Santa lsaluel de los Reyes, vemos que, en efecto, allí están la calle y el callejón de San Marcos. Estaba cerca de los Tintoreros, según el documento número 591: «Casa en la que moraba Juan Petrez el Gallego, en el bartio de San Autolín, cerca de los Tintoreros, dentro de Toledo, lindante con easa del clero de San Andrés, con casa de la Catedral Santa María, con el mesón llamado de María Mozola y con la calle adonde da la puerta (año 1251).

Una calle iba desde las tiendas de los Tintoreros a la iglesia de San $\Lambda$ ntolín, calie con la cual lindaba una casa sita s en la colación de Santa María, cerca de la de San Autolín, la del Puzo Amargo y de las tiendas de los Tintoreross, lindante con casas de Domingo Julián el Sillero, luego de Sahta Lencadia, de junto al Alcázar, y de doña Orabona, esposa de Pedro Jiménez; la compra (1266) el presbítero de San Andrés, D. Martín(núm. 627).

También se cita en el mismo barrio el adurve del Morchent: una casa pequeña, junto a otra grande, que usufructuaban los racioneros de San Antolín, y a la de Lope Juanes, daba a este adarve y la compraban en 1283 Pedro Juanes y su mujer doña Munia (oúm. 675).

39. Barrio de San Lorenzo. - En este barrto se cambiaban, en 1156, dos casas: una de Diego Estéfanez y Maŕa Sancho, junto a las de Micael ¿Abrasto?, Lázaro ben Jálaf y Suleimán el Fermant, por otra de Omar ben Selma, casado con Dominga, contigua a las casas del obispo de Avila y del cafd D. Pedro Petrez (núm. 796). Estaba cerca del bafio de Yaix, según la compra que Martín Domínguez lacía en 1242 de una casa de María Arnaldo de Esquaivias, contigua a otras de Eulalia la Gargantera, de las monjas de Santa María en Alhicem, de Teresa, hija de Pedro Juanes el Escribano y de Udeba y su esposo Pascual (núm. 559); esta misma casa se vuelve a vender en 1255 a dona Solí Petrez, hermana del notario García Petrez, y se añade en su delimitación que la calle adonde da la puerta va por detrás del baño de Yaix (núm. 594).

Entre los bienes que a su muerte dejo Teresa, mujer del escribano Pedro Jua. nes el Guadiexí (1276), se cilan una tienda y dos casitas juntas en el barrio de San Lorenzo (núm. 962).

40. Barrio de San Marcos (شنت مركش). - También cerca de los Tintoreros, por una parte, y por otra de San Antolín, estaba el barrio de San Marcos, que no era el actual San Marcos, sinu que debía esta: pur las calles que aún se llaman de San Marcos, por encima de Santa Isabel de los Reyes. Una casa, con casita y sótano, junto a la casa y adarve estrecho (que era calle) de D. Pedro Bayán el Ciego, compra el canónigo D. Seguín, en 1193, a Leocadia Domínguez, esposa de Pedro 
Lorenzo, y lindaba, además, con casa del sacristán Alrojís y de la familia de los Bayán (núm. 236): el canónigo dejó estas fincas para su aniversario y la Cátedral las vendía, en 1202, a Dominga, hija de Aburebia Suleimán ben Otmán, y al describirla se dice que la casa del sacristán era entonces de Feliz el Albañil (núm. 309).

Con la iglesia misma de San Marcos lindaba la casa sila « en el barrio de San Marcos y ide Sarr Antolíns, que Colomba Martín había adquirido en su dote y ven. día a Pedro Lázaro, presbílero de San Antolín, en 1205 (núm. 342); a su lado estaba la casa de Gualid ben Garún (núm. 342); otra contigua a ésta de Gualid y que lindaba al Norte con la iglesia de San Marcos, aunque sita en el barrio de San Autolín, compraba el mismo Pedro Lázaro, en 1211, a Micael Cehrián ( núm. 388).

La casa de doña Dominga, hija de Suleimán, pasó a manos de Guler García, y en 1266 el canónigo Sancho Martínez compraba a Esteban Juanes otra casa colindante con aquélia, y con cáa del maestro Lope, despités de fa Catedral, con dos caIles, una sin salida; enfrente de la casa habia una botica, linde con casa de Orabona, viuda de Gonzalbo Juanes, antes de Pedro Jiménez, y con otra de doña Luna, esposa de Martín el Sirafí (núm. 1.114).

41. Barrio de San Andrés ( San Andrés cerca del Pozo Amargo. Por 1183 vemos ya citado el barrio en la venta de la casa que poseía María, hija de Martín Elaití, casa que antes era de Abdala ben Omar y contigua a la de Abdala ben Hasán, lindante al Oeste con uma calle y al Norte con callejón sin salida (núm. 167). También en este barrio se menciona la casa de D. Ramilo el Zapatero, cuya cuarta parte sus hijos vendian a la Catedral por 1250 , al lado de las casas del caíd D. Pedro Jiménez y del escribano D. Feliz; tué la casa del canónigo $\mathrm{D}$. Juan Cebriánez y de su hermana doña Orabona, los nielos de la cual son los vendedores (ním. 577).

Cerca de la misma iglesia estaba la casa que el canónigo Bernaldo Astur compraba, en 1237, a los hermanos Abril y Alfonso Díaz: daba a dos calles, una por detrás de la cual estaba la iglesia y otra ccrca de la casa que fué de Lope Fernández; también tenían casa en este sitio doña Estefanía Robert y D. Diego Gonzálbez, hijo del alguacil $D$. Gonzalbo Juanes (núm. 602.). En la misma colación vivía, antes de 1280, Fernando Petrez, hijo de Pedro Juanes el ¿bolsero?, que manda en su testa-mento a su hermano Juan la casa en que habitaba en San Andrés (núm. 1.033). Otra casa en esta parroquia carrespondió (1288) a Colomba Vicente en la parlición de los bienes de su madre doña Sol (núm. 1.046).

42. Barrio de San Cebrián (شنت سبريان). - Sólo hallo citada una casa en este barrio, que debe ser por donde está ahora San Cipriano, más allá de San Torcuato, en direcci6n a la calle de las Descalzas y del Calvario. En 1187, los testamentarios de Abdala ben Baxar vendían a Micael el Subdiácono y a su hermano Pedro, hijos de Pedro Alhasán, una en el barrio de San Cebrián, que lindaba con casas de Do- 
mingo Alcochit el Pescador, de Martín Haruba y de Dominga, esposa de Juanes el Ancuri; por el Norte de la casa pasaba la calle (nim. 192).

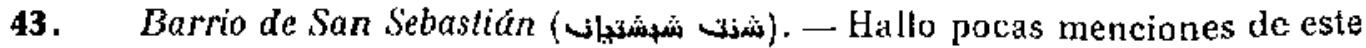
barrio: en 1168 los albaceas de Samsi, hija de Cháfar, compran para la hermana de ésla, María, menor de edad, la mitad de una casa en el barrio de la iglesia de San Sebastián, que lindaba con casa de los herederos del alguacil Sid, y con otra en que éstos tenían una sala, con la calle cerca de la Puerta de los Curtidores (al Oeste), donde daba la puerta con un corral, y con la otra mitad de la que era partición (número 89). Otra casa contigua a la del alguacil Sid, a la de Lorenzo el Carpintero y a la del Hachequí compra (1189) Pedro Lazaro, de San Anlolín (ním. 204). La puerta

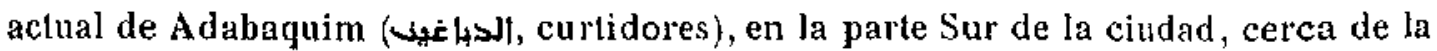
Puerta del Hierro, nos permite localizar este sitio (1).

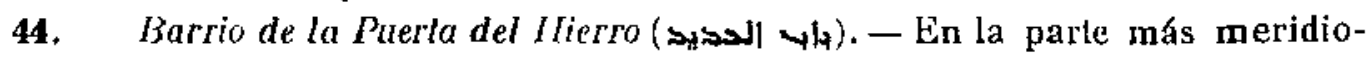
nal de la ciudad se encontraba el barrio de la Puerta del Hierro o a Puerta del Fierro $>$, que se cita casi siempre como existente dentro de Toledo (núms. 272 , 356, etc.) y alguna vez fuera, v. gr., en la venta de una casa de tenería (Sاد الدياغن) a favor del convento de San Clemente en 1176 (núm. 124). Se le menciona mucias vevas junto con el barrio del Handac (الحندن), Andaque actual (níms. 572, 819, 913); y alguna

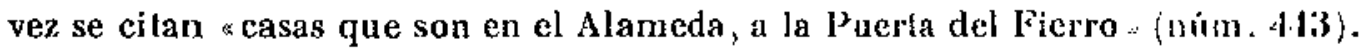

Samsi, hija de Yaix, vendía (1197) a Martín Domingo y su mujer una casa en este harrio, colindante con casas de Domingo el Polichení, de Micael Jaques, de Sid Abináchar (núm. 272), casa que se vuelve a vender en 1207 (núm. 336). Wl presbítero Pedro Lázaro, de San Antolín, compraba (1210) a Kamilo, hijo de Pelro ben Fotuh, otra casa al lado de las de Yahya Abuzacaría y Gálib el Sufi (núm. 380). Otra casa de los hijos de Martín el Pescador lindaba con casa de Raimundo el Sastre y de doña Leocadia (núms. 430 y 1 13). El arcipreste D. Martín Chofré labía adquirido, por compra a Orabona, viuda de Juan Fidalgo el Sastre (12:16), una casa en el barrio del Hierro, en el Alhandac, contigua a las de Domingo Martín el Carmadi, luego del alguacil Pedro Suárez; otra que fué de Orabona y luego del alguacil Guter Fcrnández y otra de Martín Juanes (núms. 572 y 913 ).

Punto de referencia para este barrio es también el Baño del Hierro (

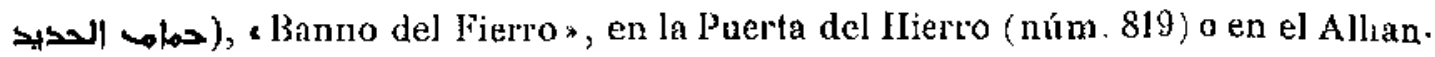
dac (nún. 913): en el barrio àel Baño del Ferro se siiúa la casa de doña Orabona, atrás citada, y que la compró (1239) el arcipreste D. Martín Chofré (núm. 534).

(1) Ano 1140, Julio: Alfonso VIf da a la Catedral los molinos que están en la presa de a Molinellis et inter civitatem iuxla portam de ddabakim, et ex altero parte molinos ot aleurnam de Sancta Maria, ex altera parte presa de Nolinis de Deiean, ut faciąs ibj unam casam de molino cum duabus rotis, " (A. H.N., Cart. 1, fol. 49.) 


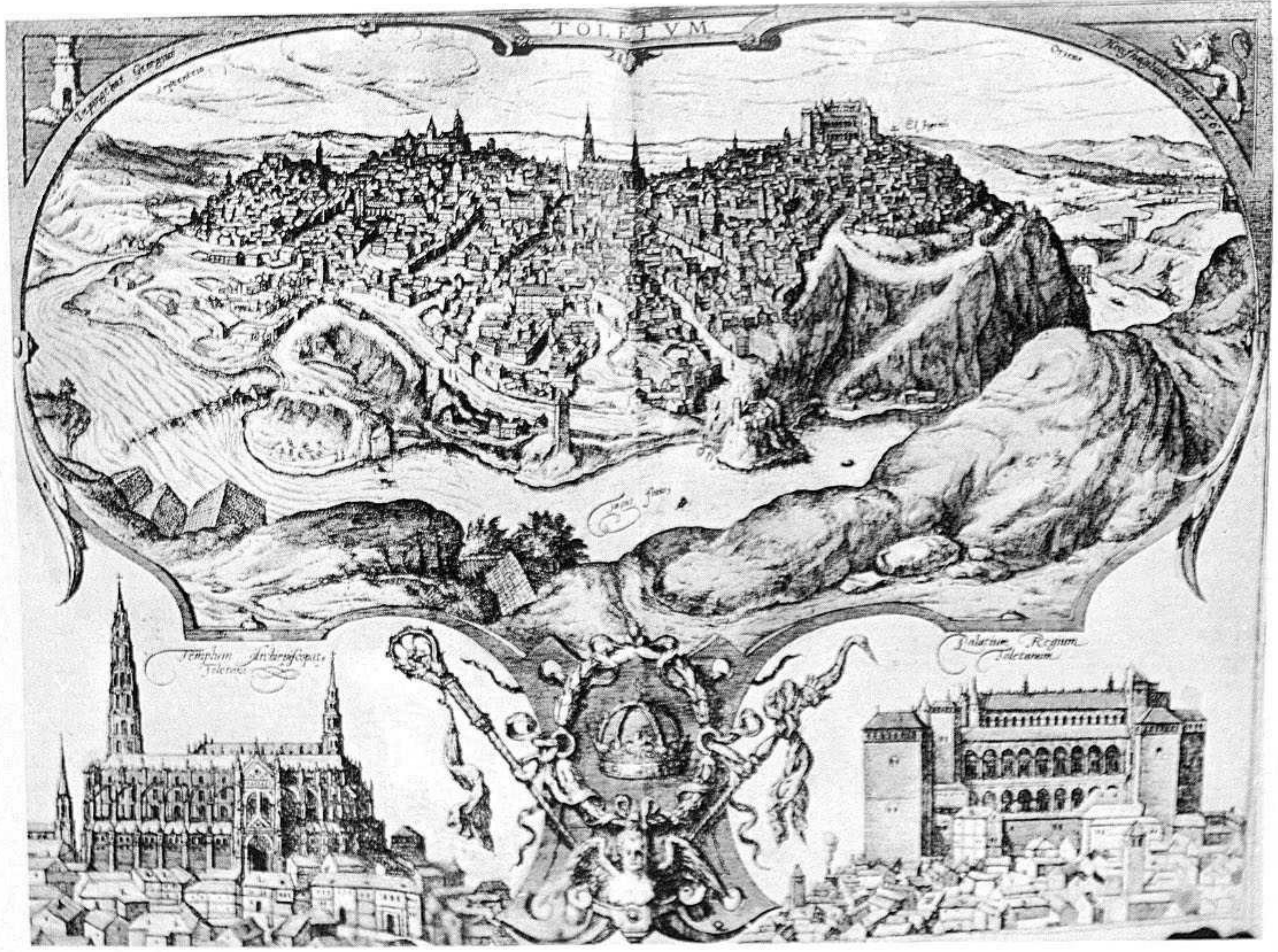


En el barrio de Puerta del Hierro, fuera de Toledo, se sitúa (1176) una casa de tenería, lindante al Este con el ¿jarroyo? que va a Hamán Ferro, al Oeste y al Norte con las murallas de la ciudad y al Sur con el camino, cuya mitad compra el con. vento de San Clemente, dueño ya de la otra mitad (núm. 124). En el barrio del Alhandac, cerca de la Puerta del Hierro y del Baño del Hicro estaba la casa que el alguacil y alcalde D. Gonzalbo Vicenle daba (1259) a Colomba Petrez, a cambio de otra en el barrio del Porniello, cerca de los Tintoreros (núm. 819).

En la Puerta dél Hierro se citan el molino de en medio (núm. 841) y una casa de tenería y un hospital frente al inismo baño (núm. 738).

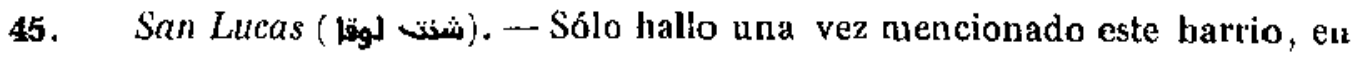
1157: Pedro y Domingo, hijos de Said, poselan una casa alli, contigua a las casas del obispo de Avila, de Abenalrim y de Eulalia, y se vendía a Saadán y Farech, hijos de Yahya (núm. 56).

46. Batrio de Sañ Miguel. - Pocas referencias hay de esta iglesia, que estaba por debajo del Alcázar, por donde está la casa de los Templarios y donde todavía hay calle de San Miguel, callejón de San Miguel y cobertizo de San Miguel y plazuela del Seco.

En 1228 se cita a uno que vivia junto a San Miguel (núm. 838). Por 1259 , a cambio de unas tierras en la alquería de Torres, dan Pedro Juan y su mujer doña Luna a la casa que tíenen en la colación de San Miguel, dentro de Toledo, lindante con casa que era de Munio el Curtidor, alora de dofia Andresa la Bisntera, con otra del hijo de Sofín la Musulmana, con otra que era de Jaan de España y con la calle,

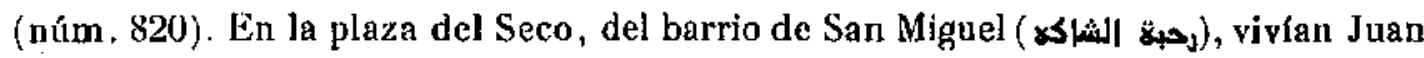
Marcos y su mujer Marfa Fernández en 1280 (núm. 665); y en el mismo barrio se dice que vivían García Gonzalbez y María Juan por 1290 (núm. 878).

47. San Justo (شنش - - Suhiendo desde la Catedral, al lado de la Alcudia, frente a los Tintoreros y Carniceros y hasta bajar a la Magdalena, situábase el barrio de la iglesia de San Justo (núms. 156, 717 y 961). Una alhochra sobre la casa de Pedro Paris y Orabona, contigua a casa de herederos de Pedroche, era comprada por Orahona, en 1177, para sus hijas María y Solí, que poseían la casa y alhochra contiguas (núm. 135). Cerca del rincón donde los carniceros degüellan sus reses (año 1181), en San Justo, cerca de la Alcudia, tenía su casa D. Raimundo Guillén el Gasco y la vendía a Benedicto l'ctrez el Tuerto, casa que estaba contigua a las de Pedro Domingo y Raimundo de Coca (núm. 156): esta misma casa, situada en el barrio del baño de Caballel, se vendía en 1206 a los carniceros Pedro y su señor Juan (núm. 346). Con la casa del atrás citado Pedroche el Arquero lindaba también la casa, entre dos calles, cuya cuarta parte vendían (1186) Paris y Cecilla, hijos de Mur. tín el Calero, a su madre doña Eulnlia (núm. 185); los testnrnentarios de doña Solí la venden en 1215 (núm. 425). Con casa del ¿Soguero? y con otra de Raimundo, lnego de Benilo el Bizco, lindaba la casa que compraba (1190) Domingo Petrez, so. 
brino de D. ¿Quematero? el Carnicero (núm. 210). $\Lambda$ la Calzada daba la puerta de la casa de San Justo, contigua a la de Pedro Domingo hen Charrah, que empeña. ban, en 1213, Lope, hijo de Alvaro el Zapatero, y su esposa Orabona, hija de Juan el Axiq, en poder de Martín Illán el Pescador (nún. 953).

El Cabildo de la Catedral adquiere, por compra a Gonzalbo Pelrez Asacaz (año 1241), la casa del barrio de San Justo, lindante con casas de Bartolomé $\Lambda$ sacaz, de l'edro López y del clero de San Justo (ním. 543).

Lindando con la misma iglesia de San Justo estaba la casa que la Catedral cedía (1260) a D. Gonzalbo Guteriz, junto a las casas de D. Vicente el Zapatero hen Razac y de otra que poseía la iglesia de San Feliz (núm. 823 ). Al lado de un corral hundido de este mismo D. Gonzalbo Guteriz, y lindante con dos calles, una que iba hacia la iglesia de San Jasto, compraba doña Marquesa, mard re del secretario de Al. fonso $X$, Sancho Idartínez, dos casas que habian sido del canónigo D. Pernando Gar. cía; también en este lugar lenía su casa Micael el Vainero (núm. 1.115).

La vendedora de pescado de mar doña Marla y su esposo D. Juan adquiran, en 1275, una chsa con sus sótanos debajo, cuya puerta daba a la calle alta cerca de la casa de doña $A$ ndresa, y la puerta de los sótanos daba a la calle que baja de la citada calle hasta la esquina de la casa de dona Guiomar, antes de Domingo Andrés el Carnicero, lindante todo con casa de Domingo Micael el Curtidor, que antes fué de Saloinón el Alcalde (núm. 645).

El cementerio de la iglesia de San Justo se menciona en 1280 , en la escritura de venta de este corral en ruinas, cerca de la iglesia, propiedad de Gonzalbo Guteriz, a favor de la misma dona Marquesa, y lindaba con casa de su hijo Sancho Martinez, que antes era de García Pérez de Vargas (núm. 663).

Ea 1285, Marla Juan compraba, por 400 mizcales, a doña Urraca, hija del to. cionero Gutex Domínguez, rdos casas hundidas * en el barrio de la iglesia de San $J$ usto, en la Alcudia, contiguas una a la otra, dentro de Toledo: a una le dicen «la casa del Pozor, y a la otra sla del Corrał". En la casa del pozo hay una habitación, y sobre ella una *algorfa * de un hermano de la vendedora, ecuya puerla sale a la calle grande, que va hacia la iglesia mencionadá. Entre los lindes estaba col corral donde se degiiellan los carneros, llamado de los Musulmanes*, casas de María Petrez, de la Catedral, de la Iuminaria y cotra segunda calle que baja al baño de Caballel». La puerta de la casa del pozo estaba cerrada, y antes salía a la calle grande que va hacia dicho Baño, del lado del corral en que se degüella la carne (núm. 684). La nisma doña Marła Juan, en 1291 , vendía a Juan l'etrez, por 3.000 mizcales, sa casa con cinco tiendas contiguas, en el barrio de San Justo, cerca de la Aleudia, lindante todo con un salar de la aljama de moros de Toledo, en donde degüellan los carneros, con casa de Juan Martín, con otra de los canónigos de Santa Leocadia, junto al Alcázar del Rey, que antes fué de García Martín, con dos casas de la Luminaria de la iglesia de San Justo, con la calle que pasa, a ln cual da la puer- 
ta de la casa, y con otra calle, a la cual dan las puertas de las tiendas (números 709 y 889 ).

I.a mitad de una casa y dos casitas y de dos algorfas superiores adquiría, para ampliar la suya, contigua, el alguacil don Alfonso Femández, en 1294, a la viuda de Micael Jomínguez, amín de la Hucrta del Rey: las puertas de las casitas daban a la calle que sube al barrio de Santa Maria Magdaiena; has puertas de la casa, a la ealle que va al barrio de la Catedral. Allí mismo tenía sus casas Pascual Petrez el Carnicero, y su botica doña Colomba, hermana de Alfonso Fernández (núrn. 717).

En esie barrio de San Justo estaba, pues, el matadero de los musulmanes hasta fines del siglo XIII, por lo menos.

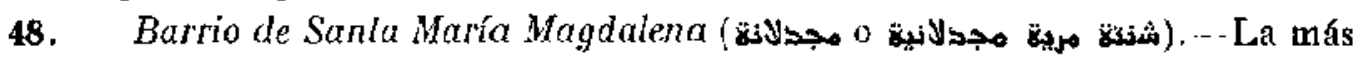
antigua mención de esfe barrio es de 11533 , fecha ( $n$ que se vende un corral al lado de la casa de Justa, madre de Raimundo Mengo, que poseía Pedro de Cuenca (núm. 44).

Se sitúa este barrio en el arrabal del Rey, en documento de 1176, donde Alda la Tuerta, hija de Guillermo «Ruta Chivo», vendía a Micael Tarín un sótano que posefa junto a casa de D. Ponce y a una tienda de D. Paris (núm. 128).

La iglesia de la Magdalena poscia unas tiendas en una calle junto a la misma iglesia, al lado de la casa que el Cabildo Catedral cambiaba (1192) con la cofradía de los Francos, al lado del corral de doña Urraca y de un lugar ruinoso de los hijos de Assofar (núm. 801). Conocida en el barrio, por 1205, basta el punlo de excusar su descripción, era la casa ne Juana, esposn de Asíl Duro, rodeada por la casa de Martín Ancuín (núm. 343). Junto a un mesón de los frailes del Hospital de San Juan y a otro de la Catedral, poseía doña Galiana, esposa de Arnaldo Tolosano, otro mesón, que vendía en 1209 al tesorero de la Catedral, D. García Estébanez (núm. 366); lindando también con la casa de los frailes estaba otra casa con su algorfa, propiedad de Pelayo el Rafaquí, que se vende en 1214 (núms, 409 y 119 ).

Don Juan de Ainsa el Caballero y su mujer doña Luna adquirian, en 1244, dos casas, una botica y un establo, todo contiguo, en este barrio de la Magdalena y cerca ya del Alćázar del Rey: la puerla de la casa de arriba y de la botica daban a la calle «detrás de la cual está el $\Lambda$ lcázar»; la casa de ábajo daba al adarve, donde daban también las casas de D. Micael el Carpintero ben Alcarmán y de D. Servando Assammar; el establo lindaba con la casa de D. Micael, con el horno y con casa de la iglesia de la Magdalena; tenían, además, casas coliodantes los frailes de Uclés, donde vivían Rodrigo el Arráez; D. Mart'́n, medidor de granos; Domingo Caro, medidor de vinos, y un hijo de Sálih (núm. j61). Todavia perdura la plaza del Horno de la Magdalena y la calle del IIorno de los Bizcochos, detrás de la cuad está el Alcázar.

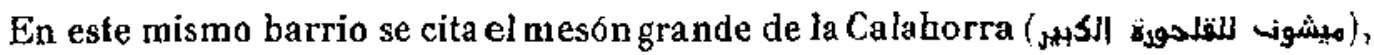
que era propio de la Catedral; las casas de Juan Canamero, tratante en caballos, y 
de la mujer de Rodrigo ¿Achen?, que estaba junto a un solar de corral que compraba el deán D. Micael Estébanez en 1256 (ním. 597 ) (1).

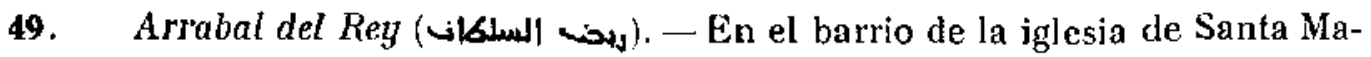
ría Magdalena se silúa este arrabal o barrio (núms. 366,474 y 597), que ya en el dorso de los documentos es identificado con * Bar de Rey * (núm. 614) y con *Barrio de Rey* (núms. 128 y 440). Todava hoy se llama "Barrio Rey* a la calle y a la travesía que van desde la iglesia de la Magdalena a \%ocodover.

Una plaza había en este barrio por 1174 (núm. 112). Un mesón que se vende en 1193, lindaba con la calle que iba a los guarnicioneros y a lns estereros (números 318,740 y 1.100 ). Ėn el mismo barrio poseían mesones el alguacil I). Melendo ben Lampader (núm. 978), el alguacil D. Esteban Petrez, los frailes de San Juan (ním. 474), doña Elvira ta Cordonera y el convento de monjes de San Pedro (núm. 318).

También en el arrabal del Rey estaba la Alcaicería a fines del siglo XII (número 978 ), entre cuyas tiendas se mencionan las de los zapateros ${ }^{\{2\}}$.

50. Santa Leocadia, de junto al Alcázar.-- El Alcázar del Rey se cita ya en 1244, detrás y encima de la iglesia de la Magdalena ( núm. 561 ), y en los siglos XIr y XIII se menciona la iglesia de Santa Leocadia, de dentro de Toledo o de cerca del Alcázar (núms. 332, 627, 654, 655, 671, etc.). La iglesia actual de Santa Leocadia está muy lejos del Alcázar.

Los racioneros, ancianos y ntables de la iglesia de Santa Leocadia, de dentro de 'Toledo, daban, en 1164, a Clemente el Monje, una casa, sita al Este de la iglesia, en la plaza de Abuzeid el de Baeza y de Domingo Martín, a cambio de otra casa que Clemente poseía, sita al Norte de la iglesia, frente a su puerta, lindante con un corral de Yaix, con una calle estrecha y pina que va a la ealle grande, y por el Sur con otra calle que divide entre la iglesia y la casa, a la cual daba la puerta (núm.974). Otras dos casas, en la misma colación de Santa Lencadia, dentro de Toledo, vendía, en 1199, dofa Colomba, hija de Gonzalbo Petrez, al arcediano D. Garcia, casas que

(1) Dicgo Petrez, inlex, y ku esposa Sol, dan coño 1213, Agnsloj a la Catedral, para sı aniversaró, la mitad del mesón Caluforre (cuya milad restante es de los cenonizos), que estó cerea de «Zocadones. (A. H. N., Cart. 1, fol.66.)

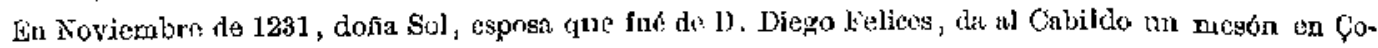

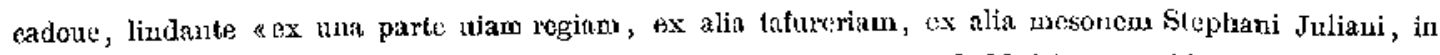
quo uenduntur folfio, ex alin meeonem de Calaforra, ex atia dowum de Madritrana, * (A. H. N., Cart. 1 , fol., 20, múm. ถ̈.)

(2) El my da (año 2166, Noviembre) a Juan Znjaicro e unam tendana que est ín Aleaceria, babons ante so sellariob, et posi sc spartarios, in superiori vero parte hahens dins tendas iuxta portam illam que ascendit ad scicladores a inferiori quatuor tendas que ad publican vian deflumts. (A. H. X., Cart. I, tol. 63.) 
estahan junto con otras de D. Feliz, hijo de Domingo Hasrún, de los herederos de Pedro Esteban ben Mayún y de Gonzalbo el Molinero ( núm. 292). A un solo adarve daban dos casas, una casita y una alhochra contiguas que doña Luba Micael, esposa de Sancho Segura, junto a casas de D. Micacl Petrez y doña Orabona, compraba (1201) al subdiácono D. Juan Juanes (núm. 332) (1).

En España: sus Monumentos y Artes.- Su nafuraleza e Historia, tomo III de Castilla la Nueva, publicado por Quadrado y Vicente de la Fuente (Barcelona, 1886), pág. 53, se dice que Alfonso VI, «abandonando el Alcázar suspendido a gran altura sobre el Tajo, al Oriente de la ciudad, sucesiva residencia de los monarcas godos y de los vaĺes sarracenos, labró otro nuevo para si en la más elevada cima, junto al barrio denominado del Rey, que cedio a uno de sus más ilustres campeones*. Sj el Alcázar, pues, estaba ya en el siglo XII donde está ahora, la iglesia primitiva de Santa Leocadia debi6 de estar por allí cerca.

51. Zocodover (سوله الدوأب). - Al lado del barrto de la Magdalena, de un lado, y del de San Nicolás, de otro, estaba el zoco de las bestias, *Cocodoeb, (dorso del documento núm. 900). La mención más antigua que encuentro es de 1176 , fecha en que Pascuala, hija de Juan de Madrid, empeña una casa (que a su vez ella tenía empeñada de Urraca, hermann de Majcolas el Escudero), sita en Zocodover, dentro de Toledo, contigua a las casas de Pedro Esforzat, luego de Pedro Estéfano, de Arnaldo Maleo y de D. Román, y que por el Norte lindaba con el zoco (núm. 900).

S6́lo cuatro menciones hallo del famoso zoco en el siglo XII (núms. 179, 248, 267 y 738 ), acaso parque no hubiera ẩ dquirido la: importancia comercial que luego tuvo. El alguacil y alcalde D. Esteban Julianes poseía un mesón en Zocodover (1187), junto al cual tenla otros dos dońa Sol, hija de Micael ben Sabes, que se los dió a sus sobrinos Micaed y María, hijos de Pedro Alcarmán (núm. 738); otro poseía Melendo Fernández, hijo del alguacil y alcalde D. Melendo, muerto en 1212 (núm. 1.025). Los herederos de Guillermo Petrez vendían, en 1196, al canónigo Domingo Abad, la mitad de un mesón en Zocodover, lindante con otros varios: el de doña Dominga, viuda del alguacil Esteban ben Omar; el del convento de Santo Domingo; los de Pedro Lamberto y el alcaide Pedro Díaz (la otra mitad pro indiviso era de los herederos de Pedro Navarro) (núm. 267).

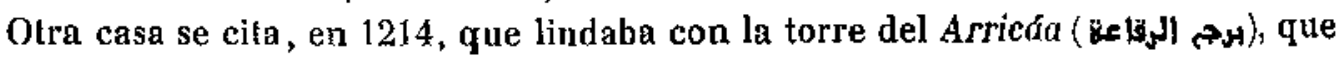
otras veces leo Arrifáa ( ¿Moaguía9; por delante de la torre pasaba una calle, que dividía entre la torre y la casa de doña Narbona, y al otro lado estaba la casa de Domingo Juanes: era aque-

(1) Año 1178, Septlembre. Sinancas: Alfonso Vul confirma a la Catadral de Toledo y n su arzobigdo G.[erebruno] la donación que el conde Nuno, « uir pis recordationis», con asentimfento de su esposa Teresa y de sus hijos, había hecho de la mitád de Alcabón y del palacio que está cerca del Alcázar real de Tolodo. Fecha el año sagundo después de la towa de Cuence [1179]. (A. H. N., Cart, 1, fol, 37.) 
lla casa de Juan el Francés, hijo de Pedro de Castro, y la adquirieron Martín de Va. Iencia y su mujer Maura (núm. 410).

A mediados del siglo XII abundaban los mesones en el Zocodover: en la venta * de una casa que es mesón *, propiedad de Pedro Juanes el Cebadero, se mencionan entre sus linderos: mesón en poder de doña Urraca, que era de su tío el canónigo D. Fernando Domínguez; mesón de las monjas de San Yedro en Alhicem; oresón del clero de San Nicolás; mesón de dona Orabona, viuda de Cionzalbo Juanes ben ¿Daxdel? (núm. 579).

Otro mesón, lindante con el horno de los frailes de Calatrava, con mesón de la Catedral y con tienda de los herederos de Juan Garcfa, adquirín D. Lope Fernández en 1290 (núm. 830).

En Zocodover habitaban Juan de Muniz el Vinatero (núm. 474) y Pedro Juanes el Cebadero (núm. 791).

Seguramente el enfanehe posterior, hasta legar a la gran plaza actual, hizo que se modificara sustancialmente el plano de Zocodover.

Por detrás de Zocodover se menciona ya Santa Fe, de los frailes de Calatrava: D. Pedro Sancho, de la parroquia de San Román, dejaba en su testamento (1253) 100 mizcales a los frailes de Calatrava para la canstrucción de la capilla que están haciendo en Sanla Fe y para que lo entierren en esta capilla, en la pared de ella (ním, 1.029).

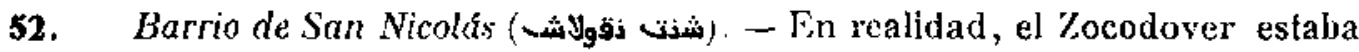
dentro del barrio de San Nicolás y cerca de el (núms. 522, 563, elc.).

Desde fines del siglo XII se menciona ya este harrio: una casa y tienda de Roberto, presbítero de San Nicolás, sita en este barrio, al lado de casas de herederos de D. Godel y de Pedro Criador, es coruprada (1197) por los albaceas de Melendo Pérez para fundar su aniversario en ha Catedral (núm, 277).

Cuatro tiendas para vender harina poséa en San Nicolás la familia del algua. cil y alcalde Melendo ben Lampader (1201): tiendas que lindaban con el mesón del hierro y del carbón, con otra de D. Alvaro Alvarez, con otras de Gonzalbo Juanes y de Juan Alguacil, y con casa de Gonzalbo Juanes (núm. 946). Estas mismas tiendas, más prolijamente delimítadas, son vendidas en 1226 por el canónigo D. Alfonso Meléndez, a favor de la abadesa de San Clemente (núm. 483). La misma abade. sa adquiría (1229) la tienda que poseía en el zoco de los Sastres, contigua con la puerta y el pasadizo que va al corral donde se vende el hierro y el carhon, y a otras tiendas de la madre de la abadesa, doña María Peláez (núm. 496). También el convento de San Pedro en Alhicem poseía en este barrio, y por el Iado de Zocodover, una casa junto a la del presbítero D. Juan, hijo de dona Colomba, y a la de Martín el Podador (núm. 522); y por el lado de Zocollover compraban taminién una casa Pedro Juanes el Cebadero y su mujer María Román (1244), al lado del mesón del convento de San Pedro, del mesón de Gonzalbo Juanes y de la casa de 
Juan, hijo de doña Colomba, luego de herederos del canónigo Fernando Altala. bi (núm. 563).

En este mismo barrio se cita la casa donde estaba instalada la casa del Refugio en 1244 y 1230 : lindaba con el muro de la ciudad, con la calle que va a Zocodover, con casa de Micael Camsino y con olra de Domingo Petrez, de Colmenar de Oreja, quien compra aquêlla a Fernando Petrez ( $\mathrm{ntim}$. 477) y la vende luegn (núm. 501) a Gonzalbo Ruiz. Este, a su vez, la vende (1240) a Orabona, criada del alcaide D. Es. teban Petrez, y añade al citar las lindes: * La calle que pasa de dos lados, uno de ellos cerca de 7ocodover y de la Puerta de Tefálin» (núm. 537). En 1246, Orabona vende esta misma finca al musulmán Abuitıasán Alí el Baxirł (ním. 570), indicando lindar con casa de doña Leocadia, hija del alguacil y alcalde D. Esteban Julia. nes; el musulmán la traspasa el año siguiente a Micael Petrez, el ¿portero de Calvachares? (¿Golpejares?), de la jurisdicción de Burgos (núm. 573). Ya no hallo noticias posteriores de la casa llamada del Refugio.

El canónigo D. Juan Cebrínez moraba, en 1250, en una casa del barrio de San Nicolás, cerca de Santa Cruz (شنذي كروز) y de Bab el Mardom, es decir, en la actual calle del Cristo de la Luz ${ }^{(1)}$; estaba la casa al lado mismo de la iglesia de Santa Cruz, su puerta daba a una vía púbii ca que pareé́a callejón, y contiguas estaban lax casas de Ruy Martínez y el corral de doña Colomba, hija de Juan el Bacal (núm. 578). También al lado de la iglesia de Santa Cruz, y subiendo, estaba la casa que Juan Ponce vendía, en 1260 , a su hermana Inés, hịja del alguacil I). Pedro Juanes: lindaba con la casa grande del alguacil citado, con la casa donde hacian sombreros de fieltro, y con la calle que iba detrás de la casa de Ruy Sánchez; una de sus puertas daba al adarve de D. Pedro Juanes, y otra a la calle pública, cerca de Santa Cruz (núm, 609).

La casa más importante de este barrio parece que debió ser la del alguacit don Pedro Juanes, padre que fuć de D. Gonzalbo Petrez, obispo de Cuenca primero y luego arzobispo de Toledo. En el mismo adarve del alguacil, donde estaba ya la casa de su hijo el obispo, vendía Alfonso Domínguez al canónigo D. Pedro Abril, en 1275, otra casa colindante con la de aquellos, con otras de Pedro líartín y de Laocadia Petrez, manja en San Pedro, y con el corral del citado obispo (núm. 644); Gonzalbo Petrez, siendo ya arzobispo de Toledo, la compraba (1293) a los hijos de una sobrina del canónigo Pedro Abril (núm. 712), con lo cual ampliaría su palacio.

En el mismo adırve estaba la casa de D. Ponce Petrez, hermano del fufuro arzobispo: D. Ponce empeñaba (1259), en manos de su cuñado Suero Gonzálbez, hijo

(1) Año 1187, 30 de Jnnio: El arzobispo D. Gonzalbo, at instancias del rey, instaura la iglesia de los Hospitalarios, bajo la invocación de Santa Cruz, en la puerta do Valmardón, quedando sujeta a la jurisdicción del arzobispo. (A. H. X., Cart. 1, fol. 40.) 
del alguacil Gonzalbo Juanes, *la mitad de una casa nueva, que era de sus padres, en la colación de la iglesia de San Nicolás, dentro de Toledo, pro indiviso con su hermano D. Juan Ponce, lindante con otra segunda casa de su padre, ahora de su bermano el maesiro Gonzalbo, y con la calle que baja al barrio de Santa Cruzs (númcro 908). Los acreedores de Ponce Petrez, difunto (1262), hubieron de cobrar, después de un pleito, de los bienes que dejara, entre los que están «la mitad de al. gunas casas contiguas, con sus establos y cuadras, conocidas como propiedad del al. guacil D. Pedro Juanes y de su mujer doña Teresa, en el barrio de San Nicolás, en el adarve llamado Tente Juanes. (núm. 958).

Doña Solí, viuda de Micacl de Golpejares, vende, en 1283, la enitad superior de una casa (que no crèo debe identificarse con la atrás citada del Refugio) conocida como propiedad de Domíngo Micael, apodado Boca de Sabalo, pescador, cuya puerta daba a un callejón sin salida, y contigua a las casas de Juan de Forteda, después de Alfonso Meléndez, y al corral hundidd de los herederos de Juan Garcla de Selay (núm. 673).

Para fundar su aniversario en San Nicolás compraba, en 1285, el presbítero D. Pedro Juanes una casa, que era de doña Leocadia, al lado de casas de Solí, hija de Feliz el Pescador, y de otra de Gálib el Pescador (níms. 685 y 673). Doña Leocadia, hija de Adam, adquiría, en 1282 , la casa y algorfa superior que poseía Juan Petrez, lindante con casa de Gálib Assammar, con callejón sin salida y con una plazo. leta, a la que daba la puerta (núm. 826); esta misma casa se vendía en $1310^{3}$ (número 726 ).

Debajo de Zocodover, y en el mismo barrio de San Nicolás, pegada al muro de

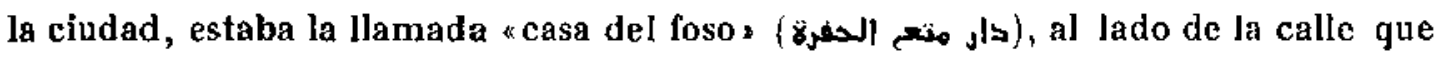
pasaba y de casas de Esteban Petrez y de Pedro Tomás el ¿Triguero?; la vendía en 1280 Sol, esposa primero de Micael de Golpejaces y luego de Juan Martín, maestro de los albaniles de la Catedral, la cual la había adquirido del musulmán Bosquiri el Hanat (núm. 668); casa que Pedro Tomás la vendía, en 1283, a Alfonso Petrez (número 676) con otra que el tenía y con una almazría, todas contiguas y sitas en el foso.

Además del adarve de D. Pedro Juanes o de Tente Juanes, atrás citado, se menciona en este barrio el adarve de D. Fernando Vicente (núm. 1.034).

Se salía de este barrio al Arrabal por la puerta de المركو (4) que era la llamada Pluerta del Mayoriomo, en el documento número 48 (véase después, párr. 65).

Por su proximidad a Zocodover tenía también este barrio imporlancia comercial. Hallamos citadas las tiendas para vender harina (núms. 619,626, 629, 633 y 946); mesón del hierro y del carbón (núms. 483, 496 y 946); el zoco de los sastres

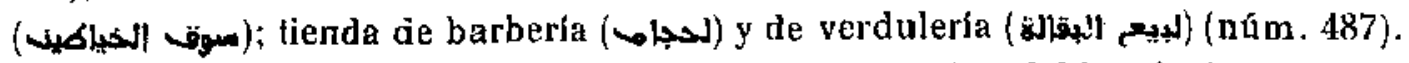

53. Barrio de San Vicente. - No hay muchas citas del barrio de la iglesia de San Vicente (núms. 91 y 149). Una casa de Aceituna (ذإ الزيتونة) posé́an (1201) en el 
barrio de San Vicente, dentro de Toledo, los hermanos Gonzalbo y Orabona Petrez (núm. 1.056).

El deán de la Catedral, maestro Atherto, compraba (1226) dos casas contiguas, muy cerca de la iglesia de Sau Vicente, al lado del corral y casas de D. Fernando Benayas y de las de Juan Melero y Juan Petrit, casas que procedian de María Gonzálbez, hija del alguacil don Gonzalbo (núm. 482).

En el mismo barrio vivía doña María Fernández, esposa de Gonzalbn el Campanero (núm. 606).

Don Rodrigo Juanes, obispo, posefa en el adarve pequeño de la colación de San Vicente un par de casas, contiguas a las de sus primos Gonzalbo, Alvar y Teresa García, y a otra de la Caledral (núm. 825): una de estas casas vino al convento de San Clemente (1280) por cambio con algunas fincas rísticas.

54. Barrio de San lomán ( $\sim$ los $(33)$. - La más antigua mención de San Román que encuentro es de 1161: el alguacil y aicalde Doningo Anlolín manda en su testamento la casa que poséa en San Román, con el corral contigno, a su esposa doña Leocadia (núm. 1.014). Años después, en 1165, Micael y Domingo Jtanes compraban a los hijos de Andrés de Hachach una casa en esta colación, que daba a un callejón sin salida, cantigua a otra de los dos hermanos y a casa de los herederos de Domingo Cebrián; encima del zaguán de la casa vendjda había una algorfa que era de Feliz Sánchez (núm. 74). Una casa en San Román posefan, pro indiviso, los hijos de Micael ben Jálid en 1189 (núm. 1.129).

Estaba, comu ahora, deniro de este harrio col convento de San Clemente: con el convento lindaba la casa que las monjas compraban (1204) a Lucía, esposa de Pedro Esteban, contigua, además, a las casas de Torcuato el Alfarero y de Dominga, mujer de Gonzalo Estébanez (núm. 339\}. Asimismo compraban las monjas (1212) a los nijos de Esteban Felices, nietos del alguacil Feliz Sánchez, otra casa ruinosa, con el cuarto y la alcobita que quedaban de su algorfa, cerca también del con. vento, y lindante con corrales hundidos del mismo convento, contigua a la casa de Abenalasfar (luego de D. Gonzalbo), y a la casa de Micael Esteban (núm. 395). La casa de este D. Gonzalbo, sucesor de Alasfar, que lindaba con el corral de los herederos de Feliz Sánchez, ya adquirido por al convento, y con las casas de Micael Esteban, la compracon las monjas (1213) (núm. 423); la casa de Micael Esteban, contigua a corrales del convento y a la de Alfonso, hijo del alguacil y alcalde Esteban Julianes, la compraba la abadesa en 1217 (núm. 437). Doojingo, esposa de Gonzalo Estéfanez, daba sus casas y corrales al convento (1214) por amor de Dios y para que las monjas le tengan presente en sus oraciones (núm. 755). Con estas adquisiciones, el convento podría ampliarse.

Los hijos de Esteban Aadrés, uno de ellos Orabona, abadesa en San Clemente, partian los bienes del padre (1219), entre los cuales hahfa una casa grande y otra pequeña en San Román (núm. 985). 
Junto a las casas del canónigo D. Micael Esteban, posefa casa y mesón Alfonso, racionero de San Román, que vendia (1217) el mesón al presbítero I.ope ben Abdala (núm. 438).

I, viuda del notario García Petrez, Teresa Juanes, compraba (1265) un corral pequeño en San Román, cerca del convento de San Clemente, en la calle que bajaba desde la esquina del convento, cerca de las casas que fueron del alcalde D. Diego Petre $z$, y lindante con otra calle que separa el corral comprado de la casa que fué de los herederos del alguacil Pedro Martínez (núm. 624).

Gonzalbo Alfonso cambiaba a Lope Fernández (1296) parte de un corral y casa en él consirnída, en San Román, contiguo a casas de Pedro Benedicto, de Colomba, y de herederos de Día Petrez, por parte de una tienda en Zocodover (núme. ro 830 ).

Cerca de la iglesía de San Román estaba el corral de D. Diego Ruiz, que lindaba ya con el arrabal de los Judías (nxim, 674).

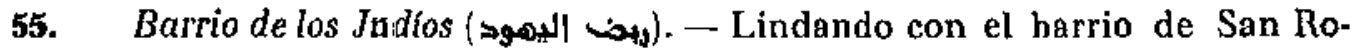
mán por un lado (núm. 1.146), con el de San Martín por otro (núms. 311, 560 y 1.097), y con Santo Tomé por otro (núms. 556 y 1.143), encima de Santa Leocadia de afuera (núm. 1.038), estaba el arrabal de los Judíos o «barrio de Judíos *. A parte

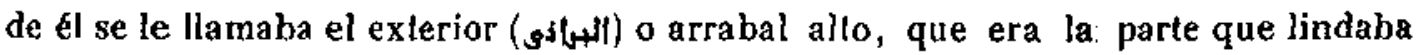
con San Román (núm. 674), separada del barrio cristiano por un adarve (núm. 674), el cual tenía una puerta (núms. 1.148 y 1.149).

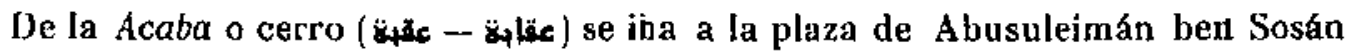
por una calle (núm.1.151). En la Acaba adquiría el Cabildo dos casas y una almazrfa contiguas, por 1283, que eran de Yúsef el Fasal y de Dona, hija de Bartel, junto a casas de Abuyúsef el Malahi, de un Abenpesat, apodado el Fulo, y con corral del alguacil y alcalde Diego Ruiz (núms. 674 y 1.146). Ea la misma plaza de Abensosán se cita otra casa de Esteban ben Falcón, al lado de las de Isaac ben Bacuda e Isaac ben Zizá, y junto, también, al corral de Diego Ruiz (núms. 1.148, 1.149 y 1.151).

Cerca de esta plaza de Abensosán estaba el adarve del Barcelones (البرجلولى ), que por un extremo lindaba con el corral de Diego Ruiz, y por otro con la calle del barrio del adarve, hasta la plaza, y con la puerta que separa al barrio judío del barrio cristiano (núms. 674 y 1.147 ).

Bajarido desde el liarrio de Ja Acaba hacia el Monte del Alcohol (الكحل الكب), cstaba el adarve de Abengalún, o $\Lambda$ bgalón, donde la Catedral compraba a Abuibrahim Caxares una casa grande, otra casa pequefia, que fué del hijo de Saadia, y tres casitas pequeñas encima de la grande: las puertas daban al adarve de Abengalún y estaban linderas cor chsas de Yínus ien Cajiat, de Yehudá bèn Alhanat, de Masa Alcohen y de Ali ben Tello; una de las casas pequeñas daba a la calle grande que bajaba desde la Puerta de Assuica hacia el barrio de la Puerta de San Martín (núme- 
ro 635\}. Otra casa se cita en este adarve, lindante con la casa de Madero y la de Benacutín (núms. 1.138 y 1.139 ).

Otro barrio dentro del arrabal de los Judíos era el de la Puerta del Portiel (Por-

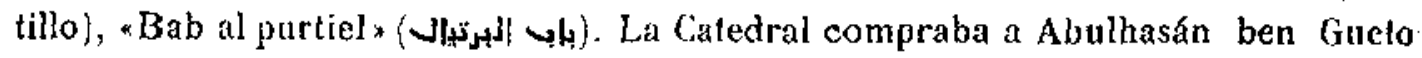
y a Simha, hija de Yúsuf ben Cag, una casa y dos sótanos bajo ella, en este barrio que daba a un adarville, junto al callejón o pasadizo de Hacay ben Marabón, y a la casa de Abuishac Navarro (núm. 648,1.142 y 1.144). Cerca de la Puerta del Portiel estaba la sinagoga de Almaliquim, que fué constrúda por David ben Salomón ben Abudarham (núm. 1.144).

El barrio más grunde del alrabal judio era el llamario adarve de la Sueca: co-

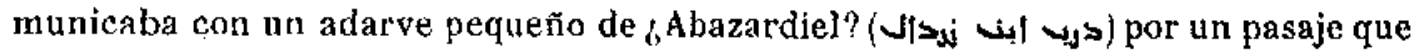
subía desde el barrio de la puerta de la ciudad, llamada Puerta de los Jndíos, hacia la plaza de Santo Tomé. Una casa, sólano y establo anejo se vendían, en 1254, en un adarve sin salida, junto al de Abazardiel, contiguos a las casas de Isaac ben Podenco, luego de Salomón el Barcelonés, y a tierra de Elí hen 'Talfa, después de su here. dero Esteban Lllán (núms. 67.t y 1.143).

En los arrabales exteriores del barrlo judío, cerca del corral llamado Alquería,

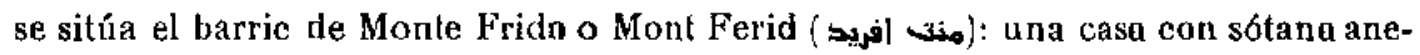
jo, la vivienda contigua y una almazría alta, estaba contigua a las casas de la viuda de Mar Salomón él Llusí, después de Yahya Tazaret, a la de Mosé ben Partal o Bar. tel, a la de Haim ben. Elró, luego del tintorero apodado Pipión, a la de José ben Durán \& El envenenado ; la calle que por alli pasaba terminaba en el adarve nuevo (núms. 714 y 1.137). - A este adarve nuevo acaso haya que referir el kbarrio nue. vos (الحاره ذوبة), donde compraban Diego, Orabona e Inés Alfonso, una casa para San Clemente, según disposición de su madre doña Luna, casa que lindaba cou otras del jeque Abulhasán Salomón ben Abidirhem, de García Meléndez, marido de Inés Alfonso, antes propiedad del mismo Abulhasán, del notario Garcla Pe. trez, de Ishac de Andújar y dos calles sin salida (núm. 605).

Uno de la familia Sosán compraba, en 1270, una casa «situada en nuestro arrabal (de los Judíos), en la calle que era adarve, en el adarve llamado o Ueld Elazri *, y dicha calle comunica, por su principio, con la via que se dirige de nuestra * Sueca , hacia el adarve sin salida conocido por * Adarve del Olivo, y por su fondo co. munica dicha calle con la vía que se dirige de la puerta de nuestro castillo nuevo a la puerta del castillo viejo». Sc incluía en la venta una casita aneja que da a la pla. zuela, a la cual comunican también algunas tiendas separadas de la casa que había sido de Mar Mosé ben Caparela, luego de Javid ben Abidirhem y de José ben Amir; con estas tiendas y casa lindaba aquélla, y con la casa de Jacob ben Sadaya y el co. rral de los herederos de Yehosef IJaleví (núm. 1.135).

Todavía se citan el adarve de Abenmatiner (núm. 1.141) y el de Algunderí (nám. 965); cl bano de Zejd, cerca de este último adarve (núm. 965). 
Por el barrio de Arriasa, y cerca de las tiendas de los carniceros, cstaba el castillo nuevo de los Judios: el convento de San Clemente adquiria, en 1292, tres casas, una almazría, un sótano y seis tiendas que habian sido del presbítero Domingo Juanes, y anles del alguacil Abulrebía ben Sadoc y de su esposa Dona (núm. 710). Junto al castillo nuevo había un horno de pan cocer (núms. 674 y 1.135).

El castillo viejo se cita, en 1163 , en la hípoteca de una casa nueva, junto con otra exterior contigua, en el castillo de los Judíos, sobre el Tajo (núm. 897).

Fntre las puertas que de este arrabal se nombran, están la Pucrta de los Jadíos, encima del convento de San Pedro y cerea de la huerta de la Alhofra (Foso) (núm. 322), cerca de la iglesia de San Martín (núms. 560 y 1.097); el muro cle la ciudad (núm. 311), cerca de Santa Leocadia de afuera (núm. 1.038); la Puerta de As.

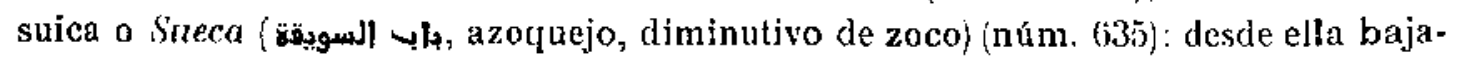

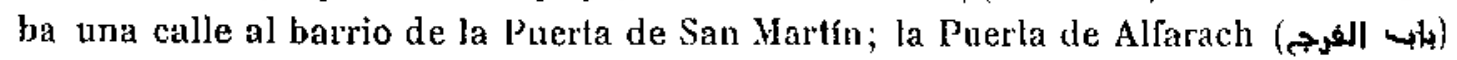
(núms. 669 y 683).

Por entre la Puerta de los Judíos y el barrio de San Martín se menciona el Handac Arranuc (núm. 311) (1).

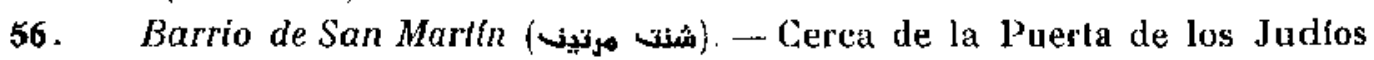
empezaba ya el barrio de San Martín. María, esposa de Andrés Alberchines, vendía (1168) a Pedro Maharis una casa en este barrio, cerca de la iglesia y de la Puerta de Jos Judíos: la puerta daba a la calle que pasaba cerca de la Puerta de los Judfos, y entre la casa y la iglesia dividía otra calle aledaña, y otra calle discurría por entre la casa y el muro de la cindad (núm. 1.097), no teniendo más lindero con casa que la de Juan ben Alyasrí. Esta misma casa, con otıa más, dos mesones y una tienda, se vendian (1212) por Pedro ben Ali ben Maharis a Pedro Lázaro, de San Antolín (número 311), citándose aquí entre sus linderos el Handac Arranuc y la casa que fué de Domingo el Bastari.

Loba, hija del alguacil y alcalde don Esteban Julianes, vendia (1211) a su hermano Juan, para pagar ciertas deudas, una casa en este barrio, junto a las casas de Tarfa la Judía, esposa de Bellido ben Asaia, de Mursí el judío el Bacal, antes de don Lorenzo el Carpintero (núm. 391). La misma doña Loba vendía (1214) a su hermano García, el tesorero, otra casa, una alhochra superior, que habla sido del judio apodado Belal, lindante con dos calles, una grande que iba a la Puerta de los Judíos, y con la casa de Ishac Ang Essalt (núm. 414).

Otra easa se cita cn el mismo barrio, contigua a las casas de Pedro Juanes y de

(1) Año 1188, Diciembre, 20: Alfonso VlfL cambia con ol Cabildo la mitad de un molino, de los dos \& quí ultra flumen sunt in azoda de Beb-al-Portcl, gui scilicet molendinus ex parto Azude curu duabus de melioribus tendis do halhantes que sunt in vico Judeormo ut serviant prenominato molendino in perpetuum ad molenduw», por las casas en la colación de San Nicolás, que la infanta doña Sancha, hermana del emperador, dió a la Iglesia tolediana por su alma. (A. J.I. N., Cart. 1, fol. 51 v.). 
Domingo....., que era de María Pérez, hermana de Juan de Burgos el Cerero (número 516). Un nieto de Micael Sabib traspasaba (1243) a Aznar de Avila un mesón en este mismo barrio, cerca de la Puerta de los Judíos, cuyas puertas daban a la calle que iba a la Puerta de los Judíos y a otra, y estaba contiguo a otro mesón del rey y a la casa de una nieta de Sid, hija de Micael ben Gaiter (núm. 560).

La Cofradia de preshíteros de Tuledo compraba (1265), a los albaceas de Pedro Esteban, una casa en San Martín, cerca del horno que era de Gómez Gonzálbez contigua a la casa de este don Gómez, a un callejón sin salida y a la calle que va a Ia Puerta de San Martín (núli. 623). Otra casa poseía Pelayo, pregonero del alguacil y alcalde don Gonzabbo Juanes, en este barrio, liudante can casas de Maria Díaz, del clero de Santo Tomé, y con la calle (núm. 1,044).

Como barrio especial, dentro del de San Martín, se cita, en 1184, el arrabal de Arranuc (ليض الرنوقى), que es el mismo lugar de Ilandac Arranuc, citado al lado del barrio judío; el conveñto đe San Clemente vendía a Domingo Ahat una casa en este barrio, al lado de las que allí tenía Benaix, hermano de Pedro Castaño, Martín Alhafi el Hortelano y Juan el Hortelano (núm. 170).

La Puerta de San Martín se señala como situada encima de Santa Leocadia (1258), en el documento número 915: el convento de Snn Clemenle arrendaba a Mateos el Hortclano un huerto en el distrito de la iglesía de Santa Leocadia, debajo de la Puerta de San Martín.

57. Barrio de Sanio Tomé (log6 شن - Pocas referencias hay de casas de este barrio y ninguna del siglo XII. Tocaba por una parte can el arrabal de los $\mathrm{Ju}$ díos ( nutims. 524, 533 y 556) y había en él calles que iben una a San Cebrián y otra a San Cristóbal; estos documentos se refieren a la misma casa: la propia de los descen. dientes de Pedro Hobais, contigua a casas de Ishac el Judio y a un corral hundido de los herederos de Ferrand Juanes. No debía de estar muy lejos de ésta, si es que no era la misma, la casa que antes vendía Domingo Lorenzo a Juan, hijo de Pedro Hobais, lindante con casa de los herederos del judio Royuelo, con casa y corral de Ferrand Juanes y con otra de Pedro Valterra; pero no se indican las calles de antes.

58. Barrio de San Cristobal. - Poco se menciona este barrío (núm. 960). Leocadia, hija de Adam y sobrina del escribano Domingo Juanes, poseía en San Cristóbal una casa, partición de otra de D. Romero, sobrino del canónigo Lope Domínguez, y contigua con la de Bartolomé el Pescador : casa que caubiaba por otra de San Nicolás (núm. 826).

59. Arrabal (ريض مكينة كليكلة). Al Norte de la ciudad se cita el Arrabal, que se encontraba ya a mitad del siglo XIl bajando desde la puerta del Mayordomo o Valmardom por calle que desembocaba en el arrabal (núm. 48). A este arrabal se Te

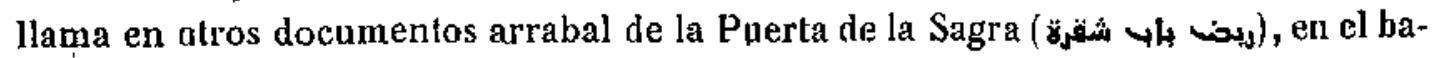
rrio de la iglesia de Sanliago (núms. 100 y 121), o sea la Puerta vieja de Bisagra. Llegaban sus casas por el Norte hasta la misma muralla de la ciudad (سود كليكلة) (ní. 
meros 101 y 353 ). Se le llamaba \& Santiago del Arravalde o de a laravald (nímero 353$)$.

En este arrabal tenía, ya por 1187, el convento de San Clemente una alfarería (دار العمل الفكال), con la cual findaba por el Este la casa que vendía Pedro Juanes a Domingo Pelrez el Chuaih, y que se destinaba a albergueria (المبرغلية) (núm. 187). Otra casa vendía (1207) el escribano D. Nicolás, habitante en el mismo barrio, a Domingo Crespo el T'inalero o Tinajero (núm. 359).

60. A mitad del siglo XIII se cita ya (1256) el barrio de la Torre Nueva ) en el arrabal de Toledo: el convento de San Clemente adquirfa, por donación del presbítero Domingo Martín, para su aniversario, el manantial de agua que posee dentro de su casa.... para que las aguas se empleen en los baños que el convento tiene en et citado arrabal. La casa donde está la fuente linda con casa de Artal el 6 Pedrero?, con otra del citado presbitero y con la calle, adonde da la puerta, que es la calle última del barrio de la Torre Nueva * (núm . 780). El baño del arrabal lo reconstruía el convento en 1255 , según contrato para las obras que figura en el número 987, y que más adelante se estudiará.

Otro Barrio Nueve (الحارة نوبة ) se menciona a fines del siglo XIII en el arrabal de Toledo: Diego Sánchez, refilorero del Cabildo, adquiría para sí « una botica, con la madera, tablas, instrumentos de una almácera y piedras que hay en ella, sita en el arrabal de Toledo, lindante con casa de los fraires de ta Orden de San Vicente de la Sierra, con otra de doña Urraca, hija de 1). Fernando el Carnieero, y de su hijo Mar.... Gordo y con la calle que sube cerca del Barrio Nuevo, a la que da la puerta ( (núm. 704).

Un horno de pan cocer, propiedad de doña Luna, esposa de Alfonso Vicente el Alguacil, se cita (1236) en la escritura de venta de un trozo de corral que era del vicario D. Nicolás (núm. 519).

Cerca de la Puerta de Bisagra estaba el cementerio de los musulmanes antes de 1210: Pedro Lázaro, de San Antolín, compraba a María Micael «la tierra de prado que alí posee en el término lel cementério de los musulmanes, cerca de la Puerta de la Sagra , en donde tenían tierras el mismo comprador, el presbitero Benmaharis y los hijos de D. Esteban (núm. 379).

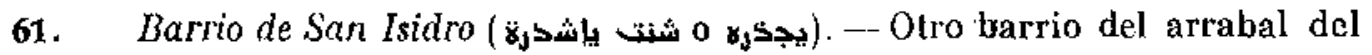
Norte lo formaba el núcleo de casas alrededor de la iglesia de San Isidoro o San Isidro. Lindando con el taller de alfarería que el convento de San Clemente poséa en el arrabal, atrás mencionado, compraba, en 1175, el presbítero Domingo ben Alrim, de la iglesia de San Clemente, dos caselas, colindantes, además, con casa de Domingo Colaudra y con callejón sin salida (núm. 122). Alvaro Juanes tenía, pro indiviso, cierlos derechos en el Daralhamel o alfarería citada, "que está en el arra. bal, en la colación de la iglesia de San Isidro, arrabal de Toledo $»$, derechos que ha. błan ido a parar al convento de San Pedro en Alhicem; éste los vendía al de San 
Clemente en 1:27 (núm. 487). Eu el dorso del documento se llama a esta finca * mesón que es de Sant Esidrio. Otra casa del misnto barrio, que por el Este lindaba con el muro de la ciudad, cuya puería daba al camino, contigua a dos corra. les, uno en ruitas y otro del arcediano, la compraba, en 1195 , D. Juan, diácono de San Justo (nún. 260).

Ia iglesia de San Isidro tenía la propiedad de una alberguerta, en su misma co. lación; Iindaba con esta alberguería casa de Marlín Corral, de Orgaz; patio del presbítero Domingo Martín, y casa que D. Benedicto, canónigo en Santa Leocadia, de junto al Alcázar del Rey, vendía a Martín Domingo y sli mujer (núm. 662): estos últimos la traspasaban (1280) a D. Lorenzo el Peletero y su esposa Estefanía (núl mero 667).

62. Otro barrio del arrabal era el de San Pedro. Maria, hija del alguacil Mair Temain, daba a la Caiedral (1137) la parte que por herencia de sa padre le correspondia de una huerta en el arrabal, en el barrio de San Pedro, conocida en tiempo de los musulmanes como propiedad de Abenaljanaxi (núm . 727): esta misma huerta fué cultivada y repoblada por Clemente el Monje (núm. 1.050).

También se cita (1198) en el arrabal, cerca del Prado del Cadí o Marzalcadí (مرجج (لكاذىى), y de la iglesia de San Pedro, un buerto, llamado del Aihofra, o del fuso, rodeado de tierra de prado de Martín Martínez y de su hermana Eulalia, y por otro huerto de la Catedral: al dorso del documento se sitúa el huerto «cerca de los mollnos del pra[dol que dicen del atrabai» (núm. 288).

De este barrio e iglesia de San Pedro no quedan hoy vestigios.

63. También en el arrabal se cita el barrio de la Puerta de Pedro Benián

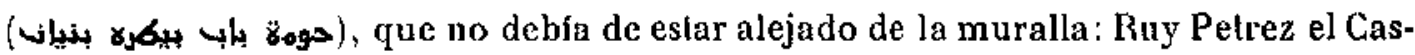
tellano compraina (1288), para su ahijada María Garcia, Ia casa que fué de Juan Gan. zálbez el Calero, contigua a casa de dona Juliana, la veıdedora de gallinas, a un corral hundido de I)omingo Lozano y al muro de la ciudad (núm. 1.119).

Como no veo $m$ ás citas de este barrio, fuera del hecho de indicar que algunos habitan en él, no puedo deducir hacia dónde cáa deulro del arrabal del Norte.

64. Santa Leocadia de fuera. - Es de las que más anliguamente se cilan. Un Domingo, presbítero de la iglesia de Sanla Leocadia, fuera de la ciudad de Toledo (خارجה مذبئز كليكلة), figura en una carta de compra de fincas en la alquería de Dar Aljázin en 1107 (uńm. 5). La reedificación y restanración de la iglesia, rque nunc exstitit dextructa et ruinosa $(1121)$, se debía empezar así que ciertos cultivos em. prendidos en la alquería de Dar Aljázin hubieran dado algunas utilidades (número 966). Un huerto, sito en el arrabal, eneima de la iglesia de Santa Leocadia, fuera de Toledo, que ai Este lindaba con el camino de los huertos, y al Norta con el ca. mino que iba al Tajo y contiguo a otros huertos de Alvaro Sánchez y te la misma iglesia de Santa Leocadia, era comprado por Pedro de Tolosa (1146) a Martín ben Otmán y a Socni, hija de Suleimán (núm. 33): este mismo huerto lo donaba 
(1168) la viuda del caid D. Pedro de Tolosa al convento de San Clemente (núme. ro 733 , indicando que está fuera de la Puerta de los . Iudios. Fuera de esta Puerta, y cerca de la iglesia de Santa Leocadia, estaba el huerto del alguacil Abuzeid, que su hijo Pedro ben Abderráhmen dała (1172) a sus hijas Marla y Cecilia, monjas en San Clemenle (núm. 1.038). Fl convento de San Clemente arrendaba (1258), a Mateos el Hortelano, un huerto en el distrito de la iglesia de Santa Leocadia, debajo de la Puerta de San Martín (núm. 915).

65. Puerias. - Partiendo de la Puerta de Bisagra, atrás citada al hablar del arrabal, hacia el Este, se encontraba la Puerla del Mayordonı, aín Vatmardem

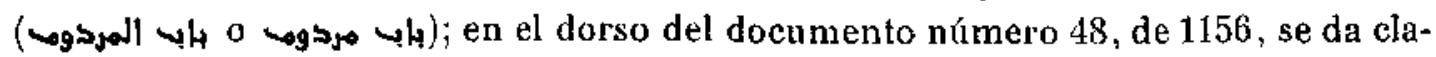
ramente la equivalencia: "Carta de dos mesones a la Puerta del Mayordomo*, mesones que estaban ken la calle que pasa desde la citada Puerta del Mayordomo* yendo hacia la iglesia de Santiago. El convento de San Clemenie vendía (1221) una vifia en Alaitic, y su precio, cinco mizcales de oro, "se habían de emplear en la construcción de la casa de alfarería que poseía el convento debajo de la Puerta del Mayordomo, en el camino de la Puerta del Vado* (núm. 463).

La. Puerta del Vado (a) estaba junto al Taja, cerca del lugar conocido por Roca del Cuerno: un jardín lindando con el rio y un prado contiguo, junto al prado del sacristán, se vende en 1132 , con derecho a utilizar el estanque y la acefa grande (núm. 162).

Una tenería de ¿Alccrno?, juntoial Tajo, que había side de Mateos ben Furón y luego de dos judíos, se menciona en 1239 (núm. 1.141 bis); creo que este Alcorno o Cuerno debe identificarse en el mismo lugar que la citada Roca del Cuerno.

EI término de la Puerta del Vado se identifica con el de la Puerta de Atefálin (6de los grederos?) (1) (aúm . 294), y se sitúr a la orilla mísma del río Tajo y cerca del Vado; el huerto más importante de nquel témino debía ser el de la Sacristania de la Catedral (núms. 257, 262, 368 y 369). Un huerto que lindaba al Norte con éste del sacristán, se sitúa en Bab el Tefálín, encima de la Puerta de Alcántara, sobre el Tajo (núm. 243). Una calle iba desde el barrio de San Nicolás a Zocodover y Bab el Tefálin (núm. 537).

Entre la Puerta del Mayordomo o Valmardom y la que ahora se ve frente al puente de Alcántara, estaba, pues, la del Vado o de Atefálin, ilos grederos?

Hemos señalado atrás la Puerta dol Hierro, la Puerta de Adabaguín (cultidores), hoy Adabaquim, la Puerta de San Martín, la Puerta de los Judios, que parece poder identificarse con lá actual del Cambrón, o al menos estaba en sitio muy cercano, y varias puertas de entrada al arrabal de los Judíos.

Un trarrio de la Puerta de Alfarach, * Beb Afarage», dentro de Toledo, se men- 


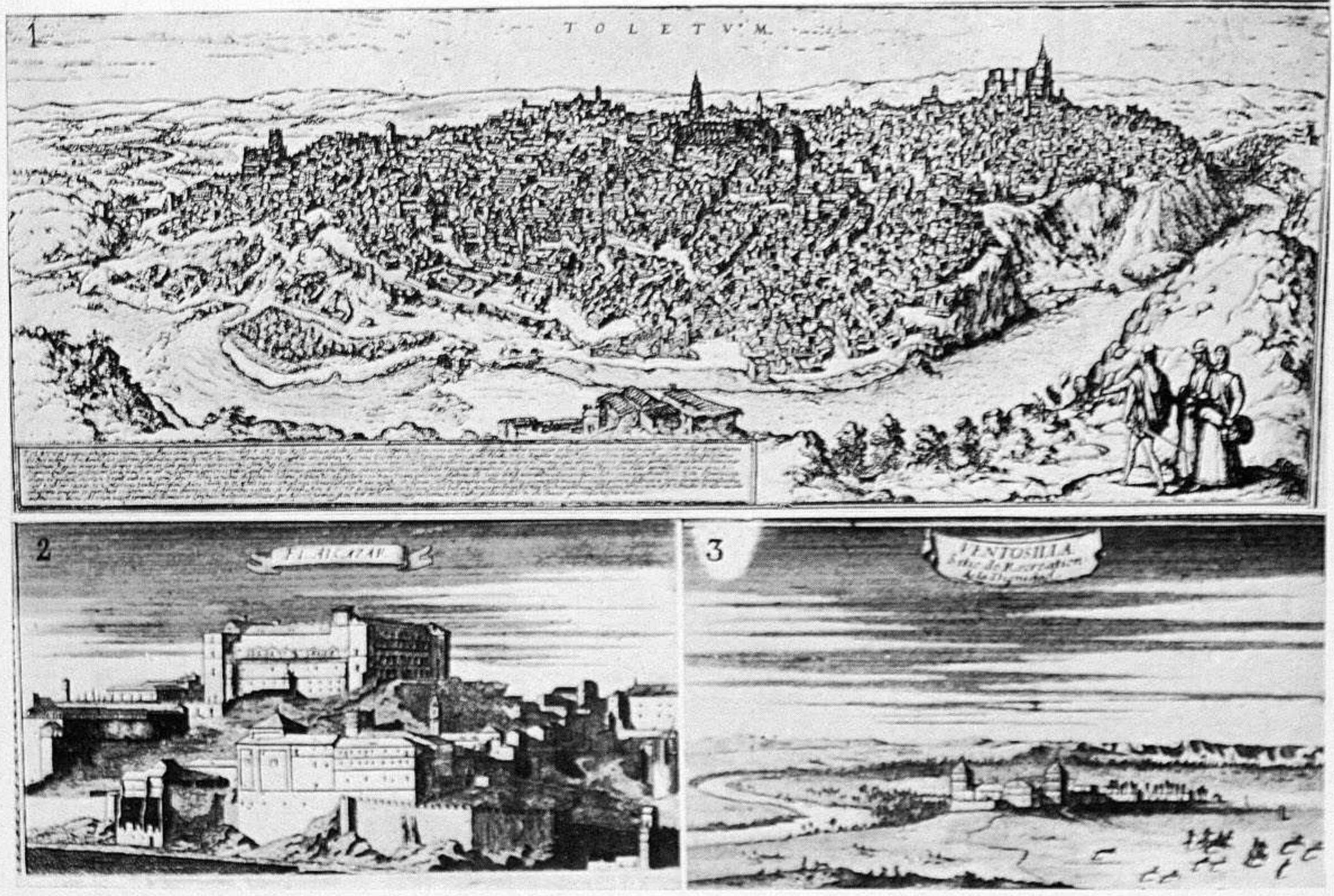

1. Vista de Toledo, segün un grabado del siglo XVI. - 2. El Alcazar de Toledo, a fines del siglo XVII. según el Mapa de Portocarrero, en el Archivo de la Catedral. - 3. La Ventosilla, segün el mismo Mapa. 
ciona en 1187 (núm. 189): estaba en barrio judío, según liemos visto atrás (números 669 y 6833 .

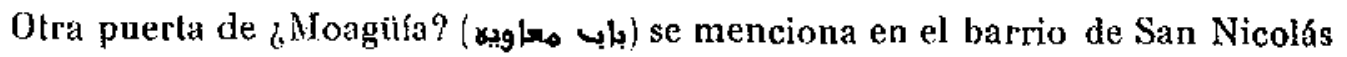
encima de la puerta y delante de la torre de Arrifáa o Arricáa, había una casa, por cuya posesión se pleiteaba en 1216 ( núm. 954).

Para el manienimiento de las puertas de la ciudad dejaba una manda de un mizcal en su testamento (1185) Eulalia Petrez (núm. 1.016), y otro tanto Cristina, hija de Andrés, en el suyo de 1192 (ním. 1.020).

66. Datos sueltos. - Algunas olras noticias sueltas, de interés topográfico, arrojan los documentos. Sobre los mnros de la ciudad, varias veces mencionados atrás (núms. 101 y 1.119), vemos dos datos referentes a su reconstrucción: en 1248, el noble D. Diego Lópe\% contraía una deuda proveniente de los dineros que gastó en la fortificación y defensa de Toledo (núm. 847). La fábrica de las murallas deb́a de continuar en 1266, ya que en su testamento de esta fecha declaraba Alfonso Matcos tener en su poder, de los fondos para la construcción de las murallas de Toledo, 114 mizcaies, para gastarlos en dicha obra (núm. 1.030).

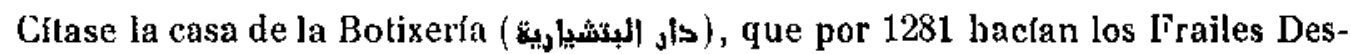
calzos, en su casa de Toledo, y para cuya fábrica se mandeban 100 mizcales en un testamento (núm. 1.03\%). También se menciona la Claustra (التشكرة) del Sancti Spirilus cono lugar de enterramiento (núm. 1.034).

El adarve de D. Juan de Selaya (ním. 1.082), la casa de Abenalbazo (núm. 32) y la casa del caid D. Esteban Petrez (núm. 673) se dan como puntos conocidos de referencia.

En la puerta de la iglesia de San Salvador se celebraban los juicios (número 965$)$.

En un zoco de la ¿carne? (سوق القنرةi? ) era pregonero D. Cebrián el Bacal (número 608 ).

67. Alrededores de Toledo. - Entre los sitios cuya identificación cerca de Toledo puede hacerse - ya que el alfoz (دوز) de Toledo comprendía un extenso territorio - es uno el Prado del cadi árabe (núm. 973), sito en el arrabal de Toledo, cerca de la iglesia de San Pedro (núm. 288), cerca de la ciudad y al Norte de ella, uno de cuyos lindes era la rambla que allí se junta con el río; también alli estaba la Larca y el sendero que iba a la barca, llamandose desde muy antiguo (1174) *Ajuneina *, diminutivo de chuerto» (núm. 114). Linderos de este huerto estaban otro de los frailes (núm. 293) y otro de Alhanaxí (núm. 967).

Contiguo al * Ajuneinas se mencionan los molinos de Asomail o Azumel: en este pago, de la jurisdicción de 'Toledo, se cita un huerto inculto y con sus frutales cortados por desırozo de los musulmanes en 1199 (núm. 293), señalándose el azud y el molino de Azumel (núm. 639). Clara es la identificación de este lugar con lo que se llama hoy Safont. 
Por la parte Noroeste se encontraba (1202) el * Huerto de la Alhofra, (foso), cerca del convento de San Pedro, debajo de la Puerta de los Iudíos, junto a otro huerto del arzobispo, que también decian del c Alhofra*, con tierra de prado de lllán Esteban y con el camino (núm. 322), que acaso sea el orto qui dicitur Alhutra *, en el documento número $\$ 69$, y quizá haya que referir a esle lngar cl huerto en el término de San Pedro (nám. 1.025), aunque dudo, por haber olro San P'edro en el arrabal.

No sé cuáles serían los molinos de $A x a m$ (رحية الشام) cuyo barrio se cita solo una vez, en 1158, tlamándolos a Molinos de la licinas, y mencionando un horno en este barrio (núm. 1.068) (1).

Al otro lado del 'Tajo se citan varios lugares proximos a 'Toledo. Lno es el molino donde se hace el vino en el harrio de Puerta del hierro, al otro lado del río

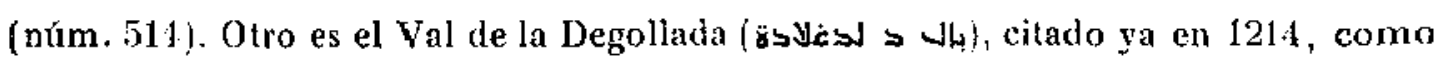
un pago o término de la Sisla, pero con mención del "I3arranco de la Degollada, (núnıs. 412,679 y 686) y del majuelo del «Bum, (núm. 6:26), que debe ser cl hoy Jlamado "Cerro del $\mathrm{Bu}$ *.

Camino del río hacia el monte, con la indicación a aquí en Toledo *, al dorso del documento, estaba el "Barranco de Gafron* (كندف غفرون), al olro lado del Tajo, ba . rranco que se llama también a Valle de Johanis Potaloris, y *Val de lerrand Roiz, (nums. $3 \tilde{5} 8$ y 400 ).

No debía de estar muy lejamo el \& Barranco de lálid, (كندت كالد), citado como del alfoz de Toledo (núm. 130).

Se mencionan, además, San Servando, para el arreglo de cuyo camino se hace una manda testamentaria (núm. 1.020); la Huerta del Rey, cuyo amin era Micael

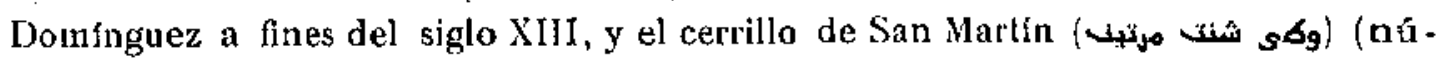
mero 1.045).

(1) Alfonso VII daba a la Catedral (Julio de 1142) el sitio cinter moos molinos, qui sume in la presa de Molinellis et inter civitatew, inxta portam de Adalsakjm; et ox alia parke molinos et aturnam de Sa neta Mariu; ex altora parte prexa de molinis de Icam: II faciss unam casan de molino, chm dhibus rotis». (Cart, 2, fol. 55.) 
Para la identificación de los nombres de lugar se han tenido presentes los mapas del Instituto Geográfico, otro del cardenal Portocarrero, que guarda la Catedral; la lista del Indice del Archivo de la Catedral y otras fuentes indicadas en su caso.

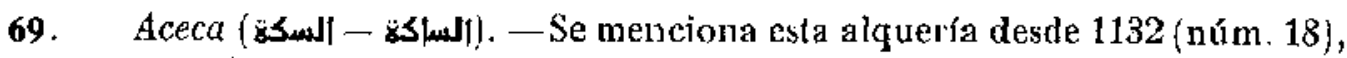
por la cual pasaba un camino hacia Melgar (núm . 689), otro hacia Figares (núm. 731) y otro a Azucaica (núm. 903). En el mapa del Instituto Geográfico se ve la casa y el molino de Aceca, al Sur de Villaseca de la Sagra.

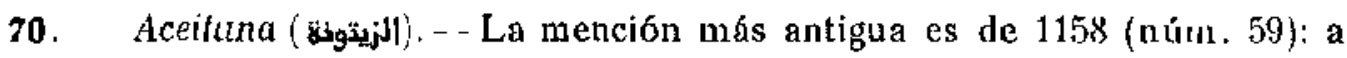
orilla del Tajo, al otro lado de la ciudad (núm. 151), se la sitúa en la Sisla (número 521), junto a la alquería de Mancel ¿Sihra? (núm. 756). Al dorso de los docamentos se le Jlama *Aseyluna*, "Dazaituna*, eAldee dazeitona* (núms. 151 y 418).

Por ella pasaba el río Xaras a Guadaxara ( $n \mathrm{k}_{\mathrm{m}}$. 464). Acaso baya que referir a este lugar la actual casa del Aceituno y arroyo del Aceiiuno, que figura en el mapa del Instituto Geográfico, al Norte de Guadamur y debajo del 'lajo.

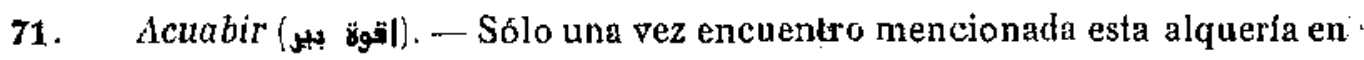
1227 (núm. 764); la traducción de este nombre sería \& Agua de Pozo. Debía de estar entre las alquerías de Daralmazán, Burnoza y Aceituna.

72. Ain (4) - Alquería de la jurisdicción de Toledo, mencionada por vez primera en 1127 (nú.n. 16). El lugar de esta alquerja, que apenas si se cita en el siglo XIII, estaba por la vega de Toledo, y se recuerda en la actual casa de Ahin, citada en el mapa del Instituto Geográfico y Estadístico, a la izquierda del Tajo, yen. do a Algodor.

No creo que sea la misma que se llamaba exúm, 351).

73. Ainaldic (عين الذيك), Fuente del Grallo. - Esta alquería, no mencionadá. antes de 1237 (núm. 517), ya en esta fecha se dice que la lla maban Val de Mozárabes, y luego se llamó San Julián (núms. 616 y 778 ).

Véase Valdemozírabes.

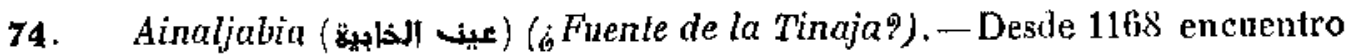
mencíon de esta alquería o pago de la jurisdicción de Toledo (núm. 88), con indica. ción de un arroyo que en ella había. Alguna vez se dice pago de s l)ajla Ain Aljabia, (كلة عين الذابدية), o sea de la entrada a Ainaljabia (núm. 962). En la pronunciación vulgar se cambió en c Bonalhavia (núm. 266), *Benalhavia (núm. 283) y hasta en Belavia (núm. 716). El nombre corriente en los documentos romances es. 
Benalavia o Benhalabia, forma esta última bajo la cual figura en el Indice del Archivo de la Catedral de Toledo.

75. Ajofrin (الجفرينش). - La mencion primera que veo sle este lugar es de 1266, donde se le llama •Cortijo de Ajofring (القرتيجه متع الجغرين) , con sus habitaciones y tiendus, corral, cementerio ¿de los nobles?, establo, pajar, chozas, lindantes con el corral del cura» (ním. 1.030). De este lugar hacía mayorazgo D. Alfonso Mateos, hijo de D. Mateos, hijo de Micael ben Furb́n, en 1266, previo acuerdo con su hermano Fernando, poseedor de parte de este lugar.

Era una de las alquerías de la Sisln (núms. 901 y 989 ), que en el dorso de los documentos es transcrita por «Aljofŕn s (nám. 989) y exhofríns, y perdura hoy todavía con el nombre de Ajofŕn.

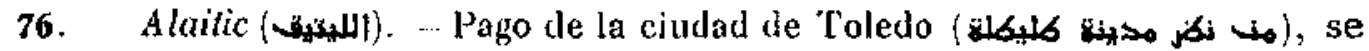
le menciona desde el año 1111, o sea pocos años después de la reconquista (número 7); se le sitúa al Oriente de Toledo (núm. 24), por el lado de Zalencas (número 149). En él había una torre (núm. 377) y un casar (núm. 466); en sus cercanías estaba la Torre de Abenracrún (مرج الث رتشون) y la viña de la Fanega (núms. 466 y 469). Lo atravesaba el camino que iba hacla los huertos (uúm. 523), y huertos había en su propio término (núm. 582), asi como viñas (núm. 738), entre las cuales se citan las llamadas de los Aniversarios, que eran de la Catedral (núm. 766), y la «de las cinco filas (núm. 799).

Se le llama "Aletic, "Aleylic, *Alletic, aletic, y "Al-llaylich" en el Indice del Archivo Caledral, .... Parece, pues, que estala en la vega de Toledo.

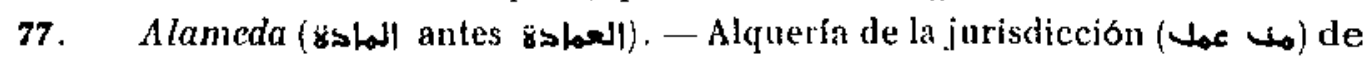

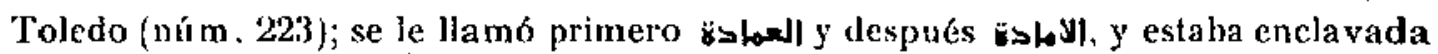
en la Sagra (númı, 250). La mención primera que hallamos es de 1184, y precisa-

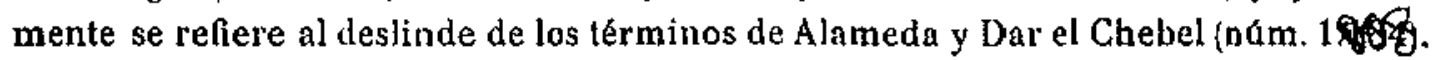

La alqueria era de la Catedral (1) y la gente de Dar el Chebel se habla metido en tierras de Alameda. El cauce de una rambla grande separaba los dos términos, y pertenecía a Alameda todo el terreno hasla que se llega al cauce pequeño, cuyas aguas desembocan en la rambla citada, en el sitio donde está una fuente grande, encima del sitio que era antiguamente ¿de los pobres? de Alameda. Otro límite era el Jugar que dividía las aguas que vertian hacia el linde de la alquería de Alfondega. Al Saliente estaba Dar el Cíiebel. Otro punto de partida para el deslinde fué la senda que pasaba descle la alquería de Cebolla.

(1) El Cabildo da a poblar y cultivar la mitad de la villa a varios (Agosto de 1160): ban de pagar la décima parto de los frutos; hnn de dar a la tierra tres labores; si hacen heertos, pagarán como los de lolodo, y llovarán la sexta parte de la nva al lazar de la Catedral. Si parten la lierra, senín dos partes jaca los eultivadores, la otra para la Catedral, quo tiene, adenas, derecho de tanteo y rotracto. (Cart. 2, fol . 60.) 
El terreno litigioso parece que habia sido en un principio de Dar el Chebel, pero lo habian ocupado los de Alameda hacia cerca de cuarenta anos, y como treinta bastaban para la prescripción, los de Alameda se querellaron contra la intromj. sión nueva de los de Dar el Chebel.

Todavia perdura el pueblo de Alameda de la Sagra.

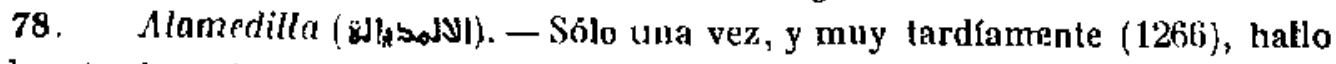
citada esta alquería, que también podría transcribirse por la Olmidiella (núm. 1.030), y que no sé con qué identificarla.

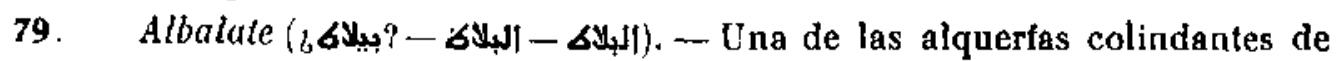
Valdemozárabes era Albalâte, menclnnada por ve $z$ primera en 1274 (núm. 642). No

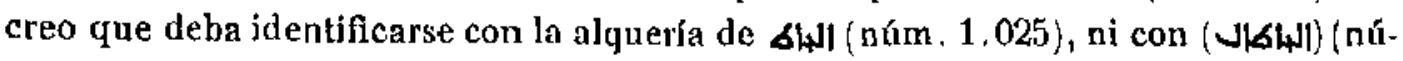
mero 980), Jas cuales, por Jo demás, no se citan más que una sola vez.

80. كAlberca? (6) اليجيقة) - Estaba a orillas del Tajo. Su dueño, Rodrigo Salvatores, mandaba en su testamento (1211) a su madre, doña Sefi, $\times$ toda la heredad de la alquería de ¿Alberca?, conforme se encuentra, con todos sus bueyes, utilidades y derechos en el río Tajo» (núm. 1.024).

81. Albuera (البوحيرة - البحيرة) Pago de Toledo, al otro lado del Tajo, por el lado de Loches (núms. 145 y 169). Se le da ya en el dorso de los documentos el nombre de Albuera s.

82. Alcapillat (القبّلى) - Alquería del término de Tuledo, lindante con Dar Asudán y con Rucbel (que fué luego la Ventosilla). El arzobispo D. Rodrigo compraba, en 1202, la mitad deliazud que habia en esta alqueria hasta los sembrados (núm. 322).

En el Indice del Archivo Catedral se cita Capillas y Alcubilet o Alcobalel, que sospecho sea una misma cosa (1).

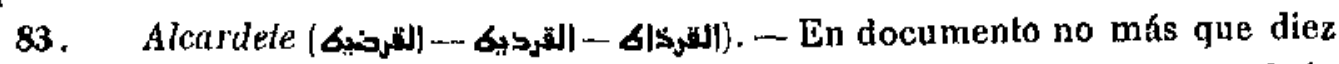
años posterior a la reconquista, o sea en 1095 , se cita ya este pago de la ciudad de Toledo (núm. 4), al Oriente de ella (núm. 11) y como sitio de vega (núm. 672). Menciónase en este término una hoya, en la cual está el prado (núm. 734). En época muy avanzada (1281) se le da el nombre de alquería (núm. 1.045$)^{(3)}$.

Era conocido en su término el q huerto de D. Gonzalbo Diaz (núm. 1.125); de él salía un camino a Torres y otro camino al molino; y entre varios nombres de

(1) Alfonso VII da la villa de Alcubelet a Dowingo Oidiz (afio 1150) (Cart. 2, fol. $89 \mathrm{v}$. ), y luego, a 1). Diego Lopez de Haro, la heredad que se linma Alcubelet ( 11 de Diciombre de 1108). (Cart. 2, fol. 80,) Don Diego y вu mujor Tota Petrez la dan a la Catedral (8 de agosto de 1211). (Cart. 2, fol. 2B.) Véanso otros documonios sobre este lugar en eI mismo Cart., fol. $80 \mathrm{v},, 81 \mathrm{v}$.

(2) El alguacil Julián Petrez da a la Catedtal, pora su anivereario (1168), una vifa on Alcardei, \& supra viam que vadit ad Calabazas ex parte montsums. (Cart. 2, tol. 61 v.) 


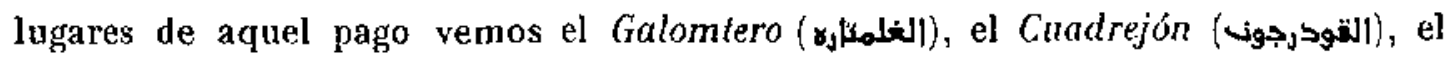

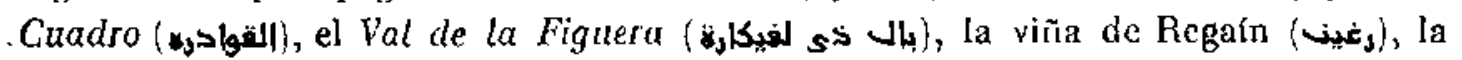
tierra del foyo, cerca de las plantas de inches?, la tejería (المخربة) (núm. 1.015).

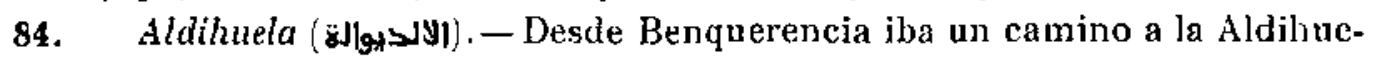
la, que no se precisa sí era alquería o si era algún sitio o finca del propio Benquerencia (núm. 696).

85. Aldimas (الديموس) .-- Sólo una vez hallo citada esta alquería, en 1261, en la cual tenían alguna lieredad I). Asuero Juanes y su esposa doña Soll (núm. 957). ¿Podrá transcribirse por Ademuz? En el mapa de Portocarrero se ve un Adamuz, al Norte de Cobeja.

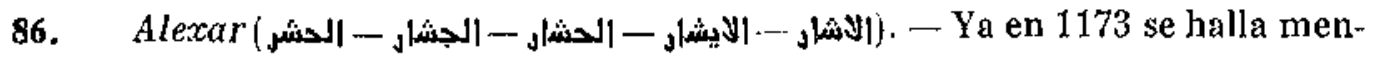
ción de esta alquería de Alexar o Alhisar, no lejos de Cobeja (núm. 106). La Catedral adquirló la mitad del sexlo de esta alquería en 1190: Cobcja, Villaseca, Aceca, Cabañas y Boroxos eran alquerías colindantes de Alexar (núm. 211). "Alhisar ", "Alexar * o * Alessar * era la forma de Iranscribirlo en la Edad Media (1).

Alexarejo (إلشاراجه debía ser una especie de anejo de Alexar: en aquel Jugar vivia uno quc vendía tierra en Alexar (núm. 248) ${ }^{(2)}$.

87. Alfach (الفجم). - Este pago se cita sólo una vez, en el camino de Olfas (núm. 507).

88. Alfondega (لفنذف). - Alquería que lindaba con Alameda de la Sagra (núm. 1.008).

89. Alforigüela (الفحيرولة) - Alquería de la Sisla, no mencionada sino en 1293 (núm. 920): María Alfonso, hija del alguacil athaquim D. Alfonso Marlínez, arrendaba sus tierras en esta alquerla. Al dorso del documento se le llama aAlgoriuela .

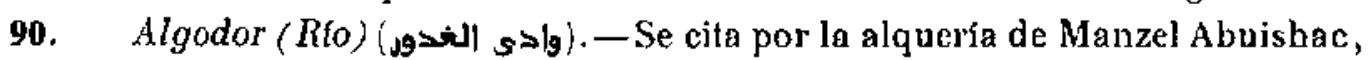
de la Sisla (núm. 596), por Benquerencia (núm. 622), Jlamándole Arroyo de Algodor

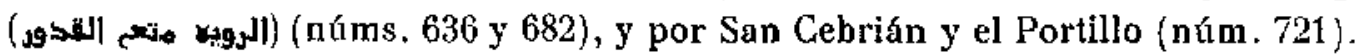

91. Algordel (الغرخالى). - Se menciona esta alquería únicamente en el documento tiúmero 957, para indicar que en ella tenian propiedades D. Asuero Juanes y su esposa doña Soli. No sería aventurado suponer que estaba cerca de la alquería de Aldimus o ¿Ademuz?, mencionada en el mismo documento.

92. Algorfela (الغرفالة). - Alquería lindante con Camarena (núm. 333) y con Argance ( $n$ úm. 744); un molino estaba cerca del linde de las dos alquerías (Argance

(1) Gl Cabildo Catedral, a chya mesa pertenecia esla alquevía, la da a polblar a varios individuos en Mayo de 1155, con las mismas condiciones que Cobcja (Cart. 2, fol. 77.) Otra semejante, de 1170, se ve en el fol. Bo.

(2) Guter Perrez de Reinoso tomb́ en arriendo del arzobispo D. Raimundo la villa de Algesareio, con la condición de darle la décina parte de los frulos (Julio do 1149) . (Cart. 2, fol . 102 v.) 
y Algorfela). Una tierra poséía el convento de San Clemente en esta alquería, sita entre las de Ocas, Villamarín y la Algorfela (núm. 810); debajo del camino de Á. gance a la Algorfela tenía un huerto San Clemente (núm. \$13).

La mención más antigua que veo de ella es de 1197 (núm. 1.126), y se la lla. maba *Algorfiella, y Algorfiela .

93. Algundarln (الغندرs) - Azud sobre el Tajo, en el término de Corral Rubio, con unos molinos (núm. 914), que se ve citado desde 1125 (número 1.012). Fn 1149 se da testimonio de que el linde de la tierra de D. Mido, padre de Micael Midis, en Algurlderí, era el cerro del Cabrón (القبرون), encima del Tajo (núm. 1.005). Como lugar de referencia de una viña está en el documento número 1.012. Don Fernando Mateos ben Furón dej 6 a la Catedral los derechos que le pertenecían en esta presa (núm. 1.064) (1).

94. 6Aliso? (اليسم) - Sólo una vez se cita este lugar (1202), junto con la alquería de $\dot{a}$ Albatel?, y sin que la referencia permita precisar más (uúm. 960).

95. Aljares (الجارس- - الكارش). - Salinas propiedad del convento de San Clemente, que las arrienda en 1260, por seis cahíces de trigo bueno (núm. 916). Las hijas del canónigo Bernaldo Astur tenfan algunos derechos en ostas salinas (1281), y en las que hay entre Borox y Seseña (núm. 1.045).

Deben ser las mismas las que aparecen bajo el nombre de Bechares (بجارسن), en el documento número 973 de 1160 .

96. Almahchuda (المحجودة). - Pago, probablemente de la vega de Toledo (núm. 1.029). A los presbíteros de San Andrés se les nandaba en el testamento de Fernando Petrez (1280) una viña en este pago (núm. 1,033).

El azud de Almahchuda estaba debajo de Santa Colomba (ním. 307).

97. Almenares (المنر|س). - Alquería citada ura sola vez (1207), jumto con las de Daralbelio, Alaín, Tello Diaz y Chonán Daud (núm. 351).

98. Almonacir (المكاس - الهذسير). - Alquería de la Sisla, que se menciona desde 1211, situándola entre las colindantes de Ilaica o ¿Alique? (núm. 389), y por la que pasaba camino desde Benquerencia (ntim. 682): en ella estaba el valle de Almonacir (núm. 682).

Es el Almonacid que entre Nambroca y Campo Rey figura en el mapa de Portocarrero, y no el Almonacid actual, en el partido de Orgaz ${ }^{(2)}$.

(1) B arzobigpo D. Juan, a 30 de Noviembre de 1164, da a Micael Julianis, \& presam filam quis eqt in l'ago mub Agonderim.... de Corral Rubio, quan tonot Felix Piscator s, para que levante molinos; unia vez hechos, la mitad serán del arzobispo. Si hay nocesidad de reparaciones, pagará el arzobíapo la mitad de 'Ios gastos. (Cart. 2, fol , 68:) (Véaso Daraljuzin.)

(2) En 1132, por carta fecheda en Guadalajara: ago Ildefonsns, gracia Dei imperator isjanie, et rex Sancius, et rex Ferrandus, facimus pagina testamenti ad uos comite don Pons de Caijrera, tam present\}- 


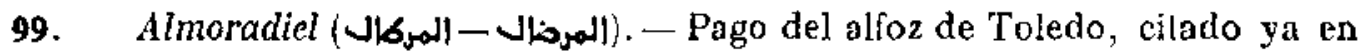
1197 en la venta de una viña (núm. 275). Debía estar en la vega misma de Toledo (núms. 303 y 375 ), al lado del pago de Alcardete, del cual salía un sendero hacia Almoradiel (núm. 1.045).

Al dorso se transcribe por a Almoradiel», "Almoradil». Y nada tiene que ver con la Puebla de Almoradiel, del partido de (unintanar.

100. Alogón (العيون). - Pago al Sur de la ciudad de Toledo, mencionado ya en 1119 (núm. 12), situado cerca de la iglesia de Santa María de la Sisla (núm. 589), y por su termino pasaba un camino que iba a Cobisa (n11 m. 635) (1).

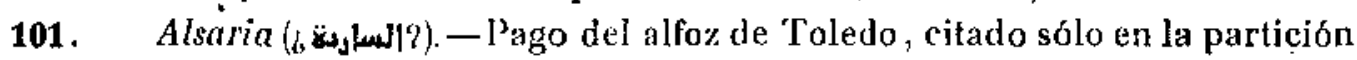
de los bienes del canónjgo Bernaldo $\Lambda$ stur (núm. 1.045).

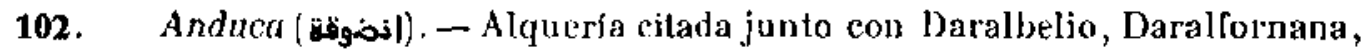
Chonán Daud y Botch Abenyunus, y por tanto de la Sisla de Toledo (núm. 281).

103. Annuail (النوايل). - Creo que dche identificarse esta alqueria con Añover de Tajo, que lindaba (1193) con Alameda de la Sagra (núm. 250). Se menciona un Cebrián de Annuail (núm. 471). Acaso a este lugar haya que referir el que se cita en el número 896 , de difícil lectura (2).

104. Arcegal (إj). - Alquería contigua a Melgar, en Valdeearábanos (número 557).

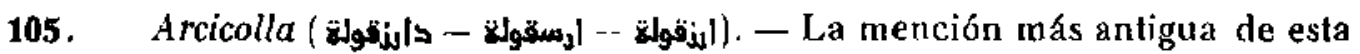
alquería (año 1144) tjene la forma Darcicalla, xcasa de Cicolla», y estaba cerca de Villa Algariba y de Moraleja (núms. 31 y 34); después, al menos desde 1193, se dice Arcicolla siempre (núm. 25!). La mitad de esta alçuería cra de Colomba, hija de Gonzalbo Petrez (1199), y la vendía al arcediano don García: entre los títulos de pro-

bus quam futuris. Et sie nobis damus et confirmamus fita aldea quod dicitur Almonecir cum suos terminos quaulum ad illam pertinet per heredilare, quam haheatis per wender et per dar uel tot ura. uoluntale facere per yecula cuncta amen. (A. H, N, Calatrava, docs. reales, vol. 1.)

(1) Año 1165, Agosto, 11 : a Ego Adefonsus tocius H yspanie itoperator una cum taxore mea domina Rica imperatrico et cum flliis suois Sancio of Ferıando reyibus tibj Michaeli Auenaçar tamen et Adalil el fratr suo Abubacal, Andree Capatero et Michaeli Zalema, Petro Stephaniz et Martino Granadixii, Justo Johanni et Ilialia Johanni, Zaidi et Dominico Janderu, Dowinico Auezael, Petro Juliauni, Dowinico Michaeli et Michael Eructnsu et filits nestris omnique generationi uestre. Facio cartam donationis de illa aldea que est ultra flumen Tagi in Ual-de Carnuant el nocatur Aloitu..... et hoc facio ut Michael Anennacar et filii tul ot omsia generatione tua habeatis de illa alden medietatem et omnes alii supra nominati et hlíi eorum et omnis generatione eorum labeant et possideant aliam medielatem iure hereditario in perpetuum et hoc melum factum semper git firmum. (Cart. 1, fol. 533; Cart. 2, fol. 64.)

(2) Afo 1177, Agosto, 19: sIn obsidione de super Conclan. Cones Petrus..... vendo nobis domino Cerebruno, Toletano archiepiscopo ..... patrino weo pro C. morabetinos amnen illaw hereditatem quantamcumquo dominus meus rex A. inter Anoel et Barciles wihi dedit...... (Fn presencia y con uprobación del rey.) (Cart. 1, fol. $41 \dot{\mathrm{r}}$ ) 
piedad que entregó doña Colomba, estaba la carta del emperador donando esta alquería al arcediano D. Juan de Segovia y a Arnaldo de „Corvín? (núm. 292).

Un camino de Tomellares (الكوملاويس) pacaba por esla alquería (núm. 694).

Tenía alguacil y alcalde por los años de 1201 (núm. 1.131); y los derechos de la Iglesia, de pan, vino, etc., eran del arcediano D. Garcla, atrás mencionado, quien arrendaba su propiedad en 1205 ( núm. 909) (1).

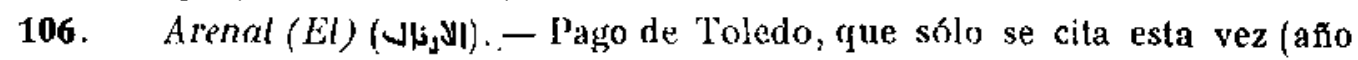
1157) (núm. 53).

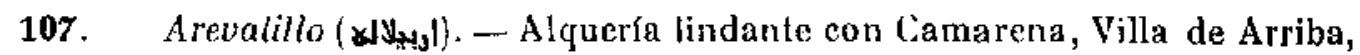
Pantoja y Pozuelo (mím. 331).

108. Argance ( 1 (إغنس - Alquería que pertenecia por mitad al rey Alfonso VI y al conde D. Pedro Solís: los cultivadores de esla alyuería pagaban el diezmo de sus frutos por mitad al representante del rey y al del conde. El rey quitó al conde la propiedad de su mílad, que pasó de señor en señor; siendo siempre co. nocida la mitad del rey como suya, sin que bubiese cultivador que no pagase el diezmo, salvo Cid Marlínez y Jair ben Paris.

Sus límites, en 1176, los marcaba la línea que iba a las fuentes del ltano en el Carrascal, entfe Monte Petruch y Camarena, hasta el monte pequeño, entre Monte Petruch y Monte de la Calera; seguía por el berrocal del camino de Bimal, debajo de Argance, y el berrocat del camino de Rielves, entre el Monte Lebrero y el de Penta del Lobo; por el barranco de esta Peña que corre hacia Canales; por los barranquilos pequefios que van lacia los confines de Rielves; por el principio de Val de Fi. guera, cerca del camino grande que iba a Avila; por el principio de Valdisita, donde están las dos fuentecillas salobres, en el lugar que se dividen las aguas entre Valdisita y Algorfela hacia Arretuerta, que cstá en el ró Mardalon, dando vista a las alquerías de Argance y AIgorfela; por Val de Alhorri, harranco al principio de Monteagudo, hacia otro barranco que va hacia los lindes de Camarena: entre Monteagudo y Val de Alhorri había un sendero que iba de Argance a Moraleja (núm. 1.006).

El convento de San Clemente pretendía (1179) que la alquería de Argance era suya, y aun logró algán testimonio de uno que ofa decir a su padre que los labrado. res de allí daban el diezmo a San Clemenle; pero otros testigos, entre ellos el alguacil D. Julián ben Abilhasán ben Albazo, declaró que esta alqueria era del rey en su

(1) El emperador Alfanso VII dí́ a don Juan, arcediano de Segovia, y a don Arnaldo de Corvín, canónigo, la villa de Arcicolla con los términos quo tenía en tiempo de los moros, por cartá de 6 de Majo de 1146. Por documento de 17 de Junio de 1151 ke lizo la partición de $A$ reicolia entre don Juan, obispo de Osma, y Arnaldo de Corvín, delizitando Ja parte de cada mo. (Carl. 2, 101. 66.) Despléer, en Marzo de 1165, Arnaldo da su cnitad a pohlar a varios. (Dbid, fol. 67.) - Afo 1168, Abril: Tesimonlo do que Johan, obispo Oxomense, dió la mitad de la aldea Arcicolla a su sobrina Placencia y a su marido Gonzalbo Petríz. (Cart. 1, fol. 65.) 
totalidad (núm. 1.052), y otros declararon que era de Alfonso VII; que todos sus cultivadores pagaban el diezmo al representante del rey (ثق) ; que esta costumbre había seguido después de su muerte, y que nadie había poseido en esta zilquería parte ninguna, sino que en su totalidad era de la reina (núm. 1.051).

109. Argés (ارحشارجإ) - Alquería de Toledo, cerca de Pozuelo y de Layos (núm. 693). Hoy Argés.

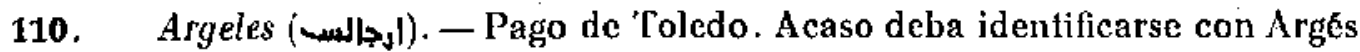
(núm. 14). Sólo se cita una vez, en 1124 .

111. Artal $\left(\mathrm{N}\left|\mathbf{b}_{\mathrm{J}}\right|-\mathrm{J}\left|\mathrm{k}_{\mathrm{j}}\right|\right)$. - Esta alquería se llamó primero Artal y luego tomó el nombre de Villaseca, juntándose en una Artal y la Mezquita (núm, 393). Desde 1154, por lo menos, la vemos citada por Villaseca en Valdecarábano (número 46) y siluada dentro de la Sisla (núms. 575 y 576 ).

Don Juan Petrez daba testimonio de que en la carta del emperador, por la cual concedió el dominio de las alquerías de $\Lambda$ rtal y la Mezruita, figaraban el propio D. Juan, Domingo el Herrero, el presbitero Micael el Carpintero y otros más (citados en el documento núm. 1.049). Dos de ellos, Juan Petrez y Juan Cristóbal, eran amines respecto del privilegio real y tenf́an la cuarla parte de las alquerías, pór preferencia a los demás, según escritura que conservan; y han mostrado esta escritura a los partícipes (núm, 1.049).

Uno de los pueblos lindantes que se mencionan es Melgar (n. 689). Debe identificarse acaso con el actual Villasequilla de Yepes, y no con Villaseca de la Sagra.

112. Assuic (السويقن). - Alquería cerca de Camarena (núms. 333 y 823).

113. Assueca (الصويقة) - Alquería de la Sisla, cerca de Daralbclio, Chonán Daud, etc. (núms. 296 y 392 ).

114. Auria (8agl). - Pago de Toledo: no se dice sino que hay cerca un 6 cabezo? (núms. 715 y 1.046).

115. Azaña (الم|نية - أسانية - Alquería de la jurisdicción - de Toledo (núm.97), en la Sagra (núm. 161), que se âirmaba ser propiedad de la Catedral en 1168 (núm. 87).

El rey D. Sancho, hijo del emperador Alfonso VII, hizo donación al judío Abulhasán Yehudá ben Odra de cinco yugadas de terreno en Azaña, a cambio de la mitad de la alquería de ¿Cerones?, que dí a los frailes (1158) (núm. 175): Otra heredad, propia de la familia del conde D. Ponce de Minerva, la adquiría (1197) el arcediano de Calatrava, D. Julián, hijo de Tauro (luego San Julián, obispo de Cuenca) (núm. 274). (Véase más adelante, párr. 356 .)

Es el Azaña de hoy, partido de Illescas (1).

(1) La carta de partición de Azaña, entre Jos canónigos y el conde Ponce, puede verse en el Cart. 2, fol . $90 \mathrm{v},:$ Alfonso Vill concede (año 1185, Soptiembre, 10) in perpetuum a la Catedral shereditatem de 


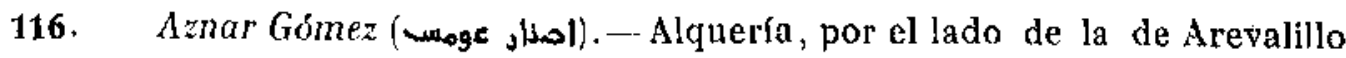
(núm, 334).

117. Azobirńn (الزبيرينس - الموبيربن) - Alquería de Toledo (núm. 818), cerca de Rielves por un lado (núm. 816) y de Canillas por otro (núm. 702).

118. Azucaica (السكيكة). - Pago del alfoz de Toledo, cerca de Manzel Razín o Mazarrazín, que se menciona ya desde 1113 (núm. 9) y que estaba a las orillas del Tajo. Unas rocas de A tucaica figuran como lindes de una finca (núme. ro 17). Se le transcribe por *Aȩuqueca* $\mathrm{y}$ *Aẹucheca».

El monasterio de San Servando poseía en este pago un huerto con frutales y aceña (núm. 49).

En el mapa publicado por el Instituto Geográfico y Esladistico figura con el nombre de Azucaica (hoja núm. 629).

119. Ballesteros (بلشئيرين). - Pago de la jurisdicción de Toledo, al otro lado del Tajo. Había allt una barca para paso de hombres y de bestias (núms. 921 y 925). El azud de los Ballesteros se menciona junto con el de Santa Colomba, ambos lugares del alfoz de 'loledo (núm. 307) (1).

120. Barcience (برسط ) - Alquería de Toledo, que se menciona muy pocas veces (núm. 783 ). En el camino de Toledo a Barcience se hallaba una dehesa (sأف) (núm. 932).

Hoy es pueblo en el partido de Torrijos.

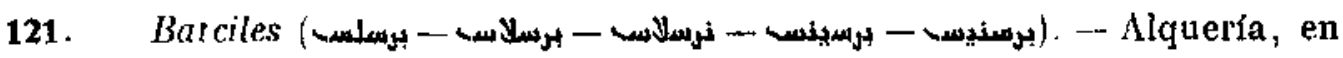
la Sagra, por el lado de Cobeja, de Borox y de Villascca (núm. 106). Alguna vez se le escribe «Barcines» (núm.662 y 667); pero con el nombre de Barciles figura en el Indice de la Catedral de Toledo (2).

122. Bargas (بs (برغ - - Pago del alfoz de Toledo. Lo veo citado por vez primera en 1179 (núm. 142). Un camino iba desde Bargas a Ainaljabia (núm. 289); otro desde Olías (núm. 422), y por este lugar pasaba el camino de Segovia y el ca. mino de la vega (núm. 465). Otro camino de l3argas, acaso desde Toledo, se menciona en 1192 (núm. 942).

Hoy sigue llamándose Bargas, partido de Toledo.

Fazania, quondaso almoxarifo A venzzara dicto Bonvida nomine possessam, quata vos cum consilio donint G. Toletasi Archiepiscopi..... pro quingentis aureis cuistis, iuro heredilario in perpetuum habendam et. irrevocabiliter possidendam (Cart. 1, tol, 52.)

(1) Iñigo López y su mujer łraría, su hija Anaya, y Ermildo Diaz, casndo con su olra hija Sancha, dan al monasterio de San Servando la mitad de la villa llamada Albiliztalín o Albelezterín, el 29 de Bep. tienbre de 1098, con sus alivas y sus morales y sus árboles, frutales o no, wás las vinas de Almoradiel, $y$ una tierra con sus almendros. (Cart. 2, fol. $63 \mathrm{v}$.)

(2) Compra el arzobispo D. Cerebruno (19 de Agosto de 1177), al eonde D. Pedro, una heredad entre Anoel y Barcilos, tal como se la había dado el rey Alfonso. (Cart. 2, fol. 74.) 
123. Benalhabia. - Véase Ainaljabia.

124. Benquerencia (بيان كر|نسية - Alquería de Toledo, que se cita desde 1233 (núm. 509). Entre los lugares de su término, se mencionan : la fuen.

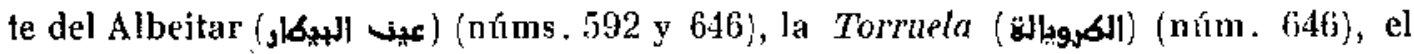
Val de la Torre (núm. 705), el Cudriello del Gumonal, el Atojar (núm. 682), la Vega (núm. 696), Valgordo, la Caba, el Val de María Rodrigo, el Val de Pedra da Muchacho? (núm. 682), el Arroyo (núms, 696 y 705), ¿Bonavalle? (يونة (número 696 ).

Cútase el castillo, en el camino de las eras (núm. 718), y el camino que baja desde el castillo de Benquerencia a San Cebrián (itúms. 678 y 688), y el camino de Benquerencia a Toledo (núm. fi2').

La iglesia de Santa María de Benquerencia (núm. 708), poseía alguna tierra núm. 682). Una casa de I). Medar era alberguerta por 1290 (núm. 708), fecha por la cual parece que trnía aún importancia el cultivo de la morera en esta alquería.

Estaba cerca de las alquerías de Val y de San Cebrián. Aunque no figura en e] mapa de Portocarrero, consta en el Indice del Archivo Catedral.

125. Bermejillos (بومجالش). - Alquería o lugar de la Sisla, por el lado de Layos, Setmo y Burguillos (núm. 692).

126. Berrocal de Domingo Sidis (ريدال كمنقه سيدس) Lugar limitado por el carrascal de Menasalvas, y en el cual se venden unas losas o artefactos de caza, y que no se describe por su mucha notoriedad (núm. 494).

127. Besines (بشيلش). - Alquería citarla a fines del siglo XIII (níms. $280 \mathrm{y}$ 282). Algunas veces se dice que es alquería de la Sisla y se indica su situacion por cerca de Pulgar, Santa María y Totanes (núm. 525); otras veces se la pone como de la Sagra (núm. 1.045).

128. Bimal (بيمال). - Alquerfa entre Camarena y Assuic (núm. 333): el camino de Bimal iba por debajo de Argance (núm. 1.006).

129. Binal ( $\mathrm{N}(\mathbf{\mathrm { N }})$. - Pago de la jurisdicción de Toledo, que se cita ya desde 1133 y por cuyo término pasaba el camino que iba al castillo de Mora (núm. 19). Al dorso del documento número 996 se le identifica con Piniel. Snpongo que estaría en la vega de Toledo; pero no figura en el Indice del Archivo Catedral.

130. Borch Alanáchir (برجه الاواجر) - Corre de Alaguachir: alquería de la ciudad de Toledo, no citada más que una vez en 1197 (nán. 906). Al dorso del do. cumento se transcribe este nombre por "Salavajo". (Véase Canales, nota.)

131. Borch Abenyânus (برج ابن يونس ). -Torre de Abenýnus: alqueifa de la Sisla de Toledo, al lado de Daralpelio, Daralfornana, Chonán ben Daud, ¿An. duca? (nums. 281 y 296).

132. Borch Assodũm (برجم الحدأه). - Torre de Assodam: lugar entre el camino de Arroyo y Camarena (núm. 333 ).

133. Borch Abenracrún (برج ابن رقون) . - Torre de Abenracrún: debía estar 
por Alaitic, en la vega de Toledo. Se cita el camino de la torre de los herederos de Abenracrún, que la posee luego doña Leocadia, viuda del alguacil y alcalde don Munio Petrez (núm. 469).

134. Borox (بروششُ- - Alqueria que primero se llamaba Boroxos (año 1173), que estaba por el lado de Cobeja, Pantoja y Alexar (núm, 106). Desde mediados del siglo XfII se escribe Borox (núm. Of6). En ella habla nnas salinas (núm. 1.015).

Hoy es el pueblo de Borox, partido de Illescas.

135. Buchel (بجالى - Alquerla sila cerca de Dar Assodam y de Alcapillat o Alcubilet ( $n$ ú m . 322) y citada desde 1202. Después se llama Ventosilla (1260, núm. 988), y debe situarse por donde la finca de csle nombre.

136. Burguillos (بن - - - Alquería de la Sisla, lindante con Cobisa: cítase varias veces el camino entre ambas alquerías (uńms. 650 y 692 ). Para la fábrica de la iglesia de Santa María de Burguillos se manda un mizcal en testamento de 1209 (núm. 1.022).

137. Burnoza (هرنوسة ( Alquería al lado de Daralmazán, Acuabir y Aceituna (núm. 764).

138. Burujón (بووحون) - Alquería cerca de Torrijos (núm. 726). Todavía perdura hoy .

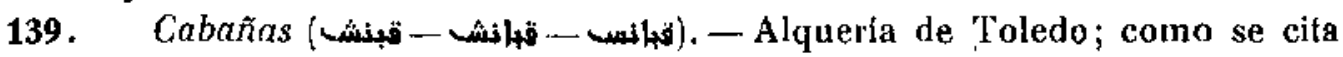
un camino de Cabañas por Olías (núm. 762), debe ser la aclual Cabañas de la Sagra, aunque en los casos que no se indica otra referencia (núm. 211) bien pudiera ser Cabañas de Yepes, del partido de Ocaña. La veo citada ya en 1173 (núm. 993) (1).

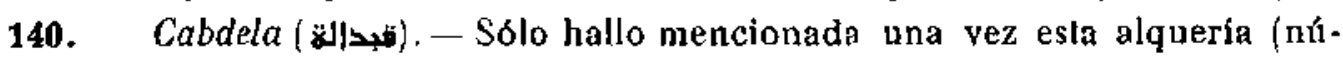
mero 431), que supongo será la Caudilla que ccrca de Maqueda señala el mapa de Portocárrero; hoy en el partido de Torrijos.

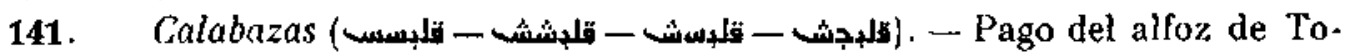
ledo, citado desde 1190 (núms. 562, 567 y 978), por el que pasaba el sendero que iba al Coscojar (núm. 568), y debía de estar lindante con la alquería de Torres (núm. 615), y con Alcardete (núm. 1.015). Los ducños de este pago, que no se indican, eran también dueffos de un soto que en él babía (núm. 562). Tenía un nódir o veedor, y parece que pagaban un tributo especial los hacendados de dicho sitio (núm. 615).

(1) Alfongo VIt, por carta tochada en Toledo el 11 de las kalendas de Abril de 1150, hace donación al 4 Concilio Sancti Micholis, citando nominatim a cuantos lo componian, *de duabas villis, scilicot, Cirre. los et de Calbanass. ( A. II, N., Calatrava, cajón núm. 10).

La villa de Cabañas de Yepes, ciusta (Meaniam et dos Barrioss, la compra el arzolispo $\mathrm{D}$. Rodrigo al abad de Silos por 90 suteos, a 3 de Marzo de 1213. (Cart. 2, fol. 30.)

El arzolsispo D. Rindigo da su aldea de Cabafias, oque est in via que ducit de Toleto ad Illebcas», a la Catedral para luminaria (21 de Junio de 1213). (Cari, 2, [0], 29.) 
Figura, en el mapa de Portocarrero, entre Toledo y Villaseca. La casa de Cala. bazas está cerca de la vía del ferrocarril de Algodor a Toledo, en el kilometro 21, frente a Higares (Mapa Inst. Geogr.). Hay Calabazas alla y Calabazas baja.

142. Calaña (قلانية) - Castillo, encima del azud de Alfita, en el Tajo (número 94). También habia malinos en Calaña (núm. 110).

143. Calbin (El) (الكلبين) - - Se citan siempre juntas las alquerías de El Calbín

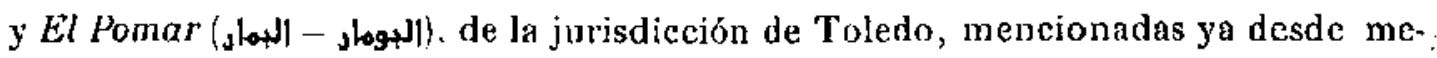
diados del siglo XII (núm. 37) y divididas en 82 suertes. Ėstaban encima del rio Guadarrama (núms. 153 y 233). Hoy se conserva el Calbín najo, a la orilla derecha del Guadarrama, según el mapa del Instituto Geográfico y Estadístico.

144. Calvir (El) (القلبير). - No creo que pueda identificarse con la alquerfa de El Cablón; sólo se la cila una vez (núm. 958), como junla con la alquería del lledal (اليلاكان).

145. Camarena (تمبيانة - Alquería de Toledo, lindante con las alquerias de Borch Assodam, Manzel Chazu, Bimal, Assuic, Villa Mazín, Algorfela, Argance, no lejos del río Guadarrama ( núm. 333). Entre varios nombres de su término, hallamos el Carrascal, Valderas, el Fenollar o Hinojar, el Labachos, el Arroyo, el Potrero.

Es la Camarena de hoy, en el partido de Torrijos.

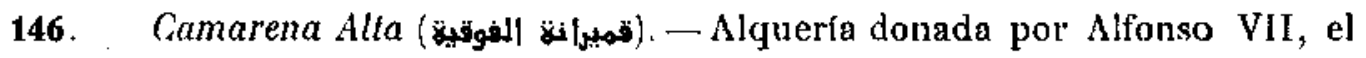
emperador, a Domingo Dominguez (núm. 292). Había un alguacil en esta alquerfa; que en 1239 cra Martín Juanes (núm. 1.062).

Debe ser la actual Camarenilla, en Torrijos.

147. Cambrillos (3) - Cara hacer las puertas de la alquería de Cambri. llos se mandaban en un testamento cinco micales (núm. 1.030). Hoy es lina dehesa, en térmíno de Albarreal de Tajo.

Desde Canillas iba el camino a Cambrillos y Torrijos (núm. 702).

148. Caminchal (قمنجال). - Se cita un camino a Caminchal por Toseneque (núm. 831). ¿Será el Lominchar de hoy, llamado también Villanueva de la Sagra?

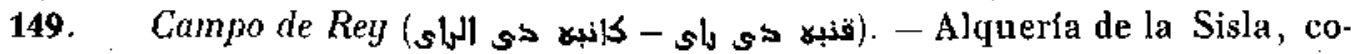
lindante con el Villar de D. Pedro Cruzado, que adquiere, casi en su tolalidad, ef . arzobispo D. Rodrigo Jiménez de Rada en 1242 (núms. 1.107, 1.108 y 1.110).

Figura entre Almonacid y Diczma en cl mapa ne Portocarrero (1).

150. Canales (فالش) -Con este mismo nombre debia de haber varios lugares distintos. En castillo de Canales se sitúa cerca de Villa Algariba, en la Sagra (nú-

(1) Fl emperadar, en $11.6 \mathrm{t}$, da a Ifair fili Theebet, in tribus rationibus, et Pclaio Martiniz, et Pedro Pedriz, et Petro Gastellano, et Johanni Sibili, et Rainatdo Portogueira, ef Johamni ibidem Melden, et Stephamo Juliani, et Sebastiano ibidem Fule\%, et Fedro Jobannis», lat villa de «Campam Regis, sitam Toros et ueque Benquerenciams..... eum torminis quos habuit in tempore maurorum, (Cart, 1, fol. 52 v.). 
mero 28). A este Canales hay que referir el pago de Asnaqui (ألسوى), "los canales», citado en los documentos númeres 31 y 34 . Otro Canales se señala jróximo a Talavera (núm. 193); otro por Argance (núm. 1.006), y otro sin indicar referencia a otro lugar (núm. 98). Teńa alcalte en 1173 (ńm. 993).

Canales figura en el mapa de Portocarrero entre Camarena e llescas. Hoy se llama Chozas de Canales (1).

151. Canifllas (قنيالش) - Alquería colindante con Manzel Obaidalá, AlbaIate, 'Torrijos, Cambrillos, Azobairín y no lejos del río Guadarrama. En una sola escritura compra (1290) doña Marquesa, madre de Sancho Martínez, secretario del rey $\mathrm{D}$. Alfonso $\mathrm{X}$, cincuenta y cinco fincas, de cuya descripción se deduce que los propietarios de aquel lugar eran pocos. Cítanse, entre los lugares de su término,

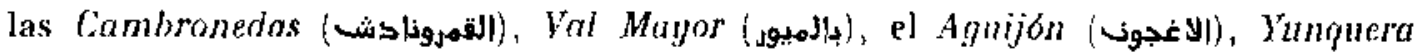

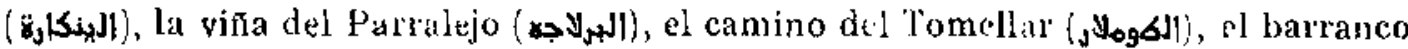

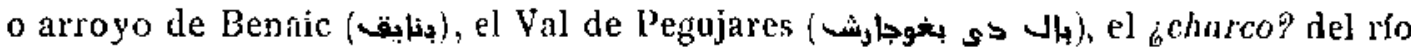

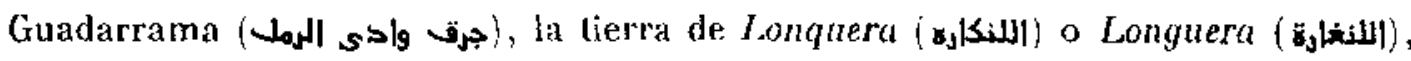

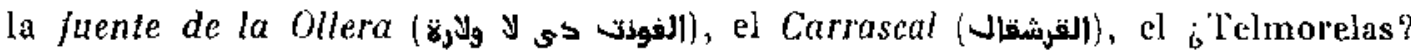

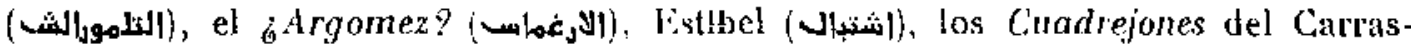
cal (القودرجنش sى القرشقاله) y la tierra llamada la Cuadra grande (القودة الكبيرة) (números 702 y 707 ).

En el mapa del Instituto Geográlico ligura la casa de Canillas y el camino de Estiviel.

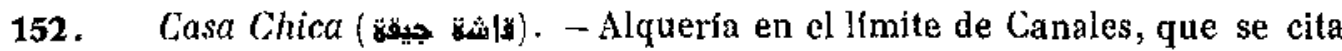
sólo una vez, en 1173 (núum. 993).

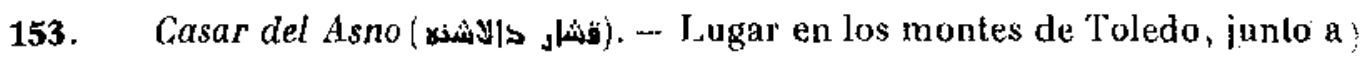
Cuerva, Menasalvas y Jumella (núms. 459, 1.115\%, 1.156, 1.158 y 1.159).

(1) Año 1143, 21 de Agosto: «Adefonsus, Hyspanie Imperator, una cun nxore mea Berengaria, ..... pro awore filiorum meorum Fredenandi et Adofonsi, qui in Toleto nati et in ecolesia beate Marje pontifiedi baptizati ot Deo super altare ilidem oblati fuere, castrum meum Canales, inter Vimos et roletum super Goderaraam situm, prefate ecclesio .... et do:nino Raymundo einsden ceclesic areliespicopo..... dono. hereditarium dono liberom et in perpetuum concedo.... ita.... quod milus alcaedorom qui ueque nunr: ibi fuere nnliusque alius homo hereditutem nisi quaw deinceps sors ei dederit infra eius terminos habeat nec eam ibi requirat; hoc excepto que si aliquis iuste, ut terre consuctudo est, allquam ibi hereditatem conparauit et quasi..... populatoruu pro ea seruierit, eam libero possidest. Qnod si noluerit, zorte dividatur co:) muni et alteri detur qui pro ea seruint. . .... Dono iam dietum castelium Canales..... eum terminis quos aly. antiquo ipsum babuisse probatur, et quos ei nodo concedo et affrmo habendos. Concedo ujdelicet babendum ei terminum ex parto utbis Toleti illam uillolam quam dicunt Recas et illam alian quam dicunt Borgelauager id est Bouedollam cum omnibus earum terminis et possesionibns quodcumgue nel nbicumqure sint. Bx parte Vlmis concedo hahendun ai terminum Racachiol. Fix altera parte Godorame Zedonilum usque ad matoren carroran qua itur de Magerido ad Toletum.... Ego Adofonsis..... anno VILL" mei imperii confirmo.* Confirman: «Habib, Zahalmedina. Geraldus, ocriptor.» (Cart. 1, fol. ó.) 
154. Casas Buenas (كونش (6) - Alquería de la Sisla, entre Poláll y Layos, que todavía perdura (núm. 532 ).

155. Casilla (Camino de) (تشفالة) - Desde 1177 se menciona este camino o sCarrera de Casliella (núm. 1.015), que pasaba por Olías (núm. 815) y se indica en la delimitación de fincas (núms. 1.014 y 1.129). Un pago del camino de Castilla se menciona cerca de Jaralnmocara (núm, 607).

156. Cebolla (سبولية). - Sólo una vez, en 1184, veo citada esfa alquería, a la cual iba una senda desde Alameda (núm. 1.008).

No debe ser el pueblo que hoy se llama así en el partido de Talavera.

157. Cerva Longa (مرية لنفة) .-- Alquería de Ia Sisla, que se nombra siempre junto con Villamuelas, de la cusl adquiere varias partes el arzobispo D. Rodrigo Ji. ménez de Rada el año 1211 (uúms. 386, 387, 389 y 390). El nombre de Villamuelas se transcribe al dorso de los documentos bajo las formas: «Villa de Molis * *Vi. llamolass y *Villamuclas».

Por este lugar pasaba un camino a Mora.

El cura de Villamuelas se menciona en el documento número 680 .

Hoy subsiste Villamuelas.

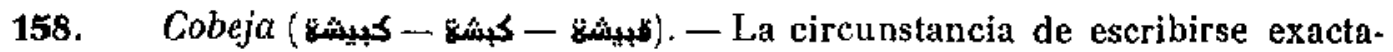
mente igual en árabe los nombres de Cobeja y Cơbisa hace difícil distinguir claramente las referencias de estas dos alquerías.

Cobeja estaba en la Sagra (núms. 157 y 237), doncle todavía perdura, entre Ala. meda, Yuncler y Villaluenga. Ya en 1173 se situaba cerca de Pantoja, Boroxos, Barciles, Villaseca y Alexar (uńm. 106). Tenía un fuero especial en la venta de fincas (núm. 134), seguramente por ser alquería de la Catedral (núm. 253), aunque no se indica en qué consistía ese fuero. - En el dorso de los documentos se transcribe "Covexa " „Covessa " Coluessa * y *Coveixa .

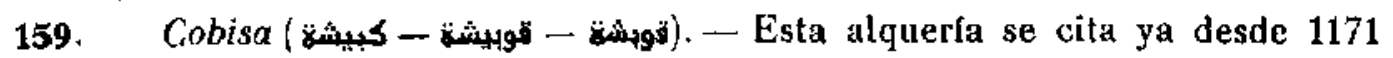
(núm. 99) en los alrededores de Toledo (núm. 251), por las cercanías de Aloyón (núm. 638) y en la Sisla (núm. F.116). Hoy está eritre Argés y Burguillos.

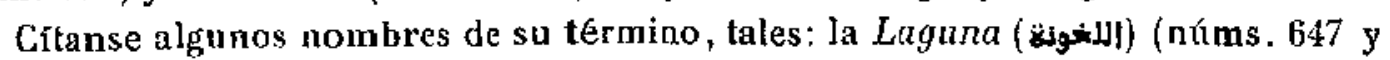
657), Val de la Casa (nún. 657), el sendero que baja a la alquería de Abentrado

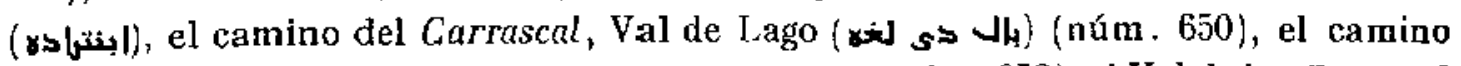

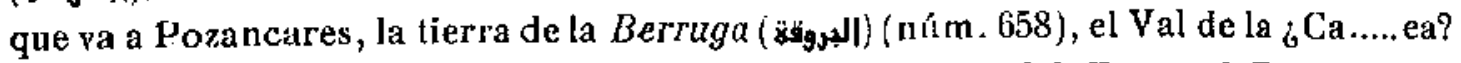

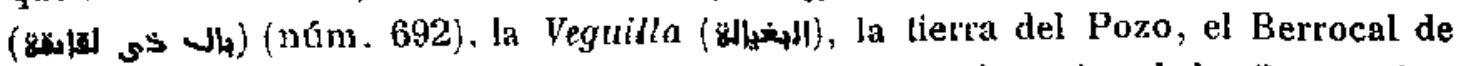
Azobiat (الصبياتى), que lo cruzaba el camino de Seleno, el camino de los Carrascales, la ticrra de la Alameda (núm, 693).

En el dorso de los documentos sólo se transcribe una vez por *Covixas (número 103).

160. Colmenar (El) (القالمثار). - Alquería en el alfoz de Bugiel o la Ventosilla (núm. 988). 


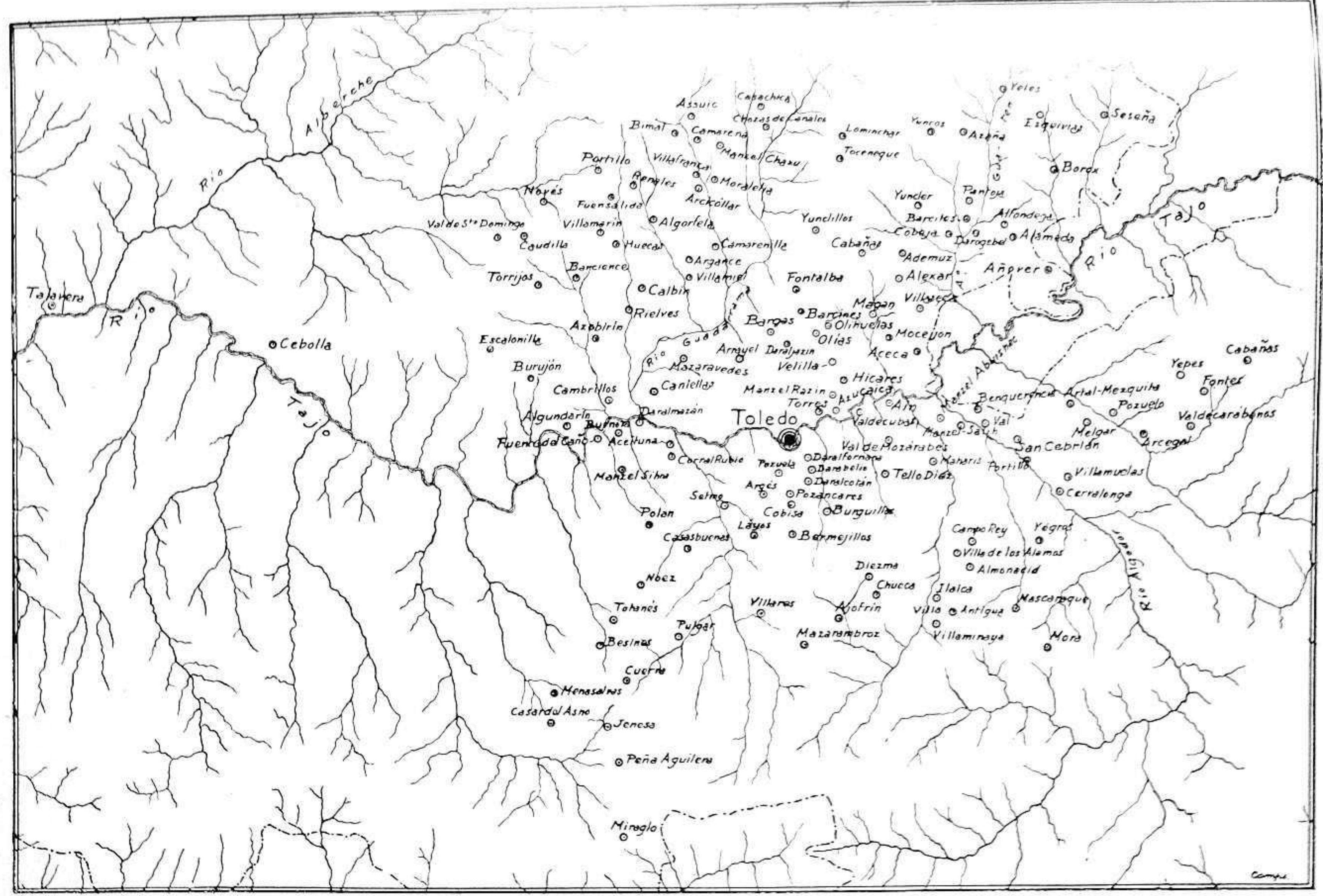


161. Consira (كنسئ (ك) - Castillo, para el cual se manda una cantidad en tes. tamento (núm. 1.021). ¿Podría ser Consuegra?

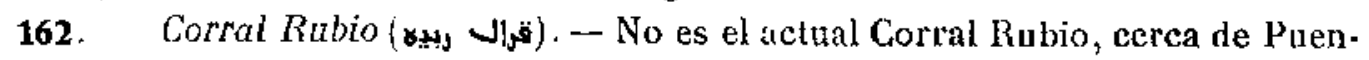
te del Arzobispo. Se le menciona ya desde 1162 (núm. 70), y se cita el lugar de la

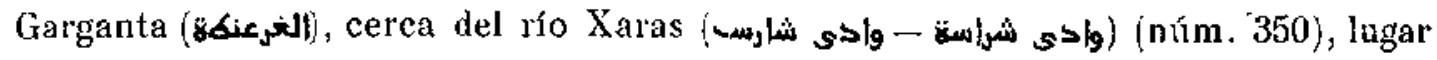
que estaba debajo de Corral Rubio (ním. 475 ). Un camino iba a Corral Rubio desde Manzel Yaix (núms. 926 y 927 ). También se nombra el nódir de esta alquerá (número 447) y los azudes y molinos sobre el Tajo (núms. 1.054 y 1.064).

163. Cozcolla (zjsjs). - Alquería citada solo una vez, en 1236 (núm. 995), en mión de otra, Cozcolliella (كليلية). - Debieron pronunciarse Coscoja y Coscojuela.

164. Cuerva (قورئ). - Alquería cerca de Jenesa, en Peña Aguilera (nú. mero 458), que se llama también Villar de Corva (núm. 460). Èntre sus términos, y con ocasión de delimitar losas y olros aparejos de caza, se mencionan los nombres de Puerto de Huaid (دوايد) ollauair (حوايد), Puerto del Ballenar (البلار), Pnerto del

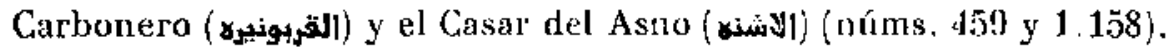

Es el Cuerva de hoy, al lado de Menasalvas.

165. Chebel Addóa la (جل) - - Lugar del alfoz de Toledo (núm. 398).

166. Chenán Daud (جوان (ج) - Alquería de la Sisla, por Daralbelio y Daralfornana, Borch Abenyúnus y ¿Anduca? (núm. 281 y otros).

167. Choca (جوقة (ج) - - Alquería de la Sisla, cerca de Dezma (núms. 770, 771 y 772). Iloy se llama Chueca, no lejos de Ajofrín.

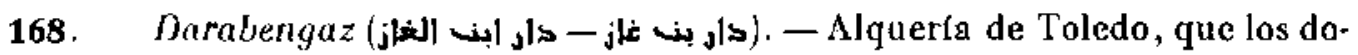
cumentos transcriben a veces * Dirabengax > (núm. 530) y « \łaravengaz (núm. 506). Se le menciona ya en 1158 (núm. 972).

169. Daralbalio (دار اليالي) - Alquería de la Sisla, colindante con Daraltornana, Chenán Daud, Borch Ahenyúnus, etc. (núm. 137). Una cuarla parte de esta alquería era de Ueld Bachicas (núm. 221); otra cuarta parte era de Román Marlfnez el Adalid, en dirección a Rielves, y otra de D. Julián, hijo del alguacil Sid (números 270 y 278 ).

Un octavo era de Juan Petrez Abenbachicas (núm. 296) y otro de Domingo luanes de Bachicas (núm. 324). Juan Marłínez poséía otro octavo (núm. 321).

Se transcribe por "Daralviego *, o sea *Daralviejo" (núm. 281); por * Daralviello* (núm. 304), y por \& Darvello = (núm. 392).

170. Darulbicha (s) (sاد البيجة) - Alquería solamente citada una vez (número 1.034).

171. Dar el Chebel (\$ار الجبل). -- Alquería lindante con Alameda, en la Sagra (núm. 1.008). En el Indice del Archivo Catedral se le llama Daragebal.

Véase Alameda.

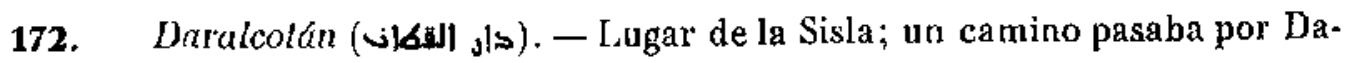
ralbelio en dirección a Daralcotán (núm. 304). 
173. Daralfornana (utista). - Alquería de la Sisla, colindante con Daralbelio, Chenán Daud, etc. (núm. 281).

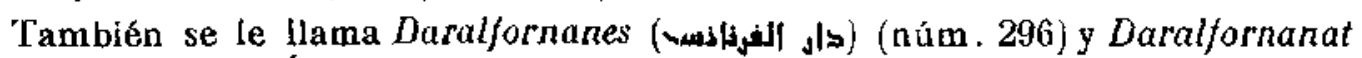

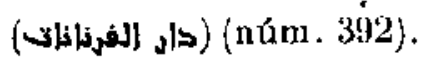

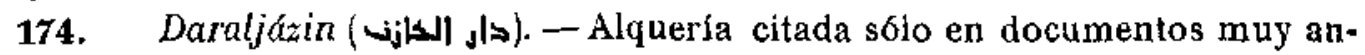
liguos, todos del siglo Xll; el primero, de 1107 (núm. 5). Se la silúra en el alfoz de Moxatir, y debra de estar por el lado de Olias, pues se cita un camino grande que bajaba de Olías a $\Lambda$ jázin (núms. 58 y 61 ). En ella tenía heredades el presbitero Mair Abdelaziz ben Sohail, según testamento de 1125 (núm. 1. 012).

La traducción del texto árabe sería *Casa del tesorero*

Se identifica con Algundarín en el documento número 966, que en su parte latina lo copia el Carlulario 1, fol. 69. (Véase atrás, párr. 93.)

175. Daralihudi (sار اليهوs). - Pago de la jurisdicción de Toledo, que al dorso del único documento en que se cita (aúm. 328) se le llama Daralchudia. En el Indice del Archivo Catedral figura Daralcudia, que acaso podiera referirse a este nismo lugar.

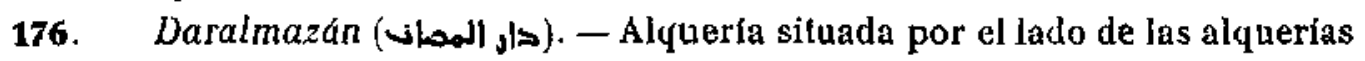
de Burnoza, Acuabir y Aceituna, en la Sisla (núms. 764 y 1.045). Se le llama Daramaçan. Debe ser el Darameso que figura en el mapa del Instituto Geográfico al Norte de Guadamur.

177. Daralmocara (s) - Pago cerca del llamado Camino de Castilla, acaso por el lado de Olias (núm, 607). En el Indice de la Catedral de Toledo se cita un Daralmagra, que bien pudiera ser el mismo.

178. Darassudan (sار السودان). - Alquería cerca de Alcapillat y de Buchel, o sea la Ventosilla (núm. 322). No puede corresponder, por tanto, con el Azután de hoy, en el partido de Puente del Arzobispa.

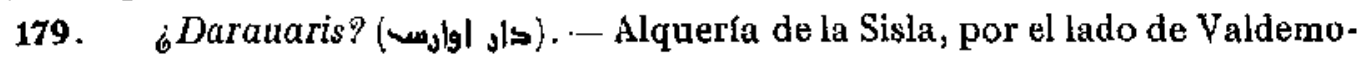
zárabes y de Almonaeir (núm. 781).

180. Dezma (zojs). - Alquería de la Sisla, cerca de Chueca (núm. 770). En el mapa de Portocarrero se le llama Diezma.

181. Escalonilla (اشكلونيلة). - Solamente se cita una vez como residencia del otorgante de una escritura ( $n$ úw $4 \mathbf{5} 5$ ). Hoy es del partido de Torrijos.

182. Esparlinias (اشبرتينشا). - Se menciona una vez al cobrador de las Salinas de Espartinas en el año 1283 (oúm. 675).

183. Esquivias (4) (1). - Alquería cuyo señorío va comprando el Cabil-

(1) Año 1188, 13 de Febrero. Toledo. Alfonso VIII dona a la Catedral de Toledo esolares, hereditates et quicquid habeo in uilla que dicitur Esquibias, prope Yeles et inxta Ileseas sita, cum onuin regali iurs». (Cart. 1, fol. 40.) Fernando $\amalg I$ confirma la donación hecha por Alfonso VIII de Esquivias, Torrijos y Talaunanca, a 4 de Junio de 1218, (Gart. 2, tol. 36.) 
do, por partes, en 1261, a sus anteriores dueños Lope Petrez, hijo de D. Pedro Juanes, hijo de D. Juan Alguacil (núm. 618), a Diego y Lope Petrez, hermanos del anterior, y a D. Bartolome, hijo de Micael el Sillero, marido de Orabona Petrez (números 620 y 621 ).

Es el conocido pueblo del partido de Hlescas.

184. Ficares (فقارش). - Alquería en el alfon de Tolcdo, lindante con Aceca (núm. 244). Se le cila desde 1159 ( núm. 731); con el nombre de Iligares figura en el Indice del Archivo Cafedral y en el mapa de Porlocarrero. Consta en el mapa del Instifuto Geográfico con el mismo nombre de Higares (casa y tejar) (1),

185. Fontalba (كنت الدة) ( $)$. A tres lugares distintos parecen referir'se las citas de esta alquería. Una vez se la sitúa en la Sisla (a) (núm. 526); otra, se la idenlifica con Novés, annque poniéndola en la Sagra ( múm. 1.030); y las demás se la sitúa en la Sagra, mencionándola desde 1123 (núm. 1.012), o simplemente en el alfoz de To. ledo, pero con referencia a lugares de la Sagra (núms. 745 y 1.126).

En el Indice del Archivo Catedral y en el mapa de Porlocarrero figura (en este último con la forma Honlalba.)

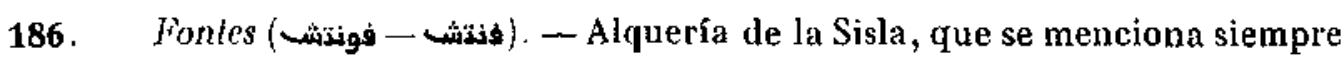
en unión de la de Yepes (núms. 107, 408, etc.). En el Indice de la Catedral figura un Finentes, que acaso pudiera ser este mismo (3).

187. Fuensalida (فونلث شليدة). - Alquería cercana a Portillo, donde tenía heredades y señorío el convento de San Clemente por 1232 (núm. 911). Fuensalida y Portillo figuran junlos en el mapa de Portocarrero, y hoy, en el partido de lorrijos.

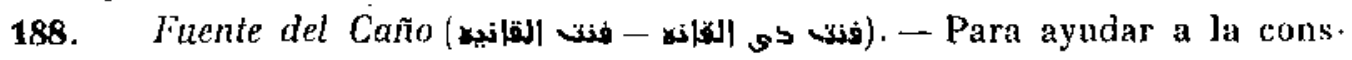
trucción de las puectas de la iglesia de Santa María de Fuente del Caño manda don Alfonso Mateos en su testameuto (año 1266) dos mizcales (núm. 1030 ). En el mapa de Portocarrero figura este ligar, al Norte de Guadamur.

(1) R. Roderlei manda en su testamento (sin fechy) una tercera parte do Figares al arzohispo D. G., otra al Calnddo y otra a su hijo Gurcia kuiz, cautivo de los moros, si vólvía vivo. (Cart. 2, fol. 75 v.) En documento de 1189,11 de Junio, da a la Caledral la mitad de Figares, para los canónigos y el arzobispo, para su aniversario. (Cart. 2, fol, 93 v, :

(2) Alfunso VIL da, en 1176 , la herodad que tiene en «Fonte Alba, ultra Tagum, versus Burguillosy, a Micael Dominguez. (Cart. 2, fol . 98.)

(3) Ā̄o 1145, 24 de Agosto : Allonso VII da a Martín Muniz ol Adalil, Pelay Godínec, meo hátlestero, A. Pedrí, meo cevadero, Gonzalbo Xeménez, Pedro Alforcem, Martín García, Munio Garcíez, don Celal, Pedro Pedrez el Rubio y a sus hijos y sucesores la villa sque vocatur Fontes». «Facta carta quando imperator iacebat super Gaen expectando naves Francoram que debebant venire ad Sibiliam. * (Gart. 1, tal. 51.)

A]fonso VIIL dona a la Catedral el amortuariunx de las aldeas de Yepea y Fontos, por privilegio do 22 de Agosto de 1213. (Cart. 2, ful. $25 \mathrm{v}$.) 


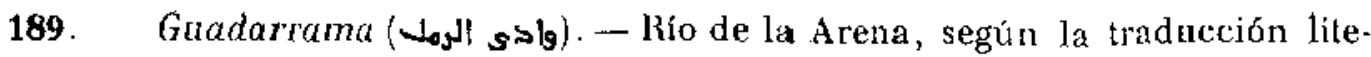
ral. Se mencionan en sus márgenes las alquerías del Calbín y Pomar (núms. 153 y 233) y la alquería de Fernando Muñoz (núm. 1.099) por la mitad del siglo XII. Un camino de Guadarrama se menciona por Camarena (núm. 333).

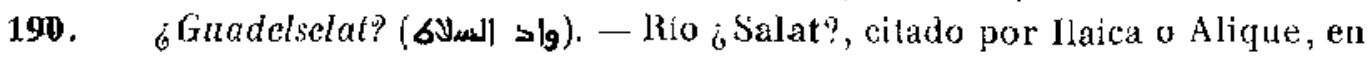
la Sisla (núm. 389).

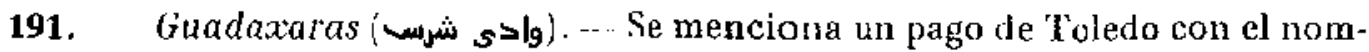
bre de Garganta de Guadaxaras (núm. 214), nombre transcrito al dorso del documento por "Ssaraz» y "Xaraz. Es el río titulado en el mapa de Portocarrero Guadaxara; en los mapas modernos se le llama Guajarax.

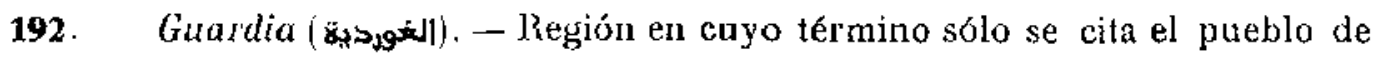
San Cebrián (núms. 720,722 y 992 ) (1).

193. Hameda (z) ( $)$ ). Pago de la jurisdicción de Toledo, citado sólo una vez, en 1182 , y que no sé si podría identificarse con Alameda, ya que a ésta se la

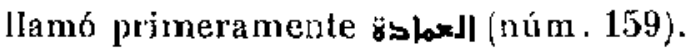

194. Hinojosa (هذوجوشش) - Castilio que antes se llamó Zuheruela (número 493).

Véase Zaheruela.

195. Horcajo (El) (الفرقاجه). - Alquería sólo citada una vez (nútm. 921), y transcrita al dorso por \& Forcaio,.

196. Lluerta $\left(8 \sigma_{29}\right),-\cdots$ Alquería que debe identificarse con la actual Huerta de Valdecarábanos, pues se menciona junto con ella el camino desde Benquerencia (núm. 182), el camino a Toledo y el camino a Melgar.

197. Hnecas ( nombre (núms. 930 y 931), hoy en el partido de Torrijos.

198. Ilaica (اليك). -..-Heredad en la Sisla: debajo del cerro de la alquería de Almonacir, divide el límite con Villa Antigua y Villa Minaya; llega hasta el barranco del agua del río \&Selat?, y linda con la fuente del Yunquer. El emperador Alfonso VII y su hijo D. Sancho hicieror donación de esta heredad a Hosain ben Furón (núm. 389).

¿Podrá leerse Alique? No hallo hoy referencia a esle lugar.

199. Iledal (El) (اليلاك/) . Alquería soblo citada nna vez con la del Calvir (número 958 ).

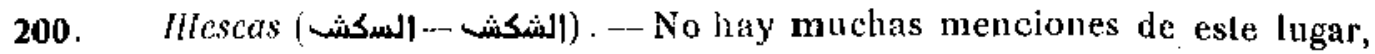
y sí de algunas personas de alli (níms. 156 y $3: 16$ ). Un camino iba de Cobeja a lllescas (núm. 237j. Solo una ve\% hallo mencionados bienes en fllescas, en 1181, en la

(1) La villa de la Guardia Jué donada por fernando III a la Catedral, par privilegio do 28 de septiembre de 1213. (Cart. 2, Lol. 24.) 
donación que Garcia Ordonez, de la Catedral, hace a esia instilución de los bienes que su padre tenía en aquel pueblo (núm. 1.121).

Al dorso del documento se transeribe por "Hylesques, " $"$.

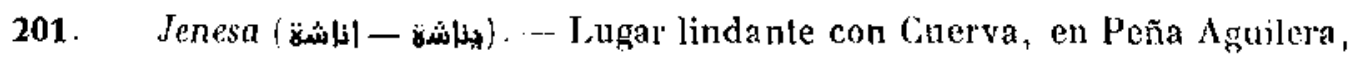
en la región de los Montes de Toledo (núm. 458); en otro lugar se le llama Villar de lenesa (núm. 460). Se le sitúa cerca de Jumella y de Casar del Asno (núms. 1.155 y 1.159 ).

202. Jumella (alla ) - Alquería cerca de Jenesa y de Casar del Asno, en la Sisla; citada en el número 1.155, que al dorso transcribe el nombre por .Jumella , y en el nímero 1.156 , que le transcribe a Inmelas.

203. Layos (لیوش). -- Alquería de la Sisla (núms. 692 y 824 ) que se recuerda en el pueblo actual de este nombre, del partido de Toledo. Se mencionan eu su tér.

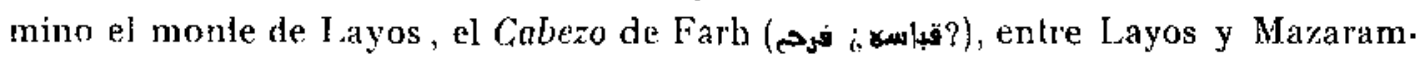
broz (núm. 527), la Sierra de Layos (الشيارة) (núm. 592), un camino a la cual iba desde Cobisa (núms. 6.57 y 692 ).

204. Loches (لوجش) --- Alqueria del alfoz de Toledo, citada ya desde 1156 (núm. 50), que estaba al otro lado del Tajo (núm. 943), y del cual no encuentro hoy vestigios. En el Indice del Archivo Catedral se menciona; y al dorso de los documentos se transcribe por "Lohes: y por "Loches".

Alguna vez se le nombra junto con Albuera (núm. 169).

205. Lorita (لوينة - لورينة) - Alquería de Toledo, citada ya en el primer tercio del siglo XII (núms. 21 y 22) y cuya última mención es de 1211 (número 1.058). Al dorso del documento número 194 se le llama «Lorta», lo que me hace sospechar que a fines del siglo XIII ya no tenfa interés este lugar, pues no lo conocía el que arreglaba los documentos del Archivo. No figura en el Indice del Archivo Catedral.

206. Madrid (مجريك). - La mayor parte de las referencias de este lugar son de personas en él residentes (núms. 248 y 559). Citase, no obstante, el camino de Olías a Madrid, en 1191 (nún. 800); y el arzobispo D. Rodrigo compraba, en 1244, por 120 mizcales alfonsíes, una yugada de tierra menos un sexto en la alquerfa de los Viveros (بيجاروس) ( (nún. 564).

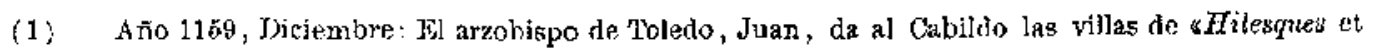
Fazaniams, que el rey Sancho IIL tabía dádo por su alma y para aniversario de su padre el emperador: para que bagan tres aniversarios: el día de la defuncion suya, del emperador y de D. Sancho. Y que aquellos dias dez de comer en su refectrio a los que vayan. (Cart, 1, fol. 38.)

Año 1176, Julio. «Super ripam Hyberi, iuxta Calagurram cum asset Rex in expeditione »: Alfonso VIII $y$ su esposa doña Leonor dan a la Oatedral de Toledo y a su obispo Gerebruno eduas uillas quae gunt in ter. mino de Toleto, scilicet Mliescas et Fazanniam s . (Cart. 1, 10l . 38.) 
207. Magam ( ( ro 261), que es el Magán de hoy.

208. Maharis (هحارس - Alquerfa sólo citada una vez (núm. 642) por Valdemozárabes, en la Sisla.

209. Manzel Abulshac (منزى إبى اسحقى). - Alquería de la Sisla, hacia la cual jba un camino desde $\Lambda$ leardete (núm. 182). Se la cila desde 1186. En la delimitación de varias fincas vendidas en 1255, se la sitúa al lado de las alquerías de Val, Manzel Sálih, Velilla, el Molino y el río Algodor. Figura, entre los lugares de su término, el camino del molino, el camino de la almadía o barca, el barranco del fastor, el barranco de las Cañas (3) , no lejos del río Algodor (núm. 596), y el pago

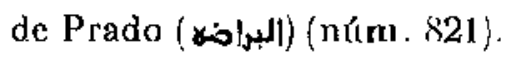

Se recuerda este lugar en la actual casilla de Mazaralbuzaque, un poco al Sur de la estación de Algodor, que figura en el mapa del Instituto Geográfico.

210. Manzel Chaza (مزي) - Alquería cerca de Camareara, unje sólo se cita una vez (núm. 333).

211. Manzel Maisara (مئل o - Pago que se menciona, en 1158, una sola vez (núm. 972). Probablemente estaba por Aloyón, Olihuelas, Azuqueica y Darabengaz.

212. Manzel Mosca ( mino de Toledo a Aicardete, citada ya en el año 1095 (núm. 4), donde estaba la viña del Cochol o Cojuelo. Como de la jurisdicción de Toledo era en 1112 (núm. 8), y no la vemos mencionada más allá del segundo tercio del siglo XIl (ním. 1.014). En el dorso del documento número 78 se transcribe este nombre por «Menzel Mosca y por «Mázaramesca (1).

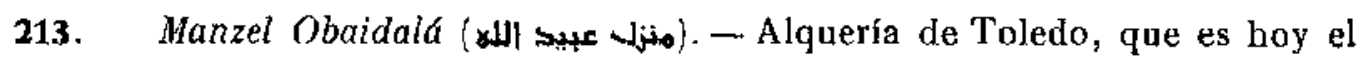
despoblado de las Mazarabedas, fijado en el mapa del Instituto Geográfico y Estadístico. Era alquería de la Catedral, sobre el Guadarrama (núms. 239 y 263). En el dorso de los documentos se van dando las formas intermedias desde «Manzel Oveit Allah» (núm. 230), a Menzel Oveit Allas (núm. 239), «Miazarahobeidala (núm. 120), "Mazariobeidalla, (núm. 176), «Mazarabedolla» (núm. 455), «Mazarabedala* (número 363), «Mazarnveda (núms. 3633 y 910$)^{(2)}$.

214. Manzel Razín (مزله (مزين). Se cita ya esta alquería en 1092 (núm. 2),

(1) Alfonso VII da a Ratmundo, obiepo de Osma (28 de Octubre de 1123), una viña ein loeo qui dicitur Mazalalmosca, que erat iuxta T'agum $₫, y$ los molinos que sunt in Tago in latere civitatis, circa vicmur judeorum in loco qui vocatur Beb al Portels. (Cart. 2, fol . 55 v.)

(2) Li arzobispo D. Rodrigo, con consentimiento del Cabildo, da a D. Diego López de Haro la villa que se llama Mazaraveitola, por dosumento de Agosto de 1211 . (Car1. 2, fol. 28 v.) -- D. Diego la da a la Catedral para su aniversario, en 24 de Septiembre del mismo affo. (Ibid., fol. 32.) 
cerca de Azuqueica (núm. 9), al Oriente de Toledo (núm. 17). En el dorso de va. rios documentos se llama *Mazarrazín. (núms. 200 y 738).

En el mapa del Institulo Geográfico se sitúa la casa de Mazarrazín entre Azuqueica e Higares.

215. Manzel Salih (مزلى (م) - Alquería de la Sisla, por el lado de Manzel $\Lambda$ buishac y de Val (núm. 596). Parece que no dehía estar lejos de Bonquerencia (número 696).

216. Manzel isihra? (8) en la Sisla (ním. 756).

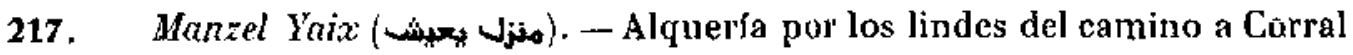
Rubio (núm. 926), al otro lado del Tajo (núm. 798). En el dorso del documento 926 se le sitúa en la vega de San Román, y en el número 927 en la vega de San Martín, en Corral Rubio.

218. Mascaraque (مشقرقاق) - Alquería de la Sisla, citada solo una vez (número 449) y transcrita al dorso por * Mascarac». Todavía perdura hoy.

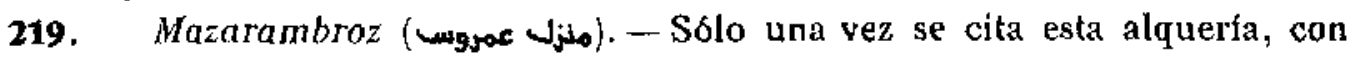
ocasión de la venta (1238) de una tierra en Villares, alquería de la Sisla, sobre el arroyo de Manzel Ambros a Amrus, entre el monte de Layos y el cerro llamado Cabezo de Farh (núm. 527).

Hoy es pueblo del partido de Orgaz.

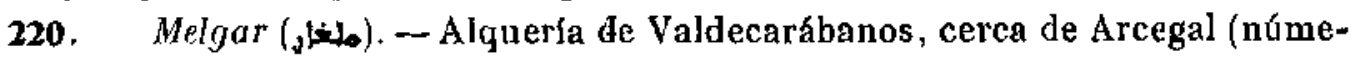
ro 557), y de San Cebrián (núm. 719 y 720), que todavía figura con este nombre en el mapa de Portocarrero, entre Huerta y Villamuelas. Mencionanse varios lugares

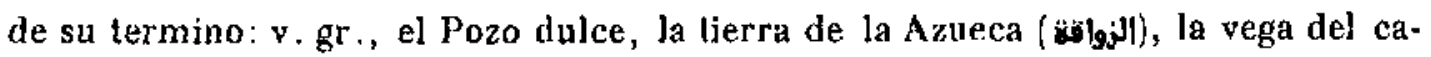

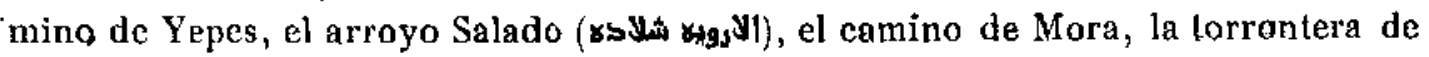
Alcoroza, ¿Torre helecho? (الكرهلاجه), el Villachuelo (البلاجهوالها), el camino de Alpera

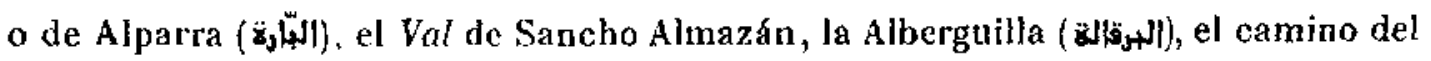

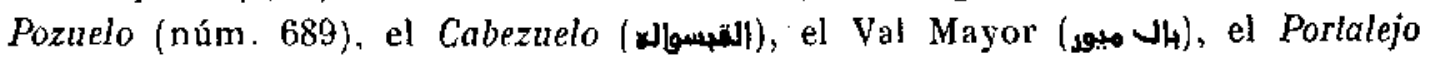
(البرثالاجها: (núm. 700).

221. Menasalbas (مانش البش). - Iugar cerca de Cuerva, en los montes de Toledo, con el cual lindaban las losas del Berrocal de Domingo Sidis, por el lado del Carrascal de Menasalvas (núm. 494).

222. Mezquila (La) (المبسجد). - Véase Artal.

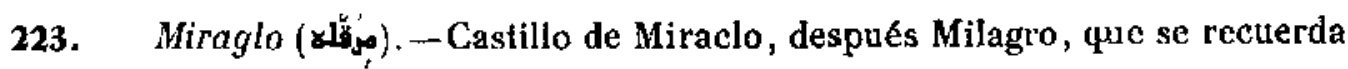
hoy en el l'uerto niel Milagro y rín del Miiagro, en los montes de Toleấn. Junto con

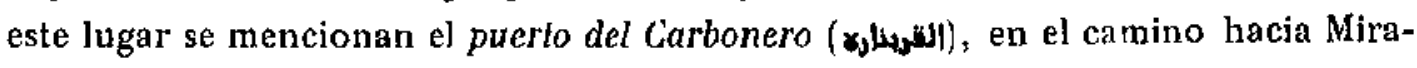

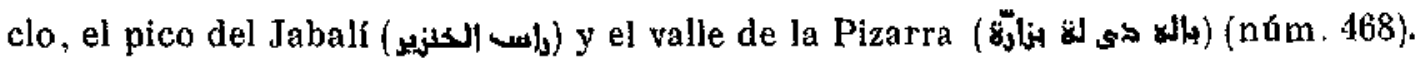
Desde Peña Aguilera iba un camino hacia Miraclo (núm. 956).

224. Mocejón (مزفجوف - - Sólo dos referencias a personas de esta 
alquería se hallan en los documentos: debia ser la misma que en la actualidad es bien conocida (núms. 244 y 587 ) $\mathrm{hl}$.

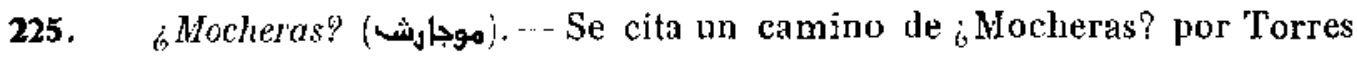
y Alcardete (núm. 1.045).

Una casa de Mochares pone el mapa del Instituto Geografico al Sur de Cuerda, no lejos de la carretera de Madrid a Ciudad heal.

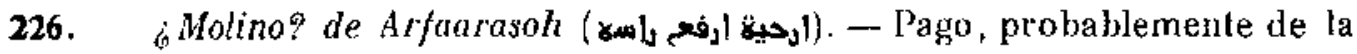
vega de Toledo (núm. 627 ).

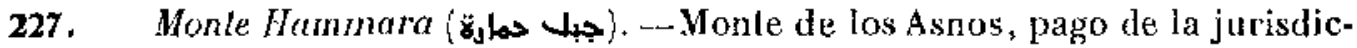
ción de Toledo, que no podemos identificar: en él se da tierra para plantarla de viña (núm. 928).

228. Monlurque ( $\mid S_{3}, g 3$ sis). - Pago del alfoz de Toledo, probablemente no lejos de Alaitic (núm. z(j).

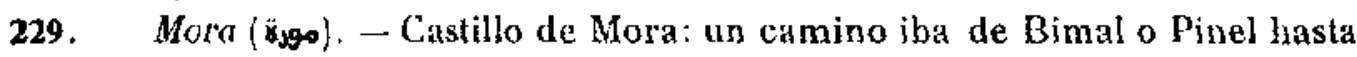
el castillo en 1133 (núm. 19).

230. Moradiel (مورalq). - Alquería cercana a Villa Algariba, en la Sagra, cerca del castillo de Canales y de la acequia de Camarena (núm. 28).

No tiene nada que ver con el pago de Almoradiel, ni con la aclual Puebla de Almoradiel.

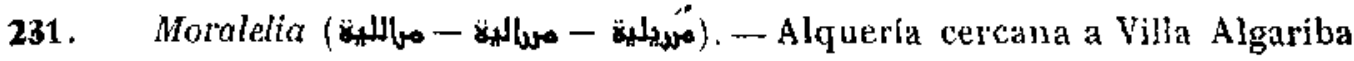
y Darcicolla (núms. 31 y 34), por la cual pasaba el sendero hacia Argance (número 1.006). Moraleja mayor y Moraleja menor figuran en el mapa de Portocarrero, entre Navalcarnero y Humanes; pero algo lejos de donde citan los documentos a este Moraleja.

232. Moratitla (هيلة (0) - Lugar en donde se venden dos viñas el año 1110 (número 6).

233. Murillo (مولي) - Alquería por el lado de Algorfela, Villamiel y Camarena (núm. 813).

(Pudiera ser error de lectura por ardarelia, o Moraleja.)

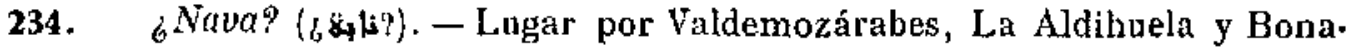
valle (núm. 696).

235. Noez (jg). - Alquería de la Sisla, lindante con Alcanabat, Casas Buenas, Polán y Borch beu Yúnus ( núm. 532).

Perdura este pueblo en el partido de Navahermosa.

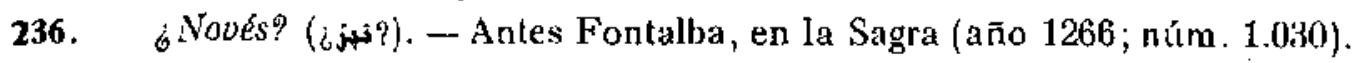

(1) Alfuso VII, por carta flrmada en Toledo en las kalendas de Diciembre de $116 \hat{b}_{1}$ dona avobis Petro lioderiei de A zaçra, meo fideli militi, aldea illa que Hoseion vocntur, in toletano territorio, que est etiąn iuxta Uilla sicea, otme omxibes pertinentifs suist, etc. (A. IT. N., Calatrava, tomo I de perguminos.) 
237. Ollas la Mayor (اوليش الكبرى). - Alquería de la Sagra, cuya primera mención es de 1146 (núm. 32). Estaba dividida en octavos, enlre los cuales se citan el de Abenalá inúm. 35j; el de Juanes ben Filorent o Florient (11úm. 43), que tenía 18 yugadas ( $n$ úm. 178); el de Abenbahłul, con 10 yugadas ( $n$ úm. 280), y el de Aben. badah (núm. 102), el de Abdeselam (núm. 127), de Abenmoxquiq (núm. 320), de Abensocala (núm. 373).

Citanse entre los lugares de su término el collado de Martín Abjlbeca, eutre

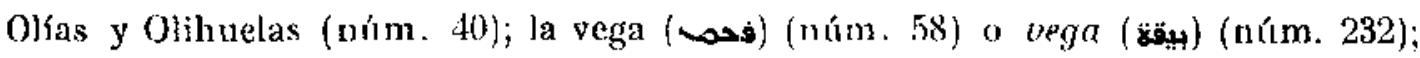

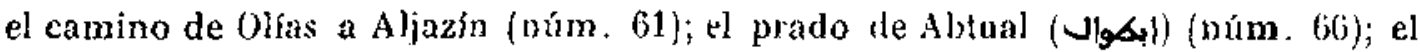
castillo viejo, cuyo solar fué de Micael ben Albazo, y estaba encima del camino de ¿Pesines? y de las fuentes de Olías (núm. 288); el pago del Torrente (مسول) (uúmeros 383 y 397); la "carrera de Olías" (núm. 307); el Cabezuelo (núms. 612 y 601); las viñas de for Parraies (برالش) por cuyo lugar había fuente y arroyo (núm. 797); la mezquita en lo antiguo (año 1169), que luego era corral de la gente de la alquería (núm. 797); el pago de la Torre del Gasco (num. 817); el Cabo Ameros (قبو عماروبس) (núm. 985).

Es nno de los lugares más mencionados en estos documentos.

238. Olías la Menor u Oliolas (اليولش الصغرى - اوليولش). - Se menciona ya

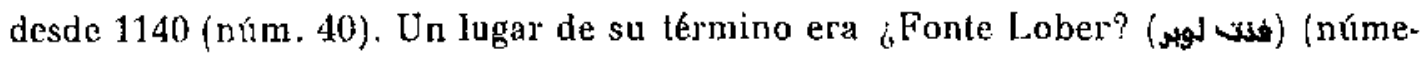
ro 725). Al dorso de un documento se transcribe este nombre por oliyulas* (túimero 261 ).

239. Onclelos, Oclelos. - Véase Yunclillos.

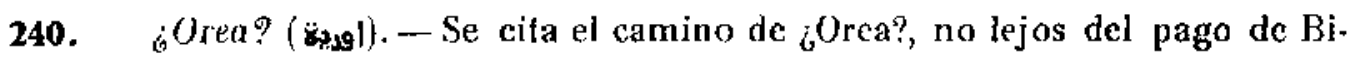
nal o Pinel (núm. 777).

241. Pagés (بشيشي). - Alquería de la Sagra, sólo citada una vez (núm. 1030).

242. Pajares (بجارش). - Salinas. Acaso las mismas que otra vez se llaman Aljares o Alchares (núm. 1.126).

Ahejares en el Almocaz de 1234 (vid. adelante, parr. 340).

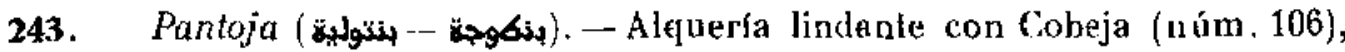
Villaneca y Alameda (núm. 237), Arevalillo y Pozuelo (núm. 334). Citada ya desde 1173 , perdura fodavía con este nombre.

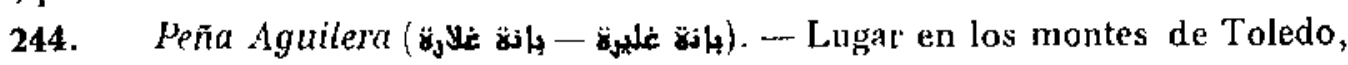
cerca de Cuerva y de Jenesa (núm. 458) y de Casar del Asno (núm. 956), en el camino del Puerto del Carbonero (nńm, 956). Entre otros nombres toponímicos de su

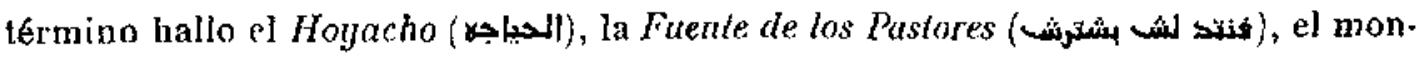

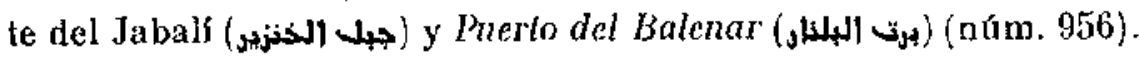

Transcríbese en el dorso de un documento por «Penna Guilera” y cPeña Aguilera»; recuérdase boy en el pueblo de Ventas con Peña Aguilera, en el partido de Navahermosa.

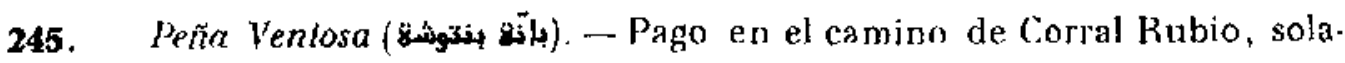


mente citado en documento de 1162, transcrito en el dorso "Pennae Ventosae» (nưm. 70).

246. Perales (برالش-...Salinas, mencionadas en 1161, y que al dorso del documento se transcriben por «Peraleios*; «Peralejos» (núm. 1.014).

Cítase también uma alquería del mismo nombre (nún. 1.030).

247. Polán (ئل)... Alquería de la Sisla, lindante con Aleanabal, Casas Buenas, Noez y Borch Aben Yúnus (núm. 532). Es el Polán dé toy.

248. Pomar (EI). -- Véase Calbln (EI).

249. Portal de Calatrava (بوخال هلعة رياح). - Pago del altoz de l'oledo (número 654), cerca de la ciudad, encima de Va\} de la Degnllada (núm. 679) y no tejos del Regachuelo (núm. 691). Supongo que a este lngar hay que referir el pago del Portal (البرانلى) mencionado en documento de 1187 (núm. 738).

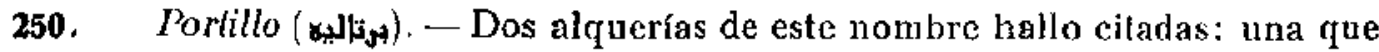
sería el actual Portillo, cerca de Fiuensalida (núm. 911); otra, alquería de San Cebrián, en la Sisla (núm. 721).

251. Pozancares (بزنكرش ). Pago cercano a Cobisa, en la Sisla (nún. 658).

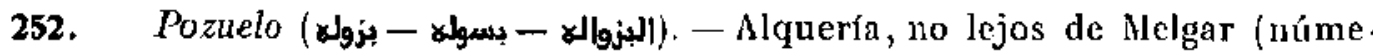
ro 689). Se cita una viña en el Monte, en la entrada de las viñas de Pozuelo, y otra viña con olivos (núm. 1.033), y el lugar de los Cabezos, en su término (núm. 1.140).

Las alquerías de Cobisa y Pozuelo parece que estaban juntas en la Sisla, según los datos que arroja el documento número 693.

En el Indice del Archivo Catedral figura un Pozuela, y con este mismo nombre se ve en el mapa del Instituto Geográfico, al S. de Toledo.

253. Pulgar (J|خلب), - Alquería de la Sisla, cerca de Pesines y Totanes (número 525), que todavia hoy perchura (1).

254. Regachuelo (EI) (الرعجوله - الرغجوله). - Pago del alfoz de Toledo, cerca del Portal de Calatrava (núms. 612 y 691). A el debe de referirse un llamado molino del Regachuelo (núm. 738), y en su término habla un berrocal grande (núm. 1.009).

Cerca de este lugar estaba la Torre del Gasco (núm. 1,009), en otro lugar lejdo

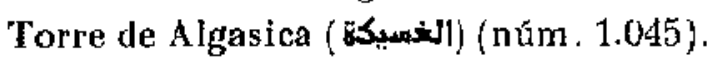

255. Renales (j الشالش) - Alquería próxima a Arcicolla; entre ambas habla una cabaña de ganado a fines nel siglo XI1 (núm. 1131).

(1) Wl conde Poncio y Formando Roderici dan a Pedro Rufo y a su mujer la mitad que tienon de Pulgar, para que lo cultiven, $y$ la tercera parte sea de ollos (Diciemore de 1105). (Cart, 2, fol, 108).

El rey Fnrique I, «attendens utilitatem toletane civitatis et regni mei, et ut esset via tuta que vadit de Toleto ad Miracnlam», da a la centedrat al villar de Pulgar, por carta de 6 des Noviembre de 1214. ¿Cart. 2, fol. 28.) 
Renales se sitúa entre Camarenilla, Argance y Huecas, en el mapa de Portocarrero. También figura en el lndice del Archivo Catedral (1).

256. Rielves (ريبش - - Alquerín de la jurisdicción de 'Toledo, citada ya desde mitad del siglo Xll (núms. 38 y 39). En sus términos estaba la aldea de Temam el Rotlequí, llamada villa לAnsí? (úms. 38 y 971), y el pago de Sarcat (ấm. 427), y la alquería llamada Borch Modafar (núm. 805). Un sendero bajaba de Rielves a Albatate (núm. 702), y tanbién al camino del castillo de Santa Eulalia (núm. 805) y al de Argance (núm. 1.006).

Subsiste hoy, en el partido de Torrijos.

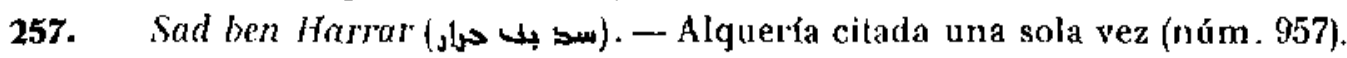
En ella tenia fincas el alguacil don Juanes, y debia de estar por Algordel y Aldjmus.

258. Sagra (إلشقة), - Region al Norte de Toledo, citada ya en 1140 (número 28). Los pneblos que se citan como de la Sagra smı: Alameda, Añover, Azaña, Barciles, Besines, Cabañas, Cobeja, Darelchebel, Fontalba, Pages, Ocner o Yuncler, Olias, Villa Algariba, Vargas, ctc.

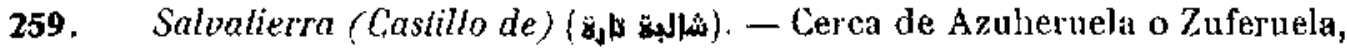
de Salbón y de $\Lambda$ larcos (núm. 481). Pạa su tábrica se mandaban en th testametto 100 mizcales en 1211 (núnı. 1.024).

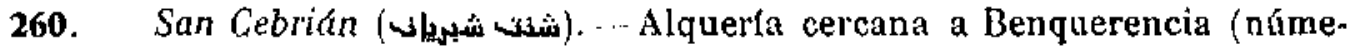
ros $(222$ y 682 ), en la Sisla de Tolcdo (núms. 680 y 719 ). En documentos más tardios, de fines ya del siglo XIV, se la llama aldea de la Guardia (núms. 719 y sigs.). En el mapa de Portocarrero figura entre Calabazas, Villaseca y Villamuelas.

261. San Esleban (شنت اشغابن). - Pago de Toledo, al otro lado del Tajo (números 71 y 1.039), "allende la puente de San Martín. (núm. 929), por donde debería de estar el convento del mismo nombre. Por cerca andaba un corral de los hijos de Málic (nóm. 71).

Las pocas referencias que hay de este sitio son todas del sigio XII.

262. San Feliz (شكت فليس - شغن فليج) - En 1112 se menciona ya este pago (núm. 8), sito detrás del Tajo (núm. 179), Jlamado así por la iglesia de San Feliz

(1) Año 1161,26 do Junio: aAdefonsus, Hygpanie itoperator, una cun uxore mea imperatrice Rica, et cum fliis meis Sancio et Fermando ... . . facio cartam donacionis . . . . Deo et. monasterio Sancte Marie de Batres et uobig magistro Hugoni el Juonachis in eoder monasterio commorantibus . . . . de illa heredilate que ext intor Reinales et Turrelium; dono nobis jparm hereditatem ut faciatis jbi aldeiam et djuldatis cun 'Reinales et cum Turrellum et cum Sancto Nicholas el cum Puzola et cum Purtellu, et habeatis cam nos el ownes succesores uestri iure hereditario in perpeluum . . . . Regnanite iposo Imperatore Toleti, Legio ne, Gallecia, Casiella, Naiara, Saragocia, Baccia et Almaria. Comes Barcilonie, Uassallus Imperatoris.

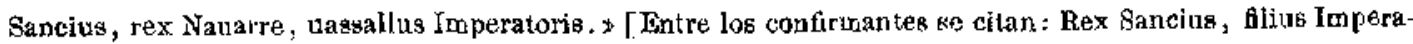
toris; Rex Fernandus, flius Imperatorìs. - Steplanus Aberbran, zafalınedina, - Cinter Reuderiguiz, aluaide in Toleto. J (Gari. 1, fols. 1 v. y 2.) 
(núm. 25), al lado de la cual debía de haber un convento de la misma advocación (núm. 57). Menciónanse como de esle pago الؤ (núm. 25), y cercanus a él, la 'lorre de los Diablos (برجم الشباكبل) (oúms. 47 y 73 ), el pago lal Monle, al otro lado del Tajo (núm. @i2). Para la fábrica de su iglesia se mandaba algo en teslamento de $1209(1.022)$.

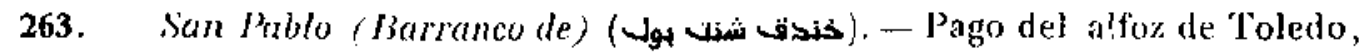
mencionado ya en $115 x$ ( $n$ úm. 972 ), donde existla una iglesia (núm. 972).

Jebía de estar por los alretedores de la ciudad.

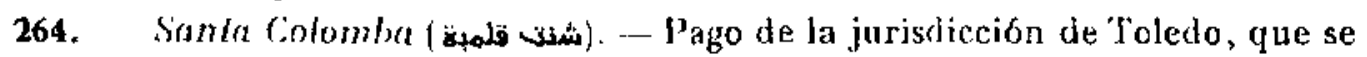
llamaba de la iglesia de Santa Colomba (núm. 158): un camino a la citada iglesia, que estaba a orillas del Tajo, sc menciona en el documento número 301 . También había alli una presa, llamatla de Santa Colomba (núm. 307).

265. SSclcaldima? - Alquería de la Sisla, mencionada una sola vez (núm. 515).

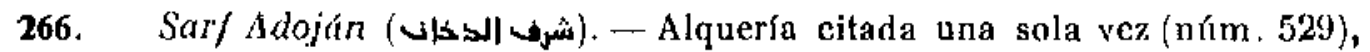
sin referencias que puedan permilir su identificación.

267. Seseña (ش人) - Alquería que conserva el mismo nombre (núm. 1.030), y en la cual se mencionan unas salinas (núm. 1.045).

268. Selmo o Setemo ( ro 657), Val, Burguillos, J3ermejillos, etc. (nóm. 692).

No encuentro referencia actual.

269. Sisla (شفلة - ششالة).... Región al Sur de Toledo, cilada por lo menos desde 1192 (núm. 229). La iglesia de Santa María de la Sisla daba nombre a su pago (vúms. 412 y 747), y para la lábrica de esla iglesia se dejaba una manda en 1209 (núm. 1.022)

Las alquerías o pagos que se incluían dentro de la Sisla son: Ain Aldic, Valde. mozárabes y San Juliáu, Ajofrín, Albalate, Alcanabal, Algorihuela, Almenares, Almonacir, Aloyón, Artal y Mezquita (luego Villaseca de Valdecarábanos), Aceituna, Alaín, Benquerencia, Besines o Pesinas, Borch ben Yúnus, Campo Rey y Villar de D. Pedro Cruzado, Casas Buentas, Chonán Daud, Chueca, Cobisa, Daralbelio, Daralcotán, Daralfornana o Daralfornanes, Duralmazán, ¿Darauaris?, Dezma, Fontal. ba, l'ontes, Maharjs, Manzel Abuishac, Manzel Sálih, Manzel ¿Sihra?, Noez, Polán, Palgar, San Cebrián, San Mrrio, Setmo, سلت الsones, Tilla de los Alamos, Villa Antigua, Villaminaya, Valle de Silos, Villar de D. Pedro Cruzado, Los dos Villares, Yegros, Villares (I,os), Yepes y Fontes.

270. Sua/i (لبسوافى). - Alquerra en la que tiene bienes (1160) la familia de Abenfurón (núm. 973).

Suponiendo errata de leclura, por سواقیى, podrla acaso identificarse con Canales, traducción de esta palabra.

271. Tujo (xali).-.. Se naencionan en la orilla del río Tajo los siguientes luga- 
res: Alaitic, Alberca, Albuera, Alcardete, Algunder, Aceiluna, Azuqueica, Mazarrazín, los Ballesteros, Corral Rubio, Canales (Talavera), Garganta del río Guajarax, Loches, Lorita, Manzel Abuishac, Manzel Mosca, Manzel Yaix, Montel y Canales, Zalencas, Monte de San I eliz, San Román, San Esteban, San Feliz, Santa Colomba, Torre de los Diablos, Talavera, Villar, cerca de Albiches ('lalavera), Zambranos (Talavera), Torre Alba, Torres, Valera, Villamuelas y Cervalonga .

Entre sus alluentes se citan el Algodor, el Guajarax y el barranco de Alcolea, en Talavera.

Los azudes o presas que se citan en el Tajo son: el azud de Alfita (1), debajo del castillo de Calaña (núm, 91), donde se mencionan el azud del Caid (núm. 150) y el azud de „Odair el Caram?: en este azud habla dos molinos, en dos casas distinlas, uno al lado de ací del Tajo, otro del lado de allá (nútm. 584); el azud de Algundarín en Corral Rubio (núms. 914 y 966); el azud y los molinos de Azumel, atrás citados (núms. 554, 555 y (i39); el azud de Baños, en el barranco de Alcolea, en Talavera (núm. 418); el de Bibas, en Talavera (núm. 984); el de Juja (هوجأ), cerca de la confluencia de este río con el Tajo (núm. 984); el azud de Matsbur (6. (6)? (número 111) y el de Santa Colomba (núm. 301).

En Azuqueica se mencionan, por 11/9, los pies de una noria antigua (núm. 143).

272. Talavera (6). - Se menciona bastante esta importante ciudad, por la circunstancia de tener alli fincas y un convento anejo (Santo Domingo) el convento de San Clemente de Toledo, que nombraba alli su nádir (núm. 492). La más antigua mención es de 1139 (núm. 26).

La iglesia de Santa María parece haber sido la principal (núms. 141 y 360), dando nombre al barrio, al igual que en Toledo (núm. 743). Otras iglesias cran Santiago (núms. 360 y 385), Sarrlo Domingo y San Justo, que estaban por el muro de la ciudad (núm. 306) y Santa Justa (núm, 413) y San Antolín (núm. 224).

En el arrabal estaba la iglesia y barrio de San Miguel, donde tenía una huerta San Clemente (núm. 188); otco barrio era el de la puerta de Zamora y de Santiago, donde estaba la alberguería (núm. 119).

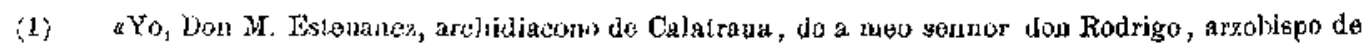
Toledo e primat de las Fspanmas, que bios mantenga, amen. - Doi toda aquella derechura que yo e en los molinos Inajita et en termino de Toledo en Trio o lo que io e hi es la meetad de dos molinos a la meetad del Rio e la meetad Aznda e dogalos con lodas sns derechnras e con exidas e con quantol pertenesce en Jio e luera de IRio, e dok lo que e en (jamarena de Suso aquello que conpre de mi ermana don Urraca, con los labraciores de pobiado e lo por poblar, con quanta derechura io hi e, e dol la quarta parte de aldea de Areualislo que herede de mio auolo Don Golzaino Alguazil, en la quall labran los de Camarena de Siso. - Is dol la orta del Grandal que se tiene con la orta de la Tesorerta que fuera de los muras de Toledo, con entradas e con exidas e eon ladas sus derechuras, - i por esta orta que sea tenudo el arzobispo don liodrigo e los otros arzobispos que despues del seran de fazer mio anniuersario cada uno en eud casa depues de mi fin. (Cart. 2, Jol. 47 v.) 
Más de una vez se menciona. la muralla de la ciudad (núms. 119, 338 y 413), junto a la cual estaba el Alcázar del Rey (núm. 338).

Dentro de la ciudad, y en el barrio del Mercado, por la puerta de Cortes (números 802 y 803 ), debe situarse el acerro de las tiendas (عقبة الحوإنيت) (núms. 729 y 1.048); se mencionan las tiendas de Ainoles (عينولش) y del Samal (الشملان) (núm. 802). Por deterioro del documento número 300 , no se puede saber en qué barrio estaba el horno allí vendido. - Entre las Puertas de la ciudad se ven citadas la de los Carros (مراكب), dentro del muro (núm. 497); la de Cortes, "Porta de Qurtes" (nú.

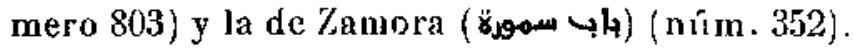

En el alfoz de Talavera hallamos el pago de los Aviones (الابيونش), "Noria de los Aviones (núm. 432), el de Aljarich, que parece llamarse Torremocha (número 432), la alquería de Albiches (1) (البجيش), al olro lado del Tajo (núm. 807), alguna vez llamada Balviches (núm. 491), la alquería de ¿Altasrica? (6) (número 807), la البركذية, al borde la cual estaba la huerta del hijo de Almach (núm. 729); la viña de la Acrela (التعقاكة), de la 6 greda? (núm. 743), y la viña de ¿Albacora? (número 743). Alguna vez se cita el camino a Alcoba (núms. 327 y 492).

OIros pagos de Talavera eran el de los Bañuelos (بنيولش), llamado también الحماهات, en las afueras de la ciudad, donde había una fuente (núms. 207 y 1.007),

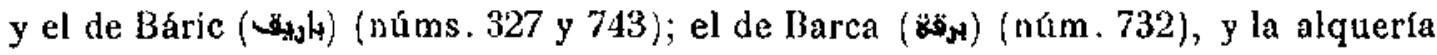
de Bonelas (بوالش) (núm. 807). Ya hemos mencionado el azud de Baños sobre el Tajo (núm. 448).

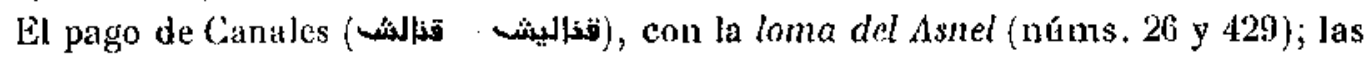

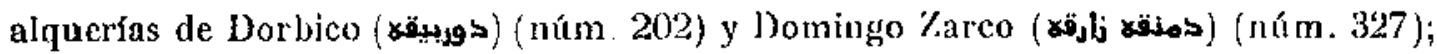
la Dehesa (الذف|شة) y el Carrascal (núm. 385); el camino de la Calera, en el Carrascal (núm. 123); el camioo del \&Yeso? (اليسه) (núm. 743) y el camino que baja al corral de dofía María (núm. 385), son Ingares en la ciudad.

Otros pagos eran el de Fontanellas o "Fontaniellas" (núm. 995) y el de Lamca

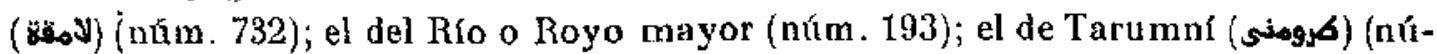
mero 802); cl de los Zamoranos (السمرانيف) (núms. 193 y 1.048). La alquería de Fornillos (فوالشالش) (núm. 1.057); la Torre del Sultán, por el lado del azud de Juja (número 984); el sitio llamado Tebuis (تبويش) (núm. 132); la Torre de la Alfondega

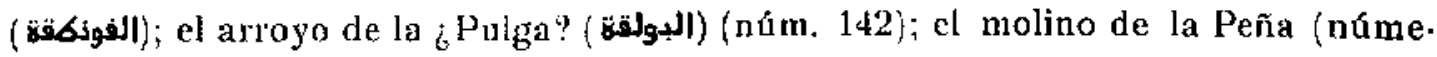

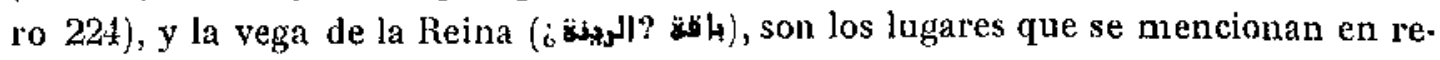
lación con Talavera.

273. Tello Diaz (نل ديس). -Alquería de la Sisla, junto con Daralbelio, Alain, Almenares y Chonán Daud (núı m. 351).

(1) Alfonso VIII da a (xonzalbo Pérez do Santa Cruz, dos yugadas de tierra en aluilehes, in tar. mino Talaveras ( 13 de Febrero de 1192). (Cart. 2, fol, 19.) 
274. ¿'Tlienda Fambra? (تيذذة غمرة) - Nombre de la alqueria, llamada antes Torres, año 1245 (númo. 569 ).

275. Toceneque (كوانs). - - Alquería cilada solamente en el número 831 , y que debía estar cerca de Caminchal ( 2 Lo minchar?). Figura en el Indice del Archivo Catedral con el nombre de Tozemaque.

276. Torre Alba (لكوي). - Alquería cerca del Tajo (núm. 784).

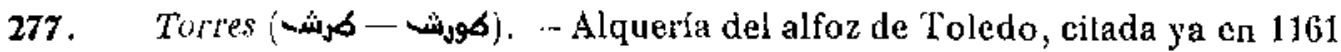
(núm. 65), al horde del Tajo \{núm. 90\}, que por 1245 se llamaba ilienda Fambra? (núm. 569).

Tenía el señorio la Catedral, y los dueños de fincas alli se sujetaban al fuero o costumbre corriente de pagar a la Catedral lo que le pertenecía en los fíutos (nú. mero 110), que era la sexta parte (núm. 65).

En el Indice del Archivo Catedral figura Torres. Al Sur de Azuqueica, en dirección al Tajo, se ve el camino de la Torre, en el mapa del Instituto Geográfico.

278. Torrijos (كوريجوش - كوريجش - كرليش). - No hay muchas referencias de este pueblo, que todavía perdura. La primera mención que hallo es de 1182 (número 161). Se habia del camino a (ambrillos y Torrijos (núm. 702), y se nombra a varios individuos procedentes de all (núms. 726, 827 y 828). Uno de sus lindes era la alquería de Barcience (núm. 932) (1).

279. GTosabor? (s) - Alquería que no he podido identificar: sólo se cita como punto de procedencia de un testigo que firma la escritura número 362.

280. Totanes (شib). - Alqueria de la Sisla, lindante con las de Pulgar, Pesines y San Mario (núm. 525). Perdura hoy con el mismo nombre.

281. Val ( - Jl). - Alquería de la Sisla (núm. 596), lindante con Benquerencia (núm. 708), y en la cual había un camino a las caleras (núm. 596) _ ¿Se deberá identificar con la llamada Val de Mozárabes?

282. Var Baniosa o Pefosa (4) بنيوش). - Pueblo que acaso perteneciera a la jurisdicción de Talavera (mútn. 497) (2).

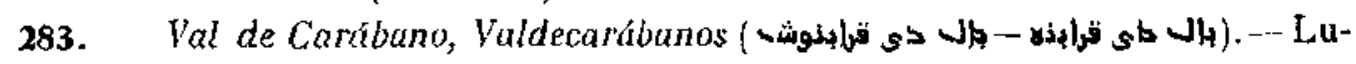
gar que se recuerda hoy en Huerta de Valdecarábanos, mencionado ya desde 1154 (núm. 46), cilado alguna vez como alquería (núm. 54). En su término se incluán las alquerías de Villaseca, Melgar, Arcegal (núm. 557). Estaba dentro de la Sisla (núms. 566, 599 y 600 ).

(1) Fernando III confirma a favor de la Caiedral la donación de la aldea do Torrijos, de Ezquivins y 'Trlamanea, a 4 de Julio de 1218. (Cart. 2, fol. 38 .)

(2) Año I208, Mayo: Juan, prior de Valle Pennose, vende al arzobispo D. Martín la casa llamada de doǹ Maria de Cldiello, en Talavera, en el bario de Santa Maria, yor 60 norabetís alfunufes, gegún fuero de Toledo. (Cart. 1, fol. $71 \mathrm{v}$.) 


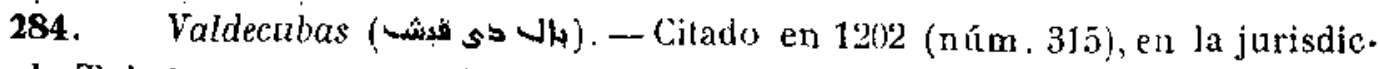
ción de Toledo, y otra vez (núm. 1.130) en el alfoz de Toledo. Figura en el Indice del Archivo Catedral.

El monasterio de San Servando tenía fincas en aquel término. Situada entre Azuqueica y Valduerme, vese hoy la casa de Valdecuba en el mapa del Instituto Geográfico.

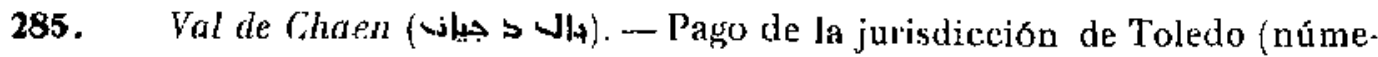
ro 95$)$, que al dorso del documento número 1.129 se transcribe .Valdegaen» (อก๊o 1189).

286. \& Val Dios? (بالل ديس) ... Pago del alfoz de Toledo, mencionado en 1177 (núm . 976).

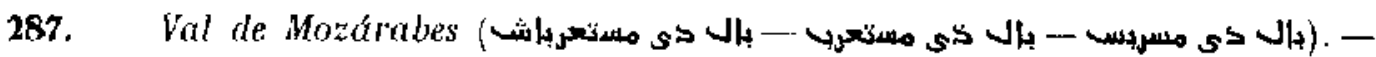
Alquería de Ja Sisla, llamada prineramente Ain Aldic, y que ya en 1237 se llamaba Val de Mozárabes (núm. 517), vecina a las de Almonacir, Albalate, Maharis, Benquerencia y San Cebrián (núm. (442). Al dorso de los docımentos números 778 y 779 , vemos que se la llamó después San Julián. Por Val de Mozárabes figura en el Indice del Arcbivo Catedral.

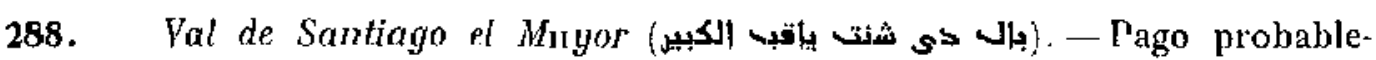
mente de Olias (núms. 817 y 1.153 ). Val de Santiago figura en el Indice del Archivo Catedral.

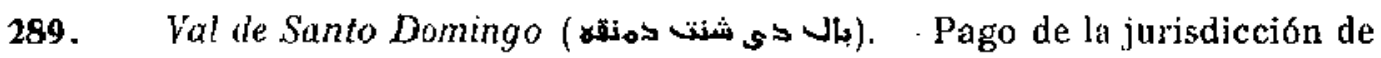
'loledo (nim. 431), hoy en el partido ule Torrijos.

290. Valera (4) (4) - - Pago del alfoz de Toledo (núm. 85), donde el rey tenía una viña (nútm. 148), y otra se llamaba Elbib (البيب) (núm. 85).

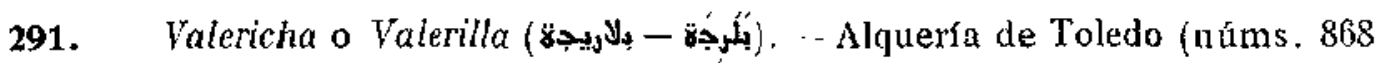
y 919). Me inclino a suponer que es el diminutivo de Valera, Valerilla, transcrito con la pronunciación vulgar de la $l l$ por ch, corriente todavía en el habla toledana.

292. Velilla (بلاية). - Alquería cerca de Manzel Abuishac (núm. 596), desde la cual iba un camino, y en ella habia un soto, lindante con uquélla. Figura en el Indice de la Catedral de Toledo. En el mapa del Instituto Geográfico se la sitúa entre Mocejón y la estación de Algodor.

293. Ventosilla. - Antes Bugiel.

294. Villa de los Alamos (بلغ د لثب التموش). - Alquería, al otro lado del Tajo, en la Sisla (núm. 414), lindante con Almonacid o Almonacir: el patrón de la alquería, o sea la lista de las personas a quienes sc concediera el terreno, estaba en poder del arzobispo de Toledo por los años de 1220 (núm. 45̄3).

295. Villa Algariba (بيلة الغريدة). - Alquería de T'oledo, citada ya en 1140 (núm. 28), sita cerca de Moraleja y Darcicolla, en el pago de las Canales (núms. 31 y 34). Después se la llamó Villafranca, y la primera vez que vemos esla nueva denominación es en 1190 (nóm. 209); a partir de este documento se dan siempre los 
dos nombres: números 210,252 , etc. - Èn el Indice de la Catedral figura en Villa Algariba o Villafranca.

296. Villa Antigua (بلة انتقوة) - - Alquería del alfoz de Toledo (núm. 172), por el lado de llaica o Alique, o sea en la Sisla (núm. 389), acaso no lejos de Mascaraque (núm. 149). En el dorso del uómcro 1722 se la llama "Villa de Vieja".

Por Villa Antigua figura en el Indice del Archivo Caledral (1).

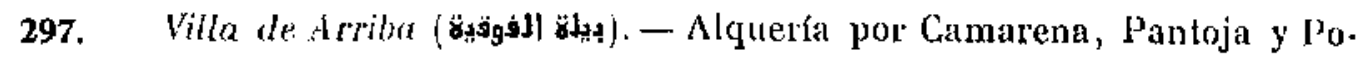
zuelo (núm. 334).

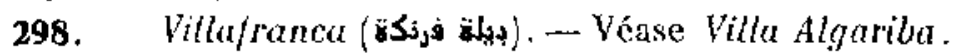

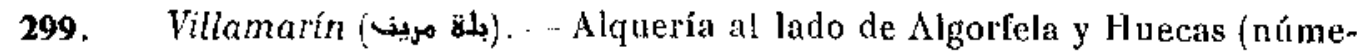
ro 810). Otras veces parece leerse Villamazin (مزئ) (núms. 333 y 1.137), pero se la sitúa en el mismo lugar.

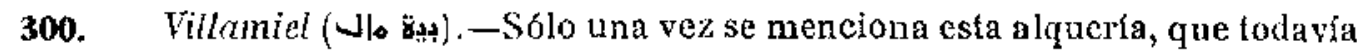
perdura en el partido de Torrijos faim. 809\}. Al dorso se transcribe por *Bilamil. y «Vilamiel». Nótese la transcripción $y$ por $l$, propia de la pronunciación toledana.

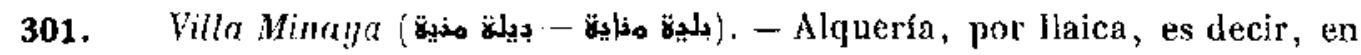
la Sisla (núm. 389). Hoy perdura entre Cilneca y Mascaraque.

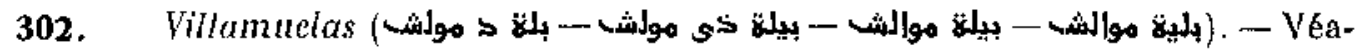
se Cerva Longa.

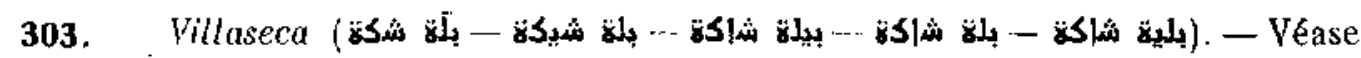
Arlal.

304. Villa de Silos (بيلة ذي شلش - Alquería de la Sisla (nú mero 511).

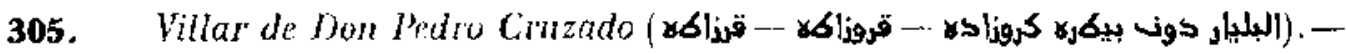
L.ugar de la Sisla, junto a Campo Rey (núms. 773 y 1.107) (2).

306. Villares (Los) (البلاراشی). - Lugar de la Sisla, sobre el arroyo de Nanzel Amrus, entre el monte de Layos y el cerro Cabezo de liarb (núm. 527).

307. Villares (Los dos) (البلاريذ الآنيف). - Lugar cerca de Aceituna, enlre Daralmazán, Burnoza, Acuabir y Azeifuna (núm. 764).

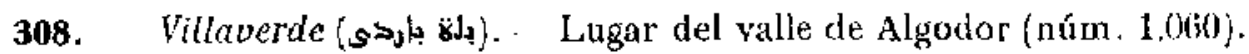

309. Viveros (Alquetía de). - Véase Madrid.

(1) Alfonso el Emperador (1160, a 22 de Marzo) doma a e Dominu Focera el Bracadou» «illo villar qui ost inter montem de Altuonacir et fontem de Innear.... sicut deterninat enm Alnonacir el cum Villa-Antigua, et cum villa de Menaia et cum illo arroyo qui vocaiur Guadaceleth̀ .

Hecha la parta en Toledo, th ato tertero en que fué tomada Baeza y Almería . (Cart . 1, fol. 8 v )

(2) Año 1124, Febrero, 6 : Alfonso VUl da \&letru Cruciato, meo alferiz, et filio qui es de moa criationes, la aldea del «Vilar que iacet inter Campue de Kei et Almonacit ot Falvat, ei Agudur». (Cart. I, folio 5i; Cart. 2, fol. 92, 10 fecha en 1164.) 
310. Yegros (نغرشڤ). - Alquería del alfoz de la Sisla (núms. 531 y 546), que al dorso del documento número 229 se transcribe ‘Egros».

Al Norte de Almonacid se conserva atun el despoblado de San Marcos de Yegros, que señalan los mapas modernos.

311. Yeles (يالش) - Alquería, cuyo nombre perdura todavía (núm. 873).

312. Yepes (ئسب- - Alqueria muy citada, especialmente en el siglo XIII. Lindaba con Melgar (núms. 689 y 700). El arzobispo D. Rodrigo fué adquiriendo por partes esta alquería y la de fontes a los herederos de los primeros pobladores, a quienes el emperador Alfonso VII se las diera (núms. 748, $749,750$ y 753$)$.

Codavia perdura este lugar (1).

313. Yancos (ئش) - Solo se cita uno que fué vecino de Cobisa, luego de Yuncos (núm. 157): este pueblo persiste en el partido de Illescas.

314. Yancler (اكني - - - Alquería de la Sagra, que se la nombra por Ocner, aunque al dorso del mismo documento se traduce por «Yuncler,; "Ocner' (nú. mero 806), y en olro por cYunquer (núm. 798). Otras veces se da la forma Yuncler (núm. 1.030), Subsiste en el partldo de Illescas.

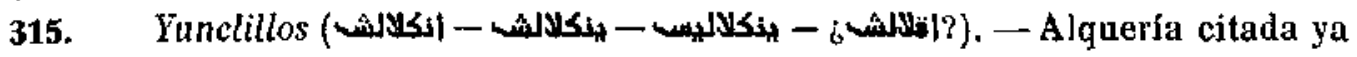
en 1161 (nám. 66) con la forma de Onclelos, que a veces es Oclelos (núm. 1.129). A ella iba un camino desde Olías (núms. 279, 505 y 512).

Subsiste todavia en el partido de Illescas.

316. Zalencas (جلثقس - - Pago del alfoz de Toledo, que se

(1) Aflo 1215, Marzo: Partición de los tórminos entre Yepes y Ocaf́a. «En nombre do Dios. El reDon Alfonso, que Dios perdone, cubio su carta a Alcside don Diago et a don Llan el Alealde que Iuesemos de partir el termino de lepes et de Occanna. Jil so fío, el rei don Enric, que Dios de vida, enuio nus dezir que assi chuno mandara su padre que fuessemos nos a departir el termino. El nos filemos con machos omes buenos de Toledo el con omes del Arçobispo et con omes que dizen que eran herederos en Yepes. Et uinieron buenos omes de Occannet con su Comendador doi Gil. Et fuo don Béla et gll yerno et Domingo Diez et. sus erwanos at otros omes buenos con ellos de Occanna et tuemos todos onsemble et paramos nos orialla de la Xara cerca del Ajgibiollo et leyowos la carta del emperador. La qual carta dize cuemo el emperador dio al Conceio Sant Nicholas Yepes con su Castielio ot con su Xara et con sl1s pasturas ct con sus agoas et con entradas et con exidas et cun quautol pertenece. Et quanto nos Don Diago et don Illan aulemos oydo egta carta, dixiemos a los de Occanta: auedes carta o recalbdo algano que nos demostredes; el dixieron ellos non nuemos otro recabdo lacia carta del emperador con que fue poblada Occanna et que bramos et que teuewos. Et dixiemos nos: amostrad nos essa carta del emperidor; el dizieron ellog: al rei ta auewos cnuiado, mas auewos el rescripto della; et dixiemos nos: venid mannana et aduzid nos el rescripto et otro recabdo alguno gi auedes. Lit fueron et otro dia mennana uinieron et demandawos les si traen carta o recabdo et dixioron: nu futemos carka ni otro recabdo sino la carta que enbiamos al rei. Et quando nos Don Díago et Dor Illan odiemos esto dixiemus: Semeia a nos segund la carta del emperador dize que esta Xara la que iaze entrel Algi-

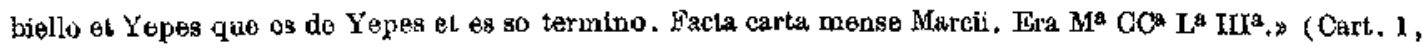
folio 19.) 
menciona en el documento más antiguo de la colección, de 1083 (uńm. 1), citando la viña del Cochuelo o Cojuelo. Debía de estar lindando con Azuqueica (núm. 588), pues al dorso de un documento (núm. 723) se traduce el lugar de la flnca vendida, diciendo *Huertas de Azuqueica*.

"Celencas*, "Calencas, suele verse al dorso de los pergaminos; por Zalencas figura en el Indice del Archivo Caledral.

317. Zuheruela, Zuferuela (شهماوولة - المحبرولة - شمرولة), - Castillo y alquerfa entre Salbon, Alarcos y Salvatierra (núm. 481), que el arzobispo don Rodrigo va comprando en parles a la familia le Armildez. En 1228 se dice: "El castilla de $Z u$ heruela, Ilamado ahora Hinojosa (هذوجوشة), (núm. 493). 



\section{I $\mathrm{V}$}

\section{R A Z A S}

\section{A) LOS MOZÁRABES}

318. Sabido es hasta la saciedad que se dió el nombre de Mozárabes a los cristianos que siguieron viviendo en territorios conquistados por los musulmanes: مستعري = sel que se asimila al árabe», cel que, no siendo de raza árabe, viene a ser como árabe (1). I a dominación política que los musulmanes ejercieron sobre esta población cristiana ha sido objeto de apasionados estudios. Signiendo el tópico, frecuente durante mucho tiempo, de considerar a la España musulmana dividida en dos bandos, moros y cristianos, empeñados en una lucha a muerte, se han entonado elegías scntidisimas a aquellos infelices cautivos que durante centenares de affos hubieron de soportar la mísera condición del oprimido por un yugo apenas resistible. El docto catedrático de Granada, D. Francisco Simonet (2), fué el más esforzado paladín en defensa de la memoria de aqueilos «mártires», cuya cultura y civílización, superior, segín él, a la de sus enemigos, fué ahogada y aniquilada por sus bárbaros opresores.

Pero conforme han avanzado los tiempos y se ha profundizado en el estudio de la cultura y civilización musulmanas de España, se ha ido viendo que aquellos dos pueblos, hermanos de raza, aunque de distinta religión, se pelearon, es ver-

(1) Biberatein-Kazimirski, Dirtionnaire arabe -francais, s. v. - tye.

(2) Historia de los Mozírabes de Espana, Madrid, 1807-1003. 
dad, muchas veces, pero estuvieron otras muchas juntos, aunque fuera sólo parcialmente; se conocieron uno y otro lo suficiente para imitarse; y se toleraron uno y otro lo bastante para que si unas veces toco al cristiano estar sometido políticamente, pudiera haber mozárabes, y si otras fué dominador el cristiano, perdurasen los mudéjares.

No ban tenido en cuenta los elegiacos cantores de la opresión contrá los mozárabes un hecho, que resalla principalmente en Toledo: Ia persistencia misma de la raza mozárabe, con su religión cristiana. Si durante foda la dominación islámica en Toledo se manlicnen iglesias cristianas; si, como nota Simonel ${ }^{(1)}$, se conserva hasta la silla metropolitana y se nombra arzohispo (aunque los nombres de algunos no los conozcamos hoy), ¿dónde estaba la persecucion? Y si después de la reconquista por Alfonso VI, aquellos cristianos siguen llamándose con nombres árabes y empleando la lengua árabe para sus contratos particulares, para sus propios testamentos, ¿podrá decirse que les farzaban a ello sus tíranos opresores?

Creo que una de las consecuencias más útiles de la publicación de esta colección de documentos será çue los doctos puedan comprobar el grado de islamización en los cristianos toledanos, que, sin embargo, les permite seguir profesando su religión.

No habrá, pues, que atribuir a presión politica la afición que los mozárabes mostraron a la lengua árabe, sino que se habrá de explicar por la ley inexorable en el desarrollo de la humanidad de que la civilización más fuerte domina sobre la más débil : Graecia capta....

319. Privilegio de 1101 y confirmaciones. - Pocos documentos se conservan del periodo inmediato a la reconquisla de Toledo por Alfonso V1 en 1085: sólo cuatro figuran en nuestra colección (oúms. 1 -4). Pero en ellos se sigue la legislación cristiana: la fórmula corriente de traspaso de dominio, en el documento número 2 , del año 1092, dice: aAdquiere la propiedad como cualquier propietario en su here-

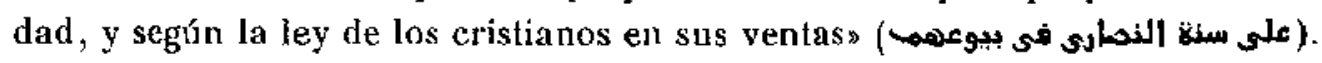

Y' una razón económica va a ser causa del privilegio primitivo de los mozárabes, otorgado por Alfonso VI el año 1101. El original de este documento se guardaba en cl archivo secreto del Ayuntamiento de Toledo, y all lo copio, por los años de 1740, D. Pedro Camino y Velasco: ya entonces andada *muy maltratado; la tinta en mu. chas partes desmayada, y hasta en lugares, ilegible. Lo reproducimos de la transcripcion de Camino (2):

Sub Christi nomine. Ego Adefonsus, Dei gratia toletani Imperii rex et magnlficus triumphator, una pariter cum dilectissima uxore mea Helisabet regina, ad totns Mozarales de Toleto,

(1) Op. cit., cap. $\mathrm{XXXIV}$.

(2) Noticia históricueronologica de las nobles fanilias de Mozarabes de la imperial vimdad de Toledo, 1740, págs. 38-89. Figura también en Mufoz Ronero, Fueros mutricipalew, 184i, 1, pág. 360 . 
tam eavalleros quam pedones, pacem in Christo atque perpotuam salutem. Chm preteritis tentporibus fuerint factus in loleto nultas pesquisitiones super cortes et heredilaws, sir de prosuria

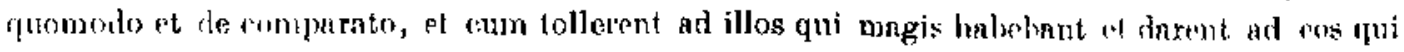
nichil aud geti pauco tabebant. Nune ego ixm quero imponero linem ant istam crusum et nolo ut amplius fiat. Ideo autem in mense Mareio unandavi ad domino Iohnne, aleati qui preposilus ipsius civitatis t juridicus Indax erat, ut cuw alvacit Don P'etro et nlis decom ex melioribus

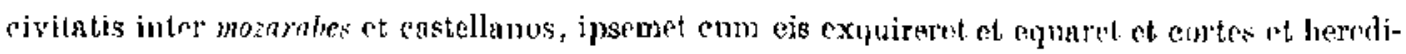

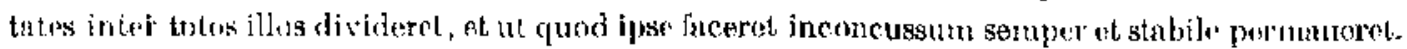
Qund thmen secundum neum imperiun confactum fuit atquo completum. Nune ego, a supre-

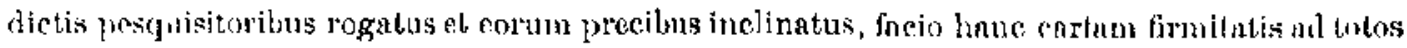

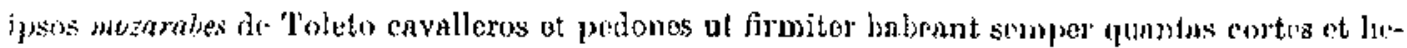
reditates sive terras aud vinens hodie in suo ture retinent, of pro mulla c'xquiwitione nom perdant inde quiequan, nec pro nullo rege subsequente, sive \%nfalmedina aud comito sal principe militir, de quanto hodie pertinet, quía pro meo indicio vendieavorunt sibj in .... piternum. Jit do eis liberlatem nt azi fuerit inter eos pedes et voluerit et posse habuerit at militel, at vendondi, dandi vel possidendi vol do possesione sua quod voluerit faciendi, liberam in alei nomino habent potestatem. El si inter eos fuerit ortum aliquod negotium de nliquo iudicio secundum ..... tontiam in libro Iudicum antiguitus constitutam discutiatur. Et do qunnla ealnmpnin fecerint, quinlum solummolo persolvant, ut in carta Castellanorum resaonat, exetples do furto et do morte judei vel uauri; et de omni calurnpia talea ois mando habero consuetudinem gualon et castollanis in Toloto commorantibus. Et si voluerint vineas aud faliag achores planture and res. taurare, jlli qui fuerinl peditus decimam inde portionem solummodo ad regalo palatium persolvant. Hoc autem facio pro renedio anime mee ot parentum merum, ot ul vos omnos phos in hac urbe semper amavi et dilexi, seu de alienla torris ad populandum adduxi, semper habeam fideles et nratores. Idenque absolvo vos ab omni fece pristine subiectionis et prescriple libortati trado ut horlicmo tlie ct deinceps nce vos nee filii aud herodeo vestri ab liae preseripta rogula recedatis, et in isto foro semper permanentis evo perenni et per secula cuncta. Amen. Si quis autem, quod fiert minine credo, aud ego, aud aliquis homo de propinguis mpis vel extrancis, contra loc motun factum ad irrumpendum venerit, quisquis ille fucrit quj talia commiserit, sit excomunicatus et cliristianae fidei libertato separatus, ot cum Datan al $A$ biron, cuos terra vivos absorbuit quia mandatis Dei rebelles extiterunt, et cum Iteda domin traditore "ui laque ye suspen lit et sic vitan cum visceribue fudit in profnndo inferni etornas pe'us lueraturus, dimorgatur. Ft hoc meum lactum in cunctis plenam obtinent firmitatem. Facta antem hac stalilitatis carta in era $\bar{I} . \mathrm{CXXXV}$ VIII et noto die XIII" kalendas aprilis. Toe autrm non volo jecterniter: quonian mando ut populator vendat ad populatorem et vicinue ad vicinum, bed non yuero at aliquis de ypsos populatores veodanl cortes aut hereditates id nullo comito val polestate.

$\uparrow$. Ego Adefonsus, Dei gratia totius Hispanje Imperator, quod feci, confirmo.

[1." columna.] Elisabeth regina, ınood domino meo fieri placult, confirmo. \& Leymundus, totius Gallccie comes, Regieque gener, confirmal. \& Urraca, Inperatoris filia, Roymondique comitis uxor, confirm. \& Henricus, Portugalenais ot Colinbriensib provincia comes, conf. * Tarasia, Regis filia, Henrici comitis uxor, conf. Bernardus, Toletane sedis sirehie- 
piscopus, confirraat. \& Tohannes, Toletanorum populi Iutex atque propositus, conf. \& Petrus alvacit el ..... icus, conf, * Michael Cidiz, Princep toletane militic, eonfirnat.

[2." colununa] Petrus Ansuriz, comes, confirm. \& Frnanclus Monioz, M[aiordomus Regis, confirm. * Garcia Alvariz, Armiger Regis, conl. \& Gome\% Nartiniz, confirm. Didago Gonsalviz, confirm. * Gulier Bermudi», confirm. * Gonsalvo Ansuriz, confru, * Petro Sonnaz, confirm. \& Didago Alvariz, confirm. * Pelagio Petriz, confirm. * Kuderigo Petriz, confirm. Gutier I'errandi\%, confirm.

[3." columna.] D.... itis toletanao...* Garcia Xinenones, conf. Lohanne Ramiriz, conf., Gonsalvo Stephaniz, conf. * Toderigo Ordoniz, conf. \& Saucio Amariz, conf. * Johanne Didaz, conf. \& I'ctio Diduz, conf. \& Pelagio Gudesteiz, conf.

Pelaggius Trigis, cogno mento Botan-, guod notavi, confirwo. [Monograwa de a Pelagius ».]

Se deduce de este documento que, después de la conquista de Toledo, los vecinos y moradores de la ciudad adquirieron tierras y fincas en el campo, tanto por derecho de presa, como por compra ( sic de presuria quomodo et de comparato ); pero hubo muchas pesquisiciones acerca de todas aquellas adquisiciones, y a unos quitaron lo que tenían, mientras a otros dieron lo que no era suyo. El rey, para poner fin a aquella cuestión y para evilar que en lo futuro se reprodujera, comisionó a] alcalde D. Juan y al alguacil D. Pedro, con otros diez hombres buenos de la ciudad, mozárabes y castellanos, para que hicieran un reparto justo y equitativo de aquellas fincas. Hiciéronlo, y rogaron al soberano que dicra firmeza a aquella partición, como el rey lo hizo, concediendo a aquellos mozárabes, caballeros y peones, que poseyeran en firme cuantas fincas tenfau entances en su poder, sin que por nadie pudieran ser molestados: ni por el rey, ni por el zalmedina, ni por conde o jefe militar alguno.

Y aprovechando esta ocasión, les autoriza para que el peón que pudiera, fucse caballero; y para disponer libremente de su prapiedad. Les asigna por ley el Liber Judicum, para caso de pleilos. De calumnia sólo habían de pagar el quinto, como los castellanos, excepto del hurto y de la muerte de un judío o un moro.

En las plantaciones nuevas, los que fuesen peones sólo tendrán que pagar al rey la décima parte.

Después de la fecha, limita la libertad de disponer de aquellos bienes, diciendo que el vecino venda al vecino y el poblador al atro pobladors, pero que no pudieran vender a ningún conde o potestad.

La lista de los privilegios que, a partir de éste, van dando los reyes a los mozárabes, puede verse en la citada obra de Camino y Velasco (págs. 2 y sigs.), aunque casi todos son confirmaciones del primitivo.

Pero no tardó en unificarse la legíslación de las diferentes razas que en 'Toledo 
se juntaron después de la Rcconquista. Alfonso VII, en 1118, da su fuero ad omnes cives toletanos, scilicet, Castellanos, Mozarabes atque Francos (alguna vez en lugar de Francos nombra "Gallecoss), "propter fidelitatem et equalilatem jllorum *, y mejora y confirma los privilegios de Alfonso V1 (1).

Señala el Liber Judicum como cuerpa legal para que juzguen diez de los más nobles y sabios loledanos en unión del juez de la ciudad. Exime a los clérigos del pago de diezmos y a los soldados del portazgo de caballos y de mulas, y esto mismo a los cautivos.

Los regalos que el rey diece a los soldados de Toledo, se repartirian entre los castellanos, gallegos y mozarabes, proporcionalmenle a su nimero. Aquellos soldados no barian anubda, sino un fossado annal; el que no lo hiciera, pagaría diez sueldos de oro al rey.

Jas armas y eaballos que pudiera un caballero tener, las heredarian a su muerte sus hijos o parientes; y si quedase sólo la viuda, sería homrada en honor del marido.

En caso de ausencia a Francía, Castilla o Galicia, el caballero habra de dejar otro en su puesto. Si se ausentaba a sus heredades al otro lado de la Sierra, habra de eslar en Toledo de Mayo a Octubre, bajo multa de sesenta sueldos.

Determina el modo de cobrar los diezmos, "cum veridica et equali mensura, videntibus duobus vel tribus fidelibus civitatis, y declara la condición exenta de los cobradores del diezmo.

Los autoriza para que libremente puedan construir molinos, norias y * piskeras* en el róo Tajo, *et habeant ipsi, et filii sui, et heredes eorum omnes heredilates suas fixas et stabilitas usque in perpetuum, et quod emant el vendant uni ab al. teris et donent ad quem quisicrint, et unisquisque faciet in sua hereditale secundum suam voluntatem,.

Ofrece las tierras que pudieran recuperarse de los moros. Kistablece las penas para los bomicidas y traidores, y el que matare a cristiano, a moro o a judío sería juzgado por el Liber Judicum.

El estado social de aquellos calamilosos tiempos de guerra continua se refleja en la cláusula referente a la mujer: « Et mulier ex mulieribus eorum, fuerit vidua aut virgo, non sit data ad maritum invita, non per se nec per aliquam potentem personam. - Similiter, et nnllus erit ausus rapere mulierem de mulieribus eoritm, mala si fuerit, aut bona, non in civitate, nec in via nec in villa. Et quis unam ex inlis rapuerit, morte moriatur in loco,

(1) Reproducc cste fuero Muñoz Romoro, ob. cit., pág. 365, tomándolo de la capia en la colección diplomáticu del P. Burriel. Este lo copió do atra copia simple coetánea, que so conserva todavía on el Archivo secreto del Ayuntamiento de Toledo. 
En caso de lítigio de cristiano con moro o judfo, intervenga el Tribunal cristiano.

Que no salga ningún caballo de silla ni arma alguna de Toledo para tierra de moros.

Que nuguna persona tenga beredad en Toledo, sino el que more en ella con sus hijos y su mujer. Que la fábrica de las murallas se haga con los ingresos de Toledo. Que si algán castellano quiere irse a su fuero, vaya libremente.

Otro privilegio del mismo emperador Alfonso VII, del año $1137^{(1)}$, concede somnibus christranis qui hodie in Toleto populati sunt, vel populari venerint, Mozarabos, Castellanos, Fraucos, quod non dent portaticum in Toleto in introitu, neque in exitu, nec in tota mea terra, de totis illis causis quas comparaverint, vel vendiderint, aut de alio loco secum adduxerint *

Pero, a pesar de todo, el comercio debía mantenerse con las regiones musulmanas, porque añade: Hli vero homines qui cum mercatiiras ad terram maurorum, de Toleto exeuntes perrexerint, dent summ portaticum secundum sum forum.,

También exime a los cristianos del diezmo (salesor = العشوي rey, y del kpan, vino u otira labor, para cualquier otro trombre .

$Y$ estas privilegios los concede omnibus thristianis qui in Toleto habuerint casam, vel hereditatem, et mulierem, ut habeant et teneant illos ipsi et filij eorum, et omnis generatio sua praesens et futura, jure hereditario in sempiternum».

Estos fueros los confirma Alfonso VIII, incluyéndolos en su carta de 1176, que reproduce Mnñoz Romero (ob. cil., pág. 380)(2).

320. Los moź́rabes toledanos. - En nuestra colección no abundan las cilas de Mozárabes: deberja considerarse que no era preciso decir de una persona que era mozárabe, cuando su familia era conocida como cristiana antigua, de público y notorio. Manejando los documentos romances de la Catedral, al menos los reproducidos en los dos Cartularios que se guardan hoy en el Archivo Histórico Nacional (3), después de leer estos documentos árabes, se saca la impresín de que las personas que intervienen en ambos grupos son las mismas. Todos los cristianos de Toledo eran mozárabes, y ya veremos cómo hasta los francos se llamaban con nombres árabes.

A pesar de esto, hay algunos casos en que se indica el origen moztrabe de las personas citadas, v.gr., un Abenmartín el Mozárabe (المستعرئى), mencionado en 1150 (ń́tu. 40); un Juan Mozárobe (núm. 98); un Dominicus Mistarabs, que firma el documento número 141; un Abenomeya el Mozárabe (núm. 152); un Martín Sa-

(1) Muñz Romero, ob, cit., pág. 875 .

(2) Bl thero de los castellanos aparece oitado alguna vez en nuestros doeumentos: por primera vez en 1195 (núm. 1.037), y en materta de arras (num. 720), y de bienez gananciales (núm. 963).

(3) Codices números 087 y 996 . 
lama ben Abihocha, a quien se llamaba Martín el Mozárabe (núm. 153), cuyos hijos vendían una suerte de tierra en Calbín y Pomar (núm. 213); un Pedro Mozárabe, hijo de Abderráhmen el Macrub (núm. 231); un presbítero mair Domingo el Mozá. rabe (núm. 928).

Mucho más raro es llamar a uno cristiano (نمراني): vemos un Pelayo Nazareno (núms. 309 y 1.129) y un hijo suyo llamado Feliz (núm. 299). Acaso deba considerarse este caso como un segundo nombre. Y una vez se ve el denominativo Acha$m i$ (العجمى): Teresa, hija de Domingo Micael ben el Achami (núm. 702).

321. Nombres de persona. - puede verse la lista completa de los usados por los mozárabes, lanto latinos como árabes, en el índice nomóstico que figura al fin de este volumen, por lo que no creo necesario repetirlos aquí.

La transcripción árabe que en cada caso adoplan puede verla el curioso lector en el documento a que el 1́ndice refiere.

322. Duplicidad de nombre, árabe y romance. - Muchas veces vemos que los documentos dan dos nombres a una misma persona, cuidando mucho de fijar la personalidad de cada uno, sobre todo si aparece como firmante en algún documento.

De un Juai ben Omar se dice al pie que es «Sálih, el de la iglesia de San Lucas» (núm. 134); a un Juan ben Fárach se le idenlifica como hijo de Sidaní el Alfarero (núm. 163); •Clemens, filius Johannis», era Abenabdelazi\% el Hamamí (número 233); Domingo Sebastián era conocido por Omar (núm. 548); Domingo ben Suleimán firma de su puño y letra en el mismo documento alálid ben Suleimán. (núm. 109); el presbítero mair Petrus de un texto latino, es Abdelaziz hen Sohail en el texto árabe (núm. 966); «Petrus, qui dicitur Annaya», aparece en las firmas del número 969. Otras veces eran nombres moros los que habia que identificar: así Aznz, esclavo moro libeslo, era llamado Rodrigo ben Moamar (núm. 789); a Ibrahim el Tuerto, el Cojo, llamaban Domingo Rubio (núm. 1.030); Yńsuf ben Abdelaziz el Chábir, era Micacl ben Alchábir (núm. 183). Los hijos de un Yahya ben Sidabihi se llaman de apellido Juanes, porque Yahya equivale eu árabe a Juan (uím. 381); un Pedro ben Jaan ben Guálid hen Cásin, es hijo de Yahya ben Guálid ben Cásim (número 359).

$Y$ hasta en documentos latinos consta el hecho de la duplicidad de nombres; véase uno de 1115: "In Dei nomine ego Dominico Petriz, yui jta uocor in latinitate et in algariua Auolfaçan Auenbaȩo; similiter et ego Dominiquiz, qui ita uocor in latinitate et in arabia Aulfacam Auencelema, una pariter cum uxores nostras Colum. ba et Leocadia, uendimus una uinea que habemus in Monte Aurio a tibi magistro Petrus, gramatico ecclesie Sancte Marie de Toleto....., (1)

(1) Cart. 2, fol. 90 . 
Estas fluctuaciones en materia lan fundamental como cl nombre y que se man. tienen durante casi todo el siglo XII, quieren decir bien claramente que los nombres cristianos eran algo como pegadizo, puesto que en la vida tamiliar y sucial, en los casos solemnes cuando había de surtir efecto la persontlidad, habia que ad. vertir que aque] hombre era llamado de otra manera, a la arabiga.

Hay casos en que el nombre árabe, al dar la filiaclón, Heva cn la tercera generación o en la cuarta a un nombre cristiano, que debió de ser el primilivo de la familia, acaso durante la dominación islámica: Omar ben Yahya ben Gaudius (número 241 ). Cilanse mucho familias de apellido romance: como los Lampader, los PolichenI, los Albazo, reunidos en el indice onomástico final.

Usase también dar nombre árabe al hijo de un padre cristiano: Cadín ben Pedro (núm. 74); pero es mucho más frecuente dar nombres cristianos a hijos de padre nombrado en árabe: "Barlolomé jben Hamor (núm. 301); Lope ben Don Saad (núm. 638); o dar al nombre árabe la forma del apelljdo cristiano en $i z$ : Lupus Habibez ( حبيدس) (núm. 304). A veces se pone a nombre crisliano el abu árabe: Abuchil el Albañil ( $n$ úm. 179); o, aunque tenga nombre cristiano. se le añade la $\mathrm{cu}$. nia árabe: Juan Abuzeid era el nombre de un hijo de Abderrábmen ben Mesaud (núm. 147). No fallan ocasioncs en que el cristiano firme, recordando la forma ára. be: «Micael Dominico, filio de Dominico Petri» de Pedro Acem. (núm. 347); al modo crístiano, sólo hubiera escrito: "Micacl Dominiquiz.;

A veces se dan nombres duplicados por razón de oficios o cargos o acaso motes: Martín Ancuin» es jdentificado con Martin Domingo* (núm. 343); Dona, hija de Abdala ben Yabya, es llamada ‘Dona de Archaliel» (núm. 295)

323. Apellidos. - Lo corriente es usar como apellido el nombre del padre, con la terminación en $e z, i z$ : Andrés Petrez, es el hijo de Pedro; Esteban Julianis, es el hijo de Julián; Orabona Dfaz, es hija de Yaco Petriz (núm. 694) .

A veces se ve el apeilido como después lo hemos usado en España: María Vicente es hija de Sancho Vicente (núm. 531), cuando lo normal hubiera sido llamar. la María Sánchez. En ocasiones, hermanos no llevan los mismos apellidos: Pedro Ponce, Ponce Pelrez e Inés, hija de Pedro Juanes, son hermanos (núm. 609); los hermanos de Fernando Alfonso eran María e Isidro Laurent (núm. 657); Marfín Cubero y Pedro León eran hermanos (ním. 298).

324. IIjos de clérigos. - Cítanse, a veces, hijos de presbítero (núms. 33, 36, 662 y 667 ), de diácono (núm. 261), de racionero (núm. 311), de socio de Santa María (núm. 681), de canónigo (núms. 672, 1.045, 1.114 y 1.117), hasta de arzobispo

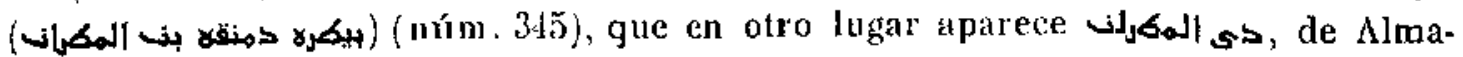
trán, como si fuera nombre de lugar (núm. 578). Una sola vez hallo citada también a la madre: Juan y su hermano Julián, hijos del preshítero Domingo Ramds, e hijos de doña María, de Benquerencia (núm. t661).

325. Filiación por hembras. - A la mujer casada, cuando se la menciona 
junto con su marido, casi sicmpre se prescinde de su filiación; no se le pone apellido ni se dice ser shija de Fulano* (nútms. 416, 417, pass.).

En cambio, hay bastantes casos en que a uno se le da el apellido de la madre, sin el del padre, v. gr., los herederos de Alí, hijo de María (núm. 249); Rodrigo el de la Navarra (uúm. 345), el ctlal era militar y fundaba un aniversario por su madre (lo que quiere decir que no era persona de baja extracción); Maria, hija de Milia (núms. 519 y 587): Fernando, hijo de María, hermana de Matea (núm. 677); Pedro, hijo de María Andrés (uúm. 681); Domingo, hijo de Columba (núm. 1.078). Alguna vez está claro quie debe tratarse de mujer viuda, que ha alcanzado relieve en la vida social: así cuando se nombı a D. Fernando Petrez, hijo de doña Eva, racionero de la Catedral (nims. 708 y 711 ).

326. Tílalos honoríficos: «mair» $y$ *don». - En los documentos más cercanos a la Reconyุuista, durante el primer tercio del siglo XII, el título de Mair o Maior (مئ - oqualia al dominus que luego prevaleció. De 1121 conservamos un do. cumento bilingïe ( nú m, 066), y en él se ve traducido a Maior Andrea * por a Dominus Andreas, "Maior Xristotori» por aDominus Xristoforus" y * Maior Agostin,

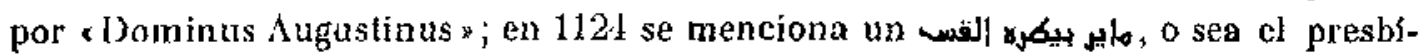
tero Maior P'etro (núm. 15); otro presbítero, Maior Abdelaziz bea Sohail, firma en 1125 (núm. 1.012); Maior Jair (núm. 966), el presbítero Maior Bahlul ben Uazlán (núm. 33 ), elc.

Alguna vez desorienta un poco el empleo del mator: por cjemplo, cuando se dice a el aiguacil maior 'Temam \$ (núm. 727), o el apreshítero maior Clemente (número 145), por el uso que en tales casos ha tenido el mayor en romance; pero creo que se trata siempre de un título honorífico y acaso deba leerse maior y no mair, como hemos venido haciendo, mes annque la íbrma usual en árabe es اير (alga-

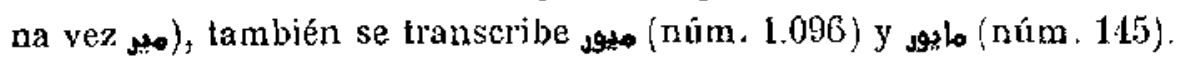

La fecha más reciente en que veo usado el Maior es en 1194 (núm. 251).

En los primeros años del siglo XII no vemos usado el don (sig - sوs) como título honorifico. La primera vez que lo hallo es en documento de 1149 (núm. 38): la monja don Eugenia y su hermana dona Cristina, bijas de 'Temam el Rotlequi, venden a don Rodrigo Muñoz y su esposa dona Cecilia; a un Raimundo, sobrino de Pedro de Tolosa, se le pone don en 1153 (núm. 44); lo mismo se hace en 1158 con el preshíhero de San Loreuzo, Domingo ben Alrim (ricún. 58). Después, a medida que avanza el tiempo, se prodiga más el don, y durante el siglo XIH se aplica a todo el mundo, siendo caso raro el no hallarlo junto con el nombre.

Al arzobispo se le llama domno (مَ's) en documento de 1137 (núm. 727).

No faltan casos en que se pone el don a nombres árabes: Don Hosain ben Amir (núm. 361), el presbítero Don Abdelaziz (núm. 421), Don Hasán ben Arrachel (número 765), Don Yaix ben Abiljáir (núm. 302).

327. Apodos y motes. - Abundan los nombres de apodos y motes, tomados 
unos de las cualidades físicas (cojo, tuerto, rubio, mudo, bizco, etc.), y expresados unas veces con nombres árabes, otras con nombres romances; otros formados arbitrariamente. lìn casos se transmitía el apodo con el apellido: Juan Crespo era hijo de Domingo Crespo (núm. 359 ).

Véase la lista alfabética de los que aparecen en esta colección :

\section{APODOS Y MOTHS}

\begin{tabular}{|c|c|c|c|}
\hline & N.O. & & N." \\
\hline Abarcardón, ابرقدون , & 377 & ¿Assanuga?, الشذوغة8, & 385 \\
\hline Abasta, & 796 & Astil Duro, اشتيل ذوره, & 343 \\
\hline 'Abenabdecubo?, ابلث عبد قده, & 90 & Azrac (ISl) (de ojos azules), اللاند,, 281, & \\
\hline Abenalgariba, ابن الغريبة, & 401 & 392,465 & 5006 \\
\hline Abidirhem, ابى كئهم, & 605 & Axxaquiq, الشقيقت, & 985 \\
\hline 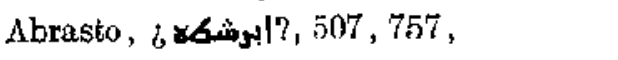 & 796 & Azzoeueh, & 480 \\
\hline 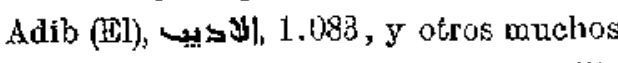 & & 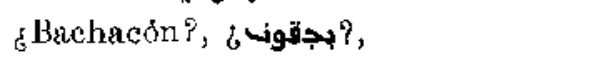 & 776 \\
\hline Afrán (El) (de larga cabellera), الافرعبرة? & $?, 316$ & Bachicos, بجية 221, 251, 296, 324, & \\
\hline Ainainfirasu (Li) (ojos vuel tos), المعينين & & $4: 6$ & 751 \\
\hline , فى راسهة & 375 & Barba Roja, برية روية, & 193 \\
\hline Alabcar, الإكى, & 971 & Bar?ut, بيوي, & 88 \\
\hline Alascar, & $B 7 !$ & Albarchiens, البرجيالنشك, & $3 \check{s} 8$ \\
\hline 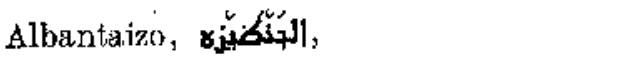 & 214 & 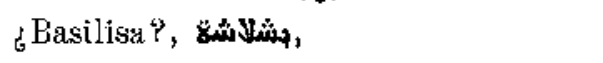 & 389 \\
\hline ¿Albarran \%, البرانس & 909 & Batato, 765 , & 996 \\
\hline Albibo, البيجيه, & 656 & Becero, بزاره, & 790 \\
\hline ¿Alboniva?, لبتية|, & 216 & Bereto, براك, & 328 \\
\hline ¿Aldokano?, الدوزئة, & 179 & Belal (E'l), البلكل, & 41.1 \\
\hline Algar, إلغال, & 160 & Belecastos, بالاقشتشى, & 283 \\
\hline Algara, $\ddot{z}_{\jmath} \mid \dot{d}_{\text {, }}$ & 788 & 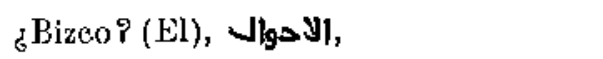 & 359 \\
\hline Algazil, الغزيل, & 939 & Iboca de Sábalo ol Pescador, sa sar & \\
\hline Aliatín, أليخئ. & 168 & شاربلة الحوات , & 678 \\
\hline ¿Aljaro fi seco?, الخراه في س|قه, & 413 & Boeach (Doningo), بكاجه, & 408 \\
\hline Almojarife dmigoso?, المشرف هشغسيك, & 628 & 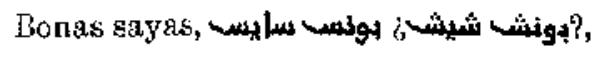 & \\
\hline 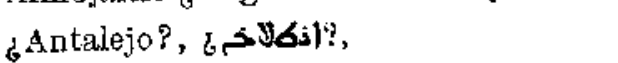 & 743 & 586 & 610 \\
\hline Aragonés, ارغوناساس & 328 & Borgán (d Barragán?), برتات & 675 \\
\hline Arillo, اريليه, & 1.007 & Bosquiri el hanat el moro, البشكيرى & \\
\hline Ardón, & 1.046 & , للحلاكا المسلم , بسقير الحذاك, & 668 \\
\hline Asfar (E) (amarill & 437 & 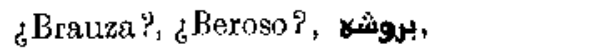 & 873 \\
\hline Asgar (El), الاصغر, & 581 & 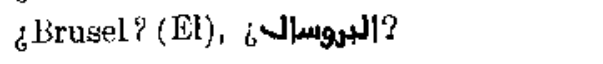 & 710 \\
\hline & 747 & 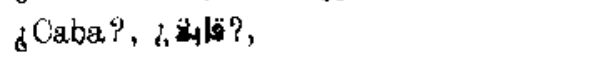 & 713 \\
\hline
\end{tabular}




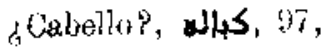

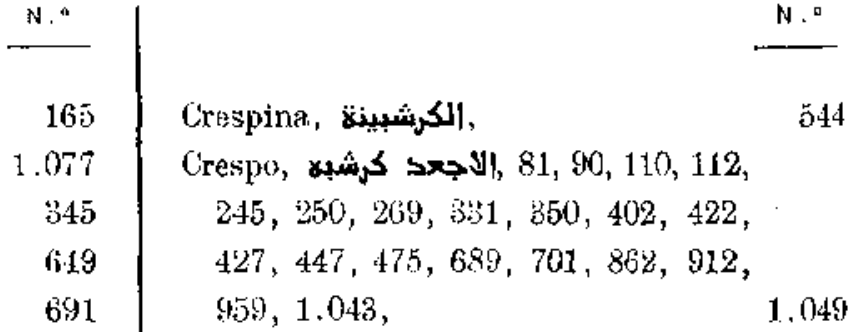

Caberalba, قبيس الجئة,

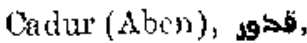

Criador,

¿Caidas?, قيدش,

Cruciato, $3 \times 0 \times 0$,

¿Calabaza?, قلبيسه,

Cubito, ت340,

¿Calaudra?, كُلودة

\&Cabo? (E1), القوية, 541, 560,

964

Calbaj, فالَبُخح,

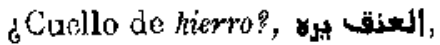

934

Calvel, قلبات , 224,

(Cusich, الكوبسيج),

645
805

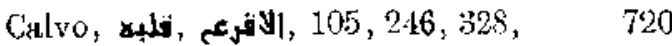

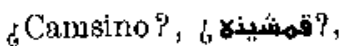

¿Alchabur?, الجيجار,

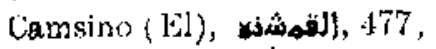

¿Alehacramen?, الجفرماذن,

675

Chafah (El), الججان

Alchamar (Juan), جوانج),

¿Canco?, قانقة 380 bis ,

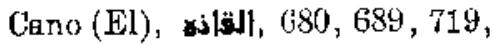

Cansina, فمشينة

407

865

74

Capocho,

1.104

671

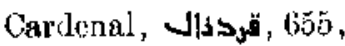

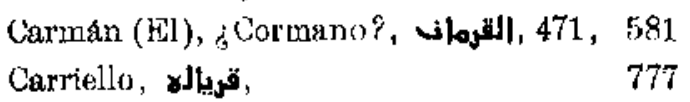

Castellano, قמشتلانه,

74

Catroba, ف3روبة,

224

Cerralbo, سرالبه.

64

Ciego, الעعهى 701, 7055,

959

Cobisa, قوبيشئ 8),

1.070

Cochit, قوجت,

192

Cojo,

951

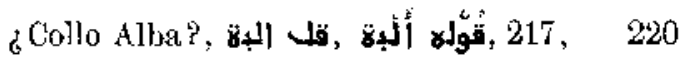

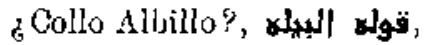

228

¿Comeno", asj,

596

Conejo, قراجة 468 ,

956

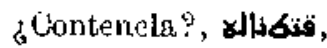

539

Cordel, ل/s 420 ,

1.049

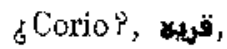

1.049

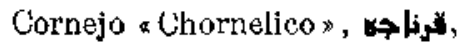

248

Corral, لهراله,

673

Corvo (Bl), القفربه,

526

Cosa, كوشة 2477.

Cosuch, قaموج,

Chico, جרيقن, 96, 244, 471, 738

dChueho?, جُوجُه

Dirhem y medio, 430,

949

Domincach, دمغقاجم, 283

Duro, ros, 549, 587, 762

Duque, الیخ,

¿Escarchir?, $\quad 1.065$

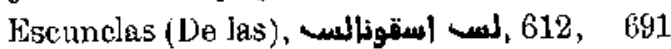

¿Espiga?,

Esquerdo, اشكرخه 10, 103, 230, 397 . $899,479,497,762$,

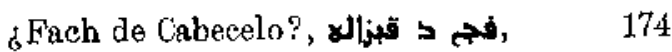

Fanegn, فغيتزة

Faura cяқаs, 145

Fecac (El), S|Soll, 729, 732

Febrero, فبريد, 380 bis

Ferrero, 762, 763

Ferrerolo, xhas, $\quad 400$

Ferro, $x_{j} / 6,253,269,366,427,449$, 494 ,

Fidalgo, لفاله, 


\begin{tabular}{|c|c|c|c|}
\hline & N." & & H.V \\
\hline Filias (De las), & 731 & Mincach, مذظج, & 819 \\
\hline Forcacho, فرقاجه, & 455 & ¿Almoabar", & $42 \%$ \\
\hline Fuero, فوإ), & 408 & 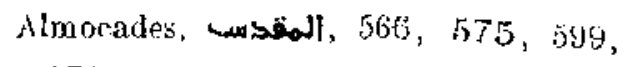 & \\
\hline Fulo, كوكلة, & 674 & 974 & $1.0 \% 0$ \\
\hline ¿Galapago?, العلبقا, & 295 & ¿ Nocrecho?, هقرجه, & EIKi \\
\hline Gallega, الغليقة, & 530 & Nochii', مجيب, & 1.024 \\
\hline Gallego, غليقه , 104, 204, 406, 498,536, & & Moeho, المجنج, & 1.099 \\
\hline $501,600,754,750,818,955,1.107$ & 1.110 & Monchcl, المنجال, & 1.0is: \\
\hline Caratelo, غ غ غ & 137 & Monje (IS), المنجم, 154, 160, 314 & $5+18$ \\
\hline dGarda Razon?, غرذ زرون, & 857 & Morato, 86 loge, & (6) \\
\hline Gurganta, غرغ & $18 \%$ & 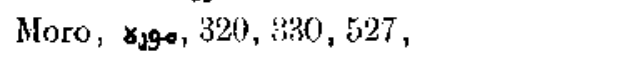 & 602 \\
\hline 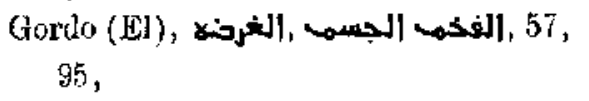 & $82 \%$ & 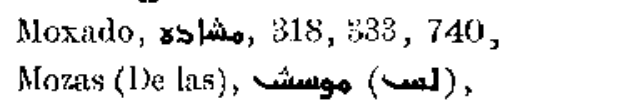 & $\begin{array}{r}1.700 \\
5,633\end{array}$ \\
\hline Grande, $\mathbf{S i}_{\mathbf{j}}$ & 157 & Mozcla, م201,401, 407, 411,513,591, & \\
\hline Haruba, ¿joroba?, حروبة, & 192 & 765 & $1.12: 3$ \\
\hline 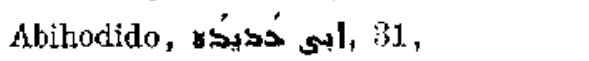 & 34 & Muchacho, oمجاجه, 415, 682, & 1. (KMi:I \\
\hline 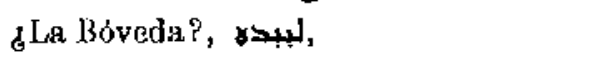 & 232 & Muda, البكمة", & $1.07 \pi^{2}$ \\
\hline Favadlo, لبدو6, & 1.044 & Navarra (La), النبارة, & 345 \\
\hline 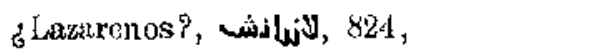 & 1.045 & Negro, $\gamma_{\gamma} \dot{\boldsymbol{k}}, 59,73,161,285$, & 9.40 \\
\hline J,echugga, الجوغة، & 551 & Prirdetal, بردسال & 805 \\
\hline 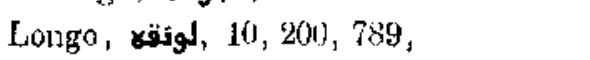 & 955 & Pardu, برذه: 524 & 5383 \\
\hline Lozano, xilogd, & 1.1103 & 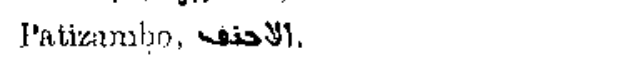 & fikj \\
\hline 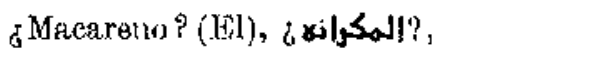 & $65 i$ & [re]lejn, & $4:(t)$ \\
\hline Macucho, مقوجها? & 333 & l'erdigucro, بردغاره, & 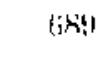 \\
\hline Madididena, $\left.8\right|_{>y} D_{0}, 637$, & 670 & Peroso, بروشه & $\pi$ \\
\hline Magam, & 397 & I'erro, $8 j$ ju & $1,0.58$ \\
\hline Malija (ولد), (عليذة (203,312,316,375, & & dPetrit?, بكريك, & 482 \\
\hline 949 & 950 & 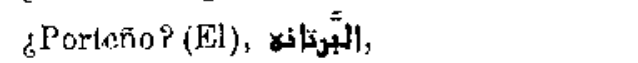 & $6 \cdot 25$ \\
\hline Marcolin, مركلين, 298, & 347 & Quewado, uslos. & 61.4 \\
\hline Marqués, مركاس", & 513 & 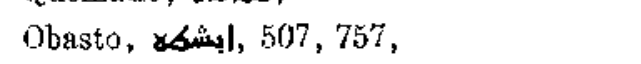 & 790 \\
\hline ¿"Mlatair'es? (El), لمكيرش), & 939 & ¿Ojos vulettos?, عيذهيه فى راسه, & $30 ;$ \\
\hline Mata Moros, & 1.054 & Orcallel, البيل & $x t i$ \\
\hline Almaxito, الهشبيكة. & 802 & Rabato, & bis (C) \\
\hline 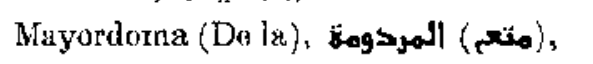 & 1.082 & Ragusón (Ii), الرغسون,, & 465 \\
\hline 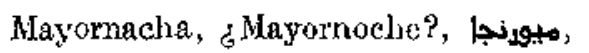 & & ¿Rasea pieles?', رشكهة بليشى, & 186 \\
\hline $298,280,394$ & 890 & Amyach, الرياج, & 1006 \\
\hline Mellado, الهلاكه, & $8: 38$ & 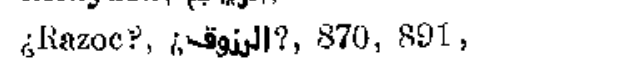 & 892 \\
\hline Mellizo (El), الاذذيفي?, & 88 & Tivehico, נجيقية , 677 , & 829 \\
\hline Merchán (EI), إلمرجلن, 655, 671, & 829 & ¿Rileno?, \& $\mathbb{V}_{j}$ & 700 \\
\hline \&Midras?, مخر|س, & 283 & Rizdaqui, נلذفى, & 111 \\
\hline
\end{tabular}




\begin{tabular}{|c|c|c|c|}
\hline & $\mathrm{N} \cdot 0^{\circ}$ & & N.O \\
\hline Romo, & 931 & Serrana (La), الشرالة), & 210 \\
\hline Rovira, & 689 & 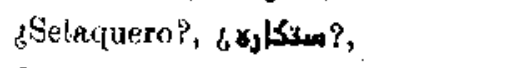 & 672 \\
\hline Rubia (La), الريبة), & 989 & Sirfis (Martin), هيnd, & 820 \\
\hline Rubio, , 145, 202, 470, 658, 821, & 978 & Sordo, شرده, & 1.051 \\
\hline 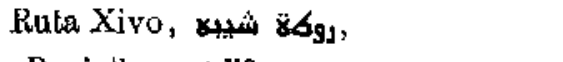 & 128 & ¿Sotaquedo", & 322 \\
\hline ¿Ruziol, \& жijl? & 88.4 & Tente Juanes, أنس يوالشى, & 847 \\
\hline Sabico, سبيكية, & 729 & 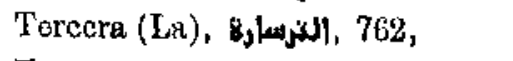 & 768 \\
\hline Sacatín (El), المقكين،", & 606 & Tercero, $x_{j} / w_{0,3}$ & 237 \\
\hline Safuro, سفوره $314,518,608$, & 751 & ¿Tórtoln?, 68 \& $6,6 ?$ & 425 \\
\hline 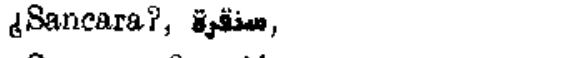 & 266 & 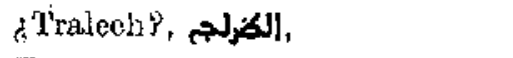 & 1.064 \\
\hline ¿Sanquero?, & 259 & 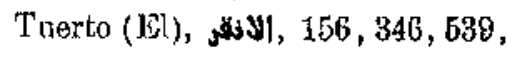 & 1.026 \\
\hline Seco,. . & 1.102 & Yamero, d usfor, 701, 959, & 1.043 \\
\hline 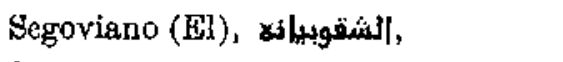 & 468 & Tanorano, سمصراله, & 222 \\
\hline Segura, شقوة $382,082,1.125$, & 1.126 & Zuncada, سنكاs, & $\therefore 398$ \\
\hline Sendino (El), الشنذينه, (647, & 980 & Zancudo, سלכלים, & 208 \\
\hline ¿Sequedo?, شئاد, & 288 & ¿Zobehot, \& هاalaj?, & 247 \\
\hline
\end{tabular}

Anotemos, después de los apodos, una serie de nombres que aparecen con la terminación $e l$, seguramente ellus latino, y que debian de tener significación des: pectiva, como indicó el maestro Codera en su Discurso en la Real Academia Espanola (Madrid, 1910, págs. 25, 55-57):

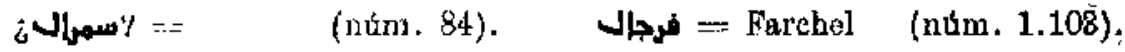

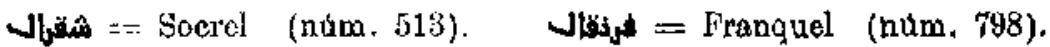

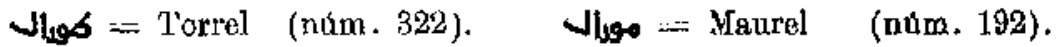

328. Lengua. - De lo dicho al tratar de los nombres se deduce que estos cristianos toledanos eran bilingües. Al principio de la Reconquista y durante el siglo XII, predomin 6 entre ellos el uso del arabe; en el siglo XIII va dominando el castellano, sin que se pierda del todo el empleo del árabe ni aun en el siglo XIV; conocido es que en documentos romances de este siglo se ven todavía firmas árabes.

A partir del siglo XIII, o fines del XII, es frecuente ver en los documentos, inmediatamente antes de la fecha, la formula: «Hecha después de explicarles a todos su sentido en lengua que entendieron y declararon entender, (núm. 1.098), o cDes. pués de habérselo leído en lengua romance * (núms. 981 y 1.104). Esta formula apa. rece por primera vez en documento del affo 1169 ( $\mathrm{n}$ (́m. 1.098), y luego no se ve hasta documentos de 1193 ( $\mathrm{núm} .1 .100$ ); y conforme avanza el siglo. XIII, es más frecuente verla.

Confieso que tal formula, tantas veces repetida, me desconcert 6 al estudiarla, 
porque la primera idea que ocurre es pensar que los otorgantes de aquellos documentos no conocían la lengua en que los redactaban, y esto resullaría extraño. Quedaba siempre la explicación de que el empleo del árabe estaría en relación con aquel precepto del fuero, que decía: rPopulator vendat ad populatorem, el vicinus ad vicinum*; o seh, la manera de demostrar que los bienes se transraitían finicamente entre mozárabes, sería escribir sus documentos en árabe; además tendrían de ese modo las exenciones fiscales concedidas en los privilegios. Pero bien estudiadas todas las fórmulas de esta clase, se llega a la conclusión de que ésta era una semejante a la que se emplea siempre al leer el docunento a Ios que lo otorgan; la mayoría de las veces dice que se leyo el documento a las partes contratantes en lengua que entendieron y declararon entender, y si es verdad que hay casos en que declaran que la lengua era la romance, hay otros en que dicen que se aleyo letra por letra, en árabe y romances (múm. 984); lo que Imbía de quedar claro es que los otorganfes se habian enterado de lo hecho y los testigos de lo que iban a firmar.

329. El arabe, - La lengua empleada en estos documentos es siempre el arabe, aunque con notorios vulgarismos, lo que nos prueba que cra hablada a la vez que escrita.

Hemos dejado en la transcripción del texto árabe los vulgarismos y malas graflas, v. gr., la supresión del hamza cuando se hubiera requerido; el empleo de alif de prolongación en vez de ye de prolongación; el uso de la ta de femenino por $\rightarrow$, y otros frecuertísinos.

Entre otros vulgarismos, podrían anotarse:

a) Uso del $\mathbf{S}$ como preformaliva delante del fulwro.

Donde degüiellan los carneros, حيث كتخديم الكماشش,

كيجذها:

961

كياكذ, كيريح, ,كيناجر,

كتكونى,

log sons,

b) Uso de las particulas $\mathbf{s}-\mathbf{s}-\mathbf{b}$ $y$ on lugar del régimen de genitivo.

Es $\tan$ frecuente, que no he tomado nota de los ejemplos. Do las veces más antiguas que se omplear متك as en el numero 193. c) Empleo de particulas en forma distinta del arabe elásico.

التهال الذي كانه الى ريمند اشتىى ,الى

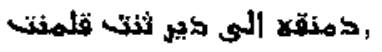

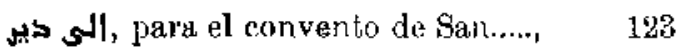

الى 198

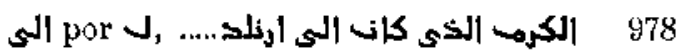

7الى

الى 1.0570

er por 1.057

a) Empleo de letras $(1-9-s)$ donde el árabe usa mociones o vocales «fatha», «damma» o "quesra».

loagl por lob su madre,

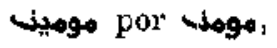




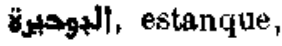

المسلمة por musulmana,

e) Supresión de algma letra caracterisica en la flexión.

الدار •

f) Camtjio de letras que sutenan lo nismo.

مفلمى (do abajo),

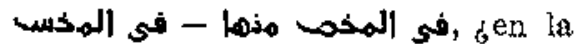
parto peor de Map (Tierra), 926, 527

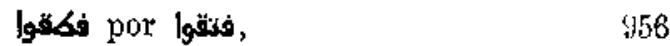

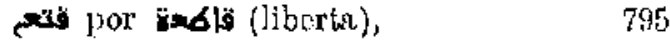

g) Empleo anómalo de los pronombres.

stol por sol, «delante de nt", 1.087

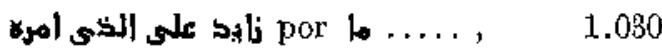

Anotamos algunas que no figuran en los Diccionarios árabes usuales:

\begin{tabular}{|c|c|c|c|}
\hline & N." & & N. ${ }^{\circ}$ \\
\hline 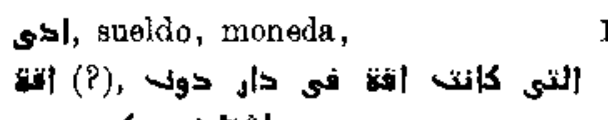 & $1.01 y$ & 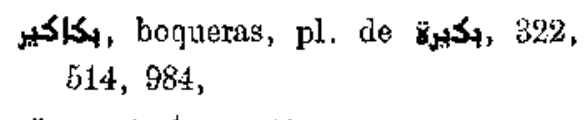 & 988 \\
\hline | أشتاينف بيكربس & 673 & 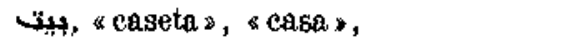 & 122 \\
\hline اللوانى, pl. relativo fem. alas que», 170, & 923 & بيوتى, chozas, casa en el campo, & 250 \\
\hline 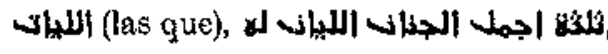 & 3, 368 & 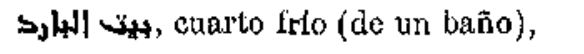 & 987 \\
\hline 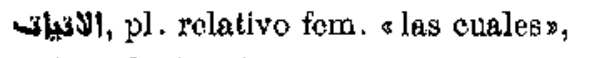 & 740 & , بيتت سجونت , habitación caliente (de un & \\
\hline 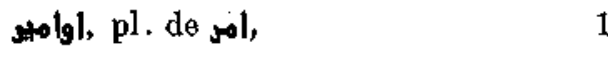 & 1.004 & baño), & 987 \\
\hline mol, capellán, & 1.022 & إيكا سخذ & \\
\hline البهيرة píscina (de un baño), & 987 & casa, & 583 \\
\hline تهريح & 960 & & \\
\hline Sus, calciera (de un baño), & 987 & un bañol, & 987 \\
\hline
\end{tabular}




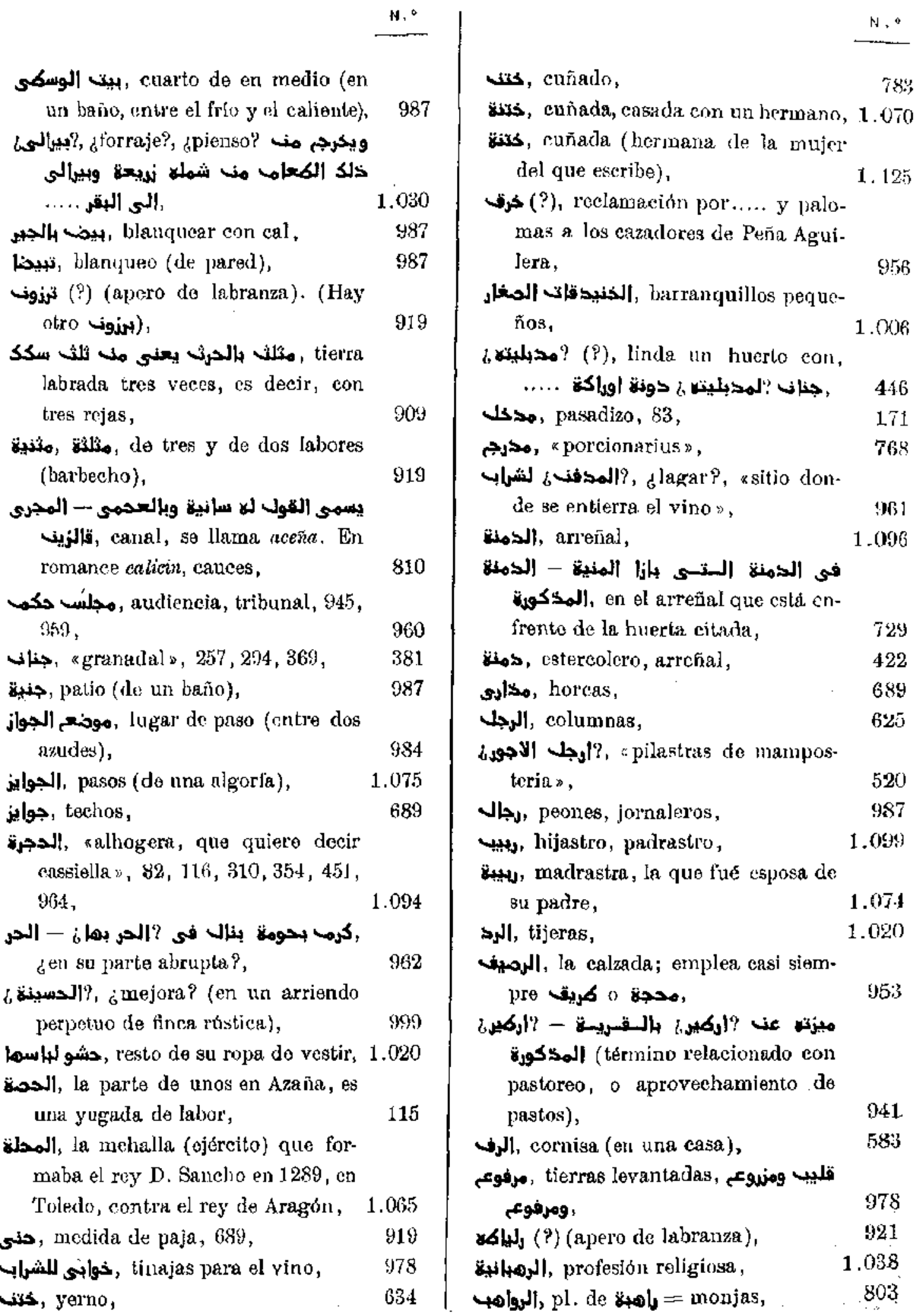




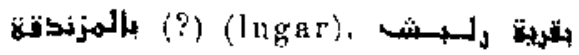
, بالمزندقة

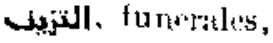

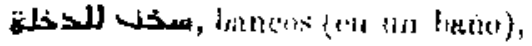
¿.

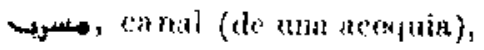

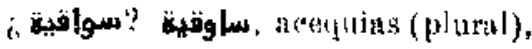

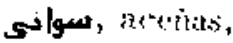

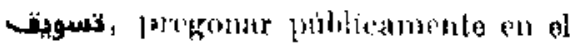
zeren,

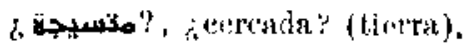

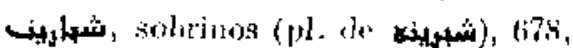
$693,7(0)$

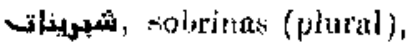

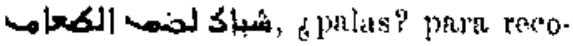
ger ol trigo,

, an el barrio do San Cristibal en ..... en ella.

شريس , sirtio, ha hecho sernicio, vertoo bo de origen romatre". - ش

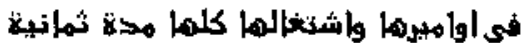

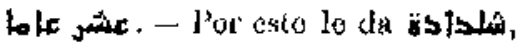
soldala anual,

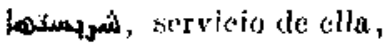

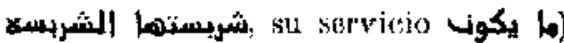

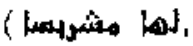

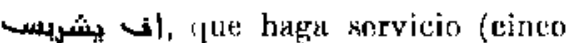
ถ กัos),

, sirsa .....

1.034

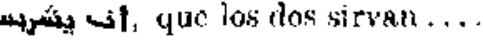

sullik acetres (plural), 432,433, 384,

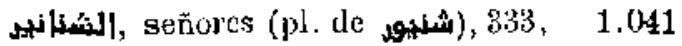

solikil, mezacir, cantidad que un efelavo debia jagar cada mes por su rescate,

4ha (?) (apero de labranza). (Hay otro (شt),

16وش, sótano, 63, 128, 138, 548,

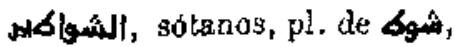

squ, soto,
6)

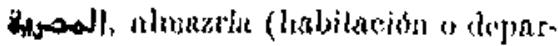
camento suporior Rislado). $-\times \mathrm{Al}$.

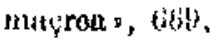

tabal, ostablo,

So, dpor Sw, camino?,

i. .008

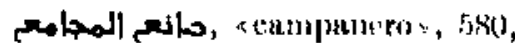

boi

sow, yerno (de doña Atilin, mariclo do doìr Minri, lija do doña siliar).

sas, yetne (de Murtin do las Mizan, casado ron Mltrina, hija do Mar. (in),

$56 ; ;$

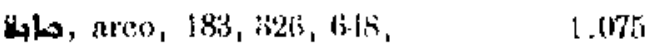

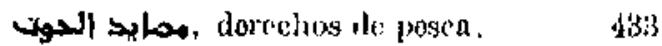

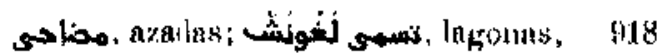

مضربة tojwí,

Hb, niño (menor),

silgo, hapias (18l. do salk),

962

on almadias? (en un aziad)

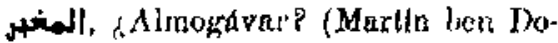
mingo Juanes ben.....), $\quad 1.064$

Yjobl, habiención alta, $\quad 668$

4te, fuchada (clo una casa), $\quad 987$

whe majuelos, 47

(الكرئ carta empeionis sunius inajolit s,

273

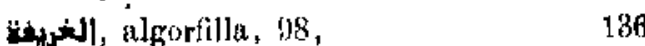

غ aigorfa, \& gobrado*, 138

ijl, algorfas, «sobiadillos» (phural de Bastil|),

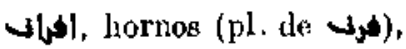

idl ba, nared do Gvallas" (do una viña),

4\%), cupulas (do un baño),

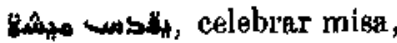

*ank, entierro. (Para los gagtos de los rezos el día de su ontierro, $10 \mathrm{miz}$ cales),

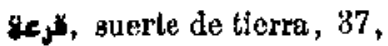


un pariente, por la entrega de cinco sueldos y una medalla,

إلقيكاع, moneda,

ملبه, labrar, dejar de barbecho una.

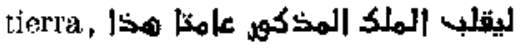
rasts

قلأبيب, barbecho, 363 ,

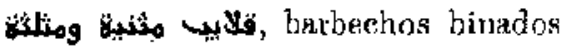
$y$ terciados,

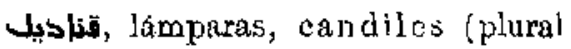

de (تخديل ),

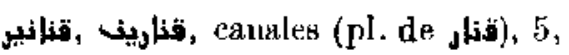
$322,754,984$,

(?), yugos on sus ....,

(?) (eubo) y .....,

كبنوان (?) (apero de labranza),

ن̈, nuera,

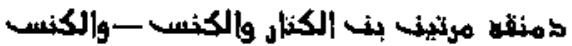

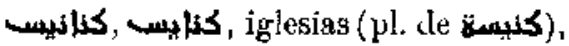

1.012 ,

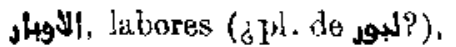

تلبيس revestimiento, enlucirlo de pared, 987

خلذs, alifafe de jalde,

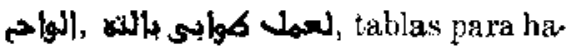

cor tapins, con sus instrumentos,
1.024

1.030

1.019

1.029
$N, 0$

list? (P) , . . . encima de la habitación de la botica de Beni Sálih, incluida en la ventin del 561, $\quad 561$

مرأس , cuerdas (tiros), 689

مكريج, matriz (acequia principal),

$590,968, \quad 1.041$

هذاsيل, manteles (1pl. de مكذيل), 1.175

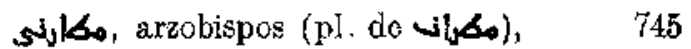

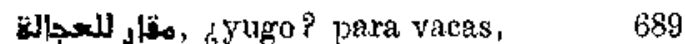

مoل, esclavo. Casi siempre 987

مبأشين, mesones (pl. de ميشون), : 742

ميجون , mesŏn, 902

ميجونين, mesones, $\quad 978$

مجاجين, mesones (pl. de ميجون), 1.099

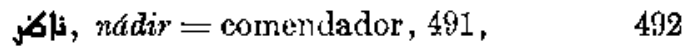

مذكّر (ascoplo, $\quad 689$

نقاف (apero de labranza), $\quad 921$

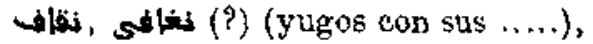
689 .

Whl, horederos (pl. de \& $\$ \log l ?$

1.007

(Vianse, ademais, las listas de objetos de los rums. 371 y siguientes.)

Algunas firmas o palabras árabes, escritas en romance, dan idea de la pronun-

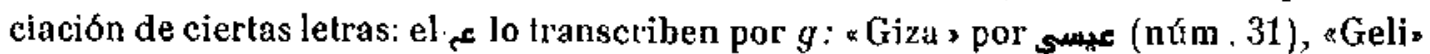
por على (núm. 20), "Garab" por (núm. 94); aunque una vez vemos $h$ : "hua cu-

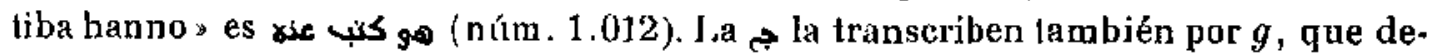

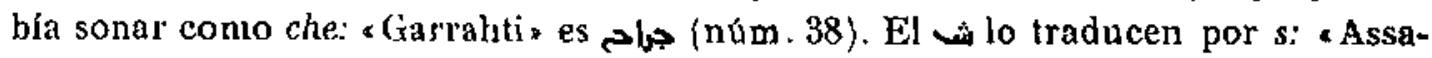
rag de الشرى compra (núm. 342). El Iا se debra pronunciar con alguna aspiración: * Haberáa * es transcripción de sul, libertó (número 792).

330. El estilo. - Fin general es el narrativo, propio de escrituras notariales, que se sujeta, en su mayor parte, a fórmulas jurídicas obligadas. Pero a veces, po. cas, por desgracia, se pone en boca de un personaje el relato de un suceso del cual da testimonio. Modelo de un relato en estilo llano es el número 572.

En otras ocasiones se reprodace el diálogo, al dar fe de un sncedido: así, el testigo que declara baber visto verificar un cambio de fincas, dice haber oído de uno de 
los otorgantes preguntar al otro: - - CComo nos las arreglaremos con tu esposa? Yo desearía que me lograses su aprobación en este cambio, porque temo que se oponga a ello. * Y que el interpelado respondía: „- No tengas miedo por causa de ella: yo conseguiré que te apruebe lo hecho, y si quisiera oponerse, la haré desistir de su propósitu: me obligo a ello * (núm. 806, B).

También se ve muestra de este estilo directo, en que se repite el diálogo de los personajes, en algunos documentos que son convenios o actas judiciales (nums. 944, $947,954$ y 975$)$. Es curiosa la referencia del diálogo sostenido, antes de 1173, entre el arzubíspo D. Juan, oculto cicrto día en la alquería de Cabañas, y unos labradores de Canales, que iban con D. Félix Negro y D. Julián alcalde de Canales, a suplicar al arzobispo merced para Inlián de Casa Chica, que ocupaba esta alquería (núm. 993).

Acaso el relato de esta clase más ingenuo y sencillo que nos coloca en mitad de las calles de Toledo a fines del siglo XII, y nos hace escuchar una conversacion junto al Pozo Amargo, es el que trae el núm. 1.001. Oímos nosotros, como oyeron los testigos que declaran, a un Domingo reclamar a Sancha Juanes siete mizcales y cuatro sueldos que le debía, y a ella contestarle con buenas palabras para lo futuro. El acreedor la aprieta para que señale fecha, y la deudora da la de fines de mes. Pcro el acreedor duda, y exige algo más que palabras, tantas veces repetidas y nunca llevadas a término; Ia mujer se quita su manto de escarlata y se lo entrega al acreedor como prenda; pero él, generoso o condolido, le devuelve su manto, aunque advirtiéndole que, si no hace efectiva la cantídad adeudada, se verá obligado a tomar el manto y venderto. Y la mujer lo autoriza para hacerlo, sin necesidad de orden judicial y comprometiéndose a pagar la calonia que hubiese. Ni aun entonces debió cumplir su palabra la tramposa, por cuanto en el mes de Febrero siguiente el acree. dor había dé apelar a este testímonio.

Impresionante es el relato de inn testamento verbal, hecho por los años de 1232, en la alquería de Aceituna, por María Domingo; postrada en su lecho de muerte, es requerida por el marido para que mande su última voluntad, $y$ ella contesta: *Todo lo que yo tengo es tuyo, pues tí lo has gadodo. , Dispone algunas maadas para su fragios y para la fábrica de la Catedral, y dice a su esposo: «El remámente de mis bienes, pocos o muchos, que sea para ti, como donación que yo te hago, y que nadie se oponga a ello, puesto que tí lo has ganado.s Y luego oyeron hablar a la enferma de una gran tragedia de su vida, cuyo recuérdo tutrbarfa su alma puesta al borde del sepulcro: habló de la muerte de su hijo, muerte violenta, cuya responsabilidad parece alcanzaba a un Fernando, portero del convento de San Clemente, y delante de los testigos dijo la moribunda cristianamente: * Yo lo perdono.* El testimonio recoge sencillamente aquel acto de generosidad (núm. 1.027).

Otras veces el relato envueive noticias de disgustos domésticos, de relaciones entre suegras y nueras, cambios de disposiciones testamentarias (núm. 1.032). 
Y no falta el documento de redacción pedantesca y oscura, en fuerza de querer ser literario (num. 923).

331. El romance. - A la vez que el árabe usaban los toledanos el dialecto romance; pero como apenas si lo escribian, es difícil hallar hoy sus caracteristicas. Por tanto, resulta de interés recoger las voces romances que aparecen en estos documentos, transcritas siempre, excepto algunos nombres propios de firmas, en carncteres árabes, o sea, un verdadero aljamiado.

Tres grupos principales de voces romances pueden anotarse: uno formado por nombres propios de persona: en el índice onomástico final damos la lista de los nombres disados por lов mozárabes; otro constituído pen nombres de lugar, cuya lista alfabética puede verse en el índice topografico de este volumen; y el último lo integran las voces comunes intercaladas en el texto de los documentos. También he recogido las voces romances o latinas, que figuraban en documento original con ca. racteres latinos, y aparecen on las copias con caracteres árabes; estas palabras con tribuyen muchas veces a fijar el sỉstema gráfico de transcripción usado por los escribanos.

No repetiremos aquf la lista de nombres de persona y de lugar, en otra parte del libro registrada; sólo dainos la lista die voces comnnes, toojo lo completa qun nos ha sido posible, incluyendo aquí los nombres propios, escritos originariamente en romance o latín, pero conservados en copias árabes.

\section{LISTA DE VOOES ALJAMIADAS}

$$
\text { (LATIAB Y ROBANOEB) }
$$

\begin{tabular}{|c|c|c|c|}
\hline & N. ${ }^{\circ}$ & & $\mathrm{N} \cdot \cdot^{\bullet}$ \\
\hline 1, abadcsa, 429 , & 580 & \multirow{4}{*}{\multicolumn{2}{|c|}{ 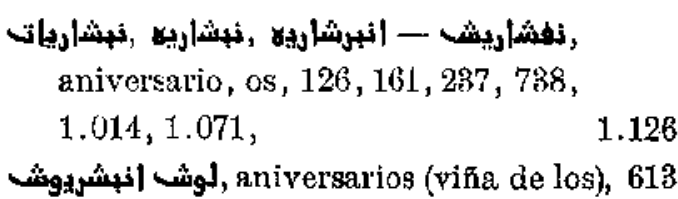 }} \\
\hline slbw, acetres, & 322 & & \\
\hline 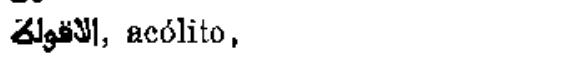 & 942 & & \\
\hline 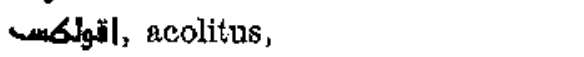 & 942 & & \\
\hline اغذاش, Agnes, & 731 & 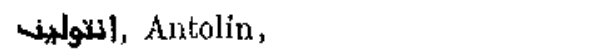 & 168 \\
\hline الجي الهزب , Albar Alvarez, & 802 & 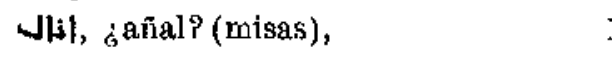 & 1.027 \\
\hline 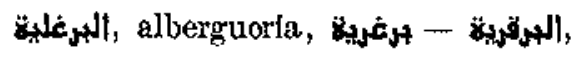 & & 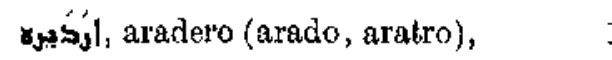 & 1.062 \\
\hline $119,187,662$ & 1.028 & , dالونشدنيف. , daranzadas?, dos, & 559 \\
\hline القبالة, alcabala, 910,911 , & 915 & 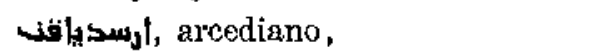 & 130 \\
\hline الذعفويه , aldofoyo, & 540 & ارجخئاقتت & 126 \\
\hline ¿ról?, samo?, & 498 & ارجهياقنش , archid̉iaconus, & 941 \\
\hline$\checkmark 6 \mid a-31$, anfidiato (ahijado), 729, 1.012, & & 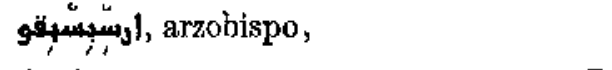 & 941 \\
\hline $014,1.015,1.018,1.020$ & 1.033 & Areipreste, & Passim \\
\hline
\end{tabular}




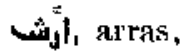

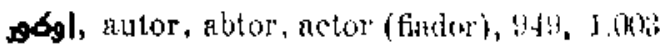

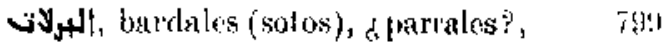

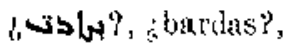

, براذّة , barrona,

برنونشو, barzones,

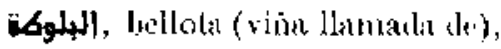

, bodega del vino,

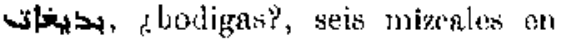
.... para los funerales de su entierro,

arbs, botica, 561,717 ,

1.111

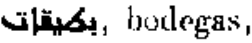

لقابليد, caballero (cl),

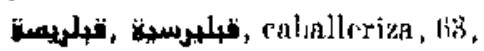

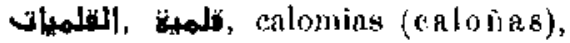

836,863, , 109, 015, 9:49,

"لنح , calouche (en Santa Marla),

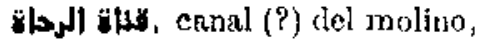

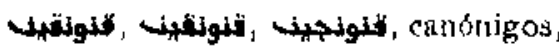

, capellaniaria?,

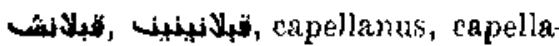
nes, 714,744 ,

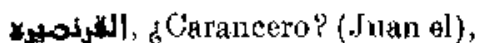

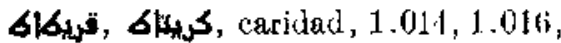

1. 020 ,

1. [Ro

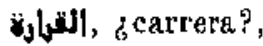

1.0128

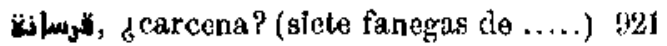

ر|lil, casar ( $\theta \mid)$,

6gs, 6tigl, cautum, multa, 839, 840, $842,843,814,846,849,850,851$, $852,8502,854,855,856,857,858$, $860,861,862,863,864,866,868$, 873,894 ,

shijl, Cebreco (ol),

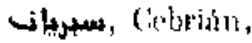

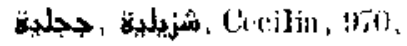

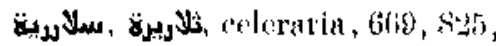

I. 1968

, Clelles",

828

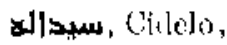

B 87

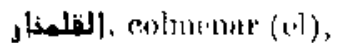

2

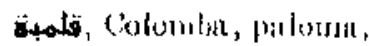

1. $(169)$

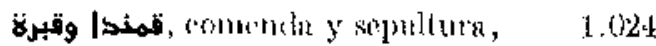

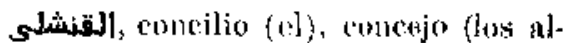

[maciles y i)

90

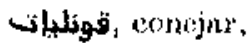

Niso

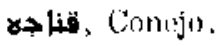

sis

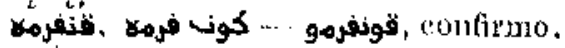
21 is, 731 ,

9.12

然

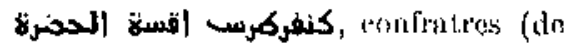
Iss frestiteros de ln ejuldnd) $\quad 1.080$

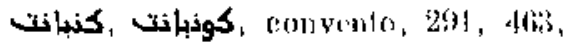
187.

8jat, colpero,

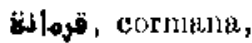

bot $\left.\right|_{0,3} \mid$, cormanos (Bus), primos hermanes,

الئيجرة cortijo,

061

قشفليار, coscojar (sondrri al),

508

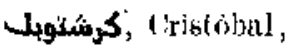

168

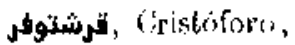

212

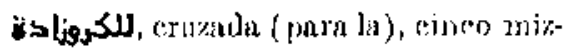
cales,

S, cutho,

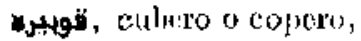

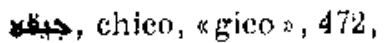

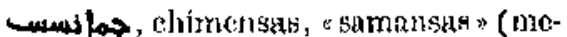
dida de losas, de conejures), 459,

Ib, do, casi siempre usan s's, st, s, 904

Withs, diaconus, 268

דorinico, 37

هis, Jominticls, 112

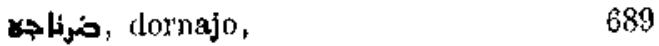

ujlg , dueña, 11

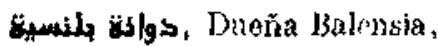


לانة Dueña, hija de Ábdelaziz. En el mismo documanto 8 sig.

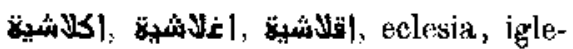
sia, 212, 744, 802, 941,

اقاكه , ego, 168, 946,

إيوشت sاهي

الكخّة, decto,

أذتذاكة, entenata,

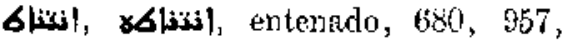
1.035,

اشكرئibano:

1.076

ها لئهlalia,

اوجانية , Eugenia, 25, 256,

اوجأنيوشي , Eugenius,

الفامة. haza (la),

فلجيج, Feliz (usual, فليسط),

هرنفه: Fernandus,

فيلى , filii,

فليشى, filius,

فولورنسية , Florencia,

هرناج, fornacho,

ألرن, forno, 300, 698 ,

الفولد, foro, concilio, tribunal judicial.

(D. Vjecnte, reclamado en pleito, * lo negaba ante el foro $)$,

ثرايلى , fraile,

افرايلينس, frailes,

الفوإير, freile,

19., fuero,

نغ gawella,

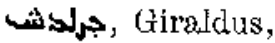

جذاشئ, Gines,

تليله, Gillem,

غهلمه Guillelmo, Guichelmo (Pedro), 340

غذهالبو, Gonzalloo, 641,

1.125

لllst, hospital,

لافil, Infante (el),

نि1, isto,

شواوش, ¿jabeos?
الجيان. Jaén,

يوانى, Juan, 55, 1.014,

جواذشي , Juanes, 72, 79, 1.016, 1.017

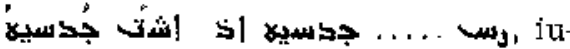
dictio,

جليان, Juliản, 11s, $\quad 1.096$

جليانس , Julianus, 2, 328

الجيس, jus (derecho), $692, \quad 720$

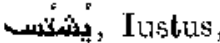

id

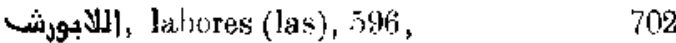

sل, las Ijlias (de),

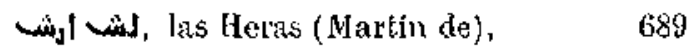

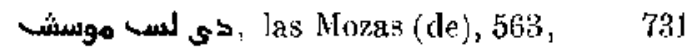

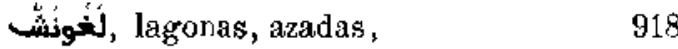

لوقية), I,eocarlia,

لب. J.ope, Lop, $\quad 550$

اللوشير

(3), losas, 458, 459, 494,

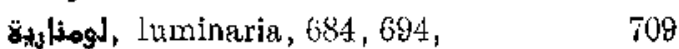

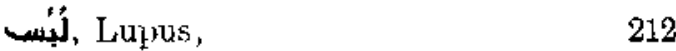

مبيشانرك, maestro, 373, 182

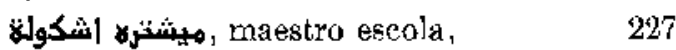

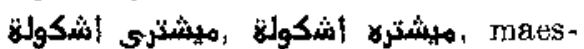
trescucla,

"Maiolo Sancii *, $\quad 57$

s/o, maior, 928, 966

مينوين, mayordomos, $\quad 775$

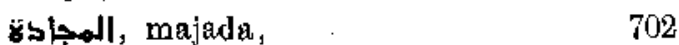

مخاوشي, Mateus, 380 bis, $\quad 1.022$

Matrino?, 701

منالية ,مدالية الئة

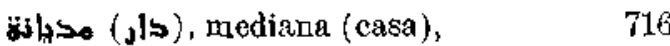

ملانكى, Melendi, 946

ميجون , ميشون , سيخد , wesón, 55, 77, 99, 100, 103,111 , 113

مقيالدي , Micaelis, a Forrand Migael ", 550

منشكرية , monasterio, 731

هillonacello?, 1.131

الهرتورون (mizcal del), 1.030

Muelas, molas, موالش (بيالة) , مولث)

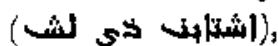

682 
14i, dnicta?,

8̈j, nuera,

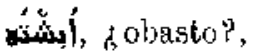

1. 0.32

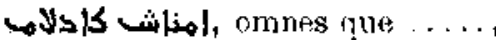

Onfidiato, a; onfiliato, a (ahijado).

Véase anfidiato.

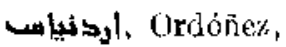

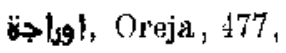

1.013

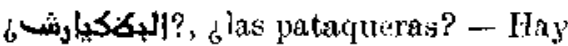
sembradas 25 fanegas de trigo, un cahiz de cebadi, exeepto.....

sar, Paulo,

هرئite perteguero (de la catedral), (j)ortelos,

8, بيtro, 26, 108,

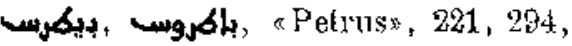
296,380 bis, 404, 732,

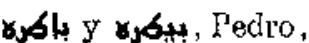

1.049

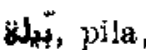

1. 049

689

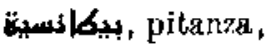

1.084

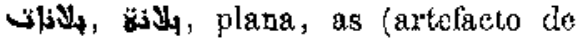
noria) , 432, 433, 914, 984,

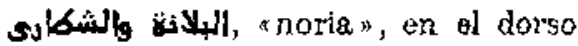
del docnmento

, porcionarius,

ألجرته , porto,

4, pozolo,

preboste,

بردئن , predicti, 714,

, presbiter, 168, 221,

"رشختهم: préstamo,

8xy, prima,

6lasp, Primado de España,

, primo, 603,

ألبريورة, priora, 487,

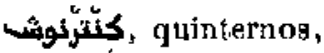

الهينة (Rabino? (viña del),

, racionero,

sist, refitor, 354 ,

4.59

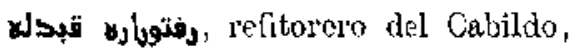

"Reliceturero",

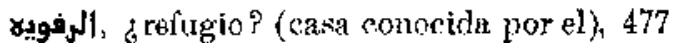

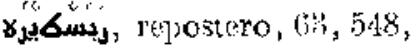

898

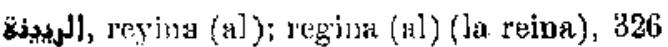

هي

322

شئبيا

941

شقريسكانة sacristin,

580

إلشطوبرتين salohres (las dos fuenteci-

lias),

1.000

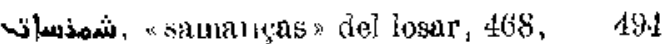

شيون, sayón (lie la cofradía de Santa

Marin),

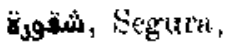

شمركرين , سمكير , sendero, 05, 73, 114, $142,222,237,345,505,512,567$,

$568,571,596,930$.

1.006

, شئل, seliores, 1097,

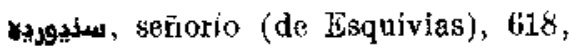
620 ,

شريلنش , شرباتوشي, Servatus, 936, 937, 938

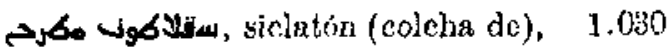

شرينة , soldino, a, 69 ,

123, 209, 210,

858

8े >lat, soldada, 957

ش, soror, 731

731

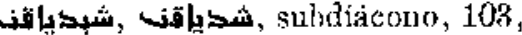

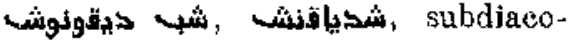
nus, 946,

السببريورة|, sulpriora (la), $187,58 \%$,

إلشيبةارية, subvicario (ol),

شقرة suegra, $98,109,181,531,556$, $645,748,829,901$,

شقر, suegro, $506,590,632,657,701$, 962,

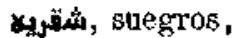

1.028

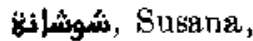

731

, tesaurarius,

988 


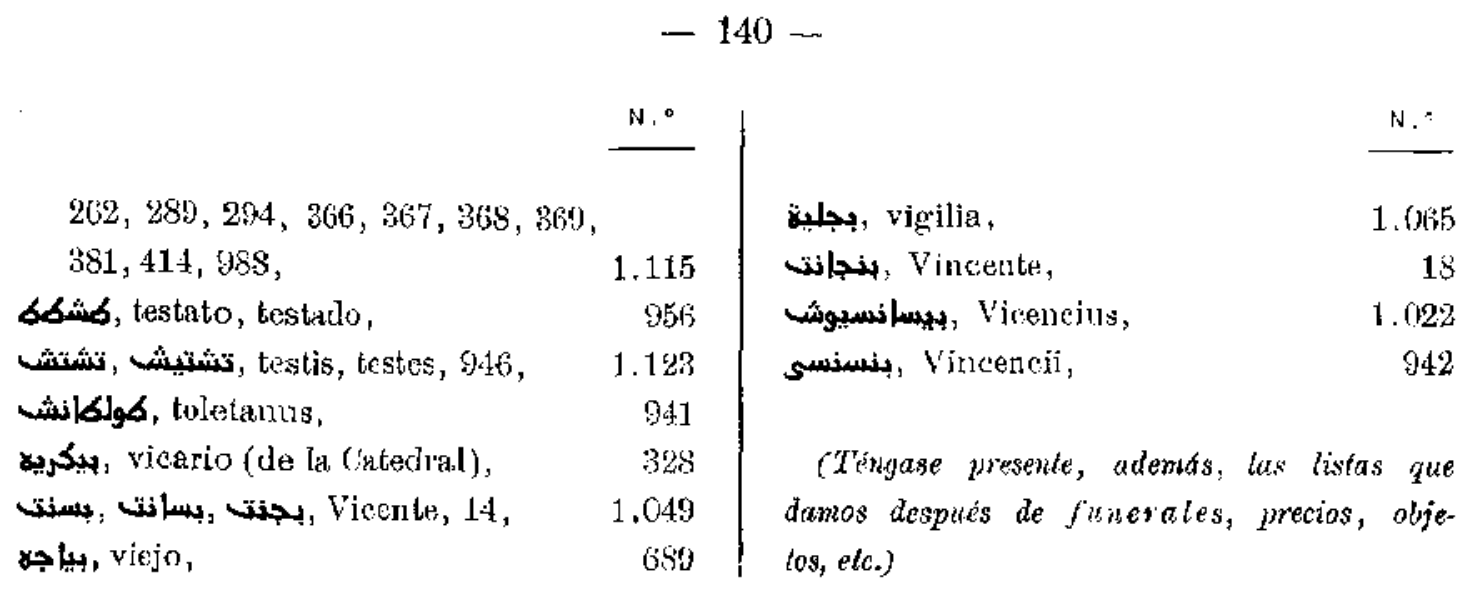

\section{3) L.OS FRANCOS}

332. Ya hemos visto cómo Alfonso VII, en su privilegio de 1118, trató de unificar la legislación para las diversas razas cristianas que vivían en Toledo, e incluyó en su privilegio a los francos.

Eran éstos los descendientes de los que ayudaron a Alfonso VI en la Reconquista, que se establecieron en la ciudad y debieron ocupar el barrio central, Ilamado Arrabal de Francos, cuya delimitación queda reseñada atrás; aunque, naturalmente, no todos vivirían dentro de aquel barrio, pues vemos citado a un Francés de Zocodover (núm. 179).

A fines del siglo XI, en 1093, ya vemos a uno con casa en el Pozo Amargo (nú. mero 3). Y no tardan en sufrir la influencia mozárabe: en 1095, o sea, diez años no más después de la Reconquista, ya se cita un Abdalá ben Chelabert, un hijo de franco que ha tomado el nombre árabe (núm. 4). Y que no debió de ser circunstancia aislada, lo demuestra el hecho de ver alguna otra vez nombrados a estos francos con nombres árabes: un Yahya ben Temam firma en documento de 1182, y el escriba cree necesario identificar su persona y dice al pie: «Es gascón del Arrabal (número 160). No es infundado penser que no sería sólo este caso, y es posible que detrás de muchos nombres árabes hubiera francos de origen en lugar de toledanos.

Damos la lista de los nombres de francos citados en los documentos:

\section{LISTA DE NOMBRES DE FRANCOS}

Alardo,

$-\mathrm{N.}$
75
1.104
$980 \mathrm{bis}$

Armengot,

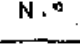

Almeric, 346, 655, Arnaldo 'I'olosano,

Anchevin, Astor Sequín, 


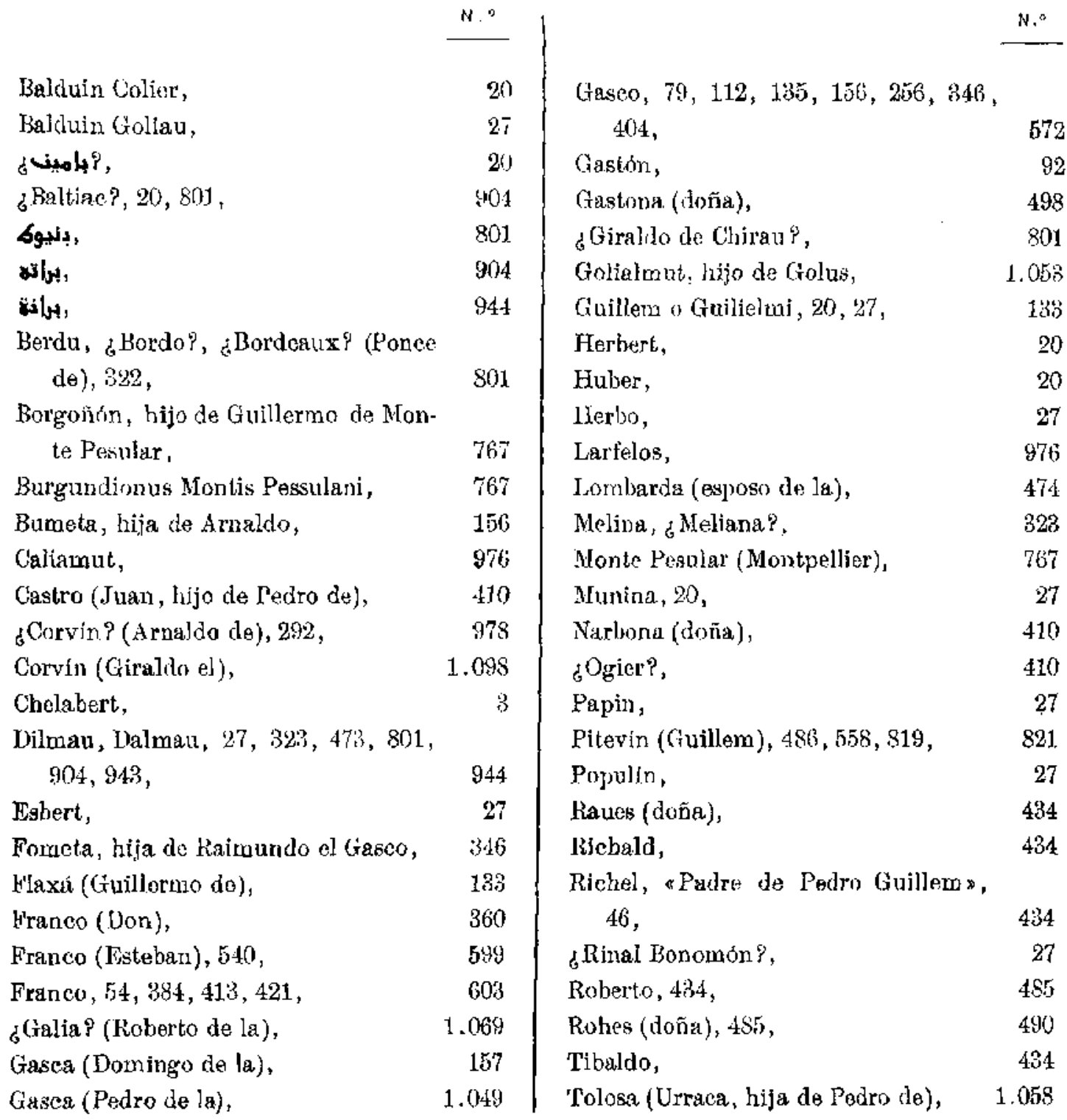

Tenían los francos una albergueria, en el barrio de la Catedral, no lejos tel Matadero, que servía también de hospital. El año 1192 fué malo y estéril; la multitud de gente que acudio a la alberguería, el amontonamiento de enfermos y desgra. ciados fué tal, que la casa resultaba estrecha para tanta gente: y hubo la cofradía. de los francos, directora de la alberguería, de rogar al Cabildo de la Catedral que les cediera una casa contigua para ampliarla; los canónigos se allanaron, y recibie. ron a carailio de la casa cedida otra en el barrio de Santa Maria Magdalena (nú mero 801): notase la lista de personas que asistieron a aquel acto, en representación de la Cofradia, que serian los directores (ميف:

La Cofradía de los francos poseía en 1224 un meson en Santa María Magda- 
lena (núm. 474). Y doña Matea, viuda de D. Gonzalbo ¿lRechico? el Peletero, residente en el Arrabal de los Francos, dejaba en su testamento (1282) 10 mizcales a los cofrades de la Cofradía, más el escamno en que ella dormfa, una ¿xádica?, una Gkesia? y un cabezal de lana, para que sirviese de cama en la alberguerfa, y dispuso que se vendiesen la cansadera de su cama y las almohadas y con su precio se comprasen ropas para una segunda cama en la misma alberguería (núm. 1.035).

\section{C) JUDIOS}

333. Otro gran núcleo de población de Toledo lo constituían los judíos, establecidos y arraigados ya desde la época visigoda y durante la dominación musul. mana (1). Por los dfas de la Reconquista se ve citado un liabi Buishac ben Nehe. mias, de la familia ilustre de los Nehemías o Nahmias: el año de 1083 compraba una finca en la alquería de Zalencas, en docunento otorgado s segín la ley de los musulmanes (núm, 1). Por 1110 otro judío, Yúsul ben Yaix, vendia a Martín el Arcediano (nútn . 6).

El fuero de 1101 ya señala qué calonia corresponde a la muerte de un judio, equiparándola a la de un moro. Siguieron, pues, en Toledo viviendo libremente los judíos durante el siglo XII, poseyendo fincas rísticas y urbanas, y disponiendo de ellas a su albedrío.

Donde más judios aparecen, en nuestros documentos, es en las cartas de préstamo (aparte de la serie inclúda en el Apéndice II, tomo III, de documentos liebreos). Se Jes llama de ordinario con la voz Israell, aunque hayamos registrado alguna vez la forma Yeludianí ínúm. 1.069).

Poco se puede vislumbrar de la organización politica y social de la judería toledana en estos documentos, casi todos de carácter meramente particular. Vivían en barrio aparte, atrás descrito minuciosamente. Había entre ellos un alguacil llamado el de los dos alguacilazgos (núms. 279, año 1197). Se cita más al alguacil, simplemente, cargo desempeñado por Abuomar Sosán (núm. 290), por Abuomar el Barcelonés (núms. 639 y 1.083), por Abulrebia ben Sadoc (núm. 710). Debían de existir varias chases de alguaciles: el alguacil alhaquim o gobernados, desempeñado por individuos de la familia de los Nehemías (núms. 680, 719 y 862), de los Barcelonés (números 530 y 637), de los Éstaleha (núm. 579), de los Ábencebra o Abenziza (nú. mero 945); éste debía ser el director político de los judíos; el alguacil almojarife, en-

(1) Vúze Graetz, Les juites d'Eiplagne, Parts, $187 z$. 
cargado del almojalifazgo o aduauas, catgo que vemos desempeñado únicamente por individuos de la familia de Sosán (núms. 277, 280, 358, ete.); alguacil sahibazorla, desempenado (1192) por Abuharúm ben Allarits (oúm. 1.055).

Empleaban preferentemente el árabe en sus documentos, hasta el extremo de redactarlos en árabe con caracteres rabínicos, dando lugar a los curiosísimos que forman el Apéndice II (tomo III), en que están mezcladas lás palabras do las dos lenguas. Las copias de muchos documentos están legalizadas por el Tribunal correspondiente, dentro de la legislación talmúdica (núms. 1.134, 1.135 y 1.137).

Son frecuentes en los documentos mozárabes las formulas de respeto, al nombrar a un judio, v. gr.: xje ols (núm. 331); y a veces son tea rimbombantes como las empleadas con las personas de más relieve entre los cristianos, sin excluir al propio arzohispo; véase como muestra las puestas al nombrar a Abuomar Sosán, alguacil almojarife: الموزي إلاكمل المهشرف الاعز الافخذل , lo cual quiere decir que en Toledo eran considerados los judíos, especialmente hasta la segunda nitad del siglo XIII.

Judíos representaban al convento de San Clemente en Toledo (núm. 432 y 442) y en Talavera (núm. 448) y al propio arzobispo D. Rodrigo (núm. 564); con judíos cambia fincas el convenlo de San Clemente inúms. 802 y 803); a judíos compran cristianos (núten. 258); a judios hasta los heredan cristianos, coino Esteban Mllán liered6 a Ell ben Talía en 1254 (núm. 1.143).

Ć́tanse entre los judíos algunos oficios manuales, como sastre, herrero, hornero, etc.; alguna vez se les ve ejercitanda la plantación de viñas (ú́m. 80). Pero de lo que nos quedan más docamentos es ie la actıración de lns judłos como nrestamistas, aunque no falte el caso de que el judío sea deudor. Más adelante estudiaremos el aspecto jurídico de esta cuestión; sólo señalaremos aqui el hecho, bastante repetido, de ventas de fincas hechas para cobrarse préstamos (núms. $320,391,572$ у 573 ).

De la vida religiosa de los judíos apenas nada trasciende a estos documentos. Debían de estar organizados en Aljama en Talavera, ya que en 1204 dos de ellos, en representación de los judios de aquella ciudad, vendían una casa al apoderado del convento de San Clemento (ním. 338). Dícese que la sinagoga de "Aimaliqum ", en Toledo, dentro del barrio judío, la había construído $R$. David ben lk. Salomón ben Abudarham antes de 1271 (aúm. 1.144).

La ley que regulaba la vida jurídica de los judíos toledanos parece que era el Talmud, aunque, naturaimente, en sus relacianes con cristianos se sometín a las leyes de éstos (núms. 373,385 , etc.). Pero cuando las ventas eran entre ellos, se acoglan a la ley de Israel, bien que indicando la posibilidad de acogerse a la ley de olros pueblos (núm. 1.132).

Los documentos que conservamos, exclusivamente entre judios (núms. 1.132 a 1.151), son todos títulos de propiedad, y a la cesión o traspaso de la propiedad se refieren, bien sea por venta, o por donación, o por renuncia. En la donación que Tusí, 
hija de R. Salomón ben Falcón hace a su hermano Samuel ben Yehudá ben Caś (año 1282) de todos sus bienes, *se reserva para si misma, de su riqueza, cuatro dirhemes de plata, a fin de apartar de ella cualquier pretendiente a su herencia». Si gasta algo de su capital mientras viva, se entenderá disminứda la donación en aquella cantidad gastada; si hipoteca algo, el donatario lo podrá rescatar (núm. 1.150).

334. Familias judias toledanas. - Tanto como para el estudio topográfico de la judería toledana, como para el conocimiento de las familias principales de esta raza en Toledo, son del más alto interés los documentos que publicamos:

LISH DL FAMILIAS JUDAAS TOLEDANAS (1)

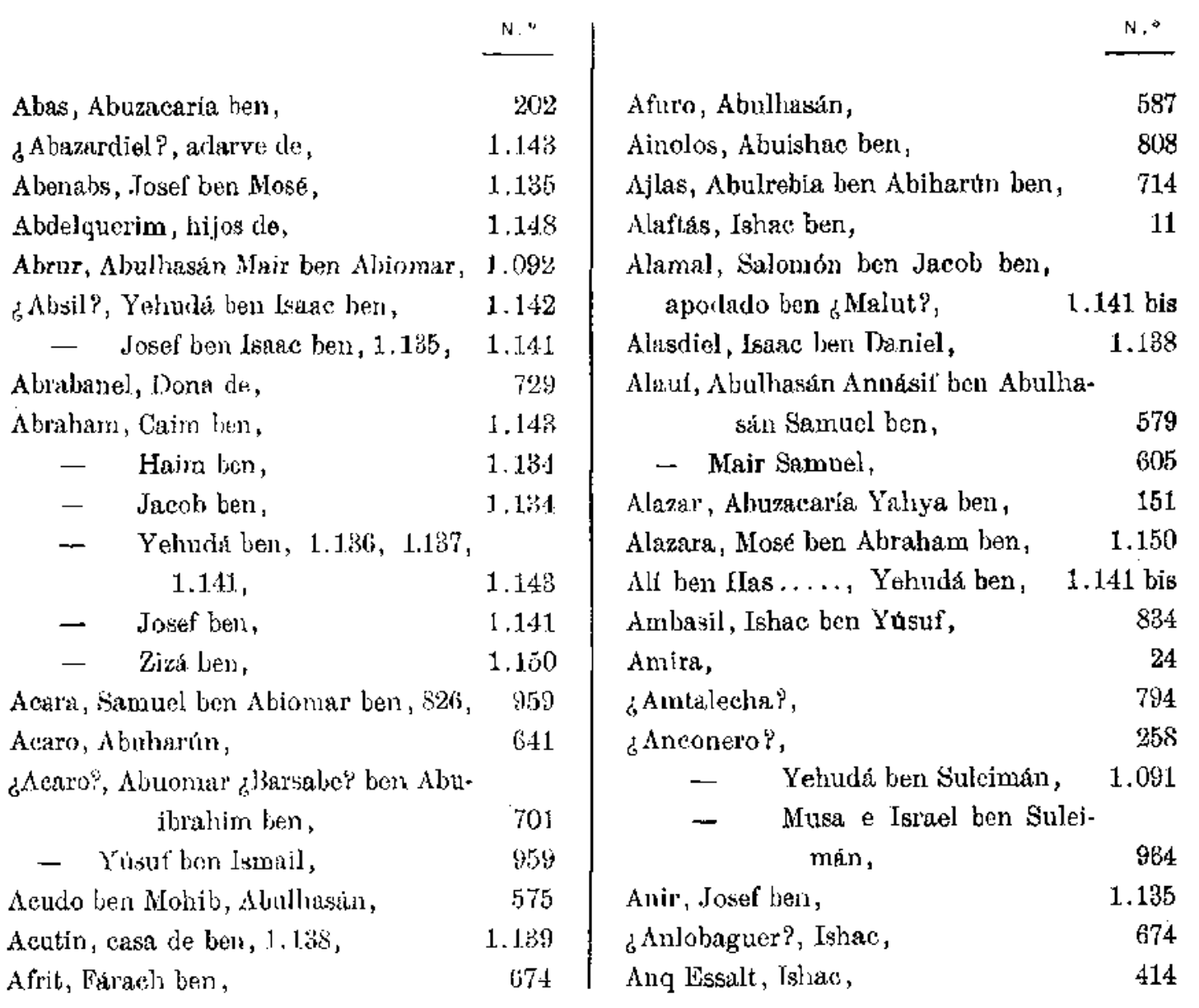

(1) La circunstancia de ser nuas veces transeripeión de cextos árabes y otras de textos hebreos, pro-

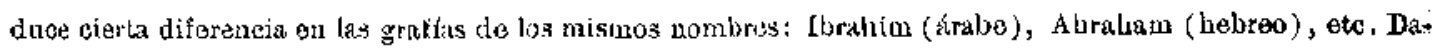
mos esta explicación para ocurrir a la dida que pndiera surgir al exudito lector. 


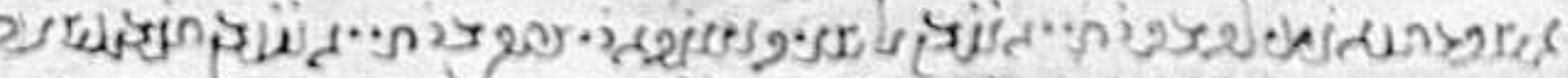
(12)

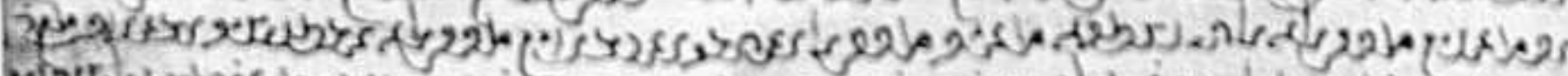

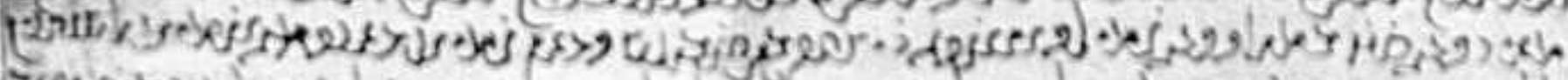

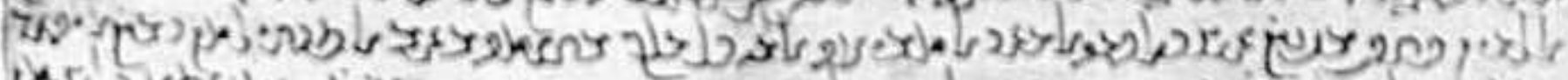

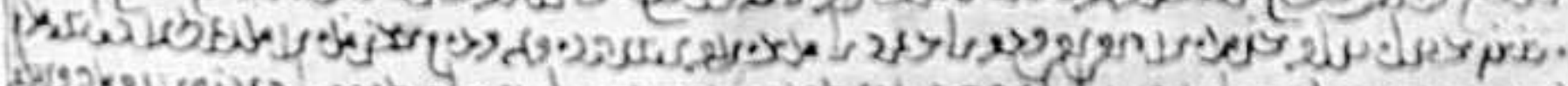

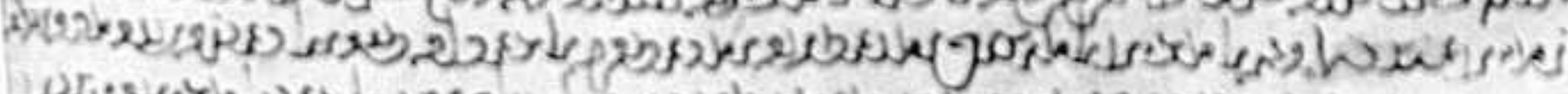

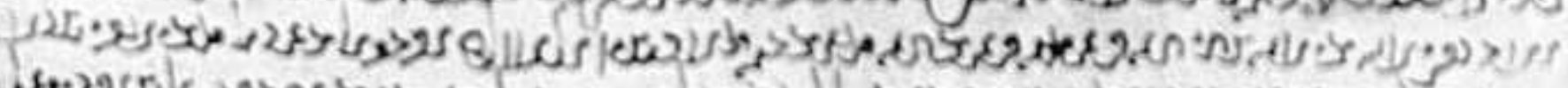

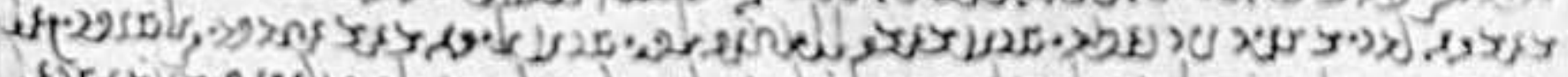

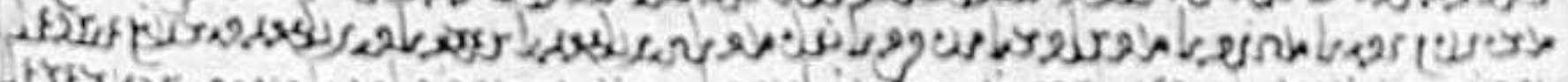

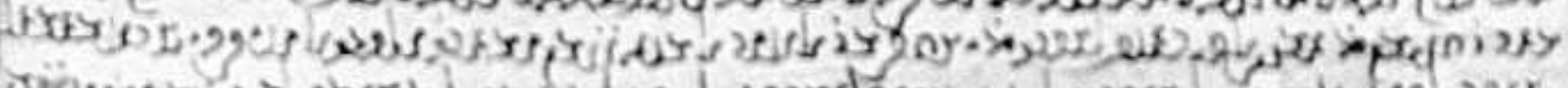

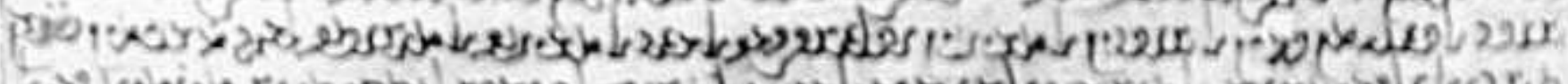

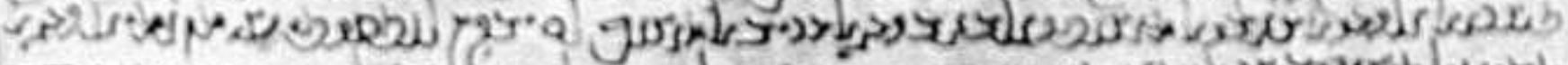

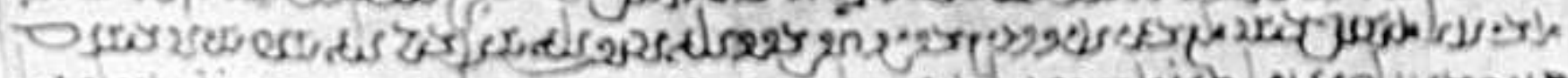

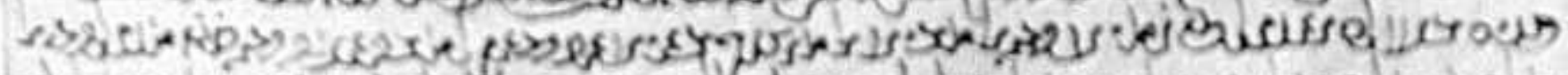

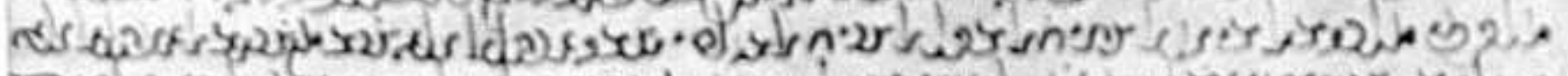

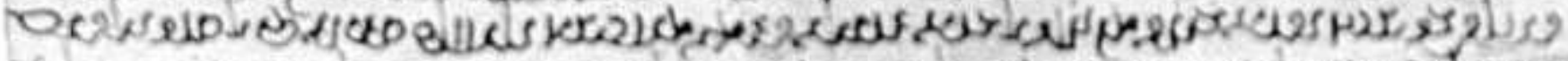

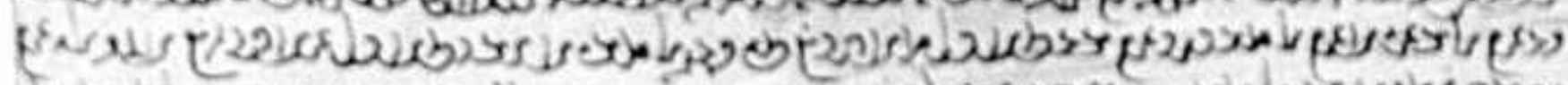

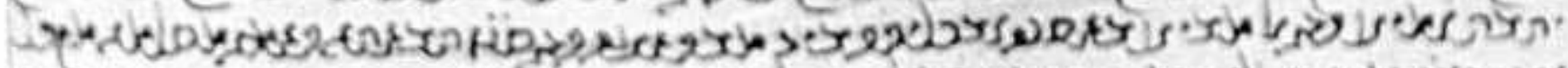

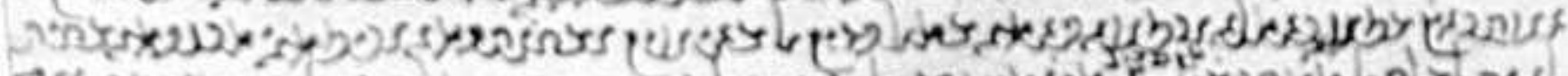

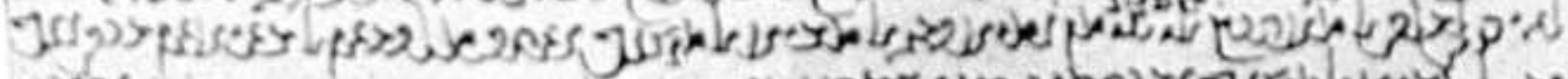

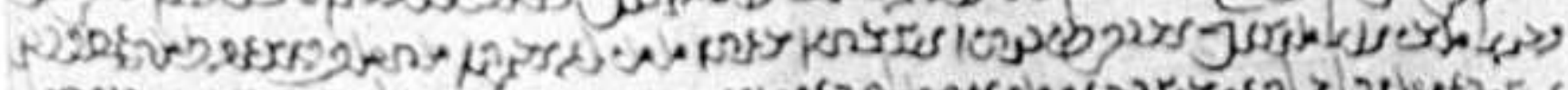

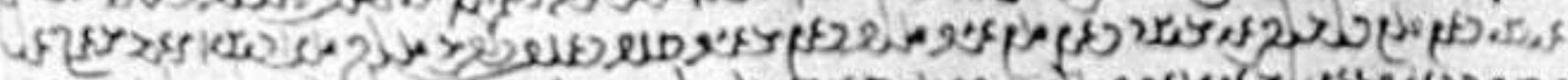

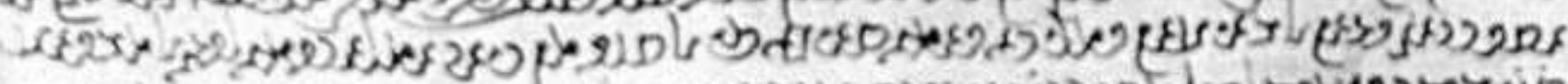

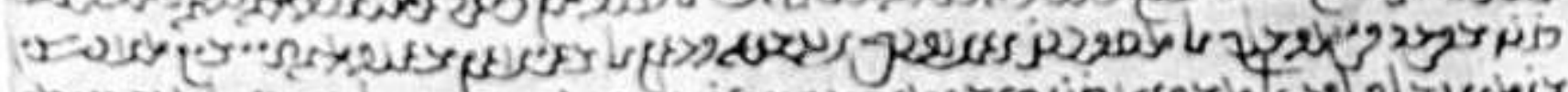

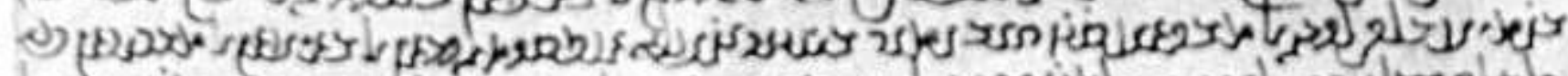

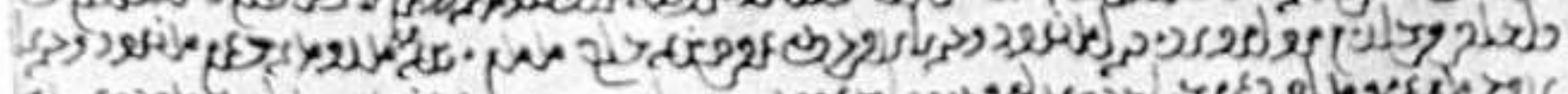

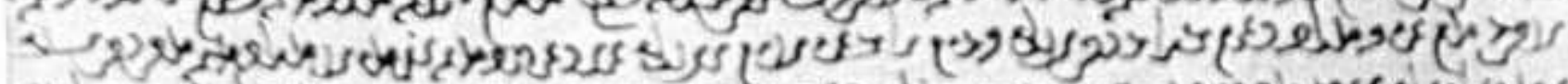

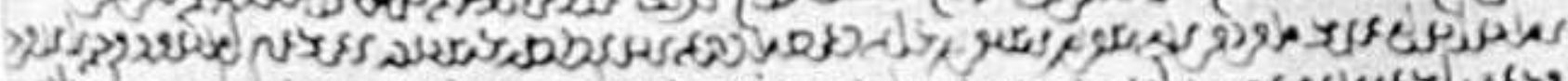

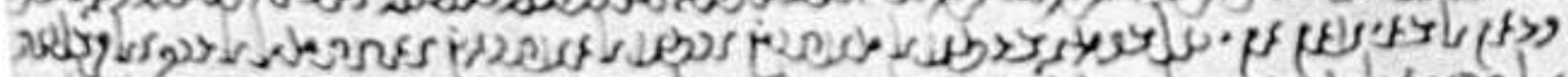

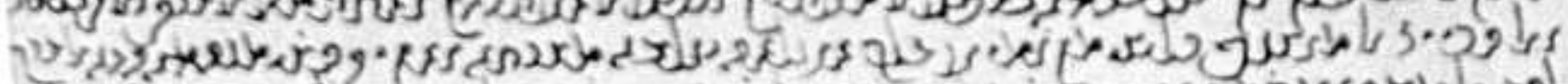

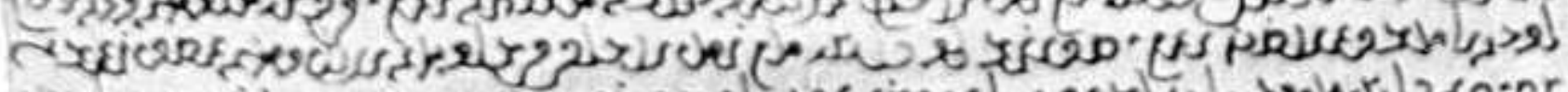

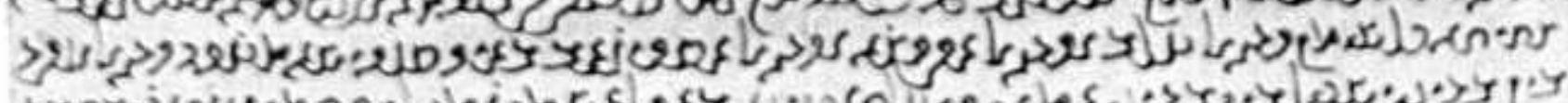

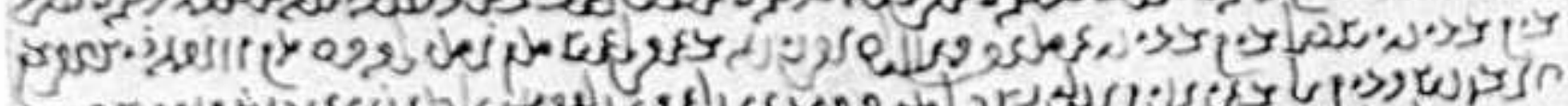

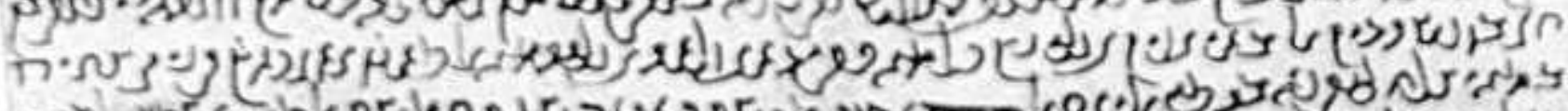

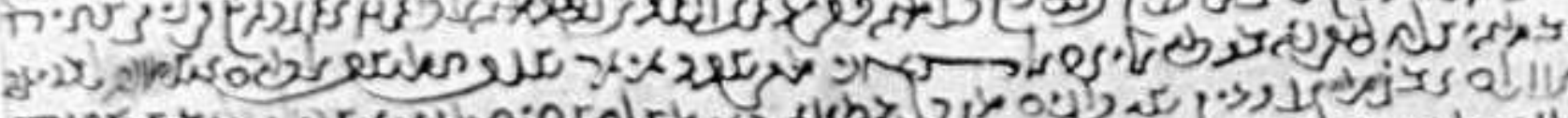

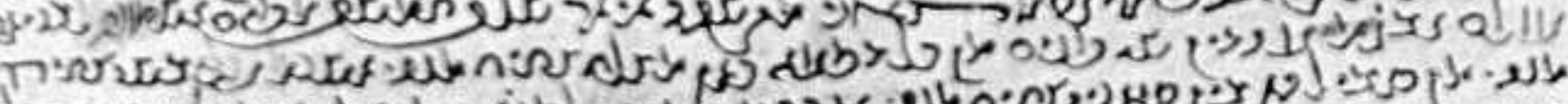

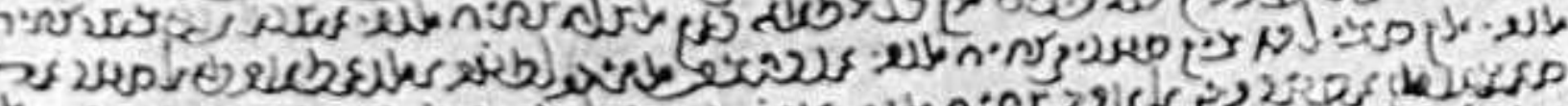

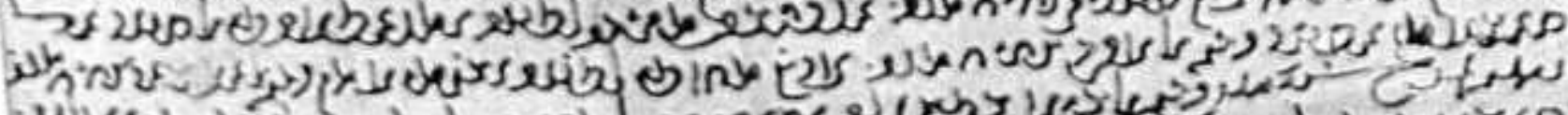

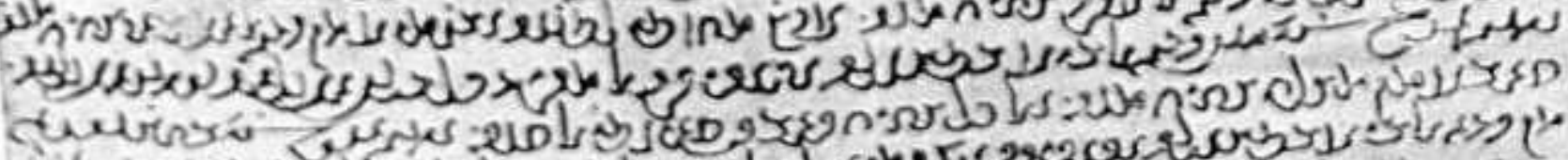

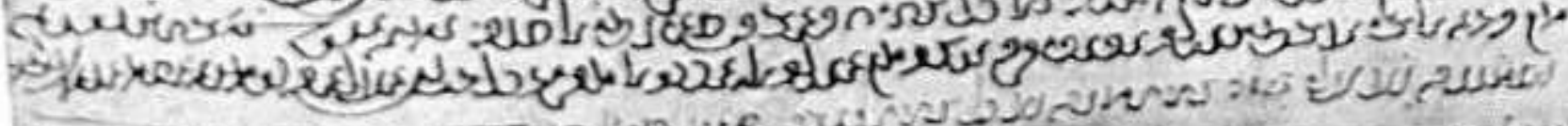

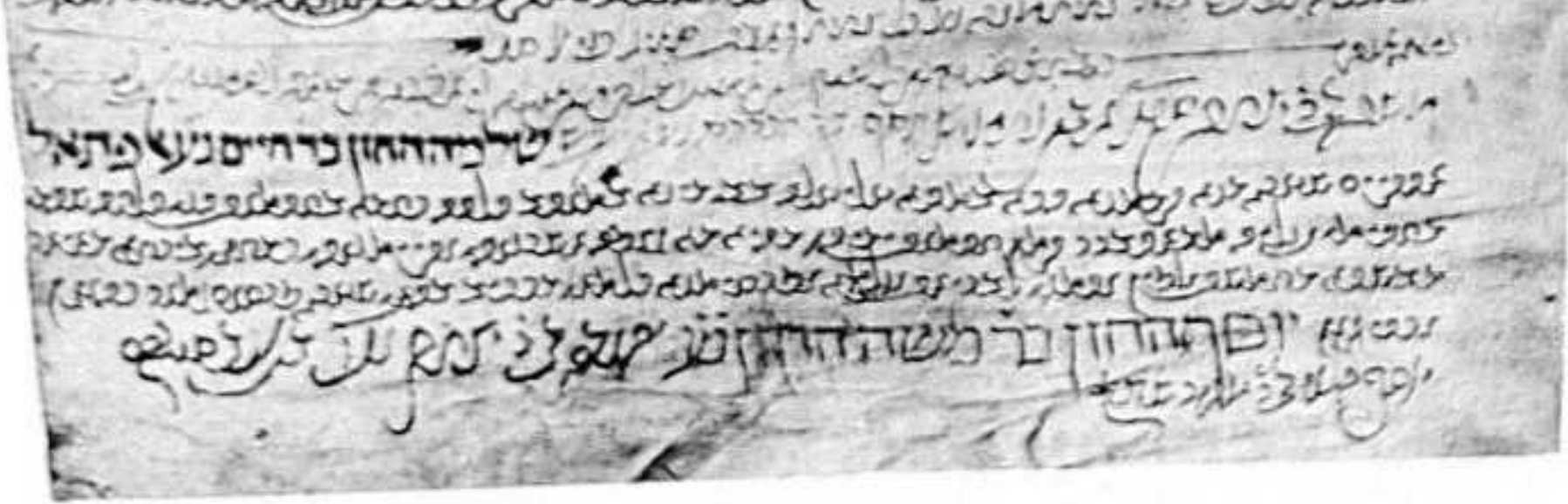


¿Anlobaguer?, LIaim,

Aquica, darion? ben Abraham ben, 1.136 Ardut, Aben,

Arroyo, Abuishac ben,

965

- Simhá, hija de Mosé lyen,

1.138

Asala, Bellido ben,

¿Atlas?, Sibbona, hija de Mose ol Macs.

$$
\text { tro ben, }
$$

1.387

Axer, Y'usef bell,

363

Azher, Yahya ben Ishac,

929

Azri, Abusamra ben,

Azur, Abulfatah,

1.089

Bacuda, lsaac ben,

1.148

¿Baiston?

Bahlul, Istrael ben Yahya ben,

- Suleimán ben Yahya,

¿Balaam?, Abuharún ben,

\&Balqueto?, Aber,

Abenalbana, Abuhasan Majr ben Abi-

burún ber,

Albansoll, Yehudá Hahazán ben Josét

Hahazán ben Hosé Hahazán,

Baqlul, Ismail ben Yahya ber,

b Albaquero ?, Abraham, apodado $\mathrm{Na}$ -

varro, ben Jacob ben

1.144

¿Barbiah?, Chamila, hija de,

Barcelonés, el,

564

53:17?

- Ishac ben Azar el,

1.143

- Salomón ben,

1.083

- Jacoly ben Axer el,

- Yisuf ben Jarob ben el, 588,793 ,

784

- Yúsuf ben Benyamín el, 1.083

- Abuishac ben Abillusín Benyamin el, 639,

- Abulhasán Axer ben Abighac ben Abilhasan Axer el,

Abulhasán Benyamin ben Nbilhasán el, 664 , 572 ,

VOLOHRN PIIZLININAIZ

93
N.

Barcelones, Abnomar ben Abilluasán

Axer el, 554, 555,639, 1.083

- $\quad \Delta$ buyúsuf al, $303,312, \quad 340$

- Jacob el, 530

Parluchif el Badir, Muse el, apodado

el Belal,

Barrac, Yeliuda ben el, $\quad 1.138$

Alharin, Musa ben, $\quad 391$

I3artel, Miusa ben, $\quad 7[4$

Isartuj ben Abibrahim cl Cohen, Abul.

lasán, 798, 794, 958

¿Barujel', Hobi, Jijja de Josef ben, 1.185

¿Barzal?, Yehuda ben Josef ben, 958, 1.151

Baso, $\quad 972$

לNIbatol $\gamma$, Jacob ben Isaac, 1.144

Basti, Xbraham ben Isaac el...., 714, 1.137

Belás, Selila, lija de Abilhasán Bo. no el,

429

Alberuchi, Musa ben, $\quad 834$

Buro, Abulliasán, $\quad 429$

Bonsolf, Abulitasán Yehudá Alhazd́n el,

Burt, Ibrahim of, $\quad 497$

Brur, Mair Y'tsuf́ ben Abi, 885, $\quad 1.092$

Cachich, Yúsế, $\quad 674$

- Samuel ben salomón, 1.141 bís

icafacha?, R. bon, 793, 794

Alcahil, Abusuleinán ben Abilhasán

Salih ben,

Alcajal, Dona, hija de Isaan ben, $\quad 1.137$

- Samuel ben Hiya ben ol, 1.136

$1.1 \% 4,1.145$

1.146

Acamalo, Dona, lijia do Isbac ben, $\quad 714$

Caprarela, Mar Mosé ben, $\quad \mathbf{1 . 1 3 5}$

Carballo el Sagtre, Musa ben Ishace, $669,68 \%$

Cardenal, Abulhasán dziz bon Abilhasán Yehuda ben,

- Abuomar ben Abilhasán Iiecha ben,

1.124

Cardinal, Isaac ben Abraham ben,

1.148 
Casares, Abuibrahim Ishac,

- Abulhasán Salomon ben All ben Ishac,

- Amira, hija do Abraham ben, 635 ,

1.136

Casi, Chamila, hija de R. Samuelbes, 674 ,

1.149

Casi, Isaac ben Samuel Aben, L.135, 1.148

- R. Samuel ben Yehudá ben, 674,

$$
\text { 1.148, 1.149, }
$$

Casim el Sofor, R., 793 ,

Abencebra?, Abulrebia Suleimán

ben,

Cemah, Simhá, lija de Jacob ben,

1.144

Cobén, Musa el,

- Rabl Mosé,

1.132

- Mosé Hacohén ben Josef ben Abraham,

1.134

- familia,

1.132

635

648

Colo, Ishac ben Jacob ben, 635,

Crecento, R. Guedalia loen Abrahan

ben Assolsi, llamado, 674,

1.147

Crespo, Abuyusef ben Abiomar ben,

Alchabir, Ishae, hijo de,

720

834

Elchahat, Josef ben Joel ben,

1. 136

¿Chamila? .....,

1.141

A)chaní, Chamila, hija de Hiya ben, 1.142

Chanuzi, Jacob ben Sarauel el, 1.138, 1.139

¿thibicho?, lbrahim,

261

Chor Nogab, apodo aBuey acometedors,

Daniel Hulevi, Ychudá Haleví ben, 1.148,

Dar, Ishac ben Daud ben el,

Darham, Aben, 1.132, 1.13\%,

$1,146^{2}$

- David ben Abi,

1,135

- David ben Salomón ben Abu, 1.144

- R. José ben Salomón ben Abu, 1.132,

1.133

- Mose ben David ben Abu,

Abidirhem, Abulhasan Salomon ben Abusuloimán ben, $\quad 605$

- Abuomar Yúsé tuen Abilhasán Balomón ben,

Daud, Yehudá ben Am-,

- Salomón ben Ibrahim ben, $\quad 71.4$

David ben Abiyusef, $\quad 897$

Oavid ben, José ben, 1.141

- Salomón ben, $\quad 1.151$

Diun, Richlá ben Jacol, ben, $\quad 1.091$

Dogdi, Isare ben Salomón len, $1374, \quad 1.149$

Duráa * el Envenenado», Josef ben, 1.137

Eliesef, Rab1, 586, $\quad 610$

Lovenenado, el, $\quad 1.139$

¿Estalecha?, Abuishac bon dbibraJim, $\tilde{5} 7 \boldsymbol{~}$

- Ibraluim ben Islanc ben lbralim,

Fadajil,

Faleón, Fstela, hija de Ibrahion ben, $674,1.148$,

- Jacob Hahazan ben Isaac ben, $674,1.147,1.148,1.149$ 1.150,

- Jacob ben ¿ Nahchán? ben,

- Mosé ben Salomón ben,

- Mose ben Salomón ¿Natán? ben,

- Tusi, hija de Salomón ben, 671, 1.150

Faquirol, R. Ishac ben Eleaxar ben, 674 ,

1. 146

Faracl, Farach ben Bono ben, $\quad 639$

-_ Musa ben l'úsul bes, $\quad 605$

Abenalfarj, $\quad 970$

¿Faro?, 193

Feluqu, Chamila, hija. del, $\quad 834$

Filiola, doña Set, $\quad 250$

Franco, Aben, $\quad 148$

Fuirol, Musa ben, $\quad 258$

Gabi, Yudá ben Joel el, $\quad 1.003$

Abgalón, Albraham ben Mosé, 1.140 
Abgalon, adarve de, 1.138,

Gayat, R. Jacol ben,

- Simhá, hijo de R. Jacob ben, 1.132 ,

1.133

Gualid, Abuishac Ibrahim ben al,

- Ibrahim ben Ishac ben, 432 ,

- Musa ben Ismad bern, 129

Guedalia, Sitbona, hija de R. ben Menahem, 6.7.

Gueto, Abulhasán Salomón ben Abibrahím ben (1), 648

- Ishat ben, 648

-- Abuharún Musa ben Abiomar ben,

- Yúsuf ben Musa ben,

- Salomón ben Isaac ben,

Gụiat, Chamila, Jijø. de José ben,

$$
1.138 \text {, }
$$

- Salomón ben Josef ìen,

Habil, Ishar ben lbralim ben,

- Musa ben libraluim ben,

$-\quad$ Simhá, lija di Isaac,

1.143

Hadida, José ben R. Abraham ben,

1.133

Hafs, Domingo, hijo de Mbu,

- ben .... ber Abilfarech,

Halevi, familia,

1.135

- ben Samuel Haleví, Johosef,

Haluzo, Isuac Pardo, covocido por,

Hamán al Albañil,

Alhanat, YYeluudá ben,

Hani, Yúsuf beu Ibrahim ben,

1.135

1.140

80

635

Haquim, Isaac ben Haquim,

1. 069

1.141 .

Harils, Harits Yehudá ben,

1.055

.... Abuhartu ben,

907

Abuharún, Ibrahim ben,

193
(1) Al dorso del documento se transeribe: salomón Cag aven Getto.s
Ilasán, Abuishac Ibratiun ben Abiharún Mosé ben, 959 - Abuishac ben Abilarion ber, $\quad 701$ Hasbones, R. Isaac ben Ala ben R. Hiya ben, 648 ,

1.142

Allaseb, Abrahum ben Isaac ben, $\quad 1,143$

Alfauad, Aben, 1.184, $\quad 1.148$

- Abraltam ben Yehudá, 1.147.

$$
1.118,1.149, \quad 1.150
$$

Hayati, 528,

815

- el Dacac,

- Ibrahim ben Musa.

1.087

- Jacob ben Ibrahim, 1.087

-.. Abuyúsuf ben Abishae ben Abiomar,

1.087

¿Hayón?, José ber,

1.136

- Isaae ben,

1. 136

- Josef ben Mosé ben,

1.136

Layún, Jacob ben,

910

- Yúnus ben Ishae lirn, $\quad \mathbf{1 . 0 6 9}$

Hicat el judio, $\quad 11$

Ifiya ben „Hachbonus?, Lsaac ben, 1.142

- ben Alehani, Chamila, Jija de, 1.142

Hobi, hijn de Josef ben ک Jarnjel?, 1.135

Abuibrahim ben Abiyusef, $\quad 897$

- Alouomar ben, $\quad 714$

Ishac, 521 ,

- el Cambista, Tsare ben, 794,

$$
1.132, \quad 1.133
$$

- Abu, ben..... Asabag. $\quad 794$.

- ben R. Yúsef, Rabi, $\quad 074$

- Efraim ben, 1.134

- Josef ben Meir ben, $\quad 1.145$

- Isracl bon R., 1.132, 1.1333, 1.135 ,

- Neir Haleví ben R., 1.132, 1.134, $1.135,1.148$

- Saadia Huhuzán ben, 1.148, 1.149

- Simeón ben,

1.148

- Salomón ben R.,

1. 135

- Yelnudá ben, 193, 


\begin{tabular}{|c|c|c|c|}
\hline &. & & N..$^{\circ}$ \\
\hline ac & 385 & Malut $\mathrm{P}$, Ben (apodo), & $.141 \mathrm{big}$ \\
\hline _. l'úss & 363 & Maquir, Mosé ben, 1.141 , & 1.148 \\
\hline maill, & 802 & Matiner, adarve de ben, & 1.141 \\
\hline Abuomar ben, & 690 & Masudia, David ben Mlosé ben, & 1.151 \\
\hline - e] Catib, Abuomar ben Rabi, & 1.088 & Marabón», «Itacay, fi de, 648, 1.142, & 1.144 \\
\hline - Istrae ben, & 711 & Mleir, Alraham ben Rabi, & 338 \\
\hline ... Ishac ben Yúsuf ben, & 677 & - Josef Halevi ben, & 1.142 \\
\hline - Hasiler, Isaac ben, & 1.147 & - Rali Yusef ben IR., & 648 \\
\hline - Ismol ben ishac hen, & 711 & - Salomón ben Isaac ben, & 1.143 \\
\hline - Israel hen Yúsuf ben, & 677 & Menahem dar Benyamin, & 802 \\
\hline - Josef ben Saúl ben, & 1.140 & Almerint, Haim, & 1.151 \\
\hline - Isa bon Lshae ben, & 1.089 & Mesina, Salomón ben Isaac, & 1.140 \\
\hline & 711 & dMigas?, Isaxc Halevi hen Meir ben, & 1.150 \\
\hline $\begin{array}{l}\text { ada, Mosé Halevi ben Haim Hale- } \\
\text { ví ben, }\end{array}$ & 1.139 & $\begin{array}{l}\text { Mocacaxa, la judia, } \\
\text { ¿Almocalal?, Amira, hija de Mar }\end{array}$ & 580 \\
\hline $\begin{array}{l}\text { - Clara y Dona, } \\
\text { cef; vide Xúsuf. }\end{array}$ & 1.139 & $\begin{array}{l}\text { Alirahum, } \\
\text { Mohachir, Amira, hija de Abraham }\end{array}$ & 141 bis \\
\hline olt, Ibrahim ben Alsibraluim, & 497 & ben, & 1.148 \\
\hline $\begin{array}{l}\text { - Abnomar al, } \\
\text { ehitin?, Abulharún ben Abjhrahim }\end{array}$ & 497 & $\begin{array}{l}\text { Mohib, Abuishac ben, } 579 \\
\sim \quad \text { Abuishac ben Abiharin ben, }\end{array}$ & $\begin{array}{l}587 \\
991\end{array}$ \\
\hline & 965 & - Nbulhagán Yehudá, & 549 \\
\hline $\begin{array}{l}\text { ir, Haim Lon Abraham ben, } 1.147 \text {, } \\
1.148,1.149 \text {, }\end{array}$ & 1.150 & $\begin{array}{l}\text { - Aluomar ben Abilháán Yehu- } \\
\text { dá ben, }\end{array}$ & 641 \\
\hline ngo, Saúl ben Daví ben el, 635, & & Monudfas, & 1,048 \\
\hline $719,960,964,1.003,1.090$ & 3.120 & Mordecai, Jogef ben Abraham, & 1.135 \\
\hline Ismail ben, & 1.039 & Mosé, & y otros \\
\hline 81, Salomón lien Salosión el, & 1.137 & _- Haim ben, & 1.185 \\
\hline as, Mair ben lahac Len, 834, 897 , & 929 & - Isarc ben, & 1.160 \\
\hline $\begin{array}{l}\text { - Mair ben Yúsce, } \\
\text { Almalartas?, Abulhasán flaim ben }\end{array}$ & 897 & $\begin{array}{c}\text { - Hahazán, Josef Hahazán ben R, } \\
\text { 1.132, 1.135, 1.141, }\end{array}$ & 1.142 \\
\hline Mbiyusef, da apodado, & 1.003 & - el Colién, & 635 \\
\hline adero, casa de, 1.138 & 1.189 & - Abuharún, & 837 \\
\hline , hija de Ilsrahim ben & 674 & Mozah, Abularin Musa ben, & 436 \\
\hline ralial, José kern Salomón ben, & 1.146 & - Daud ben Suleimán ben, & 335 \\
\hline hali, Abuyúsef el, & 674 & Muel, R. Musa ben, 965 & 1.147 \\
\hline jmón, $Z \mathrm{i}$ & 808 & Murst, Yúsef el, & 414 \\
\hline lalii, Abuor & 385 & Naginan, Isaac ben, & 1.137 \\
\hline laqui, $\Lambda$,raham be & 1.143 & Isaac ben Mosé ben, 714 , & 1.137 \\
\hline - Abu Zacuria Yalyya ben & & Josef ben Mosé ben, & 1.146 \\
\hline Ali el, & 158 & - Yúsuf, & $\begin{array}{l}674 \\
669\end{array}$ \\
\hline
\end{tabular}


Alnajert, Abraham ben,

1.138

Nahmias, famllia,

- Aben,

1.141

- Abuibrahim ben,

903

- Ibrahim ben Don Musa ben, 965

- Tbrahim ben Masa bon Yúsuf, 680

- Mair ben Ishac ben,

- Mair ben Daud,

- Mair ben Ibrahim ben,

- Meir y Abraham ben Josef ben David ben Isaac,

1.134

- Josef len Isaac ben Mosé ben,

- Rabi Buishac ben,

- Mosé ben Isare ben,

- Rabi ben, 1,

- Abulhasan ben Abiomar ben, 680 ,

- Abuomar ben, 680, 719,

- Abuomar, hijo del jeque Abusuleimán ben Abiomar ben,

- Abuomar Yúef ben Abisuleimán David ben Ábiomar ben, 673,

Navarro, Abraham,

- Abuishac,

Nehemias: vide Nahmias.

Noak, Yehuda ben Abraham Aben,

$1.135,1.136$,

Oclera, Doña,

1.089

Odra, Abulhagan Yehuda ben,

- Amira, bija de

- Chamila, hija de,

- Hodasa, hija do,

- Sethona, hija de,

Omán, Ishac ben Yisuf ben,

Abuomar,

1.002

1.144

Omtalecha ol Haquim,

Onquira,

1.090

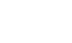

N. “

Onquira, Aludhasán Yehadá ben Abilrebia el, 1.090

- Abulhasán Israel ben Abilrebia el,

Orgaz, Sajomón de,

1.140

Pueuda, R. Haim ben,

674

- R. ishac bon,

¿Palat?, Jacol Hahazán ben lsaac,

1.137

¿Palomba?, Doña,

1.145

Pardo, Chamila, hija de lsaac, $\quad 1.150$

- Isaac, conocido por Haluzo Jacob ben Salomón, $\quad 1.140$

Partal, Mose ben YaJia, $\quad 1.137$

Yartel, Dona, hija de Jbrahim ben, 674

Alpatal, Salomón ben Hahazín ben

Haim,

1.142

*P'erneados, Benjarnín ben Pascual, conoeido yor el,

1.144

Posat el \&Pollo?, Yahin ben,

1.146

- apodado Fulo, Yahya ben,

¿Pipión?, hijo del Sacanera, Saadia el

Tintorero,

1.137

¿Podenco?, Isauc ben,

1.143

- Salomón ben,

1.150

"Pollon, el, apodo de Mar Yahia ben

Pesat,

1.146

Arramac, Aben,

154

- Jálaf ben,

258

Reubén, Isaac bon Jacob ben, $\quad 1.140$

Roel el Judio,

Roi, Haim ben Sasón ben el, $\quad 1.137$

Elrofé, Josef ben Jusef ben, $\quad 1.136$

Royuelo, el,

428

Saaba, Vito ben Yahya ben,

929

Sardia, Josef ben,

1.143

Sadia, Aben,

685

Sabaj, Musa ben Yahya ben, 258

Sabat, Dona, hija de Yissef ben, $\quad 258$

Alsabi, 1.146, 1.147, 1.148

- Abraham ben, 674, 1.146

- Abraham ben Josef ben, 1.151 
Alsabl, Dona, hija de Abrahana, 1.146, 1.147

- apodado dCresente?, Guedalia ben Abrahaw ben,

1.147

- Yacub ben,

803

-- Josef ben,

1. 148

480

Assucur, lelias,

$\begin{array}{ll}\text { Sacanera, Saadia ol 'T'intorero ben al, } & 1.137 \\ \text { Sadaia, Aben. } & 1.135\end{array}$

- Jacob ben, 1.135,

1. 136

Sadoc, Abulrebia ben,

794

- Abulrehia ben Abihrahim ben,

Sadón, Eleazar ben,

Sadrin, sucgro de,

710

812

648

Safata, Jacob ben Abraham ben, $\quad 1.151$

Sahalón, Mosé ben Hiya Aben, 1.147, $1.148,1.149$,

1.150

Assahat, Abuharún ben, 320, 331, 373, 374 ,

- Ibrahim ber,

- Yúsuf ben,

Salbaticl, Jacob ben Isaac ben, 1.137,

1.145

1.146

Salomorn, Jucob ben,

1.150

- Dona, hija de Abulhasín,

635

Samuel, Josef ben, 1.135, 1.136, 1.137, $1.144,1.145,1.146,1.147$, 1.148, 1.149,

1.151

- Meir ben,

1,135

- ben Yúsef, Abullısán,

¿Sapato?, Daniel hen द̧Joel?,

1.138

Santaroni, el,

- Jshac el,

¿Sarean?, Alchahab Chafir, Aben, 373

Sariaj, Ismail ben Yúsef, 145

Sarur, Abuishac ben Abiomar el, $\quad 961$

- Abulhasán Mair ben Abionar, $\quad 964$

Sasón, Salowơn ben, 1.141, 1.148, 1.149

Sem Tob ben Farah, Sasón ben R.,

$1.134,1.136,1.187,1.143,1.144$,

1.145 ,

Senar, Abon,
Senaa el Char, Ibrahim ben Ishac ben, 674

Setbona, 373, $\quad 714$

Sotila, $\quad 385$

Sevillano, Ibrahim ben Omar el, $\quad 794$

Sosrin, familia, 282, 284, 344, 648, 668, $674,720.1 .141,1.142,1.143$, 1.144,

1.145

- Abraharn ben,

808

- Abuibrahim ben, 344, 668, $\quad 812$

- Abulhasan Mair ben, $\quad 668$

-- Abulhasán Sadoc ben Abulrehia ben, $\quad$.. 720

- Abulhasán \$amuel ben, 720, 942

- Abulrebia ben, 279, 344

- Abuomar, 276, 279, 280, 282, $284,290,297,335,344$;

- David ben Abraham ben, $\quad$ 1.151

- David ben Jacob ben, $\quad 720$

- Isaac ben Yúsef ben, 344, $\quad 1.143$

- Josef ben Meir ben Isaac ben Abraham ben, 335 ,

1,144

- Meir ben Isaac ben, 648, 1.135, 1.142,

1.144

- Nosé ben Isaac ben Abraham ben,

1. 145

- Musa ben,

- Suleimán ben Yúset ben, 335

- Sithona, hija de Isaac ben Aliraham ben,

6.Sico?, Ishac ben,

1.120

Sidabihi, Abuzacuria Yahya ben, $\quad \cdot 381$

Sigilmesi, Salomón ben David ben el, 1.135

Simon, Ishac ben Ibrahim ben, $\quad 958$

Sofo, Salomón ben Yohudá ben, $\quad 714$

- Samuel ben, $\quad 720$

Suti, Seti, hija, del, 391 , . $\quad 834$

Assuiya, Chamila, hija de R. Hiya lyen, 648

Taaban, Musa ben Obadia ben, . 258

Talfa, Elí ben, $\quad \therefore \quad \ldots 1.148$

Tarfa, $\quad 391$

70 Tazaret, Yahya ben Sebamuin, 714, 1.137 


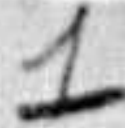

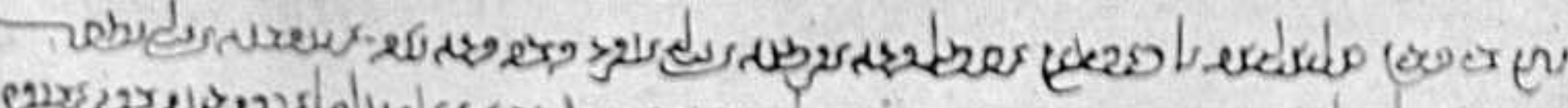

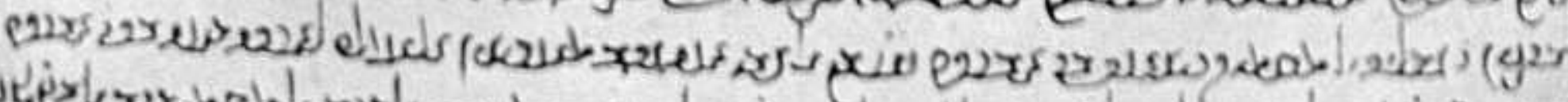

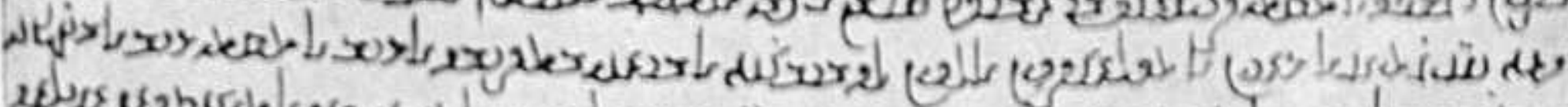

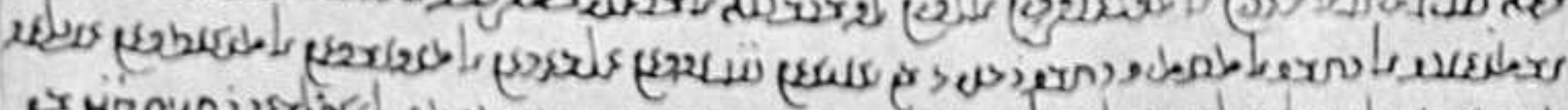

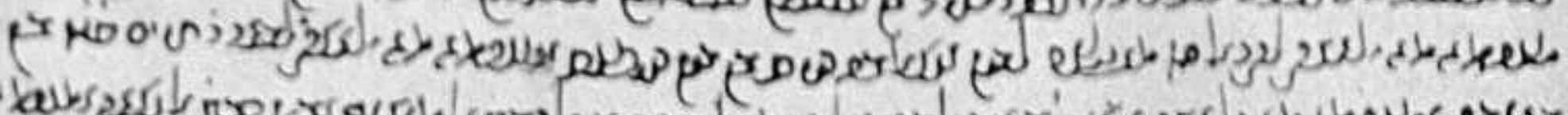

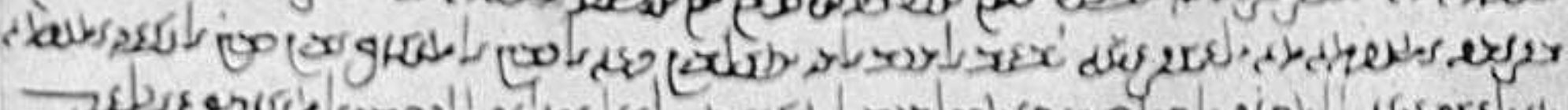

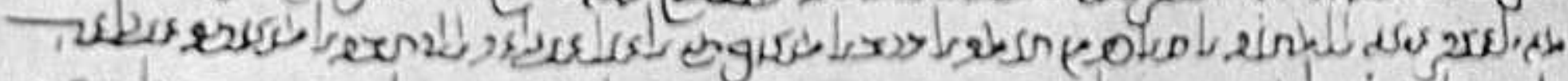

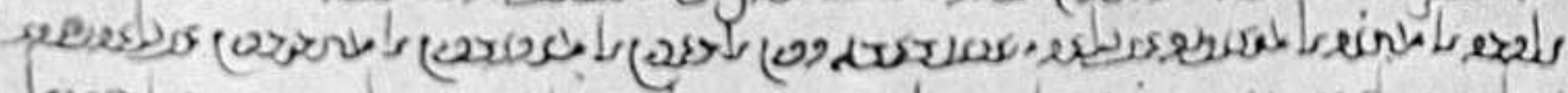

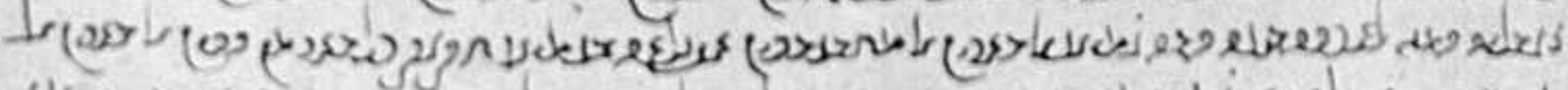

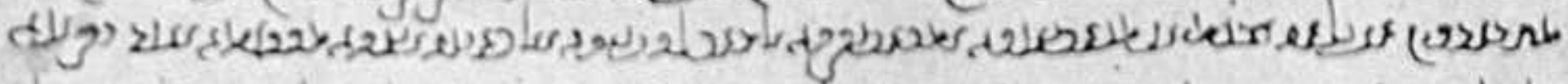

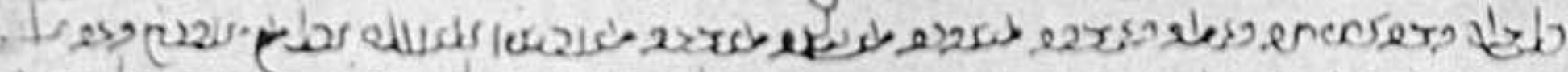

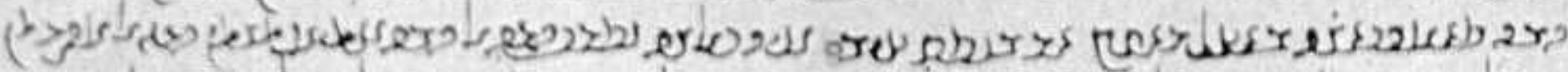

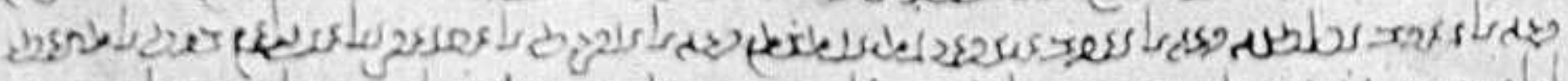

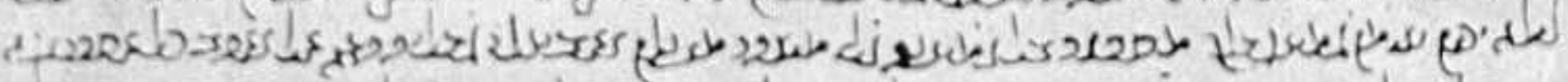

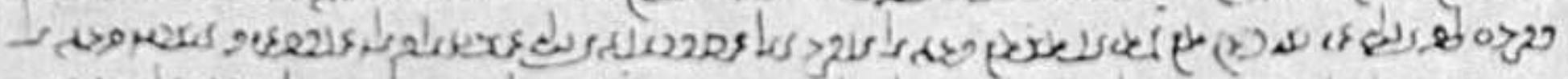

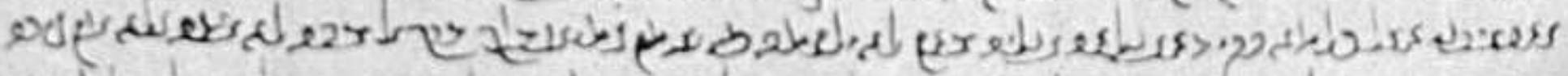

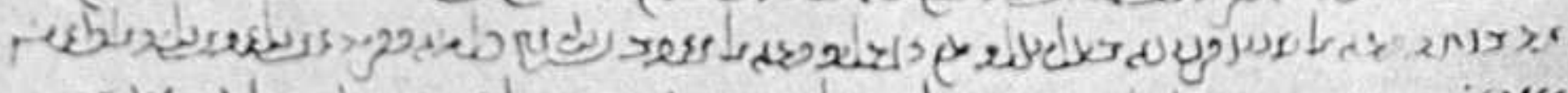

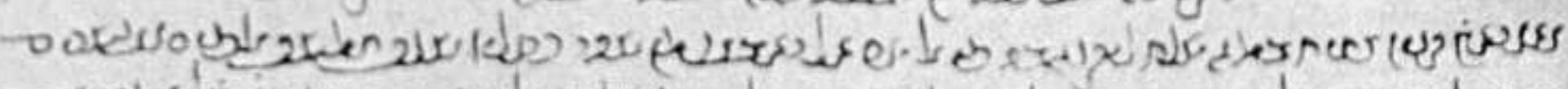

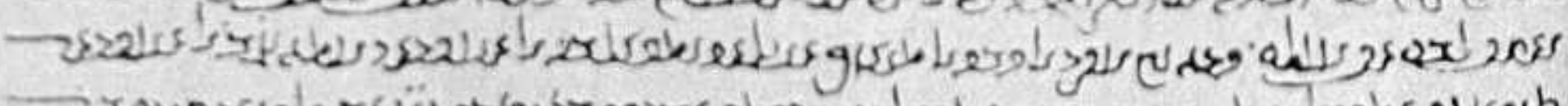

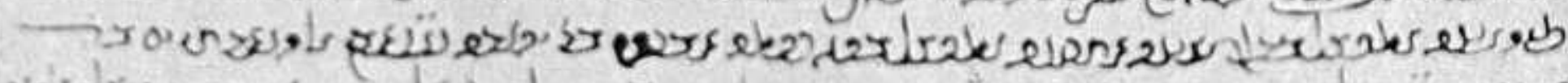

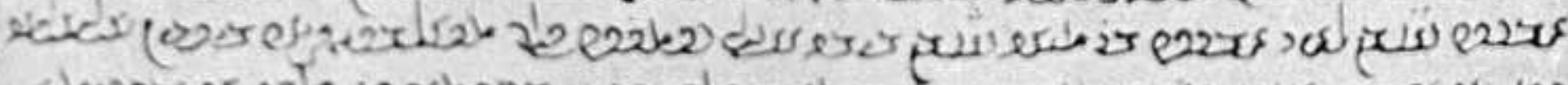

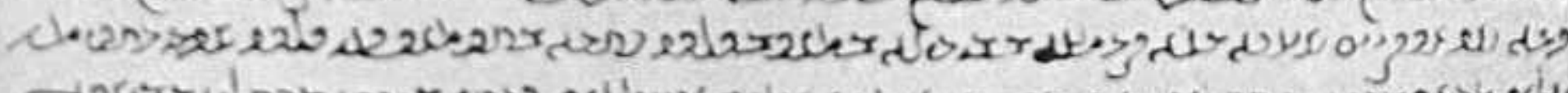

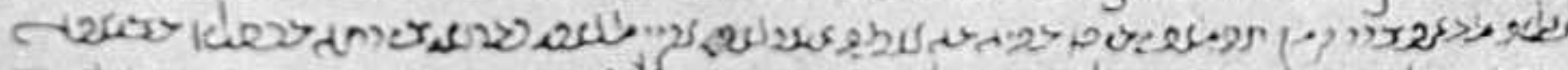

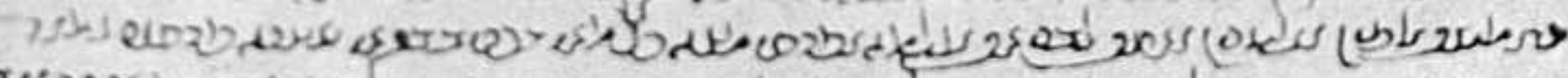
ir (e)

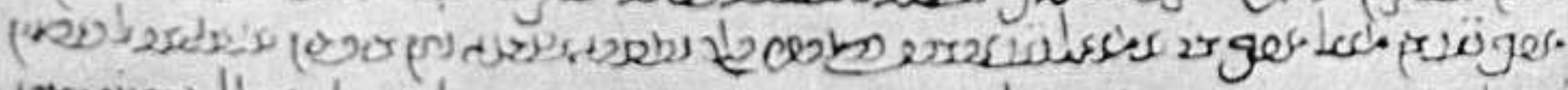

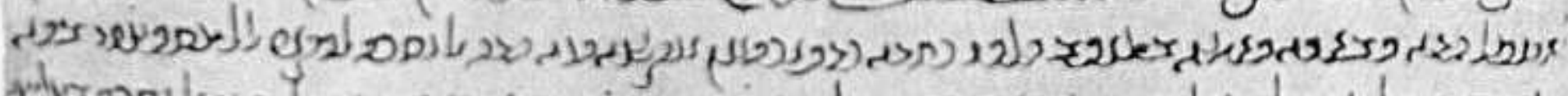

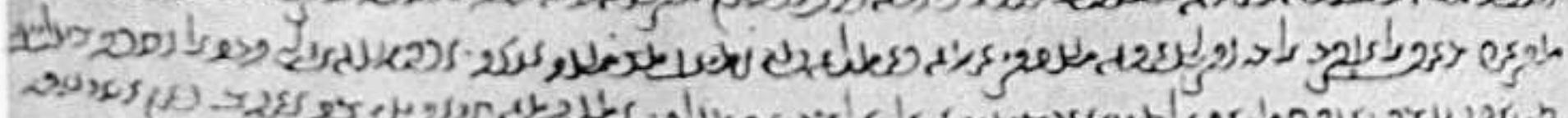

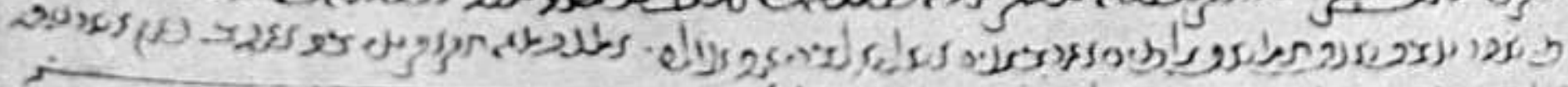

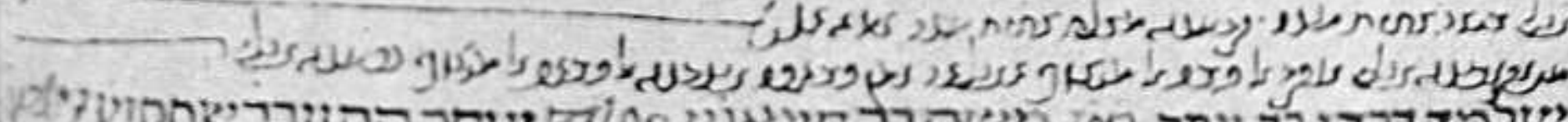

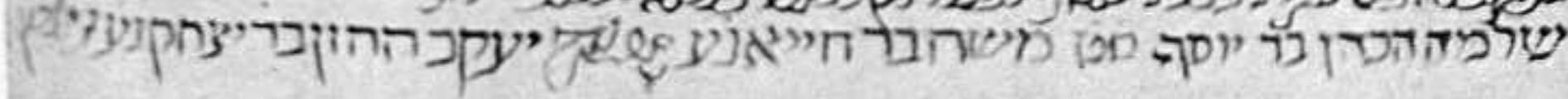


Tobi, Abuomar ben Abjlhasan Yehudá

$$
\text { ben, }
$$

- Isaac ben Simeón ben,

1.143

Todros hen Al-levi, Chamila, hija de llalevi ben,

Thuriel, Aben,

- Hasilai ben,

¿Uagwarech?, Haim ben Isiac ben, 1.145

Valenciano, lbrahim ben Ismael el,193, 808

Viva, Abraham ber Mosé ben, 639 , $648,674,714,1.136,1.13 i, 1.144$, $1.145,1.146,1.148,1.149$,

1.150

Yacob Yehudá.

- Josef ben,

- Dona, hija de Rabi

Yahium, Yehuda ben lshae ben,

Yaich, Josef ben Abrahan ben,

1.142

- Salomón ben Abrabam ben,

$$
1.14 .3 \text {, }
$$

Yaix, Yahya ben, 275

- Yúsuf ben

6

¿Yamin ?, hija de José ben, 674, 819, 1.148

¿Yajunes?, Efraim ben R. Isaac ben, 1.133

Yebudá, Abraham ben,

1.134

- Yehudá ben Abraham ben,

1.144, 1.145,

1.146

- Samvel bar,

802

Yudá ben Thrahim el Herretero, 630, 648, 720

Abuylúsef,
Abiyusuf, Abuibrahim Ishac ben I8 mail ben, 70

- Abulhasán Samuel ben Abilhaskin, 571,615 , Abuomar ben Abibrahim ben, 674

- Isarc ben Josef hell, 338, $683,1.120$, 1.146

- Jacoh ben Josef ben, 674, $1.146,1.148,1.149, \quad 1.150$

- Yehudá ben,

- Josel ben Isaac ben, 1.146

- Hahazán, Mosó Hahazán ben, 1.148 , 1.149

- Salomón Hacohen ben, 1.147.

1.151

- Saunel ben, $1.141 \mathrm{bis}$

- Saul ben,

1.138

- Zizá ben Ishac ben,

Zabara, Imac ben Eleyzar Albana ben, 1.142 ,

1.144

Abuzacarla, Yahya ben, 167 Cag, Simha ben Yacub ben, $\quad 648$ Zardel, adarve de Abon, $\quad 674$ Zaragozano, Abucatsar el, $\quad 641$ Ziat, Aben, $\quad 275$ Ziza, 198

- Bibach ben, 193

- ben Abiyúsuf, $\mathrm{R}$. Ishac ben, 674, 1.148

- Yahya ben Yehudá, 193

\section{D) MOROS}

335. Naturalmente, es la raza que menos infuencia ejerce en la vida social, después de la Reconquista. Quedaron moros en Toledo, a juzgar por el fuero de 1101 ; pero, perdido para ellos el papel director, no vemos gentes de relieve entre los moros citados por nuestros documentos.

El único docamento otorgado según la ley musulmana (núm:1) es de 1083, o 
sea dos años antes de la Reconquista, y va fechado según la hégira y en el mes de Ramadán.

La costumbre de llevar nombres árabes los cristianos confundiría para distinguir a los musulmanes; por eso, cuando se cita a un moro, se advierte y se dice que es musulmán (núms. 23, 116 y 242); parece, pues, que cuando nada se dice, debeentenderse de cristianos.

No habia en Toledo harrio moro aparte; las casas de los moros estaban entre Ias de los cristianos (ntims. 150 y 417), citándose alguna por Santa Justa y San Ginés (ním, 348).

Sabido es que la mezquita mayor fué consagrada para catedral, y que estaba en el mismo lugar que ocupa el tenoplo actual. Pero nos encontramos, además, con otra mezquita, en el barrio mismo de Santa María, que era propiedad de dos hermanas cristianas, y que es adquirida en dos mitades por el arcipreste D. Nicolás, en los años 1167 y 1170 (núms. 82 y 92). Los albaceas de dicho arcipreste venden en 1178 su casa y su establo, "que antes habia sido mezquita „, donde se ve el destino que se habja dado al antiguo templo musulmán (núm. 141). La mezquila en uso para los mutulmanes toledanos sometidos parece que estaba en el barrio de Fraucos (1uúmero 317).

Una gran parte de moros mencionados en nuestros documentos son libertos, bien por conversión al cristianismo, bien por rescate. Más adelante estudiaremos las condiciones jurídicas de estas emancipaciones. Y muchos de ellos se dedicaban a oficios manuales, por lo que cran muy apreciados: un Abentaurino el Mulsumán era am'n de los alfareros en 1135 (núm. 23).

No tendría, crecmos, interés dar la lista circunstanciada de los nombres moros que salen a plaza en estos documentos: si se exceptúa a Zafadola, el último Abunloud, cuya casa estaba en el barrio de la Catedral, al lado de las tiendas del rey (número 130), no encontramos persona de algún relieve histórico. Un Almoguac (الهواف), bastante cilado, debía de tener posesiones en Toledo (núms. 581, 898, 738 y 302 , etc.); se les ve vivir entre los cristianos, y por eso, al describir las casas de éstos, salen como vecinos y aledaños algunos moros: Asaquia (núm. 1,094), Ahmed Assafar (núm. 348), Ueld el Helá (núm. 581), Rabahí (núm. 138), Ayub Algacel (núme. ro 242), y hasta mujeres, como Soffa la Mora (núm. 820).

Parece que debía de ser mulsumán un Jálid Moro (مo) citado en 1187 (núme.

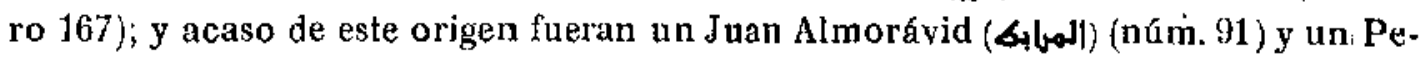
dro Almorávid (núms. 249 y 943). Claro que no hay duda respecto a los que al nom. bre árabe perfecto añaden un denominativo inconfundible: así aúı quedan en Toledo ansartes (staili) (mims. 1, 793, 935, 936 y 939), alguno procedente de Ubeda (número 794), y alguna mujer (Omalhada, hija de Hasán el Ansarí) con el calificativo de gallega (الجلياقئ) (núm. 793). Se ve un Baxirr (núms. 570 y 573), un Curi (núm. 803), un Dodrl (núms. 570 y 573), un Fabarí (núm. 793), un Fihrl (núm. 1), un Hadrami 
(núm. 793), un Aljanaxí (núm. 737), un Lamtí (núm. 793), un Rabadí (núm. 1). Y entre los denominativos basados en pueblos de origen, vemos el Baslí (de Baza) (número 787), el Garnatí (de Granada) (núm. 793), el Gaź (de Gaza) (núm. 934), el Sinhechí (de Sinhacha) (núm. 790) y algunos sevillanos (núm. 793); otros de Marchena (nín. 793) y de Loja (núm. 934), y una negra de Marraquex (nún. 682).

No deblan ser infrecuentes los matrimonios mixtos, de musulmanes y cristianos: cuando la madre era musulmana, heredaban los hermanos del marido (cristianos) con preferencia a los hijos del matrimonio mixto (núm. 945).

También contrataban con los cristianos: un moro y su suegro prestaban cierta cantidad a un cristiano: con garantía de una casa; vendida la garantáa, el moro cobró la cantidad prestada y se obligó a satisfaccr cualquier reclatnación que pudiera aducir su suegra (núm. 242). Pero en las fianzas para manumisión de esclavos moros no firman ni intervienen más que moros (núms. 935 y sigs.). 



\section{INST I T UCIONES}

\section{A) LA CATEDRAL}

336. Carla de dolación. - Seguramente dentro de la Edad Media la más poderosa institución de Joledo fué la Catedral, y así se revela en nuestros documentos.

Apenas reconquistada la ciudad, el dáa 15 de las kalendas de Enero de la era 1124, o sea el 18 de Diciembre de 1085 , Alfonso VI firma la carta de dotación de la iglesia de Santa Marfa, habiendo nombrado por elección arzobispo a don Bernardo, monje francés de Ciuny. Este importante documento, tal como lo conserva el Cartulario primero de la Catedral de Toledo ${ }^{(1)}$, dice así:

De dote donacionis facte sacro santo altari Sancte Varie et domino Bernardo, arehiepiacopo Toletano.

In nomine Domini et Saluatoris nostri Ihesu-Christi, Qui est Dous de Deo, Lumen de lumine, Creator et formator toclus mundi, Redomptor atque Saluator omnium fidelium, qui ai ab initio mundi fidei deuntione plaeuerunt. Jgo, disponente Deo, Allefonsus, Hespanie imperator, concedo Sedi Motropolitune, scilicet, Sancte Maric urbis Toletanne, honorem sedem secundum quod preteritis temporibus fuit constitutum a Sanetis patribus. Qne ciuitas, abscondito Dei inditio, CCCLXXVI annis possessa fuit a mauris, Chrisli nomen comuniter blasphemantibus. Quod ego, intelligens ssse opprobium ut, despecto nomino Christi abjectisque Christianis atque quibusdam eorum gladio seu fame diuersisque tormentis mactatis, in loco ubi Sancti nostri patres

(1) A. H. N., Códice núm. 987, B, fol. 1. 
Deum fidei intentione adorauerunt, malcdicti Mahomet nomon innocaretur, postquam paren. tum meorum, ladelicet, patris mei Regis l'redenandi et matris mee sancie regine, Deus mirabili ordine mihi pactatum tradidit imperium, belluw contra barbaras gentes assumpsi. A quibus, post multa prelia ct post innumeratas hostium morles, ciuitates populusas et castella fortissima, adiuante Dei gralia, cepi . Sicque, insprrante Dei gracia, excreitum contra istam urbem moui in qua olim progenitores mei regnauerunt potentissimi atque opulentissimi. Kixistimans fore acceptabjle in conspectu Domini si hoc quod perfidin gens, sub malefico duce suo Mahomet, Christianis alstuleral, Fgo Adefonso imperator, duce Christo, eiusdem fidei cul toribus reddere possem. Quamobrem, amore Christine religinnis dubio me periculo submitens, nume magnis et frequentibus yreliis, nune ocultis insidiarum cirenmuenientibus, nec nero apertis incursionum deuastacionibus septom annorum suolutionem, gladio el fame simul ct captinitate, non solum huius eínitatis sed ct totius huius patrie habitatores aftlixi. (2uippe josi indurati ad sui desiderii maliciam, iram Domini super se publica infestatione prouocauerunt. Ideireo, tinuor Domini et mentis inualitudo irruit super eos. Quibus rebus coacti, ipsiwet ianuas urbis mihi patefecerunt atque imperium, quad uictores prius inuaserant, uicti perdiderunt.

Tunc ego residens in imperiali aula, atque a profundo cordis mei gratias Deo reddens, summa curare cepi diligencia, promodo Sancto Marie Genitricis Dei inuiolate, que olim fuerat preclara, recuperaretur ecelesia, Qui rci conslituens diem conuocani cpiscopos, et abbates, necnon et primates mei imperii ut essent mecum Toleto, die XV Kalendarum Ianuari. A quorum consensu, ibi digno Deo ellgeretur archiepiscopus, astibus probus et sapiencia ckrrus. Et quorum officio domus erejta diabolo, Feelesia Sanela dedicarctur Deo. Quorum consilio ot prouidentia est electus archiepiscopus nomine Bernardus ct, dio prenotato, consecrata ecclesia sub honoro Saneto Dei Genitwicis Marie, el Saneti Petri Apostolormm principis, et Saneti Stephani protomartiris; ct omnium Sanctorum, ut sicut ackmes fuit habitatio demonum, ab hine permancat Srerarium Celestium uirtutum, ot omnium Christicolarum.

In ruorum presentja episcoporum et Collegio meorum primalum, Figo Adefonsus, gracia Dei totius Espania imperator, facio dotem donationis sacro santo altari Sancte Marie et tibi Bernardo archiepiscopo, necnon et omnibus elorieis hoe in loco honestam uitam ducentibus, pro remedio anime mee uel parentum meorum, villarum quarum hie sunt nomina: Barcelles, Cnbeise, Alcobneta, Alwuniar, Cabunnas de Sagra, Rutcllas, Tuirus ducen. In terra de Talauera, Aleoleja. In terra de Aleala, Lousolus. In terra de Guadalfaiara, Burioca et Aimunian que fuit de Abeniernia cum suo orto. Et illos molinos de Habib et de ompibus uineis quas ego babeo in Uilla Setina, medictatem. Et omnes illas hereditates seu casas ot tendas quas habuit hiis temporibus quibus fuit mesquita maurorum, do ei et confirmo, quam est facta ecclesia Christianorum, insuper partem meorum laborum que habuero in hac patria similiter, et lerciam partem decimarum omjium ecclesiarum que in eius diocesi fuerint consecrate; sed et omnia monasteria que fuerint in hac ciuitate constructa siue Doo dicata, tue prouidentie omni modo perspicienda esse mando; hoe antem etiam adhue ad cumulum honoris addo ut episcopos, abbates seu et clericos mei imperii, qui preerit huic ecclesie, preuideat indicandos; has uero predictas villas cum terminis et pertinenciis sujs, Sancte ecelesie et tibi Bernardo archiepiseopo ita libera dozatione concedo ut neque pro omicidio neque pro rauso neque pro fossutaria neque pro aliqua calumpria, ab aliquo irrumpantur, eadem roboratione roborentur et illas quas ego adhuc addidero, aut tu ab aliquibus acquisieris hee omnia supra seripta ea mentis intenderc ad honorem Saluatoris nostri 
Dei eius Genitrici offero ut qui hic uenerabili nita nixerint possint habere temporale subsidium. Et ego post huius uito cursum meicar habere eternm refrigerium.

Guod si quis, quod absit, aliquomodo violture sundente diabolo perlemplanerit, sit particeps majediccionis Datan ot $A$ biron yui ol execrandam suprrbiam terra wiuos degluciens et ad inferos transmisit. Sitque hoc factum indiolabile atque firmum quamdiu perduranerit seculum. Ipso regento et in morum ueniam pecatorum concedonto qui diuit et reguat cum Palre et

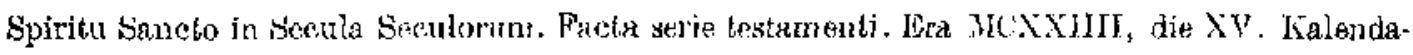
rum Ianuarif.

Ego Adefonsus, impratator hoc pritilegilum manu unea, conf. \& Wgo Constancia, regina,

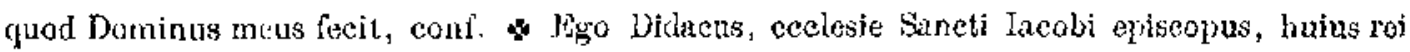
factum, conf \& Petrus, gracia Det Jegrionensis episeopus, conf. \$ Osmundus, Astoricensis eplscopus, conf. * Raymundus, Palentine Sedis episcopus, conf. \$ Gonez, cpiscopus, conf. * Petrus, Nazarensis episeopus, cont'. Amor, lucensis episeopus, coni. * Arias, Ouetensis episcopus, conf. * I'etro, Auriensis episcopus, conf. * Adericus, Tudensis episcopus, conf. * Cresconius, Coimbriensis episcopus, conf. * Gundissaluus, Menduniensis episcopus, conf. * Ego uero Vrraca Iredenandi, regis filia, conf. * It ego Geloira, una cum sorore mea, conf. * Petrus Ansuriz, comes, cont". Garsias Ordoni\%, comes, coni', * Hattinus lilaine\%, comes, eonf. * Fredenandus Didaz, comes, conf. Froila bidaz, comes, conf. \& Rudericus Ordonez, armigor regia, conf. * Sisuandus, Conivibriensís consul, conf. * De Castella, Gunsaluus Nuniz, conf. * Aluarus Didaz, conf. \& Xemenus Forhmiones, conf. \$ Lupus Sanz, conf. * Didacus Sanz, conl. * Petrus Albariz, conf. * Rudericus Gonsaluiz, conf. \& Pelağius Bellidia, conf. * Albarus Ulimiz, conf. \& Emenegildo Ruderiquiz, economus tomus l'egis, conf. * Fredenandus Petriz, conf. Petrus lohannis, conf. Menendus Petriz, conf. Fredenandus Menindez, conf. * Petrus, testis. \& Pclagius, testis.

337. Privilegios de la Catedral.-- Consagrada, pues, la antigua mezquita mayor para iglesia cristiana, y hasta dotada con los propios bienes habuses o píos que la mezquita poseía, a más de las demás baciendas y derechos que el rey le dió, empezó a vivir bajo la dirección del arzobispo D. Bernardo, quien ya antes de la Reconquista había procurado por el esplendor de su cargo (1).

De la organización de la Catedral y su desarrollo durante cl resto del siglo XI y el primer cuarto del siglo X11, no hallamos documentos que nos to indiquen, salvo la bula de Urbano 11 , de 15 de Octubre de 1088 , restaurando la primacia de la Sede toledana (2). La primera mención que hallamos en nuestra colección de la Catedral

(1) A 22 de Junio <le 1083, Alfonso, con consontimionto de su mujor Isahol, concede al arzolsispo de Thledo, $\mathcal{U}$. Beruardo, los dismos tueros para so casa que para la roal: "Ut omnia sua propria palacia ita sint honorala et in omnibus talem babeant consuetudinem sicut et mea jalatia habent.s (Cart. 1 , tolio 6.)

(2) Citada por Estella, El fusdacior de la Catedral de Taledo, Toledo, 1926, pág. 109. 
es de 1124, en que al describir una viña se le asigna por uno de sus límites otra de. Santa Maria (núm. 14).

Hay que llegar hasta 1123 para encontrarnos un curioso documento, de privilegios a la Catedral, otorgado una vez por Alfonso VII, a 29 de Noviembre de 1123, y otra vez por dofa Urraca, como gobernadora del reino, a $1 .^{\circ}$ de Diciembre del mismo año. Decía el rey:

Adefonsus, dei gratia Hyspaniarum Rex ,.... dono atque coneedo Domino Deo et beate Mario, domno Bernardo, Toletano Sedis Archiepiscopo ct sancle Ecclesie Romana legato, tociug. que Yspanie primati einsque successoribus.... decimam partem omnium meorum reddituum quos in Toletana habes uel acquisiero ciuitate uel in eius terminis, tan intra quam exterius, par nis scilicet et uini, molendinorum, furnorum, tendarum tocius fori, alfondegarum, monetarum, balneorum, de almuniis quoque et piscaris do canalibus, de sale, de omne portatico, de illa etiam greda de Magan, et de omnibus calupnịis, de lizoribus, de omni peicho, de guardiis, de illo aleisore et de omnibus gananciis quas ego siue mei suceessores predicta urbe fecerunt..... si comes, si vicecomes, si dux, si marcio, si princeps, si alcaidus, si alcadius, si zahdlmedina, si almusarifus, si ecclesiastiea secularisus persona contra hane mee constitutíonis paginam ad irrumpendum..... uenerit..... (1)

La reina gobernadora decía:

Urrack..... Hyspaniarum regni secptrum et regimen tencns atque gubornans, bone memorie clementissimi regis Aldofonsi filia atque piisimi conitis domni Raymundi uxor, que me pecatorum sarcina aggrauatam totam sentio.... domim Bernardo, Toletane sedis Archiepiscopo..... eiusque successoribus.... dono et concedo decimam partem omnium regalium reddituum cuos in Toletana habeo uol habuero urbe ac in eirs terminis..... (2)

Normalizado ya en el poder Alfonso VII (3), por su carta dada en Burgos a 18 de Junio de 1136, confirma a la iglesia de 'Toledo los fueros que tenía desde tiempo de su abuelo Alfonso VI: «Que todo clérigo vaya ante el arzobispo, en caso de calumnia; que ningún zahalmedina ni snyón pueda entrar en casa de ningún clérigo. Que si un lego se querella de un clérigo, vaya ante el arzobispo. Que si un lego hiriese a

(1) Escribio la carta al obispo de Sigitenza, por mandalo de D. Bernardo. Confirma : Bonotus cappellanu domini Papa Calixti secundi , Merendo Bofini y ccobomo de la casa real y alcaide do Madrid (Maierit). (Carl. 1, fol . 2.)

(2) Igual que en el otro. Affade : ¿Barcorum ..... pecho..... tossato. . La pena del que infrinja esto son 12 líbras de oro aauri obrizi s. Confirman los mismos. Escrita, de orden de la reina, por mano de Guillelmi Narbonensi, escriba.

(3) Véase el resumon histórico de este turbulento período en $\Gamma$. Aguado Bleje, Mamual de Fistoria de España, 4. "a edicíon, 1024 , tomo 1 , págs. 212-218. El documento anterior es interesante, por la te cha (1128) en que ya presenta actuando como rey a Alfonso VII. 
un clérigo, se le juzgue, según los cánones. Que si un clérigo hace algo malo, responda ante el arzobispo (1).

Poco después (12 de Mayo de 1137), estando el emperador en Toledo con Berengaria, su esposa, da a la Catedral sdecimam tocius monete que in Toleto fuerit fabricata" perpetuamente, "et quicquid inde habuerit in uestitura solummodo canonicorum expendants (2).

Las rentas del Cabildo debieron haber anmenlado bastante, y no parece que reinara la mejor armonfa entre el Cabildo y el arzobispo $D$. Rajmundo, sucesor de D. Bernardo, y que goberno la diocesis desde 1125 hasta 1150 ó 1151 . Hubieron de llegar a un acuerdo, que retleja el siguiente privilegio de 1138:

Privilcgium super diuisione et partitione facta canonicis per dominum archiepiseopum 'l'oletanum.

Quoniam rerum gestarum memoria eum tempore defluens cito transit et omnino adnullatur nisi scripto aliquo tenealur, Ego Raymundus, Dei gracia Toletane Sedis archiepiscopus, tociusque Hyepanio primas, bono animo el spontaner uoluntale, una cum consilio et consensu conprouincialium episcoporum, uidelicet dompnỉ Petri Seeobiensis et domuni Bernaldi Segontini, et dompni Bertrandi Oxomensis, et dompni Bernardi Zamorensis, et dowpni Berengarii Salmanticensis, et dompni Enegonis Abulensis, facio cartan diuisionis et reruna nostrorum partitionis sunonicis heate Maric de T'oleto.

Dono eis mediam partem panis ot uini de terciis ecclosiarum Toleti et tertinm partem omnium redditum quos hodie habet ecelesid Tolotana uel in anten acquisierit, sciliect, de terris cultis te incultis, de uineis laboratis et non laboratis, de colendinis, de balnois, de furnis, do tendis, de alfondegas, de piscariis, de canalibus et de amni portatico ot de decimis imperatoris.

Insuper do eis modietatem de illa alcauala de Talauera et tertiam partem de ipsa Talauera et de Maqueda et de Sancta Eulalia et do Escalona, de Alfamin, de Ulmos, do Canales, de Calatalifa, de Magerit, de Talamanca, de Puytrago, de Guadalfaiara, de Aleala, do Fita, de Pena-Fora, de Belenna, de Cugullut et de populandis ecclesie Tolctane pertinentibus.

Item de mortuorum helemosints, si fuerint XX solidi sini canonicorum, et si fuerint amplins, medietas archiepiseopi et medietas alia sit canonicorum. Similiter de animalibus et de auro et argento operato et non operato, de suppellcetilibins et indumentis fiat. Eitiam de oleo de tereiis et de fabas et de garbanços, terciama partem dono. Si contingerit quod quislibet uiuus siue mortuus aliquam hereditatem ecclesie heate Marie tribuat, due parles sint archiepiscopi th terciam clericorum. Nit si aliquis super altare aliquid posuerit, V solidos habeat inde sncricustos, alii sint slerieorum. Et si amplius quam XX ti solidi fuerint, ut supra dictum est, medietas sit arehiepiscopi ot alia clericorum.

Hec omnia ideo dono canonicis beate Marie tam presentibus quam futuris ut eorum cesset

(1) Cart. 1, fol. 33,

(2) Cart. 1, fol. 85. Es de importancia esto dato para la numismática espadola. 
murmuratio et intor tae et. illos git vera pax el dilectio; of nolo ut ita libere habeant suam domum ot omnia que ega eis dono, quod ipsi prepositum sum et seruiciales suos mutcnt et eiciant sicut uoherint et quomodo uoherint et prepositus et seruiciales non intrent nisi per ca. pitulum ct non responderant nisi espitulo.

Numerus canonieorum XXIIItr maiores et VI inizores de quibus uno defuncto communi consilio arehiepiseopo ot canonjcorum alter in loco cius substituatur.

Archiepiscopus curn familia sua in dio pasee et pentecoslew et natiuitatis Christi of assumptionis beate Marie in refectorío cum canonicis reficintur.

Quicumque autem hoc meum factum infregerit, sit a Dëo et Sanctis eius maledictus et ana. thcratizatus et cum Iudn tra rlitore in inferno dampnatus. Fit qui hane meam diuisionem uiolauerint cum Datan ef $\mathbf{A}$ biron quos terra uiuos absorbuit, eternis suplicis erucietur.

Egro Adefonsu Hyspanie imperator hane cartac contirwo et hoc signum propria manu feci. Ego idem R., gratir Dni Toletane sedis archiepiscopi, manu mea subseripsi (1).

338. Aumento de los bienes de la Catedral. - A partir de esta fecha va aumentando gradualmente el capital del Cabildo, a to cual debio contribuir no poco la cos. tumbre de que los canónigos dejasen a la Culedral para sufragios por su alma una determinada cantidad (solía ser por lo menos de 30640 mizcales de oro), que se invertia en fincas para con su renla atender a los sufragios. Tal costumbre, que adquiere carácter obligatorio en las Constituciones de 1246, formuladas por cl arzobis. po D. Rodrigo (2), debí existir durante los dos áltimos tercios del siglo XII; en 1182, el capellán D. Raimundo, de la Catedral Santa Marfa, compraba una suerte de iierra en la alquería de $\Lambda$ zaña por 100 mizcales y declaraba que los dineros con que pagaba provenian: « 40 mizcales, manda del arcipreste D. Cristóbal, para aniversarios a los señores [canónigos] por su alma en la Catedral, según coslumbre; 30 de D. Jofre, de Canales, por la misma razón, y el resto del dinero de la iglesia citada, (núm. 161).

Prescindiendo de los datos que dan los cartularios de la Ciatedral y los docu. mentos del mismo Archivo, anotaré las adquisiciones que la Catedral va haciendo en documentos árabes, durante un siglo, hasta llegar a 1234 , fecha en que reremos un resumen de lo que podrfa llamarse presupuesto de ingresos de la Catedral.

Las tiendas de los bienes piadosos (موانت الادباسه) ya se citan en 1134 (núm. 20); en Olias posela una tierra inculta (1154, núm, 45), en el pago del Arenal una vifia (núm. 53), la alquería de Azaña (núms. 87 y 97 ), un carral en el barrio de San Ginés (núm. 113), el corral llamado del Albeitar, en Santa Justa (por el mesón del lino) (núm. 116); compra un mesón en el barrio de los Correeros por 70 mizcales,

(1) Cart. 1, 10l. 7. Estella, fil fundator de la Catedval de Foledo, pág. 166, da noticia de este do. eumento, segin el original existento on al archivo Caloulal.

(2) Estella, ob. cit., prig. 181. 


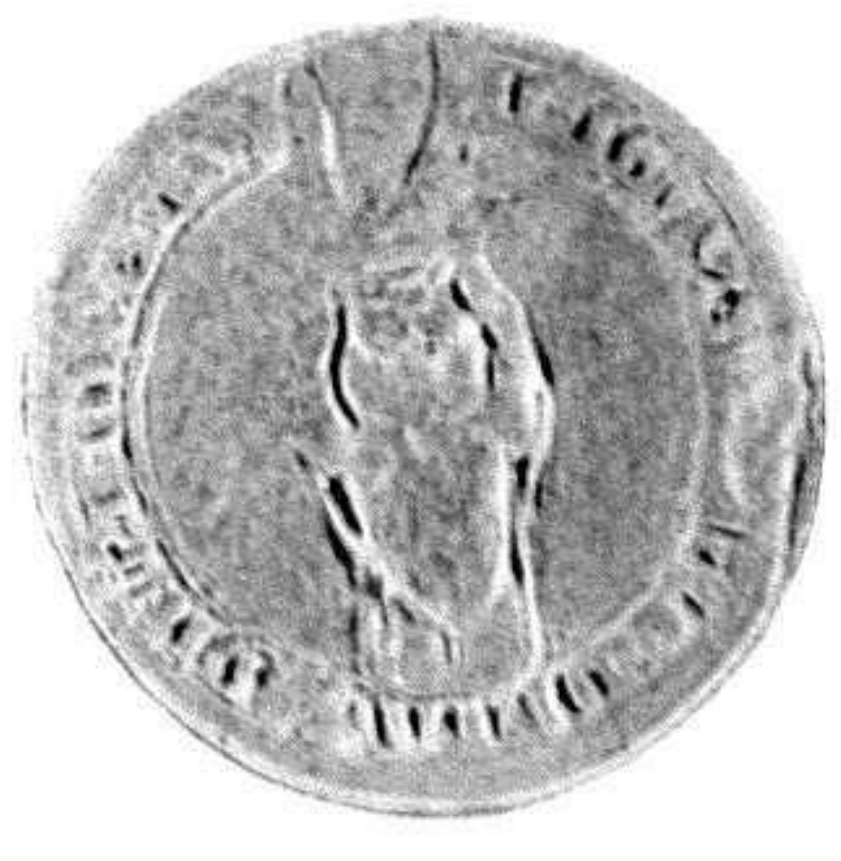

Gonzalbo, arzotispo de Toledo. Aก๊o 1184 .

(A) N , hum dis)

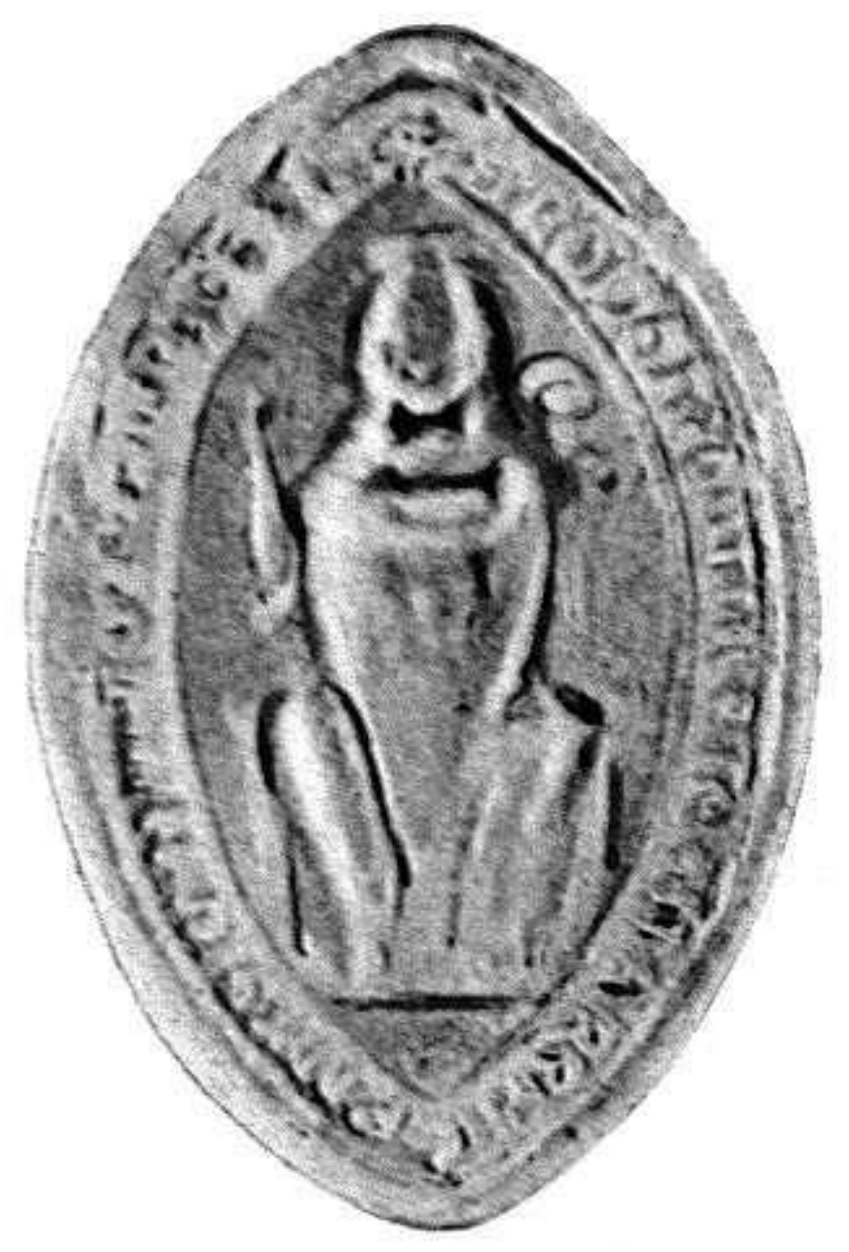

D. Rodrigo Jiménez de Roda. arzobispo de Toledo. Año 1243.

$$
\text { (A. H. N., nùm. A15.) }
$$

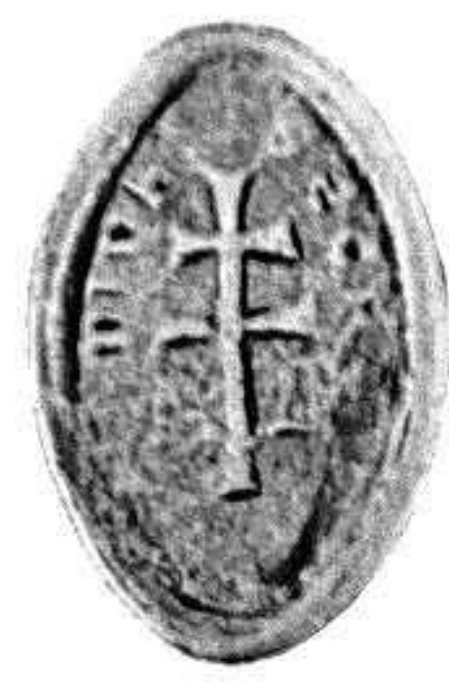

Contrasello del sello del obispo de Cuenca, D, Garcia.

(Documento num: 1.023)

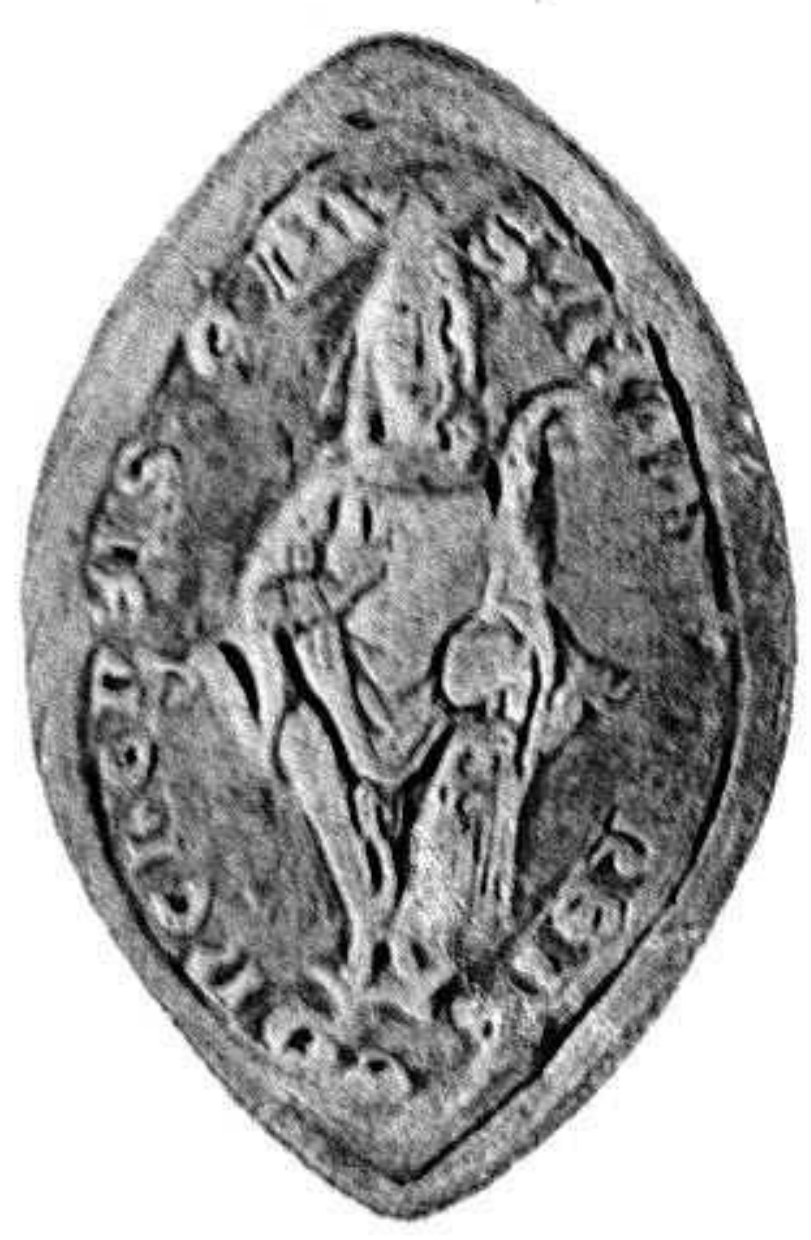

Sello de D. Garcla, obispo de Cuenca. Año 1211.

(Documento hüm, 1023.)

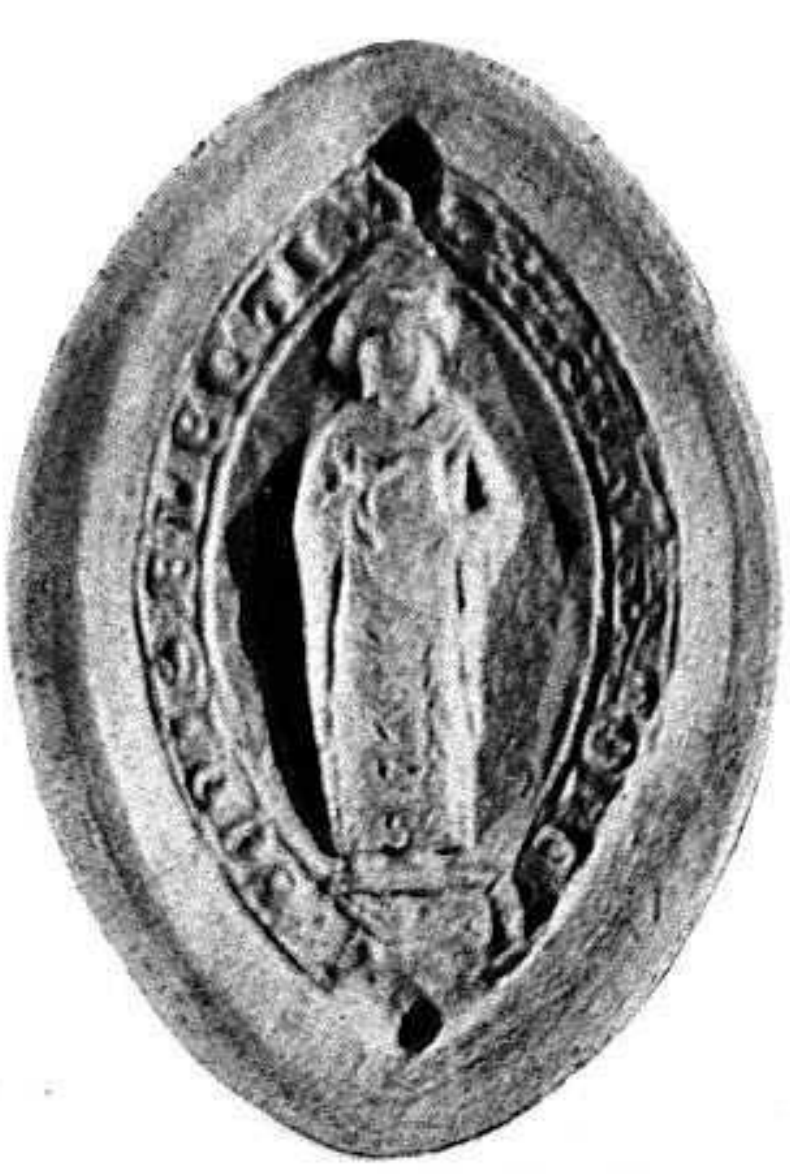

Infante $D$. Sancho, electo arzobispo de Toledo. Año 1262. (A. H. N., nùm. 416.) 
para el aniversario de Pedro Mauro y su mujer Solí, tomados del fondo de los aniversarios (núm. 126); adquiere, para el fondo de aniversarios, una casa en el Arrabal del Rey, que compró doña Urraca, hija del caid D. Pedro de Tolosa, por 19 mir. cales (núm. 166); compra, por 500 mizcales, a las hijas del alguacil slmojarife Abul. hasán Yehudá ben Odra el Judío las heredades que el rey D. Sancho, hijo del emperador, había dado al judio (núm. 175); a sil fondo de aniversarios había ido a parar la viña que fue de Pedro Alcocer y que sus herederos vendieron al canónigo luan Alvarez por $7 \frac{1}{2}$ mizcales (núm. 182).

El capellán D. Raimundo, preboste de los canónigos, y ell representación y con dinero del Cabildo, compra, en 1187, las beredades que en Alexar tenia, pro indiviso, Domingo Pérez, de la criazón del rey, por 31 mizcales (núm. 191), y por otro tanto dos suertes de tierra en Alameda (núm. 199); las heredades de Alexar, antes ciladas, las acabo de comprar el preboste D. Guillén, en 1189 (núm. 206), quien adquiere (1191) una tienda y ana casa en ruinas en el barrio de los Herbolarios por 20 mizcales (ním. 215).

La Catedral era dueña de la alqueria de Manzel Obaidalá (núm. 239), del shuer. to del Sacristan" en el pago de Bab el T'efalin (num. 243), de la alquería de Alameda, donde tenía fuero especial psira la venta de viñas (núm. 245), de la alquería de Cobeja (núm. 253); compraba, por medio de su dén Domno Español, a I). Juan de Aragón, lierra para tres yuntas en Azaña por 300 mizcales, de los cuales 100 los regalaba el vendedor (núm. 255); posé́a la alquería de Manzel Obaidalá (núm. 263), una casa y tienda en San Nicolás, por el aniversario de l). Melendo Pérez, valorada en 50 mizcales (núm. 277), un huerto en la vega de Toledo, cerca de Marzalcadí y del huerto de la Alhofra (ním. 288), la mitad de la alquería de Arcicolla (número 292), un huerto en el término de Bab el Tefalín (núm. 294), trua casa en San Marcos, cerca de los Tintoreros, que dejo para su aniversario el canónigo don Sequín y vendida por 131 mizcales, y otra del presbitero D. Pedro Bayán (número 309).

El arzobispo D. Martín López compraba, en 1202, para la Catedral, el huerto de Alho/ra, cerca del convento de San Pedro, por 110 mizcales, y la milad pro indiviso del azud de Alcapillat (núm. 322) y tres casas en el barrio del Portal o Pornicl, cerca de la iglesia de Santa Trinidad, por 160 mizcales (ním. 329). El capelfán don Roberto compraba hacienda en Camarena por valor de 710 mizcales, de los cuales 450 eran de la Catedral y el resto lo poula él y lo daba para su aniversario (número 333 ).

La Catedral adquiere (1204) el cuarto de la alquería de Arevalillo por 40 mizcales (núm. 334), dos mesones y tres tiendas en San Ginés por 250 mizcales (núme. ro 335 ), la heredad de la familia de Abensosán, en Olías, por 300 mircales (núme: ro 344), una viña en Azuqueica por 39 mizeales, donacion de Rodrigo de la Navarra para el aniversario de su madre (núm. 345), una vina en Olías por 110 mizcales 
(núm. 349), una casa en el adarve del caid D. Sabid, valorada en 60 mizcales, que da al refitor un criado del arzobispo D. Gonzalbo Pérez (núm. 354).

Tenía una tienda el Arzobispado en San Ginés (núm. 355); arrendaba sus dexechos en Manzel Obaidalá por 60 mizcales anuales (núu. 363): poséa como bien habus un mesél en Santa Marfa Magdalena (núm. 366); se quedaba con una tierra de cuatro yugadas y media de cabida ea Olías, par valor de 381 mizcales, por una deuda que el judío Abuharín Axxahats habla contraído con el arzobispo D. Martín (nú. mero 373 ); Ienía casa en San Juan (nún. 382 ).

El arzobispo D. Rodrigo adquirió para la Cátedral o para sí parte de la alquería de Villa de Muelas y Cerva Longa, en la Sisla, por 42 mizcates (núms. 387 y 389); la heredad de llaica, en la Sisla, por 24 ( $n$ úm. 389); una suerte en Daralbelio, por 56 (núm. 392); un oclavo de la alquería de Villaseca, en Vaidecarábanos, por 68 (ním. 393); parte de un corral en los Tintoreros, por 8, donde tenla ya una casa el Cabildo (núm. 396); Yepes y Fontes, por 306 (núms. 407 y 408); parte de la alquería de Villa de los Alamos (núm. 153).

En Aloyón tenía fuero especial la Catedral, consistente en cobrar el sexto de los productos de aqueltas fincas (núm. 416).

El convento de los canónigos compraba un sexlo de un huerto en Alcardete por $33 \frac{1}{3}$ mi zcales (núm. 446); varias tierras en Manzel Obaidalá, por 30 (núm. 455); una calleja en el zoco de los camiceros y de los zapateros, con el dinero que dejó don García Estébanez, arcediano, para su alma y fiestas, por 8 mizcales (núm. 437); una casa en el barrio del Bornel, por 200 mizcales (núm. 470); un mesón en el Arrabal de los Francos, por 220 (núm. 473); otro en el Arrabal del Rey, para el refitor, por 65 (núm. 474); parte del castillo de Zuferuela, por 60, 90 y 60 (núms. 481 493 y 508); una casa en el barrio de la Alcudia, por 90 (núm. 484); los derechos en dos tiendas y sus algorfas en el barrio de la Aleudia, que eran 4 mizcales de alqujler anual, por 10 mizcales (núm. 488); dos yugadas en Barciles, por j0 (núm. 503); una casa en San Juan, cerca de los Plateros, por 60, fomados de los 150 que el mástro Abril mandó para su aniversario (hám. 504); una viña en la vega de Olías, por $6 \frac{1}{2}$ (núm. 512).

Por donación adquirió la Catedral, según consta por los documentos árabes, parte de ana huerta en el arrabal, en el barrio de San Pedro, que era del alguacil Mair Temam (núm. 727, año 1137); nna tierra en Alcardete, de Jałim ben Jatim (año 1170, núm. 734); una casa en la Alcudia, por María, mujer de Juan Dnmínguez el Cojo, para su aniversario, y a condición de que los sénores dieran dos arrobas de harina cada mes y tres sueldos cada domingo, mientras viviere (núm. 739); un mesón, por Rodrigo Diaz (núm. 742); una viña en Fontalba, por Micael ben Domingo ben Otsmán (núm. 715); varias partos de Yepes y Fontes (núms. 748, 749, 750 y 753), a favor del arzohispo D. Rodrigo, por sus dueños pro indiviso; una tierra en Zalencas y el alquiler de las tiendas de los almacenistas de granos, por Fernando 


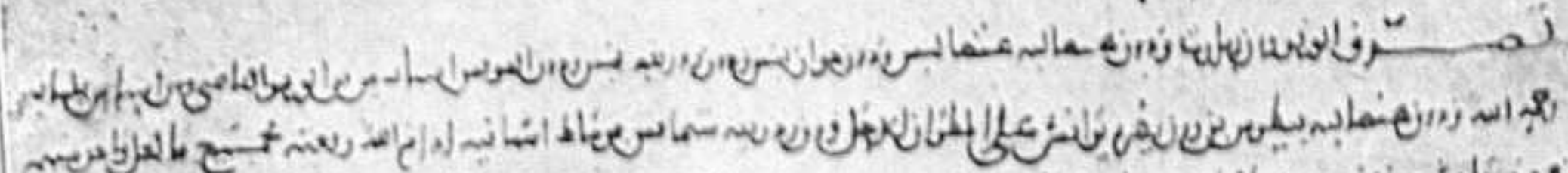

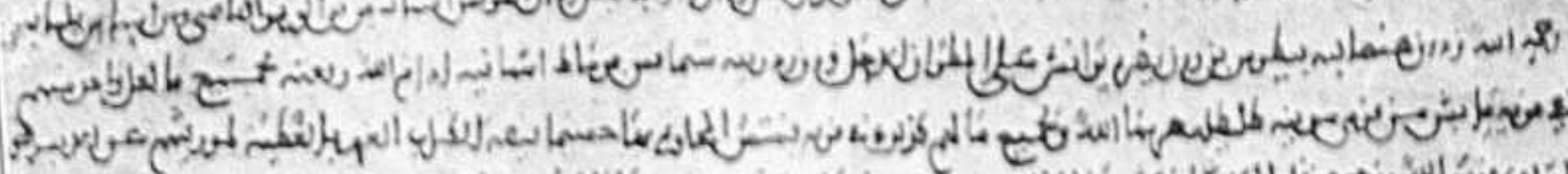

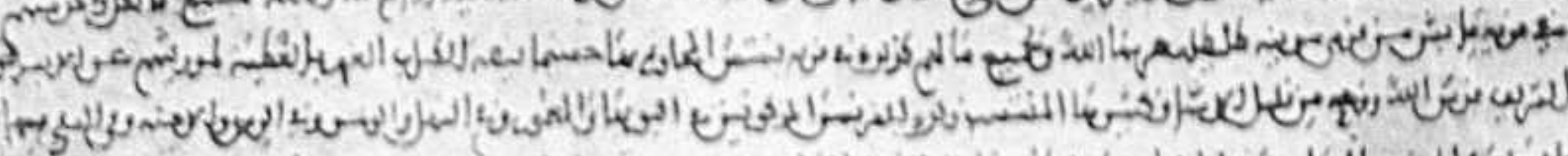

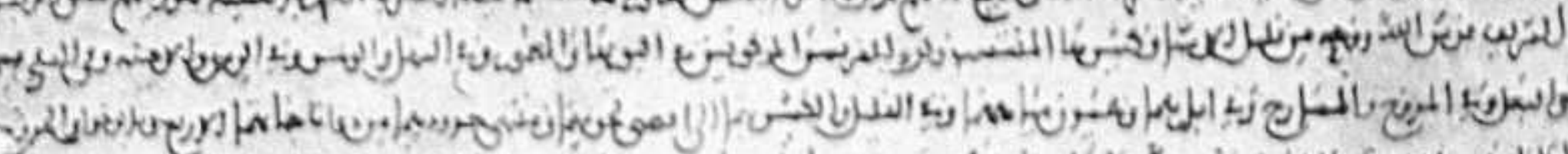

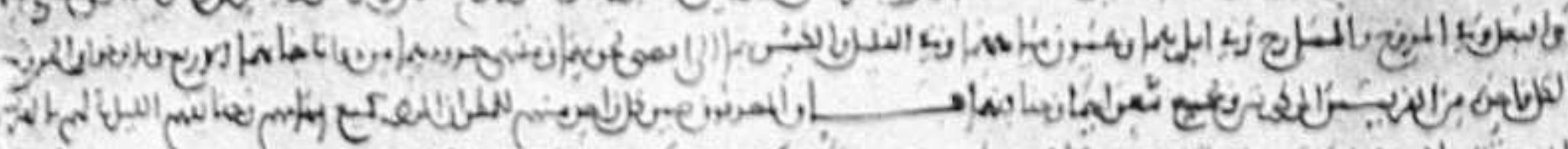

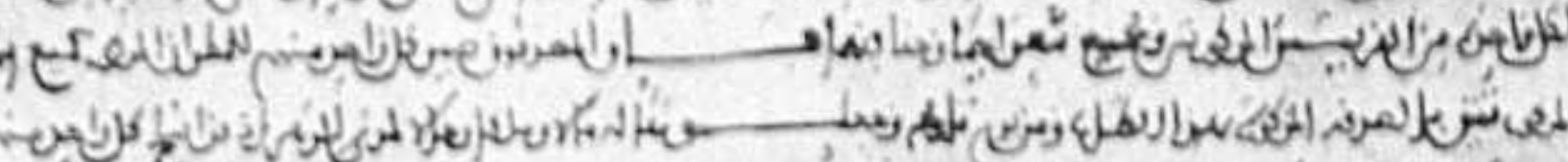

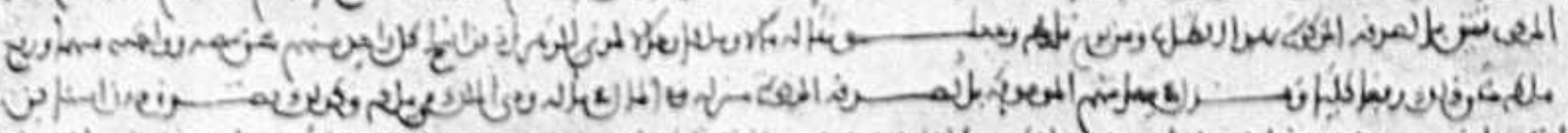

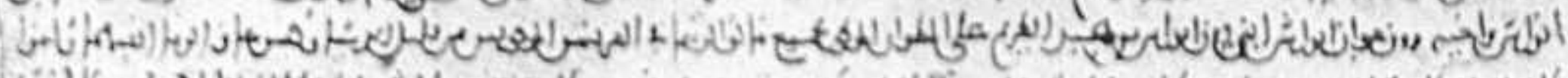

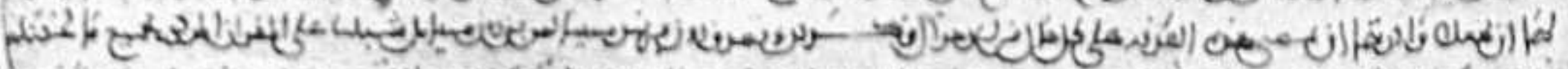

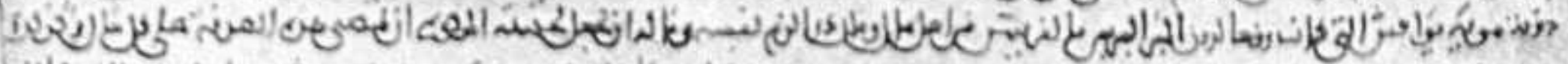

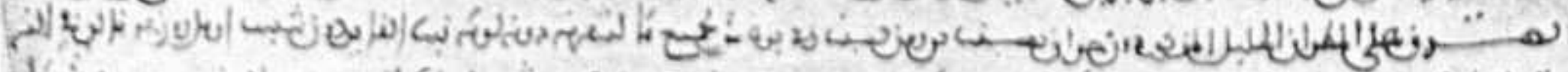

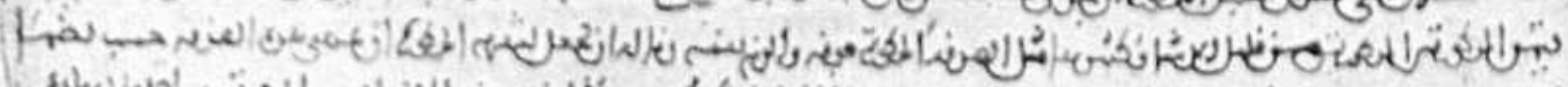

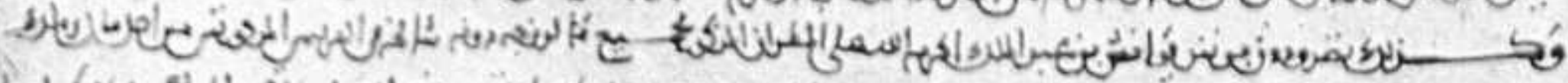

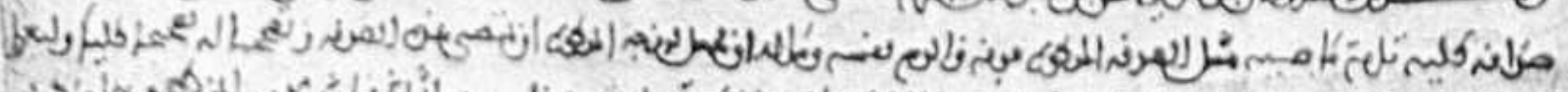

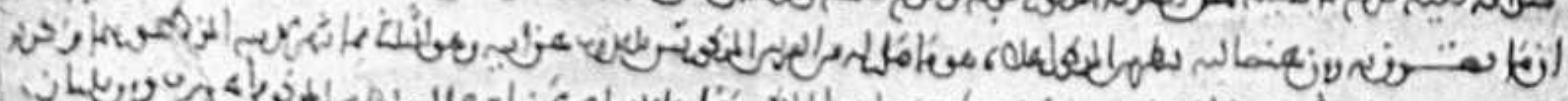

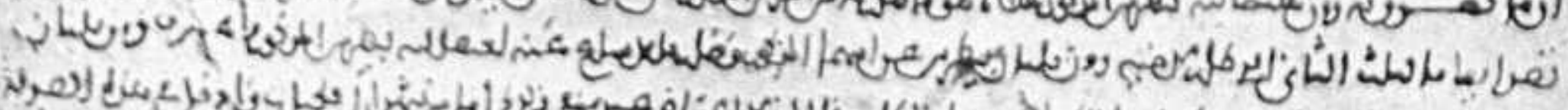

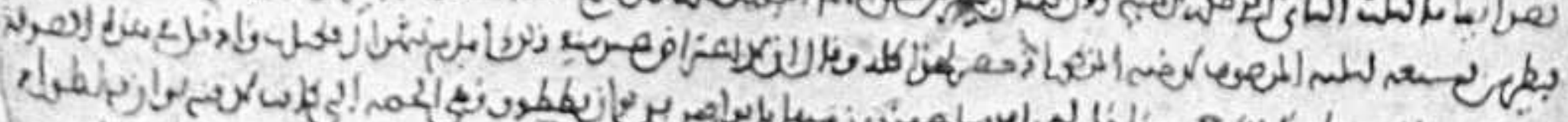

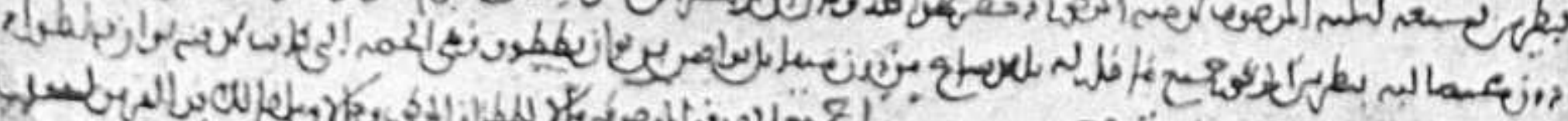

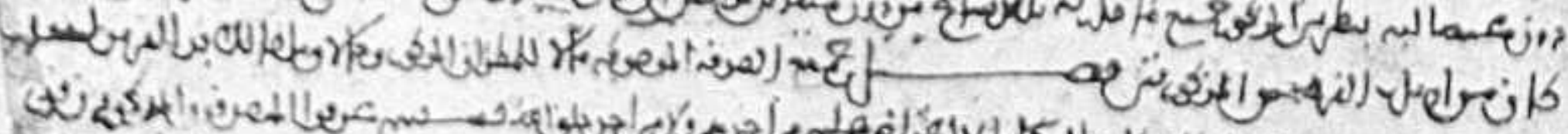

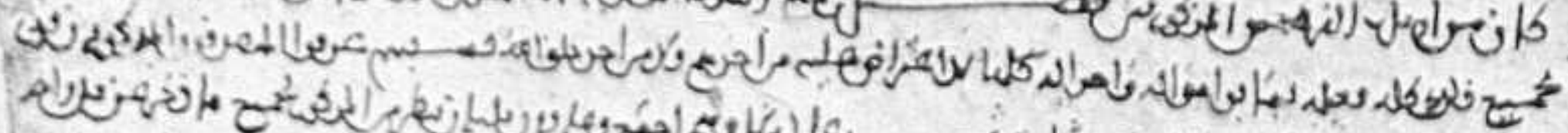

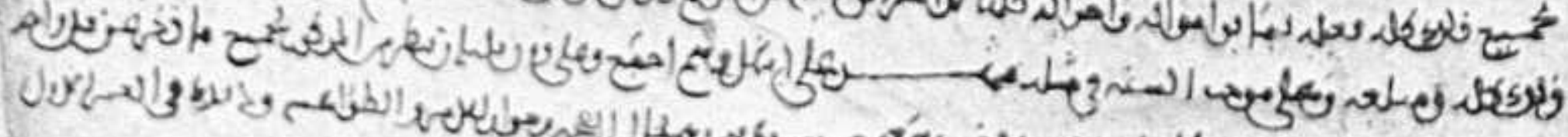

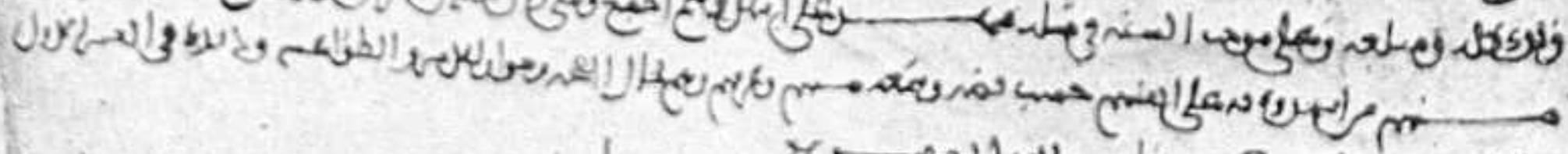
(obanponf

Donación al arzobispo D. Rodrigo: $1 .^{a}$ decena de Abril de 1213 (núm. 748) 
Juanes ben Abdelmélic (núm. 758); tres partes de una viña en Alaitic, en el lugar llamado Viñas de los aniinersarios, por Gonzalbo Juanes (uúm , 766).

Y en casi todos los testamentos se ve una manda para la fábrica de la catedral, siendo el primero en que hallamos esta manda del año 1161 (núm. 1.014), en que Domingo Antolín, alguacil y alcalde, manda unas alhajas, una yegua y 2 mizcales para la fábrica de la iglesia de Santa María la Mayor, con más el cuarto de las salinas de Perales. En los testamentos de fecha posterior, hasta 1282. se suele ver la manda para la fábrica, que unas veces es de 2 mizcales (núms. 1.022 y 1.027), otras de 10 (núms. 1.029, 1.030, 1.033 y 1.034), de 20 (núm. 1.028) y algunas liasta de 50 (núm. 1.035).

También se le mandan en testamento un corral y tiendas en San Ginés, por Ar. naldo Seguín, en 1156 (núm. 1.013), más 5 mizcales; tres arrobas de aceite para alumbrar un altar de la iglesia, habiéndose de gastar diariamente un tomín hasta consumir la citada canlidad (núm. 1.014); 10 mizcales, con la condición de que el Cabildo entierre y haga el funeral del testador, Pedro ben Suleimán (núm. 1.015); 1 mizcal para el altar de Santa Maria, madre de las Juces (núm. 1.023); 20 miz. cales para liminaria del altar de San Pedro en la Catedral y 10 para su cape. llán, por doña Matea, viuda de Gonzalbo Rechico el Bellutero (año 1283, námero 1.035).

339. Ingresos de la Catedral en 1234. - Al finalizar el primer tercio del siglo XIII era rica la: Catedral; así lo demuestra un documento conservado en su archivo (X, 10), redactado en $1 .^{\circ}$ de Mayo de 1234 , en que da la lista de todas las rentas que cn aquel momento percibia. Por el interés que tiene para la historia de la Catedral y para la topografía toledana, lo reproducimos integro ${ }^{(1)}$ :

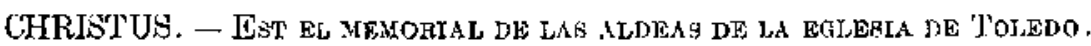

Lab primeras Ylicscas, sobre ol arzobispo D. Rodrigo y el arcediano D. Beltrán, LX; y L" Mor. cadanno. El primer tercio deue ser pagado el primer dia de Mayo; el segundo el primez dia de Setembre. El tercero el postrimero dia de Decembre. E quando será ol era $\mathrm{M}^{\mathrm{a}} \mathrm{CC}^{\mathrm{n}} \mathrm{L} \mathrm{XXIIIJ}$ deuen dar 1 CC $C^{\circ}$ Mor. eadano.

Yeles, sobre el arcediano J. Bellrán, $\mathrm{C}$ y XXX Mor. cadanno; deue pagar el segundo dia de Febrero.

Façanta, sobre D. Mllán y D. Feliz, CCCCos. Mor.; decien pagar el primer tercto mediads Janero, el segundo mediado Mayo, el tercero, mediado Setembre.

La tercia de Façanna, el préstamo fué apreciado XX Mor.

(1) Esiella (op, cit., pág. 179) lo cía y resune el uńmero de villas, aldeas, viñas, tiendas, moli nos o casas, ete. 
Couexa, Alexar, Alaweda, sobre Johan Diaz y $\$$. Aator y Gutierrez Dlaz, X: CCCos. XXII Mor,; deuen pagar por tercios segund Fazamna.

Sobre Guillén Répostero, por duas iugadas en Couexa, V Mor.; plazo, San Martin.

En Alexar, la heredad que fué de D. Cristoual, sobre D. Lop Abentiema, et una vinna en Accea, XX Mor, al annu; plazo, mediado Janero.

Mazarauedula, sobre cl arcidiano D. Bartolomeo, CC y XL Mor,; deve pagur el primer tercio, exida de Decembre; el segundo, cxida d' Abril; el tercero, exidn d' Agosto.

Arcicolla, sobre el areidiano D. Gil, CC Mor.; plazo, primerv exido Abril, después de coger pan et vino; (1) segundo, exido Agosto; el tercero, exido Decembre; y esto por tercios.

Fuent del Madero, sobre el thesorero D. Diago Zapata, LXXXV Mor.; deue pagar por tercios, segund Areicolla.

Cincostiella et la heredad de Mazarrazin et la orta el la vinna d'Azuqueyca, sobre D. Diago el capellán, XXX Mor.; págalos todos dia de San Martin.

Azuec, sobre mestro Lop de Fitero, XIUII. Mor ; plazo, por Natal.

Alcauon el Cespedosa et el molino de Maqueda, sobre el areidiano masstro Aznar, CC et XXV Mor., por tercios; el primer tercio, postrimero dia de Marzo; el segundo, el primer dia de Julio; el tercero, postrimero día de Setembre.

Cazarena de Yuso, sobre Ruy Pérez el canónigo, XXVI Mor.; paga segund Maza. rauedula.

Ocas, sol.re el arcidiano D. Martín de Madrit, X Mor.; plazo, por Resurrection.

Algorfiella, sobre maostro Jiohan, XVIU Mor.; plazo, segund Hazanna et Camarena.

Hil corral de Zalencas con la heredad de J. de Sedfila et el granadal de P'edro Lázaro, et el sexmo de las vinmas et duas planus de Zalentas et planas de Alleche, sobre Gutier Diaz, XXXII Mor., et deue pugar por tercios, segund su carta et el dia del anniuersario de J. de Sedfila deue dar IL solidos a la ración et deue conplir la orta de Allcebe de ararda a los tícmpos, él o quiquier que lo tenga .

Fuente Altamia, sobre Fedro Illán, XV Mor.; plazos, segund Fazanna.

Hazmin, sobre J. Pérez d' Olleta, VI Mor.; plazo, Natal.

Las casas de Scalons é la uinna que fueron de Pedro Maza, sobre D. Lllán el Zapatero, II Mor.; plazo, Agosto.

La bodega del capellán D. Arnald, XV Mor.; deue pagar el que la tiene por tercios del anno, segund su carta.

Las uimnas del Cadafalio, sobre D. Rodrigo el Maderero, XX Mor.; plazo, Cinquesma.

Là heredad clel Morȩe (P), que fué de Steuan Pérez, vna yugada et más et uinnas et orto et casas et tinaias et duos cabos; fueron apreciadas VII Hor.

Habeniel, et la uina en Maqueda en el Aguijón, la vina de la cuadra, sobre D. Servando, annado de Garcia Pallestero et D. Gómez, XVIII Mor.; plazo, primer dia de Febrero; el segun. do, 1." Mayo; el tercero, primcro setembre.

En Madrid, las casas et las uinnas que fueron de donna Marla la Ollera, sobre D. I Lorenzo; plazo, Ovaniuin Sanctorum .

En Madril, otras casas sobre el arciprest de Madril, II Mor. et tercia.

Carauanchiel, sobre Pedro Domingo el chanceller, XXX Mor.; plazo, Febrero o segund su carta. 
Cortes, sobre D. Gómez Dalmoguera, L Mor., los Xl. Mor. todauia de los canónigos et los $\mathrm{X}$ del Refitor; plazo, el medio de Slayo después del coger.

La heredad de Cortes, duas yugadas que tiene maestro Do Pascual, XII Mor. cadanno; plazo, Natal.

La tercia de Cortes fué apreciada XXV Mor. et no es arrendada.

T'odas las aldeas que son escritas, las pagas de ellas son después de coger pan et uino.

Wh rengalengo, nuestro tercio solue D. Alazar, D IXXXXII Mor. et tercia en guerra, et en ${ }^{3}$ a DCC et XXXITr et bercia; paga cuemo Yliescas por tercias del anno.

Las tereias de Toledo fueron apreciadas, CC. et L Mor. el non son arrendadas.

El diezmo de Magam, pan et uino, fué apreciado LXX Mor. y no es arrendado.

Las salinas de Abcjares, sobre Marctios el Conejero, $X$ kahices cadanno en so uida; debe pagar segund su carta.

Ias salinas de Perales sobre donna Mayor de Martin Pardo XXI kafices y denelas tener este snno; plazo, Julio.

El aluazilado fué apreciado L Mor, sobre don Godiel.

Los canónigos de Runta Leocadia, V Mor., el dia de Santa Leocadia.

los canónigos de San Vicente, V Mor., medio Agosto.

Los canónigos de Talauera, V Mor., por natiuitas Sancte Marie de Setembre.

Eat dis MemORTAL DE LAS vinNab.

Las uinnas de Alectic de los anniuersarios, sobre D. Feliz el Ferrador, XXXH Mor; el primer tereio, exida de Decembra; el segundo, exida de Abril; tercero, exida de $\Lambda$ gosto; en so tuida.

Las tres uinras que fueron de Gonzalo Yuannes sobre D. Feliz el Ferrador, V Mor.; plazo, San Johan o San Pedro en Iunio.

En Zaleucas, la uinna que tiene maestro scuela y la orta, en so uida, por V Mor.; plazo, San Johan.

Las uinnas en Azuqueica que fueron de la madre de D. Rodrigo de la Nauarra, sobre donna Domenga la Crispina, IYU Mor. en so uida; plazo, en quaresma.

Las uinnas de Ruy Fernández en Aloyón, sobre I, ombre de Olias, II Mor, y tercio; plazo, Yanero; en so vida... [Una partida tachada.]

Las uinnas que tiene don Steuan de Ribas, la una en Ual de Cubas; atra en carrera de Bargas; otra en Bergoza; en so vida, XII Kor.; plazo, lo medio por Sar Martín, lo al por hesurrection.

La uinna de J. Suárez en Ual de Cubas, sobre J. Stevan XX sols en so uida; plazo, Janero.

Las nimnas que fueron de Pedro Salbat; la una en los ualles de Oliolas, otra en Santa María de la Sisla, otra en carrera de Arges, sobre Feliz Gastón, IIII Mor, et medio; plazo, segund su carta o en lanero.

Las nimnas que tieue don Illán Abenbarragán, una en Ual de Santyago, otra carrera d' Oltas, otra en Ual de San Polo, IX Mor.; los VI paga por Jaenero, et los tres por Mayo, en so vida.

Las uinnas que tiene Lop. F. en Mazarabuzac, XI Mor, plazo, medio Mayo, en so uida. 
La uinna de D. Harna en los Enforcados, otra en ¿'Daralmagra?, sobre D. Garcja Arbeión, ll Mor. et medio; plazo, medio Agosto.

La uima de Darallaud, sobre D. I.op el Cucharero, II Mor. et medio; plazo, por Natal, en so uida.

Las uinnas que tiene Maestro Cialtcr; una, carrera de Castiella, otra, al pozo de D. Codiel, otra, a Ja zarza.

Las uinuas de Maestro Albert, carrern de Canales, sobre D. Andrés d' Olias, VI Mor.; plazo, medio agosto; en su uida.

Ia uinna que tiene D. Roman en Olias.

La dima que fué del arceriano D. Genes en Benallauia, sobro Martín Pérez Abentorel, JII Mor. y cuarto: plazo; Nayo, setembre y Janero; en so uida.

La wima en Bennhauia, sobre D. Moriel, lllI Mor.; plaz, sim Narlin; en so uida.

Las uimnas de D. Crisíbal en Benalhavia, sobre Juan Migrael, nieto d' Almogabar, ct don Geromes, VII Mor.; plazo, Febrero; en so uida.

Las uinnas que tiene D. \& Nuño? el tendero en Benalbauia et en Alloyon, II Mor.; plazo, resurrection; en so vida.

La uinna do Corral Rubio, sobre D. Lope el cucharero, INor. et medio: plazo, resurrection.

Las uinnas, ILL, en Loches, sobrc D. S., el sobrino de Tope Dominguez, V Mor; las que fueron de Fernando Lázaro; plazo, meatat en Febrero y lo al por Resurrection; en so uida.

Las ninnas que tiene Maestro Juan, carrera de San Román; deuelas lexar pues de sos dias.

La ninna que fué de $\mathrm{D}$. Rodrigo de la Navarrá en Loches, solbre D. Sebastián el ollero, II Nor. y medio; plazo, medio Janero.

Ia uinna que tjene D. Aluar d' Olias en el Albufera, I Nor; plazo, Resurrection.

La vinna que tiene A. Meléndez el Arcediano, de yuso de eu torre, II Mor.; plazo, medio liebrero.

Los tres pedazos de Poçancaras, sobre Steuan Yuancs, de Santa Leocadia, XW Mor. menos quarto; plazo, San Johan.

I a vinna que tiene Pedro Fermández en Font Alba, IX Mor.; plazo, Mayo.

La uinna de Font Alha, sobre J. Nicholas y D. Adam, LII Mor.; plazo, Resurrection ct Santa Marfa do Agosto.

La dinna que tiene Domingo Pérez Abentoriel en Ual de Cubas, IU Mor.; plazo, Mayo Selembre, Jiznero.

La uinna de Font Alba, cerea el corral d' Abenbarragan, sobre D. Nicholas el tegero, med. Mor., et non deve dar nada estos IIIT annos.

La uinna que tiene D. Feliz Barragan on Peniel, I mor. et medio; plazo, Cinquesma.

Ia dinna que tiene J. Fradet, en Peniel, LII Mor.; plazo, Janero el Agosto, o segund su carta.

Las duas uinmas en Almoradiel, sobre Pedru Sales, V Mor.; plazo, Janero et liesurrection.

Las uinnas de Torres, VIT Fazas et el seśmo, sobre D. Cristóbal, et una uinna ell Almoradiol, XXXII Mor.; plazo, Janero, Mayo et Setemblre; en so uida.

Las uinnas d' Aleardeth, duas fazas y media quarta, sobre el Capiscol, XVIII Mor.; plazo, San Martin.

La uinna d' Alcauon, sobre D. Nunio, Ir Mor'; plazo, Febrero. 
Egt eg memorial DN TAS ORTAS.

La orta de Allectic, sobre D. Iuchas el orebze et Jolian Illôn et D. Diego el caxpintero C. et JX MLr.; 1res plazos: medio Agosto, san Martín, Janero; por I anno.

Is orta de Allialleseia, sobre el arecdiano D. Beltrán, X Nor.

Ja orte de Aleardchl, solore 1 . Diego ol ortelano, XIX Mor. por IUL annos; plazo, San Aligael.

Ja orth de Talawira, solme D. Mareos el areineste, II Nor; plazo, Natal.

La orta de Canales et la uinua sobre D. Marchos el areipreste, I Mor.

Vua ticra on Bissagra, solje F. Garcia, V sol. 'lierras en Alcardeth.

Tierra en Ganeth, solre D. Trop.

EST IS MEMORLAL LW LOS MOLINOS.

El molino de anedio del Fierro, sobre sBenaix? C et LX Alar; plazo, por tercios, et empieza el arrendamicnto en $X X$ días de Febrero.

Il tercio del molino del Capibeol, XXXVI Mor.; empieza el arrendamiento el primer dia de Setembre el que uienc.

El molino trapero, solure D. Steuan et su mugier dona Juana, XII Mor. ot medio; paga por tercios: Mayo, Setumbre et Decembre.

El molino que fizo Ruy l’órez, XJX Mor; li jart de los canónigos, que es tanto quanto an en ol molino trapero.

Isl molino y sexuno de la Reyua, sobre nonna Eluira, XI, Mor.; cn so uida; copjeza el anno el primer dia de Sitembre que uiene, et deue pagar por tercios del anno.

Jos molinos de Talaucra, sobre IIezmeel Abrnmueiella et Ayhya $\Lambda$ benzumbal, O, XI, y V Mor, pagan por lercios; se conpicza el amo primer dia de Junio el que viene, por II annos.

Los molmos de Alcardeth y Jatfamin, sobre Gonzalo Garcia, XIII Mor.; plazo, Santa Maria de Agrostu.

Ia plana de Torres, sobre D. Godiel, XX sol,; conpicza el anno por San Feliz.

La plaria de Jorita, es por arrendar de San Feliz en adelant.

La plana de Corral Ruuio, es por arrendar otro si.

ERT RS MEMORLA IJ LAS CABAB PLBPETUAS QUE TIENEN LOB CLERIOOB.

Las casas deI arcediano D. Beltrán, XII MLor ; paga por tercios.

Las de Maestro escuela, VIr Mor.; paga por tercios o todo en Natal.

Las casas fuce tiene Gonzalo Iuanes et los mesones, $X$ Mor.; Ios syete por Santyrgo et log tres por San Nicholas.

Las casad que tienc D. ¿Roinery?, IV MIor.; conpieza el arrendamiento en Mayo; paga por lercios. 
I as casas que tiene Lomingo Illán, LII Mor; conpieza el arrendamiento en Nayo; paga a la. fin del anno pasado.

las casas qute ticne Doningo Xuanes, el clérigo de Sant Antolin, LI Mor. et medio; paga segund sa carta et deue meter en lauor de las easas XIL Mor. o más.

Ias casas que tiene Marstro Steuan el organista, V'llJ Mor.; paga por tercios.

Las casas que tiene el arcediano de Alearaz, IlI Mor,; conpieza el arrendamiento en Mayo, paga passado ol anno.

Ias casas que tiene D'trlro lópen, IX Mor ; paga por tereios.

Las casas que ticne ol ileán D. Migrael, IX Mor.; paga por tereios.

Las casas que tiene 1). Aristóbal, Ill Jor.; conpicza el anno primer Mayo; paga el anno passaritu.

Las casas que tiono D. Binayas, III Mior.; conpieza el aryendamiento en Marzo; paga el auno passado.

Jas casas que tiene Lope Dominguez, Il Mor.; paga en Janero, exida del anno.

Las casas que ticne la Obra, LX Mor. y medio; paga por tercios.

I as casas que tieno B. Aztor, XII Mor.; conpicza ol arrendamiento on Febrero; paga el anno passulo.

Las casas que tiene el capellả D. Iaurtholomeo, III Mor.; paga asji euemo B. Aztor.

Las casas que tiene Garcla Aluarez, IJII Mor.

Las casas que tiene el arciprestr. T). Matheos, IX Mor.; paga por tercios.

Las casas que tienc D. Nunio, X Mor.; paga epgund su carta.

Jas casas que tiene Maestro Lop do lititero, VlI Mor.; conpieza el arrendamicnto dia de San Bartolomeo ol gua lielle; pagal los l.II Mor': ; p Febrero et los IIII passado el anno.

Las casas que tione ol arcidiano de Calatraua D. B., VI Hor; paga por tercios. [Una partida tachada.]

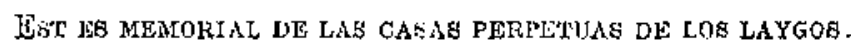

La casa que tiene D. Nicholao el alfagem, II Mor.; paga por tercios.

La quo tieno Maria Perez, $Y$ Mor.

I, a que tiene D. Riehard, I XIor.

La que tiene Domingo Garela, V Mor.

La que liene fi de J. Guteres, XIIII Mor. el quarto.

La que tione D. Lorenz, X Mor.

Las casas que tiene la Crispina, XVIII Mor.

La que tiene D. Arnald el perptrtero (?), XV Mor.

La que ticne D. Yago el labernero, VIIl Mlor.

La que tiene D. Steuan, yerno de la Crispina, vur Mor.

I a que tiene D. Fernando el spartero, IIII Mor.

La que tiene I'edro Martin, sobrino de D. Garcia de la Reina, IX Mor.

La que tiezze D. Komản, I Mor. 
La que tićne D. Lope Alfayath, VI Mor.

La que tiene P'cdro Endura (?), X Mor.

La del Prioc, LII Mor.

La que ticne Seruando Sobastian, V Nor. et medio. Las de Arnaldo de Polinac, U Mor.

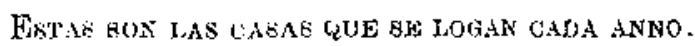

bl mesón de lal pee, Xlill Mor., sobre D. Fernando y su mugier.

La casa que lience Garcia Botero, XXI Mor.

Ia que tione Martin Péréz el Alfayath, VIJI Mor, monos tereia.

La que tiene Slartin Martin, fi de Martín Durgel, XVII Mor.

La que tiene donna Orabuena, XY Mor.

La clue tiene Martín Domingo, XV Mor.

Las del múrmol, sobre J. Pérez, LX Mor.

las que tiene D. Kodrigo cerea d' Alpolinac, VIT Mor. et quarta.

ad uesón rueue, solre l'edro Martín Abengurrón, XX Mor.

El otro que tiene Jo Almarracost, XXII Mor, ot medio.

Las casas que tieno D. Munin, XVIII Xior.

Las otras, sobre Beneito, XIJII Mor.

Las dol canto del Capidlo, sohre D. Pelayo, X Mor.

Ja tienda que partiomos del Aleana, VII Mor.

Lí mesón del Alcana, sobre Johan d' Ultramar, II Mor.

Ia otra tionda de fuera, sobre D. Pedro el Balestero, $V$ Mor , menos III sol.

Lat que tiene D. p'olayo el Pedrero, II Mor.

La do Sire Buey, sobre Pedro Johan el ollero, VI Mor et quarta.

Lu tienda de] Canto, sobre Ali Alfugem, VI Mor.

Las casas cerca la tionda, sobre Aldonza, VII Mor .

lis tendezuela chicu, sobre D, Pedro, I Mor. et medio.

Las que son a puerta d' Aleintara, sobre Marla Martin, VI Mor.

Las que son corca el adarve de D. Seruanda, Wr Mor. th yuarta.

La que tiene María Guillán, IU Mor. menos quarta.

El mesón de las chuas puertas, sobre D. Jurenzo, VIU Mor.

Ias que son en la calleja de los Olleros, sobre Pascual Román, VI Mor.

Ira tienta de los olleros, sobre D. Sebastiain, XI Mor.

Las casas que fueror de Pedro Lázaro, sobre D. Lop el Pescador, V Mor.

Lil mesón grand de Sanete Justa, sobre D. Gonzalo d' Uzeda, XL Mor.

La tjenda de los Ferreros, sobre D. Martín, VI Mor.

La casa que fué de Melén Pérez, sobre D. Pedro, III Mor.

La tienda de Melén Pérez, por alogar.

La casa que tieno la Coxa del Arrabald, I Mor. y V octayos.

La caka de la carneceria, sobre D. Lázaro, VII Mor.

La del Sotalo por logar. 
El corral de los Olleros, sobre Alazrac, XY Mor, et quarta.

La casa o fieren los bofordos, sobre Domingo Yuannes, VII Mor.

El mesón del Archo, sobre donna Maria et donna Theresa de Sancto Domingo, XX Mor.

Fil Sotalielo, sobre Leocadia, V Mor. et quarta.

El mesón que fué de liernando Dominguez, XXX Mor.

Las casas quo fucron de D. Rubert, solure Domingo Marciclla, IX Mor, et quarta

El mesón de dona Sol, XXLX Mor. et medio.

La calahorra, sobre Pedro Martín ef su mugier, LIII Mor.

Ill mesón de Johan de Cotunda, sobre Cazew, XIJ Mor.

Las que touo Domingo Mocho, solro Martín Stéuanez, VIII Mor. et medio.

Las que touo Martin Sardina, VI Mor.

Las del areo, sobre Domingo (sil, IחL Mor. at meditr.

Las quales tiene con las del archo sobre, ¿Domingo d Feb́n?, Wl Mor.

Las del archo, sobre Domingo el medidor, V Mor. et medio.

Ja otra casa cerca della, sobre F. Felices, VI Mor. et quarta.

La casa del canto, sobre Theresa, तJT Mor. et modio.

El mesón que fué de D. Fernando, sobre dona Vrraca, VI Mor.

El mesón cerca la tafureria, sobre Fernando el Corio. VI Mor. menos quarta.

Las que fueron tafureria, sobre dona María la l'erdiguera, X Mor. et medio.

La casa chiea, sobre Domingo Guerra, I Mor.

La tienda que auemos con D. Oxtmeior, sobre Martín Abehantar, XXVli sólidos.

La otra niodia tionda, sobre Dowingo dlbino, IIJ Mor.

La tienda que fué de Joan Zapatero, solure D. Jodrigo ct Domingo Iuannes et D. Steuan XXX Mor.

La casa que es sobre la carneccria, XXVI.I sólidos.

El mesón nueno que flyo Ruy Pérez, $x X$ Mor.

Las casas que tienc Beneito el carnicero, V Mor.

Las que tiene D. Mamés, V Mor.

I as que tiene Steuan Alauxi, Ir Mor. et medio.

Eil mesón de la Aleudia, sobre Dowingo el peón, XV Mor.

Ia casa que es en el adarve de D. F'rancés, sobro D. Steuan el camicero, III Mor, et quarta.

Jas tiendas con los sobrados, que fucron del obispo D. Gareia, sobre D. Feliz et gobre el Fidalgo, XXIIII Mor.

Las casas trea que tiene Poequibón, IUI Mor.

El corral ante el banno del Caualiel, por logar.

El tercio del banno del arzobispo, por logar.

La tienda a. San Just, por logar.

La casa cerca el forno de Murfa Afin, sobure Abzeyth, JU Mor.

Las quales tiene con esa, sobre Vincent \&Alculipán?, II Mor, el medio.

Las del banno del Fierro, sobre donna Dominga, IL Mor.

16) sobrado a Poz Amargo, sobre D. Marchos el de D. Guillén, II Mor, et quarta.

Las casas que fueron de Martin Furon, sobre Maestro Galter, IH Mor.

Las que tiene Maestro Martin de la obra. 
Las que ticnc Pedro Illán Barragán a Sant Antolin, II Mor.

Las que son a Satut Felis, sobre Jnan Femández, III Mor.

El mesón que liue do Haria Muzucla, sobre Rodrigo, ILU Mor. et medio.

Las casas que tiene Pexlro Guillén do Barcelona, II Mor. et medio.

El sobrado a cmrizm sanchorum, sobre Martín el Peón, II Mor. menos quarta.

Wl mesim que fac de l'edro Lazaro a San Martin, sobre Domingo Munnoz, VII Mor, et medio.

La casa de medio, solire Garela Fernándea, V Mor.

La que es cerca el muro, sobre Joan d' Aragón, Il Mor.

Ja de la nuesa, sobre la mugier de Munno, V Mor.

La que es cerca de ella sobre Loba, III Mor.

[i] mesón nuruo y las casas do los bannos derribados, sobro donna Maria, mugier de Joan Perdiguero, et el fiador don Lazaro de Maria Corres, VIU Mor.

Jas casas que nos dio fon Gonzalo de Carmena pues de sos dias.

Las casas que nos dio don Jofre de Segonia a Sant Vincent, sobre F. Jelizes, MU Mor.

La otra casa del Canto, sobre don Jllun el clérigo, III Mor.

El forno a San Genkés, sobre J. Cuillén, XVII Mor.

El formo del arzobispo, nuestro tereio, sobre J. Martín, XI Mor.; conpieza el anno por San Martín.

La teneria de los correeros, sobre don Remondo, VWI Mor. et medio.

La tcueria mayor, sobre Jac ob Alfolue, גII Mor. et medio.

I a teneria nuena, sobre Yefudh, XUII Mor. et quarta.

Jos mesones del Alculia, que rretieron en la obra, XXVII Mor.

bas tiendas quo nos dió Polay Gutiérrez on Y'liescas, XXVIII Mor. menos II sólidos et medio.

Her EA MEMORIAL DE LAG TIENDAS DEL A LOANA.

El plazo del Aleaná conpicza en primero dia de Marzo.

Ja tiencla de Pedro Illán, $X^{x}$ Mor.

La tienda Mofomath, $1 \mathrm{X}$ Mor. ct octaua.

I.a tienda de Abzeyteh, XII Mor.

I a tienda de Ali de Yúnez, XIr Mor. et medio.

La. tienda del Gasco, VIII Mor. et quarta.

La tienda de Johan Pérc\%, VW Mor.

Ja tienda de Mozimodi, VI Mor.

La tienda de Ali de Domingo, XI Mor. et medio.

La tienda de donna Orabuena, XI Mor.

La tienda de Mari Garefa, III Mor. et medio.

La tienda de clon Domingo, VII Mor. et octaua y medio.

Ja tienda de Feliz, ni Mor, menos octana et medio.

Ia tienda de Juan Martin, III Mor, et medio et media octaua.

La tienda de Colomba, I Mor. 
La tienda de Maria la lauandera, I Mor.

La tienda de Joan Alfonso, Y Mor.

La tienda de Mayor, I Mor.

Ia de Alascar, I Mor.

La de Domingra, I Mor.

Las duas tiendas, sohre Marta Simón, II Mor.

Ja de Znleimán, II Nor.

La de lomingo Martín, l Mror.

Otra sobre Petro llin, II Aror.

E todos estos plazos gue son sobredichos en esta carta deucn jagar aquellos que algo tienen del refitor et si por auentura non se acorlaren el alogador con el cogedor mucstre su carta et segund su earta pague. E si por auentura alguna cosa se olhidi que suflo seer dol refitor, que no es aqui escripta, deuela auer cl arrobispo.

Facta carta prima die Aladii anno incarnationis Domin us $\mathrm{M}^{\circ} \mathrm{CC}^{n} \mathrm{XXX}^{\circ} \mathrm{IHI} \mathrm{I}^{\circ}$. Era $\mathrm{M}^{n} \mathrm{CC}^{n}$ $J_{L X X}$ secunda, de omnibus redditibus quas tunc temporis hatheat refectoritum capituli ocelesie toletane (1).

Totalizando los diversos conceptos de este Memoríal, vemos que las rentas de la Catedral ecan:

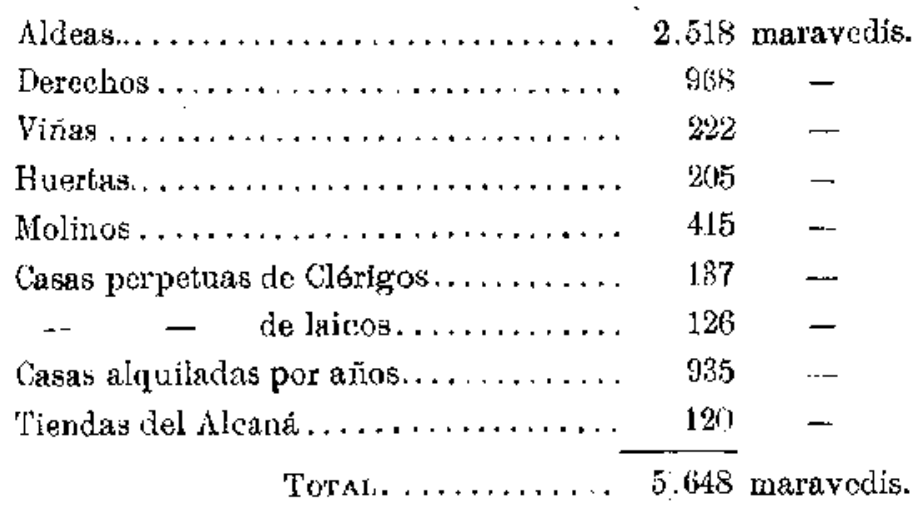

Sin contar algunas fracciones y partidas que estaban sin arrendar aquel año.

340. Prosperidad económica de la Catedral. - La prosperidad económica del Cabildo continúa aumentando en los dos áltimos tercios del siglo XIII (2), y se refleja en los documentos árabes.

E) Cabildo o el arzobispo compran en 1237 un trozo de viña en Alaitic por

(1) Arch. Cat. Toledo, X, 10.

(2) Para conocer el sistema interior de adwinistración, véaso la citada obra de Esstella, pág. $280 y$ siguientes, en que gualiza la constitución de 1246 . 
4 mizcales (nún. 523); la novena parte de la alquería de Pesinas, en la Sisla, por 150 mizcales (núm. 325); una suerte en Fontalba, por 10 mizcales (nún. 526); otra en la alquería de Xarf $\Lambda$ ddoján, por 10 (núm. 529); una casa en San Jusı, por 40 (núme. ro 543); una casa en San Juan, contigua a otras dos que ya poséa, por 110 mizcales (núm. 5-14); diversas en San Justo, por 100 (núm. 547); un mesón en el Arrabal de los Francos, por 140 mizcales (núm. 550); una botica y corral en el Arrabal, por 180 (núm. 551); una casa con corral en Santo Tomé, por 170 (núm. 556); ofra en barrio de San Andrés, cerca del Pozo Amargo, por 50 (núm. 577); un sexto de la alquería de los Viveros, de Madrid (núm. 564); los derechos de medianerła en una casa del barrio de Santo Tome, por 3 (nútm. 383); una vina con olívos en Alaitic, por 30 (núm. 585); otra viña en el mismo pago, lindante con tres que ya eran de la Cate. dral, por 30 (núm. 588); el tercio de la mitad de un huerto en Mlcardet, por 100 (núm. 590j; un patio de corral en el lrartio de la Magdalena, junto al mesón grande de la Calahorra, que ya poséa, por 50 (núm. 597); una casa en el adarve de don Bernaldo, por 130 mizcales, procedentes de cuatro aniversarios, tres de ellos a 30 mizcales, y ofro de un canónigo, a 10 (núm. 608\}; un corral que servía de maladero en la Alcudia, por 200 mizcales (nom. 610) (1); una huerta con dos pozos en Alaitic, por 500 mizcales (núm. 613); in mesoncillo en larrio del hey, por 20 (número 614); la mitad del sexto del señorio de Esquivias, por 250 (núm. 618); un cuarto del tercio del mismo señorío, por 125 (núm. 620), y un tercio de la mitad, por 500 (núm. 621); unas algorfas o sobradillos encima del mesón de la pez, por 40 (núm. (25); una cása y dos sótanos en el barrio de la puerta del Portillo, por 500 mizcales blancos del fondo de 2.000, que el areediano de Madrid, D. García Muñoz, habia dejado para aniversario y capellania (núm. 618, año 1275); una casa y una habitación en el adarve de los canónigos, por 213 mizcales blancos, para aniversario del tesorero $D$. Pedro Roldán (núm. 660); dos casas en el barrio judío, en la Acaba, por 2.000 mizcales blancos, del dinero que dejo a la Catedral cl deán D. Sancho Martínez (núm. 674); uza casa en la Trinjdad, lindante con la capilla de San Juan del arzobispo, por 400 mizcales (núm. 716).

Algunos otros derechos adquiere la Catedral, como la posesión del azud de Corral Rubio, que fué de Fernando Mateos, en 1276 (núm. 1.064).

Otras varias posesiones de la Catedral se anotan en los documentos arabes: el huerto de la Sacristanía (núm. 369); huerto en Alaitic, donde tenía otro el arzobispo (núm. 452); olru que fué de Abenmoharech (núm. 495); otro en Zalencas (núm. 580); la llamada huerta del $\Lambda$ rzobispado en Alaitic (núm. 582); la huerta de los canónigos en el mismo pago (núm. 582); la casa y tienda de la Alcudia, lindante con la

(1) Este corral lo había adquirido el vendedor por el precio de la madera quo vendió a la Catedral antes de 1260 . 
carniceria (núms. 586 y 610); la casa que fué de María Mozola (núm. 765); el mesón de los Tintoreros (núm. 818); un mesón en Zocodover (núm. 830); las heredades de Cobeja y Alameda, dados por D. García, objspo de Cuenca (núm. 1.023); la tenería del Corno (nóm. 1.141 bis); la vína en Pinel (núm. 996).

Para administrar toda esta hacienda tenía el Cabildo un tesorero, que por e] año 1241 lo era D. Pedro Román, diácono (núm. 912), y por 1265 era D. Pedro Roldán, canónigo (núm. 918). A veces el tesorero obraba por medio de sit repre-

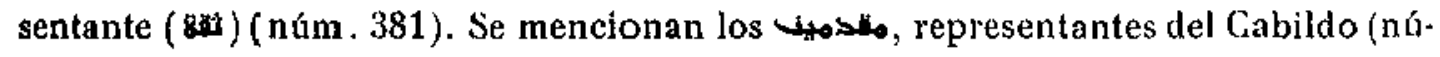
mero 821), y el inspector de las obras en las propiedades del refitor de la Catedral (núm. 627). Parece que alguna vez actúa como adiministrador de las casas del Cabildo el judío Abulhasán Benyamín ben Abuishac el Barcclonés (año 1216, número 913 ).

341. El templo de la Catedral. - Escasos dalos arrojan nuestros documentos acerca de la Catedral como templo. Al altar de Santa Maŕa la Mayor se le manda$\mathrm{ba}_{1}$ en 1161, tres arrobas de aceite para alumbrar una lámpara, en la cual se habia de gastar diariamente un tomín (núm. 1.014); y otra manda de un mizcal se le hace en 1211 (núm. 1.023). El altar de San Miguel estaba construído ya en 1197 (número 1.126). Para la luminaria del altar de San Pedro se mandaban, en 1282, 20 miz. cales y 10 para el capellán (núm. 1.035).

\section{EL CABILDO}

342. a) El arzobispo. - Dentro de la Catedral (8sc|lli), llamada alguna vez

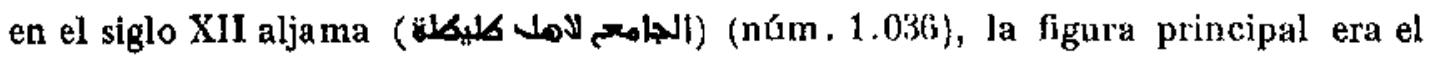

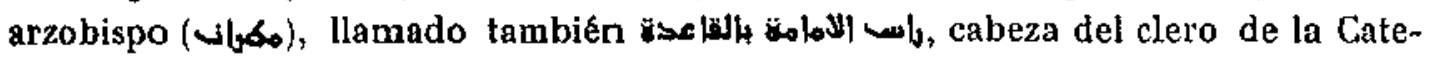
dral (núm. 966). Yemos citados en los documentos árabes los siguientes arzobis. pos (1):

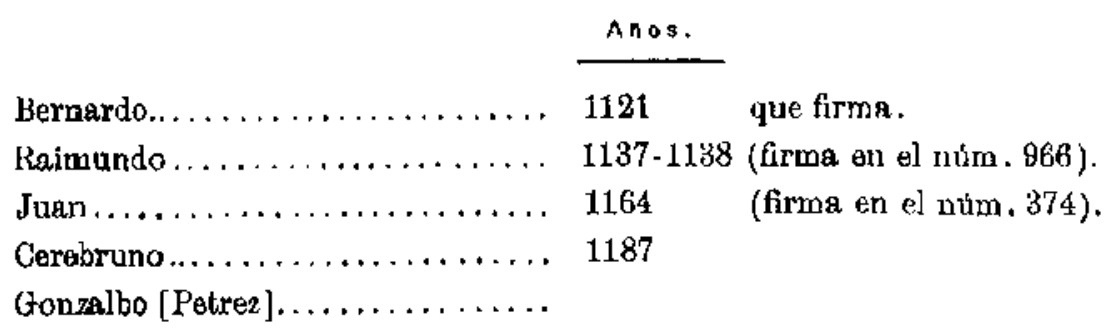

(1) Én esta lista y en las siguientes, de capitulares, prescindimos de dar la reforencia del documento en que se citan, por sor fácil averignarlo seudiendo al indice general alfahético. 


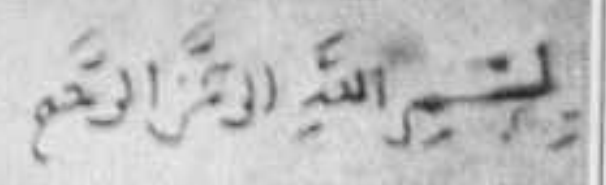

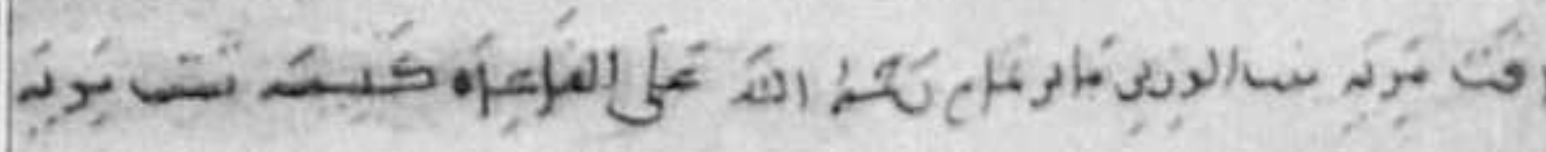

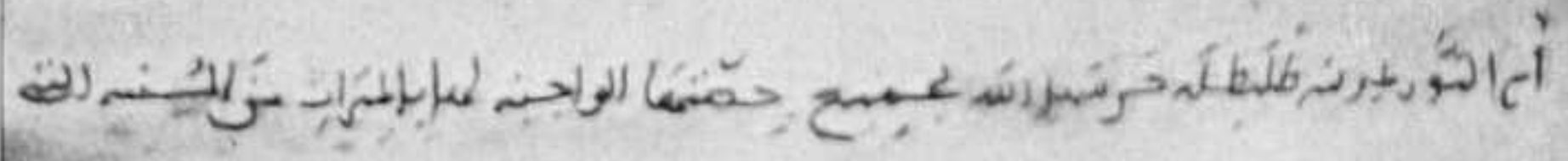

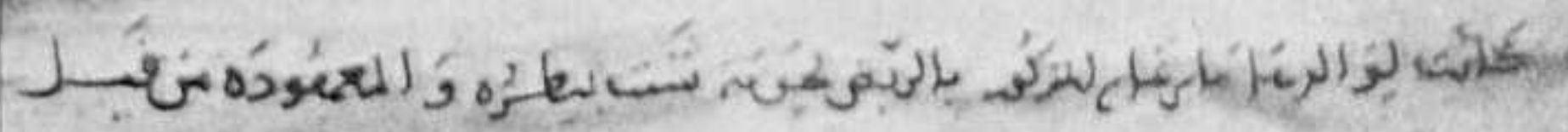
=

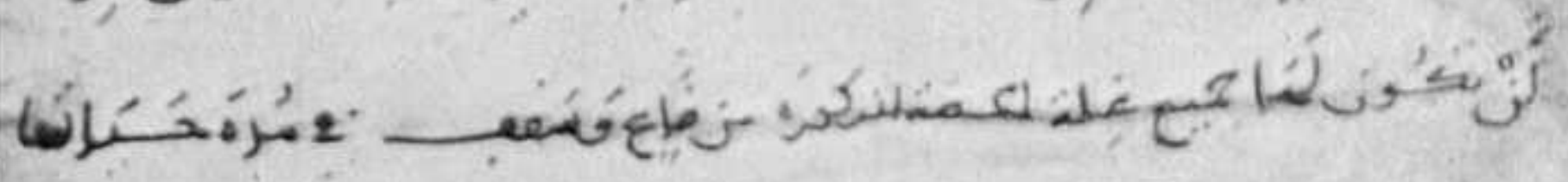

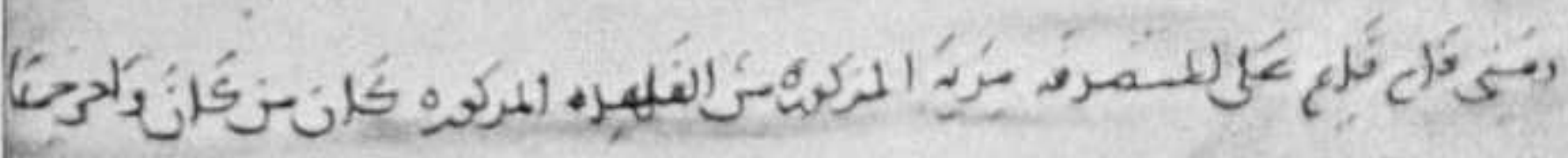

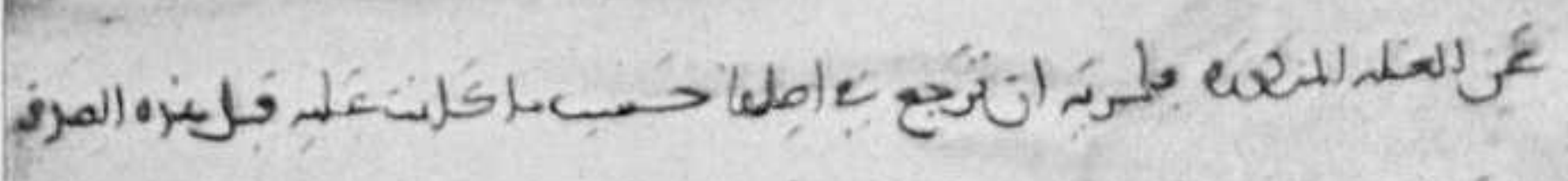
s

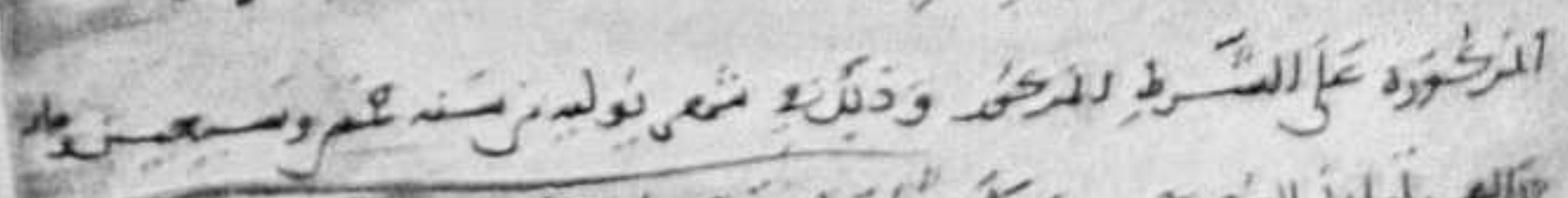

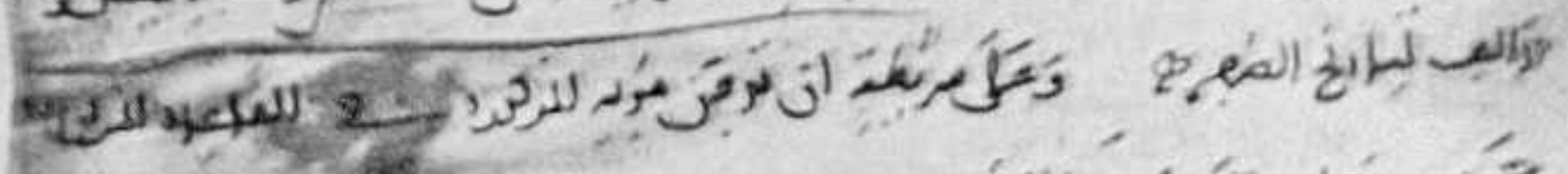
enter دالم

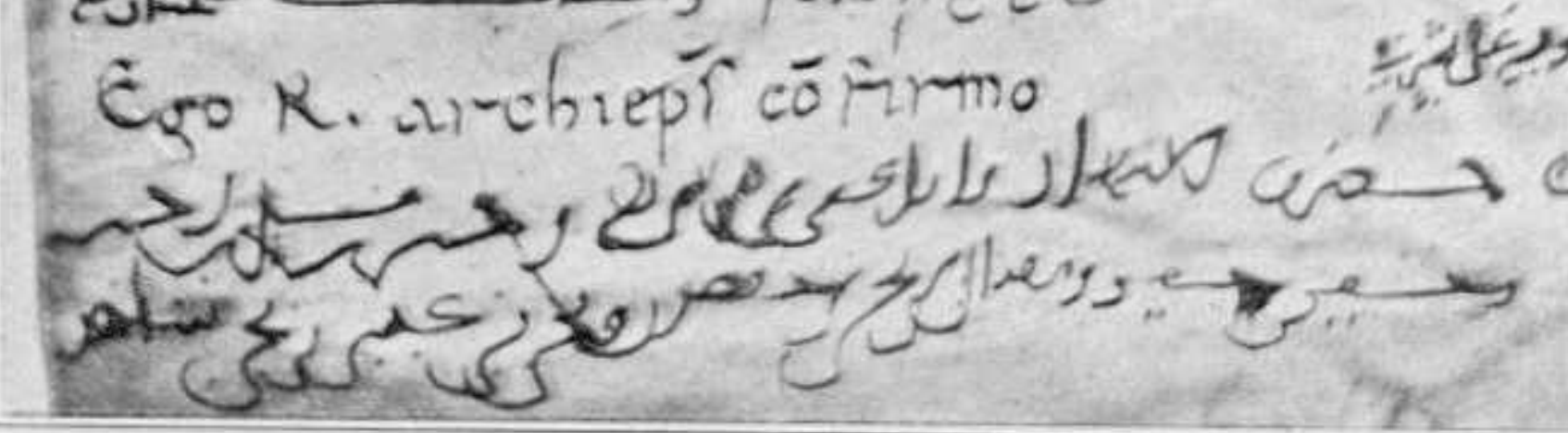

Donación: Julio de 1137 (nüm. 727)

(Firma del arzobispo D. Raimundo.) 


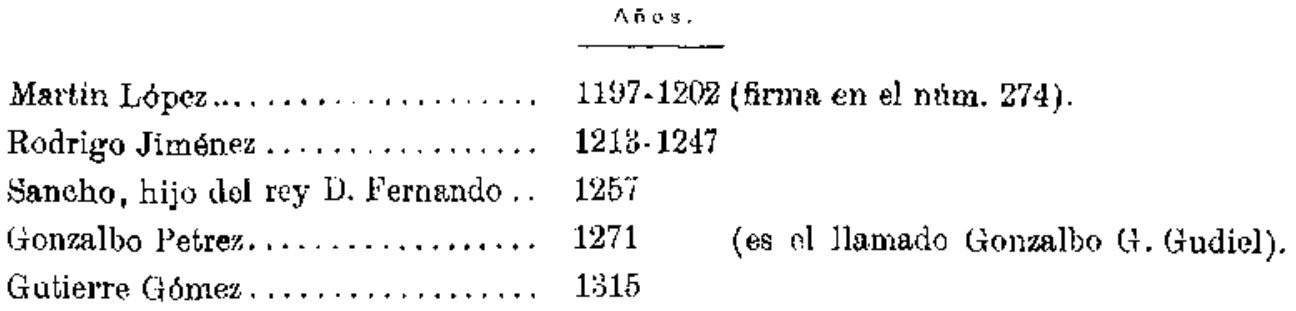

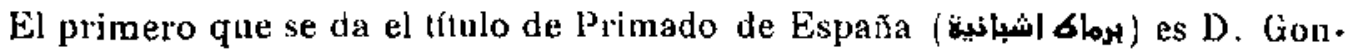
zalbo, en ficma de documento de 1186 (úún. 941)(1).

El arzobispo intervenía (1186) en la venta de bienes de conventos (núm. 941); el Cabildo era consultado por las monjas de San Pedro en Alhicem para vender una finca (1199), apretadas por la necesidad (núm. 291).

343. b) El deán. - Al principio del siglo XII se llamaba prior el presidente del Cahildo: ast firma un A. prior, en 1138 (núm. 968), y otro W. prior en $1170 \mathrm{y}$ 1173 (núms. 96 y 103). A fines del XII lo llamaban prebosle, del latín praepositts, y el capellán D. Raimundo era preboste de los señores de la catedral en 1187 y 1188 (números 191 y 199), que acaso lo fuera diez anos antes, aunque solo se le nombre ael capellán D. Raimundos (núms. 138 y 161). También era preboste, de 1189 a 1191 , D. Guillén (núms. 206 y 215), y un Pedro Giarcła en 1197 (núm. 1.126) (2).

Pero desde antes de esta fecha ya nombra el dean, del latín decanus. Es el primero que hallamos titulado Domno Español en 1194 (núms. 255 y 1.127). Siguen a éste:

\begin{tabular}{|c|c|}
\hline & Ános. \\
\hline Johannes, arcediano de Cuellar..... & 1997 \\
\hline Raimundo.................... & 1211 \\
\hline Rodrigo Rodriguez............. & 1220 \\
\hline Maestro Alberto.............. & $1222-1228$ \\
\hline Micael Rstébanez...... & $1231-1254$ (irma en los núms. 770 y 911 .) \\
\hline Domingo Pascual ............. & $1250-1260$ (firma en el num. 823). \\
\hline Pedro Pérez, teniente de deán ..... & 1266 \\
\hline Gunzalbo Petrez (deán) .......... & (luego arzobispo). \\
\hline Sancho Martínez................ & $1279-1285$ \\
\hline
\end{tabular}

344. c) El arcipreste, - Sospecho que a este cargo debía referirse la pala-

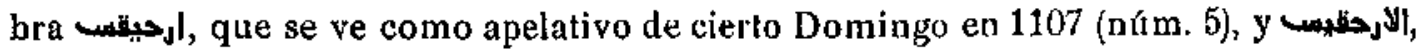

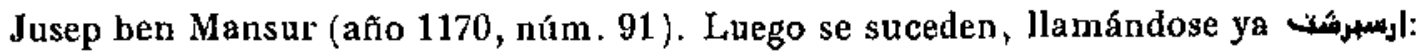

(1) Fs interesante este dato para el estudio de la enrevesada cuestión de la primacía toledaca. Cir, Estella, ob. cit., pág. 109.

(2) Son 1230 figura como prior D. Jtau de Brihuega (nún. 768), Dabiaron ser despuéa dos cargos distintos. 


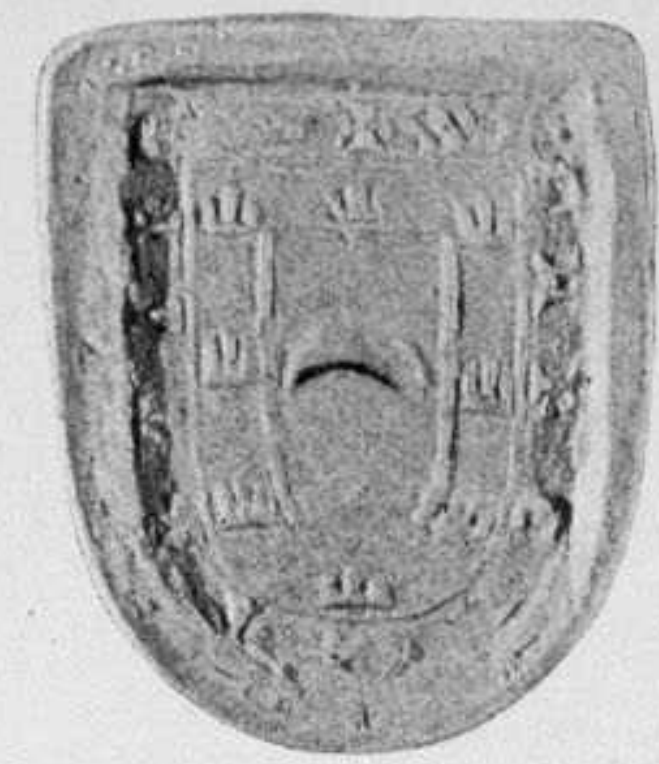

Garcia Martinez, alcalde de Madrid. Año 1266.

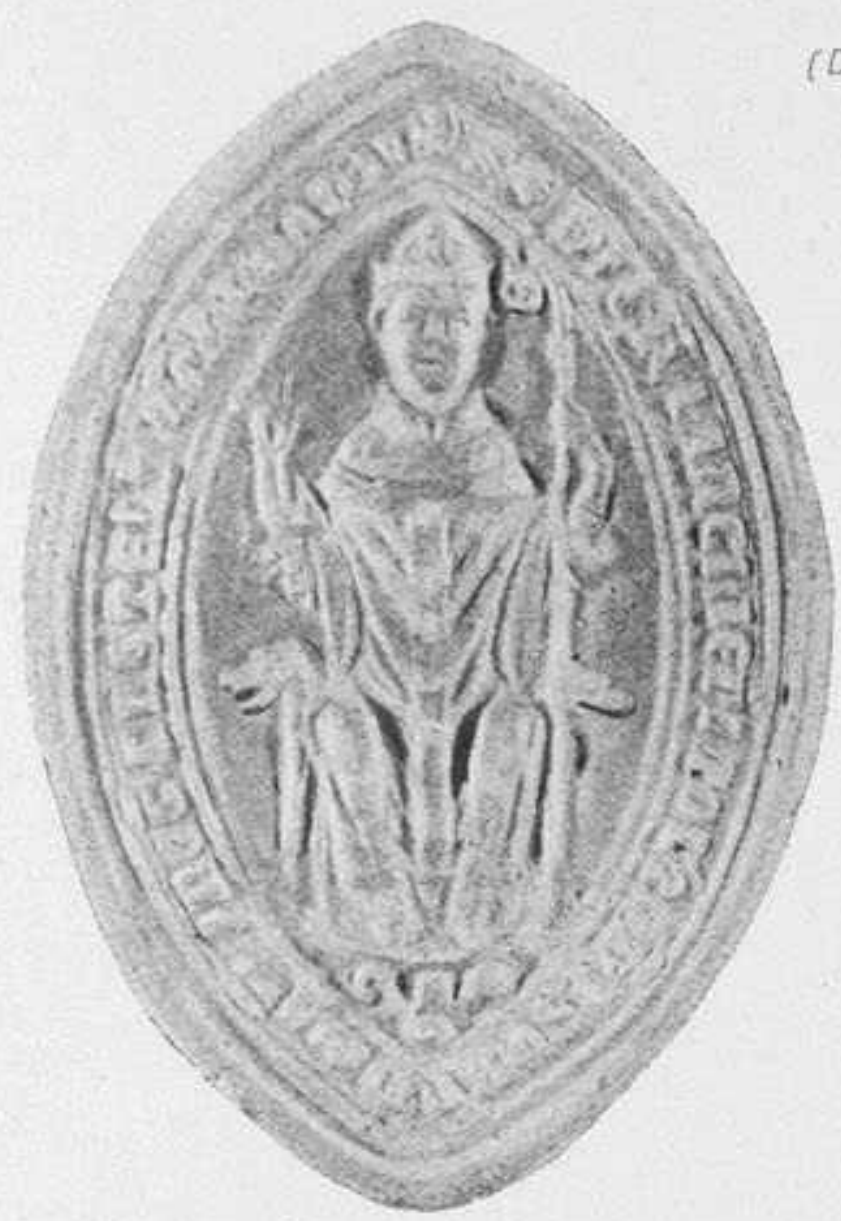

D. Sancho, arzobispo de Toledo. Año 1269.

(A. H. N. núm. 417.)

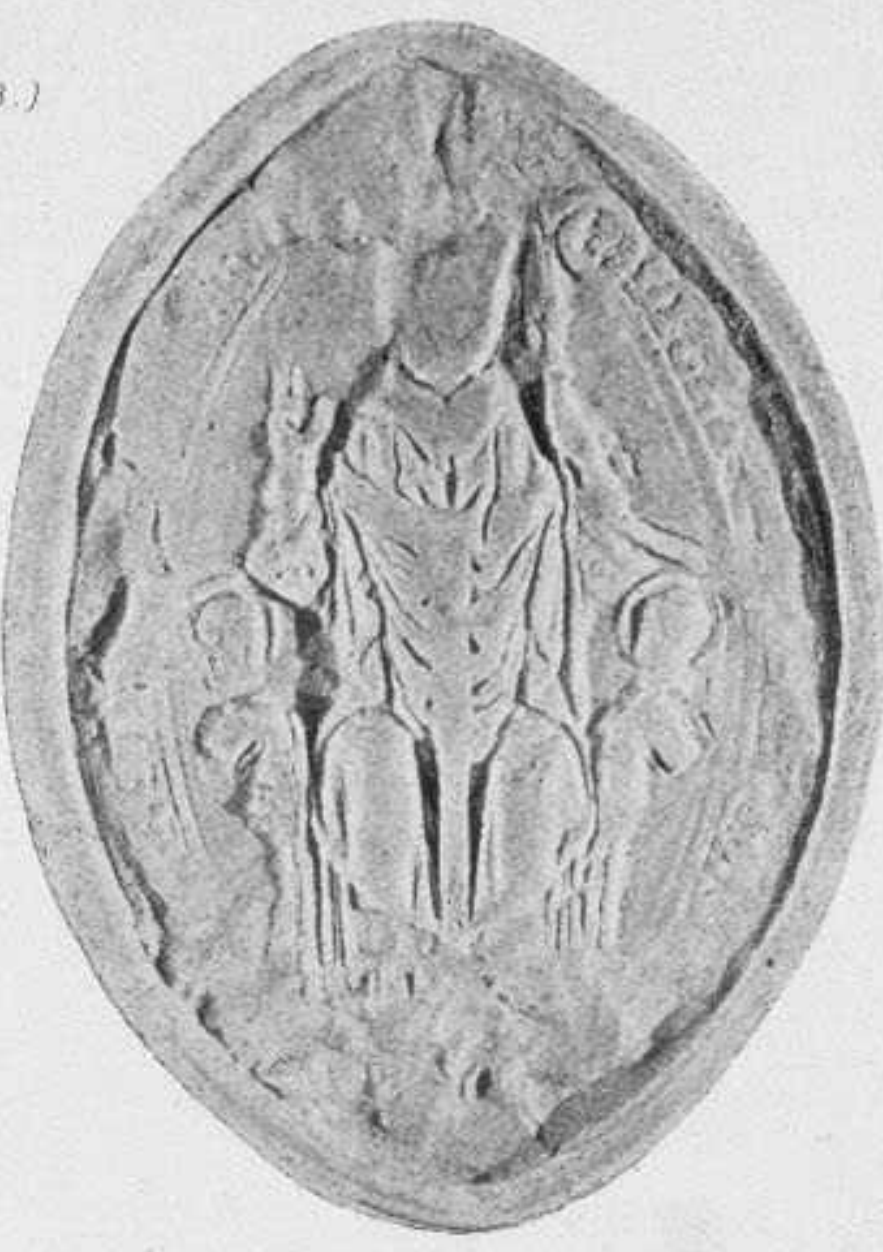

Gonzalbo, arzobispo de Toledo. Año 1300.

(A. H. N., nüm. 418.)

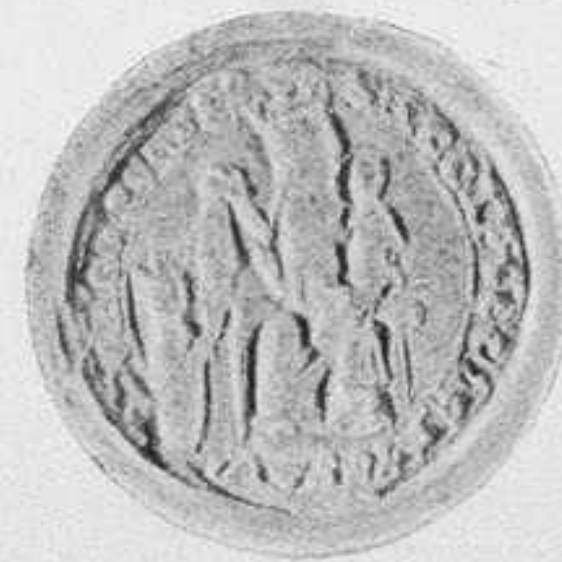

Contrasello.

Gonzalbo, arzobispo de Toledo. Año 1300.

(A. H. N., nu.m. 418.) 


\begin{tabular}{|c|c|}
\hline & Arito. \\
\hline Nicolás. . . . . . . . . . . . & 1162 \\
\hline Dominicus.............. & 1164 \\
\hline Garcia, arcipreste de Maqueda..... & 1174 \\
\hline Domingo b. Abdalá el Policheni..... & 1173 \\
\hline Pedro Micael $\ldots \ldots \ldots \ldots \ldots \ldots \ldots$ & 1192 \\
\hline S[imeno] Cayetkno, arcip. tolet..... & 1190 (frma el num. 298.) \\
\hline Pedro de l'alavera . ............ & 1199 \\
\hline Pedro Guillén $\ldots \ldots \ldots \ldots \ldots \ldots \ldots$ & 1221 \\
\hline Servando, arcip. de Montalbán..... & 1230 \\
\hline Mateos.................. & 1234 \\
\hline Martín Chofré .............. & 1231 (frma «M. Gaufredi», en el n. ${ }^{\circ}$ ö45.) \\
\hline Pedro, arcipreste de Illescas... . . . . & 1259 \\
\hline
\end{tabular}

Parece que habla más de un arcipreste a la vez.

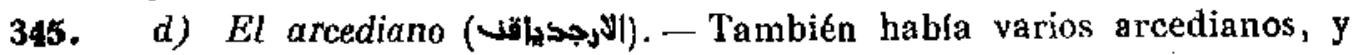
unas veces se les nombra indicando el lugar de su arcedianato, otras sin indicarlo:

\begin{tabular}{|c|c|}
\hline & A ก̃o: \\
\hline Bernardo $\ldots \ldots \ldots \ldots \ldots \ldots \ldots \ldots \ldots \ldots \ldots$ & 1121 \\
\hline P., areipreste de Segovia . . . . . . . . . . . . . & 1138 \\
\hline 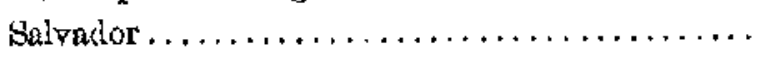 & 1156 \\
\hline Gonzalbo $\ldots \ldots \ldots \ldots \ldots \ldots \ldots \ldots \ldots \ldots$ & 1175 \\
\hline 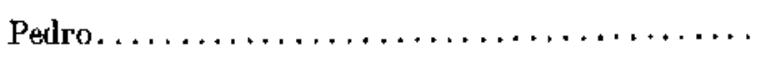 & 1177 \\
\hline F., areipreste de Calatrava $\ldots \ldots \ldots \ldots \ldots \ldots \ldots$ & 1178 \\
\hline D., areipreste de Cuellar . . . . . . . . . . . . . & 1178 \\
\hline Domingo el Polichent, arcipreste de Madrid..... . & $1181-1209$ \\
\hline Domingo González. $\ldots \ldots \ldots \ldots \ldots \ldots \ldots$ & 1178 \\
\hline Gundisalvo, arcediano de Toledo . ............ & 1190 \\
\hline Raìmundo $\ldots \ldots \ldots \ldots \ldots \ldots \ldots \ldots \ldots$ & 1192 \\
\hline Garcia Dlaz. . . . . . . . . . . . . . . & $1192-1207$ \\
\hline G., arcipreste de Madrid . . . . . . . . . . . . . . . & 1208 \\
\hline Domingo Garcla $\ldots \ldots \ldots \ldots \ldots \ldots \ldots \ldots \ldots$ & 1195 \\
\hline Julán ben Tauro, arcipreste de Calatrava........ & 1197 \\
\hline 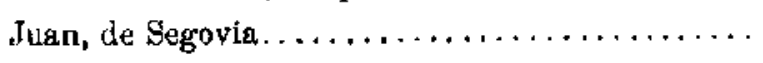 & 1199 \\
\hline 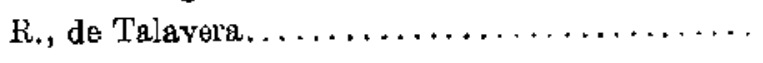 & 1202 \\
\hline Sagcho, de Madrid. . . . . . . . . . . . . . . . . & $1202 \cdot 1209$ \\
\hline Pedro ben Amir, de Guadalajara. ............. & $1202-1207$ \\
\hline$G$, toledano. . . . . . . . . . . . . . . . . . . & 1208 \\
\hline Maestro Mauricio $\ldots \ldots \ldots \ldots \ldots \ldots \ldots \ldots \ldots \ldots$ & 1209 \\
\hline 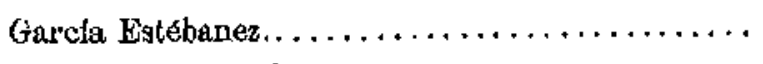 & $1215 \cdot 1220$ \\
\hline Pedro Ruiz, de Calatrava.................... & 1220 \\
\hline
\end{tabular}




\begin{tabular}{|c|c|}
\hline & Anos. \\
\hline MI., de Calatrava..... & $1220 \cdot 1225$ \\
\hline 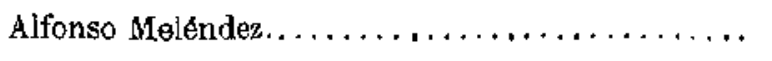 & $1226-1252$ \\
\hline Beltrán........................... & $1230-1232$ \\
\hline Fernando Gil $\ldots \ldots \ldots \ldots$. & $1248 \cdot 1249$ \\
\hline Pedro Ruiz................. & 1252 \\
\hline Bartolomé.................. & $1257-1277$ \\
\hline Maestro Junién, de Guadalajara............... & 1.257 \\
\hline G., de Madrid $\ldots \ldots \ldots \ldots \ldots \ldots \ldots \ldots \ldots \ldots$ & 1259 \\
\hline L., de Alcaraz & 1259 \\
\hline Ruy Martinez de Mosquera, de Calatrava......... & 1260.1262 \\
\hline Gonz, bo Petrez, de Toledo $\ldots \ldots \ldots \ldots \ldots \ldots \ldots$ & 1271 \\
\hline Garcla Muñoz, de Madrid ................... & 1273 \\
\hline 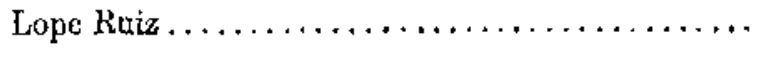 & 1273 \\
\hline Pedro Muñoz............................... & 1290 \\
\hline Alfonso Meléndez, & $1290-1297$ \\
\hline
\end{tabular}

346. e) El maestrescuela o rmagister scholarums. - Ya figura este cargo en la constitución de D. Cerebruno, hacia 1173 o 1177, como nota Estella (1).

Hallamos mencionados los siguientes:

\begin{tabular}{|c|c|c|}
\hline & Afos. & \\
\hline Petrus. & 1190 & \\
\hline J[ohannes $], \ldots \ldots \ldots \ldots$ & 1192.1197 & (antes babia sido canónigo). \\
\hline Alfonso Melendez........ & 1257 & (era arcediano en 1249). \\
\hline Juan & 1257 & \\
\hline
\end{tabular}

Parece, pues, que tenía más importancia este cargo que el de arcediano.

347. f) El vicario. - No los hallamos mencionados antes de 1230 . Los vicarios son:

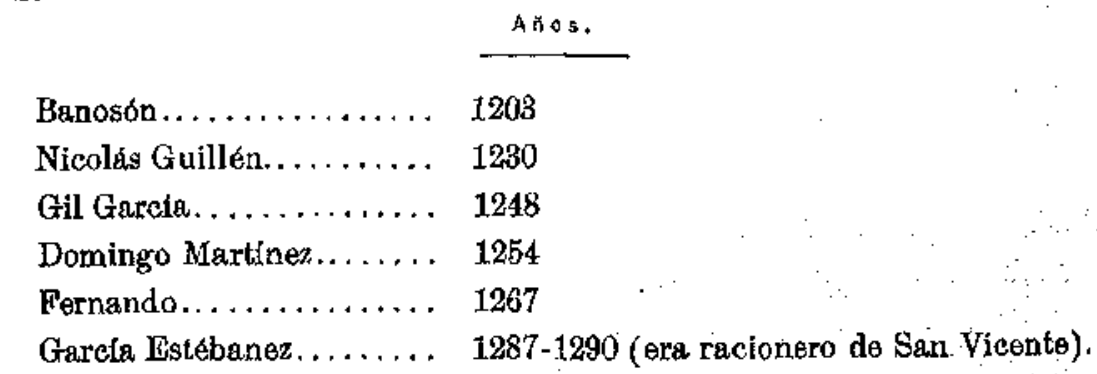

En 1295, el vicario tenía un subvicario, que era sobrino de aquél (núm. 718):

(1) Ob. cit., pag. 168 . 
348. g) El capiscol (caput scholae). - Se llamaban en árabe imam (número 73), que se ve traducido por acapellán de coro" en los números 96, 1.098 y 1.09!, y por epercentor o eprecentor (núm. 1.069). Parece que ya exisfía este cargo en 1093, pues una nota del dorso del documento número 3 dice: "Carta venditorum qui vendiderunt domos l'recentori»; en este caso era cl comprador un Jáir ben „Rocni?, a quien acaso haya que considerar como el primer capiscol de la Catedral después de su restauración. Hallamos después:

\begin{tabular}{|c|c|}
\hline & Afios. \\
\hline Raimundo. & $1161-1170$ \\
\hline l'edro Chelabert o Gilbert.. & 1164 \\
\hline Jorden . . . . . . & $1184-1199$ \\
\hline zuan $\ldots \ldots \ldots$ & $1199-1214$ \\
\hline Domingo Abad . . & $122 \% \cdot 1282$ \\
\hline Juan ......... & $1239-1241$ \\
\hline$\ldots \ldots \ldots \ldots \ldots \ldots \ldots \ldots \ldots$ & $1241-1242$ \\
\hline 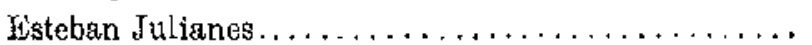 & 1255 \\
\hline
\end{tabular}

349. h) El capellán (ألقبلان). - Parece un cargo de la Catedral. El primero que se menciona (1) es Domingo, el capellán en Santa María la Catedral en 1161 (núm. 65); otro, llamado Roberto, se menciona por 1204 (ń́m. 333), y un Juan en 1212 (núm. 1.023). Al canonigo I). (ruillén Repostero se le llama varias veces capeILán de la catedral, especialmente en los números 778 y 779 (año 1252).

Cítanse, además, D. Raimundo (año 1248), D. Bartolomé (año 1249), D. F. García, que se firma *capellanus mayor ct canonicus ecclesic Toletane, en 1259 (nú. mero 608) y D. Servando (año 1266).

El arzobispo tenía su capellán, que no sé si serfa cargo a la vez capitular: Didaco lo era en 1187 (núm. 1.053); el canónigo D. Esteban lo fué del arzobispo D. Rodrigo (cítase en 1.248 y 1.249 ); Munio Juanes lo era por 1284. - Había también capellanes de altares determinados: un Guillermo lo era del altar de Santo Tomás (año 1178, núm. 141); Micael López, del altar de San Pedro (año 1282).

350. i) El tesorero. - Encontramos citados:

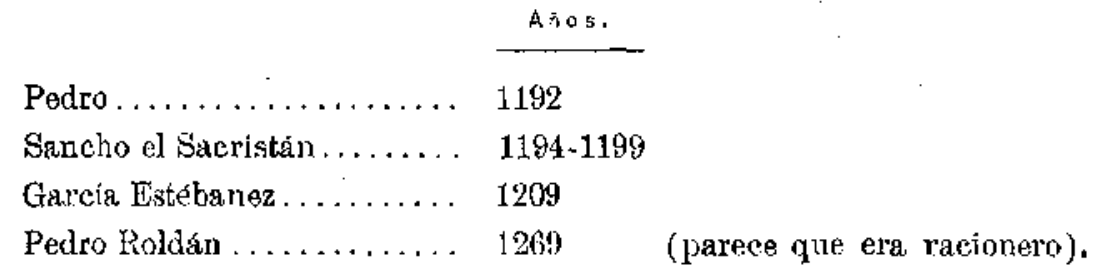

(1) Prescindo de la mención de un Rodrigo, capellán del rey, que era de Lçón, on 1092 (núma. 2). También era capellán del rey, en 1284, el camónigo Ruy Martjuoz (núm. 679). 
351. j) Las canónigos (الشنانير -- القنونقونس). - El número de canónigos era de 24 en la constitución de D. Raimundo (año 1138), de 40 en la de D. Cerebruno (1173 6 1177), de 40 en la de D. Martín López (1195), con otros 20 no mansionarios o forinsecos (1).

Los que aparecen citados en nuestros documentos, por orden cronológico, son:

\begin{tabular}{|c|c|c|c|}
\hline & Ai:a. & & Año. \\
\hline Zaimundo Crespo (cl Calonelie)...... & $11 \overline{15}$ & Pedro Achembert............. & 1213 \\
\hline Jordán . . . . . . . . . . . . . . & 1178 & Pedro Ruiz. . . . . . . . . . . . . . . & 1213 \\
\hline$\ldots \ldots \ldots \ldots$ & 1178 & Bartolomé. ................... & 1215 \\
\hline Pedro Soler. . . . . . . & 1179 & Garela $\ldots \ldots \ldots \ldots$ & 1216 \\
\hline$\ldots \ldots \ldots \ldots$ & 1181 & $\mathrm{~S}[$ ancho $] \ldots \ldots \ldots \ldots \ldots \ldots$ & 1217 \\
\hline Micacl Petrez. & 1181 & Gercía Guillén . . . . . . . . . . . & 1221 \\
\hline Juanes de Habia... & $11 \$ 2$ & J'ernando Domlnguez ben Altaiabi... & 1224 \\
\hline Juan de Talavera.................. & 1184 & Gonzalløo Fernánde $\%$. . . . . . . . . & 1224 \\
\hline 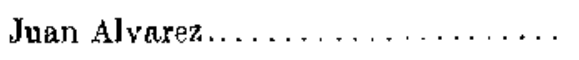 & 1180 & Alfonso Meléndez............... & 1226 \\
\hline Feliz Micaelis . . . . . . . . . . . . & 1187 & Jordán. . . . . . . . . . . . & 1227 \\
\hline Paulo $\ldots \ldots \ldots \ldots \ldots \ldots \ldots \ldots$ & 1187 & Cristobal, hijo de l'orcuato........ & 1227 \\
\hline Cipriano $\ldots \ldots \ldots \ldots \ldots \ldots \ldots \ldots$ & 1138 & G. Johannis.................... & 1228 \\
\hline$W[$ ilelmus $], \ldots \ldots \ldots \ldots \ldots \ldots$ & 1189 & Iiuy Petrez, de Fornillos............ & 1228 \\
\hline Pedro Sobrino (diácono)............ & 1193 & Martin Furón . . . . . . . . . . . . & 1231 \\
\hline Domingo Abad ................. & 1194 & Martin Gaufredi o Chofré........... & 1235 \\
\hline Rodrigo Petrez.............. & 1196 & Pedro Gebert................. & 1239 \\
\hline Cristóforo & 1197 & Maestro Guillem.............. & 1240 \\
\hline Juan de Brioga... & 1197 & Bsteban $\ldots \ldots \ldots \ldots \ldots \ldots \ldots \ldots$ & 1240 \\
\hline Marco... & 1198 & Domingo Illan . . . . . . . . . . . . & 1241 \\
\hline Pedro Garcta................. & 1202 & ton $\ldots \ldots \ldots \ldots \ldots \ldots$ & 1241 \\
\hline Micael. & 1203 & Guillén, de Segovia ............ & 1248 \\
\hline Juan de Sethila . . . . . . . . . . . & 1203 & Rodrigo Petrez............... & 1249 \\
\hline P. Gutiérrez (diácono)............ & 1203 & Román $\ldots . \ldots \ldots \ldots \ldots \ldots \ldots$ & 1249 \\
\hline Juan Martín . . . . . . . . . . . & 1204 & Juan Cebriánez.................. & 1250 \\
\hline Pedro Abad ................ & 1204 & Bernaldo Astur $\ldots \ldots \ldots \ldots \ldots \ldots$ & 1251 \\
\hline 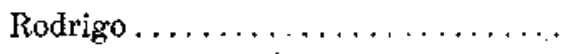 & 1205 & Ruy Martinez, de Mosquera......... & 1253 \\
\hline 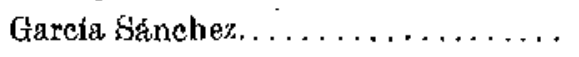 & 1206 & Maestro Asensio $\ldots \ldots \ldots \ldots \ldots \ldots$ & 1258 \\
\hline Lope Fernández.............. & 1209 & Gil Garcia..$\ldots \ldots \ldots \ldots \ldots \ldots$ & 1258 \\
\hline S. de Beruga.... & 1212 & Domingo Petrez, de Montreal. . . . . . & 1259 \\
\hline Egidius. . . . . . . . & 1213 & D. Roldán . . . . . . . . . . . . . & 1209 \\
\hline Micacl Estébancz................ & 1218 & Munio $\ldots \ldots \ldots \ldots \ldots \ldots \ldots$ & 1259 \\
\hline
\end{tabular}

(1) Puede vorse el extracto de las constiluciones y de las de D. Rodrigo, en la cilada obra de Estella, pág. 168 y siggs. 


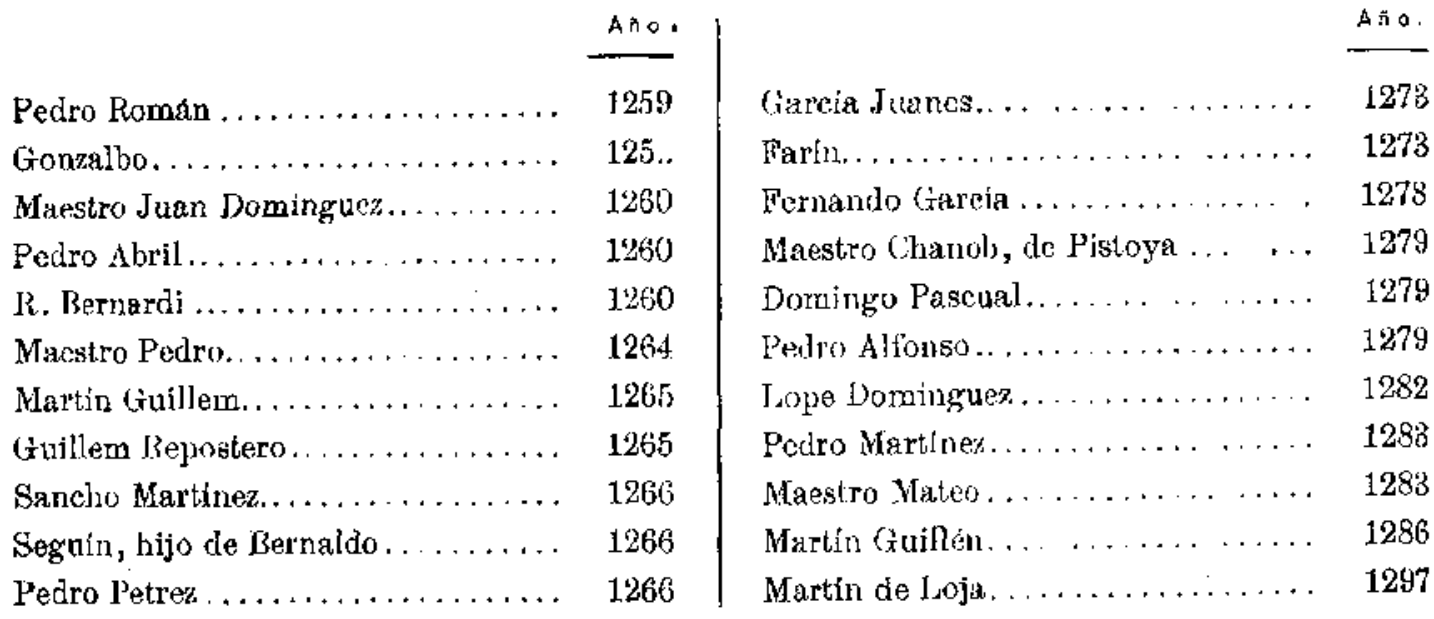

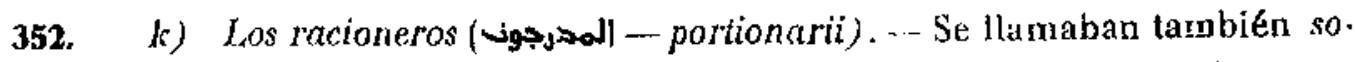
$\operatorname{cios}(4|0|)$ (núm. 575), y aparecen por primera vez en las constituciones del arzobispo D. Martíu López, del año 1195, que autorizaban a tener hasta 30 racioneros. Don Rodrigo, en 1238, elevó su número hasta 50 (1).

Debieron principiar siendo una especie de servidores, pues alguno ni siquiera sabía firmar (núm. 274, año 1187), y muchos eran criados de algún canónigo.

En muchos casos tampoco eran presbíteros, sino sólo diáconos o subdiáconos.

Los mencionados en nuestros documentus, cronológicamente, son:

\begin{tabular}{|c|c|c|c|}
\hline & Año. & & Aกัa. \\
\hline onzalbo Fernandez $\ldots \ldots \ldots \ldots \ldots$ & 1197 & Juan Kamilo....... & 1250 \\
\hline Micael Juanes. . & 1214 & Pedro Romáll.. & 1253 \\
\hline Inan Petrez el Policheni............. & 1217 & Martin Guillén ........ & 1254 \\
\hline Esteban Petrez .................. & 1219 & Rromán ben Esteban ben Motarrif.... & 1256 \\
\hline Martin Armildez ...., ........ & 1226 & Beltrán ........ & 1257 \\
\hline Bernaldo Astur................... & 1230 & Alfonso Petrez, .. . ...... & 1266 \\
\hline Gil Kuiz..................... & 1232 & Maestro Micnel . . . . . . . . & 1273 \\
\hline Gutierre Dominguez $\ldots \ldots \ldots \ldots \ldots$ & 1240 & Ruy López........ , . . & 1278 \\
\hline Pedro Ruiz..... & 1241 & 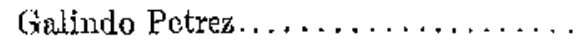 & 1285 \\
\hline (uil Gareia (presb, de S. Andues)...... & 1241 & l'ernando Petrez................. & 129 \\
\hline Juan Dominguez $\ldots \ldots \ldots \ldots \ldots \ldots$ & 1248 & Fernando Juanes, de Valverde...... & 1293 \\
\hline Domingo Juanes.................. & 1249 & Martin Alfonso $\ldots \ldots \ldots \ldots \ldots \ldots$ & 1294 \\
\hline Licael Juanes ben Abilija & 1249 & & \\
\hline
\end{tabular}

Quizá fueran racioneros muchos llamados clérigos de la Caledral: «diácono en la Catedral* (núm. 166), «clérigo de Santa María la Mayor» (núm. 128), «suhdiácono en la Catedrals (núm. 538). Algunos serian cantores (núm. 481).

(1) Estella, ob, cít., pág. 168 . 
353. I) Otros cargos en la Catedral. - Vemos el sacristín (núms. 236, 257, 734,976 y 1.053 ), años 1170 y 1177 ; el perteguero, que los documentos traducen portero (núm. 701); el campanero (núm. 606); el refitorero (núm. 704); el mayordomo (núm. 237), que era seglar y casado, alguna vez.

También se mencionan el mayordomo del arzobispo, D. Rodrigo, a Fray Esteban (núm. 393), y sn repostero, D. Gujllem (núm, 420).

El maestro de los albañiles de la Catedral, hacia 1280, era Juan Martín (número 668), hijo, probablemente, del maestro Martín, que Estella ha indicado como constructor del indicado edificio (1).

El deán, D. Domingo Pascual, se tiłulaba cápellán del Papa en 1260 (número 821).

Dudo si un * Petrus, Magister *, que firma en 1138, pertenecería a Ia Catedral (número 968 ).

354. $m$ ) Clero de fuera de Toledo. - Algunas menciones de obispos o canónigos de fuera de Toledo pueden tener interés.

A dos objspos, Juan el Marxení y D. فالكسب, se les hacen mandas en 1161 (número 1.014), sin que crea yo, como Pons, que se trataba de un obispo de Marchena, sino sencihlamente de un apellido, y que scría uno de tantos clérigos toledanos que fueron elevados a la dignidad episcopal. Un llamado Aiss/b, era obispo de la cora de Lebla o Niebla por 1186 (ním. 941).

Aparecen citados varios obispos de diócesis sufragáneas de 'Toledo, oriundos, sin duda, de la capital: así, D. Juan de Osnua (nums. 259 y 979); D. Gonzalbo Gutiérrez, de Segovia (núm. 307); el obispo de Albarracín, que tenía un buerto en Algorfela en 1214 (núm. 812); un obispo de Avila en 1156 (núms. 56 y 796 ).

De Cuenca, aparte de San Julián, de quien después se trata, se nombra a su inmediato sucesor D. García Ririz, que firma ya en documento de 1211 (núm. 1.023), que antes de 1221 fundaba un hospital en Toledo, en el barrio de la Catedral (número 758), que deja sus tincas en Cobeja a la Catedral de Toledo para su aniversario (núm. 1.015), y que en 1227 ya habia muerto (núm. 488) (2).

Tambien se cila alguna vez a I). Gonzalbo Juanes, ya desde el año de 1232 (números 1.083 y 1.106 , y al sucesor de éste, maestro Gonzalbo Petrez (núms, 639) y 644$)^{(8)}$.

Un obispo, Rodrigo Juanes, se menciona en 1280 , sirr indicar la di6cesis que gobernaha (núm. 825).

Gil, canónigo de la iglesia de Calatrava (núm. 420); Rodrigo Juanes, maestres-

(1) Ob. cit., pág. 1999 .

(2) Cfr. Mufúz Soliva, Obispos de Čcenca, Cuenca, 1860, pág. 29.

(3) Ibid, págs. 33 y 90 . 
cuela de Cuenca en 1230 ( núm. 768), y Alvaro Juanes, arcediano de Cuenca en 1281 (número 1.034), aparecen entre los clérigos extradiocesanos.

Quizá se quiera reterir a curas de alma al nombrar قسيس a uno de Yepes (Gon. zalo ben Domingo ben Juan) (núm. 685), y a otro de Fuente del Caño (núm.1.030).

355. n) San Julian, obispo de Cuenca. - Se rectifica, gracias a documentos ahora encontrados, la biografía de este santo personaje. En la última decena de julio de 1197, el ilustre D. Julián, hijo de Tauro, arcediano de Calatrava, compraha por 600 mizcales una finca en Azaña, de Ia Sagra de Toledo, a D. Gonzalbo, hijo del noble D. Pedro Garcés de Lerma, abad de Santa María de Huslllos; finca que éste había adquirido par herencia de su madre doña Sancha, hija del cande D. Ponce de Minerva, de quien esta señora la había heredado ( núm. 274).

Como ni Garcés de Lerma ni su familia eran de linaje mozárabe, no cabe duda que esta escritura se redacta en árabe por scr mozárabe el otro contratante, o sea, D. Julián ben Tauro, arcediano de Calatrava. Parece, por tanio, que debe rechazarse la tradición, comúnmente admitida, de proceder el santo de tierra de Burgos (1).

Otro eryor en que caen sus biógrafos, sin fijarse en el anacronismo, es hacerlo esludiar en la Universidad de Palencia: creóse, en efecto, Este Estudio general por Alfonso Vill en los años de 1212 a $1214^{(2)}$, es decir, varios después de haber muerto San Julián (1208). Como la cosa mús natural, afirman los biógrafos que el santo pasó de joven a Córdoba, a escuchar allí las lecciones del célebre $\Lambda$ verroes Dejando a un lado la confrontación de fechas, recuérdese que los estudios filosóficos entre los musuimanes españoles eran materia prohibida, y que sus cultivadores habían de recaiarse ante el pueblo, y más ante los alfaquíes, de tales aficiones; el mismo Averroes hubo de ser perseguido, y sus libros fueron quemados como heréticos (3).

Se da como firme la fecha de junio de 1196 para el nombramiento y consagración de San Julián como obisp̧o de Cuenca; el documento alrás reseñado manifiesta que en julio de 1197 todavía era arcediano de Calatrava.

Y que este mismo ilustre D. Julián ben Tauro, que compraba la finca en Azaña, en cuya escritura de compra firmaban las más altas personalidades toledanas, principianda por el arzobispo, eır el que poco fiempo desoués ocupana la sede de Cuenca, se comprueba, sin género algnno de duda, con el siguiente documento, fe. chado en el IX de las calendas en Noviembre de 1201, que transcribimos íntegro por su interés:

(1) Véase Muñox Soliva, Obispos de Cuenca, Cuenca, 1860, pígs. 16 y siga. liesuute otras biografías más extensas do San Julián, como la del P. Alchízar, etc.

(2) Véase Agnado Bloye, Historia de Esparia, 4. ed., 1924, tomo I, pág , 307.

(3) Veasf A. González Pnlescia, Historia de la Líteralura arábiyoespanola, Barcelona, 1928, págipas 220 y sigs. 


\section{$\underline{4}=\underline{\varepsilon}$,}

P.

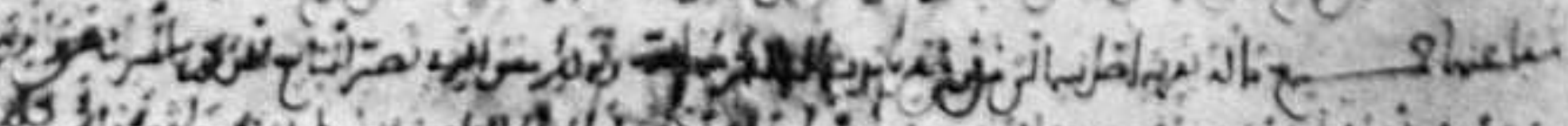

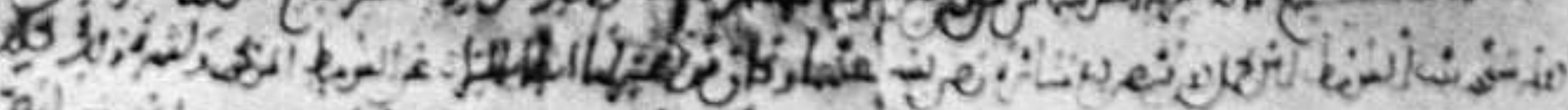

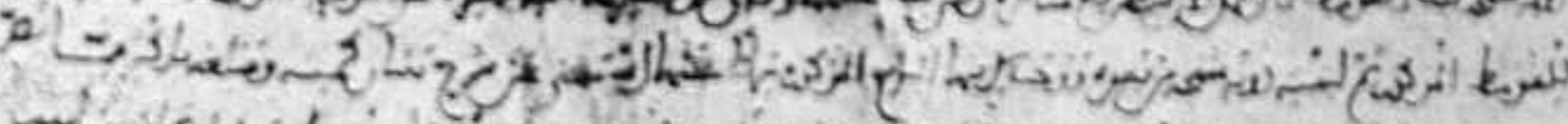

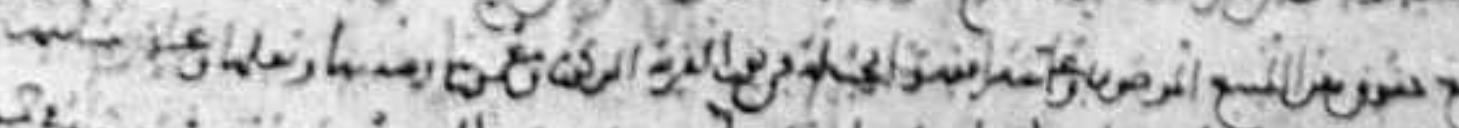

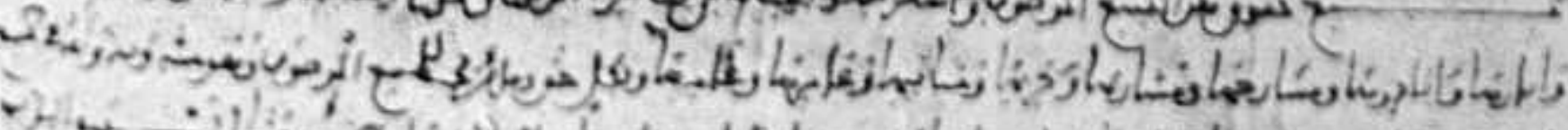

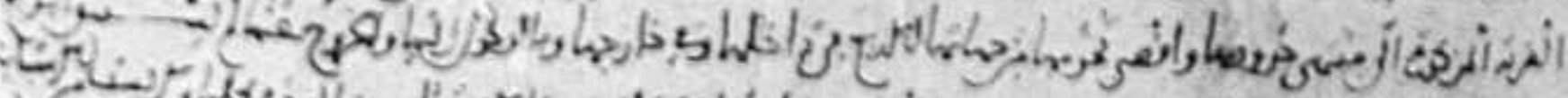

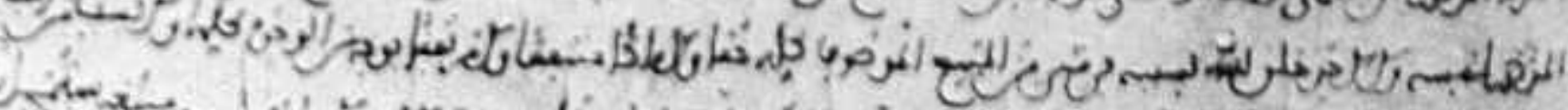

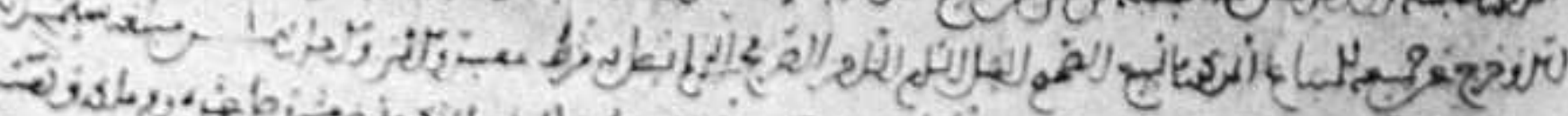

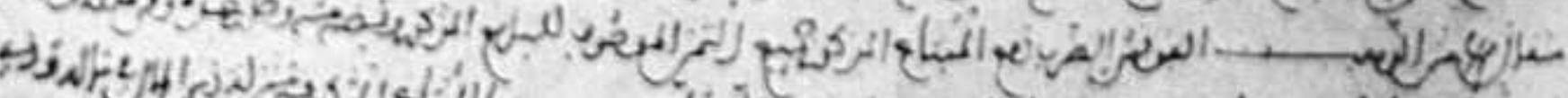

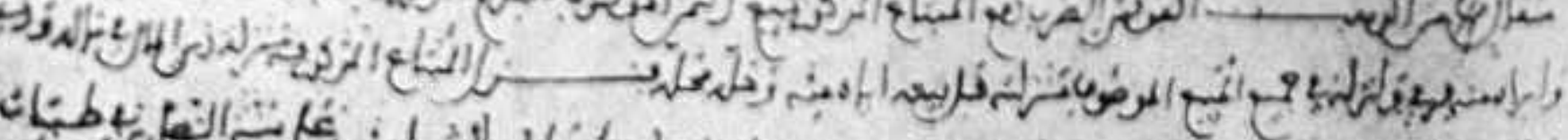
-

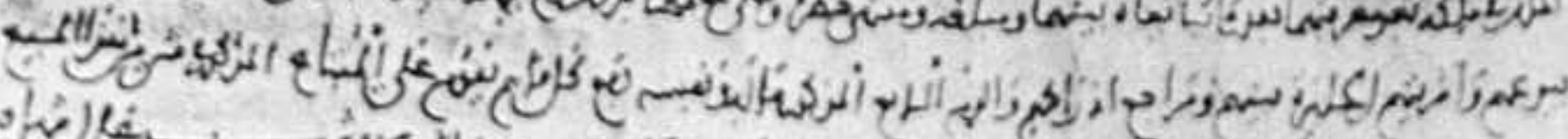

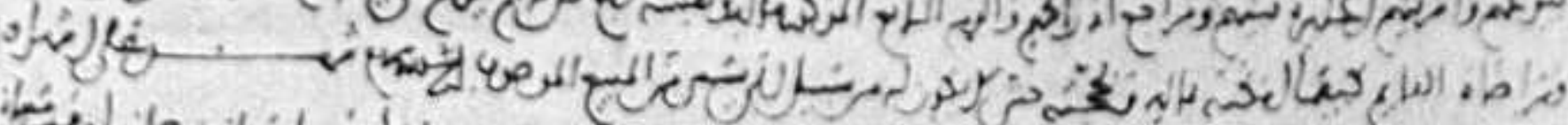

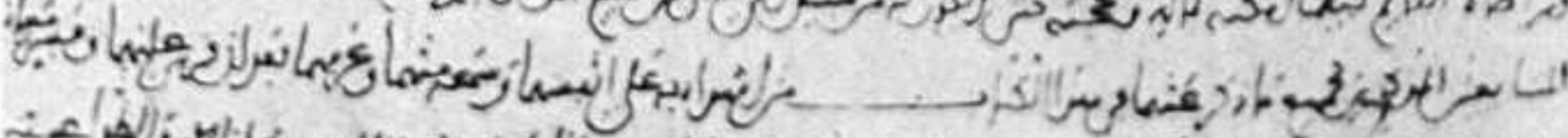

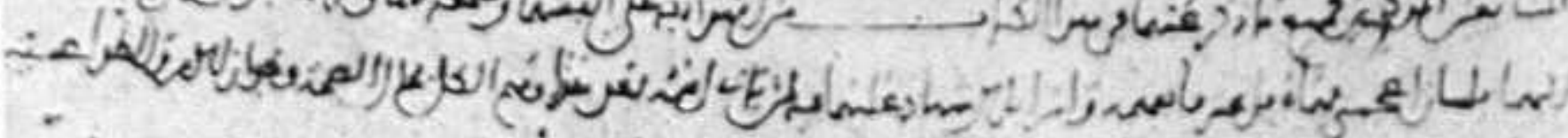

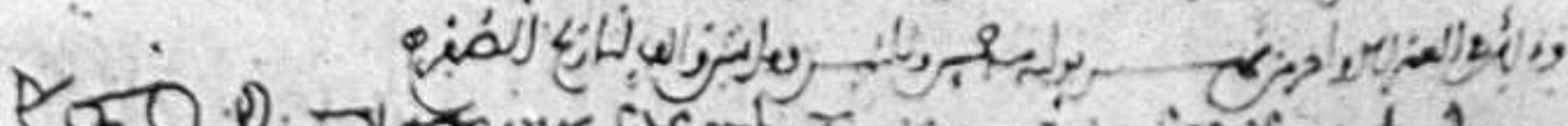

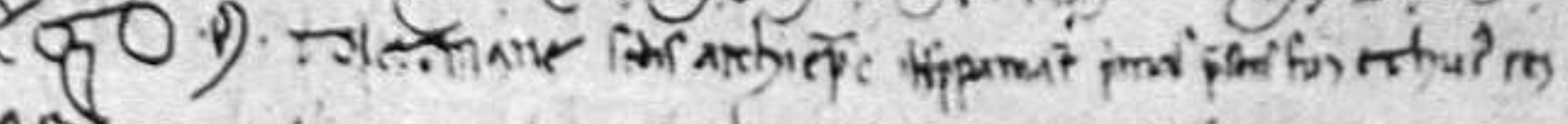

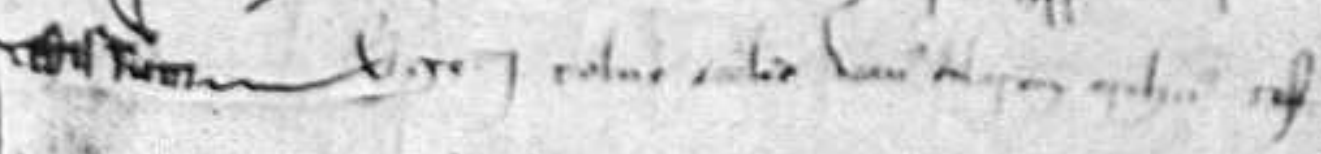

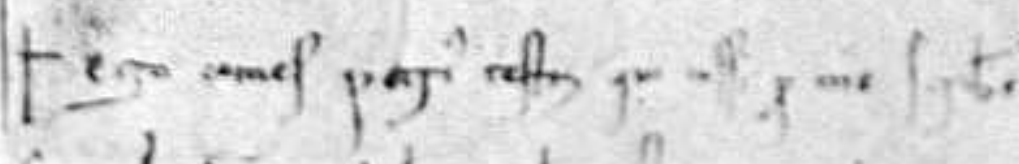

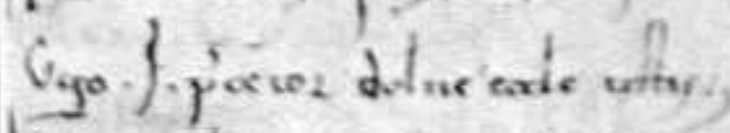

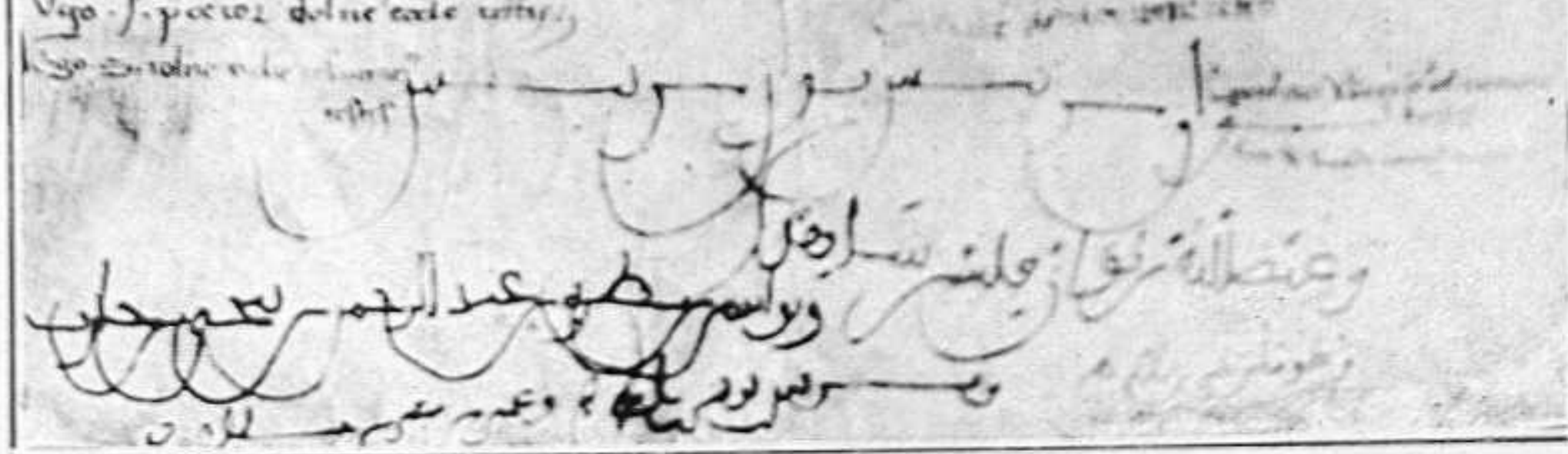

Compra de finca en Azaña, por S. Julián, obispo de Cuenca: $3 .^{a}$ decena de Julio de 1197 (núm. 274). 
Notum sit tam presen libus quam futuris quod ego I. Dei gratia, Conchensis episcopus, do atque concedo fratribus ct canonicis meis Toletane ecclesie uniuersis hereditatem illam de Fuzania, dum in ecclesia Toletana essem archidiacono, de patrimonio rueo pro sexcentis morahetinis emi a Gundisalun Petri, abbate Sancte Marie de Fusellos, filio Petri Garsie de Lerma et domine Sancie, filie comitis Poncii de Menerua, quam hereditatern idem Gundisaluns, filio Petri Garsie de Jerma, ex parte eiusdem matris sue iure hereditario habuit; tali, inquam, tenore atque conditione do atcque concedo fratribus meis et canonicis Toletane occlesie ut ego et fratrer meus Martinus, archidiaconus, toto tempore uite nostre iltam hereditatem nomine esrum teneamus atque possideamus; ita tamen quod si fratcr meus superuixerit, idem frater mens teneat et possideat dum ujxerit, et in die anninersarii mei singulis aunis $\mathrm{XX}$ moralietinos pro anniuerserio meo predictis canonicis inde persoluat, et si forte idem frater meus premortuus fuerit, alius quem ego voluero sui) eadem lege atque conditione eamdem hereditaten in uita sua teneat et possidcat; ila tamen quot hac donatione mea ad terciam personam nullatenus trauseat, sed libere et absolute cum sex iugis boum et semine et ceus bouum et ctun omni apparatu suo ad iam predictos fratres et canonicos meos redeat, et quicquid emolumenti inde haheri poterit in die anniversarii mei prescriptis lratribus meis et canonicis pro anniuersario meo totum singulis annis erogetur.

Ego Julianus, Doi gratia, Conehensis episcopus, manu propria subscribo et sigilli mei appositione, confirmo. Égo Rodericus, Dei gratia, Seguntinus opíscopus, roanu propria subscrihu et sigillum meum apono. Ego G., Jei gratia, Secobiensis episcopus, manu propria subscribo et sigillum meum ayono. Ego M., Toletane sedis archiepiscopus, Hyspaniarum primas, confirmo et sigilli mei munimine roboro. * Facta carta apud T'oletum. Fra M.CC.XXX.IX Kalendas Nouember (1).

Se ve, pues, que San Julián dejaba la heredad que había comprado en Azaña, por 600 maraved's, al abad de IIusillos, D. Gonzalbo Petrez, hijo de Pedro García de Lerma y de doña Sancha, a la Catedral de Toledo para su aniversario, con la condición de que la poseyera su hermano Martín, arcediano también, mientras viviera, pagando 20 mizcales al Cabildo por el aniversario del obispo de Cuenca. Es la prìmera vez, que sepamos, que aparece en la vida de San Jutín este hermano Martín; pues aunque Muñoz Soliva dice que el santo samante del esplendor del culto divino, donó al Cabildo de Toledo la heredad de Hazañas» (2), no debi 6 de haber visto el documento.

Creo que habrá que reivindicar para Toledo y su raza mozárabe la gloria de haber sido madre de tan gran santo.

(1) El original de este docnmento se conserva dentro de una arqueta del Relicario de la Catedral de Toledo, en el Ochavo; lleva pendiente el gello do cera del santo. Esta copiado en el Cartnlario primoro de .3a Catedral, guardado en el Archivo Hisiorico Nacional, al fol, 64.

(2) Ob. cit., pág. 24 . 


\section{IGLESIAS Y CONVENTOS DE TOLEDO}

356. Recogidlos ya en otro capítulo los datos topográficos referentes a las iglesias de Toledo, base de la demarcación de la ciudad en la Edad Media, procuraré dar aquí noticia de las iglesias y conventos como instiluciones (1). Sigo el orden alfabético de las advocaciones.

357. San Andrés. - Cítasc por vez primera en 1156, documento número 47, donde vemos firmando un «Petrus Petri filius, sancti Andree presbiter». Fn 1182 otorga un testimonio Pedro Cebrián ade la aljama de la iglesia de San $\Delta$ ndrés. (número 164). De otro presbítero, Tomás, de San Andrés, se ve mencion en 1202 (número 313); de un Mateo, diácono (núm. 417), y de varios presbíteros más (núme$\operatorname{ros} 417$ y 446 ).

Una Dominga la Gallega, viuda de Juan Andrés el Músico, era parroquiana de San Andrés por 1238 (núm. 53u), y al clero de esta parroquia pertenecla Gil García, racionero a la vez de la Catedral en 1241 (núm. 548), y el maestro Marlín, también socio de la Catedral (ntim. 638).

Una casa tenía el clero de esta parroquia en el barrio de San Antolín (ním. 591). Para su fábrica mandaba su feligrés Fernando Petrez el Bolsero, en su testamento de 1280, 10 mizcales (núm. 1033), y Fernando Martínez dejó en su testamento una casa en la plaza del Platero, cerca de San Juan, a los presbíteros de San Andrés, con la condicion de que éstos hicieran tres aniversarios anuales perpetuamente: uno por cl alma de su padre, el dla 11 de Iiciembre; otro por su madre, el 3 de Agosto, y otro por el testador, el día que muriese: debiendo celebrarse en cada aniversario misa y vigilia (núm. 1.065).

358. San Antoltn. - La mención más antigua de esta iglesia es de 1187, en una escritura de compra de $D$. Pedro Lázaro, presbítero de esta parroquia (número 189). Este mismo presbitero: sigıe comprando fincas (núms. 204, 227, 247 y 283), y en 1200 debía ser el párroco, pues se le llama imam, o sea, jefe o director de la oración (núm. 301); no se dice si como tal párroco, o por su cuenta, interviene en Ias compras de años posteriorcs (núms. 311, 325, 342, 348, 372, 375, 376, 379, 380, 388,394 y 411). Por 1214 lítigaba con Gonzalho Domínguez sobre la viña que había plantado el * Hijo de Maliha s, en Almoradiel, y se convenía con la otra parte entregando 9 mizcales alfonsies ( $\mathrm{n}$ ím. 952).

(1) Podrá completarse alora en parte el documenlado libro de R. Ramirez de Areliano, Las parro* quias de Toledo, 1821 , cuyos datos apezas si cr contudíximos canos so remontan más arriba tel siglo XV. 
Algunos feligreses de San Antolín, v. gr., Gonzalbo, intervienen como testigos para dar fe de la pobreza de una viuda, que se ve obligada a vender bienes de menores (núm. 331). Otras veces se mencionan diáconos de la iglesia, como Rodrigo (námeros 376 y 379 ); presbíteros, como Félix (núm . 440); feligreses, como Juana Dom(nguez (núms. 536 y 600); socios, como el presbítero Martín Domínguez (núm, 675). Don Melendo Fernández, hijo del alguacil y alcalde D. Melendo, dejaba en sa testa. mento (1212) 5 mizcales a esta iglesia (núm. 1.025).

359. Calatrava (Frailes de). - Hacia 1185 vemos que un fraile de Calatrava, Fray Fernando, hacía una compra de parte de un olivar para las monjas de San Clemente (núrn. 177), que debía ser el mismo Fernando Juanes que dos años inás tarde seguía sienda apoderado de las mismas monjas y comprando olivos en Talavera (núm, 193).

Poseía el convento viñas en Figares (núm. 241), casas en el barrio de la Catedral, cerca de la Alcudia (núms. 611,637 y 670), y viña en Auria (núm. 1.046) y horno en Zocodover ( $\mathrm{n}$ ím. 830).

Era comendador en Madrid de la Orden un Pedro Juanes que intervenía en la venta de unos esclavos moros en 1266 (núm. 630).

Fernando Juanes, hijo de doña Marquesa, deja en su testamento (i216) el remanente de todos sus bienes a los /reires de Calatrava con condición de que lo reciban en su Orden y en sus oraciones y entierren su cuerpo entre ellos, como uno de tantos (núm. 1.026). Pedro Sancho, parroquiano de San Román, manda (1253) a ja misma Orden 100 mizcales para que lo entierren en Santa Fe y le hagan exequias; como si fuera fraile, ordenando que aquel dinero lo inviertan en la construcción de la capilla que estaban por entonces haciendo en Santa Fe y que lo enterraran en: aquella capilla ( núm. 1.029).

El maestre D. Rodrigo dejó 4.000 mizcales de los sueldos blanoos en poder de Alfonso García de Solomayor, para que con ellos compraran heredades para el convento de San Clemente y con sus rentas se dijeran dos misas diarias perpetuamente: una, por el alma de D. Fernando Pefrez Ponce, y otra, por el propio maestre; con aquel dinero compraron las monjas, en 1292 , varias casas y tiendas en el barrio de los Judíos (núm. 710).

360. San Cebrián o San Cipriano. - Ea 1125 aparece ya la firma de un Johanes, presbitero de San Cipriano (núm. 1.012), y entre el clero de esta iglesia se mencionas el presbilero Esteban ben Suleimán (núm, 305), otro Petrus, presbiter (núm. 475).

361. Sania Colomba. - Convento, s6lo citado una vez, en 1209 , con motivo de la manda de un mizcal que le hace dona Charina, esposa de D. Mojiel el Carnicero (núm. 1.022).

362. San Cosme ( bién para su fábrica 1 mizcal, y a al presbítero que está en el convento de San Cos- 
me, por caridad, 1 mizcal (núm. 1.022); pero en olro testamento de 1211, de Rodrigo Salvatores, aparece la manda para la iglesia de San Cosme: a su fábrica, j̃ mizca. les (núm. 1.024).

363. San Cristobal (Parroquia de). - Un feligrés de ella, Pedro Micael, tenia una viña en Lorita por 1187 (tím 13:4); a su clero pertenecía el presbítero D). Feliz ben Micael ben Jasimil (núms. 212 y 227), y Andreas, presbílero (núm. 1.122); a su parroquia, Juan Pérez (1191, núm. 214), Domingo Iaurens (núms. 428 y 556), y Gonzalbo Petre\% ben Abdelmélic (núm. 1.118).

En 1:265 era uno de los prebostes de la con/ratría de presbíteros de Toledo don Adam, del clero de San Cristóbal (núm. 623).

364. Santo Domingo (Convento de monjas de). - En 1159 era su abadesa doña Eugenia (núm. 731), y otra monja, Dominga Estefane\% se menciona por 1167 (núm. 1.096).

El mayordomo de Santo Dontingo, que interviene en una compra como apoderado de San Clemente.(1187), sospecho que fuera del convento de Santo Domingo de Talavera (núm. 186).

İl año de 1193 fué estéril y calamitoso; estas monjas se vieron obtigadas por la necesidad e para evitar los apremios por las deidas contraídas en el convento en este año estéril, en que llego a venderse la cebada a cuatro fanegas por un mizcal y el trigo dos fanegas por el mizcal , a vender una casa en San Antolín; con parte del precio compraron otra casa, y el resto to gastaron; era abadesa doña Solí, priora doña Eulalia (núm. 249).

Poseía el convento un mesón en Zodocover (año 1196, núm. 267). A fines del siglo XII era abadesa doña María Paris (núm. 299), y segúa siendo priora Eulalia.

Tenf́a el convenlo parte, pro indiviso, de una alfareŕa del Arrabal y de dos tiendas en San Nicalás; puestos de acnerdo el convento de San Pedro en Alíicem y el de Santo Domingo, cedieron (1227) sus derechos al de San Clemente; era abadesa de Santo Domingo doña María Micael, subpriora doña Sangíesa y monjas María Martín y Gosabel, que aprucban la venla en nombre de la comunidad (núm. 487).

Doña Charina, en su testamento (1209), les dejaba por caridad 1 mizcal (número 1.022); D. Gonzalbo Gil, por el mismo concepto, 5 mizcales (núm. 1.028), y otro tanto D. Alfonso Mateos ben Furón (núm. 1.030).

Figura como abogado (وكيل) en el convento (1231) Salut, hijo de Esteban Salut (núm. 814). Ĺn Suero Micaelis renuncia a toda reclamación contra el convento par unas viñas en el pago de Fontanelas (Talavera), donadas por Alvaro Juanes y doña Misia (núm. 995).

En 1251 la abadesa Sancha Dáa, la subpriora María Petrez, la sacristana doña Oria y la partera doña Vita, en nombre del convento vendian n Gonzalbo Petrez, campanero de la Catedral, una viña en Zalencas, por 10 mizcales, dinero que invier. ten en pagar el resto de los 50 que debían a Mokakaxa la Judía por media casa que 
le habían comprado en Montefrido, arrabal de los Judíos (núm. 580), casa lindante con las que compra la Catedral en 1283 a varios judios (núm. 674). Un Juan Mar* cos era criado de las monjas de Santo Domingo en 1279 (núm. 1.116).

365. Santo Domingo (Frailes de), - Un Fray Pedro, de Santo Domingo, dentro de Toledo, compra, en 1176, para el convento de San Clemente, fincas en Talavera (núm. 123).

366. Santo Domingo (Convento de), en Talavera. - Se vende, en 1188, una casa junto al convento de Santo Domingo de Talavera, a favor de San Clemente (núm. 195). Los frailes de Santo Domingo compran otra casa en la colación de Santo Domingo y San Justo, en Talavera, en 1201 (núm. 306). Frailes del mismo convento aparecen comprando a nombre de San Clemente (núm. 338).

367. Sancli-Spirilus (Convento de). - Eran monjes descalzos (لحمجئ الحمال), que no se citan antes de 1239. Para vestidos les manda D. Gonzalbo Giil (1233) 20 mizcales (núm. 1.028); D. Pedro Sancho manda (1253) a los Descalzos del SanctiSpiritus y a los Predicadores de San Pablo, 6 mizcales para que se los repartan (núm 1.027); otra manda de 5 mizcales, que en el codicilo amplia a 7 , les hace don Alfonso Mateos ben Furón (núm. 1.030); 10 mizcales les manda Fernando Petrez el Bolsero, en 1260 (núm. 1.033), y otro tanto dofia Matea, esposa ne Gonzalho Rechico (núm. 1.035). Fernando Ruiz (1281) dispone que su entierro ssea como el de un fraile descalzo de Sancti-Spiritus, y lo entierren en la iglesia de éstos, en la claustra de ella, en tierra $», y$ les manda para la casa de la *botixerías, que esta. ban haciendo los frailes en su casa, en Tolndo, 100 mizcales, más 20 como pitanza, más 80 para vestidos, a condición de que le cedan lugar para su enterramientu) (nú. mero 1.034).

368. San Esteban (Convento de). - Al otro lado del Tajo. Antes de 1184 había sido su prior Domingo, hijo de ¿Cais Ardid? (núm. 1.170), y despaés no tenemos otras noticias que varias mandas que le hacen en sus testamentos: Dona Charina, 1209, 1 mizcal para su fábrica (núm. 1.022); D. Alfonso Mateos, 1266, 5 mizcales, para que lo tengan presente en sus oraciones (núm. 1.030); Fernando Petrez, 1280, 4 mizcalus de caridad (núm. 1033); Fernando Ruiz, 1281, 4 mizcales de pi. lanza (núm. 1.034). - No sé a qué Orden pertenecerían estos frailes.

369. San Eugenio (Convento de). - Sito fuera de la ciudad y cerca de ella; para su fábrica manda 1 mizcal doña Charina, 1209 (núm. 1.022). - No hallo otra noticia de este convento.

370. Santa Eulalia (Iglesia de). - Las menciones que hallamos de esta iglesia se reducen a firmas de personal a ella adscrito; la más antiguạ es de 1195, en que aparece la firma de Salvador, diácono de Santa Eulalia (ńmm . 1.040); Pedro, presbítero (1196, nńm. 266); Dominico Abbas (1209, núm. 373); Micael, presbítero (1210, núm. 38); Johannes, acolitus (1212, núm. 399); Micael, diaconus (1220, números 453 y 459 ). 
Una sola vez se cita una viña de Santa Eulalia, al delimitar el majuclo que poseía D. Clemente el Serrach, en el pago de la Torre del Gasco, en el Regachuelo ( rím. 1.009, año 1251).

371. San Feliz (Convento de). - Ya en 1112 , tenía este convento una finca de legados píos en el término de Manzel Mosca (núm. 8). Y no hallo más noticia de él que la de una manda que en 1192 le bace doña Cristina, hija de Andrés, de 1 mizcal para su fubrica (núm. 1.020).

372. San Cinés (Iglesia de) - En el lestamento de Annald Cequín (1456), se manda a la iglesia de San Ginés un tercio de un corral y de unas tiendas, pro indi. viso con la Catedral y con las confratres de Sama María (núm. 1.013). Varios pres. biteros de San Gines se mencionan: Esléfano, en 1185 (núm. 180); Justo, en 1193 (tón. 245); Pedro Abad, en 1207 (núm. 1.122); el subdiácono Juan, en 1214 (número 406), y los parroquianos Iuan Dominguez y sus hermanas Setí y Soli, en 1250 (núm. 578).

373. San lldefonso (Iglesia de). - No hallo otra cila de esta iglesia que la manda que le hace en $1211 \mathrm{D}$. Rodrigo Salvatores, de 20 mizcales para fábrica

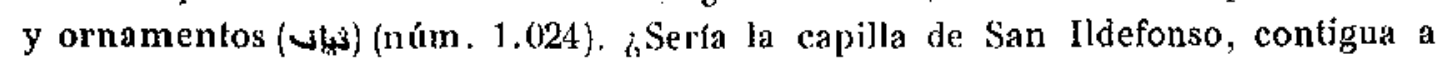
Santa Leocadia de Afuera, a cuya fábrica mandaba 1 mizcal dona Charina, en 1209 (núm. 1.028)? Ĺn el testamento de Rodrigo Salvatores (1211), se cita a Santa Leocadia, la que está junlo a San Ildefonso (núm. 1.024).

374. Sun Juan (Iglesia de). - En el arreglo a que dio lugar la ejecución del testamento del presbítero maior Abdelaziz hen Sohail, en 1125, figuran como testigos dos presbíteros de San Juan: Stefanus y Johanes (núm . 1.012). Otro presbítero, Sancho, firma en 1196 (núm. 741) y en 1207 (núms. 9:18 y 1.057); éste debía ser el mismo que como maestro de enseñanza de Rodrigo Salvatores, recibe una manda de 2 mizcales por su maesiria, en el teslamento de éste (núm. 1.024). Su sobrina Sancha tenfa una tierra en Alcardel (núm. 435).

Otros presblteros son: Egas, en 1207 (núm. 1.037) y Servando, en 1210 (número 382) (en la firma de este se dice: ‘S. Juan Bautista»); Marcos, que compraba tierras en Olías, por 1215 (núm, 422); Selvando, que era albacea de Mateos, abad de San Vicente del Monte (núm. 544); Juan Petrez, que cambiaba fincas en 1282 (núms. 726 y 826 ).

La iglesia posef́a una casa en su propio barrio, lindante con casas del deán don Micael Estébanez, 1231 (núm. 504). Por los diezmos que hubiera olvidado en el tiempo que vivió en aquella parroquia, le manda 5 mizcales D. Alfonso Mateos ben Furón (núm. 1.030).

375. San Juan del Hospifal (Frailes de). - Frailes del Hospital de San Juan se llaman eb el primer docnmento que los hallo (núm. 366), año 1209; como duefios de un mesón en el barrio de Santa Marja Magdalena, mesón que se cita varias veces (núms. 409,413,440 y 474). La Orden (ونجة) de San Juan posela una tierra en 
Manzel Abuishac o Mazarabuzaque, en la Sisla (núm. 596), y una viña inculta en Binal (núm. 715). En el testamento de Gonzalbo Gil (1233) se ve la manda de 1 miz. cal al Hospital de San I uan de Ultramar (núm. 1.028).

376. San Justo (Iglesia de)..... Dos presbítcros de ella, Micael y Petro, firman el convenio sobre el testamento de Maior Aldelaziz ben Sohail en 1124 (número 1.012 ). En 1177 se vende la casa que fué de Jacai) ben Jacob, subdiácono de San Juslo, en el barrio de la Catedral, por su allracea (núm. 130). Entre el clero de esta iglesia están el presbíleco Marlín (núm. 2ï6), el díácono D. Juan (núm. 260), los diáconos Rodrigo, Martín (núm. 425) y Micael Juanes (núm. 490), y el presbítero D. Martín (núm. 508).

Daña Cristina, hija de Andrés, mandaba en su testamento (1192) 2 mizcales para misas a esta iglesia, más 1 mizcal de caridad al clero de ella, y para su fábri. ca, 2 mizcales (núm. 1.020),

Poseía casas en el barrio suyo (nón. 543) y en el barrio de la Catedral (número 765). Entre sus parroquianos se contaba doña Soli, hija de Pedro Illán y hermana del notario García Petrez (núm. 594).

377. Santa Justa (Iglesia de). - La mención más antigua que hallo de esta iglesia es de 1156, on nue Arnalde Çequín manda a los racioneros de ella 3 mizcales (núm. 1.013). Una familiar del presbítero Benbéder, del clero de esla iglesia, compraba (1163) una casa én el barrio de la Catedral (nám. 1.095). Un arcediano, D. Micael, que era feligrés de Santa Justa, vendía un mesón en San Ginés (núme. ro 99), que luego iba a parar a manos del canónigo D. Salvat (núm. 103). .

Eintre los individuos de su clero vemos al presbítero Pedro ben Alt ben Maharix, que vende mesones en San Martín (1202); a Pedro I.azaro (núm. 311); Salvador, el presbítero (núms. 311, 382,759 y 996); Pedro Esteban, subdiácono (núm. 362); Salvador ben Yalya (núm. 371); Pedro ben Mofárech, llamado el *presbittro el jeque* (núm. 466), que vende vin̆a en Alaitic; Alfonso Domínguez (núm. 644); Gonzalbo Domínguez, socio (núm. 662); Domingo Martín ben Suleimán (núm. 780).

lieligrés de esta parroquia era Lope, hijo de Micael de Algar, que vendía una huerta en Campo Rey; parece que eran descendientes de nno de los pobladores de esta alquería de la Sisla (núm. 1.108).

Poseía la iglesia una tierra para aniversario en el Regachuelo (núm. 371), y una casa en el baño de Yaix (núms. 434,485 y 490):

378. Sar Lazaro (Convento de). - Para su fíbrica manda 1 mizcal dofla Charina, en su testamento de 1209 (núm. 1.022), y no se halla otra mención en nuestros documentos.

379. Santa Leocadia de Afuera (Iglesia de). - En 1121 se firmaba un convenio acerca del cultivo de un predio en Dar Athazín, donde tenía una heredad Sanfa Lcocadia «de foris»; un presbítero de San Justo, llamado Pedro, se quedó con la parte de Santa Leocadia, y, al terminar el plazo de su plantación y arreglo, 
partió por mitad con la iglesia; pero al pedir la parte de los gastos hechos para construir una noria, la iglesia, por boca de su prefecto, el sacerdote Micael (en árabe, el preshitero maior Yaix ben Abdalá), contestó que no tenfa dineros. Entonces el arcediano Bernardo los ofreció, con la condición de que le dieran a cultivar la parte de la iglesia, y cunndo ha plantación produjera fruto y utilidad, se intentara la reedificación y restauración de la iglesia, por entonces «dextructa et ruinosa», y luego se dividiera la heredad en cuatro partes, tres para la iglesia y una para el dicho arcediano. Así lo aprobó el arzobispo y lo firmaron yarios, que algunos probablemente serían del clero de la iglesia. En época posterior, el arzobispo D. llaimundo da al obispo de Zamora esta viña, por su vida, y que después de su muerte vuelva a la iglesia (núm. 966).

Don Domingo Antolín mandaba, en 1161, a la fábrica de Santa Leocadia 2 mizcales (núm. 1.014); doña Charina (1209) mandaba a sus racioneros, por caridad, 4 mizcales, más 1 mizcal para la fábrica y otro para la capilla de San Ilde. fonso en ella (ním. 1.022), y Rodrigo Salvatores, para su fábrica, dejaba 10 mizcales (num. 1.024).

380. Sanla Leocadia de junto al Alcázar o de dentro (Iglesia de). - En los funerales por el alma del alguacil y alcalde Domingo Antolín (1161), los racioneros de Santa Leocadia, «la que se halla en el interior de la ciudad de Toledo*, asistieron durante los nueve días siguientes al del sepelio; además, se les mandaba en el testamento 1 mizcal y la tela de tisú para el fronial del altar (núm. 1.014)(1).

A esta iglesia se le llama «Santa Leocadia la vieja» en el dorso del documento 971, del año 1164, de gran interés: Ios racioneros, ancianos y notables de la iglesia se convienen, con permiso y consejo del arzobispo, con Clemente el Monje, acerca del cambio de unas casas contiguas a la iglesia, la de Clemente por el $\mathrm{N}$., y la que tenía la iglesia por el $\mathrm{E}_{\text {, }}$; cuatro individuos de la iglesia se comprometen a dar a D. Clemente, mientras viva, tres cahices de trigo, sesenta arrobas de vino y $1 \frac{1}{2}$ mizcal de oro para vestidos, cada año, y a su muerle se obliga el clero de Santa Leocadia a decir ana misa anuth por su alma. Firman el documento namerosos testigos, algunos en latín, la mayor parte en árabe, presbíteros, díaconos y subdiáconos, y seglares, que formarían el conjunto de racioneros, ancianos y notables de la iglesia.

(1) Fin 12 de Warzo de 1162 se firmaba la ordinación y constitución do la íglesia de Santa Jeocadia, bajo la Regla do Ban Agustín (G. P’rior), bajo la próteceión de la Cakchral .

Santa María te da las iglesias de «Beati Auditi, Sanctorum C [osme] et D [amiani 7, Saneti Petri, Sancti Pauli, Sancte Narie do Císla, Sancte Fulalie in ville eodew nowine, Sancto Mtario de Almainn, Suncte Marie de Tocha iuxta Mlagerianm», con todaa sus posesiones.

-Ad juditium et ad contérmationem huius carte statuínus ut ecolesia S. Leocadies dé cada año cen la festividad de la santr, 10 morabetinos, ja mitad para el arzobispo y la otra milad para el cabildo. (Cort. 1;, folio bl.) 
De gran relieve social debía de ser el prior de esta iglesia, pues se cita sin nom-: brarlo, el cuñado del que fúé prior » en 1179 (núm. 142). Individuos de esta parroquia o aljama, como Juan Julián (núm. 390), o como el presbítero D. Abdelaziz (núm. 121), Benedicto Pełrez (núm. 244), o Colomba Gonzálbez (ním. 292), o el diácono Domingo Abad y Juan Domínguez y Juan Martínez (núm. 321), el racio. nero D. Pedro Felices (núm. 85̄4), cl sacristán Pedro Fclices (núm. 679), intervienen en la vida de la corporación. Benedicto, canónigo de Santa Leocadia, vendía, por 1279, una casa en el arrabal, colación de San Isidoro, cerca de la alberguería de csta última iglesia (núm. 662). Y D. Alfonso Mateos ben Furón, cn su testamento de 1266, mandaba a los socios de Santa Leocadia, pm los diezmos olvidados en el tiempo que fué parroquiano de ella, 50 mizcales (núm, 1.030).

381. San Lorenzo (Iglesia de). - Un Julián, de San Lorenzo, aparece entre los testigos del número 966 (año 1121), convenio sobre el predio de Dar Alhazín y una viña de Santa Leocadia de afuera, y otros presbíteros de la misma iglesia firman en documentos del siglo XII: Domingo, en 1157 (núm. 729), y 1158 (número 1.068); Pedro ben Andrés, en 1163 (núm. 1.095); Lope, en 1197 (núms. 275 y 312); Vincencio, en 1199 (núm. 291); Juan Petrez (núm. 412), ete.

Los testamentarios del citado D. Lope entregaron(1211) la cantidad die 16 tnizcales, mandados a una María la Muda, 10 de ellos que se los debía, y los otros 6 por su voluntad (núm. 1.078).

382. Sian Lucas (Iglesia de). - I a mención más antigua de esta iglesia es de 1188 , en que Juanes, hijo de ¿llamili?, presbitero a clla afecto, vende una viña en Manzel Razín (núm. 200). Otro presbítero era Abenduncas el Calvo, 1192 (número 231). La iglesia poseía liesra en Azucáica (núm. 827).

383. Santo Marfa en Alhicem (Convento de). - Se llamaba Alhicem (الحزاهi) al recinto amxtrallado (1), segutamente junto al Alḉzar, o parte más fortiôcada de la población. Dentro de este recinto habfa, como veremos, varios conventos.

El de Santa María era de monjas; no sé a qué Orden pertenecerfan. En el tes famento de Cristina, hija de Andrés, de 1192 (y es la mención más antigua que hallo), se mandaba a la fábrica ne este convento medio mizcal (nún. 1.020); Gonzalbo Gil también les mandaba (1233), por caridad, 3 mizcales (núm. 1.028).

Una casa poseía en el barío de San Lorenzo, cerca del Baño de Yaix, por 1242 (núms. 559 y 594). La monja Martina, bija de Ramilo el Zapatero, apárece vendiendo y comprando con sus hermanos en 1250 (nńms. 577 y 578 ).

En 1253 era abadesa doña María García; priora, su hermana Elvira García; capiscola, Pascuala Sánchez; sacristana (sacra en el texto), Leocadia Petrez; portera, María. Estas, en representación del convento, vendieron una huerta, viñas y tierras

(1) Vid Dozy, Supp, aux dictionnaires arabes, s. v. 
que tenía la casa en Alaitic, por 200 mizcales, y con ellos, y 90 más de los fondos del convento, compraron dos terceras partes de un tercio de un molino harinero en el azud de Allita, completando así la propiedad del molino (pues eran dueñas del resto); a ello las decidió la consideración de ser los molinos de más utilidad para la casa y de menos trabajo que la huerta, viñas y tierras (núm. 584).

Don Alfonso Matcos les mandaba ea su testamento (1266), por caridar, cinco mizcales (núm. 1.030).

384. Santa María de Burguillos (Iglesia de). -.. Le manda 1 mizcal en su testamento doña Charina (núm, 1.022).

385. Santa Marta Magdalena (Iglesia de). - Un Sancho Garcia, de Santa María Magdalena, firma en 1158 (núm , 60). Pocas noticias posteriores hallamos: que poséa dos viñas en $\Lambda$ lailic y un prado (núm. 523), una viña en Azuqueica (números 598 y 601), y un mesón en barrio de Francos (núm. 829).

Don Pedro Sancho, en su testamento de 1253, mandaba que se diese a esta iglesia 16 mizcales que le debía por diezmos olvidados de pagar en la época que fué su parroquiano (núm. 1.029).

386. Santa María de la Sisla (Iglesia de). - Doña Charina le manda en su testamento 1 mizcal (núm. 1.022).

387. San Marcos (Iglesia de). - Por los años de 1155 fírmaba en un documento Cebrianus, el presbítero de San Marcos (núm. 58), y para la fábrica de su iglesia mandaba Leocadia, hija de Juanes, en 1180, medio mizcal, tomado del pro. duclo de la venta de sus ropas y su manio fino (núm. 1.018).

El presbítero de esta iglesia, D. Jnan Pedro el Marchení, vendía, por 1226, una casa en el barrio de la Catedral, cerca de los Tintoreros (núm. 186); y a esta parroquia pertenecía el racionero Martín Alfonso, que compraba, por 1297, dos huertas en Zalencas en 1.900 mizcales blancos (núm. 723).

388. San Martín (Iglesia de). - Tenía una heredad en Dar Alhazín, en 1121, según se desprende del convenio para el arreglo del azud de Algundarín (núm. 966). Un Pedro Juanes, de San Martín, firmaba en 1156 (vím. 49); el presbitero maior Domingo el Mozárabe daba una tierra en el Monte Hanmara, jurisdicción de Toledo, para ser plantada, 1159 (núm. 928); y parroquiano de esta iglesia era Laurent, de Dos Barrios, que da testimonio de cierto testamento verbal (número 1.027.)

389. San Mateo (شis (Iglesia de). - - S6́lo hallo onencionada una vez esta iglesia en 1127; entre los linderos de una viña que se veṇde en la alquería de Ain, se citan los del O. y N.: a una vifia de los legados píos (مدبس) de la iglesia de San Mateo en la capital citada” (núm. 16).

390. San Miguel (Iglesia de). - Un Pedro, diácono de la iglesia de Śan Miguel, firma en 1174 y 1178 (núms. 111 y 141); un Johannes, subdiácono, en 1185 (núm. 172), que no sé si será el del mismo nombre que, como díácono, aparece 


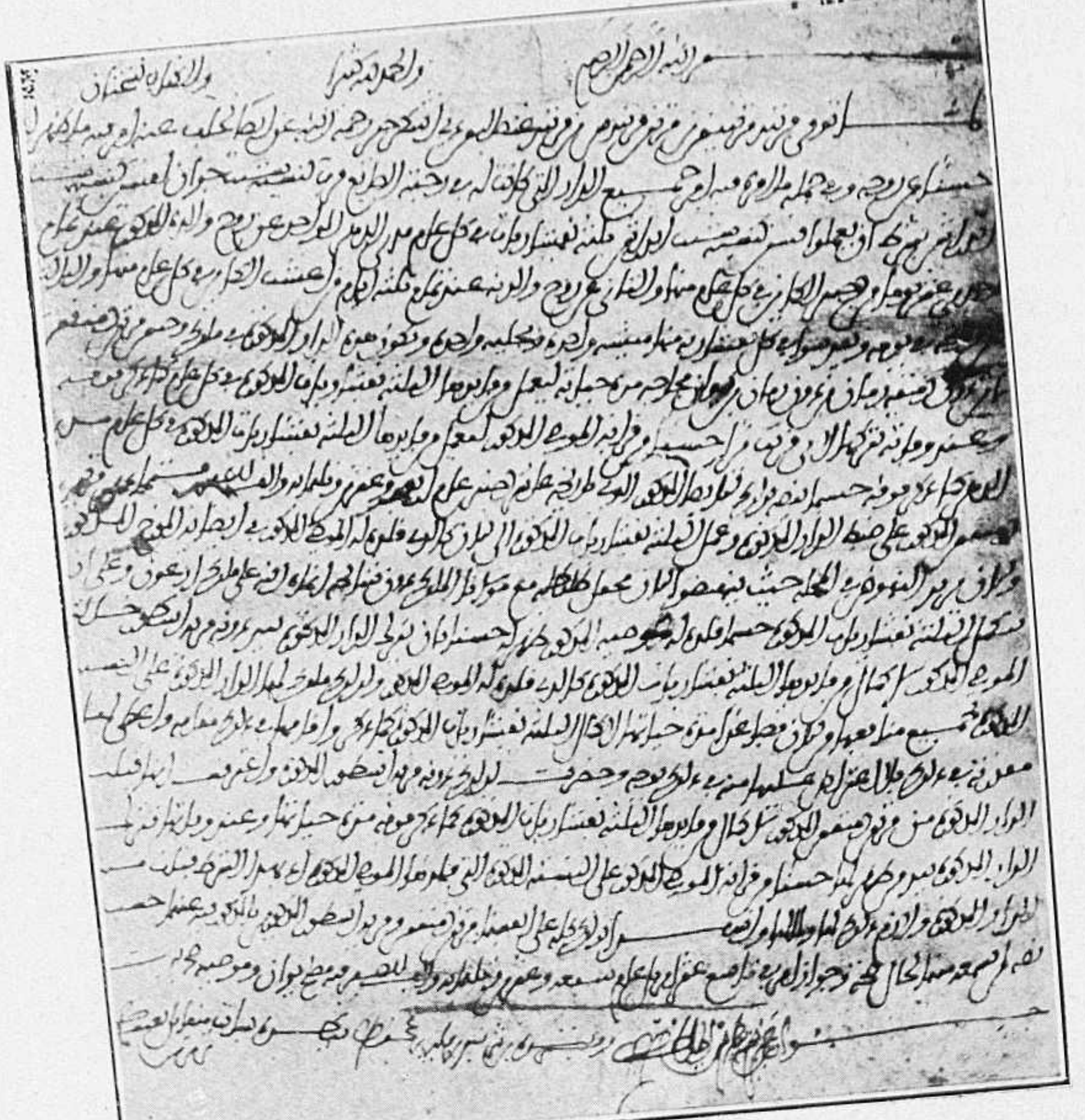


en 1204 y 1207 (nún1s. 333 y 948). Como presbíteros de esta iglesia figuran Salyador (núms. 397 y 179) y Antonio (núm. 412).

391. San Nicolás (Iglesia de).- - Es mencionada desde muy antíguo. El presbítero de San Nicolás, Martín, aparece entre los que firman, en 1125, en el convenio sobre ejecución del testamento de Maior Abdelaziz ben Sohail (núm. 1.012). De su clero vemos al diácono Domingo en 1146 (núms. 33 y 34); al presbílero Juan en 1146 (núm. 34); Gonzalbo ben Simón (núm. 34); al subdiácono Micael en 1175 (núm. 121); al parroquiano Pedro Micael en 1177 (núm. 131); los presbiteros Roberto (1197, nú m. 277); Micael Juanes (1196, núm. 741), y laimundo (núm. 267); los * coronatus" (clérigos de tonsura) Pedro y Servaudo Juanes, en 1197 (núms. 267 y 277); al sutdiácono Juan, hijo de Juan Dominguez, racionero en 1204 (núm. 332); Diego Suárez (núm. 1.123); (rarcía de Bolonia (núm. (603); Pedro Juanes (núums. 685 y 726) Micael Juanes, Juan de Roma (núm. 400) y l’edro Alvarez (uúm. 403).

Varios de ruestros documentos ( 380 bis, 408 y 1.123) citan la donación que hizo el emperador Alfonso VII a los parroquianos de San Nicolás, de las alquerfas de Yepes y Fontes, para plantarlas y cultivarlas, adquiriendo así la plena propiedad de ellas. Es un privilegio de 24 de Agosto de 1145 , atrás reseñado (1), de donde arrancaban los derechos de los sucesores de los primeros pobladores, y citado al hacer trausmisiones de dominio de fincas en aquella alquería: asi el presbítero D. Tomé (núm. 424).

Citemos entre sus parroquiaicos a María la Conejera, viuda de Juan Navarro el Conejero (núm. 520). Rodrigo Salvatores manda (1211) al clero de esta iglesia por comenda y sepultura durante un año 12 mizcales, y, además, 100 mizcales para que se compre una finca con cuyas rentas se alumbre perfectamente el allar de dicha iglesia, y con lo que reste se liaga un aniversario por el alma del testador (námero 1.024). Melendo Fernández también le manda (1212) cinco mizcales (número 1,025); D. Pedro Sancho (1253), por los diezmos que se le hubiera olvidado pagar, 1 mizcal (núm 1.029), y por la misma razón Fernando Ruiz (1281) 30 mizcales (utímero 1.034).

392. San Pablo (Convento de). - Al que había, al parecer, en la vega de Toledo, acaso por el lado de la puerta de los Judíos, mandaba para su fábrica doña Charina (1209) un mi\%cal en su testamento (núm. 1.022). Probablemente es el mismo que luego se menciona como de los Predicadores (bc|l(اله), al eual D. Pedro Sancho le manda 7 mizcales en su testamento de 1253 (núm. 1.029).

Fraile de la Orden de los Predicadores de San Pablo era D. Pedro Fernández de Pantoja, hijo de Fernando Petrez el Portugalés y de dona Mayort; cedió a su madre la parte que le loeaba en la hereneia de su padre y ella se compromete a

(1) Véuse pág. 98 .

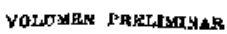


pagarle 160 mizcales alfonsíes (1260): los 60, en la deuda que él contrajo en París cerca de los frailes de la Santa Trinidad; los 100 duranle la vida de ella; si muriese sin pagarlos, el fraile tendrá derecho a retener de la herencia sus dineros (núm. 859).

Alfonso Mateos mandaba primero a los Predicadores 5 mizcales cn su testa. mento, y después, en el codicilo, ordena que se les den en lo que parezca oiros 2 mizcales, y aún tes manda otros 2 mixcales más (núm. 1.030). También les man. dan 10 mizcales lemando Petrez el Bolsero (núm. 1.033) y Fernando Ruiz, de pitanza (núm. 1.281).

393. San Pedro en Alhicem (Convento de). - De monjas, situado dentro del recinto amuraliado, por lo cual alguna vez se le nombra (1196) por San Pedro en Alhicem, contiguo al Alcázar del rey (núm. 740). Era de la Orden del Cister, a juzgar por la nota puesta al darso del documento número 1.173 .

La mención más antigua que de él hallo es de 1191, fecha en que su abadesa Rufina aprueba la venta que una de sns monjas hace (núin. 217). Bienhechora del convento fué doña Cristina, hija de Andrés (1192): les mandó una viña en Torres, para que la enterraran en el; para la fábrica de su iglesia 4 mizcales; y de caridad, 2 mizcales más, para que la tuvieran presente en sus oraciones (aúm. 1.020). También Domingo Andrés, apodado gMoxado?, daba (1196) a este convento cuatro quintas partes de un mesón en el Arrabal dei Rey, por amor de Dios, en sufragio de las almas de sus padres y de la suya; el convento, del que era abadesa doña Sancha, se comprometia a tener presente en sus oraciones al donante mientras viviera y a hacer por su almı un anivel'sario anıal, despnés que ruuriese. La quinta parte del mesón se la compraron las monjas por 40 mizcales, que dieron de los fondos del convento. Firman con la abadesa la priora, Domina Domenga y las monjas María Petrez, Eugenia, Domenga Vicent, Leocadia Dominici y Sol López (núm. 740).

Malos años corrían para el convento. Por Febrero de 1199 se vieron precisadas a vender un mesón en el Arrabal de los Francos por 40 mizcales de oro alfonsí, para emplear su precio en lo necesario para las monjas y el convento, eporque no tenían recursos ni aun para coner, a causa de la escasez y miseria que les alcanzó en los pasados años. Para no morit de hambre se reunierou las munjas en consejo, y pidieron parecer a los canónigos de la Catedral, los cuales, convencidos de la estrechez y necesidad que reinaba en el convento, aprobaron la venta sobredicha $>$. Seguian siendo abadesa doña Sancha y'prioca Dominga, y entre las firmas vemos las de las monjas Leocadia, Anastasia, Sol Lópẹz y Eugenia, a más de las de varios sacerdotes de distintas iglesias (núms. 291 y 323 ).

Pero no pudieron salir de apuros con aquellos dineros: en Octabre de $1202 \mathrm{ha}$. bieron de deshacerse del mesón del Arrabal del Rey, que les donara Domingo Andé́s, por 135 mizcales de oro alfonsí; la causa de esto fué "la necesidad por que pasó el convento este año, que llegó a no tener que comer, por lo cual el arzobispo don Martín López autorizó esta venta * (aúm. 318); todavía eran Sancha, abadesa y Do- 
minga, priora, y de las monjas firman Cecilia, Eugenia, Leocadia Dominici, María Pedrez y María Silvestre.

Poseía el convento la mitad de un huerto en el pago de Asomail o Azumel, por el derecho de doña Dominga, hermana de Pedro Sobrino, dos de cuyas hijas eran monjas (núm. 293) .

Dona Charina les mandaba en su testamento: (1209) un mizcal, por caridad, para que la recordasen en sus oraciones (uím. 1.022); Gonzalbo Gil les manda, de caridad, 5 mizcales (núm. 1.028); Alfonso Mateos 10 mizcales, y otra manda a la monja Mayorí Esteban (núm. 1.030).

Por lus años de 1221, siendo abadesa doña Orabona, hija del alguacil Juan ben Ayub, vendía el convento una parte de viña en Alailic, por 5 mizcales, que se hablan de emplear en la construcción de la casa de alfarerfa que poseía el convento debajo de la Puerta del Mayordomo, en el canino de la Pucrta del Vado; era priora Marina Fernández y monja Urraca Gonzálbez (núm. 463).

No debía ser esta alfarería la que poseían pro indiviso los conventos de San Pedro, Santo Domingo y San Clemente, que cedían los dos primeros al último en venta de 1227; era abadesa en San Pedrb dońa Solí Ruiz, priora María Raiz y mon. ja Uraca Muñoz, que aprobaron la venta (núm. 487).

Suero Micaelis se apartaba, en 1236 , de la reclamación que venía haciendo a este convento, y a los de San Clemente y Santo Domingo, por las viñas que Alvaro Juanes les había donddo en Frontanclas (Talavera) (nñm, 995). Posela, además, el convento una casa en San Nicolás (núm. 522), un mesón en el mismo barrio (núm. 563), otro mesón en Zocodover ( $n u ́ m .579$ ), una viña en Azuqueica (núm. 593), una tierra en Alcardete (núm. 1.045). La monja Leocadia Petrez posefa una casa en el adarve del alguacil Pedro Juanes, en San Nicalás (núms. 641 y 712); la priora Gracia Esteban y la monja María Fernández, hija del alcalde D. Fernando Maleos, compraban una esclava mora, en 1280 , por 240 mizeales blancos, sin que indiquen que es para el convento (núm. 664).

Por Octubre de 1278 se firmaba um convenio entre la monja Macía Meléndez, hija de Martín Dominguez, y sus hermanos García, Pedro, Urraca y Orabona Martínez, acerca de la herencia que a la monja tocaba de sus padres. En lugar de darle los 200 mizcales blancos, que le correspondían, le entregaron la posesión de un tercio, pro indiviso, del mesón que tenían en Zocodover, y un tercio de la casa en el adarve de D. García Juanes de Meana; la monja cobraría las rentas y alquileres de estas fincas hasta que los hermanos le pagaran los 200 mizcales; si moría antes de cobrarlos, el convento la sucedería en sus dercchos.

Aprobaron el acto de la manja la abadesa, doña Colomba Gonźlbez; la priora, dona María Esteban; la subpriora, doña Juana Guiraldo; la capiscola, doña Gracia; la celeraria, doña María Pascual; la camarera, doña Tercsa López; la portera, doña Teresa Gonzálbez, y la sacristana, doña Teresa Alfonso. 
Hasta el afio 1314 no cobró el convento los 200 mizcales, y siguió con las fincas empeñadas; cra entonces abadesa, doña Isabel Gutiérrez; priora, doña Mayor Esteban; subpriora, doña María Pérex; celleriga, doña Marina Petrez; sacrislana, doña Gracia Petre»; capiscola, doña María Pérex; camarera, doña Mencía López, y portera, doña Mayor Alfonso (núm. 1.173).

La monja doña Berenguela, hija de García Martínez, vende una casa derruida en el barrio de Ios Judíos, en 1280; los cargos del convento, que aprueban la venta, son: abadesa, Colomba Gonzálbez; priora, Gracia Esteban; stupriora, Dominga Gutiérrez; capiscola, Mayar Petrez; celeraria, María Pascual; camarera, Soli Martínez; sacristana, Teresa Alfonso (núm. 6699).

La monja Urraca Alfonso poseía tierra en Alcardete (núm, 672). Un «Johannes Dominici, subdiaconus Sancti Petri », que firma en 1207 , sería clérigo afecto al convento (ním. 352).

394. San Pedro (Convento de). - Por la Puerta de los Judios, en la vega' dofia Charina le manda 1 mizcal en su lestamento (núm. 1.022).

395. San Román (Convento de). - Al otro lado del T'ajo: la misma señora le deja también otro mizcal (núm. 1022).

396. San Román (Iglesia de). - Citada ya en 1125; en el convenio acerca del testamento de Maior Abdelaziz ben Sohail, firma un Domingo, presbitero de San Román (núm. 1.012). También se mencionan el presbítero Hartín en 1173 y 1176 (nútus. 923 y 1.00(1); el diácono Domingo en 1189 (núm. 1.129); D. Juan, en 1190 (núm. 905); el subdiácono Bartolomé (núm. 806); el diácono Domingo (núm. 319).

Je csta parroquia eran los hijos de Lorenzo Mofárech, que vende sa parte en Daralbelio (núms. 264 y 268). Entre sits racioneros se citan a Juan Lorenzo (número 268); Domingo Abad (núm. 270); Domingo Alhasar, presbitero, que tenía empeñada parte de Daralbelio, que cl Cabildo de la Catedral compraba a los hijos de Domingo ben Servando en 1211 (̣úm. 392); Alfonso, racionero de ella, que vendía un mesón en 1217 (núm. 438); el presbítero D. Crescén (núm. 1.076); el presbítero Juan Laurens, que compraba viña en 1217 (núin. 436); los presbiteros D. Bartolomé y D. Micael (núms. 810 y 811 ); el presbítero D. ¿Marasah?, que tenía viña en Alaitic (núm. 463); el racionero Felnando Johannes (núm. 768).

Don Gonzalbo Gil disponía en su testamento de 1233 que se diera a la iglesia de San Román 30 cahices de grano, mitad trigo y mitad cebada, que le adeudaha por diezmos; que en el año de su muerte le dieran al clero de esta iglesia todos los producios de sus viñas, por lo que pueda quedar a deberles de los diezmos, y les ruega que lo perdonen. De la suma de 500 mizcales, tomados del quinto de sus bienes, manda que se compre por 150 una finca para San Román, y con sus rentas se haga una capellanía diaria y un aniversario al terminar cada año, pudiendo añadir hasta completar 160 , si no hubiere bastante (núm. 1.028). Por $120 ̄ 4$ aún no habían resuelto los albaceas la compra de la tinca para la capellanía; este año vendían los al- 
baceas al Cabildo Catedral la mitad de un huerto en Alcardete, y dan como razones: la necesidad de pagar los gastos de construcción de una acequia principal y un estanque; el ser la finca pro indiviso con los canonigos y producir poco, siendo mayor su precio que su utilidad, prefiriendo esto para la hija del testador; y cumplir la disposición del testador respecto a la fundación de la capellanía de San Román (núm. 590).

Don Pedro Sancho también mandaba (1253) al Cabjldo y racioneros de San Román 2 mizcales de caridad para que orasen por él (núm. 1.029); y D. Alfonso Mateos (1266) también les hace una manda por los diezmos olvidados en el tiempo que vivió en aquel barrio (núm. 1.030).

397. San Salvador (Iglesia de). - La primera mencion que hallamos de esta iglesia es en 1180, en que dona Leocadia Juanes manda en su testamento 2 mizcales al clero de esta iglesia, y dispone que la entierren en ella y que le den las tiendas que ella poseía (núm. 1.018).

El presbítero Juan Meléndez vendía, en 1185, una suerte de tierra en Villa Antigna (núm. 172). Sol Micaelis hace donación (1137), en vida, de sus bienes, y entre otros capítulos, "manda que se dé el mesón que ella tiene en Zocodover, frente a la cása del conde D. Nuño, difunto, a la iglesia de San Salvador, cano legado pía, con la condición de que el clero de esta iglesia haga cada año un aniversario por su alma y por la de su marido Gil, difuntos (núm. 738).

Citanse, entre los presbíteros de su clero, I.ázaro (núm. 262); Juan Domínguez (núm. 381); Gonzaibo Dominguez (núm. 1.035), ete.

poseía la iglesia una casa en el Arrabal de los Francos, junto a las tiendas del rey, para alfareros y drogueros (nóm. 473).

En el atrio de esta iglesia se sustanciaban los pleitos y se hacía justicia (párr. 490).

398. Sanliago (Iglesia de). - Un Micacl, presbítero de ella, aparece firmando, en 1125 , el convenio sobre la ejecución del testamento de Maior Abdelaziz ben Sohail (núm. 1.012). En la venla de una casa en la propia colación firman varios, y se advierte que todos son parroquianos de la iglesia (núm. 101). Los presbiteros Domingo (núm. 223) y Domineach (núm. 245) pertenecían a su clero. Parroquiana y bienhechora de la iglesia era doña Charina, viuda de D. Mohiel el Carnicero (1209); presbítero de Santiago era su maestro D. Paris, a quien mandaba 1 mizcal; en el claustro de ella mandaba que se la enterrase, junto a la sepultura de su marido, por lo cual daha al clero de ella 4 mizcales; deịba a sus racioneros 2 mizcales para misas; y para la construcción de su altar o de otros altares, o para lo que a los racioneros pareciese mejor, otros 10 mizcales; a la confratria de esla iglesia, 4 mizcales, que empleará en lo que quiera; dispone que sus albaceas, juntos con el clero de esta iglesia, compren por 200 mizcales una heredaò, que será legado pío de ella - con la condición de que cada día del año se diga una misa en el altar de San Gabriel, perpetuamente, por el alma de la testadora, de su esposo y de sus antepasa- 
dos». Si el clero dejase de decirla, manda que pase la heredad al clero de Santa Leocadia para que cumpla lo mandarlo (múm. 1.022).

Los albaceas de doña Charina, el presbítero de Santiago, D). Paris (su maestro) y D. Cebrián ben Jáir, vendían, por Octubre de 1209, un majuelo en Almoradiel por 35 mizcales, "que habian de invertir en bien del alma de la testadora. (nútm. 375); uno de los testigos era Nieolás, presbítero de Santiago. Los mismos albaceas vendían, en la misma fecha, otra viña en Almoradiel, por la misma razón (núm. 376). Fueron los albaceas ejecutando el testamento, y, al fin, hallaron que no disponían de los 200 mizcales mandados por doña Charina para la capellanfa, sino de sólo 65; con ellos compraron (Febrero, 1210) una viña en Oliolas para aplicarla a aquella nuanda; todo con aprobacián de los presbíteros Pelayo, Nicolás, Martín y Guillermo y de los demás presbíteros, subdiáconos y servidores de la cilada iglesia, obligándosc el clero a decir dos misas cada semana. (En lugar de D. Paris actía como testamentario el presbítero D. Juan) (aúm. 378).

Con motivo de la compra, en 1213 , de una easa en el harrio de la Catedral (la casa de María Mozola), por el presbitero D. Pelayo, (lel clero de Santiago, figuran como testigos Ios clérigos de ella Nicolás y Paris (núm. 401); esta casa, que a partir de la compra por D. Pelayo sirvió para taberna, fué vendida en 1234 por la sobrina de D. Pelayo, a quien éste se la había darrado (núm. 513).

399. Santiago (Orden de), - La mención más antigua que hallo de la Orden en estos documentos es de 1181, fecha en que ya se dice que poseían una vína en Zalencas (ním. 1ð̆4). 'También poseían fincas en Algorfela en 1201 (mím. 1.127), llamándoseles aquí frailes de Uclés. Al maestre de la Orden lo llaman Abi (st) en documento de 1199, que lo era Alvaro Juanes (núm. 724).

El comendador D. Gil Marlínez, comendador de la casa de Santiago del Hospital y encargado de los bienes de mandas plas de ella, cambiaba un prado en $\mathrm{Ar}$ gance por nna heredad en Algonfela, en 1213 (núm. 810); otras tierras en Val de Rio.... por otras de Algorfela, en 1214 (nún. 811), y varias tierras en Algorfela en 1214 (núm . 812); en este último documento se dice de una finca que \&ahora en po. der de los frailes de Villamiels, que sospecho sería la misma Orden de Santiago.

El freire Juan Domínguez era comendador de la Orden en Villaverde de Val de Algodor en 1227 (núm. 1.060).

La Orden posefa una viña en Oliolas (núm. 404), una casa en el barrio de la Magdalena (núm. 561) y una tíerra en Rielves (núm. 931).

400. San Sebastian (Iglesia de). - Hallamos mención de esta iglesia en 1181 con motivo de la venla que hace el presbítero de ella D. Just. Abrituélic, como albacea de Yahya ben Mofárech el Platero (núm. 155). Entre sir clero se citan el presbítero Lázaro (ním. 291), los diáconos Paulo (núm. 101) y Pedro Abad (números 480 y 506), después presbítero (núm. 530), y además canónigo (núm. 529); los presbíteros D. Salvador (núm. 506) y Pedro Felices (núm. 962). 
401. San Servando (Convento de).-No son muchas las referencias que hallo de este convento. La primera es de 1156 , en que se dice que posee un cuarto dc viña en Azuqueica (núm. 51). Se indica que poseĺa otras fincas en la misma alquería (núms. 84, 143 y 201), y una vin̄a en Valdecubas (núms. 315 y 1.130).

402. Santo Tomé (Iglesia de) - Lin 1125 firm a un Lomingo, de Santo 'Tomé, en el convenio sobre el testamento de Maior Abdelaziz ben Sohail (núm. 1.012) y otro presbitero, Marcos, es testigo en 1157 (núm. 729). El presbitero de su clero don Feruando, como albacea de Domingo Benaix, interviene en la venta de parte del azud de Alcapillat o Alcubilet en 1202 a faror del arzobispo (núm. 322). Un subdiácono, Juan Petre\%, de la familia Alpolichesı́, vende, en 1209, un pedazo de hiterto en la puerta del Vado (núm. 369), que debe ser el mismo que, siendo diácono y ra. cionero, compraba en 1234, la casa donde se vendía el vino (núms. 513 y 766 ).

Cítanse, además, entre su clero, los presbíteros Domingo Micael (núm. 512), Gonzaibo Petrez (núm. (i23), Juanes Albruzel (núm. 710); entre sas parroquianos a Pedro djlán (núm. 1.076).

Una casa poseía el clero de esta iglesia en el Arrabal de los Francos (número 1.044$)$.

403. San Torcuato (Iglesia de). - Como albacea de Abdalá ben Baxar vendía nna finca en San Cebrián (1187) el presbítero D. Micael Juanes, del clero de San Torcuato (núm. 192). Racionero de la misma iglesía era el subdiácono Pedro ben Yahya ben $A$ bilharits en 1190 (núms. 212 y 227); presbíteros en ella Feliz (nú. mero 247), Maleos (núm. 417) y Lázaro (núms. 430 y 436).

404. Santa Cruz (Iglesia de). - Véase atrás, pág. 71.

405. Santa Trinidad (Iglesia de). - Poseía esta iglesia una tierra blanca en Lloyón en 1179 (núm. 735). $\Lambda$ su clero pertenecía el presbítero Juan en 1211 (número 389), y estaba conslituído en cofradía en 1212; eb esta cofradía figuraba Melendo Fernández, por lo que le mandaba en su testamento de 1212,5 mizcales (número 1.025). Todavía se cita en 1294 (ním. 716).

406. Santa Trinidad (Orden de la). - I.a mención más antigua es de 1253, en que Pedro Sancho deja en su testamento a los freires de la Santa Trinidad ropas para una cama, con los ¿caballos? del testador (núm. 1.029). A estos mismos frailes deja 1 mizcal D. Alfonso Mateos (núm. 1.030). Los de esta Orden en París habían prestado 60 mizcales al fraile predicador Pedro Fernández de Pantoja (número 859$)$.

Poseían una casa en el Arrabal de los Francos (núms. 655, 671 y 829 ).

Fernando huiz les mandaba en su testamento de 1281, 5 mizcales de pitanza (núm. 1.031), y Fernando Pelrez, 4 mizcales de caridad (núm. 1.033).

407. San Vicente (Igtesia de). - Dos de sus presbíleros, Domingo y Micael, firman el arreglo re 1125 acerca del testamento de Maior $A$ bdelaziz ben Sohail (núro 1.012), y no escasean durante el siglo XII las firmas de clérigos de esta iglesia; 
Micael (núm. 33), Pedro (núm. 923), Nicolâs (núm. 114), Juan (núm. 735), el acólito Simón (núm. 786), los diáconos Pedro y Nicolás (núm. 149).

El presbítero I). Pedro vendía, con otros, en 1174, un huerto en Marzalcadi al convento de San Clemente (núm. 114\}; cl diácono Domingo vendía, en 1175, una viña inculta en Zalencas (núm. 117); el preshítero Pedro Muñoz vendía a sus bermanus sus derechos en Alaitic en 1229 (núm. 495).

Entre su clero se citan Paricio (núm. 362), Domingo Alascar (núm. 371), Diego Petrez (núm. 482) y Domingo Torcuato (núm. 472). Socio de esta iglesia era el vicario D. García Esteban (núm, 687).

Posefa la iglesia tierras en Azucáica (núms. 827 y 828 ); era su parroquiana Estefanfa, hija de Domingo el Gordo (núm. 829); D. Pedro Sancho mandaha en su testamento (1253) 2 mizcales a esta iglesia por los diezmos que le debía (núme. ro 1.029$)$.

408. San Vicente en el Monte (Convento de). - Pocas menciones hallo de este convento. Una es de 1241 , con motivo de la compra de una casa en el barrio de San Juan, que hahía sido propiedad del sabad benedicto D. Mateos, abad de los canónigos del convento de San Vicente en el Montex, y que sus alloseas habían vendido (núm. 544).

Dehe ser la misma casa que con el nombre de « frailes de la Orden de San Vicente de la Sierras, se dice que poseían una casa en el Arrabal de Toledo, por 1290 (núm. 704).

409. San Zoel o San Zoilo (Iglesia de). - En 1185 interviene en la venta de u na viña de Eulalia, hija de Pedro Iuanes, uno de sus albaceas, D. Pedro Domínguez, del clero de San Zoel (núm. 174). Era esta familia parroquiana de la iglesia, según se deduce del documento núm. 736, donde se díce ser maestro del donante Juan Petrez Mocarram, hermano de Eulalia, el presbítero D. Domingo, del clero de San Zoel. Un Domingo ben Román, المذاكر, de San Zoel, firma en 1188 (nú. mero 199). Varias veces aparece como testigo el presbítero Domingo Martín, entre 1202 y 1207 (núms. 318 y 440); el diácono Pedro Abad (núm. 438), el presbítero Pedro Fernández (núm. 490), el racionero Domingo Pascual (núm. 562).

Andrés, hijo de D. Pascual y hermano de Domingo, cotmpraba, por 1244, un pedazo de viña en el pago de Calabazas (núm. 562), viña que por cambio iba a manos de Pedro Juan, en 1259 ( núm. 820).

Parroquiana de esta iglesia era Leocadia, hija de Juan Petrez el Malah, en 1206 (núm, 345). 


\section{EL CONVENTO DE SAN CLEMENTE}

410. Capítulo aparte merece este convento, por la circunstancia de ser procedentes de él una buena parte de los documentos que vamos estudiando, como ya se djjo atrás (1). Era y sigue siendo de monjas bernardas, y no tenemos ningán dato acerca de su fundación.

En nucstros documentos aparece ya por vez primera en el ano 1132, fecha en que, representado el convento por el preshítero 'Tirso, compra una viña en Aceca (uúm. 18). Pasada la primera mitad del siglo XII, ya se cita frecuentemente, en especial a partir de 1157 y 1158 , en que conocenros el nombre de su abadesa.

Debía de tener como especie de casa filial el convento de Santo Domingo en Talavera, según se desprende de documentos de 1160 (núm. 732). La monja de Santo Domingo, viuda que era de Domingo Pelrez el Fecac (sospecho que de Talavera), llamada Dominga Estébanez, donaba a San Clemente, en 1157, todos sus bienes: olivos, viñas, higueras, ete., por amor de Dios y por la salud del alma de su hijo y de sus padres, y para recibir la protección del patrono del convento; con condición de tenerlo y usufructuarlo durante toda su vida, pero sin que pueda cambiarlo o venderlo (núm. 729). Otra monja de Santo Dominga de Talavera conıpraba para San Clemente de Toledo, en 1167 (núm. 1.096).

Desde 1158 hasta fines del siglo XIII tenemos noticias de sus abadesas, $y$ durante el siglo XIII de los distintos cargos del convento.

Las abadesas, con indicacion de las fechas extremas en que aparecen, fueron:

\begin{tabular}{|c|c|}
\hline & Años. \\
\hline Matri o Matris.... & $1108-1193$ \\
\hline Cecilia .............. & 1201.1213 (muere a fines de este año). \\
\hline Orabona $(2) \ldots \ldots \ldots \ldots, \ldots$ & $1214 \cdot 1248$ \\
\hline Leocadia Fornández......... & $1256-1280$ \\
\hline Urraca Petrez.... & $1284-1292$ \\
\hline
\end{tabular}

Durante el período de doña Matri, no aparece ningún otro cargo dentro del convento, aunque es de sospechar que los hubiera. Intervienen en los contratos las

(1) Vease pág. 10 .

(2) Hija de Juanes ben Aynb, algnacil y alcalde (núm. 496). 
monjas Solí, hija de Sebastián (año 1158); Cecilia Pelrez y María Petrez (año 1172); Eulalia, Leocadia, Sol y Eugenia (año 1173).

En tiempo de doña Cecilia era priora doña Orabona (1206-1213), que le sucedió como abadesa. Monjas en esta época eran María Ralo y Dominga Sebib (año 1206); Orabona Pelrez, Luna Juanes y María Esteban (año 1210); Orabona Andrés, Leocadja Pelrez, Eugenia, María Vélez y Lrraca, "hermana del obispo* (año 12!3).

En el largo perfodo de mando de la abadesa doña Orabona, elevada al cargo siendo priora, van figurando como subpriora Luna Juanes (año 1219, 1232 y 1234) y Urraca Gonzábez (1222). En 1225 era priora Uraca Micael; capiscola, Urraca Gonzálbez, y monjas, Luna Juanes y Especiosa. Crraca Micael, hermana del canónigo Alfonso Melóndez, figura como priora enlre 1219 y 1234 . En estc último año segufa siendo priora Urraca; subpriora, Luna Juanes, y capiscola, María García. Desde 1241 la priora cra Leocadia Fernándex; la capiscola, doña Éspeciosa. Entre las monjas citadas en este período, se ven María Velez (año 1214), Elvira García (1222), Luna Juanes (1225), Especiosa (1225), Estefanía Fernández (1231), Orabona, hija de Armaldo Muñoz, y Munia Armíldez (1232), Leocadia Fernández (1234), María Martínez (1236), María Sancho (1241).

Ascendida a abadesa la priora dỗa Leocadia Feruández, fueron con ella: priora, doña Margalita; capiscola, Urraca Petrez; celeraria, Luna Petrez; portera, Mara (año 1280); monja, Matrí Alfonso.

Con la abadesa Urraca Petrez, hija de Pedro lllán, eran: priora, Leocadia Estébanez; subpriora, Orabona Gonzálbez; capiscola, María Garća; celeraria, María Dominguez; portera, Elvira Marcos (año 1292).

Las capiscolas o x cantor * fueron: Máría García (año 1219), Crraca Gonzálbez (1225), Luna Juanes a precentor (1222), Especiosa (1244), Urraca Petrez (1280).

En alguna época babía dos monjas porteras: doña Mayor y doña María Martín (afno 1231).

Al servicio de la igiesia del monasterio estarían los clérigos.que de vez en cuando aparecen bajo el nombre del convento: v. gr., Diago Ennego (núm. 448); Domingo Martín, aLevita Sancti Clementis * (núm. 448); Dominicus (núm. 1.038); F'ray Esteban, capellán que fué durante varios años (1206.1281) del monasterio; Bartolomé de San Climent (núms. 774 y 1.027 ).

Como adıninistradores del convento hallamos a Fray \$). Jün, por los años de 1215 (núms. 421, 811 y 812); a Fray Micael el Comendador, por 1247 y 1248 (números 491,789 y 790$)$; a Garcín Guillén, que parece era comendador o administrador de los bienes del convento en Argance, por 1255 y 1261 (núms. 917 y 987). Alguna vez se les llama e fraile de la Orden del comvenlo de San Clemente» (núm. 803). A veces lo representaba un fraile de Calatrava (núm. 193) o un seglar, v. gr, , en Olías (num. 539). 
También parece que había en el convento algunos hombres, bien clérigos, como cl presbítero Domingo ben Alrim, «que está en el convento de San Clemente* (año 1177, núm. 131\}, hien seglares, como Domingo Muftoz el Pastor, que consagra su persona a bios y al convento de San Clemente, y le hace donación de un quinto de sus bienes en 1239 (núm, 77.1).

411. Bienes del convento de San Clemente. - Aparte de la adquisición atrás seĩalada por el presbítero 'Tirso, en representación del convento, en 1138, la abadesa, dona Matri, recibía, en 1158, sparte del horno que hay en el barrio del Molino de Axxam (o de la Reina), con compromiso de que una monja pague, a la muerte de su madre, a otra hermana seglar, lo que ha recibido anticipado, y la monja no percibiría node de la herencia de la madre hasta lanto que haya pagado a su hermana (núm. 1.068).

En 1160, doña Dominga, monja de Santo Domingo en Talavera, donaba a San Clemente dos majuelos cerca de esta cindad (núm. 732), y la abadesa compraba finca en Olias (núm. 62). Otra monja de Santo Doningo compraba (1167) para San Clemente, y con dinero de éste, olivos en l'alavera (núm. 1.096). Doña María, viuda del caíd D. Pedro de Tolosa, le hacía donación (1168) de un buerto, que había heredado de su marido, síto fuera de la Puerta de los Judíos (núm. 733). Con motivo de la profesión religiosa, en este convento, de María y Cecilia, su padre, el algua. . cil y alcalde D. Pedro ben $\Lambda$ bderráhmen ben Yahya ben Harit, hace partición de sus bienes y les da la sexta parte de un liuerto cerca de Santa Leocadiaide fuera, entre. gando la escritura a la doadesa; valía aquella parte 167 mizcales, igual que los bienes adjudicados a sus olros hijos.

Por inlermedio de Fray Domingo compraba el convento, en 1175, un corral en el arrabal de Talavera (núm. 119), y por medio del presbitero Domingo ben Alrim, unas casetas al lado de la alfarería que el monasterio posefa en el Arrabal, barrio de San Isidro (núm. 122). Otro Fray Pedro, de Santo Domingo, dentro de Tuledo, compraba, en 1176, para San Clemente, un pedazo de tierra plantada de viña, encima del Carrascal de Talavera (núm. 123), y en 1177, el citado Domingo ben Alrim, dos pies de orvo en Montel (Talavera) (núm. 129); olros los adquiere en 1185 (número 177).

Por 1179 se decía que San Clemente cobraba el diezmo en Argance (número 1.052), en virtud de la donación que se suponía haberle hecho de esta alquería el emperador Alfonso VII (núm. 941).

El presbítrro Julián ben Fatjún, mayordomo de Santo Domingo, compraba, en 1187, la mitad de un prado en Bañuelos (Talavera), para San Clemente, que ya era dueño de la otra mitad ( $n$ úm. 186), y un corral con unos pies de morera y un pozo de agua, en el arrabal de Talavera, en la colación de San Miguel (núm. 188); para comprar otro corral, colindante a éste, dio el convento su representación al comendador Fernando Juanes (núm. 190), para la adquisición de varios pies de olivo y al- 
guna noguera, en diferentes lugares de Talavera (núm. 1933), para la compra de una casa en esta ciudad, junto al convento de Santo Domingo (núm. 195̃).

También poséa el convento tierra inculía en el pago de Bañuelos (Talavera) (núm. 207) y otra en Olías (núm. 208), un quinto del azud de Asomail (núm. 293), una ticrra en Rielves (núm. 805), una tierra en Fornillos (Talavera)(núm. 1.057), una viña en Azucáica (núm. 345), otra en Corral Rulsio (núm. 350) y la plana de Figares (núm. 1.058).

Una casa en el barrio del Alcharar del Rey, en Talavera, lindante con el conven* to de Santo Domingo, compraba Fray Pedro, apoderado de doña Cecilia, abadesa de San Clemente, en 1204 (núm. 338). La reina doña Leonor, esposa de Alfonso VIII, representada por su camarero D. Aparicio, compraba en 1203 , por 700 mizcales, la casa que había sido del alguacil D. Feliz Sánchez, en la colación de San Rumán, de Toledo, para hacer donación al convento de San Clemente, con quien lindaba (núm. 326). Otra cása, contigua al convento, compraba su representante, Fray D. Marlín Petre\%, en 1204 (núm. 339), y otra, ruinosa, de los nietos de Feliz Sánchez, también cercana al convento, en 1212, su procurador, Fray D. Juan (núm. 395).

En 1211, representado el convento por D. Franco, compraba tierra en Talavera (núm. 384); en 1215, por el freire D. Juan adquiría una lierra inculta, que fué viña, en Valera, del alfoz de Toledo (ním, 421); en 1216, un olivo en Canales, Talavera (núm. 429) el tercio de una noria (plana y canales) en el pago de los Aviones, Talavera (ním. 432), y los derechos de pesca y en las norias de Torremocha y del Hey, en el Tajo (433); en 1217 la mitad de otra casa en el barrio de San Román, contigua a corrales del convento (ním. 437); en 1218, una ticrra con siete olivos, corca de Albiches, jurisdicción de Talavera, lindante por tres lados con olivares del convento, que estaba representado por el judío Ibrahim ben Ishac Algualid (núm. 442), que también es su apoderado en la compra de unos derechos en el río Tajo, en el azud de Baños (núm. 448); en 1221, tres octavos de la alquería Azeituna (núm. 464).

El convento, representado por su capellán el presbítero D. Fray Esteban, compra, en 1222, el tercio de una tierra inculta en Valera (núm. 467); en 1223, una viña en la vega de Olías, lindante con viña del convento (núm. 472); en 1224, otra viña en el pago de Garganta, debajo de Corral Rubio, contigua también a otra del convento (núm. 475).

Ia abadesa doña Orabona, con el dinero que Urraca Micael, priora, había heredado de su madre doña Marła Peláez, compraba por 300 mizcales (1226), al canónigo Alfonso Moléndez, cuatro tiendas contiguas al hilo, en la colacion de San Nicolás, al lado del mesón del hierro y del carbón (núm. 483); y en 1227 se quedaba con los derechos que Alvaro Juanes tenía en la alfarería del arrabal y en dos tiendas de San Nicolás, y habra pasado a ser de los conventos de Santo Domingo y de San Pedro en Alhicem, pro indiviso con San Clemente, tasados estos derechos en 30 mizcales; los otros dos conventos los vendieron a San Clemente (núm. 487). 
El comendador D. Fray Miguel compraba para el convento, en 1225 , un cuarto de unos nueve pies de olivo, que estaban en tierra del convento, en Talavera (número 491), y una viña en el camino de Alcoba (núm. 492). Don Esteban adquiría la mitad de un pedazo de tierra destinado a era, en Olias, lindante con otras dos eras del convento (núm. 499).

Recuperaba la abadesa, en 1237, un octevo de la alquerín Aceituna que otra abadesa había dado al encargado del convento en esta alquería, comprándoselo a los hijos de éste (núm. 521).

Algunas mandas lestamentarias a lavor del convento podemos señalar: dona Charina, por caridad, 1 mizcol, para que la mencionen en sus oraciones (nút mero 1.022); D. Melendo Fernández, un huerto en Alaitic y una casa en San Nicolás, para que lo recuerden en sus oraciones (núm. 1.025); D. Gonzalbo Gil, por caridad, 5 mizcales (núm, 1.028); D. Alfonso Mateos, otro tanto (núm. 1.030); doña Luna encargó a sus hijos Diego Alfonso, Orahona e Inés que eompraran por 100 mizcales una casa, cuyas vtilidades fueran para las monjas de San Clemente; adquirieron una casa en la Judería (1258) por 103 mizcales (núm. 605).

Poseía el convento un baño en el Arrabal, cuyo contrato de construcción estudiaremos después (núm. 987), La abadesa arrendaba el huerto de Santa Leocadia por 26 mizcales anuales en 1258 (núm. 911), y se arreglaba con Vicente ben Saad en cierta reclamación contra la herencia de Alvaro Juanes y su mujer Misia, prima del Vicente, sobre terrenos en Fontanellas, Talavera (994).

La abadesa y el convento manumilian (1235) al esclavo Alí el Bastí por 30 miz. cales (núm. 787).

No podía disponer de los bienes del convento sin aprobación de las monjas y del arzohispo, según afirmaban en el pleito acerca de la propiedad de Argance en 1186 (núm. 941). Por donación que hizo al convento el prebítero Pelayo, de un quinto de sus bienes, que importaban 12 mizcales, obligó la abadesa, por la vía judicial, a vender una casa, para cobrarse, pues el hermano y heredero del donante no quería cúmplir su promesa de pagarlos (núm. 955).

\section{COFRADIAS}

412. Desde muy a principios del siglo XII hallamos mención de cofradías: la noticia más antigua es de 1125 y referente a la cofradia de preshíteros (número 1.012).

Parece que las habia en cada iglesia, aunque, naturalmente, no se citen todas. En Santa María la Mayor funcionaba ya por 1156, fecha en la cual Arnald Cequín 
mandaba en su lestamento el tercio del corral y las liendas gue poscia a los con/ratres de Santa Maria (núm. 1.013j. En 1tij aparece un Perlo Diaz, sayón de la misma cofradla (núm. 75). También D). Conzabo (inl, en su teslamenlo de 1283,

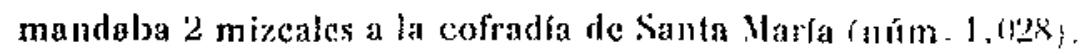

La cotrarlía cle Silu Ildefosso poseía viña por el pago le la liorre del Gasco

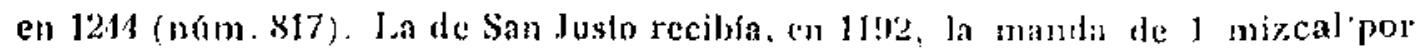

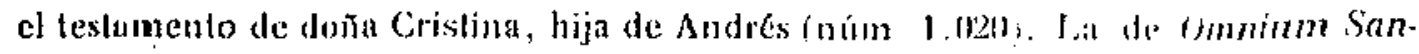
clorum compraba, en 1,243 , por medio de su apoderado 1). Pedro felices, del clero de San Sebastián, la casa de Pedro Jistehan el Malinero, y su vinda, doña María, en el harrio de San Sebastián, a cuyas espaldas estaba el bano hambido (ním. 1.162). A In de Santiago divaloa dona Charina, hija de Andres. en 1:4hy, 1 mizcales, para que los emplearn en lo que quisiera (núm. 1.122); y esta coliadfa posefa una vina en Val de Sanliago al Mayor, lérmino de Olfas (nóm 817 , La de presbíleros de la Trinidad, a la que pertenecía D. Melendo liernández, lenía una manda de éste por 5 mizcales (núm. 1.(125).

No estí claro si estas cofradías eran sólo de elérigos, pero parece que tamblén las integrahan seglares (1).

413. La colradla de presbiteros de Toledo. La cofradla de los presbiteros de Toledo es antiqufsima: ya funcionaba anles de 112, fecha en la que el presbitero Maior Abdelaziz ben Soliail manda a la confratro de sus hermanos y com.

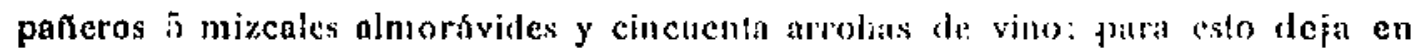
poder de los albaceas mo viña y de los probluclos de la viña, despenes de pagados los gastos de cultivo, se habian de sacar las cinecuenta arroban, y del resto se harfan tres partes: una para aceile, incienso y lena; otra para los chuticos, y otra para los pobres, desputis de sacar de esto para la conmemoración en el día de su muerle (núm. 1.012).

Dona Charina, epara que la recibnn por con/ralresa, en la confratria del clero de las iglesins de Toledo, mandala en su leslamenlo de 1209 (5 mizcates (núm. 1.022).

lid fln primordial de la eofradía era lacer sufragios por el alma de los cofrades, y estos sufragios, segím la costumbre ordinariamente recibida, comsislían: en una nigitia la víspera del día del aniversario, misa en este dta y rezo de la sepultura o responsu; esto se comprometio a lacer la cofradia con doña Luni. esposa que fué de J). Alionso Viente, que le dono (1233) unas casas y unos dineros para tres aniversarios. Estos funcrales se hacian en las iglesias donde estaban sepultados los interesados. Y la corradía acostumbraba a hacer asi ceon todo aquel que pertenece a ella y do sus ropas por el bien de los vivos y pur la salud de as almas de los nuerlos) (11úm. $1.11 \mathrm{j} 8$ ).

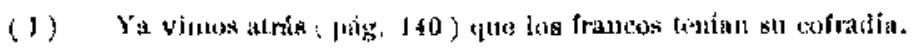


Al frente de la coliadía había dos prebostes, que eran dos sacerdotes, cada uno de iglesia distinta, y que debian renovarse en el cargo con alguna frecuencia. En 1238 eran prebostes D. Domingo Pelrez, de Santiago, y D. Martín Abad, preposito de la iglesia de San Isidro (núm. 1.168); en 126j lo eran Gonzalbo Pelrez, de Santo Tomé, y D. Adam, de San Cristóbal (núm. 623), quienes con los 10 mizcales que les había mandado Pedio Esteban, para su aniversatio aunal, compraban, en 1265, una casa del propio Pedro Ésłeban a los albaceas y a su viuda, duefia de la décima parte (núm. 623); en 1267 eran prebostes D. Esteban Martín, de San Nicolás, y don Juan Marlín, de Sanla Lulalia, quienes compraron a María Alfonso una casa en el barrio de San Vicente, que habia sido te Hifao; el precio se completaba con varios cantidades, mandadas para aniversarios por Domingo Juanes ben Alpardesal, por D. Adam, de San Cristobai, y por Micael Julianis, de San Lucas, resultado de la venta de fincas de la Congregación (núm. 1.164).

En 1279 eran prebostes Alfonso Mntinez, de San Vicente, y Bartolome Petrez, de Santiago, y compraban una almazta, sobre casa que la cofradia tenfa en San Lorenzo, con los dineros que para aniversarios habian dejado Marina Petrez, Fernando Ruiz y Mencia Alfonso (núm. 1.165). En 1285 era uno de los priostres Garcfa Juanes, que alquilaha a Alfonso Petrez el Carretero una casa de la cofraaia en San Lorenzo, por dos años, y por 12 mizcales anuales, pagados por cuatrimestres (núm. 1.172).

Por manda testamentaria de D. Pedro Sancho (1253) se dejaba a la cofradía 12 mizcales para comprar una finca, y con sus prodnctos hacer un arriversa. rio por cl álma del testador; preveíase el caso de que los presbiteros no quisieran hacer el aniversario ( $¿$ acaso por ser corla la cantidad?) y entonces quedaban fa: cultados todos los albaceas para vender la finca y emplear su precio en sufragios, como mejor les pareciere (núm. 1.029). Para un amiversario par el alma de su tía doña Solí mandaba Alfonso Mateos, en su testamento (1266), que se comprara una heredad por 15 mizcales, y se entregara a la cofradia de presbíteros (núm, 1.030).

Para los preathteros de Coledo dejaba 60 mizcales en su testamsnto de 1281 don Fernando huiz, para que hicieran un aniversario por él y por su hermano Gonzalbo, y en un mismo día (uím. 1.034).

Por donación de Alfonso García y sus hermanos, hijos de Garcla Juanes, adquiría la cofradía, en 1279 , un mesón, cerca del hỉesón de la harina, oọ la obligacíón: de hacer tres aniversarios (nim.1.169).

Alguna vez aparece la cofradía prestando dinero: v.gr., al vicario D. Alfonso, del clero de San Justo, con la fianza de sus cufados Pedro Parisí el Zapatero y su mujer (oúm. 1.171).

Es de creer que la cofradía poseía, además de las propiedades resef́adas, las fịncas cuyos títulos de propiedad se conservan en su archivo: una casa en el barrio de 
San Andrés, que había sido de Abdalá ben Omar (núm. 167); la casa del barrio de Santa Eulalia, llamada casa de Clemente (núm. 1.157); otra en el barrio de Puerta de Hierro, que era de Julián ben Hilel (1.160); otra en el barrio de Alhandac, que fue de una hija del apodado Ainaín fi rasu (núm. 1.161); otra en el mismo barrio y contigua, que fué del alguacil y alcalde $D$. Servando, alcalde de la corte del rey (núm. 1.163); la viña en el pago de las carcavas, de Zalencas, que fué de Micael Juanes Assafar (núm. 1.166) (1).

Parece que las relaciones de estas cofradías de clérigos con el arzobispo no fueron siempre mantenidas dentro de rigurosa disciplina. El papa Lucio las hubo de condenar, a juzgar por el siguiente documento ${ }^{(2)}$ :

Nobis siquidem intimatum est quod fere omnes parrochizles uestri cleriei in tantam sunt prolapsi nequiciam ut uobis obedire contumaciter contradicant, nouas et detestabiles conspirationes et coniurationes pretestu confratearum aduersus uos ineuntes et sub tali forma malig-

(1) Sobre la documentación posterior de esta institución, véase Al Arohivo dal Cabildo de Parwocos de Toledo, por Antonio Sierra Corella. Extr. de la Kevista de Archivas, 1928.

(2) A. H. N., Car. 1, fol. 99. También estaria en relación con estas diferencias el convesulo que los clerigos celebran en 1189 con el arzobispo D. Conzalbo Petrez, por el que prometen «nt archiepiscopo karltatem spontaneam sicut antecessoribus ejus fecermi, libenter tribuant et cum aliquas rationnbiles petitlones pro suis manifestis necessitatibus ipsis clericis porrexerit ut flii exaudiant. Item quod conueniant simul cum necesse habuerint saluo iure ot reuerencia domini archiepiscopi el cathedrali ecclesie, coniratennitatem quoque celebrabunt cum eius uicariis et canonicis uaioris ecclesits, sicut solebant facere. Item quod cum uieario menorati archiepiscopi dcciuas tritici et ordei, sicut hucusque consuetudo fuit, diuidant archiepiscopus quoque ompem querimonian quam habobal super tertis quas ad opus fabrice ecelesiarum oxigebat ot mandato apostolico ecclosiis fucrant adiudicare, wisericoriiter deponcit. Tercias etiana super quibus impetebantur eis, omnino dimitii.....» (Ibid. , fol. is.)

Todavía en tiowpo del arzobispo D. Rodrigo seguian las diferencias. El 9 de abril do 1288 , el arzobispo comunicaba desde Bribuega al deín y cabildo toledano la golneion a las disputas que tenían con los clérigos de Toledo.

El clero de Toledo de antiguo concurría a la iglesía mayor en ciertas solemnidades: ir a las procesiones, y en la fiesta de la translación a san Eugenio, llevar el arca de las reliquías, y en los dias de teniza y de Paresceve, a tomar la ceniza y a adorar la criz en el coro, y el Sábado Santo llevaban la luz nueva a las 1rílesias antes de que el cirio fuese bendito y las campanas tocadas, y al dín siguiente, en la Resurrección, se hacia la procesión antes que en las demás iglesias se celebrara.

Manda que en las solemnidades y letaníss a que hasta ahora venían, sigan viniendo, «et tam in procesBoufbne quam in aliis more solito, quamque in capis, quamque in superpelliciis, secundum que qualitas temporls exigerit, nestrum studeatis ut decet offecium adimplere, prohibentes ne processiones siant is parrochis uel campane pulgentur, nisi secundum quod actenus feri consucvit. De portatione vero archo in festo trasJacionis beati Eugevii, nolumus ad presens aliqnid diffuire, sed questionem istam duximus differendam donec utraque pars nostro se conspcetui reprosenteut. Volumus etium et mandanus quod capellanias habeant in ipsa ecclesia clerici ciutatis sicut cas haclonus habuorunt, presertim cum nullnf sulper cis statun tum factun fuerit a capitulo secundum quod iđem Decanus et Cantor requisiti a nobis in nostra presentia protestrti . (Ibid., fol. 14.) Este documento lo extracta Eatella, ob. cit., pag. 107. 


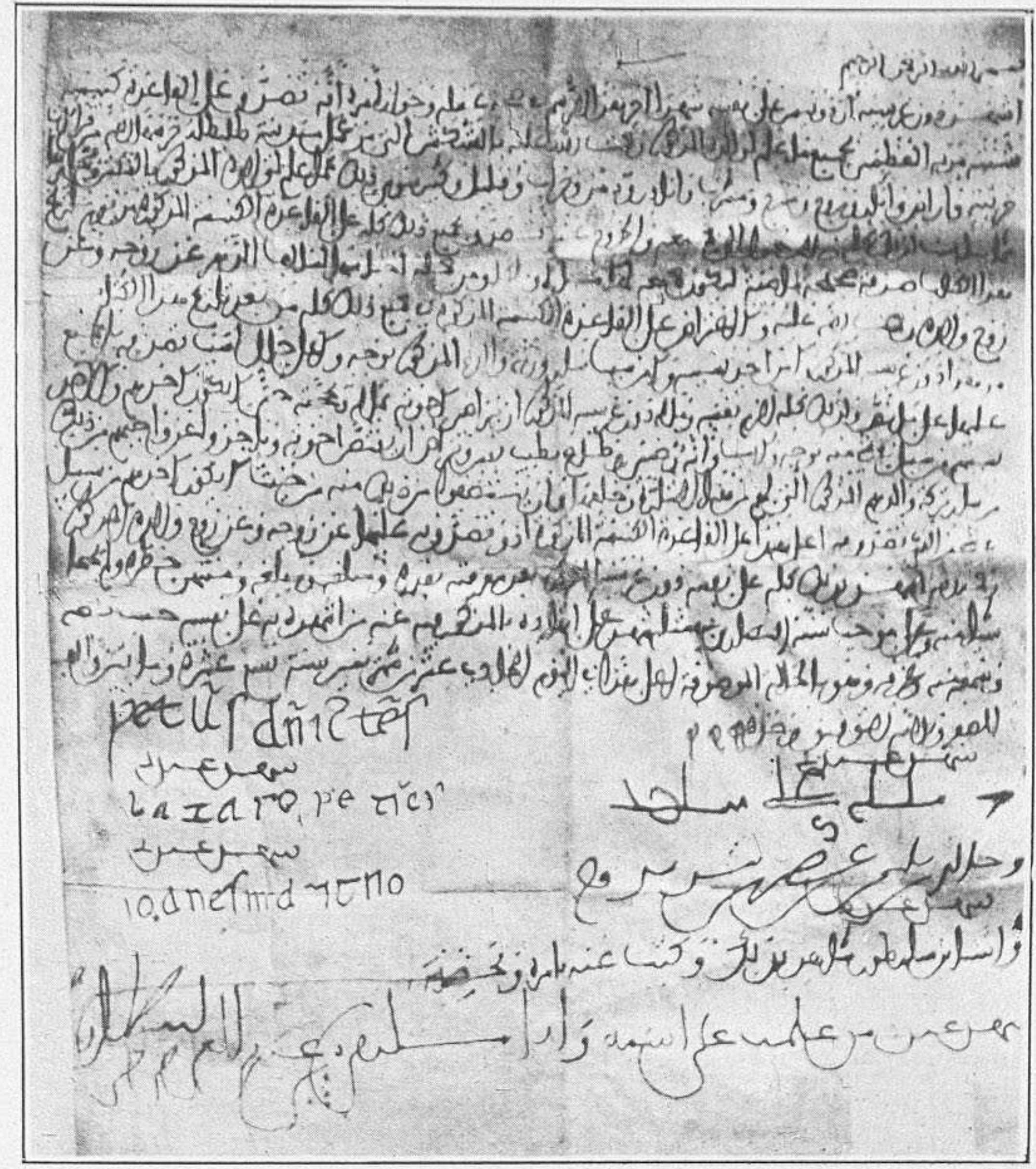

Donación: 21 de Enero de 1181 (núm. 1.121). 
naw simulantes astuciam fratroas et conuenticula statuerunt, ex quibus prouenit manifesta pernities et summarum iniquitaturo generantur exempia. Accedit ad hec quod quocicns uolunt conuenticula sua congregare, uocati a uobis uenire negligunt, interdicta uestru seruare recusant of consueta et debita seruitia uohis substrabere noiiuntur. Fit quomodo tantarum iniquitatum et presumtionum excessum non possumus nec debemus aliguatenns relinquero, in correctum prefatas confratreas, que, ut dicitur, fratree possunt uerius appellari, ad exempiar pie recordationis alii Pape predeccssoris nostri inctoribato omnipotentis Dei et beatorum Petri et Pauli apostolorum eius de comuni fratrum consilio nostrorum, penítus extiriamus ot tam eas quarn eartas el sigilla pro earum inslitucione confecta perputua cassatione dampnamus; procipientes firmiter et auctoritate apostolica prohibentes at nollam deinceps habennt inter se sive cum lajcis clerieis confraternitatem, nce in unum audeant convenire, nisi cum a uobis uel a vicaris vestris fuerint conwocati. Si qua tamen in eis fuerint qque fioneste utilitatis obtentu sine westro et ecelesiarum preinditio uideritis toleranda, ca in statn suo concedimus perma. nere......

\section{ANIVERSARIOS, MISAS, CAPELLANIAS Y FUNDACIONES I'IADOSAS}

414. No sólo las cofradías de presbiteros, sino todas las iglesias cumplían la misión religiosa de ofrecer sufragios pur las almas de los difuntos, cuya celebración solian prevenirla los interesados o sus familiares y daban una remuneración por caridad o por pilanza a los clérigos, seculares o regulares, que bablan de encar. garse de celebrarlos.

Ya antes del año 1125 el preslfitero maior Aldelaziz ben Sohail mandaba celebrar cuarenta misas en sufragio de su alma (núm.1.012), además de disponer un pa. tronato para que la cofradía de presbíleros cclebrara perpetuamente su aniversario; pero como las rentas de la viña no fueran suficientes para cumplir las cargas, el alguacil y alcalde, a instancia de los albaceas, y después de consultar con los grandes de la cindad a quieacs correspondá, entre los racioneros, los mozárabes y los castellanos, resolvió adjudicar la viña como bien pío a la Catedral «a causa de la exiguiidad de las utilidades que percibra dicha iglesia y la multitud de las alenciones de la misma»; el Cabildo se obligó a incluir al testador en la lista de los canónigos muer. tos en la referida Catedral. Anald Cequín disponía, en 1156, que se cobrase una deuda que tenía a su favor, imporlante 28 mizcales, valor de un asno que habla prestado, y se emplease, por el alma de su tío Aibert, en misas y en limosnas de los pobres (nún. 1.013). Para un aniversario perpetuo que por sil alma babía de hacer el clero de la Catedral, les mandaba el alguacil y alcalde Daningo Autolín los derechos que tenía a las salinas de Perales y lo demás que alli poseía; y dejaba a su esposa y a una hermana el encargo de distribuir cada una 6 mizcales durante el año en misas (núm. 1.014). 
El clero de Santa Leocadia se compromelía, en 1164, a decir una misa anual por el alma de su bienhechor Clemente el Monje (ním. 97i). Bernakdo Archent dejo a la Catedral para su aniversario la mitad de su casa, y su viuda hubo de ven(ber al Cajildo (1174) la otra mitad por 50 mizcaies (nim. 1.671). La Catedral recibra, en 1170, la donacion que le bacian Játim y su hermana Marła, de una tierra en Alcardete que una tia de ellos babia dejato en testamento para sufragios por su

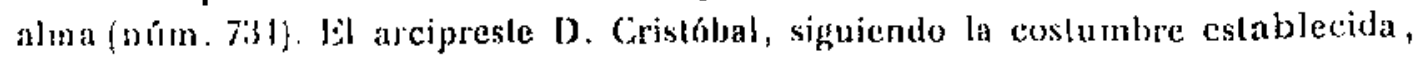
dejaba a la Caledral de mizcales para su aniversario; la Calcedral, con este dineroy con ulro de b) kofre, de (Canales, por el mismo motivo, compraba tierra en Azaña en 1182 (ním. 161). N año siguiente compraba olra finca en el mismolugar, por 32 mizcales, para aniversario de D. Vedro de Cardona y del presbitero I). Vidal (número liij). Al fondo de los anversarios de la Caledral paso la casa yue doña Urraca, hija del caisl 1). Pedro de Tolosa, compró en 1183, con el quinto de los bienes de su hijo difunto, D. Pedro Matcos (núun. 16i(i); y para el mismo fin piadoso de sufragios por la lestadora, comprahan los alhaceas de lofia liulalia l'etre\%, en 1185, finca en Jisinal por 21 mizcales (núm. 17.1).

l'ara misas diarias dejaba fi mizcales dofá Sol Micaclis, en 1187 , y para aniversario, en San Salvados, por ella y su esposo D). (iil, dejaba un mesín en Zocodover (ním. 738), y parte de las ropas y del manto fino de dona Leocadia .Iuanes, se inverta en misas ( $11 \mathrm{~m}, 1,018$ ). [ara sufragios par su alma y la de su padre daba, en 1181, (rarcia todonez a la Caledral los bienes que si padre tenia en lilescas (número 1. 121); otra donación recibía la iglesia mayor de una casa en la Alcudia (1189), de Mtarn, viuda de Juan bomínguez el Cojo, para aniversario perpetuo y para que Jos seiforps la mencionaran en sus araciones (núm. 733).

Cualro mizcales para misas dejaba Cristina, hija de Andrés: 2 al convento de San l'eảro en Allicem, 2 a la iglesia de San Justo (wúu. 1. (120); para misas y para los polbres dejalua, en 115.5 , el remanente de su herencia Orabona Salvador ben Fadl (nim. 1.021).

Los atbacens de Melendo Perez compraban (1197), con 50 mizcales, una casa y liemotit en Sim Nicolás, para un aniversario en la Catedral (núm. 277). I)espués de valrias incidenciats y pleitos, llego la Catedral, en 1197, a un acuerdo con los herederos cle Marfa cimzalloez, y se compinomelio a encorgar a un presifitero del altar construfdo hajo ha advocacion de San Mignel, en la Catedral, y que dijera allí una misat diaria perpelua por el alma del fundador Gonzalbo Diaz, de su esposa Marfa Gonzallee. y de su suegro Gonzalbo Pelkez, y además, hacer un aniversario perpetuo en el cabo de año de la muerle de cada uno de los tres (núm. 1.126). Tamlién st obligaron los canónigos, en 1201, a hacer un aniverserio por el capellán D. hoberto, que donó una cantidat de dinero (núm. 333). Para aniversario les daban Rodrigo Diaz y su esposa un mesón en 120)4 ( 1 úm. 7.12).

Dona Charitua disponía en su testamento (1209) la celebración de una misa per- 
petua en el altar de San Gabriel, de la iglesia de Santiago, por capellán que éstá había de poner: y para ello dejaba 200 mizcales, que se invertirían en una finca; disponiendo, además, un aniversario el día de San Gabriel, con autorización al clero a comerse en este día el resío de las rentas de la finca mandada (núm. 1.022); pero, en la ejecución del testamento, los albaceas hallaron que no había más que $65 \mathrm{miz}$. cales de fondos y cornpraron con ellos la finca: el clero de Sanliago se obligó entan. ces a decir sólo dos misas a la semana (núm, 378).

En 1211 el obispo de Ciuenca, D. García, mandaba a la Catedral sus posesiones en Co6eja y Alameda para su aniversario; y como dejaba usufructuario de las fincas. al preshítero I). Lope Ruiz, le ordembn dar al cabildo cada año 5 mizcales parn ariversario del obispo y 1 mizcal para el altar mayor de la Virgen (núm. 1.023). Rodrigo Salvatores, el mismo año, mandaba, para una capellanía en la Catedral, 300 mizcales: la carga de la capellanía era misa diaria, perpetuamente, en cualquier altar, y aniversario, según los usos y costumbres; a la iglesia de San Nicolás le man. daba finca por 100 mizcales para alumbrar perpetuamente el altar de esta iglesia, y con el resto bacer su aniversario (núm. 1.024).

Melendo Fernández mandó (1212) que se dijeran dos mil misas por su alma (nú. mero I.025). Para misas o para limosnas a los pobres, scgún lo creyeran mejar sus albaceas, dejaba 4 mizcales Fernando Juanes en 1216 (núm. 1.026).

La Catedral compraba, en 1220 , finca por 8 mizcales stomados del dinero que dejó el arcediano D. García Estébanez para que compraran una finca, con cuyas rentas hiciesen sufragios por su alma cada año en las fiestas de San Román y de: Santa Marina, con cuatro capas, según es la costumbre (núm. 457); recibía del jeque D. Gonzalbo Juanes tres pedazos de viña en Alaitic, en las viñas de los aniversarios (núm. 237), aś como sus derechos en los árboles frutales, etc., para hacer un aniversarin por su alma y tenerlo presente en sus oraciones (núm. 766); adquirfa, en 1231, finca en barrio de San Juan para aniversario del maestro Abril (núm. 504),

Doce mizcales para misas anuales (añal) mandaba María Domingo en su testamento de 1232 (núm. 1.027), y 150, que podía ampliarse a 160, D. Gonzalbo Gil a la. iglesia de San Román, para comprar fincas y con sus rentas fundar cina capellanía. con misa diaria y un aniversario anual (ním. 1.028). El prior D. Juan de Brioga había dado (1232) una casita para su aniversario (núm. 1.106).

En alguna ocasión no eran fincas rústicas o urbanas lo que se daba para sufra: gios: María Guillén, hermana del vicario D. Nicalás, compro (1237) * una escrilura romance llamada breviario, y lo dí por el alma de su hermano* (núm. 519).

Compraba el Cabildo, en 1254, una casa en el adarve de D. Bernaldo, con 30 mizcales, del presbítero García de Bolonia, de San Nicolás; otros 30 de Lucía, criada del arcediano de Madrid, D. Bartolomé de Argades; olros 30 de María Velasco, y otros 40 del canónigo Fernando Pétrez, todos mandados para aniversarios (número 608). 
Altonso Mateos, en su testamento de 1266 , mandaba comprar fincas o casas por 180 mizcales, que tendría su esposa mientras viviera; con las rentas se fundaria una capellanía para misa diaria y aniversario anual, en Santa Leocadia, donde se mandaba enterrar, y con obligación de decir la misa en el allar que liabía cerca de la sepultura del testador. El sobrante de las rentas lo emplearian en mejorar las fincas; el patronalo de la capellanía lo tendría siempre el pariente más cercano del fundador ( $n u ́ m .1 .030$ ).

La Caledral adquirıa, en 1273, una casa en el arrabal de los Judios, por 1.250 mizcales blancos, para la capellanía y para el aniversario de D. García Muñoz, arcediano que fué de Madrid (núm. 835 ), y en 1275 olra casa en el mismo arrahal por 500 mizcales, procedentes del fondo de 2.000 que habia mandado el areediano (núm. 648); con cargo al dinero que mandó para su aniversario el tesorero D. Pedro ¿Roldán?. se compraba, en 1279, una casa y una habilación en el adarve de los Canónigos (núm. 660).

Don Fernando Petrez el Bolsero mandaba 100 mizcales er su testamento (1280) para misas por su alma, que se habían de decír en la iglesia y por el capellán que sus testamentarios quisiecan, y una viña en Almahchuda a los euras de San Andrés para que le hicieran un aniversario (núm. 1.033). Fernando Ruiz mandaba que se celebraran mil misas y una misa diaria dumante ocho meses por sa hermano Gon. zalbo, para cumplir una deuda que con el tenfa, y que terminaran la construcción de su scpultura (núm. 1.034). Doña María Mateos ordenaba, en 1282, que se gastasen 50 mizcales en misas por su alma, en la cantidad y en la iglesia que sns lestamentarios designaran (núm. 1.035).

Clara está la idea de lo que lucgo fué patronato de una capelianía en la fundacibn hecha por Feruando Martínez de ¿Escarchir? en sa testamento de 13 de diciembre de 1286: dispuso que en la iglesia de San Andrés se celebraran tres aniversarios con misa y bigilia, uno por su padre, el 11 de diciembre; otio por sa madre, el 3 de agosto, y otro por él mismo el día que muriese; para esto dejaba una casa en la plaza de los Platerns. El patronu de esta fundación era Martín Domínguez, que tendra la casa roientras viviera, y luego nombraría patrono al pariente que mejor le pareciera, y con sus rentas harían los aniversarios, El patrono cumple lo dispuesto, pero como se quisicra ir con la mehalla que formaba en Toledo el rey D. Sancho en 1291 contra el rey de Aragón, le parece lo mejor dejar la finca en manos de doña María Astur, tía del fundador, para que ella siga haciendo los aniversarios; ella acepta y dice qute a su muerte se la dejarł al pariente del testador que mejor le parezca, joes con esta condición acepta la casa y responde de ella con su persona y bienes (núm. 1.065).

En el convento de San Clemente mandó que se fundaran dos capellanías el maestre de Calatrava D. Rodrigo, para lo cual dcjó 4.000 mizcales, con parte de los cuales compraba una casa el convento en 1293 (núm. 714). Unas huertas en Azu. 
cáica se compraban en 1297, para capital de las capcllanias que en su testamento fundara el arcediano D. Alfonso Meléndez, y se entregaban aquellas fincas a una hermana del arcediano (núu. 723 ).

\section{ENTIEIROS Y FUNGRAJES}

415. Casi todos los que otorgan testamento se preocupan de señalar el punto referente a su entierro y funerales. Algunos se limitan a indicar una cantidad que ha de ser empleada en ellos, v. gr., Amald Cequín, en 1156, 10 mizcales y 5 por sitio para sepultura en el corral de la Catedral (núm. 1.013); Eulalia Petrez, en 1185, 6 mizcales, disponiendo, además, que se construyera la sepultura de su abuelo por medio mizcal, y la de su padre con otro medio (núm. 1.016). Otros se liınitan a decir que los funerales scan los acostumbrados, y disponer el lugar de su enterramiento: v. gr., Leocadia Luanes, que dice lá entierren en San Salvador (número 1.018).

Solemuísimos debieron de ser los funerales del alguacil y alcalde D. Domingo Antolfn, en relación, sin duda, con su rango social. Lo primero que mandó en su testamento de 1161 fué, «que después de su nıuerte, luego que Dios sea servido de llevarle, se dispongan Ios funerales para el tiempo de su entierro, y durante los tres dias siguientes, con todo el clero de las iglesias, invitando a los obispos y racioneros que puedan asistir en razb́n de su dignidad o jerarquía, y si estuviere presente el arzobispo, sea también invitado y se agradezca y recantuense si asistencia (1); y háganse solemnes exequias, con aquellos que asistieren, por espacio de los tres días iudicados. Pasados estos Ires días, continuarán los racioneros de la iglesia de Santa Leocadia, la que se halla en el interior de la ciudad de Toledo, con los funerales, hasta terminur los nueve dlías.» Acaso por esta molestia mandaba al alzobispo 5 mizcales, a otros dos obispos 1 mizcal y a los racioneros de Santa Leocadia otro mizcal. Y disponfa que su esposa distribuyese 20 mizcales entre los clérigos de las iglesias, invitados durante los tres dias dichos, y lo que de ellos sobrare, fuera repar. tido, para bien de su alıne, entre los pobres y'enfermos; y que su esposa distribuyese como le pareciese 6 mizcales para la celebracion de misas en el transcurso del año, y su hermano otros 6 para lo mismo (núm. 1.014).

(1) Pedro Martín mandaba 8 mizcales al arzobispo para que fuese a su entierro, on 1188. (Cartulation 2, fol. 101.) 
Del fondo de la herencia se sacaban a veces los dineros precisos para los fune. rales, o del quinto de libre disposición ( $\mathrm{núm}$. 977); y alguna vez se indica que la cantidad a gastar en funerales se emplee en 6 bodigas?, mandando dar a los cria. dos lo que parezca, sin coniar el luto (núm. 738).

Para entierro y rezo de la sepultura, mandaba doña Cristina, en 1192, que se gas. taran 4 unizcales (núm. 1.020); y duña Orabouja Salvador (1195) permitía gastar hasta 10 mizcales, tomados del precio de los muebles de casa y tinajas (núm. 1.021). Dona Charina (1209) dejaba 20 mizcales para su entierro, rezos de sepultura, misas durante ocho días, a partir del desu entierro, cera, incienso, ofrenda, sacrificios, etc. (núm, 1.022).

Los gastos ordinarios de un entierro en 1214 solían elevarse a 5 mizcales: para mortaja, rezo de sepultura, etc. (núm. 953). Cuando era de más calegoría, se le hacía funeral en su mortaja, en los días de visita a su tumba y en su entierro; así lo disponía Roài igo Salvalores en 1211, mauciando, además, que se le enterrara en la Catedral, en la sepultura de su padre: por su entierro, y para que los canónigos lo tuvieran presente en sus oraciones, les mandaba 20 mizcales, y para misas por su alma, repartidas entre el clero de las iglesias de la capital, 100 mizcales. Este mismo señor manuaba al clero de San Nicolás, por comenda y sepultura, durante um

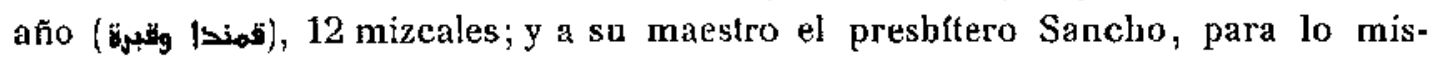
mo (1), 12 mizcales (núm, 1.024).

Otros disponf́an que se pagara su mortaja y entierro kcomo conviene a su clase , peru sin que tenga más luces grandes que dos cirios, como hacían los frailes; así, Gonzalbo Gíl, en 1233 (núm. 1.028). Como convenía a su clase, mandaba también que se procediera $D$. Pedro Sancho (1253), en lo tocante a entierro, mortaja y honras de los días del entierro, y encargaba que la mortaja fuese de lana, pudiendo gastarse 12 mizcaies (nim. 1.029).

El opulento D. Alfonso Mateos ben Furón dispuso (1266) las honras en su mortaja, sepultura y funeral, según lo corriente en gentes de su clase; pero con la condición de que la mortaja fuese de lana, la más basta que se hallara en el mercado, y que se le encenciieran dos lámparas, con un cuarlitio de aceite solamente, y otras dos más pequeñas, de cuatro mechas cada una, que alumbraran miantras estuviesen sus ¿restos? en su casa. El lugar de su sepultura sería en Santa Leocadia, en la misma de su abuelo, al lado de su padre. Se le haría funeral a los cincuenta días, y otro al cabo de ano, según costumbre, teniendo en estos actos las lámparas como se ha dicho. Se celebrarín migas por su alma todos los días, desde el de su entierro hasta el séptimo siguiente, y en cada uno de estos siete días se habria de repartir a los pobres 1 mizcal (núm. 1.030).

(1) ¿Querre decir responso: 
Entierro, mortaja, honras de los días de la sepultura, de cabo de los cincuenta días y de cabo de año comprendían los funerales de aña Teresa, mujer del escri. bano Pedro Juanes (año 1270, núm. 962), que se había de pagar del quinto de su li. bre disposición. Igual disponía Fernando Petrez el Bolsero, en 1280, salvu que nombraba las honras del séptimo día y que mandaba para los rezos del día de su entie-

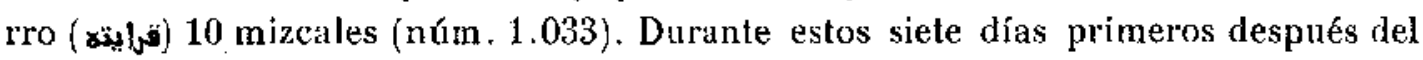
enticro rezaba el clero de alguna iglesia y celebraban misa diaria: por ello daba de pilanza D. Fernando Ruiz (1281) al clero de San Nicolás 20 mizcales, quien disponía su entierro, mortaja y rezo de sepultura, según lo acostumbrado en su clase, salvo que la mortaja fuera igual a la de cualquier fraile descalzo del Sancti Spiritus, en la claustra de caya iglesia, y en tierra, se mandaba sepultar; para ello daba a los Descalzos por pilanza 20 mizcales y para $\Varangle$ vestirlos? 80 , con la condjción de que le dieran lugar para sepultura en la clausira, y si no le daban este sitio, quedaba sin efecto la manda; y mandando que se le hicieran funerales el septenario, el cincuentenario y el cabo de año mandaba también que se terminara la sepultura de su hermano Gonzalbo Ruiz (núm. 1.034).

Conforme a su clase manda doña Matea, viuda de Gonzalbo Rechico (1282), que se hiciera su entierro, morlaja y rezo de sepultura, y funerales al cabo de los siete días, de los cincuenta días y del año; y disponía que la enterrasen al lado de donde estaba su marido (núm. 1.035).

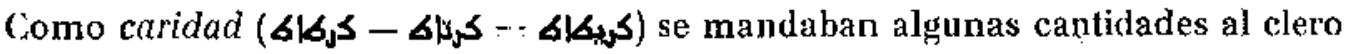
de la Catedral (núm. 1.014), de San Zoel (nún. 1.016), de San Justo (núm. 1.020), o a los conventos, como Santo Domingo, Sau Clemente, Santa María en Alhicem, San l'edro en Alhicem, Descalzos del Sancli Spiritus, Predicadores de San l'ablo, frailes de la Trinidad y frailes de San Esteban: esta caridad parece que era limosna para sufragios (núm. 1.030).

Una como manda forzosa era el llamado mizcal mortuorum, que un testador disponía, en 1266, se pagara de sus bienes (núm. 1.030).

\section{LIMOSNA A LOS POBRES}

416. Se consideraba la limosna como un sufragio y en muchas ocasiones se mandaban cantidades indistintamente para misas o para pobres (núms. 1.021 y 1.026), y con bastante frecuencia se mandaba para las dos cosas (núms. 1.013 y 1.026). A veces se indicaba la elase de socorro qne se había de prestar a los menesterosos, y principalmente era para vestirlos: doña Charina dejaba (1209) para vestir a los pobres 18 mizcales (1022); D. Rodrigo Salvatores, en 1211, 100 mizcales (núme- 
ro 1.024); D. Melendo Fernández, en 1212, dejaba el remanente de su herencia para vestir pobres, religiosos y otros parecidos (ním. 1.025); olto lanto laacia don Gonzalbo Gil (айo 1233, núm. 1.028).

En el testamento de D. Alfonso Mateos (1260) se especifican tres clases de limosnas a los pobres: una debja ser el reparto en metálico de 10 mizcales; otra era un donativo para vestidos, en lo que se había de emplear cierta deuda; y otra era acaso la composición de un homicidio: "por el alma de Domingo l'etrez...., el que murió en las viñas de Ajofrín, 3 mizcales entre los pobres de la alquería de $A j o$. frín> (núm. 1.030).

En los dias del seplenario, después del entierro, se repartían dineros de limosna a los pobres (núm. 1.034); y el remauente de los bienes de un teslamento de 1282 dispone la testadora "que se emplee en comprar vestidos a los pobres vergonzantes de Toledos (núm. 1.035).

No consta claramente en los documentos que hubiera institución especial encargada de repartir estos donativos y vestidos entre los necesitados; pero parece deducirse que las cofradias de presbíteros llenaban muchas veces esta función, pues vemos que una de las condiciones para obtener los sufragios de ellas era que los cofrades adiesen sus ropas por el bien de les vivos y por la salud de las almas de los muertos s (núm. 1.168).

\section{ALBERGUERIAS Y HOSPITALES}

417. Ya en 1149 se cita un Pedro Esquerdo, de la alberguería de Bab Sacra (núm. 38), que debía ser la tnisma del arrabal de Santiago, para la cual se compraba una casa en 1187, contigua por un lado con la alfarería del convenlo de San Clemente (núm. 187).

Los francos tenían una alberguería, que ya hemos dicho atrás lo estrecha que estaba el 1192, a causa de la miseria de aquel año (núm. 801). Si no era esta misma, no debía estar muy lejos la alberguería de Santa Trinidad, a la cual se le hacía una manda de 5 mizcales en 1233 (núm. 1.028). La iglesia de Sau Isidro del arrabal tenía otra casa para alberguería (oúm. 662).

Cítanse además alberguerías en Talavera (núm. 119) y en Benquerencia (nú . mero 708).

También sospecho que tenía carácter benéfico la casa llamada del Refugio, sita en el barrio de San Nicolás, aunque me extraña un poco que se transmitiera el local entre particulares, en vez de pertenecer a alguna iglesia o cofradía (núms. 477 y 501 ). 


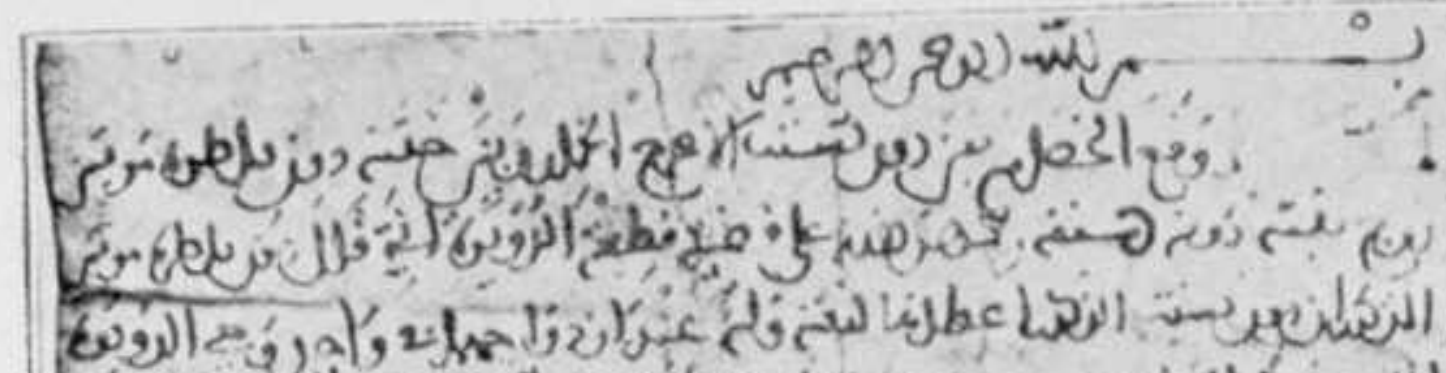

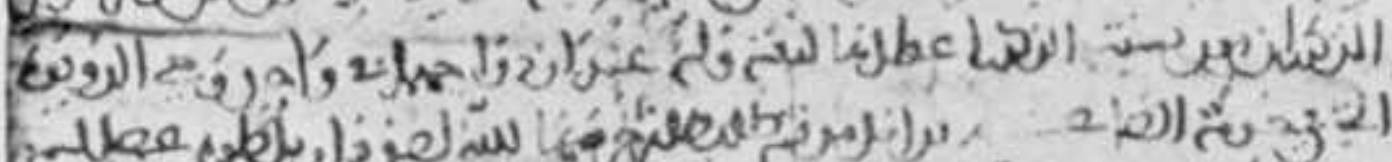

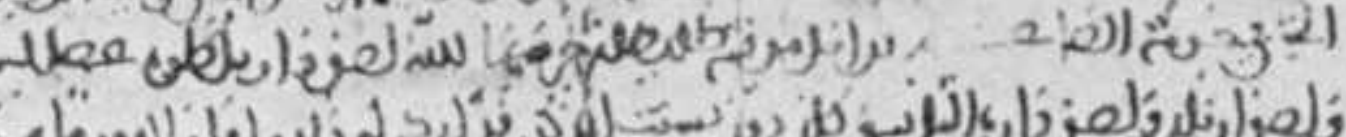
كل

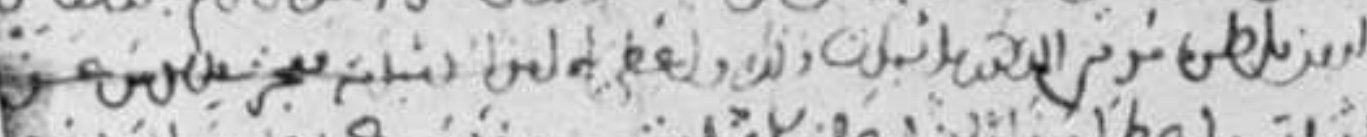
कि

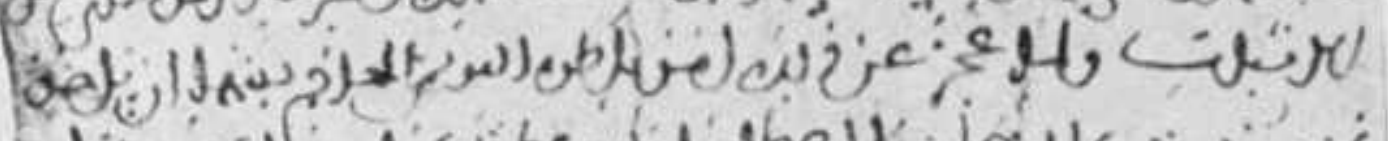

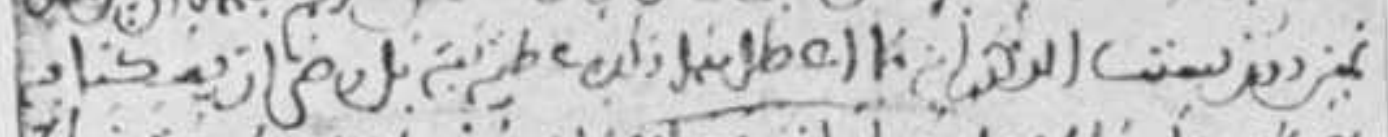

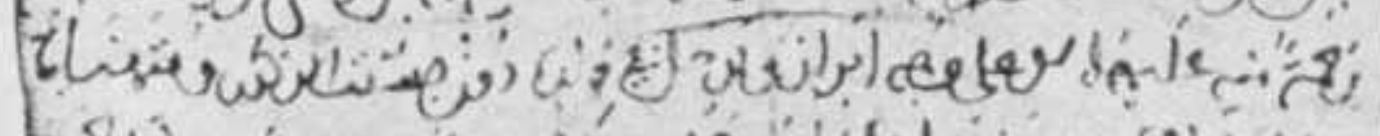

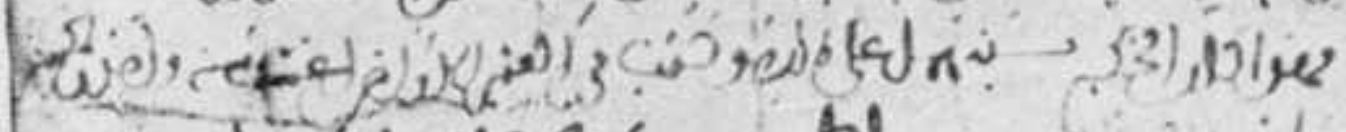

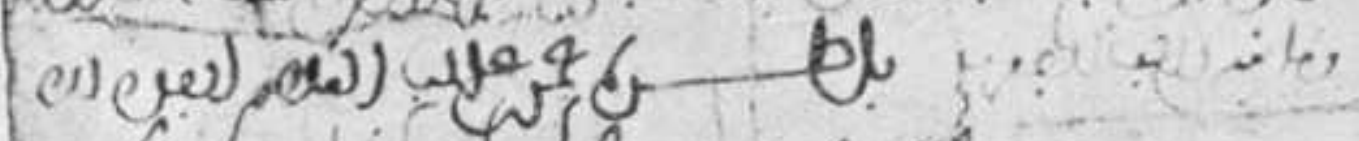
(e) dur dur ionfly

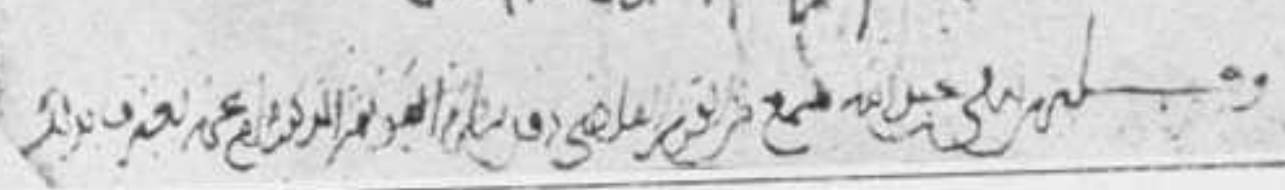

Pleito: 1." decena de Agosto de 1213 (núm. 951).

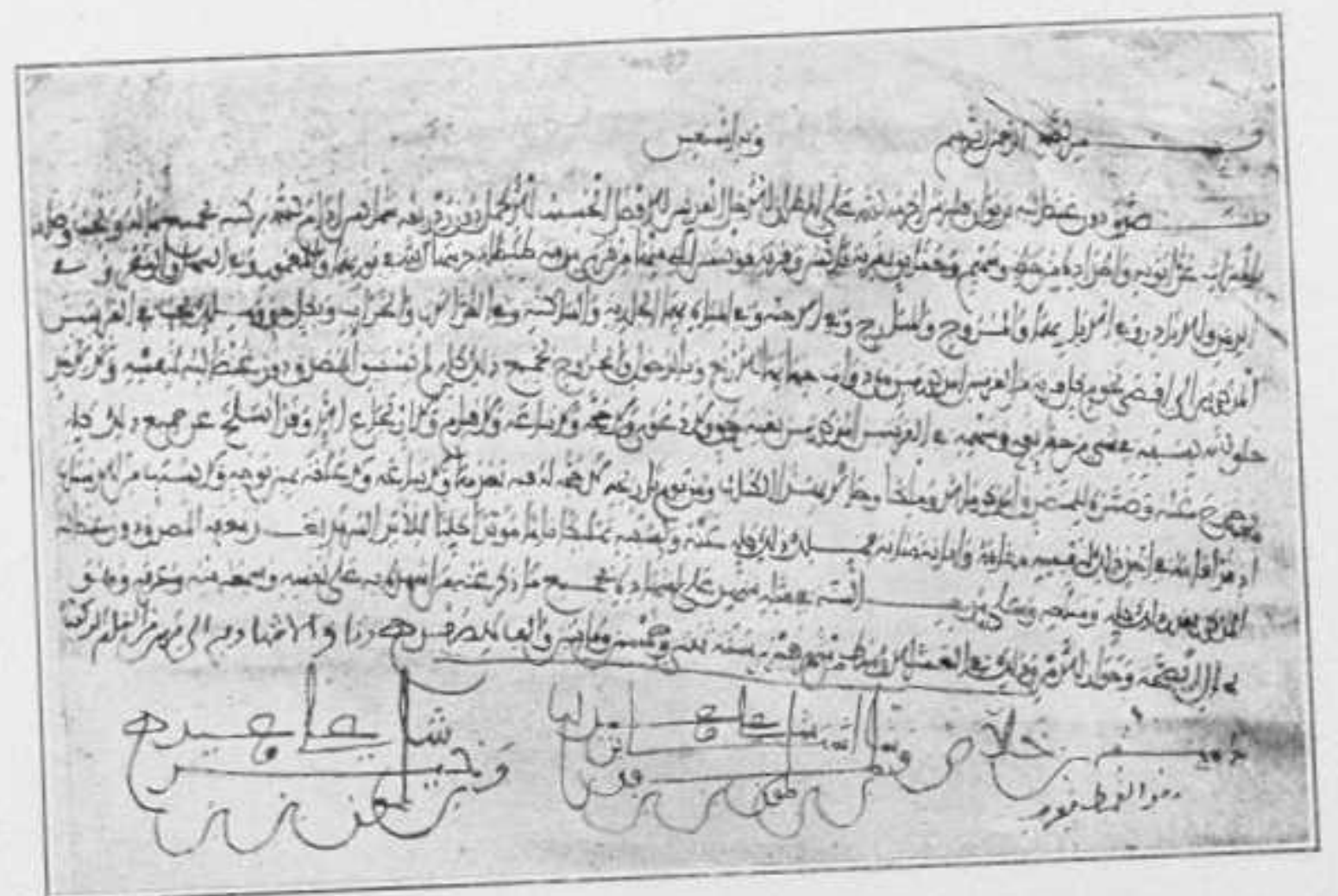

Donación a favor del arzobispo D. Rodrigo: 2." decena de Febrero de 1214 (num. 753). 
Un mesón de peregrinos había por 1174 - y no debra ser mucho más antiguo en la Alcudia (núm. 111) (1).

La noticia más antigua respecto a hospitales es de 1187: dona Sol Micaelis man. da que sus sobrinos y herederos posean la habitación y la algorfa que ella tiene frente al baño del Hierro, para que en ella vivan los enfermos cristianos que a los sobrinos pareciere, y además una alhochra (casita) junto a sa casa principal on el adarve de Abenmoharis, para to mismo, por amor de Dios y para los pobres y enfermos (núm. 738). El obispo de Cuenca, D. Garcia, habra cmpezado a construir un hospital en el barrio de Santa María antes de 1221, utilizando el solar de cuatro tjendas que eran de doña Dominł̧a, t'́a de Fernando Juanes ben Abdelmélic, con la que cambí otras cuatro suyas (núm. 758); acaso este hospital fuera la primera base del futuro Hospilal del Rey.

Atrás anotamos la existencia de la Orden del Hospital.

Para la Cruzoda hallamos mandas de 1280 y 1282 (núms. 1.033 y 1.035).

418.

CARGOS PUBLICOS

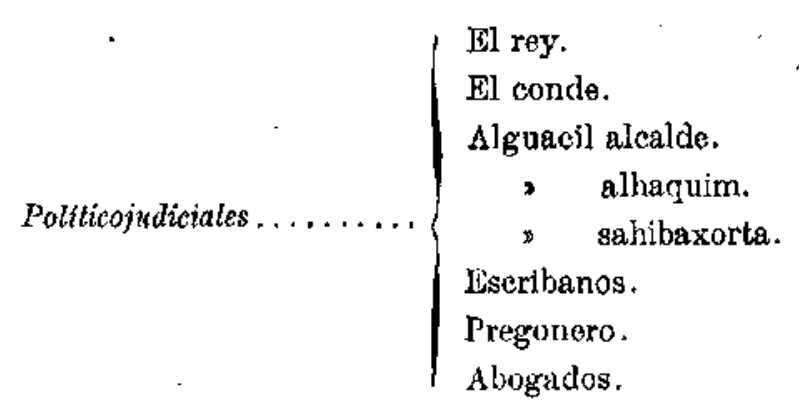

Administrativos ......... $\left\{\begin{array}{l}\text { Alguacil almojarife. } \\ \text { Amotacén. } \\ \text { Nádir. } \\ \text { Repostero. }\end{array}\right.$

Militares............ $\left\{\begin{array}{l}\text { Caid o aleaide. } \\ \text { Adulid. } \\ \text { Arráez. }\end{array}\right.$

Mrestros.

(1) A un cristlano se le llama Garcia el Hath (poregríno) ben Rịfáa en 1184, acaso porquue hubjera eglado on Jerubalẹ́ (núm. 171). 
419. El rey. - Aunque en estu colección no hay ningún documento real, $\mathrm{d}_{\mathbf{e}}$ vez en cuando se encuentran referencias de los reyes de Castilla .

De el emperador Alfonso VIl se menciona el documento por el que dí a poblar Jas alquerías de Artal y la Mezquita (núm. 1.049), el de donación de la Torre del Sultán (núm, 984), el de las alquerías de Yepes y Fontes a la aljama de San Nicolás (núm. 1.123), el de Campo 1icy y del Villar a D. Pedro. Cruzndo (núms. 1.107 y 1.108), las tiendas de los Alfareros que poseja en Toledo (tú́m, 902).

Sólo una vez se nombra al rey D. Sancho III en 1184, documento número 1.008 .

Alfonso VIII, hijo de Ferdilando (núms. 1.051 y 1.052), «el emir noble, el rey justo (núms. 255 y 1.006), confirma la donación de la Torre del Sultán a San Clemente (núm. 984). Cítase un camarero de la areginas doña Leonor (núm. 326).

Del Rey Sabio se balla la mención de su carta donando a Fernando de Robredillo una casa en Toledo (núm. 1.113); y se traduce un documento suyo romance, con sello, por el que se mandaba juzgar de la prioridad y preferencia de unos acreedores (núm. 958); aparte de otras citas incidenlales, v. gr., al nombrar a su repostero Fernán Ruiz (núm. 702).

También incidentalmente se habla del rey D. Sancho IV : por su secretario Sancho Marlín, muy nombrado (núm. 1.066); por un esclavo suyo, de oficio albañil (núms. 698 y 701). Huyendo de su ira, se escapaba de Toledo un Diego García, que no volvía hasta después de la muerte del soberano (núm. 784).

Salen a veces los nombres del infante D. Manuel (núm. 630), dél rey de Aragón, contra el que se preparaba ejército en 1289 (núm. 1.065).

Entre los bienes del patrimonio del rey, se nombran: viñas de Mazarrazín (número 2), viña en Aceca (núm. 18), viña en Valera, llamada Elbib (núm. 85), viña en Zalencas (núm. 117), pago llamado del Sultán, en Talavera (núm. 433), tienda y corral en el zoco de zapaleros y carniceros (núm. 457), mesón en San Martín (número 560), tierra en Valera (núm. 467), viña en Fontalba (núm. 745), tierra en Altasrica, en Talavera (mám. 807).

Se cita un empleado en el património real (المستخلم) (núms. 379 y 383), un capellán del rey (núm. 679), un vaquero del rey (núm. 271), uno de la cámara del rey (núm. 610) y un carcelero del alcázar del rey (núm. 711)(1).

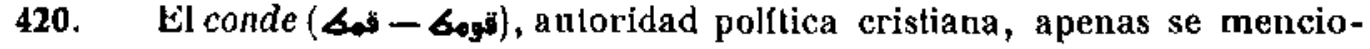
na y siempre incidentalmente: el conde D. Pedro Solís, dueño de la mitad de Argance (núm. 1.006); el conde D. Nuño (núm. 738); el conde D. Ponce de Minerva (núm. 274).

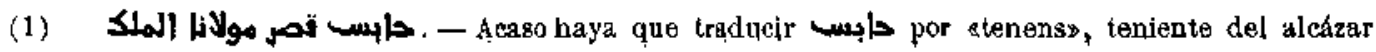
dol rey. 
En 1114 era seĩor del castillo de Mora, Jaques Gómez (núm. 940). Otro Ruy Petrez, castellano del castillo, se cita en 1288 (núm. 1.119).

421. Alguacil alcalde. - Casi siempre a los altos funcionatios se les llama con el título generico de alguacil: así vemos alguacil alcalde, alguacil alhaquim, algttacil almoxarife. Parece que con la palabra alguacil se quería indicar el cargo respetabilísimo de visir (alguacir) en la organización islámica, que al pasar a la organización administrativa cristiana paso con las misimas altas prerrogativas que tenía entre los musulmanes: después, la multiplicación de individuos con el mismo cargo, fué causa de la pérdida del prestigio del mismo.

Damos a continuación la lista de los alcaldes de Toledo, con la indicación de la fecha primera en que se les cita (1):

\begin{tabular}{|c|c|}
\hline & Anos. \\
\hline 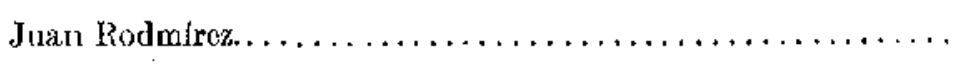 & \\
\hline bulhasán Hátim ben Hátim (cadi supremo) $\ldots \ldots \ldots \ldots \ldots$. & 1115 \\
\hline 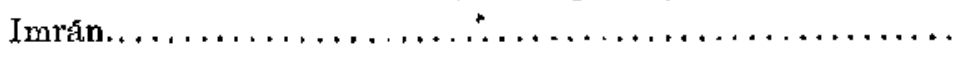 & 1115 \\
\hline buzeid ben Hárits $\ldots \ldots \ldots \ldots \ldots \ldots \ldots \ldots \ldots$ & 1115 \\
\hline buzacarta ben Cureis ( judex $\left.)^{\prime}\right), \ldots \ldots \ldots \ldots \ldots \ldots \ldots \ldots$ & 1121 \\
\hline 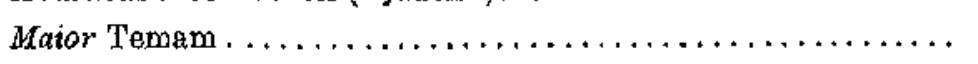 & 1194 \\
\hline aziz ben Lampader . ........ & 1125 \\
\hline & 1135 \\
\hline$\cdots \cdots \cdots$ & 1144 \\
\hline muerto ya en 1186, núm. 182)......... & 1161 \\
\hline $80 \ldots \ldots \ldots$ & 1162 \\
\hline$\ldots \ldots \ldots \ldots \ldots \ldots \ldots \ldots \ldots \ldots \ldots$ & 1165 \\
\hline Yahya ben Hórits.. & 1166 \\
\hline $8 \ldots \ldots \ldots \ldots \ldots \ldots \ldots \ldots \ldots \ldots \ldots$ & 1167 \\
\hline$\ldots \ldots \ldots \ldots \ldots \ldots \ldots$ & 1168 \\
\hline uerto antes de 1.209, ním. 365$) \ldots \ldots \ldots \ldots$ & 1170 \\
\hline$\ldots \ldots \ldots \ldots$ & 1172 \\
\hline rrákmen ben Yahya ben Hárits............. & 1172 \\
\hline Abuhafs Omar ben Abilfárach $\ldots \ldots \ldots \ldots \ldots \ldots \ldots \ldots$ & 1182 \\
\hline $\begin{array}{l}\text { Munio Petrez (muerto después de } 1210 \text { y antes de } 1221 \text {, nume- } \\
\quad \text { ros } 377 \text { y } 463) \ldots \ldots \ldots \ldots \ldots \ldots \ldots \ldots \ldots \ldots \ldots \ldots \ldots \ldots\end{array}$ & 1181 \\
\hline Lelendo ben $A$ bdelaziz ben Lampader (herederos). & 1190 \\
\hline$\ldots \ldots \ldots$ & 1191 \\
\hline & 1192 \\
\hline ma & 1192 \\
\hline
\end{tabular}

(1) Prescindimos de dar las referencias a los documentọs en que se les mencioxa, por ser fácil hàllarlas en el índice geveral alfabético. 
Años.

Pedro Mora................................... 1198

Pedro Alguacil. .............................. 1196

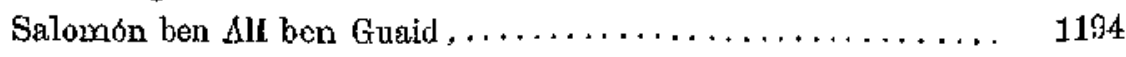

Mlán Estébanez............................... 1198

Esteban ben Omar............................. 1196

Paris.................................... 1197

Didaco Petrez.................................. $\quad 1199$

García Rodriguez.......................... 1201

Abuharún Musa Axxahats (judio).................. 1202

Juan Petrez, hijo de Pedro Alguacil . . . . . . . . . . . . . . 1203

Félix Sánchez............................... 1203

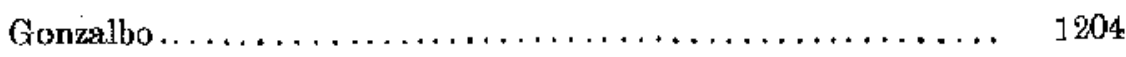

Egteban Salowin.............................. 1204

Juan ben Martin ben sälih...................... 1205

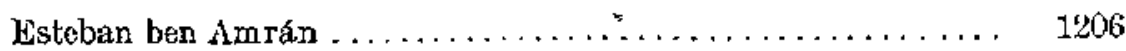

Sancho Segura............................. 1207

Micael ben Domingo ben Otmán ben Guazlán . . . . . . . . 1207

Pedro Alfonso................................ 1209

Domingo Cebrián. $\quad \ldots \ldots \ldots \ldots \ldots \ldots \ldots \ldots \ldots \ldots \ldots \ldots \ldots, 1210$

Martin Micael. .............................. 1210

Juan Mictelis............................... 1211

Pedro ben Isa . . . . . . . . . . . . . . . . . . . . . . . . . 1212

Esteban Petrez............................. 1212

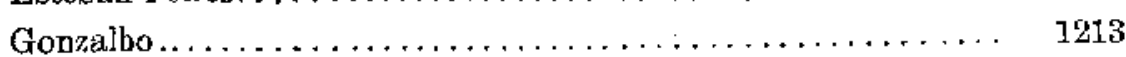

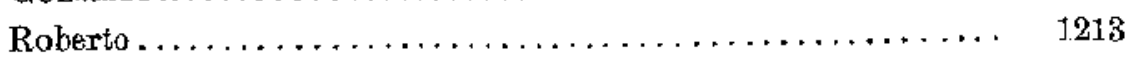

Domingo Petrez............................... 1214

Dicgo Petrez............................... 1216

Pedro ${ }_{6}$ Escarjir $. \ldots \ldots \ldots \ldots \ldots \ldots \ldots \ldots \ldots \ldots \ldots \ldots, 1217$

Pedro, hijo de Juan Pctrez Alguacil . . . . . . . . . . . . . . 1222

Arnaldo Guillén................................. 1222

Fsteban Juliavis (difunto ya en 1260, núm. 988).......... 1824

Esteban Petrez................................. 1224

Juan Ponce (difunto antes de 1248 , núms. 847 y 848 ) . . . . . 1226

Gonzalbo................................ 1226

Juan Estébanez (alcaldo de los $\Lambda$ dules, num. 770$\} \ldots \ldots \ldots \ldots . \quad 1228$

Pedro Juanes (difunto ya por 1260, núm. 1.083).......... 1231

Guter Fernández . . . . . . . . ....................... 1224

Alfonso Vicente.............................. 1236

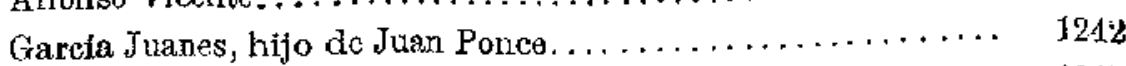

Pedro Suírez ................................. 1247

Fernando Mateos ben Furón (alcalde del rey, núm. 961)...... 1248 


\begin{tabular}{|c|c|}
\hline . & Anas. \\
\hline Juan Petrez, Tentejuanes... . & 1248 \\
\hline 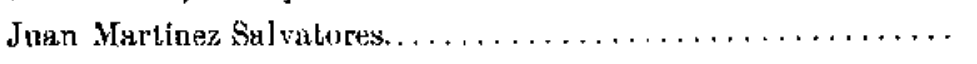 & 1249 \\
\hline Feliz ben Yahya ben $A b u l a l a . \ldots \ldots \ldots \ldots \ldots \ldots \ldots \ldots$ & 1263 \\
\hline Julián Estébanc\% (difunto yu por 1262, nún. (613) . . . . . . . & 1254 \\
\hline 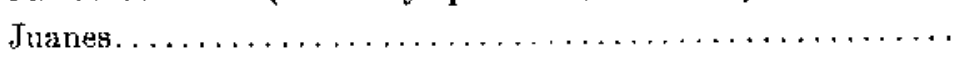 & 1254 \\
\hline Gonzalbo Vicente ben Otman hen Alrimt................ & 1255 \\
\hline Gonzatlbo Jurnes ......... & 1257 \\
\hline Mienel Domínguez..................... & 1257 \\
\hline Domingo Petrez............... & 1258 \\
\hline 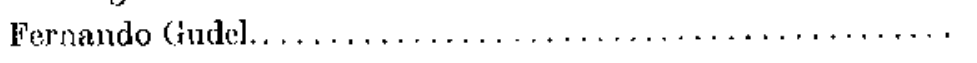 & 1259 \\
\hline Abuomar ben $A$ bilbasín $A$ xer el larcetonés (judio).......... & 1260 \\
\hline Pedro Gonzálbez $\ldots \ldots \ldots \ldots \ldots \ldots \ldots \ldots \ldots \ldots \ldots \ldots$ & 1262 \\
\hline 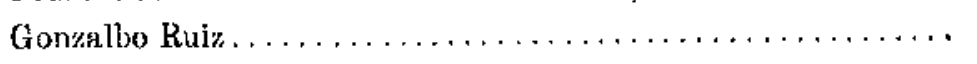 & $12(54$ \\
\hline 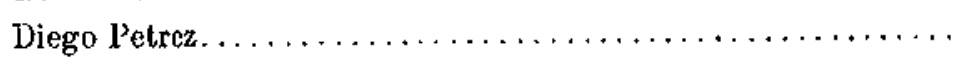 & 1265 \\
\hline Juan Iernánde\% Micael............................... & 1265 \\
\hline Martín Salvatores $\ldots \ldots \ldots \ldots \ldots \ldots \ldots \ldots \ldots \ldots \ldots \ldots \ldots \ldots \ldots \ldots$ & 1265 \\
\hline $\begin{array}{l}\text { Servando ben Domingo ben Servando (alcalde do la corte del } \\
\text { rey, num. } 627) \ldots \ldots \ldots \ldots \ldots \ldots \ldots \ldots \ldots \ldots \ldots \ldots\end{array}$ & 1266 \\
\hline 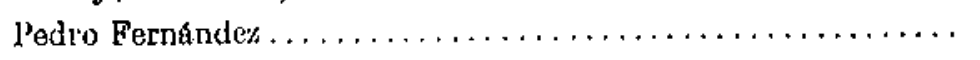 & 1276 \\
\hline James (alcalde del arrabal des los lírancos, núm. 652)......... & $127 \theta$ \\
\hline Juan Fernandez. $\ldots \ldots \ldots \ldots \ldots \ldots \ldots \ldots \ldots \ldots \ldots \ldots$ & 1281 \\
\hline Micael Domínguc ${ }^{\prime}, \ldots \ldots \ldots \ldots \ldots \ldots \ldots \ldots \ldots \ldots \ldots$ & 1283 \\
\hline Pedro Juanes ben Jtan Domínguez................. & 1288 \\
\hline Diego Ruiz . . . . . . . . . . . . . . . & 1283 \\
\hline 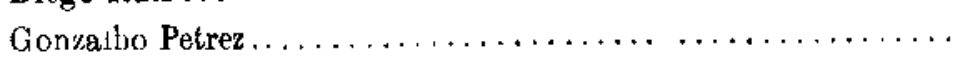 & 1286 \\
\hline Gonzalbo Diaz . . . . . . . . . . . . . . . . & 1289 \\
\hline Gonzalbo Juanes . . . . . . . . . . . . . . . . . & 1290 \\
\hline 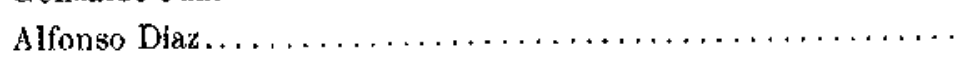 & 1290 \\
\hline Alfonso Domingue...$\ldots \ldots \ldots \ldots \ldots \ldots$ & 1290 \\
\hline Marcos Garcia . . . . . . . . . . . . . . . . & 1290 \\
\hline Juan Garcia Cortés. ........................ & 1290 \\
\hline Fermando Petrez... $\ldots \ldots \ldots \ldots \ldots \ldots \ldots$ & 1290 \\
\hline Ruy Ponce $\ldots \ldots \ldots \ldots \ldots \ldots \ldots \ldots \ldots$ & 1290 \\
\hline 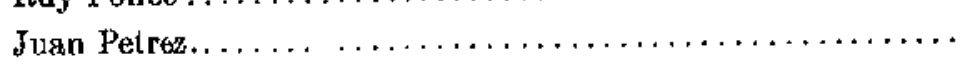 & 1293 \\
\hline Diego Juanes . . . . . . . . . . . . . . . . . . . . . & 1294 \\
\hline Fernando Martin $\ldots \ldots \ldots \ldots \ldots \ldots \ldots \ldots$ & 1294 \\
\hline Alfonso Fernández. $\ldots \ldots \ldots \ldots \ldots \ldots \ldots \ldots \ldots \ldots \ldots$ & 1294 \\
\hline Alfonso Vicente...................... & 1295 \\
\hline Diego Alfonso $\ldots \ldots \ldots \ldots \ldots \ldots \ldots \ldots$ & 1800 \\
\hline Gonzalbo Vicente.. & 1800 \\
\hline
\end{tabular}


Menciónanse, además, algunos alcaldes y alguaciles de varios pueblos: D. Tello, alcalde de Talavera en 1152 (núm. 729), donde también lo fueron el Casbirí en 1187 (núm. 193), y Vicente ben Yahya el Sevillano en 1192 (núm. 224); en Arcicolla era alcalde Juan Domínguez y alguacil Diego en 1199 (núm. 1.131); de Ayllón era alguacil Micael en 1199 (núm. 292); de Calatrava cra alguacil Pedro Péláez en 1187 (núm. 191); de Camarena de Arriba, Martín Juanes (nún. 1.062); de Canales era judex Domingo Antolín en 1205 (núm. 909); de Yeles era alcalde Sancho (núm. 922); de Madrid eran alcaldes Gil Pérez y Garci Martínez en 1266 (núm.628).

Se ve, pues, que los alcaldes eran varios a la vez en Toledo, y que, además del alcalde supremo, que se cita sólo en los doeumentos más antignos, tiahia una clase especial llamada alcalde del rey o alcalde de la corte del rey, que ya existía a media. dos del siglo XIII; otro era el alcalde de los adales o notarios, y lenían, además, sus alcaldes propios los judíos y los francos.

Muchas veces, en lugar del nlcalde actuaba su teniente (هستناب) . Y, ordinariamente, el cargo pasaba de padres a hijos.

422. Alguacil alhaquim (الداكم - الحكيهم). - Era algo así como delegado del alcalde, para juzgar. En su presencia declaraban los testigos en una información verbal hecha en 1115 (núm. 940), aunque los reclamantes habian acudido al alealde.

La lista de ellos es más reducida, acaso porque eran alguaciles y alcaldes, que por delegación llenaban las funciones de háquim (núm. 964):

\begin{tabular}{|c|c|}
\hline & Arios. \\
\hline Martin Garcés............................... & 1115 \\
\hline Yahya ben Selma..... & 1168 \\
\hline Domingo ben Alf ben Guaid $\ldots \ldots \ldots \ldots \ldots \ldots \ldots \ldots$ & 1170 \\
\hline Abenjatab.................. & 1191 \\
\hline 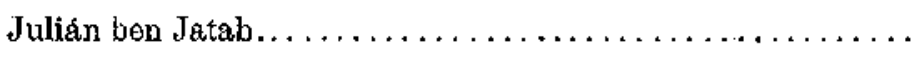 & 1255 \\
\hline Fernando Juanes . .............................. & 1264 \\
\hline Martin Reimóndez............................ & 1289 \\
\hline Martin Petrez, padre de $\ldots \ldots \ldots \ldots \ldots \ldots \ldots \ldots \ldots \ldots \ldots$ & 1293 \\
\hline Alfonso Martinez.. & 1293 \\
\hline
\end{tabular}

Entre los judios se mencionan:

\begin{tabular}{|c|c|}
\hline & Años. \\
\hline Abuzacaria Yabya ben d Negro? .... & 1158 \\
\hline Abuzacaria Yahya ben Alazar. ....... & 1181 \\
\hline Abenziza.................... & 1196 \\
\hline Ibrahim ben Abpibrahinn of Labli................. & 1229 \\
\hline abi Jacob el Barcelonés . . . . . . . & 1238 \\
\hline ulhasán Samuel . & 1247 \\
\hline
\end{tabular}




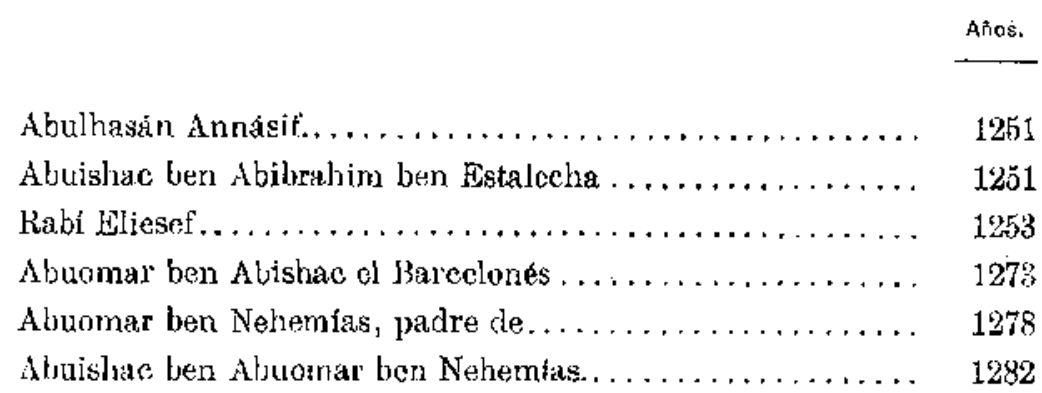

423. Alguacil sahibaxorta. - Sólo hallo mencionado uno en 1192, el judio Abuharún ben Alharit (uúm. 1.055).

424. Escribanos, notarios y secretarios. - Cítase con frecuencia el cargo de $c a ́ t i b$, escribano o sencillamente escriba, scriptor, que no significa otra cosa que el redactor material de los documentos. Muchas veces quería decir tanto como secretario después, o nolario. Se les llama escribanos de arabe y escribanos de romance. Hay escribas de muchos documentos que no se les llama cálibes; algunos están es. critos, a juzgar por la letra, por alguaciles y alcaldes; v. gr., Salomón ben Alí ben Guaid.

La lista de los que intervenian en la redacción de los documenlos es como sigue:

\begin{tabular}{|c|c|}
\hline & Aĩos. \\
\hline 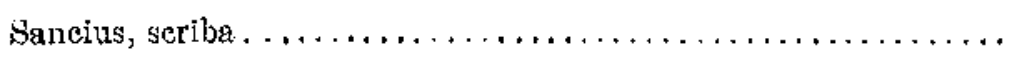 & 1121 \\
\hline 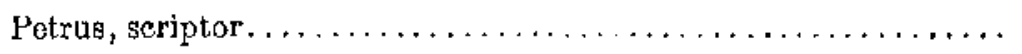 & 1138 \\
\hline $\begin{array}{l}\text { Pedro ben Omar ben Gálib ben Alcallâs (manda en testamento, } \\
\qquad \text { num. } 1,016) \ldots \ldots \ldots \ldots \ldots \ldots \ldots \ldots \ldots \ldots \ldots \ldots \ldots \ldots \ldots \ldots \ldots \ldots \ldots\end{array}$ & 1184 \\
\hline Pedro Alfonso . . . . . . . . & 1193 \\
\hline 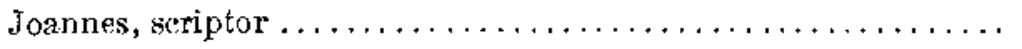 & 1194 \\
\hline 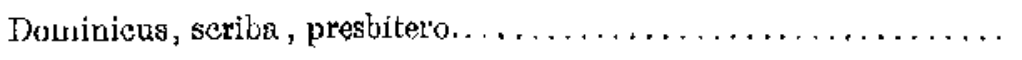 & 1203 \\
\hline 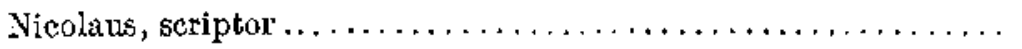 & 1207 \\
\hline 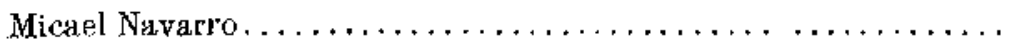 & 1207 \\
\hline Feliz ban Yahya ben Abdala. . . . . . . . . . . . . . . . & 1222 \\
\hline Alfonso Juanes Yetrez ben Yaix $\ldots \ldots \ldots \ldots \ldots \ldots \ldots \ldots \ldots$; & 1235 \\
\hline Domingo Servando $\ldots \ldots \ldots \ldots \ldots \ldots \ldots \ldots \ldots \ldots \ldots$ & 1242 \\
\hline Salomón Domínguez $\ldots \ldots \ldots \ldots \ldots \ldots \ldots \ldots \ldots \ldots \ldots \ldots$ & 1242 \\
\hline Pedro ben Juan ben Esteban el Guadijeño.................. & 1242 \\
\hline Rodrigo, sacerdos et seriba......................... & 1244 \\
\hline Garcia l'etrez (notario del rey $D$, Alfonso $X) \ldots \ldots \ldots \ldots \ldots \ldots$ & 1264 \\
\hline 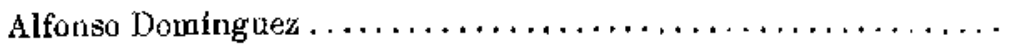 & 1269 \\
\hline 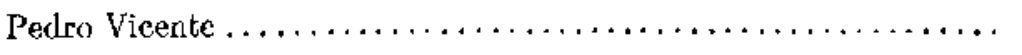 & 1276 \\
\hline Sancho Martinez (secretario de D. Alfonso X y D. Sancho IV).... & 1278 \\
\hline Jomingo Juanes......... & 1282 \\
\hline
\end{tabular}




\begin{tabular}{|c|c|}
\hline & Años. \\
\hline Pascual Sánchez (eseribano de romance) $\ldots \ldots \ldots \ldots \ldots \ldots$ & $128 ;$ \\
\hline 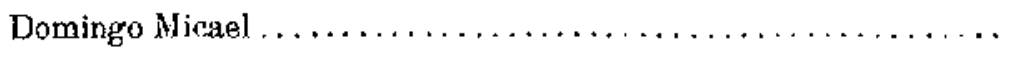 & 1284 \\
\hline 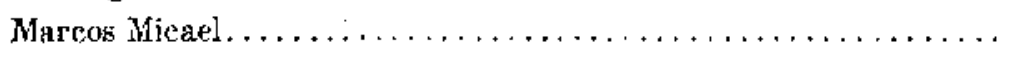 & 1284 \\
\hline Rodrigo Juanes $\ldots \ldots \ldots \ldots \ldots \ldots \ldots \ldots \ldots \ldots \ldots \ldots \ldots$ & $12 y d$ \\
\hline l'ernando Domingo (eseribinn de árabe). . . . & 1294 \\
\hline Alfonso Dominguaz.............. & 1297 \\
\hline Alfonso Hartín . . . . . . & 1303 \\
\hline
\end{tabular}

L̇n alguna ocasión se cita algún escribano de Córdoba (núm. 634) o de Madrid (núm. 628). Los documentos judíos, de época muy posterior, mencionan a los escribanos Alfonso Ferrández y Alfonsn García en 1391 (núm. 1.140).

425. El pregonero. - Uñas veces se les llama WJ, delal, como a Juan el Ciego en 1199 (núm. 944); a García el Ciego, que lo era en 1218 (núm. 955), o Cebrián

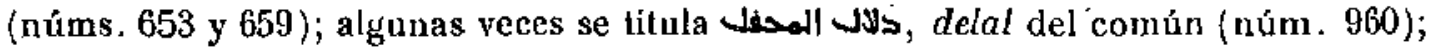

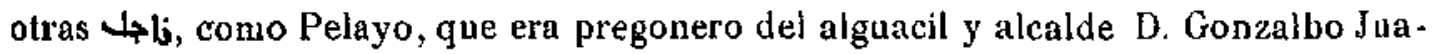
nes, por 1272 (núm. 1.044); otras $\mathbf{P}$, añadiendo * del pueblo de Toledo*, v. gr., Ferrán Martínez, en 1289 (núm. 964)

Tenía sus derechos de pregonería, y declara haberlos cobrado en venta de fincas por deudas hecha en pública subasta (núm. 964).

En ocasiones el delal o pregonero ejercía el oficio de corredor para la venta de ciertos artículos, hecha de ordinario en púbica subasta, como sucede todavia en los mercados marroquíes. Hallamos un pregonero del zoco del Alcaná (uúm. 199); un delal de los esclavos en Toledo (el judio Abuomar ben Israel) (núm . 690), de los verduleros (nún. 476), de las bestias (الدوال) (núm. 474), de los caballos (núm. 597).

426. Abogados, apoderados y procuradores. - - Solia llamarse al abogado con el nombre وكيل g, corriente en árabe. A bogado del alguacil y alcalde D. Juan Ayub era D. Gonzalloo en 1192 (núm. 942). No sólo se le daba la representación al abogado cn asuntos litigiosos (núms. 701 y 954 ), sino en materias administrativas o económicas; asi, era el abogado rejresentante para liucer una compra (núm. 489), o al delegado del convento de San Clemente en la alquerla Aceituna (núm. 521), o en Olías (núm. 539), o de las monjas de Santo Domingo (núm. 580) (1).

Se ve que el وكيل genía solo delegación para un asunto determinado, como el que otras veces se llama comendador. *hombre de confianza", era el encargado de cobrar las rentas'en 1176 (núm. 1.006), y así llaman al que cobraba los diezmos de Argance por el rey en 1179 (núm. 1.051). Representantes o apoderados de la abadesa de San Clemente

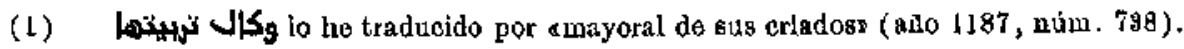


(núm. 953), del tesorero de la Catedral, por cuyo poder compra (núm. 366), del arzobispo (un judio que enlrega el precio de una venta en nombre de aqué) (ná. mero 561), del infanle D. Manuel, co Rodelas (núm. 630), del deán (núm. 962), de D. Fernando ben Hateos ben furón, en Olmidiella (núm. 1.130), son designados con el nombre de ust.

Alguna vez se cila el jazim (الحمبمه), : procurador * un 1). Vicente (núm. 645), un Crabriel Petrez (súm. 999), un Marlín Rajmóndez (núm. (670).

427. Alguacil almojarife. - Lia, como es sabilo, el encargado de la colsranza de las renlas. Hallamos citados:

\begin{tabular}{|c|c|}
\hline & Años. \\
\hline Domingo hen Suleimnn... & $\$ 174$ \\
\hline l'exira Junnes. & $118 \mathrm{~d}$ \\
\hline Abulhatean Sohuda ben Odra (jurdio, almojarife on Fezania)....... & 1185 \\
\hline 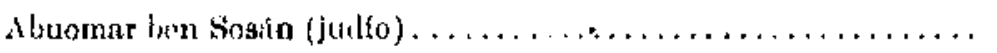 & 11117 \\
\hline 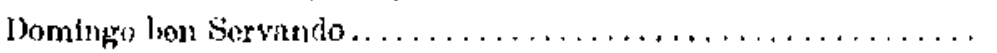 & 1244 \\
\hline Abuhasan Mnir (judio) $\ldots \ldots, \ldots \ldots \ldots \ldots \ldots \ldots \ldots \ldots$ & 1247 \\
\hline Abu $A$ margulm undio $), \ldots \ldots \ldots \ldots \ldots \ldots \ldots \ldots$ & 1247 \\
\hline Martln Alicuel............. & 1247 \\
\hline Abuibrahim bon Sonán. . ................. & 1280 \\
\hline Abulhasan Mutr ben Bosán. & 1280 \\
\hline
\end{tabular}

428. El almolacén (4) - Oficinl encargado del contraste de pesas y medidas, $y$, a veces, con un sentido amplio, mayordomo o administrador, o sen, el encargado de llevar las cuentas.

No se mencionan muchos en nuestros documentos: D. Jázim, a quien a la vez se le llama amin o fíl, en 1181 (núm. 153); un Domingo Esteban, repetidamente citado en la primera miat del siglo XIIl; un Domingo Asaar, que debio obtener aquel cargo alrededor del año 1245 (núm, 569); un Domingo Mical ben Ruy Draz, del segundo tercio del siglo Xlll.

429. Ll stádir (إلداكة) o comendador, el mayordomo, el ray. - El hadir era el que tenia a su cuidado los bienes de una instilución: a el que estáal cuidado de

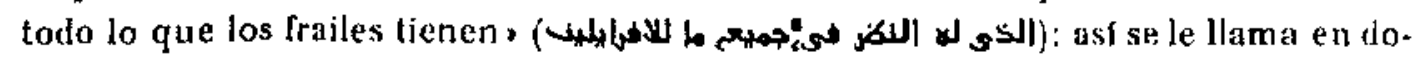
cumento de 1180 (núm. 737). Se menciona ya este cargo en 1114 (Martino, annádir, núm. 940); un Pedro, en 1167 (núm. 83); Domingo Garmán, en 1175 (núm'. 117); Domingo el Tuerto, en 1186 (nam. 181); Juan Fornero, en 1196 (núm. 246); Pedro Juanes, en 1214 (núm. 415); Bartolnmé, en 1231 (núm. 814).

Habia nádir encargado de las distintas haciendas o alquerias: v. gr, de Calabazas fueron Juan Petrez (1259), Domingo Dáz y Bartolomé; de Azucáica, Domingo, en 1154, y Fernando, en 1208; de Corral Hubio y Garganta, Juan Crespo.

El convento ne San Clemente tenía también este cargo: D. Fernando Juanes lo 
era en 1187 (núm. 190); el que era capellán y nádir en 1210, tenía a su cargo el archivo y no encontraba una escrilura de donación (núm. 746); y fray I). Juan, nádir de los bien es del convento, cambiaba ciertas fincas con el comendador de la Orden de Santiago (núms, 811 y 812 ).

Las mismas funciones qưe el nádir desempeñaba el comendador, en las Ordenes militares. El comentador D. Gil, comendador de la casa de Santiago del Ilospital y encargado de los bienes de mandas pías de elia (وعلى حبوسطات الرتبة) cambiaba, en 1213, con la abadesa de San Clemente y con el nádir del convento (núms. 810, 811 y 812). En el año 1228 se llama indistintamente a fray $\mathrm{D}$. Miguel, comendador y nádir del convento de San Clemente en 'Talavera (núms, 491 y 492). Y más tarde, jivr 1247 y y 1259 , un fraile comendador aprobaba la carta de emancipación de dos esclavos que hacla el conven to de San (ilemente (níms. 789 y 790), y cobraba las rentas por fincas rústicús (núm. 915 bis). El comendudor del convento de San Clemente era, por 1255, D. García Guillén (núm. 987), al menos en Argance.

Menciónanse también el comendador de Villaverde (núm. 1.060) y el de la Orden de Calatrava en Madrid (núm. 630).

En otras ocasioncs se llama el que desempeña este cargo con el nombre de mnyordomo ( Mardomo», transuribe el texto de algún documento, núm. 998), acaso aplicado a haciendas más pequenas: aś vemos cilado al mayordomo del arcediano D. Gonzalbo, è 1175 (núm. 121); el mayordono del obispo (núm. 944); el de la reina, en 1197 (núm. 1.126); el del tesorero D. Sancho (núm, 262); el de Santo Domingo (núm. 186); el del arzobispo (núró. 393); el del deán (núm. 482); el de doña Luna (núm. 428), y los de algunos particulares. A un matrimonio se les llama «ma. yordomos $*$ del convento de San Clemente en Argance (núm. 775, año 1.243).

Un presbitero, b. Sancho, tenía administradora o ama de llaves (مكصفة (número 516):

Acaso $\omega_{j}(\mathbf{J}$, citado alguna vez, tuviera la función del mayordomo o administrador: Juan Bahlul el Jázin (núm. 131) y Pedro Micael (núm. 370).

El cobrador de las alcabalas de las salinas de Espartinas se llamaba mero 675).

Funciones semejantes a las del nadir sospecho que ejercería el que a veces hallo nombrado sl, ray, c veedor, *inspector. Un ray de Alexar se menciona en 1190 (núm. 211), y otro Domingo, ray, del Arrabal (núm. 539). En los documentos romances también encuentro este cargo: María Mingo, filin del ray Pedro Ové. quez, vendía en 1216 una yugada de tierra en la aldea de Manzahubedalla (1).

430. El repostero ( como despensero. En 1160 se cita una hija de Martín Repostero (núm. 63); el arzo-

(1) Cart. 1, fol. ts. 
bispo D. Rodrigo lenía, como repostero, a un Guillem, que luego fué canónigo (ná mero 420 y otros); Fernando Ruiz era repostero del rey D. Alfonso X (núm. 702).

431. El caid o alcaide. - Jefe militar. Hallo citados:

\begin{tabular}{|c|c|}
\hline & Alios. \\
\hline licael Mitis.. & 1141 \\
\hline Sabib ben Abderráhuen . . . . & 1156 \\
\hline Podro Petrez............... & 1156 \\
\hline Pelayo Petrez, de Frómista...................... & 1157 \\
\hline Guter................... & 1158 \\
\hline 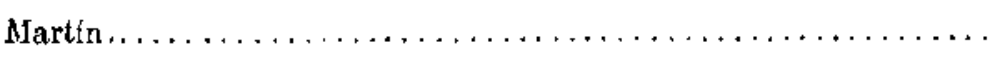 & 1160 \\
\hline 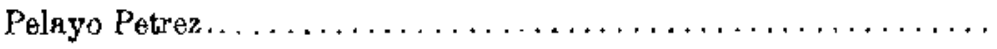 & 1163 \\
\hline 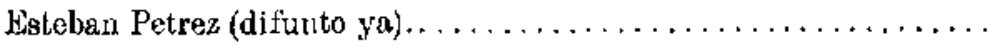 & 1166 \\
\hline 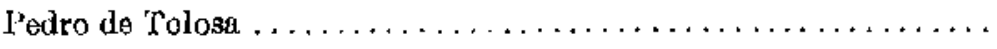 & 1168 \\
\hline 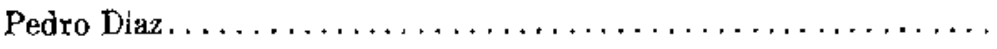 & 1186 \\
\hline 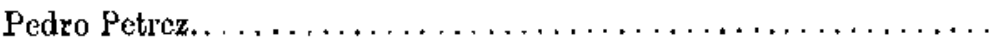 & 1197 \\
\hline Raimundo el caid el Zapatero $\ldots \ldots \ldots \ldots \ldots \ldots \ldots \ldots \ldots \ldots$ & 1205 \\
\hline 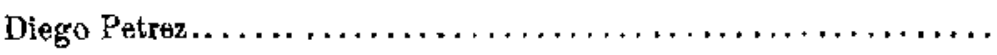 & 1224 \\
\hline Esteban Petrez ben Lampader $\ldots \ldots \ldots \ldots \ldots \ldots \ldots \ldots \ldots$ & 1227 \\
\hline 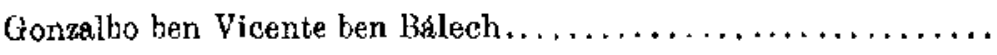 & 1288 \\
\hline 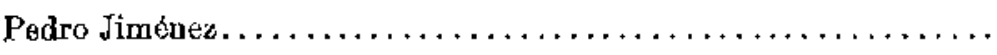 & 1250 \\
\hline 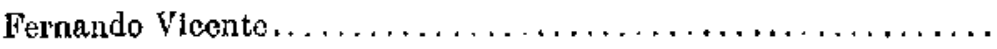 & 1278 \\
\hline 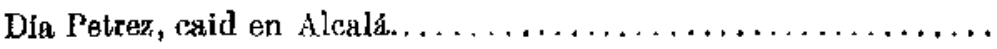 & 1213 \\
\hline Rodrigo Pelrez, alcaide do Canales................... & 1205 \\
\hline Pedro, caid de la Vega.... $\ldots \ldots \ldots \ldots \ldots \ldots \ldots \ldots$ & 1218 \\
\hline Pedro Ruiz, caid de la Guardia (caballero de Atenas)... & 1257 \\
\hline
\end{tabular}

432. El adalid (الدليل). Cargo militar; guía del ejércíto. - Hállase la men. ción de los siguientes:

Domingo Marcelo (cantivo por 1167, núm. 898) .......... 1160

Melendo ....................................... 1171

Pedro Moro . . . . . . . . . . . . . . . . . . . . . . . . 1180

Domingo Chicn. . . . . . . . . . . . . . . . . . . . . 1180

Domingo de Calatrava.......................... 1185

Juan Petrez $\ldots \ldots \ldots \ldots \ldots \ldots \ldots \ldots \ldots \ldots \ldots \ldots \ldots \ldots \ldots \ldots \ldots$

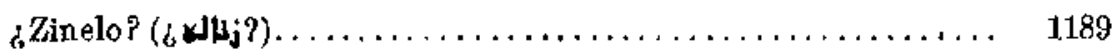

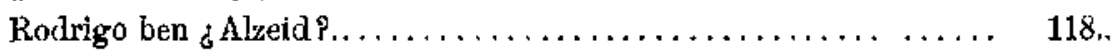

Pedro Domingo.............................. 1193

Román Martin................................ 1197

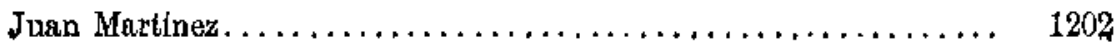




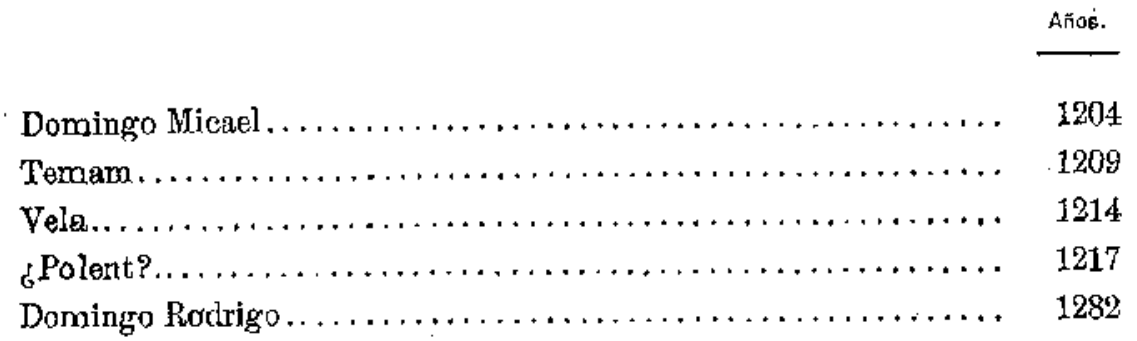

433. El arracz (ألىألسا) - Jefe de maribá. Menciónanse los siguientes:

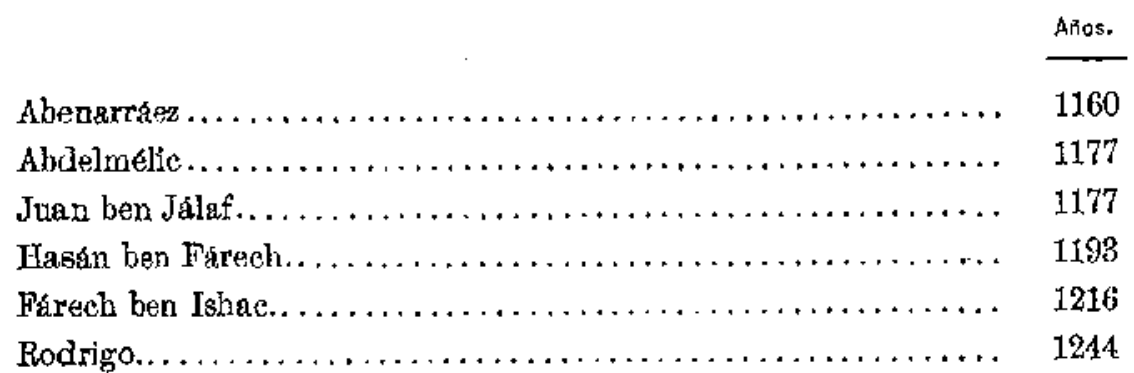

MAESTROS Y ENSENANZA

434. No arrojan dutos bastantes nuestros documentos para poder conocer el estado de la ensenanza. Parece deducirse que era meramente privada, y que no tenia intervención alguna ni el poder civil ni la iglesia. De la organización de la schola catedralicia nada sabemos, más que debía existir, ya que aparece a fines del siglo XII el magister scholarum. Ea nucstros documentos, especialmente en los tes. tamentos, suele aparecer, casi siempre la primera, una manda para el maestro (معاه) del testador, como muestra de gran respeto.

El primer maestro que encontramos es el preshítero Domno Juanes, del clero de Santa Leocadia, a quien su discípulo el alguacil y alcalde 1). Domingo Antolín le mandaba 2 mizcales en su testamento de 1161 (nún. 1.014). De 1179 era el presbítero D. Doningo, de San Zocl, maestro de Juan Petrez Mocarram: una nieta de este Juan, Llamada Eulaia, recibe la donación de una finca de sr abuelo, con la conäición, entre otras, de entregar 1 mizcal al maestro del donanle (núm. 736). Eulalia, en su testamento de 1185 , deja 1 mizcal a su maestro D. Servando (núm. 1.016). El maestro de doña Leocadia Juanes, la cual testaba en 1180 , era el presbítero Jonás o Ginés, a quien dejaba mandado 1 mizcal por su maestría (núm. 1.018). En esta misma fecba aparece cilada una María la Maestra (المئشتره) barrio de San Ginés (núm. 146).

En un convenio entrc padre e hijo de 1190, aquél da por libre a éste de todos 
los gastos que le ocasionó la enseñanza y educación del hijo para llegar a la orden * sacerdotal » a que pertenece (núm. 978).

El maestro de Cristina, hija de Andrés (año 1192), era el presítero D. Juan Bayán, a quien por su maestría dejaba 1 mizcal (núm. 1.020); no se nombra al maestro de dona Orabona Salvador (1195), de quien también se acuerda en su testamento (núm. 1.021). Doña Charina (1209) tenja por maestro a D. Paris, presbítero de Santiago (núm. 1.022).

El subdiácono Juan, hijo de Pedro Juanes el Polichení, de la iglesia de Santo Tomé, antes de 1209 , se dedicaba a enseñar a leer a hijos, nietos y parientes de gentes nobles de Toledo, y por eso le luacian regalos, con lo cual puede comprar fincas (núm. 369).

Don Rodrigo Salvatores (1211) dejaba a su maestro D. Sancho, preshítero de la iglesia de San Juan, 2 mizcales por su maestra, y otros 10 mizcales para que dijera misas durante un año, en comenda y sepultura (núm. 1.024); D. Melendo Fernández mandaba (1212) a su maestro, el presbítero D. Juan el Capellán, 1 mizcal (núm. 1.023); otro tanto mandaba al suyo, sin nombrarlo, María Domingo, en 1232 (núm. 1.027); 1). Pedro Sancho, al suyo, D. Servando, presbitero, 3 mizcales en 1253 (nún. 1.029).

Un hijo de María Petrez la Maestra aparece vendiendo un esclavo en 1273 (námero 634). Y otro maestro judío en 1294 (núm. 1.137).

Se ve, pues, que casi todos los maestros eran clérigos. 



\section{I \\ CONDICION DE LAS PERSONAS}

435. Los nobles, - A los grandes de la ciudad (كبال المئيك), tanto mozárabes como castellanos, consultaba el alguacil y alcalde, en 1125, acerca de la conmutación de fincas de una obra pía (1.012). Se da a los individuos de esta clase social los nombres de الزعيمس y الشريف, aparte del de caballero, a cuya condición ya vimos que el fuero permitía ascender a todo aquel que pudiera costearse el caballo ${ }^{(1)}$. Entre los nobles vemos citados:

\begin{tabular}{|c|c|}
\hline & Ax̃os. \\
\hline Gonzalbo Cansado........................ & 1227 \\
\hline Guillermo de Montpellier $\ldots \ldots \ldots \ldots \ldots \ldots \ldots \ldots \ldots \ldots \ldots$ & 1228 \\
\hline Armaldo Meléndez $\ldots \ldots \ldots \ldots \ldots \ldots \ldots \ldots \ldots \ldots \ldots$ & 1228 \\
\hline Maria Armildez (su hija) $\ldots \ldots \ldots \ldots \ldots \ldots \ldots \ldots \ldots \ldots$ & 1228 \\
\hline 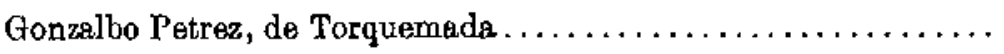 & 1228 \\
\hline 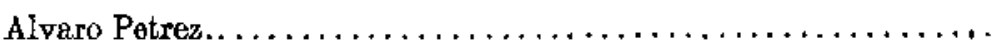 & 1231 \\
\hline Martin Micael $\ldots \ldots \ldots \ldots \ldots \ldots \ldots \ldots \ldots \ldots \ldots \ldots$ & 1282 \\
\hline Domingo Petrez (cabaliero) $\ldots \ldots \ldots \ldots \ldots \ldots \ldots \ldots \ldots \ldots$ & 1232 \\
\hline Gonzalbo Garcia $\ldots \ldots \ldots \ldots \ldots \ldots \ldots \ldots \ldots \ldots \ldots \ldots$ & 1233 \\
\hline Garcia Petrez, \& de Fontelmasi $\ldots \ldots \ldots \ldots \ldots \ldots \ldots \ldots \ldots \ldots$ & 1288 \\
\hline Juan de Ainsa (caballero) $\ldots \ldots \ldots \ldots \ldots \ldots \ldots \ldots \ldots \ldots$ & 1244 \\
\hline 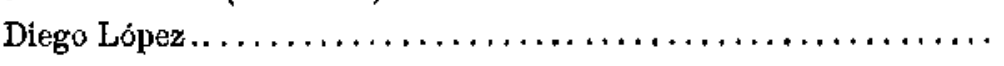 & 1248 \\
\hline 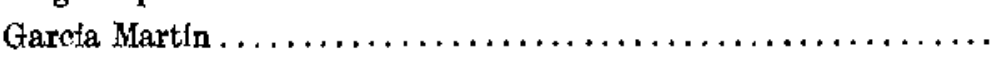 & 1253 \\
\hline Gareja Fernández. . $\ldots \ldots \ldots \ldots \ldots \ldots \ldots \ldots \ldots \ldots$ & 1258 \\
\hline 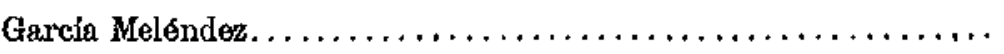 & 1258 \\
\hline
\end{tabular}

(1) Véage atrás, pág. 120. 
En la segunda mitad del siglo XIII, las personas privilegiadas, con las que en ocasiones se prohibía contratar y en especial venderles fincas, cran: «caballero, hijo de caballero, esposa de caballero o dueña, hospital, orden religiosa, clérigo * (núms. 831,832 y 1.128 ). Hin un testamento de 1266 se mandaban 50 mizcales para

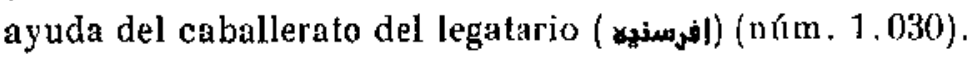

436. Sefroríos, solariegos y fueros especiales... Escasos datos arrojan nues. tros documentos acerca de señoríos, fuera de los que la Catedral tenía en algunas alquerías, a consecuencia de los conlratos de población, que se iban celebrando a través del siglo XII. Derccho en los solariegos de Fuente el Caño tenía por 1266 don Fernando Mateos ben Furón (núm. 1.030), y lambién en Ajofrín y otros punlos (núm, 961). Los solariegos, a fines del siglo XIII, podían poseer fincas rústicas: asf, Salvador, que lo era de Ilego Lábez de Mendoza y Juan, que lo era de D. Gonzalbo Vicente, en Toceneque ( $\mathrm{n}(\mathrm{im}, 831$ ).

El señorio llevaba anejas las renlas de la alquería, los diezmos del pan y del vino, los homicidios, las calonias (1) y los demás dereohos (uúms. 618 y 979). La Catedral tenia fuero especial, derivado del señorfo, en Alameda, cuyas viñas le habían de dar el sexto de sus productos anuales (núms. 223 y 245); en Aloyón, con el mismo privilegio (núm. 416); en Arcicolla, que no se define (núm. 1.128); en Azana, que le pagaba su tributo (núm. 165); en Binal o Pinel, donde recibía el sexto de los productos (núm. 152); en Calabazas, donde recibía el cuarto de los produclos (náms. 562 y 615); en Canales, donde no se podía vender librenente (número 993); en Conisa, que seguía costumbres especiales, en lugar de la ley gerneral de los cristianos en sus venlas y compras (núms. 134 y 147); en Esquivias, donde el vendedor de parte del señorío se obliga a no vender la otra parte que le queda sino al Cabildo comprador de la primera, suma por suma (rectificada luego hasta la cantidad de 250 mizcales), y sólo si el Cabildo no lo quiere, queda libre para venderlo a quien le parezca (núms. 618,620 y 621); en Manzel Obaidalá, cuyas viñas se vendían con arreglo a la costumbre de pagar a los dueños de la alquería la parte correspondiente (núms. 176, 230 y 239); en Torres, donde la Calcdral percibía una parte de los productos (núms. 110 y 565), parte que era la sexta (núm. 65), y en Zalencas, que tenía también costumbre especial en la venta de las viñas (núms. 117 y 580 ).

El convento de San Servando tenía un fuero parecido en Azucáica, donde percibfa el cuarlo de los produclos de las vifas (nims. 201, 593, 598 y 601 ).

437. Religiosos. - Podemos anotar algunos datos curiosos acerca de la situación jurídica de personas dedicadas a religión.

(1) La calonia o calomia se menciona frecuentemente, v. gr., ntims. 363, 836, 909, 915, 039 y 1.001, Ia coubramza del diezmo era señal de señorio o dowinio (núms. 1.051 y 1.052). 
Podían ser monjas las viudas: asi, Dominga Estébanez, que había sido esposa de Domingo el Fecac, entraba en el convento de Santo Domingo de Talavera por los años de 1157; donaba al convento todos sus bienes, así olivos como viñas, higueras, etc., por amor de Dios y por la salud del alma de su hijo y de sus padres, y para recibir la protección del patrono del convento, con la condición de tenerlos y usufructuarlos durante toda su vida, pero sin que pudiera venderlos o cambiarlos (núms. 729 y 732). Otra señora, casada y con hijos, se hace monja en San Pedro, y muere en el convento; su nieta aprobaba despues la venta de una finca donada por aquélla al monasterio (núm. 291).

Solían las monjas recibir su legitima al proiesar; pero podían lieredar al padre, entrando a partir con sus hermanos y renunciando a la parte que como legitima les diera el padre con motivo de su profésión (núm. 1.038); en algún caso cedían los derechos de legílima a favor de sus hermanos ( núm. 320). Lo corriente era que la comunidad poseyese los bienes del convento, y la abadesa no podía disponer de ellos sin aprobación de las monjas y del arzobispo (núm. 941); pero también las monjas podían poseer bienes individualmente; así, una monja de San Pedro en Alhicem poseía casa en el barrio de San Nicolás ( núm. 644); dos monjas, y no el convento, compraban una esclava mora (ú́m. 664). Sobre los bienes de una que habla de ser monja y vivia ya en en el convento se paclaba en 1219 (núm. 985).

'También algún fraile (D. Gonzalbo Petrez) vendía una finca suya, sin intervención del convento (núm. 435). Un fraile (D. Sancho Segura) podía ser alguacil a la vez (núm. 358). Notable es cl caso del traile I). Estebinn de Mochares, el que habitaba en el barrio de Santa Leocadia (1261); no vivía, por tanto, en comunidad: compraba bienes en Arcicolla y se obligaba, respecto al Cabildo, a no venderlos a persona privilegiada, según el fuero que en esta alquería tenía la Catedral (núm. 1.128).

Por medio de una dunación se adęilrfa la condición de familiares del colvento: v. gr., San Clemente (núm. 762).

438. Padrinos y ahijados. -- La madre por el bautismo, es decir, la madrina, se encargaba de la carta de mejora de su ahijado, menor de edad, hasta que llegase a ln mayoría (año 1185, núm. 1.037). Es frecuenle ver legados hechos de los ahijados (anfidiati, onfliati), tanto por sus padrinos como por sus madrinas (nismeros $1.021,1.025,1.026$ y 1.029 ), a'gunas para ayada de su dote (núm. 1.029).

439. Oficios manuales. - Damos la lista de nombres de oficio que aparecen en nuestros documentos, y que pueden permitir formarse una idea de la vida obrera en la capital durante los siglos XII y XIII (1). En algún caso anotamos los nombres de los oficiales por su interés artístíco o social; en los demás casos nos limita-

(1) Cuando el nombre va en cursiva, es que en el texto está en romance; en los deunás casos suolo o mplcarse el tipo moríológico corriente do los nombres do oficio árabes, 
mos a dar la referencia, ya que no creemos importa nada conocer los nombres de los que ejercieron muchos oficios.

Abarquero, núm. 634.

Alarife, núm, 603. Alfonso Juanes.

Albacero, núms. 445 y 762 .

Albañil (البذا). Se mencionan los siguientes (1):

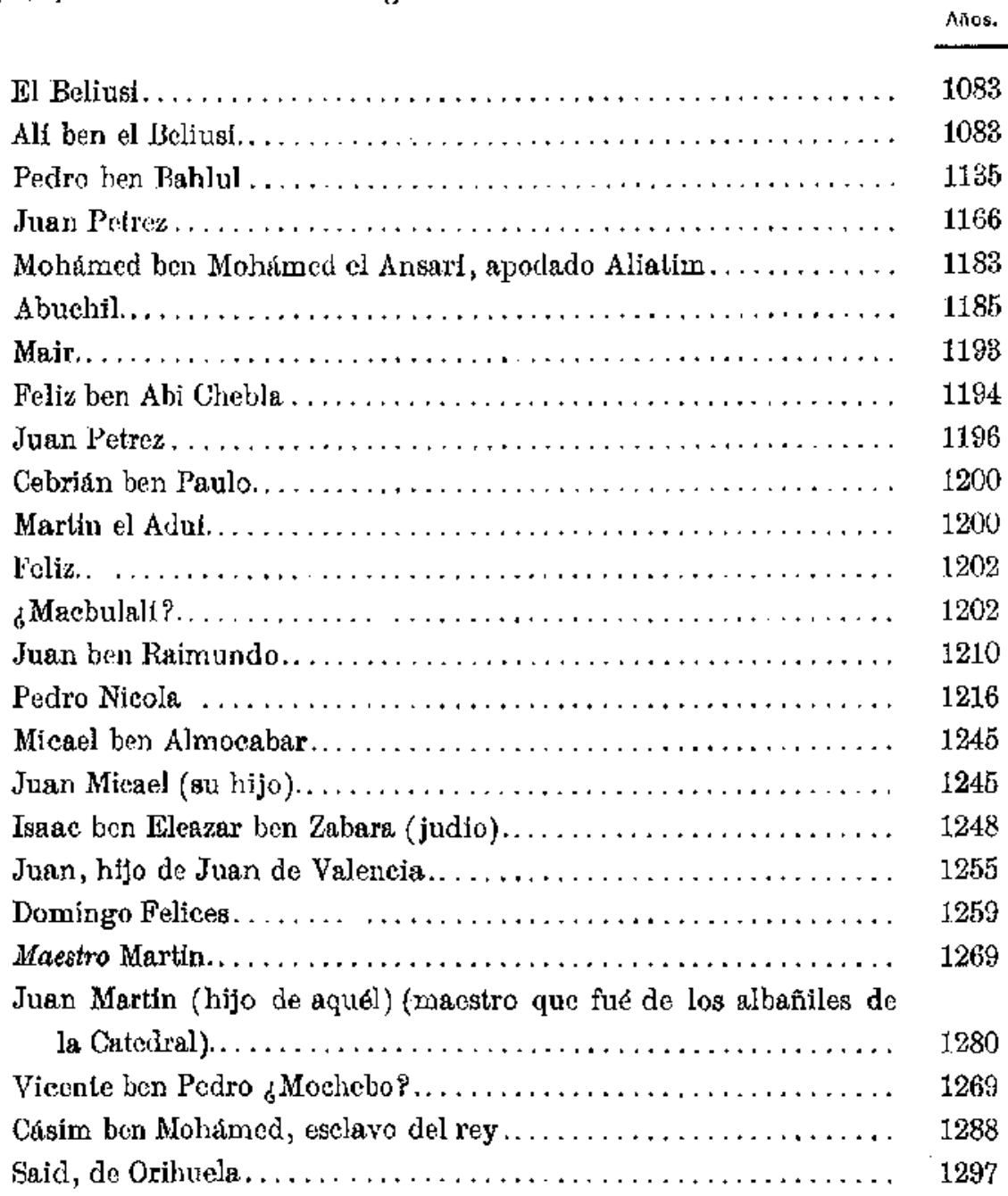

Se conserva un contrato de obras de albaffilería de 1255 , para la reparacion o sconquerda de una pared que era cabo el banno*, que el convento de San Clemente tenía en el arrabal de Santiago (núm. 987).

El albañil D. Juan, hijo de D. Juan de Valencia, se comprometfa a derribar

(1) Las referencias a los documenentos pueden verse en el Índice general alfabético. 
la habitación caliente (البيتك السكون), que está cerca de la caldera (برمها) y a ha-

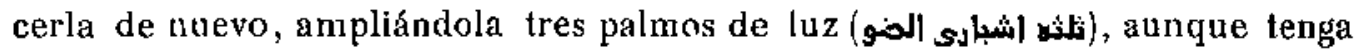
que reducir el patio (الجئية) que en ella hay y tenga que quitar el patio de ln habitación de en medio (لهيت الوسشى) y que hacer una tercera habitación fría (البيت البارد), contigua de la caliente, a lo largo de la citada habitación de en me-

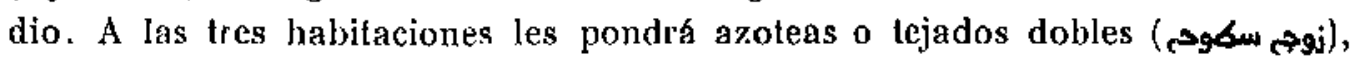

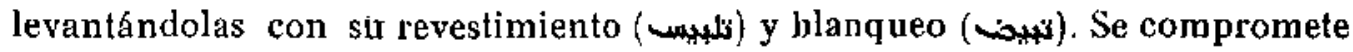
t ambien a construir Jas dos paredes del fornacho (حيكان الفوناج) y a cubrirlas. El convento levantará a sus expensas la azotea del baño completa y el albañil hará una habitación para vestuario (بيت المسلحي) en el espacio que ocupaba la pared antigua que había sobre la piscina (البحيرة) (البحة) levantando sabre el cimiento de la pared vieja la citada habitación fría, llegando hasta la pared contigua a la

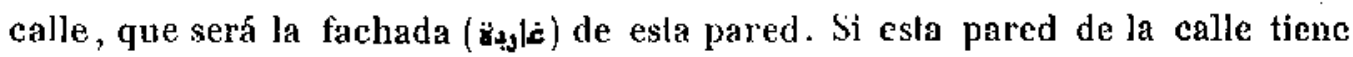
resistencia, hará la citada portedá y sl no, la liará de nuevo y la pondrú tejado, la revestirá y la blanqueará con cal (يبيمه بالجبير); abrirá puerta al baño en la cilada portada y hará los bancos precisos (سكن للدكلة), cubrirá la habitación del vestuario y hará en ella lo que haga falla.

'Todo ello se cumprometía el albañil a hacerlo de buena obı'a, sin poner más

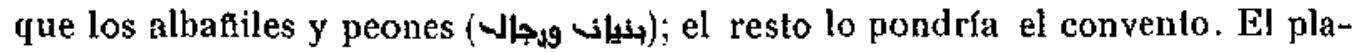
zo era el día de San Miguel próximo a la fecha (30 de Mayo). Li albañil recibiria por su trabajo un sueldo de 100 mizcales, de los cuales le anticipan 40; el resto lo percibirfa al terminar las cúpulas (4) de la habitación caliente. Si el albañil no terminaba su trabajo en el plazo señalado, el convento no pagaría basta que no concluyera las citadas cópulas.

Albeitar (السها)), núms. 561, 673, 685, 726, 729, 777, 826 y 939.

Alfarero (الض)| (الفمار):

\begin{tabular}{|c|c|}
\hline$=$ & Años. \\
\hline Aloen Taurino, $n$ musulmán, Amin do los alfarerss. . . . . . . . & 1135 \\
\hline Yahya cl Alfarero.$\ldots \ldots \ldots \ldots \ldots \ldots \ldots \ldots \ldots \ldots \ldots \ldots$ & 1173 \\
\hline Pedro Asayab. . . . $\ldots \ldots \ldots \ldots \ldots \ldots \ldots \ldots \ldots \ldots \ldots \ldots$ & 1175 \\
\hline Vicente ben Said y Ayub ben Jálaf, alfareros do Talavera......... & 1182 \\
\hline 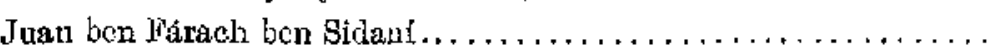 & 1182 \\
\hline Pedro Aliaxar . . . . . . . . . . . . . . . & 1184 \\
\hline Cebrián ....................... & 1188 \\
\hline Domingo Esteban Alfarero $\ldots \ldots \ldots \ldots \ldots \ldots \ldots \ldots \ldots \ldots$ & 1192 \\
\hline Torcuato $\ldots \ldots \ldots \ldots \ldots \ldots \ldots \ldots \ldots$ & 1204 \\
\hline Abuishac ben Alhaquim ben Alfajar $\ldots \ldots \ldots \ldots \ldots \ldots \ldots$ & 1227 \\
\hline 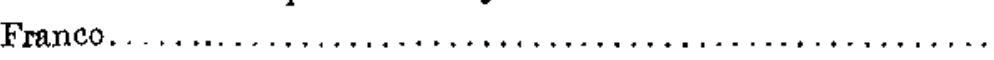 & 1257 \\
\hline Domingo Micael $\ldots \ldots \ldots \ldots \ldots \ldots \ldots \ldots \ldots \ldots \ldots \ldots \ldots$ & 1288 \\
\hline Lope .................. & 1315 \\
\hline
\end{tabular}


Alpargatero (القراقى), nl im. 83.

Arquero (الرامى - القواسي), núms. 30, 72, 185, 310, 417, 548, 603, 702, 707, 751, 982, $956,962,991,1.030,1.05 \%$ y 1.111 .

Arricro (stos ll), núms. 412 y 530 .

Ballestero, núm. 340 .

Bañero (الحمامى), núms. 233, 444, 559 y 594 .

Barbero (الحجاهol, alfageme; stht), níms. 24, 130, 509, 592, 708, 734, 790, 997 y 1.106.

Batanero, núars. 461 y 759.

- Belás (الللاسب), fabricante o vendedor de fieltros o telas bastas que se ponen sobre el lomo de las bestias de carga o sobre los bastes, núm. 429.

Bellutero, - En tal forma he transcrito casi siempre la palabra árabe البلكير, inter. pretando tratarse del oficio de terciopelero, en valenciano vellaler, y aún se cita en documento de 1181, un Juan Belutor (núm. 157). Pero en un caso se ve la grafía بليكي, que había que transcribir por Pelelero (núm. 662); y otra vez al

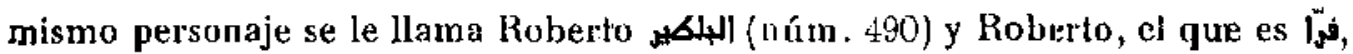
palabra árabe que significa "peletero $=$ (núm. 485).

Me parece, pues, que debe corregirse el texto de la traducción, siempre que diga Bellutero, Bellutir, por Peletero, Peleter.

La mayor parte de ellos son francos. - (Véase Peletero.)

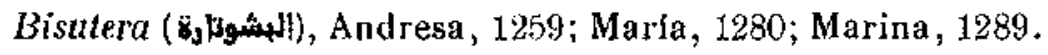

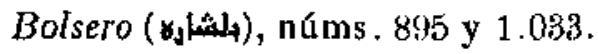

Bordador (jhbاله), Pedro, hijo de Domingo (año 1202).

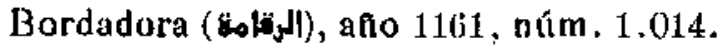

Boticario (الهيكئ), núm. 22.

Bruñidor ( الكهال), núms. 589, 631, 946 y 1.113.

Calderero (اللح|س-1), núms. 136, 139, 348, 409, 419, 440, 798, 794, 801, 949, 950,955 y 1.015 .

Calero (الجيh), núms. 184, 185, 425, 815, 964 y 1.119.

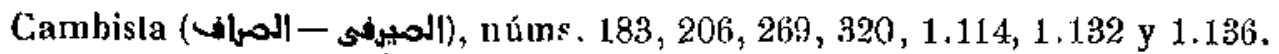

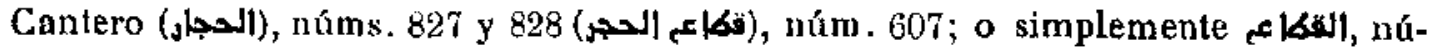
meros $820,1.020$ y 1.077 .

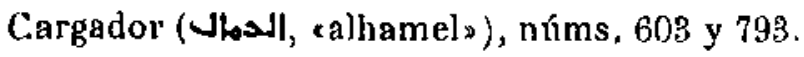

Carnicero (اللداه- الجزال); esta segunda forma se aplica al que vende la carne, aunque jo mate las reses. Había carniceros judíos (núm. 80), musulmanes (números 82,219 y 854) y cristianos: núms. 6, 100, 112, 146, 210,303, 312, 341, 346, $375,376,378,459,567,586,610,611,615,637,645,670,704,717,801,820,863$, $867,928,931,950,964,1.005,1.022,1.059$ y 1.109 . 


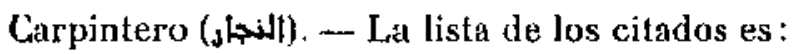

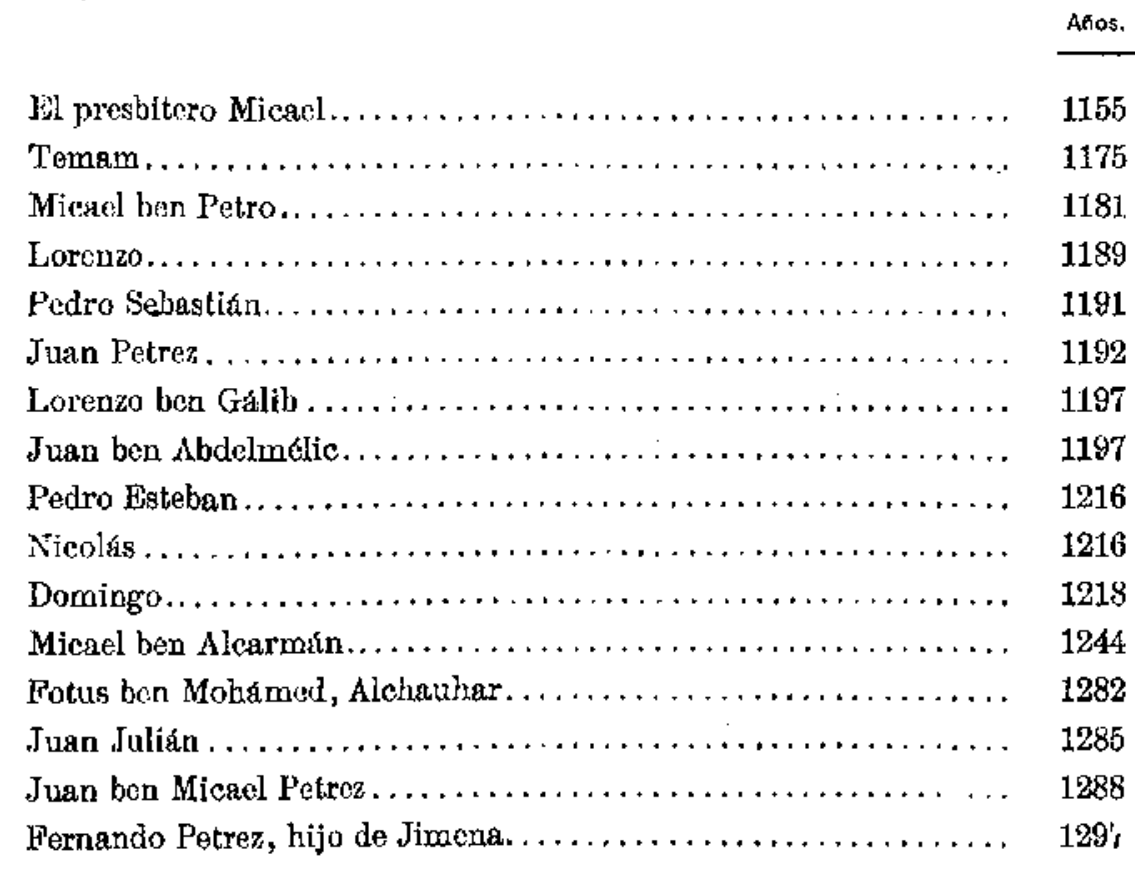

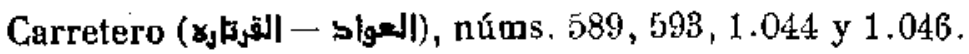

Cazador ( الهيا\$)). - Estaban organizados Ios cazadores en gremio, con sus directo. res (المقذمين), y tenían el fucro de los Conejeros (núm. 956). Celebraban sus juntas en la Catedral, según se deduce de los documentos que se refieren al pleito del gremio cou el canónigo D. Alfonso Meléndez, en 1226, por ciertos derechos en los monles de Toledo (núms. 956 y 1.174). La Conejería siguió en el siglo XV al lado de la Catedral, por detrás de lo que es ahora capilla de Santiago, según se deduce de Ia donación del sitio a D. Alvaro de Luna en 1430. (A. H. N., Osuna, leg. 1.734). Cflanse cazadores, además, en los núms. 460, 731, 95் y 9505.

Cebadero (الشعار). - Debe corregirse la traducción de ePeluquero*, dada en los números 791 y 1.001 , puesto que $\mathrm{el}$ Pedro Juanes de este oficio es el mismo a

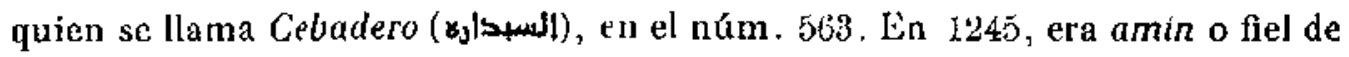
este grenio un Domingo, que luego fué almotacén (aủm. 571): núms. ๖68, 569, $571,579,615,791,849,850,852,854$ y 1.001 .

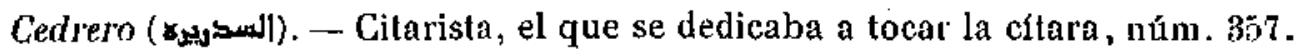

Cerero (rأشأl), núm. 43.

Cirujano (الجياحم), náms. 55, 81, 586, 953, 1.095, 1.105 (una mujer, Leocadia) y 1.114.

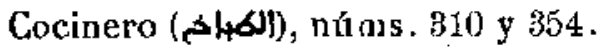

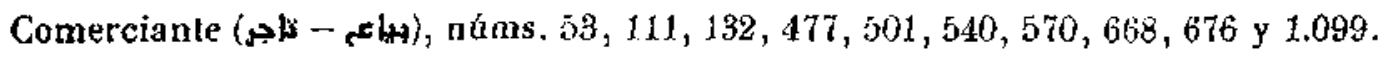

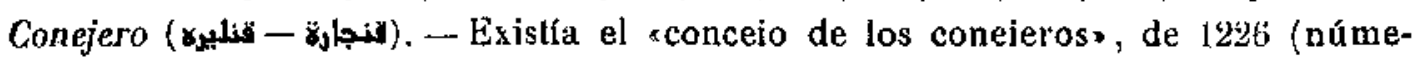
ro 956), y lentan privilegio de Fernando III, dado a los cazadores de Talavera, y fuero especial (vease Cazadores), núms. $246,335,355,362,458,520,943$ y 956 . 


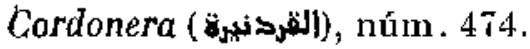

Corredor (الحراجي - السمسطار) (vgente intermediario para las ventas; sinónimo de Delal, o pregonero (véase atrás, pág. 224): núms. 236,558 y 715.

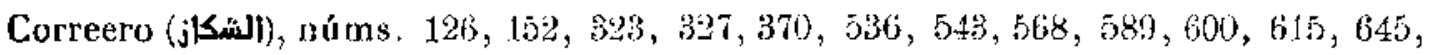
$698,701,962,1.035$ y 1.046 .

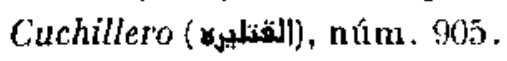

Curtidor (الذباغع), núms. 89, 383, 397, 506, 518,607, 820 y 1.109.

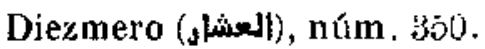

Droguero (s|axl), núms. 316, 317, 397, 473, 479 y 498 .

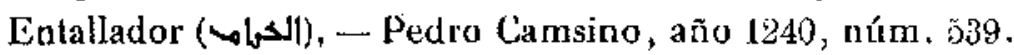

Enterrador (الفالغار), núm. 271 .

Escriba, copista (j|bwl), ním. 506, Alazrac.

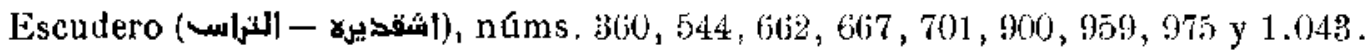

Espadero (لسيانساسل), núm. 803, año (195. Pedro ben Said.

Listerero, espartero (الحمار), núms. 25, 77, 232, 279, 314, 344, 346, 349, 342, 412, 506, $580,612,653,817,952,1.103$ y 1.123. Cítase un Domingo Alhasar el presbitero (núm. 392) y al amín de los estereros, núms. 231, 701, 942 y 959.

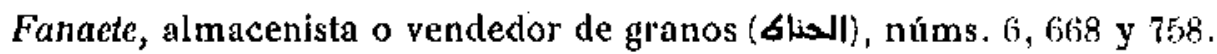

Inulero ( 6 ( 6 ). ¿Encargado de preparar las trampas, en el oficio de cazador?, nám. 950 .

Galinera, vendedora de gallinas (بايعة الدجاجم) 1) 1.119.

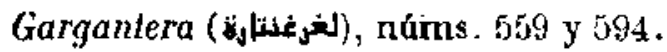

Gorrero, bonetero (القلاس), núms. 304 y 361.

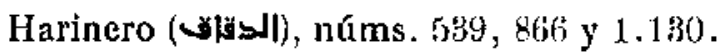

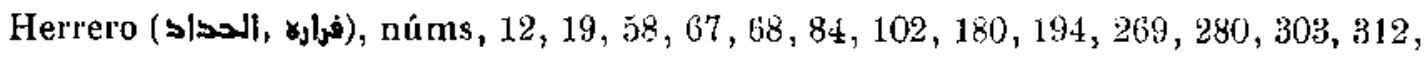
$316,375,380$ tuis, $400,436,480,536,546,551,600,653,692,737,762,768,805$, $835,905,938,949,950,952,1.020,1.049$ y 1.123 .

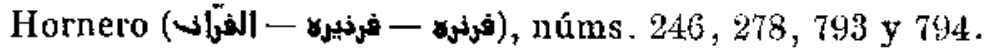

Hortelano (نالجانان), múms, 150, 230, 256, 380 bis c), 407, 498, 547, 584, 598, 601, 613, $828,918,1.049$ y 1.050 .

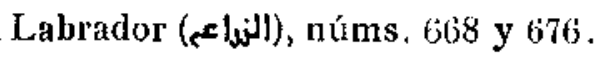

Lechero (اللجانا). - También significa fabricante de ladrillos coeidos al sol. Alguna vez se transcribe لجير, lechero (uúm. 26) : oúms. 55, 156 y 1.095.

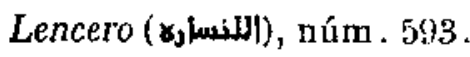

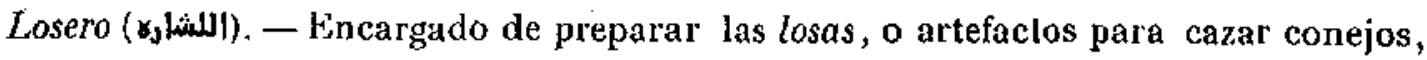
núm. 956.

Maga, hechicera (الرئím), núm. 465.

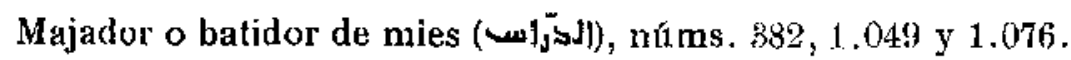

Medidor. - Unas veces se llama simplemente القياس (núm. 952); otras, كياس o 


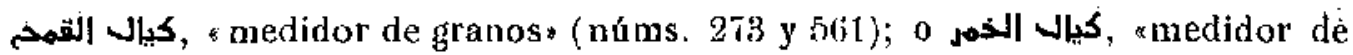
vinos, núm, 563 .

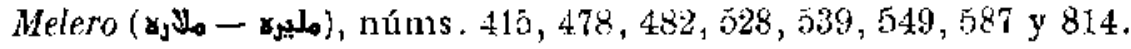

Minero (الذقابِ), núm. 302.

Molinero (المليناله - المرحونى - ألرحاوى - الرحوى), náms. 179, 292, 456, $531,546,551$, $572,776,841,913$ y 939 .

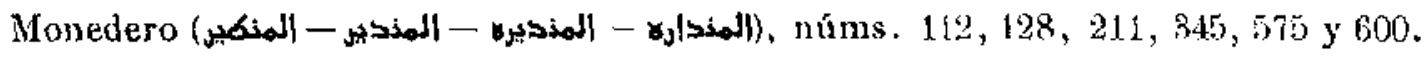
La traducción de monedero dada a la voz الغكاع (núm. 1.077), parece equivocada: conviene mejor a cantero, acortador de piedras $\triangleright$, aunque podría también aplicarse al que bace la moneda قكاع sار الخريب. (Dozy, Suppl., s. v.)

Músico, tañedor de laúd (العواد), núm. ذ30. (Véase lambién Carretero.)

Panadero (الكباز), núms. 303 y 634.

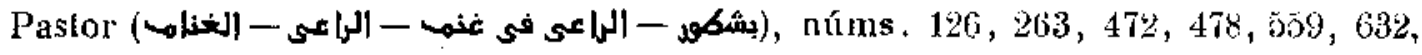
$641,631,657,640,689,719), 765,774$ y 1.049.

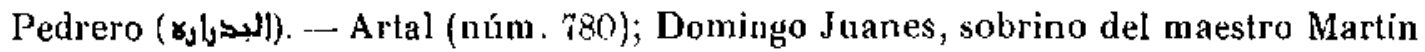
el Albañil (núm. 960); otro hijo del Pedrệo (núm. 1.136).

Peinadora (

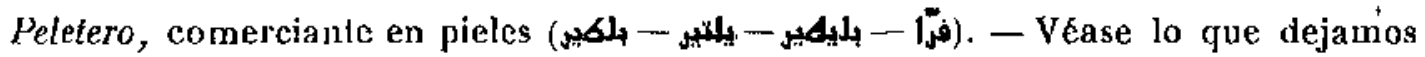
dicho atrás (Bellutero) acerca de la transcripción de estas palabras. - La lista de los que aparecen es:

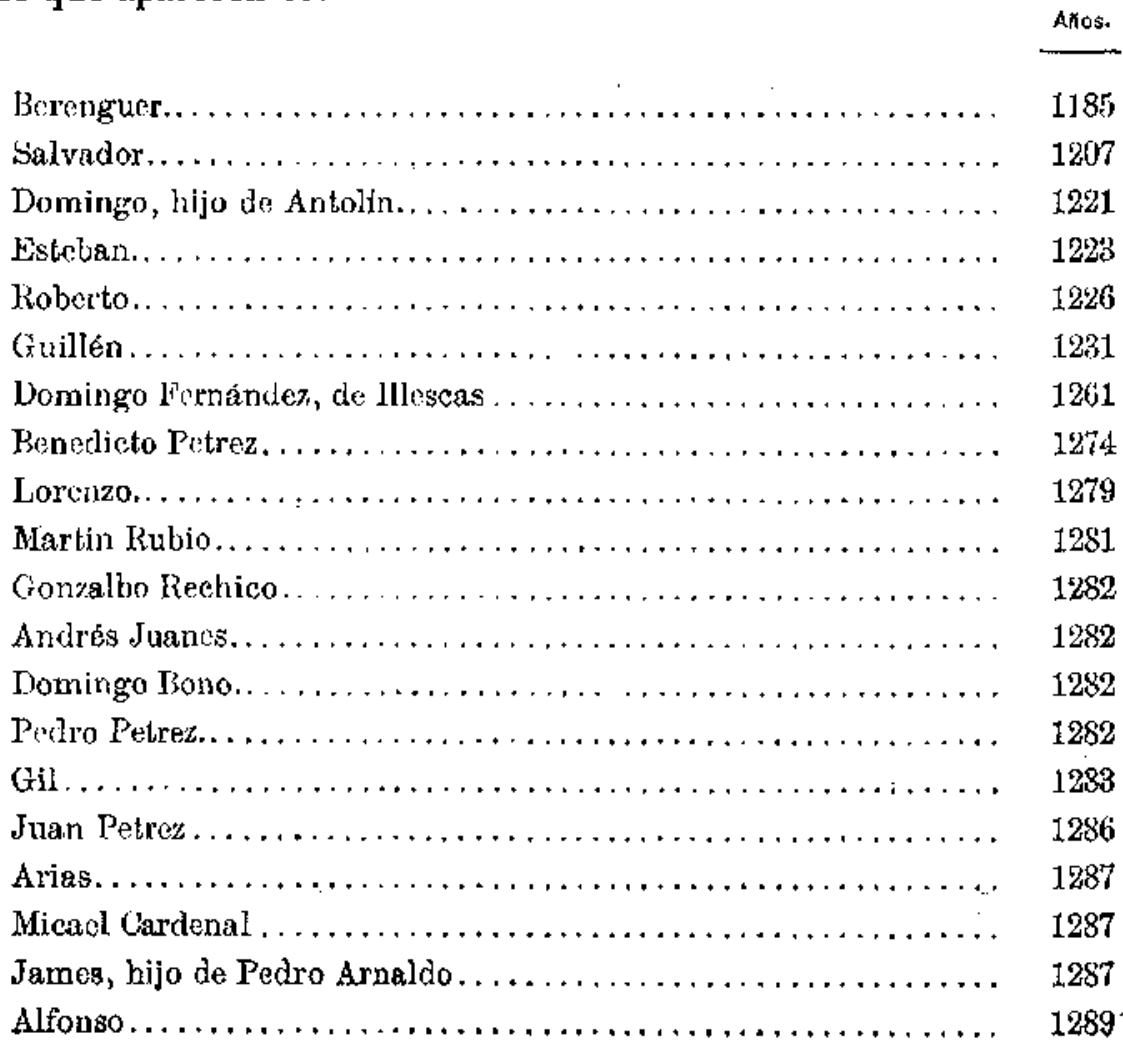


Peón, jornalero del campo (كاس), núm. 378.

Perrero (البّرادر) núm. 5988.

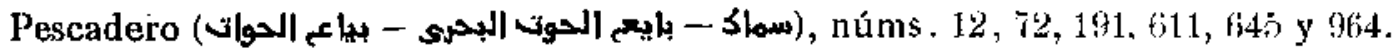

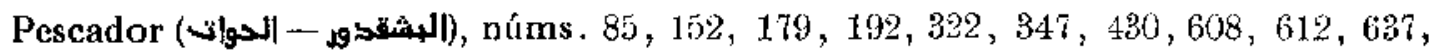
$653,673,691,711,743,826,953$ y 1.054 .

Picapedrero. - Véase Cantero y Pedrero.

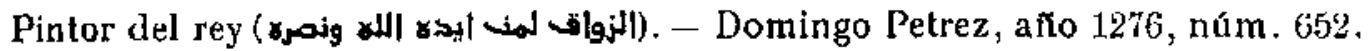

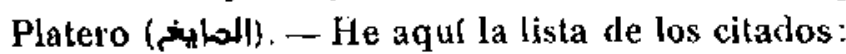

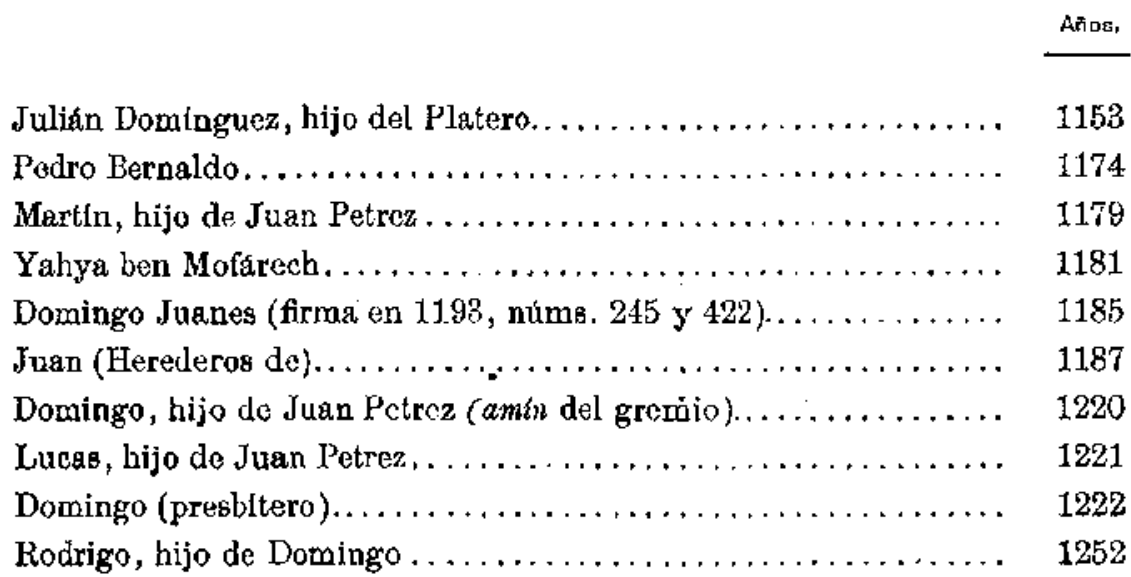

Podador de viñas (J4الز 1.030. Aunque esta palabra shoj significa scopisla», y así la he traducido en el documento número 820 , creo que debe corregirse, según Dozy, Suppl., s.v.

Portero (الهوابه), núms. 354 y 1.027.

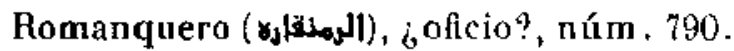

Roquero (إلركير), 6oficio?, 165.

Salinero (الملاهم), núms. 205, 345, 894, 956 y 9966.

Sastre (الخياك), núms. 20, 181, 323, 430,443, 477, 534, 545, 572, 573, 1631, 634, 6838 , $640,645,653,658,672,686,689,691,700,705,793,794,811,892,962,964$. $1.015,1.025,1.034,1.045,1.088,1.105,1.109$ y 1.124 .

Sedero (إحري). - Un Harirí en 1092 y otro Alı ben Halirí (núm. 2); otro Juan el llarirí en 1289 (nún. 964).

Sedero, comerciante en seda cruda (القزا)), núms. 328, 330, 689, 798, 794, 1.020 y 1.043 . Sepulturero (الجزاز), núm. 465 .

Sillero (الساجم), el que hace guarniciones para las sillas de montar: núms. $397,479$. $482,507,620,627,715,817,820,826,1.009$ y 1.114 .

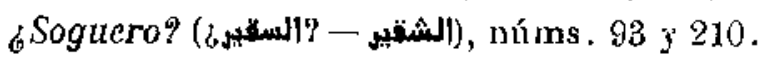

Tabernero (bار (6), núms. 592, 666 y 682 . (Véase Vinatero).

'Tejedor (الح|يك), núm. 543. 


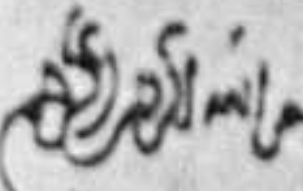

(i)

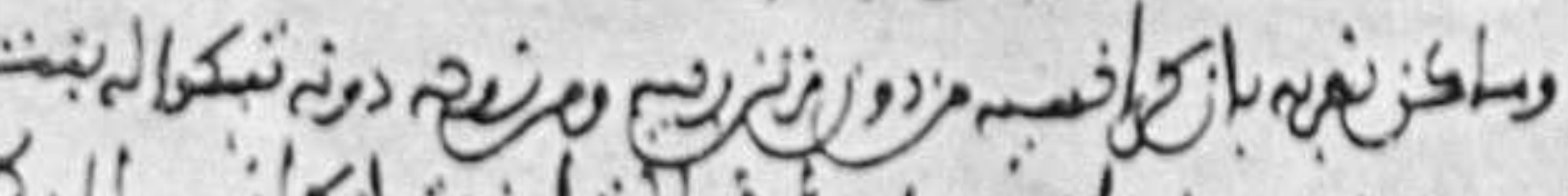

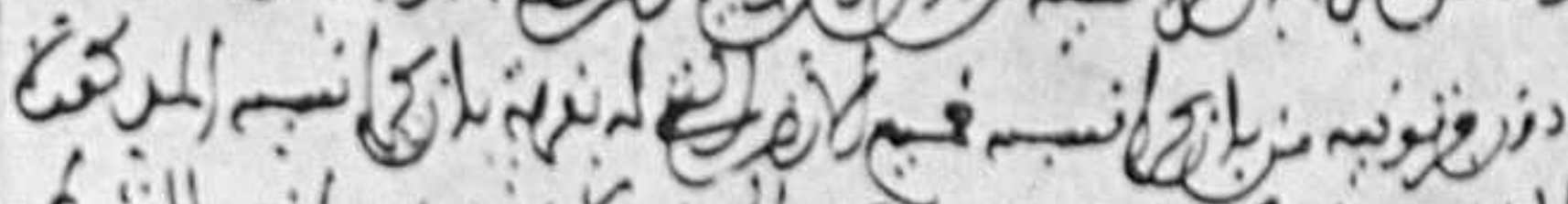

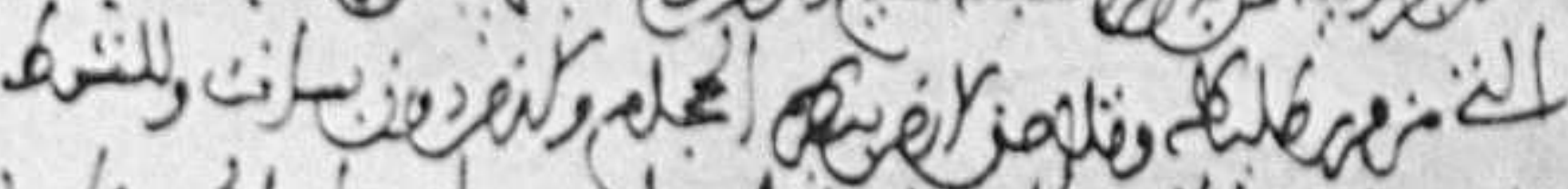

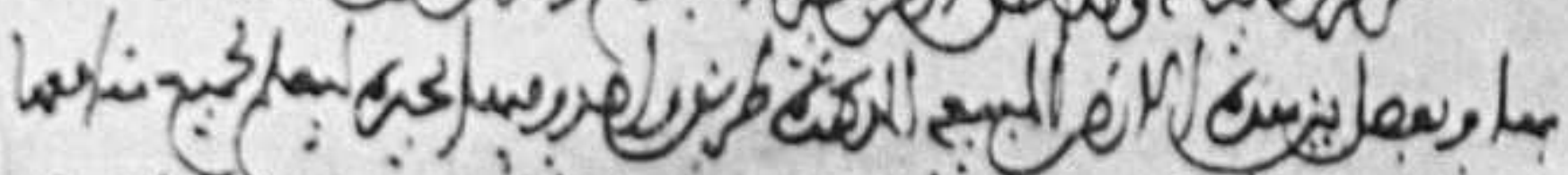

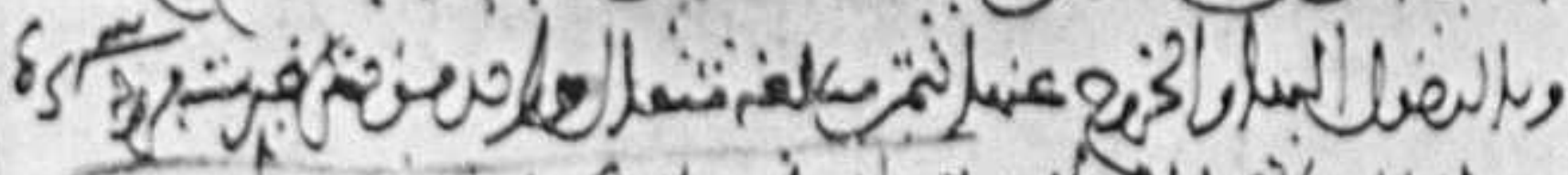

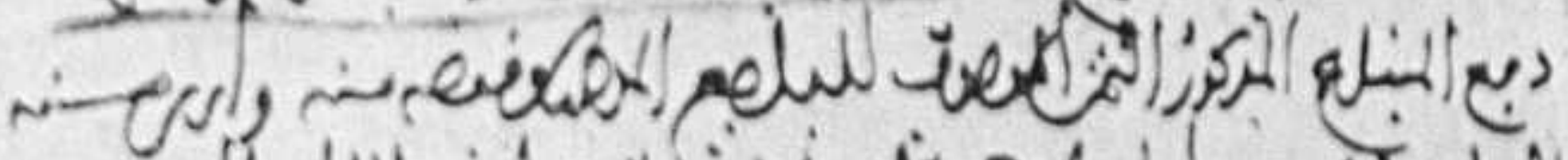

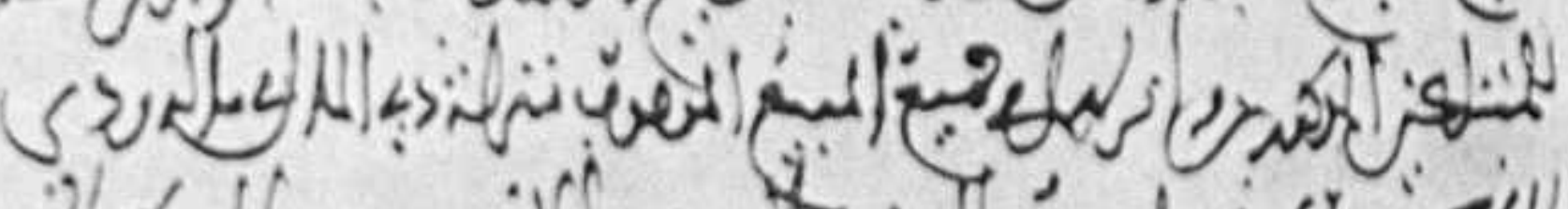

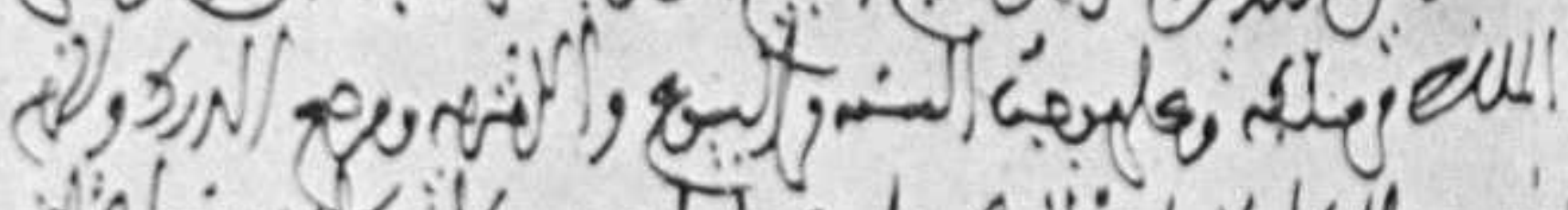

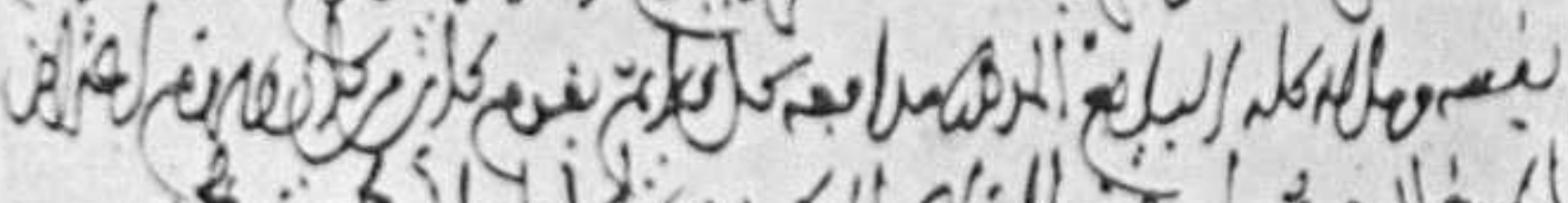
الم Sim

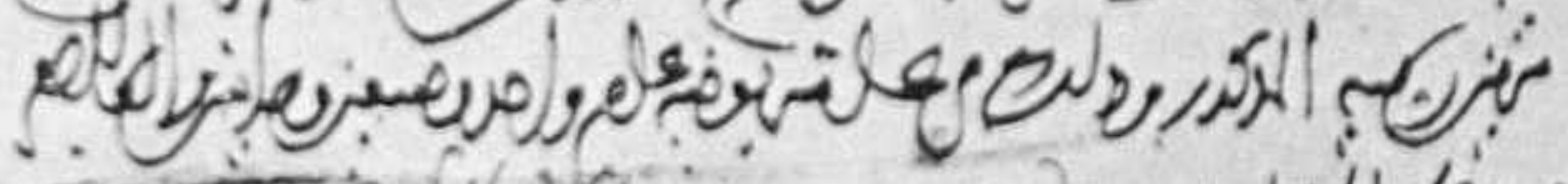
क.

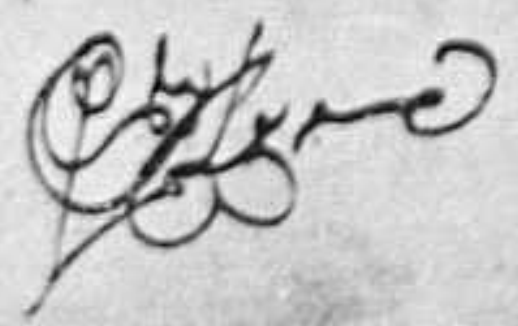

Compraventa: 10 de Jurio de 1233 (num. 5C9) 


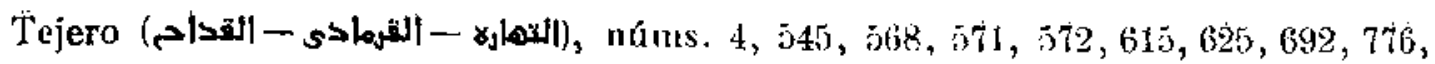
$820,913,934,1.009,1.028$ y 1.086.

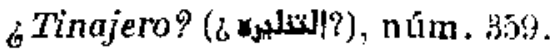

'Tintorcro (المباغع), núms. 21, 57, 95, 219, 358, 396, วิ13, 793, 1.067 y 1.137.

Tornero (الحَّآكا), núms. 350 y 1.130.

Trapeto (الكرئ), núm. 514.

Vainero (s/otit), núms. 663 y 1.115.

Vaquero, boyero (الجثار), núm. 1.030.

Verdulero, tendero al menudo de comestibles (الجقالى), núms. 184, 216, 391,476, $578,608,638,650,653,657,658,659,747,824,974$ y 1.102 .

Vidriero (الزجاج), núm. 461 .

Vinatero (الخمار - الشراله), núms. 116, 138, 340, 474, 653, 659, 739, 951 y 985. -(Véase Tabernero.)

Zapatero (الصبكير - السبكير) - Alguna vez الخراز (núm. 894) : núms. 68, 69, 74, 83, 98, $106,128,201,283,284,291,323,328,341,343,344,371,401,477,501,520,522$, $537,563,570,577,578,579,580,589,593,598,601,603,611,637,638,656,668$, $670,676,691,715,819,823,853,870,890,891,892,958,978,998,1.009,1.077$, $1.107,1.109,1.110$ y 1118 .

Cítanse a menudo las tiendas donde muchos de estos oficiales vendían: las tiendas del rey, cerca de la Catedral, parece que eran de los alfareros y drogueros (búmeros 20, 27, 29, 130 y 473); barbería en San Nicolás (núm. 487); carnicería (número 488); tienda del carbón y del hierro, en el zoco de los Sastres, en San Nicolás (números 483 y 496); tiendas de los herreros, en Santa Justa (núm. 116); verdulería, en San Nicolás (núm . 487); casa donde se vendía el vino, en el barrio de la Catedral, en los Tintoreros (núm. 513).

\section{CRIADOS}

440. Se les llama, de ordinario, كرياك 0 تريية, anque no faltan ocasiones en

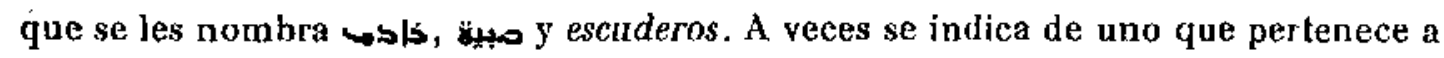
la casa de fulano (v. gr., uno de la casa del arcediano Domingo el Polichení, núme. ro 355), o que es de la criazón del rey (núm. 191). Los dueños son desde el rey y la reina (núms. 715 y 717) hasta humildes comerciantes (una bisutera, núm. 961), pasando por el arzobispo, el deán, los canónigos, los alguaciles, alcaides, etc. Los criados de los eclesí́sticos eran muchas veces clérigos la mbién, o por lo menos racioneros; en casos, no obstante, eran casados (núms. 347, 384 y 645). 
Los criados parece que tenian la plenitud de derechos civiles. Ellos compran: asi, un racionero, criado del arzobispo, compraba y advertía que era con su dinero propio y para sí (núm. 302); otro compraba a su mismo duefo finca en Alaitic (ntimero 469); y lo mismo hacian un criado del macstrescuela a otro criado de un particular (núm. 1.118), otro criado de las monjas de San Pédro en Allócem (núme. ro 1.116), otro del arcediano D. Alfonso Meléndez (núm. 1.112); y hasta una criada del canónigo Maestro Mateo adquirła, por compra, una esclava mora (núm. 703). Ellos venden: aś, criados del deán Maestro Alberto (núm. 490), del alguacil D. Gonzalbo Fać́ndez (núm. 474), del caid D. Estrban Pelrez ben Lámpader y de su mujer doña Orabona (núm. 570), del canónigo D. Guillén Repostero (núm. 616), del arcediano D. Fernando Gil (núm. 1111), de las monjas de San Pedro (núm. 692) y otros más (núms. 608, 615 y 616 ).

La soldada ndual de urv que se dedicaba al servicio era, en 1281, de 20 mizcales blancos nuevos de 15 sueldos (núm. 1.004).

Los criados y sirvientes son recordados de ordinario en las mandas testamentarias; a una criada se le manda, en 1125, un toro, el tercio de las mieses y 2 mizcales almorávides, y a otra, si se casa, 5 mizcales para atender a los gaslos de su casamiento, y a otra, "la que vive con él y se dedica a su servicio , le deja las ropas de la cama de ella, tres jergones, la harina que hubiera en casa para que coma y un cántaro de vino (núm. 1.012); a otra se le dejan, en 1156, dos bueyes y tierra de labor para ellos en Olías (núm, 1.013); a un escudero se le ofrecen 20 mizcalcs y el rocín del testador si se queda con él hasta que muera, y a los demás escuderos 10 mizcales a cada uno si quedaban sirviendo en la misma forma (núm. 1.021). Se ven también mandas a la mujer de un criado (núm. 1.025); a otro, que se le dará cuando se case o cuando se ordene de sacerdote (núm. 1.030); a otro, una muda torda, o en su lugar 30 mizcales, y que sea libre como los demás cristianos y se vaya donde quiera (núm. 1.030). Don Fernando Mateos menciona varios criados suyos y de su familia (núm. 1.030); y a otro criado se le mandan ropas de vestir y dinero en 1281 (núm. 1.034).

\section{ESCLAVOS}

441. In la compraventa de esclavos el vendedor solía garantizar al comprador sde robo o hurlo, y los gasios que hiciera el comprador en el salario de sus bom. bres, en el alquiler de bestias y en los desembolsos del viaje para dirigirse a cual. quier lugar en husca del vendedor y a causa de la expresada garantfa sean a cargo del dicho veṇdedor y sus bienes ( núm. 630). Cuidábase el comprador de averiguar la procedencia del esclavo que adquiría; una vez se entregà la que podríamos lla- 
mar guía, o sea la escritura romance, por la cual conslaba que el esclavo había sd. lido en almoneda pública en Córdoba, según testimonio del escribano del rey y del inspector del diezmo en aquella ciudad (núm. 634). En tales casos se anotaban las señas personales del esclavo: "Marcado en la espalda con un sello, en cuyo centro había un castillo, y sobre el castillo una cruz, y a su lado una venera* (núm. 634); y, como de ordinario, se garantizaban al comprador Jos gasios que hiciera en busco del esclayo, si es caso que huía. También solía exigirse un antor (l), fiador, que respondiera de la venta (ním. 1.003); los bienes de este fiador se ejecutaban para cumplir.

En Toledo había un delal o corredor de esclavos, por cayo intermedio se hacían las transaccioncs de esta clase; en 1286 era delal de esclavos Ahuomar Israel (núm. 690).

El valor de los esclavos variaba, naturalmente, según las condiciones personales de edad, aptitudes, etc. Tres esclavos moros valían 50 mizcales en 1240 (número 934); dos esclavas se tasaban en 47 mizcaies en 1260 (núm. 1.n43); uno, en 30 mizcales en 1262 (núm. 615); una madre y una hija, cinhechíes, se vendian por 155 mizcales en 1279 (nún. 1.003); mientras que por otro, moreno, albañil, se pagaban 400 mizcales blancos en 1286 (núm. 690).

Los esclavos se trataban al igual que cualquier otro bien, muehle o raiz, que tuviere el dueño; una esclava se adjudica en una partición al lado de unos pendientes (núm. 1.042), a se valúa después de un jumento o unos manteles en una carta de dole (núm. 1.175). Los esclavos entraban (1143) como bienes en una sociedad, pero dos de ellos sou adjudicados a cada uno de los socios; su precio, de rescate o de venta, había de dividirse lambién entre lus socios (núm. 969). El testador (1266) cuidaba de especificar cuáles esclavos eran de su mujer, cuáles suyos propios y cuáles de los dos a medias; disponía que se vendiera el derecho suyo en dos para pagar el testamento, y en otros dos mandaba que se le pagara a su mujer el derecho que en ellos tevia, como regalo que el testador le hacia, y quedasen propios de ella sola (núm. 1.030). Se traspasaban los decechos en un esclavo junto con los derechos en unas fincas (núm. 783); se mandaban esclavos en testamento lo mismo que cobertores, vestidos o joyas (núm. 1.034).

El esclavo podía casarse con persona libre (núms. 936, 938 y 939), y en algún caso vemos a un mameluco del rey, el albañil Cásim ben Mohámed, comprando casas (núm, 698).

La manumisión de los esclavos se hacia de dos maneras: una mediante rescate y otra por espontánea voluntad del dueño.

(1) 3969 , derivado de abtor, actor. Tn este sentldo de flador para el saneamiento de una ventn lo vemas en documento cristiano de 1381 . Vease El Condado de Valverde, por el marquís del Sitilillo, número 7. (Cuenca, Biblioleca diocesana, tomo VI, en prensa.) 
Si se trataba de rescate, se señalaba un precio que el esclavo había de pagar, ordinariamente, a plazos, unos mensuales, otros anuales, o en dos o tres veces la cantidad total. Desde que firmaba la escritura de emancipación, el esclavo podía vivir libremente y trabajar en Toledo y su alfoz, sin guardianes ni capataces (número 793), libre de hicrros y cadenas (núm. 938), aunque a veces había de ocuparse en los asuntos del dueño, tanto en la capital como fuera, siempre que ell se lo mandase (núm. 936). Si cl esclavo no pagaba tres plazos consecutivos, salvo caso de enfermedad; si huía y se le encontraba; si se mezclaba con gente mala; si se le cogía in fraganti delito de rolso o infidelidad (núm. 788); si el liberto bebía vino o salía fiador de otro rescate (núm. 793), perdía la cantidad que hubiera abonado ya y volvia a la esclavitud.

El convento de San Clemente daba la liberlad a Ali el de Baza, en 1235, por 30 mizcales en tres plazos : de momento, 10 ; al pasar dos años, otros 10; al concluir el tercer año, los 10 restantes; el liberto habia de trabajar sin salir de Toledo, y fueron sus fadores la esposa y el hijo. Parece que sólo pagó 24 mizcales (núm. 787).

El precio del rescate puesto por el canónigo D. Agustín a su esclava Cecilia, convertida al cristianismo, en 1241, era de 40 mizcales, pagaderos en plazos de 10 sueldos cada mes; durante el plazo de pago de su rescate ella tendría derecho a su soldada, en comer, beber, vestir y 孔ochavos? (núm. 778). Doña Colonba Gutierrez ofrecía la libertad a su esclava Onalhada por $280 \frac{1}{2}$ mizcales alfonsies, para que se casara con Yaix el Sastre, y los dos pagánan el rescate con el producto de su trabajo, en plazos de 2 mizcales cada mes. En este caso el marido se habla de obligar al pago, junto con la liberta, so pena de prisión y encarcelamiento, sin necesidad de mandamiento judieial. También se habian de obhigar a dar a la señora en sus tres fiestas algúu regalo, sin excusa, ni pretexlo, ni relraso; y la liherta había de coser en casa de la señora cuanto ésta necesitara y sin salario alguno. Y no sólo Yaix, sino olros muchos inusulmanes, casi todos libertos, labían de salir fiadores de aquel conlrato, que por fiu no llegó a firmarse (núm. 793).

En ocasioncs se traspasaba a poder de un prestamista la escritura de liheración del esclavo para que aquél fuera cobrando en los plazos marcados (núm. 849).

El punto mís delicado en las cartas de rescate era la fanza, por el temor natural a que el liberto huyese antes de terminar de pagar la cantidad señalada. Unas veces eran fiadores los padres; en un contrato en el cual el liberto hahía de pagar 48 mizcales al convento de San Clemente, por plazos de 1 mizcal cada mes, en cualro años, los fiadores habían de pagar al convento 100 mizcales de multa si el rescatado húa y ellos no lo presentaban o pagaban por él; y en caso de rebusar el pago de la mesada y de los 100 mizeales dicnos, la ahadesa podrła embargar sos bicues sin necesidad de niandamiento judicial (núm. 935).

Otras veces era fiadora la esposa del liberto; en caso de huida, el señor podría cogerla a ella y esclavizarla en lugar del marido, siı mandamiento judicial, ni calomnia 
(núm. 936), o bien se comprometía a pagar 500 mizcales blancos si se escapaba el marido ( $n$ úms. 937 y 938), cantidad que se rebajalsa a 300 mizcales blancos de 10 dineros, dando facultad al arzobispo dueño para reducirla a la esclavifud mientras no se presente el marido o ella no pague, sin necesidad de mandato judicial, fuero o calomnia (ńm. 935) (1). El fiador que había de pagar por su fado podía repetir contra él; así, un judío se concertaba con la heredera de su fiado para cobrar a me. dias lo que pudicra sacarse de la venta de los bicues de este último (núm. 1.003).

También liabía otro rescate, mediante prestacion personal de trabajo, en lugar de dinero. El convento de San Clemente emancipaba, en 1247, a dos esclavos moros a cambio de pue ellos cultivasen ana viña del colvvento en Ol\}as durante cinco años con las labores precisas, habiendo de ser la poda de cuenta del convento, que se llevaría la cosecha; al acabar cl plazo de cinco años serían libres; pero si huían o no terminaban el trabajo, volverfan a la esclavitud, perdiendo lo que hubieran puesto (núm. 789). No debió, acaso, dar resultado el contrato anterior, por cuanto vemos que el convento, en 1248 , da la libertad a otros cuatro moros a cambio de que tra-

(1) Doeumento ronance del siglo XIV ya (affo 1315) compruela esto mismo. Véase el Biguiente, conservado en el Archivo del hitituto de Valeneja de Don Juan, Ad. 211 :

a Sepan quantos exta carta vieren cómo yo, Hariota, fija de Caçito el pargaminero, e muger que fuy de Yuçaf, o jo, su fije Axa Miras, moradores en Loledo, olorganos c conoscemos qua fiamos la has do Mahomad, anrido de mi la dicha Axa, o moro gue es de vos Don Gulierre, arçobispo de Toledo, o fiamos la has daste. Mahomad a vos ol sobrodicho señor en tal manera que si tol doy techa esia carta en adelant en qual-

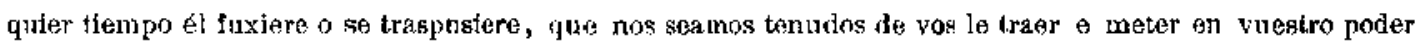
en 'foledo, bivo o muerto, del dia que el fuxiere o se traspusicre fasta dies días; et si falleçeremos de lo complir assi que vos demos e pechemos por él mill e quinientos mr. de la won. blanca de dies dineros tl mr. en que es apreciado. El que por esta rrnón que ayades poter vos o qui quicer que esta carta musstre por vos de prender nuestros bienes, lus entrar o guier que los talledes e vender ende lo que quisierdes e entregadvos de los dichos mill e quinientos mr, e demás desto, si aver nou nos fallardes para vos entregar de nos desto que dicho es, quo ayadea poder, o qui quicr que esia carta uncsire, do nos paendor los cherposo quier que nos fallades a mueted nos en qual prisión quisierdes e non nos saquedes onde si non quisierden fagta que seades entregado de todos los dichos mr., e todo quanio dicho es que lo fagades sin mandado de alcalle e de otro jues e sin pena e sin fuero o sin calota ninguma, costas e missiones que por esta rasón fagades, e danos e menoscabos que rrecibades en qual inanera quier sobro nos e sobro nuestros bienes sean. El somos en pagar e cumplir tody quanto aqni diso segund dicho es, anas a dos de mancomún a bos de una cada una de nos por todu que demandedes e prendedes e prendades i qual quisierdes de nos por todo o dexedes a qual quisierdes.

Fecha ta carta voyute e quatro dias de julio era de mill o cee e çinquenta el tres años.

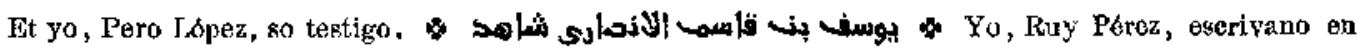
Toledo, so kestigo. Abdallá, fijo de Don Fanaet, so testigo.

Al pie: بيكر s99. 
bajaran ocho años la misma viña; se obligaban, como los otros, a hacer las labores precisas; pero, además, se compromelian a segar en la época de la recolección de la cebada quince días sin salario en cualquier alquería del convento del alfoz de To. ledo durante los dichos oclıo años; si dejaban terminar el trabajo de la viña o no segaban los días señalados; si huían todos o alguno, o se mezclaban con gente mala, o robaban, perderían lo trabajacio y volverían a la esclavitud; si se escapaba uno y no parecin, los restantes quedaban obligados a hacer su trabajo después de terminar el plazo señalado. Los días que alguno no trabajase, los completaría también fuera del plazo. Podían vivir en cualquier alquería del convento y tendrfan derecho a un subsidio para comer y besber (núm. 790).

A veces no cumplía el liberto las condiciones eslipuladas: el dueno cedfa sus derechos a un tercero (núm. 791 ).

La manumisión por espontánea voluntad del dueño solfa hacerse en los testamentos: así, manumitía el alcalde $\mathrm{D}$. Domingo Antolín, en 1161, a su esclavo Pedrp Ferragut, que tendría todos los derechos y deberes de los libertos cristianos, sin que nadie pudiera alegar derecho alguno sobre él; le mandaba ariemás un par de camisas, dos pares de zaragüelles, an ferreruelo encarnado y usado, las zapatonas y las calzas; y disponía que quedbise con la viuda a su servicio, pero como libre, hasta la recolección de la cosecha, y después sería libre de su albedrío y su persona. $\Lambda$ dos esclavas libertó también el mismo alcalde: una sin condiciones; olca con la de servir a la sefiora un año después de la muerte del testador (núm. 1.014).

Por haher recibido el bautismo oblenfa, en 1163 , la líbertad olra esolava de don Román bon Selma (núm. 785); y con la condición de que se bautizara y sirviera al marido de la testadora, quedala otra libre, en la mitad, habiendo de pagar el marido por la otra mitad cinco mizcales (núm. 1,018). Otra recibe la libertad por diez mizcales que el merido de la esclava habia dadn a la testadora (núm. 1.020). Ua converso al cristianismo sería libre si servía cinco años a la esposa de su dueño (núm. 1.028), y otra conversa, desde luego, y además la dejaron 10 mizcales (núm. 792). Con la condición de servir cuatro años a un pariente del testador (núm. 1.929) o a la legataria de dos esclavos, mientras vivieran (núm. 1.034), oblendrían tambińa ỉa libertad otros esclavos. Finalmente, una monja de San Clemente, en 1292, emancipaba a una esclava, con aprobación de la abadesa, con la obligación de seguir al servicio de su dueffa mientras ésta viviera (núm. 795).

El eselavo liberto pagaba su diezmo en el alnojariiazgo, annque no sabemos qué cantidad era (núm. 795). 


\section{C $\Lambda$ U'T IVOS}

442. Preocupaba, naturalmente, la suerte de los cautivos en países islámicos. La iniciativa familiar facilitaba medios para el rescate: asf, vemos que la mujer de Domingo Marcelo el Adalid, cautivo, empeñaba fincas, en 1167, para rescatar al marido (núm. 898); y Mjyuel Lázaro escribía a varios primos suyos, que llegaban a Toledo desde Calatrava por Jos años de 1197, ordenanòo que vendieran su casa y sn viria, y con su precio comprasen algo con que rescatarlo del cautiverio; hubo de intervenir el alguacil y alcalde D. Esteban Julianis, quien mandó vender la viña, empeñada en 10 mizcales, por 19, de los cuales se pag6 la deuda y el resto lo emplearon en comprar con qué rescatar al cautivo (núm. 943). Otra finca se venñe, en 1266, para rescalar a un prisionero de los moros en Ronda (núm. 628).

Son corrientes en los testamentos las mandas destinadas a la redención de cautivos. Desde 1125 vemos ya una manda para rescatar tres canlivos, y el mismo testador deja a umo un caballo, para la guerra, con la condición ıde que libertase a un cautivo (núm. 1.012). Era una atención piadosa, equiparada a los sufragios: la mitad de una casa se destina para el rescate de cantivos o para sufragios en 1143 (numero 969). Para este mismo empleo. se mandan 10 mizcales en 1161 (núm. 1.014), el remanente de una nerencia en 1185 y 1192 (núms. 1.016 y 1.020), cierta contínad. en 1187 (núm. 738), 30 mizcales en 1209 (núm. 1.022), 500 mizcales en 1211, más otros 100 mandados para fundar una canonjía en Talavera, en caso de que no llegara a establecerse (núm. 1.024); 20 mizcales en 1212 (núm. 1.025), 60 mizcales en 1233 (núm. 1.028), lo que costase redimir dos personns en 1253 (núm. 1.029), 10 mizcales para ayudar a rescatar uno en 1266 (núm. 1.030), 20 mizcales en 1280 (núm. 1.033).

La redención se intentaba por medio de personas de crédito, hombres buenos de quienes se fiaban los que daban el dinero, y si no hallaban hrimbres de estas condiciones, entregaban la cantidad a los frailes de la Trinidad; en esta forrna se mandan 100 mizcales, en 1280, para ayuda del rescate de un cautivo (núm. 1.034). 



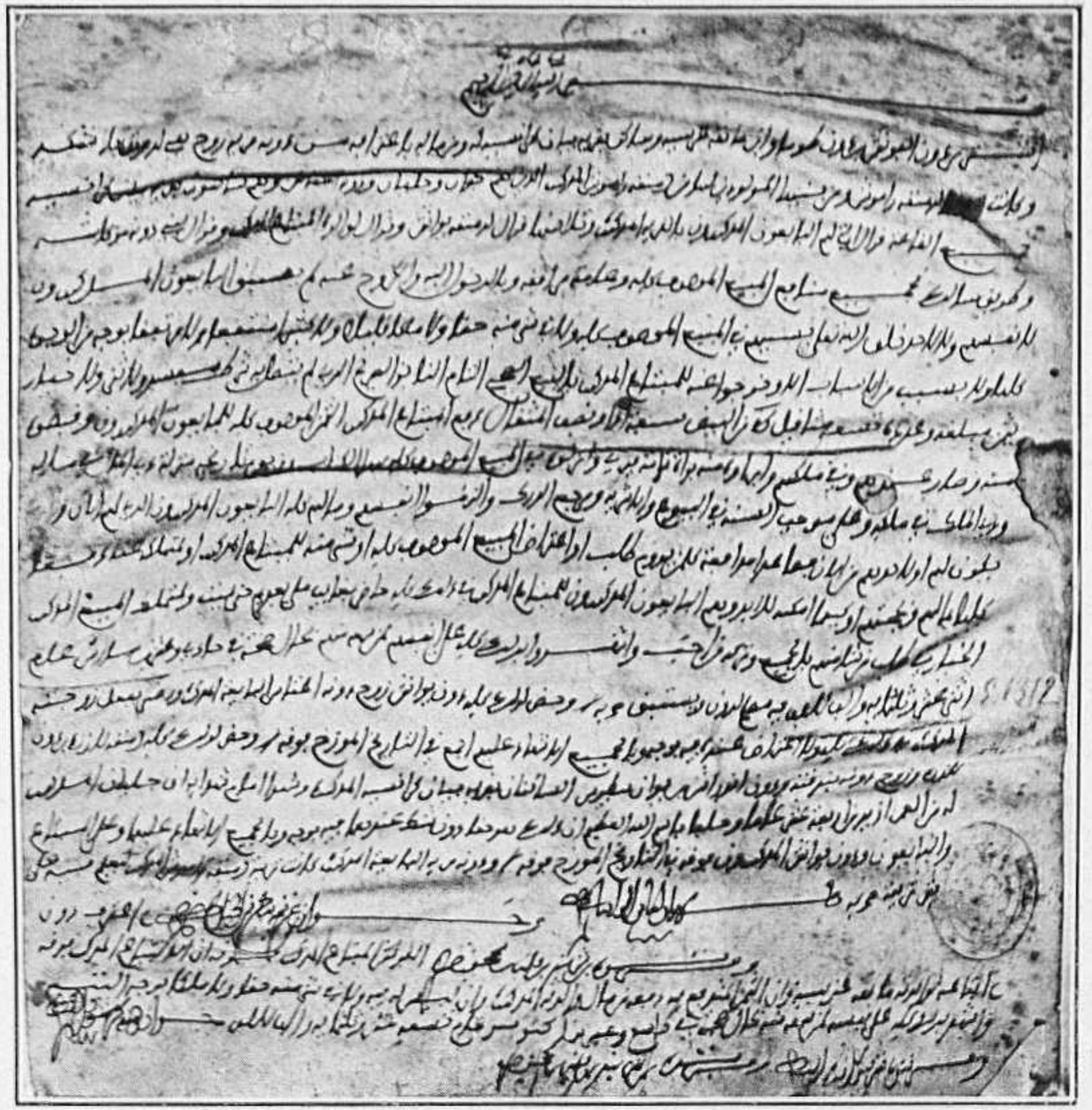

Compraventa: 21 de Marzo de 1274 (núm. 640). 


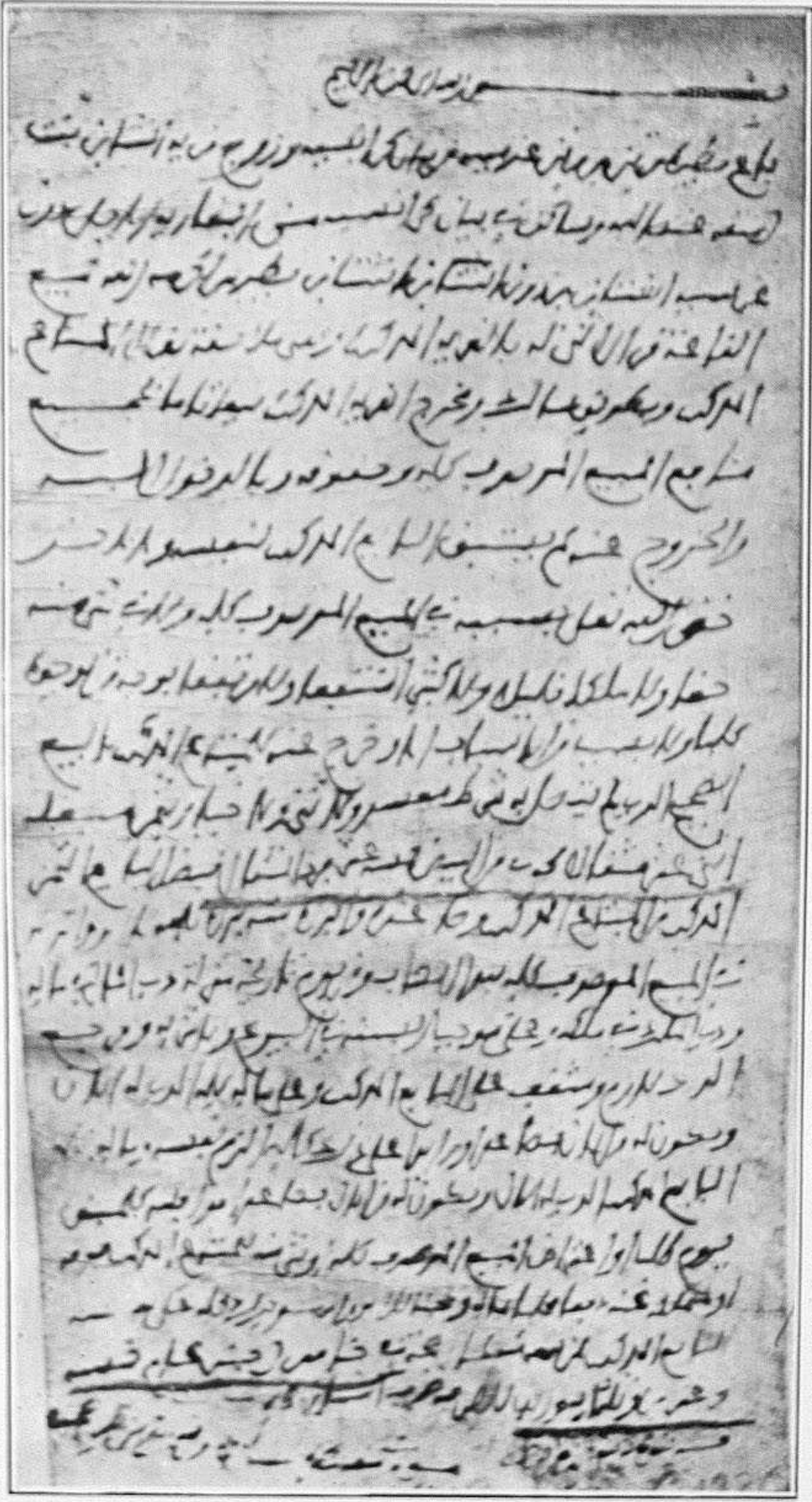

Compraventa: 5 de Diciembre de 1287 (num. 695) 


\section{I I}

\section{ADQUISICION DE LA PROPIEDAD}

443. Siendo la colección de documentos que vamos esludiando en su inmensa mayoría títulos de propiedad, es claro que los datos más numerosos que arrojan sirven para conocer el aspecto de la vida jurf́dica del pucblo que los redactó. Agru. pamos las notas interesantes para conocer el modo de adquirir la propiedad con arreglo al cuadro adjunto:

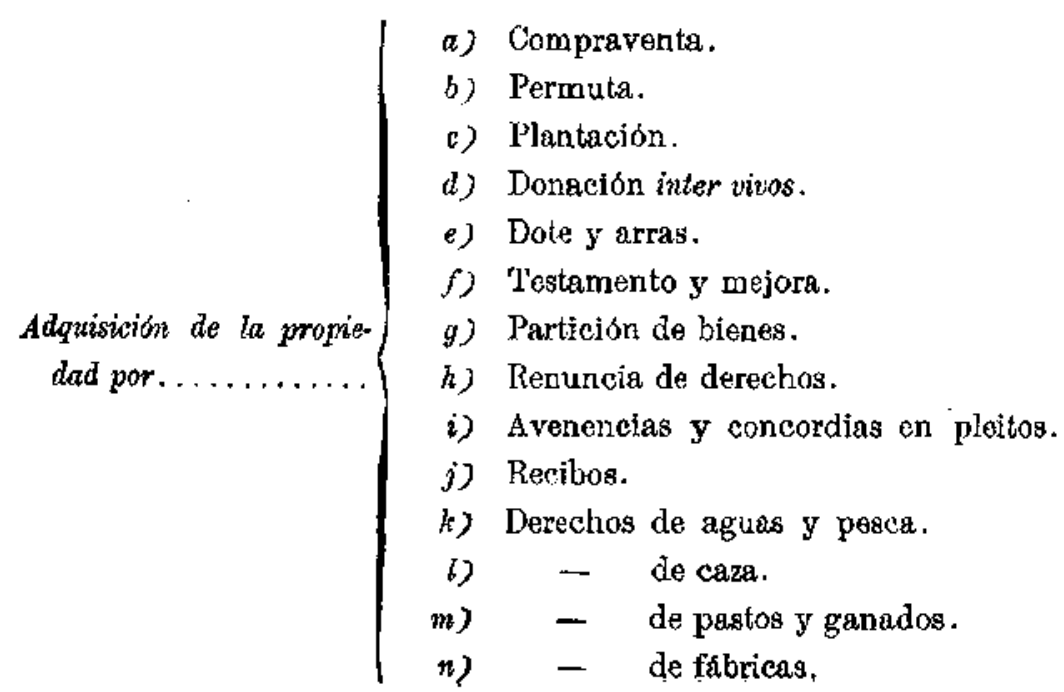




\section{A. COMPRAVENTA}

444. El mayor número de documentos de esta colccción lo forman las escrituras de compraventa, que suman hasta 766 , sin contar las redactadas en hebreo.

Casi todas las escrituras de compravenla se desarrollan con un patrón igual:

1. Indica las personas que intervienen en el documento y el objeto de la compra: casa, finca, derecho, etc.

2. ${ }^{\circ}$ Sigue luego una formula, uniforme casi en toda la coleccion, fórmula que se ha suplido ect la traducción del texto arabe, y que dice, poco más o menos: *Con todas las utilidades completas, y con la tolalidad de sus provechos, en toda clase de especies, así en el suelo como en el aire, con los derechos y propiedades a esta venta sobredicha en ella o por causa de ella pertenecienles, así dentro como fuera de ella, y lo mismo en sus entradas o salidas; sin reservarse el citado vendedor para si, ni para nadie por él, cosa alguha de la lotatidad de la venta meocionada, derecho ni propiedad algun, pequeña ni grande, ulilinad ni provecho, por ninguna razon ni motivo alguno, sino que lo aparta de este derecho el comprador por una venta perfecta, completa, jrrevocable, pura, sin mácula ni defecto, que no lleva aneja cordición viciosa, ni clásisula de retroventa ni de opeión» (1).

$3 .^{\circ} \quad$ Precio.

4. Formula de posesión y de evicción: e Entregó el cilado comprador todo el dinero referido al vendedor, quien lo recibio de él, viniendo a sus manos, a su dominio y a su poder; y le dió en toda la venta descrita la posesión especiai del dueño en su cosa y del propietario en su propiedad; después de haberse enterado las dos parles de la cuantía de la venta, de la suma del precio y de la conclusión del contrato; sin ignorar nada de él, y siguiendo la ley de los cristianos en sus ventas, compras y devolución del daño o evicción.

$5 .^{\circ}$ Testigos: *Fué testigo, a ruego de ambas partes, en to mencionado, quien da testimonio de que ello ha pasado según se dice, y lo oyo de las dos partes, y las conoce, y sabe que están en el pleno uso de sus facultades y con capacidad legal para coniratar * (a).

(1) Véase el tomo I, pággs. va y vin.

(2) Las fórmulas empleadas en los documentos hebreos son sustancialmente las mismas, como puede verse en el documento núm. 1.136; solo quo en éstos puede seguirse la loy de Ierael o la ley de otros pue. blos, micntras que en los mozárabes se sigue siempre la ley do los cristianos.

También tiene la distjpción do que muchos docuwentos son certificaciones expedidas por tribunal logal (mim. 1.184). 
445. Evicción y saneamiento. - Naturalmente que estas fórmulas no son tan matemáticas que pueda decirse que en todos los documentos son iguales. En la fórmula indicada en el anterior apartado $4 .^{\circ}$ hay diversos matices, en el punto referente a la evicción y sancamiento de $s_{j}$, o Marjadraque, de los documentos cristianos (1).

Algunas veces, raras, uno de los vendedores no se obliga a la evicción (múmero 639) o a toda reclamación s6lo por una mitad de la cosa vendida, mientras que por la otra mitad se compromete nada más a la evicción y saneamiento usua. Ies (núm, 490). Otras mnchas el vendedor se obliga a satisfacer cualquier reclamación que se haga sobre la venta, sin duda porque no estaría claro su título de pro. piédad (núms. $81,159,212,274,292,302,315,411,422,443,452,461,471,493,514$, $519,551,560,722,1.099$ y 1.106 ), indicándose en ocasiones la persona que pudiera reclamar algún derecho: la esposa u utra persona por ella (núms. 455 y 1.110), el hijo (núm. 458), los parientes del marido de la víuda, que vende en unión de sus hijos (núm. 284), la hija menor de la vendedora (núm. 147), de la esposa, de los hijos habidos en la primera mujer, de los otros que tenga, de su hermano y de cualquiera otro (núm. 1.105). El vendedor tambien podía obligarse a satisfacer la reclamación y a la vez a que aprobasen su acto las persones que pudieran resultar inferesadas, v.gr., los hijos ausentes (ním. 139), la esposa (ṇím. 64), el dueño caulivo, si vuelve del cautiverio, o su representante, si no vuelve (núm. 120).

Cuando esta cláusula de cvicción no podía cumplirse, el comprador se compromelfa a devolver el precio de la venta (núms. 49 y 51), o el precio doblado (núm. 33) o triplicado, ssegín dice la ley" (núm. 446); o cargaba la obligación sobre un hermano (núm. 544), o sobre varios (núm. 715). Pero lo más seguro era poner un fiador, que el comprator aceptase (núms. 105, 232, B04, 606, 627 y 700), que podía ser de la familia del vendedor (núms $561,598,1.113$ y 1.118), un apoderado (ntimero 580) o persona de su casa (núm. 662) (2); los judíos presentabun como flado. res a otros judíos (núm. 714). En otros casos, además de obligarse a pagar el duplo del precio, se afectaba como garantía de la evicción a otras fincas del vendedor ( $\mathrm{o}$ h. meros 446, 673, 674 y 675); a se ponía el fiador, que con fincas suyas ciladas expresamente garantizaba la evicción (núms. 112, 474 y 559); o se compromelía a duplicar el precio y pońa, además, fiadores (núm. 33).

A la eviccibu de ana venta en Azaña habfa de salir el rey, pues el había dado al causante de las vendedoras la finca a cambio de otra, según documento que en-

(1) Sobre Marjadraque, según fuero de Toledo, veage un articulo del P. Fita en el Bolettin de la Real Aealemia de le Bistoria, VII, pág. 360 .

(2) So comproucte a la cyicción de una venta tivira Petrez, la que vive con el vendedor, canónigo de Santa Leocadia. Estri presente y aprueba la venta ella (num. 662). Nota curiosa para el estudio de la condición jurídica de las barraganas. 
tregaban (núm. 175). Si el rey o alguno se hacía (lıeño de las casas vendidas, cl fiador quedaba obligado a la evicción (núm. 561). En una venta se estipulaba por las dos partes contratantes que esi la gente de Segovia reclama a la Catedral (compradora) por la casa vendida y el rey la da a los de Segovia sin sentencia judicial, no está obligada la vendedora a la evicción; pero si el rey la da después de sentencia judicial, la vendedora se obliga a devolver el precio íntegro de la venta a la Catedral* (nó. mero 334). Se excluye de la evicción el derecho a usar una ventana y un vertedero de aguas de las fincas vendidas (núm. 1.146).

Si por razón dol derecho en unas tierras padiera tocar algo a la finca vendida en eras, casas o huertos de la alquería donde eslaban enclavadas, el vendedor sc obliga a unir estos derechos a la finca en cuestión, y mientras no se haga, no habrá evicción y saneamiento de la venta (núm. 178).

El vondedor de una casa por deudas se obliga a satisfacer cualquier reclamación que pudiera hacerse acerca de la venta, como si la casa pudiese estar hipotecada antes (núm. 240).

446. Tltalo de propiedad. - No suele omitirse la indicación del título de propieded que el vendedor tiene para poder oforgar la venta, y de ordinario se inserta dentro de la primera parte del documento. Se detalla minuciosamente la transmisión de la finca hasta llegar a poder del vendedor ( $n$ úm. 280); se especifica la procedencia de las fincas vendidas (núms. $321,378,599$ y 600); si se trata de varias fincas distintas, se señala la procedencia de cada cual: herensla, compra, donación, etcétera ( oúm. 107), y si son varios trozos de la misma finca, se cletalla la proceden. cia de cada uno de ellos (núm. 368).

Se adcuiria la propiedad, por merced del rey, a los pobladores (moratores) de una alquería (núm. 745), alguno de los cuales compraba la parte de otros (número 393). Fin el Repartimiento de Sevilla por Alfonso $X$, obtuvieron alguna finca los hermanos García Pelrez y Gonzalbo Petrez (núm. 990). En ocasiones, la licrra por donde pasaba el río Tajo y luego se desviaba, se la apropiaba alguno y la cultivaba, adquiendo así derechos de propiedad (núm. 421).

Cuando la finca se adquiria por herencia, bastaba con decirlo, sin ser necesaria otra justificación (núms. 24, 449,453 y 540 ); el heredero podía vender, alguna vez con aprohacíón de los albaceas (núm. 269). Indícase que la finca procede de herencia del padre (núus. $35,223,228,231,387,422,443,564,617$ y 716 ), a veces vendida para pagar las deudas de! padre y los gastos del entierro (núm. 254); o por herencia del padre, por el tercio en que mejoro a uno de sus hijos (núm. 171); o por herencia del padre y del marido (núm. 199); o del padre y de un hermano (núme. ro 533); a del padre on la partición con sns hermanos y cuñados (núm. 561); o por herencia del padre a su hija, que la poseía por herencia de su madre, y ésta de su padre (núms. 280 y 525); o del abuelo, a quien hereda su bija y luego el hijo de ésta (níns. 16 y 274); o de la madre (núms. 330, 377, 392, 482 y 500); o de la madre, 


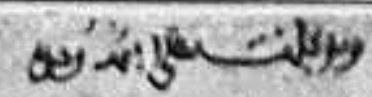

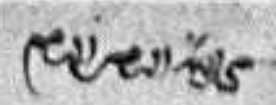

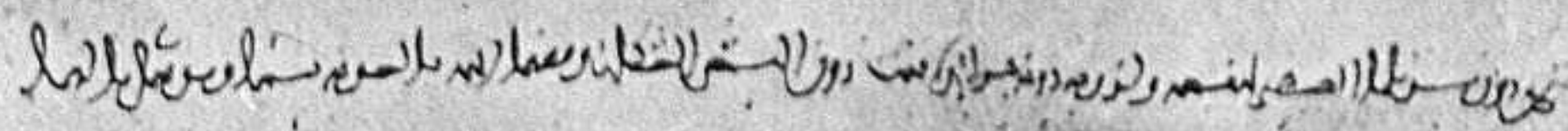

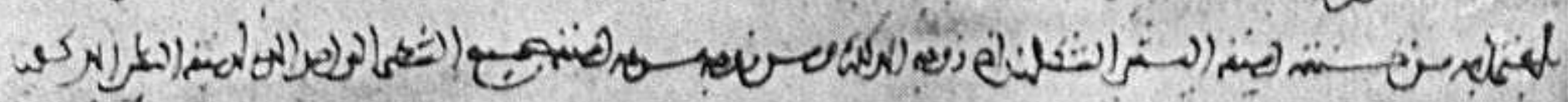

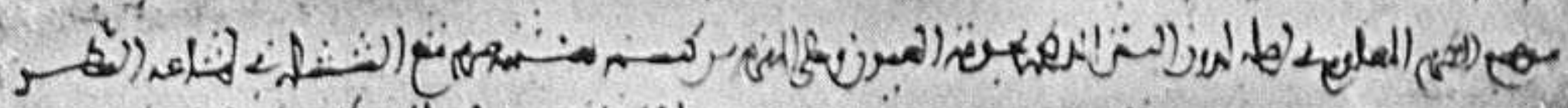

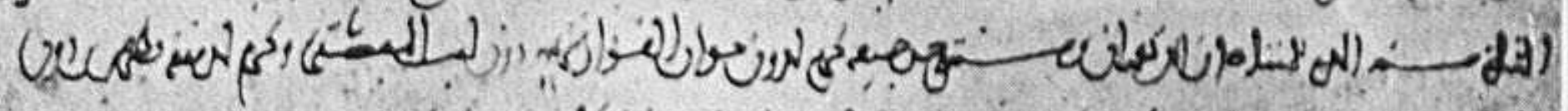

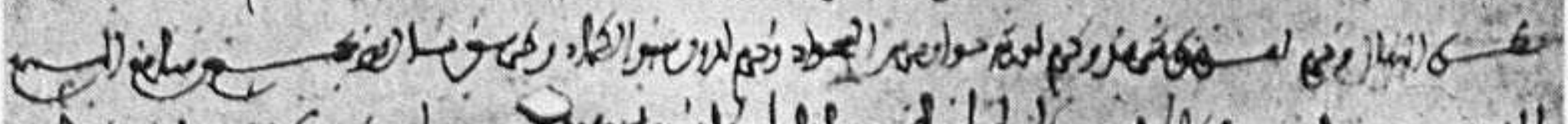

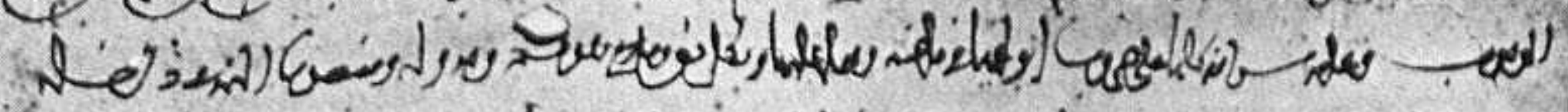

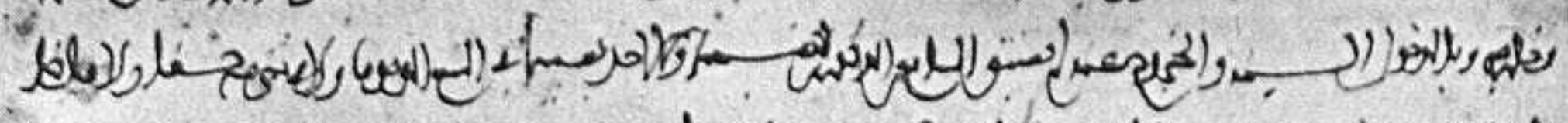
(20)

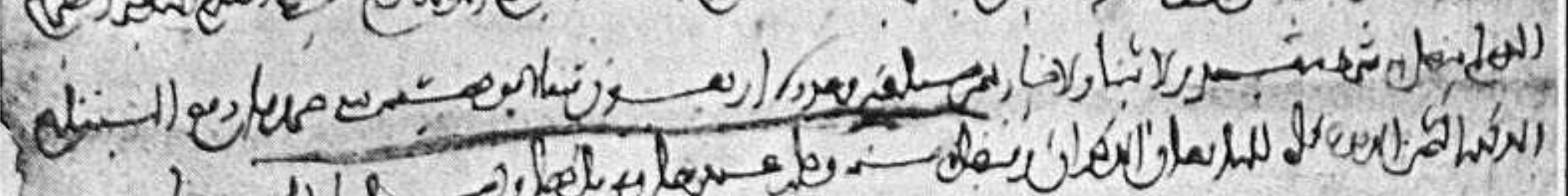

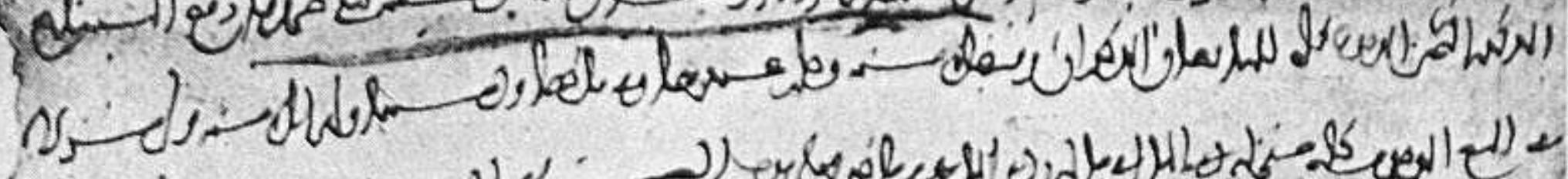
(t)

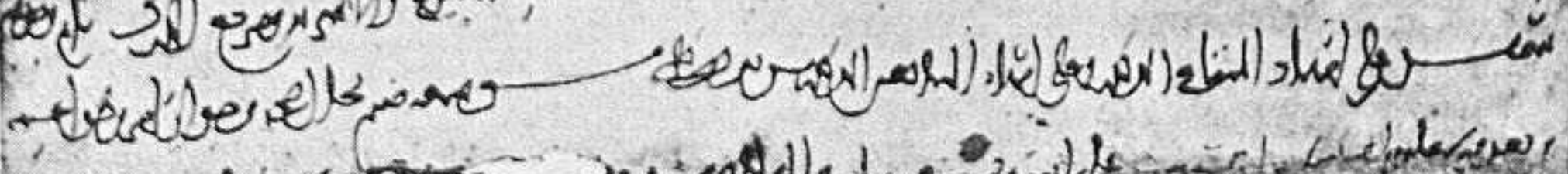

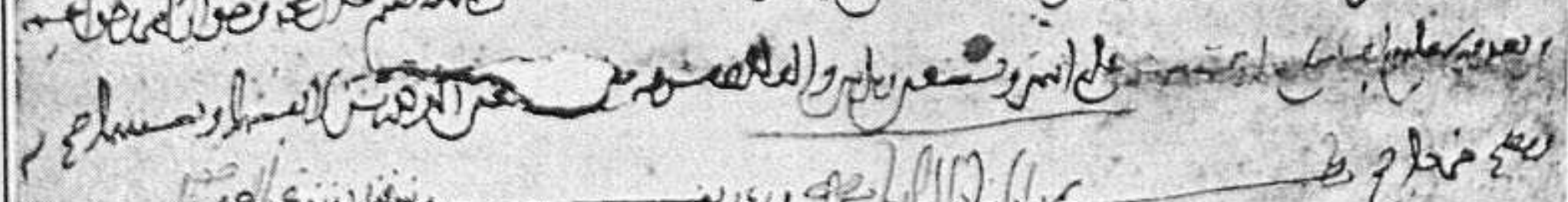

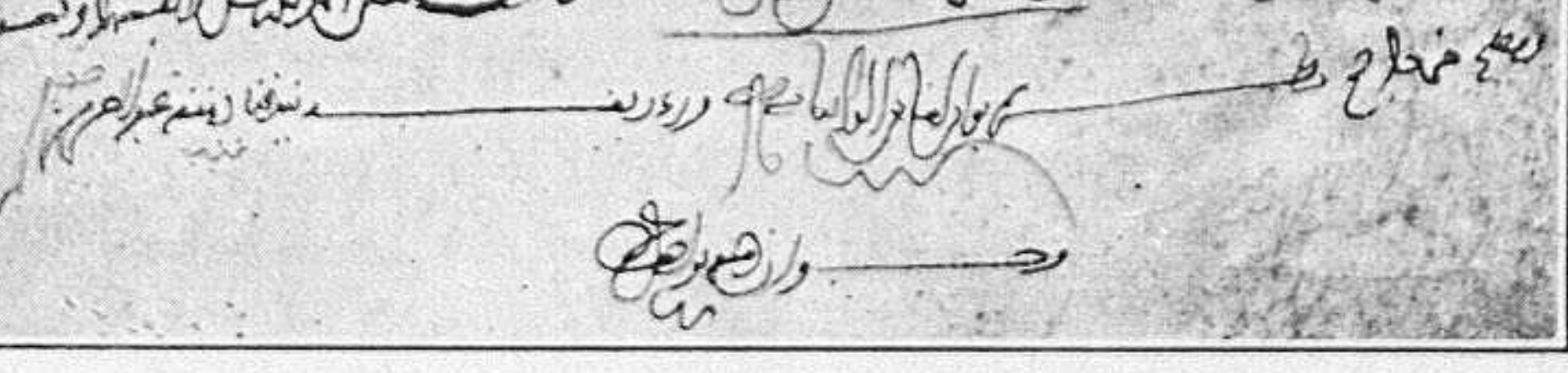

Compraventa: ¿7 de Agosto? de 1254 (núm. 589). 
partida con sus liermanos ( núms. 24 y 645); o por herencia y donación de la madre (núm. 345).

A veces, las fincas eran heredadas de un tío (nútms. 157, 337 y 644), aunque los bienes procediesen de la línea del marido de la tía carnal (núm.704); se entregaba entre los títulos de propiedad el testimonio de la entrega de la casa por los albaceas a la heredera (núm. 1.111); se declataba la procedencia de la finca vendida: mitad por herencia de una tía y la otra mitad por deudas del marido de aquélla ( núm. 490). A veces se heredaban las fincas de los abuelos (núms. 109, 252, 315,348 y 416 ), o de un hermano del abuelo (núm. 444), o de un hermano (uńme$\operatorname{ros} 420$ y 421 ).

También se indicaba como procedencia la partición de los bienes del padre con otros hermanos (núm. 153), o la partición con el padre (núm. 301), o la partición con el otro comprador ( núm. 285), y la donación (núms. 362, 406, 45̃1 y 535)), en ocasiones del padre a una hija, declarando haberla hecho con anterioridad a la fecha en que la hija vendia (núm. 85), o de la madre (núm. 483), o de tío a sobrino (núm. 642), o de la abadesa de San Clemente a un empleado del convento, de cuyos hijos la vuelve a comprar el monasterio (núm. 521).

Cuando no babía título de propiedad se podia suplır con una información testifical: así se da testimonio en 1146 de que unas tierras blancas de Talavera, que plantaron unos judíos, eran de Monudías, y, a su muerte, de Micael Madlas (número 1.048); o de la Iransmisión de un sexto de Algorfilla, casa en San Vicente (Toledo), y huerta en Alaitic, que Oraborn Jos dí́ a su hermano Gonzailbo; de éste los hereda su esposa y de ésta pasan a manos de la Catedral (núm. 1.056); o de que el arcediano de Guadalajara, D. Pedro, tenía una tierra debajo de Talavera, en la aldea de Fornillos y en el mejor lugar de esfa aldea, de cabida de cuatro cahices de simiente de trigo o más; la tierra era del convento de San Clementę y el arcediano decín: "Cuando la abadesa sepa que yo estoy en Talavera, envícme un delegado suyo y le entregaré dicha tierra; si no, la perderá (núm. 1.057); o de que tres partes de viña en Valdecubas eran una sola primitivamente, que se había partido con el convento de San Servando, más de treinfa y un años antes de la fecha, en virtud de conteato de plantación (núm. 1.130); o de que un colmenar en Bachel era de Chábir Buchel, $\mathrm{y}$ antes había sido del alguacil y alcalde D. Esteban IJIanes; que tres individuos lo poblaron por encargo de los herederos del alguacil, y que el arcediano, D. García Ésleban, lrijo del alguacill, lo había poseído durante sa vida (nám. 1.059); a de que una habia tenido una yugada de tierra en Torre Abenyúnus, por labrarla y cultivarla en representación de la dueña, levantando allí una casa, pagando los diezmos usuales y beneficiándose de sus productos (núm. 1.062).

Los plazos de prescripción eran de treinta años y de cincoenta años (núnero 941).

Cuando la finca sendida habfa sido adquirida por compra (núms. 111, 227, etc.), 
solia entregarse la escritura anterior (1), que se reseña sumariamente. A veces consta la declaración del comprador de haber recibido los iftulos de propiedad (nóms. 280 y 679). Otras veces se entregan unas y se excusan de entregar otras es. crituras de propiedad, por haberse perdido (núm. 675); olras, se obliga el vendedor a entregar los lítulos en el plazo de ar año, así que hayan hecho la parlicion de los bienes (púm. 566); o hace notar que goarda vatias escritaras para el saneamiento de la compra, con obligación de enseñarlas siempre que fuera menester (núm. 720); o se muestra la escritura de parlición y se obliga el que la tiene a mosirarla y entregarta a los compradores de fitucas que en ella se incluyen, si fuere preciso para registrar ante el nádir la compra (núm. 684); o se enseña el título de propiedad, que se queda en poder de la vendedora misma (viuda que adquirió por compra a su marido); o se entrega el t(tulo de propiedad del corral donde luego el vendedor había construido una casa (núm. 238).

Si faltaba el tifulo de propiedad, podia suplirse con una declaración de los due. ños anteriores de haber vendido la finca (núm, 74), y hacer un leslimonio nuevo de haberse hecho la transmisión (núm. 291), y si se había perdido la escritura, se excepluaba la parte de finca a que se referfa, en olra posterior (núm. 21).

En ocasiones, se hacían las ventas de palabra solamente, y después se daba testimonio de haberlas becho (núms. 251 y 317 ), indicando, de ordinario, el tiempo transcurrido desde el otorgamiento verbal: doce años (núm. 30), diez años ( $n$ ŕn. mero 143), más de un año (núm. 422), dos años (núm. 423), tres años (núm. 496), cuatro años (núm. 569).

A veces, se refundían en una sola tres escrifuras de compra, hechas a su debido tiempo (núm. 243); o se hacia una declaración de venta, sin las fórmulas corrientes, sino como teslimonio dado por el vendedor ( núm. 317).

Se cuidaba escrupulosaarente dic anotar ios linderos, rectificando la errata de uno de ellos (núm. 216), añadiendo algunos a los dados en el texto (núm. 316), rec. tificando el nombre de los colindantes, si se habian equivocado (núms. 548 y 679). Si se vendían suertes enteras, partes completas de 9ncas (un octavo, un cuarto, etc.), no solian delimitarse, seguramente porque estarian las fincas todas bajo una linde (núm. 54).

La compra se registraba ante el nódir, y para eso so presentaba el título viejo $\mathrm{y}$ el nuevo (núm. 684). Había que pagar un diezmo en venta de casa en 1270 por 252 mizcales, sLa milad de su diezmo era 12,5 mizcales (núm. 1.135). El diazma se

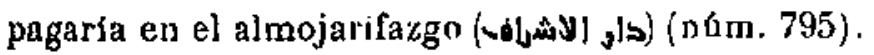

447. Compraventa por medio de apoderado. - Cuando el que otorga una escri-

(1) Ontto la roferencia de los docuuentos on quo consta este detallo de entrega de escritura anterior, por ser muy numerosos : una grall parte de los contratos de compraventa de nuestra colección lo indf. can, como puede comprobarlo el lector con bólo hojear el tex to de nuestros volúmenes I y U. 
tura de compra no es el mismo interesado, se dice claramente que interviene en nombre y con dinero de otro (núms. $98,121,257,284,288,417,486$ y 1.114), bien scan de la familia: hijos (núm. 281), hermanos (núm. 12), tíos (uúm. 541), bien sean mayordomos (núm. 482), o representantes de alguna institución, como el Cabildo Catedral (núms. 126,161 y 191 , etc.). Y si después de redactada la escritura, algún otorgante no puede comparecer, se indica que a la firma de los testigos compareció otra persona en su representación (núms. 195 y 543).

A veces declara un comprador que lo hace con su dinero propio, y al final del documento rectifica, diciendo que el dinero es de su padre (núm. 382); o siete años después declara en el mismo documento que compró con dinero de su madre y para ella, y que no tiene en la cosa comprada derecho alguno (núm. 640); o que la com. pra la ha hecho para una fundación de capellanías que dispuso un tercero, y con los dineros que éste dejó para tal fin, por lo cual entrega la carta de compra a la hermana del fundador, que sería patrona de la fundación (núm, 723); o que la compra que se hizo a nombre de uno (Nicolás) onee años atrás, habra sido con dinero de otro (Feliz Micael, canónigo), y por tanto que la casa era de éste, que recibe la escritura de compra y asiste al otorgamiento de este testimonio (úm. 1.053).

En varias escriluras se haoía constar que una madre colapraua para su hijo con dineros propios de éste, que el rey le daba dé su sueldo de secretario (núme$\operatorname{ros} 663,692,693$ y 1.115). Y no obstante tal declaración, hizo la señora un documento independiente afirmando esa tmisma circunstancia de ser de su hijo todos aquellos hiehes asi comprados (núm. 1.066).

El apoderado, en una compra, declara que la hace por encargo de la reina, y según la carta que ella liabía escrito a dos alguaciles y al arcediano (áím. 326). Una compradora, ama de cura, dice que si ella muere antes que el sacerdote será la casa comprada para éste (nim. ō16).

Lo mismo ocurtria si una persana vendía en nombie de otra (núm. 698). Tres testigos declaraban haber visto al dueño de una casa, ausente en Calatrava, y que el les había dicho estar conforme con que sus hijos, presentes en Toledo, vendieran una casa (núm. 121); y dos tesiigos declaraban con juramento que uno, al salir de viaje, hahía encargado a su esposa que vendiera una casa (núm. 498).

448. Precio. - Lo normal es que el precio se entregue en dinero, mizcales, o sca monedas de oro, aunque alguna vez se pague en especie: barbecho en Canales, el grano que había ea esta alquería, el asno y la vaca, valuado todo en $7 \frac{1}{2}$ mizcales (núm. 98); o se pague en diaero y una víía (núm. 4); o se ponga como precio otra finca, lo que es, en realidad, una permuta (núm. 406). Si quedaba parte del precio por entregar, la venta no se formalizaba; y muerto el comprador, sus herederos se presentan a pagar el resto, y entonces se otorga cl testitaonio de venia (núm. 364). Alguna vez se anticipa a cuenta de la compra (núm. 126).

El deseo de completar una finca, comprada en varịas partes, solía pagarse: una 
viña adquirida en tres veces, vale, en los dos primeros tercios, 95 mizcales, o sea $47 \frac{1}{2}$ cada tercio; el último cuesta 52 (núm. 9).

Ordinariamente no se hace constar la procedencia del dinero del precio; pero a veces se dice, ya sea procedente de la venta de otras fincas (núm. 469) (y esta declaracion la hace la compradora en presencia de su hijo, núm. 466), ya se tome del quinto de libre disposicion de un hijo difunto, para cuyo aniversarin se comprn la finca ( $n u ́ m .166$ ), ya de mandas testamentarias, en dinero y en muebles, y de regalos que el comprador recibla de las personas nobles por coseñar a leer a sus hijos, nietos y parieutes (núm. 369); ya de mandas para fines piadosos (núms. 161, 710 y 714).

En ocasiones, el precio de la venta lo entrega una tercera persona en nombre del comprador, aunque la venta se hace a nombre de éste (núms. 245 y 544); o aunque la compra la haga un convento por su apoderado, entrega el precio no éste, sino un judin, administrador acaso del convento (núim. 432). Con el precio de la venta se paga, si es caso, a los acreedores del comprador, judíos (núms. 549 y 573); y, alguna vez, como el precio total no alcanzaba al de la deuda, el vendedor, deudor, ruega al comprador, acreedor, eu untón de gentes houradas, que dispense la falca, y el acreedor se do por satisfecho (núm. 575); y otra, por el contrario, el vendedar deja de percibir hasta una tercera parte del precio, regalándola al comprador, que es la Catedral (núm. 255).

Rara vez se hace la venta a plazos: se cobra el precio parte al contado, parte unos meses después (ním. 110); o se enlrega parte dol precio, comprometiéndose el comprador a entregar el resto unos meses más larke, y, en caso de no pagar, quedaba libre el vendedor para vender la finca a quien quisiera y cobrarse el dinero restante; se haća constar la entrega de parle del segundo plazo (núm. 281). En una venta por $5 \frac{1}{2}$ mizcales queda el comprador debiendo el medio mizcal: por esto no se firina la escritura hasta fecha posterior, en que da un cuarto de mizcal, y el vendedor le perdona el otro cuarto (núm. 135). Se formaliza la escritura a la compra del último tercio, cerca de dos años después de comprados los otros dos tercios (núm.9). En la compra a plazos de una viña, el comprador dib en su vida uoa cantidad rorr la finca; después de muerto, su hermano dío el resto, y los dueíos de la viña le hacen testimonio de haber vendido al difunto (núm. 182.)

Se estipulan tres plazos para una venta: uno al pasar Semana Santa, otro para San Juan, y otro para San Miguel. Si no paga el comprador algún plazo, ln vendedora tiene derecho a empeñar, sin mandamiento judicial ni respeto a fuero alguno, los bienes del comprador y a venderlos. Si la compradora alzara sus bienes o se opusiera al embargo, la vendedora le podrá imponer una mudta de la cantidad del plazo que se negara n pagar y doblacla, y empeñar por esta cantidad sin manditio judicial. Pagados los plazos, la vendedora entregaría los títulos de propiedad (consta la entrega del primer plazo) (núm. 259). 
(बiर2)

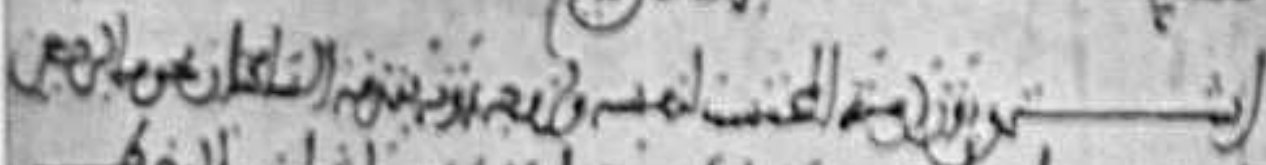

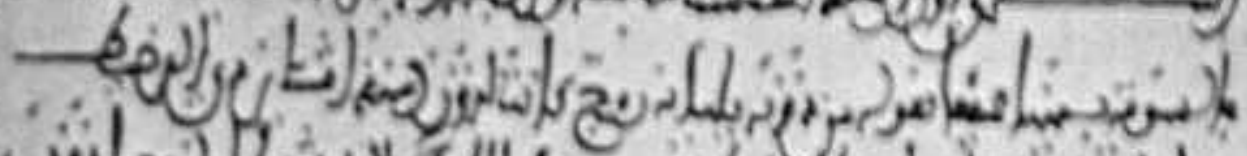
ن सा

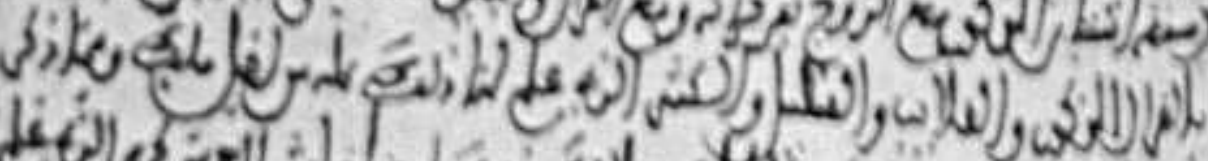

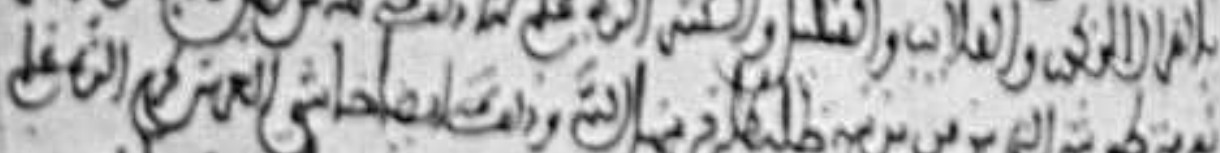

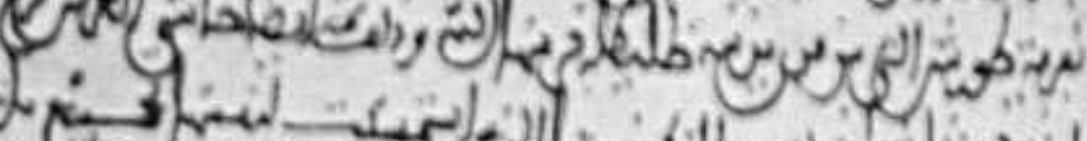

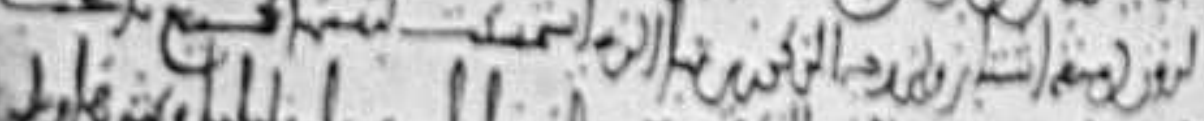

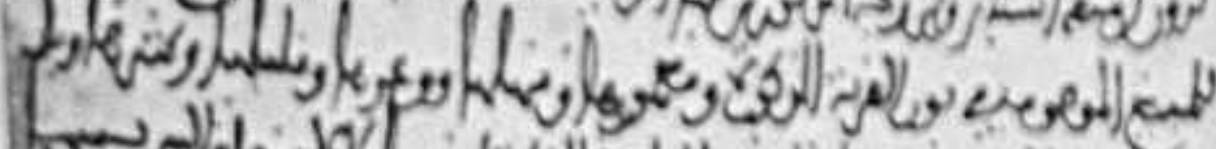

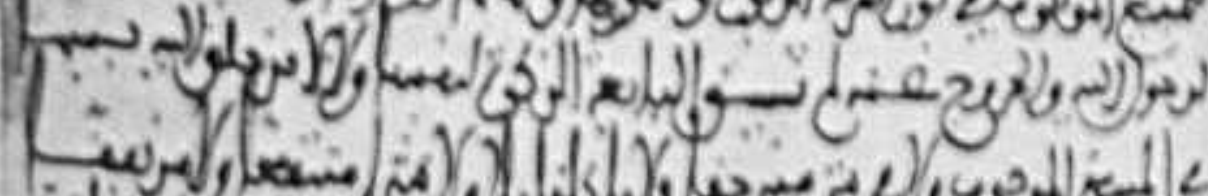

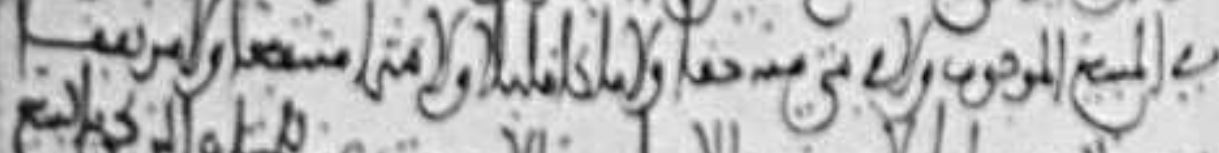

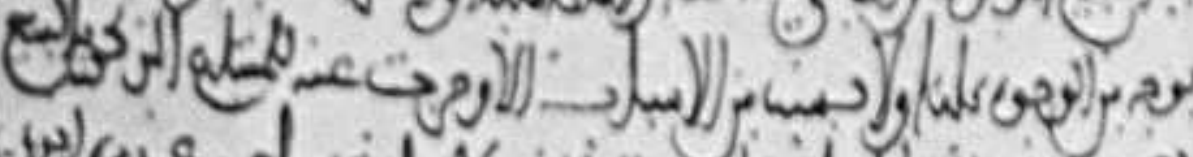
(5) of el el

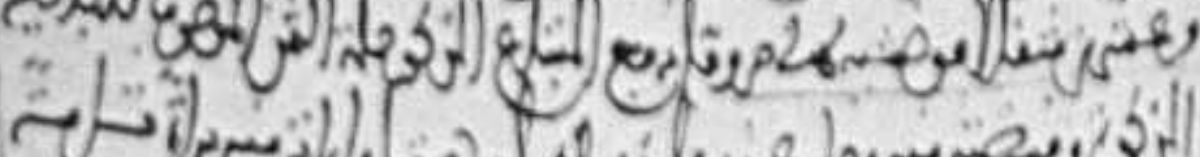

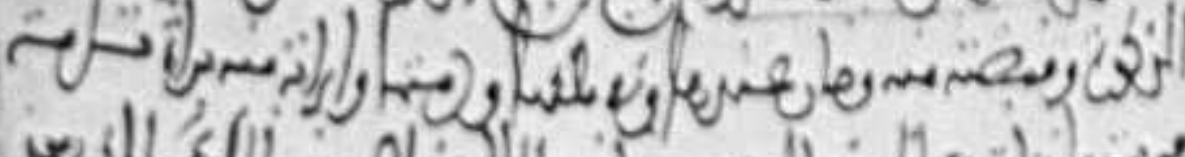
wo

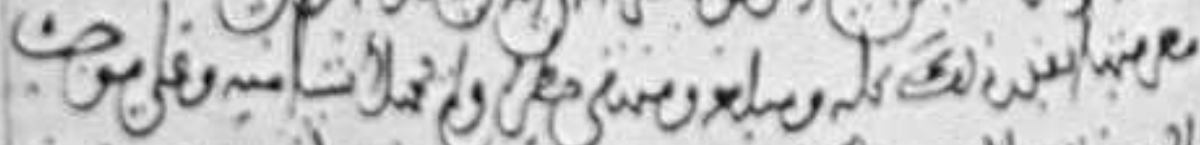

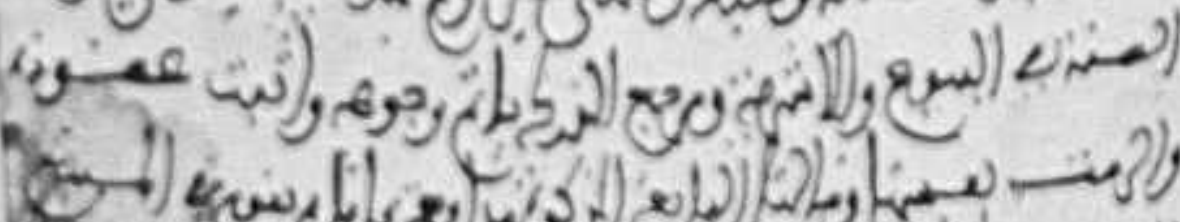

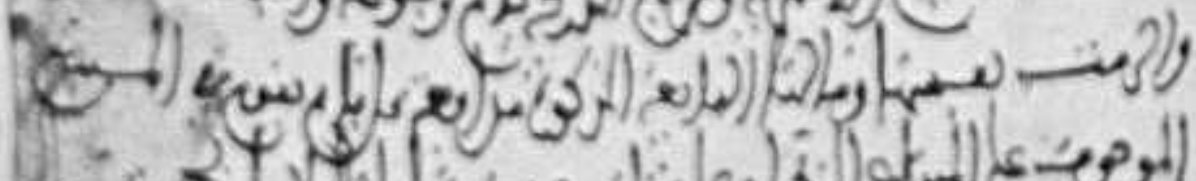

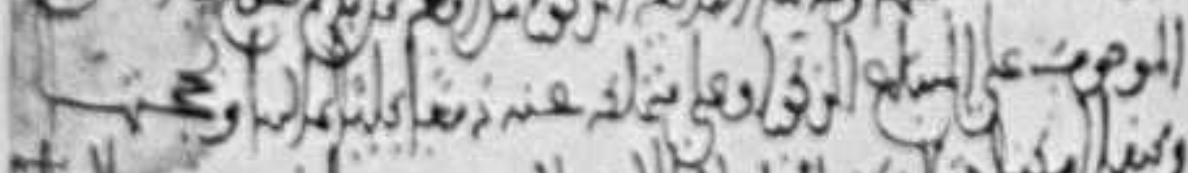
the $\leftrightarrow$ « (4)

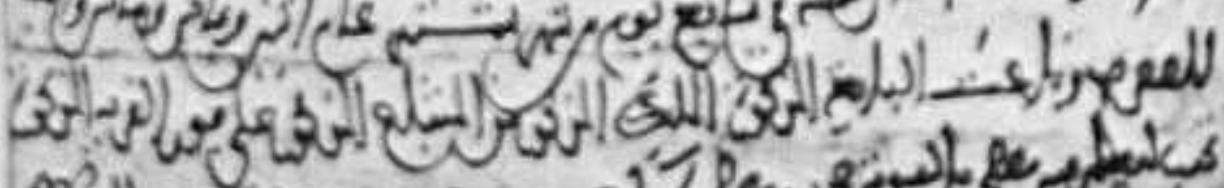

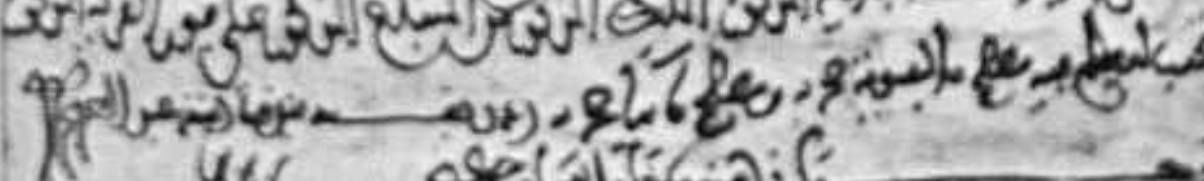
Solkids

Compraventa: 7 de Septiembre de 1244 (núm. 565) 
En algunos documentos se dice: "Por tal precio, cuya mitad es tal ; parece que esto debe entendersc por razón del diezmo (núms. 436 y 1.135).

449. Testigos. - Cuidadosamente se procura poner siempre bien claro lo referente a testigos y su personalidad. Se les identifica en numerosos casos, en todos aquellos en que pod́a surgir alguna duda respecto de sus personas (núms. 92, 163, $183,191,233,245,337,348$, etc.); $y$, casi siempre, al pie de las firmas se ponen las cualidades personales que pueden permitir la identificacion: *el que vive en los Herreros », a el cunado de Domingo Juaness, a el hijo del Pardesal (núm. 1.055), - el sobrino del arcipreste de Uccua * (núm. 983), * el de la Aljama de Santa María Magdalena» (uím. 954), "el carpintero", zel pregonero del zoco del Aícaná (número 199), *el bijo dei alguacil de Calatrava", "el hijo del pescadero (núm. 191), cel primo de $A$ buhafs el Alcalde ( $u$ úm. 163), *el cambistas (núm. 183), sel alfu. rero de Talavera * (núm. 160), "el que vive cerca de San Salvador \# (núm. 134), sel mayordomo del arzablapo en Talavera (uúm. 134), * el Lorquí, cl que vive cerca de Santa María * (núm. 134), "el jeque, el que fué amín en el zoco del Alcaná (núm. 92), kel conocido por Domingo de Mayornoche (núm. 199), sin contar muchos casos en que se indica qutén es el padre del tesígo.

Hay testigos que sólo son de parte del vendedor y no más (núm. 403); o judíos que sólo dan testimonio de los judíos que otorgan contratos con cristianos (números 639 y 964); o que s6lo atcstiguan la recepción del precio (núm. 14); o haber ofdo olorgar la venta at marido y no a la mujer, según dice la escritura (núm. 168). Se retrasa más rle un mes la firma de un documento, y al fin se declara que los iesti. gos son por parle de los vendedores, y que el comprador no pudo presentarlos (nú. mero 290).

En el acta de reconocimiento de una escritura y de la firma de los tesligos, comparándolas con las de otros documentos en que figuran firmatdo, se certifica de que coinciden letra por letia, y cada testigo certifica de la legitimidad de cada firma en particular (núm. 1.093). Se tacha y rectífica lo escrito de haber estado presente una persona al otorgamiento de la escritura, pues no lo estuvo (núm. 808).

Figuran a veces como tesligos las mujeres (núms. 53, 73 y 1.016), y cuando se trata de monjas, naturalmenle, firman muchas de ellas en Ios documentos que otorga el convento.

A veces las firmas se ponen unos dias después de hecho el documento, acaso por duda sobre la aprobación de algunas personas que debian hacerlo (núm. 96).

450. Posesión. -- Ordinariamente se da la posesión al comprador por la mis. ma escritura de compra y en el mismo acto; pero a veces consta el testimonio de haber dado la pusesion de las lincas vendidas, por documento adicional (núm. 689); - la obligación de los vendedores de entregar la cosa vendida en cl plazo de nueve días, bajo pena de pagar 1 mizcal diario de multa, hasta que la entregaran, sin necesidad de mandamiento judicial, ni excepcion de pago, etc. (núm. 599). 
El vendedor de varias yugadas en Olias se obliga a completarlas, caso de que el terreno resulte falto, hasta lo que es corrictute en la alquería; y si sobrara sería para el comprador (núm. 373). En la venta de diecisiete tierras se advierte que ha de bastar para dos yuntas de bueyes, barbecho y sembrado, y si no, que se completarán con otras fincas a más de las descritas (núm. 682).

451. Venta forzosa. - En ocasiones no es voluntario el otorgamiento de una venta por parte del vendedor; tales venias forzosas son, casi siempre, para atender al pago de deudas (uúms. 392,579 y 632 ), indicadas las causas, v. gr., por compra de un caballo al alguacil D. Esteban Julianes (núm 288), o por deudas contraídas por otros coparticipes, parientes de los dueños (núm. 147), o para pago de deudas y rescate de un prisionero de los moros (núm. 628).

A veces la venta se hace por mandamiento judicial (núm, 463), en la forma de subasta, según la costumbre, de cuyo precio se pagaba a los acreedores (núm. 312). Intervenía en tales venlas el alguacil y alcalde: previo el testimmio de dos personas acerca del préstamo, y el reconocimiento que hace la dueña (que tenía la finca pig. norada en favor de uno de los compradores), mandaba vender la finca (núm 75); pregonaban la venta por los mercados durante los días acostumbrados, que solía ser hasta treinta, y después de eerciorarse de que no había quien pagase más, la mandaba vender al mejor postor (núm. 303) (1).

452. Servidumbres. - No es raro ver a unos construir y poseer fincas dentro de solares de los que no son dueños. De la venta de una suerte de tierra se excluye un corral que hay en la tierra ( $r(1 \mathbf{m}$. 296). Lo corriente en tales casos era comprar el solar, después de hecha la edificación (núms. 197 y 374); y se advierte que lo "gastado en cimientos, piedras, yeso, tejas, maderas y puertas, y en hombres jornaleros, no entra en la venta, puesto que ya les pertenecía a los compradores * (número 27). En la venta de una viña entraba un corral y choza, con la condician do que cl vendedor había de vivir en ella un año; pasado este plazo pagaría el vendedor al comprador 3 mizcales y se quedaría dueño del citado corral; si, trancurrido el plazo, no pagase los 3 mizcales, saldría del corral y de las chozas, y pasaría esto a ser propiedad del otro contratante, igual qua el resto (núm. 321). En una flnca constroye una aigorfa un hermano de la dueña; al vender la finca no se vende esta algorfa, y se le da autorizacion al hermano para que abra puerta por otro sitio, y se le permite construir otra algorfa, si quiere (núm. 684).

lid veodedor de una hacienda se quedaha con an corral nuevo en la finca vendida (núm . 642); y alguna vez se venden olivos enclavados en tierra de otro (número 442), o se exceptúan almendros de las orillas (núm.1.136).

la puerta de entrada a una viña era común a otras de otros dueños (núm. 2).

(1) Véase más adelante el capilulo de Procedimiextos, párr, 491. 
Se excluye de la evicción el derecho a usar una ventana y de un vertedero de aguas en las fincas vendidas (núm. 1.146).

453. Mediazerfas. - El comprador de un corral había de hacer pared medianera con el corral y casa de los vendedores; la milad de la pared scría propiedad decada cnal ( núm. 44). Én nua casa, que se parhe, la pared, desde los cimientos de la entrada del zaguán, se construye a expensas de ambos copartícipes por igual (número 89 ). Se vende la habitación de una casa, en Talavera, y se estipula que entran en la venta las paredes oriental, occidental y norle, y la mitad de la pared ancha del sur, coth la que cubre los límites de la habitación vendida; pero que si se levantaba la habitación comprada, ha de levantarse lo que se hundiera con motivo de las obras (núm . 195).

Al lado de una casa, en el barrio de la Catedral, se construye, por los años de 1202, unn almaznra y se vende la almazara: "Con in condición de que el agua necesaria para la almazara ha de correr por entre la parte restante de la casa de don Astor, y de que en los bordes de la almazara haya doce brazas, y en lo ancho, ocbo brazas de espacio para que pase el agua por encima de la casa, y se desvíen estas doce brazas en los bordes do la casa, como límites de la almazara, para su entrada a lo largo, y las ocho brazas a lo ancho para el curso del agua, pues así corria el agua antes de que tuviera casa el arcediano y construyera de nuevo obra para el paso del agua por la almazara y no por la casa de b. Astor. El arcediano [comprador de la almazara] construirá a sus expensas la pared que separa la casa de la al. mazara* (núm, 313).

La Catedral adquiria, en 1207, una algorfa hundida, encima de الهقى suyo; se estipulaba que si la vendedora necesitara hacer los pasos que habia antes por el lado del pasadiza (اله|a ), que los panga, uno en la pared de su easa, y orro en la pared del lado de la calle de la algorfa vendida (núm. 1.075).

Se levanta una botica o tienda en un corral, y para construir el tejado hasta el línite de otro corral, sc abona ana indemnización a la dueña del corral segundo (núm. 519).

El Cabildo, comprador, podía tapiar la ventana que daba a la casa de la ven. dedora; pero no podría levantar cl techo de la algorfa de su casa, conligua a la pared, sin levantar o igualar la cornisa que hay encima de la pared, cornisa que es de la vendedora; $y$ cuando el Cabihdo hubiera de hacer obras, iabría de procurar no tapar esta cornisa (núm. \% 83 ). El comprador de una casa hundida liene derecho a cerrar la puerta que da al corral, y abrir otra que da a la calle (nám. 669).

Para terminar una disensión entre vecinos, por la vertiente de las aguas de dos casas contiguas, en la alquería de An̂, se hega a nn acuerdo, en virtud del cual una de las casas se hará a dus aguas, y luego la pared que divide los corrales, causa de ta disputa; para ello se da un plazo: desde la Virgen de Agosto hasta San Cebrián, pasado el cual todo quedará como estaba, si no se ha hecho la obra (núm. 982). 
454. Limitaciones. - Aceptan, en ocasiones, los compradores de fincas alguna limitación a su derecho de disponer libremente de la cosa comprada; así, ei comprador de una finca en Binal acepta el fuero particular de esle término (núm. 152), como otro la compra al fuero de Zalencas (núm. 580), y otros al de Torres, o al de otros lugares (1); o la condtción de no vender lo que compra a un tercero (cuñada, dueña de la otra mitad de la casa), bajo la multa de 100 mizcales, cuando el precio de la compra eran 50 (núm. 1.109).

\section{B. PERMUT $\Lambda$}

455. Los documentos de esta clase, poco abundantes, suelen tener la siguiente estructura: Se enumera la finca que cada uno de los otorgantes entrega (a cuya descripción suele acompañar la formula 1 de las escrituras de compraventa, rCon todos sus derechos, propiedades , elc.); y luego se pone una fórmula, aproximadamente igual en todas ellas, de este tenor: "Cada uno de los dos cambiadores citados da al otro la posesión de los dichos bienes, que vienen a ser igual que el resto de su hacienda; después de conocer el valor legal de este cambio, su alcance y la conclusión del contrato; según la ley de los cristianos en los cambios corrientes entre ellos, y con la obligación de la evicción y sarıeamientlo. La formula de testimonios es igual que en los demás documentos de la colección.

Permutanse casas dentro de Toledo: dos en el barrio de San Lorenzo en 1156, una más cara que la otra en 25 mizcales (núm. 796); la Catedral cambiaba (1192) una, sita cerca sel matadero de reses, por otra de la crifinadía de los Francos, en la Magdalena, y un corral en San Ginés (núm. 801); el algtacil D. Gonzalbo Vicente, en 1259, daba una casa en el barrio del Alhandac, cerca de la Puerta del Hierro y del Baño del Ferro, a cambio de otra ruinosa, sita en el barrio del Porniello, cerca de la Catedral, que era da doña Colomba Petrez (núm 819), y esta casa del Porniello la daba en el mismo año a la Catedral a cambio de una viña inculta con pe. dazo de tierra blanca contigua, en Manzel Abuishac, de la Sisla, lindante con viña del propio D. Gonzalbo (núm. 821); una casa con algorfa superior en San Nicolás se cambiaba por otra casa en San Cristóbal, y dos pedazos de viña en Almaradiel (ń́m. 826); un mesón del Arrabal de los Francos, tasado en 2.000 mizcales de 15 sueldos, se cambiaba en 1287 por otro en el mismo arrabal, tasado en 500 , abonando 2.000 mizcales por la diferencia (núm. 829 ).

(I) Véase atrás, Señoríos y tueros especiales, pág. 232 . 


$$
\text { 政, }
$$

$1 \%$ 4he

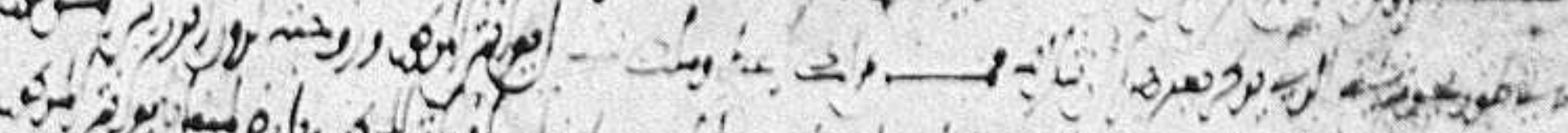

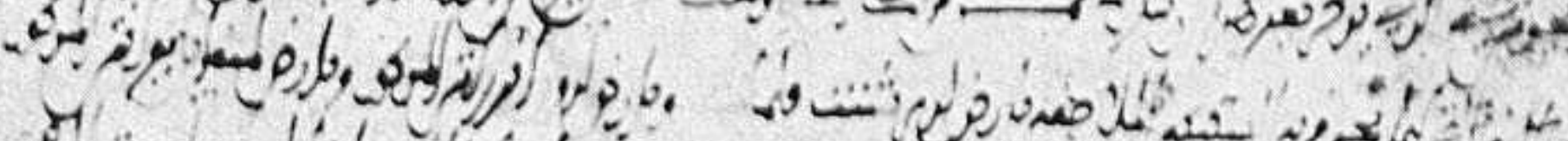

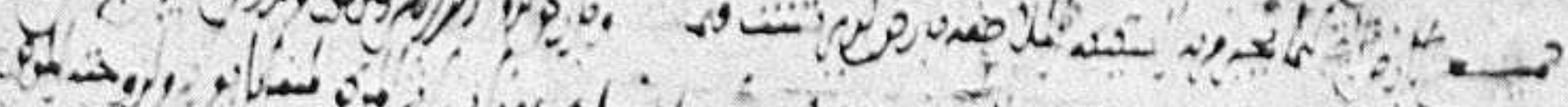

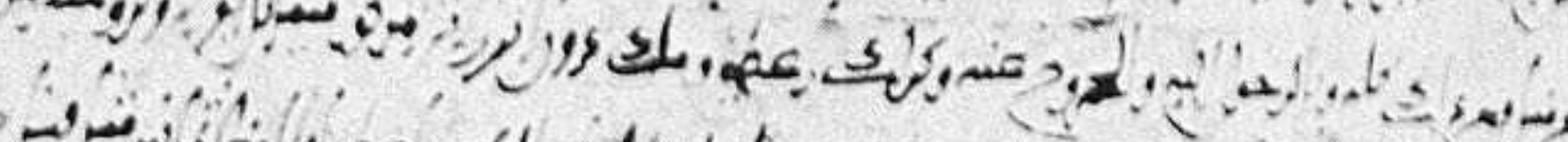

S.

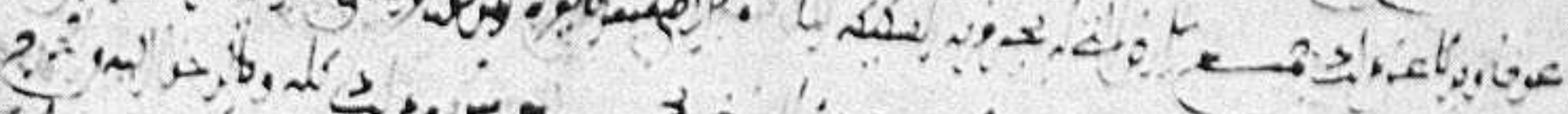

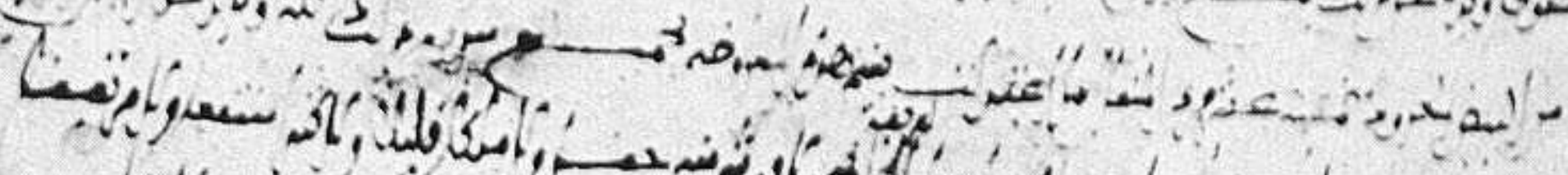

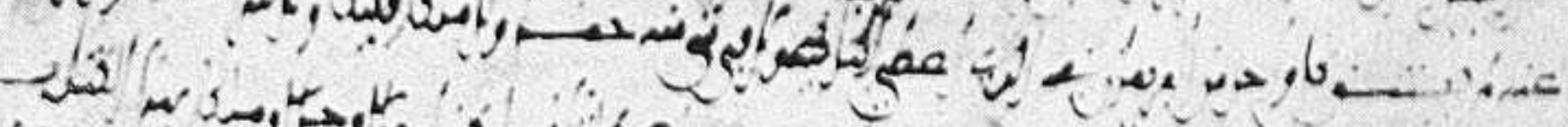
(4)

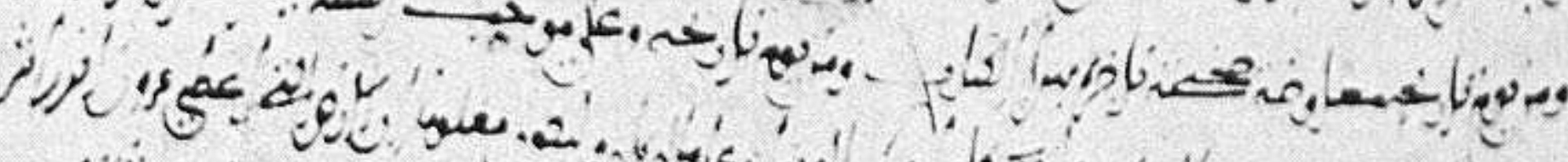
م \%

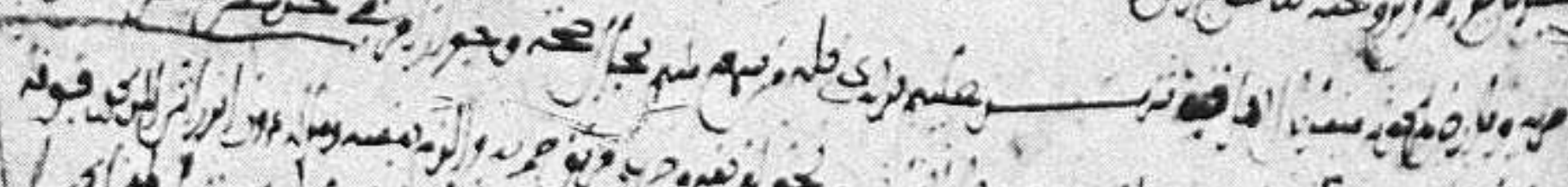

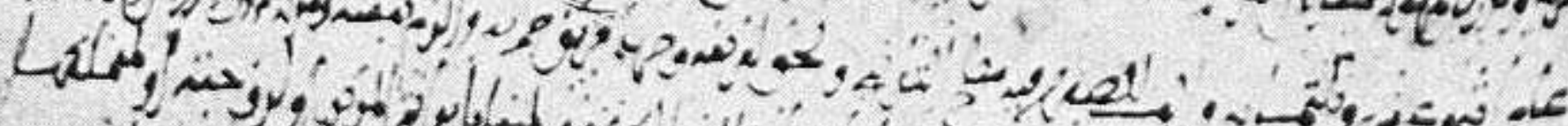
ع

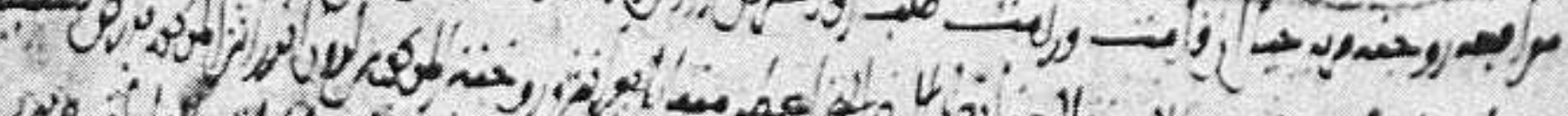

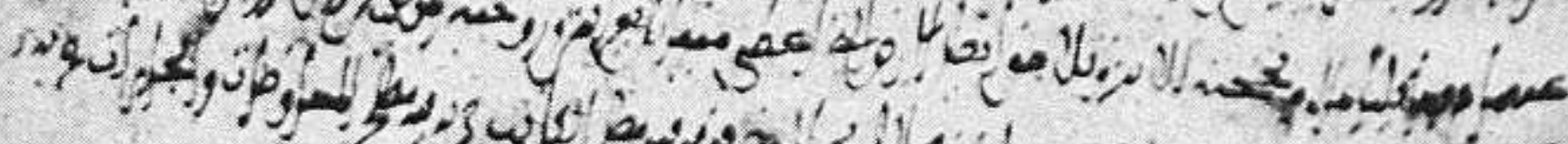

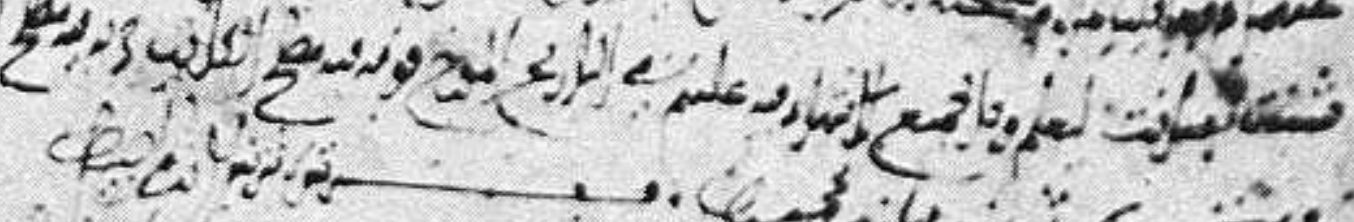

$$
\begin{aligned}
& \text { is: } \\
& \therefore=2 x^{2} \\
& \text { niveos }
\end{aligned}
$$


Otras veces se cambian fincas rústicas por urbanas: Gonzalbo Fernández daha, en 1239, su hacienda de Rielves (tierras, sembrado de dos cahices de trigo y dos cahices de cebada, dos bueyes con sus aperos, un corral y una parte de viña) a su hermano J,ope, a cambio de un mesón en cl Arrabal de los Francos, más 20 mizcales alfonsies de a 15 dineros (núm. 816); otros hermanos permutaban también, en 1254, viña en Azobirín y los derechos en dos herencias por media casa en los Tintoreras, pro indiviso con la otra media (núm. 818); una casa del barrio de San Miguel se trocaba, en 1259, por una heredad para dos yuntas en Torres, con su corral, chozas y palomares, más $67 \frac{1}{2}$ mizcales alfonsíes (núm. 820); el Cabildo catedral daba, en 1260, una casa en San Justo y un pedazo de tierra inculta en Asuic a Gonzalbo Guteriz, a cambio de otra casa en la Trinidad, cerca de las tiendas de los Tintoreros: (conzalbo tenía una huerta junto a la lierra inculta que así adquirla (número 823); cinco sextas parles de una casa que fué del obispo D. Rodrigo Juanes, en San Vicente, se tasaban, en 1280, por unos derechos de tierras en Villamazín, Algorfela, Olías, Cuerva, etc. (núm. 825).

También se ven cambios de tiendas: el convento de San Clemente, en 1210, cambiaba con un judio unas tiendas en el mercado de Talavera, pudiendo juntar así dos tiendas (núm. 808); un cuarto y un octavo en el solar de corral y de choza, en el barrio de San Román, se cambiaba (1296) por un octavo de tienda en Zocodover (núm. 830); una tienda de un judf́o, en el mercado de Talavera, por una tierra blanca en Tarumní, más 11 mizcales, con lo que el convento de San Clemente completó sus tiendas (núm, 802).

Pero abundan más los cambios de fincas rústicas: tun corral en Olías se trocaba, en 1169, por ticrra blanca entre las viñas, por una parte en las higueras de la alquería y por derechos al río contiguo a la fuente de los Parrales (núm. 797); el quinto de varjas heredades en Ocner se daba, en 1179, por mna viña en Manzel Yaix, al otro lado del Tajo, oás 13 mizcales alfonsíes (núm. 798); varias fincas en Monasteles, pro indiviso, por otras en Moraleja, en la misma forma (núm. 799); una suerte de tierra en los ochavos de Abenbahlul por otra, menos cuarto, en los de Abenbadah, en Olíes (núm. 800); beredad en Daralbelio por otra en el umsmo sitio (núumero 270); tierras de labor y blancas, con corral y majuelos, más 30 mizcales en Alameda, por una viña en Alameda, colindante con otra del que da lo primero (número 804); una yugada de tierra mala en Rielves, de ocho cahices de sembradura, y otra de vega, en 1198, por una viña en el caminu de Bargas, más dos mizcales de oro alfonsí (núm. 805); viña en Fontalba por heredad en Ocuer o Yunquer (número 806); tierras en Talavera por otras donde el convento de San Clemente tenía olivos, para adquirir así la propiedad del suelo y del vuelo (núm. 807); tierra en Ocas a cambio de heredad en Villamiel (núm. 809).

La Orden de Santiago y el convento de San Clemente cambiaban (1209-1214) varias fincas en Algorfela, en Argance y Val de Río, para completar sus respectivas 
posesiones, especialmente el convento ( $n$ úms. 810,811 y 812 ); esta misma casa adquiría tres cuartas partes de un huerto y de un prado en Algorfela a cambio de una cuarla parle de otro huerto y de otro prado, con lo que se deshacian dos pro indivisos (núm. 813). Por este mismo procedinienlo redondeaba el monasterio fincas en Olías (núm. 811), habiendo en ocasiones de abonar indemnización en metálico (núm. 814), o dando fincas en otros lugares, como Val de Santiago el Mayor y Torre del Gasco (núm. 817), o ampliaba fincas en Azucáica, adquiriendo los predios colindantes (oúm. 828).

Un corral con dos chozas en Layos, más una haza de prado y heredad pro indiviso para seis cahices de sembradura, más un pedazo de viña incuìta, se cambiaba, en 1264, por un corral con dos chozas, una cubierta de paja, en Cobisa, más una haza de prado, una mitad de haza de vega y tierras para seis cahices de sembradura (núm. 821).

En ucasiones se cambian árbo les, sin trasmitirse la propiedad de la tierra en que estaban enclavados. El convento de San Clemente, en 1193, daba a un judío 12 pies de olivo en una huerta de la Puerta de Cortes, en Talivera, y una morcra, a cambio de 12 pies de olivo eu Canales, sitos en huerta del monasterio (núm. 803).

Naluralmente que al entregar unu finca por cambio se adjudicaban con ella los derechos que pudiera tener etr lo futuro: asi se partiese la alquería entre sus due. ños - dice un documento de 1264 - y tocase a Garefa Martínez más tierra de los 6 cahices, será para él lo que exceda; y si Alfonso l'elrez obluviese algún derecho a la huerta que posee ahora García Juanes, este derecho se lo ha de traspasar a Gar. ć́a Martínez ə (núm. 824).

\section{PLANTACION}

456. Es bastante frecnente ver en las escrituras de compraventa la indica. ción de que la finca vendida, sobre todo si se tratn de viñas, ha llegado a poder del vendedor por derecho de plantación (núms. 50,70,80, 84, 250, 303, 304, 375 y 404).

Desde la primera mitad del siglo XII constan ya contratos de plantación que reflejan la escasez de brazos; para estimular el cultivo del terreno se ofrecía una parte de la tierra, libremente poseida y adquirida, al terminar la plantación y estar la finca en explotación.

El contrato de plantación más antiguo es de 1121 , y se refiere al predio de Daraljázin, que en los documentos latinos se liama Algunderín. Sito al Oeste de Toledo, este predio estaba inculto desde la época de los moros y la noria y alberea de. rrádas. Los dueños se convinieron para cullivar la tierra y arreglar lo que fuera 


\begin{tabular}{|c|}
\hline 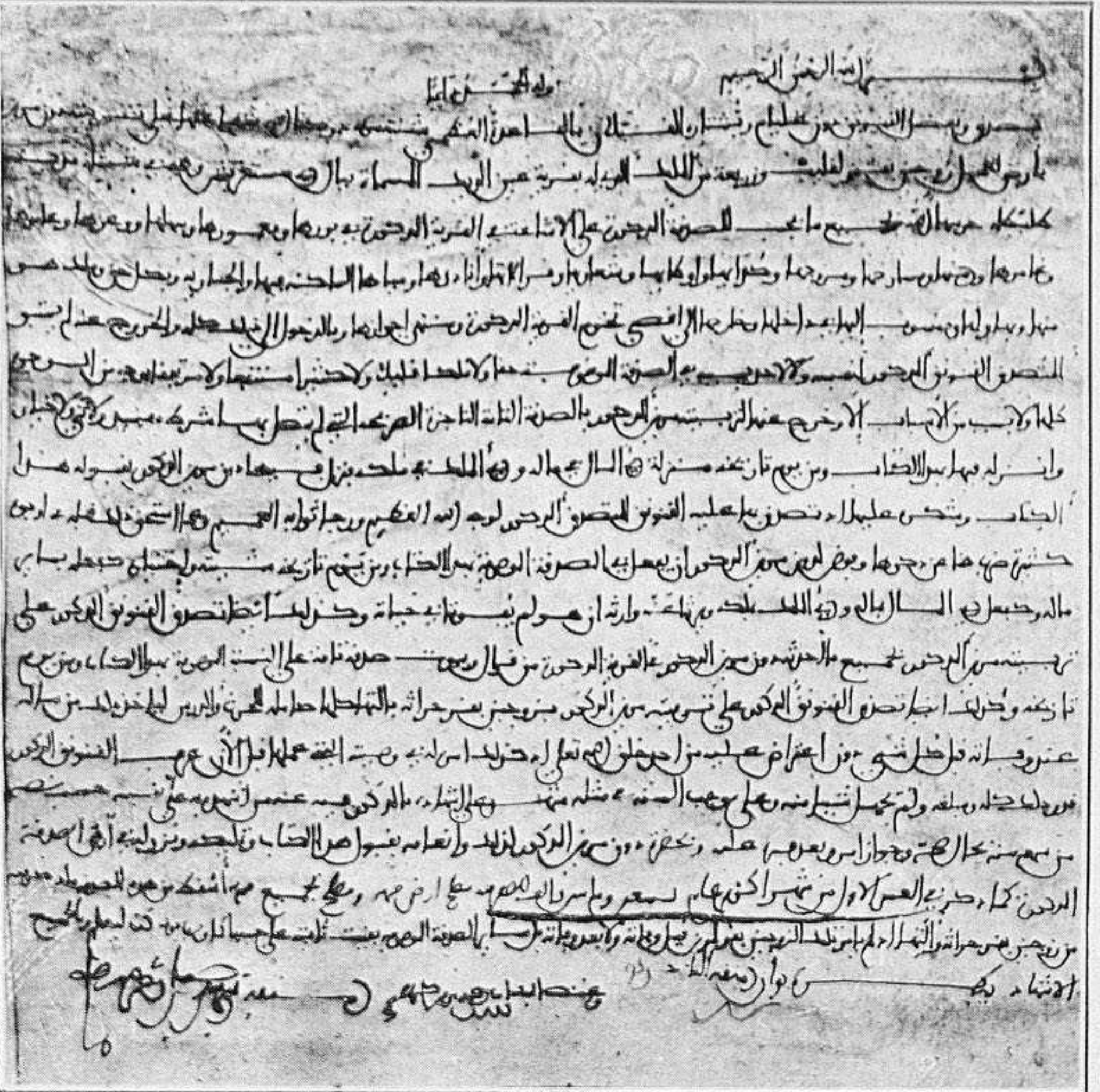 \\
\hline
\end{tabular}

Donación: 1. ${ }^{a}$ decena de Octubre de 1252 (núm. 778). 
preciso. Habia dos heredades: una de Santa Leocadia de fuera, otra de San Martín. Los clérigos y legos que querian cultivar acudieron a las iglesias, y éstas dijeron que no podían gastar lo que era preciso, y que se consultara al arzobispo. Este mandó que se diesen las tierras a cultivar por plazo de tres años y puso las condiciones. Si las iglesias pagaban a los cultivadores la mitad de los gastos de arreglo de la noria, recibirían la milad de las heredades cultivadas; si no pagaban esto, sólo habrian de recibir la tercera parte.

En estas condiciones fomó el presbítcro Pedro, de San Justo, la parle de Santa Leocadia. Acabado el plazo, se nolificó al arzobispo, que nombró peritos para la partición. Hicieron dos partes: la mejor, a Oecidente, se quedo para Santa Lencadia; la otra, a Orienle, para el preslítero Pedro. Luego pidió Pedro la mitad de los gastos en la construcción de la noria, que eran 160 sueldos, según el convenio primero con el arzobispo. El prelado, viendo que la cantidad era crecida, lc rogó que rebajara los 60 , a to cual accedio Pedro. Pero el prefecto de Santa Leocadia declaró no tener dinero para pagar los 100 sueldos. Entonces el arcediano Beruardo se ofreció a pagarlos por Santa Leocadia, con la siguiente condición: que se cultivaría la heredad de la iglesia; que asl que produjera frutos, se emplearían en la reedificación de la iglesia; y si él muriese mientras durase la reedificacion o después, sc dividiría la heredad en cuatro partes, ftres para la iglesia y la ofía para lo que él dispusiera en su vida.

El arzobispo y el senado de sacerdotes lo aprobó como conveniente para la iglesia, que de otra tranera no podría benefieiarse de una finca inculta (ním. 966).

La forma corriente de hacer estos contratos de plantación en el siglo XII era: el dueño de la tíerra cedía el terreno (en los Ballesteros, núm. 924; en Manzel Yaix, núm. 926; en Monte Hammara, núm. 928; en San Ésteban, núm. 929). El plantador o plantadores habían de ponerla de viña y de los áfboles que les pareciera, de cultivarla todo el año con las labores necesarias (levante, poda, cava, bina), siendo de cuenta del plantador todos los gastos ocasionados. El plazo de duración del contrato solía ser hasia que la viña llegaba al período completo de su explotación, cuatro años ( núm. 927), cinco años (núms, 928 y 929). Cuaodo la viña habla crecido y daba ya fruto, se partía la vina y los árboles frutales que en ella pudiera hater, tomando el dueño de la tierra la mitad (núms. 924, 926, 927 y 929) o la tercera parte (número 928); el dueño de la tierra podía escoger la parte mejor (núms. 921 y 928). Los frutos çue diera la viña en el período de planmeión eran, de ordinario, para el plantador, aunque a veces el dueño recibía la cuarta parte (núm. 926). Si el plantador no trabajaba como era debido, perdía sus derechos y su trabajo y salía de la finca núm. 926).

Habia, además, alguna cláusnla especial para cada cano; en tierra quo tenía dos pozos, el plantador los podfa ntilizar y se quedarfa con uno al partir la finca; en este mismo caso los plantadores daban, además, al dueño de la finca, 18 mizca. 
les almorávides (núm. 924); si el dueño queráa construir noria n estanque, el plantador habría de contribuir con lo que le correspondiera, según esa costumbre en la instalación de tales artefactos, y además se obligaba a sacar las piedras de la finca (núm. 926); se comprometía el plantador a levantar una pared por el lado del carni. no que lindaba con la vina (núm. 929).

Se asociabian a veces distintas personas para plantar viñas en tierras de otro. En este caso, uno era el que se entend́a con el dueño de la lierra; su socio le abonaba parte del dinero que habría de dar aquél y se convenían en partir los frutos, en no reclamar ninguno de ellos, sino después de salir de la plantación, en no asociar a ninǵ́n otro, en no partir la tierra sin ponerse de acuerdo con los dueños de ella (núm. 925).

Persona que dedicó sus esfuerzos a este género de plantaciones fué un Láaaro ben Alí, entre los años 1144 y 1165 (núms. 924, 925, 926, 927 y 929). Uno de sus socios, para plantar en tierra que Lázaro había contratado, cra Julián Jomínguez; éste había plantado la tierra de viña, segín I ázaro liabía canvenido; había trabajado con el dos años en el cultivo de la finca; vendio luego la parte que a él le tocaba (la cuasta parte de la viña) a su socio Lázaro por 14 mizcales, y éste continuó hasia cumplir el contrato (núm. 927).

El mismo principio da la participación en la propiedad al plantador informaba los contratos de cultivo de buertas. Así, vemos a Clemente el Monje cultivando la «huerta de las Moreras en el arrabal, barrio de San Pedro, propiedad de María, hija del alguaell mair Temam. Q Quedaban en clla algunas moreras viejas de tiempo de los moros; pero estaba tan inculta y abandonada, que por ella se metían lns ganados, bueyes, carneros y caballos. Clemente ocupó esta parte, con permiso de la dueña; plantó higueras, granados y moreras; solto la aceña y rego; cultivó la huerta y la seumbro, y repartió sus frutos con doña María uno o dos años durante la vida de ésta. Y los testigos, muchos de eflos trabajadores que habian sido de la finca, declaraban que no habían oído reclamar a dona Marfa contra Clemente; y hasta decían que doña María afirmaba que la milad de la huerla y de lo plantado sería para el plantador, a la muerté de ella (rím. 1.050).

Los contrntos de plantación que vemos del sigio XIII son cnsi todos de fincas de San Clemente. El plazo de duración es de scis años (núm. 930), de nueve (número 931), de cinco (núm. 933). Las labores son las usuales (arranque, poda, cava, etc.); los frulus, unas veces son para lus ptantadores, otras para los dos contratantes; la finca se divide en dos partes iguales, una para cada cual: ahora que cuando el piazo es de nueve afios, sc obligan a partirla a los seis (núm. 931); también si el plantador no cumple su trabajo, pierde los frutos del año que deje de trabajar, auniue no se dice que pierda su derecho. Pero si el plantador quisiera vender su parte, estará obligado a vendérsela al convento, siempre que este quiera comprarla.

Otro modelo de contrato de plantación era cl de cultivar el plantador y sus he- 


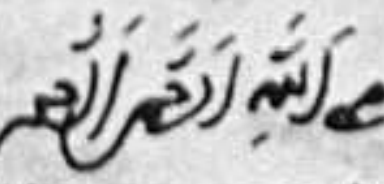

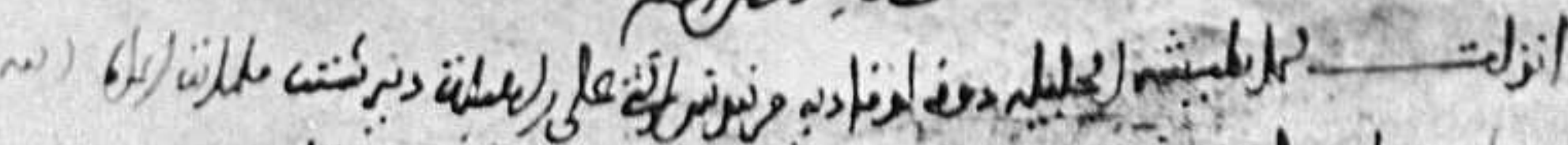

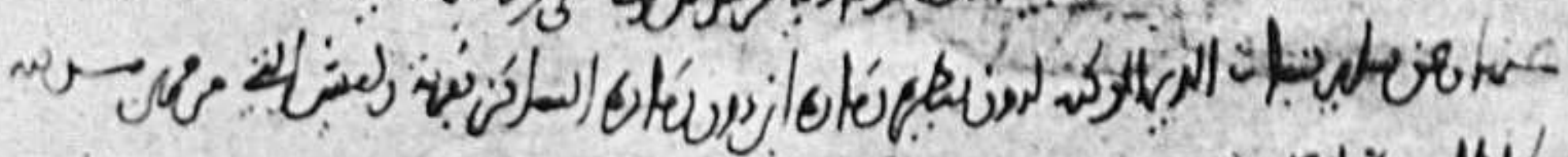

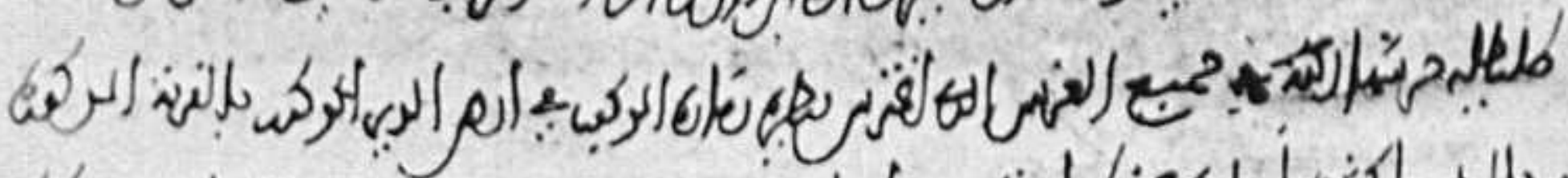

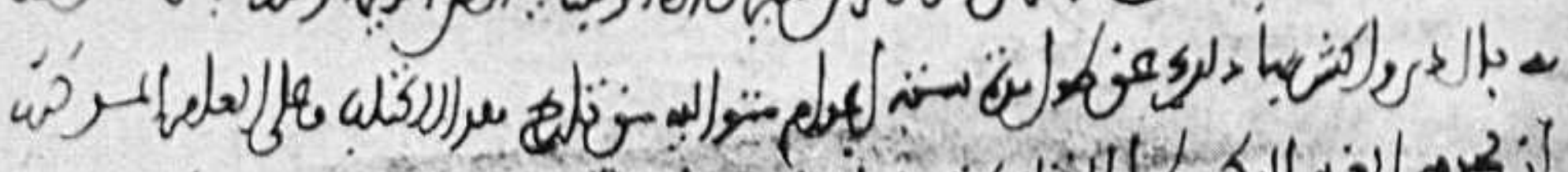

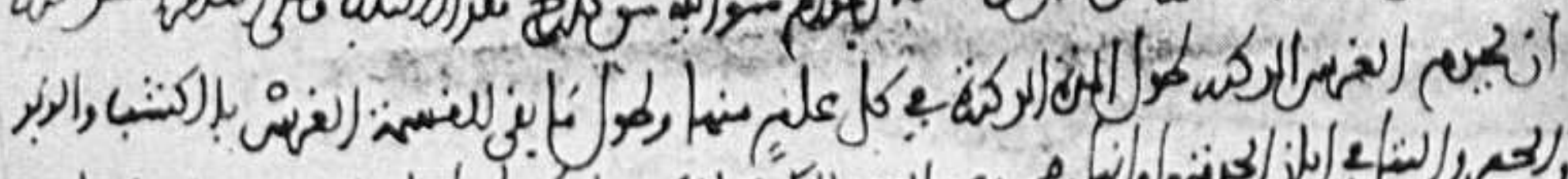

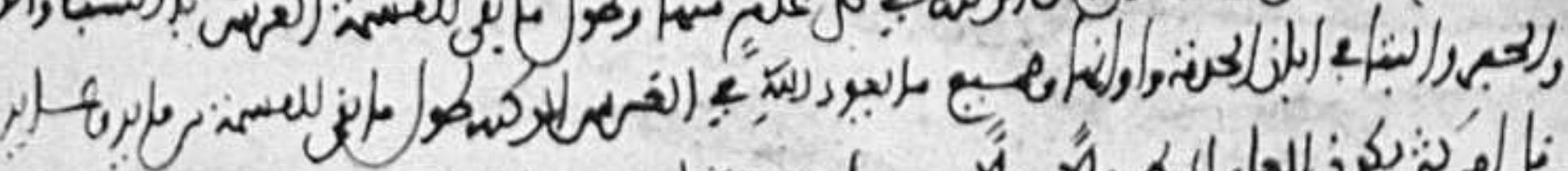

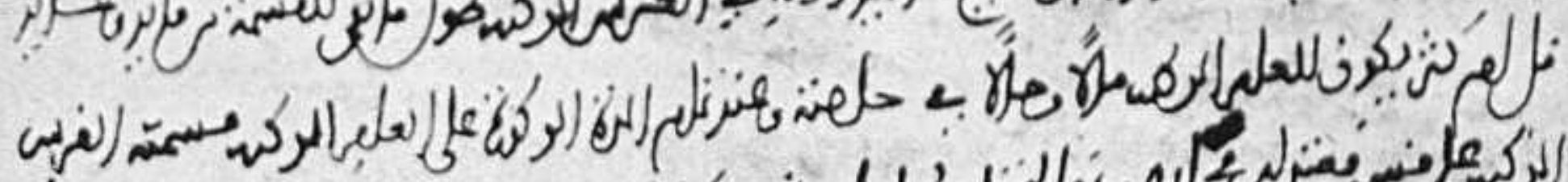
Lل́

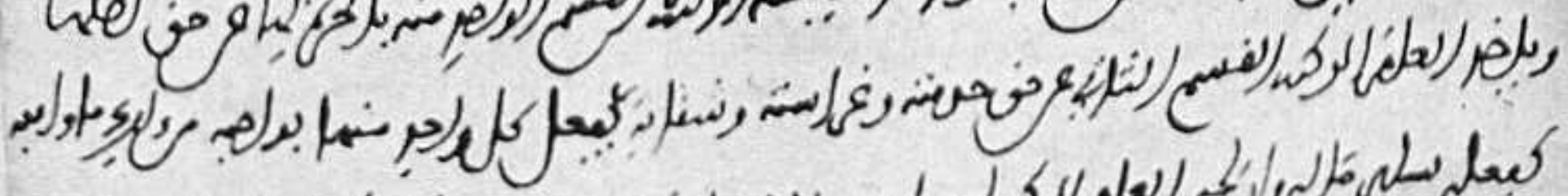

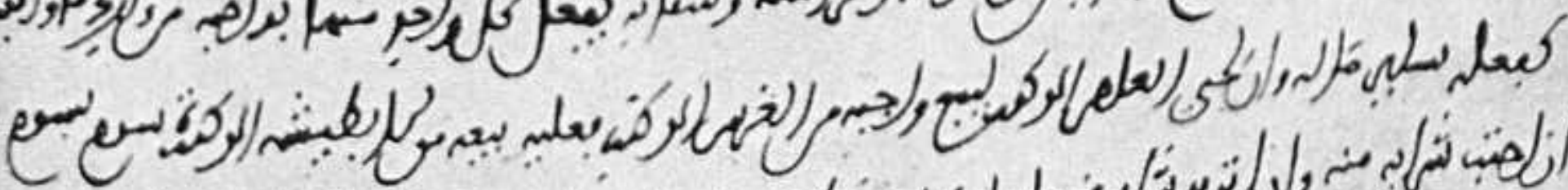

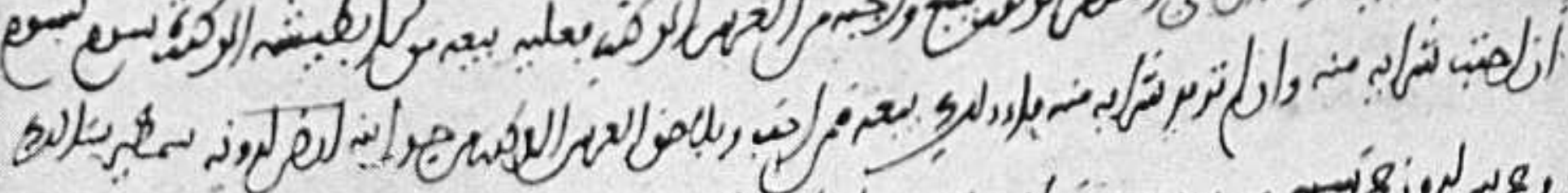

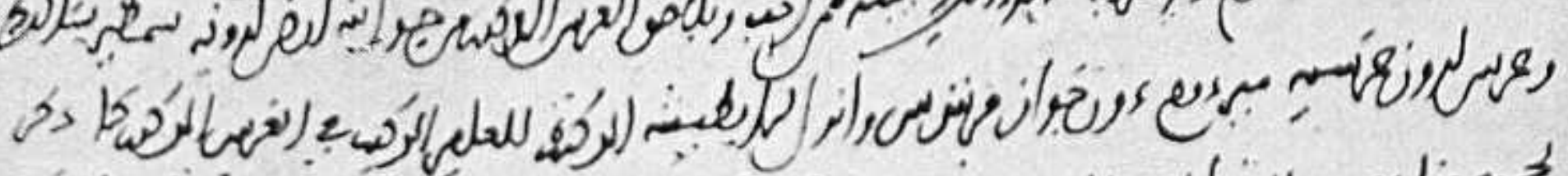

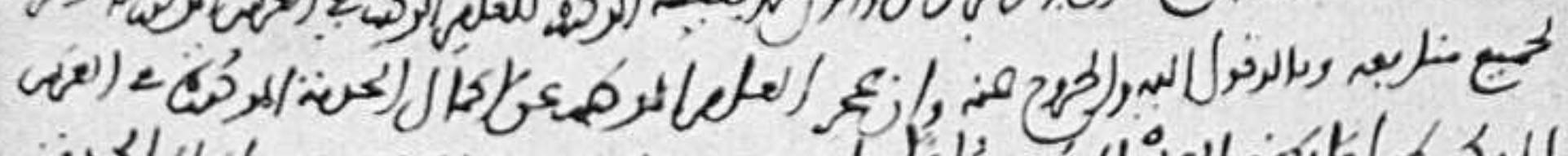

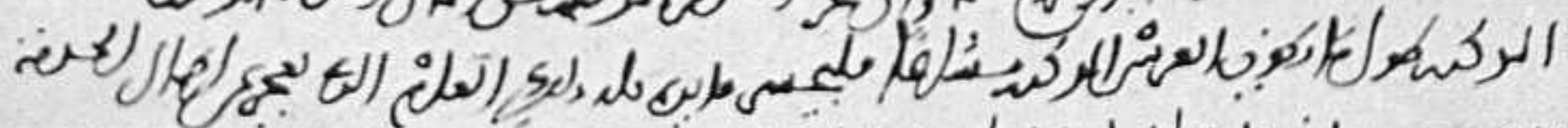

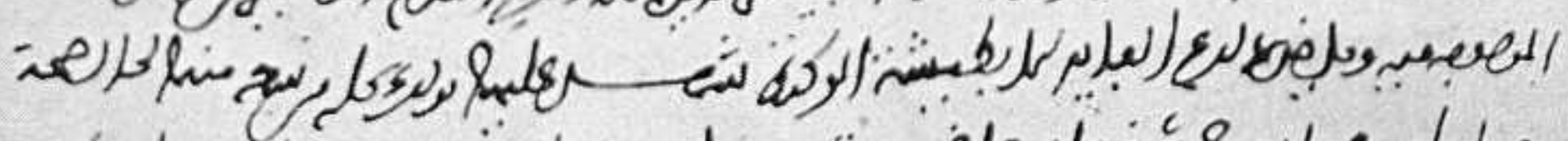

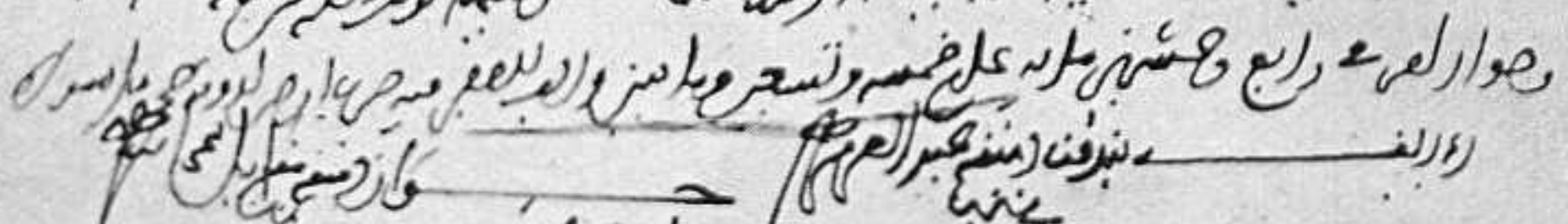
6

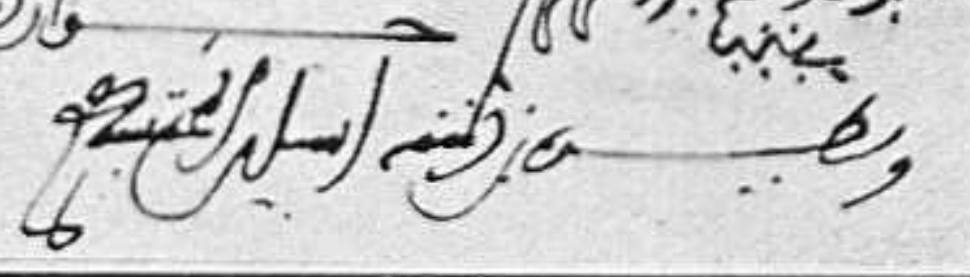

Contrato de plantación: 24 de Mayo de 1257 (núm. 930). 
rederos perpetuamente la finca, y dando al dueño y los suyos la sexta parte de los productos; la viña sería del plantador al acabarse la plantación, y podría hacerse allí casa para él; se obliga, hasta que la viña de fruto, a laborarla con arado (número 932 ).

Las causas que excusaban de cumplir un contralo de plantación (o de trabajo) eran: enfermedad, aecidente en el lugar, escasez, esclavitud, no encontrar quien le ayude, o sea jornaleros (núm. 932). Si el plantador deja de trabajar un año, con causa justificada, no pierde nada; si deja el trabajo en el segundo año, pierde las ntilidades de aquel año; si es en el tercero, pierde todos los productos (núm. 932).

Alguna vez vernos que se dí́ el caso de no cumplir el eontrato, cuyo plazo era de seis años, con la condición de que si dejaba el plantador de terminar su trabajo durante un año, perdia lo hecho, y el dueño de la tierra habría de ocuparla como esluviese. Demostróse que los plantadores rehusaban seguir su trabajo; cl heredero del dueño de la terra la ocupó. El plantader se presenlaba (124\$) al heredero, en unión de olros hombres buenos, pidiéndole que por atención a ellos y por amor de Dios y por el alma del difunto dueño, le diera 5 mizcales por la parte que le podría corresponder por los trabajos de plantación y gastos. Accedió el heredero; y meses después hizo la misma petición la majer del plantador, por la parte que a clla podría tocar, y también recibio sus 5 mizcales. Pero antes de recibir este dinero, los plantadores declaran que la viña había quedado inculta desde hacía dos años y que ellos habían perdido todos los gastos, debiendo agradeccr a la generosidad del hereslero la cantidad que les daba (nún. 986).

No falta documento en que se declara haber recibido cantidades como precio de jornales por trabajos en viña dạda en arriendo, para evitar posibles reclamaciones de derechos de plantación (núm. 992).

Las labores propias del cultivo de la vina cran sascnaje o arranque;

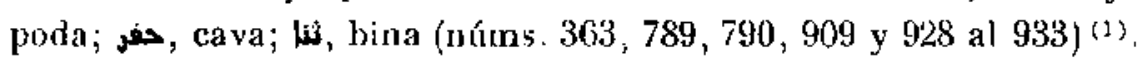

Las planticiones de viñas segúan otro régimen jurídico distinto del de las tierras. En una venta (1147) se excluían las plantaciones de viñas hechas antes de la

(1) Los documentos la1tnos confirman los datos expueslos. En 1149, la reina dona Sancha, hermana del emperador, daba a parios una viña incnlta en Mazarrazin, para que I flanten de viña: hasta que haya crecido, le darían una cliarla parte de los frutos; cuando se haya hecho viña y a ambas partes les parezca, harán la división en fos milades, set accipiam meam medjetatem, sicut est consuetudo, illi equidem prelati urecipiant suam medtetatem similiters. (Cart. 2, fol. 64.)

El deán de la Catedral duba, en 1212, la sema de Fazafia para plantarla de viñas, con los cultivos precisos, escilicet, seavare, putaro, cavare, el binares; el que no ompezare la plantación desde la fecha (dicienobre) hasta la próxiwa Pascua de Resurreción, pechará 5 maravedis, y perderá la tierra; el Cabildo percibirá la sexta parte de estas viñas nuevas, y cuando quisiere podrá partírlas, dividiédose por mitades. (Cart. 2, tol. 50,) 
fecha del otorgamiento (núms. 35 y 122), ya fueran propiedad de los vendedores, ya de los plantadores (núm. 102); obligándose, no obstante, el comprador a satisfacer la reclamación posible de los otros dueños de tierras de la alqueria, contra el que se reserva una viña (ním. 178).

En la venta de la mitad de una vina pro indiviso con el plantador y cultivador de la tierra blanca (1156), se conviene en que si el comprador es despojado de la finca, por̂ reclamación posterior, el vendedor se obliga a devolver el precio que entonces tenga la finca (núm. 47). Y al entregar títulos de propiedad, no deja de advertirse el caso de haber adquirido la tierra por derecho de planlación (núm. 142), o el heclo de plantar en la tierra pocos meses después de concertada la compra del terreno (núm. 218), o la circnnstancia de ser viña planiada en tierra de olro (números 203,287 y 724 ).

\section{DONACION "INTER VIVOS*}

457. Son relativamente abundantes en esta colección las cartas de donación inter vidos. Después de expresar la materia de la donación y las condiciones especiales que impone el donante, o las razones que le han impelido a otorgar aquel documento, añade esta formula, común a esta clase de escrituras, con ligeras variantes:

- El donante no se reserva para sí, ni para otra persona alguna por su causa, ningún derecho o acción de los que tiene en las mencionadas alquerías, ni facultad para pedir, reclamar, proseguir, alzarse o recurrir, sino que se despoja de todas estas propiedades y se aparta de ellas y las entrega al donatario mencionado, como bienes, heredades y propiedades suyas, por esta escritura y a partir del día de su fecha, sin que pueda después de clla reclamar, proseguir ni suspender su valor por causa ni unotivo alguno, ya que ha puesto al donatario en su lugar y en su nombre para que lome para sí estas beredades, y lo ha hecho dueño de todas cllas en su nombre y por su causa, con una propiedad perfecta, real, total, para siempre jamás, después de conocer el donante el valor de todo lo que hace y su alcance, según dispone la ley en estos asuntos ¿ (núm. 754).

En ocasiones, sobre todo si sc trata de fincas rústicas o urbanas, añade al describirlas la fórmula [1] de las escrituras de compraventa.

La índole misma de esta clase de documentos hace que no tengan apenas uniformidad, ya que en cada caso el donante tendyá una razón para hacer lo que hace, sobre todo cuando el dbnatario es un particular. $\Delta$ si, dos hermanas dan a su hermano (1152) la parte de una casa que era del padre, sis condición alguna (núne- 
ro 728$)$, y la abadesa de Santo Domingo da (1159) una viña a un Benedicto, hijo de Pedro (núm. 731).

La nieta, donataria de su abuelo de una casa con sus muebles y de una viña, se obliga (1179) a dar de comer, beluer y vestir al abuelo, mientras viva; a enterrarlo con los finerales de costumbre; a dar por él 5 mizcales en la forma que la parezca; y a dar 1 mizcal al maestro del donaute, tomándolo todo del yuinto de sus bienes (nútm. 7\$6). Se hace la donación a un pariente (1179) por el alma de los donantes, las de sus padres y las de sus hermanos (ním. 735). Una señora dona (1187) al mayoral de sus fincas de labor una casita, con la condición de que, si muere sin sucesión, vuelva la finca a las sobrinas de la donante; a utro le da una viña desde luego y 5 mizcales para después de muerta; y a dos sobrinos les deja casa, dos mesones, tenería, varias fincas rúslicas (con condición de que den al mayoral una yugada de tierra), vestidos, mucbles, etc.; y da también una casita para hospital (núm. 738) (1).

Sin condiciones especinles da un canónigo a su sohrino casa y viñas (número 751 ), y un suegro a su nuera viña en la Sisla (núm. 747), y un racionero a su hermana la parte que poseía en Azeituna, por compra a una tía (núm. 756), y el obispo de Cuenca (1224) a su sobrina una casa, que la recibia ota persona para entregarla después a la muchacha (núnt, 176), y un presbítero de Saniago, de] Arrabal, a su sobrina, casa en el barrio de la Catedral, cerca de los Tintoreros, y viña en Olihuelas, que él mismo había plantado en tiersa de otro (núm. 765), y el deân D. Micael Fstébanez y otros hermanos de su hermano Juan, alcalde de los adules, de la parte que tenían en Chueca y Dezma (núms. 770 y 771 ).

El nieto aprueba (1228) la donación de su abuela de tierra y prado en Algorfela (núm. 767). Por amor de Dios da (1230) el prior de la Cialedral la casa en que vive a sus sobrinos (núm. 768), y Domingo Petrez, al escribano Alfonsb Juanes, dos tercios de una suerte en Campo de Rey (núm. 773), y un yerno a su suegro los derechos en casas, viñas, muebles y raíces que le tocaban por muerte de su madre (número 776).

Por amor de Dins y por los méritos del donatario, que no es preciso enumerar, una suegra dona a su yerno una viña ( núm. 777), y un canónigo a su criado tierra

(1) Esto docutento parece un testamento; pero la donante entrega a los donatarios la escritura de donación y los pone an posesión de sus bienes, aunque hay en ella disposiciones para después de la muerte; ella pierde la propiedad y las rentas de todo.

El mismo carácter tiene la donación que un tío hase a su sobrina (1185) de 20 mizcales, purtc de los 100 que él josseía on tma finca do villaseca : la sobrina los linifa de recibir a la muerte del donante, peró los tomó desde cntone ts y nudie se los podría reclamar. En caso de marir el donanto y la donataria, el esjoso de ésta seguiría poseyendo la parte de finca, y nadio podría quitársela sin que le hubiese dado 10 mizcales de oro, como si no le huljiese dado nada a su osposa por lal finea, hakta jagarle los 20 mizcales dichos (ním. 1.073). 
para dos yuntas de labor en Valdemozáabes, anticipando disposición teslamentaria que establecía lo mismo (núm, 778), a su sobrino lierra también para dos yuntas en la misma alguería (ú́m. 779), y a otro criza tierra para una yogada, más una viña, con una choza y su frozo de corral correspondiente (núm. 781 ).

Para agradecer los beneficios recibidos del dén [). Gonzalbo Petrez, su hermano Fernando le dio (1266) todos sus bienes en Toledo y en Talavera (núm. 782). Un padre cede los derechos que su hija (huérfana) tenfa por herencia de su cradre, a favor de un cuñado, con la condición de que cuando los herederos de los abuclos de la huérfana arreglasen la coenla de las dotes, si lo donado es más de lo que toque a la niña, el padre abonará en metálico al tro la diferencia, y viceversa (número 783 ). Una madre da a su hijo varias fincas para igualarlo a sus hermanos, varones y hembras, en lo que han recibido de su madre, segin consla en las escrituras que ellos poseen; con la condición de que si reclama o pleitea el donatario con alguno de sus hermanos, quede nula esta donación: la donante retiene en su poder los bienes mientras el donatario eslé ausente de Toledo (de donde había húfío por miedo al rey I). Sancho IV) (núm. 784).

Cuando el donatario es una institución como la Ciatedaal, o el convento de San Clemente, es más uniforme la cansa de la donación: casi siempre sufragios por el alma del donante. María Teresa daba (1137) a la Catedral la huerta de la Nihofra, con la condición de que las rentas de la finca serían de la donante mientras viviera, y si alguien de la Catedral quisiera quitárselas, quedaba ipso facto revocada la donación (ú́ı. 727). Una señoı viuda donaba, en 1189, a la Catedral una casa en la Alcudia: los señores habian de hacer por ella un aniversario perpetuo y de menciowarla en sus oraciones; ella podrsa habitar en la casa, o alquilarla, mientras viviera; el Cabildo le había de dar desde la fecha de la escritura dos arrobas de harina cada mes y tres sueldos cada domingo (núm. 739). La Catedral adquiria lambfén por donación varias suerles en las alquerias de Yepes y Fontes (uúms. 748 y 1.123). El alguacil D. Micael Domsnguez ben Otmán taba, en 1207, a la Catedral unas fincas «por amor de Dios el grande y en espera de sus crecidas recompensas *, y como re. tribución por las ulilidades y benefieios que había recibido de la Caledral, por medio de sus canónigos y arzobispos, pasados y presentes (núm. 745). Don Fernando Juancs ben Abdelmélic le donaba (1221) una tierra en Zalencas y 4 mizcales anuales del alquiler de las tiendas de los fanaetes en la Alcudia, para yue la Catedral hiciera cada año un aniversario por una tía del donanle y otro por él misno, en los días de si muerte (núm. 758).

También se daban fincas para celebrar aniversarios a la iglesia de San Salvador (núm. 738) y ul convento de San Pedro en Alhicem (núm. 740) (1). Rara es Ja 
donación que los frailes de Talavera hacen a uno de una casa, que ellos poseen frente a la del donatario, para que éste la levante y la construya como quiera; a condición de que si los frailes reclamai, darán al donatario to que haya gastado en la ohra y quedarán dueños de la casa, condición que acepla cl donatario (núm. 737).

Se conservan muchas cartas de donadon a favor del convento de San Clemente. En 1196 dan testimonio dos fresbíteros de haber oldo decir a donn Estefanfa que daba al convento parle de un luuerto en Alatice, reserváudose la posesión mientras viviera, para un aniversario por su marido y por su hijo (11úm. 741). Con la misma condición de tener el usufructo vitalicio, le daba la mujer de Gonzalbo Sandino casa y corral, viñas, árboles y hasta once timajas para el vino, en Talavera, en sufragio del alma de su hijo (núm. 743). Por amor de Dios y para alcanzar la vida elerna daba doña Agnesa al convento, en 1207, unas tiersas cerci del molino de Algorfiella (núm. 714). Por el bien de su alma y la de su hijo, y por 200 mizcales de los fondos del convento, tiaba Urraca Diez (1213) su hacienda en Ocrner n Yunquer, aunque reservándose el usufucto mientras viviera (núm, 752).

Por el alma de la esposa (núm. 751), por la del hijo (núm. 755), por la de los propius donantes (núms. 757, 764 y 775), o de los parientes, hijo y esposo (número 759), por la de los padres (nóm. 780) se hacea también donaciones al eenvento. Unos familiares del monasterio, marido y mujer, le donan la mitad de los bienes que poséan en Olias, pro indiviso, reservándose el usufruclo; a la muerte de uno irían al superviviente; y cuando faltara el áltimo, al convento (núms. 763 y 764).

El hijo confirma la domación que su madre había hecho al convento, y redacta nueva escritura por haberse perdido la primera (nún. 746), y advierte la abadesa que el hijo se habia quedado en ariendo la finca y no habia pagado el sexto de sus productos. Un matrimonio dona a San Clemente el quinto de sus bienes, pro indiviso; al morir el marido quedó este quinls, junto con el que a la mnjer pertenecía, en poder de ésta, por cesión que le hizo la abadesa; la cual, si quiere, lo podrá tomar; y si no, después de que muera la mujer, junto con el quinto de ésta (número 769).

Los mayordomos de Argance donaban a San Clemente: el marido un tercio de la mitad de sus bienes, y la mujer tres cuartas partes de su mitad; el documento se entregó a la abadesa; la cual, en unión de la priora, dió posesión de la citada donación a los donanles, para que la poseyeran hasta su muerte, entendiendo que cuan. do faltara uno de eltos, su narte quccinra propiedad del eonvento (mím. 775).

A cambio de un aniversario anual por su alma y las de sus padres, donaba (1256) el presbitero de Santa Justa, Domingo Martín, a San Clemente, el manantial de agua que tiene dentro de su casa, en la última calle del barrio de la Torre Nucva, arrabal ide Toledo, para que las agums se emplearan en las baños que el convento tiene en dicbo arrabal ( $n$ úm, 780 ).

En ocasiones es el convento el donante: así al canónigo Alfonso Meléndez, her- 
mano de la priora Urraca Micael, le da (1225) un cuarto del tercio de los bienes de la madre de ambos, más un tercio del derecho que el convento tenfa en cuatro tien. das que la madre poseía en San Nicolás (núm. 761); y la abadesa doña Orabona daba (1234) a Juan Estébanez los derechos que al convento podían pertenecer en Chueca, que ella habia beredado de sus padres y abuelos (núm. 772).

Muchas veces se indiea expresamente la aceptación por parte del donatario (nú. meros $727,743,744,752,779,781$ y 782 ).

En los documentos heloreos también hay alguna donación, en especial la hecha para después de la muerte de la donante de toda su fortuna; da además, como garantía por todo lo que en lo sucesivo pueda adquirir la donante, 200 mizcales que puede exigirle la donataria, aparta la reclamación de la herencia, cubriéndose con uno de los velos de su cabeza (núm. 1.145). También figura la donación de los derechos de unas casitas (núm. 1.146) y la de otras dos casas, olorgada entre hermanos (núin. 1.147).

\section{E. DOTE Y ARRAS}

458. Escasa es la representación de cartas de dote en esta colección y tampoco abundan las referencias a esta materia.

La boda, o sea el acto de tomar esposa legal y compañera aceptada, se celebraba según la religión católica y las costumbres generales (núm. 1.010), que no permitian que el matrimonio se hiciera sin dote (núm. 1.175). La mujer aportaba su dote; el marido, según el fuero de los castcllanos, daba artas a su mujer, que podían ser fincas (núm. 720), o una cantidad en metálico (núm. 957); además le hacía un regalo de boda (z) ro 1.033). Esic regalo, en una carta matrimonial de 1185, consistía en pendientes, una albanega, manto, velo de la cara, botines y medias, y era de libre disposicion (núm. 1.010). En otra carta dotal de 1285, desgraciadamente incompleta, estaba formado por ‘Alholla (túnica), alguilella, Nezque de .... Almudenat, Almoatac, Elcana, alcabrea de Almudenas, Piel de almudennas en Penna blanca, Atride, dos al...., a.....mait et calciamenta pedum .

La boda se hacía después de haberse entregado mutuamente los anillos y las arras, previamente benditas (núm. 1.010). El novio se obligaba a dar a su prometida, por razón de su matrimonio, la décima parte de todos sus bienes, muebles y ráces (núms. 1.010 y 1.175). Los gananciales del matrimonio eran por partes iguales o segín el fuero del país. La mujer casada pndía disponer de la dote (múm. 342).

El novio se obligaba a cumplir lo estipulado y lo mismo la novia y sus padres, después que cada uno de los novios había recibido el anillo de arras (núm. 1.010). 
Por fortuna se conserva una curiosa carta de dote, otorgada entre Rodrigo Ponce y Mayor Alvarez el 3 de Julio de 1285, documento que guardan las monjas de San Clemente de Toledo (1) y que figura en el Apéndice de este tomo con el nún mero 1.175. Tiene dos partes: una redactada en latín, con primor caligráfico y hasta con letras capitales y mayúsculas miniadas, en la cual consta el regalo de bodas, la décima parte de los bieues del ntarido como dote y el régimen de bienes gananciales; otra, redactada en árabe, que es el inventario detallado de los bienes que lleva al matrimonio la mujer y de los bienes del marido, todo valuado partida por partida. La suma de los hienes de la novia inportaba aproximadamente 41.196 mizcales alfonsíes de a diez sueldos, de los blancos. El capilal del novio era o unos 17.000 mizcales, cuya décima parte, o sea 1.700 , se añadía al capital de la novia.

Es del mayor interés la lista de las ropas, cosas y heredades que la novia aporta al matrimonio. Era - dice - lo que acostumbraba a llevar una seffora toledana como ajuar con motivo de su boda. Cansistía en cortixus de scda; cama; colchas; terceras (?) hordadas, llenas de pluma; cansaderas de fustan; colchones; almohadas; cojines revestidos de piel; cabias o vestidos de tafetán y de otras telas; almenara; vaso y jarra de latón; barreño; almireces; caldera, calderos y sartén; tinajas; esteras para los criados; cama o tapiz; salero de plata; la cabalgadura de la señora; alhacenas; manteles tablados y escacados, hasta sumar 28 pares; almalafas bordadas y de lazo; camisas de murciana, con cenefa de seda unas, anchas y estrecbas; tocas en número de 38 ; sartales; una alhaja en lorma de alondra de oro; varias arracadas; peine de plata y otros objetos de tocador; collar de plata; bocas ie manga, y varios esclavos, entre ellos una esclava bordadora (").

A estas ropas y utensilios de casa había que añadir las fincas rústicas y urbanas siguientes: heredad en la alquería de Besines, en la Sagra, con tierras de labor, co. rrales, chozas, cras, solares, bueyes y sus aperos, grano, semoracios, etc., valuado ea 10.000 mizcales; la heredad de la alquería de Guadarrama, que valia otros 10.000 ; su parte en la alquería de Raimundo Zaragoza, por 300, y en la de Torrecilla, por 300 ; la viña que fué de dona Orabona, por 500; su parte en el huerto del Malagueño, por 700 ; la casa donde vivia, por 7.000 ; ¿cosas pequeñas?, 2.000 ; la casa en que vivía Alvaro, por 500; su parte en Alcardete y en la huerta de San Pedro, por 500; su partc en las casas de la ¿Alcudia?, que eran del alcalde D. Julián, por 200.

Importaba el total de los bienes de la novia unos 41.196 mizcales, cantidad de la que había de responder el marido.

\footnotetext{
(1) He de expresar públicamente mi gratitud a la reverenda madre sujeriora do Sall Clemente por an amable lícencia para folografiar el documento y para cotojarlo después. Me dió noticia de su existencia el erudito archivero D. Antonio Sierra Corella, a cuya diligencia y solicilud quedo muy reecnocido y obligado.

(2) Véase el valor de cada objeto en las págs. 209 y gigs.
} 
Hácese después el inventario de los bienes del novio, para saber a qué cantidad asciende la décima parte, que pasará a ser propiedad de la novia, y son los siguientes: heredad en la alquería de Huecas, por valor de 5.000 mizcales; su parte en la alquería de Villamozaín, por 2.000; su heredad en la alquería de 'otanes, en la Sísla, por 3.000; su parte en la alquería de Argés, por 300; su parte en las heredades de Calatrava la Vieja, por 500; sus caballos y bestias y armas de madera y de hierro, por 2.000 ; su parte en el corral de los Judíos, por 400 ; el regalo de la novia, por 2.000; dos vestidos del novio, por 500 ; una deuda a su favor de 1.000 mizcales.

Montaba el total del capital del novio unos 17.000 mizcales, cuya décima parte, o sea 1.70n, se añadía al caoital de la novia, que quedaba constitúda por 42.896 , mientras que el del novio era 15.300 .

Alguna vez la dote de la novia la daba persona distinta de los padres. Ast, el canónigo D. Guiltén dába, en 12:40, a su sobrina María, con motivo de su boda con D. Benayas de Maqurueda, 500 mizcales alfansles de 15 dineros, con la condición de que Benayas habia de comprar con ellus una heredad para Maŕa en el término de dos años; ella podría usuffuchuar la heredad, pero no enajenarla; si muriese Benayas sin haber tenido sucesion, la heredad volvería a poder del canónigo; si, pasados dos años, Benayas so hubiese comprado la heredad, devolvería a D. Gailtén o a su poderhabiente dicha cantidad, pudiendo éste tomar de los bienes de Benayas lo suficiente para reintegrarse de los 500 mizcales indicados; si Maria tuviese sucesión de Benayas, sus hijos heredarían las fincas compradas con los 500 mizcales (número 1.080$)$.

Personas piadosas se preocmpaban de ayudar a la celebracián de matrimonios, dando generosamente cantidades para dotes, especialmente a doncellas (núms. 1.010 y 1.033), a criadas (núm. 1.030), condicionando a veces la manda, como la del que deja a una 6 anizcales, «si es buena mujer en el camino recto; si no es asf, que se gaste en sufragios por el testador * (núm. 1.029); a muchachas abijadas (núm. 1.029), llegando hasta a comprar finca para elia, por bien del alma del comprador y para ayuda del casamiento de la moza (nún. 1.119); a parientas (uúm. 1.033); a huérfa. nas (núm. 1.028), debiendo suponer alguma isıstitución, precedente de fundaciones posteriores, dedicada a procurar el casamicnto de las huerfanas, ya que aiguien deja en su testamento 100 mizcales para ayuda de casar a diez huérfanas (núm. 1.034). En caso de manaa de cierla cantidad a tres hermanas, para ayuda de su dote, que la habían de cobrar al casarse, se dispone que si una uturiese soltera, se ácrecerá su parte a la de sus hermanas supervivientes (núm. 1.030). 


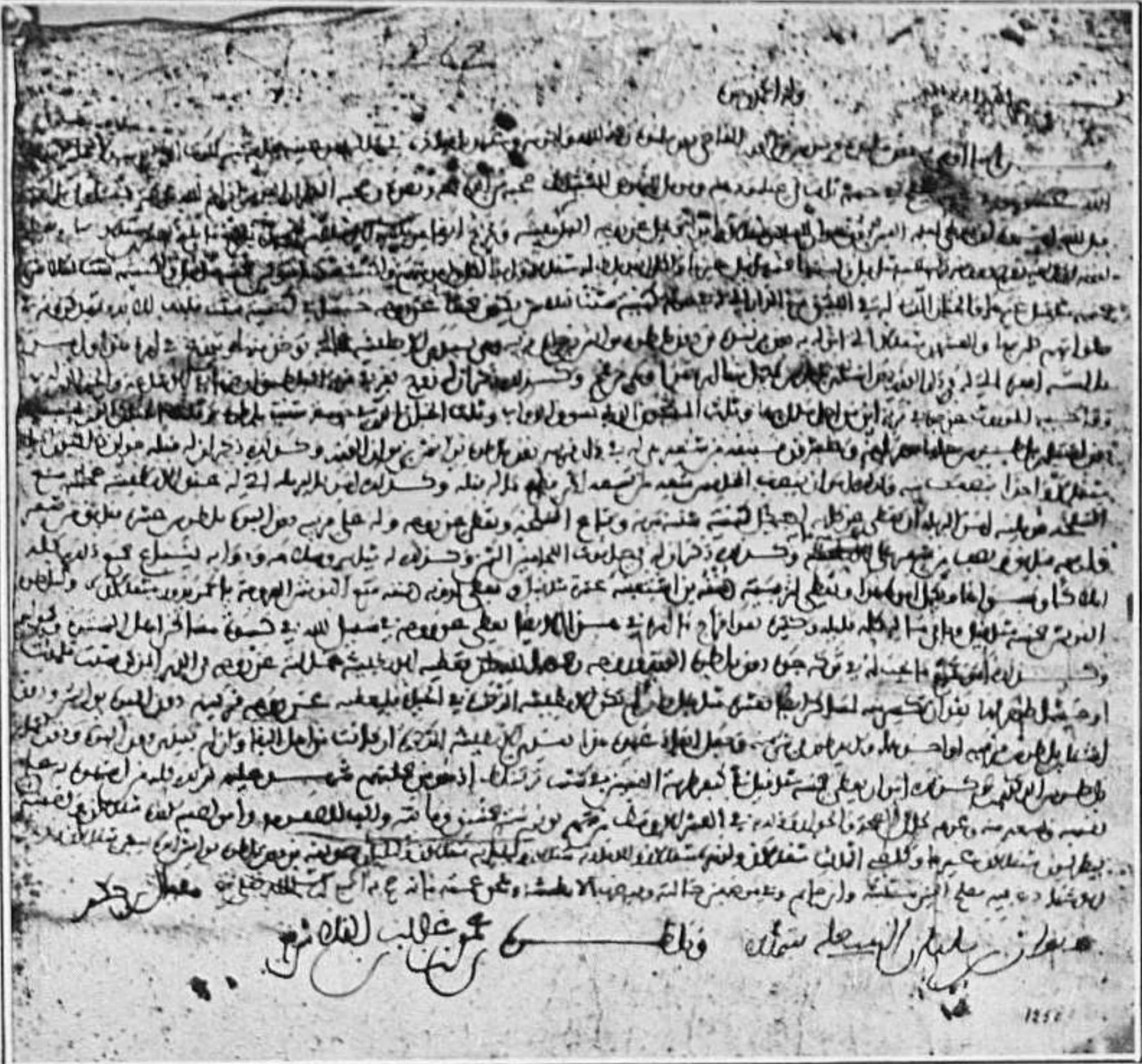

Testamento de D. Melendo Fernández: $2{ }^{a}$ decena de Noviembre de 1212 (núm. 1.025).

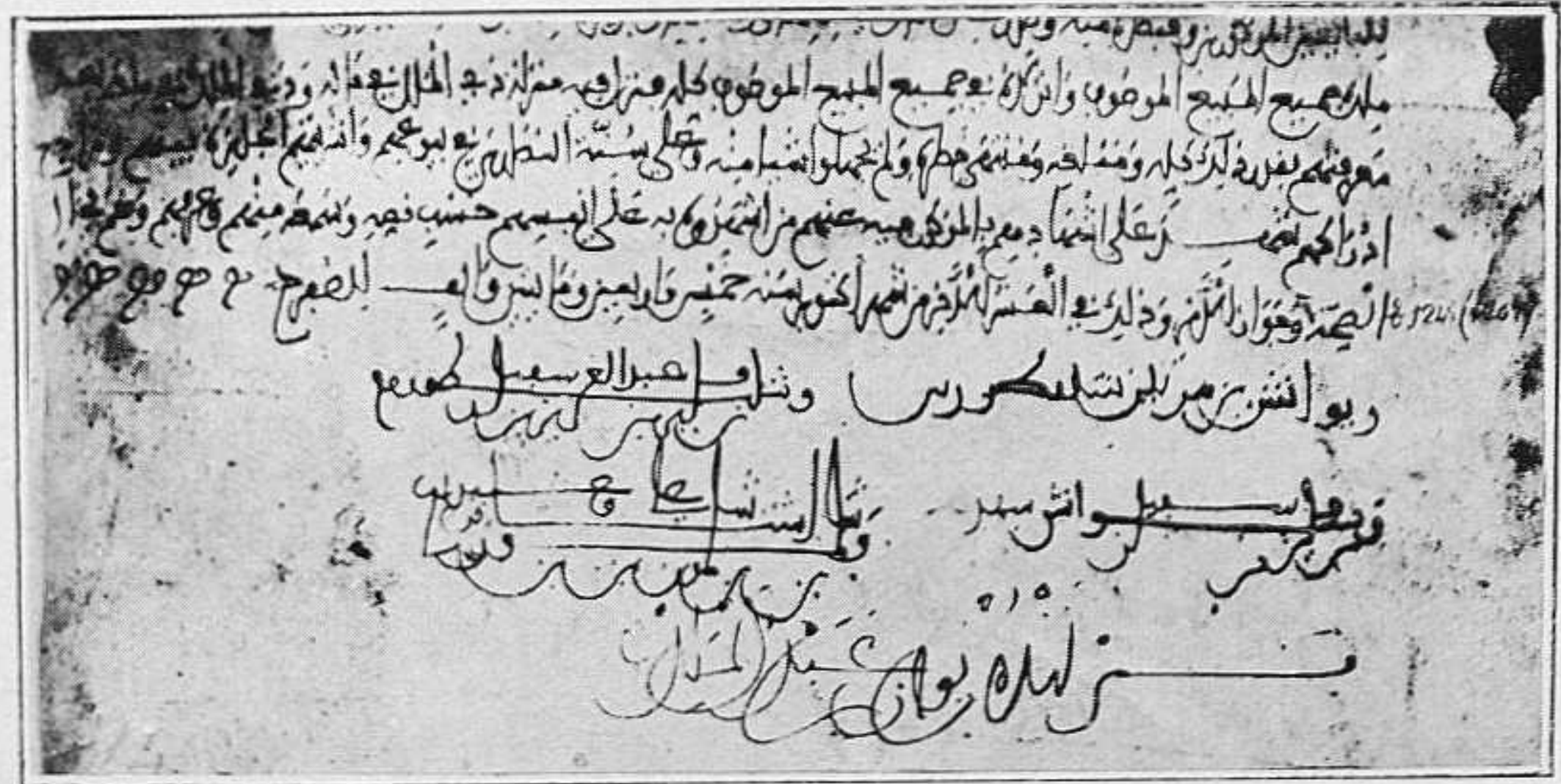

Firmas del documento núm. 358, 3. ${ }^{a}$ decena de Octubre de 1207. 


\section{F. TESTAMENTOS, MAYORAZGOS Y MEJORAS}

459. Son, acaso, los testamentos los más curiosos texlos de nuestra colección, y su lectura ayuda a evocar lácilmente la vida toledana en los siglos medievales, viéndose en ellos moverse a los hombres con su peculiar psicología y carácter, descubriéndose a través de los renglones, amarillentos por la acción de los siglos, los cariños, los rencores, las pasiones, los dirgustos familiares; la vanidad, el ansia, siempre insaciada de la humanidad, de perpetuarse en fnndaciones que, después de la muerte, recuerden la persona y los hechos del que no se resignaba a que el polvo de su persona se mezciára y aventara con el polvo de sus conteniporíneos.

El más frecuente es el testamento in scriptis, olorgado ante testigos, y con la declaración previa hecha por el lestador de hallarse en estato de salud, ode enfermedad corporal; pero con capacidad legal, y de buen grado (ním. 1.012), o cabal en juicio e inteligencia ( $\mathrm{n}(\mathrm{m} \mathrm{ms} .1 .013,1.014,1.016$, etc.). Hace luego declaración de fe religiosa: cree en el Padre, en el Hijo y en el Espírilu Santo, un solo Dios; en el Símbolo, regla de la fe, en los cuatro Evangelios y en lo que mandaron creer los Apostoles y los Santos Padres, y teme la muerte, para la cual no hay remedio, y de la cual nadie puede librarse ri escapar (nútns. 1.012, 1.014, 1.016, 1.018, etc.).

Suele ser la disposicion primera la referente al entierro, funerales y sufragios (núm. 1.014, año 1035), y después la de mandar que se haga inventario de sus bienes, para luego repartir la herencia. Dispone de sus bienes, haciendo mandas a criados, amigos o parientes, bien en metálico, bien en efectos de casa, muebles u otros objetos; o para rescatc de cautivos, o liberación de esclavos, o para iglesias, conventos o cofradias, capellanias, canonjias, o para los pubres. Recuerda las deudas en su favor o en su contra, disponiendo lo que le parece. Nombra heredero universal para el remanente de sus bienes y señala albaceas ejecutores del tesfamento (1).

En ocasiones no se llegaba a escribir el testamento; y para dar valor legal a esle testamento verbal, bastaba que dos testigos declarasen cuál había sido la volantad del testador; asi se hizo con el testamento de Pedro hen Suleirnán, que después de detallarlo, concluye: «Esto les dijo a los testlgos que era igual que st lestarnento, es. tando en sano juicio y en su raxóns, en 1177 (núm. 1.015); o respecto a la declaración de María Domingo, delante de testigos (que la reproducen en 1232): el marido

(1) Como el intento de analizar cu dotalle cesda testamento nos condnciría a repelirlos todos, reco.

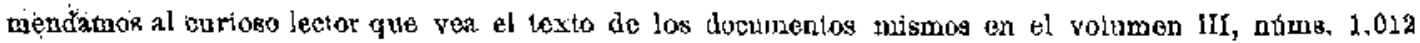
a 1.035 .

VOLUWEX rRRISMINAR 
le preguntó qué quería mandar para sufragios por su alma; y ella contestó : Todo lo que yo tengo es tuyo, pues tú lo has ganado. Mando ahora que, cuando yo muera, des de mis bienes, en sufragio de mi alma, 12 mizcales para misas 6 anuales?, según te parezca; a mi maestro, 1 mizcal; a la fábrica de la Catedral Santa Mará, 2 mizcales. El remanente de mis bieses, muchos o pocos, que sea para ti, como donación que yo te hago, y que nadie se oponga a elln, puesto que tú lo has ganarlo; y aparto a mi pariente más próximo de mis bienes, con 5 sueldos y una medalla que tú le darás (núm. 1.027). Otras veces el testamento tenía la forma externa de dona. ción para después de la muerte, como la disposición del obispo de Cuenca, D. García, respecto a ciertas fincas en Cobisa y Alameda, para su aniversario (número 1,023 ).

Tambićn vemos el testamento de mancomún: Munio Armílez y su esposa Sancha disponían, en 1185, que cuando muriese uno de ellos, el otro pagara los gastos del entierro, seglin costumbre, y diera al pariente más cercano 5 stioldos y una medalla, para apartarlo de la herencia, y se quedara con los demás bienes del difunto, sin que nadie se pudiera oponer a esta determinación (núm. 1.019).

El testamento quedaba en poder del testador durante su vida; y se da el caso de que él mismo lo muestre a los testigos de una donación de ciertons bienes, que esta. ba inciulda también en el testamento \{rúm. 755\}. Se olorgaba con arreglo a lo que disponía la ley y publicaban los cánones (núm. 1.026).

El lestádu' dispcúra libremente del quinio de sus bienes (núm. 1.028), para lo cual se lracia inventario antes de empezar a ejecutar el testamcnto (núm. 1 030).

Solfa señalarse heredero universal del remanente de la hacienda, esposo (números 1.013 y 1.018 ), hermanos (núms. 1.014 y 1.033) o personas ajenas (núm. 1.029). Heredaban los descendienles y los ascendientea por línea recta (núm. 428); y hay algán caso de desheredación (o) . La canlidad eon la cual se apnrtaha a los herederos no forzosos de su derecho a la herencia, era la de 5 sueldos y una medalla (meaja) (núms. $738,977.1 .018,1.019,1.021,1.022,1.026,1.027$ y 1.037). A veces, además de señalas los 5 sueldos y la medalla, si el afectado era legatario, el testador disponfa que no se le entregara la manda eu caso de reclamación (níms. 1.025, 1.026 y 1.030 ), obligando en algún caso al legalario a que por escrito se comprometa a no reclamar (núm. 1.030). En ocasiones, se ve entre las líneas de las cláusulas de desheredación el reflejo de disgustos familiares hondos: así, la referente a la hermana desheredada en el número 1.021, y la clánsula del oúmero 1.021, en que se nombra heredera universal a la madre del testador, que tendrfa los bienes darante su vida, y a su muerte se emplearia todo en sufragio del alma de los dos, de modo que no quede nada de su patrimonio para su liermana, sino su parte, segün el convenjo hecho; y si le dieran algo, los parientes del testarlor, por parte de su padre, podrían quitárselo y repartírselo; a esta hermana le deja sólo 20 mizcales, por amor de Dios. 


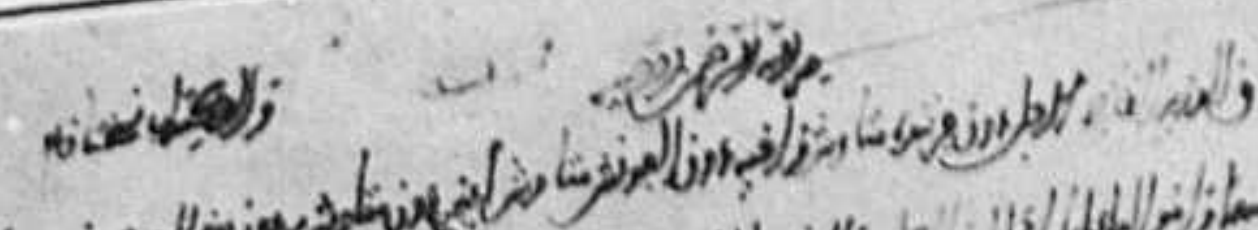

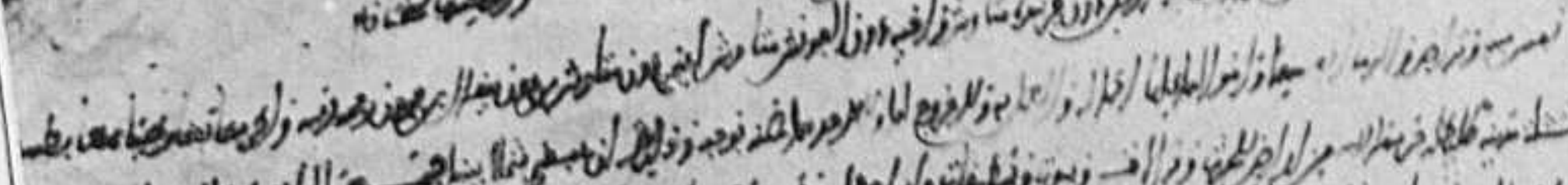

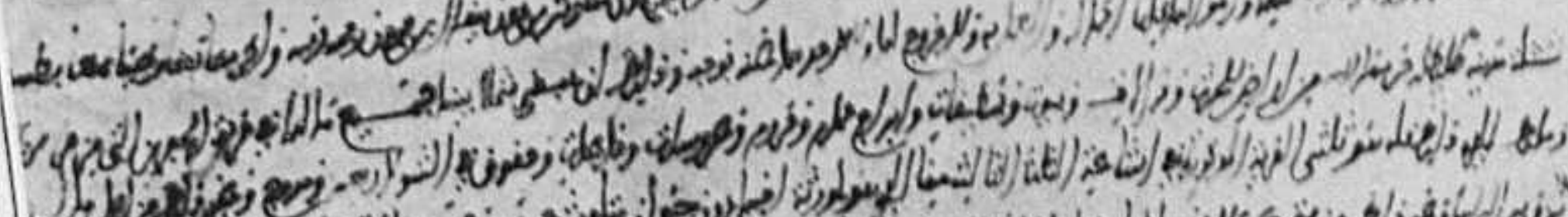

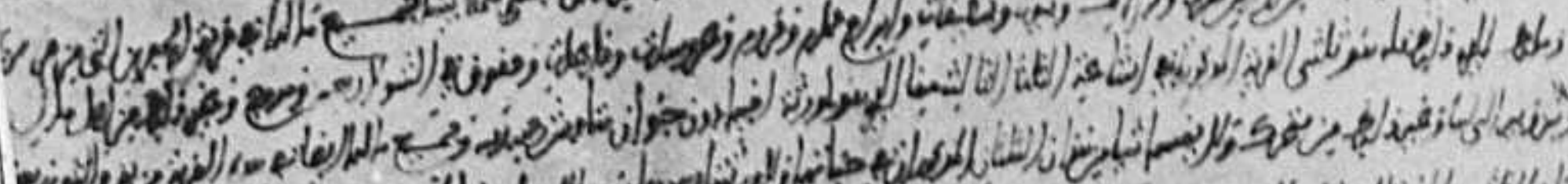

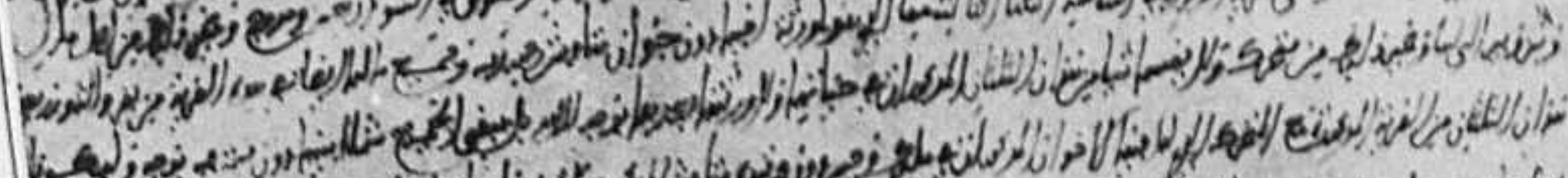
ba

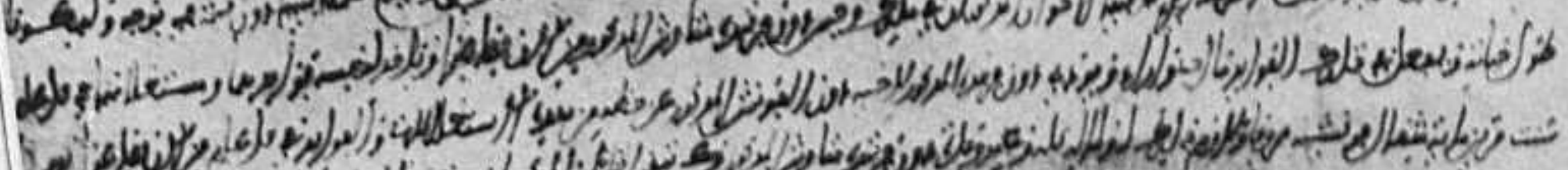

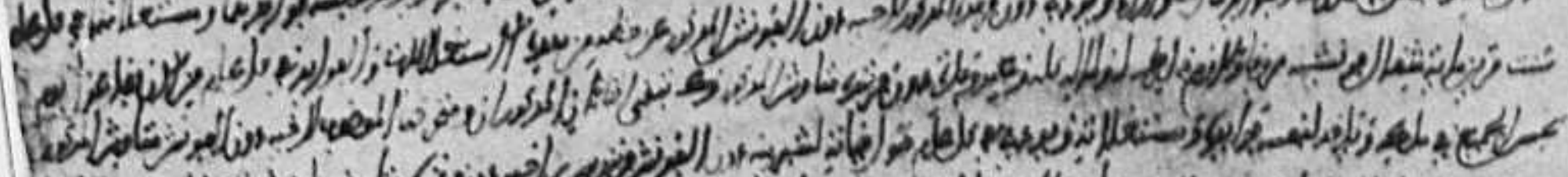

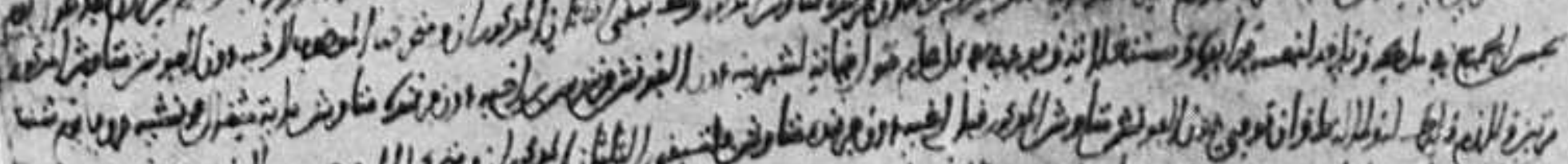

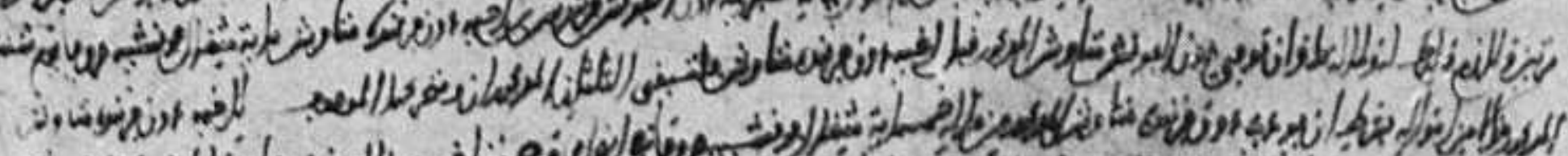

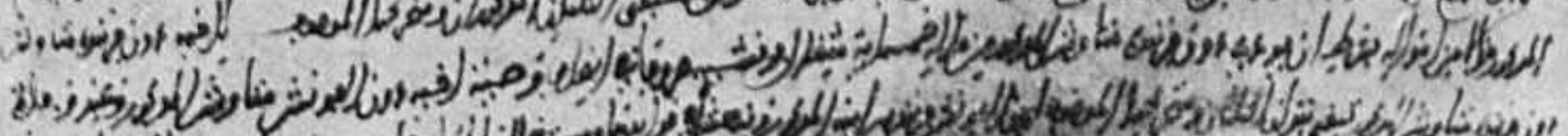

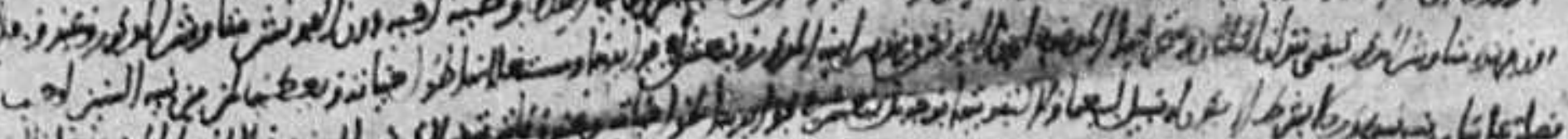
Dis

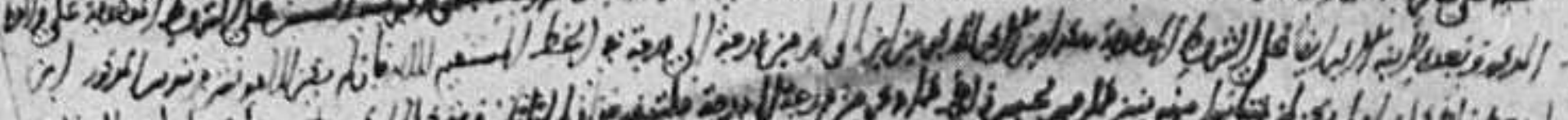

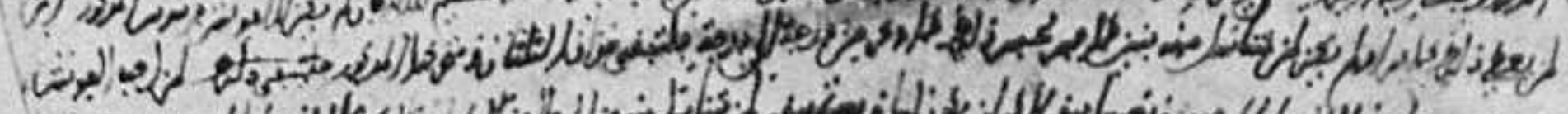

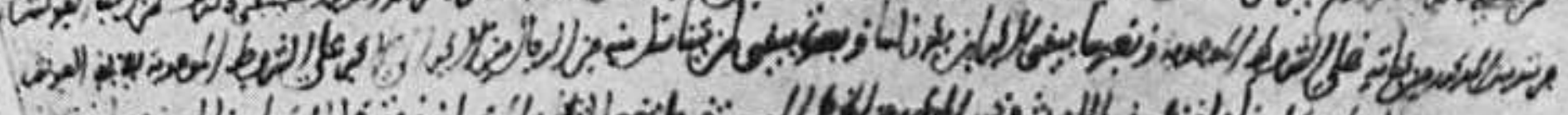

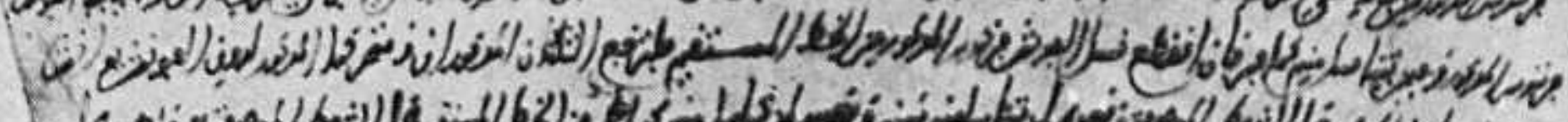

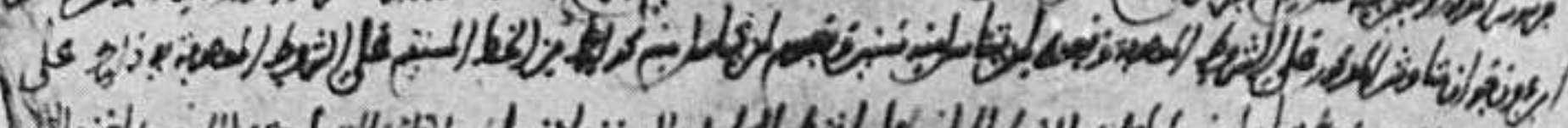

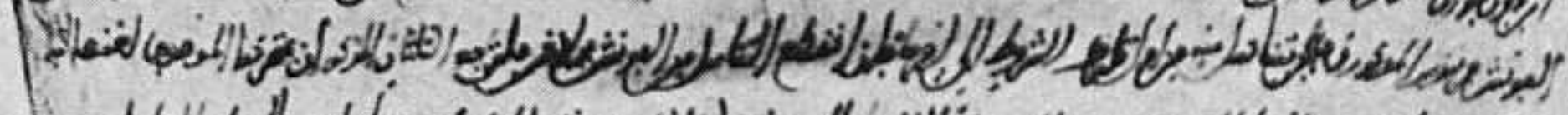

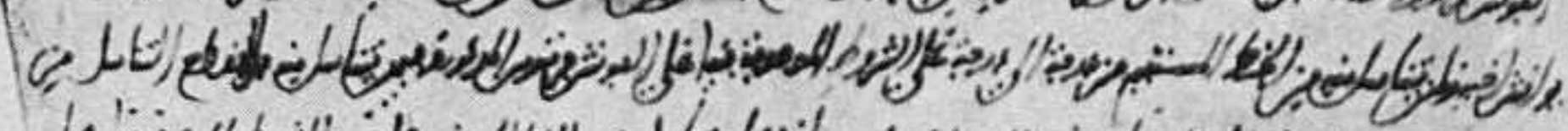
jo id

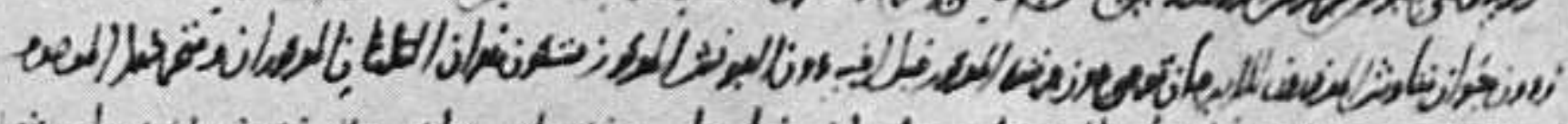
-

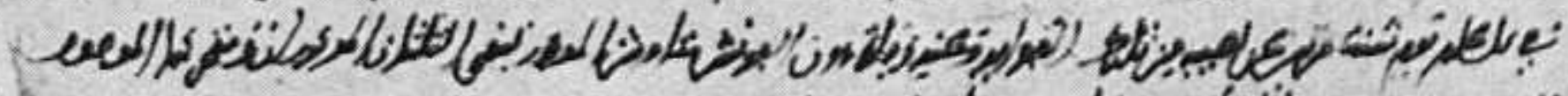

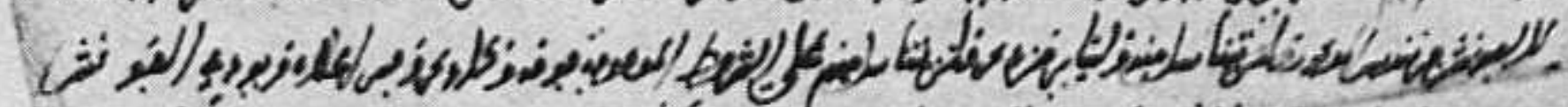
is

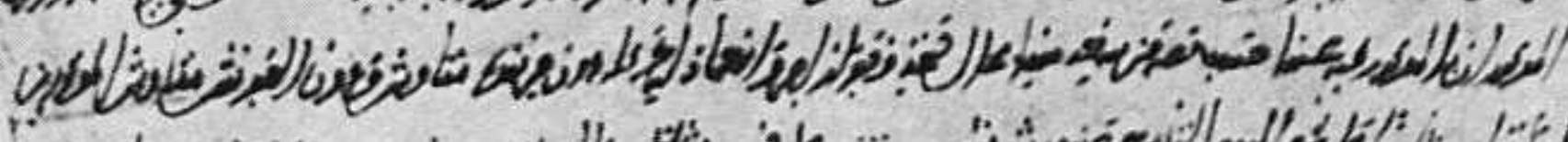

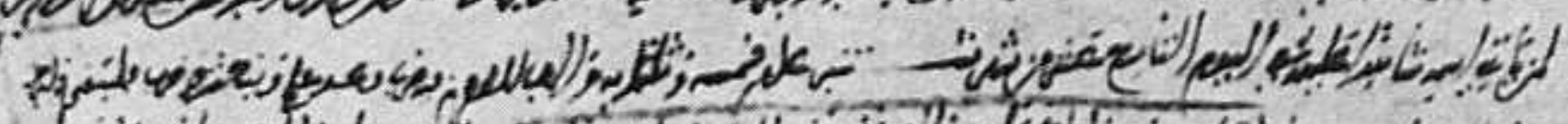

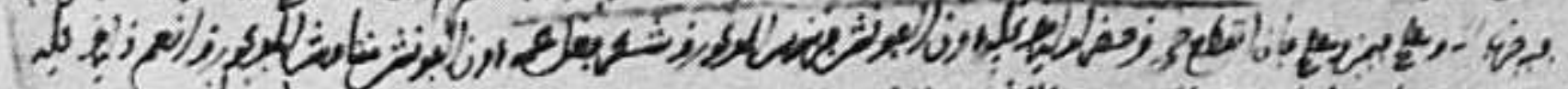

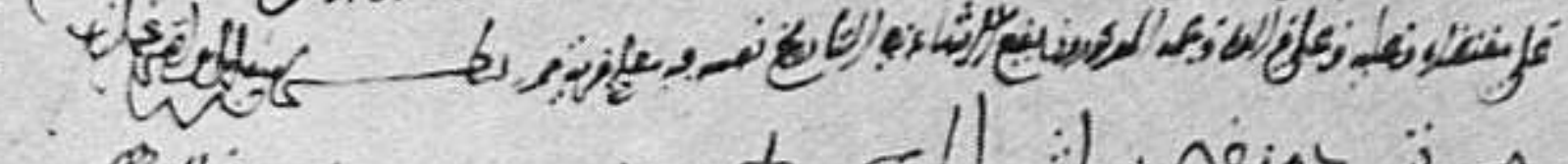

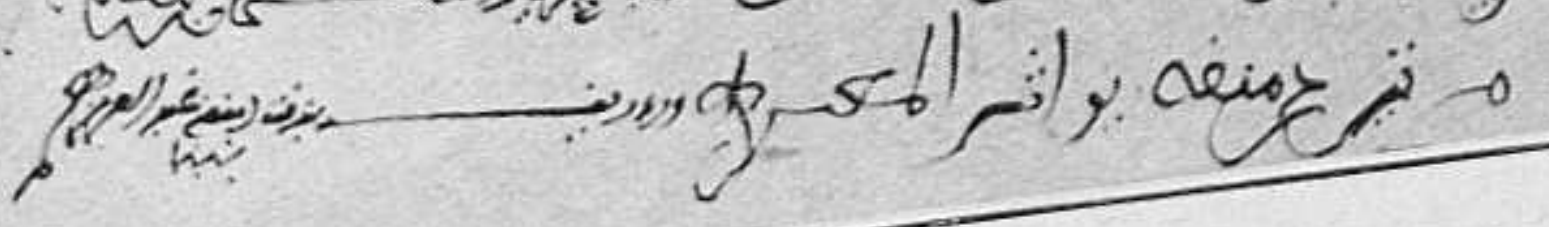


Una de las más antiguas fundaciones de mayorazgo que conozco, es la hechà en 1265 por Alfonso Mateos ben Micael ben Iuurón (núm. 1.030), ratificada en 1267 y 1271 (níms. 961 y 989). Los hermanos Fernando y Alfonso Mateos se convinieron en tener junto lo que poséan en Ajoftín (que cran dos tercios de la alquería, pro indiviso con el otro tercio, propiedad de los herederos de su hermano Juan Mateos). Decidieren no partirlo durante su vida, y que a su muerte no lo partieran tampoco sus herederos. Lo poseer Alfonso cada año, el día de San Marlín, 100 mizcales; a la muerte de Fernando, lo poseería Alfonso, yne daría los 100 nizcales a su sobrino Alfonso Fernández, hỵo de aquél. Si Alfonso moría antes que Fernando, todo sería de este, con obligación de entregar 500 mizcales para pago del testamento de Alfonso. A la muerte de Fernando sucedería su bijo Alfonso Fernández, y a éste su hijo mayor, que no podría vender ni gastar los bienes, y a su moertc le sttcedería su hijo mayor, con las mismas condiciones, siempre de mayor a menor, de hijo a hijo, de grado a grado y en línea recta. Si Alfonso Fernández no tuviera hijos, podría sucederle una hija, y luego pasaría al hijo mayor de ésta. Si Alfonso Femández no tuviera hijos, sucederfa Alfonso Juanes, hịo de Juan Mateos, en las mismas condiciones. Si faltase la descendencia de Alfonso Juanes, sucedería su hermano Gonzalbo Juanes, etc. De modo que los biemes no salieran de la descendencia de Fernando, Alfonso y Juan Mateos.

Si murieae Fernaado antes que su hermano Alfonso, los bienes vendpian a és. te, que habfa de dar a su sobrino Alfonso Fernández los 100 mizcales dichos por San Martín. A la muerte de Alfonso Maleos le sucedería Alfonso Fernández y sus descendientes, pagando los 500 mizcales para el testamento de Alfonso, si no los hubiera pagado ya Fernanio.

Todo este corvenio lo aprobó Alfonso Fernández. Fernando Mateos poseyó los bienes mientras vivió su hermano Alfonso. Murió Alfonso Fernández, y pocos días después su tío Alfonso Mateos; Fernando pagó su testamento y siguí poseyendo la hacienda de Ajofrín. Como en este caso la fundación llamaba a gozar del mayorazgo a Allonso Juanes, hijo de Juan Mateos, y sobrino de los fundadores, D. Fernando entregó a su sobrino todos los bienes (tierras, casas, esclavos, muebles) y el sobrino lo aceptaba en 20 de Septiembre de 1271, aunque unos moses después dejaba todo lo recibidu en poder de su tíd, para que los poseyera durante su vida (uúme. ro 961), que debi6 llegar basta 1275 (núm. 1.064).

Alfonso Mateos, en testamento de 1266 , repite la fundación del mayorazgo, Hamando a Altonso Juanes, y a sus hermanos Gonzalbo y García, y a los descendien. tes de su hermano Juan Mateos, nunque varias casas y corrales los deja en usufructo a su mujer, mientras viviera. Este Alfonso debia ser muy aficionado a mayorazgos, porque dejaba a su sobrino García Juanes su hacienda de Fontalba (excepto los granos, que babfan de venderse para ejecutar su testamento\}, con carácter vincula- 
do; el mismo carácter da a los legados hechos en favor de sus sobrinas Teresa Jaanes y Mayor Juanes, de fincas en Yuncler, llamando a la sucesion a Lope, hijo de

- Teresa, y sus descendientes, y a falta de ellos, a García fuanes, hermano de Teresa, y sus sucesores.

La esposa tenía derechu a la décima parte de los bienes que el marido aportase al matrimonio, en calidad de vindedad, aunque no se bubiere estipulado en los ca. pítulos malrimoniales (núm. 1.014): una vez el marido mandaba a su espósa algu. nas fincas (casas, corrales, majuelos, huerta), algunos dercebos en salinas de Perales, ropas y muebles de casa, bneyes, el tercio de la cesecha de trigo y de vino, y el lercio de la barbcchera, a cambio de su décima parte, eon condición de que no pida, ni pretenda, ni reclame ofra cosa; si no acepta eslo, manda que se le dé su décima parte nada más, según la ley. También tenfa derecho la esposa a la mitad de los gananciales: en ocasiones, el msrido le mainda so propia mitad, junto can otros bienes muebles y raices (núm. 1.029); o declara el marido que su mujer lenía par. te en las compras y mejoras de ciertas alquerías que él vinculaba; a cambio de este derecho de su esposa, le daba en usufructo olras heredades, y mandaba a los titulares del mayorazgo que dierain a la viuda, o a quieu ella dispusiere, 100 mizcales; o reconoce que la finca comprada después del malrimonio es de la mujer sola, y si el marido puso algún clinero, se lo perdona y se lo regala (núm. 1.030).

La hermana monja hereitaba a sus padres, aunque a veces prestase la cantidad heredada a sus hermanos (núm. 845). Otro tanto ocnrria cun el hermauo fraile: la madre se comprometía, con escritura de deuda, a pagarle su parte en la herencia del padre, importante 100 mizcales, más 60 de una deuda por el fraile contraida; y si la madre muriera sin haberle pagado, los olros herederos no podrían posesionarse de la berencia sino después que el fiaile hubiera cobrado (núm. 859).

Una vez conocido y valuado el total de la herencia, por almoneda hecha entre parientes que pudieran presenciarla y personas peritas (núm. 1.043), se pasaba a la ejecucion del testamento por los albaceas, que vendían lo preciso del caudal hereditario para cumplir las mandas o les sufragios dispuestos por el testador (núms. 69, $130,141,149,155,192$, etc.). Se vendían primero los bienes muebles (ním. 1.014), y cuando con el producto de ellos no había suficiente, se vendja alguna finca para sacar el quinto de la herencia (núm. 216). Se vendía la finca, se pagaba el décimo a la viuda, mujer eu segundas nupcias, por su dole, y cl quinto que el lestador había dispuesto para sufragios; el resto se entregaba al hijo de la primera mujer (núm . 1.099). Los albaceas exponían al alcalde que una finca de la testadora estaba ruinosa y que querían venderla para empleat su precio rectamente en favor de los hijos de la difunta, menores; el alcalde se infornó de la personalidad tix los albaceas, estando presente el mayor de los huérfanos, que tenía ya dieciséis años, y autorizó la venta obligándose los albaceas a emplear el precio en otra finca más útil para los muchachos (núm. 250). Si de las fincas del testador no podía hacerse partición completa, 
se vendía alguna de ellas (núm. 457). Otras veces se vendía finca, heredada por la viuda y por los hijos menores; la mitad se quedaba para la viuda; de la otra se sacaba el quinto para sufrogios, y el resto quedaba en poder de la viuda para entregarln en su día al hijo menor ( núm. 216). Cuando los albaceas vendían finca, daban las razones que a ello les obligaban: necesidad, por ejemplo, de pagar gastos de una matriz (accquia princspal), de otras accquias y de un estarque, y teniendo cuenta de que la finca era pro indivișo y mayor el precio que la ulilidad de su renta, así podían cumplir cl testamento y fundar una capellanía (núm. 590). A veces, ejecutaban el testamento en todas stis partes, salvo algumas, v.gr., en lo referente a uaa viña dada para su patronan. Ln este caso, resultando insulicientes las renlas para cumplir lo dispuesto por el testador, se comunicaba al alguacil y alcalde, que consul. taba con los grandes de la ciudad de Toledo, a quienes correspondía consular entre los racioneros, mozárabes y castellanos, y decidieron rogar a los albaceas que aceptarạn la propuesta de entregar la viña a la Catedral, y ésta se obligase á incluir al testador entre sus canónigos. El arzobispo también aprobo y consintió, asistiendo al otorgamiento de la escritura correspondiente (núm. 1.012).

Los albaceas aprobaban ventas hechas por vindas de los testadores (números 269 y 641), y, en ocasiones, salían iladores para la evicción y saneamiento (número 608).

También, a veces, los albaceas habian de comprar fincas para cumplir las disposiciones del testador y entregarlas a los legatarios : la legalaria (núm . 89) compare. cía y se daba por pagada así como sn marido, y se daba por entregada de otras mandas; aunque no adquiría la propicdad definitiva, por no ser mayor de edad, condición impuesta por el testador. Adquirían fincas para fundar con ellas los aniversarios dispuestos (núms. 277 y 674). Y si el haber heredilario no llegaba a la cantidad mandada para la fundacion, los albaceas adquirían por la cantldad con que podían con. tar, procurando que la institución legataria aprobase el aclo (núm. 378).

El albacea daba posesión de la herencia a la heredera (núm, 1.063), o al Cabildo, de ciertos derechos en el río en Corral Rubio (núm. 1.064); o declaraba haber recibido alguna caul idad adeudada al testador (num. 1.072), o retener en su poder 70 mizeales de los 100 en que se había vendido un libro, Texto de curatelas, para cumplir el testamento (rú́m. 1.084).

Podía ser albacea cualquier persona mayor de edad, varón o hembra (alguna vez es sólo una mujer, núm. 685). Se les encomendaba la ejecución del testamentn porque cl testador * tiene conocimiento de la fe y religiosidad de ellos, y para que hagan en todo esto lo que hace todo aquel que sabe que a Dios no se le oculta cosa alguna en la lierra ni en el cielo. (núms. 1.014, 1.024 y 1.030, etc.).

Ias nuandas se hacían en metálico, en objetos, muebles, fincas, derechos, etc, como puede verse en los mismos textos documentales.

Si la manda era condicional (a un sobrino ausente, en caso de que regrese en el 
plazo de dos años), pasado el plazo sin volver el legatario, ni saberse si estaba vivo, los albaceas vendían la finca (núm. 436).

De las herencias y mandas se daba recibo, sobre lodo en caso de arreglo y cesación de reclamaciones (núms. 1.070 y 1.071 ).

460. Mejora. - Los padres podían mejorar a uno de los hijos sobre los otros, hasta el tercio de la hacienda. A ano lo mejoran sus padres (núm. 1.157) sobrc su hermana, en una casa del barrio de la Catedral y los diversos utensilios de ella: esto, después de la muerte de los padres, sería para el hijo, por el tercio que le pertenecía, en caso de que la hermana lo aprobase; si no lo aprobaba, disponían que correspondiera al hijo su tercio en la casa y en el resto de la herencia, y quedaran los dos hermanos iguales por mitades en el remanente, después de haber tomado el hijo su tercio, según dispone la ley de los cristianos respecto a mejoras (núm. 1.036). Otra madre daba a su hija el tercio de todos sus bienes, a partir de la fecha (1185), con las signientes condiciones: Que quedara pro indiviso con el resto de los bienes hasta que muriese la madre; ésta emplearía la renta en los gastos que la hija necesitara, sin que la hija pudiera reclamar, y obligándose la madre a completar lo que faltase, si no alcanzaran; que niuguno de los hijos de la donante, habidos o por haber, reclamaría uada contra la hija mejorada, ya que esla mejora es la que concede la ley a los padre que puedan hacer a algnono de sus hijns, según fuero de los castellanos; y para cortar el derecho a la herencia, disponia que la hija mejorada diera a sus hermanos cinco dineros y una medalla. Aceptaba la hija, y como era menor, guardaba la escritura su madrina (núm. 1.637).

Un testador disponía (1211) ciertas mandas con cargo al tercio en que lo mejoró sil padre, que era a la vez el tercio con que a éste lo mejoró su abuela (uúmero 1.024).

Una forma especial de mejora podemos considerar la empleada por una madre que declaraba con juramento (1281) que su hijo Fulano la había servido durante dieciocho años; que le debía haber dado de soldada al año 20 mizcales blancos nuevos de 15 sueldos, y no le habia dado nada; que se obligaba por la suma total, que se le habría de dar de sus bienes, a su muerte, antes de que se partieran (núrm. 1.004).

La mejora se podía revocar: así consta por testimonio que una madrc había llamado a la testigo y a su nuera, ahijada de aquélla, para decirles que habf́a mandado micho a su hijo en cl testamento; que le quitaba todo lo que antes le había mandado, excepto las viñas y el corral; y disponía que partiera con sus hermanos legalmente: la madre estaba enferma de la enfermedad de que murió, y en cama, pero con su juicio y entendimiento cabales (núm. 1.032). 


\section{G. PARTICIONES DE BIENLS}

461. Constan en la colección que vamos estudiando algunas actas de partición de bienes, casi todas ellas redactadas para dirimir las contiendas y disputas entre diversos copartícipes en herencias, naturalmente, intestadas. EI documento más antiguo, de $11 \tilde{3} 8$, contiene el arreglo y particion de bienes entre tres hermanos y la madre, sobre la herencia del padre y marido: disputaban en lo referente a tierras y viñas, y después de dos meses de consultas llegaron al acuerdo, y se adjudica. ron cada cual su parte, que se detalla (núm. 972). Madre e hija se partían un corral en Olías ( núm. 983).

Más difícil era el arneglo cuando babian de repartirse varios hermanos de madre, dos del primer marido, otro del segundo, los bienes de la madre y del primer marido: el hijo del matrimonio segundo se comprometía (1160) a no reclamar, por si y por otros dos hermanos, ni de esta herencia, ni del quinto de la de su madre; si reclamaba, se obigaba a devolver lo que en este arreglo recibfa de sus hermanos, los del primer matrimonio; y si estos últimos reclamaban, sería nulo (núm. 973).

Al intentar tres hermanos, uno de ellos presbitero, partir los bienes de su padre, vieron que tenfan muchas deudas: los dos seglares rogaron al presbitero que se quedase con los bienes nuuebles para pagarlas, aunque reconocian que su valor era menor que la suma de las deudas; el presbítero accedio, y se comprometió a pagar las deudas contraidas por los tres antes de la fecha (1189); partieron luego las fincas rústicas en Olías y Valdechaćn, reconociendo los tres que la parte del presbítero era la mejor: éste dió una cantidad en metálico para igualar on jusncia; sólo les quedó pro indiviso una casa en San Román (núm. 1.129).

Ios esposos tenían los bienes comunes, por milad, segron hemos dicho. Muere el marido, y uno de los hijos reclamo a la madre su parte de la mitad del padre, y pidió a la vez que se ajostase la cuenta de hi que una hermnna casada llevó de más de esa parte en su dole y ajuar. Arreglaron la cuenta la madre, el hermano reclamante, otro mayor y la casada (habia tres hermanos menores que no intervenian, sino su madre por ellos), junto con personas honradas y entendidas en particiones. La suma de los bietıes correspondientes al padre !or su mitad eran 70 mizcales de oro alfonsíes, de los que había de rebajar 5 mizcales de una deuda y 4 que había valido el quinto de un huerto que el padre dejo a dos de sus hijos (el reclamante y otro) cn la alquería de Ain. Quedaron, pues, de tondo 61 mizcales. La dote de la hermana (dinoro y ropas y la mitad de la caniidad total que pudiera corresponder a la madre) se calculo en 35 mizcales: Quedó en poder de la hermana, por la mitad de su madre en las ropas que le asignaba la dote, la cantidad de $17 \frac{1}{2}$ mizcales, hasta 
que se arreglara con sus hermanos, después de la muerte de la madre. Se aumenta. ron los $17 \frac{1}{3}$ mizcales restantes con los 61 anteriores y quedó un haber hereditario de $78 \frac{1}{2}$ mizcales, a partir entre la madre y sus hijos, legalmente y por igual. Tocaba a cada uno 11 mizcales, 2 octavos y medio y un quin to de octavo; a la casada tocaban $6 \frac{1}{2}$ mizcales menos dos oetavos y medio y un quinto de octavo. El reclamante había de haber 11 mizerdes, etc., más 2 por el ruinto del buerto, y por la parte de los 6 mizcales y medio que su madre había de dar a cada hijo por dos vifias. I a mradre se obligo a dar a sus tres hijos menores la parte que les correspondía (núm. 942).

Los hijos pedian a veces a la madre parte en bienes que Esta labía adquirido fuera del matrimnnio: después de algunas discusiones, los hijos se ven forzados a re. conocer que los bienes eran de la madre, par partición legal con un tercero; y la madre y un hijo se conformaban en que la hija tomara su parte de los bienes del padre, dando a su hermano pur su derecho una cantidad en metálico, y esta hija se compromete a contribuir lamblén al pago de las deudas de la herencia paterna (número 980$)$.

Complicada y dif́cil era la particién cuando los coparlícipes eran de un lado parientes, de otro alguna institución, como la Catedral: los bienes de Gonzalbo Díaz y de su hija María Gonzálbez, en Alcardete, se dividían (1203) entre la Catedral y Urraca Rodrjguez, de un lado, y Rodrigo Díaz, de otro. Los señores se quedaban con la mitad superior, que se delimita, con el pozo de la aceña de la parte alta, los frutales, etc.; la segunda milad era para Rodrigo, con la mitad del estanque que echa su agua a las dos aceñas, hasta que se dividieran con alguna pared, más la mitad del canal entre las dos milades; y do aremás a los señores 80 mizcales, después de haber hecho almoneda entre ellos. En la mitad de los canónigos tenía Urraca un tercio pro indiviso, y no más, y en la parte de Rodrigo no tenía ella nada. Se estipulaba también que los gastos de construcción del pozo que labía empezado a construir don Gonzalbo de la parte que dió a los señores, sería de cuenta de éstos, pero las aguas se habrian de usar igual por las dos partes contratantes (núm. 1.041).

Hubo largo pleito (1206) entre María Melendez, viuda de Juan Martínez, en nom. bre de sms hijos, con otros hermanos de su marido, por la herencia de la madre de estos hermanos, Dominga, mujer del álguacil Esteban Amrán. Marf́a reclamaba la herencia de doña Dominga, más lo que habia tocado a su marido, y el tercio en que lo había mejorado su madre; y la parte que el difunto temía en las construcciones y gastos hechos en las fincas por el marido de la causanie. Los sobrinos de la reclamante replicaban que la causante, doña Dominga, había reconocido que vcndía la herencia a un tercero, con lo eual éste se reconocía deudor de ella por 300 mizcales. Con la intervención de gentes buenas, se llegó al siguiente arreglo: que la herencia del algdacil Esteban Amrán, marido de doña Doniinga, se dividiera en tres partes para sus tres hijos, y a ella no tuvieran derecho alguno los nietos, hijos del difunto y de la reclamante; que de la herencia de dona Dominga se apartase un tercio para 


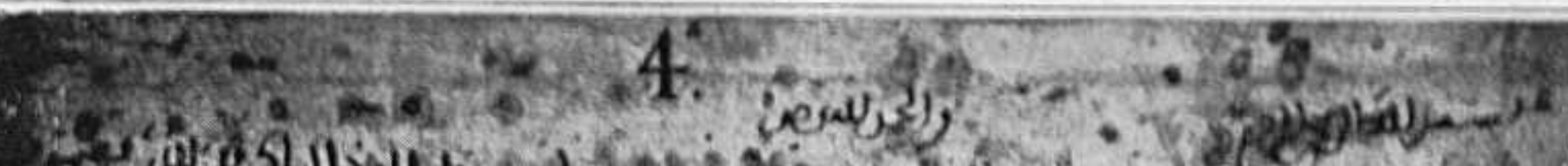
7. tats

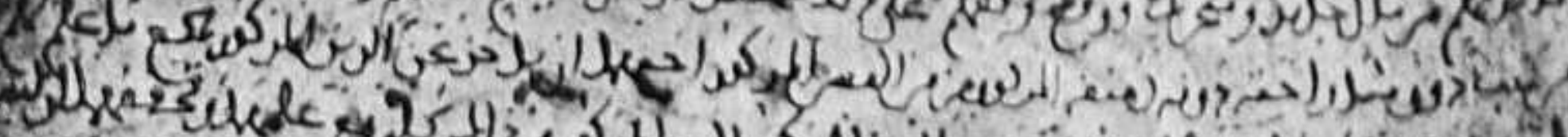

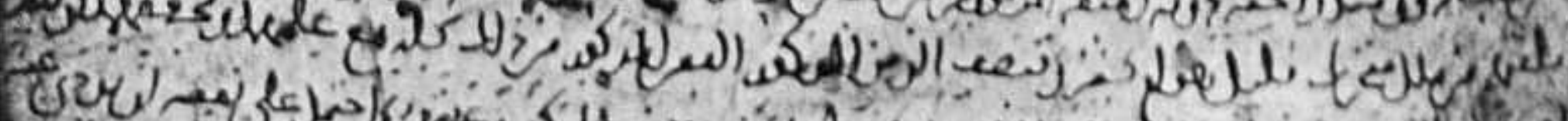
(us

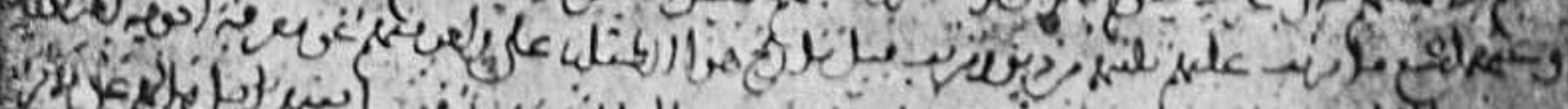

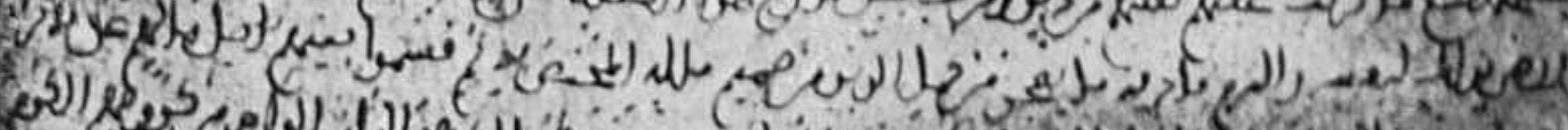

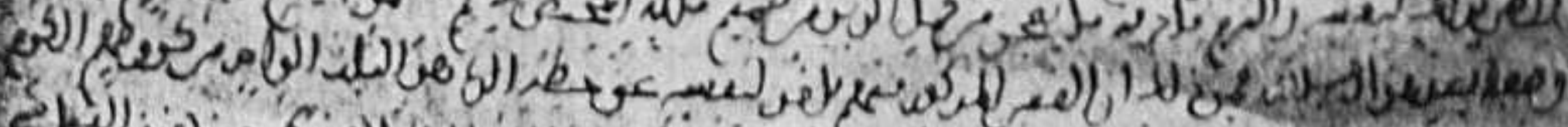
F ev?

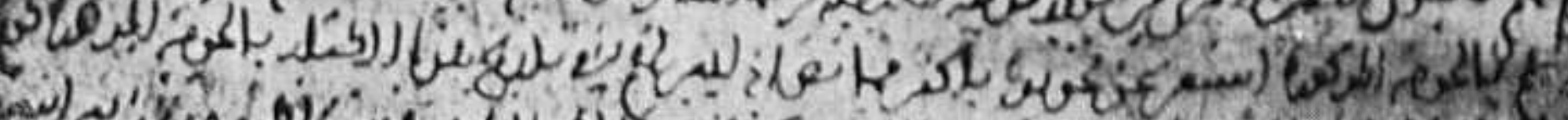

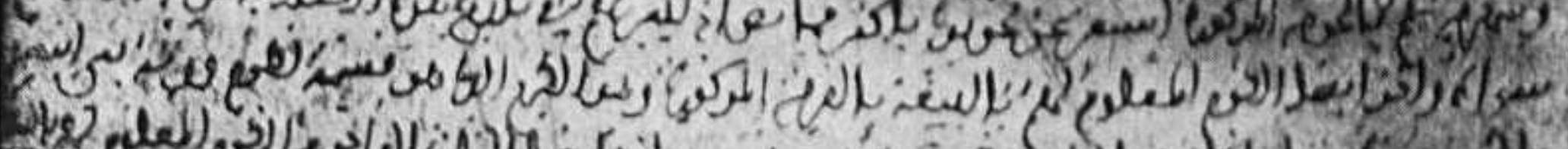

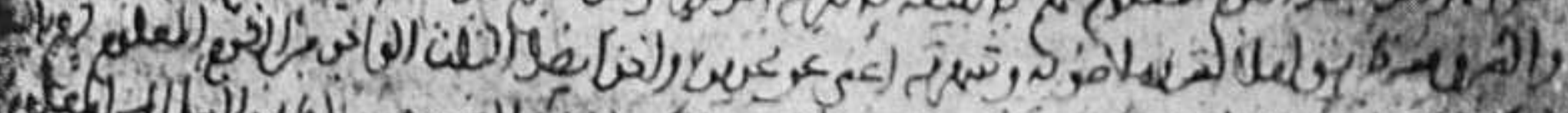

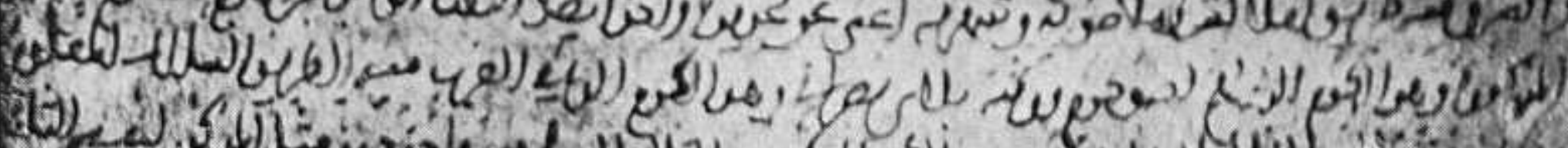
(iv) (vis)

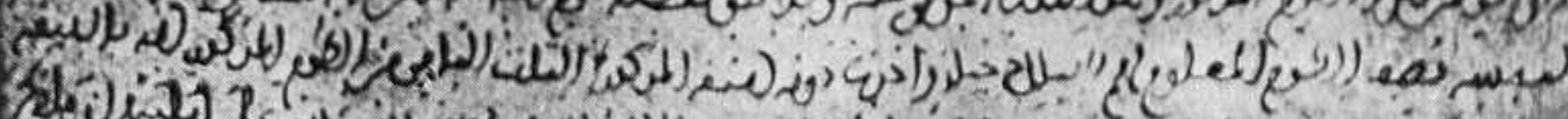

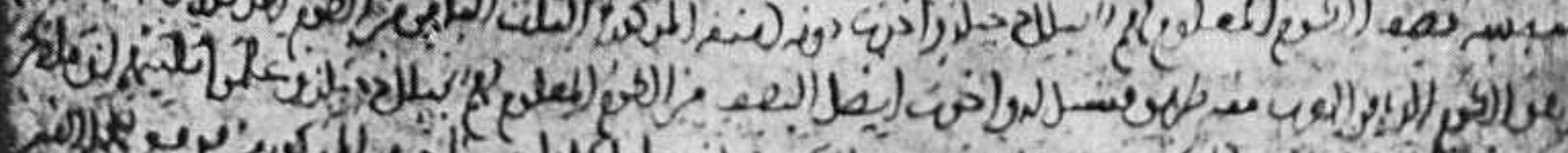

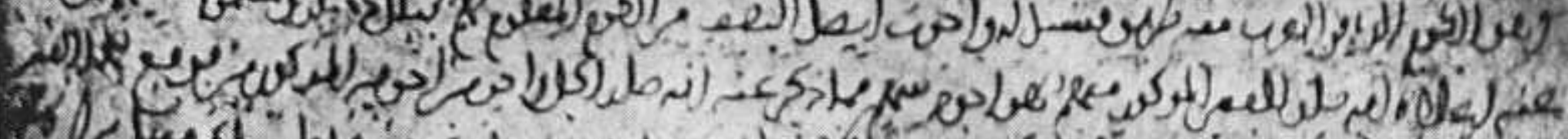

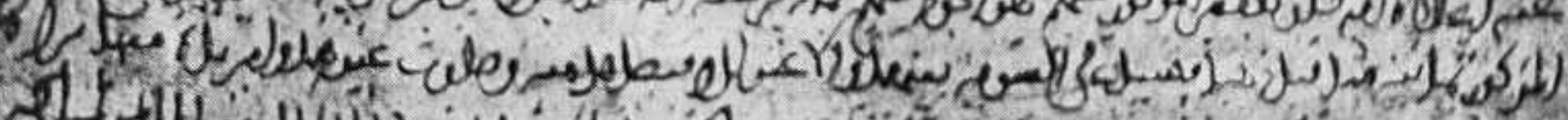

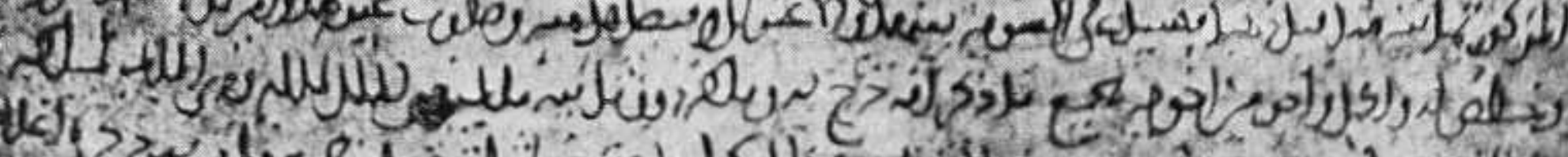

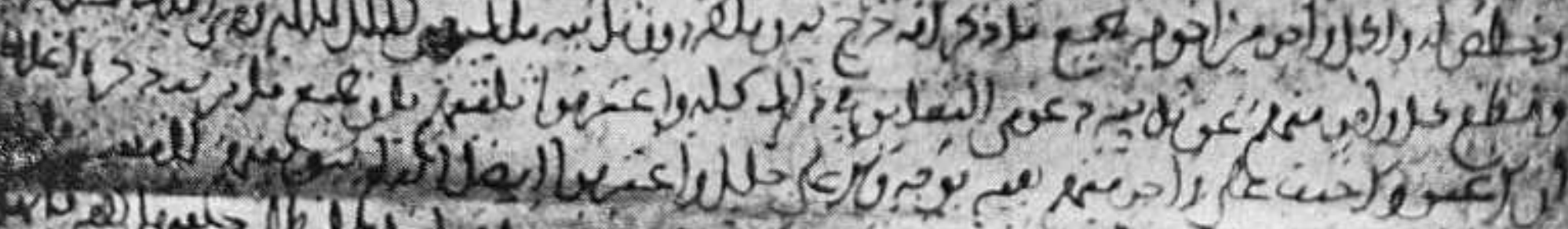

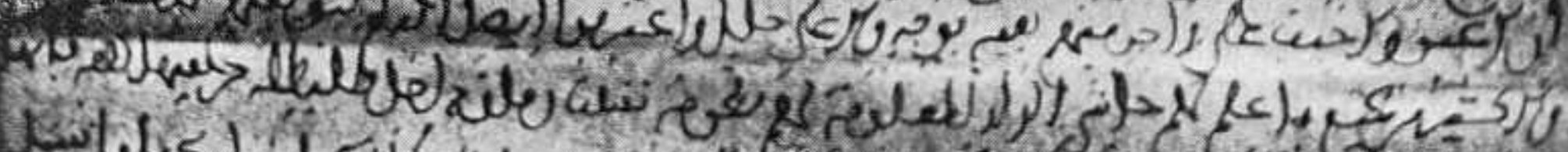

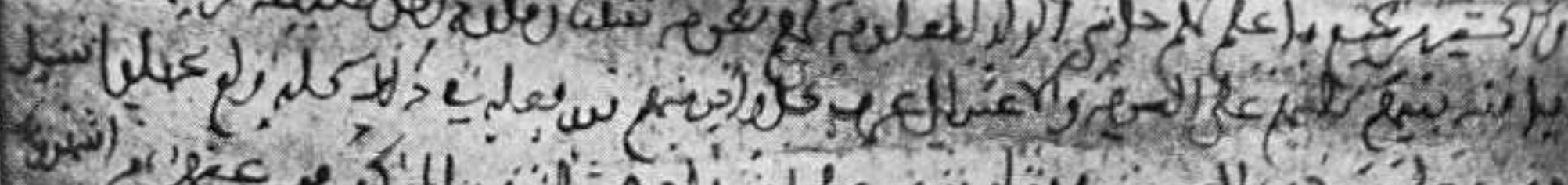

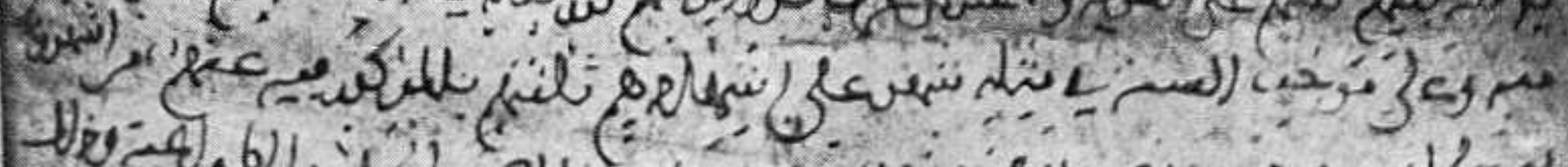

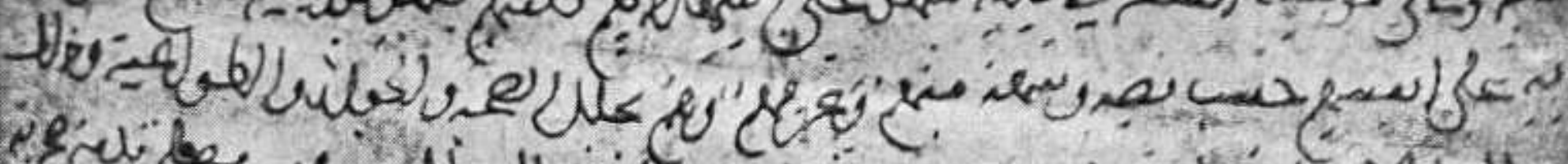

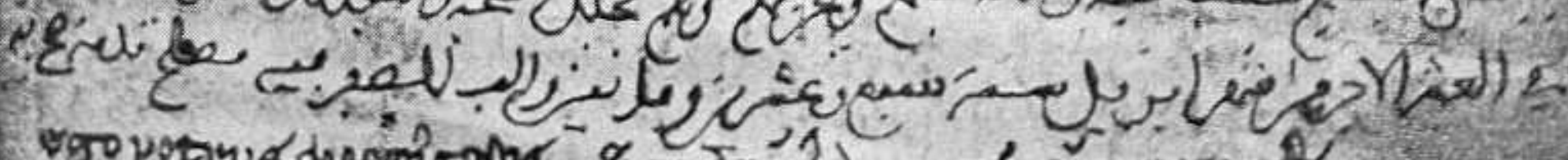

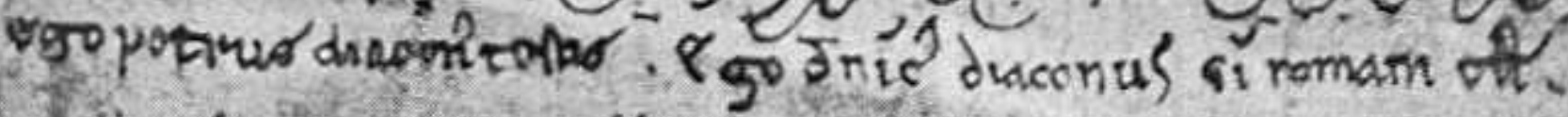

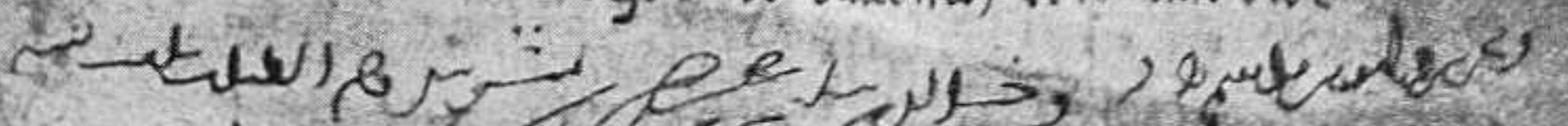

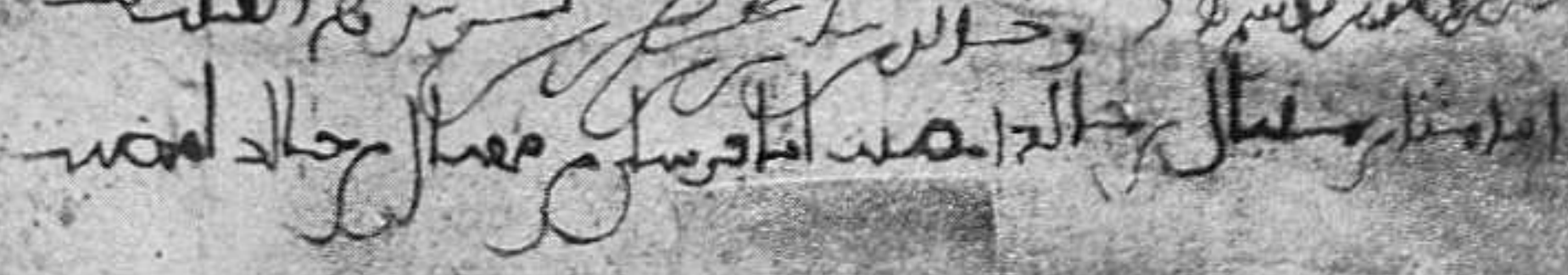


D. Juan, su hijo difunto, por el tercio en gue lo había mejorado; y el resto se divi. diese en tres parles, una de ellas para doña Marfa y sus hijos (núm. 947).

La partición du los bienes de Luna de Yamero, en 1260, permite formar idea clara de la forma de hacer estas operaciones (núm. 1.043):

1. HIso:

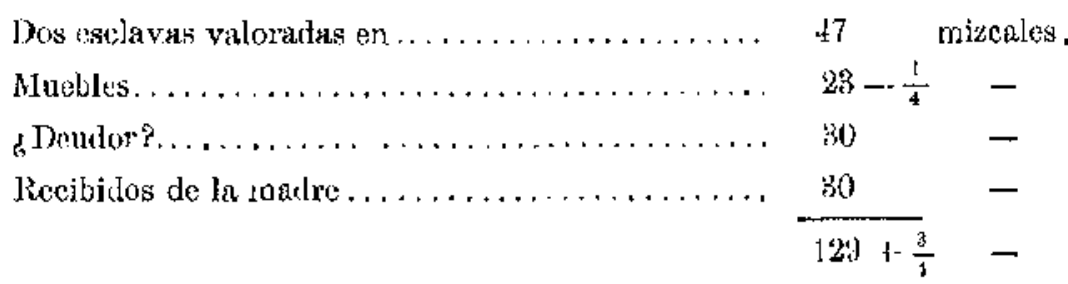

2. Nifrog, irfjos De miJa:

Viñas.................................. 37 mizcales.

Muelles.. . . . . . . . .

Dote de la madre......................... 60 -

Parte en casa .......................... $\frac{20}{127}-$

$3 .^{\circ} \quad$ HIJA:

Parto en casa........................ 70 mizcales.

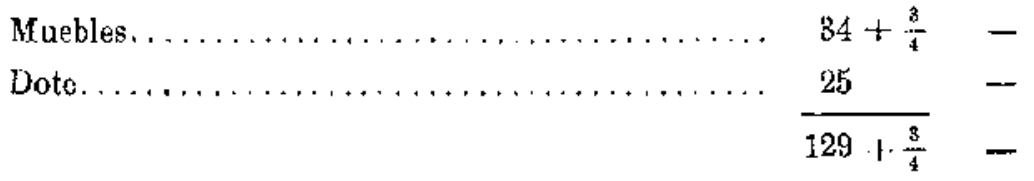

$4 .^{\circ} \quad$ Hiso:

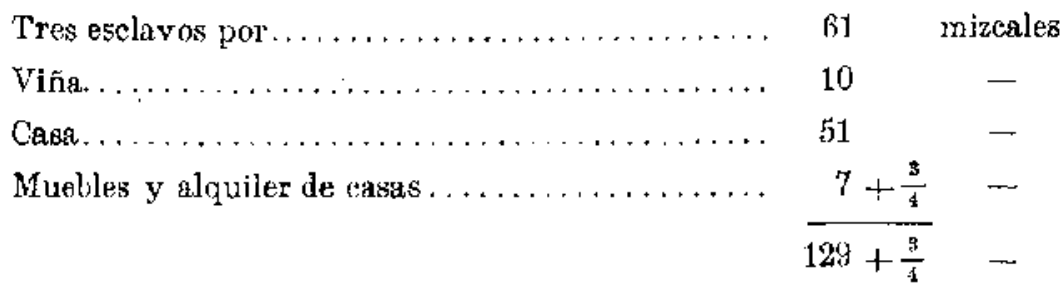

5. Hijo:

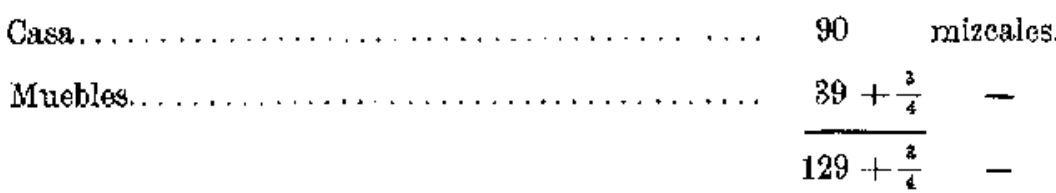

Los hijos del alcalde D. Gonzalbo Juanes partían con él (1272) la herencia de su madre, en lus bienes que ella posé́a antes del matrimonio y en los que posefa pro indiviso con su marido (gananciales); reunidos el padre, los hijos y algunos hombres buenos, hicieron el inventario de los bienes de la difunta; los de antes del 
matrimonio cran una casa en el Arrabal de los Francos; de los gananciales adjudicaron a los bijos una casa en San Martín, más 100 mizcales y 4 sueldos en metálico, más $20 \frac{1}{2}$ mizcales por la mitad del vaso de plata que tenía el matrimonio, más la mitad de las cosas de plata, ropas, muebles y utensilios de casa: de lodo to cual se dan por pagados y recibidos los dos hijos (núm. 1.044).

En la reclamación que un neto hace a su aboelo de los bieoes de su madre, lija de éste, por el derecho de la abuela, difunta, se principia por señalar la cantidad que llevo en dote cada una de las hijas casadas, sumando el valor de bienes ráces y el de ajuar y ropas; se descuenlan los gastos oćasionados en este capital, con motivo del testameoto de la hija, también dilunia. Al pedir el padre dis nícto su parte en la herencia de su abuela y de su madre, el abuelo presenta todos sus bienes ante gente honrada y perita, quienes adjudican al nieto ciertas fincas y ciertos muebles y ropas. El padre del nieto, menor, da recibo de todos aqueHos bienes y se compromete a entregarlos a su hijo, cuanilo sen mayor, y se delimitan las fincas, ya que este documento había de ser el título de propiedad (número 962).

Si la partición se hacía entre hermanos, procurábase adjudicar a cada uno fincas de yalor equivntente, o supłáa uno la diferencio de valor, en metálico; olras fincas se partían, y algunos derechos (en pozo, estanque, etc.) quedahan pro indiviso (núm. 1.045). Si los hermanos estaban casados, aprobaban la partición los esposos respectivos (núm. 1.046).

Una forma especial tiene In particián de los bienes del alguacil Pedro Juanes: sus hijas Gracia y Teresa Petrez aprobaban (1291) la hecha con sus otros hermanos, el arzobispo D. Gonzalbo, D. Ponce Petrez, Juan Ponce, Fernando Petrez y doña Inés, de los bienes de sus padres, según las cscrituras de partición, que no se pre. sentan; se conforman a pue el arzobispo tenga y posea los lieves de los lermanos difuntos (núm. 1.047).

Con molivo de la profesión religiosa de alguna hija, solfan hacer los padres partición de bienes, para dar su dote a la futura monja. El alguacil y alcalde Pedro ben Abderráhmen dalua, en 1172, a sus hijas María y Cecilia, que habian de profesar en San Clemente, la parte que les correspondia en sus bienes: la sexta parte de un huerto, valuada en 167 mizcales; los productos de esta sexta parte serían para las dos hijas. Si a la muerte del padre querían hacer partición y las monjas preferían la citada cantidad, podían quedarse con ella, cumpliendo la ley en lo bucante a los hermanos; y si no querían quedarse con ella, pagarłan cl precio señalado y se partirfa la herencia del alguacil, según la ley, entre las monjas y los demás hijos (número 1.038). La abadesa aprobaba el documenio (núms. 1.038 y 1.042) en que sc hacia la partieión.

A veces la partición de bienes entre hermanos se hacía por acta judicial (número 684). Otras veces se parten fincas compradas entre varios, y se adjudica cada 
cual su porción (núm. 1.039), teniendo cuidado, al hacer la división, de que indemnice el que lleva la mejor parte (ním. 200).

La fórmula general con que se redactaban las escrituras de partición, después de delallar el acuerdo de cada caso, era ésta, tomada del documento número 1.045 : *Cada una de las dos [hermanas] entca en posesión de la parte que le ha tocado en el tolal de bienes parbibles, según se ha dicao, lo nismo que cuaiquier propietanio respecto de sus bienes y heredades, en virlud de la partición perfecta, cumplida, jusla, clara, sin condición viciosa, ni pacto de retro, ni de opción, que se hace por esta escritara y a partir de su fecha. Sin que cada una de las dos se reserve para si, ni para nadie en su propio nombre, derecho ni acción algnna en lo que ha tocado a sa otra hermana, en la forma descrita más arriba; sino que cada cual de ellas dispondrá libremente de su parle, ya mencionada, como lo hacen en el resto de sus bie. nes. Esta partición hace que cese entre ambas toda reclamación de acción pasada, o mención de frande o de injuslitia, con sibncin completn y perpetuo. Y las dos hermanas convienen, además, en que si alguien reclamara parte de lo que a cualquiera de ellas ha tocado del total de los hienes partibles, arriba dicho, y lograse arrancárselo, sea cual sea de las dos, la otra está obligada a plejtear por su hermana por la mitad ch: la parte que le nayan arrebatado" (núaıs. 1.134 y 1.139).

\section{H. RENUNCIA DẼ DERECHOS}

462. En varios documentos hallamos la declaración terminante de la perso. na que pudiern alegar algín derecho, renunciando a él (núıo. 572). Un hijo declara que la compra que su padre había hecho era la misma que luego vendio a otro, por lo cual el declarante no tiene derecho alguno en la finca vendida (núm. 506); asimismo, una hija declara no tener derecho alguno en una esclava liberta (núm. 791), o unos judíos y un pariente de la primitiva dueña se apartan en el acto de la venta del derecho que pudieran aducir a una vina (núm. 587). A veces, sin indicar el motivo de su intervención, alguien comparece para declarar que no tiene ningún derecho a la finca vendida, ni se opone a la venta, sino que la apruelsa (núm. 197).

El arzobispo D. Juan reclamaba, por 1173 , contra el poseedor de la alquería de Casa Chica; a instancia de algunos labradores de Canales que visitaron al arzobispo en Cabañas y le pidieron que renunciara a su reclamación, y que no limilara a Julián su dominio, el arzobispo renunció, con la condición de que el poseedor cul. tive la alquería, y si la quiore vender, lo haga a persona que se obligue a cumplir las leyes de Canales. Al momento rectifico y dijo que la podía vender a quien quisiera, pues el arzobispo pondría por condición al comprador que se obligara a las 
leyes de Canales, pues esta alquería estaba en los límites de Canales. Tres testigos presenciales deciaran lo sucedido en la entrevista (núm. 993).

Renuncia al derecho a unos pies de olivo, aparlándose de la reclamación que hacía contra las monjas de San Clemente ( 1 úm, 994). Cesan en sus reclamaciones y pleitos contra el mismo convento los parientes de una monja, declarándose pagados en sus derechos con la viña que reciben (núm. 996). Se desiste de la pretensión de ser suya cierta casa, vendida por otro (núm. 997.) Se declara paladinameute no tener dereclio alguno a cierta linca de la Catedral, salvo la mejorn que hizo el Cabildo a uno de los reclamantes en al arriendo que éste tomó de las fincas por toda su vida (núm. 999). Se renuncia a la compra que otro había hecho en Villamuelas, de varias fincas (núm. 1.000$\}^{(1)}$.

\section{AVENENCIAS Y CONCORDIAS EN PLEITOS}

463. No tienen apenas uniformidad los documentos de esta clase, ya que cada uno de ellos resolvía un caso distinto jurídico, en relación con las conveniencias de los olorgantes, que cedían algo cada cual de su pretendido derecho en aras de la paz comín.

Eil más antiguo es de 1124: García Temam cedía a su tía Hind lres cuartas partes del huerto de $\Lambda$ lhanaxí, en March alcadi, que ella había de poseer durante su vida, y a su muerte volvería al sobrino; de este modo se evitarían disputas, y si se hiciera alguna reclamación, sería nula (núm. 967). En otro pleito sobre viñas y tierras plantadas por un judío, se arreglan los litigantes (1147) eediendo una dos cuerdas de lierra blanca y la otra una viña (núm, 970). La disputa acerca de una aldea de Lielves se soluciona (1150) quedándose uno de los pleiteantes con el huerto que tenía el pozo, y el otro con las viviendas, y partiéndose el resio de la al. dea por igual (nínn. 971).

Curioso es el convenio de 1164 entre los racioneros, ancianos y notables de la iglesia de Santa Leocadia y I). Clemente el Monje, apodado el Santo. La iglesia daba a Clemente una casa frente a ella, a cambio de otra contigua. Cuatro personas, acaso cu nombre de la iglesia, se obligaban a dar a Clemeale cada año tres cabices dc

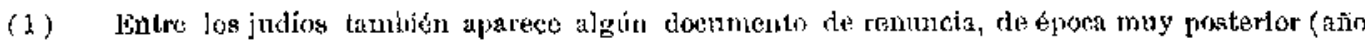
138\%) de $s$ todo derecho, título, garanlía y pretonsion que les correspondiera en lo presente y en lo fu-

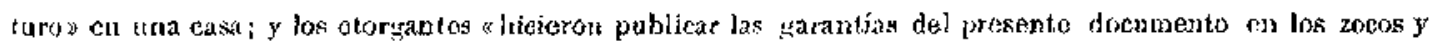
anunciarlas eu las rennionus, a tin do que no haya nada orulio, fino que sua txplícito, eonocido, firme $y$ ciertos (nún, 1.130). 


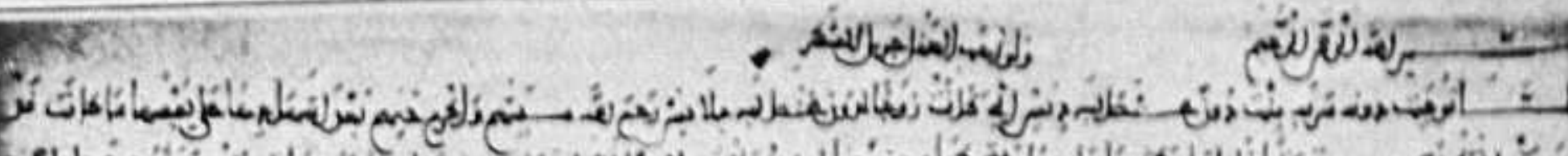

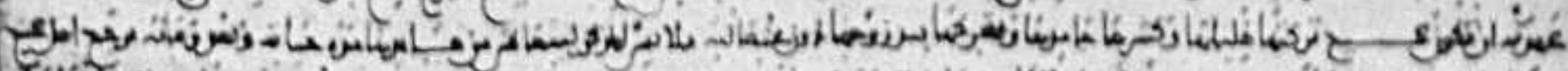

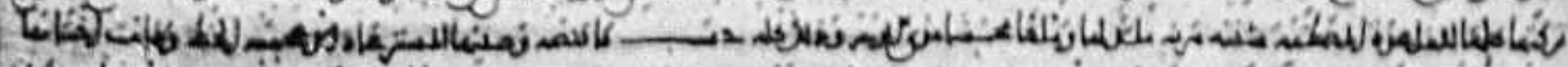

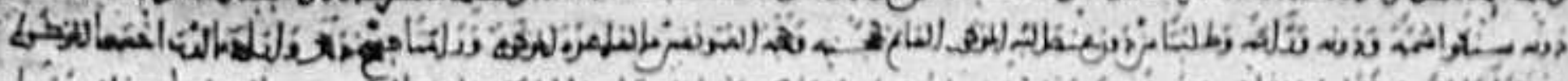

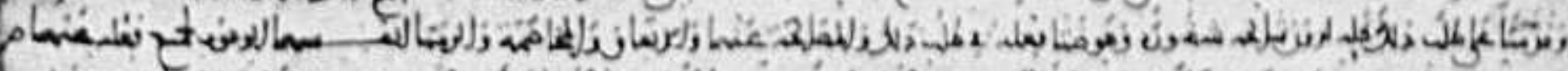

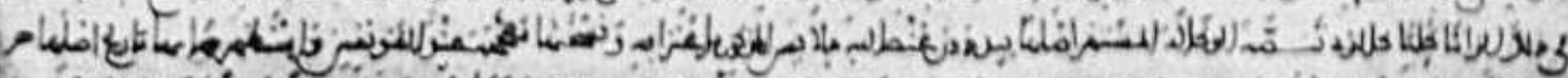

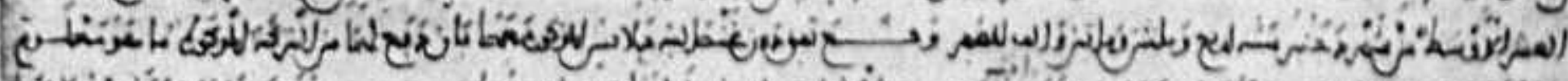

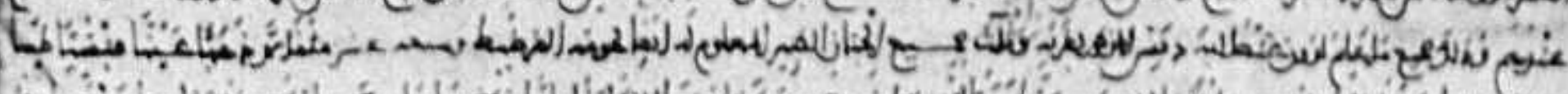
gres >

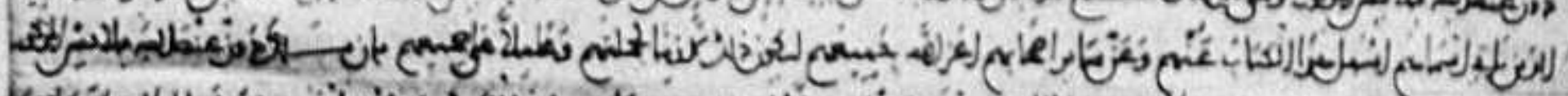

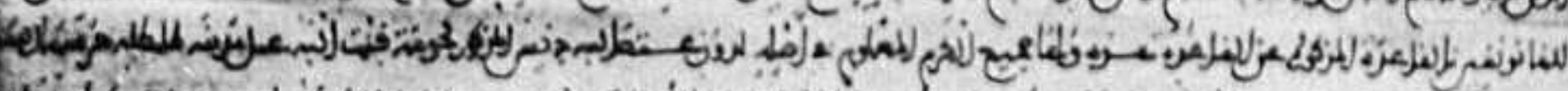

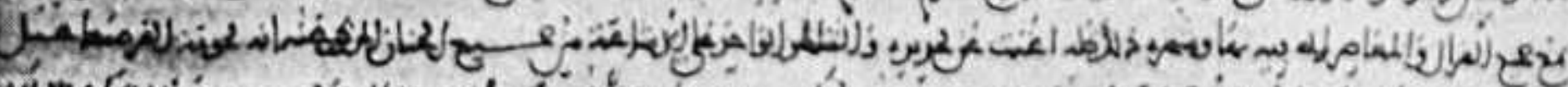

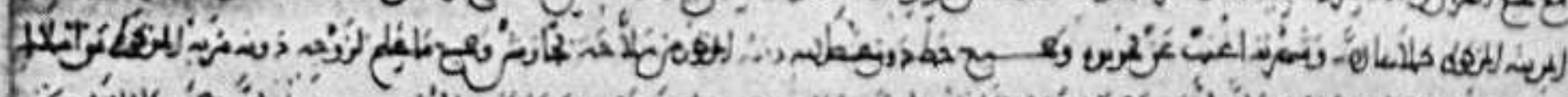

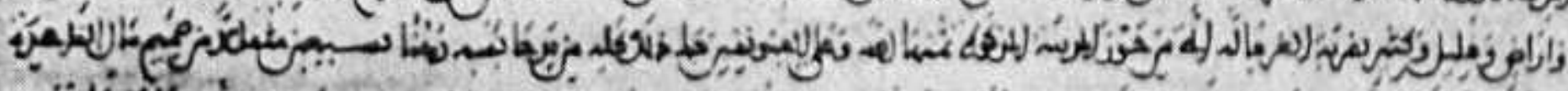

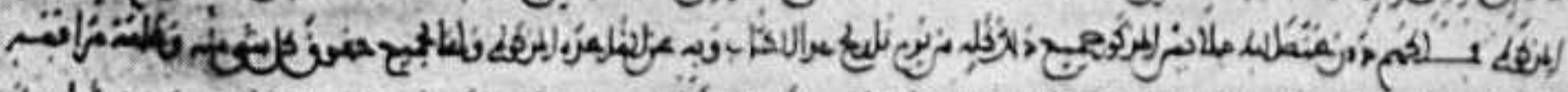

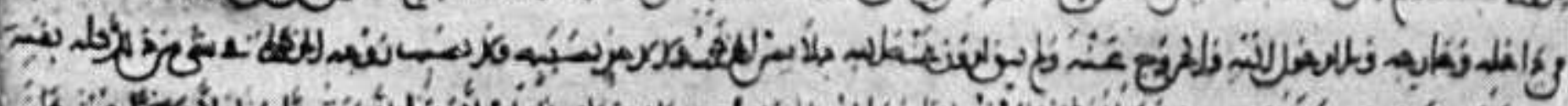

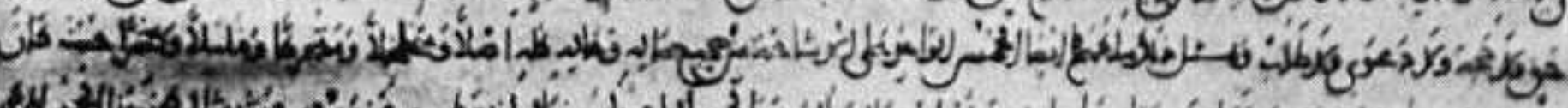
(4y-30

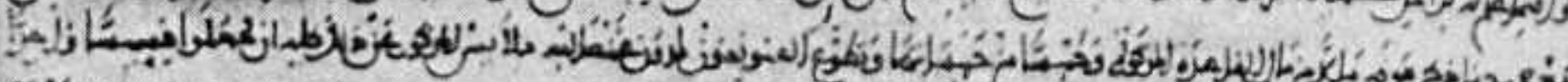

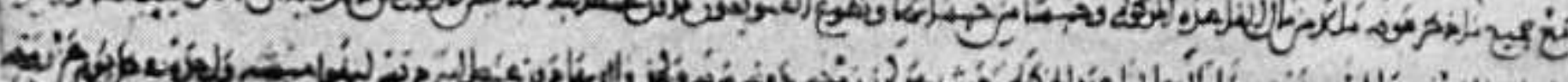

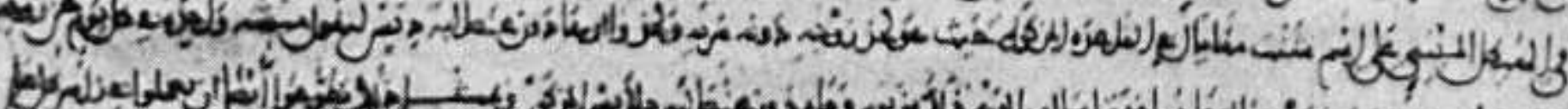

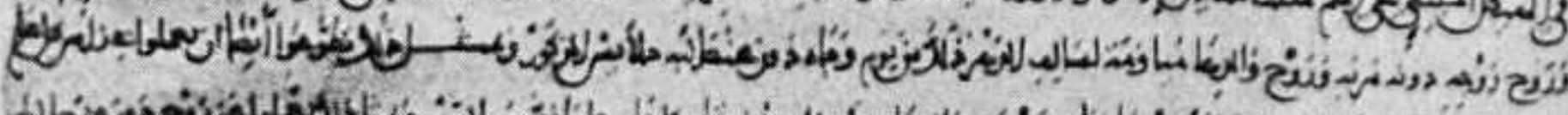

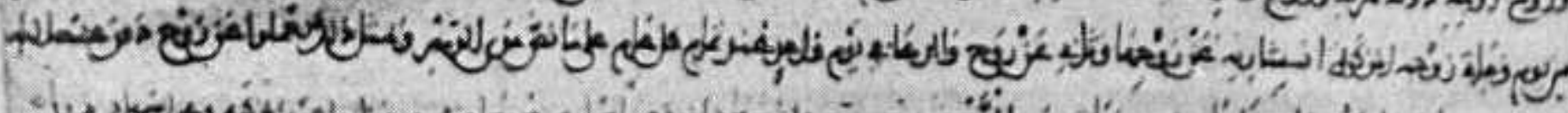

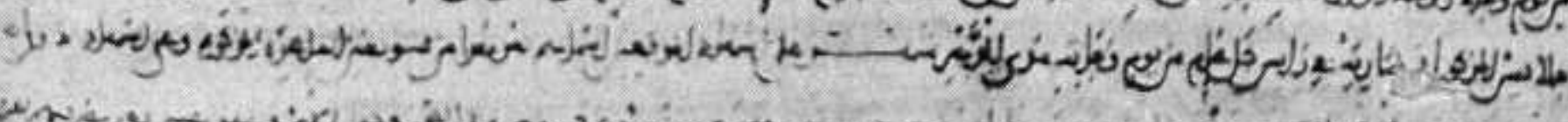

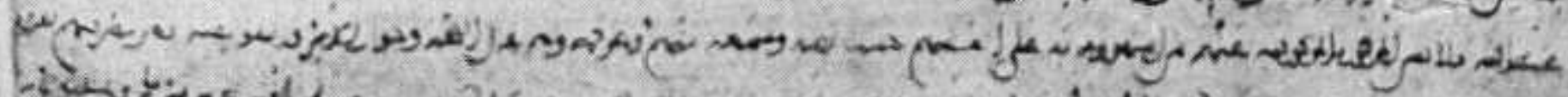

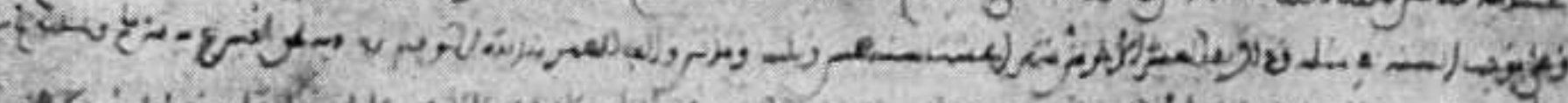
بx

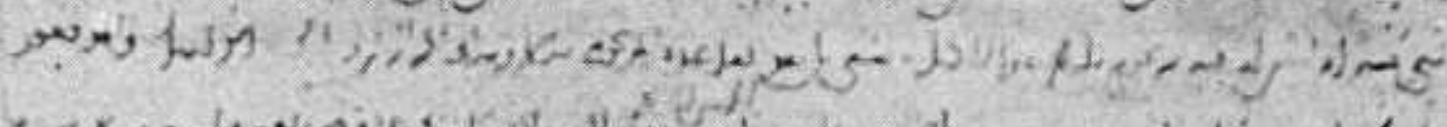

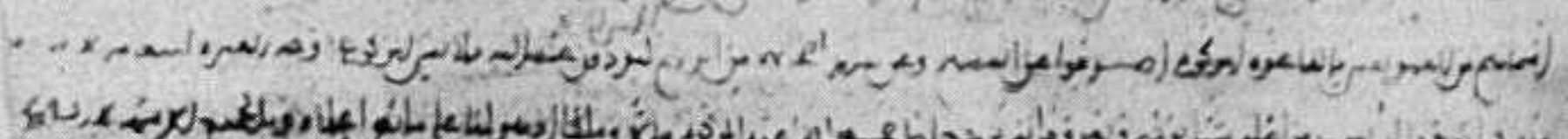

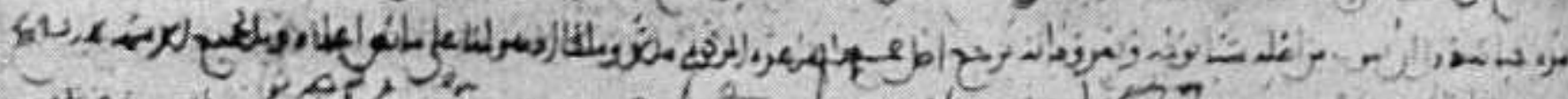

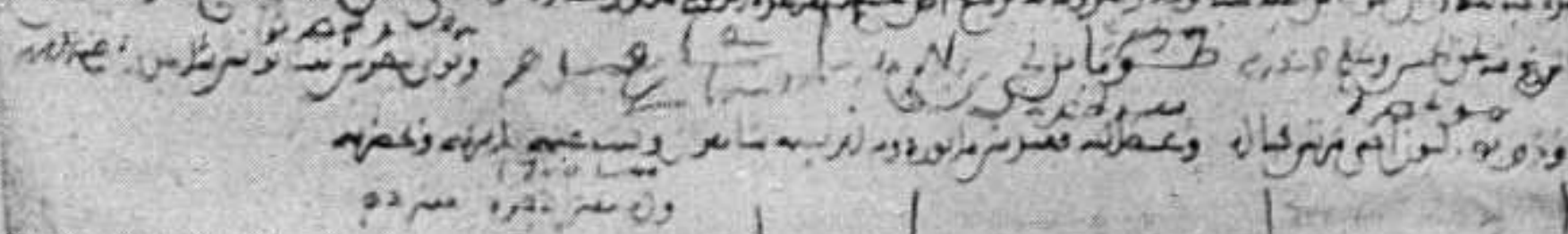

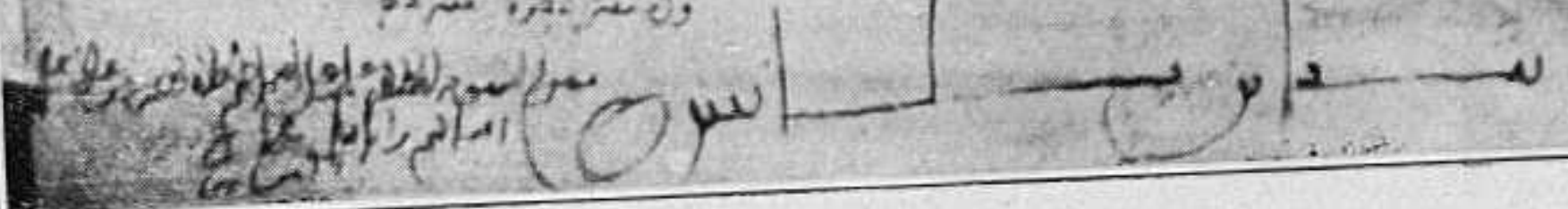


8. Corred

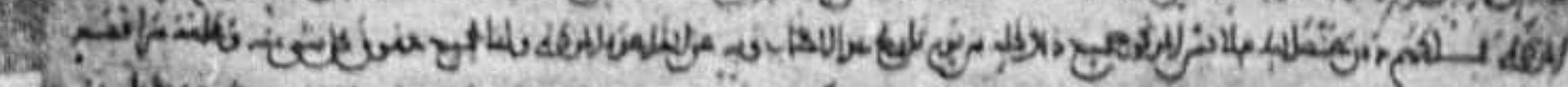

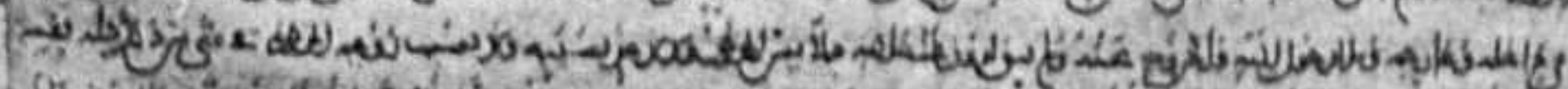

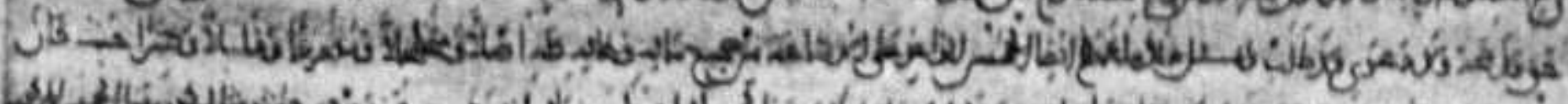

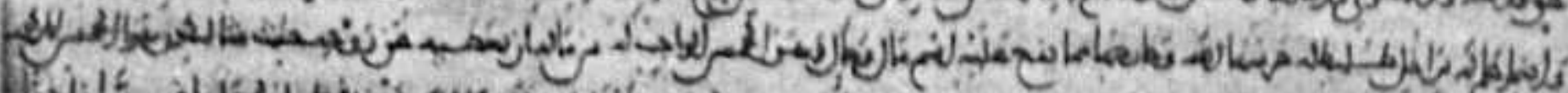

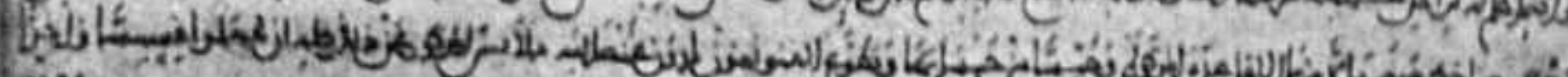
Qit)

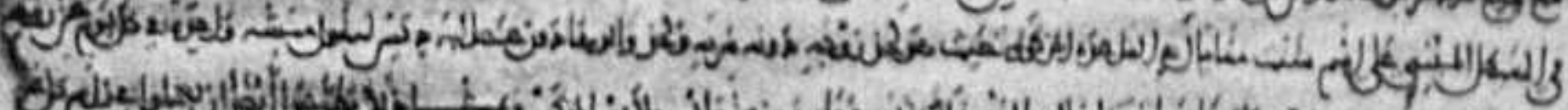

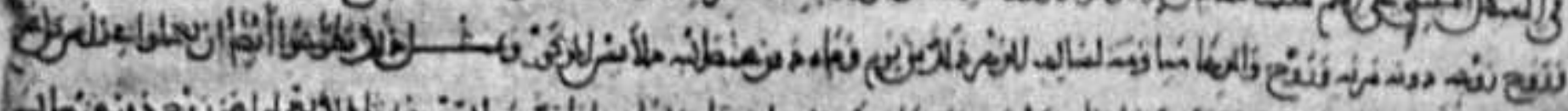

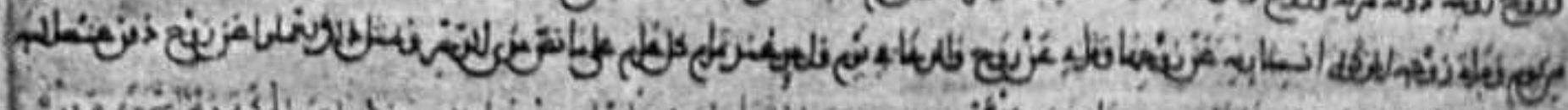

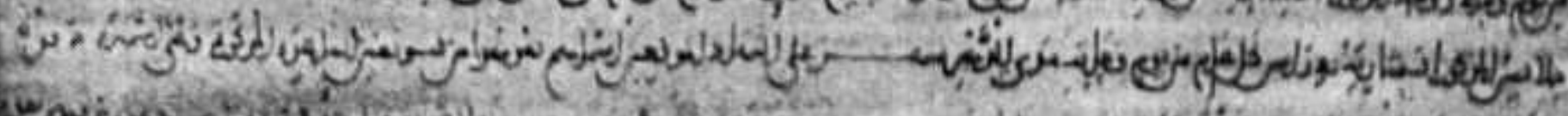

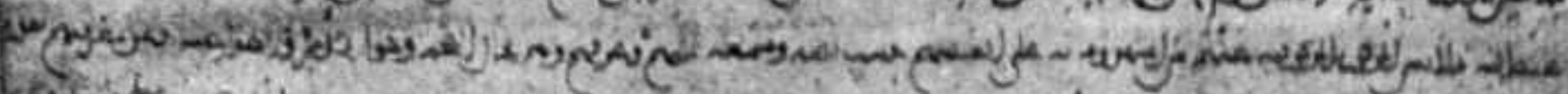

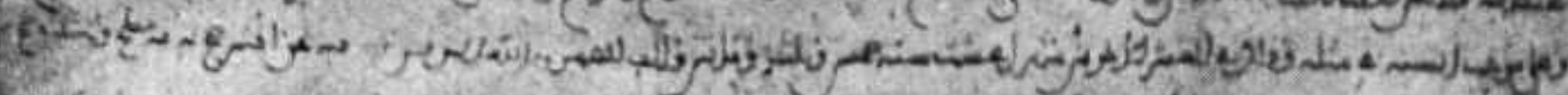

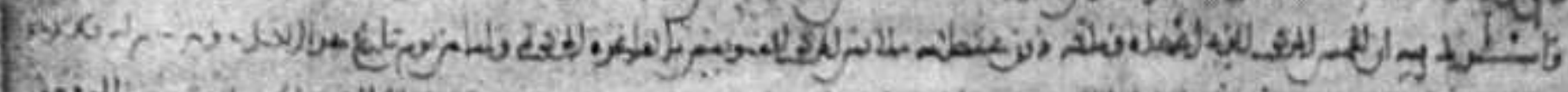

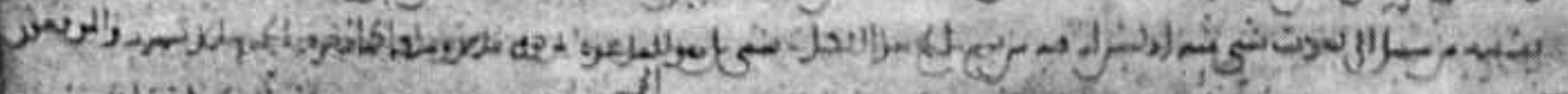

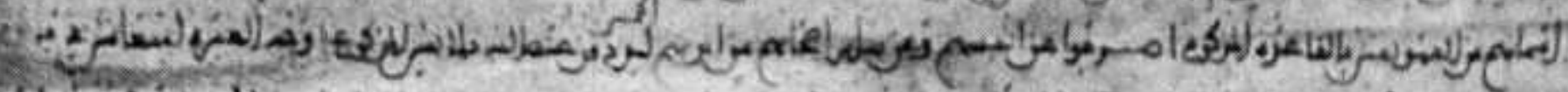

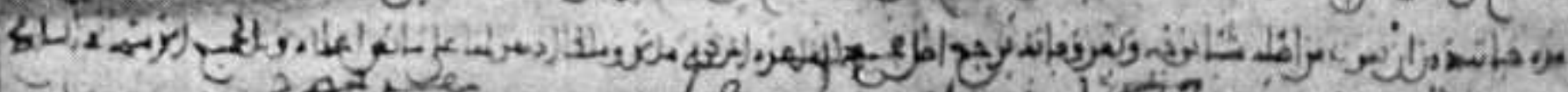

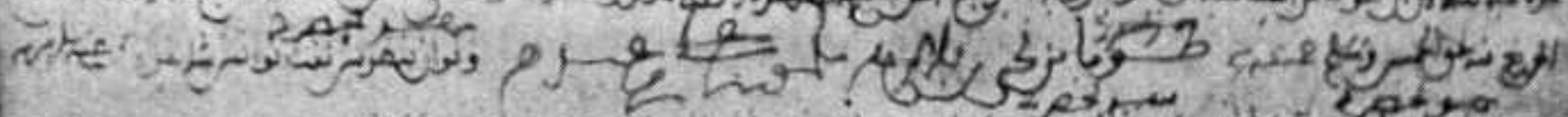

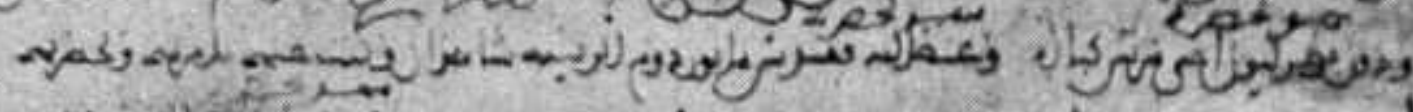

Fiva 0 is

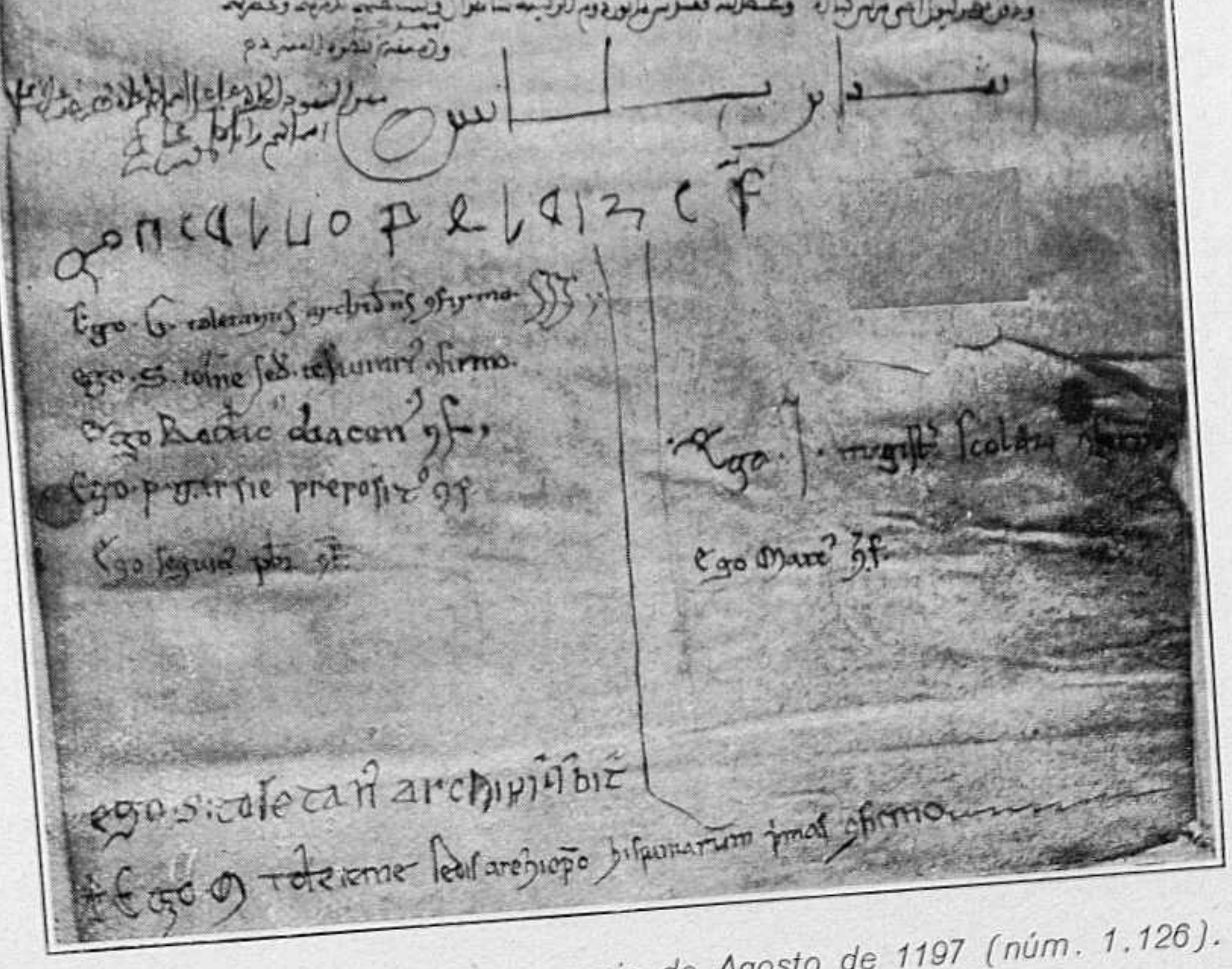

Firmas de la escritura de convenio de Agosto de 1197 (núm. 1.126). 
trigo, 60 arrobas de vino y mizcal y mcdio para vestido, durante su vida; y después de su muerte, a decirle una misa anual; fodo con consejo y permiso del arzobispo'. Don Clemente se comprometía a dejar, a su muerte, a los racioneros de Santa Leocadia, 10 mizcales de oro para misas, $y$ ellos vuelven a comprometerse a decir la misa indicada por el donante (núm . 974).

Mignuélez, en nombrc de su soirina María, reciamaba a Pascuala tres cuartas partes de la casa emperiada a favor del padre de Pascuala, porque era de la sobrina; más los esclavos, muebles, enseres, elc. Intervinieron genles que invitaron a la concordia y se arreglaron mediante la entrega de Pascuala a Miguélez de 5 mizcales (núm. 975). Otros arregłos se concerlaban repartiéndose viñas en litigio (itútm. 976).

Si se trataba de bienes pro indiviso, era más complicado el arreglo. Lin un caso de éstos (1190) una parte daba a la otra un cuarto de tierra y otro de viña; si alguna de las dos quenía que se partiera la alquería, había de dar al otro tierra equivalente al cuarto de viña; mientras no se partiera, seguíra en manos de la parte prinera citada (porque era dueña de tres cuartas partes pro indiviso), que habría de dar a la otra un cuarto de las rentas y derechos del sefforío. Se estipulaba la forma de partir la alquería, siendo tres cuartas partes para uno y la restante para el otro, lo mismo en fincas que ell casas.

La herencia de María Gonzálbez, viuda de Gonzalbo Peláez, díb lugar a largos pleitos, que se terminaron con una concordia en 1197. Ella había dejado su hacienda a su marido en usufructo y, a la muerte de el, había de pasar todo a la Caledral, en virtud de testamento legal, escrito en romance. Las hermunas de la testadora, Cincuésima y Urraca, pusieron picito al viudo, pleito que se resolvió con la intervención de Sancho Segura, apoderado de las dos hermanas. El viudo daba a sus cuf́adas lo que cl matrimonio posé́a en Ocner (Yuncler), un tercio del huerto grande de Alcardete, más 17 nizcales alfonsíes en dinero. (Consta la escritura de convenio con Cincuésima, por la que su cuñado la ponía en posesión de su mitad de estos bienes, reservándose una cuarta parte de lo sembrado en Ocner; abril, 1197, núm. 1.125.)

Después se arreglan el vindo y los canónigos de la Catedral en la forma siguiente: D. Gonzalbo da a la Cateủral la vina de Fonialba, con el corrál y las aimáceras que hay en él; más un tercio pro indiviso del huerto de Alcardete; más el derecho que tenía en las salinas de ¿Pajares?; más las heredades y tierras de Algorfela, con la obligación de los canónigos de levantar ta hipoteca de 70 mizcates en que estaban empeñados estos bienes, con el tonio die la Catedral.

Todo esto lo da desde el día de la fecha; con todos los derechos y utilidades.

Da también a la Catedral el quinto de sus bienes, de libre disposición, como le. gado pío.

Los canónigos se comprometen a poner un capellán, en el allar construido bajo la advocación de San Miguel (donde está enterrada María Gonzálbez y su padre), para que diga misa diaria perpetua. 
Y a hacer en el cabo de año de la muerte de María un aniversario por su alma y por la de su padre; y otro por el alma del fundador, el día de conmemorar su muerte.

El quinto de sus bienes lo seguiría usufrucluando el donante mientras viviera, aunque la nuda proptedad era de la Catedral, ya que ésta lo dejaba en manos de D. Gonzalbo (núm. 1.126).

Aún dio lugar a otro litigio la herencia de María Gonzálbez. El deán y cabildo de la Catedral quisieron poner pleito al Convento de San Clcmente, an le el arzobispo D. Arartín López, sobre los bieues que eran de Gonzalbo Petrez y de su hermana Orabona, es decir, un sexto pro indiviso de la alquería de Algorfela. El deán créa que esto era de la Catedral, por derecho de Cronzalbo Petre $z$ a favor de su esposa María Gonzálbez (que luego caso con Gonzalbo Peláez), y de esta María vino a la Catedral, por donación. La abadesa decía que la mitad de aquella finca era del convento, por el derecho de Orabarta Pefrez, que había eitpeñado la finca en poder del convento. Con intervención de gentes buenas se liegó a un arreglo (1201): que se partiera lo que había sido de los hermanos Gonzalbo y Orabona Petrez, por partes iguales, entre ambos litigantes; se enumeran las lincas que tocaban al convento y las que tocaban a la Catedral, y se advertía que todos los demás ìienes que pudieran hallarse en Algorfela, o fuera de elia, como propiedad de los causantes, se partirian entre el convento y la Catedral por partes iguales (núm. 1.127).

Para cancelar una deuda y librar de la pérdida una casa empeñada por 40 mizcalcs, los padres se la donan al hijo (1206), como anticipo del haber hereditario de su padre; los padres le daban también 20 mizcales, el hijo ponía los otros 20 para pagar la deuda, y si algún otro hermano reçamaba, se le podría atender con la mitad de los bienes del padre, porque los de la madre ya habían sido dados (núme. ro 981).

El convento de San Clemente y Martín Polent pleiteaban sobre la propiedad del azud de Juja y el de Bivas, originado en la reclamación del convento de las fincas de la Torre del Sultán, según la donación de Alfonso VII a Micael Mides y la confirmación de Alfonso VIII; de Micael hahía pasadn al convento. Se llegó a un arreglo (1217), cn virtud del cual Martín y su hermana Colomba tendrían el usu. fructo de aquellos azudes micnlras vivicran; a medida que fueran muriendo, su parte irfa a parat al convento. Colomba aprobaba el pacto, en documento de fecha posterior (núm. 984).

La abadesa del mismo convento intervenfa (1219) en el arreglo entre varias hermanas, una de las cuales estaba viviendo con las monjas, acaso de novicia, y un tío de ellas, respecto de los bienes del padre. Se reparten los bicnes y se indica la porción de cada cual. La abadesa había de dar sóle 10 mizcales por el empeño que habla hecho sobre tales bienes, todo con aprobación de las monjas. Pero advertía que se obligaba a cumplir el pacto mientras la novicia estuviese en el convento: si profe* 
saba, el convento se quedaría con su parte en los bienes; si se salía y no quería cumplir lo pactado, el convento se obligaba a responder a sus hermanos y familia de los bienes que había recibido por la parte de ella (núm. 985).

También pleiteaban la Catedral y Mayor Estébancz sobre la alquería de Bugiel, llamada ahora (1260) la Ventosilla, y sobre el colmenar que en ella había. Pretendía la Catedral que era suya toda la alqueria; decía el representante de Mayor que ćsta tenía allí un sexto (que poseía D. Domingo Vícente de Bugiel) por parte de D. Esteban Illán, padre de Mayor. Y presentaba escrilura de compra por lllán Esteban a su bermano García, lesorero de la Catedral, de un sexto de lo que su madre tenf́a en Bugiel (año 12l1), y otras escrituras por las que constaba que Esteban Illán poséa la mitad de Bugiel. Se convinieron en que Afayor tendria un sexto de la milad de Bugiel y del colmenar, o sea, una dozava parte de la alqueria; las once partes restantes serían de la Catedral (nútn. 988).

Madrastra e hijastra plcitcaban sobre varias propledades en Algordel y Alöimus: ella decía que sn esposo le había dado en arras 1.000 mizcales sobre aquellas fincas, que, según ella y refiriendose a datos de la primera mujer, madre del hijastro, las había comprado el marido con su soldada. El hijastro decía que la finca de Aldimus la habia comprado su padre con los dineros que había vaiido en venta otra finca de la madre; y reclamaba a la vez de la herencia de su padre 1.000 mizcales, que este le debia, por haber vendido su madre fincas de sus abuelos en esta cantidad, para rescatar al padre, caulivo de los moros (mitad de un huerto y mitad de un horno). Tras largo pertodo tle tiscusión, se llego a un acuerdo (1261): la madrastra se quedaría con la mitad de las heredades de Algordel y Aldimus, que eran de dofia Solf la Vieja; el hijastro rccibiria la otra mitad, excepto una yugada en $\Lambda$ Igor. del que su padre y su madrastra habían dado a su criado; la madrastra daría además 500 mizcales. Todo con aprobación de atro hijo del segatrdo matrimanio (número 957).

Hay también convenios acerca de bienes, sin que haya habido pleitos. Los hermanos Gonzalbo Petrez (luego arzobispo) y Garefa Fetrez hicieron un convenio en 1271

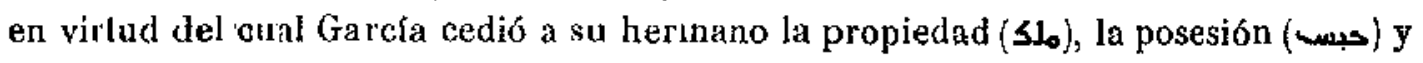

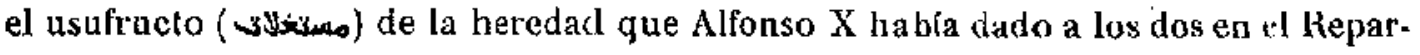
timiento de Sevilla ${ }^{(1)}$, consistente en olivares, molinos de aceite (ag) casas, tierras, etc. (núm. 990).

(1) Ea el Repurtimiento de Sevilla, insogrto on la Segunda parte de la Ifistoria y granclezas de la gran eizudad de Sevilla, por Pablo de Espinosa do los Montoros (Sevil la, 1630), consta que a Garcia Péroz de Toledo, notario mayor de Andalcucla, le dío el rey el heredamiento de Tereia (Troya en el fol. $13 \mathrm{v}$ ), a que liamaron Gioledaña, aque es en el término de Sevilla é avía en ella cinco mil pies de olivar e figueral ; $\theta$ por medida setenta y dos arançadas. E fué asmada $\theta$ dada por cien arançadas, con calorce arançadas do viñas e veyn. te arangadas de olivar de Calicheoa ( pág. 5). No hallo oitado a Gonzalbo Petrez en el Repartimienio. 


\section{J. RECIBOS}

464. Ên ocasiones, el recibo de una cantidad era el título de propicdad para lo futuro. Así era el recibo de medio mizcal almorávide, resto del precio de una tierra blanca, que era de $4 \frac{1}{2}$ mizcales; cobrados los 4 , parece que no debió de extenderse la escritura hasta aquel momento (1134), pues en ella se indican los lindes de la finca vendida y se ponen las fórmulas usuales de las compraventas (número 1.067). Igual sucede con otro recibo por 45 mizcales baesies (1161), precio de una vin̂a en Zajeneas, cuyos lindes se indican: quedan, en virtud de este documeato, dueños los compradores de los siete oclavos de la viña, pues el octavo restante pertenecía a la Catedral (núm. 1.069); o con otro por 12 mizcales, precio de una algorfa hundida, que en algán lado Jindaba con la Catedral (nán. 1.075); o con otro por 40 mizcales (1210), precio de una casa en San llomán, otargado por la madrastra a favor de su entenado, en el que se incluye también el recibo de la décima parte que a ella tocaba en los bienes de su marido, que no entro en la escritura de convenio que ellos habian hecho doce años atrás ( núm. 1.076).

También era frecuente el recibo para hercncias y legados (núm. 1.074), otorga. dos por los herederos para evitar pleitos y reclamaciones (núm. 1.079). Bastaba la declaración de testigos del recibo; dos personas atestiguaban (1210) haber entrado cierto día en casa del albacea en unión con uno de los herederos, y que el albacea había declarado baber oobrado ya de aquel heredero y de su hermano la cantiad de 30 mizcales, a cambio de los cuales su tía mandaba que se les diese la casa donde ella vivía; igual declaraba otro sobrino de la testadora (núm. 1.077).

La hijastra daba al marido de su madre reciloo de 120 mizcales, 11 medidas de víno, vestidos, telas y ofros bienes macbles que le carrespondfan por la herencia materna (núm. 1.081).

Se da recibo de un legado (1254), y se dice que, si aparece una escritura de deuda a favor del legatario y contra la persona que paga el legado, sea nula (número 1.082). Makra Juan se da pdr pagada (1254) de todas las deudas y se aparta de las reclamaciones que hacía a Domingo, esposo de Juana, mayordomo del alguacil D. Juan; y se obligaba a que su padre se apartase también de cualquier reclamación (núm. 998).

Las formulas usuales en los recibos varían alga, según la materia de que se da el recibo: dineros, fincas, herencias, derechos, etc. La más general es ésta: "No queda [al acreedor] ningún derecho, petición, reclamación o exigencia que hacer [al deudor] por ningún motivo (núm. 1.082). Y también es frecuente añadir: « Co. noce la otorgante el valor de todo esto, sin ignorar nada, según lo que dispone la ley en tales materias* (núm. 1.074). 


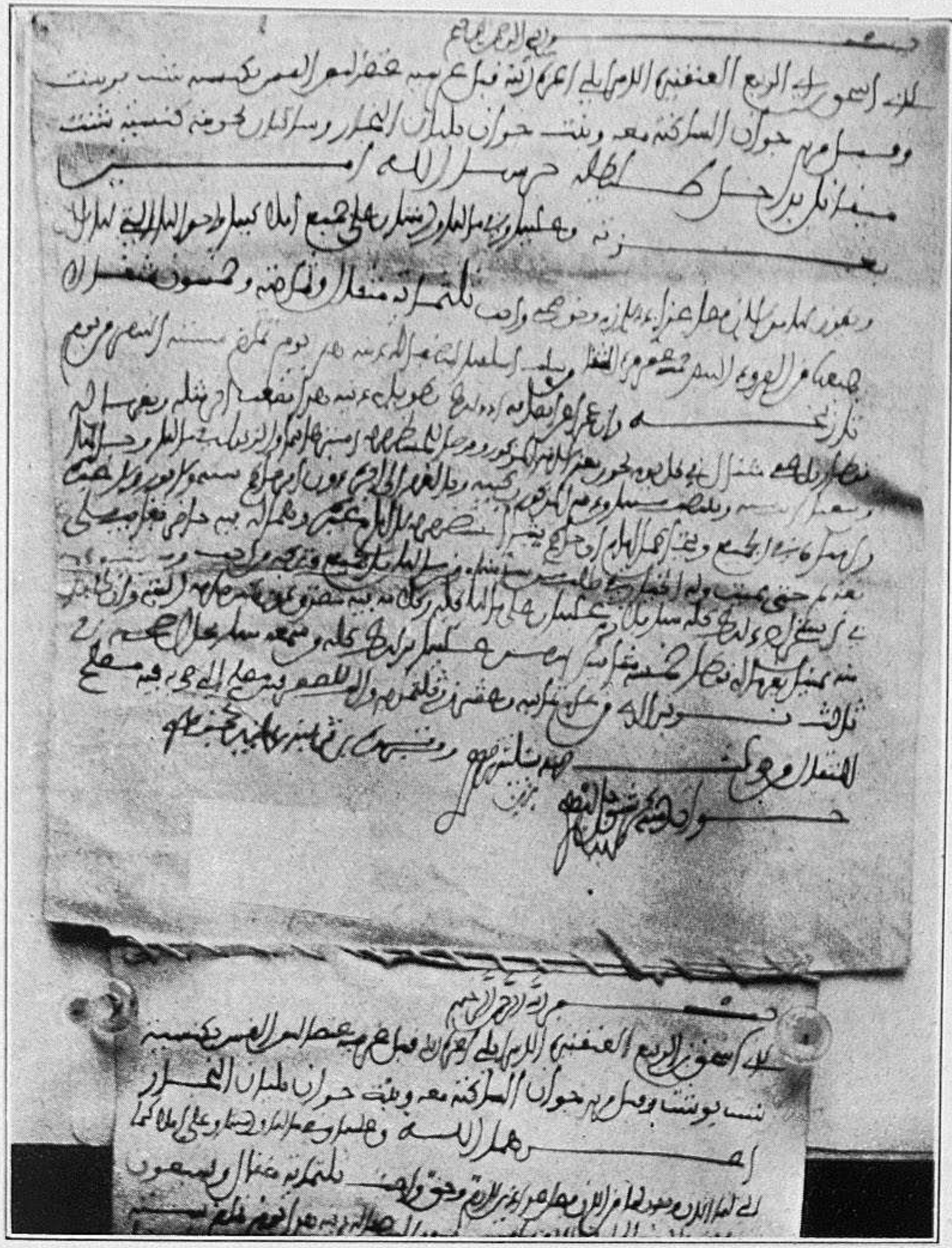

Préstamo: 3 de Noviembre de 1290 (núm. 879). 


\section{K. DERECHOS DE AGUAS}

465. Era muy apreciado el derecho al agua, ya para usos agrícolas, ya como fuerza motriz y aun para el abastecimiento doméstico. Atrás (1) anotamos algunos de los molinos y azudes más nombrados de Toledo y su regín.

El azud o presa de Alfita se vendra, en 1178, con río y tierra, plana, castillo, corral, lozar y ticrra blanca (num. 140). Los azudes de Corral Rubio, que eran propiedad de la Catedral, los había tomado Feliz el Pescador antes de 1189; puso en uno tres piedras de molino, hizo la noria con dos planas, posey6 otro azud encima de aquel y subarrendaba a su vez sus derechos a los pescadores por alcabala (número 1.054$\}$.

Como derechos de un azud (el de Alcapillat o Alcubilet) entraban en su venta (1202): boqueras, canales, acelres, solar del molino, pasos y cuanto le pertenece en el río, en el royo, en lus abrevaderos y en el suto (núm. 322).

Los derechos de agua comprendian, pues, molinos y muelas, canales, aznd y río (الئه), o sea el agua misma (núms. 164, 554, 721, 754 y 1.064). El conjunto de plana y acetre se llama noria en el dorso del documento número 432.

Las monjas de Santa Mara en Alhicem vendían (1253) huertas, viñas y tierras del convento en Alaitic por 200 mizcales, y con el precio de esta venia compraban cuatro sextos pro indiviso de un tercio de los molinos del azud de Alfita, con los derechos en el molino, en el azud, en el rio y en lo que en ellos había, añadiendo de los fondos del convento los 90 mizcales que fallaban; y daban la razón de hacer esta operación porque era de más utilidad para la casa y de menos trabajo que la huerta, viñas y tierras (núm. 584).

Los derechos de agua prescribían a los treinta años de no usarlos: la mitad del derecho de la plana de Figares, entre Figares y Lorita, que habia sido de Urraca Petrez de Tolosa, despues de su marido y su hijo Rodrigo, y n su merte paso a poder de San Clemente, se perdió por hacer más de treinta años (núm. 1.058).

Alguna vez, con el derecho al agua, se tenía tambicn el de artefactos para pesca (مهايد الحوت) (núm. 448); por eso vemos a pescadores como arrendatarios (número 1.054 ).

Cuando las fincas eran de regadio solía indicarse en los contralos los derechos referentes al agaa: acexa, esianque, etc. (num. 162), o a la fuente que habia en la tierra, con todos sus aprovechamientos (núm. 169), o al pozo, que se decía ser de

(1) PAg. 100 . 
otro colindante, pero a cuya agua tenfa derecho el dueño de la tierra (núm. 672). En la venta de un hucrto se reservaba la hermana de los vendedores el derecho de tomar agua del pozo de ese huerto para regar otro contiguo (núm. 661). Se estipulaba en la partición de un huerto la parte del estanque, cuyas aguas caían a dos aceñas, y del cañal matriz, y se indicaba de cuenta de quién había de correr la terminación de un pozo en construcción, cliyas aguas se habian de usar igualmente por las dos partes contratantes (núm. 1.041).

El pozo de la casa de $\mathrm{l}$. Juan de España, en el barrio del haño de Caballel, cuya agua fué lnego al baño del Arzobispo, lo adquirieron los canónigos por cambio con lierras en Manzel Obaidalá, entre ellas el «uerto de las moreras * (núm. 455), así como el convento de San Clemente adquirió el agua que taanaba en una casa particular para sus baños del Arrabal (núm, 780). Las utilidades de una fuente pública en Fuente el Caño se evaluaban en 8 mizcales anuales por los años de 1266 (núm. 1,030).

En un contrato de plantación (1144) influye la cuestión de poner una barca en el Tajo (núm. 924).

\section{DERECHOS DE CAZA}

466. En los montes de Toledo, por el lado del castillo de Miraglo y el pueblo de Cuerva y Casar del Asno, debía existir, desde principios del siglo XIII, por lo menos, organizada una industria de caza. Se hacia por medio de losas, a cuya reunion sc llamaba el losar, y estas losas formaban la samansa o chimensa: cada samansa de conejar constaba de 20 losas, que podían estar todas contiguas, o separadas en distintos lugares (núms. 459, 460 y 468).

El vendedor de losas de conejar se obliga a sacar las losas, y enseñarlas al comprador, y contarlas, hasta completar el número de las vendidas (núm. 494); o presenta con él a un tercero para obligarse juntos a satisfacer cualquier reclamación (núm. 468).

El comprador de losas, casi único, cra el arcediano D. Alfonso Meléndez, que llega a sostener pleitos con los conejeros por el año 1226. Los conejerns celebraban las Juntas de su gremio en la Catedral, por detrás de lo que ahora es la capilla de Santiago, y que hasta el siglo XV se llamaba la Conejeria (1), y nombraron sus represen.

(1) Vido "La capilla de D. Alvaro de Lnna en la Catedral do Toledo», en Archivo espenal de Arte y Arg̨ueologia, núm. 1s, Enera-Abril, 1829 , páge. 109 -122. 
tantes, a los que dieron plenos poderes, para llegar a un acuerdo con D. Alfonso Meléndez (núm. 1.174).

El pleilo se origino por la falta de cumplimiento, por parte de los conejeros, del pacto que habían hecho en 1104 , en virtud del cual D. Alfonso les permitia la entrada en sus losas, que ya tenía arregladas hace tiempo en Peña Aguilera, con determinados límites; acuerdo que después fué confirmado, con ù anuencia do los cazadores. A pesar de este acuerdo, no obstante que se les había dado por sentencia de alcalde, los cazadores no se apartaron ni dejacon de entrar, "y rompieron mis lo- . sas - dice el arcediano -.- ; cogieron las que quisieron, e hicieron lo que les vino en ganas. Por eso les reclamaba las indemnizaciones que la ley manda o las multas correspondientes, y para que confesasen o negasen.

Los conejeros confesaron la veracidad del aserto de $D$. Alfonso; pero dijeron que no querian discusiones ni pleitos, sino un arreglo pacffico, y prometieron reti. rarse de las losas, y no entrac ni cazar en ellas, en cumplimirnto te lo mandado por el rey D. Fernando III a los cazadores de Talavera. Don Alfonso les prohibio, además, dormir en ellas, y les señalo los sitios de paso: cl Hoyacho, donde se reunen las águas, y la fuente de los Pastores, hasta pasar el camino de Miraclo. Los cazadores aceptaban, pero querían que I. Alfonso les perdonase lo que les ieńa reclamado por respecto de caza de palomas y otra cosa. El arcediano les delimitó aún más claramente los lugares hasta donde podrian llegar, fuera de cuyos I(mites no podrian entrar, salir, ni dormic; el infractor pagaría como multa la caza que lleva. se más 60 díeerus de a 5 sueldos el mizcal; y la palnbra del arcediano o de quien lo representara, sería creída en juicio. Ellos aceptaron; el arcediano les perdonó las reclamaciones, imponiéndoles silencio desde aquel día en adelante, puesto que una tercera parte de ellos se habsa comprometido así delante del alguacil y alcalde (núm. 956).

\section{DEREGHOS DE PASTOS Y GANADERIA}

467. Escasos [documentos se conservan a este respecto, pero interesantes. Uno es el aeta; acéfala, del pleito que seguimn (1186) los lierederos de Abdelmélic ben Harún con el convento de San Clemente sobre ciertas lierras en Argance. Además de las tierras, reclamaban los derechos de pastos, reclamación que era rechazada por varias razones: una era haber dejado pasar dos períodos de treinta años y de cincuenta años, sin reclamar la posesion. El Tribunal fallo a favor del convento (núm. 941).

Otro es un testimonio de $\mathbf{1 1 9 9}$ por el que aseguran los firmantes que «el vier- 
Ies, 24 de Agosto de 1199, se presentaron en casa del alguacil D. (rarcía Rodriguez, xijo de Rodrigo Domínguez, el cual estaba en cama, por cansa de enfermedad, pero zn su sano juicio y entendimiento. Daba luan Domínguez, alcalde de la alquería te Arcicolla, por sí y por sus compañeros, en una sociedad de tres, al citado alguazil D. García, 30 mizcales de oro alfonsí, con la condición siguiente, que le puso ante testigos, diciéndole: "Yo hago esta sociedad con sus compañeros acerca del pastorco de la cabaña de ganado que está entre la alquería citada y la alquería de Renales, todo del alfoz de la ciudad de Toledo, y digo que tú tienes derechos en esta cabaña y nos convenimos contigo, sin gastar delante del alcalde, por 30 mizcales, con la condición de que ló satisfarás cualquior reclamación que se nos haga pol causa de la cabaña y del pastoreo, ya sea por el rey, ya sea por otro cualquiera que reclame en razón de esta sociedad, hasta que no le quede ya nada que recla. marnos. „Contestó D. Garća: *Está bien y yo me obligo, y con esta condición recibiré los 30 mizcales. \& Y los recibió, y vinieron a su poder \(núm. 1.131).

Como se ve, es muy antiguo el empleo de las acciones hiberadas en las sociedades industriales.

\section{N. FABRICAS}

468. Tampoco hallamos apenas datos que puedan referirse al movimiento fabril en Toledo en aquellos siglos.

Se mencionan almáceras (núms. 489 y 1.126 ) que se traduce por lagare en el

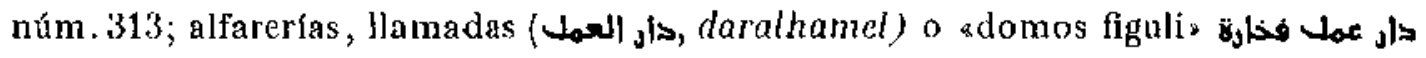
(núms. 122, 187 y 546): el convento de San Clemente la poseĺa en el Arrabal de San Isidro (núm. 487), y el de San Pedro, debajo de la Puerta del Mayordomo, encima del camino de la Puerta del Vado (núm. 463); tintorería, en una casa del adarve del caid D. Sabib (núm. 476); tenería o casa de curlidos (núms. 30 y 124); f́́brica de sombreros de fieltro, en una casa entre San Nicolís y Santa Cituz (núm. 609). Citanse varias salinas: las de Perales (núm. 1.014), las de Espartinas (núm. 675), y las de Alcharis (núm. 916), o Aljares (núm. 1.045), Bechares (núm. 973), o Pajares (ním. 1.126), que estaban entre Borox y Seseña (núm. 1.045), y que en el que podríamos llamar presupuesto de ingresos de la ('atedral, en 1234, se llaman Abejares (1).

La lista de oficios manuales que en otro lugar quedan reseñados (z), da idea clara de la pujante vida industrial toledana; pero no nodemos, desgraciadamente, ofrecer datos de cómo vivían aquellos gremios y oficios.

(1) Vease atrás, pág. 185.

(a) Véase atrás, pág. 238 y sigs. 
MONEDAS

469. lín el documento más anliguo (año 1083) de la Colección (oúm. 1), el precio de la viña vendida son « 300 mizcales de los que ahora corren por Toledo, de a 10 dirhemes el mizcal $*$ y el contrato se hace segín la ley musulmana, acaso el único en que se sigue esta legislación. A fines del siglo XII (año 1092) corrían por Toledo los dinares البريزإ (núm. 2), dinares que signen circulando en 1095, de valor de 10 dirhemes (núm, 4 y sigs.). En un documento de 1111 se da la equivalencia de eslos dinares con el mizcal oriental almamuní éste tiene dos dineros y un sexto (nún. 7).

Ya en 1112 se cilan los nizcales de oro almorávide viejo (núm. 8). Siguen en a ños posteriores empleándose estus mizcales, aunque figuren también los dinares (núm. 10, año 1117), los dinares de los sueldos corrienles ahıra (núm. 13, año 1121). En 1129 aparecen los dinares de sueldos medios, con la equivalencia de 4 dinares el mizcal almorávide (núm. 17), aunque con preferencia se usan los mizcales almo. rávides. Alguna vez (núm. 22, año 1134) se paga una misma venta con un mizcal almorávide y con un ninar de los sueldos medios. Los mara vedis se llaman reales meriníes en 1139 (núm. 27), en 1140 (núm. 28), en 1141 (núm. 29).

Desde 1142 aparecen los mizcales de oro almorávide real del cuño de Almería (núms. 31, 32, 1.099 B, etc.), sin que dejen de emplearse los maravedís meminies (ń́m. 34, año 1146). Los de Almería tenían como fraccionario un cuarto de mizcal (núm. 37, año 1149), y un medio mizcal (núm. 39, año 1150). También se citan en 1144 los mizcales almorávides del cuno de Sevilla (núms. 924 y 925).

Bajo el nombre genértco de mizcales almorávides se comprendían los merinfes reales y los ayadíes (núm. 40, año 1150), y poco después se cita por vez primera los mizcales de oro de Haeza, con sus medios mizcales (núm. 42, año 1152), que alternan con los ayadíes (núm. 44, año 1153). Durante los años siguientes se signen empleando los mizcales de Baeza hasta 1172 (num. 102); sin que dejen de correr los mizcales meriníes reales (núm. 57, año 1158), los ayadres (núm. 59, año 1158), los saadíes (núm. 63, año 1160), los marroquies meriníes (núm. 64, año 1160). En el número 102 se les llama umizcales de oro de Baeza, saadí (núms. 97 a 100, ano 1171 , y nú́m. 101, año 1172.)

Lástima que la primera vez que se nombran los mizcales alfonsíes sea en documento de lectura dudosa (núm. 81). La fecha es de 1166 (?). En el siguiente (número 82), del año 1167, se citan los mizcales de oro, escuetamente, y hasta Febrero de 1173 (núm. 103), no encontramos citados claramente los mizcales de oro alfonsí, que en Marzo del niismo año se llaman a mizcales de oro alfonsí toledano (números 104, 108, 116, 117, 130, 161, etc.). 
Je aquí en adelante se emplean siempre los mizcales alfonsíes, con los medios mizcales (núm. 115), tercios de mizcal (núm. 125), octavos (núm. 169), cuartos (núm. 170), sextos (núm. 306, año 1201). También se cita la medalla o meaja (número 977).

Alguna vez se emplean aún los mizcales de Baeza (núm. 137, año 1178). En 1187, pon el mes de Mayo, se citan los mizcales de oro alfonsí de los ouevos (núm. 188), nombre que se les da en junio del mistno año (núm. 190), en octubre (núm. 192), en enero del siguiente (núm. 195), en septiembre (núm. 202). En adelante se emplea el nombre de mizcales alfonsíes, sin calificativo alguno. $\mathrm{Y}$ asi hasta 1223 .

En Noviembre de este año 1223, se vende una viña en Olías la Mayor, por 30 mizcales de oro alfonsi, que ahora bace correr la ceca de Toledo (núm. 472). Esta indicación de la novedad en la circulación de los mizcales de oro alfonsí se repite en otra venta de viña, por 7 mizcales, en Corral Rubio, el 12 de Marzo de 1224 (núm. 475) y en la venta de una casa en Toledo, en el barrio de la Catedral, por 250 mizcales de oro, en la última decena de Mayo de 1224: aquí concreta el valor, diciendo que cada mizcal es de 15 dineros (ntim. 476); y en la venta de otra casa en el barrio de San Nicolás, en Toledo ( 7 de nunio de 1224) se nota el valor de 15 dineros por cada mizcal, y se dice que los mizcales son de la acuñación de Segovia (núm. 477). En Agosto de 1225 (venta de viñas en Aloyón) figuran 8 mizcales y $10 \frac{1}{2}$ sueldos (núm. 480).

Signen figurando los mizcales alfonsíes, de este tipo, que no eran de nro, o por lo menos no se dice. Todavía, en 1258 (núm. 605), se les llama mizcales alfonsíes de a 15 dinerós; $y$ en 1260 (ńm. 610), 1261 (núm. 611), 1262 (núm. 613), 121 (número 618), 1265 (núm. 623), dándoles como valor 15 sueldos (فرد), acaso por dineros en 1265 (núm. 626), o ، 15 sueldos de piplones ( (núm. 628), ya oue 14 mizcales menos 18 sueldos vale una finca en 1264 (núm. 621). Pero, con excepción de estos documentos, se les llama sólo mizcales alfonsíes.

Aparecen en Noviembre de 1271 los mizcales de sueldos blancos de 7 sueldos el mizcal (núm. 633, 1144); siguen nombrándose en 1273 (núm. 634) y en los docu. mentos inmediatos posteriores, aunque a veces se citan escuelamente mizcales ( namero 638), basła 1278. En Linero de 1278 (núm. 655) se citan «mizcales de los sucldos corrientes ahora,, frase que se aclara en otro documento de Abril del mismo año, llamándolos anzcaies blancos de los heohos en liempos de la necesldad prj. mera *, o de los apuros primeros del erario o de la guerra primera (núm. 656); estos mizcales eran también blancos y valían $7 \frac{1}{2}$ sueldos (núm. 657, año 1278). En documenlo de 1276,650 mizcales alfonsies equivalían a 1.600 mizcales de los sueldos blancos aque ahora corren *; 70 mizcales alfonsíes vendrían a ser 280 de los de 15 dineros (núm. 962).

Pronto varía otra vez el valor de la moneda. En Agosto de 1279 (núm. 662) se 

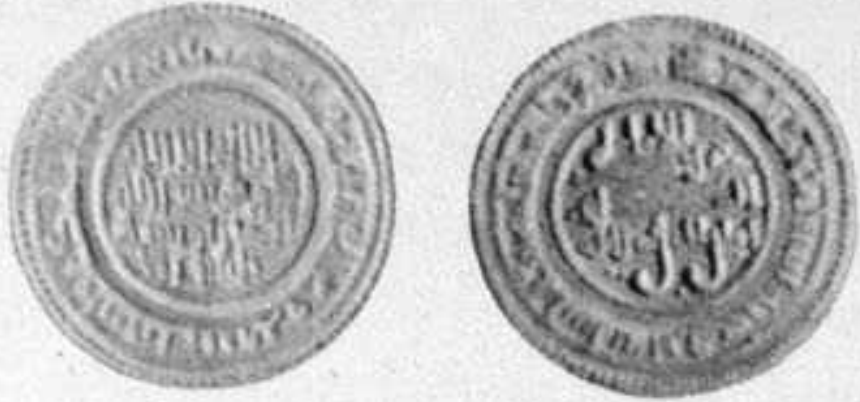

Dinar almorávide de Yüsuf ben Texufin.
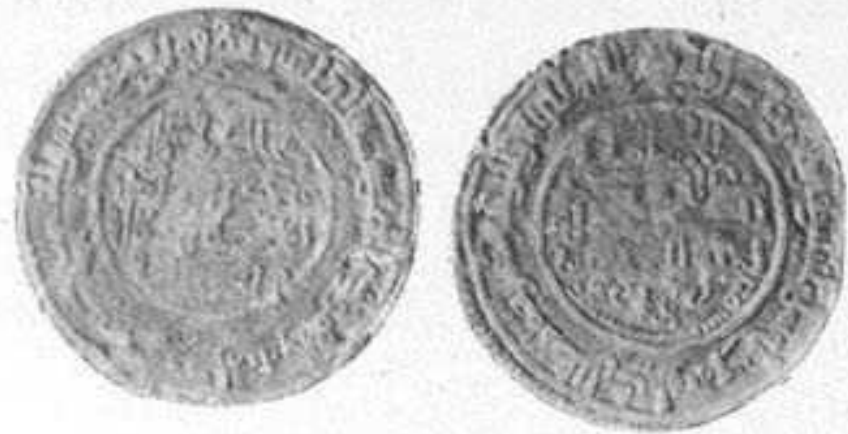

Dinar de Abenayad de Murcia (ayadi).
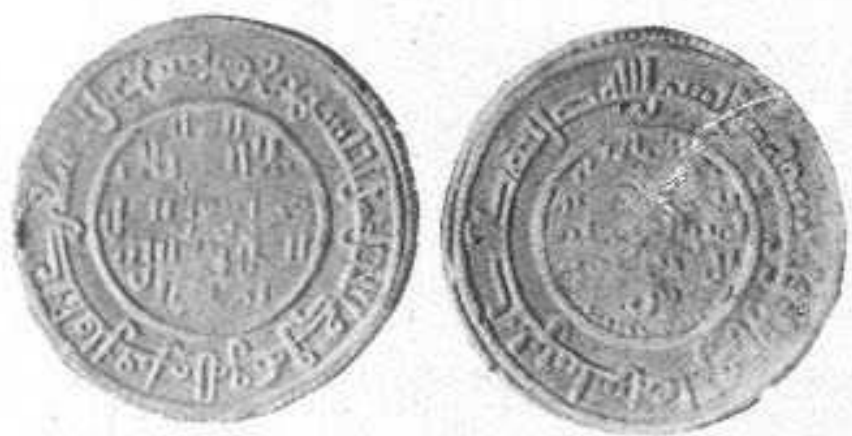

Dinar anónimo de Baeza (baesi).
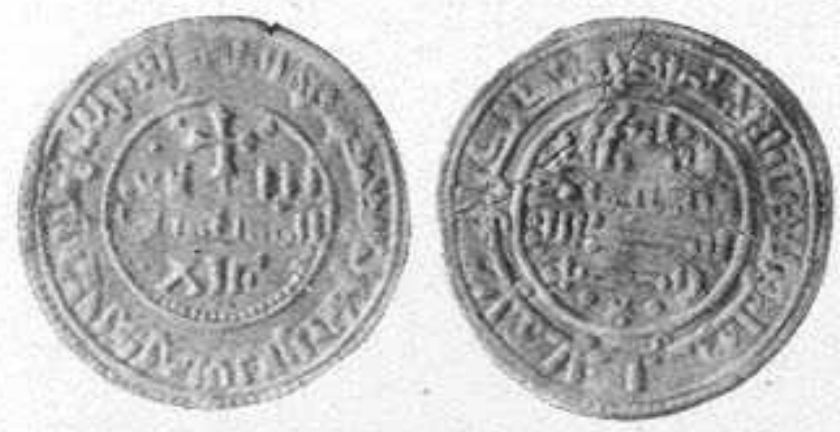

Maravedi alfonsi (inuevo?).

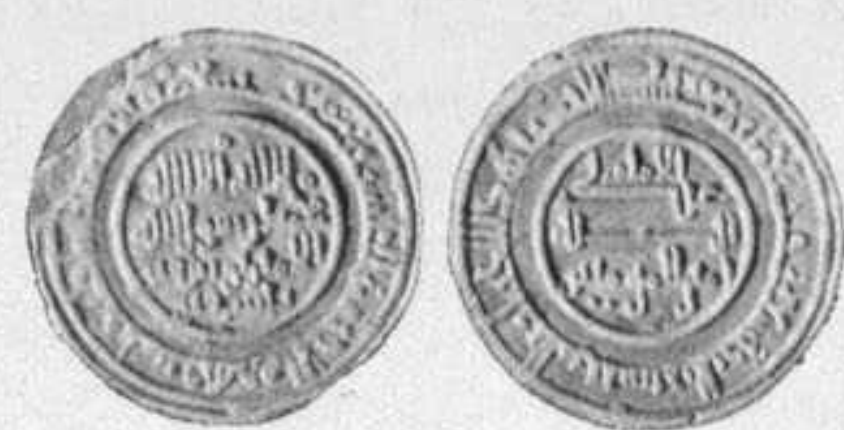

Dinar de Yüsuf ben Texufin.

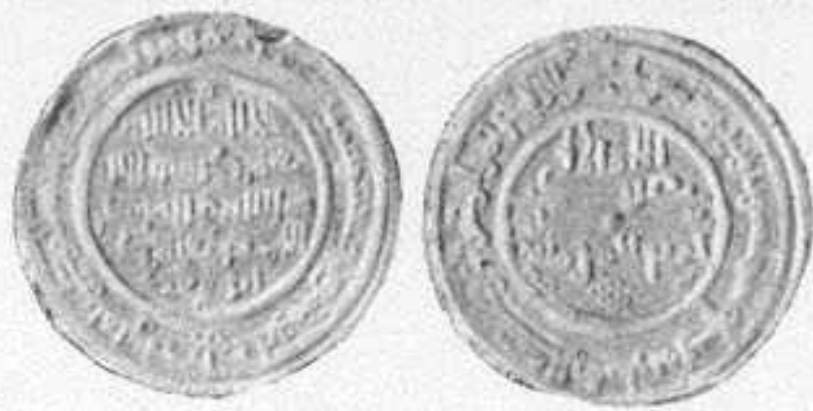

Dinar de Mohámed ben Saad de Murcia (saadi).
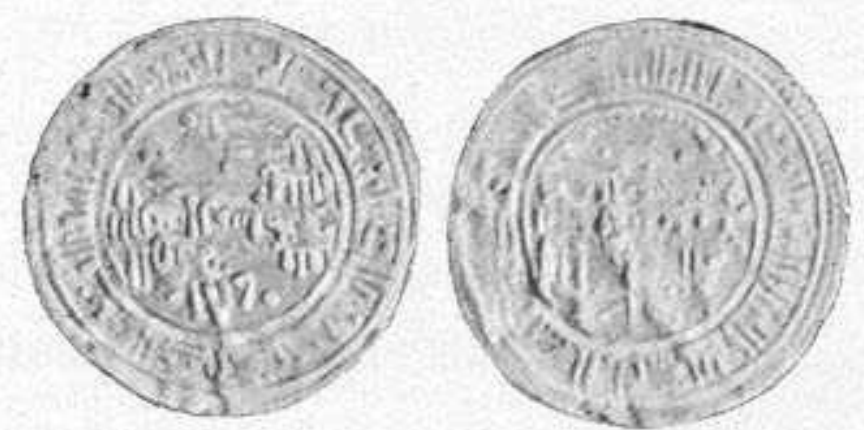

Maravedi alfonsi (¿antiguo?).
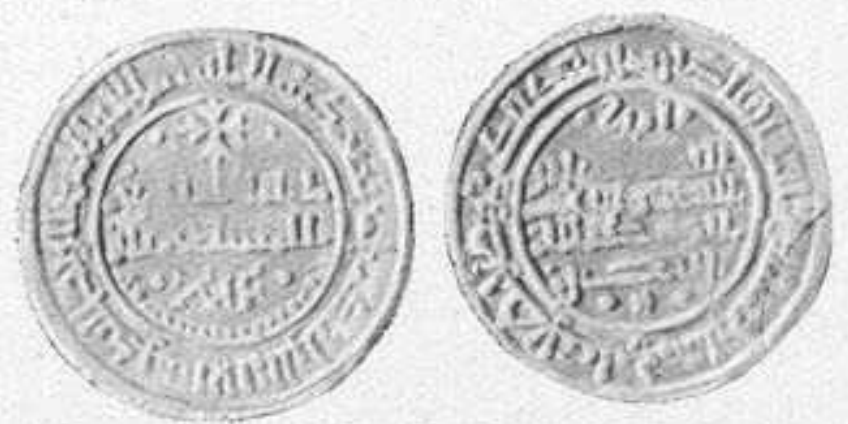

Maravedi alfonsi

(acuñado en tiempos de Enrique 1). 
usan los mizcales de sueldos corrientes ahora de a 15 sueldos el mizcal, Y aunque se emplean alguna vez los mizcales blancos de $7 \frac{1}{2}$ sueldos (uúm. 661, año 1279), después sólo se ven en las escrituras los mizcales blancos de a 15 sueldas, que aún se les llama nuevos en 1280 (núms. $666,667,668$ y 1.117 ), de los que 2.600 venían a valer lo que 1.400 de $7 \frac{1}{2}$ sueldos (núm. 655 y 671) y que se dicen *corrientes en el mercado* en 1287 ( oúm. 692) y en 1290 (núm. 702).

Parece que a fin del siglo XIIl debió de variar otra vez la ley de la moneda, pues en Junio de 1297 (núm. 938) se paga en *mizcales blancos, que ahora corren, de a 10 sueldos el mizcal »: en documento de Sepliembre de 1296 todavía son mizcales blancos; en el año de 1300 (núm. 725) se les llama cmizcales blancos que ahora corren., y en 1303 (núm. 726) se vuelve a decir que son * mizcales de sueldos blancos de a 10 sueldos el mizcal.

Y éste es el documento más moderno de la serie de compraventas.

Todavía, a fines del sigio XIV (ano 1391), se habla de mizcales de moneda antigua de a 10 sueldos el mizcal (núm. 1.140).

\section{MEDIDAS}

470. Escasísimos son los datos que arrojan los documentos. Los granos se medían por cahices y fanegas. La cabida de la fanega se vario alrededor de 1272, pues en documento de esta fecha se emplea para dar la fanega pequeña vieja, y para cobrar la renta se emplea cla grande que ahora corre (núm. 919).

La paja se media por la sádica ( ga (núm. 991, año 1290).

Como medida de longitud vemos, en 1184, el cobdal, a de brazas, de las usadas para medir telas desde el tiempo del rey D. Sancho, corrientes ahora en los mer. cados de Toledo, (núm. 1.008).

También se empleaba la arroba (núm. 739). 


\section{ROPAS, ALHAJAS Y UTENSILIOS}

471. Cítanse en algunos casos los precios y el valor de los objetos mencionados. Otras veces se nombran las cosas, sin asignarles el valor. Las listas de cosas ciladas tienen interés.

a) Ropas $y$ vestidos.

Almalafa, الملحفة, ẫo 1.192, 1.020

Almalafas bordadas y blancas, ملاحف

مرقومة año 1276,

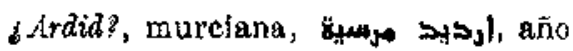
$1276(1)$,

Calzas, 3 القالس|، año 1161.

Camises (do0),

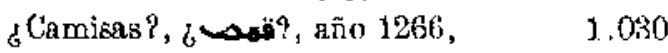

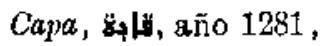

Conejo (piel de), السلخذه لقونليه, año 1212, 1.025

4Cuello vorde, الكلة الحضرة (2), año

1192,

1.020

Falda, كلذ, año 1281,

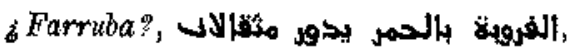
año 1212,

6 Farribilla , con la piel de conejo,

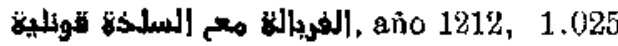

Ferreruelo encarnado y usado, الفرويل

إلحمر الهالى , año 1161,

Manio (do escarlata), año 1197.

1,001

Manto negro, año 1282 ,

Pelliza, بلبة año 1161,

¿Polchaina?,

1.034

(1) ¿Será aredi $:$, muy citado en documantos moriscos do Granada?

(2) ¿Será الحلة tú⿴囗十́â?
Sayo, Ân, año 1281, $\quad 1.054$

Tocas, الكواله año 1289, $\quad 964$

Velos, دوil, añ 1282, $\quad 1.085$

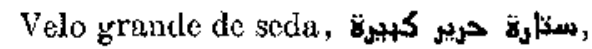
año 1276 ,

Velo murciano cun oro y su orla de tafelán amarillo, قنيسة هرية 1962

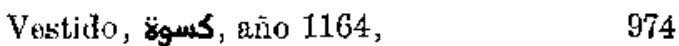

Kesin, كسيج, año 1282, 1.035

Vestido (alquicel), الكسأ, año 1192, 1.020

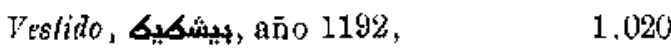

lestido blanco, الايبله 1180 ,

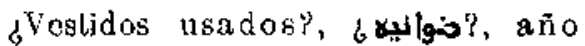

$1281,1.034$

Zapatones, الصبكوذاته año 1161, 1.014

Zaragüelles (dos pares), زوجين سياويل. año 1161 ,

Eu carta matrimoníal de 1285 (núm. 1.175), el novio regala a la novia, como donación propter nuptias, los objetos siguientes:

Alholla.

Alguileta.

Nesque de....

Aluudenat.

Almoatac.

Hilcana.

Alcabrea de Almudennas.

P'iel de Almudennas en Penna Blanca.

Atrido.

A ..... mait, et acalciamenta pedum *. 


\section{b) Alhajas.}

Alondra de oro, ابو مليحم الذلهي 1161, 1.014

Anillos, خوإن , año 1161,

1.014

Cáliz, كاس اللتقديس , 1.014

Copa de plata, كاس الفكنة, año 1161, 1.014

Copa \&de forma de haba?, الكاب الثولد,

aก̃o 1161 .

1.014

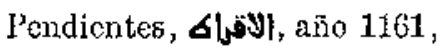

1.014

c) Vtensilios de cama.

Alforza (almoladón de), هذ حز, año 1161 ,

1.014

Alifates, الفحاف, año 1289 ,

Alifafe de algodón, w|لكاف| año 1192 ,

Aliffate de jalde, لحاف كلدي, año 1268, 1.080

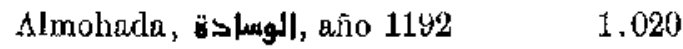

Almohadas, año 1.187,

Almohadas, المحايد, año 1281,

1.034

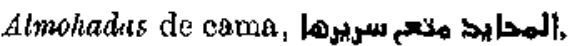
año 1.282 ,

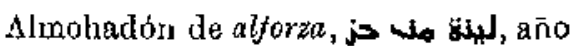
1161,

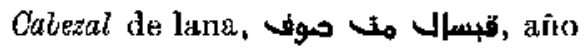
1282 ,

Cama (con el esctño, la cansadera y las ropas do tlla), waño 1216,

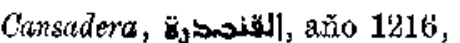

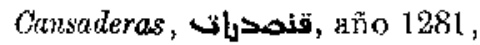

1.034

Cansadera de cama, القنحدرة منحم سرير, año 1282 ,

Cansadera de pluma, año 1187.

Cansaderas llenas de pluma, فنحفرام مهلوة ريش, año 1276,

Cansadera llena de pluma, año 1289 ,

Cobertor de dormir, 1192 ,

Cobortores, الحنى, año 1281,

1.034
Cojines bordados llenos do pluma, año 1276, 962 Colchas, ano 1289, 964

Colchas do siclaton, الحاف ستلكونى, año 1276 ,

Golehóls, الهono 1192 ,

1.020

Colchón, المخرية, año 1289, 964

Golchón de siclaton, año 1268 ,

Colchones, مخريات , ano 1281 , 1.034

Colchones llenos de lana, 800 فو, año 1276 ,

Cortina, لحفى año 1276,

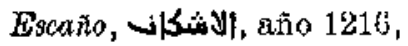

1.026

Escaño donde duerme, الإقطانه حبث

ill los/3j, sĩo 1282 ,

Facirolas bordadas llenas do pluma,

ريشا Mizntas, 1 , año 1161 .

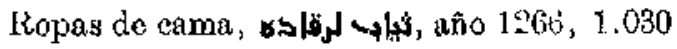

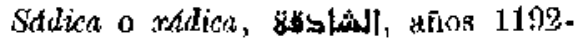

1282 ,

$1.020-1.035$

Tapiz, 6البساة, año 1192 ,

i. Tarsir?,

964

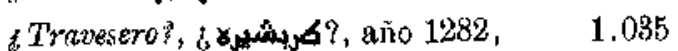

\section{d) Lnseres de casa $(\mathbf{3}|\mathbf{3}|)$.}

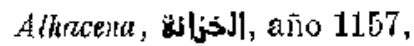

Altucenas o arquetas (las buenas do la casa en que viven), زوجم كزايلس الخير

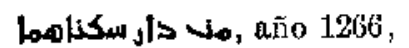

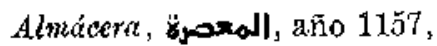
1.036

Utensilios de ella, عون المحصرة, año 1157 ,

Almirez, jlood, año 1157 , 1.036

Armario de Sevilla, خزانة اشبلية, año 1276 , ¿Cedazo?, ठف6ةa?, año 127b, Cofr'e grande, الخئوت الكبير , año $1282,1.035$ 
Cubas (para vino), $\mathbf{W}-\mathbf{3}$, año 1205 ,

¿Jarras?, الإبواقى, año 1157,

Sillon grande اللكرسى الكييى, año 1282, 1.035

Tallas y piedras (instrumentos de una كلياتى almicera, o molino de aceite) , وحجير año 1274,

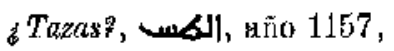

Tizajas para cl vino, خوالى للشراب , año 1192,

Tinaja, خابية اوان الششر|ب, año 1246,

Tinajas grandos para ol vino, sos , كيار اوانى للكمر , año 1276,

Tinaja de barro para el vino, كابية 1, año 1206,

dTinajas?, str, año 1157,

linajas, كوأب, año 1179 ,

Tinajas (1), sوأs, año 1187,

(P), 年, año 1157,

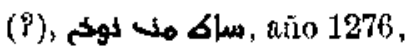

(?), زوجم وزابد, año 1276,

\section{e) Telas.}

Algodón, wis, año 1192,

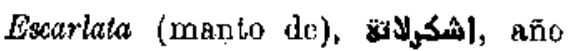
1197 ,

Fronfal (tela de tisu para), فtis, año 1161,

(1) Parece quo aquI debe ser «vajilla *
Jalde (alifafe do), tafetản, خلد, año 1268 , 1.030 Jalde, tafetán amarillo, خلدي امغر, año 1276, 962 Siclatón (coleha de), بوفة año 1268 , Siclation (colchas de), año 1276 , Tola de paño, ثلف año 1228 , 962 898

\section{f) Armas.}

Aimas, mandadas en testamentos:

La coraza, الجذرع

EI casco de metal, البيهنة La espada,

La mejor lanza, El escudo, الميف البميف احسن رمحث التراس إس

Calzas de hierro, فالدساق الحديد, año 1161 ,

Casco, بئiño 1230 ,

¿Barrigueras? (de armadurn), البوقير|ت, año 1233,

Rocin, coraza, barrigueras, casco, coraza del caballo, año 1233 , ¿Axaquefa? de hierro oscura, شa|ف الحذ|> السمانو, año 1266,

Corazas de caballos y do yegua, barri-

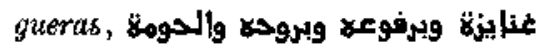

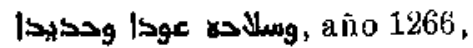
Armas de madera y de hierro y sus corazas, ลก̃ก 1266 , 


\section{PRECIOS}

a) Vestidos y ajuar de casa.

471 bis. En documento de partición de bienes de fines del siglo XII (número 1.042), se dan los siguientes precios:

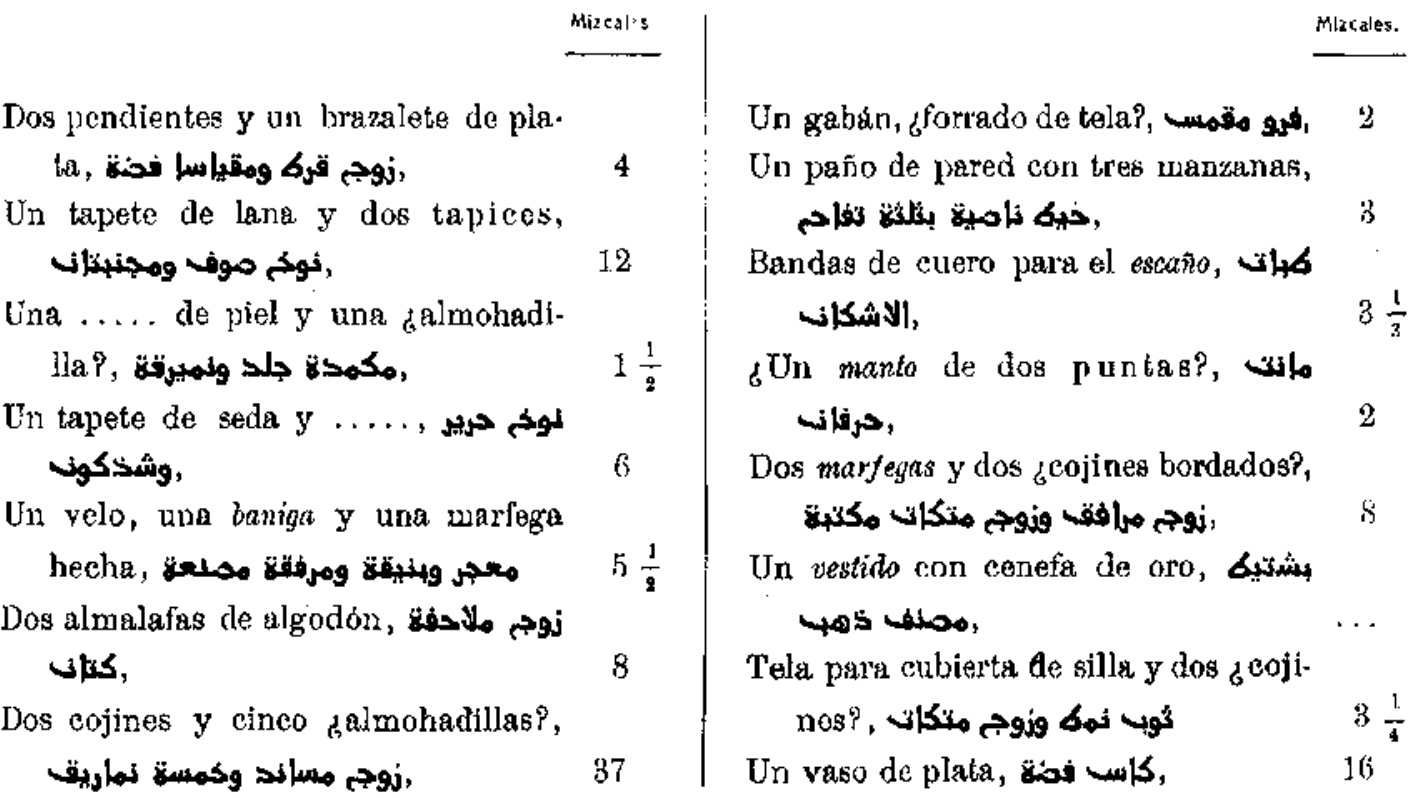

En carla dotal de 1285 (núm. 1.175), se valúan los objetos entregados a la novia en la forma siguiente:

\begin{tabular}{|c|c|c|c|}
\hline & Sales. & & crstes. \\
\hline Cortina de seda, قركينة هل حريي, & 400 & 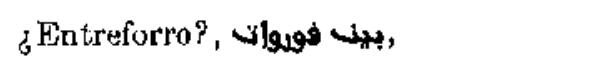 & 10 \\
\hline 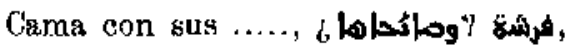 & 200 & Colchón, مضري, & 20 \\
\hline $\begin{array}{l}\text { Colcha de ....., لحاف من مكقف, } \\
\text { Dos colchas de seda con .... por el }\end{array}$ & 250 & 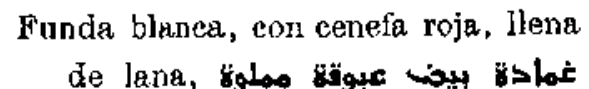 & \\
\hline Iegra y blanca, & 150 & موفا. & 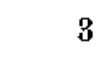 \\
\hline 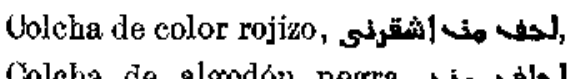 & 100 & 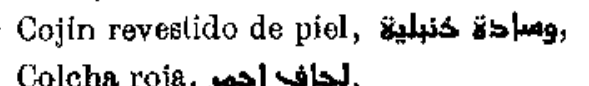 & \\
\hline 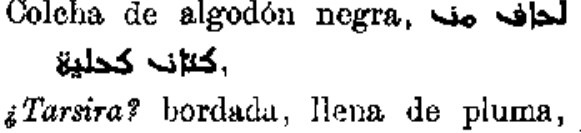 & ) & 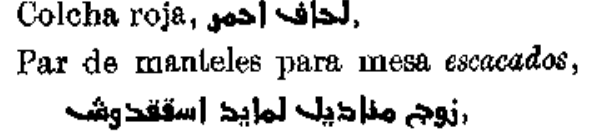 & 50 \\
\hline & 31 & & \\
\hline 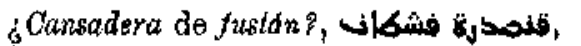 & 38 & Idem de seda escacados y tablados, & \\
\hline
\end{tabular}


(?) bordada de lazo, هj עل 20

Almalafa bordada,

Almalafa bordada,

Almalifa de lazo,

Almalafa murciuna con la cenefa de seda,

Camisa de murciana, con conefa de

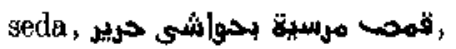

Camisa ancha fina, de ribete, de murciana,

Camisa estrecha blanca,

كوقة مقنفية 4ast.

Toca con oro,

Toca murciana de seda roja,

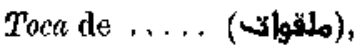

Toca corriente,

Bocas de mangas, wolo s vol,

Cobtia (vestido) de tafetán amarillo,

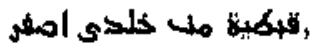

Cobtu (vestido) (le color de yeso, قهية إن

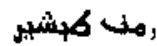

(?) del pals con su forro de tafetán,

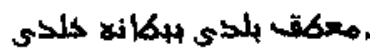

Un tafetán rojo, كلs إs,

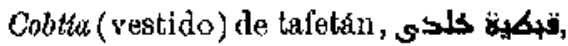

Sartal, له

Una alondra de oro, 40s

¿Arracadas? de oro pequeñas,

\section{ر بs}

Otras de oro con perlas,

(?) poine de plata y pomo con .....

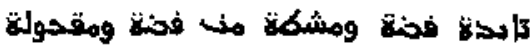
,

Collar de plata, مقلد فهزة,

Almenara, 8هر.

'Tinajas (dos), خوا بيها (1),

Barreño de latón para cl agua, مغروفي

, مثر

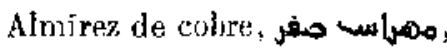

(l) de cobre pera guardar agua, كانتيقت مفر لخول في ماء

100

60

250

25

10

5

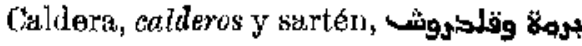
وهلى

Sulero de plata,

(?) pequeño de gran medida, كاب

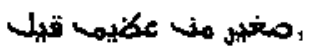

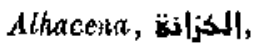

75

Dsteras (dos) para criados, zية 20

Cama o tapiz, مطرs, 10

Jumento, callalgadura de mujer, , 300

Esclava bordadora (a)

Esclave, $\quad 500$

Esclavas (dos), $\quad 350$

Eselavos (dos), $\quad 500$

Esclavo pequeño, aprendiz de albañil, 200 Vaso de plata, $30 \cdot \frac{1}{2}$ mizeales de $7 \frac{1}{2}$ sueldos (año 1272, nim. 1.044).

(1) Aquí parece que tiene también mejor sentido si so traduce por a vajillax. Ls demasiado precio para linaja.

\section{b) Libros.}

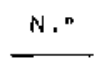

Texto de curatelas (libro) تشكله 5

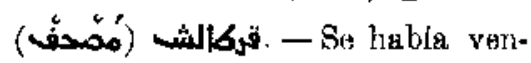
dido en 100 mizcales, aunquo le fallaban cuatro quinternos,

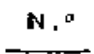

Un libro de salmos, مصحف زبور, $3 \mathrm{mz} .1 .042$

Breviario, بريباريه. Sc compra uno por 10 mizcales alfonsies, $y$ se da por el alma del vicario don Nicolás, 


\section{c) Animales.}

Cuatro cerdas, jdos con ería? (con cerdos) y dos cerdos, tasados eI

10 mizcales, año 1262,

Ternera (عجالن), tasada en 5 mizcales.

Dos pares de bueyes, con sus aperos, dos rejas, dos arado con sus ..... dos trillos, dos yugos y gamellas, tagados en 40 mizcales.

Animales, año 1266,

De la parto del testador en vacrs, carneros y ganado de los dos es. posos, tomarú la esposa las beatias y al ganado; las vacas zeran para pago de este testamento.

Los djumentos? y puercos tomara en parte la esposa.

Manda a uno el rocin y la mula nogra.

El caballo y otra mula para pago del testamento.

Acémila para la esposa.

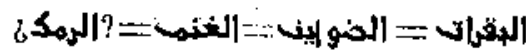

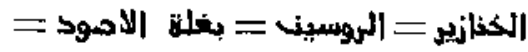

$$
\begin{aligned}
& \text { فريس الزاملة الحودة }
\end{aligned}
$$

El asno que ahora monta o si no está ya a su wiuerte, 20 mizales en su

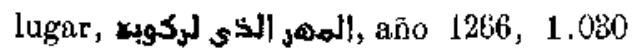

Mula torda, o 30 mizcales, البغلة لركلة الشهية, año 1266 ,

Rocin,

Su caballo segundo (al primero do lla.

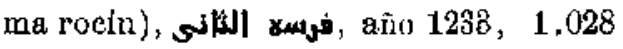

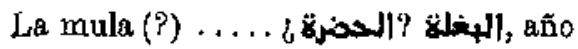
1283 ,

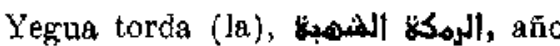
1131 , 1.014

Asio (⿻o) , 28 mizcales se debian por uno comprado al deber, año 1186, 1.013

Caballa. - Manda 50 [mizales almo. rávides] para comprar uno que sirva en la gueira, año 1125 ,

Dos pares de bueyes: 24 mizales. Dos bucyes: 11 mizcales, años 1205 y 1217 , 900 y 510

Rocin Rlazdn, cales, al fado. Cerrado de dientes, comprado con sus chalidades inter. nas y externas, año 1250 ,

Pareja de bueyes, 14 mizcales alfonsiç, año 1208 ,

Mula negra de montura y 50 mizcales con que corppre otra, año 1266 ,

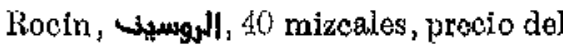
rocin que le mandó en el testamen. to, año 1266 ,

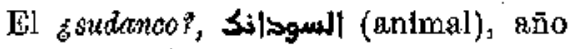
1281 .

Asno. - Por su mitad en un asno, un mizcal, año 1142 ,

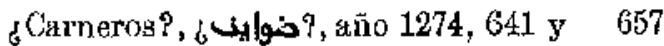

Pollino, jo, año 1270 ,

Dos vacas, 120 mizeales blancos de 15 sueldos, año 1287,

Una pareja de bueyes, 14 mizeales, año 1208 ,

Una pareja de monos, 3 mizcalos, año 1205 , 


\section{d) Otras cosas.}

\begin{tabular}{|c|c|c|c|}
\hline & $\mathrm{N} .{ }^{\circ}$ & & $N, 0$ \\
\hline Cebada: 4 fanegas, un mizcal, año 1198 , & 249 & Trescientus urrobas de noosto, 12 miz- & \\
\hline Trigo: 2 fanegas, un mizcal, año 1193 , & 249 & cales, año 1205 & 340 \\
\hline $\begin{array}{l}\text { Con } 50 \text { mizcales se funda un aniversa- } \\
\text { rio en la Catedral, año } 1197 \text {, }\end{array}$ & 277 & Un escląro, 90 mizcales, año 1262 & 615 \\
\hline
\end{tabular}

\section{1 ter. PRECIOS DE CASAS Y FINCAS VENDIDAS}

Mitad de viña, en Zalencas, $300 \mathrm{miz}$ cales de a 10 dirbemes el mizcal,

Viña en el principio de Manzel Razin, 60 dinares,

Casa on la plaza del Caxali, Toledo, 40 dinares,

Huerta en Manzel Moxca, 82 dinares, más una viña,

Mitad de dos quintos de la alquería de Dar Aljazín, 45 dinares,

Tres viûas en ‘Moratilla?, 32 dinares,

Mitad pro indiviso de un huerto en Alaitic, 200 dinares (el mizeal almamuni tiene $2 \frac{1}{6}$ dinares,

Tercera parte de huorta, con árbolcs, pozo, estanque y alberca, y derechos de entrada en Manzel Mosca, 10 mizcales de oro almorávide viojo,

Tercera parte de viña en Manzel Razin, 52 1d., id.; por los dos tercios anteriores, $95 \mathrm{dd}$, , $1 \mathbf{d}$.,

Casa on ol barrio de Ja Alhóndiga del Rey, Toledo, 41 dinares,

Viña en Alcardete, $O$, de Toledo, 33 mizcales almorivides,

N.
1
2
3
3
4
5
6
7

Viň̀ en Aloyón, S. de Toledo, 13 tdem, idem,

Viña con almendros en Argeles, 10 dịnares,

Casa exterior, con cullejón de entrada a la interior, en el Arrabal de San Antolín, 40 dinares; la misma por 7 dinares (cuatro años dospués), 13 ,

Mitad de viña en Ain, $3 \frac{8}{3}$ mizeales almorávides,

Suerte de tiorra en Manzel Razín, 8 dinares de los sueldos medios, de a 4 dinares el mizcal almorávide,

Viña en Acecha, 9 mizcales aimorávides,

Plantio de viña con tierra blanca en $\mathrm{Bi}$ val, 4 id., id.,

Mitad oriental de un mesón y corral contíguo, Arrabal de los Francos, $50 \mathrm{id.,} \mathrm{1d.,}$

Parte de la alqueria de Lorita, $1 \frac{1}{2}$ id., idem, 7 Viña inculta en Lorita, 1 mizcal almorávide y 1 dinar de los sueldos mediaxlos, 


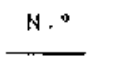

Casa, corral y caballeriza (debe ser en 'olodo), 80 mizcales almorávides,

Pedazo de viña con tierra blanca, en Alaitic, 6 id., id.,

Viria en Algnaad, pago de san Feliz, $3 \mathrm{id} ., \mathrm{kd}$.

Olivar de $12 \frac{1}{9}$ pies, en Talavera, 10 id., id.,

Corral; donde el conuprador habiaconstruído habitaciones, en el barrio de la Catcilral, $30 \mathrm{id} ., \mathrm{id}$. ,

Cuarta parte de la alquerfa de Villa $\Delta l$ gariba, 4 mizcales de oro almorávides rexl merini,

Dos tiondas con sus sótanos y alyorfas, en el zoco do los Kstereros, 20 nizcales almorávides,

Corral en el barrio de la Caledral (Pono del Caxali), $6 \frac{1}{2}$ id., id.,

Un octavo de Villa Algariba, 5 mizca. Ies almorávicles de Alınería,

Una yugada de tierra, un corral y la parte de era correspondiente a la yugada, en Olias la Mayor, 7 idem, Idem,

Huerto en el arraba], tucima de Santa Leocadia, exiramuros, 20 id., id.,

Suerte de tierra en Villa Algariba, 5 mizcales almorávides merinles,

Dos yugadas de labor, menos $\frac{1}{4}$, en Olias, oetavo de Aben Alés, 10 miz. cales almorávides de $\Lambda$ moria,

Plantío de viña cn Azuqueica, 25 mizcales almorávides,

Dos sucrtes, de 82 , del Calbin y Pomar, $4 \frac{1}{4}$ mizcales almorávides do Almeria,

Aldes de Rielves, 41 mizcales almoravides,

Mitad de esa aldea, $20 \frac{1}{2}$ Id,, id.,
Viña entre Olias y Oliolas, 14 id., id.; de ellos 5 meriníes rcales, 9 ayadies, . 40

'Tierra ruinosa, donde luego se hizo un horno, en el Arrabul de San Justo, Toledo, 2 mizcales almorkides de Almeria,

Pedazo de corral, ahora tierra blanca, en Olias, $3 \frac{1}{2}$ mizcales de Baeza,

Yugada de ticrra, en Ollas, sin corral ni era, 12 id, , id.,

Corral en Santa Marfa Magdalena, de 'Toledo, 42 mizcales ayadies y bae. sles,

Vîna plantada por el vendedor en tiera de otro, 4 mizcales baesies,

Suerte de tierra en Villaseea, 1 mizcal de Baeza,

Media viña y la tierra blanca contigua, en Torre de los Diablos, alfoz de Toledo, al otro lado del Tajo, 15 1d., id.,

Dos mesones en el Arrabal de Santiago, 40 1d., 1d.,

Viña en Azuqueica, cerca del corral de Azuqueiea, 13 1d., id.,

Majnelo en Loches, 1 id., $\}$.,

Octavo de viña, menos cuarto, cn $A r a$. queica, $8 \mathrm{Id}$, fd.,

Gasa en el barrio de San Antolín, Tole. do, 35 id., id.

Viña abandonada, en el pago del Arenal, 8 id., id.,

Media suerte en Villaseca y Mozquita, 4 td., id.,

Mesón en la Alcudia de Toledo, 23 id. , fd.,

Casa en Santa Leocadia (o San Lueas), dentro de Toledo, 60 dd., ld.,

Ticrra con alzoendros, a la orilla dol Tajo, al S. de Toledo, 10 mizcales merintes reales,

0

41

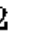

8

4

5

6
6 
Dos pedazos de tierra blanca en la vega de Olfas, 3 mizeales de Baeza,

I os otros dos pedazos, 2 id., id.,

Cuarta parte de la alqueria Aceituna, con tierras cultivadas e incultas, prados, etc., 5 mizeales ayadies de oro,

Casa en el burrio, entre la iglesia de Santa María y la do San Ginés, Toledo, 40 id., dd., corrientes on Toledo,

Viña en Olias, 11 dà. , id .,

Casa en el barrio de Santa María, llamada de lu Rodela, con un solar y todas sus construcciones, sotano debajo de él y cabalteriza, 40 mizcales, 30 saadies y 10 bacsles,

Viña en Talavera, al otro Indo del Tajo, llamada viña de Tarakib, 6 mizcales de oro marroquies y merintes,

Viña en Torres, con fuero del $\frac{1}{8}, 4$ nizcales de oro de Bacza,

Una yugada do tierta blanca en la vega de Olias, de extensión corriente en las suertes de Olfas, $1 \frac{1}{\mathrm{i}} \mathrm{ld}$, Id.,

Tereio pro indiviso de una casa, con corral y abtano, en el barrio de la Catedral, bajando al Pozo Amargo, 31 id., Id. ,

Casa en San Antolín, Toledo, 40 id., id.,

Mitad de majuclo en Peña Ventosa, camiso do Corral Rubio, so fd., id.,

Viña en San Lsteban, Toledo, 30 mizcales baosles,

'Tierra inculta, en Zalencess, con los árboles, frutalos o no, y dorechos de pozo, acequia y estanque, $4 \mathrm{ld}$., ld.,

Majuelo en Torre de los Diablos (San Feliz, Toledo), más dos pedazos de viกิa, $13 \frac{1}{2} \mathrm{~d}$. . $1 \mathrm{~d}$.,
Casa en San Rowán, Toledo, $45 \frac{1}{2}$ id., 1 d.,

Casa en el barrio de la Catedral, 61 id. , id.,

Tres pedazos de viña: uno en Alaitic, dos en Monturque, Toledo, $4 \mathrm{fd}$, id.,

Mesón, ahora ticnda, con sótano y algorfa, en Toledo, barrio de los Brancos, 40 id., fid.,

Mesón, con algorfa encima y sólano debajo, en la colación de la Catedral, Arrabal de los Francos, $40 \mathrm{fd} .$, id.,

Jos viñas en Manzel Mosea, pago de: Toledo, 18 id., id.,

Iabitación (4-4), al N., do una casi on 'Foledo, cerea del baño de C'a ballel, $7 \mathrm{ld}$, id,

Majuelo en Pozo Almara, afueras do Tolodo, 4 id. , id.,

Casa en San Jnsto, junto aI horno do Mair Yahya, 6 mizeales alfonsics,

Media mezquita, un la colación de Santa María, en Toledo, 18 nizcales do oro, 82 ,

Cusa en Omnium Sanctorum, 20 y tantos mizerles do Bacza,

Mitat do un majuelo en Aruqueica, $5 \frac{1}{9}$ id., id.

Viña en el pago de Valera, alfoz do Toledo, $4 \mathrm{do}$., id,

Vina en Alaitic, 12 id., id.,

Parto (سهم) do la alquerin de Azaña, de la Catedral, 1 id., 1 d. ,

Yugada de tierra blanca cn Ainaljubia, 2 ld., id.,

Mitad de una casa en San Scbastián, de Toledo, $14 \frac{1}{8}$ id., Id.,

Tereio de viña en Torres, pro indiviso, $10 \mathrm{dd}$, , $\mathrm{d}$.,

Viăa en el pago de Venta de Sen Pa- 
blo. (Para eumplir Lustamento), 52 mizcales baesies,

Mitad de una mezquita en el barrio de la Catedral (es la del 82), $18 \frac{1}{8}$ id., id.,

Tirra blanca para una yugada, cn Olias, 15 id., id. .

Cuarta parte, pro indiviso, del azud de Alfita, on el Tajo, por Calaña, $22 \frac{1}{2}$ td., id.,

Vina en el pago de Yal de Chien, 16 id., id.,

Casa en el barrio de la Catedral, en of lugar llamado Alasabin (horbolarios), 38 id., id.,

Parto (جه) en la alqueria de Azaria, por un hermano a otro, $5 \frac{1}{3}$ mizcar les de oro saadi,

'riendas con argorfilla contigua, encima de otra vivienda, en el Pozo Amargo, junto a la casa del com. prador, 16 mizerles de oro de Bae-

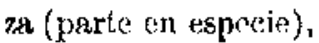

Mesón en San Ginés, ł15? id., id., Mesón con la algorfa de encima, en el Arrabal de la puerta Bisugra, cerea de Santiago, 6 mizcales de oro sand,

Casa en al Arrabal de Santiago, $28 \frac{1}{2}$ id., id.,

Yugada de labor en el octavo de Alombahlul, en Olias, 12 mizcales de oro baesi y saadi,

Mesón en San Ginés, Toledo, 30 miz cales de oro alfonst,

Majuelo en Manzel Obaidalá, Toledo, 6 mizcales de oro alfonsí toledano,

Mitad de una heredad en Manzel hazin, pro indiviso: comprende tie. rras, viñas, huertos, daceñas?, ete.
104
Mitad do un soto y de los árboles, 12 mizcales de oro alfonsi,

Tierra para media yugada de labor en Cobisa, que son cinco medias, 8 id., fd.,

Media yiña en olias, pro indiviso, 15 id., íl.,

Casa en San Juan, 60 1d., Id.,

108

Gasa en San Juan, Toledo, 60 id., id., 109 Tercio de viña en 'lorres, pro indiviso, 9 1d., id.,

Mesón en la Alcudia, cerca de las Tien. das, Toledo, 35 dd ., id.,

Casa en el Arrabul del Rey, Toledo, $31 \mathrm{ld} ., 1 \mathrm{~d}$. ,

Casa con algorfa en San Ginés, 71 idom, ddew,

Media huerta pro indiviso en Marzaleadi, Toledo, 200 1d., id. ,

Yugada de tierra en Azaña, de extengión corrtent $\theta, 5 \frac{1}{2} \mathrm{fd}$, Id,

Habitación sobre un mesón propiedad clel comprador, on Santa Justa, To. ledo, 14 mixcales alfonsles toloda. nos,

Viña inculta en Zalencas, $4 \frac{1}{9}$ idem, idem,

Casa en cl Pozo Amargo (venta entro hermanos), 8 mircales alfonsies,

Corral en el Arrabal de Taluvera, con mitad de una pared, $10 \mathrm{dd}$., íd.,

Majuelo en Manzel Ohaidalá, 7 td., id., Casa en ol arrabal de Puerla de la Sagra, barrio de Santiago, 52 id., id.. Dos casetas en el arrabal de San Isi. dro, 8 id., $1 d$.

Pedazo de tierra, plantsdo de viña, cerca del Carrascal de Talavera, $2 \frac{1}{2}$ octevos de oro alfonsi, ta del Hierro, Toledo, comprada 
por el dueño de la otra mitad, 20 mizeales alfonsics.

Dos tercios de yugada en ochavo de Aben Badah, OHas, $9 \frac{1}{3}$ dd., id.,

Mesón y algorfa en barrio de los Curtidores, $70 \mathrm{id} .$, id.,

Yugada de terrono en Olías, en el oetavo do $\Lambda$ bdeselam, 14 Id., id.,

Sbtano, bajo la casa do los compradores, en Arrabal del key, barrio en la Magdalena, Toledo, $10 \mathrm{fd}$, id.,

Dos olivos en Montel, :s fd., id.,

Casa en barrio de la Catedral, vendida por testementarí, 73 mizcales alfonsies toledanos,

'Tierra blanca on la vega do Olías, 1 mizeal de oro ulfonsi,

Tierras, por herencia, en Talavera, 12. id. , id. ,

Casa en Arrubal de los lirancos (Catedral), $20 \mathrm{fd} ., \mathrm{dd}$,

Un cuarto y media, pro indiviso, de lierras, eras, corral, casetas, cuatro palomares, huerto, etc., en Cobioa, 10 td., id.,

Décima parto de la mitad de los tres cuartos de unos bienes en Cobisa, $12 \mathrm{ld} ., \mathrm{ld}$.

Alhochra on San Justo, Toledo, $5 \frac{\mathrm{k}}{8}$ fd., fd.,

Casa en la colación do la Catedral, laacin el P'ozo Amargo, $160 \mathrm{dd}$, id.,

Modia sufrte (قرع) en Daralbelio, Toledo, 1 mizcales de oro de Baezr,

Mesón con ulgorfa, en los Herreros, 24 mizcales alfonsies,

Tienda en los Herbolaríos, cerea de la Catedral, 27 id., id.,

Mitad de $\frac{1}{6}$ en azud Alfita, pro indiviso con otros varlos dueños, $10 \mathrm{id} ., \mathrm{d}$.,

Cara, sotano y establo de enfrente, ba- rrio Catedral, hacia Pozo Amargo, 202 id., id. (núm . 63),

Viña en Bargas, 41 id., id.,

Viüa cn Azuqueica, 2 id., Id.,

Medio azud Matsbnr, 2 id., Id.,

Tierra con almondros on Albuera, al otro lado del 'Tajo, Toledo, 7 idem, id., td.,

N."

Mesón (del núm. 10k3) en San Gines, 21. 1d., id.,

Media parte (الحصة) do uno en la alqueria do Cobisa, 12 ld., id.

Viña en Valera, con el solo contiguo, 8 la., ld.,

Viña en el pago de Alaitic, 20 íd., Id., 149

Mitad del $\frac{1}{8}$ azud Alfita, 11 id., id., . 150

Un cuarto de alquería de Aceituna, 5 id., id.,

Majuelo en Binal, $3 \frac{1}{2}$ Id., Id.,

IIvorto en la alqueria do el Calbin y el Pomar, 38 id., id.,

Hucrto y viña contigua en Zalencas, 75 td. , Id. ,

Casa en San Juan, Toledo, 37 ld ., id.,

Casa en San Justo, 12 ld., fd., 156

Viña y casa en Cobisa, 16 id., Id., 15 ?

Viña en el pago de Santa Columba, Toledo, 55 id., id.,

Viña en Hameda, Toledo, 11 ld., td., Tercio de casa pro indiviso en Santa Maria la Catedral, $4 \frac{1}{\mathrm{~g}} \mathrm{fd}$, id. Los atros tercios los posela ya el comprodor,

Suerte (s, con Azaña, con la siembra hecha y dos parejas de bueyes, 100 1d., id. toledanos,

Jardin ["granadal»] en la puerta del Vado, 'Toledo, más tierra de prado, contigrua, con derechos on la aceña grande $y$ en el estanque, 12 id., id. 
Media yugada de terreno en Cobika, 4 mizcales toledanos,

Heredad, con su casa, en Azaña, 32 td., Id.,

Casa con sotano on Arrabal del Rey, Toledo, 19 ́d̉., h.,

Casa cn San Andrés, 'loledo, 40 id., id.,

Allochra en Sanctorum Omnium, 16 id., id.,

Tierra inculta en Loches y Albuera, con una fuente manantial, $2 \frac{1}{3}$ 1d., id.,

Casa on Arrabal de Arranuc, San Martin, Toledo, $8 \frac{1}{1}$ id., íd.,

Caca en el barrio de la Catedral, corca del Pozo Amargo, 90 id., Id.,

Sucrte en Villa Antigua, alfoz de Tole do, $3 \frac{1}{1} \mathrm{id} .$, Id.,

Suerte en Olias, ochavos de Aben Badah, con una era, 10 id., 1d.,

Viña en Binal, 24 1d., Id.,

Horedad on Azana, con tierras para

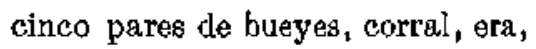
grano, barbecho, elc., 500 id., Id., Viña on Manzel Obaictala, $13 \frac{1}{2}$ idem, Idem,

'Tereera parte de un pie de olivo en dLuna? Montel, 1 id., fd.,

Yugada y media de tierra en Olías, ochavo do Aben Florent, mas un corral, más el barbecho. Se exceptúa una vî̃a, 24 id., íd.,

Viña en San Feliz, Toledo, 12 mizcales, $\quad 179$

Viña en Alaitic, 8 mizcdles, 178

Majuelo y tierra inculta, contigua, en Loches, $4 \frac{a}{8}$ mizcales alfonsics, 180

Viña inculta en Azuqueica, 1 id., id., Viña en Alcardete, $7 \frac{1}{8}$ id., icl.,

Mesón derruido y algorfa, contigua a la Catedral, 21 id., id.,
N.:

Huerto en Alcardete, con la mitad de la aceña, alberca y estanque, 26 id., id. ,

184

Un cuarto de casa pro indiviso en co. lación de San Justo, Toledo, 8 $\frac{1}{2}$ id., ld.,

Mitad de prado on IBañuclos, Talavera, medio mizcal alfonst,

Casa on barrio de Bantiago, Arrabal, para albergueria, $8 \frac{1}{8}$ id., Id.,

187

Corral on Talavera, con unos pies de higuera $y$ el pozo, 5 mizcalea de oro alfonsi d $\theta$ log nuevog,

Corral en Puerta de Alfarach, 'Toledo, $1 \frac{1}{1}$ mizcales alfonsies,

189

Corral en Talavera, Arrabal de San Aliguel, 5 mizcales alfonsíes nuevos; 190 Media heredad en Alexar. Tierras y viñas pro indiviso con Garcla, a quien le habla vendido la otra mitad. Solo: casa y corral, con sus habitaciones y construcciones, dos nalomares, eras, etc., 81 mizcales alfonstes,

Casa en San Cebrián, Toledo, 10 dd. 1d.; 192

Viría en Lorta, Toledo; 1 ld., Id.,

184

Catorce pics de olivo, ¿ una noguera?, en jurisdicción de Talavera; ocho en Canales, dotrés del río; tres on pago de Rio Mayor; otros tres, y la noguera, en el pago de los Zamoranos, 28 mizciales alfonsies nuevos;

193

Habitación de una casa, contigua al convento de Banto Domingo, en Talavera, $81 d$, , id.,

195

Viña en Loches, Toledo, 3 mizeales mo nos $\frac{a}{8}$ alfonsies,

Solar de corral en Olias, edificado ya por of comprador, 3 mizcales monos $\underset{8}{\frac{2}{8}}$ de oro alfonsi, 
Viña en Vaiera, Tolodo, 3 mizcales alfonsles,

Dos suertos de tierra en Alameda, 31 id., id.

Tercio de viña en Mazarrazín, $3 \frac{1}{2}$ fdem, idem,

Finca en azuqueica, $2 \frac{1}{2}$ id., Id.,

Parte de la alqueria di Dorbico, Talavera (con corral, tierra, frutales. etectera), $27 \mathrm{id}$, $1 \mathrm{~d}$.,

Tereio de majuelo en Ainaljubia, al duenूo de los otros dos tercios, pro indiviso (arroyo y agta), $8 \frac{\mathrm{t}}{4} \mathrm{ld}$, id, ,

Casa en el barrio de Sau Sebastián, Toledo, 6 id., td.,

Pedazo de tierra en Ioches, $1 \mathrm{dd}$, , id.,

Tierra en Alexar, 16 dd., 1d.,

Tierra inculta en Bañuclos, Talavera, $3 \frac{1}{3}$ id., id.,

Majuolo en Olins, $18 \mathrm{id} .$, id.,

Una parte do la alqueria de Villa Algar riba., 6 id., id.,

C'asa en San Justo, T'olesto, 19 id., id.,

Mitad del sexto de la alqueria de Alexar: son diez yugadas, 45 id., id.,

Viña en Loches, 26 Id., jd. (cir. 227),

Suerte de tierra en cl Calbin y el po. mar, Toledo, 6 id., id.,

Viña en Garganta del IRto Xuras, ticrra inculta con cuatro pies de olivo, $6 \mathrm{id}$, id.,

Tienda y casa on ruina, en los Herbolarios, Toledo, $20 \mathrm{ill}, \mathrm{dd}$.,

Huerto el Alcardet, 52 id., id.,

Un tercio de casa pro indiviso un el Pozo Amargo, 10 1d., id.,

Un tercio de casa en larrio de la Catedral, debajo do Ios Tintoreros, 10 Id., id.,

Media suerto pro indiviso en Dardbe-

lio, $10 \mathrm{k}$, , id.,
N. ${ }^{*}$

\section{1}

Dos viruas en Villafranca, más la mitad de un corral pro indiyiso, 12 ld., id.,

222

Viña y corral en Alameda, 24 id., id., . Huerta en barrio de San Antolin, Talavera, con 47 pies de olivo, cinco morales y dos higueras dentro de la huorta y dos pozos (uno hundido), $70 \mathrm{ld} ., \mathrm{dd}$.

Heredad en Olías, tierras, casas, ruinas, estorcolcros, carros, huertos, eras, corrales, majuelos, $7 \mathrm{id}$, , $1 \mathrm{~d}$.,

Corral, con palomar y huerto, en Cobissa, 3 id., ld.,

Viña en Loches, $28 \frac{1}{2}$ id., id., 227

Cusa en larrio de la Catedral, encima del Pozo Amargo, 100 id., id., 228

Suerte de tierra en alqueria de zYegros?, en ly Sisla de Toledo, $1 \frac{1}{2}$ id ., id.

Majuelo en Manzel Obaidala, 8 łd., Id., Yiña en Aloyón, $9 \frac{1}{4}$ 1d., id.,

Majuelo en la vega de olias, 40 id. , id., Suorto de ticrra on el Calbin, $7 \frac{\mathbf{l}}{\mathbf{3}} \mathrm{Idem}$, idem,

Majuelo en Cobisa (o Cobeja), 8 dd., id., Viña en Cobisa (o Cobeja), 12 id ., id., Casa en San Mareos, con una casita y su sótano abajo, enfrente de la casa, $110 \mathrm{id}, \mathrm{id}$.,

236

Siete tierras en Cobeju, $1.5 \mathrm{id}$, , id.,

Casa construida por' el yendedor en solar comprado pocos años antes, en Olias, 17 ld., 1d.,

Viña en Manzel Obajdala, majuelo en la misma alqueria, casa cerca de la iglesia, seis tinajas para vino, 16 id. , id. ,

Jn tercio de alqueria en Villa Algariba, 15 id., ld., 
Viña en el pago de Aloyón y majuelo contiguo, 19 mizcales alfonsies,

Casa describa en el núm. 401, $60 \pm d$., 1d.,

Huerto en Bab el Tefalín, paro de lo. ledo, tierra con áxboles $y$ do prado, en el mismo pago, camino del puente de Alcántara, tierra y bancal, con cl tercio de los árboles, 18 id., fd.,

Viña, con pedazo de tierra inculta, on Ficares, Toledo, 3 id., td.,

Viña en Alameda, alquería de la Catedral, 11 id., id.,

Viña en Azuqueica, 14 ld., 1d.,

Viña en Loches, 70 id., Id.,

Medio majuelo pro indjviso en Alexar, Toledo, $6 \mathrm{dd}$, , id.,

Casa en barrio de San Antolin, Toledo, corral jequeño, junto a San Marcos, casita, 120 dd., Id.,

Heredad de Alameda, yugada de labor en Alameda, tres vifías, mitad de un majuelo, corral con dos chozas y dos palomaros, 74 id., id.,

Viña en Cobja o Cobexa, 6 menos $\frac{1}{4}$ id., id.,

Dos quintos de la cuarta parte de Villa Algariba, más derechos en vij̃a $\mathrm{y}$ huerto, $36 \mathrm{fd} ., \mathrm{dd}$.

Casa y huertecillo en Cobeja, 5 idem, idem,

Chozas y majuelo en Arcicolla, 13 id., id., 4 por las chozas y 9 por el majuclo,

Tferra para tres pares de labor a dos hojas, con chozas, corrales, dos parejas de bueyos con sus aperos, el barbecho, más la paja que se recoja en el verano del año de la fccha. en Azaña, 800 idl., id.,

Casas en San Justo, 60 id. , id.,
Huerto en las afueras de Toledo, junto a la Puerta diel Vado y a la de $\mathrm{Te}$ falin, $31 \mathrm{kd}, \mathrm{dd}$. 257

Viña en Chaleneas, $10 \mathrm{isl.,} \mathrm{id.,}$

Heredad de Arcicolla, pro indiviso con la actual y lo giue en lo iuturo la podria pertenecer a la vendedora, derechos adquiridos o por adquirir, heredado, donado, ete, 200 id., id., a tres plazos,

Casa en arrabal de San Isidro, $12 \frac{1}{2}$ id., id.

Viña en Oliolas, 28 Id., id.,

Pedazo de huerto y tierra de pralo contigua, en Puerta del Vado y de Tofalí, con el canal del agua del rio a la aceña y derechos a la aceña y al prado, 16 id., itt.,

Majuelo en Manzel obaidalá, 7 id., id., Un quinto pro indiviso de dos suertes en Daralhelio, 8 fd., Id.,

Mitad pro indiviso de una viña en el Calbin y el Pornar, $7 \mathrm{fd}$, $\mathrm{ld}$.,

Majuelo en Ainaljabia, ticrra blanca contigua, 70 id., id.,

Mitad pro indiviso de un mesón en el barrin de Zocodover, dentro de Toledo, $70 \mathrm{id} ., 1 \mathrm{i}$.,

Quinto de dos suertes pro indiviso en Daralbclio, 11 id., id.,

Casa on el adarve del caid D. Sabib, $40 \mathrm{jd} ., \mathrm{id}$.,

Media suerte menos quinto de la alqueria de Daralbelio (cambio con media suertc),

Yugada de tierra en alquería de Cobisa, alfoz de Toledo, $2 \frac{1}{2}$ mizcales alfonsies,

Casa an barrio de la Puerta del Hierro. Toledo, $4 \frac{1}{4}$ id., id., 
Majuelo en Villa Algarita, con otro más pequeño, 8 mizcales alfon síes,

Heredad en Azañ (la compra San Julián de Cuenca), 600 id., id.,

Viña on Almoradiel, $7 \mathrm{~d}$., id.,

Dos suertes en Olias, ochavos de Aben Badah, 50 id., 1d.,

Casa y lienda en barrio te San Nicolás, 50 id̀ , idi.,

Media suerto en Daralbelio, $7 \frac{1}{8}$ idem, idem,

Pedazo de tierra blanca en Olías, 10 Id., id.,

Yugada de las corrientes en Olias, ochavo de Aben lahhlul, más solar de corral, con cl horno que en el hay, en el solar del castillo gntiguo, más una viña en la vega de Olias, $40 \mathrm{fd}$., Id.,

Suerte menos cuarto, pro indiviso, en Daralbelio, Daralfornana, etc., 15 id., fd.,

Etra en Olias, 3 fd., id.,

Viña en Aln, $\frac{1}{3}$ de mizcal alíongl y 5 ochavos,

Viñt en Olias, $6 \frac{1}{4}$ mizcales alfonsies,

Pedazo de viña on Villa Algariba, $5 \frac{1}{3}$ id. , id.,

Una suerte, menos un quinto, en Dalalbelio, 11 td., id.,

Viña en Villafranca, 6 td., fd.,

Un tereio de un buerto, pro indiviso, ch el arrabal de toledo, cerca de Maryaleadf, comprado por hijo de la duena de los otros dos tercios, $18 \mathrm{kd}$. id.,

Majuelo en Ainaljabia, 160 id., id.,

Mitac de una ora, pro indiviso con el comprador, on Olias, 6 id., Id. Tercera parte sólo, scgún declaración final de las vendedores,
Mesón en barrio de Francos, cerca de los Herbolarios, 40 id., Id.,

Dos casas en Santa Leocadia, dentro de Toledo, media de la alquería de Arcicolla, más milad de cla viña del obispo, en clla, parte yro indiviso de la alquería de Camarena Alta, 1.100 id., id.,

La mitad pro indiviso de un buerto en el pago de \&Azomail?, Toledo, 24 id., dd.,

Pedazo de huerto en Bab el Tefalin, Toledo, $50 \mathrm{dd} ., \mathrm{kd}$.

Casa en la colación de la catedral, en el adarve del arcirrreste D. Nicolás, 53 id., $i d$. ,

Suerte y un octavo de otra en Daralbolio, $21 \frac{1}{2} \mathrm{fd}$., id.,

Dos mesones con tres tiendas, descritos en el documento numero 335 , 250 id., fid.,

Mesón en San Giness, 23 Id., id., 298

Corral en Olias, $6 \frac{1}{2} \mathrm{ld}$., id.,

Medio horno en Talavera, on el mercado, en el barrio de San ..... 40 [mizcales] de los sueldos corrien. tes en Taluvera,

'lierra de regadio de huerta on el pago de Santa Colomba, Toledo, más une viña contigua, 12 mizcales alfonsies,

Mitad de casa pro indiviso y medio corral contigroo, en la Alcudia, 32 Id., id. ,

Dos tercios pro indiviso de una viñ́a, adquiridos por derecho de plantación, en Almoradiel, 27 menos $\frac{1}{3}$ id., id.,

Un tercio de majuelo, pro indiviso, por derecho de plantación, en Darallelio, 16 fd, , id., 
Parte rle Ia alqueria de Villa Algariba (Villafrunca), 60 mizcales alfonsies, Casa en la colación de Santo Domingo $y$ cle San Justo, an el adarve, dentro del rauro de la ciudad de Talavera, $6 \frac{1}{5}$ id., fel.,

Un ockavo de la milad de molino Jundido en Ia orilla del azud del latko de ack del 'lijo, en el axud do Sarta Culomba y de los Ballesterus?, I'oledo, 7 id., ld.,

Mitad de un corral en Villa Algariba, mitad de dos pedazos de viña pro indiviso con la otra mitad del coral y de las chozas quo posien los compradores, parto de la heredad, que es de los vendedores, 20 id. , 1ủ.,

Casa en San Marcos, cerca de los Tintoreros y corral delante, 131 id., id., Alhochra en adarve del caid $\mathbf{D}$. Sqbib, 10 id., id.,

Dos casas y tionda en San Martin, 88 id., Id.,

Un tercio de majuelo en Almoradiel $y$ una viña vieja, 30 id., fd. (cfr. 803),

Aimdera en barrio de la Catedral, Toledo, 18 id., Irl.,

Caka en adarve del caid D. Sabib, 78 id., Id.,

Viña en Valdecubas, 20 id., id.,

Mitad pro indiviso de pedazo de viña on Almoradiel, tíerra blanca, 4 id. , id.,

Mesón en barrio de Francos, en los Cambiadores, 31 ld., íd.,

Mesón en Arrabal del Rey, 135 1d., id., Casa en barrio del Pozo Amargo y Bano de Yaix, 20 íd., fd.

Heredad en Olias: tiorras, estercole- ros y eras en el ocharo de Aben Mosquiq, 80 id., id.,

Huerto de Ia Ahofra, 110 id., id.,

Media suerte pro indiviso en Daralbelio, en el actayo de Juan Martine\% el Adalid, corral y unit choza, I6 1d. , id.,

Mitad pro indiviso del azud de la alquerta de Aleapillat, 60 id., id.. 322 (b)

Casa en Arrabal de Prancos, harrio do la (atedra), $62 \mathrm{fcl}$, id.,

Media suerie en I ar'alluelio, con un corral y las chozas, $14 \mathrm{Id}$., id.,

Huerto on Aleardete, 52 tà., id.,

Casa en San Román, al lado del con. vento de $\operatorname{San}$ Clemente, $700 \mathrm{1d}$, id,

Viña on el pago de I3aric ('Talavera), máe la mitad de dos olivos, on el dicho pago, en viña de la alquerta de Domingo Zareo, 18 menos cuarto $\mathrm{Id}, \mathrm{id}$.,

Majuelo en Darelihudr, 30 menos $\frac{1}{8}$ id., Id.,

Casa en barrio del Portal, cerca de la Santisima Trinidad, $160 \mathrm{xd}, \mathrm{id}$.

Casa en colación de Santo Domingo, Talavera, 7 id., id.,

Solur de corral en Olias, 9 id., id.,

Casas on un adarve en la colación de Santa Leocadia, dentro de Toledo, lindante con casas de Micael Petrez y de Orabona, 70 id., id.,

Heredad en Camarena, compnesta de 39 fincas, más dos pares de bueyes, con paja, grano y lo sewbrado, 710 td. , 1d.,

Un. cuarto de la alquerla de Arevali. llo, 40 id., ld.,

, Dos mesones con tres tiendas en barrio de San Gines, zoco do los Alfare. ros, en Toledo, 250 id., id., 
Dos quintos de la cuarta parte de la alqueria de Villafranca, pro indiviso, 66 mizcales alfonsies,

Alhochra en la Catedral, barrio do los Tintoreros, 13 id., id.

Crasa de los judios, de Tralayera, en barrio del Aleázar del Rey, 10 id., id.,

Casa on San Roman, lindante con al convento de San Clemente, 26 id., id.,

Casa, mesón y tienda en san Martin, 34 id., 1d.,

Casa en barrio de la Catedral, cerca de ella, donde degüellan las reses, ..... td., dd.,

Casa en San Marcos y San Antolin, junto a la iglesia de San Marcos, 20 id, , id.,

Casa on Santa Maria Magdalena, 12 id., id.,

Majuelo plantado por uno de los vendedores, 300 id., Id.,

Dos pedazos de viña en Azuqueica, 39 id., id.,

Casu en barrio Baño de Cabullel, cerca del homo, 15 id., Id.,

Casa en barrio de Santa Justa y $\operatorname{San}$ Gines, 36 id., id.,

Viñe en la vega cle Oliag, $110 \mathrm{id.,} \mathrm{id.,}$

Mesón en los Alfareros, cerca de San Ginés, 38 fti, fll.,

Dos pedazos de viña on Corral Rubio, 2 id., ta.

Una suerte menos quinto en las alqueriss de Darallselio, de Alain, de Te. llo Diaz, Mlmenares y de Chonán Daud, 46 id., Id.,

Solar de terreno en la puerta de Zamo. ra, Talavera, 6 1t., Id.,

Casa en Arrabul de Santiago, 38 idem, Idem,

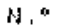

Casa en el adarve del caid D. Sabib,

$60 \mathrm{id}$., id.,

Meson en San ciness, junto a las tiendas de los Alfareros, 36 id., id.,

Casa en Puerta del nierro, folodo, A id., id.,

edazo de tierra en Olias, 1 id., id.,

Vina grande en Jandac Gafrón, en 'Toleslo, pedazo des viña eontiguo, 60 id., id.,

Casa en tl Arrabal de Santiago, $8 \frac{1}{8}$ id., id.

Casa en la colación de Santa María, de Talavera, $20 \mathrm{fd}$., id.,

Suerte en Daralbelio, i $4 \frac{2}{\mathrm{~s}}$ icl., id.,

Casita on San Ginés, Toledo, 20 ddem, idem,

Heredad en Villa Algariba, 32 id., id.,

Dos mesones en los Carniceros y los Rruñidor'es, 131 id., id.,

Mesón en Santa Maria Magdalena, Arrabal del Rey, 40 1d., id.,

Mesón en Santa Marir, Arrabal de los ['rancos, 65 ld., ill,

Tres trozos do huerto a orillas del Vado del Tajo, fuera de la Puerta del Vado y Puerta de Tefelin, 'loledo, 85 id., id.,

Pedazo de huerto con frutales en Pnerta del Vado y de Tefalín, más un pedazo de tierra do prado,

Solar de corral cn Olias, $5 \frac{1}{\mathrm{~g}} \mathrm{i}$ il., id.,

Yiña en el lago del Regachnelo, dol alfoz de Toledo, $2 \frac{1}{3}$ id., id.,

Casa en San Antolín, $14 \mathrm{fcl}$, id.,

Cuatro yugades y media de labor en Olias, ochavo de Alien Socala, de las corrientos en aquella alqueria, mís 2 y media yugadas en ochavo do Aben Moxquiq, més un corral, $38 \mathrm{id}$., id. 


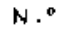

Mcán y tro\% de corral en el corra] del comprador, on Olias, 16 mizcales alionsies,

Viña en Almoratlit:l, $35 \mathrm{ftl}$., $\mathrm{i} 6$.,

Vina en Aluwaradiol, 23 ld., id..

l'edazos de viña $y$ Jucréto on Alaitic, 9 fd., id.,

Viña en Oliolas, $60 \mathrm{fd}$, id.,

'licrra de prado cerea del cementerio moro, th la Puorta Bisagra, 5 talem, ídem,

Casa en la Puerta del tIlerro, 18 tdem, idem,

Parte en la alyueria de Yepes, parte de de la de Fontes, $\frac{1}{2}$ id., fít.,

380 bis (a)

Id. , Id., 1 id., id., 380 bis (b)

Id. , fd., $\frac{1}{2}$ id ., id., 380 bis (c)

Id., fd., $\frac{1}{8} \mathrm{id}, \mathrm{ld}$,

Fl., id., $\frac{1}{2}$ id., id.,

'T'rozo de huerto en la Puerta del Varlo, 21 id., id.

Casa on barrio de San Juan, 40 dd., id., Viña en Olias, paygo del Torrente, 45 jd. , id.,

therra con seis oliyos en Talavera, 8 id., id.,

Viña en el Carrascal, de Talayera, 27 fi., id. Lindes por el lado del pueblo y por el lado de la debesa, encima del camino que baja al corral de doña Maria,

Novena parte de la alqueria de Villamuelas y Cerva Longa, $11 \mathrm{jd}, \mathrm{jd}$,

Octavo y medio pro indiviso de la a]quería de Villamuelas y Cerva Lon. ga, 19 fd. , id.

Casa en San Antolin, 80 id., Id.,

Hercdad llamada Iláica, en la Sisla, 24 id., id.

Octavo de Villamuclas y Cerva Isonga, $6 \frac{1}{4}$ id., id.,
Octavo menes la mital de un quinto del octavo, $5 \mathrm{id}$, , id.,

Octavo, $12 \frac{1}{2}$ id., $1 \mathrm{k}$. . 389 (d)

Oetavo pro indiviso de Villamuelas $y$ Cerva Longa, $10 \mathrm{id}$, id.,

Casa en San Marlin, destro de 'Poledo, $50 \mathrm{1d} ., \mathrm{id}$.

391

Suerte menos euarto en Daralbelio, 50 Id., id.,

Oetavo, pro indiviso, do la alqueria de Villaseca, $68 \mathrm{td}$, id.,

Viña en Zalencas, $18 \mathrm{ld}$., id.,

Caga ruinose, con el cuarto y la alco. bita que queda, on San Román, cerca de San Clemente, 35 id., 1d.,

Pedazo de corral, en Toledo, entre las tiendas de los Tintoreros, $8 \mathrm{id.}$ Id.,

Vifía en Olias, pago del Torrente, 56 Id., id ; en el 383,45 id., id.

Viña en Chebel Acldoa, alfoz de Toledo, y de un majuclo contiguo, 40 1d., id.,

Viña en ...., 1 id., id. (V. el 748.)

Viña en barranco de Gafrón, Toledo, 65 id . id.,

Casa en Santa Marja, Tintororos, 53 id., id.,

401

Modia tierra de labor para yugada y cuarto, en (Olias, ochavo de Ben Florent, 13 id., id.

Dos suertes pro indíviso en la alqueria de Alcalbín, $10 \mathrm{id.,} \mathrm{id.,}$

Majuelo en Oliolas, adquirido por derecho de plantación, 105 id., id.,

Heredad en Yepes, 20 id., fd., en lu. gar do los cuales se da una viña en Azuqueica,

Varias fincas en Yepes y lontes, 300 id., id.,

Heredades en Yepes y Fontes, 6 idem, idem,

408 
Casa en Santa Maria Magdalena (sin algorfa), 26 mizeales alfonsies,

Casu en Zocodover, 60 id., id.,

Mesón on barrio de Santa Marla, en los Tintoreros, 60 li., id,

Tierra plantada de almondros, con su torre, en la Sisla, Val de la Degollada, 1 id., id.,

Casa en Santa Jusia, Tralavera, 4 idew, flem,

Casa y albochra en San Martin, 00 id., td.,

Dos suertes de viña en el pago del To. rrento, do Olias, $50 \mathrm{dd}$, id.,

Viña en Aloyón, 38 ld., Ial.,

Casa en barrio de la Catedral, adarve del caid D. Sabib, 65 id., fd.,

Un tercio de la mitad de la ajquería Azcituna, $1 \frac{1}{9}$ dd., id.,

Sala de la casa citada on ol 40y, en Santa Marta Magdalena, 15 1d., id.,

Heredad on Yepes, 10 id., id.,

ríerra inculta, que fué viña, en Vale. ra, $5 \mathrm{dd}$, , fd.,

Tres cuartos de una yugada y cuarto de labor, a dos hojas, de barbecho y de sembrado, en Olias, más un arreñal o estercolero (se excluyo un majuolo), 25 mizcales de oro corrientes en Tolcdo por esta recha,

Casa en la colación de San Romun, corca de $\mathrm{San}$ Clemente, 31 mizcules alfonstes,

Parte de uno de San Nicolás, en Ia alqueria de Ycpes, 2 dd., Id.,

Casa en barpio de San Justo, T'oledo, 24 id., id.,

linen citada en el documento nume. ro 398,30 id., id.,

Medio majuelo en Val de lifuecas, en el pago de Sareat, de Ja alquerla de Rielves. (Ilegible el precio.) 427

Casa en Santo 'l'omé, 67 mizeales alfonsies,

Un olivo dentro del hucrto del convento de San Clemente, en el pago de Canalos, del lado de allá dol Tajo, en 'lalavera, $1 \frac{1}{2}$ id., id.,

Casa en Puerta del Hierro, 'Toledo, 16 id., fd.,

Derecho en majuelo, adquirido jor derecho de plantación on tierra dol comprador, en Val de Santo Domingo, 'Toledo, pro indiviso con los hermanos del vendedor, 2 fdem, Idem,

Un tercio de los dereehos en plana y canales do una noria en el 'Tajo, Talavera, 14 id., íd. ,

Derechos de jesca en las norias del rio 'l'ajo, en los pagos de Torremocha y del Rey, jurisdicción de Talavera, $14 \mathrm{ld}$., id.,

Casa en berrio de Baño de Yaix, $28 \frac{1}{8}$ id. , id.,

Tierra blanca en Alcardete, 9 ídem, fdew,

Viña en Jandac Jálid, Toledo, Y idam, Idem,

436

Media casa en San Roman, contigua a los corrales de San Clemente, 55 id., id.,

Mesón ell San Román, 47 id., 1d.,

Viña en ....., * Valle Johanis Potatoris $=40 \mathrm{id}$. id , (N. nim . 400.)

Mesón en Santa Maria Magdalena (números 409, 419, etc.), $100 \mathrm{fd}$., id., Casa en barrio de la Galedral, en la Alhondiga del Koy, 20 id., id.,

Tierra con sieta olivos, al otro lado del Tajo, en el Villar, cerca de Albi- 
ches, jurisdicción de Talavera, más 9 olivos enclavados en tierl'a del convento, compralor, 11 mizcales alfonsies,

Casa en la Puerta dol Hierro, 23 inlem, idlem,

Suerte en Villa de los Alamos, $3:-$ id., td.

Viña en Olias, heretarla del palro, 14 mizcales menos cuarto,

Tercio pro indiviso de la mitad de un huerto en Aleardeto (la otra militd cle los canónigos), $33 \frac{1}{3}$ mizcales alfousies,

Viña on Corral Rubio, alfor do Toledo, 3 id. , id.,

Derechos de aguas en el azud de Baños, en Talavera, 2 id., id.,

Tres suertes pro indiviso de la alqueria do Villa Antigua, una suorte en Mascaraque, 24 id., id.

Casita en barrio de la Catedral, en Ios Tintoreros, $7 \mathrm{dd}$, id.,

Viña en Alaitic, 25 id., ld.,

Dos partes de la alquerla de Villa de los Alamos, en la Sisla, 4 íd., id.,

Una parte de heredad en la alqueria de Artal y de la Mezquita, en la quebrakla llamada Val de Caráljano, 4 ill, ill.,

Media yugada do labor en dos hojas, barbecho $\mathrm{y}$ sembrado, en Manzel Obaidala; medio corral, con ehozas y palomar, mitad del huerto de las moreras, con mitad do las moreras y derechos a elles, $30 \mathrm{iu.,} \mathrm{ficl.}$

Pedazo de viña en pago de Aloyón, $3 \frac{1}{8}$ Id., Id.,

Calleja que era tielldi y ahora está arruinada, en el Zoco de los Carniceros y de Ios Zapateros, en barrio de la Catedral, 8 Id., fd, "Calleía

que compramos en los carniceros",

Losas en Jenesa y Corva (Poña Aguile. ra), 4 ja., fa.,

Losas en el Puerto del Carbonero, que son 32 samansas, $21 \mathrm{id}$., fd.,

12 samansas de Conejar, de 20 losas ea da uno, 5 mizeales alfonsícs, Casita en barrio de la Allóndiga (Caterlral), 12 1d., id.,

Casa en barrio de la Catesiral, Arrabal de los francos, $100 \mathrm{da}, \mathrm{d}$.,

Viña en Alajtic, del convento de San Perlro en Alhieem, 5 ill., id., N. 457 458 459 460

'Tres octavos pro indiviso en la alquerin Azeituma, al otro lado del Tajo, con sus derechos, incluso del agua del rfo Xaraz, $8 \frac{1}{1}$ dd, , id.,

Viña en Bargas, cerca del camino de Segovia y ol que va a la Vega, 134 id., id.

Viña en Alaitic, en dondo ostá ol casar, con el casar y los derechos a él anejos, $11 \mathrm{ld}$, id.,

Tercho pro indiviso de una tierra inculta que antes fué viña, en tiem. po de los radres del vendedor, en Valera, affoz cle 'loledo, $1 \frac{1}{4}$ them, idem,

11 sanansas del losar, más 8 pro indiviso, on Miraclo, 6 id., Id.,

Cinco pcuazos de viña contiguos, cultivados o incultos on Alaitic, con los granados y dos olivos, con el casar, on cuyo interior ests el pozo demolido, y los derechos a este pozo, 11 id., id.,

Casa en el Bornel, con un corral contiguo, $200 \mathrm{fd} ., \mathrm{dd}$,

Casa en Ownium Sanctorum, Toledo, con casita y corral, $50 \mathrm{id}_{+}, \mathrm{id}$., 
Majuelo en la vega de Olias, con otro trozo de viña que separa aquélla, 30 mizcales alfonsios,

Mesón en Arrabal de lirancus, 220 fd. , fd.

Mesón en al Arrabal uel Rey, barrio le Santa Maria Magualona, 65 id., id.,

Viña en (xarganta, ielajo de Corral Rubio, 7 mizcales alfonsíos de los nuevos,

Cana en barrio de la Catedral, adarve tho D. Sabib, 250 mizcales alfonsies, de 15 dineros, que ahora haces co. rrer la ecca tle Toledo,

Caca en San Nicolás, 38 wizcales, tle 15 dineros,

Viña en la vega do Olias, 30 mizeales alfonsfes,

Viña en Olias, pazo del Torxente, 50 id., id.,

Viñ en Aloyón, 8 mizcales y $10 \frac{1}{2}$ sueldos,

Castillo y alqueria de Azuheruela, 60 mizcales alfonsies,

Dos casas en San Vicente, cerea do Ia iglesia, $58 \mathrm{id}$., Id.

Cuatro tiemclas en San Nicolás, $3(x)$ mizealea, de 15 dineros,

Casa, on la $\Lambda$ leuclia, luundida, calto quo livide con la Catedral, 90 il., jik,

Casa en barrio de lario de Yaix odel Hierro, 45 kd., isl.,

Casa en barrio de la Cateriral, cerca de los 'Tintoreros, con alhochra y sotano, $200 \mathrm{Aa}, \mathrm{id}$.

Mitad pro indiviso de los dercelios que los conventos do san pedro y de Santo Doningo tenfan en la alfare. ria del Arrabal de San Isidro; idenı de dos tienclas en San Nicolás, 15 id., id. I a otra mitak, de San Clements: comprador,

487

Derecho en dos tionktas, que tenía por hereveia clel obispo de Cucnea, clon Garcia. l’arte igual la tería ya la Catedral por donacion. Valía cl al. quiler 4 mizcales. Se vende la mi tad del derecho por 10 id., í.,

Dos polazos de viña en Val de Jaen, $20 \mathrm{kl} ., \mathrm{id}$.

Casa en harrio tlel Paño de Yáax, 20 ld., td.,

Olivos en una tierra de San Clemente (en total, 9), en Tulavera, 11 id., íl., cuarto pro iscliviso,

Viña cn cl camino de Alcoba, alfoz de 'Talavera, 24 fil., id.,

Mitad del castillo to Soherueta, ahora llamado Irizojosa, cerea tle Alareos, 90 il., i.,

Treinta y ocho samansas en las losas del Berrocal, de Iomingo Sidis, cerca de Menasalbas, 18 id., id.,

Heredad on Alaitic, $20 \mathrm{fd}$, , id.,

Tienda en Zoco de! Jos Sastres, en San Nicolús, cerca de la tienda del hiepro y del carbón, $60 \mathrm{jd}$, fd.,

Casa en el barrio del Baño de Caballel, $50 \mathrm{kl}, \mathrm{d} \mathrm{dl} .$,

Mitad pro indiviso de tierra para era, en Olias, 1 idl., ld.; cuarta parte de la tierra citacla, $\frac{1}{2} \mathrm{id}$, , 1d.,

Cuarta parte pro indiviso de una heredad en Alaitic, 45 id., fd.,

Casa del Refugio, en barrio de San Nicolás, 30 id., id.,

Suerte do tierra en Villaseca, 6 mizcales alfonsies, de 15 dineros, becho y scmbrado, en Barciles, más 
los corrales que hay pn ellos, más una viña, 50 mizcales alfonsies,

Casa en San Juan, cerca de los plateros, $60 \mathrm{id}, \mathrm{id}$.,

Viña en la vega de Olias, 14 lt., 1d.,

Majuelo en Darabengaz, 1.50 mizcales alfonsics, de 15 dineros,

Viña en pago de Altach, camino ds Olias, $50 \mathrm{ide} . \mathrm{id}$.,

Sexta parte pro indiviso del castillo do Zoheruela, cerca de Alarcos, 130 mizcales alfonstes,

Tierra en Benquerencia, 1 mizcal menos 6 sueldos,

Sexta parte del castillo de Zoherctela, 30 mizeales alfonsics,

Suerte de tierra en la alqueria de Villa de Silos (Sisla), 25 mizcales alfonsles, do 15 dineros,

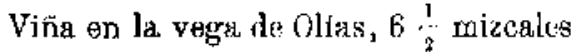
alfonstes; en el número 505,14 id., id.,

Casa en Santa Maria de los Iintoreros, donde se vende el vino, 70 mizedles alfonsies, de lis dineros,

Tierra podregosa al otro lado del Tajo, debajo del molino donde se hace vino, en el barrio de la Puerta del Hierro, Toledo, enfrente de la Puerta do la Alentia, 1 mizcal alfousi,

Suerte en سلف الديمة, de la Sisla, $1 \frac{1}{9}$ id., id.,

Casa en San Martín, 22 dd., id .,

Stuerte de tierra en Val do Mozárabos, 3 mizcales, de 15 diner'us.

Viña en Darabengaz, 53 mizcales al. fonsies,

Trozo de corral en el Arrabal de Tolodo, más de la mitad (el resto es de la compradora), 27 id., 1.l.
Parte interiox le una casa en San $\mathrm{Ni}$ colés, 41 id., id.,

Mitad de un octaro, pro indiviso, de la alquería Azeituna, 10 id., id.,

Sexta parte de un casa en San Nicolás, pro incliviso, $133 \frac{1}{3}$ id., td.,

P'odazo de viña en Alaitic, 4. jd., id., Nedia casa on barrio de Santo 'Tomé, 75 mizeales, de 15 dineros,

La otra mitat, 80 mizeales alfonsies,

Novena parte de la alquoria de P'esinas - Besines (Sisla), 150 id., id.,

Suerte en Fontalba, alqueria de la Sisla, $10 \mathrm{id}, \mathrm{i}$ il.,

Media yugada de terreno en Villares, 8 dd., itl.,

Viña on ol thito? dle Olias, $8 \frac{1}{4}$ idem, idem,

Suerte en la alqueria de Xarf Addoján, de Toledo, 10 mizeales alfonsies, de 15 dincros,

Viña en Darabengar, 32 mizcales alfonsies,

Media botica y corral en ol Arrabal, pro indiviso, 80 íl., fd.,

Toda la botica y corral:

124 id, id.,

180 id., 1il.,

Suerte do tierra para una yugada de labor, para barbecho y sembrado, en Alcanabal, alqueria de la Sibla, 18 mizcales, de 15 dineros,

Casa en barrio de Hamam Ferro, „Casas del Fidalgo», 40 miz. alfonsies,

Dos podazos de viña en Aloyón, 10 li., fil.,

Suerte en Villaseca, en Val de Carábanos, $18 \frac{1}{3} \mathrm{Id}$, id.,

Casa en barrio de San Nicolás, 33 mizcales, de 15 dineros, 
Casa en barrio de la Catedral, adarve del caid D. Sabib, 70 mizcales al-

Viña en la vega de Olías, 16 id., Id., Media suerte en Villaseca y Mezquita,

¿Obra? de una casa en Villaseca,

Casa en el adarye del caid D. Sabib,

Casa en barrio de San Juan, del abad fonsies, en Val de Carábano, $14 \mathrm{jd}$, , id.,

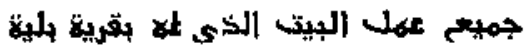
..... شاكة 7 mizcales alfonsies menos 2 dineros, 150 mizcales alfonsies,

Casas en San Justo, 40 Kd., id., benedicto $\mathrm{D}$. Mateos, 110 mizcales alfonsies, de 15 dineros,

Ciasa en barrio de Hamam Ferro, dentro de Toledo, 40 mizcales alton. stes. Vease el zúmero 534,

Casa en San Justo, 100 maravedis,

Casa en barrio de la Catedral, adarye de D. Sabib, 115 mizcales alfonsles,

Vifía en el pago de la vega de OHlas, $56 \frac{1}{8}$ 1d., id.,

Mesón en barrio de Francos, $140 \mathrm{Idem}$, Idem,

Media suerte de tierra en Villaseca, 20 id., 1d.,

Ouatro quintos pro indiviso de la mitad de una suerte en Villascea, $2 \frac{1}{4}$ id., id.,

538

539

540

541

Un quinto, más dos tercios de un quinto de otros dos quintos pro indiviso en dos piedras del molino de Aso. mail, 250 mizcales alfonsíes, de 15 dineros,

Un quinto mas un tereio del azud de Asomail, 250 mizcales alfousies,

Casa y corral en barrio de Santo Tomé, 170 1d, , id.
Una suerte de tierra en Arcegal (Val de Carábano), 4 id., Id.,

Casa, habitación y algorfa en los Tintoreros, cerca del Porronal, 62 id., id.,

Casa en barrio de San Lorenzo, ccrea del baño de Yaix, 100 id., dcl.,

Mesón en San Martín, cerca de la Puerta rle los Juclios, 100 írl., id.,

Casa cerca del Alcázar del ley y otra contigua cerca de la iglesia de Santa Marfa Magdalena; y la botica contigua y un establo, 314 $\mathrm{id} ., \mathrm{id}$,

Pedazo de viña con tierra contigua, ahora prado, con esto prado, on Calabazas, $2 \frac{1}{3} \mathrm{id}$., id.,

asa en San Nicolís, cerca de Zocodoyer, 140 id., Id.,

Yugada de tierra, menos un sexto, en la alqueria de Viveros, de Madrid, $120 \mathrm{id}$, id. .

Ileredad, con un par de bueyes de la. bor, con el corral, chozas, jaja en el corral, el barbecho, en Torres; se exceptua un plantío de viña, 21 . id., id.,

Suerte de tierra, de las mejores, en la alquerfa de Mezquita y Artal, ahor'x Villaseca de Val de Carábanos, de la Sisla de Toledo, citada en el acta de donacion del Fmperador, 20 - Id., fd.,

Pedazo de viña de caballones?, inculta en Calabazas, alfoz de T'oledo, 4 id., ill.,

Cuatro tierras y la mitad pro indiviso de un corral, $y$ la choza quemada que tiene en la alçuería de Torres, ahora ¿Tienda Fambra?, 12 id., id,; Casa en barrio de San Nicolás, 33 miz: cales alfonsies, de 15 dineros, 
Pedazo de viña fructifera en Colabazas, alfoz de Toledo, 5 mizcales alfonsies,

Casa en Puerta del Hierro, Alhankac, Tolerlo, 40 id., id.,

Casa en barrio de San Nicolás (ntimero 570$), 51 \mathrm{hl.,} \mathrm{id.,}$

Casa en barrio Catedral, $68 \mathrm{fd} ., \mathrm{ld}$,

Suerte y merlia en la alquería de Villaseea, pro indiviso, con sus derechos en colrales, chozas, dos pares de buoyes, a peros, semilias, barbechos, ete., $310 \mathrm{dd}$., id. ,

Suerte pro indiviso en Villaseca, 6 id., Id, ,

Un cuarto de casa en San Andrés, cerca de Pozo Amargo; compra el due no de los otros tres cuartos, 50 Id., id.,

Caga en San Nicolís, cerca de Santa Cruz y de Bab el Mardom, 16 id., id.,

Mesón en Zocodover, $100 \mathrm{id.,} \mathrm{jd.,}$

Viña con plantas de granados y do al. baricoques, en Zalencas, 10 id., Id.,

Casa en barrio de la CatetIral, Alcudia, cerca del adarve hundido, . . . . idl., Id,

Viña en el pago de la huerta de Alaitic, alfoz de Toledo, 70 mizeales alfonsies, de 15 dineros,

Pared medianera entre el cuarto caliente de una casa con otra casa de la Catedral, en el barrio de Santo Tomé, para tapiar una ventana, 3 id., fid.

Viña con olivos en Alaitic, 80 id., 1d., Corral (carnlceria) en la Alcudia, cer ca, de la Catedral, 200 id., Id., 586 ,

Plantio de viña en Ja vega de Olias, 80 td., id. (V. numero 549),
N. ${ }^{\circ}$

.

Viña en Alaitic, 30 mizcalos alfonsies, de 15 dineros,

Media viña en Aloyón, pro indiviso, cerca de la iglesia de Santa Maria, la Sisla, 40 mizcales alfonsies;

'Tercio do la mitad de un huerto, que posetan el Cabildo y clona Maria Gonzólbez, pro indiviso, en Aleardete, alfoz de Toledo, con sus plantios, labores, acenas y dercehos, 100 itl., id.,

Casa en San Antolin, cerca ide los Tintoreros, $140 \mathrm{id}$., idl.,

Tierra en Benquerencia, 1 dd. , id.,

Pedazo de viña inculta en Azuquejea, $1 \frac{1}{2}$ id., id.,

Casa on San Lorenzo, ccrca del Baño de Yaix, $200 \mathrm{ld}$, id.,

Heredad de un par de bueyes, de bar. becho y sombrado, con sus tierras, corrales, chozas, etc., on alqueria de Val de Mozarabes, alfoz de Toledo, 40 id., id.,

Horedad en Manzel Abuishac, Sisla, compuesta de 22 tierra, un corral con dos chozas cubiettas de paja, un solar de corral, una vina inculta, pelomares, etc., 250 id., id.,

Solar de corral en la Magdalena, Arrabal del Rey, 50 fd., id.,

Pedazo de viña inculta en Azuqueica, $5 \mathrm{td}$, id.,

Una suerte y un cuarto de otra, con sus corrales y cinco chozas cubiertas de paja, en Artal y Mezquitu, hoy Villaseca, de Val de Carába. nos, Sisla, 120 id., id.,

Suerte y media en Villaseca, pro indiviso con dos parejas de bueyes $y$ sus aperos, sembradura y barbecho, 
paja e instrumentoa para recoger el grano $\mathrm{y}_{6}$ trillarlo, 310 mizcales alfonsies,

Viña en Azuqueica, 5 id., id. (V. el numero 595),

Casa en San Andres, cerca de la jglesia, ifo il., Jd.,

Tres quintos pro indiviso de casa en barrio de la Catedral, arlarve del areediano D. Bartolomé, 101 ídem, Idem; los dos quintos restantes, 60 id., id.,

Casa en barrio te la Cintedral, carca de Pozo Amargo, $150 \mathrm{ld}$, Id.,

Casa en $;$ Harr Nuevo?, barrio do los Judios, de 'Toledo, $10 \%$ id., id.,

Viña con plantas de granados y de albaricoques, en Zalencas, 18 id, id.,

Pedazo de viña inculta, en el pago tel camino de Castella, alfoz de Tole. do, cerca del pago de ¿Daralmocara?, 4 id., id .,

Casa en burrio do la Catedral, adarve de D. Bernaldo. (Ilegible el procio.)

Mitad de una casa en San Nícolás, cerca de la iglesia de Santa Cruz, pro indiviso con otro hermano do las otorgantes, 500 mizcales alfonsies,

Casa en barrio de la Catedrul, cerca de la Alcudia, 140 id , id.,

Pedazo de viña en Portal de Calatra. va, cerca del Regachuelo, $3 \frac{1}{3}$ idem, Idem,

Huerta en Alaitic, con dos pozos, mas una tjerra con restos de parras y atros árboles, 500 mizcales, de 15 dineros,

Mesón pequeño ( mesonciello\%) en el Arrabal del Rey, debajo de .... la Catedral, 20 mizcales alfonsies,

Heredad en Torres, con sus tierras de labor, corrales, pozos, palomares, eras, etc.; más dos plarejas de bue1300 yes, con sus aperos, dos rejas, dos arados, con sus ....., dos trillos, dos yugos y gamellas (estos muebles por 40 mizcales), y con otras cosas más dos viñus incultas en Calaba. zas, 128 id., id.

Heredad de Sun Julián en Valdemozarabes, antes $A$ in al dic, $128 \mathrm{id.,} \mathrm{id.,}$

Casa en barrio de la Catedral, 140 idem, idem,

'Tres quintos de una tienda grande para vender harina, y dos tercios de una lienda pequeña, contigua, pro indiviso, en ban Nicolás, junto a las tiendas de Jos Sastres. Linda la grande con otra de Abuomar, hijo del alguacil Abuishac ben Annachar. Linda la pequeña con el horno de pan cocer, 37 id., id, ,

Derecho en unas tiendas: tres quintos vallan 37 mizcales, 3 id., $1 d$.,

Tienda del 619:

Un tercio de la mitad del quinto, 201 id, id.,

Tres quíntos de la tienda grande y dos tercios de la tienda pequeña. $38 \mathrm{td} ., \mathrm{dd}$,

Un quinto de la tienda grande, $20 \frac{1}{3}$ mizcales de $7 \frac{1}{2}$ sueldos,

Mitad de un sexto del señorlo de Esquivias, 250 mizeales, de 15 dineros,

UI cuarto del tercio del medio, 125 mizcales altonsies,

Un tercio del medio, 500 mizcales, do 15 dineros,

Pedazo de viña con tos pedazos de tiera on Benquerencia, 14 mizcales a]fonsies,

Casa en barrio de Ban Martín: son los
622 ,

621 
meve décimos, pro indiviso con el décimo restanto, que es de la vinda del dueño. la décima parte restante se vende por 2 mizcalcs, 22 mizcales alforsises, do 15 diueros,

Corral pequeño en San Roman, cerca do San Clemente (ennvento), ö5 mizeales alfonsies,

Algorfas sobre la puerta del mesón de la. I'o\% (gue era cle la Catedral), comprartas por la Catedral, 40 td., id.

Casa on Banta Maria, cerca de San Antolin, del Pozo Amargo y de los Tintoreros, 60 id., id.,

Casa en Arrabal do Ios Francos, 160 id., id.,

Venta de tres esclavos, matrimonio a hijo menor, por $5 \%$ id., id.,

Casa en Pozo Amargo, 95 id., id.,

Corral y una choza en el, en Colisa, $10 \mathrm{id} ., \mathrm{id}$.,

Esclavo moro, de oficio panadero, 145 mizertes alfinsies blances, ito $i \frac{1}{2}$ sucldos el mizeal,

Casa grande, otra pequesia contigua $y$ otras tres pequeñas, cn ol adarvo de Abengalún (barrio judio), 1, 250 id., id.,

Tierra de prado, cerca de Renqueren. rin, 8 id. , id.

Casa en barrio de la Catcdral, cerea de 12. Aleudia, 1.50 mizeales alfonsies,

Viña inculta en el pago de Aloyón, alfoz de Toledo, 85 mizcales blar. cos, de $7 \frac{1}{2}$ sneldos,

Derechos en dos molinos harineros en la casa central del azud de Azamel, en el Tajo, alfo\% de Toledo, 500 id., id. No consta la parte, por deterioro,
Solar de corral en bonquerencia, 7 id., id.,

Corral com tres chozas y almćcera, con sus iustrumentos y tres tallas y piedrias. (1)os eliozas cubiertas de paja $y$ la almácera; la toreera choza, hundida.) En Cobisa, 70 id., id.,

Heredad en Val do Moztiabes, alque. ria te Toledo (tierras, corrales, chozas, cras, etc.), corral, tres cho. zas y otra nueva que se reserva el vendedor, y lo que tenga en otras alqucrias, $250 \mathrm{itl}$., id.,

Tierra en Benquerencia, $10 \stackrel{1}{\%}$ jdem, idem,

asa en barrio de San Nicolás, en el wlarve del alguacil D. Pedro Jua. nes, $250 \mathrm{id}$., id.,

Casa y dos sótanos en San Justo, 350 id., id.,

Dos lierras en Benquerencia, una en el pago de Font del Alheitar, otra en la gorruela?, $25 \frac{1}{3}$ id., ld.

'Tierra, huerio y tierra de prado en Cobisa, $20 \mathrm{id} ., \mathrm{id}$.

Casa y dos sótanos en l'uerta del Portillo, Arrabal de los Judios, Toledo, 500 id., id.,

Tierras de labor en Benquerencia y unas plantas de morera, 10 drl., $j<l_{\text {, }}$

Dos tierras en Cobisa, $\left.25 \frac{1}{2} \mathrm{i}\right\}$, ikl., 649

Choza sen la alqueria de Cobisa, 8 iclem, fdem,

Casa en bartio de Franeos, 600 id., id., 652

Casa en artarve de D. Juan Vieente, de Vargas; se incluye ant casita

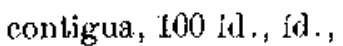

'Trozo de plantio de viña, ineulta $y$ baldía, en el pago del Portal de Ca. latravas, alloz de 'loledo. 'l'rozo de انحاص hucrto, con dos plantas de 
N. :

y plantas de olivos y melucotoneros, 35 mizcales blancos,

Pedazo de terreno con almemiros enci ma rel majuelo tel Bum, on al pidgo de Val de la Degolliarla, $3 \mathrm{mi} \%$ cales blancos, de los hechos en tiempo de la guerra primera,

Gorral y chozas y almácera en (ctrisar, efr. los nums. 641 y 650 . (ince tie rras de labor, clos buoyes con sus aperos completos, clos aralos, espuertas cle paja jara los bueves $y$ la paja que tienen, ete., (2)is iulern. tclem,

Dos tierras de labor en Cobisa, 16 id., id.,

Casa on el aklarve tle los (amónigos (deserita al nún. 653), 204 itl, jol.,

Casa del arlarve do los Canónigros (1stí. mero 653), 213 ji., id. J.os pasarlizos se arjacten en la vonta por los 13 mizcales,

Corral con cinco chuzas, dos cubiortas con praja, los con leja y uma sin er. brir, en Bencuterncia. Mus un huerto que habia dentro del corral, 73 id., idl.,

Casa en Arratual de San Istitro, 160 mizcales, ie 15 sueklos, $\quad 662 \mathrm{y}$

Parto de un corral hunulido cerce de la iglesia de San .Justo, 200 jd., id.,

Lsclava mora tle Juuvilla, Murcia, 240 id., id.,

Pedazo de tierra en Colisi, 14 id., il., Chaza, parte lundiela y parte cn pie, en Benquerencia, $7 \mathrm{id}, \mathrm{id}$.

-Casa del fosor, en Sun Nicolás, debajo de Zoeodover, $300 \mathrm{jd}$., id ,

Casita lundida y algorfa hunditla en Arrabal de los Judios, en el bajrio de Bab Alfarach, 100 id., id.,
Casa da] misuero 637, 1.080 id., id.,

Hesion tet ntunero $655,2.600$, la mi. taxl hlanoos nuevos, de 15 sueldos,

'Tierra on la nega de Aleardete, alqueria del alfoz de 'loledo, y rlercehos sobre el pro que hay en ella, 150 nizet] ]es blancos, de 15 sueldos,

Modia easa Ga San Nicolás, 400 id., id., los casits y una almazra en el Arrabal de ins .lutios, en la Acabn, 2.000 id., id.,

Casa on Sian Antolin, en el adarve del Morcheni, 400 id., id.,

$N+$

670

671

673

Mitad dir un majuelo en el pago de Fortal ele Calatciva, eneima de Val de la I cegollala, cerca de Toledo, 300 id. . is.,

Tres peclazos ke vina en la alqueria de San Cebrian, de la Sisla, 63 ídem, iklem,

Viña en la vega de Benquerencia, 155 id., id.,

Diecisiele tierras ale labor en Benuuerencia, un corral con cinco chozas y un palomar, 167 id., id. Habia de dar terreno para dos yuntas de buteyes, 200 mizeales,

Fincas del kocumento número 369 , 350 id., icl.

Dos casas hundidas on San Justo, aca- 
sa del pozos y casa del corral, 400 mizcales blancos,

Dos algorlas sobre ellas, $100 \mathrm{id}$., id., Un quinto de casa en San Nicolás, pro inthiviso, 62 id., id̀ .,

I'vdazo de viña en Val de lia Degollada, Toledo: ofr. cl número 456,20 id., id.,

Dos trozos de viña en Benquerencia, 155 id., id.,

Treinta y seis tierras, con un corral y sus chozas en Melgar, con varios aperos de labranza, 1.250 Id., id.,

Fiselavo moreno, albañil, Ali ben Said, que era esclavo de Gonzalbo Rodrigo, en Cordoba, 400 íd, , id.,

Dos pedazos de viña en el Portal de Calatrava, corca de Regachuelo (núm. d612?), 80 1d., id.,

Heredad en Cobisa: nueve tierras, corral con cinco chozes (cuatro con tejas, otra con paja), palomar, dos pares de bueyes con sus aperos, pa. ja suficionte para dos bueyes en tres meses, la cosecha sembrada, seis cabras y cuatro cabritos, 1.500 id. , id .,

Heredad en Cobisa y Pozuelo: cinco ticrras (500 mizcales), derecho cn otras, dos corrales con stus chozas (130 id.) y ol patio de otro corral, dos vacas de labor (120 id.) con sus aperos (130 id.) y la cosecha sembrada (100 id.), $980 \mathrm{ld}$., id.,

Pedazo de vina en Arcicolla, 100 idem, Idew,

Solar de corral en Benquerencia, 12 id., id.,

Diez tierras de labor en Benquerencia, 150 id. , fd. ,

Tierra en Benquerencia, $10 \mathrm{idl.,} \mathrm{ta.,}$

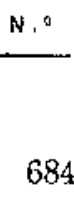

684
Casa cerca del Pozo Amargo, 250 fdem, idem,

230 íd., íd., en el nitmero

698

Corral con su choza cubierta de paja en Melgar, 19 dd., 1d.,

co lierras de labor, corral con tres chozas, una con tejado, dos cubiertas de paja; solar de corral contiguo al corral, de Melgar, 390 idem, idem,

Jeredad en Caniellas: tierras de labor, corrales, viñas, cras, etc.-Tercio en tres corrales $\bar{y}$ sus chozes y sus estancias (ماكسماك), en tres palomares contiguos, en un buerto, en tres viñas y en 55 tierras, 900 id., id.,

Fsclava mora, de Lorea, 500 íd., id.,

Botica en Arrabal de Toledo, 510 ddew, idem,

Dos tierras de labor en Benquerencia, 70 mizcales blancos,

Derechos en las dos fincas de la alquería de Caniellas, deseritas en el nưmoro 702 , por otra hermana, 1.100 fd., id.,

Ocho y media moreras en Bendncrencia: cuatro oncima del soto, junto al camino que va a San Cebrián; tres, cerca de la iglesia do la alquerfa; la octava, junto a las eras del ¿pueblo?; y la media, en la puerta de la casa de D. Medar, que es al. bergueria; más solar de corral, más una tierra, 60 id., id.,

Casa y cinco tiendas en San Justo (cfr. el num. 684), 3.000 id., id.,

'I'res casas, almazria, sótano y sus tiendas en el barrio judío, Toledo, 4.000 id., id.,

Viña en Villa de Muelas, cerca del camino de Mora, 100 1a., íd., 
Casa en San Nicolás, adarve (le D. Pe(l[? Juanca el Llguacil, padre dol Arzobispo, a00 mizcales blancos,

Jlantio de viūa us Bonquerencia, 85 id., id.

Casa en harrio de Munt Perit, Toledo, $80(1)$, id.,

Viña on ol pargo de línal y camino de Auria, alfoz de 'loledo, 780 id., id.,

Casa dorruida en Santísima Trinidad, ceres de la capillu del Arzolispo, $400 \mathrm{ld}, \mathrm{id}$.

Modia casa en la colación do San Justo; mitad do dos cavitas y tos algorfas sobre ellas, 70 ) sd.. id.,

Plantín de viña en Benquerencia, 340) iri., id.

l'ras tromos de: viña en San Cebrian, de la sisla, 150 id., id.,

Viña en San Celbrín, 3(x) ht., irl.,

Octavo de un molino en ol rio Aigodor, con les derectios en el azud, on el rio, on las muelas y en la casa, en la alqueria de sima Celuríún, llamadia Atportiello, 10 id., id.,

Corral con su choza y palnmar, en San Cebrián, 67 ld., id..

Dos huertos contiguos con ..... azud, dos pozos, dos estanques, dos corrales, sicte clozas eubiertas to te. jas, dos phrtales con tejas, en $/ \mathrm{a}$ leneas, $1.9(0)$ ill. $\mathrm{k}$.

Vina en olihechens, 80 o id., irl.,

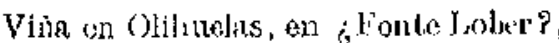
$45 \mathrm{id}, \mathrm{i}$. .

Cảa en San Nicolás, l(k) mizeales blancos, de 10 sueldos,

Venta de hura parte de corral en barrio do la Catcilral, por 8 mizcales mo rabeties. Véanse los numeros 3,30

y 118

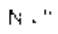

712
In çuinto de mosin tu barrio del liey, vendido por 40 mincales alfonsies, $\quad 740$

Viña en Calalsaxs, $7 \cdot \frac{1}{2}$ id., itl.,

Alhochra en ommizm Satetorum, 10 wizales ate oro basisi,

Mesón en barrio de la Cateslral, Alcudia, 20 [a., itl.,

Jos tereios de 111 pies de divos, ene'l'alavera, pro indliviso on al otro tercio, $5 \frac{1}{2} \mathrm{id}$, ill.,

Mitad on 10 pies, (i icl., id., $\quad \mathbf{1 . 0 9 6}$ Casa en San Martin, 58 id., fel., $\quad 1.097$ Casa en los Curtidores, 32 ja., id., 1 .019s

Tres mesones en zoco to los Pescadorea, 10 ) id., id.,

Un mesón (an 1142) por 23 mizcales aluoráviles de AImeria, mas parte en alquería y una viôa,

Mesón gramie en Arubal del Rey, 210 mizcales altonsies,

Viñal en Villatranca, mas el corral con la mitad do la choza, 8 id., id.,

l'etlazo de tierra en Pozancares, $2 \mathrm{miz}$. cales menos $\frac{1}{4}$,

Viña on Sin Feliz y otro pedazo, $2 \frac{2}{8}$ miz. altonsies. *Vinna de Albalies, 1.103

Vonta ale todos los dercchos a la herencia del pactro y de la madre (fu. lura) y de la parte que lo toca en la clonacion hecha sa su puile por un camónigo, $22 \frac{1}{3}$ ial, , it.,

Dos casas en Alcurlia, alarve del amin $\Lambda$ buljair, 122 mizcales alfonsies, de 15 dineros,

Casa en barrio de la Catedral, Arrabal ile los Barberos, 160 id., ial., 1. 106

Una sucrte pro indiviso en la alqueria de Campo Rey y el Vijlar de don Pedro Cruzado, $7 \frac{1}{9}$ roizcales alfonsies, 
Una suerte en Campo Rey y el Villar, 2 mizeales alfonsles,

Modia casa en harrio te la catedral. cerea do la carniceria, 50 isl., fil., 1. 10!5

Cualro suertes menos tereio do Campo Rey y ol Villar, 50 id., id. (Compárese lo poco que haljian costato suelios a los (los an bertores),

Casa en el adarve dol caicl $\mathbf{D}$. Sabib, Catedral, 30 inl, itl.,

Casa en barrio de la Catedral, cerca del Pozo Amargo, 75 id., iel.,

Casa en Poro Amargo, cerea de Sun Antolin, 91 id., id,

Casa en San Marcos y botica enfrente de ella, 250 id., id.,

Casa en San Justo, 1.000 mizcales, de $7 \frac{1}{3}$ sueldos blancos, de la primera guerra,

Pedazo de tierra en Cobisa, $9 \frac{1}{8}$ idem, idem,

Pelayo de tierra en Aleardote, 10 mizcales do los sueldos blancos, te 15 sueldos el mizerl,

Casa en barrio de la Catedral, cerca clel Pozo Amargo, 1.000 id., id.,

Caza on Puerta de Pedro Benien, arrabal, 30 td., idl.,

Pelazo do majuelo en San Cebrián, 45 id., id., ñas do la aldea de Santa María, 16 mizcales alfonsies,

Media viña restante, 16 id., icl., $\quad 1.133$

Casa en Arrabal de los Juclios, 252 thizeales,

Viña en el pago tlel Jandac, 92 id., id., 1.130

Casa, sótano, vivionla $y$ almazráa en Arrabal de los Judios, $\theta(x)$ mizeales, de 15 steldos thizcal, on moneila blanca,

Tierra lialdia en los C'abezos (Trozaclo), de $2 \frac{1}{4}$ aranzatas, 20 mizeales do 10 sueldos,

Venta de casita en adarve de Abenwatiner (juctio) ..... miz. alfonsies, 1,141

Media teneria en ¿Alcorno\%, $20 \mathrm{idem}$. flom, 1.141 bis

Casa y dos sótanos en Puerta del Portiel, Arrabal do los Judios, 282 mizcales, cuya mital son 141 , por 470 mizcalos, de $7 \frac{1}{2}$ dineros, en 1271 , $1.142-1.144$

Casa, sótano y establo en adarve do ¿A Abazardiel? (judios), 300 mizcales alfonsies,

Casitas (dos) contiguas en el Arrabal superior de los Judios. gizo nizeales, cuya cuarta parte son 230 . 1.146

Casa y corral en el Arrabal Judio, cerca de San Román, 160 mizcales alfonsies, 



\section{I I I}

\section{REGIMEN DE LA PROPIEDAD}

\section{A. ESPOSOS}

472. El régimen corriente en la saciedad conyugal era, como ya hemos dicho, de gananciales a partes jguales entre los dos cónyuges; por eso casi siempre que una persona casada adquiere fincas, especialmente por compra, se advierte que es para el matrimonio y con dinero de ambos, y por partes iguales para los dos (núms. 101, 112, 153, 198, etc.). Leída la escritura de venta a la mujer del ven. dedor, declara que vende con su marido y recibe el precio con él (núm. 635), o está presente y recibe su parte, obligándose a la evicción con su marido (núm. 528). Esto lo declara expresamente en la escritura el comprador, que la mayoría de las veces es el marido (núins. $208,249,272,273$, etc.); y si compra la mujer, lo declara igual (níms. 332 y 352); no laltando casos en que lo declaran los dos cónyuges (núms. 319 y 430). Y si en el texto de la escritura se ha olvidado tal declaración, se añade al fin (núms. 53 y 291), lo mismo que se cuida anotar que la mitad de una compra es del matrimonio, por partes iguales, y la otra mitad de un hermano del marido (núm. 222), y hasta en una venta entre hermanos se advierte que la madre había comprado la finca en unión del padre (núm. 53).

Cada uno de los cónyuges podía comprar, no obstante, para él y con su propio díncro: la esposa declara que su marido compraba con dinero de él, y que, por tanto, ella no tenía derecho alguno en la finca comprada (núm. 607 ); a veces, rectificando el texlo primitivo del documento, que decía que la compra era para los dos 
(núm. 553). En ocasiones es la esposa quien compra, viviendo el marida, con su dinero propio y para ella sola (núms. 216, 257, 259 y 624), o con dinero que le ha dado otra persona, v. gr., su hermano (núms. 591 y 594). No falta el caso en que el marido compre para su esposa y con dinero de ella sola (núm. 377), o el de que el marido deje en poder de su majar ftacas para que las venda en su nombre (número 498 ).

A veces compra el matrimonio por 140 mizcales, por ejemplo, de los cuales 100 son de la mujer, teredados de una hermana, y 10 del fondo conyugal (número 611); o venden uma fiuca y la cuarta parte es de la mujer y las tres partes cestantes son del marido (núm. 723).

La vendedora, casada en segundas nupcias, explica cómo adquirió la propiedad: ella y su marido primero compraron la casa por partes iguales; muerto el marido, heredo su milad su hija, y muorta la hija, hered 6 aquelfa mitad la madre, qte se hizo asi dueña de toda la casa ( núm. 354 ).

En un caso de cambio que otorga el marido de fincas propias de su esposa, ha. bía que lograr el consentimiento de ésta: un testigo declarabn haber oído a uno de los otorgantes: ¿ $\mathrm{C}$ C $\delta \mathrm{mb}$ nos las arregtaremos con tu esposa? Yo desearía que me lograses su aprobación en este canbio, porque temo que se oponga a ello», y el otro respondla: "No tengas miedo por causa de ella; yo conseguiré que te apruebe lo hecho, y si quiere oponerse, la haré desistir de su propósito: me obligo a ellos (nú. mero 806).

Después de hecha una compra por el marido y de declarar que es con su dinero solo, se conviene con la mujer en que, asi el moría antes que ella, quedaría ésta dueña de la finca, mediante la entrega de 7 mizcales para bien de su alma; y si moría antes ella, él quedaría dueño de la finca en la forma indleada (número 310 . En otro convenio para el régimen de bienes de la sociedad conyugal, estabiecen que sea a medias, lo mismo en los propios que en los gananciales: si ella muere sin sucesión, dona al marido su herencia, y deja 5 cineros y una meaja para apartar a los parientes de ella de la herencia, cantidad que se rebajará de la herencia de él; el marido dispondrfa entierro y funerales, y para ello mandaba la mujer 5 mizcales del quinto de sus bienes. Si fallece antes el marido, la esposa tomará para sí una mitad de la herencia (después de haberse pagado las deudas con fondos tomados del total de los bienes de aŕnbos), y la otna mitad sería para los herederos del marido, si no tiencen hijos, y de su parte sacarfase para los funerales y sufragios hasta 5 mizcales (núm. 977).

Un caso raro de venla entre cónyuges nos ofrece el documento número 236 , venta de una casa en el barrio de San Marcos, por 110 miziales, en 1193: como título de propiedad, la vendedora presenta la escritura por la cual compró la casa en Enero de 1184 a su marido, por 150 mizcales, ante el mismo cscribano; en clla figuraba como testigo el padre del comprador en la segunda escritura. 


\section{B. CONYUGli Y IUDO}

473. La mujer viuda podía casarse de nuevo una o más veces (núm. 506). Tenía derecho a la décima parte de los bienes relictos del marido (núms. 134 y 310) por razón de su matrimonio (núm. 623); por eso, en una venta hecha por la madre y dos hijos, la madre exige del precio senalado la decima parle suya y la corespondiente a otra hija, así como los hijos reclaman la suya (nún. 308). La madre hereda al hijo, muerto el marido (núms. 67, 147, 158, 378 y 407), aunque a veces con pleilos y discusión (núm. 24) y aunque le queden otros hijos menores bajo su tutela (núm. 293).

La viuda podía vender fincas del marido difunto, sola (núm, 613) o en unián de sus hijos, si las poseen pro indiviso (nún. 7), ya fueran los hijos menores (números 147,312 y 326), o mayores (núm. 190), o de las dos clases (nú ms. 9 y 381 ). Tam. bién la viuda y su nuera podian vender fincas que eran de la viuda y de su hijo difunto (nńm. 216), unnas veces obligadns por la necesidad y con la aprobación y con. sentimiento de sus hijos (núm. 183), otras para pagar deudas del difunto (números 303,312 y 641 ).

La madre viuda compra para sí y para sus hijos (núm. 308); en algún caso compra la mujer embarazada para sí, para su hijo nacido y para otro por nacer (número 653), y hasta a sus mismos hijos compra parte de la casa que, sin duda, era de la herencia paterna (núm. 185). También adquirfa fincas con el dinero procedente de ropas de sus hijos, declarando que era para ellos, declaración que repetía el marido segundo de la compradora (núm. 135). La madre, en umión de sus hijos, y con dincro de ella y del marido, procedente de una casa que éste había vendido a medias con la mujer, compraba finca, en la que le correspondía la mitad, y otra mitad a los hijos (núm. 309).

Además del décimo, al que la mujer tenia derecho por razón del matrimonio, podía quedarse con el usufructo del quinto de los hienes del marido: al vender una finca, cl comprador respeta el usufructo de la quinta parte de la viuda mientras viva, a cuya muerte adquiriría la propfedad plena; si no ocurriese asi (6porque la usufructuaria dispusiera de ella?), la vendedora, hija de la usufrucluaria, se obligaba a devolver al comprador el quinto del precio de la venta (núm. 334). Liste quinto, de libre disposición, era el que solía mandarse para sufragios; a veces la madrastra y los hijastros vendían fincas del causante para cumplir el testamento, que mandalua por su alma el quioto de sus bienes (mim. 293).

La viuda, casada de nuevo, podía vender fincas del primer marido (núm. 21), aprobando la venta el segundo (núm. 111). 
No es raro ver pleitos entre la viuda y sus hijastros acerca de los gananciales: uno se arregla quedándose la madrastra con una cuarta parte de la herencia; al morir la madrastra, sus albaceas rogaban a los entenados que aprobaran aquel pacto, respecto de la cuarta parte de la madrastra, para que ellos pudieran cumplir el tes tamento; uno de los bermanos no habfa queritlo pleitos y tabía cedido sus derechos a los olros (núm. 963). Otro pleito entre un Jijo y su padre, casado de segundas, acerca de los bienes de la madre, bienes que el padre decía haber entregado al hijo, se soluciona con un arreglo por el cual daba el padre al hijo ciertos bienes, además de 150 mizcales que ol hijo reconoce haber gastado en su enseñanza y educación, hasta Jlegar a la Orden en que esłaba (núm. 978).

El hijo podía comprar a la madre, pero haciendo constar que era con sus dineros propios, que ba ganado con su trabajo (aúm. 454); y si vendia finca propia, la madre declaraba ser de él (núm. 137). Si la madre vendía, el hijo declaraba no tener derecho alguno a las fincas vcndidas (núm. 462), o, aproba ba la venta, obligándose a la evicción y saneamiento de aquella parte que él poseía en la finca, por compra a otra tercera persona (núm. 322).

\section{MENORES}

474. El menor (16) quedaba bajo la tutela de slas padres, y podía disponer de sus bienes al cumplir los catorce años: dos testigos declaran con juramento que el vendedor tiene más de catorce años (núms. 640,712 y 1.109$)$, y lo nismo ocurre si se trataba de hembras ( $u$ úm. 579); aunque tuvieran padre, para vender la herencia de su abuela era precisa la declaración testifical de haber llegado a los catorce años de edad (núm. 577).

Ln caso de partición de bienes del padre, la madre viuda declaraba que sus hijos, con quienes parte, tenian dieciocho y diecisicte años, para que constase su declaración, ya que cra encargara de ellos (núm. 308).

La mujer casada antes de llegar a la mayor edad, no tiene la plenitud de derechos; si tiene hijos, se la considera como mayor de edad, condición que la mujer alcanzaba al cumplir veinle años (núm. 89).

La madre, con los hijos mayores y menores, podía vender fincas de todos (número 171); otro tanto podían hacer los hermanos de los inenores (núms. 577 y 578), asi como comprar la madre para sus hijos ( núm. 135). La tutela de la madre duraba mientras estaha viuda; si se casaba la perdia, y pasaha a persona de la familia o a los albaceas señalados por el padre en su lestamento (núm. 1.028).

La venta de bienes de menores no era cosa fácil: precisaba declaración previa 
de pobreza (núm. 953). Ia viuda declaraba la necesidad en que se hallaba, por las deudas ocasionadas por los gastos en comer y vestir, y en alimentos de una criada, a quien el marido mandó vestido y comida mientras estuviera con sus hijos (número 281); o para remediar la necesidad y la miseria de los hijos (núm. 331); o por la necesidad, junto con la negativa, del otro dueño, pro indiviso, a que siguiera la indivision (núm. 68); o por necesidad dic la viutla y no poder cultivar la finca diree. tamente, habiendo, además, de pagar tributo a la Catedrnl, como todos los de la alquería de Azaña, y para subvenir a los gastos más indispensables de comer y vestir, porque el año había sido estéril (1183), y pagar las deudas que tenían (número 165). Intervenía entonces el alguacil y alcalde, que se certificaba de la veracidad de la pobreza, de ordinario mediantc información testifical, y mandaba pregonar in venta en páblica subasta (núnı. $68,165,281$ y 953); Iu cgo autorizaba la venta, a veces con la condición de que se comprara otra finca para el menor, como se hacía (núm. 68), y después de cerciorarse de que no se defraudaba en el precio a los huérfanos (núm. 331); y si era a plazos, mandaba que se entregara en la fecha señalada, sin necesidad de segunda sentencia y sin más prórroga de plazos, a lo que se obligaba las partes contratantes (núm. 281).

Fl documento número 710 contiene una escritura de venta de finca por un tío en nombre de sobrinos y la madre de ellos, por sí y por un menor: el reparto del precio, que sumaba 4.000 mizcales, se hizo:

\begin{tabular}{|c|c|}
\hline & Mizcales. \\
\hline Tio, por sus seis sobrinos. $\ldots \ldots \ldots \ldots \ldots \ldots \ldots \ldots \ldots \ldots$ & 1.363 \\
\hline 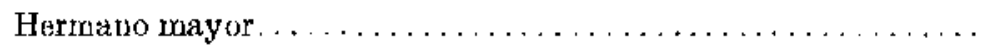 & 812 \\
\hline Viuda............... & 500 \\
\hline 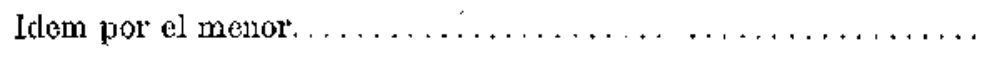 & 812 \\
\hline 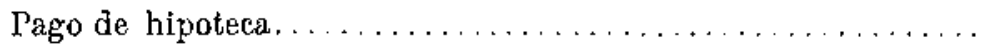 & 300 \\
\hline Resto en poder de los compradores........ & 213 \\
\hline To & 4.000 \\
\hline
\end{tabular}

Los vendedores de bienes de menor, se obligaban por él a la evicción y saneamiento cuando fuera mayor (núms. 256,330 y 1.109 ), hien fuera la madre (números 293 y 631), o el padre (núm. 783), o hermanos (núm. 395). En ocasión, la menor declara haber vendido nueve años atrás, para ratificar la venta (núm. 631); y tambien el padre, la madre del padre y utra persona, cuya filiación no se declara, aprueban una venta hecha por varios hermanos, algunos menores, y expresan no tener derecho alguno a los bienes vendidos (que serían por parte de la madre de los huérfanos) (núm. 577).

El padre del menor recibc la herencia de su hijo por causa de su madre, y se compromete a entregársela cuando sea mayor (núm. 962). Las mandas testamenta- 
rias a favor de menores quedan en poder de los albaceas (núms. 1.020 y 1.022), o de quien señala el testador (núm. 1.024), hasta que llegan a la mayor edad. En un lestamento se mandaba algo a una menor; pero «si cuando sca mayor no va por el buen camino y quiere cambiar lo dispuesto, ordena la testadora que se venda la manda y se aplique el precio en sufragios por la testadora (núm. 1.021).

La tutela poda ejercerla persona ajena a la familia, y hasta la abadesa de un convento: véase este curipso documento del año 1173 :

Madre viuda, enferma, pero en su cabal juicio, curadora de su hija menor, juzga que lo mejor, caso de su fallecimiento, para su hija, sería que desempeñara el lugar de madre y la tuiela la abatesa de San Clenzente. La madre dona sus hienes al convento para que su hija se alimentara los días de su vida, y cuando muriera la hija, pasarian a ser propiedad del convento, para que las monjas la tuvieran presente en sus oraciones.

Rogó, pues, a la abadesa que aceptara la fulela, y le dió facultad para dłsponer de los bienes propios, si los de su hija no bastaban para los gastos y vestidos que la hija necesitara. La abadesa y el convento aceptaron. Y todo esto hablado entre la madre y la abadesa, se decidió escribirlo, después de haberlo consultado con la hija y haberlo ésta aprobado (núm. 923)

\section{D). INC:A I'AC:I:S}

475. Ll incapaz podfa estar sometido a tutela de persona ajena a su familia. En 1211, Micael García recibe del testamentario de 1). Lope, presbitero de San Lorenzo, 16 mizcales que este mandaba a María la Muda: 10 por una denda que c sn ella tenia, 6 por su voluntad. Micael confiesa recibirlos para guardárselos a la Muda, obligándose a tenerla en sis casa, a alimcntarla y a vestirla, durante el tiempo que él quiera; y cuando ella salga de su casa, a darle la citada cantidad (núm. 1.078).

\section{E. COPARTÍCIPLS: PELSONAS QLE APRUEBAN COMPRAS Y VENTAS}

476. En la transmisión de dominio no dejaban de intervenir cuantas personas podían alegar algán derecho a la finca vendida, y el comprador exigía la aprobación y consentimiento de cuantos en lo futuro podian oponerse a su pacífica posesión de la finca comprada.

El marido aprobaba la venta becha por su mujer (núms. 82, 92, 140, 204, 287, 292 , etc.), alguna vez haciéndolo conslar al lado de su firma (núm. 145), y eso lo mismo si era el segundo marido ( múm. 346), o el tarcero (núm. 158), y aunque los bienes no fuesen de clla, sino que obrase como albacea de su madre (núm. 457). 
Si los bienes vendidos por la mujer eran de la dote, aprobaba el marido, y, a la vez, el padre de ella (núm. 342). En un caso de venta por cuatro hermanas, aprobaban la venta los maridos de dos y los pronetidos de las otras dos (núm. 175). Entre los judios ocurría lo mismo (núm. 1.131).

La mujer aprobaba lambién la venta hecha por el marido (núms. 154, 156, 208,241 , etc.), sin indicar el título de propiedad del marido, aunque es de pensar que se tratara de bienes gananciales (nútm. 633), a veces días después de otorgada la escritura (núm. 715). La csposa aprueba lambién las permutas (núm. 816); comp̀arece en la escrifura para declarar que no tiene derecho alguno en la finca venulida por el marido (núm. 1.104).

La madre del vendedor (casado o viudo) aprobaba también las ventas de su hijo (núms. 79, 112, 252 y 372 ); a veces acompanada por su segundo marido (número 276). La madre de los otorgantes (dos hermanos) asistía a la venta y aprababa la hecha de un hermano a otro de todos sus derechos a la herencia de los pa. dres (núm. 1.104). Si el marido tenía finca de su mujer, difunta, por herencia de los hijos del matrimonio, al venderla, el padre y el hermano de la mujer aprobaban la venta (núm. 96).

Los hijos lambién intervenían en las ventas de la madre (núms, 58, 78, 98; 272, 291 y 297, etc.), reconociendo en casos la necesidad que la obligaba a aquel acto (núms. 159 y 183), declarando en otros que la finca era de ella sola (núm. 1), 0 obligándose a la evicción (núm. 295). Si el que vendfa era el padre, aprobaba el acto su bijo (núms. 193 y 239), hija y el marido de ésta (núm. 211), o el hijo y dos nietos, que declaraban haber recibido la décima parte del precio que a ellos correspondia como herederos de su madre, la mujer del vendedor (núm. 310). Si vendía el matrimunio, tantbién los hijos habían de aprobar la escritura (núm. 599), aunque los padres estuviesen ausentes (núm. 627). Los hijos polílicos hablan de intervenir a veces (núms. 551 y 556 ).

Otro tanto hacían los hermanos (núms. 128, 381, 549 y 628), acompañados a veces de los cónyuges (núms. 101, 635 y 684), y declarancio no tener derecho alguno, aunque eran bienes del padre, por virtud del arreglo judicial de la lierencia (número 293); los tíos (núm. 819), los sobrinos (núm. 366), los parientes (núm. 639), entre los cuales deben conlarse las personas que inlervienen en las escrituras, sin que se diga la razón de parentesco que tienen cen los olorgantes (núms. 81, 193 y 195), los albaceas (núm. 558), los dueños pro indiviso de la parte de finca no vendi. da (núms. 105 y 304 ), y hasta un criado (núm. 638).

El vendedor, ausente al hacerse la escritura, aprueba la venta unas semanas después (núm. 322) (1). 


\section{F. PISO IN DIVISO}

477. Era frecuente la indivisión en el régimen de la propiedad. Labáa propiefarios asociados (شريك), que no eran de la misma familia y que vendian sus fincas comunes (núm. 48) o compralran por iguales partes (núms. 202 y 321); varios socios poseían un azud en Alcapillat o Alcubilel ( 1 ím. 322).

En las escrituras de compraventa se especificaba cuidadosamente la procedencia de cada parte de una finca poselda por varios pro indiviso (núms. 145, 252, 281 y 590), la parte de precio que cada cual cobraba (núrns. 279 y 620 ) y los títulos de propiedad (num. 281).

Naturalmente que abundan más los casos de indivision entre personas de la misma familia (núm. 233), sobre todo hermanos; as vemos vender por dos hermanos y un cuñado (núm. 119), por uno en su nombre y en el de varias hermanas, una de ellas monja en San Clemente (y no se presenta nadie del eonvento a aprobar la venta) (núm. 225), par varios hermanos, cada cual su parte (núm. 628). Se advierte que una finca estaba indivisa entre varios hermanos "para evitar disgustos ", de la cual dos hermanos vendian tres cuartas partes de yugada y cuarto, y otros dos hermanos poseían el restn (qúm. 422). Fin el reparto del precio de una venta entre varios hermanos, tocaban a la madre tres quintas partes; a los hijos, dos quintas partes: una de ellas, monja, lo había cedido a sus hermanos, por escritura ; otro cobra una cuarta parte del total, y el resto era para dos hermanos (núm. 320).

No sólo ha hesencia era la causa de la indivisión, sina a veces la compra para varios, unas veces de la familia (núms. 87, 107 y 205), otras amo y criado (por partes iguales y en justicia) (núm. 346).

Se tendía, naturalmente, a salír de la indivisión; con lo cual personas o instituciones ricas iban adquiriendo las fincas que, siendo de valor, orn dificil fracctonar. Así adquirfá el convento de San Clemente la mitad de un huerto pro indiviso, de varios poseedores, completando la finca, de la cual poséa la otra mitad (número 114); o se quedaba con fincas que eran pro indiviso de otros conventos, después de haberles propnesta que cempraran o que venảicran, scgún la tasación de peritos (núm. 487). Al fraccionarse una alçuería (Yepes), poseída pro indiviso, después de varias transmisiones, se reduce a partes tan insignificantes, que es fácil al arzobispo D. Rodrigo lograr que los dueños le vayan donando las partes (núms. 748, 749, 750 y 753); y el mismo arzobispo adquiere en varias veces el castillo de Ciheruela (núm. 493).

Entre los particulares también se procuraba resolver la indivisión, adquiriendo uno de los propietarios las partes de los otros: uno compra la mitad de una viña de 
un hermano de su mujer (que posera la otra mitad), aunque sin indicar que erä para la mujer (núm. 107); el vendedor de una mitad de finca declaraba haber vendido antes la otra mitad, con lo cual el comprador la adquiere entera (núm. 316). Finca comprada en almoneda por dos individuos, se queda para uno, que abona al otro sa parte del precio, o sea, la mitad (núm. 1.(055). Un testador mandaba que el que habia de poseer un cortijo entero, antes pro indiviso, diera a los otros copartícipes 100 mizcales para hacer una casa en la misuna alquería (Ajofrín), y así quedaŕa suyo cl cortijo cntero (núm. 1.030). Los copropietarios pro indiviso acceden a la venta para poder cobrar deudas de una sobrina (núm. 147).

Se indica, al vender, que una heredad es pariición del lolal y que la otra parte la posee Fulano (num. 250 ), o se dan los nombres de los dueños de las partes indivisas, advirliendo que se han de parlir (núun. 333). No faltan casos en que la finca es vendida en varias partes pro indiviso y en distintas épocas (núms. 194, $200 \mathrm{y}$ 295), anterioues a la firma del ducumento. En ocasiones se vende la heredad, parte partida y parte pro indiviso (núm. 252); o se rectifica el dato dado en la escritura de haberse vendido la mitad de la finca, declarando que sólo se trata de la tercera parte (oúm. 290).

En la venta de la parte iuterior de una casa, la vendedora se reserva para sí la escalera, dando paso a los otros; y queda pro indiviso para las dos partes el cuarto llamado del agua, con derecho de servidumbre de salida para el comprador (número 520 ).

El dueño die una parte pro indiviso tenia derecho preferente a adquirir las par. tes restantes en caso de venta. Vendese una guinta parte de casa: el dueño de los otros cuatro quintos puede, en un plazo de diez años, pagar al comprador los 62 mizcales del precio y quedarse con la casa entera; si el duefo de los cuatro quintos quiere venderlos, los venderá al comprador del quinto restante par el precio que otro diere y sea justo; tendrá derecho preferente a comprarlo también por los 62 mizcales, si el dueño del quinto lo vende (núm. 685).

\section{G. $\operatorname{CENSOS}$}

478. Sólo en época tardía (fines del siglo XIII) hallamos dos escrituras de censo (حكر). La primera, de 1293 , refiere cómo D. Gonzalbo da a doña Justa un solar, que antes cra huerto, para que en él construya un corral y una habitación, y los demás edificios que quiera, para habitarlos el constructor o quien quiera. Se obliga el que tenga la finca a pagar por el derecho del solar al dueno de éste, o de sus herederos, perpetuamente, por Navidad, tres gallinas buenas y seis sueldos de los 
mizcales blancos. Si dona Justa quiere vender el corral, tendrá el dueño del solar, D. Gonzalbo, el derecho de tanteo; si éste no lo quierc cjercitar, podrá vender la finca a persona que se obligue a pagar el censo; por tanto, no lo podrá vender a caballero, ni dueña, ni hospilal, ni clérigo, ni orden militar, sino a ol ra persona de su condición, que pague el cerrso (núm. 831).

Con las nismas condiciones, salvo que son dos gallinas, en vez de tres, da un solar, en Toseneque, Conzalbo Alfonso a Jirnando Martin, en 1295 (núm. 832).

\section{ARRIENI)OS}

479. ligiguran en nuestra colección bastantes contratos de arrendamiento, especialmente de fincas rústicas, que nos permiten conocer de modo preciso este aspeclo de la vida social a parlir de fines del siglo XIl.

El formulismo corriente era éste: despues de cnumerar la finca objeto del arriendo y su plazo de duración, añadía: «El mencionado arrendatario tomará para sf las utilidades de la finca arrendada, los provechos que en ella obtenga de produc. tos, rentas, calonias y derechos, poco o mucho, en cada ano durante el plazo indicado.» Exponiase después la cuantía de la alcabala o renta, y seguía: * En esta forma se obliga el arrendalario al pago de la alcabala mencionada, sin excusa, ni pretexto, ni dilación por causa ni inotivo alguno, pues así lo han convenido ambas partes $\mathrm{y}$ han aprobado el convenio, $y$ no se saldrán de ello por nínguna causa ni molivo, des. pués de conocer arabos el valor de todo lo convenido y su alcance, sin ignorar nada y según lo que manda la ley en estas cosas (núm. 911). Y terminaba con la fórmula usual de testigos.

El contrato más antigno de arrendamiento que encontramos (1197), adopta la forma de empeño: lierras, prados, huerlos, elc., para cinco pares de bueyes de labor en Torre de iAlauachir?, se empeñan en favor de otros (en tres tercios, pro indiviso), por la cantidad de 100 mizcales, por un plazo de sejs años, durante el cual los peones del pignoratirio labrarán y sembrarín la lierra y recogerán sus frutos (núm. 906).

Puede servir como modelo el arriendo que el arcediano D. García hizo en 1205 a favor de Juan Dominguez y de su esposa Uraca, de todos sus bienes y derechos en Arcicolla, que consistian en rentas de las viñas suyas y otras por los derechos de plantación; tierras labradas y sin labrar; huertos; derechos de pan, vino, etc., en la iglesia de la alcqueria; renlas y derechos en Villafranca, cerca de Arcicolla, con los derechos y calonias en ambas alquerías. El plazo del arriendo eran seis años; el pre: cio, 300 mizcales cada año, pagaderos en tres plazos: por San Martín, por Carnesto: 


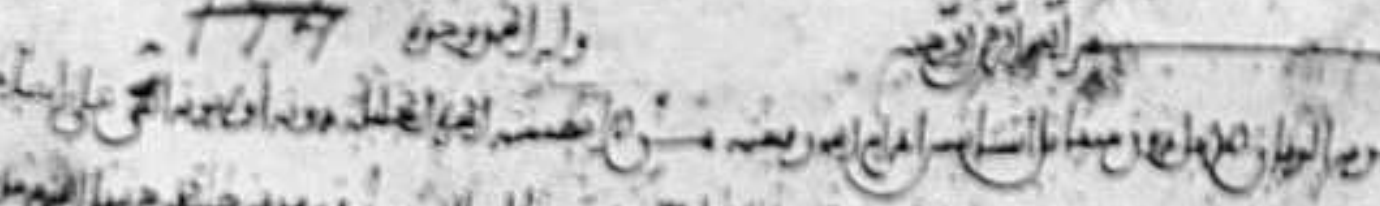

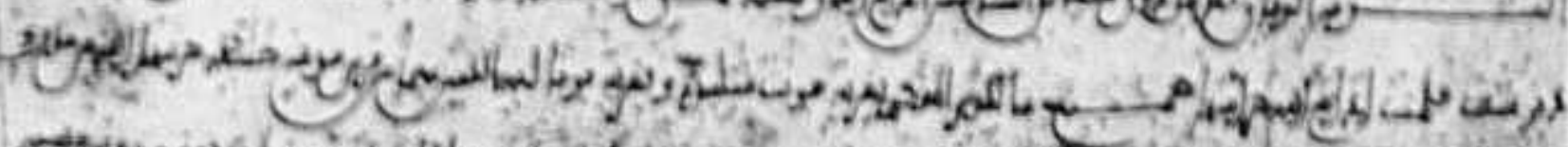

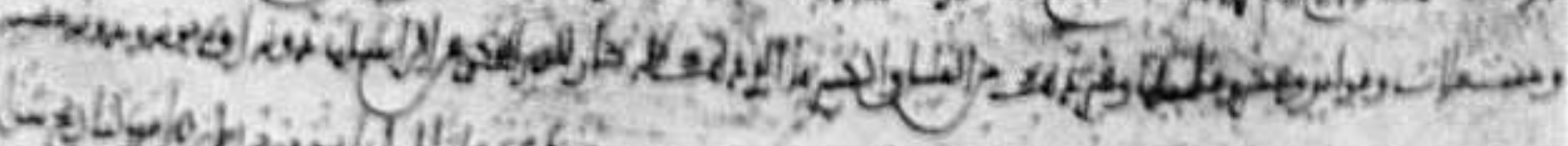

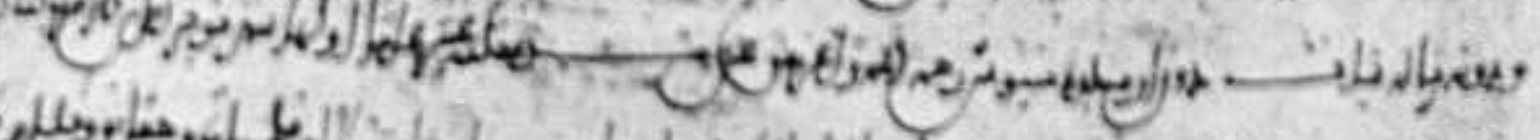

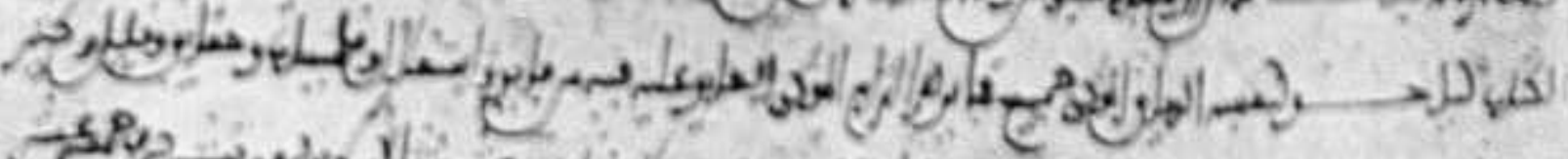

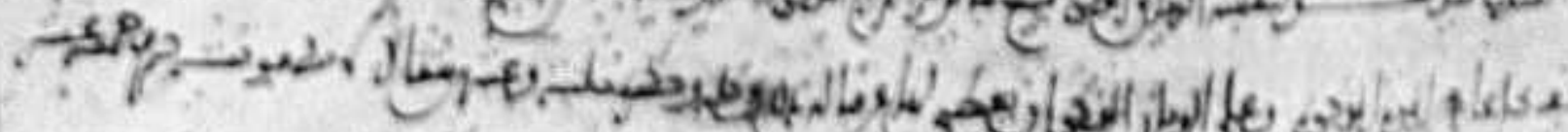

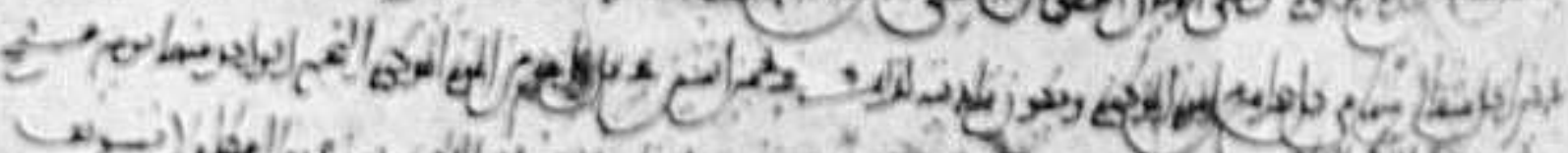
+

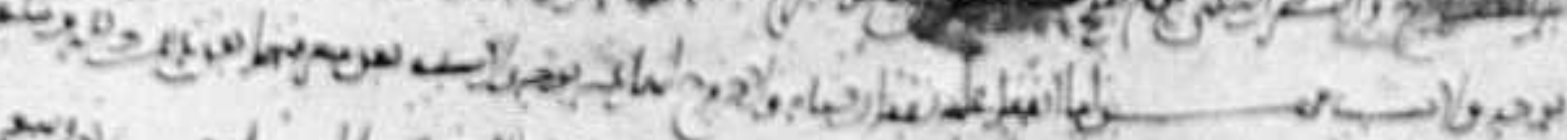

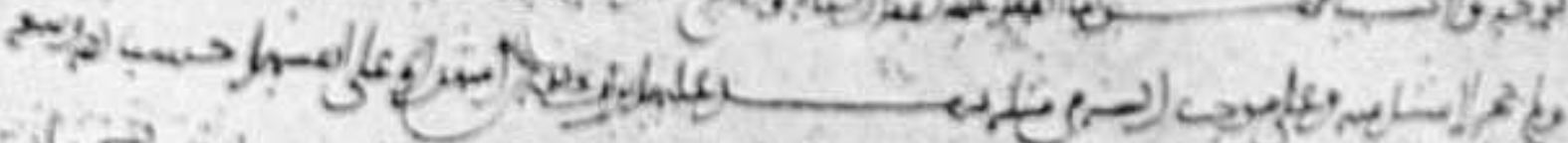

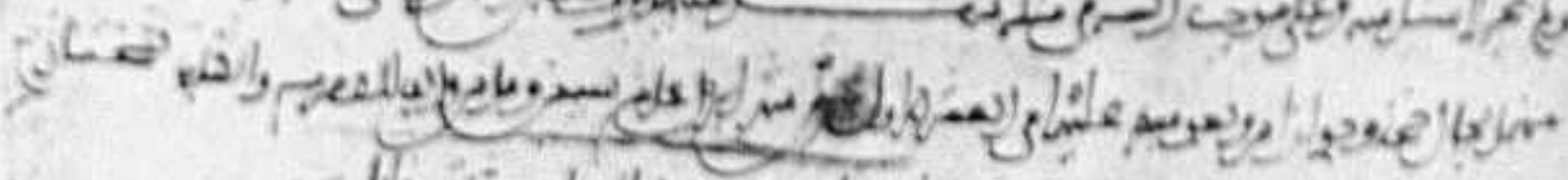

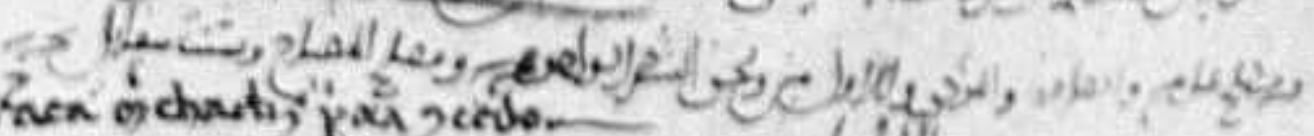

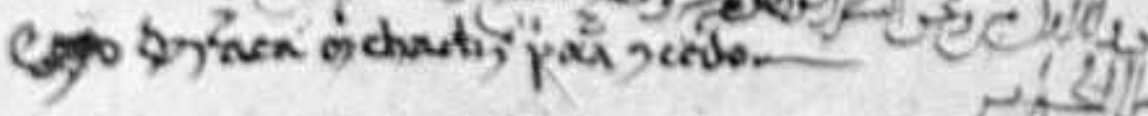

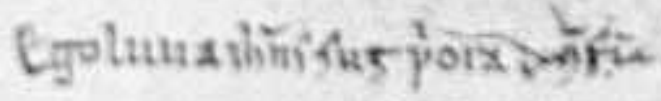

¿50 maynagaraz.

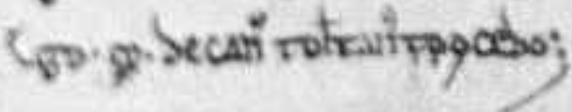

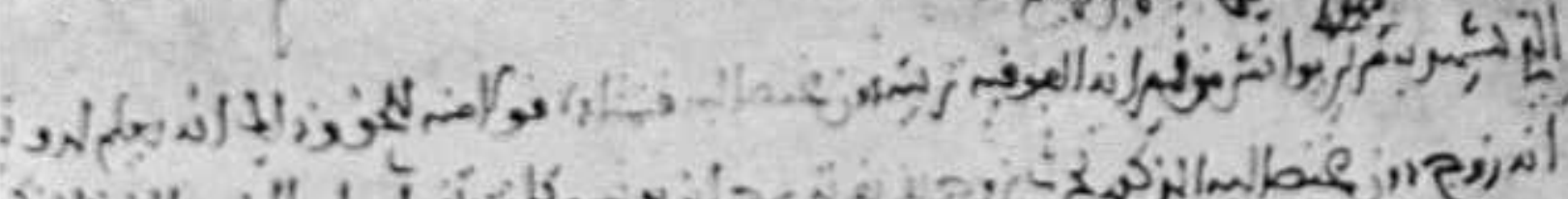

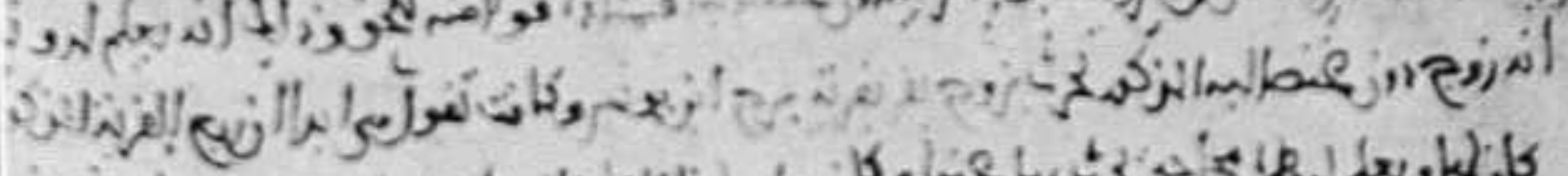

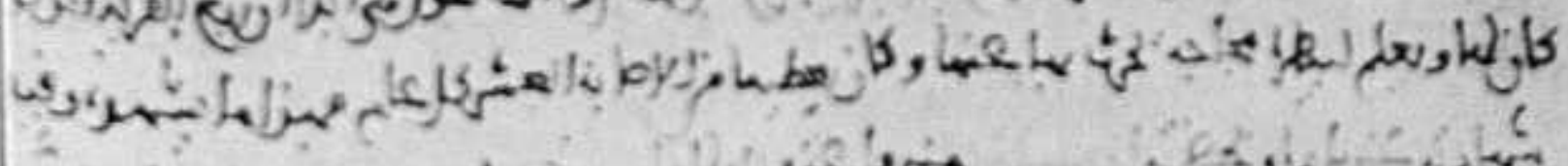

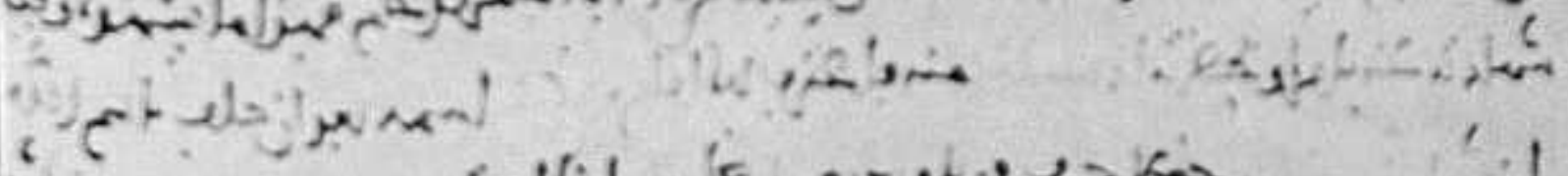

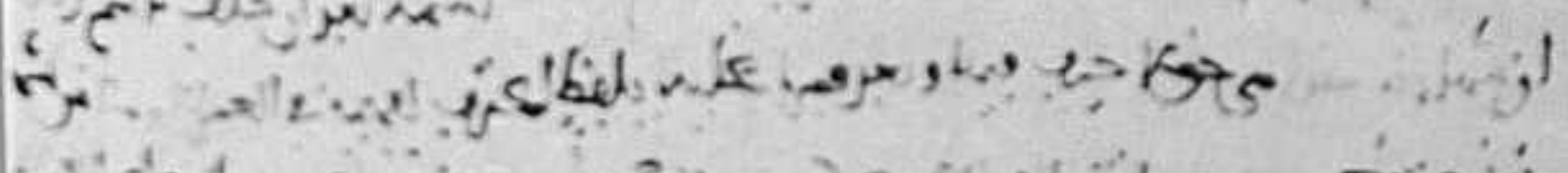

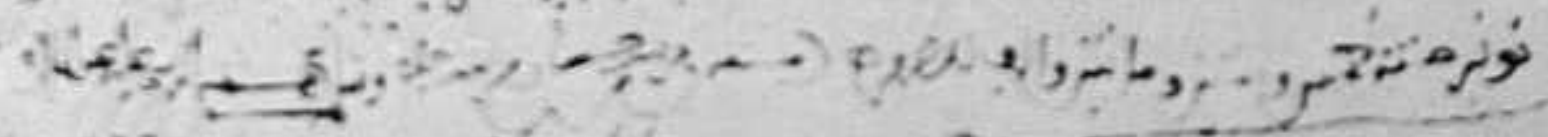

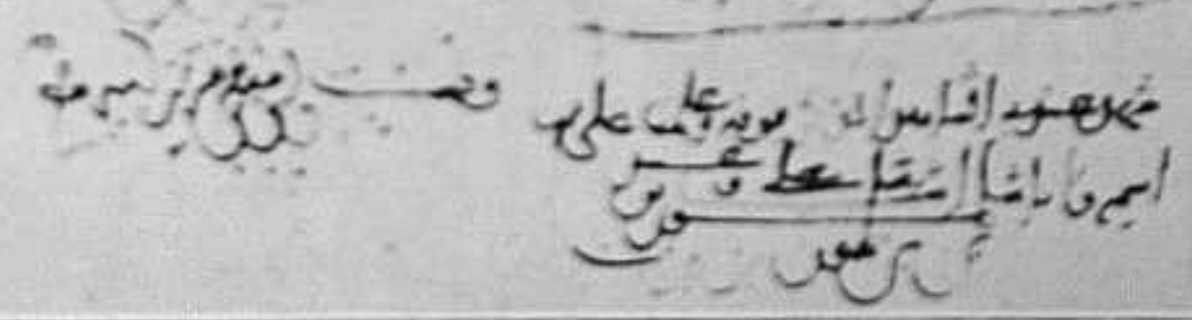


lendas y por Pentecostés. Los arrendatarios ponían como gar antfa lodos sus bienes, que se consideran empeñados para responder del pago, y además a cuatro fiade. res. Devolverian las tierras labradas como eslán; trabajarían las viñas con todas sus labores de levantar, podar, cavar y binar; guardarian los frutales del huerto, los regarían y los cuidarían. Se les prohibia trabajar en el huerto ae nocide, porqae pa. dían perjudicar a los frutales pequeños, sino que babran de cultivarlo durante el día. Cuando esturiese hecho el trabajo de las viñas, avisarían al dueño, y éste prohibiría la entrada.

Añadiase un inventario dic los nueyes, Darbechera, cabas y tinajas para el vino, aceite, granos, rejas de arado y otros aperos de labranza que los arrendatarios recibían, y a cuya devolución, o su precio, se obligaban (núm. 909).

Murio Juan Domínguez, el arrendatacio, al año segundo del contrato y quedaron debíendo los arrendatarios parte de los 300 mizcales del affo primero, y mucho tiempo después, pasados ya diez meses del segundo, no habian dado al arcediano arrendador absolulamente nada por alcabala. Reclamó el arcediano el pago a la viuda, se dirigío a los parientes de ella, consultó con gentes peritas en agricultura, a quienes reunió con la viuda $\epsilon \mathbf{Q}$ el huerto de Arcicolla, y en las viñas, propiedad del arcediano. Los peritos hallaron estrapeados algunos árboles, incultas las tierras, rotas la aceñas y otros desperfectos; como que las viñas estaban labradas sin levante, $y$ otras sin cultivar.

El arcediano reelao 6 a la viuda indemnización de lodo, según el informe de los peritos; le exigió que cumpliera las condiciones de la alcabala, que devolviera las fincas en las debidas condiciones, y estrechaba a la viuda a que pagara con sus bienes y los de su esposo, según el contrato. Ella consultó a sus parienles y amigos. Este consejo vió que la ley era terminatite, la indennizaeión grasde, la viuaja con pocos medios y con hijos pequeños; que las condiciones del contrato eran muy fuertes y ruinosas, perjudiciales para el arrendatario, aunque el arrendador nunca podía perder. Opinaron que la viuda debia rogar al arcediano que tomase las fincas que ella y sil esposo terrian en Viliafranca, y para cederlas, la autorizaron los herederos de su esposo. Coa esto entendían que se pagaha la renta atrasada y los desperfectos en fincas y árboles.

Así lo pidió la viuda, y gentes honradas la acompañaron e intercedieron por ella ante el arcediano. Acepló ésle, movido por sa victud, honradez y religiosidad, y le dieron posesión de los bienes del matrimonio, por parte de ella y de sus hijos, con aprobación de un hermano y dos sobrinos del difunto. Con esto se di6 por satis. fecho el arcediano arrendador y renunció a toda reclamación (núm. 948).

En casi las axismas condiciones arrendaba, en 1208, la Caicdral, sus tierras, viñas, huertos y casas, con la mitad de las calonias y de los diezmos en Manzel Obaidalá, junto con un par de bueyes de labor, más los aperos de labranza, la paja y los barbechas, objetos que babian de devolver al terminar el contrato, o su precio; el 
plazo era die ocho años, y el precio de 60 mizcales en tres plazos, contados por cuatrimestres a partir del 20 de Enero. Además de la condición corriente del cultivo de las viñas, con todas sus tabores, pone la condición especial de que los arrendatarios se obligan a constı'uir por su cuenta en el primer año una cuadra para dos bueyes, y otra habitacín mayor para bodega del vino (núm. 363).

Algunas modificaciones sobre estas bases añadía el arriendo que hacía, en 1217 , la misnıa Catedral de un cuarto de los derechos que tenía en Manzel Obaida. lá en el sexto de sus frutos, en el trigo, etc., más las viñas, más dos pedazos de tierra inculta que han de plantar de viña y cultivarse por iguat: el plazo era de cinco años, y la alcabala cra distinta el año primero que en los cuatro restantes: el primer año, 17 mizcales y medio sexto; en los otros, 51 mizcales y cuarto. El arrendatario disfruiaría el producto de los huẹtos hasia Enero de cada año; y devolvería los bueyes, aperos y granos que recibía, y dejaria los barbechos binados o terciados en buen estado. Si alguna mehalla de cristianos o de moros destrozase las fincas en más de la initad de daño, perderían los dueños; si en menos, los arrendatarios. En caso de que éstos dejaran de trabajar las viñas, perderían una cuarta parte de la ganancia, y pagarían la alcabala de aquel año. Garanlizaban tel cumplimiento del contrata los bienes todos de los arrendatarios, que podrían ser embargados, si un ẫo no pagaban ( núm. 910).

Por un plazo de diecinueve affos y una alcabala de 23 mizcales de 15 dineros al aĩo, en dos plazos, nitad por la fiosta de las Candetas, mitad par la fiesta de San Miguel, arrendaba, en 1232, el convento de San Clemente al deán de la Catedral las heredades, pechos, frutos, diezmos y calonias que tenia en Fuensalida y Portillo (núm. 911). Dada la condición del arrendatario, es de presumir que este subarrendaría a otras personas aquellas fincas y dereahos.

Desde mediados del siglo XIII los plazos de duración del arriendo son, por regla general, más cortos. Por dos años se arreudaban, en 1258, el huerto de Santa Leocadia, tierra y árboles frutales, por una alcabala de 10 mizcales alfonsíes, en tres plazos: fiesta de las Candelas, 15 de Agosto y día de San Miguel. Para caso de no pagar la renta, se preveía el embargo de los bienes del arrendatario; si éste reclama. ba de algo, tendría una multa de 5 mizcales; si resultara insolvente, podría prenderlo y aprisionarlo hasta que pagara, sin mandamiento de juez, fuero o calonia. Los arreglos en el pozo y naria, o en las paredes que pudierant bundirse, eran de cuenta del arrendador, y si no los pagána se desquitaría de la alcabala (núm. 915).

Pena de embargo de bienes y de 5 mizcales de multa, si reclamaba, se ponía al arrendatario de una heredad de una yugada de labor, barbecho y sembrado, que el convento de San Clemente poseĺa en Olías, por plazo de dos años, a contar desde el día de San Cebrián próximo a la escritura (1259) y con una alcabala de 12 mizcales anuales, entregados a mediados de Agosto, cuando la recoleccion, al comendador del convento ( $\mathrm{n} u$ ụ. 915 bis ). 
Por plazo de dos años, uno para labrar la tierra, otro para sembrarla, arrendaba San Clemente (1261) heredad para una yugada de labor en Argance, por una alcabala de 20 mizcales, la mitad que el arrendatario entrega por adelantado, la otra mitad al concluir el año segundo. Para caso de incumplimiento en el pago, sólo se prevé entbargo, sin necasidad de orden judicial, y se advierte que la finca la lleva en arriendo un arjado del comendador del convento, y al acahar el ptazo de este contrato se la volveráa a dejar, después de levantada la cosecla (núm. 917).

la Catedral arrendaba, en 1265, una huerta en Algorfela, con el octavo del.molino de abajo, autorizando al arrendatario para que pucda sembrar toda clase de granos que quiera; el plazo es de dos años tamhién, y la alcabala de 18 mizcales cada año, mitad por la fiesta de Pascua próxima (la escritura se otorga el 29 de Septjembre), mitad al hacer el año. Ĺn caso de incumplímiento de pago, vendría el embargo, sin mandato judicial ni oposición de fuero, y llevando al deudor a cualquier tribunal que el arrendador quisiera, $y$ nn a otro. El arrendador se obligaba a dar al arrendatario habitación en la alquería, donde viviera con loda anchura durante el plazo indicado, y a cercar la huerta con vallas. El arrendatario recibla ciertos efectos (granos y azadas), que devolvería al fin del plazo ( $n$ úm. 918).

A veces la alcabala se cobraba en especie: en el arriendo que doña Sancha Gutiérrez hace, en 1272, de heredad para dos yugadas de barbecho y sembrado en Valerilla, más un corral con tres chozas y un palomar, por el plazo de cuatro años, era la alcabala de cada año 10 cahices de grano paro y bueno, mitad trigo y mitad cebada, medido por la fanega grande que ahora corre, y puesto en Valerilla el 15 de Agosto. El incumplimiento de pago se castigaba con multa de 2 cuartos de mizcal cada día de retraso, y con embargo de los bienes al arrendatario; éste se obliga, como de ordinario, a devolver los animules, aperos y granos que recibe, valor por valor (núm. 919).

Tambien en especic ( $3 \frac{1}{2}$ cahices), y en la misma forma del anterior, había de pagar el arrendatario de una heredad de dos yunlas, con casa y palomar, en Setmo, propiedad del arcediano D. Alfouso Meléndez; con la adición de que si el arrendatario trabajaba más tierra de la dicha, pagaría una décima parte por las uididades, y con la obligación corriente de devolver animales, aperos y granos que recibía. Sarlio fiadora la suegra del arrendatario, y la fiadora hubo de pagar la deuda de este arriendo; y tres hijos suyos vendieron fincas y autorizaron al comprador para entregar al arcediano 750 mizcales de la deuda, cantidad que ei arcediauo recibió. (Tam. bién pagaron otras deudas a judíos) (núm. 991).

Con las mismas condiciones de los dos contratos anteriores, y por 6 cahices i se arrendadan, en 1293, tierras de labor y dos chozas cubiertas con tejas, más seis pedazos de viña en la alquería de Horcajo. El plazo para las tierras y parideras se empezaba a contar desde el 15 de Agosto; el de las viñas desde el día de San Martín. $\$$ if algún año dejaran de labrar las viñas, perderían en él los trutos que tiviesen; si hicię- 
ra gasto especial de cultivo, lo abonaría el arrendalario desquitándolo de la alcabala (núm. 921).

Se ven algunos casos de arriendo vitalicio: unas veces es por la vida del arrendatario; para evitar que se reclamen derechos, declara un arrendatario que no tiene derecho olguno en la finca, salvo la mejora que el Cabildo, dueño, le hace cu el arriendo por toda su vida (núm. 999). Otras veces es por la vida del arrendador: así arrendaba (1293) loda si propiedad en Alforiguela Maria Alfonso a su primo Melendo Petrez, que se obligaba a cultivar virias y huertos, y a pagar cada año de alcabala 6 cahices de grano terciado, trigo, cebada y centeno, más 30 sueldos de suizcales blancos el 15 de Agosto. Si no pagaba, tendria la multa de 1 mizcal por cada día de retraso, y embargo de bienes. Si el arrendatario moría antes que la arrendadora, todo lo arrendado quedaría en poder de ésta, y de su cuenta serian los gastos que ocurriesen (núm. 920).

Es curioso el caso que se plantea con notivo del incumplimiento de un contra. to de arrendamiento en el áltimo tercio del siglo XILl: Un arrendatario se niega a pagar el precio estipulado, alegando los gastos extraordinarios que hizo en el cultivo de vifras, $y$ vende sus fincas propias a un tercero, acaso buscando la insolvencia. - Este, amenazado en la posesión de las fincas compradas, trata de iulervenir para que las dos partes lleguen a un arreglo en sus cuentas, y retiene como arma el conIrato de arrendamiento. Si el arrendatario no se conforma con el arreglo que propongan hombres buenos y enteudidos, dará el contrato a los arrendadores para que to ejecuten (salvo en los bienes que el mediador compro). Contra el nediador se esgrime la perdida de lo comprado, en caso de que se niegue a entregar el contrato (n. 922).

El arriendo de las fincas urbanas, o alpuiler de casas, se regía por normas muy semejantes a las empleadas en el arriendo de las fincas rústicas. La Catedral arrendaba, en 1241, al mismo a quien se las hahía comprado, casa, mesón y algorfa en la colación de San Justo, por un plazo de cinco años, a contar de Agosto, por precio de 11 mirzcales de alquiler: 8 por Carnaval y 3 el día último del año (núm. 912). Otra casa de la Catedral, en el barrio de Alhandac, cerca del Baño del Hierro, la arrendaba un judío, acaso como administrador de la Catedral, a Martín Juanes y su mujer, por plazo de un año, a contar de la fecha (9 de Julio de 1246); cl precio del alquiler era $4 \frac{1}{3}$ mizcales alfonsfes, un tercio al pasar tres meses, el resto antes de que faltaran tres meses para eumplir el plazo. Si no pagaban, tendría el doble de pena y multa de 2 cuartos de mizcal por cada día de retraso, y embargo de los bienes de] deudor; y si reclamaba, tendrła multa de 5 mizcales. Les exigian poder, y habian de dejar la casa tal como la recibieron, y dar al fiador su fianza (nún. 913). La Cof́radla de presbiterds de Toledu arrendaba una casa on San Lorenzo, por plazo de nos años, a contar del 15 de Agosto, por 12 mizcales anuales, pagaderos por cuatrimestres; si al pasar uno de estos plazos el arrendatario no lo hubiera hecho efectivo, puede el arrendador empeñar los bienes de aquél y venderlos (núm. 1.172). 
Por las mismas normas se regian los arriendos de derechos, tal como el de las: salinas de Alcharis, que arrendaba en 1260 el convento de San Clemente, por plazo de tres años, y por una alcabala de seis cahices de trigo bueno, cada año, pagados entre San Juan y el 15 de Agosto; en caso de no pago, había una multa de dos cuartos de mizcal por cada día cie retraso y el arrendador tenía facultad para embargar al arrendatario y a su fiador (núm. 916).

Un verdadero subarriendo era el que se hacía en 1250 de la mitad de cuatro piedras de molino en el azud de Algunderín, en el Tajo, y de la milad de la plana de Algunderin y de Corral Rubio, derechos que el arrendador posefa por préstamo de la Catedral, y que a su vez arrendaba durante su vida, a partir del mes siguiente a la fecha; el precio de la alcabala eran 26 mizcales anuales, pagados por tercios al fin de cada cuatrimestre (núm. 914). Este azud de Corral Hubio se explotaba desde antiguo por el mismo procedimiento, pues en 1189 vemos que un arrendatario por la Catedral y el arzobispo, se lo subarrienda a otros pescadores, a se lo da por alcabalas para que ellos lo utilicen (núm. 1.054).

Además de los datos arriba consiguados anotaré otros sobre precio de las rentas:

Vin̆a en Alcardete, en un año: $\frac{1}{2}$ mizcal; ra-

lor de la viña en ventri, $7 \frac{1}{2}$ (año 1186 , nim . 182).

Mesón en la Aloudia: 5 mizcales (año 1175, núm. 899).
Yiña en Ninaljahia: sexta parte de sus utilidades (año 1210, núm. 746).

Cuatro tiendas on el barrlo de la Catedral, 4 mizeales anuales (año 1221, núm. 758).

Dos tiendas con sus algorfas, en la Alcudir: 4 mizcalcs (año 1227, núm. 488).

La esposa del arrendador aprobaba el contrato de arrendamiento (núm. 906). El arrendatario enviuda durante el plazo del arriendo, y se casa de nuevo; la esposa segunda se compromote, como la primera, en el contrato, al pago de la renta (número 918).

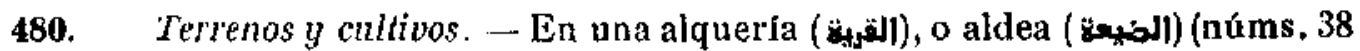
y 39), había tierras incultas y cultivadas, llanas o abruptas, de regadío y de secano, sotos, molinos y huertos, abrevadèros y pastos, corrales y eras y arreñales (núms. 43, 211,495 y 1.127), casas, mansiones, "chozas (يوتى) bodegas, palomares, pesquerias (مصايد الحوت) (núm. 784), viñas, majuelos (núms. 782 y 961), cercas, prados (número 988). Con los derechos del agua se comprendía el azud, río, boqueras, canales, acetres (núm. 488); y con los derechos de la tierra iban las bestias, bueyes de labor y vacas, cerdos, gallinas, ocas, aprovechamientos, grano, vino, ropas y demás efectos inmuebles, muebles y semovientes (núm. 985), aperos de labranza, tinajas para el vino, semillas, paja, derechos de los solariegos (núms. 393, 799, 961, 978 , 988 y 999), colmenar (núm.988).

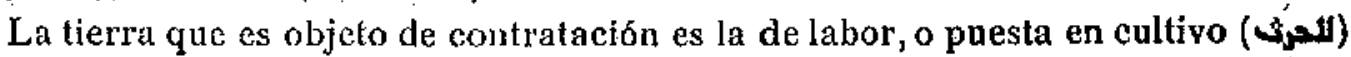
y la blanca (بيخ) sterra quae nondum laborata est, (núm. 968). Se mencionan ade. 
más la tierra llana (núm. 807), la lierra falsa (núm. 646), la tierra pedregosa (ná. mero 514), o con una cantera (núm. 17), la tierra ¿mala? (المخسw), la tierra de vega (núm. 805) y la tierra de prado o alcacer (القصيل) (núms. 379, 571, 636 y 647), a veces dividida por hazas (núm. 824), La tierra se medía por cuerdas ( دبل (ك) (2).

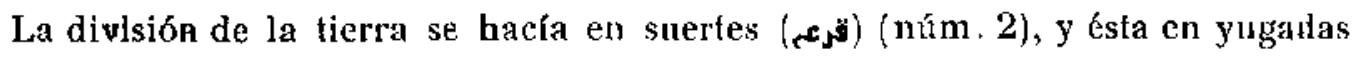

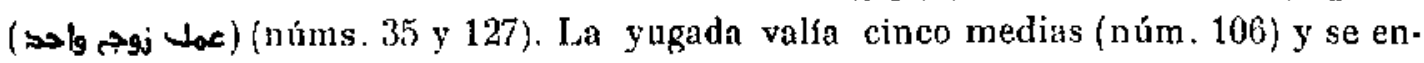
tendía comprender el terreno que podian labrar dos bueyes a dos hojas (لورقة (لوقين), es decir; barbecho y sembrado, suponiendo un cultivo de año y vez (núms. 373,422 , 509,738 y 985). La yugada se llamaba lambién (ف) (مúm. 333). El barbecho se

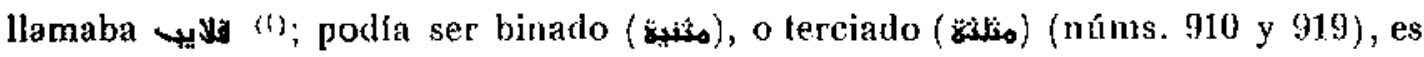

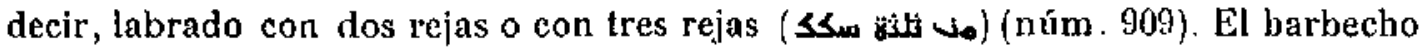
era objeto de contratación (núms. 175, 178, etc.), así como también se vendía la cosecha sembrada. (uúms. 692 y 820 ).

La proporcion de cultivos era ésta: En tierra para sembrar seis cahices, cuatro se ponfan de trigo, uno y medio de cebada, medio de centeno (núm. 824).

En las tierras de huerta, de ordinario valladas (núm. 918), o cercadas con vallas ' (núm. 689), entraban las ufllidades de alto y bajo, es decir, del suelo y del vuelo ( núm. 727) y-todos sus derechos en árboles frutales y no frutales, pozo, aceña con su alberca, almácera, etc. (núm. 154); a veces, parte estaba en cultivo de huertá y parte blanca (núm. 8), y se vendía la tierra con su bancal y con el tercio de los árboles que tenfa (núm. 243). Necesitaban los huertos culnvo especial (núm. 920) y parece que en ellos se cultivaban, a parte de los frutales, trigo, centeno, lino, ajos, cebollas, habas y garbanzos, al mellos por el año 1265 (núm.918).

Los semovientes, especialmente los bueyes, se consideraban anejos a la tierra y se incluían en las ventas ( como hemos visto atrás. En una finca de cínco yugadas de terreno, en Azaña, habia siete parejas de bueyes (núm. 175).

. El cultivo de la viña era muy abundante desde principios del siglo XII, por lo que es de creer que ya se hacía durante la dommaclón nu ustlumana. En las alquerías solían tener tinajas para el vino (شاب) (núm. 978) y a veces construían * habilación grande para bodega del vino (núm. 363)

El rentero o colono se llamaba (مسام (s), o sea, renlero al quinto (núms. 230, $783,855,861,961,986$ y 1.025$)$. Sc 1c arjendaba una viña para su plantación

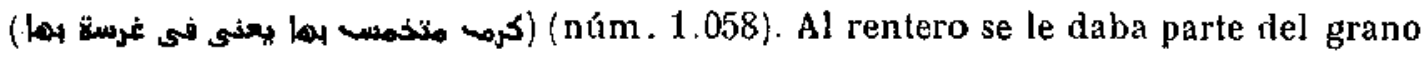
rècolectado en la finca (núm. 1.030).

(1) No puede quedar duda del significado de esta palabra, muy oscuro para Dozy, Suppl., s. v. , des-

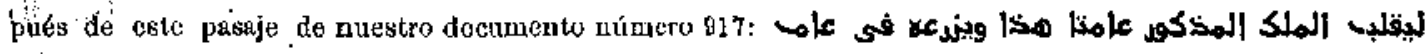

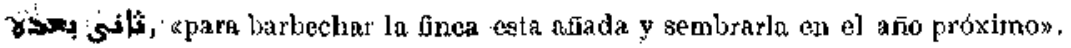


481. Arboles cultivatios. - Hallamos citados:

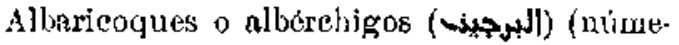
$\operatorname{ros} .580,(600$ y 821$)$.

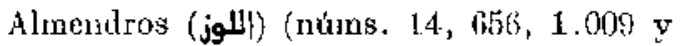
1.136). Se ponian a la orilla de las vinas. Almez (ألميبس) (nthm, 612).

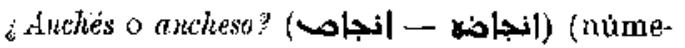
$\operatorname{ros} 596,654$ y 1.045$)$.

Duraznos (المدوإj) (num. 962).

Giranados (الرهان) (núms. 469, 580, 606, 1.045 у 1.050$)$.
Higuer'as (التيل) (nims. 720 y 1.050 ).

Manzanos (النفاكل) (núm, 743).

M(elocotoneros (سفرجلى) (núm. 654).

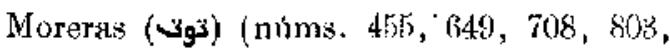
$1.045 \mathrm{y} 1.050)$.

Nogales (io y فيلة, noguera) (nums. 193 y $813)$.

()Jivos (الزئونس) (nums. 26, 129, 177, 469,584, $654,729$ y 803$)$.

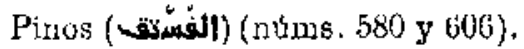

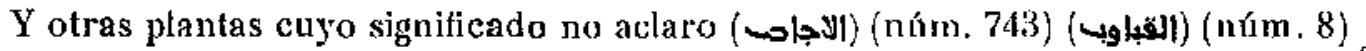
y el (سماك), que pienso sea la zumaquera (núms. 327 y 492), donde se menciona un campo de zumaque.

Los árboles se vendán sin vender el suelo en que estaban enclavados (números $177,193,243,729$ y 803 ).

482. Aperos de labranza. - Se ha insinuado atrás que en muchos contratos de arrendamiento figura la lista de aperos de labranza y de efectos, granos, animales, etc., que los arrendatarios reciben y a cuya devolución se obligan. Estas listas sirven para darse idea aproximada de lo que era una casa de labor en las alquerías toledanas. Reproducimos las más completas:

1. Heredad on Areicolla, año $\mathbf{1 2 0 5}$ (ntumero 909 ).

Dos pares de hueyes (بقر), su valor 24 mizcales.

Barbecho (4) sembrado, 6 cahices y 8 fanegas.

(bueo cahices labrarlos con tres rejas (SSa).

Veinte fanegas de harbecho levantado.

Nucve cubas ( $\mathbf{3}$ ) buenas para el vino, una de 250 arrobas, otra de 300 .

Cmarenta y ocho tinajas (كائة ) para el vino, ¿ unas de más de dos tercios?

Diez arrobas de faceite? (j) para las tinajas y cubas.

Cuatro cahices y cuatro fanegas do ixigo (لهم>

Cuatro cahices y euatro fanegas de centeno (سلتسم)
Sieto cahices de cebada (شعر).

'Tres rejas para labrar y los demás aporos (ul) de los bueyes.

(Las cubas, en el momento de terninar el contrato, habrún de devol. verso utilics para emplearlas.)

2. Huerta en Algorfiella, año 1265 (número 918).

Oeho fanegas de grano (o/a), mitad trigo y mitad centeuo.

Dos faisegas de simiente de lino (كان).

Cuatro arrobas de ajos (ثوه).

Cuatro arrobas de cebollas (a)

Media fanega de habas (فول).

Cuatro almudes de garbanzos (sمس), sic, por حمص)

Dos gazadas? llamadas lagonas (مخاحي)

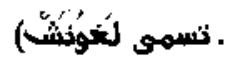


3. Heredad en Veletilla, año 1272 (número 919):

Tres toros (olgit), valorados en $66 \mathrm{mi} \%$. cales blancos, de $7 \cdot \frac{1}{2}$ sueldos.

T'res yugos (مقارين).

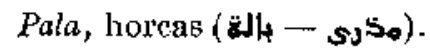

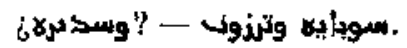

Siete cahiees de grano, medidos por la fanega vieja pequeña.

Jarbecho para dos pares de bueyes, milad con tres labores, witad con dos.

Seja كني de paja.

4. Heredad cn Cobisa, año 1278 (núm, 657).

En la venta de la tierra se incluyc:

Dos bueyes con sus apreros completos.

Dos arados $\left(\omega_{j} \mid+\infty\right)$.

Paja (-ił).

Espuertas (كيل) para:dos bueyes y la paja que titnon.

5. Horcdad en Melgar, año 1286 (núm. 689). Fn la venta de la timrra se ineluyen:

Dos pares de bucyes de labor.

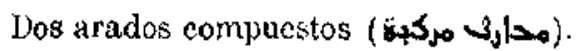

Cuatro rojas (s/)

Dos yugos (مكاريك) con sus ....

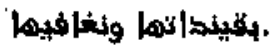

Dos barzones (بشisi).

Dos Anglä.

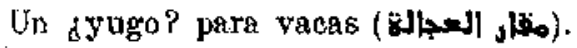

Dos everdas (otiros?) (مرإ).

Tres horces (s)lio).

Cugtro palas para recoger el grano

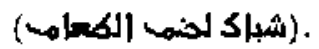

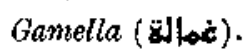

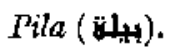

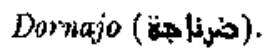

Cubo (4)

- $\log$.

Escoplo (ماقد)

Barrena (

Eejs techos (a) (a)
Medio par de tablas para hacer tapias

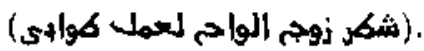

Tres llaves (هفتماحم).

6. Heredad en Cotisa, año 1287 (núm. 692).

Con la verita de la tiorra se incluyen:

Dos pares de bueycs, con sus aparcjos de labor conpletos.

I as vacas (العجالة).

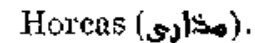

¿Cribas? (فراف)

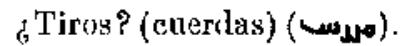

'Tres rejas (سكاد).

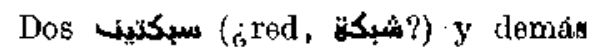
instrumentos para labrar y para recoger el grano.

l'aja, o su equivalente, suficiente jara los bueyes, deste la fecha (16 de Enero) hasta Marzo.

Seis cabras (jiso).

Cuatro cabritos (w)جيج).

7. Heredad en Setmo, año 1350 (num, 991).

Recibe el arrendatario par'a cultivo de Ja finca:

Ciento veinte mizcales de los sueldos blancos por bueyes, yugos, tiros, arados, compuertas, rejas y damás aperos para los bneyes.

Seis cahtees de grano, por la medida grande, para sembrar, para stat y pari gastos: tereindo de trigo, cebada y centeno.

Veinte sadicas (ش̂) de paja, de 25 espuertas ( ) la sédica.

Barbecho de tres labores, sulieicnte para dos bueyes.

8. Horcdad en Alforigiziela, Sisla, año 1293 (nism. 920).

Recibe el arrendatario por anticipado:

Dos pares do bueyes, tasados en 180 mizcales.

Aperos completos de labranza para ellos, 
Diez cahices de grano terciado de trigo, cebada y centeno.

Barbecho con dos labores para los dos pares.

9. Horedad en Horcajo, año 1293 (núm. 921).

Recibe el arrendiatario, para devolver valor por valor:

Dos bueyes, tasados en 180 mizcales blancos, de 15 sueldos.

Una roja vicja (ساكية بالئة).

Un arado (محر| 1 (م)

\author{
Un earro (مبركب). \\ Yugos ( $1 \mathbf{w}_{\mathrm{j}}$ )

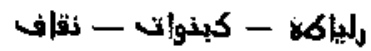

Cuntro cahices de trigo.

Tres calices de cobada.

Sietc fanegris de zcarsena? ( 8 ( dido todo por la faurga grande).

Veinte 8agsk de paja.

laurbecho con tres labores parz sem. lrar un cahiz de cobada, y con dos labors jara sembrar 15 fanegas de trigo.

\section{CONTRATOS DE SOCIEDAD}

483. Aparte del indicado atrás (1) para explotación de una cabaña de ganado, podemos señalar otros, de carácter indıstrial o mercantil.

Para construir la noria de la presa de Algunderín se asociaban (1138) el arzobispo D. Raimundo y D. Pedro, arcediano de Segovia. El arzobispo levantaría la noria en tierra del arcediano; éste le daría la tercera parte de los gastos y podría utilizar la tercera parte del agua, y tendría derecho sobre la tercera parte del canal, de la acequia matriz, etc. El arzobispo tendría derecho a la tercera parte de la tierra blanca que fuera de las paredes de las aceñas se pudiera regar ( $\mathrm{n}$ m. 968).

Rarísimo es el convenio que se pacta en 1143 entre Clemente el Monje y Marra, hija del alguacil maior Temam. Reúnen sus bienes en un solo fondo: casa (con los utensilios, comidas, bebidas, tinajas, siervos y animales), productos del huerto, ga. nado, esclavos, etc., y de todo han de disfrutar por mitad. Otro tanto hacen con los gananciales que ptiedan tener en el plazo de seis años que ha de durar este contrato. $\mathrm{Al}$ pasar este tiempo, se repartirán dos esclavas, una para cada uno, o su precio, si se rescatan o son vendidas. Si uno de los olorgantes muere antes de verificarse la partición, dejará la mitad de la casa al superviviente para que habite en ella durante su vida, y después de su muerte, se empleará en rescalar algún cautivo, o en sufragios por las almas de los dos. Cuando uno de los dos quiera partir los bienes, se partirán, excepto la esclava (que cada uno tomará la que se indica arriba). El que se oponga a la partición pagará de sus bienes al que la reclame 15 mizcales al. 
morávides, que éste percibirá sobre su milad. Si la partición se hace antes de los seis anos, cada cual tomará su esclava, la casa se dividirá en dos milades, y entre ellas se levantará una pared. Si alguno vende o rescata sus esclavos, partirá el dinero que por ellos logre. El día en que liacen la partición, Clemente tomará la mitad de los frutos de la huerta, en verduras, etc., y la mitad de la aceña (nám. 969).

Se ven utros tipos de convenio para sociedad mercanlil. 'Tal se deduce del contrato de reconocimiento de deuda de 100 cabezas de ganaro lanar con sus utilidades durante diecinueve años anteriores al documento (1265). El deudor declara que recibió hace diecinueve años 100 carneros del acreedor; los vendió y se benefició del precio. Al pedirle el acreedor su dinero, le hizo una escritura cn romance y ne le pagó la denda ni las utilidades. Por eslo se obliga ahora a pagarle las 100 cabezas, con sus utilidades y provechos, cuando se los pida. Y si se excusara, pagaría de multa medio mizcal díario, y el acreedor podría embargarie y vender sus bienes con sólo presentar esta escritura, sin plazo de tres días, ni de nueve, ni de treinta, que se dan para estas ventas, y sin plazos semejantes, sin sentencia judicial, ni fuero, etc. (núm. 860).

Otro préstamo de la misma naturaleza hizo el alguacil Juan García al judío lien Alcahil, en 1290 , de 3.000 mizcales blaucos «para comerciar con ellos telas, paños y otras cosas durante un ano, con condición que de las ganancias que tuviere en el año, diere al dueño del capital dos terceras partes y lo restante fuera para él, habiéndole de pagar su capital con más los dos tercios citados; si no lo pagaba tendría una mulfa de 20 mizcales por cada día que pasara sin hacer efectiva la cantidad prestada $\times($ núm. 965).

\section{J. P RESTA MOS}

484. Desde fines del siglo XII hallamos noticia de escrituras de préstamo, para cuyo paga se vende finca en 1193 ( núm. 242), o cuya escrilura de Fcbrero de 1197 se entrega, después de haber sido pagada la deuda por complelo en 1201 (número 303).

Las formulas de estas escrituras eran muy uniformes, y en ocasiones se ve que estaban redactadas, habiendo dejado en blanco los huecos para poner los nombres de los prestatarios, cantidad y plazo.

Después de nombrar al prestatario, dice: «Sobre ellos, sobre sus bienes y res. ponsabilidad, sobre sus heredades y sus haberes todos, hay una deuda obligatoria, cierta, legal y necesaria de tal cantidad, , Indicados los plazos de devolución, continúa la fórmula: "Autorizan los prestatarios al prestamista, o a quien en su nombre muestre este documento, para tomar prendas y para entrar en sus bienes, dere 


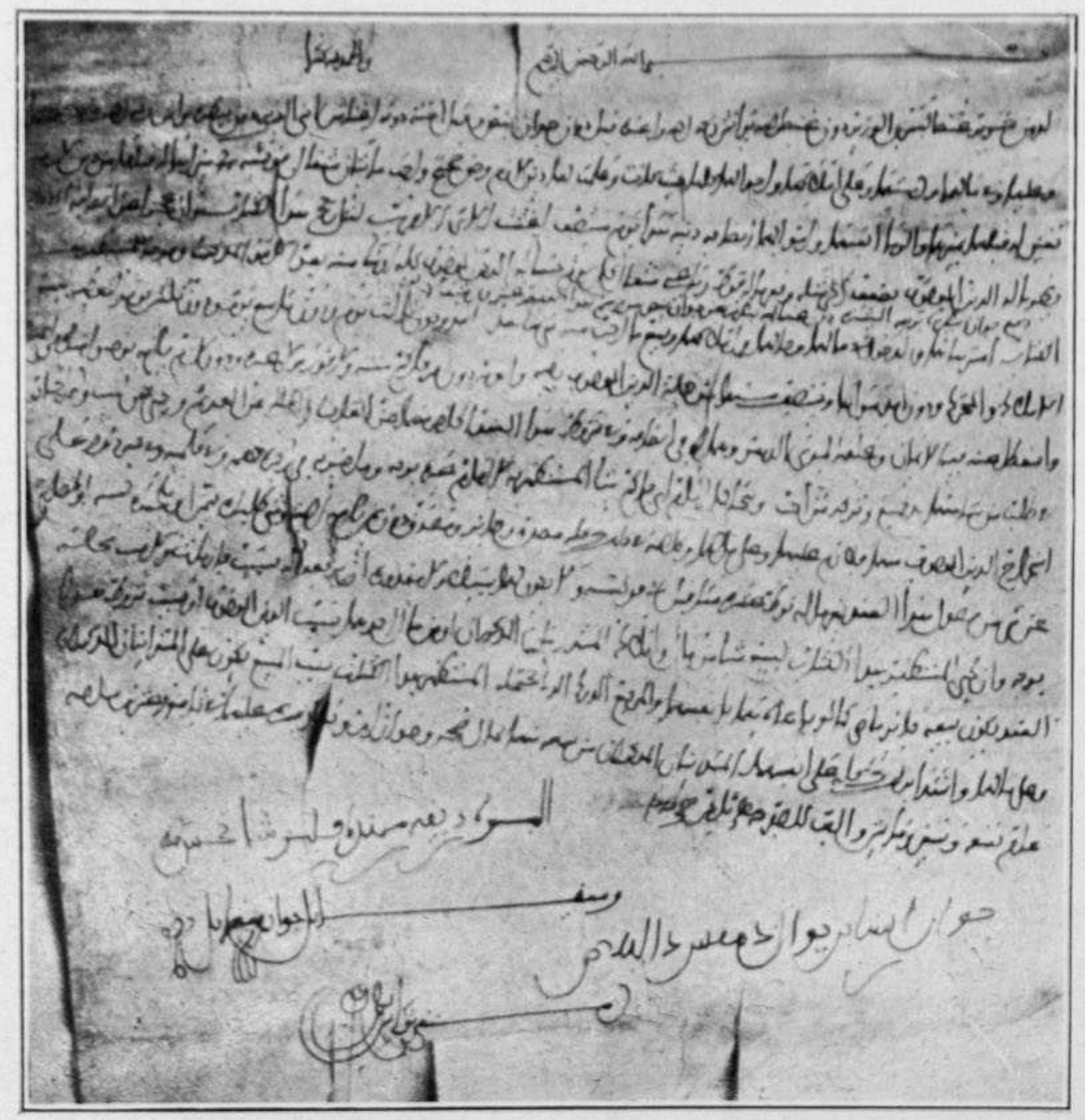

Préstamo: 28 de Mayo de 1231 (núm. 839). 
chos y propiedades, $y$ vender lo que quiera de aquéllos que tiene bajo su poder, $y$ con cllo indemnizarse de parte de ellos de la mencionada deuda, en su plazo, y de la multa, completamente, sin mandamiento judicial, ni exención de fuero o cosa parecida. Confían en él y depositan en él por cllo toda la confianza perpetuamente; y serán juzgados ante el jue $\iota$ que quiera el que muestre este documento, y no ante otro. Los prestatarios dan al prestamista poder para que obligue al presente de ellos por el ausente, al rico por el pobre, al vivo por el difunto, y le autorizan a reclamar contra el que quiera de ellos y a dejar al que le parezca; y lo que el prestamista subrogase en la determinación acerca de los prestatarios, para éstos sea obligatorio, y la afirmación del prestamista cn todo es fidedigna, sin que se crea qae le ohijga decisión irrevocable. Si los prestatarios reclamasen al prestamista que se apartase de algunas de estas cosas, le pagarán una multa de 5 mizcales, y con la exhibición del presente documento no anulará la opción del plazo obllgatorio» (núm. 858). Otros documentos ponon esta fórmula: "Sí los prestatarios reclamásea por la entrega de alguna cantidad, no les valdrá afirmación, prueba ni demostración, sino lo que haya escrito entre líneas en el presente documento (núm. 855). Y vemos, en efecto, que el abono de cantidades a cuenta de los préstamos se solla poner entre líneas de la escritura misma de la cattidad prestarla (núm. 839).

La mayoría de las veces se prestan cantidades en metálico, no muy grandes; pocas veces pasan del centenar; acaso la cantidad más fuerte que se presta es de 460 mizcales alfonsíes (núm. 856) y otra de 600 mizcales blancos (núm. 868) y de 3.000 mizcales blancos (núm. 889). Pero también se prestaba trigo, kbueno, nuevo y puros (núms. 820 y 842), s seco y granado, puesto en casa del prestamista " (número 884 ), medido por la medida grande vieja (núm. 880); dinero, trigo y cebada (número 896), que había de entregarse donde el prestamista dijera; y telas: el arcipreste se dió por pagado de las telas que habra prestado a unos que eran sastres, al quedarse con la casa de los deudores, vendida (núm. 572).

Los plazos de los préstamos oscilaban, como es natural, pero la mayor parte eran cortos: de dos a seis meses, alguna vez de un año (núms. 575, 834 y 866), y aún más, por ejemplo, número 869: mitad de la cantidad el día de San Martín próximo, mitad el día de San Martín del año siguiente. Otras veces se paga una cantidad mensual, a contar del mes siguiente al préstamo (núms. 835 y 849); o una cantidad al mes de la fecha, otra cuatro meses después y el resto unos tres meses más tarde (nứm. 841). En este coso, la falta de pago de un plazo acarreaba la pérdida de lo abonado (núm. 841). Se tomaba como fecha de término la fiesta de San Miguel (núm. 848), la de San Martín, las Candelas (núm. 579), San Juan (núm. 856), San Cipriano (núm. 843), etc.

A veces, solre una deuda se acumula otra en la misma escritura (núm. 893) o en otras (núms. 881 y 892); es curiosa la serie de deudas que van contrayendo María Juan y Garć́a Gonzálbez: toman un préstamo para pagar el anterior, hasta que 
se ven obligados a vender casas, tienda y bodega a su cuñado y fiador por valor de 3.000 mizcales, con lo cual se paga a los acreedores (núms. 874 a 885 y 889 ).

Quedaban obligados, como garantía, todos los biencs del prestatario, sin necesidad de especificarlo (núm. 837). En caso de talta de pago la penalidad era fuerte: duplo de la cantidad prestada, más una multa $(6,60 t o)$ de 2 cuartos de mizcal por cada día de retraso, o en otros casos un cuarto de mizcal (núm. 813) y hasta 1 rajzcal diario (núun. 868). Y si el prestatario reclamaba algo por la vía judicial de algún acto que pudiera intentar el prestamísta, hábia de pagar una multa de 30 mizcales (núm. 847) o de 10 mizcales (núm. 849) y ordinariamente de 5 (núms. 843, 850, $853,854,856$, etr.). Y lan fueries resultaban eslos multas, que muchos fiadores declaraban que no salían garantes más que de la deuda, pero no de las multas (núme. $\operatorname{ros} 836,855,862,869$ y 890 ). No obstante, vemos declaración del prestamista de haber recibido del fiador, por un préstamo de 56 mizcales blancos, a los dos años escasos (ol plazo eran tres meses), 112 mizcales por la dcuda y las multas, y daba este documento al fiador para que pudiera repetir contra el deudor (núm. 864); y en otro documento, aunque se advierte que el fiador no pagará multa, si hay retraso en el pago, consta en nota al dorso la declaración del prestamista de haber recibido del fiador, edemás de la cantidad prestada (60 mizcales) y oomo parte sólo de la multa, la cantidad de 100 mizcales, por lo cual deviclvo la escrilura de préstamo (núm. 1.124).

Es muy corriente la exigencia de un fiador (núms. $834,836,891,892,959$ y 1.124). El fiador habia de pagar la denda de su fiado; luego, para indemnizarse, la compra finca que valía menos que la deuda, pero con lo cual se da por satisfecho; la fórmula es la venta de la finca (núm. 575). En el dorso de la escritura de fianza se escribía la cantidad que adeudaba el fiado (nám. 641). Vendíase la finca del fiador par deudas; y éstas alcanzaban la suma de 212 mizcales, nientras que ln finca valía 400 (núm. 678). El fiador pagaba 184 mizcales por una deuda de 84 ; para ello le habian dado plazo de tres meses y otro de nueve días; la escritura de préstamo se entregaba al fiador para que puliera reclamar a los herederos del deudor primero (núms. 883 y 1.087). A veces podia el fiador cobrarse en fincas dcl fiado (número 1.088 ), o repetía contra la familia de los deudores, y lograba cobrar la mitad de lo que habia pagado (por deuda de 100 mizcales paga el flador 140 y cobra 78) (número 1.085 ).

Consta muchas veces en las cartas de préstarua el cobra de la cantidad a de parte de ella, entregada a cuenta (núms. 839,856 y 863 ), que en ocasiones sube más que el principal (núm. 579); o la prórroga del plazo (una ve\%, núm. 863), o la toma de la prenda por el preslamisa, para cobrar más de año y medio después de cumplido el plazo (núm. 834). Y también se daba recibo, en documrnto aparte, al cancelar el préstamo (núms. 1.086, 1.089 y 1.090), que eu ocasiones es recibo general de las deudas contraídas, con escritura y sin escritura, con testigos y sin testigos, 
Lith ,

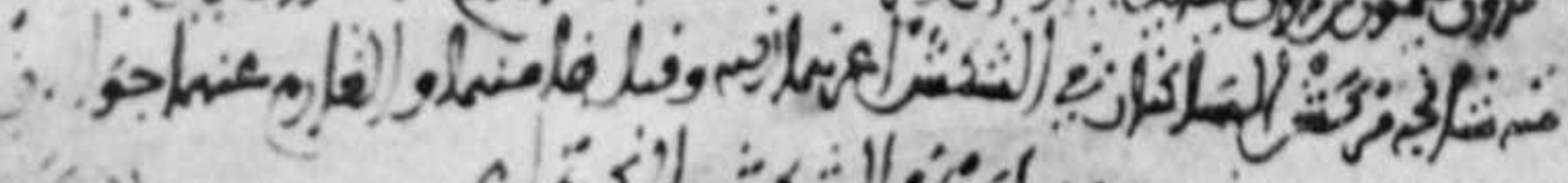

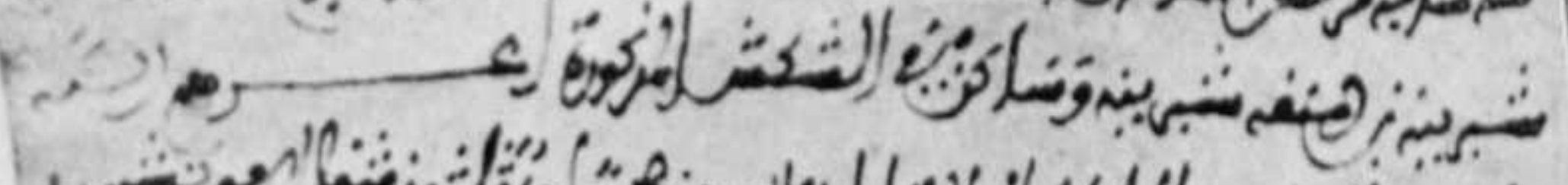

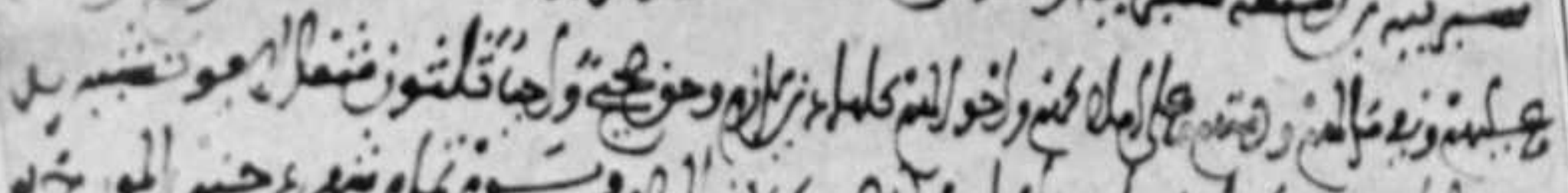

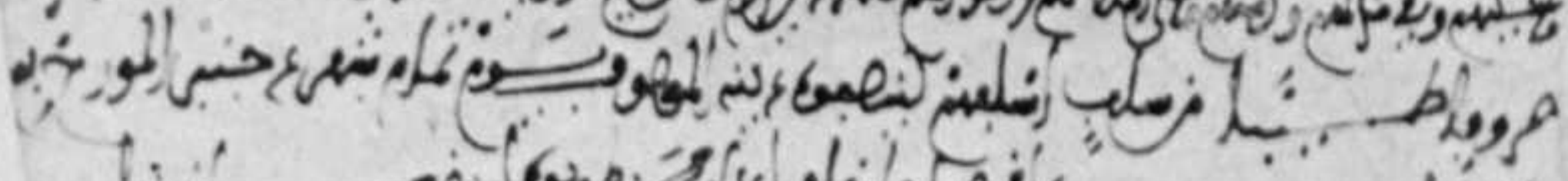

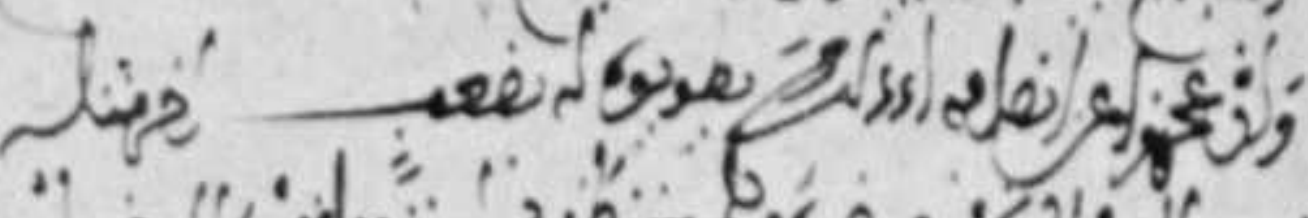

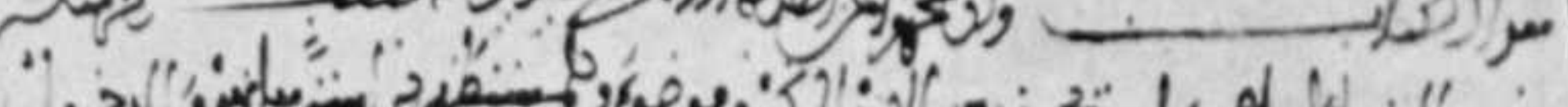
, î.

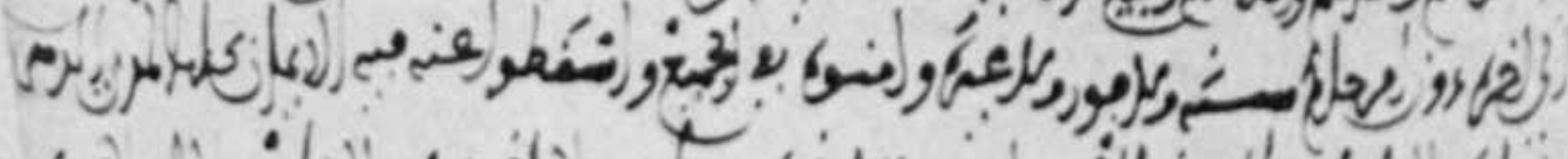

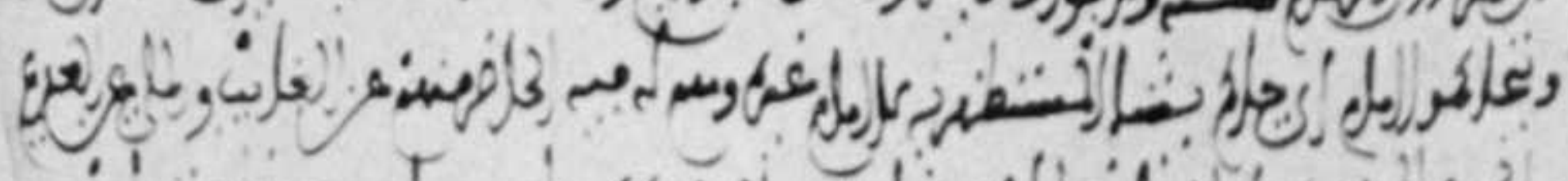

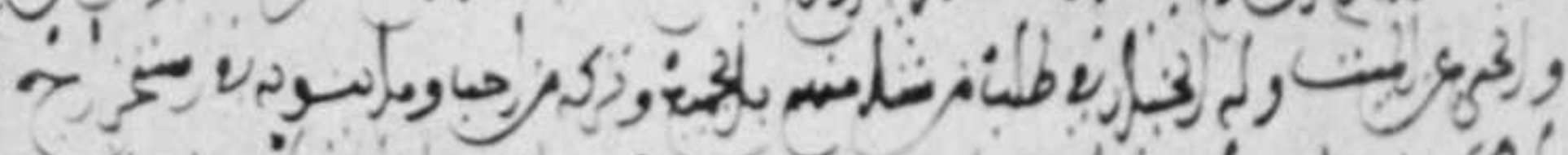
P.

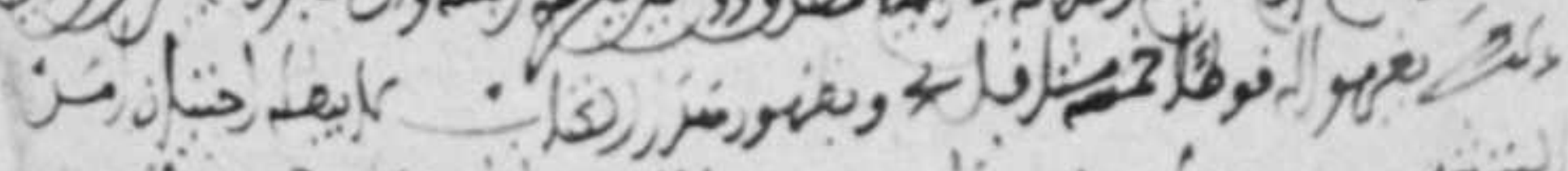
*

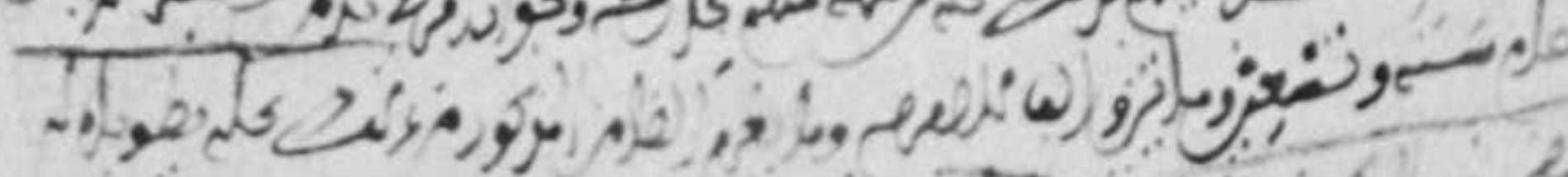

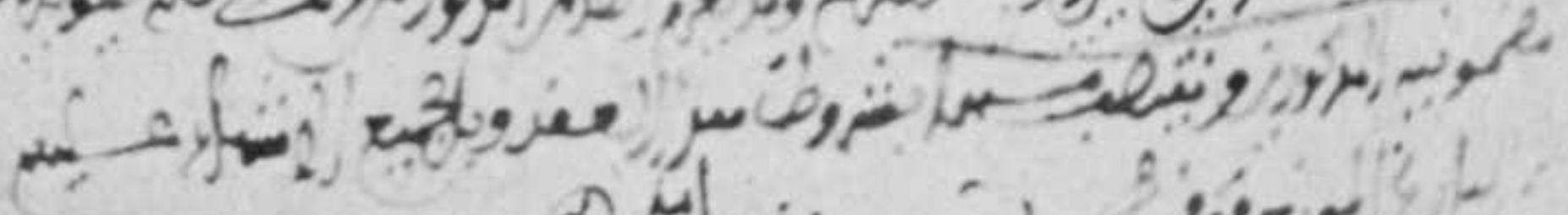

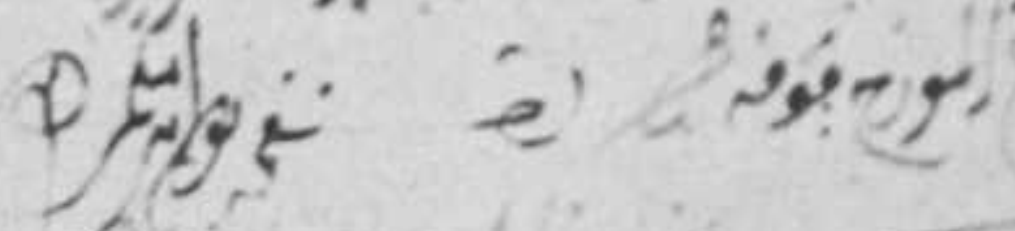

$$
\text { की }
$$

Préstamo: 8 de Diciembre de 1258 (nüm. 858) 
anteriores a la fecha (ú́ms. 1.091 y 1.092). Podía demorarse la devolución de las escrituras de préstamo algunos meses después de cancelada la deuda (núm . 575).

Alguna vez se indica la causa del préstano: gastos hechos en la fortificación o defeusa de Toledo (nárn. 847), resto del precio de una cantidad de trigo (núm. 868), pago de una compra (núm. 873), importe de un rocín alazán (núm. 852).

El interés de los préstamos no se escribía nunca. Es de sospechar que se aumentara sobre la cantidad prestada. Una vez se prestan dos mizcales y dos cuartos (número 840, año 1238): ¿serían estos cuartos el interés acumulado? Admitiendo tal bipótesis, nos daría el 25 por 100 como tipo de interés. Aunque una canlidad de 39 mizcales pagara a los tres años 68 (uúm. 99), no pucde calcularse el interés, porque ya hemos visto que, pasados los plazos convenidos, se pagaban fuertes multas por la demora (núm. 991).

El procedimiento judicial para cobrar las deudas, en la segundil mitad del siglo XIll, exigia la intervención del alcalde: mucho tiempo después del plazo señalado en la escritura, el alcalde reconoce 49 mizcales en lugar de 20 , cantidad prestada, y da un plazo de tres días al prestatario para que la abone. Ocho días después le da plazo de veinte días, "con la pena derecha que en ella dice, porque conoció ante mí en juicio e ante las firmas de este emplazaniento que ge la devie..... e esto yudgué a bos deste don Lorent e a bos de don Samuel en nombre de don Abraham..... (núm. 862). Los mismos plazos de tres dfas, de nueve días, de treinta días * del fuero», y el mandamiento judicial, se indica en otros documen tos (números $860,863,890$ y 1.124 ). La ejecución por deadas no solía ser inmędiata al fin del plazo, sino que tardaba algo más; alrededor de dos años (núm. 391). Algunas deudas quedaban impagadas (núm. 628).

Lá prisión por deudas sóı la cocontramos una vez, en documento de arrieıdo (núm. 965), atrás mencionado.

No se olvida consignar en las escrituras de compraventa el detalle de si la venta es por causa de deudas (núms. 416,580 y 711 ), a veces, hecha por el mismo prestamista para cobrarse (núm. 720), o por un deudor apremiado (núm. 391). Del precio de la venta se reservaba el comprador una parte para pagar una deuta a quien el alcalde ordenare (núm. 715). Para resarcirse de una deuda con el arzobispo anterior, D. Rodrigo contpra a los deudores, judios, fincas en Olías por valor de la suma adeudada (núm. 373). Los herederos de un prestatario declaran darse por recibidos de la cantidad que su padre debra, al vender los bienes hipotecados (núm. 320).

La inmensa mayoría de los prestamistas que aparecen en nuestros documentos son judios. Entre los cristianos figuran a veces insijtuciones, como la cofradía de los presbiteros de Taledo (núms. 1.170 y 1.171 ). 


\section{K. E M PEÑ OS}

485. De préstamos con garantía o prenda tenemos ya documentos de la segunda mitad del siglo XII, año 1163 (núm. 897).

Las formulas generales, después de ennnciadas las personas, la cosa empeñada, La cantidad recibida y el plazo, eran éstas: *Entrega el pignoratario citado todo el dinero dicho a la pignoradora, y ésta lo recibe de sus manos, y vieno adquiriendo su propiedad, posesion y dominio, y declaró absolutamente libre al pignoratario de entregar aquel dinero, y éste se vió libre. Ella le entregó la finca pignorada descrita para que la habite, la alquile o la dé para habilar a quien quiera, durante el ptazo indicado, por invilación perfecto de la pignornante y por douación completa. Y cuando pase el plazo indicado y se termine, la pignorante, dicha dofía Maŕa, retirará la prenda de manos del pignoratario, previa la entrega de su dinero, sin excusa ni pretexto, ni motivo alguno. Conocen las dos partes contratantes el valor de este con. trato he empeño y su alcancc, sin que puedan alegar ignorancia respento tle nada a él tocanle, y se hace según la ley de los cristianos en los empenos corrientes entre ellos» (núm. 904). (Si lo pignorado era finca rústica o urbana, suele afiadirse a la descripción de la finca la cláusula corriente en las escrituras de compraventa, que empieza: "Con todos sus derechos, entradas y salidas *, etc.)

Ordinariamente se prestan dincros en metálico; aunque pueden ser otras cosas: mosto, un chico (núm. 340).

La gal'antí eran casas; nuesones, viñas y tierras, esclavos, animales (nírm, 340), hasta un unanto de escarlata (núm. 1.001). El acreedor podía vivir en la casa, si de esto se trataba, o alquilarla ( $n u ́ m .900$ ), aunque de ordinario la deja al pignorante (núm. 898), si bien alquilada, cuya cantidad se acumulaba a la prestada (núm. 899).

En caso de no pago de la cantidad entregada se vende la garantía, hasta cebrarse la deuda, sin necesidad de mandato judicial, ley, ni consulta de nadie, y por la sula palabra del acreedor (núms. 897 y 907), o se queda el prestamista con la finca de garantfa (núms. 572 y 903 ), o será vendida al prestamista la finca por su precio señalado cn la escrilura (500 mizcales, de los que descuntará los 200 prestados) (núm. 908).

Si el deudor moría antes de satisfacer la deuda, manda que lenga preferencia este crédito, sin oposición de sus herederos (núm. 899).

El plazo suele ser más largo que en las escrituras de préstamo, hasta de tries años (núm. 898), cie ciñco (núm. 903).

Si la finca es poselda pro indiviso, empeĩada una parte, queda empeñada también la otra (núm. 897), con aprobación del condueño (núm. 908); y si una vez sólo 
se empeñan las tres cuartas partes de una casa, es porque la otra está ya empeñada (núm: 900).

Para saldar una deuda de 4 mizcales se vuelve a empeñar la viña en 6 , habiendo de emplear los dos mizcales para obras y reparaciones en la pared de vallas que dejo abandonadas el marido de la prestataria (núm. 903); o pasado el año de plazo, se aumenta la deuda a 7 mizcales (núm. 004); o se entrega a otro prestamista anterior, en cuya escritura se escribe, interlineada, la nota de pago, y se le entrega al segundo prestamista (núm. 905).

Si el prestatario reclamaba contra alguna accion que pudiera ejercitar el prestamista, habría de pagar una multa de 50 mizcales (núm. 908).

Se especifican, a veces, las causas que mueven al empeño: uno lo hacia la mujer para rescatar a su marido, adalid, cautivo (1167); si paga a los tres años, queda libre de la deuda; si no paga, puede prorrogar un año más el contrato; si no es posible la prórroga, el prestamista cobrará su dinero, de cualquier parte y sin excusa ni dilación (lo cobró de la venta de la casa a un tercero, según nota interlineada); la mujer se obligaba a que su marido aprobase lo hecho, a su vuelta (como lo hizo, tres meses despús ), y si él no se obligara, la mujer cumpliría este contrato en todas sús partes (núm. 898).

También se declara de quién es el disero, si tiene parte en él otra persona distinta del que contrata: hijos (núm. 899), hermano (núm, 904), o aprueban las persorias interesadas: hijos de la pignorante (núm. 904), el hermano (núm. 900).

. Una vez se ve la segunda hipoteca (año 1176, núm. 900) de una casa en Zocodover, empeñada ya por dos veces.

Del precio de una venta se separaba la cantidad adeudada (núms. 320 y 462), entregando el resto (núun. 159). Si los acreedores de un mismo deudor cran varios y con la misma garanlía, presentaban al alguacil y alcalde las escrituras de sus deudas; el alcalde se certificaba de la verdad de tales escrituras y mandaba vender la casa, después de pregonarla públicamente durante más de dos meses, al cabo de los cuales se verificaba la venta y se repartía el precio entre los acreedores, "según dispone la ley en las compras y ventas por causa de deudas obligatorias* (núm. 340). Acreedor el hijo de la madre, que le había empeñado una casa, al morir la madre, este hijo gast 6 en los funerales y sepuitura; sus hermanos le adjudican en la partición la casa (núm, 486).

En prenda de una deuda se tomaban cumo rehenes tres esclavos: el acreedor tos entrega a un depositario, que se obliga a entregar los esclavos cuando se le pidieran; o si no lo hace, a pagar su valor de 50 mizcales (núm. 934).

$\therefore \quad$ Curioso es el testimonio que repruduce una conversación callejera de 1197 : En medio de la calle, cerca del Pozo Amargo, el acreedor pide a la deudora que le pague sus 7 mizcales y 4 sueldos. Ella le da largas; pero él ya no quiere esperar más tiempo. Eilla le entrega como prenda el manto de escarlata que lleva puesto. Él se lo 
devuelve, pero advirtiéndola que si no paga en el plazo que ahora dice, se incautará del manto (núm. 1,001). El becho de haber necesitado aquel testimonio, induce a pensar que la hábil deudora supo eludir el pago.

El acreedor se apartaba de los derechos que uno tenía en ciertas fincas hipotecadas, al darle recibo de la cantidad devaelta; pero seguía teniendo en aquellas fin. cas derecho por otro préslnmo a otro copartieipe (núm. 1.083).

\section{PLEITOS: PROCEDIMIENTOS}

486. Más de una vez el jitigio no se arreglaba entre los interesados por convenios ni por los oficios de hombres buenos, y entonces intervenian los tribunales de justicia.

487. Poderes. - Si el interesado no acudía a llevar directamente la voz de su demanda, podia nombrar un apoderado (4) que obrara en su nombre (nú. mero 944). Por medio del poder, el apoderante ponía en su lugar al apoderado y lo colocaba en su propio puesto y le daba facultad para afirmar y negar, para tomar prendas, recibir testimonios, si era preciso, hacer lo que mandara la ley o el fuero, y contestar en nombre del apoderante a todas las reclamaciones que pudieran hacerse, con facultad de subrogación en otro apoderado, y después que los otorgantes estaban enterados del alcance de su aclo, sin ignorar nada, y siguiendo la ley de los cristianos en sus apoderamientos legales (núm. $1.125 \mathrm{~A}$ y B).

lìn cuatro gi'zpos principales pucden clasificarse los pleftos que figuran en nuestra colección, según que se reclamara la propiedad de casas o tierras, o herencias, o el pago de deudas, o el arreglo de dercchos de plantación.

488. Pleitos sobre propiedad de casas y tierras. - Es el más curioso el tramitado en el año 1115, que nos da idea de la organización de la justicia en la época más inmediata a la época islámica. El señor del castillo de Mora pone en él a dos te. nientes y luego pide al alguacil zalmedina de Toledo que dé a cada cual una casa en la ciudad. El alguacil da al nádir una en el barrio de la Catedral; otra al otro en el mismo barrio y cerca de aquílla. Cada cual tomb su casa, y el segundo, Suncho Carlón, vivió en ella hasta su muerte en servicio del rey.

De estos hechos daban testimonio varios, en confirmación de la caría del zal. medina, escrita en lat́n y dirigida al alcalde I). G.... y al alguacil D. Julián, por la cual daba «illas dcas casas que mi dixistis .... unam ad Sancium et alian ad Michael Vellidez, pro dare et vendere, et quaecumque voluissent facere de illas, sicut est foro in Toleto»; carta sin fecha, pero firmada por varios testigos.

El diácono Martín, de la Catedral, sucesor en los derechos de Sancho Carlón, se 


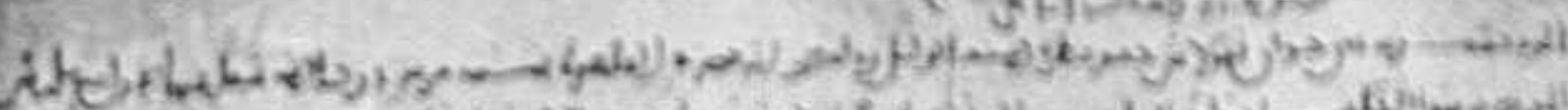

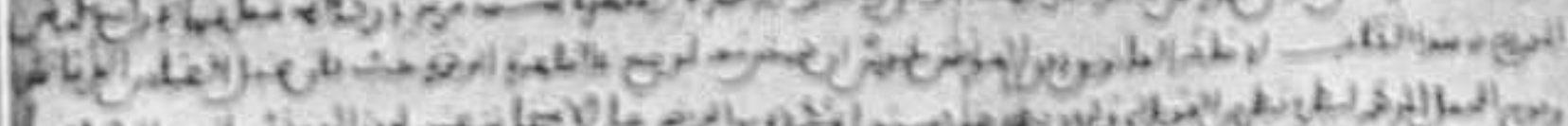

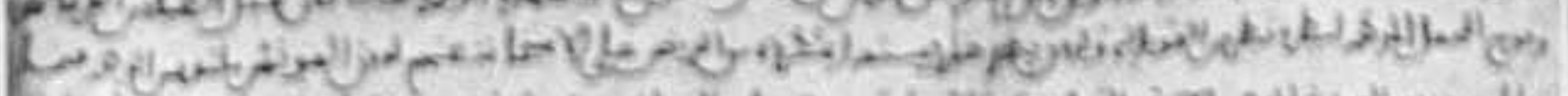

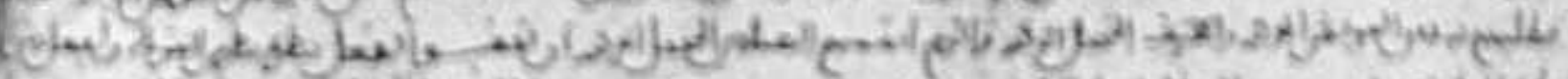
(Wigh)

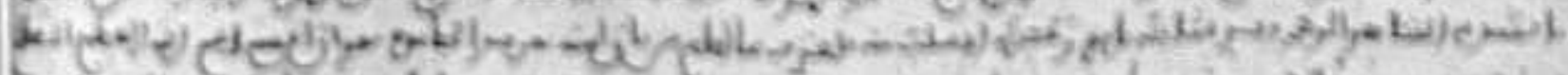

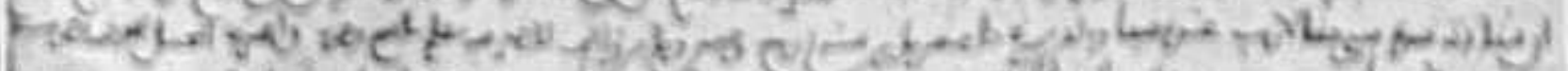

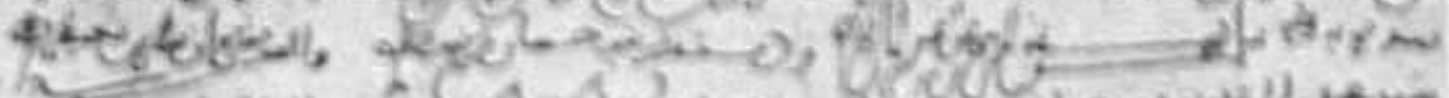

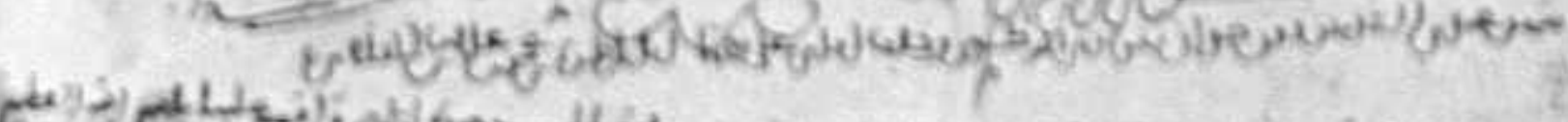
44 f

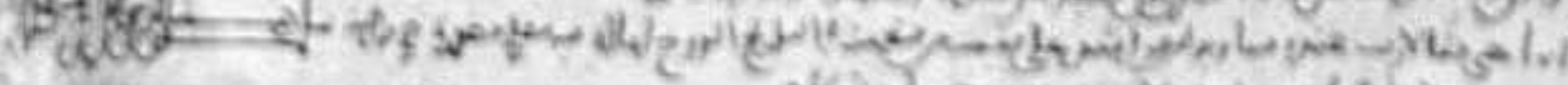

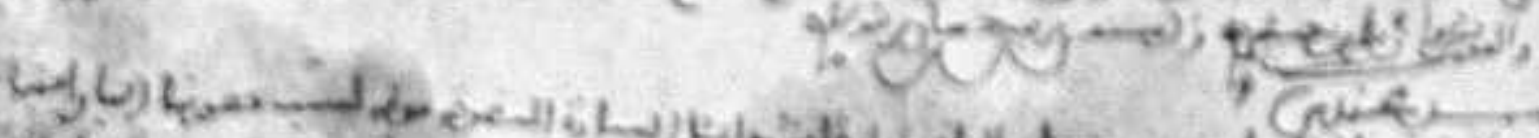

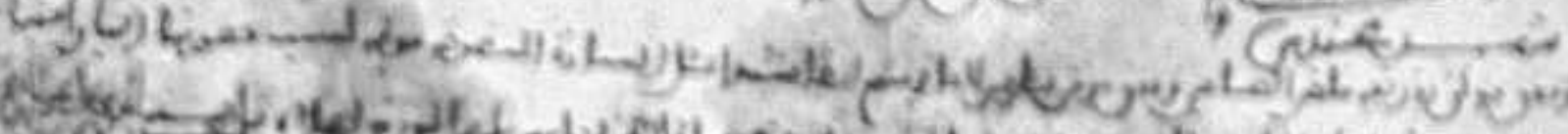

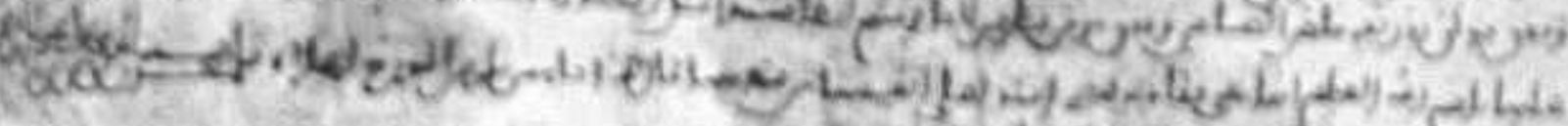

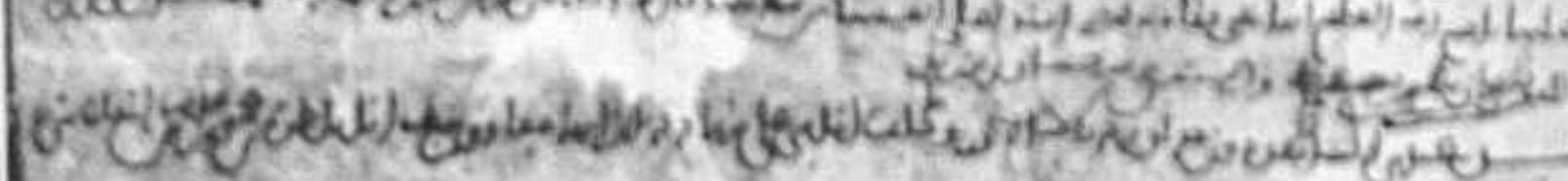

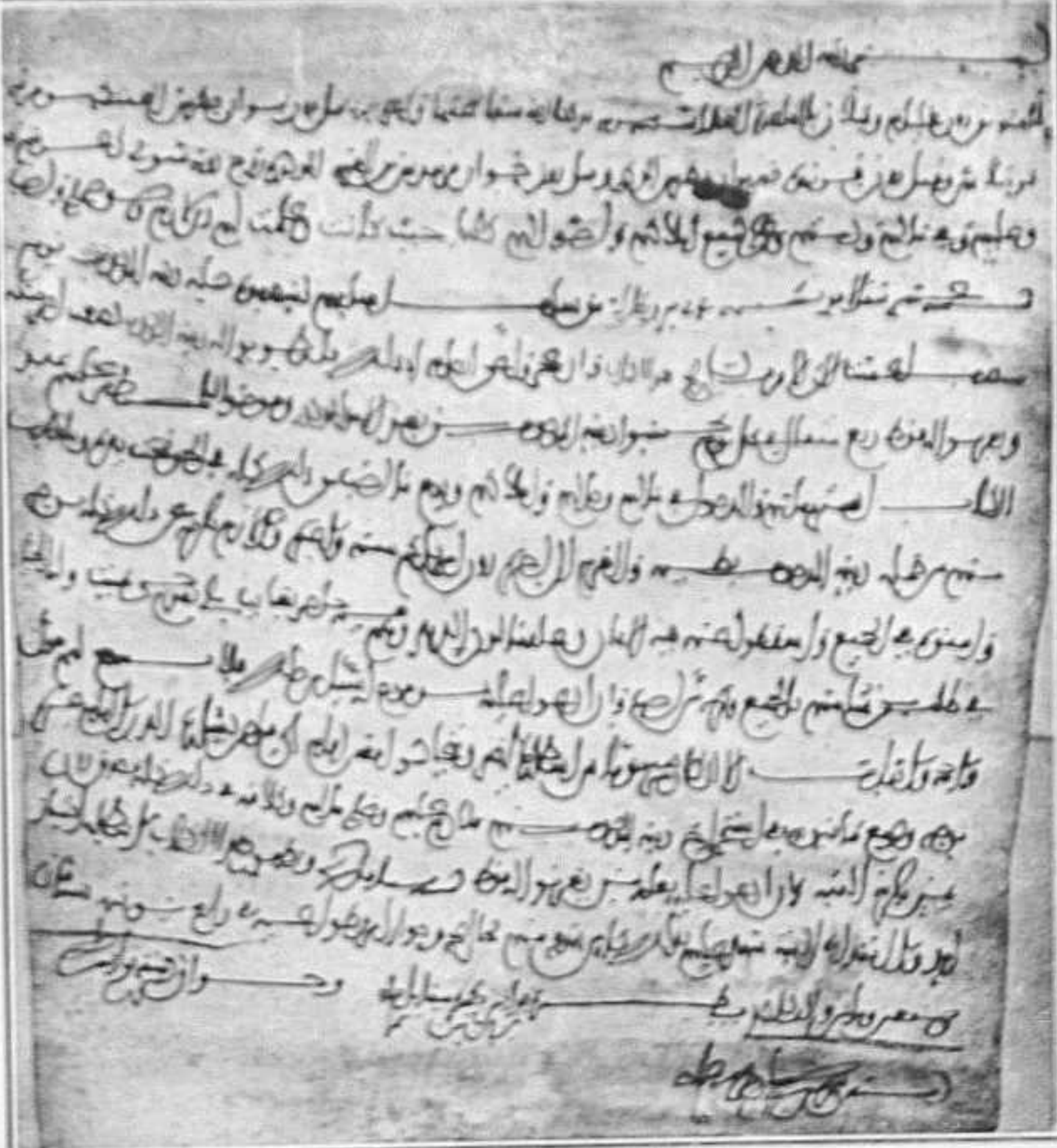


presenta ante el tribunal de los alcaldes (مجلهب القذار), ante cl alguacil y alcalde Inz. rán, teniente del alguacil y alcalde supremo Abulhasán Hátim ben Hátim, exponiendo: que el señor Juan Rodmírez, en los días de su gobierno de la ciudad, dí a Sancho Carlón una casa en el barrio de la Catedral, casa que él tom 6 y habitó hasta su muerte. Y mostró la carla de donación, alrás citada. Le dijoron que no bastaba la carta.

Entonces pidió a los dos alguaciles, el alguacil supremo Abulhasán ben Hátim y el zalmedina Abuzeid ben Harits, que le concedieran informacion verbal ante ellos y ante el concilio, respecto del citado senior. Concedida, presentó Martín a los mismos testigos que Juan Rodmírez había puesto en su carta latina; éstos declararon al tribunal, y en presencia del háquim Martín iGarcés?, que habían sido testigos, y que el zalmedina había dicho: "Yo he dado una casa a Sancho y otra a Micael Vellidez.» Los alguaciles encontsaron suficiente esta prueba, y dieron a Marlin po. sesión de la casa, con esto por senjencia (núm. 940).

No hallamos ejemplo de otro pleito semejante hasta fines del sigio XII, año 1197. Cantivo Micael Lázaro, escribía carta a varios primos suyos, que llegaban desde Calatrava, diciéndoles que vendieran su casa y su viña, y compraran algo con que rescatarlo del cautiverio, dando cuenta previamente al alcalde. Este, conocida la carta, autorizó la venta. Pero la viña estaba empeñada por el mismo cautivo a favor de Pedro Almorávide por 50 mizcales. Subastada públicamente la viña, fué adjudicada a Pedro Lázaro, por 19 mizcales (núm. 943).

Dentro ya del siglo XIII hay más pleitos y con más noticias. El primero es el seguido por Alfonso Meléndez con su madre María Peláez. Reclamaba el hijo a la madre cuatro tiendas en San Nicolás, para vender harina, que ella había rescatado de manos de Munio Amurcho con dinero del hijo y con promesa posterior de dárselas en propiedad; más parte de un mesón en los Bruñidores, que era del padre; más 20 mizcales que al hijo tocaban en un molino que vendieron al alguacil y alcalde D. Illán Estébanez. La madre rehusaba la contestación, negando que hubiera pro. metido lo que se decía, y a lo demás contestaba extensamenle. Al fin llevaron el asunto ante el alguacil y alcalde 1). Llián Listébanez; pero por intervención de gen. tes buenas se llegó a un arreglo consistente en que la madre cedfa la propiedad de las cuatro liendas a partir de la fecha, y el hijo se daba por pagado y renunciaba a toda demanda posterior (núm. 946).

Pretendía un yerno que, al țiempo de su matrimonio, el suegro había dado a el y a su esposa parte de una casa en los Plateros. El suegro lo negaba ante el foro, y éste mandó al yerno que demostrara su aserio, dándole para ello un plazo de tjempo; no lo hizo, y le día atro segundo plazo, y tampoco presentó su prueba. Entonces el háquim díb la casa al suegro (1218), puesto que no la había donado a los hijos, sino que únicamente babía permítido que vivieran en ella por deferencia hacia ellos (núm. 951). 
Ante el teniente del alcalde D. Diego Petrez reclamaba un nieto de Pelayo Ve. lázquez contra Martín de Valencia sobre una casa en San Nicolás (1216). El reclamante contestaba que él la habia comprado a un Castro, que había comprado a un nieto de Velázquez; que éstos habían poseido la casa y la cedieron por venta a este poscedor. Replicaba la parte reclamante que el bijo de Velázquez murio sin sucesion y su herencia fué a parar a una hermana. Insistía la otra parte en sus afirmaciones. El alcalde dió sentencia: Que juren dos testigos del contrato de venta por el primer Velázquez, y después no oigan reclamación contra el comprador, y que no tenga Martin de Valencia nada que ver en la casa, sirio que se la enlreguen par virtud de la cláusula adicional que escriban al final del documento de compra. Y así se hỉzo y escribió (núm. 954).

El convento de San Clemente y un particular discutían solsre la propiedad de ciertas tierras (1). El alguacil y alcalde se reúne con los del Consejo para tratar todas las alegaciones y pruebas, que cada una de las partes litigantes habian aportado respecto a los frutos y bienes ráces que cada cual posee. Ven que el emperador habia dado la alquería (de Argance) al convento, to misno que las demás alquerías de Toledo. Fallaron en favor del convento según el acta de donación. Y rechazaron la reclamacion del demandante, negando o contradiciendo sus razoncs.

Alegaba el reclamante la prescripción de treinta años y de cincuenta años. No hubo lugar a dejar pasar esos años, porque entonces la alquería estaba en poder del convento, y los bienes de la iglesia no se exceptúan de la prescripcion. A lo que decía de ciertas abstenciones de las abadesas, contestaban que éstas no podian obrar sin aprobación de las monjas y del arzobispo, scgún la ley y los cánones sucesivos.

Como el reclanante no demostró en su alegación nada de exacljtud, rechazó el tribunal su peticlón, como habla rechazado lo referente a los pastos, puesto que el documento es el acta reai anterior. Por tanlo, los herederos del reclamante habran de abandonar las tierras que ocupasen en la alquería y todo vendría a ser propiedad del convento. AsI se escribió por fallo, en Enero de 1186 (núm. 941).

489. Pleito sobre herencia. - Por los derechos a ln herencia de Martín de Andújar signieron pleito su hijo Feliz y su nieto Alvaro, ante el alguacil y alcalde don Esteban Illánez, hacia 1200.

Prelendía lieliz que le tocaba íntegra la herencia, porque la madre del sobrino era masumana, y cuando Martín murió, Feliz ura cristiano; y decía que Alvaro había cogido ya el dinero del abuelo, y ahora quería quitarle a abuelo.

Alvaro contestaba que si se habra apoderado de la herencia del abuelo, fué porque le pertenecía exclusivamente por ser nieto, y porque su abuelo lo había me- 
jorado con el quinto de sus bienes, y porque el abuelo, testamentario de su padre no le había dado la lierencia de éste.

Se prolongó el pleito, hasta que, gracias a la intervención de mediadores, llegaron a un acuerdo, tanto en los dineros, como en una casa, propicdad del causante (núm. 945).

490. Pleilos por deudas, - El més antiguo es de $1199, \mathrm{y}$ se tramitó ante el toniente de alcalde D. Diegro Pérez. La demandada, María Heláez (representada por su abogado), había empeñado a D. Lambertón y a su liermano Domingo (cuyos herederos reclamaban) un mesón en los Cambiadores, Arrabal de los Francos, por $30 \mathrm{miz}$. cales alfonsies, según mostraba la escritura de empeño que presentaban. Élla, pasado el plazo, se negaba a pagar, y los acreedores querían cobrarse en el meson.

El abogado no respondía y daba largas al asunto, hasta que el alguacil D. Mu. nio decretó que doña María entregase el mesón y pagase. Elia se negó al pago de la deuda y lo difiłió. Eil algnacil y alcaide mandó vender en pública subasta el mesón empeñado, según costumbre, y el acreedor presentó al alcalde al pregonero D. Juan el Ciego, su sobrino, a quien le mand6 vender en subasta el mesón. Lo pregonó, según costumbre, y salíb únicamente un comprador, que ofreció por él 31 mizcales de oro.

Entonces, el alcalde mand 6 al representante de los acreedores que tomase dos testigos y bajase con ellos a la deudora y le notificase la venta del meson, hecha por orden de dos jueces, segín costumbre, y que ella dijese si aprobaba o rechazaba la dicha venta. EI representante, con tres testigos, y por mandato del alcalde, bajo a casa de la deudora, y la informaron de lo ocurrido. Ella respondió, según declaran los testigos: "GPor venta del alcalde, o por mano de quién se ha hecho? - El abogado de los acrecdures le respondíb: A No podemos esperar más tiempo de lo que hemos esperado este dinero. - Ella replicó: «Haced to que el alcalde os ha mandado. $:$

Volvicron los testigos a presencia del alcalde y declararon lo sucedido: el alcalde decretó la venta; compareció a su presencia el comprador y le entregó los 31 mizcales. El alcalde dió 30 al representante de los acreedores, que los recibio en nombre de sus parientes, y dió al comprador la escritura de empeño; dejó el mizcal restante en poder del comprador, hasta que la deudora aprobase la venta, y entonces ella lo cobraría; y puso en posesión del meson que se delimita, al citado comprador.

Por segunda vez, el representante de los acreedores fue, con tres testigos, a casa de la deudora y le notific6, de orden del alcalde D. Diego, lo ocurrido. Ella no contestó nada. 3 jaj 6 con ellos también otro testigo más, y se lo notificaron por tercera vez. $Y$ en vista de la declaración de estos testigos, el alcalde decretó la venta, según se ha dicho, y así se concluy6: con testimonio de todo, de los testigos, y en presencia del pregonero que subastó, a tal fecha (núm. 944).

Los mismos trámites sigue la venta por deudas de una casa empeñada por 
Orabona en 7 mizcales; pero como Orabona ela viuda y tenía una hija menor, fué precisa una declaración de ella ante cl alcalde de que *no tenía dinero paia comer ella y su hija, y de que su marido, al morir, le había dejado estas deudas y no tenía con qué pagarlas». El alcalde mand 6 vender la casa y pagar las deudas y el entierro del esposo: el precio de la venta cran 33 mizcales, de los que 7 se entregaron al acreedor, 5 para el entierro, y el resto se entregó a la viuda para ella y su hịja por igual (previo el señalamiento de fiador respecto del dinero que había de darse a la menor). El acreedor y otros testigos declaran que la casa se había subastado en pública almoneda más de treinta días, no teniendo mejor postar, y que la viuda estaba en suma pobreza. El alcalde entonces aprobó la venta, y la viuda se com. prometió a guardar la parte de la menor (núm. 953).

A las mismas notificaciones, subastas y plazos se sujeta la venta de una casa en Olías (1218), en reclamación suscitada por el convento de San Clemente: un presbítero le habia donado el quinto de sus bienes, pero a su muerte, un incrmano del presbilero rehusó entregarlos, y luego, a instancias de la abadesa, se avino a dar 12 mizcales, en cambio; negósc otra vez, y se convinieron, por fin, en que pagaría en tres plazos. Como ni aun así pagara, se hizo la venta de la casa del donante por mandato iudicial (núm. 955).

Un verdadero concurso de acreedores plantea el documento número 958. Muere Ponce Pelrez con varias deudas a judíos, según escrituras, y su tia Lupa se queda con la herencia para eobrarse de otras que con ella tenía. Pero uno de los judíos, acreedor por 255 mizcales, reclama a Lupa ante el alcalde $D$. Gronzalbo Juanes. Presentaba sus dos escrituras, más una carta del rey, en que éste mandaba al alcalde que en cuanto viera su real cédula, hiciera comparecer a todos los acreedores con sus respeclivas escriluras de préstamo: si las de Lupa o de otro pariente son más antiguas que las del julío, véndanse los bienes y páguese primero a aquellos, y luego al judío; si es al contrario, páguese primero al judio, según fuero y derecho; y autorizaba el recurso de alzada de aquella resolución ante el rey únicamente; advirtiento, además, que Lupa mo tendría derecho a reclarnar uada contra el judio.

El alcalde, así que vió esta real carta y confrontó las diversas escrituras de prés. tamo, reclamó, con ellas delante, a Lupa los bienes de Ponce, que había retenido, y mando a los acreedores vender estos bienes para pagar las deudas por orden de su antigüedad, seǵńn mandaba el rey. Previn la reseña de los bienes, el alcalde orden $\delta$ la venta de ellos en páblica subasta, por treinta días, que pregonó el pregonero, y algunos más; el mejor postor fué una hermana de Ponce, que ofrecí 550 mizcales. Por los cuales se los venden, con aprobación del alcalde, que así había cumplido las ćrdenes del ney. El reparto de esla suma se hizo así ol judio, acreedor por 255 mizcales, le dicron 180; al acreedor por 272, le dieron 260 (la viuda del acreedor hizo gracia de atra escritura de 80 mizcales, ya que uno de los parientes del difunto deudor había sido su apoderado ); los 110 mizcales restantes se entregaron a Lupa y 
su hijo, para pago de otras deudas. Llevaron el asunto al juzgado en 1262, a los diez años casi de transcurrido el plazo del préstamo.

Otras veces, la acción del acreedor se ejercfa contra el fiador del prestatario. Reconocida la deuda por el fiador y aceptada su responsabilidad, el alcalde le daba plazo de nueve días; pasado este plazo y varios días más sin hacer efectiva la deuda el acreedor volvín a reclamar. El alcalde decretūba el embargo de bienes del fiador; no siendo suficientes para el pago, el acreedor lo solifica aś al alcalde. Este manda vender en pública subasta una casa, que se pregona por treinta dias, con el tipo mínimo de la deuda: el mejor postor ofrecía 3i) mizcales. Iil acreedor llevaba al fiador a la presencia del alcalde y le notificaba el caso, reclamando que decretase la venta. Ei alcalde preguntaba al fiador si tenfa quien diese más, o si no, que mandaría vender la casa. El fiador ofrecía presentar quien pagara más: por lo cual el alcalde le dio nuevo plazo. Pero transcurrido sin ex!lo, el alcalde hubo de mandar 1262 ) venderla por los 36 mizcales, on presencia y con aprobación del fiador.

(Se advierte que el alcalde que actuó fué otro que el indicado en el documento. Recibe el dueño de la casa 20 mizcales más del mismo comprador, pues el precio eran 50 mizcales. ¿Se ocultará la verdad del precio para evitar que el acreedor, judío, arramblara con todo?) (ním. 959)

El acreedor se convenía con los herederos del fiador para el arreglo de la deuda, $y$ se quedaba con alguna prenda. El alcalde mandaba que se quedase definitivamente con la prenda, por falla de contestación de la otra parte; y así se hute eu virtud de seutencia dada en nombre del alguacil y alcalde. Pero luego el heredero del fiador comparece ante el juez, pidiendo que el acreedor se aparte de la prenda; éste contesta que pucsto que la lia poseído más de tres meses, no la dejará.

Así estuvieron por espacio de dos años o más (1629). Hin este plazo, el heredero del fiador pidió copin de las citadas escrituras, que el alcalde ordenó darle; y murió sin haber reconocido al acreedor su derecho, ni nadie en nombre del ditunto. Por esto, el acreedor pide al alcalde que se le reconozca su derecho con preferencia a los herederos de ella. El alcaide mandó vender la casa en la forma acosiumbrada, para pagar la deuda, ya que el difunto ni pagó, ni dejó orden de pagar, ni nadie había hecho oposición. Así se hizo; pero el acreedor se quedó con las escrituras de préstamo, puesto que no había cobrado íntegra su deuda (núm. 960).

Los decrelos dando plazo de nueve días al deudor solían ponerse al pie de la escritura de préstamo (nóms. 964 y 965), así como entre líncas se anota la canlidad abonada a cuenta. Se echaba mano de los bienes muebles del deudor en primer lugar, y cuando faltaban, se recurría a los inmuebles. Aunque sólo reclamase un acreedor, se pagaba a otros, que se presentasen despues, siempre que huhiese fondos (núm. 964)

Por raro caso, el deudor ejecutado en 1294 es un judío que habia recibido del alguacil Juan García 3.000 mizcales para sociedad mercantil, por plazo de un año. 
Al pie de la escritura que presentaba cl acreedor constaba el decreto del alcalde para pago de 1.560 mizcales. Vendióse en subasta casa y tienda del deudor; salio un postor. El alcalde dijo al deudor que buscase quien diese más, o se quedase él mismo con las fincas por este precio. Respondio que no tenía quien diese más por ellas, ni quería comprarlas, ni tenía dinero pana pagar la deuda (delía de ser a fines de Mayo). El 11 de Junio, viernes, comparecío otro judío, y dijo al alcalde que la mujer del deudor tenfa cicrtas escrituras de deuda de su marido a ella, anteriores a la que motivó la demanda. El alcalde mandó que viniese a su presencia el martes siguiente ella o su representante, y trajera las escrituras para leerlas, ver sus fechas, y después obrar en justicia. El martes la esperó, durante el tiempo que administraba justicia, en la puerta de la iglesia de San Salvador, y al terminar los juicios no había comparecido la judía, ni otro en su representación; la llamó a gritos y nadie respondió por ella. Entonces el alcalde, en presencia del acreedor y del comprador, mando al escribano que redactase la escritura de venta a favor del único postor, por 1.600 mizcales. Del precio quedaron en poder del comprador $500 \mathrm{miz}$ cales, para entregarlos a quien el alcalde ordenase, para hacer la evicción legal. Al acrecdor le entregó 1.100 , de los que dío cvicción, y se quedó con la escritura de deuda, para reclamar lo restante al deudor y a sus bienes. Lo que el acreedor habia recibido antes de ahora (o sea 1.440 mizcales), habia sido parte del capilal y parte de la multa; los 1.100 de ahora, por lo mismo (núm. 965).

491. Pleitos por derechos de plantacion. - Los tres documenlos que se conservan de csta clase se refieren a la misma persona: Eulalia, mujer del apodado * Hjo de Maliha , a quien reclamaba Iuan Dominguez sobre una viña que habra plantado aquél en tierra de Martín Gálib, llamado * Dirhen y' medio*, en Almoradiel. Juan Domínguez había reclamado del aHijo de Maliha personalmente, cuando vivía, y le día por fiador a Lucas el Herrero; pleitcó con este áltimo y obtuvo sentencia, que mostraba, de que la viña no había sido plantada, puesto que cuando reclamó no pudo dar su tesiato, sino de que planto, y cuando dió por fjador a Lucas se difirio la plantación y los dos pleitearon.

Los dos litigantes replicaron durante largo tiempo. El juez mando que demostrase Juan haber litigado con el * Hijo de Maliha y que le habia dado por fiador a Lucas; y que respondiese la mujer al reclamante, para terminar el pleito según la ley. El reclamante presentó varios testigos. Después que hubieron depuesto, el juez mando contestar a la otra parte (primera decena de Julio de 1209). Como la parte reclamada no respondiese a la demanda, el alcalde sentencia que el reclamanle entrase en posesión de la viria, segín los usos y costumbres actuales (fines de Julio) (núm. 949).

Eulalia, hija de Juan Rodríguez el Medidor, el reclamante citado, pleiteaba en 1214 con Pedro Lázaro sobre viña plantada en tierra de su padre por el *Hijo de Maliha . Mostraba la sentencia atrás citada (núm. 949), la prueba de 1199 y otra 
sentencia de 1201 , con Lucas el Herrero. El alguacil y alcalde supo que Gonzalbo y su padre se negaban a contestar, hasta que intervinieron gentes que llevaron a los litigantes al siguiente acuerdo (1214): Pedro Lázaro dib a Eulalia y a su esposo $9 \mathrm{miz}-$ cales alfonsíes, que ella recibió y con lo cual se acabaron las discusiones (número 952 ).

El mismo Itan Domínguez reclamaha (1209) a los testancutarios de doña Charina ante el alcalde D. Illán Estébanez por una viña, cuya tierra decía que era de él. Los testamentarios nombraron un opositor en su nombre, el cual presentó la escritura de compra de la vina por Charina y su marido a Eulalia, esposa del «Hjo de Maliha», que la había adquirido por derecho de plantacion en la ticrra de lucas, de la cual este Iucas había tomado la tercera parte y las otras dos habían sido para los plantadores.

El alcalde di 6 la razón a los testamentarios, pues el «Hijo de Maliha p plantó viña en tierra que te cedió D. Lucas y le dió a éste la parte que le correspondía, quedándose con la otra por su derecho de plantación; y dijo que el otro litigante reclamase a D. Lucas, pues no había reclamado contra el que dió la tierra para plantio, que habia dado este derecho al plantador. (Seguramente la tierra sería de Juan Domfnguez, quien se la dí a Lucas, y éste al "Hijo de Maliha") (núm. 950).

Suero Micael cesaba (1236) en la reclamación que venía haciendo contra los conventos de San Clemente, Santo Domingo y San Pedro en Alhicem, acerca de las viñas que les dio D. Alfonso Juanes y su mujer Misia, en Fontanillas (Talavera), quienes las habian artquirido por derecho de planlacion. Snero daba a las abadesas las fincas que les habia comprado en Cozcolla y Cozcolluela por 100 mizcales. Renunciaba a los derechos que le pudieran pertenecer en la herencia de D. Alonso, que había plantado en tierra de su abuelo, que lo era también de su prima Misia. Tres quintas partes de estas viñas serían para él; dos quintas partes para los conventos, y para éstos también la parte de tierra blanca en Fontanillas (número 995).

492. Procedimiento. - Del periodo inmediatandente posterior a la Reconquista de Toledo quedan pocas noticias para reconstrujr el sistema de gobierno de la ciudad. Habia, desde luego, nn zalmedina o sáhib almedina, que en 1114 era Juan Rodmírez, con el título de alguacil; éste repartía las casas a aquellos que se distinguían en servicio del rey, y comunicaba estas decisiones a dos alcaldes; con esto el nuevo propietario disponia libmemente de su finca (núm. 940, A y B).

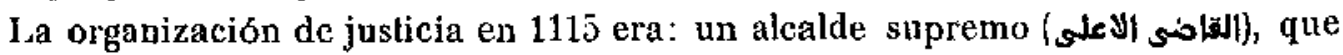
podía tener su teniente, recibía la reclamación. En caso de necesidad de prueba, el inferesado acudía a dos alguaciles, uno llamado alcalde y otro zalmedina, para hacer información verbal ante ellos y ante el concilio; presentados los testigos ante el tribunal y en presencia del háquim, declaraban los testigos; y luego fallaban (número $940, \mathrm{C}$ ). 
Los jueces del consejo o concilio que inlervienen en un pleito de 1186 son (nú. mero 941):

Arzolsispo I). Tiernardo.

Domingo, arceliano de Madrid.

Cerbanas, presbitera tolerlano.

Estebariz, de la iglesia tolexlana.

Pedro Dirz el Caid.

Hicans Sulsib.

Salomón ben Ali ben (iuaid.

Jair ben Salomón tron Ảli ben Guaisl.
Jálid iseu Suleimén ben Gasam ben Servando. ¿'aljatis?, obispo de Jel,let.

Jusepe hes Mansur, areipreste.

Iusius ben Abolnélie, presbitero.

ladro ben (Omar ben Gialib len Alcallés.

listcban .....

Rondrigo linteri\%.

De los documentos de pleitos, atrás analizados, se deduce que hab́a más de un alcaide, que actuaban simultáneamente. Llevada ante el alcalde la demanda, directamente por cl querellante o por medio de apoderado, el alcalde oía su reclamación; ofa la parte contraria; exigía la prueba documental o lestifical que le parecía necesaria. Las decisiones del alcalde se notificaban a las parles, que hab fan de darse por enteradas y aceplarlas, si era caso; en las ventas por deudas habia hasta tres notifcaciones, después de la pública subasta de la finca vendida durante treinta días o más, hecha por pregonero público. De las sentencias de los alcaldes no cabía re. curso de alzada más que ante el rey, aunque no hemos visto ningún caso de recur. so; más frecuente era llegar a un convenio, después de iniciada la acción judicial, arreglándose las diferencias con un arreglo sugerido por la intervención de hombres buenos.

El lugar donde se administraba justicia eran los pórticos de las iglesias; la de San Salvador se cita expresamente.

\section{F O R M L A S}

493. Las fórmulas empleadas en los documentos que vamos estudiando son de origen musulmán, aunque la legislación que se aplica es la cristiana.

Basta para comprobarlo hojear el manuscrito XLIV b de la Real Academia de la Historia, que contiene Actas nolariales y judiciales aplicables a los astuntos mós corrientes, obra de Abucháfar Ahmed ben Mohámed ben Moguejt el Toledano. Al folio 36 consta la fórmula de acta notarial de compraventa de una casa, que es idéntica, casi hasta en las palabras, a las empleadas en los docursentos mozárabes, como puede comprobarse cotejándola con la fórmula que nosotros damos en cl volumen I, págs. vi y vin: 


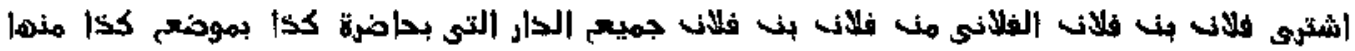

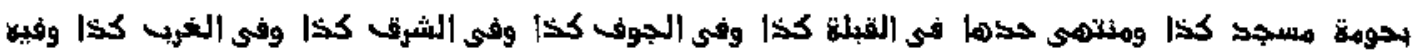

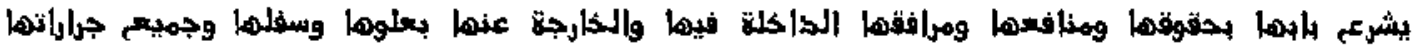

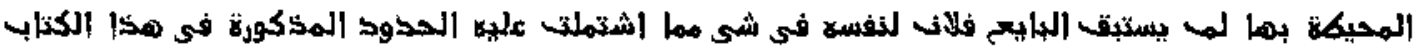

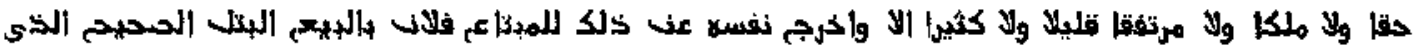

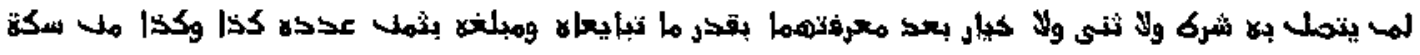

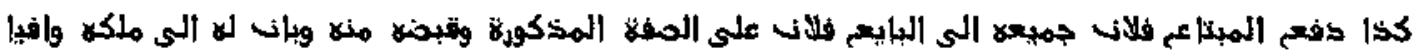

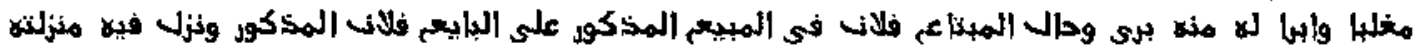

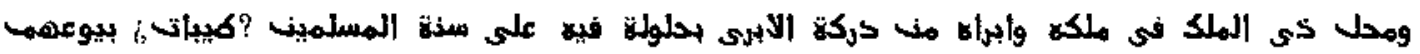

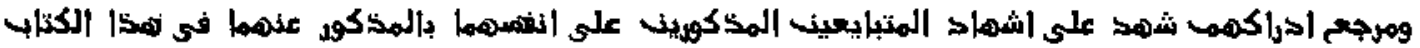

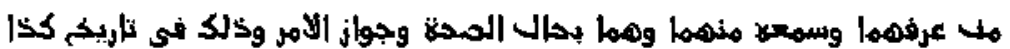

Lo mismo ocurre con la fórmula de compraventa de una heredad rística (folio 38 del citado manuscrito); la de compraventa hecha para un menor (folios $40 \mathrm{y}$ 40 v.); la de una escritura de cambio (folio 42 ), que sólo varía en la indicación «según la ley de los musulmanes»; la escritura de alquiler de una casa (folio 65 v.), de un fondac o de una tienda (folio 66); la de una sociedad mereantil (folio $72 \mathrm{v}$.).

Se ve, pues, que los cristianos de Toledo, durante la dominación islámica, debieron utilizar en sus contratos los formularios arabes, prescindiendo en absoluto de los formularios visigoticos (1). Y nótese además la influencia que estos formularios cristianos de origen árabe ejercieron en la redacción de documentos en la España cristiana, comparando la sequedad e imprecision de los contratos particulares otorgados en los reinos del Norte, al lado de la ajustada uniformidad de los contratos hechos por los mozárabes toledanos.

(1) Para la bibliografía de estos formularios véase a E. Hinojosa, Historia general del derecho espanol, Madrid, 1887, tomo I, pág. 365 .

El texto mismo de las formulas puede verse en Martchalar y Manrique, Historia de la legislación y recitaciones del derecho civil en Espana, Madrid, 1861, vol. II, págs. 37-86, o ou Monumonta Gurmaniae Historica, Formulae merovingici et karolini aevi, Hannover, 1886, págs. 572-595. 


\section{OBSERVACION FINAL}

Cuando empecé a redactar el estudio preliminar, que ahora concluye, pensé haber utilizado los datos que acerca de Toledo en los siglos XII y XIII contiene la documentacion latina y romance, $y$ en algunos pocos casos quedan mencionados. Pero el hecho de estar casi todos los documentos todavia ineditos, obligaba a repro. ducirlos, y esto hubiera dado una desmesurada extension a mi trabajo, sin contar con el tiempo que hubiera ocupado. Prescindi, pues, de la documentación no árabe.

Mas tengo la satisfacción de anunciar al curjoso y erudito lector que el INST1tuto de Valencia de Don Jian publicará lambión la colección de dactumentos latinos y romances que interesen a la historia de Toledo en los siglos XII y XIII, y entonces será ocasión para citar la bibliografía útil en la historia toledana medieval, que apenas se ha podido utilizar en este volumen.

Publicadas ahora las fuentas árabes, cuando se tengan a mlano las fuentes latinas y romances se podrá esperar que surja la historia de Toledo después de la Reconquisia, de tan alto interés para la historia de España. 


\section{A PENDICE II I "}

Integran este Apéndice algunos documentos hallados, después de la impresión del tomo III, en el Archivo del Cabildo de Párrocos, que se guarda en la iglesia de San Nicolás, en el Archivo del Ayunlamiento y en el convento de San Clemente, de Toledo.

Expreso mi gratitud a mis buenos amigos, los señores D. Autonio Sierra Corella, archivero del Cabildo de Párrocos, y D. Adolfo González. Vegue, archivero municipal, por haber tenido la bondad de comunicarme la existencia de estos documentos.

(1) Debe considerarse towo final del tomo III. I as stynaturas de eada documento véansi: on esie yolumen preljiminar, pág. 2 i 



\section{ESCRITURAS DE COMPRAVENTA}

\subsection{2}

Año 110\%, Enero.

A) Compra que hacen ¿Rifao? ben Yahya el Cantarí y su tía Alboniya y su hermana Scti, a D. Micael ben Amir el Siraff, de siete octavas partes de la casa que tiene dentro de la ciudad de Toledo, en el barrio de la iglesia de San Vicente (el octavo restante es de Socnf, hija de Munio Fernández), pro indiviso, lindaute toda la casa por el E. con casa de Nicolás, el que heredó de D. Martín el presbítero, y detrás de ella va la calle; por el $O$. con casa de los herederos de Micael ben Gálib y con parte de la casa de Juan ben Sahl; por el S. con la calle, a donde da la puerta; y por el N. con casa de Justa, esposa de Didaco, y con parte de la casa de Juan ben Sahl. Entra en la venta el derecho al sótano que está bajo la algorla de Domingo Mauricio el Pescador y los derechos que pueda tener en un solar y en lo que se construya en el solar, todo por precio de 35 mizcales de oro de Baeza.

Fecha en Enero de la era 1202.

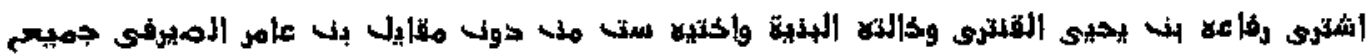

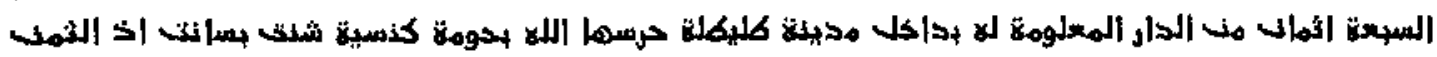

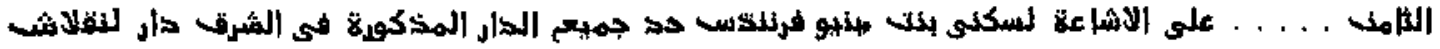

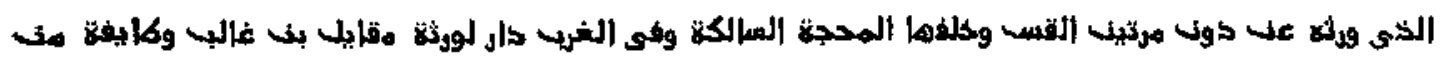

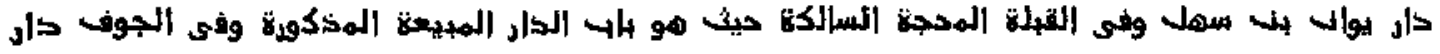

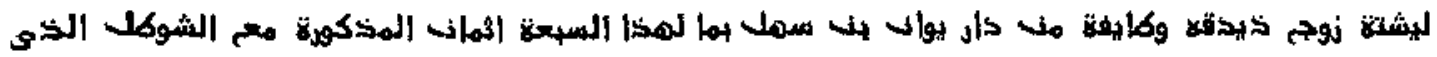

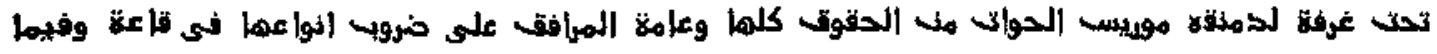

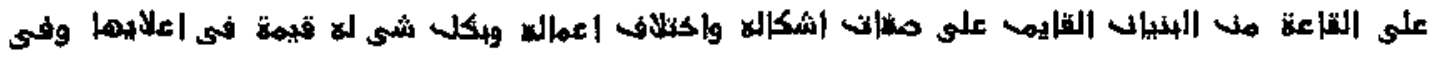

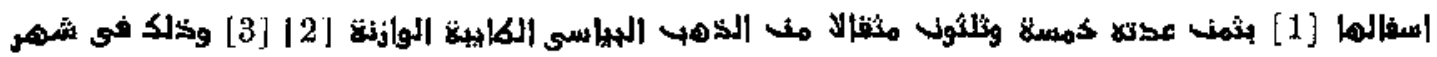

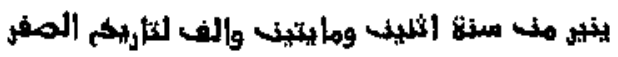


Ego Dominicus Catarusu, presbiter, testis. Hgo Stefanus, Iohani filius, testis. \& To-

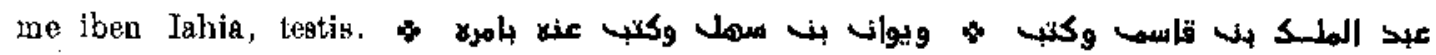
Micael Carafi, confirmo.

Año 116\%, Marzo.

B) Compran los mismos a la citada Socní el octavo restante por $7 \frac{1}{2}$ mizcales de oro de Bacza.

Fecha en Marzo de la era 1202.

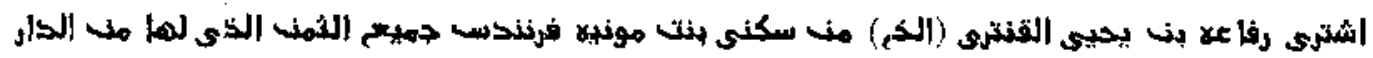

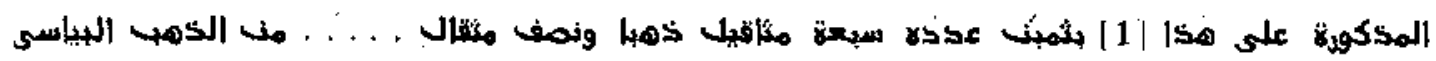

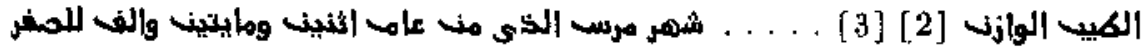

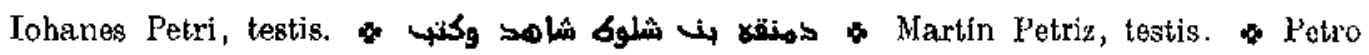
Mauro, testis. (Otras firmas ilegibles, por deterioro.)

Perganino: $0,495 \times 0,225$.

\subsection{3}

Año 1204, Agosto.

Compra que hace doña Eulalia, hija de D. Justo, esposa que fue de D. Pedro Juanes, el conocido por Hosain ben Gasán, a Domingo Juanes, bijo del amín Yahya ben Abderráhmen ben Zeid, de la viña que posee en el pago de Val de Santiago; jurisdicción de Toledo, lindante con viña de la compradora y majuelo de D. Munió Botato del Arrabal y con el camino que pasa; su noloviedad excusa mayor descripcion: por precio de 18 mizcales de oro alfonsí. Posef́a la finca por herencia de su padre y después de la partición con sus hermanos.

Entrega el vendedor dos escrituras: una la de compra por su padre de parte de la finca a Jacob, hijo de Domingo Salvador, y a su esposa doña Colomba, fechada en Noviembre de la era 1226 (año 1188), y de otra parte a D. Lope el Cárnicero y a su hermano Domingo, hijos de Esteban, fecha en la última decena de Marzo de la era 1227 (afro 1189).

Fecha en la última decena de Agosto de la era 1242.

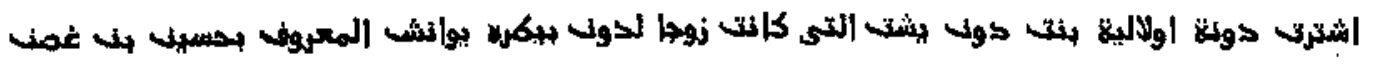

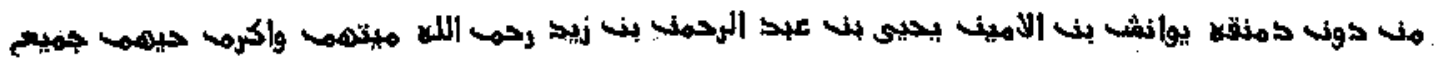

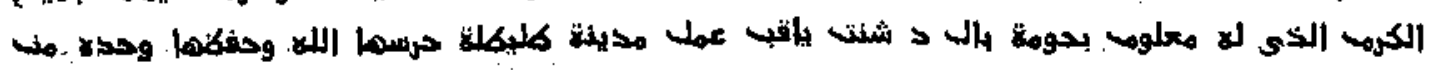




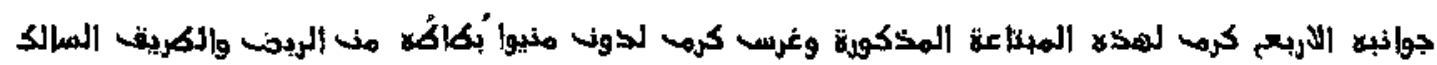

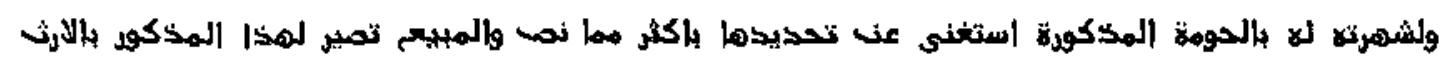

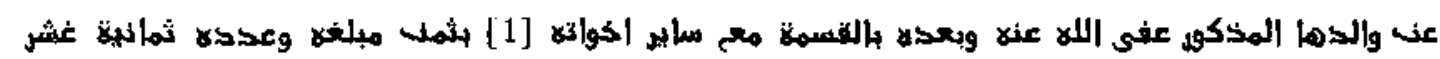

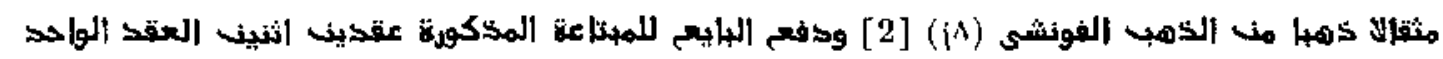

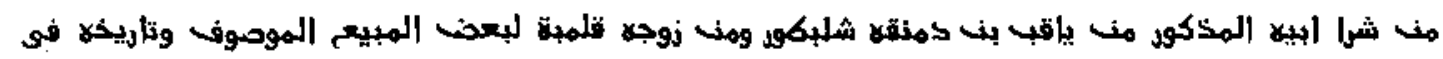

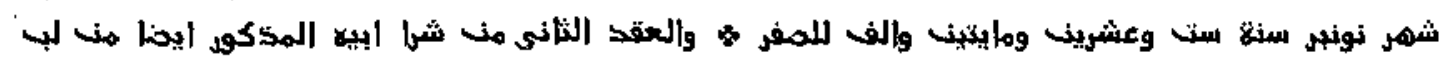

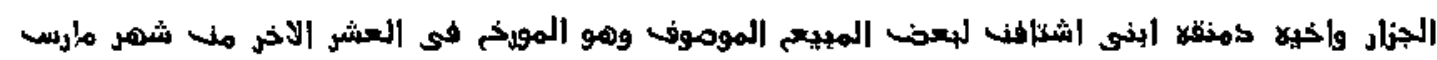

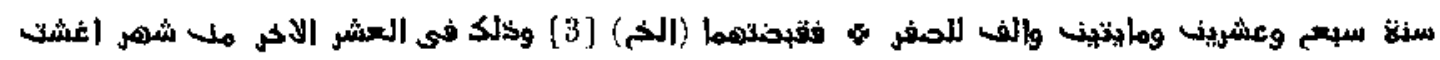

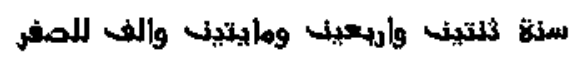

Ferrand Petri, testis. * Aldefonsus, subdiaconus, ecelesie Sancti Iusti, hestis.

Pergamino: $0,240 \times 0,325$.

\subsection{4}

Año 1219, Marzo.

Compra que hacen el canónigo D. Alfonso, hijo del alguacil y alcalde D. Melendo ben Lampader, dilunto, y su sobrino el alguacil D. Gonzalbo, hijo de D. Juan Martínez, por partes iguales, a D. Esteban ben Rinaldo y a su hermana doña Orabona ¿la Separada?, de la alquería de Peña Aguilera, de la Sisla de Toledo, que perteneció al presbítero D. Pedro Gelabert, el canónigo, tío de ellos como hermano de su padre el cilado Rinaldo, y de quien la habla heredado, por precio de 60 mizcales de oro alfonsí.

Fecha en la segunda decena de Marzo de la era 1257.

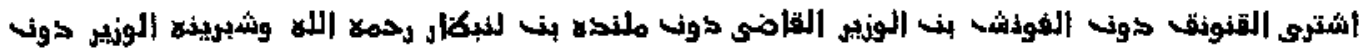

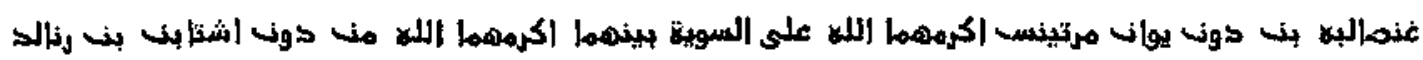

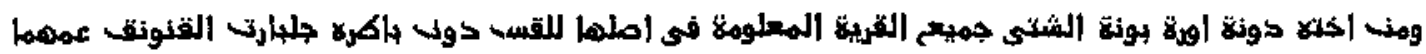

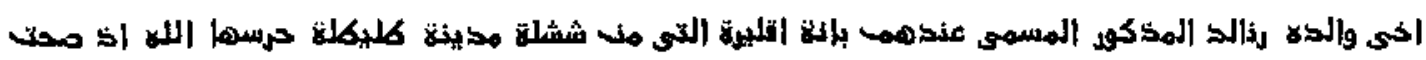

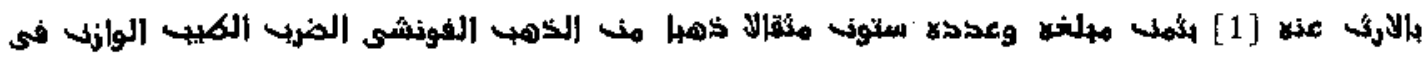

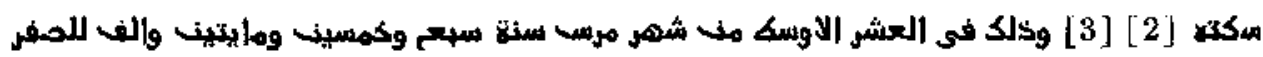

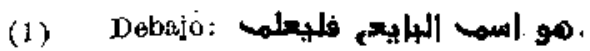




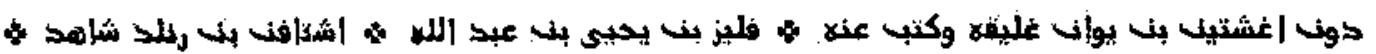

Fernandus Micales, testis. " Ego Félix, presbiter Saneti Antonini, testis. Ego Petrus Tome, testis. * Ego Rinaldus, subdiaconus, testis.

Pergamino: $0,30 \times 0,255$.

Al dorso: *Fsta es la carta de compra que compró el arcediagno D. Alfonso de Penna Aguilora de don Renalt el elérigo por JX mor.»

\subsection{5}

Año 1220, Enero.

Venta que doña Andresa, hija de Juan de Said, hace a lavor del arzobispo don Ruy Jiménez, primado de España, de la parte que a ella tocaba, por ser de su padre, en la alquería de Jumella, en la alquería de Yenesa y en la alquería de Casar del Asno, en la Sisla, jurisdicción de Toledo, por precio de 2 mizcales de oro alfonsi.

Fecha, después de leérsela a ella en lengua romance, que entendio, en la última decena de Enero de la era 1258.

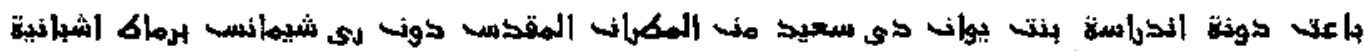

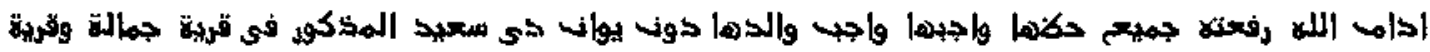

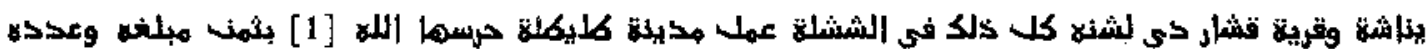

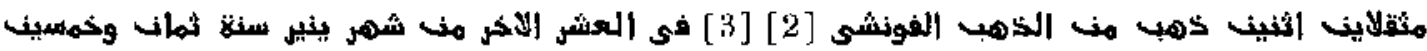

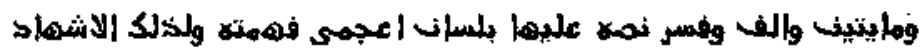

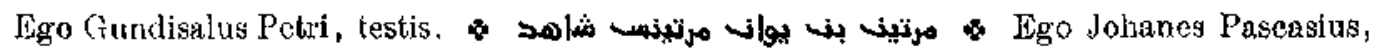

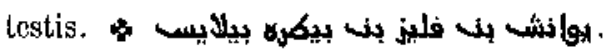

Pergamino: $0,215 \times 0,215$

Al dorso: "Carta de Jumolla e de Casar del Amo, .

\subsection{6}

Año 1220, Enero.

Venta que hace dona Loba, hija de D. Julián Petrez ben Daud, esposa que fué de Fernando Juanes, al arzobispo D. Ruy Jiménez, de una parte de las tres que su abuelo D. Micael ben Assid tenía en la alquería de Jumella, de Yenesa y de Casar del Asno, jurisdicción de Toledo, por precio de 2 mizcales de oro alfonsí.

Fecha en la última decena de Enero de la era 1258. 


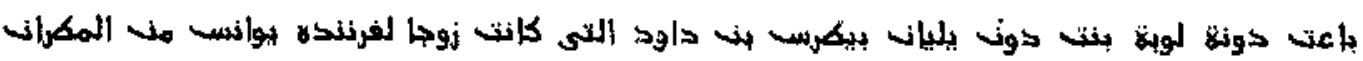

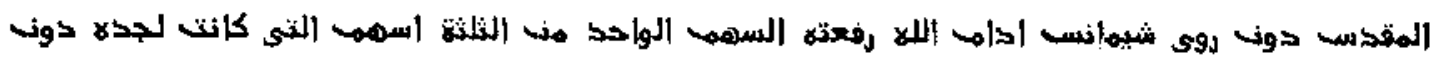

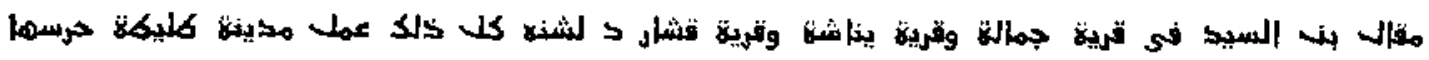

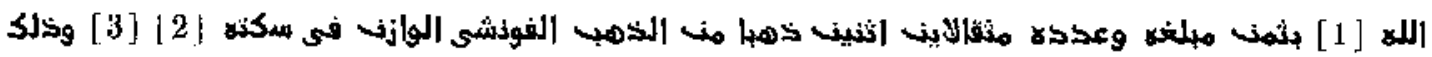

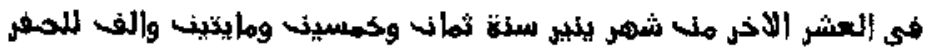

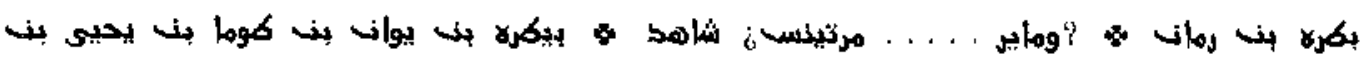

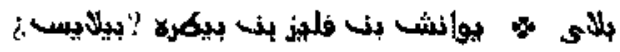

Pergatuino: $0,290 \times 0,200$.

Al dorso: "Iste V eartule :unt do Itunela et de Fnesa e do Casar del Asno.»

\subsection{7}

Año 1220, Junio.

Compra que hace doña Justa, esposa que fué de Juan de Salvatierra el Carretero, criada del presbitero D. Gálib Almogávar mientras vivió, a doña Sefi, esposa que fué del alguacil y alcalde D. Esteban Julianes, y a su hija con 6 l, doña Leocadia Estébanez, menor, de la casa que posee en el barrio de Santa Eulalia, dentro de Toledo, conocida en un principio por casa de Clemente, $y$ heredada con el resto de los bienes del alguacil mencionado; linda con casa y corral de ...., luego del dicho alguacil, y después del arcediano $\mathrm{D}$. García, su hijo, y ahora de su heredero; con la casa donde vive el presbítero D. Pedro Zarco, de Ja iglesia de Santa Lcocadia, con casa de D. Micael Petrez y con la calle, a donde da la puerta de la casa y de un sótano, por precio de 31 mizcales de oro alfonsí.

Fecha en la primera decena de Junio de la era 1258.

Entregóse la eseritura de compra a Clemente ben Daud y a su esposa.

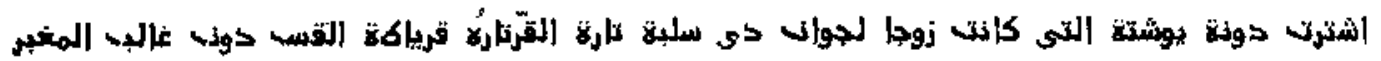

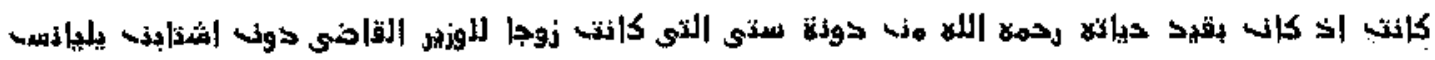

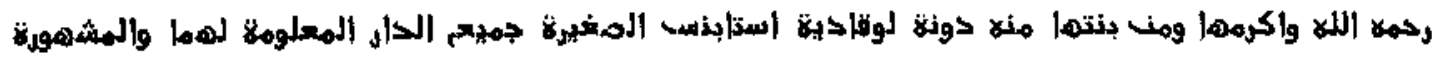

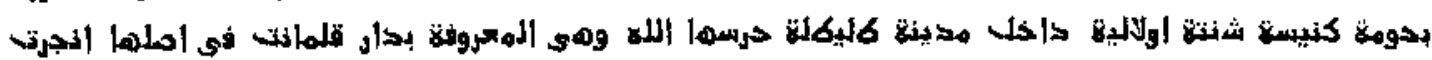

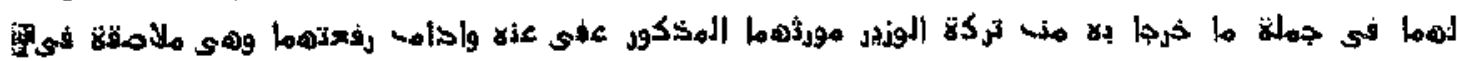

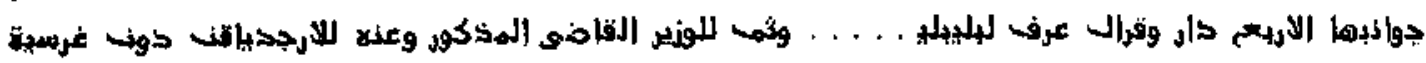

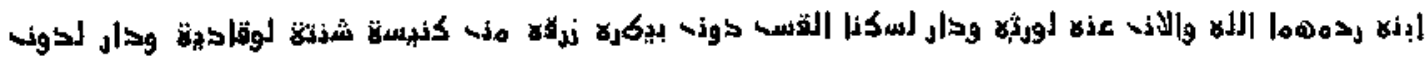

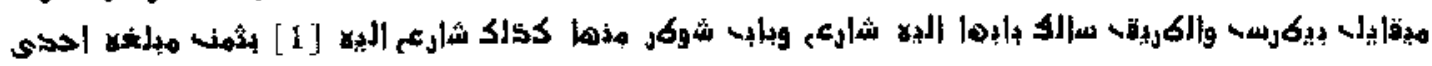




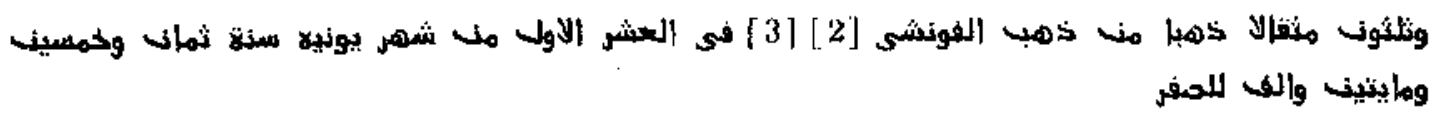

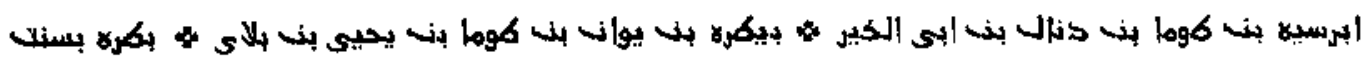

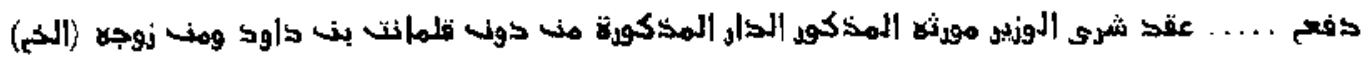

Perganino: $0,265 \times 0,225$

Al dorso: "Esta carta ce de dona Justa de la cara que compré. .

\subsection{5}

Año 1221, Junio

Compra que D. Alfonso el Canonigo, hijo del alcalde D. Melendo hen Lampader, difunto, hace a D. Juan Navarro y a su esposa María Micael, hija de Micael Petrez, de las losas que poseen en el puerto llamado del Carbonero, que son $36 \mathrm{sa-}$ mansas y media, y se toman desde el puerlo del Carbonero hasta el camino que sale del villar de Corba, hasta la villa de ¿Arangui?, hasta cl puerto de ella y hasta el puerto de Alhauir, y conforme se toma descle el Casar del Asno, hasta salir al puerto del Carbonero y al camino de ćl, todo en el alfoz de Toledo, por precio de 30 mizcales alfonsíes.

Los vendedores se obligan a satisfacer cualquier reclamación que pueda hacerse contra la finca vendida.

Fecha el lunes 21 de Junio de la era 1259.

Se indica que todo lo comprendido en los límites señalados entra en la venta, y que se han puesto las firmas después de leer a todos el dócumento en lengua romance, que entendieron.

Están presentes y aprueban lo hecho doña Dominga, hija de la vendedara, y su marido Marcos.

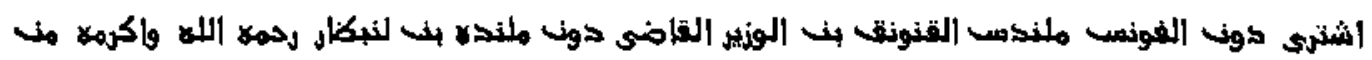

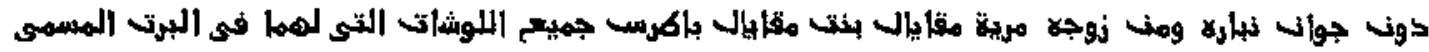

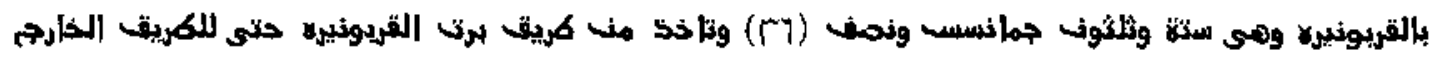

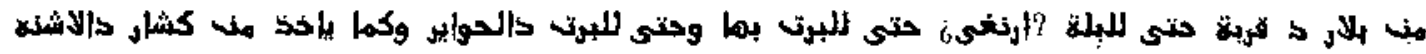

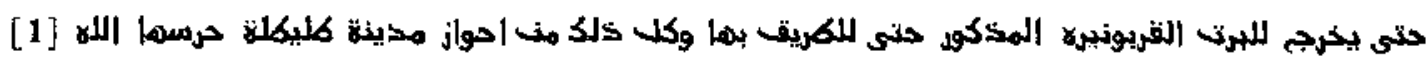

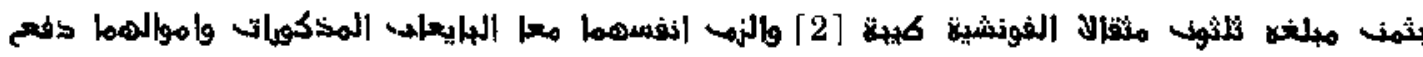

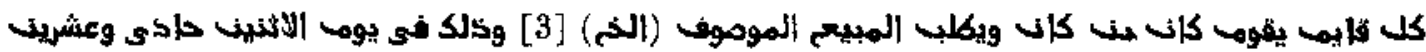




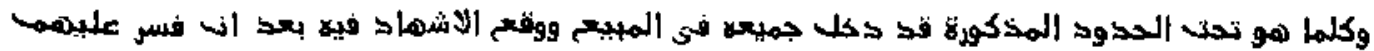

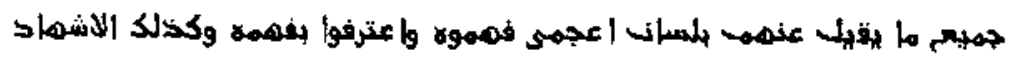

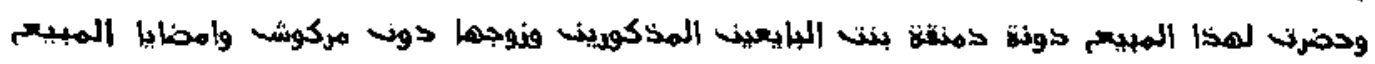
الموحوف (لنح)

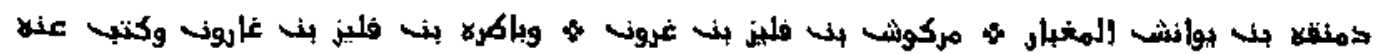

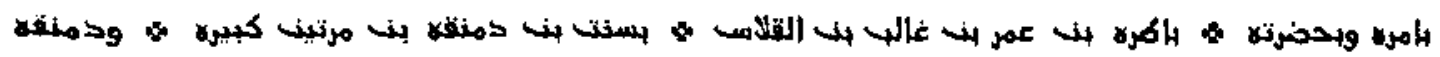

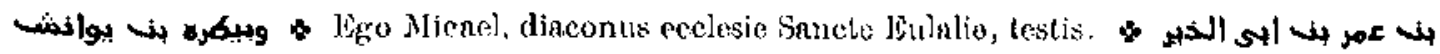
هن وليد بل قاسهـ Pergamino: $0,3: 30 \times 0,240$.

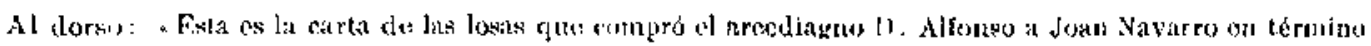
de l'enna Aguilura por XXX mor. :

\subsection{9}

Año 1221, Diciembre.

Compra que hace D. Abril Julianis, hijo de D. Julián Petrez, a D. Micael, hijo de D. Suero Peláez, de la parte que este D. Suero tenía en las alquerías de iumclia, Yenesa y Casar del Asno, de la Sisla de Toledo, pro indiviso con el tercio de las citadas alquerías, por precio de 2 mizcales alfonsíes .

Adviérlese que el vendedor no se obliga a la evicción, sino que da al comprador la finca por el título que su padre la poseía, por estar en el patrón; y ast lo acep. ta el comprador.

IFecha en la última decena de Septiembre de la ara 1259.

Declara después el comprador, D. Abril Julianis, que compra para el arzobispo D. Rodrigo Jiménez y con su dinero.

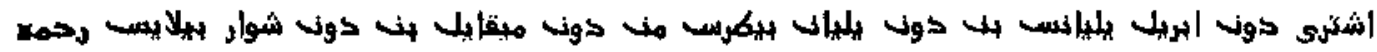

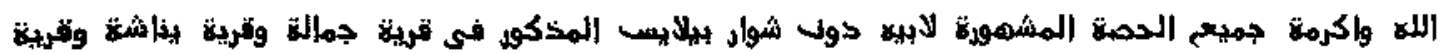

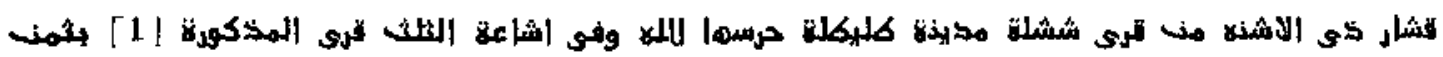

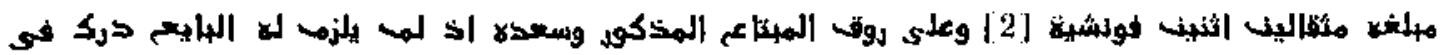

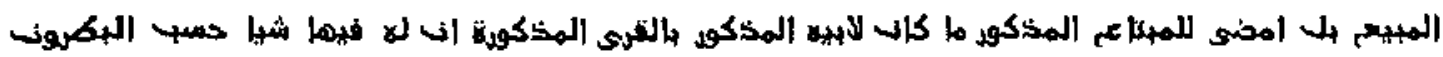

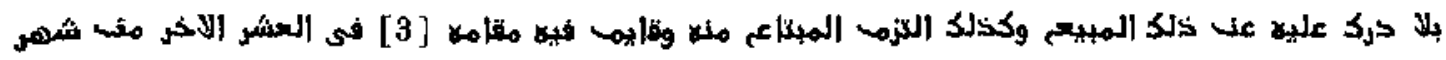

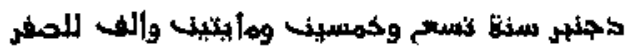

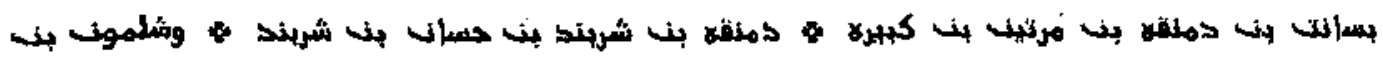

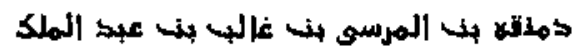




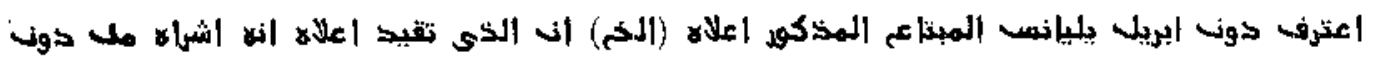

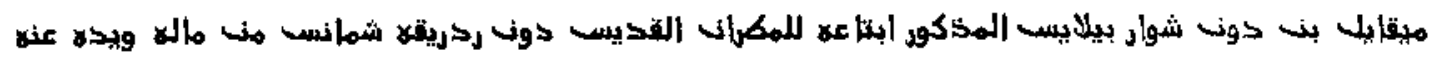

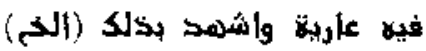

Firmas ut suprit, más la de بيكره بن بوأن بذ كوما بذ بحيى بن بلاي

Pergamino: $0,340 \times 0,192$.

Al doreo: "Carta emptionis do Casar del Asno."

\subsection{0}

Año 1222, Julio.

Compra que hacen D. Gonzalbo Domínguez, hijo de D. Domingo el Sevillano el Zapaiero, para sí y para su esposa doña Dominga, hija de D. Suleimán el Droguero, y D. Micael Juanes el Esterero, hijo de D. Juan Abuljair el Bañero, para sí $y$ para su esposa doña María, hija de D. Sancho bscrlabrado\%, por mitad entre amhos matrimonios, a D. Juan Julianes, hijo de D. Julián ben Hilel, de una casa en el barrio de la Puerta del Hierro, dentro de Toledo, lindante con casa de Servando el Ésterero, hijo de D. Gálib, con otra de Domingo Andrés Hatuto, con otra de la hija del Bequí y con otra del vendedor y con la calle, a donde da la puerta, por precio de 15 mizcales alfonsíes.

Fecha en la segunda decena de Julio de la era 1260 .

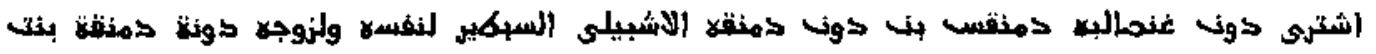

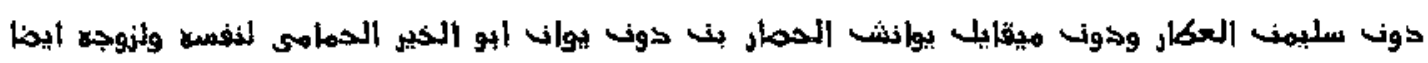

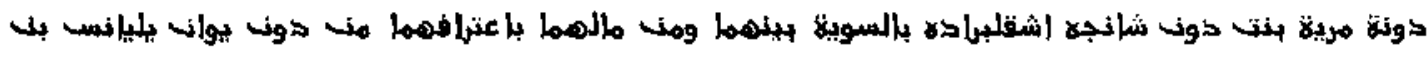

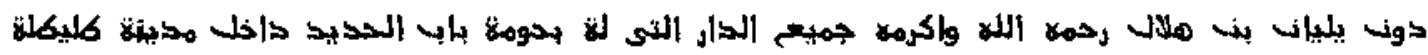

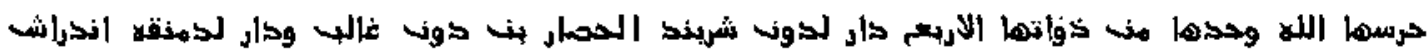

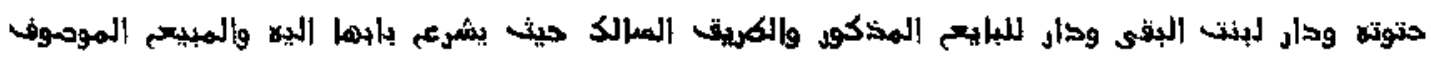

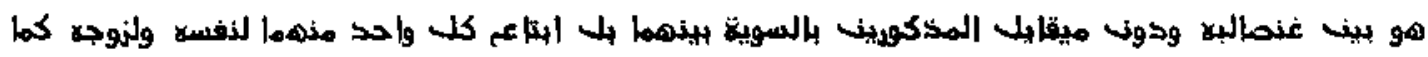

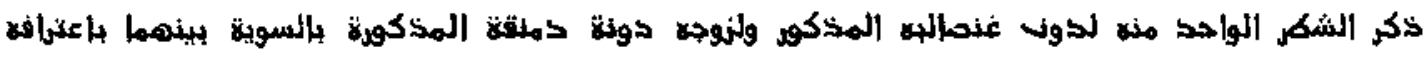

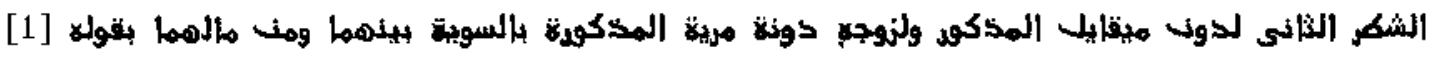

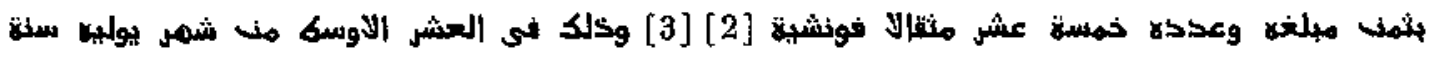

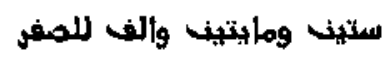

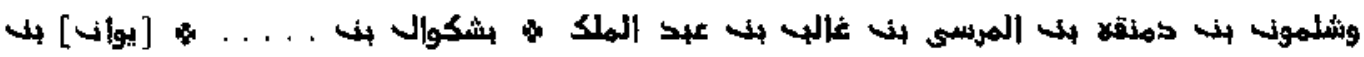
הلبلن بنس هlلي 


\subsection{1}

Ario 1227, Mayo.

Venla que hacen D. Gonzalbo, hijo del Sevillano, su esposa doña Dominga, D. Micael el Esterero, hijo de Abuljáir, y su esposa doña Maria, hija de Suncho Izquierdo, a favor de doîa María Domingo, onfidiala del presbitero D. Domingo Juanes, hija de Ainain ft rasu, de la casa que poseen en el barrio de Alhandac, dentro de Toledo, que ellos habian comprado a D. Juan Julianis ben Bahlul, y que linda con casa del cilado D. Juan Julianis, con otra de D. Juan, hermano de D. ¿Pelayo el Tornero", con otra de los herederos de D. Cebrían el Ciego y con casa de doña Solí y con el callejón sin salida, al que da la puerta, por precio de 14 mizcales alfonsies y tercio.

Fecha en la última decena de Mayo de la era 1265.

Los vendedores entregaron a la compradora la escritura por la cual ellos habían adquirido la finca.

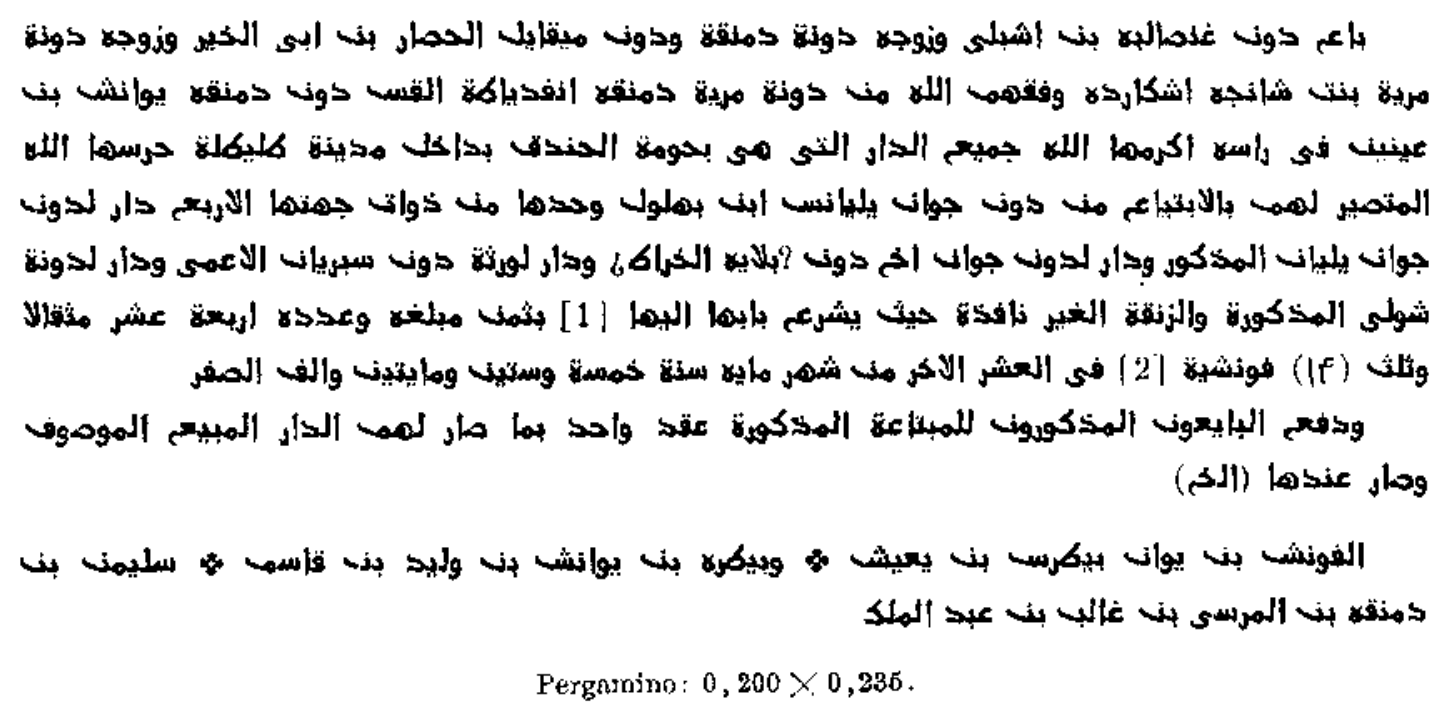

Al dorso: "Esta carta de Maria Domingo de la casa del Alhandac de lohan lllám. "

\subsection{2}

Año 1243, Enero.

Compra el presbitero D. Pedro Felices, del clero de la iglesia de San Sebastián, para los confatres de la confatría de la iglesia de Omnium Sunctorum, y con ditiero de la confatría, según expresamente declara, a doña María, viuda de IJ. Pedro Esteban el Molinero, y a sus hijos con el Juan Petrez, Estebanía y María (quienes 
venden por sí y por Orabona, menor de edad, bajo la tutela de su madre casa que era conocida como del matrimonio en el barrio de la iglesia de San Sebastián, dentro de Toledo, lindante por sus cuatro lados con casas de I). Lázaro el Barbero, de doña Dominga, llamada del Sachiraní, con el baño hundido a espaldas de la casa y con la calle, a la que da la puerta, por precio de 15 mizcales alfonsfes (1).

Fecha, después de explicársela a todos, el 7 de Enero de la era 1281.

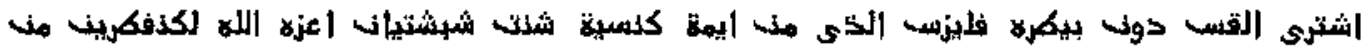

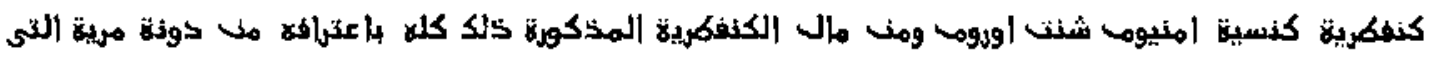

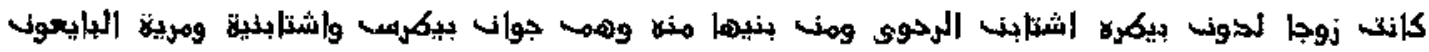

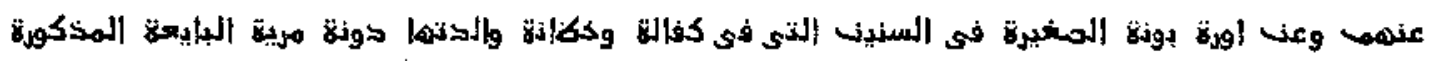

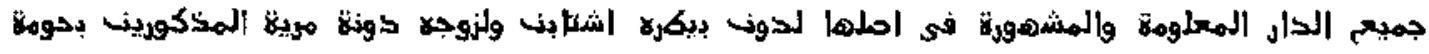

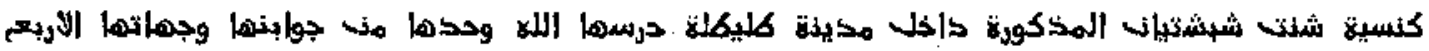

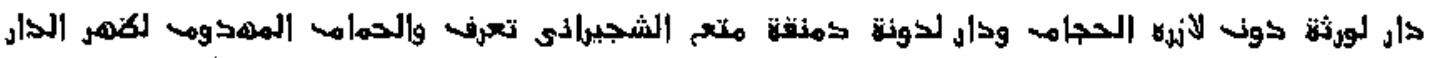

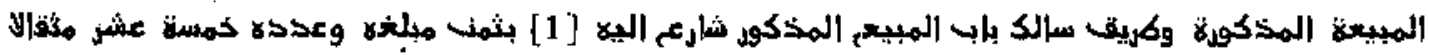

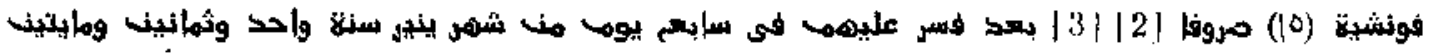
والف لمونمي

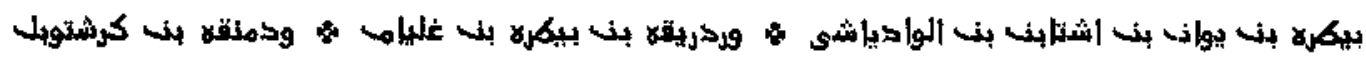

Pergamino: $0,330 \times 0,250$.

Roto, - Al dorgo: « Esta es la carta de liz casa de dona María, muller de Pedro Ristebna ol Molinero....., yor XI bol.ע

\subsection{3}

hño 1245, Febrero.

Compra que hace el alguacil y alcalde D. Servando, alcalde de la corte del rey, hijo del alguacil almojarife D. Domingo ben Servando, para sf y para su esposa doña Maria Gonzálbez, por partes iguales según el declara, a doña Loba, hija de D. Juan, esposa que fué de D. Lope el Esterero, de toda la casa que ella y su espo. so tienen en el baryio del Alhandac, dentro de Toledo, lindante con casa que era de D. Julián de Hilel, otra de D. Juau de Murcia, otra de Domingo Sancho el Esterero y olra de Abu.... y con calle sin salida, a la cual da la puerta, por precio de 38 mizcales alfonsies.

Se obliga la vendedora a satisfacer cualquier reclamación que se baga sobre la

(1) El deterioro del pergamino no permite leer la viltina parte. 
venta. Lintrega tres escrituras de propiedad. Aprueban la venta las hijas de la vendedora, doña Juana y doña Pascuala.

Fecha el 27 de Febrero de la era 1283.

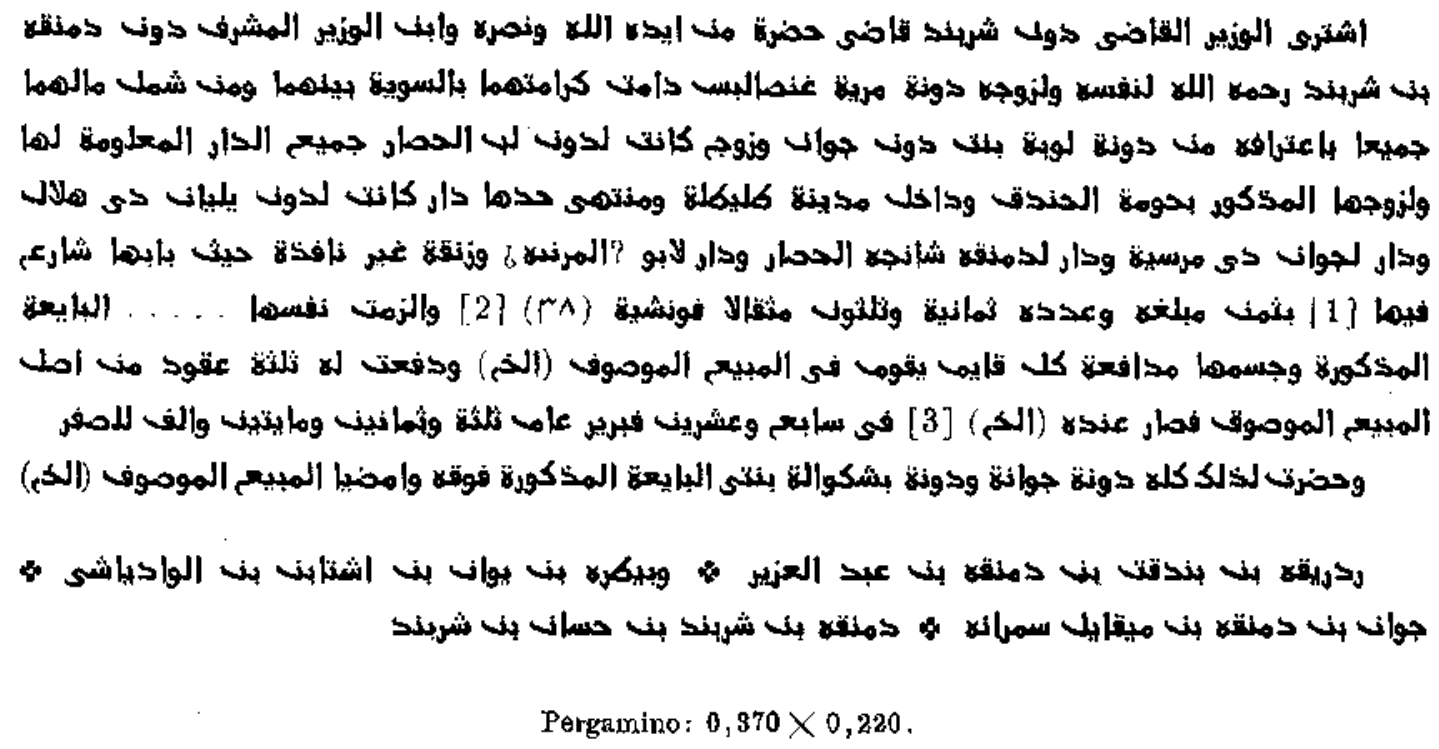

Año 1267, Septiembre.

Compra que hacen el presbitero D. Esteban Martín, de la iglesia de San Nicolás, y el presbítero D. Juan Martín, hijo de D. Sebastián, de la iglesia de Santa Ĺalalia, prebostres de la Congregación de curas de Toledo, para la confatría de dicha Congregación y con dinero de la confatra, a doña María Alfonso, hija de D. Alfonso López, hijo de I. Lope de Calatrava, esposa de D. Pedio Yicente, hijo de D. Vicente, hijo de D. Micael ben Yaix, de la casa que clla posee en el harrío de la iglesia de San Vicente, dentro de Toledo, con las habilaciones y algorfas que hay sobre ella, casa que era conocida por de Rifao. Linda con casa de Pascual Domingo, criado de D. Diego Gonzálbez; con casa de D. Diego López, hijo de D. Lope Fernán. dez, con otra que era de Domingo Petrez el Arquero, del Arrabal, y con dos calles: una que pasa cerca de la plaza de ¿Attam?, otra que baja hacia el muro de la ciudad; las puertas de la habitacín y de la adgorfa dan a esta calle; la puerta de la casa da a la calle que va a la plaza de Attam.

Por precio de 150 mizcales alfonsíes, que se reúnen en esta forma: 45 que había dado el presbítero D. Domingo Juanes ben Alpardesal a la Congregación de curas 
de Toledo, de este modo: 15 mizcales por su alma; 15 mizcales por cl arcipreste don Micael Esteban, arcipreste de Montalbán, gue ell los habia mandado en su testamento, y los 15 reslantes por el alma de su primo Domingo Petrez de Alpardesal. Otros 44 mizcales los había dado el presbitero 1). Adam, de la iglesia de San Cristóbal; 50 eran el precio de la casa que la Congregación habia vendido al presbítero D. Pedro Lópe, en el Arrabat de Toledo, y los 11 mizcales restantes se tomarou de los 20 que había dado el presbitero D. Micael Julianis, de la iglesia de San Lucas.

Intrega la vendedora cuatro escrituras de propiedad (1).

Fecha en Septiembre de lia era 1305.

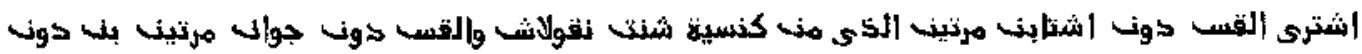

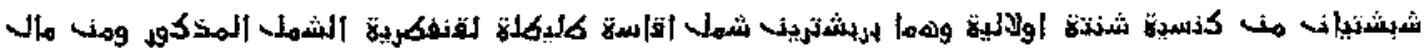

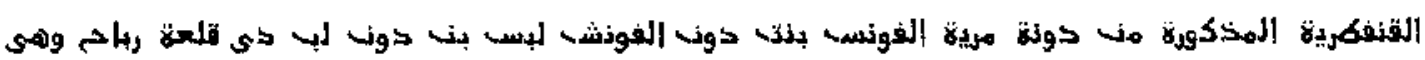

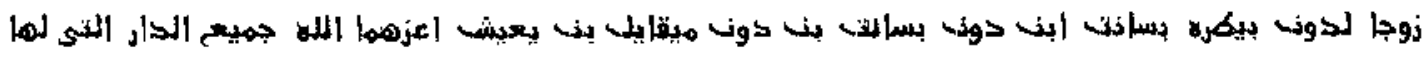

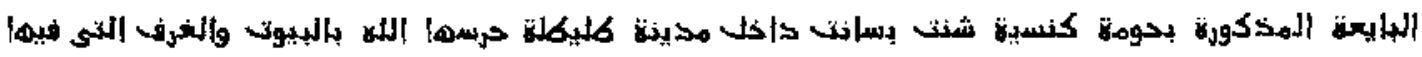

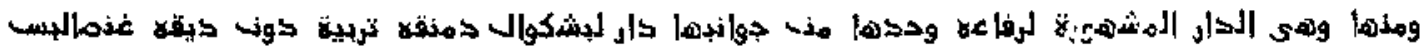

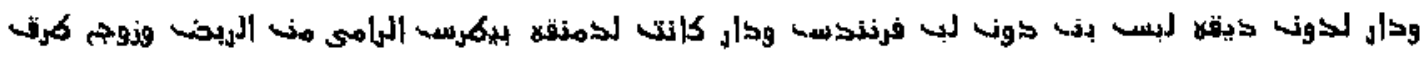

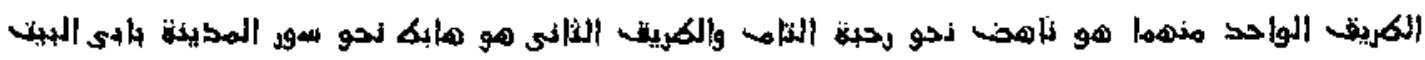

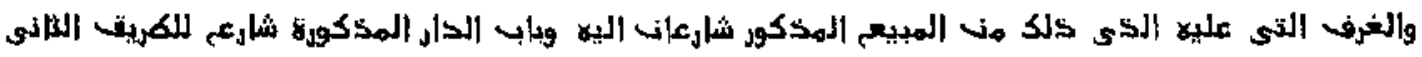

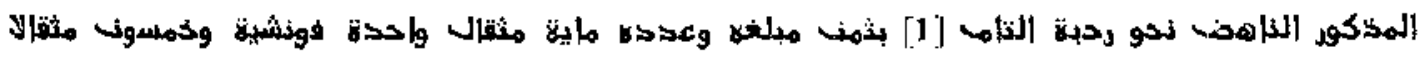

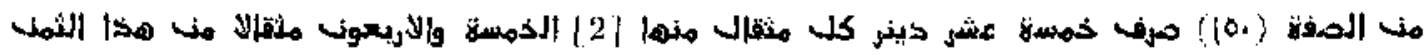

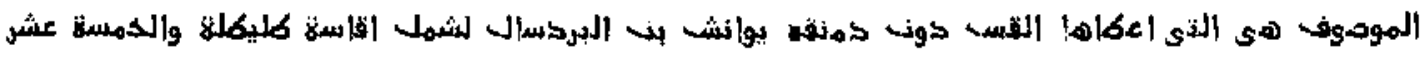

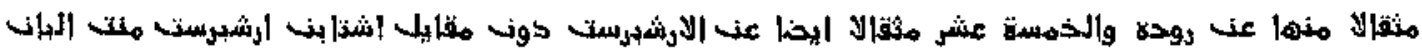

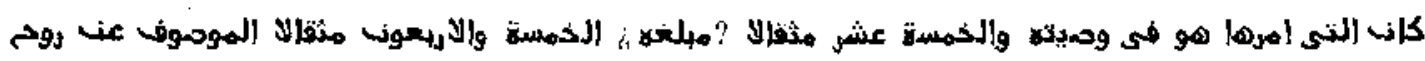

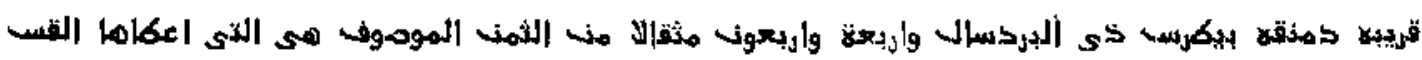

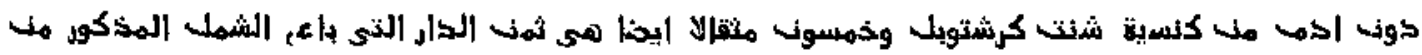

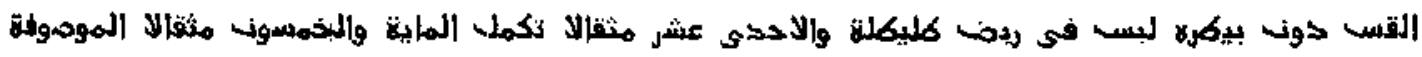

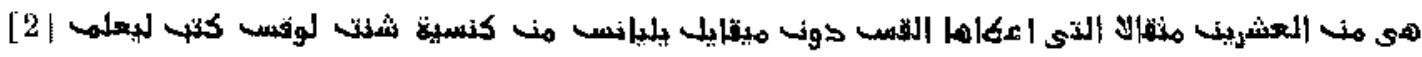

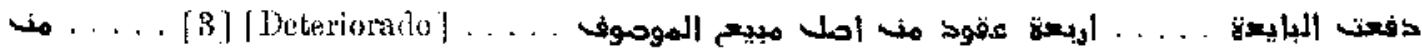

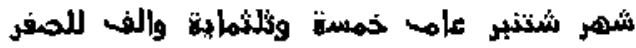

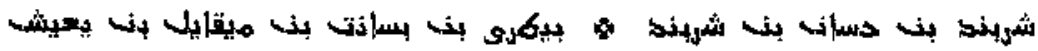

Perganino: 0, 405 $\times 0,285$.

Roto. - Ofr. ntim , 1.152.

(1) No predc teerse la descripeión de estos docunentus por deterioro del pergamino. 


\subsection{0}

Año 1279 , Mayo.

Compra que hacen el presbítero Alionso Martínez, del clero de la iglesia de San Vicente, y el presbítero Bartolome Pelrez, de la iglesia de Santiago del Arrabal, pre. bostres de la confalría del Cabildo de presbíteros de la ciudad de Toledo, para el Cabildo y con los 60 mizcales que le mando en su testamento doña Marina, hija de Pedro ¿Falabatero?, para hacer un aniversario por su alma cada año, y con los 60 mizcales que mandó para lo mismo Ferrando Ruiz, hijo de D. Ruy Domínguez; de dona Mencia, hija de Alfonso el Arruero, de la aljama de la iglesia de San Lorenzo, y de su esposa doña Maria, hịa de Cionzalbo Domingue\% de Alcantarer?, esposa que es de Micacl Petrez, arquero del rey; de la almazrín que es de sus hermanas, menores, Leocadia y Colomba, sita en el barrio de San Lorenzo, sobre la casa que allí tiene el Cabildo de curas, lindante con casa de las dos citadas menores y con la calle, por precio de 70 mizcales blancos nuevos de 15 sueldas.

Reciben los 60 mizcales de los albaceas de doña Marina y los emplean en pagar esta compra.

Fecha el 30 de Mayo de la era 1317.

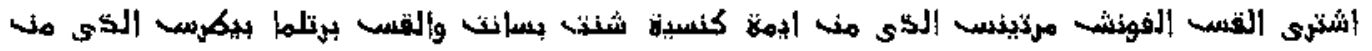

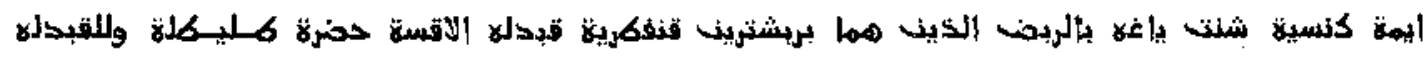

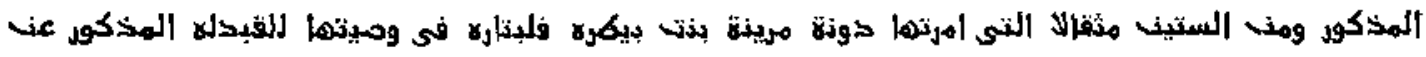

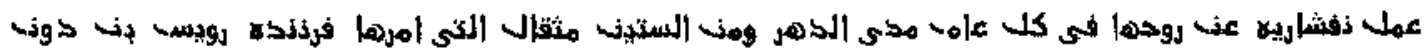

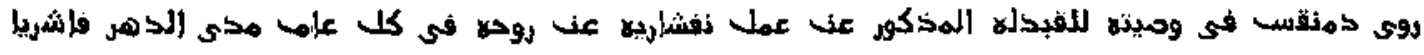

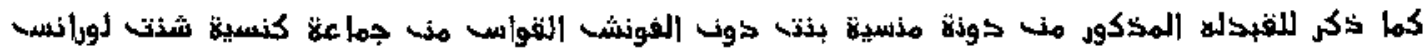

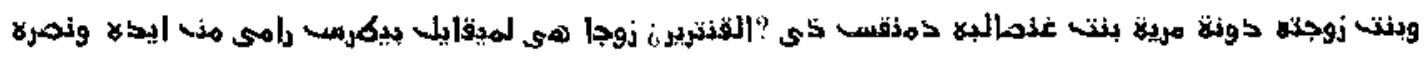

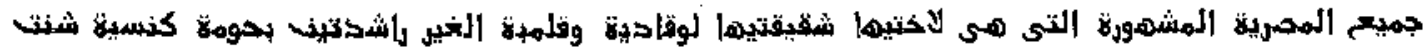

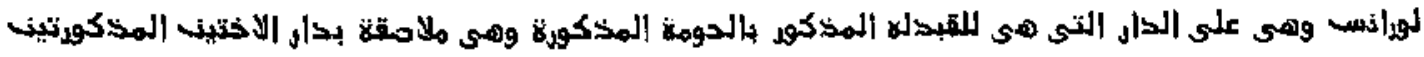

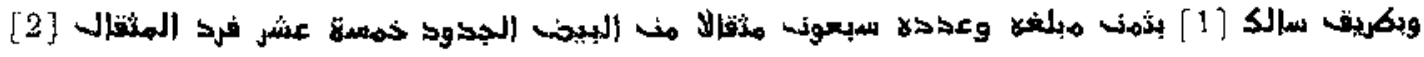

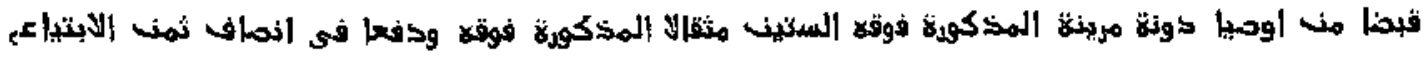

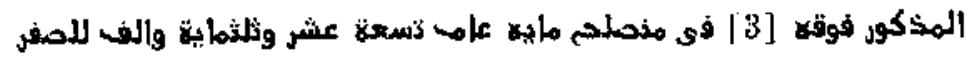

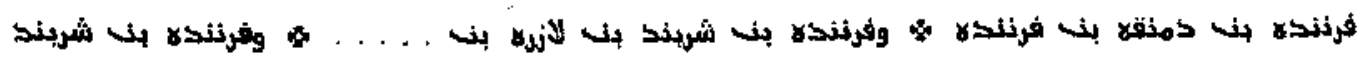


Año 1282, Noviembre.

Compra D. Servando, hijo de Domingo Petrez de Ardo (_Grado?), y su esposa dona Solí, por partes iguales, según él declara, a Micael Juanes Assafar, hijo de Juan Lopez de Albaquí, la viña que tiene en el pago de las Carcauas de Zalencas, lindante con viña de D. Tomé ......, presbitero de la iglesia de San Vicente, por precio de 16 mizcales de los blancos, de 15 sucldos el mizcal.

Fecha el 12 de Noviembre de la era 1320.

Siguc una declaración del comprador diciendo que la compra de arriba ha sido por cuenta y con dinero de D. Juan Martín, racionero de los presbíleros de la iglesia de San Vicente.

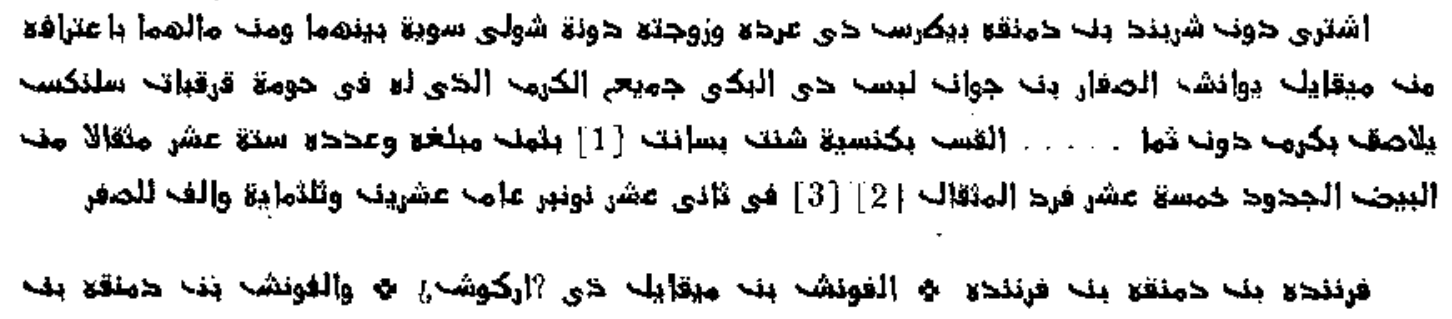

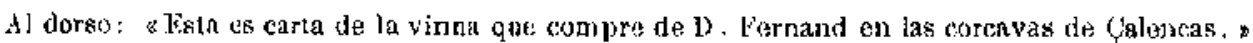

\section{CARTAS DE DONACION}

\subsection{7}

Año 1214, Mayo.

Donación que dofia Dominga, hija de Pedro Rubio, esposa del fraile D. Domin. go Cidiz, hijo de Cidmayor, y los hijos de ella, D. Pedro Guillén y D. Pedro Cidiz (en presencia y con aprobación de $\mathrm{D}$. Domingo Cidiz), hacen al arzobispo D. Rodrigo Jiménez de las heredades que poseen en Melgar, de la Sisla de Toledo, adqui- 
ridas por herencia o de cualquier otro modo, por amor de Dios el grande y en espera de su graciosa recompensa.

Fecha, después de leérsela a todos en lengua romance, que declararon entender, en Mayo de la era 1252.

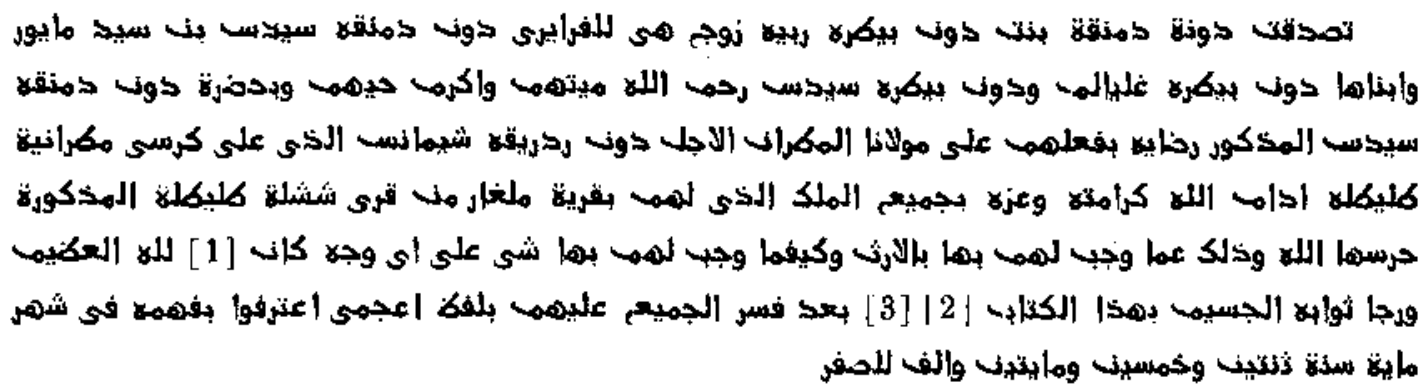

Dominicus Cielez, testis. \& Lgo Alfon, filius Melenrlo, testis. Hgo Mielnael ¿Reph. r,

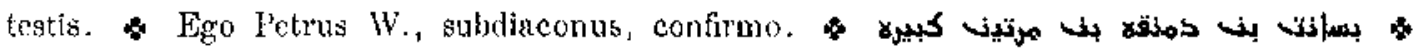
ligo Petrus Cirliz.

Pergamino: $0,202 \times 0,245$.

\subsection{8}

Año 1238, Julio.

Donación que hace la ilustre señora doña luna, esposa que fué del alguacil D. Alfonso Vicente, a los prebostes de los presbíteras, encargados de los bienes de la confratría de presbíteros de las iglesias de la ciudad de Toledo y de los gastos de la confralrfa, de una casa en el harrio de San Miguel, dentro de Toledo, lindante con casa de Domingo Arcipreste por dos lados, y de una alhochra en el barrio de la iglesia de Santiago en el Arrabal, encima de la entrada de la casa de Andrés Lechu. ga, y de 10 mizcales alfonsíes de a 15 dineros, en metálico.

Los prebostes, que eran D. Domingo Petrez, presbitero de Santiago, y D. Martín, abad, prepósito de la iglesia de San Isidro, reciben todo esto en nombre de la Cofradía. Las rentas de ello serán para la Ciofradía, cada año; pero no podrán vender las tincas ni cambiarlas. Se comprometen los prebostes a que los presbíteros de la Cofradia bagan un aniversario cada año, a partir de la fecha de este documento, por doña Luba, madre de la donante, en la iglesia de San Clemente, con la vigilia el día último de Enero, y misa y rezo de la sepultura (_responso?) el día primero de Fehrero; y otro aniversario por el alguacil D. Alfonso Vicente, marido de la donante, con vigilia, misa y responso; la vigilia el día de San Benedicto en el mes de Ju- 
nio, en la iglesia de San Clemente, y la misa a otro día, y el responso, y oiro aniversario por el hijo de la donante, Rodrigo Allonso, la vigilia el 15 de Sepliembre, y la misa y responso al otro dfa, 16 del mismo mes; esto en donde está su sepulcro, en la jglesia de San Vicente.

A esto se comprometieron los prebostes, a que la Cofradía lo hiciera cada año, según ella acostumbra a hacer con todo aquel que pertenece a ella, y da sus ropas por el bien de los vivos y por la salud de las almas de sus muertos.

Doña Luna se cercioró de todo lo que la Confratría habia de hacer y lo aprobó.

Fecha en la segunda decena de Julio de la era 1276.

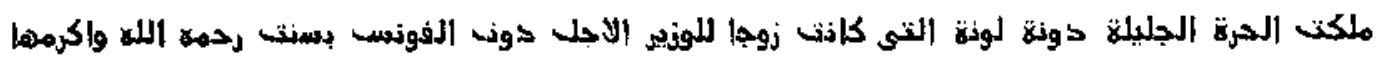

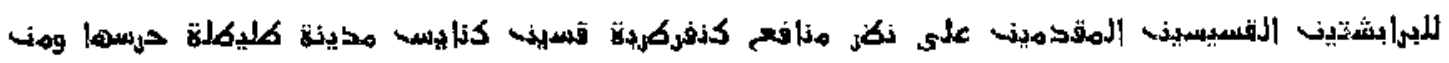

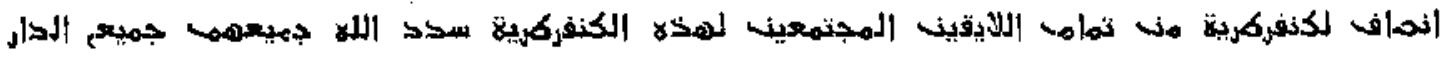

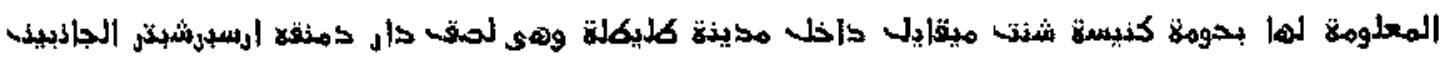

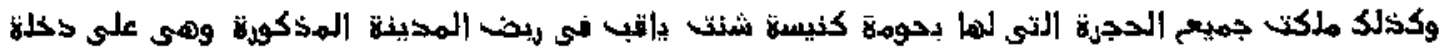

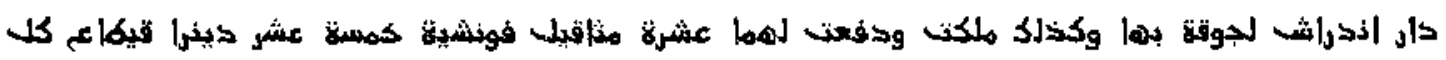

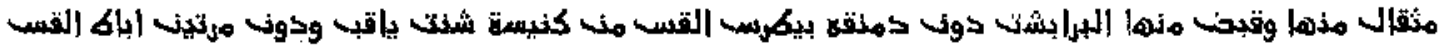

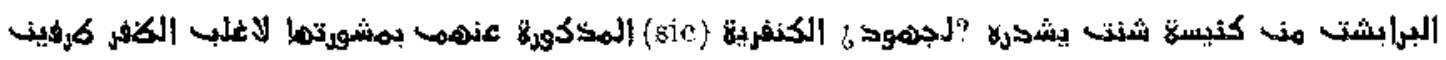

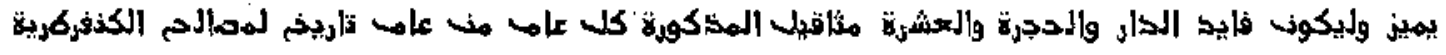

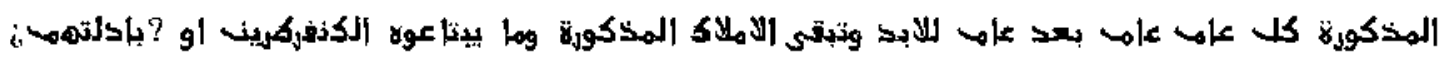

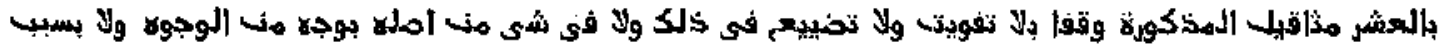

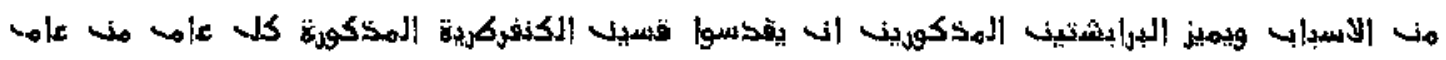

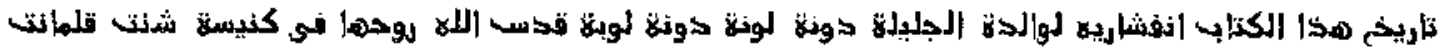

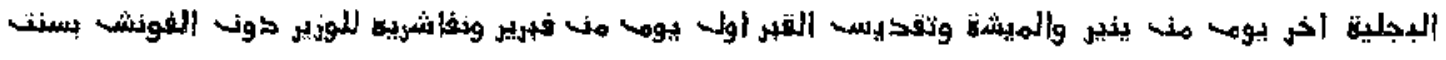

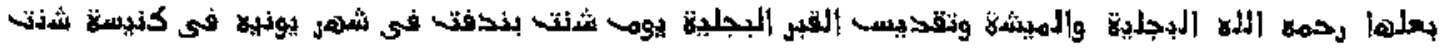

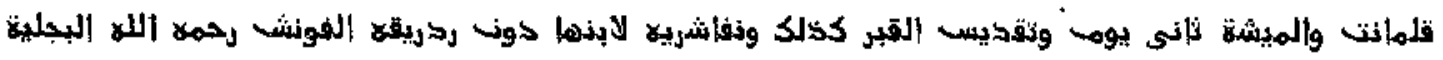

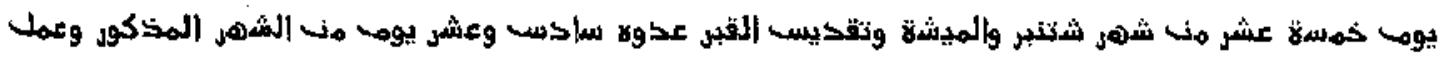

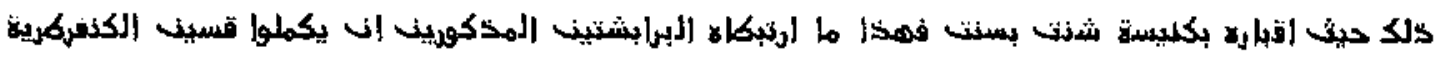

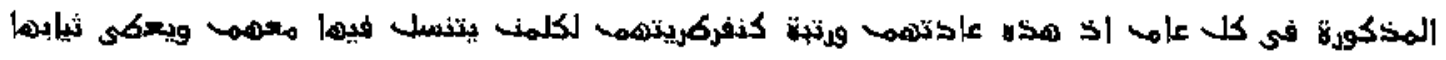

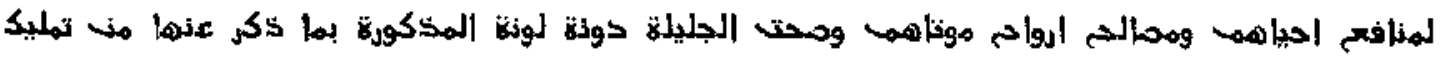

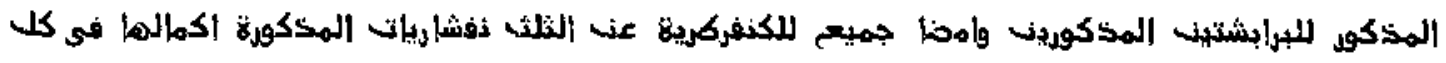

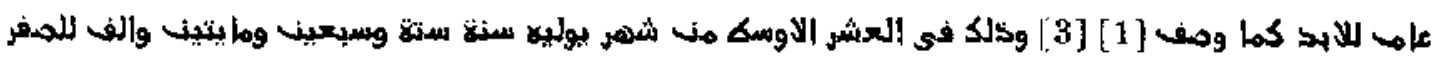

Ego Gundisalvus Johannis, presbitcr ceclesie S. Mlaria Magdalena, testis. \& Ego D. Petri, presbiter ecclesie Beali Jacobi, concedo. * Fogo Martinus Michael, presbiter Sancti Ysidori,

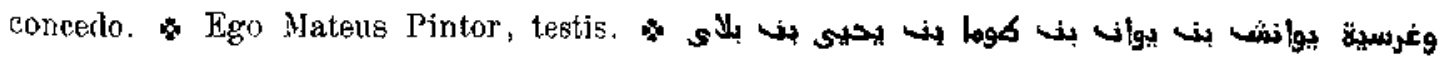

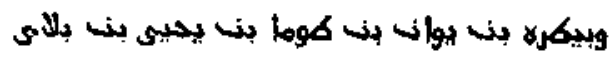

Porgamino: $0,350 \% 0,215$.

Al dorso: a Carta dé las casas que dió dona Lama, la muller do D. Alfunso ticente, y de X shor. " 


\section{169}

\section{Año 12i9, Marzo}

Donación que Alfonso García y sus hermanos Rny Ponce, Urraca García y Teresa García, hijos de D. Garcia Juanes, hijo de D. Juan Martinez, hijo del alguacil D. Martín Salvatores, por sí y por su cuñado D. Juan Julián, hijo del alguacil alhaquim D. Julián ben Jatab (en nombre éste de su hijo menor García Martínez), hacen a favor del Cabildo de presbíteros de la capital de Toledo, de un mesón que tienen cerca del Mesón de la harina, lindante con casa de D. Sancho el Tapatero, con solar de los herederos del alguacil D. Guter Fernández y con la vía pública.

Con la condición de que el Cabildo haga tres aniversarios: tno por el alma de doña Colomba otro por el alma de la hija de ésta, doña María, éste en la iglesia de San Justo, y el tercero por el alma de dona Orabona García, madre de los donantes, en San Román ; y esto cada año perpetuamente y cada cual en sn día. Juan Julián se obliga a que su hijo menor apruebe el acto, después que llegue a la mayor cdad.

Fecha en la segunda decena de Marzo de la era 1317.

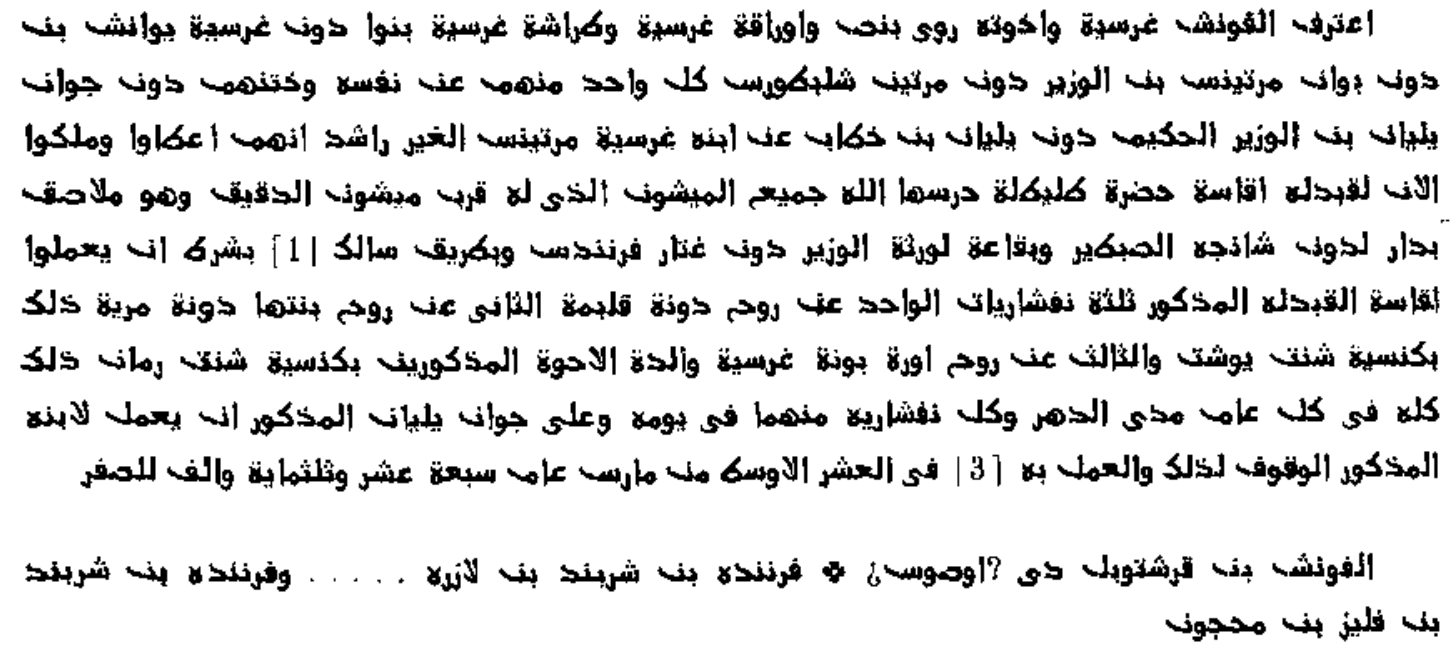




\section{ESCRITURAS DE PRESTAMO}

\subsection{0}

Año $123 \%$, Febrero.

Préstamo que el judío Abulhasán Yehudá ben Mohib hace a D. Domingo Felices Assammar ben Mahchún y a su esposa doña Maŕa Domingo, de 185 mizcales alfonsíes, pagaderos al año de la fecha. Si no lo hicieran, habrán de pagar la cantidad doblada y una multa de medio mizcal por cada día de retraso.

Fecha, después de leérsela a los dos en lengua romance, que dijeron entender, el 23 de Fehrero de la era 1278.

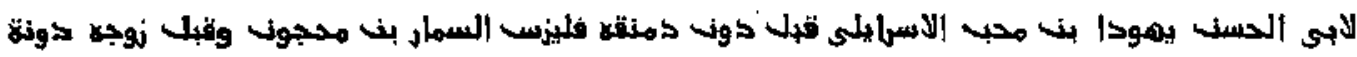

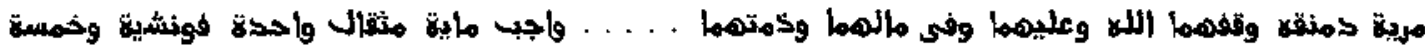

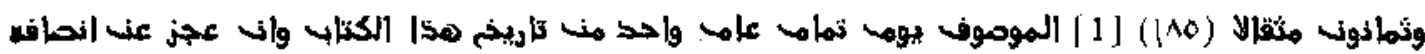

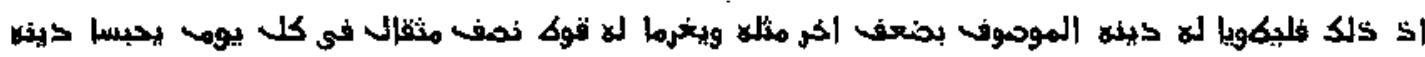

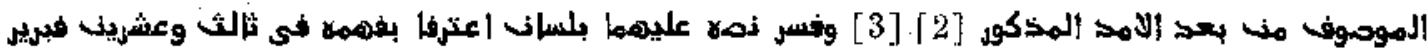

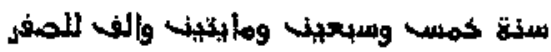

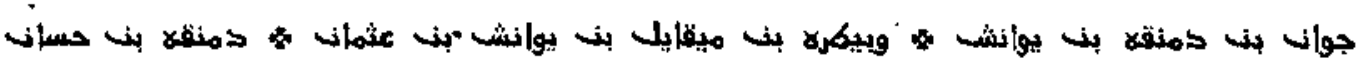
بذه شريند جوان Pergamiuo: $0,245 \times 0,215$.

Al dorso: -Esla es la carta de la dehrla que abícn los judius a Domingo Felicez el ferrador (?).»

\subsection{1}

Año 1238, Octubre.

Préstamo que la con/ratría de presbíteros de Toledo hace al vicario D. Alfonso, del clero de San Justo, que pone por fiadores a sus cuñados Pedro Parisis el Zapalero y a su esposa, de 33 mizcales alfonsíes.

Fecha en la primera decena de Octubre de la era 1276.

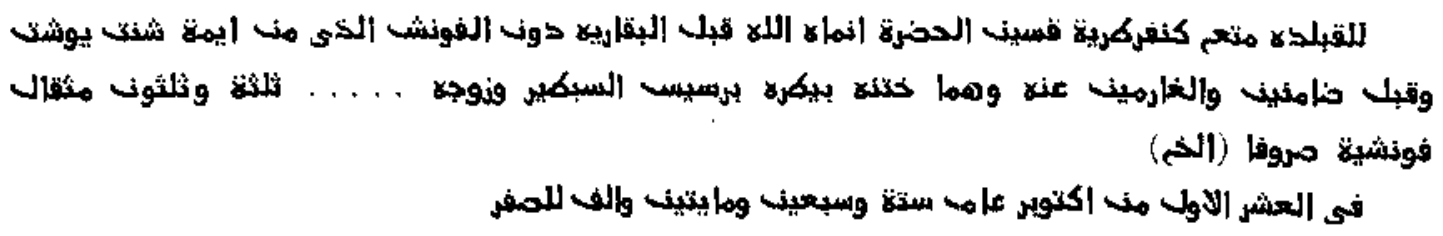




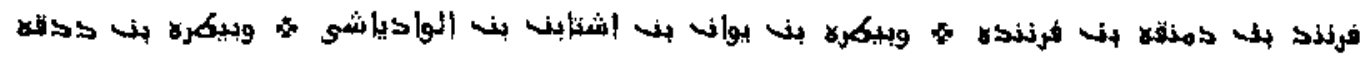

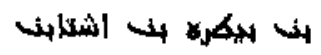

I Bintre lineas consta haber entregado a cuenta algunas cantidades de un mizcal y de dos mizcales. I - Mal conservado y de diffeil lectura.

l'ergaminu: $0,270 \times 0,260$.

\section{ESCRITURAS DE ARRIENDO}

\subsection{2}

Año 128.5, Mayo.

Alquiler que loma Alfonso Petrez el Carretero, hijo de Pedro Gronzallıo el Deni, a Garcla Juanes, presbitero de la iglesia de San Vieente, priostre de la confratra de los presbíteros de la ciudad de Toledo, de una casa propia de la Cofradia en el ba. rrio de la iglesia de San Lorenzo, lindante con otra que era del padre del arrenda. tario, por plazo de dos años, a contar del día 15 de Agosto proximo, por un precio de 12 mizcales anuales, pagaderos por cuatrimestres. Si al pasar un plazo no lo hubiera hecho efectivo el arreudalario, puede el arrendador empeñar los bienes de aquel y venderlos, etc.

Fecha el 2 de Mayo de la era 1323.

اكترى الفولشي A

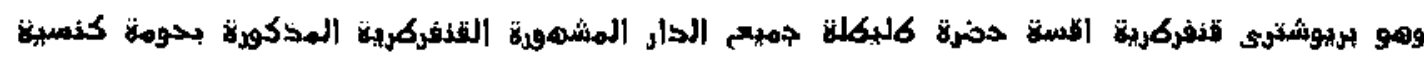

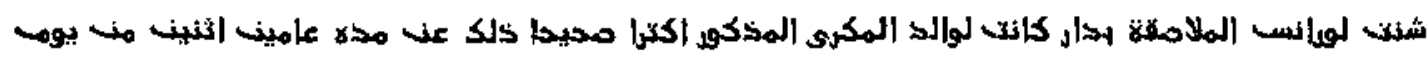

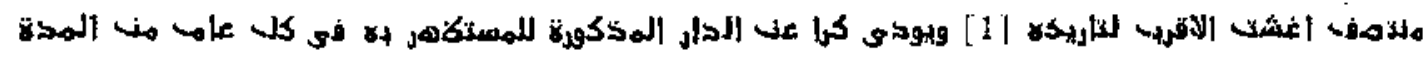

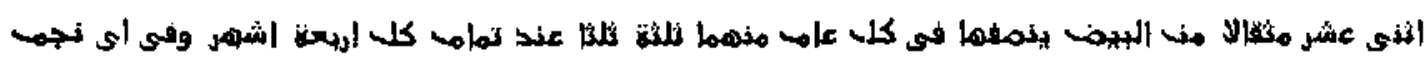

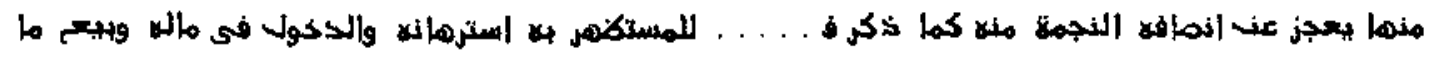

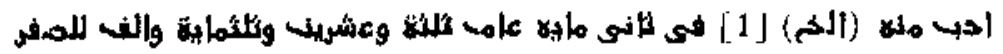

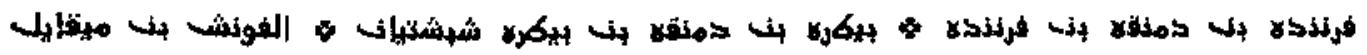
בוj

L'orgamiuso: $0,225 \times 0,170$.

Al dorso: acarta de las casas que tiene Alfon Potrez del Aradoro." 


\section{ESCRITURAS DE CONVENIO}

\subsection{3}

Año 1278 , Octubre.

Convenio entre la monja doña María Meléndez, hija de D. Marlín Domínguez, hijo de D. Domingo Juanes el Malagueño, monja en el convento de San Pedro en Alhicem (con aprobación de la abadesa doña Colomba Gonzálbez, de la priora doña María Esteban, de la subpiora doña Juana Guiraldo, de la capiscola dona Giacia, de la celeraria doña María Pascual, de la camarera doña Teresa López, de la portera doña Teresa (ronzálbez y de la sacrislana doña Teresa Alfonso) y sus hermanos D. García Martinez y D. Pedro Martinez, en su nombre propio y en·el de sus hermanas doña Urraca Martínez y doña Orabona Martínez, acerca de la parte que a doña María Meléndez tacaba en la herencia de sis padres.

Correspondía a doña María 200 mizcales de los sueldos blancos. Sus ìermanos la ponen en posesión de la tercera parte del mesón que poseen en Zocodover, pro indiviso con los otros dos tercios, que son de doña Colomba, hịja de 1). Vicente de Vargas; más de un tereio de la casa, sita en el adarve de D. García Juanes de Mcana, lindante con otra de doña Mencia, hija de D. Fernando Vicente; ella poseerá estas fincas y cobrará sus rentas para sí y sus alquileres hasta tanto que sus. hermanos le entreguen los 200 mizcales referidos; cuando se los paguen, ella dejará la casa y el mesón, y se dará por entregada en su parte ờ la hereneia de sus padres, así de bienes raíces como de muebles.

Si doña María muere teniendo en sa poder estas fincas, quedarán en poder del convento de San Pedro, que usufructuará sus rentas hasta que los hermanos le den los 200 mizcales dichos; así que los paguen, el convento dejará de tener derecho a tales fincas.

Fecha el 29 de Octubre de la era 1313.

Sigue un testimonio del convento, hecho a 30 de Abril de 1352 (año 1314), por el que se recomoce pagado en los 200 mizcales, remunciando a todo derecho en la tercera parte del mesón y de la casa.

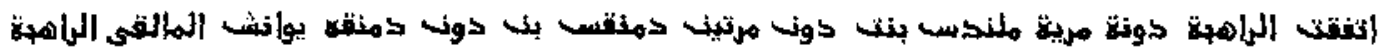

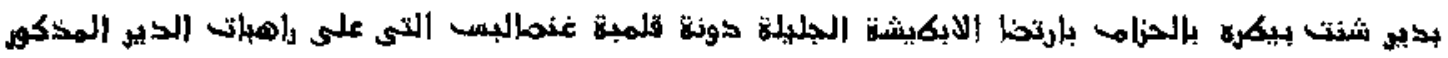

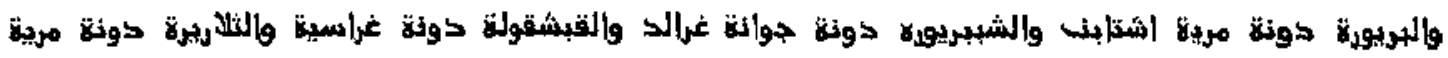

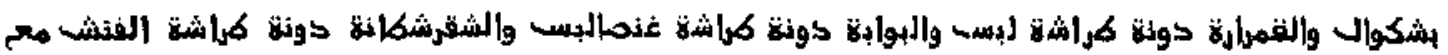




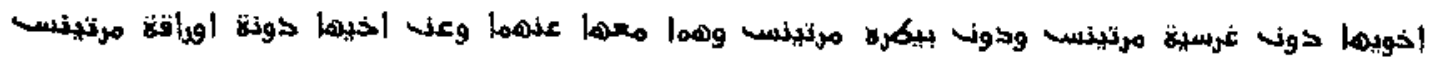

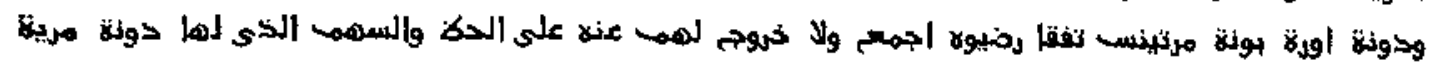

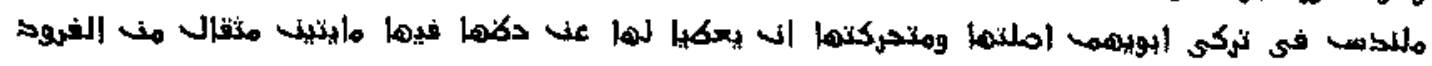

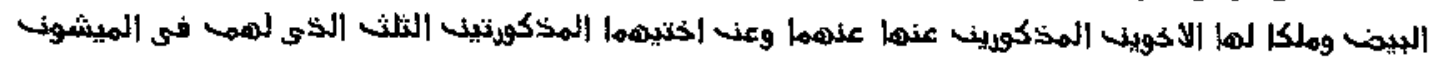

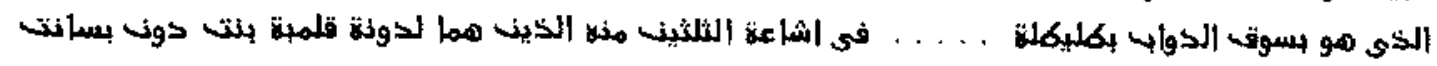

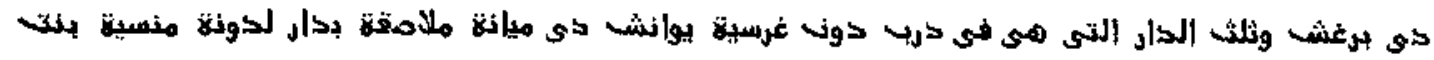

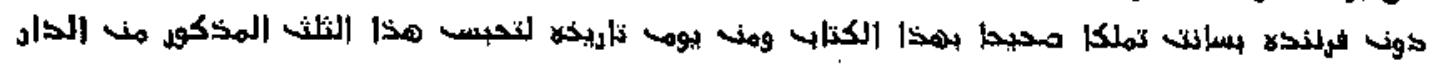

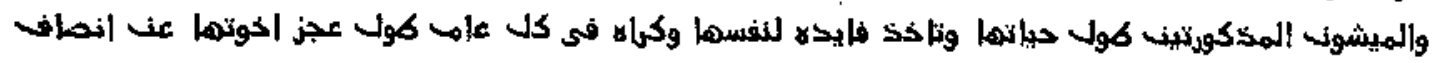

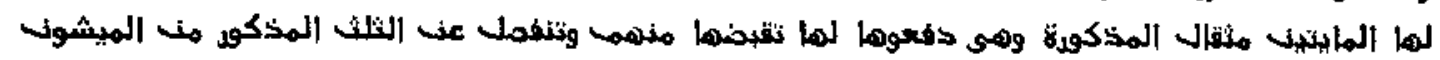

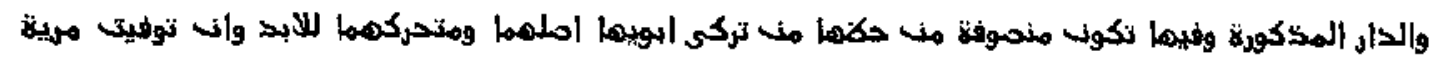

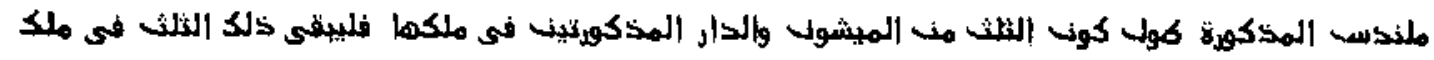

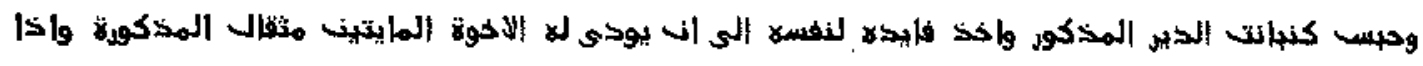

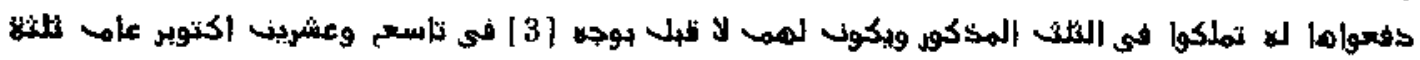

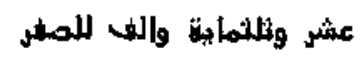

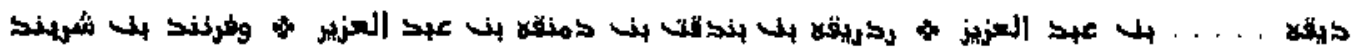

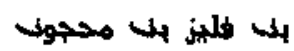

«Et nos, doña Ysabel Gutiérre\%, abadesa del monesterio de Sant Pedro de Toledo, e la priora doña Mayor Esteban, e la supriora dona María Pére\%, e la celleriga dona Marina Petrez, e la sacristana doña Gracia Petrez, e la capiscola dona Maria Pérez, e la camarera doña Mencía López, e la portera dona Mayor Alfons, monjas del dicho monesterio, olorgamos e conoscemos que somos pagadas e enlregadas por nos e por el convento del dicho monesterio de todos los dozientos mrs. que suso se contienen, e assí nos ni el convento sobredicho non avemos ni nos finca en el lercio que suso dize del dicho mesón, ni el tercio de las casas que suso se contienen, .... ni derecho, ni petición, ni poder ninguno en ningún tiempo ni ninguna manera. Fecho este escripto postrimero día de Abril era de mil e ccc e cinquenta e dos años.

Yo, Pero Lorenz, escribano en Toledo, so testigo. E yo, Gil Marlínez, escribano en Toledo, so testigo. \& Ruy Pérez, escribano en Toledo, so testigo * * (1).

Pergamino: $0,240 \times 0,260$.

Al dorso: « Monjas del Cistol, monasterio de Ban Pedro,

(1) Dohajo lleva cada firma el nombre un árabe: 


\section{ESCRITURAS DE OBLIGACION}

\subsection{4}

Año 1226, Marzo.

Testimonio que da D. Juan Nicolás, nieto de Pedro Domingo el Adalid, diciendo que el estuvo en la Catedral de Santa María el día 4 de Marzo de la fecha, porque lo llamó el canónigo D. Alfonso Meléndez para que hajara con él a un sitio en la Catedral donde celebraban junta los cazadores de ¿Alcorcanes?; encargó la junta a Pedro Petrez el ¿Conejo? y a D. Pedro, yerno de Domingo Esquerdo, del Arrabal, para que en nombre de los cazadores respondieran a D). Alfonso Meléndez en el asunto sobre que les reclamaba; y los cazadores de aquella junta se obligaron a aceptar los actos que sus delegados hicieran con $\mathrm{D}$. Allnnso y a no salirse de ellos.

Esto se pone por testimonio, en virtud de su orden y en su presencia, pues para ello ha sido rogado, y asl lo reconoce delante de quienes firman de su puño y letra, después de haber jurado en el nombre de Dios que su declaración es ver. dadera.

Fecha el 5 de Marzo de la era 1264.

Sigue el testimonio de D. Domingo Domínguez, alcalde de los cazadores, y el de D. Juan Rodrigo y D. Martín Petrez, también alcaldes de los cazadores, en igual sentido y en la misma fecha.

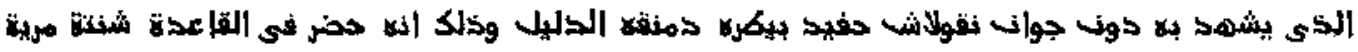

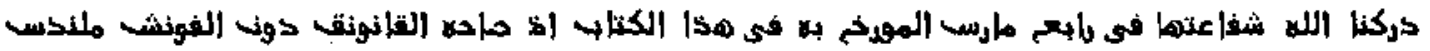

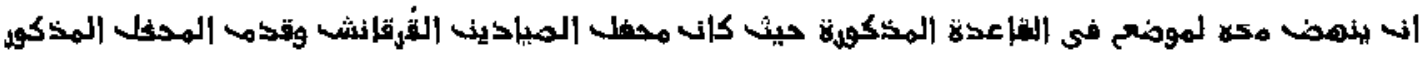

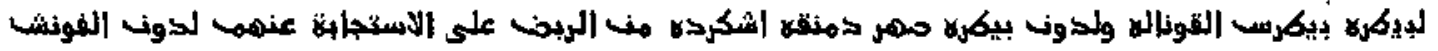

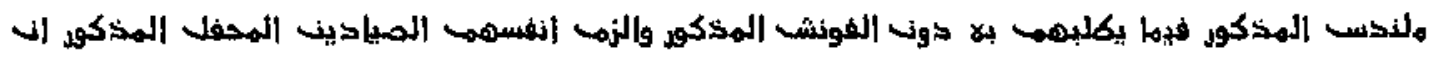

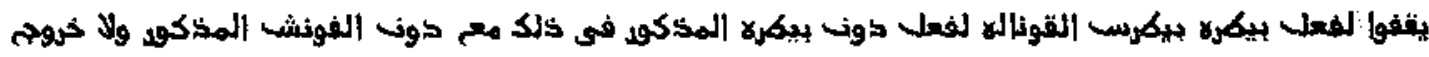

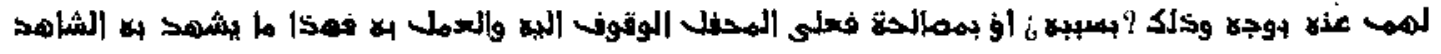

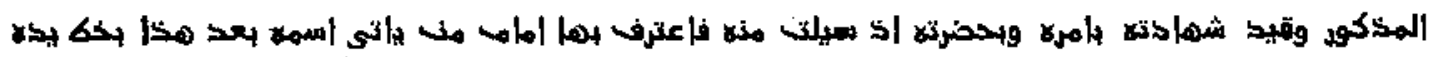

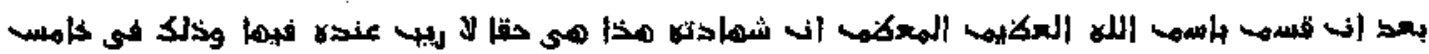

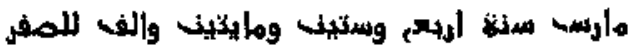




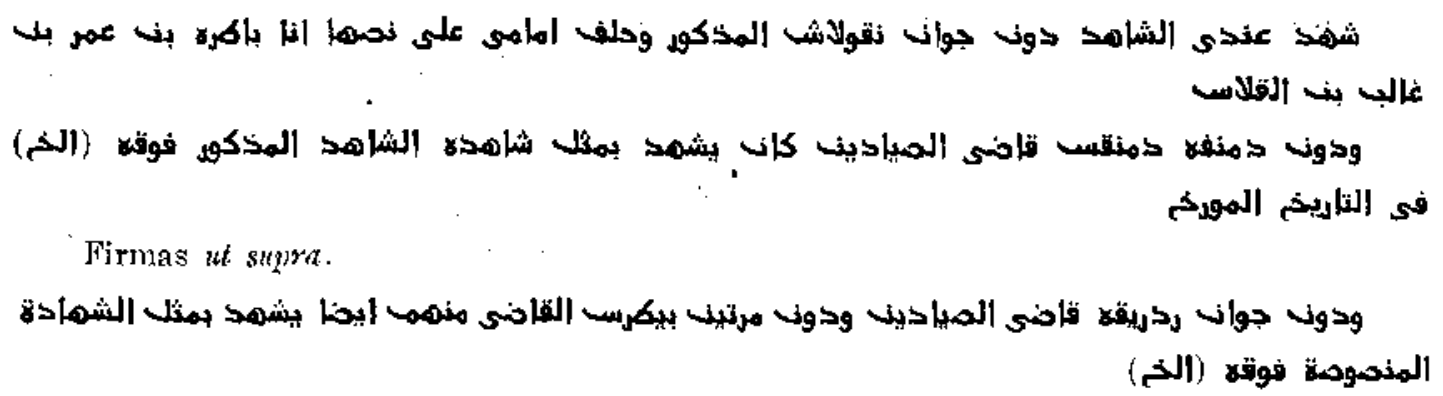

\section{CARTA MATRIMONIAL}

\subsection{5}

Aho 1285, Julio.

Sub imperio alme et indiuidue trinitatis. Patris et Fili et Spiritus Sancti, amen. Legalis est ordo moribus utentibus approbatus ut coniugium si ne dote non fiat. Quapropter relinquet homo patrem et matrem et adherebit axori sue et erunt duo in carne una. Apostolus itaque ail: Dixi: diligite uxores vestras, sicut ac Christus Ecclesiam. Quapropter Rodericus Poncii, dompni Didaqui Roderici filius, publicis et apostolicis aucloritatibus communicans, cum a Deo matrimonium sit institutum, expetiui te Maior Alvari, filia dompni Alvari, in uxore legitimam sociandam et amore nobilitatis et pulcritudinis tue et ob gratiam ex te suscipiende prolis, do tibi in donationem propter nuplias Alholla, Alguilela, Nezque de ha.... Alınudenat, Almoatac, Elcana, Alcabrea de Almudennas, Piel de Almudenas en Penna Blanca, Atride, Dos alg.... A.... mait, et calciamenta pedım. Do eciam tibi decimam parten omnium bonorum meorum que in presenti abeo et a die nostre benedictionis in antea quantum Deus nobis in lucrum dederit secundum forum patrie babeatur. Facta carta huius donacionis in mense Julii era M. ${ }^{a} \mathrm{CCC} .{ }^{a} \mathrm{XXIII} .{ }^{\mathrm{a}}$

Ideo ego supranominatus sponsus qui hanc dotem fieri iussi et testibus idoneis eam ad roborandu'm tradidi, manu mei propria hoc signum sancle crucis + feci.

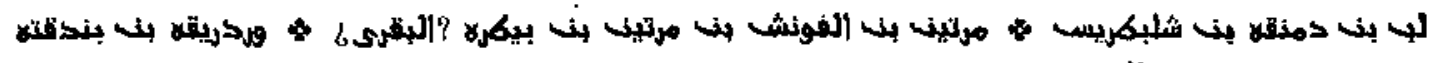

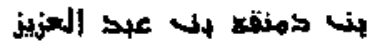

Lista de las ropas, objetos y propiedades que declara poseer dona Mayor Alvarez, hija de D. Alvaro Juanes, hijo de D. Juan Martinez, hijo de D. Martín Salvato- 
res, en el momento de su boda con su prometido D. Ruy Ponce, hijo del alguacil y alcalde difunto D. Ruy Ponce, según corresponde a una señora de la ciudad de Toledo en la adjudicación de ajuar a las hijas con motivo de su casamiento.

Todo va mencionado con su nombre y lleva la indicación de su precio en mizcales alfonsíes, corrientes ahora, de 15 sueldos el mizcal de los sueldos blancos. Con la bendición de Dios y con su ayuda.

Mis:ales

Corfina de seda......................... 100

Cama con sus.......................... 200

Colcha de ........................... $\quad 270$

Otras dos colchas de seda, con ..... por su forro, una negra y ptra blanca ........................ 150

Una colcha de color rojizo. . . . . . . . . . . . . . . . 100

Dos colchas de algodón negras. ............... 40

Ocho oterseras? berdadas, llenas de pluma ... . . . . . . 250

Nueve $i$ entre forros? colgados.................. 90

Seis cansaderas de fustón (1), llenas de ploma.......... . 200

Veinticuatro colchones.................... 480

Veinticinco fundas blancas, con cenefas rojas, llenas de lana .............................. 80

Seis cojines revestidos de piel................ 30

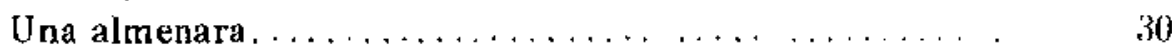

Una cablía (vestido) de lafetán amarillo............. 300

Otra cabtia de color de yyeso $\ldots \ldots \ldots \ldots \ldots \ldots \ldots \ldots \ldots$

Un .... baladl (del país), con su forro de tafetán de su color................................... $\quad 300$

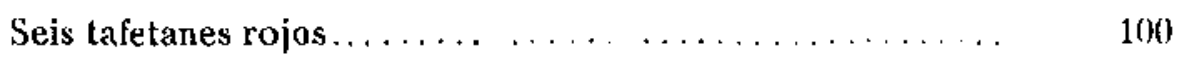

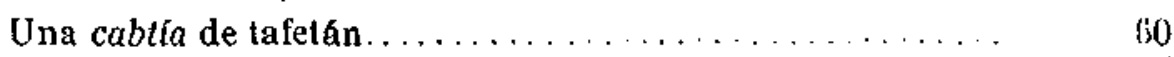

Colchas rojas...........................

Vaso y jarra de latóa .......................

Un barreño de latón para ..... el agua .............. 10

Dos almireces de cobre.................... 10

Un .... de cobre para guardar agua .............. $\quad 30$

Una caidera, calderos y sartén................... 20

Dos jesteras para los criados? ${ }^{(2)} \ldots \ldots \ldots \ldots \ldots \ldots \ldots \ldots 20$

(1) Dozy, Supp., tola de algudón y do hilo .

(2) Dozy, Supp., sin explicación, según Voc . 
Las dos linajas de la señora.................. $\quad 250$

La cabalgadura de ella ................... 300

Una cama o tapiz......................... 10

Salero de plata......................... 40

Ln .... pequeño de gran $\ldots \ldots \ldots \ldots \ldots \ldots \ldots \ldots \ldots \ldots$

Cuatro alhacenas........................... $\quad 300$

Dos pares de manteles para mesa, escacados........... 40

Dos pares de manteles lablados. . . . . . . . . . . . . . 32

Ios pares de manteles más, tablados también........... 32

Otros dos pares de manteles lablados................ $\quad 32$

Otros dos pares de manteles escacados y tablados de seda.. $\quad 40$

Otros dos pares de manteles tablados. . . . . . . . . . . . $\quad 32$

Dos pares de manteles tablados.................. 32

La suma total de manteles en esta lista es de 28 pares y 304 mizcales.

Dos pares de fazalexer? bordadas de lazo (?).......... 40

Dos almalafas bordadas...................... $\quad 50$

Otras dos almala $a s$, también bordadas.............. 60

Dos almalafas de lazo........................ 100

La suma fotal de las almalafas hordadas es de 135 mizcales (sic).

Una almalafa murciana con la cenefa de seda .......... 120

¿Cuatro camisas? de murciana con cenefa de seda. ... ... 120

Seis camisas anchas, finas, de ribete de murciana........ 150

Una camisa estrecha bordada con hilo de oro ......... 60

Una camisa estrecha blanca. .................... 8

Dos tocas rematadas con oro . . . . . . . . . . . . . . . 80

Dos tocas con oro.......................... 60

Cuatro tocas murcianas de seda roja ............... 100

Seis tocas de murciana con seda blanca .............. 120

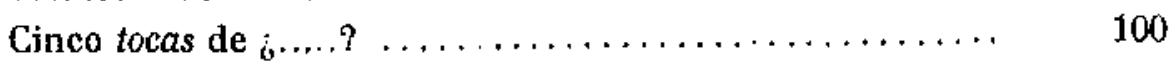

Quince tocas. . . . . . . . . . . . . . . . . . . . .

Dos sartales ................ . .............. 100

Una alondra de oro $\ldots \ldots \ldots \ldots \ldots \ldots \ldots \ldots \ldots \ldots \ldots$

Unas arracadas (?) de oro, pequeñas.............. 30

Dos arracadas de oro con perlas................. 120

.... de plata, peine de plata, un $\measuredangle$ pomo? con .... de plata. $\quad 100$ 
Un collar de plata. . . . . . . . . . . . . . . . . . . 60

Bocas de mangas . . . . . . . . . . . . . . . . . . . 60

Una esclava bordadora ...................

Otra esclava. ......................... $30 \ldots$

Suleimán ¿Hadadán?....................... 800

Las dos esclavas de la sefrora . . . . . . . . . . . . . 350

Lin esclavo críado y otro mayordomo............... \$500

Un esclavo pequeño, añendiz del oficio de albañil . . . . . 200

$\mathrm{Y}$ ciento cincuenta mizcales que a la señora le debe un $\mathrm{mu}$. sulmán . . . . . . . . . . . . . . . . . . . . . . .

Lo que ella posee en la alquería de Pesines, en la Sagra, en tierras de labor, corral, casas, cras, solares, bueyes y sus aperos, grano, sembrado, etc., como bienes muebles, inmuebles y semovientes, por valor de . . . . . . . 10.000

Lo que posee en la alquería Guadarrama, por valor de ... 10.0100)

Su parte en la alquerta de Raimundo 7aragoza . . . . . . . . 30

Su parte en la alquerfa de la Torrecilla... . . . . . . . . . 300

La vifra que fué de loña Orabona . . . . . . . . . . . . . 500

Su partc en el huerto del Malagueño.............. 700

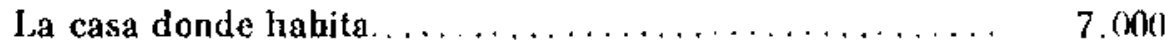

¿Deudas pequeñas? ....................... 2.000

La casa en que habita $\mathrm{Alvaro} \ldots \ldots \ldots \ldots \ldots \ldots \ldots \ldots \ldots .50$,

Su partc en Alcardete, en cl huerto de San Pedro........ $5(\%)$

Su parte en las casas de la Alcudia, que fueron del alcalde D. Juliån. . .......................... 200

Suman todos los bienes de la novia aproximadamente 40.196 mizcales, los cuales, junto con el regalo descrito en la dote, vinieron a poder del novio, y con todo ello se mostró al novio la ¿pureza? de su prometida, y se comprometio a conservar los bienes, como manda la ley.

Cuando termino este inventario, quiso el novio que se hiciera el de sus bienes rafces y semovientes, para que la esposa tuviera la décima parte de ellos, por razón de su matrimonio, según dispone la ley. Los bienes del novio eran:

Mizealu::

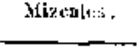

Su heredad en Ia alquería de Huecas, en tierras de labor, corrales, casas, solares, eras, viñas, bueyes y sus aperos, granos, etc., por valor de.................. $\quad \mathbf{5 . 0 0 0}$ 
Su parte en la alqueria de Villamozain............... 2.000

Su heredad en la alquería de Totanes, en la Sisla de Toledo, 3.000

Su parte en la alquería de Villaseca............... 300

Su parte en la alqueria de Argés.................. $\$ 300$

Su parte en las heredades de Calatrava la Vieja.......... 500

Sus bestias y sus armas de madera y de hierro......... 2.000

Su parte en el corral de los Judíos ................. 400

El regalo de la novia....................... 2.000

Dos vestidos del novio......................... $\quad 500$

Más mil mizcales de deudas de varias personas......... 1,000

Suman los bienes del novio, aproximadamente, 17.000 mizcales, cuya décima parte, de la novia, son 1.700 mizcales, que completan un capital de 42,896 mizcales, quedando como capital del novio 15.300 mizcales.

Dieron testimanio de todo los dos novios, segín declararon los testigos, después de habérselo leido, el 7 de Julio de la era 1323.

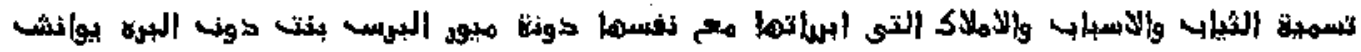

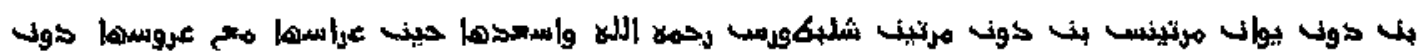

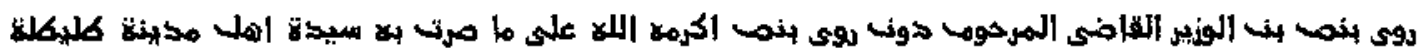

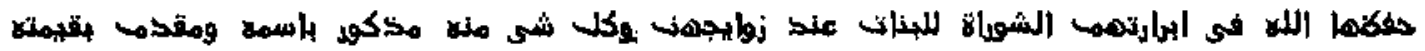

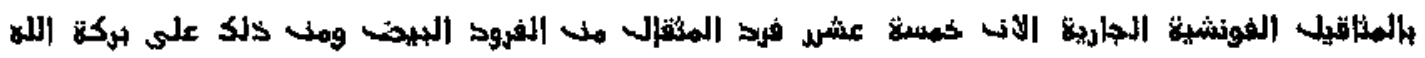

وحسيك

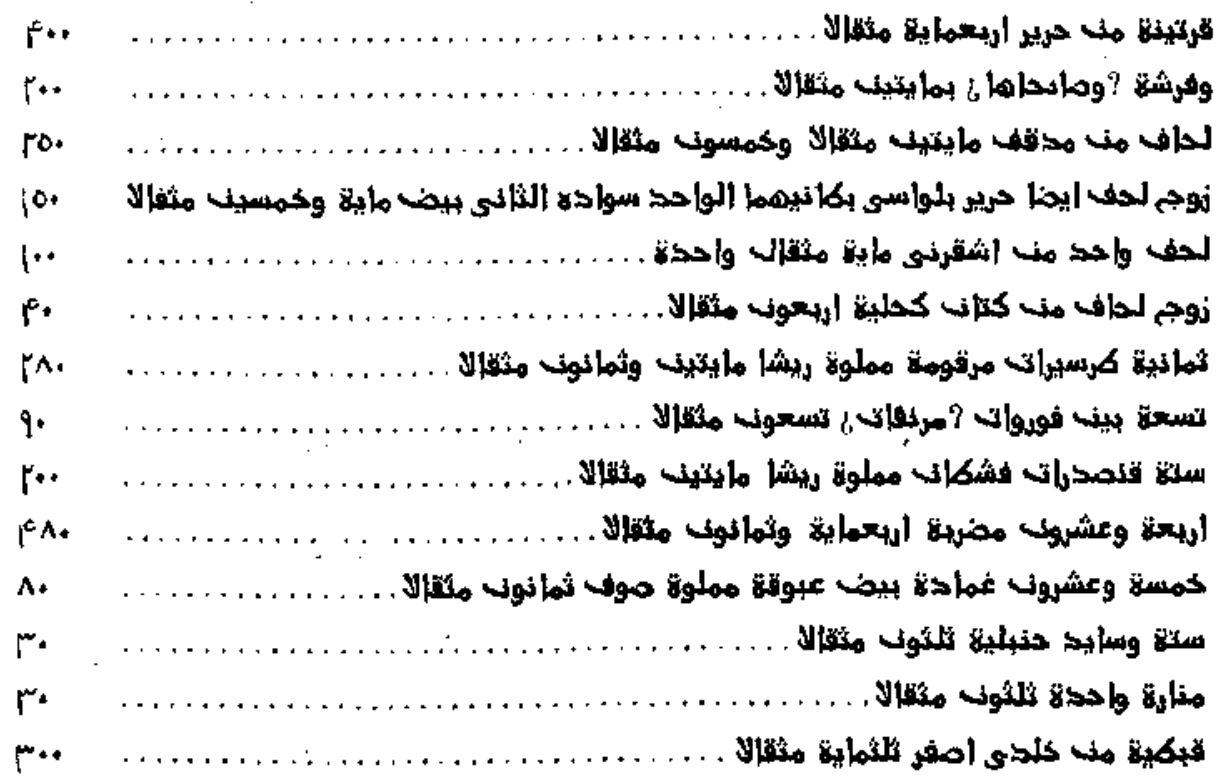




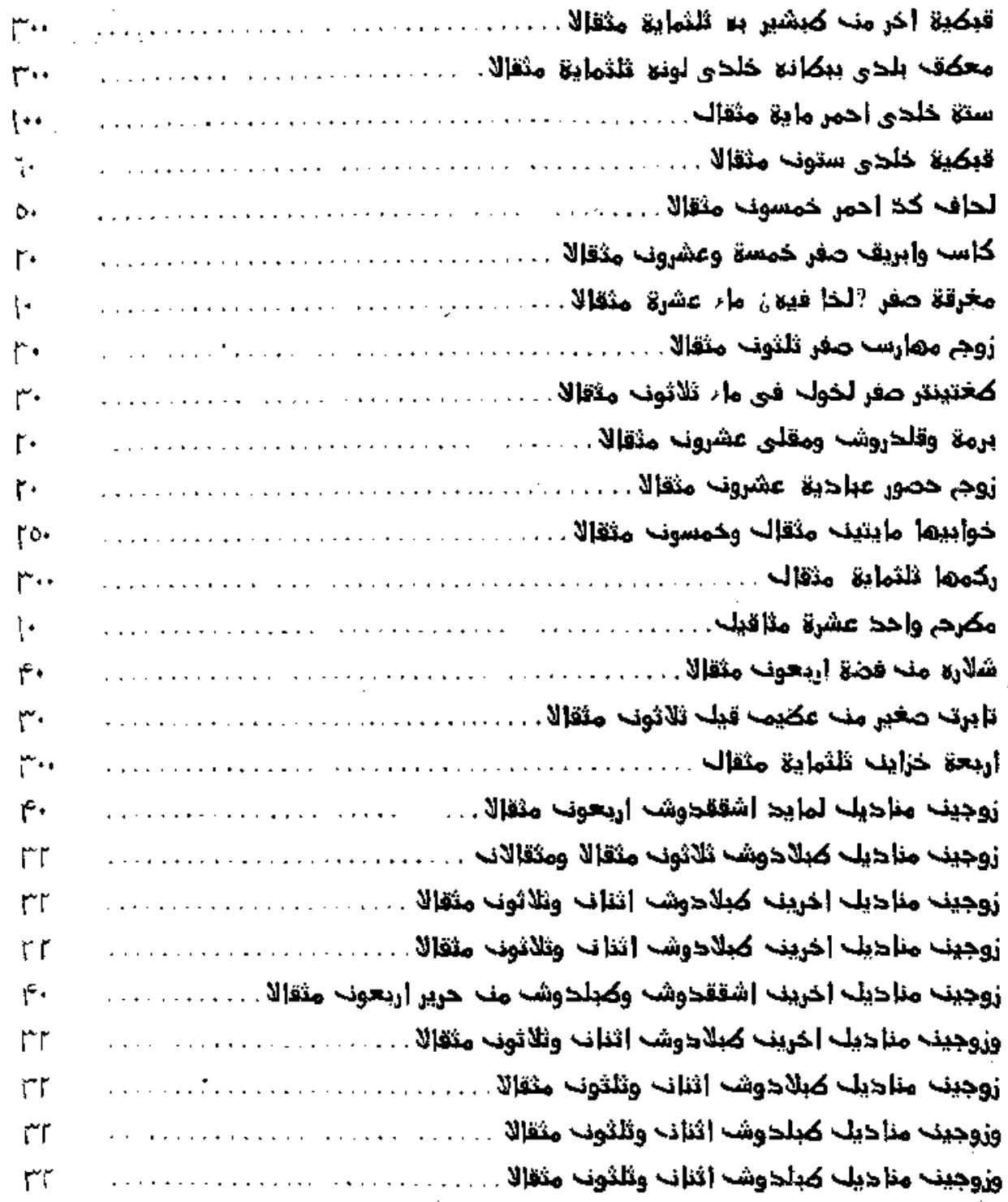

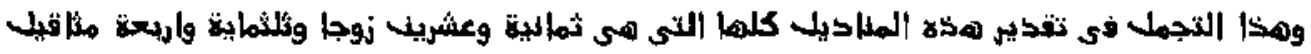

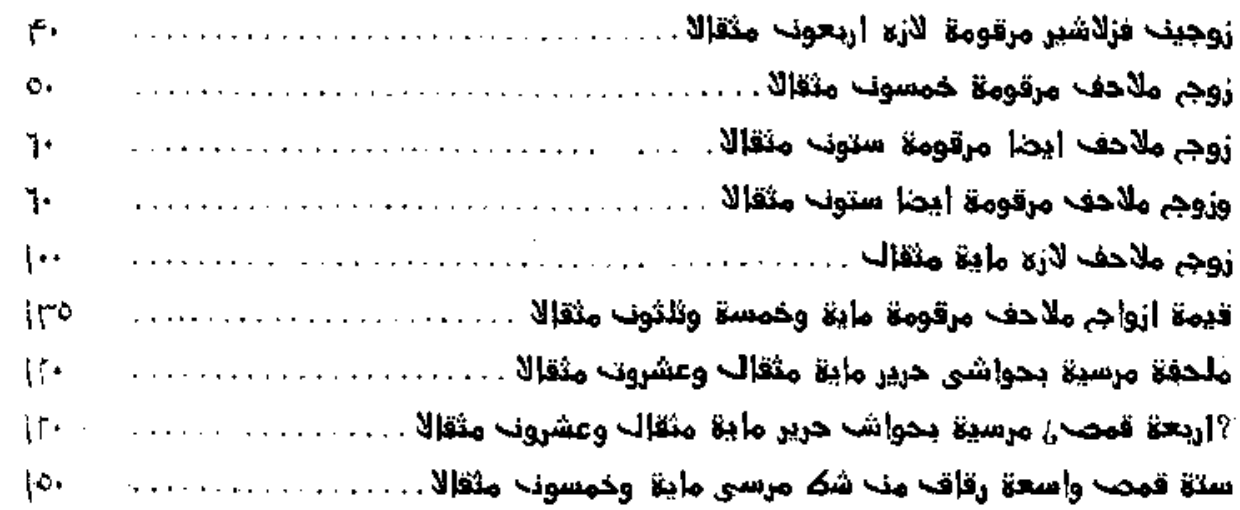




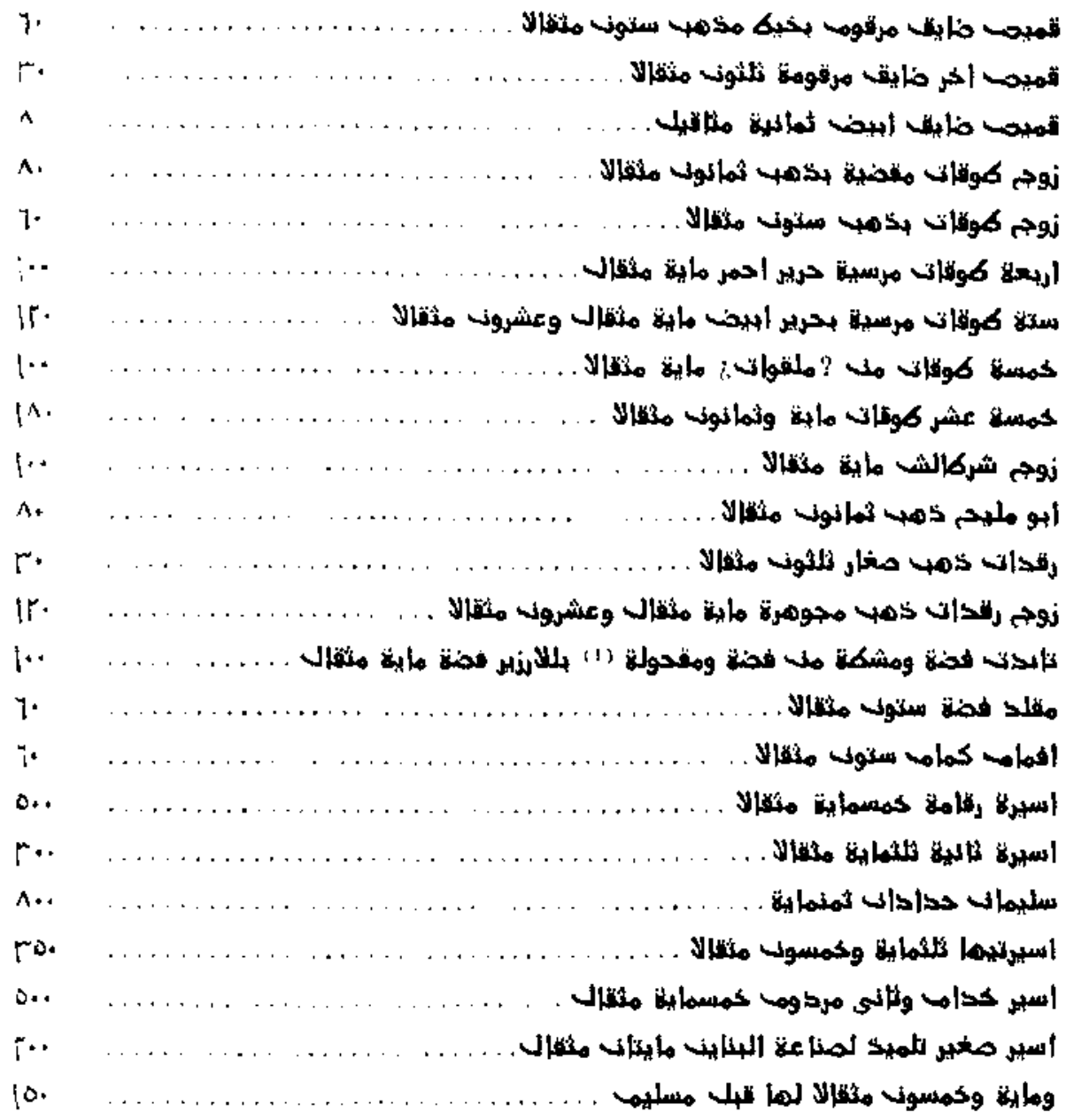

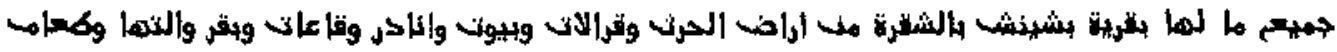

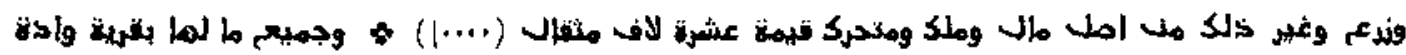

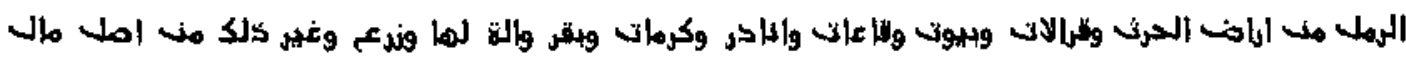

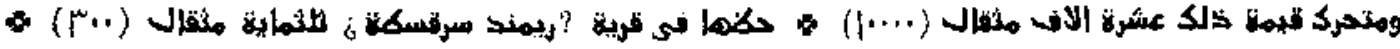

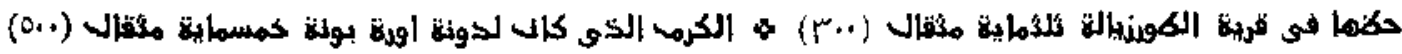

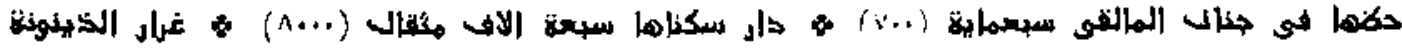

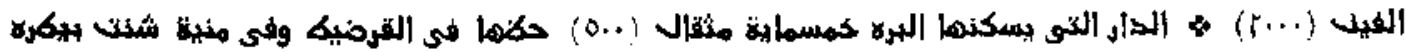

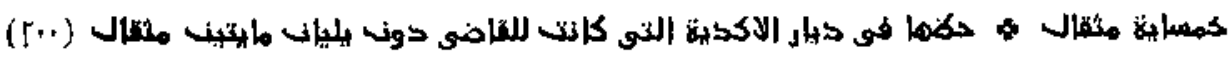

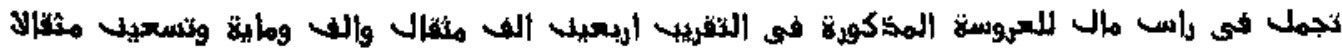

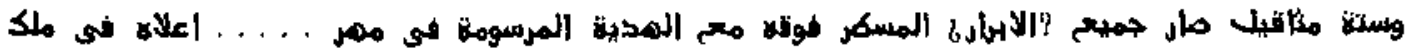

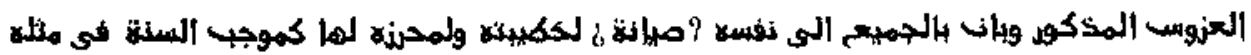

(1.) Sic, \&por abso? 


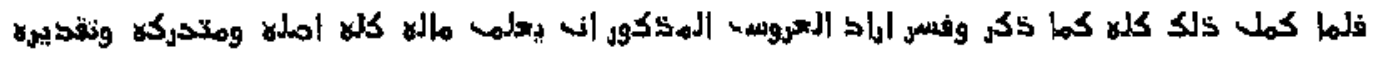

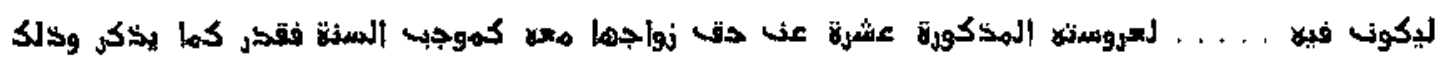

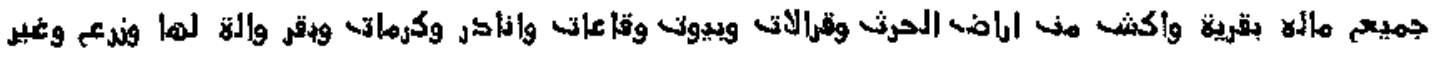

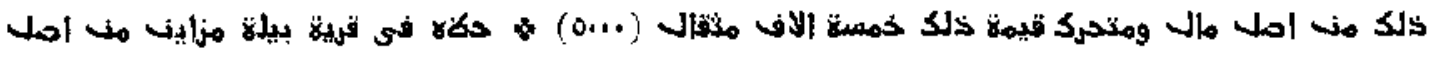

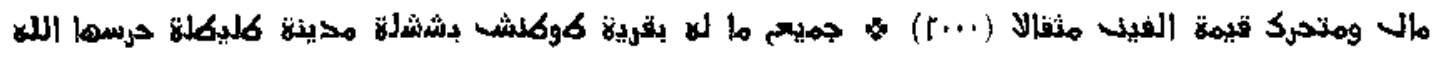

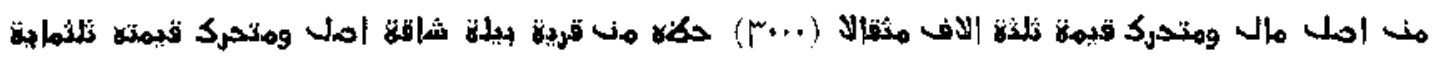

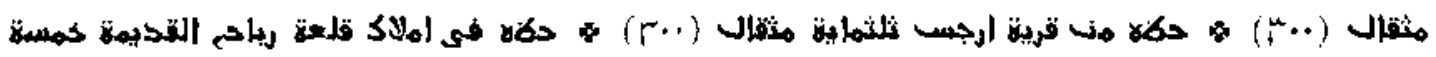

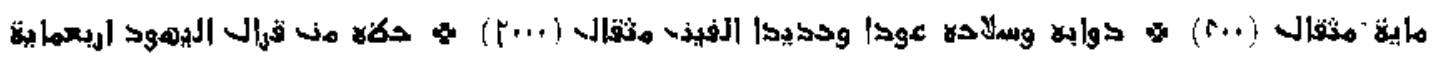

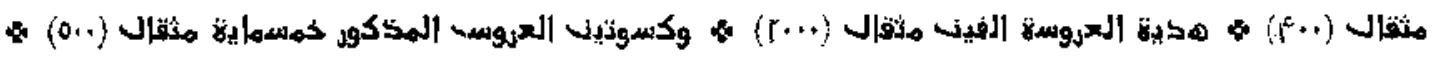

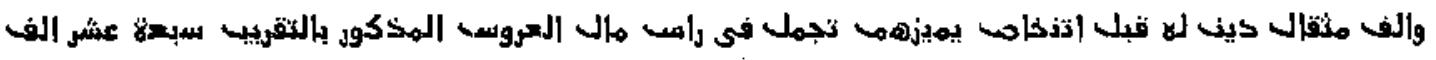

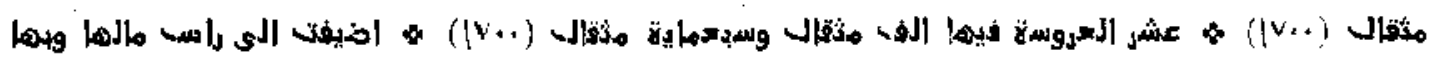

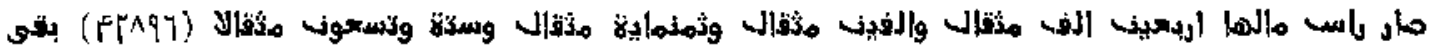

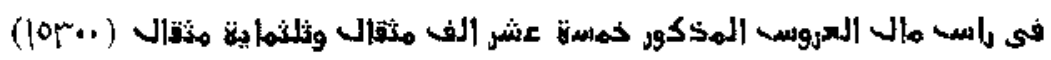

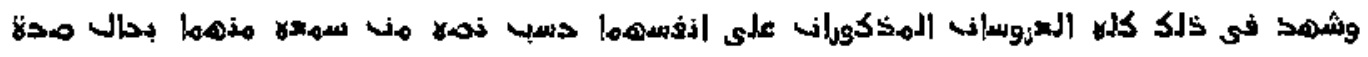

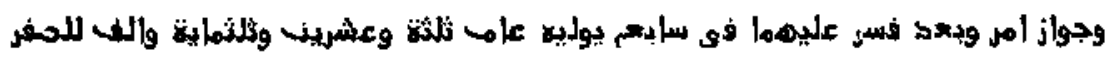

Firmas ut supra. 
I N D I C E S 



\section{INDICE TOPOGRAFICO}

Los números en cursiva remiten a las páginas del volumen preliminar.

Los números en letra corriente remíten al número del documento, en los volúmenes primero, segundo y tercero, y apéndice del volumen preliminar.

$\begin{array}{cccrrr}\text { Volumen } & \text { I. } & \text { Documentos números } & 1 \text { al } & 382 . \\ * & \text { II. } & * & * & 383 \text { al } & 726 . \\ * & \text { Ill } & * & ; & 727 \text { al } 1.151 . \\ " & \text { preliminar. } & * & * & 1.152 \text { al } 1.175 .\end{array}$

Abejares, Salinas de, $105,165,292$.

Abenala, 105 .

Abenbadah (Olias), 105.

Aberbahlul, 105 .

Abenmoxquiq, 105.

Abenracrún, Torre de, 92 ,

Abensocala, 105 .

¿Abentrado 650 .

Abenyúnus, Torre de, 92 .

Abdeselamn (Ollas), 10.5.

A bra, 634 .

Abtual, Prado de (Olías), 105.

Aceca, $18,83,86,99$, $201,211,218,244$ $302,689,731,903$, 1.028 .

Aceituna, 59, 83, 93, $98,103,113,135$, $151,204,205,224$, $267,304,315,317$, $418,464,521,756$, $764,1.027$.

Acreta, Viña de la, 110.
Acuabir, 83, 98,98 , 113,764 .

idemuz, 86.

Aguijón, El (Canie(las), 9.5

Alin, 83 .

Ahofrin, 84.

Aillon, 222.

Ain, $16,83,259,275$, $283,310,351,978$, $982,1.025$.

Ain Aldic, 85, LL2, $517,616,778$.

Ainaljabia, 83, 88 , $91,208,266,289$, $304,309,341,716$, 962.

Ajolrin , 84, 97, 216, $232,275,961,989$, $1.030,1.081$.

* Ajunaynas (Huerta del), 114, 293.

Alain, 710 .

Alritic, 7, 24, 76, 84. 86, $40,104,149$, $163,17 \%, 17 \%, 179$, $189,192,195,196$, $200,205,211,253$, $269,289,302,303$, $304,313,315,316$,
$317,319,320,325$ $377,452,463,466$, $469,495,523,559$, $582,584,585,588$, $613,738,741,766$, $799,1.025,1.056$, $1.093,1.132$

Alameda, $1,2,84,88$, $96,97,100,105,107$ $161,164,174,199$, $211,223,232,237$, 245, 250, 261, 304, $804,1.008,1.02 \%$.

Alamedilla, 80.

Alamediella? 1.030 .

Alarcos, $107,115,481$, $498,508,510$

Alaukchir, 92.

Albacora? 110

Albalate, 85, 95, 107, $112,612,702,784$, $999,1.04 \mathrm{i}$.

Albarracín, 181 .

Albarraal de Tajo, 94

Albat, 85, 1.025 .

Albatcl, 85, 87, 980.

Albelexterin, 91 .

Alberen, 82. 1.024.

Alborquilla (Melgar), 103,689 .
Albiches, 110,204 807.

Albiliztalin, 91 .

Albuera, 85, 101, 145, 169.

Albuferd, $166^{\circ}$.

Aleabon, 69, 164, 166.

Alcalá de Henares, $156,159,227,635$.

Alealbin, 313 .

Alcanabat, 104, 106 .

A lcapílat, 85, 93, 98 , $161,199,289,311$.

Alearaz, 177

Alcardete, 4, 8, 11, 85, $88,93,102,104,112$, $169,166,16 \%, 17 \%$ $182,184,188,145$, $196,197,210,216$, $271,280,285,302$, 311, 314, 315, 310, $325,341,485,446$, $565,590,672,734$, $738,810,942,1.041$, $1.045,1.117,1.125$, 1.126 .

Alcoba, $110,205,316$ $327,492$.

Alcobalel, 85.

Alcobneta, 156 . 
Alcolea, Barranco de, 109.

Alcoleia, 156.

Alcoroza (Melgar), 108.

Aleubilet, 85, 43, 199, 289.

Alchares, Salinas de, $105,202,341$.

Aldihuela, 86, 104, 696 .

Aldimus, 86, 10\%, 28\%, 957 .

Alessar, 86 .

Aletic, 84, 165.

Alexar, 5, 86, 93, 96, $106,161,164,191$, $206,211,226,237$. $248,788$.

Alexarejo, 86, 248.

Alcytic, 84 .

Alfach, 86,$317 ; 507$.

Alfamin, $15 \%, 16 \%$.

Alfiti, Azud dc, 94 , $109,140,150,192$, $289,305,584$.

Alfondega, 84, 86, 1.008 .

Alforiguiela, 86,840 , 344,920 .

Algcearcio, 86 .

Algibillo, 114 .

A] golor, 83, 86, 94, $10 \%, 10 \%, 11 \%: 113$ $324,596,622,636$ 682,721 .

Algordel, 86, 10\%, 28\%, 957.

Algortela, 86, 87, 89, $94,104,113,198$, 253, 261, 266, $26 \%$, $269,285,286,333$, $339,343,744,767$ $810,811,812,813$ $825,918,1.056$, 1.126\rfloor$,.127 .

Algorigijelts, 86 .

Alguaad, 303 .

Algundarín, 87,48 $109,192,262,341$ 914.

Algunderí, 87, 968, $1.005,1.012,1.061$.

Alhallecia, Lluerta de, 167.

Alhanaxi, Hnerto de, 967 .

Alhisar, 86 .

Alhofra, lluerto de $322,969,1.025$.

¿Alique?, $8 \%, 100,113$. ¿Aliso?, 87, 980 .
A jares, Salinas de, $87,105,292,916$, 1.015 .

Aljarich, $4: 2$.

Aljazin, 48,100 .

Aljofrin, 84.

Alleche, Planas de, 164.

Alleche,- Huerta cle, Iijs.

Alletic, 8t.

Alleetic, $16 \%$.

Al-llaytich, 8 is

Almahehuda, $87,21 \%$, $1.029,1.033$

Almenares, 87, 110 , 351.

Almeria, 113, 293.

Alwesa?, 1,045.

Almonacid, $87,88,94$, 114.

Almonacir, 87,98 , $100,112,113,388$, $642,682,781$.

Almoradiel, 88, 91, $104,166,184,198$, $275,309,310,311$, $312,313,375,376$, $826,949,950,952$, $1.033,1.040,1.046$.

Almoxátir, Alfoz de, $\bar{y}$.

Alunutia de Alseniemin, 166 .

Almuniar, 156

Aloium, $8 \mathrm{~s}$.

Aloyon, 12, $8 x, 96$, $162,162,160,166$, $199,231,232,241$, $302,314,310,316$, $31 \%, 319,416,480$, $535,589,688,694$, $735,751,942,962$, $972,1.043,1.046$

Alparra (Melgar), 10 ;. Alpera (Melgar), 103, 689,700 .

Alsaria, $88,1.045$.

Altasricar, 110, 218, 807.

Amada, 2.

Anduca, 88, 92, 97, 281.

Aniversarios, Viñá de los, 84 .

Anol, 88, 91

Annuail, 88, 250, 471.

Añover, $3,88,10 \%$, 684, 896.

Aragón, Rey de, 218.

Arcegal, 88, 103, 111, 318,657 .
Arcicolla, $81,84,47$ $80,106,161,16.4$ $222,2342,233,259$ $280,292,292,309$ $33 \%, 396,337,346$ $694,909,948,954$, $979,1.090,1.131$.

A renal, $\mathrm{Fl}, 53,89$, $160,303$.

Arovalilio, 89, 91, 105 161, 311, 334, 627 .

Argance, 86, 89, 92, $41,45,10 \%, 10 \%, 198$ $20 \%, 203,205,218$, $224,226,261,269$ $29 l, 333,339,744$, $767,775,810,812$ $917,941, \quad 1.006$ $1.051,1.052,1.127$.

Argeles, 14, 90, 302 .

Aгgés, 90, 96, 265, $27 \%, 641,643$.

Argómez (Caniellas), 95.

Arretuertaz (Argance), $89,1.006$.

Arroyo (Benquerencia), 92 .

Arroyo (Camarena), 94.

Artal, 90, 218, 31\%ิ, $454,502,576,599$ $600,1.044$.

Aseytuna, 83 .

Asncl, Loma del, 210 .

Asomail, Azud de, 195, 201, 298, 318 $554,555,639,1.117$

Assodam, Torre de, 92.

Assueca, 90, 296, 392.

Assuic, 90, 9\%, 94, 261, $333,823$.

Asuaqui, 95.

Atenas, Caballero de, 227.

A tojar, 92

Auria, $90,185,715$ 1.046 .

¿Ausenes?, 85.

Avila, 62, 65, 89, 181 .

Aviones (Talavern), 110,432 .

Axxam, Molinos de, 1.068 .

Ayn, 302 .

Azหนี่ม, 87, 90, 97, 107 . $115,160,161,161$ $165,175,182,183$ 210, 232, 255, 274 $304,305,309,310$. Azeituna. V, Aceituna.
Aznar Gómez, alqueria, 91, 334.

Azobirin, 91, 95, 201. $702,816,818$

Azucaica, 9, 17, 36, $49,50,83,84,91$ $10 \%, 103,109,111$, $112,115,148,101$, $164,165,181,191$, $192,19 \%, 199,200$, 201, 204, 212, 225. $232,246,262,30 \%$ $304,312,319,320$, $345,580,593,598$, $601,606,827,828$, $901,909,972$.

szudes del Tajo, 109.

Azuec, 164

Azueca (Molgar), 10 .

Azuhervela, 10\%, 316 .

Azumel, 109, 195, 321, 639.

Azuqueca. Véase $A z u-$ caica.

Azuqueica. Véase Azitcaica.

Azutün, 98 .

Bacza, 113, 295.

Ballenar, Puorto de, $47,459,956$

Ballesteros, 91, 26:3, $307,924,925$.

Balviches, $110 ; 491$.

Baños, Azud de; 109, $204,315,448$.

Bañttelos; 110, 186, $20 \%, 207,807 ; 1.007$.

Barea (Talavera), 110, 732.

Barcience, $94, M 1$ $783,932$.

Bar̄iles, $88,41, y_{6}$, $1015,10 \%, 256,162$, $173,316,844$

Barcines, 91, 662, 667.

Bargas, 91, 142, 165, $261,289,315,422$, $465,981,942$.

Báric (Talavera), 327, 743.

Barranco de las Canas (Manzel Abuishac), 102:

Barranco del Pastor (Manzel Abuishac), $10 \mathrm{~A}$.

Batres, Santa Maria de, $10 \%$.

Ваza, 153 .

Jechares, Salinas de, $87,292,973$. 
Belavia, s:i.

Belenna, ton.

Benaie, Barraneo de, (Caniellas). 45, 702.

Jonalavia, sis, si, fots.

Benalhabia. Vease Ainaljabio.

Benaljubia, !s?.

Benhalabia. 84

Benqureneiq, $S h, s \%$

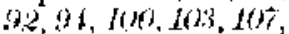
III, IIz, 4/6, 3/7, $31 \%, 320,321,322$. 342,14250502 622, 636, 640,642 , 646. 6\$6, 649, 661. 666. 1iis, 681, 682, 685, 695, 695, 690, (3)7, 7(5), 70t5, 70) $713,718,804,1.000$, $1.004,1.087,1.088$ 3. 124.

Jergroza, fisis,

Hermejillos, $4 \%$, for 692.

Herrocal ite Azobiat (Cohisa), $46 ; 658$. 693.

Berrocal te Domingo Sirlis, $52,10 \%, 3 f t$, 49.

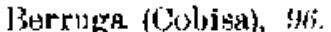

Jesines, 1\%, 107, $2 \%$ $240,254,525,809$. 1.() 15 .

l3ibas, Azud de, Iots, $245,084$.

Bilanil, Jis.

Bi] at (Algueria de). 1. 085.

Jimal, s\$, 92,94, tof $333,1.056$.

Binal, 19, $4 \%, 152$ 17.t, $189,2111,2: 32$

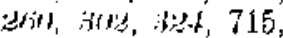
$736,777,962,996$ $1.016,1.021,1.022$.

Bissagra, 'Tierra en $16 \%$.

Bivas. Vease bibas.

Bonavalle (Benquerencia), 92,104 , 696.

Bonalhavia, 83 .

Bonetlella, 9.5.

Bomela, Ho, 807.

Borch Atoenracrún, $42,469$.

Boreb Abenyúnus, 88 , $92,97,101,106,281$ $246,392,5 \div 2,1.060$, $1.061,1.062$.
Josch Alawachir, 92, 906 .

Borch Assodan, 9: 9.6. 933.

Burel Modafar (Riel ves), $10 \pi, 805$

Borgelauarer, 6),

Borox, 8\%, 91, 93, 24:2, (116, 1.045;

l3oroxos, $8 i j, 93,9 \%$, $106,211.287$.

13u, Gerto tlel, s\%.

Buchul, 4is, 9.3, $23 \% 324$, 188,1059

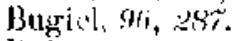

Juitrago, Jis.

Bum, Hajucho dat, dz. $322,6015$.

Burgos, $\pi$, 1 No

Burgidilos, the $93,9 \%$, $419,1014,641, \quad(551)$ 16.57. $66,5,1392,1.022$ 1.116 .

Hurines, 15\%.

Burnozy, $83,43,96$, IS, 764 .

Burujon, 9:3, 726.

Caba (Benquerencia), ij.

Cabañas, 86, 4h, 167 , $135,211,283,702$, 993

Cabantas de la Sagrar, sij, tisti.

Calnaña de Yepes, wis.

Cabrela, 0:3, 431 .

Cabezo (Auria), s).

Cabezo ile liarh (Jayos), $I 01,103,1 \mathrm{l} 3$.

Cabrzos(Pozuelo), this, $3325,1.140$

Cabazuelo, El (Mel. gar), $10 ; 3,700$.

Cabezuelo (Olias), $f(t)$.

Cabo Ameros (Otías), Litis.

Cabrón, lerro del, 87 , 1.005 .

Cadafalso, 16it.

Caid, Azud del, $10 y$.

Calabazas, 93, 107, $200,2205,232,318$, $316,321,562,567$. $568,571,615,759$, $820,978,1.018$ 1.045 .

Calahorra 101.

Calaña, 94, 94, 109, 140.

Calatalifa, 159 .

Calatrava, 90,109 ,

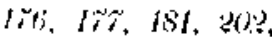

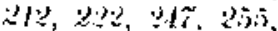
35

Calatrava la Vieja. $2)^{2}$

Galbin, 37, 4t, Hol. $53,153,213,233$. $265,303,299,403$.

Calera, $1 \%$.

Caleras (Camino de las), 546 .

Calichena, $26 \%$

hivachates, it.

Gulvir, Bl, $\%, d / \%$, !58.

Cumarema, $f i, s t i, s$,

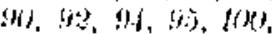

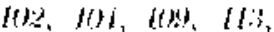

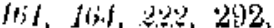
$311,333,334,813$, $1.006,1061,1.062$

Cimarenila, the lot.

Cumbrillos, yf, $111,702.1,030$.

Gatubromales (Cumic. $\left.\mathrm{Il}_{\mathrm{as}}\right), 9 \%, 702$.

Caniuchal, 9, , II, 831.

Oarnpo rle Koy, 57,4 . H.3. 18\%, 219, 26\% $32 f, 325,773,1,107$, $1.10 \%, 1.110$

Canales, l'ago de (l'a. lavera), $20,28,81$ $34,80,44,98,101$ tos, Ito, $135,15 t$, $166,16 \%, 193$, , $2(1$, 222, 22\%, 232, 25\%, 262, 283, 284, 3H. $420,729,803,993$, 1.006 .

(anoth, $\$ 67$.

Ganillas, :1, y, 4s, 32:3, 702, 707.

Canos, $59(\mathrm{i}$.

Capillas, $9:$

Cañíbcol, Molino del. Ifj7.

Caravamehlel, Ití.

Cartionoro, l'uerto del (Cuerva), 97 ,

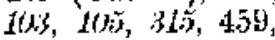
$468,9.56$.

Carraseal, 8\%, 92,94, $95,96,110,315,338$ $650,693,702$.

Casa Chica, 45, 28\%3, 998.

Casar del Asno, 95, $97,101,105,29 \%$, $450,456,1.155$, $1.156,1.158,1.159$
Casas Buenus, gti, Iol. [oti, 5i32, 68:?,

Castillu, Cannino de, $96,48,60 \%, 815$ $817,1.014,1.015$, I.129.

catdilla, 93.

Cobolla, ste m, 1.(m). Colonicts, 115.

Cerones iNlquerla), (i)

Gerva longa, , $6,16 \%$ $343,386,387,364$ 390

Cosprevtosa, difi.

bincostiella, Ifit.

Ciruolos, !3is.

Ditularl Rogl, toi.

Cluny, bos.

Cobeju, $8 \%, 91,4, m$ (x), $10 \%, 106,2 / \%$ 134, 147, 157, kil,

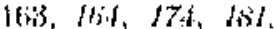
2H, 211, 221;, 234. $235,237,248,258$ $3(4), 1.023$.

Gohjon, is, $98,94,101$, $103,40,10 \%, 114$, 156, 23i, 251, 262 $271,305,30 \%, 321$, 320, 324, 325, 313. 632, 638, 641, 647, 650), $657,658,665$, 692, 613 , 824, 378 , 1.029, 1.1116

Cochol, Vina ilel, tos.

Cochuolo, Vínta del, III.

Cojuolo, Viña del, idi.

Colmomar, lal, wo, ysi.

Colmonar do (Treja. 71.

(i)llado de Murtín Abilboca (Olins), itis.

Contisira, $1 \% 7,1.024$.

Consuegra, 57 .

Córdoba, ISH; 2yA, Sialis.

Corral Rubio, 70, dr, if, 103, 105, 109, Hit, $16 \%, 173,204$, $225,27 \%, 489,3.2 \%$ $31 \pi, 341,350,447$ $475,326,927,1.054$ 1.064.

Cortas, 16\%.

Coscoja, 97 .

Coscojas (Calauazas), $5 \%$

Coseojuela, 97 , 
Coscolla, $97,359,495$.

Cozmlluella, 97, 3\% 985.

Cuadra gradede (Co niellas), $45,702$.

Cuadrejon (Alcarde. (e), $86,1.045$.

Cuadrejones del Ca rrascal (Caninlias). 95, 702.

Cuadro (Alearclett), $86,1.045$.

Cudriello del Gamonal (Bencuuerencia), 32 .

Cucilar, 176 .

Cuenca, $44,45,52.53$ $69,71,88,90,174$ $181,182,211,217$. $267,274$.

Guerda, 10.1.

Cuenva, $45,47,101$ $103,105,261,250$ $458,459,460,825$, 956.

Cugullut. 159.

Chalencas, 305

Chareo?, 702.

Chebel Addoa, 97, 315 , 348.

Choca, $9 \%$

Chonsin Datud, 85,88 $90,92,97,110,281$ $296,351,892,921$

Chozas de Canales, y5.

Ghueca, $4 \%, 90,113$. $267,2 \%, 770,771$, 772 .

Darabengaz, 97, 10\%, $317,506,518,530$, $972,976$.

Jaragebal, 97 .

Daralallutd, 166 .

Daralbelio, $87,88,90$ $92,97,110,137,162$ $496,221,264,2658$, $2,0,278,281,286$ $296,304,304,310$ $31,312,313,321$, $324,351,361,392$

Daralbieha, $1 \%$, 1.034

Daralcotán, 97, 304 .

Daralcudia, 98.

Dar al Chebel, 84, $4 \%$, $107,1.008$.

Daralfornana, $88,9 \%$ 97, 98, 281, 296 310,392 .

Daralihudi, 98, $: 11$, 328.
Daraljazin, 5, 58, 61 , पy, $87,98,139,19 \mathrm{~d}$ $192,262,302,966$, 1.092.

1)aralmagra, $48,16 t i$.

Dartalruazin, 83,93 , 98, $113,7(44,1.045$.

Daralmocara, 96 , 18 . $320,607$.

1)aral viejo, th

Daramazán, 98

Dararveso, 98

Darassudán, 85, 93, $98,32 \%$.

Darauaris, 48,642 , $720,781,869,884$.

Darcicolla, ss, toi, 112.

Darvello, 97.

Dazaituna, sis.

Degollada, Barranco de la, 82.

Dehesa (Talavera). 110,385 .

Dezma, 97, 99, 267, 770 .

Diezma, 9:, 98

Dirabengaz, $9 \%$.

Dowingo Zarco, Al. queria, $110,327$.

Dorbico, 110, 202 .

Dos Parrios \%

Egros, 94, 114

Gibib (Valera), 8h 112.

Enforeados, I,os, 166 .

Mscatona, 154, 164.

Escalonilla, 98,455 .

Espartinas, Salinas de, $98,226,242,675$.

Esquivias, $6 \%, 98,111$, $173,232,320,618$, 620,621 .

Estibel (Caniellas), 95 , 702

Estiviel, 95.

Falvat, 113.

Panega, Viña de la, 84,466

Fazaña, 91, 101, 163, 265 .

['enollar (Camarena), 4. $4,833$.

Fermaldo Muniz, $\Lambda$ l. queria de, $10 \%$.

Higares, $83,99,185$, $204,244,259,731$, 1.058 .

Fierro, Molino del, 167.
Fitia, fos

t'lorent (oliasi, los, 48.

Pontalba, 90, 10t, $10 \%$ L6. $2,16 i j, 173, \% 18$ $261,27 \pi, 285,317$ $526,745,804,1.012$ $1,000,1.126$.

Fontanel]ns, 110, 186 , $145,205,359,995$

Font del Albejtar, 321

Fonte Lober colihue. las $, 105,394$

lontes, 99, 11. 16\%, $193,218,268,313$, 380 bis, 407,408 $748,749,750,758$, 1.123

l'orcaio, $t 00$.

Eurnillos, 110, \%of. $253,1.045,1.057$.

Frailes, Huerto de los, 293.

F'uensalida, 106, 338, 911.

Fuent del Madero, 164.

Fuente del Albeitar (Benquerencia), 92.

Fuente Altamia, 164.

Fuente del Caño, 18\%, $2: 32,290,1.030$.

Fuente del Gallo, 83.

Fuente de la ollera (Caniollas), 55, 702.

Fuente de los Pastores ( $P$ ofin Agrile $r a), 10 \%, 95 \%$.

Gafrón, Barranco de, $82,312,313,358$ 400,570 .

Galomtero (Alcarie. te) $86,1.045$.

Garb, El, 795.

(iarganta, 9\%, 100, $204,214,225,316$, 350

Gaza, 15:3.

Goledaño, 287.

Golpejares? 71 .

Granada, 153.

Guadajara, Ro, 83 , 100.

Guadalajara, 56,156 , $169,176,17 \%, 255$. Guadelselat, $100,21 \%$, 389.

Guadaxaras, $10 \%$.

Gluadamur, 88, 98 .

Guadarrama, Rio, 94, $95,100,10 \%, 153$,
$243,265,2 \pi 1,335$ $702,815,1.009$.

Guajurax, 10tor, 109 4 16.

Guarelia, $100,107,720$ 722,992

Haluenicl, tos.

Habily, Molinos de, 156 .

Hameida, $700,159$.

Hazulin, 16f.

Higares, 94, 99, 105 $2 \cdot 1,731$.

Uinojar (Camarena), s.

Fincjessa, $1 \%$, 115 .

Hontallia, 99.

Horcajo, EI, too, 33\%4, i) $4.5,421$.

Hoyacho (Peña Aguil('एa), 10 กे, 956.

Huecas, $100,10 \%, 113$, 27\%, $8(19,810,917$, 930,931 .

Huerta, $10 \%, 103,682$ 689.

Huerta del Rey, 717.

Huerta de Valdecarábanos, $100,111$.

Humanes, 1il.

Itrsillos, 44, 189, 183 .

Hylesques, 101 .

llaica, at, 100, 113. $16: 313,380$

Iledtal, $94,100,958$.

[l]escess, $55,90,98,95$ $99,100,114,163$ $171,176,210,237$ \%59, 858, 1.121. 1.258

fumela, 101

Jabali, Pico del (Airaglo), 10\%, 105.

Juén, 99.

Jálid, Barranco de, $8 \dot{2}, 344,325,436$.

Jenesa, 97, 101, 105, $315,458,460,1.155$, $1.166,1.158,1.159$.

Juja, Azud de, 105, $110,286,981$

Jumella, 95, 101, 322, $1.155,1.156,1.158$ 1.159 .

Labachos (Camare 14.), 94, 363 .

Laguna, I a (Cobisa), $96,647,657$. 
Lamea (Talavera), 110,732

Layos, 90, $92,56,101$, $103,113,26 \%, 527$, $657,692,693,824$.

Lebla, 181 .

Letic, 84 .

Leon, 1\%s

loches, 50, b\%, 10t, $166,169,180,196$, $205,212,227,247$ $303,905,943,1.021$.

Lobes, 101 .

Loje, 153.

Loma de Asnel, 429.

Iominchar, $9 ., 111$.

Lonquera o Isonguera (Canicllas), t5 702 .

Jonsolus, tint.

Lorea, 323

Lorita, 21, 22, 101, $167,186,194,289$, $30 \%, 1.058$.

Lorta, 101 .

Madrid, 4t, 90, 101, $1(14,155,154,164$, $173,1 \% 6,177,185$. $190,211,212,222$, $248,559,564$ 800 .

Magén, 10\%, 158, 16\%, 261.

Maharis, 11: 642.

Manzahubedalla, 226.

Manzel Abuishae, 86, 102, $103,112,182$, $189,260,310,596$, 821.

Manzel Ambros, 10 is.

Manzel Amris, 113.

Manzol Chazo, 94 . $102,833$.

Manzel Maisara, 10\%, 972

Manzel Mosea, 4, 8 , $78,102,188,302$, $304,1.014$

Manzel Obaidalá, 95 $102,120,161,162$ $176,230,292,239$, $268,305,309,315$, $337,338,363,455$, 702,910

Manzel Razin, 2, 9 $17,10 \%, 105,191$ $200,302,305,738$, $901,908,1.099$.

Manzel Salih, to2, $103,596,622,643$, 696.

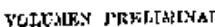

Manzel sihra?, 8\%, $1(13,756$

Manzel Yajx, $1 \%, 10 \%$, (2) $f, 26+798,926$, $92 \pi$.

Nacucda, trit:

Mareluena, 15:3, 15J.

Mardalón, Río, sis 1.006.

Mariuquéx, 15.3.

Matzalcadi, 114, $2(x)$, $288,305,967,973$.

Nascaraque, 4, Jos, $113,449$.

Matsbur, Azud de. 10.4, 144.

Yazarabetala, 102.

Mazarabedas, 10.

Mazar'sbuzac, 165.

Mazarabu\%que, 186.

Mazaralbuzaque. Jo:

Mazaralmosea, $10 \%$.

Mazaramesca, 102.

Mgzarambroz, $10 f_{1}$ 10is, 527 .

Vazarahobeidula, low.

Vazarrazín, 102, $16 f$, 218,265 .

Mazara vedola, 10 ?

Mazaravedula, 10,4

Melgar, 83, 88, 90, 700 , $103,1115,111,114$, $334,557,684,699$ $700,719,720,862$, $865,884,992,1.120$.

Menasalyas, 9:, 9.5, (47, Ji) 3,494

Mezquita, $34,40,10 \%$, $218,343,318,393$ $454,502,540,566$. $599,600,1.049$.

Milagro, Castillo de, I0:

Miraglo, Castillo de, $103,106,290,315$, 468,956 .

Mocejon, 10\%, 112, 244,587

Mochares, 104 .

Mocheras, 10h, 1.045.

Molino, El, 102.

Molino de Arfaarasob, 104

Molinos de la Catetlra], $16 \%$.

Monasteles?, 799 .

Hontalban, I7t'.

Monte, Pago del, 962.

Monte de Alameda? 1.033 .
Montearudo (Argance), $8 \%, 1(200$.

Monto Hammara, Jof, $792,263,928$.

Monte Aurio, t2\%

Monte de la Calera (Argance) 8\%

Hontefrido, 187 .

Mont lerid, 384

Mon te del Jabali, 950 .

Monte Lebrero (Argance), sit.

Monte de Peria del Lobo (Argance), 89.

Monte Potruch (Argance), $8 \%$.

Montel, 12

Montes de Tolerlo, 95. 101,103 .

Monturque, 76,104 , 304.

Mola, 19, 10, 96, 10\%, 104, 219, 202,689 , 711.

Moradiel, 28, 104.

Moralcja, 31, 34, 88 , $84,104,712,799$, 1.006 .

Moratalfaz, 45.

SMoratilla?, 6, 10: 302.

¿Morcelf, II eredad dol, tist.

Moxatir, Alfoy de, 98.

Murillo, 104, 813 .

Nabatolia, 2.

Nambroca, $8 \%$.

Nava, $104,896$.

Navahermosa, 104, yos.

Navalcarnero, 104.

Niebla, 181

Noez, 104, 106, 532.

Noves, 99, 104, 1.030 .

Ocaña 93, 114 .

Ocas, $86,87,164,261$.

Oclelos, 105, 114.

Oener, 107, 111, 261, 269,285 .

Odair' el Curam, Azud, 109.

Olias la Mayor, 32 , $35,40,42,43,58$, 61, 62, 66, 91, 98, (96, 90, 101, 102, 105, $107,112,114,125$, $127,131,160,161$, $162,164,165,166$, $178,188,197,202$, $203,20 \pm, 205,206$
$208,218,224,225$ 232, 238, 238, 261, $262,269,276,279$, $979,280,284,290$, $299,303,3014,305$, 310, 311, 31\%, 313, $311,310,316,516$, $318,311,320,131$, $344,349,357,370$, $373,383,397,402$, $415,422,445,472$, $478,479,499,505$, $507,512,528,539$, $549,587,612,691$, $757,762,763,759$, $790,797,800,814$, $815,817,825,907$, 915 bis, 933, 955. $983,985,1.013$, $1.055,1.129$.

Olías la Menor, 102, 10.́.

Oliolas, $40,45,165$, $198,261,378,422$.

Olihuelas, 105,267 , $309,324,724,725$, $765,817,972,986$. Otmidiella, 85, 225.

Olmos, 95.

Ollera, Fuente de la; 702 .

Onclelos, $10 \%, 114$.

Orea?, 105, 777.

Orgaz, $10 \%$.

Osma, 84, $102,181$.

Pagés, 105, 10\%, 1.030.

Pajares, Salimas de, $10 \%, 285,292,1.1 \geq 26$.

Palencia, Universidad de, 18\%.

Pantoja, 2, 89, 93,96 , $105,106,113,237$, $250,334,783,868$.

I'aris, 194, 199.

Parralejo (Cauielias), 95, 702.

Parrales (Olfas), 105, 261.

Pastor, Barranco del, 596.

Pastor, Viña dol, 736.

Pegujares, Val do, 702 .

Penigl, $16 t$.

Peña, Molino de la. 110, 224, 802.

Peña Aguiler.a, 97, 10t, 103, 105, 291 . 458,956 .

I'ona-Fora, 159 . 
Pcuaventosa, $70,1 \% \%$, 3ith.

Peralejos, Saliuas de, 106 .

Perales, Salinas de

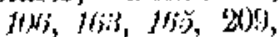
$27 \%, 49 \%, 1.014$, 1.030 .

pesines, 705, 106, 111, $173,317$.

I'ico del Jabali, 4ts

I'inel, $f(t), f(t), f a t$, Q.

I'injel, tye.

Pizarra, Valle de la (Miraglo), tos.

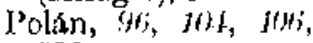
532 .

Pomar, Iil, 37, 4f, $(K)$ fot $72 \mathrm{~s}, 153,213$ 265.

Portal, 10ti,

Portal de Salatiava, $106,330,321,322$, $\{12,654,1579,69\}$, $738,963,1.035$

l'ortalejo (Melgar'), iv? 700 .

Portillo, si, lof, $16 \%$ $338,721,911$.

Potroro (Camalema), 1.1. 2033.

Pozancares, wh, Not,

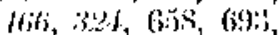
$1.018,1.102$.

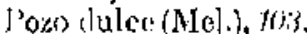

Pozo Almara, :soi.

j'nzucha, Itifi'

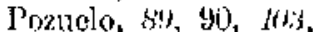
$11 \%, 106,113,3283$ $334,400,689,69 \%$ $\$ 24,1.021,1.029$, 1.033, 1.140 .

J'omelos, 60 is.

P'rulo, JE, $\$ 21$

Puebla de Almoradiel, Bs, $10 \mathrm{f}$.

Pucnto del drzobisuon, $97,18$.

Inerta de los ciarros, 316.

Puerto del Balenar (P. Aguilera), $/ t i$.

Puerto del Carbone. ro, 468.

lugrto do Huaid (Cuerva), 57.

I’ulga, Arroyo dì lá, Iio, 132 .

Pulgar, $(\%)$ lot, $\mathrm{H}$, 525.

Puzola, 10t.
Quinta)tr, 89.

Racachiol, \%).

Raimundo Zaragoza, Alqueria de, $2 \pi T$.

Trocas, $\%$ \%

Iuegrachutolo, $10 f f, t 89$ $199,31 \%, 371,612$ (i) $1,738,1.009$, 1.045 .

levgain (Nlcardet( ), oti, 1 (1) 45.

Reiss, Molino de la lij.

Reina, Vega de la lio.

Reinales, Ji

Renales, fffi, 'st\%, 1.1's1.

Rielves, $38,39,84,9 t$, $97,17), 117,148$, 21, $21,270,281$. $3(1 \%, 319,485,702$ $805,816,861,960$ $931,1.546$

Ito Mayor ('lalavera) fst.

Rotlelas 245.

Rorula, 2f 7 .

Rotollas, $/ 56$

Sad ben lfarrar, $A]$ cueria dic, $10 \%, 957$

Siagra, Ia, 2S, 42, si, sti, sis, $40,4 \%$, 9. 9f, Ho, $/(t), 107,157$, $161,250,255,281$, $274,806,1.030$ $1.045,1.125,1.126$.

Salado, Arroyo (Mel. gar), $10 \%, 506$.

Salat, lio, $(k)$.

Salboll, Hor, I15. 481.

Salvaticra, Castillo de, 11), 115,481 1.024.

Sin Cebrian, sfi, th, $t(0), 103,106,10 \%$ $112,185,194,822$

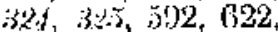
$642,649,680,682$, $708,719,720,721$, $722,992,1.120$.

San Estrian, $71,10 \%$, $263,304,929,1.06 \%$

San leliz, $x, 25,57$, $73,107,171,179$ $324,823,902,1.022$, $1043,1.103$

San Julián, 112, 390 .
Sans I áaro, Convert to de, fis s.

San Malio, $4 \%$, H.

Gan Mareos de Yogros, $1 / 4$.

San Martin, Vega de, J10:, Q18

San Nicolrás, Nhlca, $b \%$.

San Pablo, larraneo de, 51 , JАн, 962 972,970

San lionnán, Yega ile, was, $b / h$.

San Servanio, H/2, $146,232,1.020$.

San Vícente del Montc, $180,2(\mathrm{k})$

San vicente di la Sierra, Orden de, zoin.

San Zool, :2*).

Santa Colomba, $8 \%$ 91, $119,10 \%, 158$ $301,307,301311$

Santa Folalia, Castilo ble, $10 \%, f .9 \%, t \%)$ 805.

Siantie Maria de Al. maina, Iglesia en, 190.

Santia Marlat la: $\Lambda$ to. cha, Iglesia ste, fint.

Santa María de Jur gutullos, Jglesiaz de, Ity.

Sianta Haria de la Sisla, Iglesia de, for, ti)?.

Sarcit (Riolves), Jor, 427.

Sarf Adojan, $10 \$, 529$

Segovia, $41,181,252$ 2.j.f.

SSelcaldima tos 515.

Sescuia, 8\%, JIS, 292, $1.03(1,1.045$

Setmo, 92, si, $I 0 S$ $3.39,344,657,692$ $693,991$.

Sevilla, $46,47,5 !$ 25:2, 287, 29:\%.

Sierra de Layos, 101 .

Silos, it, 93.

Siphacha, 15:

Sisla, $8 \%, 86,86,87$ $88,90,92,9 \%, 94$, $16,97,98,99$, for, loh, $N 2,103,104$, $106,10 \%, 108,110$ $111,113,102,165$,

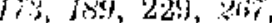
27 , 301, 管o bis, y $1,386,3 \times 7,384$ $407,412,420,444$, $453,511,515,521$, $525,526,527,532$, $552,5 \div 2,566,589 \%$ $506,599,600,622$, $642,680,992,719$, $747,770,771,772$ $778,779,781,821$. $920,961,989,1.052$ $1.015,1.060,1.062$, $1.207,3.108,1.110$ $1116,1.12 \%$

Soherueld $3 / 6$.

Suati, $108,97 \%$

Tajo, 2, 7, 9, 22, 24, $36,47,57,59,64$, $71,73,78,85,85$ sit, si, $90,91,4$. $94,97,90,10 t, J)$, It) $108,110,110$, J1) H2, 129, 14\%, $145,148,184,193$, 198, 204, 214, $2 \mathrm{t} 6$, 25: 257, 201, 301, $325,350,308,869$, $384,390,418,421$, $426,442,447,448$, $452,464,467,475$, $491,495,514,582$, $591 \% 5 !) 6,613,622$ $72 ! !, 758,784,708$, $799,807,810,924$, 925, 943, 902,094 $1.005,1.022,3.024$ $1.025,1.041,1.043$ J.c.s.

Talmanea, $M g_{1} / l_{1}$ IJ\%.

Talivera, 26, t6, 江, 9. $, 16,10 \%, 110,111$, 119, 12:, 129, 132, $141,14 \%, 456,15 \%$ 165, 16\%, I76, Lo5, $186,157,188,160$, $193,195,19 \pi, 2,11$, 202, 20$), 2(1.4,205$, $207,216,218,234$, $224,226,233,235$ $253,25 \%, 255,261$ $265,269,300,313$, 301, 305, 306, 310, $34,3 L 2,3 L, 344$ $316,32 \neq 327,338$, $352,360,384,385$, $413,462,433,442$, $448,491,492,497$, $729,732,737,743$ $802,803,807,808$, 
$984,1.024,1.028$ $1.018,1.046$.

Tarumni (Talavera), 111), 261, 802

l'ebuis, 110,132

Tolmorelas (Caniellas), $9 \pi, 702$.

thello Liaz, Alquería de, 6\%, 10, 351 .

T'emam el Roclegui, Alden de, 38,39 , [1\%, 97].

Tercia, $x^{2} 7$

drienda felumb? 11i, 569 .

'oceneryu, 111,232 , $831,862$.

\section{TOL JEDO}

Abesalbazo, Casa de 32.

A be ri no ha rech, Huerto de, Ais.

Acaba ([a) $71,17.3$ $329,695,674,1.151$

Adarvede Abazardiel, $75,325,674,1.143$.

Aurve de $A$ berngalún o A bgalón, 7, , s, (j35, 1.138, 1.13y.

Aclarve de Aleenmati. nor, 75, 385, 1.141.

Adurve de Alocumo. harris o Mihras, is?, $217,00 \%, 735$.

Alarve de Abentuair, 53:302.

Altarve de Algunde. ri, 75,965 .

Adarve do Almogiiac, is.

Adarve do D. Hertal do, $2 \%, 173,211,320$, 605 .

Aidave de 1). Metran. do Vicente, re, 1.034

Adarve de D. Fraucés, 17 .

Alarve de D. Gareía Juancs de Meana, $193,1.173$

A uarve: de D. Juan de Selaya, 81 , 1.082 .

Aclarve Ae D. Juau Vicente de Vargas, $56,321,603,653$ 659,907 .

Adarve de D. Pedro Juanes (San Nico.
[Toledo.]

Alberguerla da la Ca. tedral, $53,963,979$ $1.095,1.105$.

Alberguería de la Trinidad, 216.

Alberguerla de los Franeos, 141 , 216 , 801.

Aleaiceria, 6s, 978.

Meaná, $3 \%, 89,60$,

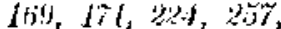
$3 \% 7,653,659,677$ $716,460,068,1.035$

Aleazar del liey, fis, $67 \%, 67,65,141,318$, $561,654,655,671$.

Aleanlara, Puerta de, bo, fis\%.

Aleudia, zo, 5is, od. $55,65,111,150$, $16 \%, 17 \%, H \%, J H 5$ $210,217,258,271$ $302,3513,3025,310$ $316,31 \%, 320,32 t$, $384,341,484,514$ $581,586,610,611$, 617, 607, 070,684, $709,789,758,890$, $957,1.005,1.105$, $1.10 \mathrm{~s}, 1.1 \mathrm{~m}$.

Alfareria del Arrabal 78.

difareria de valmar. lom, $1 / 5$.

Allareros, $\% 7$ lit, 218 , $312,335,347,855$ 801.912.

Alhandac, $6 a$, 20 , 260, 340, 572, 819 $913,1.161,1.163$

dlliecm, 14 .

thofra, Huerta del, 268.

Aluondiga del Rey, 10 , $38,30,34$ $315,337,396,441$, $461,1.05 \%$

Aljams de los moros, 66.

Alpolinac, Casa eerea ele, (biy.

Andaque, Barrio de, 64 .

Areedieno, Casa del, 960.

Areo, Mesón del, 170 .

Arrabal de Arranue. $\%, 170,811$.

Arrabal de la Iuerta do Pedro Beinian. 79.
[Toledo.]

Arrabal de los Barberos, ถิ2.

Arrabal del Rey, 67, $68,112,128,101$ $102,166,17 \%, 194$ $305,311,316,318$, $3 \pm(1,324,360,410$ $474,597,014,1315$ (953, 750),820,978, $996,1.100$.

Arrabal de San Isidrn, 75, $122,191,213$ $260,29 \%, 305,804$ $316,437,602,167 \%$

Arrabal de San I'o dro, $7 \%, 288,727$ 1.0 .50 .

Arrabal de Sumtiago, $48,7 \%, 100,101$ $121,161,187,203$ $30.5,31 \%, 31 \%, 853$ $359,4(4), 530,458$, $704,725,860,593$, $895,1950,1.045$ 1.119

Arriasa, Jarrio de, 76 , 710.

Areobisuado, IItocria dol, 173.

Aryolisuo, Casin bla 819,821 .

axud lie d3ab ol I'ortel, 76 .

Baño de Yaix, 56,62 , $189,191,314,316$, $319,434,4 \% 5,490$, $559,59 \%, 1.001$.

Baño de Zeid, 75, 965.

I3año del Arrabal, 78 $2,4,290,780,987$.

Baño del Arzobizpo, ji, 290.

l3año del Cabatl!l, .5\%, Wh, 5it, fis, bits, 79 , 170, 256, 2\%, 3(1) $312,316,346,455$ $408,684,698,701$. $1.095,1.105$.

Baño del Hierro, 56 , 6f $124,217,260$, $317,315,340,534$, $738,819,9 \mathrm{~L} 3$.

Baños derribados, $17 t$

I3arberos, 32t, 7138

Barrio de la 'Torre Nueva, $26 \%, 780$.

Barrio Nuevo, $78,8 \% 0$, 605,704 .

thbergueria del Arra bal, 78 .
Belluteros, $50,1.035$. 
[Toledo.]

Borlega lel capollán l). Aunald, tht.

Bofordos, Casa donde fieren los, $1 \%$.

Lornel, Barrio del, 55, Hi2, $\$ 15$

Botijerfa, Casa de la, sif 1.ots.

lBunidores, i7, i365, (2) 4,944 .

"Calatlova" Mesón de la, 267 .

Calaliorra, Jesson de la, $\{77,17 \%, 17,5,57$

Calabrava, Fuiles de, $7 t$.

Calvario, Calledol, bis.

Calsada, 5s, aj, 628 .

Cambiadores, is, 317 $35,5,365,904,941$

Canto, d'iembla del, lisis.

Canto del Capidio, Cusrs del, fort.

Carbón, Mesón de], 483,946

Carniceria, Casa do Ja, $169,-17 \%, 325$, 1.0.99, 1.109.

Carniceros, londaque de los, $5.3, j \%$, ,jo. $31: 35,305,610$.

Garnicoros Juklios $7 t$.

Case chica, Ja, $f 70$.

Cosar de lceituna, $7 \%$.

Casa de Madero, 75.

Casa del Areediano. .7\%.

Cusa dol Arzobispo, ij: 5 , s4.

Gasi del cain I). Estobnn Petrew, 673

Catsu dol Canto, r., (it) $/ 21$.

Casa del Corret, iat.

Casa de] foso, $\% 2,32.2$

Cessarlel Mresirescue In, irij.

Casa del Obispo don (xonzalbo Petrez 644 .

Casa del Pozo, bij,

Casa del Prior, 1tit.

Casa del Refngio, $\%$. +216 ,

Casa de la Rorlelu, 63, ist.

Cissa de Tencria, b.t.

Casa del Vicerio, ̃o.

Casa del Vino, $50,1.4 \%$

Casa de la Media, /7i.
[Toledo.]

Casa de la Mesa, 171

Casa de la Mezquila, 82.

Casas del Areo, 170 .

Casas do la Catedral. Iiiz.

Conas del Marmol, Ific)

Casas del Redomero $5 . x^{2}$

Castillo de los Julius, $710,507$.

Custillos nuorey viejo de los Judíos $75,7(j, 1.1)$

Catedral, $14,51,155$ 77 , et passim.

Caxali, Play del (Po. zo Amargo), $3,30$.

Comentexio de los nusulmanes, 78 , 376

Cementerio rle los nobles?, 1.030 .

Cerrillo de San 11 a1. tili, 84.

Cerro le ln leña (A). cudia), 52, 54

C'austa do Saneti Syrititu, 1.031

Cinmente, Casa de 20 s'.

Comercio, Calle del is 8.

Colnejeria, $2: 3 \%$, zigt

Corlonicrias, 59 .

Corral del Mlbejtar, (i) $(1, i b)$.

Corral Alqueria, 75 .

Corral de los Judios 2.\%. 1.175

Corral del liey, int

Corral de Vacas, ssi.

Correeros, 58,120 (i)o.

Cristo de la law, $7 t$.

Cuertio, Roca del, tis, 1 iti2.

Cucrno, Barrio del, 1.141 bis.

Curtidores, 3.2.5, 1.098

Darallamel o alfare. ris, 78 .

Descalans, Calle de las, 63 .

Drogueros, $5 \%, 150,829$, 945.

Esparteros, is, las, 550.

Estereros, 29, 28,68, $77,291,30,3,367$
[Trisedo.] $655,671,740,829$, $1.042,2.100$.

I'anaeles, Jos $; 8$.

Eondac, Calle tel, 5.5, $329,558$.

lioso, 8\%

Francos, Jarrio de, $20,53,57,77,133$ 140) $16 \%, 173,19 \%$ $194,19 \%, 195,2630$

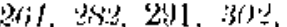
$34,33,31 \%, 32$

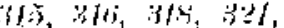
$323,810,317,4 i 3$, 17i, 185, 501, 532, $544,550,604,125$, (128, 637, 652, (655), 615, 670, S14, 829 $830,837,0194$, , I.t, $9(33,1.0 ; 35,1.049$, 1.071, 1.099, 1.118 .

Givinada, Calle de la, iil.

Guarnicioneros, 58 $68,710,1.025,1.100$.

Herbolarios o berbe. ros, $67,96,199,16 \%$, 215, 291, 365.

Herreros, $38,00,116$, $138,16 \%$

Hiorro, Mesin at, 483,946 .

Hormo, cerca rlel Prono de ciluallel, $840 \%$

Horno do D. Gómez Gonzálbez, 623 .

Hormo de Majp Yah$\mathrm{ya}, 4 \mathrm{~L}, 54,81$.

Horno de Marla $A$ fía, 170.

Horno de Sinn (iinés, [i].

Horno de Sann Mur. tin, $7 \pi$.

Holno del Arrabal, $78,510$.

Horno del Arzobispo, $17 t$

Horno del I'ozo Amargo, $\pi i$.

Horno de la Magdalona, $6 \%, 561$.

Horno de los Bizco. chos, $6 \pi$.

Forno de los liniles de Cialntraya, 830 .

Horno de los Judios, $76,674, .1 .1 \% 5$.

Hospital, isl.

Fospital del Rov, $2 \%$.

Ifosuilalarios, $7 i$.
['Toledo.'

IIuerted de la Alhofra Foso, $\pi t$

Hucrta de los Canónigos, 17:s.

Huerta del (iranadal. 109.

Huerta de las More. ras, 2tit.

Huerta del Rey, $64,8 \%$.

Jucrta de San Pedro, w1.

llurba do da lesore. ria, $10 \%$.

Ilucrtas de fa catedrłl, 167 .

Huerto de Ajuneina, st.

EIuerto de .lhanax!, 28.

Huerto de San l'edro, 1.175.

Huerto del Alhofra o del po\%, $7 t, 74,8 \%$ tit $31 L$.

Id. del Sacristán, 1 (i)

Huerto de la Sacristaluía, 80.

Judios, Barrio de los, $\gamma t, j 85, I ! H, 2(t)$,

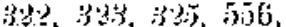
$5801,605,635,648$, $609,674,675,65 i$, $7\} 0,71-, 897,40 \%$, $1.135,1.137,1.142$, $1.143,1.144,1.146$, $1.147,1.148,1.149$, 1.151 .

Lecliuga, Calle de la, bit.

Isuminaria, 6 iff.

Maestrescucha, Casa del, 1.112

Malagueño, Huerto del, sit.

Maria Muzucla, $\mathrm{Me}-$ són de, $17 \%$.

Marzalcadi, 81,161 , $28 \pm 310$

Matadero de los Fran$\cos , 08$.

Mutadero de los Musulmanes, 66 i, 79 . 156.

Matadero en la $A$ leu(ia, $17 \%, 312,3.11$, $586,610,684,709$, 801.

Mesón del Carbon, $7 t$ 72.

Mesin ded rTierro, ro, $72,946$. 
'Toledo.'

Meson del Jino, 58 , (bi), 116.

Mesón del Pergamino, 68 .

Mesón de la larina. $1.16 \%$.

Meson do la Joza, b1.

Meson de la l'cz, 5o, 321,625

Mesún de lit sal, 56 .

Mesón do las dos puerlas, 160.

Mescon de las Monjas Je sim l'edro, 318.

Alesón nuevo, (16\%).

Mesones del Alcudia, Lit.

Ml sones del grano, 77 .

Mesonciello, El, 5 .

Merquila, 5s, 152, 295, $31 \bar{f}, 144,944$.

Molinillos, $\mathrm{N}$.

Molino da Axsam o Icam, o de la Rej. na, 82, 20.3.

Molinos, $8 \%$.

Molinos de dzunel o isomail, $8 I$.

Molinos de Iticitum, ij:t.

Molinos del Prado ilel Arrabal, $i \%$.

Montes del Alcolol, 7 7) 635 .

Monte lidido o Mont Ferid, $7 \%, 580,714$, 1.137.

Murallas, $\$ 1,101,84 \bar{\gamma}$, 1 . (3) $\% 0,1.119$.

Oleros, $53,169,170$

Orebzes (pIateros) 57 .

Omnium Sanctorum, $39,83,168,171,206$, $3(1) 4,315,232,471$ $1.053,1.094,1.62$.

Peleleros, 28 .

l'escadores, is, 324, 1.099 .

Pez, Meson te la, 160, t7?

Mlata, Calle de la, 60.

Flatero, Plaza del, 184.

Plateros, 60, 162, 353, $50.1,051,1.065$.

Jlaza de Aluenazi\%, 18 , b1.

P'laza de Abonsosár. $7.674,1.146,1.147$.

Plaza de Altam, 1.16t.

Plaza del Caxali, ó 3 3(1).
Toledo.]

Paza do los Plateros, zil.

Plaza de Santo 'l'omé rij,

Plaza del śeco. 6ó. 1.116.

I'ornel, Barrio de, 55.

I'omilolo, 5is, 5!", 6h, 161,260 .

दPorronal?, nit, 470 , $480,558,810,821$, 978 .

Porta], Barrioded, $t 51$, B2y, 311

Pozo Ámargo, 30,04, $55,56,60,63,67$ $68,98,118,13 \%, 136$. $1 \%, 170,17 \mathrm{~J}, 1 \%$ $217,228,313,305$ $311,319,3210,321$ $32: 325,434,485$, $494,574,577,603$ $604,627,631,698$, $701,728,758,959$, $1.001,1.043,1.112$ $1.113,1.518$.

Prado del Cadí o Mer. zaleadi, 79,81 .

Presa de Molinillos, 6.5.

Pouente de San Mar. tin, $10 \%$.

Puerta da Adaba. quim, $64,80,82$.

Puertic do Alcántara, 80 .

l'nerta the Alfarach, $7 t ;, 80,159,669$, 683.

'Buerta cle Assuica, 74, 76,635 .

Puerta de koagula?, 69, 81, 451 .

['uerta de Pedro I3e. nián, $\%, 3,3 \%$, 441 , $650,651,657,1.11 \%$

Puerta de San Mar. tin, $74,76, \%, 80$, 625

Puerta de Tefalin, $\pi 1$, 80, 161, 243, 294, $310,368,369,537$.

Puerta del Cambrón, 89.

Puerta del Hierro, o5, ti. $, 50,124,2(1), 26 \%$, $27,305,30 \%, 310$ $313, B 14,315,51 \%$, $319,350,880,490$, $443,514,572,738$ $819,841,899,1.160$.
[Tolelo.

Puerta del Mayolilomo, $48, \pi 1,72, \pi \%$, so, $140,292,463$, 578.

Pherla del Portiel (Portillo), 75, 10\%, 173, 321, 325, 645 $1.142,1.144$.

I'verta del Valo, 80 $162,195,199,257$, $202,2,42,294,304 \%$ $312,313,365,369$, 463.

P'urrta de la singrario o de Jisagra, $7 \%, 80$, $216,313,379,901$.

Puerta de los Curti. dores, 6f. 89 .

Puerta de los J ndios, $75,76,77,80,143$, $2(3), 311,322,414$, $560,733,1.022$, $1.088,1.097$.

Refugio, Gasa dtu, $316,501$.

Boca del Cuerno, 80.

Sicristán, Huorto del, 162, 243 .

Saeristania, Juerto de la, 173.

Sartont, 81.

Sal, Callo de la, 61 .

Sal, Mesón para vender ]a, 486.

Salavajo, 92

San Andrés, of; 6\%, $6 \%, 167,208,319$ 3.0 $577,602,1.0363$, 1.046 .

San Antolin, 13, 52, 5), $50,61,63,64$, 68, $69,249,302$, $305,304,312,313$, $319,388,541,627$, ti75, 1.11ì.

San Cobrián o San Cipriano, 192,556 .

San OJemente, is , 73 , 74.

San Cristóbal, 77 , $260,559,820,960$.

San Irelipe de Neri, (6)

Son lielix, $6 i 6$,

Sun Gines, 60, 61,09 , $103,113,160,161$, $162,763,800,208$, $301,305,310,311$, $312,335,347,318$,
['To]edo.]

$355,362,801,902$ 1.122.

San Ildefonso, Capji Ila de 190

Sian Isidoro o San Isi. dro, 78.

San Juan, 5i, 109) $155,162,2(x), 305$ $313,317,318,352$ $504,544,981$.

San Juan del Arzobis po, Capilla sle, :is 6(1), 17, 716, 9(it).

Sim Justo, 41,47, in:

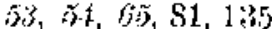
$156,170,185,210$ $2(1), 3(j), 304,211$. $318,321,328,321$ $325,425,543,547$ (510) $645,(368,078$ $684,709,717,828$ $886,889,891,412$ $958,964,966,1.020$ $1.046,1.077,1.115$

San J,orenzo, $5 f 5,58$ $61,62,260,318,319$ $340,559,594,790$ $462,1.165$.

Sam Ineas, 5(;, 65.

San Nlareos, bt, bu

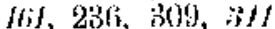
32, 325, 342, 385 1.114.

San Miarlin, $\%, \pi$ 170, 263, 284, 31 $311,312,314,3 / 7$ $318,321,384,340$ $391,414,516,5611$ $623,915,960,1.014$ 1.097 .

San Miguel, 6jo, 26il $665,820,888,878$

San Nicolás, $6 \%, 7 \%$ $76,77,80,81, \mathrm{lil}$ I $\% \pi, 2(1), 21 \%, 2.3: 3$

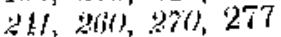
$20,310,316,317$ $318,310,320,392$ $3 \% 3,477,483,437$ $490,501,522,537$ $563,570,573,576$ $609,619,626,629$ $632,644,608,673$ $676,655,712,726$ $761,826,906,46$ $924,958,1,034$.

san Pedro, Batrio di: Arrabal, (6is, 81, Mil $162,264,322,727$

San I'edro en $\mathrm{M}$ lhi cem, 70 . 
[Toledo.]

San Román, 70,73 , $74,142,169,214$ $261,279,288,304$, $311,312,313,314$, 3\%1, 389, $895,42 \%$, $487,498,(124,674$, $755,759,830,9 \times 5$, $1.014,1.029,1.120$, 1.146

San Salvador, 81,965 .

San Sebastian, 64,89 . $204,30 \%$.

San Servanto, sw, st.

San Toreualo, 6:

Son Vicente, $7 \%, y 1$,

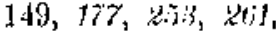
$36,482,646,825$, 1.056 .

Santa Cruz, $7 /, 2 y$, $578,609,008$.

Santa le, $70,1,02 \%$.

Santa Istbel de los Re.ye $8,(j)=$

bunta Justa, $5.6,58$, (60) 116, 160, 此 $302,312,348,603$, 045.

Santa lcocadia de jun to al Alestar, $62,60 t, 68,202,303$, 310, $311,332,627$, $655,662,607,671$, $9 \pi$ 1.J. 28 .

Sanla leocadia de Afuera, $5,33, \quad z f$ $76,79, f(s), 2(3), 26$, :26\%, 353, 735, 915 , $960,1.038 \%$

Sanla Narfa en Nhicem, $t 2,1 \%$.

Santa Marfa Magdalena, $44,83,65,67 \%$ (j), $128,141,142$ Hit, $103,194,260$, $30 ;, 312,31 \mathrm{f}, 314$ $34,366,409,419$, $440,474,501,507$, $801,1.026$.

Sinnta Maria do la bisla, so'.

Santa 'Prinidad, jos,

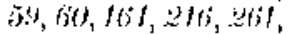
3.1, 320,716, 123 , 960.

Sancli Suliritus, Claustra tel, s\%.

Santiago del Arrabal, $7 \%$.

Santo Jomingo, (onvento de fise (ji) inl.
['T'oledo.]

Sunto Tome, 72,77 , $31.4,31 \%, 318,314$ $428,524,533,554 i$, $1.119,1.143$.

Sastres, Zoco do los $70,7 \%, 316,436$

Scicladores, $6 s$.

silleros, $j ; s$

Sinagoga de Almaliquim, $75,143,1.144$.

Siro lsuey, casa do, tib!).

Sugnero, Cilea del, (ji).

Solalo, Casi del, 169 )

sotaliello, Iti, $1 \%$.

Steca, Ja, $7 \%$

'lafureria, $68,170$.

'Templarion, $f:$.

Teneria dogAleormo?

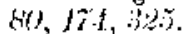

Tenerin de lon correctros, 17

Temerta mayor, $17 /$.

'Teneria nuova, Ja, 17i, $738 \%$

Tienda de barheria, it.

'liesuda en el zoeo de los Sastres, 196.

'ljeikla de verdulería, 72.

'Temclas del Neaná, I\%l.

'Tendis, cerca de la $\Lambda$ leudia, 111.

Jiendas de Jos alona. cenistas des granos chamelus 758 .

'Tiendas de la harina, $70,72,019,1326$, (j29), (633. 946.

l'jendas de los hari. neros, i2.

Tiendlas de a lathenatess, $t$

Tiendas de In Iglesia de la Mlagdalena. 801.

'Tiendas ful Sun NicoJás, 487

Tiendas del Obispo 1). (iartoly, $140,158$.

'Tiendas del Rey, 2ul, 3is. 36.5 .1 .

Tintoreros o 'Tintes vicjos, i, j, j, jo, ist

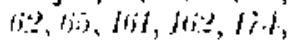
$192,217,2211,263$ 26\%, 300, 31\%, 313 $316,310,36, \quad 31 \%$ 319, 321 $337 \%$, 401 .
[Tolerlo.]

$411,451,486,512$

$50 \%, 591,610,627$,

$705,818,819,821$. 823 .

Torre del Arricara o Arrifía, fis, s1, 110, y.

Torre Nueva, liarrio de Ja, 76,780 .

Valmarciom. Vease Piteria del ilfayor. domo.

Vinn, Casa ale, 513.

\%apateros, tis, sots.

Zoco de la dCarne? 81, 605.

Zoco de la harina, Tocodover, fis, iff, $7 t$ (nt) Ho, ht, 179, fois, thit, Wh, IWt, स/ $248,261,200$. $3(4), 311,310,32 \%$ $410,474,501,522$, $537,563,573,589$, (60), 678, 675, 734 71) $1,800,84 !, 800$, $85,2,85,854,900$, $1.025,1.17 \%$

Jomellar (Canislas), $95,702$.

Tomellares, se, (694.

Torre, Ia, III, 132.

'lorre de $A$ benraceún, is fititi.

Torre de Ateryinus, 总济.

'Torre Alba, 11, 784.

t'orre de la $A$ lfondega, $110,132$.

'I'or're de Algasica, Itti, 1.045 .

Torre do los Dialjlos, 47, 73, /118, :30), :04.

Torre del Gaseo

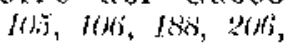
$20 \%, 1.0019$

¿Torro helecho? (Melgar), 1(1:3, 684.

Torre del Sultán, 1to,

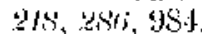

Torrectl], :2\%.

Toremocha, Nolia

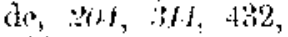
$4:$ ?

lorrente (Olias) $/\left(\mathrm{s}_{\mathrm{i}}\right.$

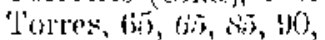
$4: 3,10.110,10$,

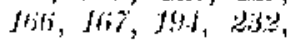
$260,261,304,305$, $318,320,565,569$
(61.5, $751,820,1.020$, 1.0.5.

Tor jos, $41,9 \%, 94$, $40,48,100,111,11 \%$, 11), 161,702, 726, s.7, 528, 932 .

Torruela (Berqueren. cia) $4 \% 616$.

Tosabor?, $/ /$, ע 62 .

Tosencque, 4.

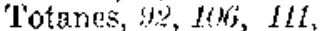
$272,525,1.083$.

Tozomatue, $/ I$.

Trapeso, Molinur, Niz.

'Trinidad, fris.

Turrelium, ff 7

T'uirus dueen, 156

Ulexta, tis:

Ueeda, 漹.

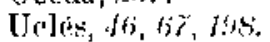

Uilmos, 1:5 .

Val, s2, IOS I0:3, fos, 111, b.)6, 70x, 1.1660.

Fal de Allorri (Ar. gance), is 1.006 (

Val Baniosn, $/ / 1,197$.

Faldecarábatro, tic, $54,85,9 \%, 60 \%, 111$ 162, $39 \%, 454,5 \% 6$, $5.10,541,552,553$ 557, $5(6(9,575), 300$ 592,400 .

Yal de lik tatsa, m, (j):57.

Valdecubas, IJ:, Jisi, Hiti, J56, 2353, $31 \%$, $315,1.130$.

Val de chaen, 45, H: $27 \%, 3(1), 3 / 6,48 \%$, 1.129.

Val de la Degollada,

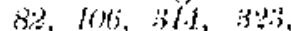
412, 656 i, 679 , tisti.

Sal Dios?, 112 to6.

$\mathrm{Val}$ de la Figuera ( $\mathrm{Al}$ cartate), $80,8 \%$, 1. $016,1.045$.

ral do Hueces, ils, 427.

Val de Inago (Cobisa), 96,650 .

Val ho Maria Roulti go (Benquerencia), g. 682 .

Falmayor (Carditlis), $9: 50: 200,702$.

valdowomatrabes, 85, 80, 95, 10: 101, 111, $112,268,31 \%, 319$ 321, 517, 595, 616, 
(19.2, $682,496,705$ $721,725,799,781$.

val de I'egujares (Caniellas). 96, 702.

Val de Pedro ¿Mu. cliacho? (Benquerencia) 98 $0 \% 2$

Val Peñoso, $1 / 1$

Val dol bio, stif, 811.

Tal de Sancho Alma. zan (MoIgas), $J(B)$, 0.80

Val de San Polo. 16is

val de Santiago ol $\mathrm{Mayol}, 1 \mathrm{~L}, \mathrm{~N} / \mathrm{s}$ $2\left(\% r_{2}, 26 \% 2,817\right.$.

ral dosanto Jornin. go, $112,3 / 4,151$.

Yal de la Torre (Bencuerencia), !y\% lisiz.

Valderas (Camarena), a. I3) is?.

Valdisita (Argance), $89,1.006$

Valduerme, II:

Valera, 85,11 s, 148 , $198,20 \%, 218,30 \%$ $311,315,421,467$

Valericha, $t / 2$

$V$ alerjla, $112,3: 39$ $3+1, \operatorname{sis}, 019$.

Valgordo (lsenquereneja), $5 \%$, 682

valverde, Condado de, 2.3ts.

valle de Ferrand Roiz, 8*.

Valle de Juan Podador, s.2, 3it.

Valle do la Pizarra, 468.

Vargas, $30 \%$.

Vega (Benquerencia) 42.
Vega de la Roina (Ta lavera), 746 .

Veguilla (Culjsa), th, $69 \%$.

Velila, $10 \mathrm{x}, 11 \mathrm{P}, 596$.

Venta de San Pablo, ind.

Vontas con Peña Aguilera, $/ 0.5$.

Ventosilla, sin, 9.:, tii, 95, 112, 287, as8,

Villa Algariba, 28,31 , $34,89,94,1+4,10 \%$, $112,200,222,240$. $252,273,255,287$, $303,305,808,309$ $310,331,364,948$, 1.101.

Villa ¿Ansta? (Riclves), $10 \%$.

Villa Antigua, $4,10()$ $113,172,19 \%, 315$, $389,449$.

Villachuclo, $103,689$.

Villa de Arriba, 89, 113. 334.

Vijla de los Alamos, JID, 162, 315, 444, 453.

Villafranca, $34,11 \%$ $209,222,252,285$, $287,304,312,324$ $336,334,364,948$, 1.101.

Villalueuga, $\$$;.

Villamarin, $57,4 t 3$, 810.

Villamazin, 44,113 , $261,323,825,1,127$.

Villamiel, $10 \mathrm{~A}, 113$, $198,26 \%, 809$.

villa Minaya, 100 , JJA, 389,855 .

Villamozain, 2⿺辶⿸

Villamuelas, $46,10 \%$, $107,113,16 \%, 284$,

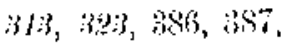
389, $390,(680), 682$, $722,858,1.0(1)$.

Villanueva do la Sizgra, : is.

Villaseca en Valdecarábano, 46,54 , 86 . (t) 91, 91, $4 \%$, Iof, 16i, $106,10 \%, 11$. His, J6\%, 211, 2.37, $26 \%, 303,313,356$, is $f 7,35 s, 310,390$, 3) $53,502,536,540$, $541,552,553,566$, $575,576,590,600$, $689,1.073$

Yjillaseca de la Singra, 83 .

Villasequilla de Ycpes, 6 it).

Villa Selina, $15 t$;

Villa de Silos, 113 , $317,511$.

Villaverde, IIs, 198, $226,1.060$.

Villar, II, 218, :3/\%.

Villar de Corva, 97.

Villar de D. F'edro Cruzado, 94, 11:, $773,1.107,1.108$ 1.110 .

Villar de Jenesa, 101.

Villares, 109.

Villares, Los dos, t.13.

Villares, Los, $113,31 \%$, 527,764

Villa de Vieja, 113.

Viveros (Mídrid), 10).

Viveros, Alqueria sle, $113,373,318,564$.

Xaras, Rio, 57 .

Xarf Addoján, 17\%, $31 \%$
Yegros: 1th, 229, 501, 54.6.

Yeles, 114, $113,2,2$, 873.

Yepes, 99, 103, 111, Ifi, $58 \%, 193,218$, $265,310,3 / 4,380$ bis, $406,407,408$, $420,424,466,469)$ $68: 1,700,748,749$, $750,753,1.123$

Yeso, Camino del (Talavera), 110.

Yoncler, $06,107,114$, $276,20 \%$.

Yuncos, $1 / f, 157$.

Yunclillos, 66, //f, $279,505,512,528$, $539,1.129$.

Yunquer, 100, 11:3, 114, $261,2 \% 4,899$, $798,80 \%, 1.030$, $1.125,1.126$

Yunquera (Caniellas), $90 \%, 702$.

Zalencas, 1, 72, 84, $115,117,142,149$, $154,16 \%, 164,16 \%$, $173,18 \%, 192,198$, 200, 208, 218, 232, $258,260,268,288$, $302,304,305,313$, $319,320,324,394$, $580,606,723,754$, 758,14069

Zamora, 190

Zamoranos (J'alave. ra), 11t, 193, 970, 1.048.

Zedonium, 95.

Zoheruela, $3 t r$.

Zuferuela, $10 \%, \quad \mathbf{H}$, 162.

Wuheruela, 100,115, $481,493,673,824$. 



\section{INDICE DE NOMBRES DE PERSONA}

Los números en cursiva remiten a las páginas del volumen preliminar.

I os números en letra corriente remiten al número del documento, en los volúmenes primero, segundo y tercero, y apéndice del volumen preliminar.

$\begin{array}{cccrrr}\text { Volumen } & \text { I. } & \text { Documentos números } & 1 \text { al } & 382 . \\ * & \text { II. } & * & * & 383 \text { al } & 726, \\ * & \text { IlI. } & * & * & 727 \text { al } 1.151 . \\ " & \text { preliminar. } & * & * & 1.152 \text { al } 1.175 .\end{array}$

A, prior, 968 .

tAaron? ben $A$ braham ben Aquice, 1.180.

A bad, Dowingo l'etrez el, 711.

Aluzartiel, $\%$, 1.4 .4 .

Abdalá, 940.

- ben Abijelaisar, 630.

- ben Abilerráhmen, 16.

- ben Abilas, 972 .

- ben Ahmed ben Mohamed el Namiri, 2.15.

-. ben Baxar, 63, 199, 192.

- el Cazzar, 1.020.

- ben Chelabert, 140.

- fijo de don Hamet, 215 .

- ben Hascin, 63 .

- cl de Loja el Cusich, 934.

-- ben Madi, 940.

- ben Mesaud, 238.

- bon Omar, 63, 208, 167.

- el Policheni, 28, 335.

- ben Richá, 430 .

- ben Sidbón, 797.

- ben Suleiwán el Policheni, 28.

Abdelaziz, Don, 125.

- presbitero, 101

- berl Aalá, 225.

- ben Sohail, $98,123,125,188$,
$180,193,166,197,194,206$ $20 \%$.

Abdelaziz ben Sufián, 389.

Abdelcui, l'edro Jázaro beu, 499.

- Saneho ben I azaro ben, 261 .

Abdelmélic, 174, 200, 256.

- arracz, 228 .

- ben Abilhasain, 216.

- cl Asar, 350 .

- el de Baeza, 1.013.

- ber Casim, 1.152.

- ben Faraan, 173.

- bes Harín, 291, 941.

- ber Jálaf, 1.049 .

Abdelquerim, lijos de, IAf: 674.

Abderráhmen, 675 .

- hijo de la de Jadajoz, 729.

- el Curtidor, 506.

- ben Domingo, 506.

- ben Mesaud, 121.

- el Macrub, 123.

- ben Yahya ben Elarits, 17 , 219.

Abdeselam, 162.

Abdi cl Carnicero, 82.

Aben Abdeselam, 127.

Abenabdelaziz el Hamami, 123.
Abenabiljair, 178 .

Abenalasfar, $73,395$.

Ahenaibaná, Abuliasán Mrir beu $A$ bitharún ben, 14.5.

Abenalbasaj, 970.

Abenelbegal, 193.

Abenalbazo, 81 .

Aben $\lambda$ lbin, 929 .

Alenalfarj, 7 tio.

Abonalhalas, 88 .

Aben Alhauad, $14 \%$.

Aberaljanaxi, $74,707,973$.

Abenalrim, Gì.

Aben Ardut, 145.

$\triangle$ ber Ardud, 1.048.

Abenarráez, 2:28, 62,

Aben Arranlac, 1.19 .

Abenaxamat, $50 \mathrm{~W}$,

Abenbace, Salvador, filjo, 207.

Abenbadah, 800,985 .

Abenbahlu], 90, 110, 985.

Aben Bálech, 76 .

Aben djalqueto?, 145.

Abenbarragán, 166 .

Abencebra, Framilia, $\mathbf{1 1 2}$.

¿Abencebra?, 905.

Abencosuch, 56,398 .

Abencureis, 208, 266.

$\Delta$ bencharrah, 512 .

Abendurneas el Calvo, 191. 
Aben Duncas (presbitero), 241. Abentarhina el Presbitero, 8 .

Abenfarín, 69.

Aben Franco, Lif

Aben Franchil, 1.

Abenfurón, $10 \%$.

Abengalún, 74, 635.

Abenluarit, alguacil y alcalde, 183.

Abenhud, Zafadola, 5\%, 152.

Abenjatab, 22\%, $231,241,955$.

- alguacil alhaquim, 800 .

Abenmartin el Mozáralue, 12.

Abenmatiner, 75.

shen Mayori, 412.

Aben Mofurech, 1.048.

Aben Moharich, Hijos de, 95 .

Aben Moxquiq, jeque, 7 .

$A$ ben Nehemías, $t i s$.

Abenomeya el Mozárabe, 1?2.

Abenpesat el Fulo, 74 .

Abensabuo, 980 .

Abensadia, 149 .

Aben s'sarcáni Alchahab Cháfir, 150 .

Aben Senáa, 150 .

Abensid, Hijos de, 1.129 .

Aben Socala, 373 .

Abensosau, 167 .

Aben Taurino, 25.5.

- el Mosulmán, 15:

Aben 'l'uriel, foss.

Abenzahir, 18.

Aben Ziat, $15 \%$

Abenziza, l.t? 2\%2.

Abgalón, Abraham ben Slosé, $346,1 . \mathrm{i} 7$.

Abolfaçn $A$ benbaço, 12 is.

A\}raham ben Alnajeri, tfo.

- ben Alsabi, 149.

- hen Isaac ben Albasti, 1.137.

- ben Isaac ben Alhascb, $14 \%$.

- bon Isade Albasti, 1.t5, 1.137 .

- ben Josef ben David ben Isaac lien Nalumias, 1.134.

... ben Josef bor Alsabi, f49.

- ben Mlosé Abgalón, 1.140 .

- ben Mosé ben Viva, 1.136 1.137.

- apodado Navarro, ben Ja. cob ben sAlbaquero? $44 \%$.

- ben Rabi Meir, 148.

- ben Salom on Almalaqui, 148.

- ben thosan?, 1 ธo.

- ben Yelrudá, 151.

- ben Vehuda ben Alhanad, 147 .

Abra, Martín Garcia do, 634. Abril, Maestro, 162, 211, 504. - Diaz 63.

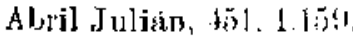

- lijo de lowgo livia, this.

- Julián d7is.

- hijo de Servande Matamo. ros, 38!).

Abu Amarguim, 2:s.

- Anarguim, alguacil almojarife, 57 in.

Alubacal ss:

Alueatsar el /arngomano, $\mathrm{N} / \mathrm{.}$

Abuclaźfar $A$ hnod ben Mo. guoit, $; 60$.

Abrichis, $2: i$.

el Alluanil, I2I.

Abugálib, $72 y$.

Alsuhars Omar ben Albilfa. rach, alc., 219, 24:3.

- ben $A$ bilfirecli, 117 .

Abuharón ben Abilurahim ben Ilehiúm?, IAs.

-ben Alharits, IfA, $1 \mathrm{i}$, 2is;.

- ben dJalanm? Afi

- Nusa ben Abiomar ben iveto, Ats.

- Musa Axxainats, alc., :2o.

- Mlusa bej Ilozab, 11s.

- ben losabat, 150 .

- Axxalials, $\mathrm{din}$ ?

Abuiluahim brendilhasin ben lswell ber R. Islanc ben Is. racl, 890 .

- bers Abiomar ben Rabl lsrael el Cátil), sit).

- ben Abishac lian Simón. 958.

- bes Abiyusef, lity.

- Ishra ben Ismail bon dibj. yisuf, tot.

- Caxares, 7.

- Ishac ben $A$ bislac Cistres, 635.

- ben Nehemials, It!.

- beo Sosín, 1.4. 2\%.

Abuishac ben Abilorahim ben Estalecha, 2:?:

- ben Alibarún ben llasiss. bit.

- ben Ahibarin lat M Mohib, lifi.

- ben Abibrahim distalecha? alguacil alhaquim, 851.

- ber Abilhasáa Benyamin el Barcelonés, 1t:5, 960).

- ber Abiomar hen dAisrur?, 867.

- ben Abiomar bon Ilayalí, 864.

- Ien Abunir ben Neliemias, $2: 3$.

- ben Abiomar ben Ntehemias, alguacil alhaquim, 865 .
Alunishue ber Atulreivia el (onquira. $12, s, 87,8,9$.

- ben linolos, lifi.

- tren Alhaquim bon Alfajar, isto.

- ben Arroyo, 1.j.

- el de Camarena. 8

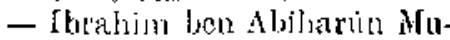
sa luen Hasian, $l l r$.

- Ibrahim bee Algualid, Af $\gamma$.

- ben Molith, JS. 858.

- Navarro, 75, 1.60

Abujalid, 2, 4.

Abujalil, $1(00$.

Abulais, 1.100 .

- ben Alydelmélie, 169, 196, $2+3$.

Abulis. the

Alulitsheg Ableinziz ben Lamparler, alcalds, 289.

- ben I anparler: alguacil y alchlle, 1.012.

Abulbea, Mastín bir, 54.

Abuleasim 'lirie Atentari. que, 2.

Abulfacam tuencolema, $1: 3$. dabultaraci bou dbisauar? 1.7.

Alsulhasín, 71

- bear Abiomar ben Nehemias, IIt.

- Acudo bes Molib, 14\%.

- ben Abdalá ben Abdelmélic el Andurjani, 178.

- Aluro, tif.

- Nli el Baxiri, "

- All el Baxir el musulmán, 571,573 .

- Ali ben Alasuati. apodado Bosquiri Alhana., 6 s.

- dinnasif?, 1.4, 2.23.

- Aziz Uen Abilhasán Yohuda ben Curdenal, 1.5.

- Bablul (amin), 12.3.

- Benyausín ben Absishac el liarcelones, fat.

- Benyamin ben Abillexain el havcelonés, $8+1,913,900$.

- ben Gueto,

- Majr ben Abiomar hen $\mathrm{Ne}$ homins, 894.

- Jiaju ben Abiyusef, al apo. lado \&Almabartas?, t.18.

- Maquim, hijo de Omar el Jaragozano, 852.

- Hatim ben Hatim, Alealile supremo, $353,219,940$.

- Israt ben Abilrebia el dOn. quira?, 149,8 tỉ.

- Ismel ben R. Ishac ol Cu. tib, 891,892 .

- itlair, 225. 
Abulhasán X[rir, n]guacil almojarife, 575 .

- Mair ben Abiharton ben Alband, 674 .

- Mair ben Abiomer Abrur, Ift. 150,874 his, 875,875 bis, $876,877,893$.

- Mair ben $A$ biomar ben $A$ bishac Nehomias, 8.j, his.

- Omar ben Abiluasin ledaldá ben Cardinal, 850 .

- Majr ben Sosin, fijo, 225.

- Sadoe ben Abulrebia ben Sosán, Jio, S8.

- Salomón. ben Abusulejmán ben Abidirhem, itti

- Salomon bon dli ben lshrec Casatras, lfti.

- Salonón ben $\Delta$ bialirhem, 25.

-... Salomon ben $A$ bibrahim ben fiveto, 1.t.

- Samuel, 2rz.

- Samuel, A guacil catib, 573 .

- Samuel ben $\Lambda$ bilhasan $\mathrm{Yu}$ suf, 151 .

- Samuel ben ibiomat ben Acara, $\$ 26$.

- Samuel ben Abiomar c] fRoyo?, 870 .

- Samuel ben Abiomar ben Arroyo, 89:3.

- Samuel hen Abiyuet ben Sosán, siby.

- Samtel ben Sosín, 150.

- Samuel ben Iúsef, joy

- Torlros ben el xeij Abulafia el Jevi, 958.

- Yehutlá ben Abibrebia el Onquira, $571,872,874,885$, 889.

- Yehudá ben Abishac bon Mohil, 849 .

- Yehudá Allazin el Bonsoli, $t-1,5$.

- Yehucla ben (14)a, 9o, 7.19, 161,205 .

- Yehudá Mohib, 1i8, 1.170.

- Yehuda ben Abilrebia el Onquira, lifs

- ben Yunus, 200.

- Zacaria el Arquero, 3, 30.

- Ziza ben David ben Abiyúsef, $8 \AA 3$.

Abulhosain el Nisar, 17.

Abulrebia ben Abibrahim ber Sadoc, 150 .

- ben Abiharún ben Ajlais, 144.

- ben Sadoc, $60,142$.

- ben Siosán, 1.0.

- Suleiman dAbencebra?, Jt6.

- Suleimán ben Otmán, 309.
Abultib, 73

Abuomar, 7.19.

- ben Alibralim. 4.

- hen Abilhasán Yehuclá ben Mobib, lis.

- Len Aljibralim ben Abiyt sef, fis.

- ben Abilhesin Axer el l3arcelones. 145, $2 \% 1$.

- ben dbilhasin Recha ben Cardenal, 1t5.

- ben Abilliasán lehuría ben T'obi, $l .51$.

- ben Aliomar ben Nehe? mias, $847,848,862$.

- bev Abishac al Barcelonés. alguacil alhaguim, 14 .

- hijo del jeñe $\Delta$ busuleimán ben A biomax ben Nehemias, 149,856 .

- l Barcelonés, $t 4 \%$

- Barsaba? ben Abibrahim ben ¿Acaro?, MH.

- ben lshac el Jarcelonés. 223.

- ben Israel, $148,224,243$

- ben Rabi israel ben Catib. $146^{3}$

- el Lebli, ifs.

- el Malahi, 148 .

- el Nácua, $1 f$.

- ben Nehemiar, 149, 223, 1.030

- ben Suarl, $1.00 \%$

- ben Samuel ben Aliomar bon el Royo, 886, 887.

- Sostin, 112, $100,225,344$.

- l'usef ben Abibrahim ben ¿Acara?, 959

- Yúsef ben Abilhasán Salo now ben Abidirhem, 14t;.

- Yúsef ben dbisuleimán David ben Abiomar ben Nehewias, lft?

- Yusef ben Axir, 910

Abnsamra ben Azri, 1.5.

$A$ busarur lidirach ben Abi Imram iMorel? 836.

Abusuleimán bern Abiharin Sabatón, 711.

- ben Alcahel? 840

- ben Abilhasán Sâlih ben Aleahi], 145.

- Davi ben Abiharín ben Sa luatón, 888 .

Abuyúsef ..... el Judio, 1.51

- ben Abilrabim ben Hayún, 880

- ben Abiomar ben C'respo, 146.

- ben Abishac ben Abiomar Hayati, $14 \vec{f}$.
Abuyusef ol Barcelones, 145.

- el Malahi, 74 .

- ol Malua]s, 148.

Abuzacarla ben Abas, 141.

- ben Curois, alc., 219.

- Yahya ben ....., 151.

- Yahya ben Alazar, 144. 2.2.

- Yahya ben Ali el Malague no, 118 .

- Yalya ben iNegro?, aIguacil alıáquim, 222,59 .

- Yahya ben Sidabihl, 100

Alnzeid, alc., 80, 2219.

- alguacil, padre del alguacil Cedro ben Abderrabmen, 1.038 .

- Domingo, 492

- Micael, 421

- el cle Baeza, 68 .

- hen Harit, zalmedina, 940.

- ben Harits, alc., 219, 353 .

Alszabone?, Lorenzo, 352 .

Abzeyth, $t 70,171$.

Acaro, Yúsuf ben Ismail, 144 059

- Samuel ben Nbiomas, 1:4, 826.

Acutin, Bern, Jtat.

Achem, Dõ̃a, 1.098 .

Achembert, Pedro, 751 .

Achumo, Paseual de, 689).

Aleramonto, Pedro de, $\$ 308$.

Adam, Preshilero, 186 .

- Don, $207,680,719,1.164$

.. presbitrro do San Cristóbal, b23.

- Petri, 756

- hijo de Sancho, 996.

- el Soriano, 689

Gidaquiel?, Maria de, 1.046.

irlefonso, hijo de lierdilando Rey, $1.051,1.052$.

Adericus, tudensis episcopus, 157.

A franuh, 289.

Agata, Agueda, 309.

Agnes, 1315 .

- Doña, 518.

- Juanes, 421.

- Petrez, 958

Agnesa, hija de Ordonio Petrez, 744 .

- Dona, 269.

Agreda, Pedro, 494, 956.

Colomba de, 980.

Aguarlo Bleye, P., 158

Aguilar, Diego Diaz de, 672.

Agustin, can., $179,2 i 4,569$. $747,788,1068$.

- Maior, 125 .

- ben Juan Gallego, 1.154. 
Ahmed, 790 .

- ben Ali, 787.

- Assafar, 15\%.

- Assafar el Musulmán, 348.

-.. el Herrero ben Alí ben, $\mathbf{M a}$. li?, $98 \%$.

- cl Iuqui. 789.

- Yúsef el Molinero, 935.

ainaín fi rast1», 208: 1.161.

Ainoles, 110.

Ainsa, Juan de, 561.

Aixa, 1.118 .

- hija, de Ahmed el sceuni, 936.

- hija de Casim ben Chobair. 680.

- hija del Dodri, $570,573,669$.

- la Murciana, 1.03 s.

- llamada la Rubia, 939.

- hija de Said el Herrero, do Jorea, 938.

Alaftás, Ishac ben, 1.119,1.120.

Alardo, 140.

Alascar, $17 \%$.

Alasfar, Nicael Juanes belt, 423.

- varios do este apellido, 1.016 .

Alastud, Omar ben, 322.

Alaui, Mair Samuel, 1ft.

Alazar, Don, 160 .

Alazrac, 170 .

- copista, 238.

Alba, Micael de, 298, 847 .

Albansoli, Yohuda ben Josef len Mose hen, 1.146.

Albaser? Juan de, 622.

Alhazo, 232, 247.

- Domingo, hijo de Juliân. 169.

- Familia, 124, 40,107, 169, $302,349,800,824$.

- Gonzalbo ben Nican, 125.

- Micacl, 2\$0, 282.

Albequi, Domingo Juanes, 638.

Albert, $209,1.013$

Alberto, Yaestro, $\pi, 1,1,2,2$, $465,482,490$.

Alberuchi, Nusa ben, 145 .

¿Alblas?, Juan Doming guez. 265.

Albond, Juanes, 145.

Alboniga, 1.152 .

- hija de Abiyahya, 30, 216.

Alboraya, Hija de, 900 .

Alcajal, Dona, hija te Isaac ben, 145 .

- Samuel ben Hiva ben, 16 .

Alealá, Rodrigo de, 1.041.

Alcantari, Domingo Petrez, 600.
Alcardete, Doringo Estelan de, 650,656 .

Alearmán, Familix, 302.

- Maria y Micael (hijos de Pedro), 728.

Alcalrate, 50.

Alchabir, lshace, hijo de, /46.

Achani, Chamila, Jija de Hiyalien, 140 .

Alcharut, Micael, 505, 512 .

Alda, Don̆a, $997,1.063,1.111$.

- Ia luerta, 67, 128.

Aldifunsus, subdiaconiss edc. sie Sancti Insti, 1.153.

Aldonza, $16 \%$.

dildozno? el l'restitero, 738 . 1fon, 384.

Nlfonso, 74, 196, 239, 485, 781 . $8(14$.

- vicario, $207,1.1 \vec{i}$.

- VI, $59,80,163,121,1+10,150$

- VIJ, 47, 50, 6i, 6.t, $82,85$. $87,88,89,40,94,95,80$, $1(t), 102,104,10 \%, 11 \%, 114$ 121. 122, 150, 158, 1013, 20\% $918,395,902,98 \mathrm{~J}, 1.008$, $1.049,1.054$.

- VIII, 69, $76,50,08,09,10 \%$ Ho, $202,204,318,255,820$, $981,1.006$

$-X_{1} 47,66,96,218,228,227$ 2.3, $702,821,958,1.113$, 1.115.

- Infizrite, n:

- el Arquaro, 902.

- el Bellutero, 702.

- Benedicto el ¿Rafegur?, 701.

- de Benquerencia, 1.086.

- ben Cristobal do jotos?, 1.16 .9 .

- Diaz, 63, 186, 596, 672

- Díaz, alguacil y alcalde, $221,702$.

- lijo de Diego Ruiz, 602.

- ben Domingo ben Pctro 1.166.

- Domíngue, $\% 1,151,221$, $22,1,27,62 ?, 614,672,712$, $1.05 \mathrm{i}$.

- Dominguez al Escribano 723. 960 .

- Dowinguez Vicente, 905.

- Dominguez, hijo de Martín, 6.12.

- hijo de Domingo Rubio, 499.

- hijo de Domingo Rubio, 660 .

- Jilias, 062 .

- el Escudero, 541.

- Esteljan, 632, 770

- Esteban Julianes, 73, 437 748.
Alfonso Fernindez, f; 221 . $224,272,845,989,1.0 \% 0$.

- Femández, escribano, 1.140.

-- Lernández, alguzei], 717.

- Fernández dícuciel? 1.140.

- Fernindez ben Maleos, 961 .

--- hijo de l'ernando Micael, 1.034.

- Fermández le Rosas, 1.140

- Garcia, 202, $28,710,824$, $1.110,1.169$.

- Caroia de Sotonayor, 285, 710.

-- Gujllén, 267

- Gutiérrez, 654, 709.

- el Haraichí, dedaraja 514.

一 SIdis?, 42.

- Jiménez, 1 rol.

- ben Juan Prtre\% ben Vaix, 1.174.

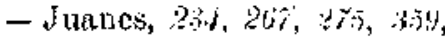
$603,718,962,6+39,1.050$ $1.10^{\circ}, 1.108,1.110$.

- Juanes el Maderero, 1.046.

- Juanes Petrez ben Yaix, 24:3.

- hijo de Juan Mateos, 1.96.

- hijo de Juan Petrez lien Yaix, 73, $1.107,1.10 \mathrm{~s}$, $1.110,1.1 \% 1$.

- Isurens, 1046

- hijo de Leocadia, 1.014.

- Lópe\%, 628, 1.034, 1.11;1.

- el Maarafi, 591, 76i).

- el Mlagarfí, 5 Li3.

- Martin, 2*4, 529, b22.

- Marlin el liscribano, izt.

- Martín, 1.03t.

- Martinez, $89,: 29 ?$

- hijo de Marlin licrnândca Pantoja, 875, 896.

- Martinez, alguaeil alhaquim, 20\%, 716, 920, 1.165 .

- Mateos ben lintón, \$1, 8f $186,18 \%, 158,191,192,19 \%$, $195,197,190,20 \%, 267,21 \%$ $21.4,216,275,201,925,1.030$, 1.031.

- Meléndez, tiv, tis, 160, itr $179,202,204,210,23 \hat{7}, 26$ $269,290,291,339,353,274$ $458,459,460,469,483,494$, $582,604,619,626,629,633$ $673,723,760,761,956,965$ $991,1.112,1.118,1.154$ $1.158,1.167,1.174$

- ben Melendo ben Abdelaziz ben Lampader, 946 .

- hijo de Mengo Garcta, 666, $681,682,1.058,1.124$.

- hijo de Micael, 127. 
Alfonso ben Micrel de AAr$\cos ?, 1.166,1.172$

- Hunem, 607,820 .

- Nicolás, 401,407, 591,1.129.

- Ordoñen, 8zi!.

- I'ctre\%, $\% 2,150,26 \%, 62 \%$, (i45, 6.58, 670, 692, 693, 701, $728,821,960$.

- hijo de Pedro Dominguez ben (harrah, 821.

- hijo de Pedro crutierre el Sastre, 964.

- Petrzel carretero, $26 \%, 490$, 1.172

- Jetrez el Escudero, 959, $1.0,30,1.043$.

- Petr'z, hijo de Mateos, 724, 725 .

- Petrez, hijo de Servatus, (390, 724, 725, 830, 831, 832, $936,937,938$.

- Ruiz, 548 .

-- ben Sid tRomano?, 1.052.

- Tomé, 640, 661, 678, 1.004, $1.087,1.085$.

- Vicente, alcalde, 78,206 , $220,221,519,596,669,784$, $820,821,1.033,1.168$.

Alfos Cidiç, 1.052 .

Algar, tope ben Micael, 1.108, 1.110.

Algazel, Pedro, 327.

Algazi, Illán, 729.

Nhanaxi, 81 .

dAlharacoba?, l'edro Martin de, 121

Alhosain ben Micue], 728 .

Ali, 1.0:00.

- ben Aludalá, 896 .

- ben Ahsterrílumen el Bastí, 787.

- Alharasit, 787.

- Alfagem, 169

- el Basti, 205.

- ben el Beliusi, 234.

-- de Domingo, 171 .

- ben Gálib el Tintorero, 95.

- el Harinero, hijo de Mlda]a del Axarafe de ievilla, 866 .

- ben IIariri, zilo.

- el Herrero, 12.

- ben María, 61, 125.

- el dMeriti?, 292.

- el Romanquero el Gomarl, 790 .

- ben said, 690.

- Mssariti, 732.

- ben 'Tello, 7i, 635.

- de Yúnez, 271 .

Aliala, Doña, 187

A jafar, 1.030 .

Aljanaxi, 153.
Almaherigry, Pedro ben Ali ben, 311 .

Almatrán, duan Dominguez de, 5.8 .

Almazén, Trumandro Juanes de, 658

Nmeric, $140,12$.

dAmocilal?, Amira, hija de Mar tbralıan, $/ 4 \AA$.

(linoch, Hijo de, 729.

Nimogabar, 16tj.

llmoguace, 15.

- al BI เısulmkin, ,5\%, 160, 302, $314,417,585,738,751$

Almonacir, Pelayo P'ascual de, $\$ 55$.

Almorox, l'ernando $\Lambda$ lvarez de, 825 .

Almuad, 205.

Anaya, Domingo, 415 .

Ainefart', Domingo Petrez de, 1.092 .

Alpiof. Nieto de, 504 .

Mrojis, sacristán, 63, 280.

Arim, Aben, 55, 61, 78, 114, $122,120,131,147,800$.

Alsabi, 140.

Altoralich?, Ilijos de, 1.020 .

Altoseli, Micael Domingo, 599 .

Alvar Gajeia, 73 .

- Juanes, 851.

- de Olias, 166 .

Alvaro, 111, 293, 840, 585, 737, 751,945 .

- Alrii, 962 .

- Alvarez, $70,130,241,304$ $326,332,339,364,467,483$, $748,801,946,1.006, .1 .127$.

- hjo de Alvar Sanchez, 182, 231.

- de . Irrobaia, 304.

- Diaz, 89, 121.

- Domingue $\%, 724,817,1.099$.

- Dominguc\%, hijo de dillbaeero?, 762 .

- el Fasal, 348.

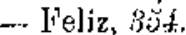

- Garcia, 525.

- Liarcia ben Avaricio García ¿Tehero?, $1.0 \$ 6$.

- Guteriz, 498.

- Juanes, $196,352,919,995$, 1.025 .

- Juanes, areediano de Cuenca, 18\%, $195,1.034$.

- Juanes, maestre de Santiago, 198, 204, 205, 724.

- hijo de Juan, hijo de Mar. tin Sulvatores, 894 .

- Juanes, arcediano, hijo del alcalde D. Juan Fernández, $1.021,1.175$.
Alvaro Juanes el Jeque, 750 . - Juanes, 487.

- hijo de Juan Illán, 693.

- Juanes Martínez, 855.

- de Luna, 290.

- Micaelis, 514, 562

- Nuñes, 18.

- Petrea, 99, 231, 527, 585, $986,1.025,1.030,1.032$.

- Pedro, apodado ¿Abenab. dceubo?, 90.

- hijo de Pedro el Escudero, 701.

- hijo de Pedro, hijo de Pelayo Véloz, $647,650,658$, 665, 1.116 .

- Ruiz, 725 .

-- Sknchez, $7 \%, 33,733$.

Alvarns Dida, 157 .

- Ulianiz, $15 \%$.

Amador de los Rios, liodrigo, $7,51,60$.

Amaya, Gonzalbo Gutiesrez de, 510 .

Ambasil, Ishate ben Yúsuf, 144 .

Amicus, 966 .

Amir ben Jálaf, 47, 1,049 .

Amira, 144, 50, 233, 237, 271, 421, 548 .

- hija de Mar Abraham ben iAlmpealal?, 1.141 bls.

- hija de Abraham el Cambista ben Casares, 1.136.

- bjja de Abraham ben Mo hachir, 188, 1.148.

- Juanes, 167.

- hija de Juan el Monje, 314.

- hija de Odra, 149.

- Petrez, 171.

- Raimindiz, 281.

- hija de Saturnino, 118, 728.

Amor, lucensis epise, $25 \%$.

Amrel, Lorenzo ben, 506 .

Amtalccha?, 14.4.

Ana, hija de Pelayo Calvo, 105 , $178,184,216,225,246,1.060$, $1.061,1.062$.

- Armilde 4,493

Anastasia, monja, 194, 291.

Ansya Iñiguen, 91.

Anconero? 144 .

- Yéludá ben Suleímán, 144 .

Anchevin, 140.

dAndrea?, Domíngo, 726.

- Maior, 125.

- la Bisutera, 236.

Andreas, presbitero, 186, 966 $1.012,1.072,1.122$.

- Dominici, 187.

- Iohannis, de Canales, 909.

Andres, 73, 319, 333; 531, 577, $578,1.072$. 
Andrós, Juan, 1.

- ben Abdala, 141.

- ben Abdalá luen Sabit, 198.

- bijo de Nbatquerim, 748.

- Alberchines, 76, $358,1.097$.

- hijo de Downingo Juanes, apodado Chicalo, 104.

- Dominguez, 115.

- Fortunio, 148.

- Girin, 51.

- de Iachach, 73

- el Hortelano, hijo de Micael de T'orrjos, 827,828 .

- Jacob, 422.

- Juanes, 239, 11!, 825, 3933, 381.

- hijo de Juan Petrez 640.

- Juanes ben Isazaro beu I Iabib, 843.

- Lechuga, 50̃1, 1.168.

- Martin, :35.

- hijo de Martitz Suleimun, 430 .

- el Melah, del irrabal, yyb.

- de Olias, Jifi.

- ben Pascual, 200, 571, (15.

- hijo do Pasenal cl Carmadi, $568,562,820$.

- Petrez, 124, 76, 1.085.

- de Rielves, 431.

- bon Sabit, 1.037.

- el Sortí, 972.

- sobrino de ben l'áric, 7b.

- Velaseo, 485.

- ben Yabya, 184, 216.

- ben Yahya ben Sitlabiti, 194.

- ben Yúsef, 179.

- Zapatero, 88.

Andresa, 66, 124, 645, 678, 804, 1.124 .

- de Benquerencia, $1.08 \bar{i}$. 1.088 .

- la Bisutera, 6is, 820.

- Domingo, 826.

- Jimén, 864.

- hija de Juan de Srid, 1.155.

- Andújar, Foliz Martín de, 945.

Anlr, Josef ben, lff.

Anisa, Juan de, 1.081.

Annaya, presbitero, 1.012 .

Antolin, $136,1,3,836,1.020$.

- ben Furón, 798.

- hijo de Galter Locues, 75.

- ben Pedro ben Irurón, 1.013.

- Petrea, 1.044.

Antón el isterero, 653

- Petrez, hijo de Yaro el Ca$110,680,719,720,86 \mathrm{~J}$

Antonin, presbitero 65, 412.

Antoninus, 1.094.
Aparicio, $801,50,82,92,141$. $223,24 \%, 323,1.059$.

- filius l3ahlul, $72 \%$.

- hijo de Domingo Domin. gue\%, 804.

- hijo de Martin Chico, 96 .

- hijo de Micael el Borchí, Both.

- el Rocafi, 6sis.

- jhijastro? del 'laluts, 144.

- ben Toné ben IDinm ben Abiljáir, 1.157.

Aquica, Aaron? ben Abraham ben, lis.

Artigion. Jitan de, thi.

dirluino\%, 181.

ironas, Tapo tle, soxi, (inot, i.073.

Arfinarasoh, 627.

Arias, ovetensis episcopus, b) 2339 .

- Moni i, 20

- Petrez, 595.

Armaldo Mlelénda\% 231, 493.

- Hmino $\%, 486,812,813,911$, t) 66 .

Armengot, $t f t$

Armildez, 115 .

- Pedro, 481.

- Maria, 493.

Arnal Getiérre\%, 1.013.

- capellán, 7i.

- el sperpantero? $b 8$.

Armaldo. 83, 113, 951.

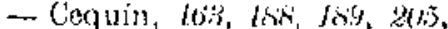

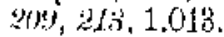

- de Corvin, so

- Carubín, 078 .

- de Esquivias, 559, 594.

- Franceseo, 75

- Cruilléll, alequde, 2206,466, 4 lia).

- Maleo, b4

- Menendez, 810.

- de I'olinas, $16 \%$

- lolosano, cir ifo.

Amaldus, 128,481 .

Arraesún, 216.

Irrim, 819,821

- Domingo ben, 797.

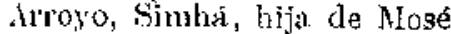
ben, $1 . x$.

Arseniuse 966

Lrtzit, $23: 39$.

- el Pedrero, 78, 780.

Asubag, hijas de, 57

Isachni, Esteban, 225 .

d sxin bey Manrel, 192.

Asaquia, 15:.

-- el Musulnán, 165 1054.

Asensio, maestro, fry, 606 .

- Aabar, 5i2, 615.
Asensio, hijo de. Dirgo, 5i1, $612,391$.

Assofar, 67.

Astjl Duro, fir.

Astor, Don, 9i, 1.106.

- Sequín, lio

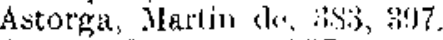

Asuero, Juants, is $6,9,175$.

Itlúm, Salvador lyen, 256

Augerius, 966.

dugustinus, 9665

- canonicus, 788 .

Aura, Doña, 211, 58().

- Petrez, 22: 260.

- hija de Domingo Custios. Iis.

Auria, Doña, 250, 485, 801.

- hilja de cindrés Velasco, 434.

Avenazara, llamado bonvi. da, 5.t.

Averuoes, 18?

Ayliva, Alenzumbal, foi.

Ayub, Algace, 152,242 .

- ben Alaf, 32.

- ben Jálaf, 23,5.

Azhar, Yalıya hen Ishac, 14.5.

Aalon, Pedro ben, 283.

Aznar, arcediano inaest $10,16-1$.

- de Avila, $\% \%, 560$.

- lijo de Juan Azriar, jol.

Azur, Abulfatah, lts, 1.089 .

Azu $\%, 123$.

Bacbequl, Lil, 61, 204.

Bachieas, leld, 47 .

Hachil, 'Temán ben, 438

Bacza, Guillén cle, 291.

Bahlul, Aben, s0s.

- rl Herrero, 194, 250 .

- Iijo de Julín el Herrero, 1 iv

- ben Martin ben Bahlul, 23.

- Suleimán ben Yaliya ben, l.t.t.

thahri ben el xeij el Curts SO $3,1.09 \%$.

¿Baisin?, 1.5.

Balaguer, Fernando, 383, 397. 5 (i)

-. tiuilermo de, 1.00 .

- Ponce Nabat de, 444.

- Yaro de, 680, 720.

Balascia, esuosa del caid don Sabib, 6\%.

Baldufn Colier, 711 .

- Coliau, H.

Banegas, liuy, 702.

- Iurenzo 702.

Banosom, vicario, $17 \%, 32 \%$.

Banun el Musulmán, 1.080

Baqui, lijo del Eseribano, 9.

Barachelas, 142. 
Barber, Aben, 1.067.

Pareelona, Ginillesmo de, 36.5. Barcelonés, 11\%, 145, 551, 55\%, 639.

¿Barcobol?, 1.096

-Barelo? Visia dle 80\%.

Barragán, 1.112.

Jartolome cauringo, 17,113 , (j)6, 510)

- lirater, 775.

- areediano, $3 \%$ fri. $/ 1 \%, 178$ $196,603,608,65 \%, 1.022$

- de Argades, 211 , .25, $60 \mathrm{~s}$

- Asacaz, tifi, 370. int:

- Calbaj. 220 ,

- el copellán, 417, 5.18, $1.11 \mathrm{~J}$.

- el Carmadi, 56r. 571, \$20,

- de Fsralona, isis.

- hen Iiamor, $1 \%$.

- hijo do Jope, $545,587$.

- hijo de Micatel el Sillero, !t: 620,821 .

- el Nadir, bis, sit.

- el 'Prstor', 689 .

- el Pescador, ,7, 682, $\$ 26$.

- Pelrez, $907,1.165$.

- presbitero, 168, $170,801$. $420,774,775,806,810,811$, $812,814,909,948$.

- hijo de Rodrigo, $\vec{i} 3 \mathrm{k}$

- de San oliment, stie, 1.02i.

- Toretrato, 608 .

- da Yepes, 636, 6906, 700, 705.

- el Zapa tero, 589 .

liaruj of Colven, $14: 5,79 ;$.

¿Tarujelt, Ilobi, hija rle Josef ben, 1.5.

Baslo, Said ben, 58.

Paso, ifis.

Baxir', ]1, 1\%2, 570.

Bayân, Lon, (33, 286 .

Beati Auditi, iglesiat de, 196 .

Belal, judio, $i$.

Beliatí. El, 272, 351i.

Belili, Perlro Mricael el, 434.

¿Belisena?, Dona, âs.

Beliuś, Ha, ar.

- el Albañil, 1.

¿Bellido?, Dowingo, 1.001.

ben isaia, $76,11.5$.

- el Herrero, 84.

Beltrún, arceliano, j2, 16:3, $167,177,768,1.078,1.166$.

- racionero, 180, 604.

Benaculin, $7 \%$.

Benaix, $7 \%, 170$.

- el Pescador, 322.

Benalcahil, 346 .

Benayas de Maqueda, z7\%.

- hijo dol djefe? de Maqueda, t. 080 .

Benbeder, m'esbitero, $19 \%$.
Benedie1a, Joña, 565, 567, 568, $5139,571,612,615,640,691$, 820 .

-. Domingues 378.

Benedicto, $; 4,236,33 \%, 866$, $9+3$.

- chnónizo, $141,662,605$.

- el Chrilecro, 637, 1.109.

- hijo de Domingro Ginés el Neliuero. list.

- Gonzallber. J63

- hijo de Juan Martinez, 1.013.

-- hijo de Marlin el Sillero, 50 .

- ben Mincacls, 819.

ben Pedro, thi

- hijo de I'edro, 244, 731.

- I'etrey, III/, z:iy Petrez el Belutir, 642.

- Petrez el 'Tuerto, fis. 156 , i) 4 .

- Kapatero, 611, 637, 6ro, 1.109.

Benedions, Frater, 209.

- Saucli..., presbitex, 73

Jeneit Johamnis, Jon, 741 .

Bennito, 169 .

- cl Carniccro, 1ito.

Benito ol Jizeo, 75,210 .

Benjarmin ben l'ascual, conoeido por bet Peruendo, 149 .

Benmaharis, $7 S$.

उёquer, 1.980

Bequi. Bi, J.160.

Berdi, Ponce le, lft.

Berengarias, Miti.

Berenguela, 05,858 .

- hija de Carcia Martinez, $166,669$.

Berenguel ol thelutir?, $97 \%$

Berenguer, *w.

- objspo de Sulamanca, 159

Berinudo Pelagi\%, 9010.

j3ernabé, 884,504 .

- hijo de Domingo de şChilo? 646

Bermaldo, Jon, 302,608 , J48.

- Archent, 2to 1.071.

- Astur, 5\%, 63. 8\%, 88, 168, $179,1 \times(), 58 \%, 602,613,625$, $672,768,821,1.009,1.045$, 1.116 .

- Balaguer, 1.096.

- jBlineo?, 128

- el Fanequi, 1.026.

- re San l'ycindo, 174 .

- Seguin, 246.

- sztor, canonicus tolotanus, 821.

- Astur, 7es

- Notoria 176.
Bernaldo, oljispo de Sigüenza, 159.

Bernardo, arcediano, 176, 263, 190.

- arzobispo, 119, 19\%, 158,174, $34 \%, 966$.

- obispo de Zamora, 159.

Berniti, Herederos del, 136 , $243,295,333$.

liertolomens, subdiaconus, 332.

Bertran, 966.

- obispo de Osna, $15 \%$.

Jeteta, Sancho, 817 .

liezais, Sancho, 734.

Bibach ben Zizá, 151 .

Bibas, Jon, $39 \mathrm{~S}$.

Bigar, 235.

lbilim, 5 .

Bituaya, Dom, ths.

Jiscaya?, Donta, 1.024.

Ylasce, 176.

Bona, Doña, 594.

- hija de D. Morehón, 1.109.

Bonafilia, 211.

Bonetus, capellanus, 158 .

liono, Msrtín, 678.

- Aluulhasin lái).

Jonus Homo, pressilero, 200.

Bonvida, almojarife, 91 .

Borac, (rouztho Petrez de, 574 604, I.118.

lkorcén, hijo del jeque D, Julián ben Boreán, 604, 1.112.

Borgoñón, hijo de Guillermo de Monta Pesular, 141.

Bosquiri el IIanat, 72 .

Botanus, 120 .

Bruna, Donia, 157, 237, 341, $346,739$.

Bruneta, 1.013

Bruno fُlond? 383.

Hirur, Mair Yúsut ben Abi, 145 .

Budesiana Micaelis, 252

Buishac ben Nehemias, I 12.

Jumela, hija de Arnaldo, 141 .

Burdegalensis Petrus, 966.

Burgundionus Montis Pessulani, 141 .

Burd, lbrahim el, 145.

Burriel, Andrés, 1.

Cacluich, Samuel ben Salomón, 11,

Cadim ben Pedro, 124.

Cafacha?, R. ben, 145.

(aim ben Nbraham, $1 \mathrm{sit}$.

Calatayud, Andrés de, 826.

Cialatmva, Orden de, 226 .

- Frailes de, $160 \tilde{.}$

- arcediano de, 168, 182

- Isope de, 628. 
Caliamut, 111.

Calix to II, papa, 158.

Callás, Pedro Aben el, 3.

Camarena, Domingo Petrez de, 172.

Camino y Velaseo, Pedro, the.

Canales, Marlín de, 253

Canamero, Juan de, 597 .

Caparela, Mar Mosé ben, Lh.

Coput, Johannes, 438 .

Carancero, Juan 6$], 1 \% \%$.

Carbali, 379.

Carmona? I'edro de, 252.

Geares, Abuibralim Ishac, if $f 6^{\circ}$.

- Amira, hija de Abraham ben $1.4 i s$.

Cashiri, El, 222.

Casi, 1.148, 1.149, 1.150.

Cásim ben Nohímed el Altid

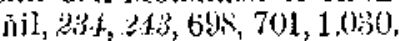

- el Sofar, R., 1ffi.

Castella, Maria Martín do, 696

Castellano, Martin, 789.

Castellanos, 1\%L, 122.

Castro, pedro tlo, 291, 317, 416, 954.

- "lero"? Domingo de, 353 .

Catalina, Dona, 625.

Cazadores, alcalde de los, 1.174 .

Gakem, 170.

Velproro, LI, 137.

Gebrian, 13\%, 29\%, 22\%, $118,700,1.113$.

- he Anmoail, Anover, 471.

- ben Don Abdelmélic el Pe. luquero, 1.001.

- el Bacal, si, 608.

- el Carmadí, 1.00y.

- ol Ciego, 1.181.

- Sarbos, 123.

- hijo de Domingo Juanes, $05: 3$.

- hijo de Domingo Martin, 949

- el l-[ortclano, is $256,498$.

- bon Jair, $198,375,376,378$. $950,1.022$

- hijo de Juan Alearraz, 330.

- hijo de Juan Billitis, 218 , int.

- Martin, 944.

- hijo lle Micuzel, 282

- Muñoz, 22\%.

- ben I'aulo

- Patrez, 507, 615, 820.

- hijo do Peilto, 984.

- el Pregonaro, 476, 653, 659,

- Ruiz ben Azzocuch, 480.

-. hijo do Vicente dSextro?, 108.
Cebrián ben Yatiya al Comerciante, 171.

- Jijo del Zamueni, 496.

Cecilia, Doña, 12:, 137, W/4, $58,39,64,313,413,645$ $953,979,1.042,1.103$.

-. esclava convertiela, 788

- abadesa, 20, 201, 388, 42\%, $743,744,807,808,809,810$, $812,1.127$.

-. monja, ly5, 1.042.

-- hija del Crespo, 689.

Eslébanez, 225.

- hija de juan el Fanequí, 1.026 .

Lijja rle Lázaro, l7i)

- Nartis, 65, 185, 954

-. hijia del minero, 302 . Petrez, 80, 202, 2013, 282, $1.03 \%$.

- lija de Seluastián, 70,923 , 973 .

Cehal, Don, yh

Celebruno, arzolyspo, jo, 69 , $88,91,101,17 \%, 17 \%, 179$, 1.053 .

Cetes, 137

Gibrián, 420 .

Cid Martinez, $89,1.606$.

- Mayor, 1.167.

Cidelo, $13 \%$

Cidiello, Maria, $/ I$.

Cincuesima, Dona, $57 \bar{i}, 578$, 1.109 .

(tonkthes, 2s, 1.125, 1.124. hija de Mirtin Giarela, 706 .

Cipriain Illanes, 29

- Petri, $27 \mathbf{1}$

Cipriana, Dona, bos.

Cipriano, canónipo, 179, 195.

Ciprianus Petri, 369,739 .

- presifítero, 96is.

Cister, Orden del, tots.

Clara Jarada, 148 .

Clemens, filius Johannis, 125.

- Iohannes, 187.

Clemente, Don, $145,414,832$, 1.049 .

- Maior, Jes

- del lrrabal, 996. - el Carnicero, 1 (650.

- ber Jaand, 1.15T. Jen Gialib, 281.

el linrero, $546,50 \mathrm{~s}$.

- el Monje, $6 s, \gamma 9,100,310$, $26 t, 38:, 34,969,1.050$

- el Serrach, $185,1.009$.

Coleri, Jianeisco, 6, 126,

Colradia de prestiteros, 77 , 3.10.

Colen, Musa el, 116.

Coja del Arrabald, J,a, 16y.
Colmenar, Domingo Petrez de, $53 \vec{i}$.

"Coloma d"Aben Jarrach", 236.

Colomba, $74,13 \%, l i 1,224$ 234, 241, $: 16 \%, 319,507,673$, $821,830,1.042,1.111,1.15 \%$ $1.16 \mathrm{j}$

-.. de Alagralit?, 9s0)

-. hija de Aludres,

- re Calalrava, 401.

-. hija de Celorián, 1.113.

lominguez, 559,600 .

hija de Estevan Chazah, 378 . hija de leviz, 1.113.

- Fernández, $/ j 7,683,704,71 \vec{i}$ Lija de Fernando bload, 290. Gonzálbez, 191, 195, 145, $292,669,683,979,1.173$.

- lija de Gonzalbo Potrez, fis, \$8, 254.

Gutierrez, 211, 7y3, 868, 922,960 hija de Jálaf el (iorúo, 57 .

- Juan, 078.

- hija de Juan el Macal, $\%$, 578.

- bija de Juanes ben Alchamar, 603.

- hija de Juan Esteban el de Osuna, 46ó.

- hija de Maria, 627.

Martin, 613,342 .

hija de Martin $A$ bad, 3.44 .

- hija de Martín ¿Alnajz?, 96 .

Meléndez, yot

hija de Micael, 316 .

- Micalis, 412.

- hija de Obaidalá, 93. Petrez, 65, 260, 223.

- hija de Pedro Illán, 819. x.1.

hija de Pedro Sanchez, 627 .

- Polent, 286i.

- Vicente, 63,715 .

-- hija de Vicente, $890,891$.

- Vicente, 1.046

- hija de Vicente de Bargas, 814, 1.173.

- hija de Zacaria el Tintore. ro, 21.

Colnmbo, Omar bus, 732 .

Columba, 193.

Concuela, hija de Viecnte Al. catad, 1.020.

Constanza, reina, $15 \%$

Cores, Pelayo, 596.

Cornelio, Don, 326.

- de Madrid, 211.

Corvin, Arnalio, 111, 292.

Cosuch, 30

- Abdelaziz ben, 506, 518.

- Aben, 217 . 
Cosuch, Gracia, hija de Micael Julián ben, 672 .

Cotarel, Lope de, 61, 862 .

Coh, Isbac ben Jacob ben, t.t5.

Cono Stefano, 114.

- Dominieus Martin, 114.

Crescon, presibitero, 19, 1.076.

Cresconius, coimbriensis episcopus, $15 \%$.

Crespo, Juan y Domingo, 126 .

Crispina, La, I6s.

Cristina, 21.1, 383,351 .

- hija de Andrés, $42,185,159$ $191,261,206,210,2,1.020$, 1.077 .

- hija de Temán el liotlecul, 12), 38, 39.

Cristóbal al presbitero, 137. $160,16+166,168,210,(60)$ $154,161,451,558,060,474$, $1.012,1.013$.

-.. ben Mbdalí ben Mesaud, 233.

- Domínguez, 1.016.

- el Esterero, 232, 279, 344, 349 .

- Juanes, 310.

- Juanes el Camicoro, 100, 146.

- Martín, 158, 213, 265, 371

- bijo de Pedro ol Arrácz, 465

- ben Said el Ribatarí, 53 , 111.

- hijo de Torcuato, canóni. go, $59,179,441,461,504$, $765,1.174$.

-- Zamorano, 222, 1.101.

Cristofar Pe..., 38.

Cristoforo, canonigo, $125,1.3 \%$ $179,274,305,368,387,420$, $449,486,512,966,1.041$.

Cuenca, Obispo de, 446,176, $488,639,768,1.028,1.053$, 1.106.

¿Cureis? Yahya ben, 4.

Cures, Aben, $366,1.040$.

Curi, El, 10:2.

Cutanda, Jueocadia. hija de Juan de, $31 s, 740,1,1(0)$.

Chatiun, Juan P'eres, 668 .

Chábir, Jsstebun ben, 506 . Buchel, \%is3, 1.059.

dChawila?, 146, $70,256,635$, $817,1.102$.

- hifa de Abuibrahim el Burí, 497 .

- hija de ibarbieh?, 14s.

- hija de Farach, 1 .

- hija del Peluqui, 834.

- hija de Hiya ben Alchani, 147 .
Chamila, hija de r. Hiya ben Assuija, 150 .

- hija de Isare Pardo, fla.

- hija de Josté ben Guirt. 1.139.

- hija de Ohira tis

- bija de Yehudi IIalevi bnn Tolris ben Al.levi, tol.

- hija de zr. Samuel ben Casi, 146.

Chanob de Pistoya, maestro, canónjo, for (ibo).

Guanuzi, Jueobo ben samuel el, 1 ib.

Charina, boña, $285,186,18 \pi$,

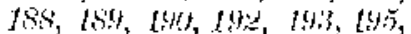
$296,196,198,2015,210,244$ $215,249,35,37,314,375$, $376,278,450,1.022$.

- bija do Indlés, 206 .

dChaves?; Domingo, f.ju.

cholabert, $\mathrm{H}$.

Chembert, Don, 1.000.

Cheralda, hija de Ellas Asacaz, 589.

¿Chibicho?, ibralim, fic.

Childeberto, Do11, 302.

Chiraldo, de Daralbelio,

Chobais, Pedio, 556 .

Chor Nogah, Jlti,

D., cantor toletanns, 481

D. Colar, archidlixcono, 141

D..... Julinni, .... diaconus, 451 .

D. ¿kodlolfi?, mag ister, 518 .

D. Sancte Harie, diaconus, 318.

Danicl ben fool SapatoP, f.o\%.

Dar, Is] ac tem Daud hen ol, Iftit.

Darham, Alien, 1t6, 1.1.44.

-- David ben Abi, lifo.

Daud, Salomón len Ibrahim ben, $I t t^{\prime}$.

Davi ben Abiyuser, $1 / 1 \%$.

David ben Abilirhem, $\%$.

- ben Abi Jarham, 1.135.

- ben Abraham ben Sosán, 700 .

- el Moreno ben Sulcimán, 986

-- ben Mose bon Masuelia, /ts

-. ben Salomón ben LindaJham, $75,143,14 t$.

¿Daxdel:, Gonzalbo Juanes ben, 578,672 .

—. Micas] Julján, 618, 621.

De Sedel, Pedro, 560, 563.

Desiderio, Jolián, hijo de, 550 .

Deusayuda Guillén, 267.

Día Díaz, 421.

Petrez, $74 ; 22 \%$
Dia Petrez, Don, caid on Alcalá, $7 b_{2}, 880$.

Díago el Capdlán, 16\%.

- Ennego, 202, 448.

- Taptata, $16 \%$

Diaz, Didaci, 26.

Didaco, $5 \%, 1 \% 8,142,171,804$ 1.152. $1.65 \%$

-.- Avare, alcalde, $21 \%, 13,15$, $18,921,925,1.012$.

- Disminguer, 1.012.

- Fermandez el Pintorero, 1.067 .

- Potrez, alcalde, 2yo, 148 $326,9-44,954,956$.

- Petri, preslriter, 182.

- Rorderici, 1.175.

- $\sin z, 10 \%$.

- Saneti Jacobi, episcopus, L.5\%.

Jidlago dlvatez, $1: 0$.

- Gonzalez, 120.

Diego, $.1 \%, 222,333,95 \vec{i}, 1.002$. alguacil cle 1 reicolla, 1.131.

-- Alfonso, 75, 205, 28, 514, $605,725,820$.

- Alvarez, 514.

- el Cadi, 1.lo1.

- el Carpintero, $16 \%$.

Diaz de Aguilar, 672.

- Nstéfanez, $6 \%, 796$.

- Felices, 68.

- Ferro, 366.

- Garcia, 218, 710, 784.

- Gómez, 1.045

- Gonzilbe $\% 3,457,546,590$, $602,613,619,628,655,671$, $672,685,725,829,856,958$, 1.028, 1.1 (j4.

- el Hortelano, $16 \%$.

- Juanes, aletide, 24.

- Lopez, \$1, 231, 558, 986, 1.034 .

- hijo de Lope Marlin ben Cureis, 1.030.

-. Isópez Fernánder, 1.1fi4.

- Lópezde Mentoza, 232, 831.

- Melénde\%, $543,985$.

- Muño\% 64.

- Ordoñez, 561.

- Petrez, alcalde, 6s, 7\% 99, $200,220,281,22 \%, 35 t, 35 \%$ $320,340,3,3,476,624,906$, †.058.

- Petrez ben al Balill, 529 .

- hijo de Pedro Juanes, 1.082.

- hijo de Pedro, hijo de Juan el alguacil, 620,621 .

- Ruiz, alcaldo, $\% 1,221,673$. 674.

- Ruiz, hijo de Ray Petrez, hijo de Pedro Moro, 602 . 
Diego Sánchez, 78, 704.

- Suárez, 198, 407, 1.123.

Dilmán, 141

Dios, Micael, hijo de Pedro de, 681.

- Ayuda, 559.

Dirhem y Medio, 3.58.

Diún, Ríchla ben Jacab ben, Liti.

Dodri, 152, 570, 575

- Aixa, hija del, 668 .

Domenches, 473 .

Domenga, $106,637,653,659$, $691,713,717,917$.

- la Crispina, 16\%.

- hija de Domingo Rodrigo, 726 .

- Estefanez, monja, 1.096.

- Gutierrez, 669.

-- Vicent, monja, $19 \%$.

- del Martomo, 998.

- hija de Micael ben Serhán. 433.

- Priora, J9f, 740.

- Sebib, 807.

- Vicent, monja, 740 ,

Domincach, presbitero, $19 \%$, 245.

1)oningta, 6\%, 6\%, 69, 73, 170 , $171,203,217,260,76,187$, $192,217,230,267,272,275$, $203,331,339,341,247,355$, $357,361,362,368,373,380$ bis (c) $404,407,416,417$ $428,430,445,489,580,597$. $603,608,611,4331,653,738$, $743,754,758,775,796,806$, $815,835,918,922,94 \%, 980$, $1.013,1.018,1.024,1.029$, $1.076,1.109,1.111,1.113$ $1.114,1.161$.

- hija de $\mathrm{abuhafs}, 149,243$.

- hija de Alulfárach, 17.

- hija de Abulrebia Sulei. mán, 6:3, 1.114

- de ilfonso, 1.025.

- hija de Andrés, 568, 615 .

-- hija de Andresa, 820 .

- Arracaia?, 465.

- hija de Benediclo, 918.

.... Cebrián, 659.

- la Crespina, $5 \mathrm{H}$.

- hija de Domingo, 1.102.

-.. hija de Domingo Jermóndiz, 2\%l.

- hija de Domingo Petrez, 85 . Domínguez, 271,553 .

-- Estehan ben Misín, 434.

- hija de Estelan el Drogue. ro, 479 .

- Fistélıanez, 186, 201, 233.

- ben Gálih, 281.
Dominga la Gallega, 184,530 .

- Gareda, 1.004.

- Gaillem, 434, 485.

- Gutierrez, 196 .

- Jacob, 422.

- hija de Juan, 821.

- hija de Juan Cristotral, 45. $502,560,599,612,601$. hija de Juan Crordel, 1.074.

- hija de Juan l'etrez, 389.

- hija de Juan Said. 1.079.

- Juanes, $305,358$. hija de Juanes ben Harún. $75 \%$.

- Julianis, 411.

- Jorenzo, 352 .

- hija cle Mlaria, 1.022.

- lija de Martín, 18i.

- Martín, 450, 321 . hija de Martin Wienel, 445

- hija de Martin Salama, 1-58.

- llamada de la Mayordoma, 1.082 .

- Meléndez 15.

- hija de Melendo Arias, 13, 15 .

- Micael, 59, 1.042, 1.129.

- hija de Micael PascuaJ, 168.

- la Norija 1.082.

- hija le Nábil, 275.

hija de Jedro, 442.

- hija de ledro Julián, 162.

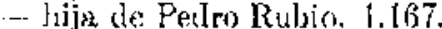

- hija de Perlro re él'ortola? 425 .

- hija de Petros de Tortosa. 6) 45, , 34 .

- bija de Donning Rodrigo, 826 .

- laija cle Román Juanes, 191.

- del Sachirant, 1.162.

- hija de Sulyador, nis 82.

- hija de salvador el Bellutero, 356.

- Sebib, 2ro.

- la serrana, 341.

-. hija de Servando, 700,959

- Bobrino, 195, t93

- lija de Suleiman, fiz, 95, (3) 1.160 .

- Vicente, 951.

- hija de Yaliya, 1.067.

Dowing $\%, 0 \%, 61,29,75 \%, 1 \%$, $17 \%, 4 \$ 1,19 \%, 19 ;, 196,10 \%$ $149,201,228,25 \%, 250,280^{\circ}$ $5,30,117,119,195,200,205$ $306,340,344,469,598,601$ $680,689,705,715,736,857$, $944,1.001,1.049,1.122$.

- Abad, $77,278,17 \%, 191,196$, $154,170,257,268,270,286$, $206,304,321,324,351,868$,
$430,476,497,505,506,512$, 817 .

Domingo Abad, hijo de Juan ben Moluc, presbitero, 267 .

- Abad len Moluc, camón. go, 289.

- Abac de Olias, 485, 487.

- len Nbelalá, 91.

- ben Audalá el Polichoni, 61 . $1 \% 6,10: 1,126,134,147,163$, 248.

- ben Abdelaziz, 12, 35, 385.

- hija re $\Lambda$ ldelaziz ben Saad, 216.

- ben dbderránmen ben Che bir, 315 .

- ben $\Lambda$ bderráhmen ben Sucro, 47 .

- Abromálic, 70.

- hon Abisaid, 56 .

- Abuzeid, 492.

- Adam, $466,700$.

- el Alura el Zapatero, 106.

$-\mathrm{Ais}, 168$.

- Alascar, 200

- Albino, 170.

- Aleochit cl Peseador, 6f, 192.

- Athasar, presbitero, 196, 238,392 .

- ben Ali ben Guaid, 222.

- cl Almotacén, $565,567,568$, 615,820 .

- Alnaya, 415.

- Alpolichén,

- ben Alrim, $78,125,20: 5,58$, $61,78,114,122,131$.

- Nyaro, 145, 425, 645, 964. Andris, 415, 434, 485, 596, 689 .

- Andrés el Carnicero, 66, 645 .

- Anclrés Hatuto, 1.160

- Andres el iMoxado?, 194, $318,7 \frac{1}{2} 0,1.100$.

- Antolín, alguacil y alcalde, $73,163,190,200,213,222$, $298,239,246,327,492,901$, $908,1.014$

- Antolin el bellutero, 836 .

- Aparicio, 383.

-... arcediano, $360,237$.

- areipreste, $61,5,902,1.168$.

- arcipreste de Cuéllàr, arcediano, 176

- Ardon el Curtidor, 1.016

- el Arjaquis, 175 .

- - Asaar, $225,237,568,015$

- el Ashali, 316.

- Assaig, presbitero, 467.

- Avezael, 88.

- Ayas, 1.094. 
Domingo ben Ayub, 58 .

- Azamae, 1.000 .

-- Azzamal, 682.

- el de Baeza, 1.12?.

ben liarbancón, 29.

- el Barhul, 36.

- el Bastarí, 76, 311.

-.. bon Jaynar, 146.

-.. Jayán, presultero, 805.

- Tielo, 206.

- Benaix, 199.

-.. Benedicto el Pescador, 012, 691.

- el Berniti, 98.

- „Bivo?, 974.

-... Bocach, 408.

- Bono, 238.

- de Busto, $50 \%$. de Caba?, 713 .

- hijo de Cais Ardid, $16 \%, 170$.

- de Calatrava, $22 \%, 172,581$.

- el „Calvo?, 316. Camo, hijo do Juan Petrez, 407.

- ¿Cansino? 4 iz.

- el Capellán, 65.

- el Capiscol, 471.

- el Carnicero, 841, $1.05 \%$.

- Caro, $67,561,502$.

-.- el Car|jintero, 143. Charión? el 7apatero, 577 . - Cebrián, 74.

- Cebriản, alcalde, 79,220 . Cebrián el Esterero, 612.

- Cidiz, 8ñ, 1.167.

- Ciprián, 224.

- Clemento, 916 .

- Calaudra, z's.

-.. dCololra?, 122.

- hijo de Columba, t\$s.

- el dConejero? $246,355,362$.

.... Crespo, 12t, 228, 245, 359 , $458,460,1.008$.

- Crespo el 'línalexo, rs;

- ben Cristobal, 283, 1.162.

- ben Charrah, 5o, 401, 411, 462 .

- ben Chazah, 378 .

- Chico, 59, $22 \%$

- Chico el Adadid, 901, y43.

- Diaz, 114, 245, 567, 615, 820 .

- Dominguez, 9: 106, 292, $366,378,1.019,1.174$.

-. Domínghez, hijo de Juan Andres, 608 .

- Dominguer, hijo de Micael ben Alrim, 123, 129.

- Domínguez el Pastor, 765.

- Elias Asacaz 589.

- Uscobán, 202.

- Escudero, 360.
Domingo Esquerdo, del Arra. bal, 1.174

- Estelitu, 225, 20, 88, 124, $218,357,397,532,968,1.085$ 1.153.

- Iosteban Mfarero, zis. Istehan hen disun, $\$ 19$. 185.

- Fisteban do Aleardete, 505, $615,65 \%, 650,820$.

- Listelya el Almotacen, 559 , 594.

- Esteban el Guadiexi, 576, 591.

- Esteban el Ruitani, \$\$3.

- Estelbmer, $: 26,729,732$

- hjo de Fisléstano, J (02n.

- lacundo el Alleitar, 820.

- ben Fadal, 1.021.

- Faro o ¿Ferro?, 253.

- ben Harbtin, 289.

- Febrero, 1.057.

- el Irecac, :ti:

Felices, $: 234,717$.

- Telices ben Alimálic, 231 $241,398$.

Feliess ol Albañil, 820 .

- Felices Assammar ben Mah. chún, 1.170.

- Feliz. 053

- Fornúndez, 222, 250, 611.

- Fernindez el carmadi, 625.

- liermandez, de llieseas, 239.

Fernando, 321.

- el IIerrero, 90.

- Perrero, $536,600$.

- Ferro, $427,682$.

- Galindo, 560 .

- Garcin, $2,168,61$.

- Garcia, arcediano, $4 \%, 804$

- ben ciarcia, presbitero, 388

- Guseo, 346.

-- (Gil, $1 \% 1), 384,655,671,781$, 860,868 .

- Gomer hijo de Juan (jómeI, 921 . Góme\% el Melladof, 83s.

- Gonzalbo, 197, 232, 288, $33 \mathrm{~L}, 689,695,697$.

- González, j2.

- Gonzilez, areediano, 176 . 141,154

Guerra, 1is.

- dHamoro?, 1.096.

- Háqucm, 193.

-.. el IIerrelo, 653, 1.020.

- Hosain, 137, 361.

- Illan, eanónigo, $168,1 \% \psi_{3}$ 511.

- Tllirn de \%arueo, 1.030.

- bijo de Iñigo, 448.

- Jacob, 400.
Domingo Jacob, hijo de Jacob el Crespo, 422.

- ben Jáir, 810.

- ben Jalaf, 93, 102, 125, 127, $164,238,952,972$.

- ben Jálaf, el llamado Do mingo 3 Hayornoche?, 280 , 800 . Juan, Gus.

- hijo cle Juan Dominguez, 67.

- ben Juan Esteban, 807.

- hijo de Juan listeban, 980

- hijo de Junn, hijo de Eoteban al Guadiexi, 679.

- hijo de Juan Lópe de dAlbequil? 6 ins.

- hijo de Juan Peltar, 410.

- hijo de Juan, hijo de I'elayo Yelaqque\%, 954.

- ben Juan Pettea s.fo.

- hijo de Juan l'etren el Platero, 452 .

- hijo de Juan Salama, 216

- Juanes, $53,54,6 \%, 73,76$ $72,168,170,180,2 \% 3,289$ $4 t(1,25 \%, 89,111,142,152$ $168,195,245,209,22 \%, 256$, $342,348,426,523,536,569$, $604,611,610,710,965$, $1.014,1.040,1.070,1.112$, $1.118,1.13 \%, 1.158,1.161$

-.- Juanes ben Alpardesal, 20\%, 1.164

- Juanes ben Pachicas, $9 \gamma_{1}$ $324,436$.

-- Juancs Domineach, $28 ే \mathrm{~b}$.

- Juares il Eseribuno, 726, 826. Juanes, hijo de Esteban al Guadiexi, 686 .

- Juanes ben Hosuin, 615, 820.

- Juanes el Iongo, 789.

- Juanes el Malagueño, 623. 1.173 .

- Juanes, apodato ben : $\mathrm{Mo}$. crecho?, 80t;

-- Juanes, hijo del apodato el Murcheni, 898.

- Juanes Orcullel, 86

- Juanes el l'latero, 180.

- Juanes el Pelrero, 960.

- Juanes, hijo de ¿'l'cllo?, 342 .

- Juanes el Zapatoro, 638, $71 \%$.

--. Julisin, 160, 372, 480, 636, 646 .

- bijo de dulián ben Albazo, 169,247 .

- Julitan el sillera, 6\%, 627.

- Julianis, 82. 
Domingo, hijo de Justa, hijo de Tomán, 38, 39.

- Justo, 1.103.

- Justo el Esterero, 412.

- Laurens, 186, 286, 428, 436.

- Jázaro, 180, 196, 205, 247, $640,1.114$.

- Iópez, presbitero, 606.

- Tóper del Arrabal, 1.128.

- Lortnzo, $7 \%, 5.56,943$.

- Lotano, $7 \%$

- hijo de Lucas, 312.

- Lucenia, 382.

- Magar, 1.049.

- de Maliaga,

- Marcelo el Adalid, 927, 247, $63,548,898$.

- Marciella, 170.

- Marlin. $68,78,79,1 \%, 200$, $204,2 t 5,53,104,139,213$, $322,383,582,540,549,587$, $649,653,943,1.014,1.028$, 1.088

- Martin ben Alquitar, 61, 249.

- Martín el Bañero, 004.

- Martín el Carmadi, 64, 545, $5 \% 2$

- Marlin el Hamami, 5.59.

- Marlin el Melah, 804.

- Marlír el Pastor, 632.

- Martín el Sordo, 534.

- Martín ben Suleimán, presbitero, $146,662,667,780$.

- Martín el Vicario, 590. Martin el Lapalero, 522,568 .

- Martinez, vicario, 17,45 , 115.

- Mauricio el P'escador, 1.152.

- - de Nayornoche, 25\%, $6 \% 4$.

- el Medidor, 170 . de Hedina, 855.

- Meschún, 682.

- Miegel, 199, 224, 228, 235, $47,300,412,578,673$.

- Mical el Abarquero, 634.

- Micael el Ada]id, 333.

- Nicael el Nifurero, 698,701.

- hijo de Micael ben Alim, (36.

Micael, hoca de Sábalo, 72.

-- Micael Cebrian, T46.

- hijo de Micael Celrian, 282.

- Micael el Curtidor, $66,645$.

- hijo de Micaci, bijo de Do. mingo $\mathrm{hbad}, 749$.

- Micaef, bijo de Micael Ruiz, 1.164.

- Micael ben Ruy Diaz, 225.

- ben Micael el 'l'oscli, 454. Mingues, hijo de Joningo Justo, 726 .
Domingo Minguez el Pastor, 641.

- el Hocho, 1\%, 1.09\%.

- Monje, 340.

- de Nora, 723

- cl Mozárabe, 125, 19\%.

- Muñoz, 171.

- Muñoz el Pastor, sedi, 7̈1.

- Nagrela, 732.

- Negro, 376 .

- Nuño, 468.

-Obasto:, 479.

- de Ocaña, 513.

- de ..., de Olfas 115

- Ijen Omar ben 1 biljár 1.158

- Pascual, dcám, 175, Lis. 150 , $181,200,407,5-44,562,577$, $578,588,610,615,630,700$, $820,82 \%, 1,003$

- Peláez, 224, R24, 261, 954

- Pelayo, 98. el Peon, $1 \% 0$.

- hijo de F'edro Algaze], 327 .

- hijo de l'edro Atsical, 589.

- hijo de Pedro de la dBribe. da', 232,349 .

- hijo de Pedro Carricllo, 777.

- hijo de Pedro Corella, 715.

- hijo de Pedro Chabes, 440.

- hijo de Pedro, hijo de Do. mingo, hijo de Pelayo Do. minguez, $7 \mathrm{i} 3,1.110$.

- hijo de l'edro Mozarabe, $281,241$.

- hijo de Pedro stamabis? 112.

- Percz Abentoriel, 156

Petrez, $65,21,161,26,216$, $220,221,231,241,26 \%, 61$ $80,155,174,191,204,210$, $23 \bar{i}, 250,271,254,297,821$. $330,376,415,459,465,477$, $494,501,506,593,652,680$ 699, 701, 728, $810,942,953$, $1.007,1.010,1.012,1.016$, $1.020,1.024,1.030,1.043$ $1.056,1.076,1.168$.

- l'etrez el Atyd, 711

- Pelrez ben Alagrifi?, 251

- Petrez el Alealite, 607.

-... Petrez el Cantar:, 552, 053 , 600 .

Petrez el Alfaqaq, 119.

- Petrez de Alnefari, 1.032.

- Petrez de Alpardesal, 1.164.

- Petrcz el Arquero, L.164.

- I'etrez cl Arrioro. 506 .

- Petrez el çBacal?, 638.

- Petrez de Camarena, 472.

- Petrez, hijo de Cecilia, 637 , 670 .
Domingo Petrez ol ie Colmenar, $537,570,668$

- Petrez el Curtidor, 32:

- Petrer el Guaih, $76,18 \vec{i}$.

- Petr ${ }^{2} \%$ de Fscaloni]la, dija.

- Petrez luen Farún, 4 śt.

- P'elrez el ficene, 20,729 , $-32$.

- l'etrez ben Hosain, 95.).

- Petrez de Marcos, 415.

- Pelres de Nonteml, chmóngo, $179,595,601,608,617$.

- l'etroz ben (obaid, 307 .

- Petrez de Oliate, li78, 688.

- Petrez, hijo dis Sabid, 1.125.

- Pelrez el Zapatero, 691, 078.

- ol Platero. $466,469$.

- el T'olichení, areipreste, j.;, $5 \%, 61,176,21,120,15 i$, 171, $176,183,226,280$, $234,235,239,25 \%, 26 \%, 272$, $297,307,305,337,355,369$, $419,1.008$.

- lay, 2\%6.

- Raimundo, $258,1.12 \%$.

- Ramos, $12 i, 640,680,829$.

- Roberto el Hortelino, 380 bis (c).

- Rodrigo, sty.

- Rodrigo el Adalid, sut.

- Rodriguez isti.

- Romenin, hijo de Juanes, 341. ben Rowán d Nontero, Rubio, fyi, 121, 275, 1.030.

- Rubio el Carnicero, 450 .

- Ruiz, 725.

- Selostin. 93.

- bcn Said, 69. ben Salut, 164, 1.15\%.

Salva tores A rrayach, 1.006.

- Suncho el Esterero, 340 , $586,1.163$.

- SWunquero?, $259,435$.

Saturnino, 122.

- Sebastian, 183,311,682,708.

- de Segovia, 431 .

- ben Selma el Batri, 174, 1.016.

ben Servando, $196,2,2,255$ $892,627$.

-. Servando el Catib, 552, 55: $(600,1.62 \%$

- ben Servando, alguacil almojarifo, 817 .

- ben Servando ben IJosain ben Servando, 1.159, 1.169, 1.174 .

Scrrano, 474

- Setaquero?, 672

- el Sevillano el Zapatero. 1.160 . 
Domingo Gidis, fot, 13, I5, lig. $179,247,494$.

sidrey, 28.1 .

- el Sillero ben Abderrahmej ben suer, 397 .

- Sobrino, 858.

- Socrún, 1.020.

- Soriano, 689, 700 .

- ben Suleiman, (i), ly, :si, sity.

- ben Suleimán el de (tua dix 52 .

- Tercero, 237

- el Tolediano, 559, 59.1.

-.. Tomé, 850, 638.

- Tomé, apodado gMandin?. $298,3.17$.

- Tome el Monedero, 345 575 , 1000 .

- 'orcuato, $200,608$.

- Toro, 271 .

- del de Tudela?, 180.

- el 'Tuerto, 22:)

- Fela?,

- Velasco, 223, 6n8, 821.

- Velasco el dChafah? ij7:

- Vicente, 287, 254,611,637. $670,711,988,1.109,1.111$

- hijo de Vicente, 682 . 694 .

-. Vicente el Cicgo, 701. - Yago, 102, 1.027.

-- ben Yahya, 8, 1.067 .

- ben Yahye ben J3arber, 734.

- ben Zacaria, 315.

- Zapata, 689.

- el Lapatero, 371 .

Dominica, priora, 291,318 .

- uxor ben Lamparter, 969 .

- ben Hafsím, 71.

Dominico Abbas, $18 \%$.

- Armentárcz, 1.012.

- Aruiag, 41 .

- Ca.... 22 .

... Fauderu, 88 .

- Iohannes, 1.015.

- Iuliam, 180.

- Lozano, 1.012.

-. Mlicaelis, 88.

- T'elsex, 144.

- Petriz, 125, 1094.

- Salbator, 1.006.

Dominicus, arcipreste, 176 $202,29,33,34,39,46,47$. $96,200,223,319,34 \%, 378$, $729,974,1.012,1.038,1.068$, $1.080,1.129$.

- Abat, 274, 362, 373, 36t.

- madridensis archidiaconis, 274.

- archipresbiter, $73,96$.

- ben Arrim, 797.
Dominicus Iroing, 84.

- Catarusu, 1.152.

Cidli $z, 30 \%$.

(irderiaorí, 169.

-- deennus toletrnus, 823 .

-.. Dominici, 125.

- Pelicis, $21,312$.

- Gerere tia.

trosenclo, tiv.

-- Cra11dissull,i, ;.?.

(iull cm, 77 .

- Tiustii 381.

‥ Ioannis, $34,2.65,265,117$, 422, 6(2), 1.075.

- I alian, 89, 25:, 274.

juca, filius, 1.10:\%.

ben RLunizatral?, 101.

- Martini, presbitoro, 201. $318,3 \times 9,396,414, .140$, $44 \mathrm{~S}$.

Martínez, 500.

... Nartinix, 24.

- Nicael, presbitero, 192, 44\%, 512 , is:3, 84s.

- Mistaralos, 1 $2 \%$.

- Pelaiz, 169.

Petri, gos.

I'ctri d,Rachdo?, 413.

...- l'etrio, 79 \%.

Petrus, 388.

ben Petrus dlbarneti, 43.

- I'etrus Zahed, 492.

-. precentor, 1.1.10.

- Rodericts, 406 .

- Rufus, 274.

- Sancti Tomé, 1.012.

- Scriba, 326, 446, 457, 74:.'

- Toreati, 466, 472 ,

Dominiqui, $t \% s$.

Dona, $\%, 43,70,74,195,290$, 137, 456, 545, $710,756,983$, $1.012,1.074$.

- hija de Abdalá ben Yahya, 1.4.

- hija de Abulhasán Salo. món, 150 . de 1 brand, 14 .

- hija de Abraham Alsabi, tot.

hija de abdolmélic, 380 .

- hija de Abderratimen, 78.

- hija de Alhalas, 88 .

- de Archaliel, 124.

- hija de Bartol, 7t.

- hija de Esteban ben Ambl'án, $94 \overline{7}$.

Estébanez, 225 .

- filia Gabdelgeziz, 43.

- hija de Gílib Alcallas, 221. 361.

- hija de Ibrahim ben I'artel, 140.
Dona, Hija the Isac ben Alea ja], 1.137 .

- hija de Ishac ben AlcameIf, If.s.

- hija de Rabí Jacob, 15 1. Jarada, $1.13 y$.

- Juanes, 145.

- hija de Molárrifif, 72

- Raimtindiz, 281 .

- bija de Temam el Cerero, 48.

-..- hija de Yobeco, 1.007

- lija de Ýusef ben Sabat, (A)

- hija do Zacaría, 86.

¿Doquela?, lija do Martín Meléndez, 1.020.

Dos I3arrios, Laurent de, 1.027 .

Dueña, hija de Abdelaziz, 138 .

- esposa de Gandio, 61.

Dulce, 958.

- hija de Bonet de Balaguer, 908.

Duminico, flio funiz?, Do1.

Duncas el Calvo, Aben, presbltero, 231 .

E. Roderici, presbitero, 1.106. Edelua, 60, 960 .

- hija do Armaldo Muñoz 813.

- Lija de Juan Dormínguez, 888.

- hija de Domingo, 868.

Efraim ben Isare, 147.

- ben R. Isare ben \&Yajunes?, 1.133 .

Egas, presbitero, $188,1.057$.

Fgitlius, canónigo, 179,228 , 420,751 .

Eleazar ben Sadón, 150.

Elena Nuniz, 18.

Elí ben Talik, $75,143,150$.

Ellas Assacar, 150, 589 .

- el Comerciante, 838.

Eliesef, Rabi, 146, 222.

Elionor, Dofia, reina, 326.

Elisabeth, regina, 118.

Blvira, Doña, $167,7,88,519$, $546,551,641,673,1.022$

- Ir Cordonera, 68, 474 .

- Diaz, 26.

- Fernandez, monja, 825.

- Garcia, priora, 191,202, 584, 710,760 .

- hija de Gonzalbo, 9

- Lija de Lorenzo ben Mofa. rech, 263 .

- Marcos, 202, 710.

- hija de Martin Ruiz de Bar. gas, 768 .

- Martinez, 1.106. 
Elvira la Nolinera, 531, 546, 551 .

- Petrez, 251, 662.

EElla?, Doña, 1.085

Emeter ben Idris, 412.

Enrique I, 106,114

invenenado, $121,146$.

Trmenegilda Rukeriguiz, enonomus domus regis, $1 \% \gamma$.

Limildo Diaz, 4 .

EEsaisia?, Don, d Copista, 820 .

Esbert, $14 t$.

Escalona, Bartolomé de, 35s.

¿Escarpir?, Pedro, alguacil, 435

España, Juan de, 820 .

- hija de Pedro León, 24.

Español, Domno, deán, 161, $175,255,1.127$.

Espartin de lllescas, Don, 509.

Especiosa, monja, (2), 100, $81 R, 817$.

Espinosa de Ios Monteros, Pablo, $88 \%$.

Esquerdo, Nicael, 747.

Esquivias, Arnaldo de, 559 , 594.

Estacia Muñoz, 3us.

Estaleha, $14 \%$.

Estalecha, Ibrahim ben Ishac ben Ibrabim, 115 .

¿Estalecha?, Abuishac Abibrahiın, 1467 .

Estasia, Dona, monja, 252, 273.

Esteban, Don, $78,16 \%, 170,239$, $360,96,379,583,430,559$, $1.033,1.034$

- apclián, $17 s, 179,181,202$, 2904, 393, 467, 472, 475, 449, $538,542,548,556,746,997$, $1.060,1.111$.

- bon Abdelazir ben Abiná lic, 43 .

- ben Abderráhnem, 19

- ben dAbduilo?, amín, 28 .

- Alavixi, 170 .

- hijo de Aleasir, $1,014$.

-- Alfonso, 628.

- ben Ali, 292.

- ben Aumrin, alcalde, Jor", $220,280,293,947$

- Andrés, $73,748$.

- hijo de Andrés, 74, 179.

-. Andrés ben Abdelquerim, 584.

- del Arrabal, 275.

... el Bacal, 1.102.

-- el Beflutír, 473.

- ben Barcán, 541 .

- el de Camarena, 73.

- el Camicero, 170.

- hijo de Cebrian, 58 .
Esteban ben Clatijir, 5or, 715.

- yermo de la Crispina, $16 s$.

- Diaz el Zapatero, 401.

- ben Domingo Mavón, 515. Dominguez, $(623,4+2,898$.

- hijo do Domingo listcban el Kitaní, 886,897

- el Droguero, 395

- ben Lstacio, 700

Esteben, 395.

Estébanez, 320, 378

- Fraleón, $\%$.

- Febrero, 380 l,ia (c)

- Felices, $83,395$.

- (raistin, 88.

-. el Coenaz, 405 .

... ben Idris, 717 .

- llian, talealde, $183,483,75$. $783,95 \bar{i}, 1.080$.

-- ben Illáu beu Borcán, 675 . Illanes, a guacil y ajcalde, 219, 240, 25:3, 354, 94, 110, $150,326,340$, 365 , 366, 367, $368,369,871,981,391,414$ $437,537,570,533,590,738$, $745,834,943,945,952,988$, $1.008,1.0+1,1.059$, 1.1.9.

- ben Jálaf Assactani, 24

- Hijo de Juan, 978 .

- Lijo do Juan Estelrar el Rubio, 202.

- hijo de Juan Petrez el Corveli, 1.114

- hijo de luan P'tetez apodado Zancada, 393

- Esteban Juanes, 63, 288 $604,726,826,1.112,1.118$.

- Jaanes el Asfar, 43 i.

- Juanes de Santa Leocadia, Liti.

- Julianes, $8 \%, 69,21,94,124$, $24,258,288,472$.

- capiscol, 178, 1.167.

- ben Lampader, 326 .

- hijo de Lope de Olias, 549 587 .

- Estcban Lópcz el Gíacatin? 606 .

- el Iechero, 55, 156, 1.095.

- J mengo, 95 ó.

- Martio, $80 \%, 1.164$

Mleléncloz, 172.

- Meruán, 729.

- hijo de Micael Petrez Asaca\%, 568, (315.

- de Mochares, 23\% 1.128.

- ben Moluc, 728,1 .036.

- Mostibar, 75 .

- de las Muelas, 692.

- ben Omar, alealde, 64, 220 , $26 \overline{7}$.

-- el Organista, maestro, 168.

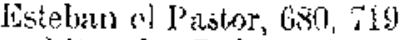

-.. hijo de Pedro Alcantari, 600.

- hijo te Perlo dsafati el Ha. sar, 817 . ben T'edro Ferro, 1.021

- hijo de Peello Julián, 647 , 65.57

- nitito de Pedro Velasco, 81.

- Pérez, 16t.

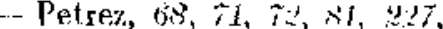
260, 331, 374, 449, 478, 505, $552,541,607,632,6648,673$ $676,688,459,692,695,656)$ $693,705,819,942$

- Petrez. alguacil, $103,431$. $474,955,1.025$

-- I'ctrez ben Lampider, al. calde, so, $2,214,570$, 668.

- Petrez, caid, 488, 587, 153. Petrea, racionero, 180.

- hijo de liemo, 118.

- Fenaldo, 118, 228, 1.154

- de Ribas, 1 (iis.

- berl Sacuab, 1.067. l,an Said el Longa, 200.

- ben Salomón, alcalde, 41 $2 \% 0.701,959$.

- bijo de Salimón ben Ali, 944

-- Salvatores, 11

- de Setiel, 139.

- ben Suleimán, prosbitero. $18 \%, 34,305$.

'Tello, 1.105 .

- el T'rapero. 514

- hijo de Vicente, hijo de PeJayo, 198

-..- Vicente, $9 ; 3$.

Estebania, 1.105.

- Petrez, 1.162.

Fslebert, Pedro, 486 .

Estefan Vincencius, 116,198

Estefania, $79,269,409,419$, $440,474,667,670,983,10 \% 5$.

- hija de Domingo el fGor. do?, 200,829 .

- Fornández, \%os 814.

- hija de Marla, 1.035.

- Robert, 6:3, 602 .

Estefano, presbitero, 188.

- ol Boticarjo, 22 Micaol, 256

Estela, hija de Ibrahim ben Falcón, 141 .

Estella, Fduardo, $9,0 \%, 15 \%$ 177,208 .

Estepano, hijo de El, 315

Eufrasia Juanes, 1.022.

Eugrenia, $138,25,62,291,318$, $409,419,440,814$. 


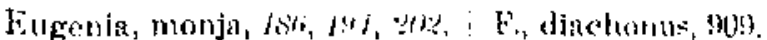
$740,7 \div 2,192$

hija de fluchlbo\%, 1.tiat.

hija de "T'en:ana el Rollegul, 1.5. 38, 39.

Jupenio, hijo de Podro Men. iो ro, 211.

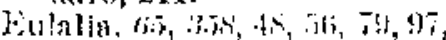

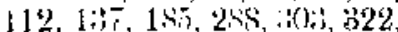

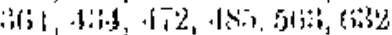

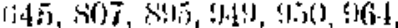
$1.114,1.025,1.11 \% 2$.

monja, $x+1 \%, 92 \%$

priora, $69 \%, 2.19,249$.

- Tija de Abdelaziz ben .1. rim, $1+7$.

lijit de lbuzncarlat, nieta re Ponee, $30 \mathrm{~s}$.

hija de Nlasfar, 1.016.

- hija de dlí, 202.

hija Nmrel, 189

hija de Antrés, 300 .

-. hija de Diego, 75 .

-... hija de Domingo Juanes el l'abali, tit.

- hija de Domingo l'etrez, 11;

- Iifja de Estebrn Tello, 1.105.

- Ia (iargantera, fi:, 5.5.

hija de Juan C'hico, i.ik.

-... hija de Juan Itominguez, 952.

-- Jusnes, $35 x, 322,393$.

--- hija de Julian el d'aulo? ben fielitu, 421 .

-... hija de Julián de dliebia? cols

- hija de Justo, 1.15:̈.

-... S,orenzo, 352

... Martin, 49\%2,

- Martinez

-.. Mocarram, 2ys.

-n hija do Mohic, 517 .

- hijar de l'edro, 7.1. - hija de Pedro, hijo de Juan,

- hija de Pedro Juanes, ¿z(k).

- hija de Pedro Juanes Mocarram, 174, 1.016 .

- hija de ¿Pellojo?, $49 \%$

- Jetrez, SL, 2Ho, 2l:3, 312, 969, 1.033.

- 'Temam, 96i.

- hija de Yahya el liognero, 165.

Eva, Doña, 708, 71. 719, 720, $721,722,964$.

-.. hija de Mieacl Chofre, 617 , 1.115 .

F., archidliácono, 141.

F. Garcia, capellán, $17 \mathrm{~s}$.

$\mathrm{F}$. , arcipreste, 176 .

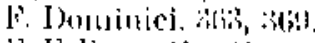

W. Felices, tiel, til.

F. (iarsin, enpellanus, 60s.

F. Iohamis, poreionarius, 7 (bx.

l. Muñz, presliter, 351.

Pabari, lit, lis?.

Pabiana, hija de Jomingor l'r. tre\% (l) (uballero,, $50 \%$.

Fudajil, Afri.

liahagu, Mntin el, 425.

liahs], E], 261.

¿lialabelaro?, Peidro, 1.16 .

Fileom, then, 1.12, 1,1:7, 1.14s, $1.14 ! 1,1.150$.

¿Faljatis?, obispo, tst, stit.

fluljis?, obispo, MI.

Funequl, (éecilia, hija do .Iuan el, 1, (miti

Burnarilo ol, 1.026.

Furaels, Furach ben Bono ben, t.tis.

bent Melue, 45

Misa ben Y'úsuf bon, Iffi.

Farech ben Ishac, $208,185$.

ben l'atyan, tis, 51i.

ben Afrit, If.s.

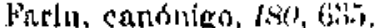

Farj, hijo de aAlmacatur?, 735 .

Paro? $t / f i$.

Hatlma, lija klo Abdala, (iso)

-- hija de ()mar y do Mrriam, ¿95.

Fatuma la l'einadora, 701.

Satumola?, 1.02\%.

dielicill”, Doña, $\% 52$.

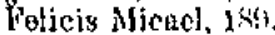

i Felilal? son.

Felipe, 6.5 782 .

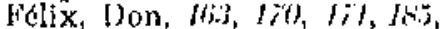
$19 \%, 21,24 \bar{i}, 410,57 \pi, 974$ 1.15 .1 .

-- el Albañil, tis, :30:3.

- ben Abdelaziz ben Iampailer, $f 7$.

- ben .tbeliebla, 23.

..- Ilvarea, 1.020, 1,077.

- ben Asim, 942 .

Barragin, 166.

- el Cátib, Don, 4165.

- hijo de Domingo Basritin, $6 \%, 252,1.054$.

- el Wseribano, 63.

-- el Ferrador, 165 .

- filii Stefanus, 60. Gustón, Mij.).

- Guillén, 77.

- Illún, 541.

ben Jáir, 910.

- Martín, 3yj.

- ben Martin, 563 .
Filix, hijo do Martin ale Andtijer, 15

ben Mistacl, is atis

Micaulis, caminizo, fis.

hijo (le Miene), 1.053.

-- ben Mijane] el Esterero. 1.123.

foen Michel ben Jnsimil, Nii, 212, 227.

ben Meruin, !!

Martluez in l'escendor, 65:

Negro, tis, (n)

tolute?

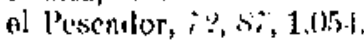

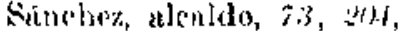

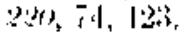

hijo di. Samcho, 924.

Sanches, algetac $i 1,82(i, 3335$. loen Vahyen ben Ablata, al-

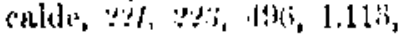
1.154 .

Foluejut, Chamila, hija del, $14 t$.

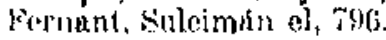

Forwess, 15!).

lijn do Juni ben otmith, $171,21 \%$.

Fermandine dinzetes? 448 .

Fernín di Jalles, Iofl. l'edro, :..

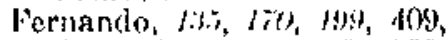
419. $440,645,814,922,052$ (45), 1.(20\%, 1.0!)

-n fray, $10 \%, 17$.

..... $1, \mathrm{ij} ; \mathrm{s}$.

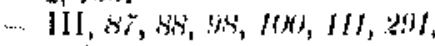
स्ist.

-. infuntr, $m, k \pi$ vicario, $17 \%, 631$

‥ Abad, 370 .

.. hijo do Abril, 10:5.

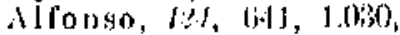
1.010. 1.087.

- Alguactin, 47.4

- Nlababl, $\%$.

- Alvurez, 562, 585, 825. trius ol liallrgo, 1.000.

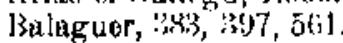

.... Isenayas, $73,482,16 \%$. Bonetieto, 3 ili.

-... Bolsén?, bijo de Maria lllán, de Maqueda, 855.

- cl C'armall, 775,934

- de Corral, 673.

- Domingo, 22k

- Domingus, $\%, 1 \%, 260$, 702,717 .

- Domingurz berr Nlialabf, canonigo, $l \%, 476,490,542$, 503,579 .

- ben Domingo ben Fernando, 1.165, 1.166, 1.171, 1.172.

- el Espartero, 108 . 
Fernando al Esterero, 530 .

- Fernández, 752.

Garcia, canónigo, 54, 66, $180,490,498,506,518,710$, 1.115 .

- Gil, arcediano, $1 \%, 242$, $1.06: 3,111$.

- Gómer de Sotillo, 695.

- Gonzalbez, 683, 868, 867 , $1.030,1.099$.

-. Gonzallo, 641, 657 .

- bijo de Gonzalbo Vicente ben simmaj, 96:

- Gudel, alcalde, 22l, 69i, $703,821,988$ Guteriz, 702 .

- Gutierrez, 610.

- Hasán, 396 Illán, 1.045 .

— hijo de Tñigo, 448

-- Junnes, $18 \%, 196,211,22 \%$, $293,198,195,20 ; 219,266$ $352,428,524,552,583,540$, $944,1.156$

-. Juanes, alcalde, 219, 224 824.

- Juanes, comendudor, $20 \mathrm{~s}$ 190

- Juanes len Abdelmélic, alcalde, 16\%, 217, 268,511 , 748,758

- hijo de Juan ben dbdelmé lie, $358,1.125$.

- Jualles berl $\Lambda$ bi Nuar, 556

- Juanes de Almazin, 658.

-- Juanes ben Assafar, 949 , 950,955

- Juantes ber Asayad, 954.

- Suanos, hijo de Marquesa, 1.026

- hijo do Juan Fernoxndez de Pantoja, 921.

- Juanes el Freire 737

- Juanes el Polichent, 390.

- Juanes de Valverde, racio. nero, 180,712

- Lazaro, 166 .

- López : $88,4151,470,558$.

- hijo de Naria, 120,677 .

- Martin, alcalde, $221,715$.

-- lijo de Juan Jemández, 8302

- lijo de Martin Petre\% 152.

- Martín ez, 194, 1.065.

- Martinez de Escarchir, 21\%.

- Mateos ben Iírón, alcalde, $5 \%, 87,1 \%, 195,220,225$, $232,212,275,647,650,055$ $657,664,671,674,692$, $829,901,989,1.031,1.045$ 1.064.

- Micaelis, 252, 496, 560 .
Fernando ben Micael hen Alclı́tir, 1.J.17.

- hijo de Nicael Julianes, 1.014.

- Len Micael Sabil, 749, 845, 816 .

- Mitis 27.

- Muñoz, leo, $9,1.099$.

-- el Nahás, 409, 419, 440 .

- Nical el Vinatcro, 340.

- hijo de Pedro drmildez 481, 143.

lijo de Pedro Góntez Gran sa? 873 .

- hijo de Pedro Juanes, 782 , 1.025 .

-- hijo de Prdro el Polichond, 749.

- Pelisez, 198, 240, 287, 887. $306,449,529$.

- Petroz, 6i3, 71, 8\%, 194, 2u, $268,282,240,308,466,467$, $469,582,586,608,613,658$, $692,694,752,965,1.047$, 1.083.

- Petrez, alendde, 28f. Petrez, racionero, 150,719 $720,721,722,1.120$

- Petroz A sacaz, 698, 701

- Petrez el Bolstro, lst, 197 19.1, 212, 210, 1083.

- Petroz, hijo do Eva, 1:5

- Padre el carpintero, hijo de Jimena, 257, 723

- I'etrez el Macstio, 1.043.

- Petrez ben coba? 992

- Petrez I'once, 185, 710 Petrez el Porlugales, 60 , $193,716,859,861,932$.

- hijo de Rrajmundo de Zara gowa, 380 bis.

- \&e Roljredillo, s.s. 1.113.

- Roderici, Ititi

Ruiz, $18 \%, 196,19 \%, 199,267$ $212,210,218,248,702,1.034$

- ben Ruiz Domínguez, 1.165.

- Sendino, 453.

- Servando, 589

- hijo de Servando ben chá bir, 704, 717

- ben Servendo ben Félix ben Mahchún, 1.165, 1.169 , 1.173.

- ben Servando ben Lazaro. $1.165,1.169$

- SSetiel?, hijo de IIasán Aben Cadur, 799.

- Vélez, 114.

- Vicente, 72, $22 \%, 656,686$, $1.024,1.034,1.046$.

-- Vicente el Zapatero, 715, $870,890,891,892$.
Feruando el Vinatero, 474

- el Zapatero, 1.009.

lermandus ('oncylyez, 581 .

- Iornnjs, 199, 228, 291, 315, $316,383,340,395,436,742$, $746,752,755,809,951$.

- Micrel, 296.

- Micales, 496, $1.027,1.154$

- Muniu, 11.

Ferotin, 14 .

Ferrán Martíne?, pregonero, 2): 964

- I’êrez, 96:

Ferrand Juaues, $\% \%, 7 \%$.

-- Mligael, 138.

- Peti, 1.15:?.

- Raiz. 8?

Jerreruela, ledro Ruiz de 608 .

Fidalgo, El, Iri, 924.

-- Martín, hijo de Jlitun, 776 .

Figuera, Micaed re la, 743 .

lihri, 15:

Filiola, 976, 1.015

Fita, P., sist.

Blaxa, Guillermo de, $t f 1$

Frlorencia, 139

Focem el Bracadon, 11:

Fomcta, luja de Raimundo el (iasco, 1f1.

fontelmasl, Garci Letrez de, $50 \%$.

Formosa, Doitt, 228

\{kiornillos?, Ruy Petrez de, 490 .

Forsan, Micael, presbitero, 1.129.

Forteda, Juan de, 673

Fortie, Martin litiz, 1.085.

Forto, canonigo, 179, 10\%, 155, su1.

Fortunio el lorncro, $5 \mathrm{~B} 0$

Fotús, 1,030

- Mohámed Nlehauhar, sia", 866

Fradet, J, 166

Francisca Petrez, 717

F'raneo, Don, 14t,

-. Fsteban, 111 .

- Fray, Don, 808

- - alfarcro, 850

- Garcia, 608.

Francos, Cotradia de los, 61, $6 \%, 1 \% 1,12 \%, 140,960$.

Fredenandus Didaz, comes, $15 \%$.

- Menindez, $15 \%$.

- Petriz, 15\%.

JProln?, $1.02 \%$.

Froila Didaz, comes, $15 \%$

l'rómista, Pelayo de, 112,904.

- Pelayo Potrez de, 734, 1.037.

Fuente, Vicente de la, 69 
Fuente de la Encina, Rlancat de, 1.003 .

Fuirol, Musa ben, LHf.

Funes, Mariln Ruiz de, 675 .

- Pedro Sánchez de, 678, 6rs.

-- Rodrigo de, 471 .

Furón, IIosain ben, 339, 923 .

- Antolin ben Pedro ben, $989,1.013,1.030,1.031$.

- Martin, 508

- Mateo Miguélez bev, 503.

- Pedro, 980.

- Scbastikin ben, 973 .

G., arediano, $1 \pi 6,1 \% \pi, 36 \%$, 821 .

G., secobiensis episcopus, $63 \%$.

G., toletanus thesaurarius, 481 .

(4. Joluanis, canonicus, Jis, 400 .

G. Tetri, 309 .

G. de Seco!ia, 466 .

Gabi, Judá ben Joel bes cl, Lifis.

Gabriel Pctre\%, 225, 961), (195.

Gaiter, Micael, 560.

dGalia?, Irobcrto de la, lit.

Craliana, doña, $67,320,373$.

- hija de Domingo Durán, 306 .

Gálib, Don, 726 .

- el Albeitar, 826.

- Almogavar, 1.157 .

- Assanmar, 72, 673, (3\$5, 939.

- el Belianí, 106.

- ben Said el Cauilli, 281.

Gálíb el Suff, 64, 380 .

- ben Suloimán, 281.

Galindo Petrez, racionero, 180, $682,087,1.000$.

- 1)omingo, 500 .

Galiolo, 783 .

Gailegos, 121 .

Galleguilos, Ruy Ciarcía do, 1.119.

Galter, auastro, 166 .

Garbi, Juan Micael el, 582 .

Garei Ferrández, 54.

- Martinez, alcalde, $14,2,22$, 628,824 .

Garcia, Don, $2,53,68,126,171$, $191,209,462,608,791,849$, 1.084 .

- arcediano, $89,223,237,245$, $250,271,292,313,326,909$ s 948.

- Alfonso, 682, 696.

-..- Alvarez, 120, 168, 825, 1.030.

- Arbeión, 166.

- arciureste de Maqueda, 176 .

- cl Arquero, 548,608, 952 .
Garcit Jiallestern, tit.

- tilius Barragin, 1.112.

-- de Botonid, plestitero, 193, $24,608$.

Botero, itj.

- Camarón, de Camareia, 77, 158, $18 \%$, $291,323$.

- canonigo, tit, $10 \%, 1.104$.

- capellanus, !66.

- el Ciego, 22\%.

- Diaz, arcediano, Viri, 266, 1.1115.

- Domingue\%, 206,654 .

- do D. Chodel, 19!).

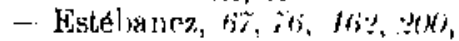
25: $267,717,1.157$.

Estébanez, aroediano, ti6, $211,426,4413,1.05 ! 3$.

Esleban $A$ xxaric, 801.

Estébanaz, tesorero, 1rt, $365,806,36 \div, 868,899,881$. $414,9 \mathrm{sin}$

- Estédunez, vicario, $1 \%, 68 \pi$, $(388,689), 693,695,696,697$, 699, 700,705, 706, 1.086, 1.088.

- Fermandcz, Irt, 2:31, 387, 596, 991.

- Franco, 6988.

- Gómet, 657 .

- Gomzálbez, 65, 33:1\%, 435, 709, $871,872,874,874$ bis, 875 , 875 bis, $876,877,878,879$, $830,881,882,883,885,889$, $1.090,1.091,1.092$.

Giuillelmo, 836, 1.104.

-- Guillén, comendador, $2(x$, :286, 837, 917, 987 .

- (ruillén, canónigo, tiv.

- Cruliérrez, 498.

- ol Jach, 217, 171.

Hanes, 25s, 292.

- de lllescus, 684 .

-. Johtannes, 153.

- filio de Juhan Ciareín el Corro, 74 .

- lijo de Juan I'clrez el Cralirgo, 818.

- Juanes, alealde, \%ry, 220, $262,275,421,484,488,554$, $504,591,611,672,702,707$, $85 \hbar, 947,991,1.0301,168$, $1.169,1.172$.

- Juanes, canonigo, $1 N(0,635$.

- Juanes ben Albacal, 824 .

- Juanes do Alcana, $155,1.173$.

- Lijo kle Julián Mieselis, 799.

-. Elazarenos?, 824, 1.045. Lopez, 1.0is.

- Martin, titi, zisi, 709 .

- Martin ben el hchaub, 962.
Garcia, hijo de Martín Gonzal. bez, $91 \%$

- hijo de Martín... el Háquim, 693.

-- Martín de Maqueda, 647.

- Martincz, 105, $\$ 62,507,556$, $669,710,824,1.169,1.173$.

- Murtincz el dMacareno?, (56\%.

- Murtine\% do Maqueda, 692, $60 \mathrm{~s}$.

- hermano do D. Mateos, 478.

- mayordomo, 930 .

- Melenilez, 75, 23t, 605, 619, $629,710,965$

- el Mellizo?, 88.

Munoz, Jis, 18.

Muño\% arcediono, fr7, 212, (itis, 648 .

- Navarm, 208.

- obispo, ti, f7o, 174, 211, 217, $2 \pi 1,476,488,758,1.023$.

-- Ordóné, 101, 210, 1.121.

- hijn de Pedro Garcta, 87, 6.5.

- Jijo do Pedro, bijo de Vi. cente de Bargas, 842 .

- Pérez de Iargas, 66.

-- Letrez, notario, $62,74,75$, IN9, 223, 252, 287, 105, 106, $261,591,594,596,605,624$, $688,689,696,821,921,990$, $1.047,1.115$.

- Petrez de fliontelmasi?, 231.

- Petrez, hijo de Illán Petrez de Bargas, 663 .

- de la KReina, Jon, 168.

_. Rodrignez, alcalde, 220 , $29)$

- Rodriguez, hijo de Rodrigo Dominguez, algtaecjl, 1.131.

-. Ruiz, 95, 658, 602, 693, 041. liujz, obispo, $181,446$.

-- Sanche\%, canonigo, 179,642 , ys1.

- Sancho, 64.

- hijo de Sancho Petraz do Tarazona, 781 .

- Suarea, 632.

- Stevatro, 406.

-- Temam, $284,967$.

- hijo de Ulreca Ruiz, 712.

- Villada, Z, 44.

- Ximenunes, 120 .

Garsias Ordoniz, comer, $t z \%$.

Garrina, 375.

Gasca, Pedro de la, 141.

$\rightarrow$ Domingo de $\mathrm{la}, 141$.

Gasco, El, It, 141, 171.

Gasiona, I) ina, 559.

Guston, $1,1, y 2$.

Gastona, $54,141$. 
Gato, Salomón ben Isaac ben, 147.

Gaudio, 58, 61.

Gruzelmus de Azeka, 966 .

Gayangos, Pascual, 6 .

Gayat, R. Jacob ben, 147 .

Gazí, Yásef el, 934.

Geli, 13i.

Geloira, infanta, $6 \%$.

Genés, Don, arcodiano, Ititi.

Geraldo Odebaz, 504.

Geraldus, 95.

(ierbanus, presbitero, 360 .

Geroncs, Don, 166 .

Gesión, Don, urestuitero, 61 , 69.

Gil, Don, 197, 210, 226, 239 , $230,738,768,820$.

- arcediuno, 164,181 .

el Bollutero, 963

- comendedor de Ocaña, 14.

-.. Jiaz, 1.028 .

l'ernándes, 453 .

- Garcia, 55, 179, 603, 915.

- Garcia, racionero, $180,18.4$ 548,558 .

- Garcia, vicario, $/ 77,997$, $1.063,1.111$.

- Martince, $L 98,810,811,812$.

- de Miraglo, 488 .

- Pérez, 44, 645.

- Pérez, alcalde, 922, 628.

- Rodrigue\%, 452 .

.. Ruiz, rucionero, 180,582 , 1.106.

-al Tejedor, 5 fi3.

Gilabert, 490.

Gilborto, Don, 295.

Gilibertus, 490.

Gónés, presbitero, 228.

Giraldo el corvin, 141 .

- re dGirati? 141 .

Giralius, serivann, 92, 242.

Giz: 134

Godad, Julian el, 681, 709.

Gorled $7 \%$.

( Godiel, Don, t65.

Godina Fortumi\%, 924, 925.

Grodino, hijo de Pelayo Godi$11 \%, 380$ bis (d).

Golialmut e] Franco, is.

-... hijo de (rolus, $14 i$.

Golpejares, Micalde, 668, 678, 670.

Gomez, Don, 164, 1999.

- episcopus, $15 \%$.

- hijo de ¿Alcarraz?, 689.

-. de Almoguera, 165.

- Cerrabn, Don, 64.

- Gonzalbez, $\% 7,525,623$.

-..- Juanes, $190,921$.

- Martíniz, 180 .
Gómez Ordonez, 561

- Petrez, $8: 2,2$.

Gondisalbus, archidiacomus, 141.

- Ferrandi, 274.

- Tohanis, 829 .

- Petri, 274.

Gonzalbo, 185, 2::3, 114, 271, 354, $285,835,500,569,581$, $630,643,646,661,660,942$.

- freir ${ }^{2}, 575,600,603$.

- arcerliano, $f t f^{\prime}, 226,121$, 141.

-.- arejpreste do Mladrid, areediano, 176 .

-- arzubispo, $71,90,302,581$.

- el Niguacil, $33,482,750$ 906.

- alcalde, 220 .

- Alfonso, $\%$, (690) 724, 725, $830,831,832,996,937,938$.

- Alvarez, 647, 650, 657, 658 , $665,1.116$

Antirés, 411.

-.. Ansuriz, 120 .

- Asueriz, $45 \bar{i}$

Bono, 678, 864, 1.124.

-.. de Burgos, 1.090 .

- ol Calero, 1.119.

. el Campanero, 13

-. canónigo, $/ 8 \%$ ).

- Cansado, 231.

capiscol, 991.

- de Carmena, lit.

- el Carnicero, 928. el rcojo?, 1.030.

-- rle ('nevas, 958

- Ditz, 8i, 210, 28i, 590, 1.028, $1.041,1.078,1.125,1.12 \mathrm{~h}$, 1.127 .

.... Dirz; alcalde, $221,964,1.087$. ben Domingo ben Juan, 182.

-- hijo de Domingo Juanes, 689,952 .

- hijo del presbitero Domin. go ben Martín Suleimán, $66 ?, 667$.

- Donínguez, 18:4, 184, $19 \%$ $553,579,6(x), 673,958$ 1.635, 1.160 .

- Fstebanez, 73, $826,839,395$, $584,702,755,985$.

- Hacindez, alguacil, 242, $419,410,474$

- Fornendez, 267, $7,9,81,404$, $453,486,550,816$.

- Fernander, canónigo, 179, 530.548.

-- Fernández, racionero, 180.

- Garcia, 73, 16\%, 231, 710, $825,932,1.115$.
Conzalbo, hijo de Garcia, hijo de Pedro Alvarez, 914.

Gil, $186,16 \%, 159,15 \%, 195$, $196,205,206,211,211,216$, $476,590,1.028$.

- Gonzálbez, 457, 748,906.

- Gouzḱlbez Comeno, 590.

- ben Gudiel, arzobispo, $17 \%$.

- Gulierrez, 66, 261, 490, 663), $726,823,983,1.115$.

- Gratierrez, obispo, 181, 300

- Cutierrez de Amaya, 510.

- Jiménez, presuítero, 1.045.

- Juanes, 45, 52, 55, 63, 70, $72, \quad 7 \%, 163,165,267,211$ $224,275,281,329,458,483$, $524,533,563,564,647,658$, $684,657,946,9.17,963,989$, $1.029,1.030$.

- hijo de Juanes, 257.

- Juanes, alcalde, $\$ 1,306$, $95,602,619,701,716,839$, $908,958,960,1.044$.

- Juanes, eanónigo, 476.

- Juanes, obispo, 1S1, 1.083, 1.106.

- ben Juan Abril, 963.

- Juanes de Albacal, 650,657. 658.

- hijo de Juan Cebrianea, 1114.

- Juanes ben Daxdel, 70,579 , 672.

ben Juan Dominguez, 818 . hijo de Juan Felices, 753, 766.

- Juanes ben Martín, 624 .

-- hijo de Juan, hijo de Mar. tin Suleimán, 662, 667.

- ben Juan Martínez, 1.154. hijo de Juan el Melejo, 528 , 539.

- yerno de Juan el Melero, 478.

- hijo de Juan Velázque?, 368.

Juanes, hijo de Pedro Chobuis, 556 .

- Juanes Ponce, 825.

- hijo de I orenzo Esteban, 701.

- hijo de Lorenzo, hijo de Es. teban ben Salomón, abogado, 959 .

- de Mo..., 1.058.

- Martin, presbítero, 270, 710.

- ben Martín Alvarez, 805.

- Martín el Herrero, 835.

- hijo de Martín Petrez, 622, 649.

- Mirtinez, 264.

- Meléndez, 683 
Gonzaliso el delero?, de Oliss, $549,58 \pi$.

- yerno del Mlelero, \$14.

- hijo de Micael ber $A$ billa. sán h?̣ Alluazo, 10\%, 12\%, 280.

-- hijo de Micael, hijo del caid Sabib, 466, 469 .

- ben Micad Vicente, son.

- el Molinero, 6\$, 282.

-- Núñez, 500.

- Pchiez, 210, 256, 446, 1.125, $1.126,1.127$.

- Pérez de Sante Cruz, 110 .

- Petrez, 7t, 73, 80, 199, 24n, $223,25 \%, 268,286,61,149$, $240,285,287,292,293,308$, $331,363,886,+28,435,527$, $580,623,741,979,1.056$. 1.1.27.

- Petrez, alsad, $1 \times 2$, ri:s.

- Petrez, alcalde, $2 \% l, 690$.

- F'etrez, arcediano, $17 \%, 090$.

- Petre $\%$, arzobispo, 59, ltz, 174, 175, 209, 282, 287, 712, 716, 859, 908, 1.047.

- Petre\%, campanero, $186,606$.

- Petrez, diacono, 175, 782.

- Petrez, obispo, 181, 639, 644.

- Petrez ben Abdelmélic, 286 , $574,604,641,657,1.112$, 1.118 .

- Petrez de Areicolla, 254.

- Petrez Asacaz, 66, 54\%.

- Petrez de fBorac?, 574, 956 .

- hijo de Pedro Crespo, 331 .

- hijo de Pedro Juanes, 748.

-. hijo de Pedro Garcés, 27 .

- Petrez ben Labib, 437.

- hijo de Pedro Gonzálbe, 406 .

- Petrez de l'orquemada, 231 , 493.

- Petri, 102, 246, 927.

- el Racionero, 302.

- Ruchiso el Bellutero, 60, $142,163,187,215,239,677$ 963

- Rodrigo, 690.

- Ruiz, alguacil y alcalde. 71 , $20 t, 212,215,221,446,501$, $537,558,570,619,658,668$, $674,692,693,1.034$.

- hijo de Ruy Gonzálbez, 1.116.

- el Segoviano, 468.

- Serdimo, 269, 1S8, 190,743, 980 .

- Sebastián, 444.

- el Sevillano, 534.

- hijo del Sevillano, 545, 1.161.
Gonzalbo ben Simón, 19:3.

- Sitephaniz, 120 .

- el l'abrutro, hijo de riómez, 606 .

-. hijo le Teresa, 1.03\%.

- de Lecda, tb?.

- Vicente, 65, 2ise, 2fot 149, $1,07 \mathrm{l}$.

- Vicente, aleakle, $2 \% 1,540$, 725.

- Vicente ben Otmán ben Arrim, alguacil $\mathrm{y}$ alcalde, $221,819,821$.

- Vicerste, caicl, $500,7 \cdot 16$.

- ben Vicento lien Juluch, a]cenide, 22\%, 525, 613, 6228, 1.062 .

-- Vicente ben Samaj, 853 .

- Xemenez, sis.

- el Zapatero, 603.

-. el Zapatero, hijo rle [tomin. go, hijo dia Juan el sinvillano, $1.107,1.110$

Gonzaluo, 733.

Gonçaluo Peláe, 1.126.

Gonzalro y Paris, Luis, i.

Gonzalez Vegue, Adolfo, 10.

Gorairo, 235.

Gordel, Dominga, hija de Juan, 1.074 .

Gosahel, Doña, 328, 487, 006.

.. Downinguez, 1.034.

hija de J arareno, 1.180 .

- murja, ton.

... Lija do Jedro Esteban, 754.

... hija de siets, 1.020 .

Gosabela, hija de Tediro Gui. léen, 628 .

Gosbel, Don. 1.045.

(iracia, Dona, 624, Bint), 701, 1.173.

- capiscola, 19i.

- Rstehan, priora, 195, $19 t$, $664,669,1,030$.

- Cionzálber. 825 .

- hija de Juan Leonardo, 590. hija de Juana, 1.043.

- Martinez, 586.

- hija de Micael Juljén ben Cosuch, 672.

- Muñoz, 631.

- Petrez, 196, 282, 1.173.

... Muiz, 770 .

Graciana, 98.

Graetz, 142.

Grangdino, Yajx el Sastre ben Ahmed el, 793.

Guadiexí, Pedro J nanes el, $6 \%$. $576,591,654,656,686,679$, 698,701 .

- bijo del, 1.018.

Guadijeño, El, escribano, 962.
Guadijeño, J3en (Tar'ún, 63, 342.

stide), Jon, 142, 27, 407, 665

- Alfonso, 692, 6913, 1.140.

Guedalia ben Abraham ben Alsabi, $74 t, 15 t)$.

Gueto, Abuilasin salomón ben, 615

- Yisuf bem An usa ben, 147 .

Guiat, Clomilat, hija de José ben, $14 \%$

Guilemus de Secolvia, 400 .

Guillelmus..... inis.

- Bernaldi, :3is.

- sancti Thromi, rapeltanus, 251.

Guillemus, presititer, 417 .

Guillem, preshitero, 250, 169 , $837,1.094$

- mestro, canónigo, $f 79,586$, $610,616,642,779,781,844$, 1.1) 80 .

- jreboste, 161, 17\%, 206, 215.

- Arraldo, 45, 604.

-- de Baeza, 291.

- de Bareplona, 576

- Boitaneiro, 4111.

-- de dChehra?, $62 \%$.

- de Cormiles, 77.

-... hijo de listeban, $\mathbf{5 8 0}$.

- I'etrez de Segovia, 267.

- I'jtevin, 558.

- Repostero, lifi, 24\%.

- Repostero, canónigo, lis, $180,22 \%, 420,517,526,529$, 5.81), 557, 595, 616, 778, 779, $860,914,960$.

Guij]én, Don, $54,181,239,27 \%$, TT. 462 .

-- Sánche\%, !s!.

-... de Srgovia, canonigo, 5̃. Lat, 538, 548, 1.063, 1.111.

(iuillerma, de lobexa, 234.

Guillemo, s8, 198,323 .

- rajellán, $178,121,168,078$.

- de lialaguer, $1.07 \%$. Jaro, 75 .

-de Montpellier, $2: 31$.

- Narbonense, jis.

- I'ctrez, 69 .

- Pitevin, 55, 819, 821.

-- liuta Chivo, $6 \pi$.

- he Socala, 181 .

Guiomar, 66, 645 .

Guiralda, Duna, 1.101.

Gundisalvo, arcediano, 176 .

Guntisalvus, 382 .

- toletanus archidiaconus. $302,300,98,1.041,1.126$.

- 1)idaci, 309 .

- Iohamnis, 524, 533, 1.168.

- Melendi, $\$ 66$. 
Gundisalvus menduniensis episcopus, tis.

…. Pérez, 541.

-.. P'etri, 1.155.

J'etriz Abdilmele, 1.112

- porcionarius, 313 .

- Roderici, 537

-- Stephanis, 750 .

Gunsalvus Nunjz, list.

(i nodo, Don, 1.015.

Guter, caid, 2ar.

- Dol, 768 .

subdiácono, racionero tle ] catedral, 1.115.

-... Arvilde $, 610,702$.

... el CCarretero?, 1.04:1.

.... Domingue $\%, 66,54$, tits, $576,580,600,672,684,700$. liernández, $64,817,1.164$.

- Fernóndez, alcalde, $22(1,511$, $5,2,663,793,826,922,960$, $488,1.043,1.115$.

- Ciarcia, ti3.

- híja de Garcja llein, de $A$ somail, $829,1.114$.

-- Gonzálbez, j4, 726.

- hijo de Gonzalbo Petrez, de Borac, $604,1.118$.

- Gutjerre\% die dllasebes?, 510.

- ben Micasl Jumes ben Meltlom?, !) Pedrex, 107

-.- Petrez de Reinoso, sis.

-- Rodrigue\%, $10 \%$

el Kapatcro, hijo rle Julián Petrez, 1.11s.

Guterins Dominiques, reclesie Toletane socius, 575 .

Gutier Bermudiz, f:o

- D)inz, $.6 \%$.

Ferrandiz, 1\%to.

Gutierre J)Ia\%, (Ii).

-Domíngues, racioncro, 150 , 5.36, 510,552

- Fernánde\%, alguacjl, 8158, 910

-. Gomez, arzobispo, fi, $26 \mathrm{i}$, (5)

-- Ruiz, 1.10)i.

-- hijo de Yela, 958

Hachana, Jien, 24

Halsils, 7almedina, 4.)

¿Hacallot. Fugenia, hija dle, 1.096.

Ifreay b: 17 Jambon, $75,1.8 \%$.

Hecer, Doña, 244.

Hacén Luenfaxax el Arráez 3 .

Hacohen, Ifis.

Hacri, Juan e], 645.

Hadasa, hija de Odra, 1.9.
Fadida, losef ben I? Ibraham ben, $1 / \%$.

Harami, di], $1: x^{2}$

- Juan el ... ben said, dfa.

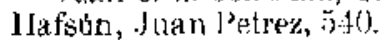

- Prdro, $4 i \mathrm{i}, 501,58 \pi$.

Itaim ben $\mathrm{Abrahom,} 1.1$. ben Nbraham ben I eir, 148 .

- Almerini, 7 s.

... AnIol)agner:, th. ben Jilroi, 75

-.. lsen Isaat ben igagmarech?, $1.1+5$.

luen Mlosé, 148.

- ben l'acnda, li, Jis.

ben Sason lien Wisui, 1.137.

IItir ben 'lalit, s.f.

Ilalaf, t:10.

Halevi, $6 \%$

laluzo, Isaac Paxilo, conocilo jor, 117.

Hamán el ibañil, $4 f \%$

Hamduch Assoca, 1,030,

dlamoro", J)omingo, 1096.

İanis, Juan Domingue, hijo de, 497.

IIanna, Don, J66t.

Hâquim ben Said, 16.

Haxiri, : $:$ itl.

llarits, Jarits Yebudá ben, fir,

Haruz, Jsmail Aharuz lem Ibralim el, th.

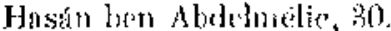

- hen Irrachel, Don, $1: 3$.

leen rárech, żest.

- lien fiarech ben Islade el Arrác\%, 434, 485. ben Ibration el carnicero, 219, , ins.

- ben liffía, 171.

llashones, Li. Islae ben Mi ben k. Hiya ben, thr.

lusda bon Turied, fis.

Glascbes?, ( i ulfer (iutierrea de 510.

Hastiol, Marlin, Els.

Halui, Jit, 496 .

Hayali, Jis.

Hayati al Dacac, $1 \mathrm{ft}$.

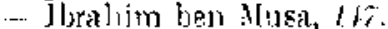

-... Jacoluo ben Ibrahim, $t f i$.

dityons. Josct ben Nosé ben, lii.

Haytil, Janeblen bel, $a n$

GHathehol?, $\Delta$ ben, 325 .

Hibil Micaed, 45 .

Hedido, Juan do öus.

Heline, Itid:

Herbert, lit.

Herlio, 1il.

Herbolario, 100. licnricus, portugalensis co mes, 11 s.

Hevira, Iominico, filio de, 71.

Heameel dbenmuciella, 167

Hiahia Iolunnis, so

Hicai el judio, 16\%.

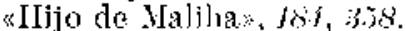

Hilali, bijaz de Ahes Iroman, 12.

Hill, (T, 1., 4t.

Hinkl, $28 ;.$

hija de Ablerráhmea ben Mohámed, 1.09.1.

- hija de Cebrian, ont.

Hind, hija do dbulcrálumen ben ILamel, 168

Hobais, I'ed ro, 428, 524, 528 .

Hobi, lija de Josef ben „̧Baraiel?, $44 \%$

Homar, fil do Iahle, itis.

Horabona, 11\%.

hija do Domingo lolacz, 135.

-... priora, $807,80$.

Josain ben Amir, Job, $1 \% 5$, 221,361 .

- ben Cadur, 799.

- ben livón, boo.

ben Gasan, 1.153

- ben Vicael, 36.

ben Micael hen l3aqqui, 24.

Huber, l. 1 .

Huesca, Marlin de, (ji)4.

l. Iugo, maesiro, $l 0 \%$.

Jumboldt, do

I., precentor, 309

1., tholetanus archiepiscopus, 974.

Jacobue, presiliter, $43 \mathrm{~s}, 773$.

Ibrahím ben Abuharun, $14 \pi$.

- ben Alupibrahim el Lebli, $2 \times 2,497$.

- ben Assaliats, fiso.

- Istrac ben Abuibrahim Ismail ben Malcun, 846 .

- ben Ishac Algualid $\Leftrightarrow 1 \mathrm{~J} \imath$. dio, $14 \mathrm{r}, 20 \mathrm{l}$

ben Ismail el Valenciano, $80 \mathrm{~s}$

- el Tuerto, el cojo, 1:3.

Illán, [lon, $/ 3 ;, 559,943$.

- Abenbarragáll, (6.).

- el Alcalde, $11 t, 60,709$.

hijo de Abderrálimen, 78 .

- Algazi, 729.

- hijo de Andrés, 7t. de Cambrillos, 1.020

- el Cleriga, Don, Iti.

- Fsteban, ajguacil, $\$ 2,28 \%$. $353,309,322$. 
Illán, hijo do Estoban, 1 to.

-.- Estéban $\%, 926,92 \%$.

- Fstébane\%, alcalde, 2:or, $920,946,98 \%$. bru Jatab: alguacil alhá. quim, s21.

- Petrez, 59, 83, 286,540 .

... I'tres, alealde, 21\%, 182.

- I trez de sBoae:, osi.

- hen sid, 25?.

- el \%anatero, Don. Ití.

Iflara, Dnna, 559, 72\%

- hija de Cebrian al Bacill, (5) $65,69$.

lliescas, Don Espartin de, 509.

- Raimando Guillén el Gas. co. de, 156,346 .

Imrún, alcalde, 2/9, 140 .

Inés, Doña, 663, 812, 992 .

- Alfonso, $75,205,605,702$, 726 .

... hija de Altinso Vicente, 784.

- hija de Inomingo Iiamos, 636 .

-.- Domingucz, 640, 661,666

- Fernández, 1.140

- Ciarcia, 702, 710, 991.

-... hija de Ordoño Petrez, 767.

- hija do Pedro Juanes, 71 , 12t, $609,834,95 \%$

- Petrez, 28\%, $1.04 \%$

Instituto geografico, \$3.

Iñigo, hijo dó Gonzalbo Cadi. no, 448.

Lopez, g1.

bijo de Mengo, 646 .

Jitguez, 24.

Ioan Barloaroia, 39

Iodunes, abad, $472,898$.

- clérigon, 34, 103, 100, 172, $262,262,343,362,378,359$, 399, 406, 513, $735,823,948$, $969,972,974,1.012$.

- Allare\%, 248.

- Barba, 898. - de Brioga, canunieis, 274.

-. de Campania, 393.

- Celeme, 166.

Ciprjani, 751.

- Dominiej, 11 $\bar{i}, 35 \%, 381,575$, (50) $607,1.058$.

- Jcruandi, 521,775, 845 .

- Gonzalvo, 74.

- iben Gribdirrehmen, 19,974 .

- Cohannis, 1.015.

-..- luliant, presbiter, 390 .

- Laurencii, presbiter, 156. 472. Jourencius, 948 .

- Marcos, 837.

- Martinis, 33\%, 393, 751.
Ioammes Martino, 7.t, 1.121 .

-- Malondiz, probjter, 172.

- Micani, $\$ 1.127$.

Orrlorit, 22, it.

- Pascasius, 92

- Petri, 40, 70, 360, 750, 760. Petris, 84 .

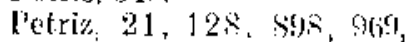
1.0108 .

Ponz, 748, 54:

- Riminiziz, Rer

- lis Pomma, diacomus, 400. sacrista, 141, 142, 255, this.

-. Sobrini, 10.5.

- ritefani, prenbitc, 1.7., 30 . $367,414,536,1.080$

Ithanmes. Yilde Itammes.

Irafi, El, :'ild.

Iraquí, in, 17.

Immando, presbitaro, 119.

Lsa ben Abulaas, 434 .

bbor Aldono?, 1?

- hijo de Micaei Miair, presbitelo, 1.09\%.

Istac ben Abraham ben CardiBal, If:5.

- ben jacula, 7j, 14.5.

ben Daniel Alascliel, J.t.

- ben Fleazar Albaná ben /abara, lat.

ben cleazar ben Faquirol, 1.1 .16 .

- ben Eleazar ben Zabara, 234 .

- Malevi ben Meir ben d $\mathrm{Mi}$. gas?, 118

-. ben Haquim hen Haquim, II:. ben flayon? lft.

- ben Hiyia ber Hachbonus? Lit.

- ben Israel Hasofor, 1 is

-. ben Isaac el Cambisia 1 ,

- ben Jacob ben Reubén, tho.

-- lien Josef ben Abu Josef, 1)1.

- - ben Mosé, Hz ben Mosé ben Namán, 1.4.

- ben Naamán, 145 . ben I'odeneo, $; 5,1.143$ ben Salomón ben Dogdi, lifi:

- ben Samuti Aben Casi, 14 . lien Simeon ben Tols, $1 ; \pi$.

--- ben [Yusef] ben susán, Liso. ben Tizá, 7t.

Isabel, 55, 1.062.

- Dominguez, 378.

-- (rutiérez, abadesa, 196 , 1.173

Ishac, tbu, lien Asabag, If\%.
Sshac ben Alaftas, 111 .

- ben Abiyúsel, 897.

hijo de Alehálir, sist.

- Ali ben R. IJiya bon Hasbones, Rubl, 648 .

- de Aullijar, zos

- eAnlobaguer, 14.

-. Anq lissalt, $76,14 i$.

- ben Axar al Bareelomis, 1.t5.

ben Llcazar ben Iruquirol Ii.. $/ f / i$. ben tiveto, 14\%

- ben dbrahim ben Habib, J\%. it Judio, is

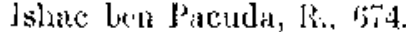

- ben li. Yusst, liabi, ili,

- ben \%iza bin Abiyusef, 151 .

Isichro Jautent, 101,65

Ismail, $1+18$.

- ben Ibrahim, hijo del Va. lenciano, 193.

- ben d,ope el judío, $1 . \$ 8$.

- ben Yahva ben Bahlul 1.j.

- bon Yúsef ben Sarjaj, Lon.

Israel, Israel ben lshac ben, 145.

- Isa ben Ishac ben, 118 .

.... Ishac ben Yusuf ben, tfs

- ben K. Isaac, $1 . f \%$.

- Ishac ben, J4s.

Israeli, 148

Ithannis de Sancti Juhannis, 1.072 .

lulian, 118.

-..- Bicens, 3088 .

- Domingiz, 737 .

-- jben lay:ar, 173.

Martiniz, 135.

- Vicent. 220.

Iuliani ben BahluI, S:

Iulianis ben Cida, 118.

- ilsen Lazar, 176 .

- Petri, Cilius, giti.

Iusta, 249

Instus, presbiter, $227,245,729$,

$\mathrm{J} z z \mathrm{i}, 960$.

J., decanns, 2 ri 4 .

J, Dominici, canonicus, 823 .

J. Guillén, 171 .

I. Guteriz, 108

J., magister scholarum, $S 01$, 1.126

J. Mfartin, Mr.

J. Nicholas, l6ti.

i. percentor: 101,274

J. Perez, 169)

J. de Sephila, canonicus, 320

Jacol, Don, 482 .

... ben Alsuhán, 14i, 150

- Alfolue, $1 \%$.

. e] Jarceloniss, 1R, 115, 22\%. 
Jacob, hijo de Domingo Salvador, 1.153

- Domingue $\%$ i.j4.

- Hahazan ben Ieaac ben lialcon, 146 .

- Habazán ben Iearat d'alat?, 1.137 .

- ben Isaac d dlbatel? 14.).

- ben Isaac ben Sulbatje], 1.137 .

- ben Jncob, 15\%.

- ben Josef hela Abu .Josef, th1.

- ben ג. Vahchin? ben Falcó, 146

- ben Sudaya, $7 \bar{z}_{1}, 5 / 3$

- ben Salomon, forl.

- ben Samuel el Chan u\%i. $1.138,1.139$

Jacolus, 170

Jair, amin, 晶 02 .

- maior, $13 \%$.

-.. el Arquero, 310

- ben Paris, \&4, 1.006.

- hijo de Richel, 102.

- bon ¿Rocni?, $1 \%$,

- bon salomón ben kli, $t 7$ 360 , วิنे $1,941$.

- ben Suleimán, 328

Jálaf ben $\lambda$ lsłalá, 2 .

- ben Arramac ol Judio, 1.4.

-.. ben Ghuad, 3

- ben lijec, 940

- bon Suletmál el P'olichentí, 972 .

Jalid Moro, fis

- ben Suloiman, $129,360,941$.

Jam

- alcalde, 221, 6552.

- hijo de P'edro Armaldo, yto

Jaques Goverez, 2Lit.

Jaracia, Hoos Halevi ben Haim Halevi ben, 148 .

Jarajchi, Alfonso, :514.

Jatim, $x / \%$

-- ben . Jálim, 76: 73.

Jázin, Don, 225.

- almotacéti, 153

Jeliosef IIalevi ben Samuel Ha lovi, $1 . t \%$

Jimen Garcia, 821, 492, 1.028 .

Jimenu, 345, 1.001.

- hija de Fermando el Carmadi, 913 .

- hija de Martin, 121.

- Rodrignez, 11.

Jimeno, arcipresle, 298, 322 347 , 355 .

- Gareía, 590.

- Juanes, 239.

Joan de Aragoin, $17 /$

- Zapatero, tít.
Joanmes, seriptor, 223.

Jofle, Arrorávicle, 75.

- de Canales doto, 210, 161

- Martin, $50:$

-..- de Segovia, $I T$.

Jolkan Día, 164.

- Itlan, $16 \%$.

- maestro, 1ji.

- Meldén, gr.

- Perez, IVI.

de Elltramar, fti

Johaunes, acólito. $18 \%$.

-- arcedians, 175 .

-..- maestrescuela, fit.

$\therefore$ Difla $z,(20)$.

-.- Dominici, I!ji.

- Pascasius, 1.155.

-.. I'iri, 1.152

- luen petro lun Cahezalbo 1.1 .53 . presbitero, this, 148 .

-. Silsili, $a x$.

- sulklícono, ly'

Jonák, presbilero, $244,1.0 \mathrm{~J}$.

Jorlan, Don, is, 107, 121, 211, 474.

canóuigo, $[7,111,136,5] 3$, 765.

- capiscol, 170, 265, 1.008

-. hijo de Domingo l'elaez, $35 \%$.

Josef ben tbrahan, Jit.

- ben R. A tratam ben dladida, 1.133 .

- ben Abraham ban Mordecai, $1+48$.

- ben Alrabam ben Vajeh. t)

- ben Alschi, Lo

- Initil Amir, $75,1.185$

-- hen David berta... 146.

- ben Dura el envenenado. (i) f:t $f \%$.

- ben Guiat, 1.138.

- bon Hayon? 147 .

- Hahazair txen R. Mosé Ha. hazin, 148

-- Halevi ber Hejr, LS.

- ben Isanac aben Alsil, 144 .

-... ben Isac bon dbu .Josof, iis.

- ben Isanc ben Mosé ben Nahmias, 149 .

- ben Joel bon Blchahat. itii,

- bun Meir ben 1sare, 147

- ben Meir ben Isace ben Abraham ben Sosan, 150

- ben Hose Aljenabs, 14t.

- ben Mrase zbon Hayón? 1.130

- ben Mosé ben Naamán, 148 .
Josef ben Sámón bern Aima. hat, J.s.

-.- becu isalomón ben Abu Larhidm, Ji., Ijt

- ben Sambirl, 150.

- ben Saul br:a I-rach, 148

Juan, Don, fiti, 111, 196, 283:, $291,370.412,445,789,905$ [4 $4,1.029,1+61$

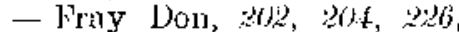
$395,432,430,803,811,812$.

- alguacil y alcalde, 119,120 288 .

arzobispo, 3\%, 101, 135, 17t. et:3, $99 \%$

- capiscol, 17i, 417

-... el Ciego, 3.5 .5

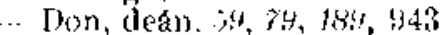

- maeslrescuta, j6, 177,228 , (i) 4 .

maestro, $16 \%$.

- oljispo de Osma, $8 \%$

-... el platero, 2.to. presbitero, $188,143,198$, 199, $20 \%$

- ben Abdelmélie, 23\%.

- ben Abderrámmen, 315.

- ben Abilhasan, apodado Abihodido, 31,305 . Abril, 601, 682, 1.118.

- Abrljair el Brnero, 1.160.

- Abuzeid, $1 \%$. de Ainsa, 67,251 .

- ban Ajsun ben Micael ben Abdelaziz, 601 .

-- Alasfar, 1.016.

- le Alba, 509

- dte Allaser?, 622. ber Albibo, 656 .

- de Alcabalán, 227.

- Alcaraceuí, 25.

Alcauar? Alcuery, $58 \%$

- Alfon, 627, 628 .

- Alfunso, $2,1 \% 2$. Alfonso el Cocinero, 310 .

- ben Alfoneo listeban, 1.035.

-... Agarir del Ticnz?, $85 \%$.

-. Algar, 1.021.

- alguacil, 70, 49, 488,946

- el Alguacil, hijo de Martín (le Sátib, 1.057 .

- Alhasán, Don, 249,269 , B38, 354,542

- Aluarracosi, $16 \%$.

- Almoravid, 15\%.

- Alvarez, loj, 1.026.

- Alvarez, canónigo, $179,182$.

- Alvaro, 144.

- ben $\Lambda$ lyasit, $76,1.097$.

- el Ancuri, 192.

- Audriss el Mrisico, J84, 5̌BO.

- bijo de Audres, 74. 
Juan, lii;o de Andrés ben Ari. zi, 174.

- Antolin, 638.

- Aparicio, 638 .

- de Mragón, 255.

- hijo de Arnaldo, $79 \%$

- hijo de Asaarani, 1.058.

- Asath el Presbitero, 1.012. Asueriz, 957.

- ben AYub, alguacil y alcalde, 195, 244, $163,496,1.049$.

- el Bacal, 653, 659, 650.

-- Bahlul el Jacin, 226;, 191.

- ben Barber, 734.

- Barbut. 88

-- Bayán, $209,1.020$.

- Belutor, 236, 157.

- Bonión, 1.070.

- Bono, 933. de Lríluega, prior, 5\%, $/ 75$, $179,211,768,1.106$.

- de Burgos el Cerero, $\gamma \tau$.

.... de Cabo, 1.120.

- Cadas, 2 .

- Cadis, 250.

+ Calabaza?, 483.

- Canamero, 67,597 .

- e] Capellán, 2\&9, 1.025.

- el Caracent, 36.

¿Caras', Fray, 1.018. el Carnicero, $346,586,863$, 867, 964.

- Castellano, $f 6$.

- Cobrián, 1.113.

- Cebrianez, canónigo, 65,71 , $179,577,578,593$. dideli?, 418 .

-.... el Ciego, \&24, 944.

- el Cocinero, 354 .

- hijo de Colomba, pressítero, $70,522,563$.

- de Cotanda, $1 \%$.

- Crespo, 126, 2\%5, 350, 353, 447,475 .

- Crespos do Riclves, 427 .

- Cristobal, 90, 80, 502, 599, 1.049 .

- de Cutanda, s18, 1.100.

- Chico, hijo de Juan Pctrcz Algara, 738 .

- el Diricono, 260.

- Diaz, 229.

- Diaz, hijo de Armengot, 482.

- Domingo el Crespo, 719 .

- Domingo el sCubo?, 511. ben Domingo Esteban, 1.045 .

- hijo de Domingo Hatim, 194.

- hijo de Domingo Juanes, 869.
Juam ben Domingo beln Juanes, 1.170

- hijo de Domiugo Juanes el Alguacil, 720.

- hijo de Domingo Juanes el ¿Ruzio?, 884.

- ben Domingo Martin, 979.

- ben Dowingo ben Mical Zambrano, 1.16\%.

- hijo de Domingo Ramos, 661,666 .

- Domingue\%, 12, 185, 194,

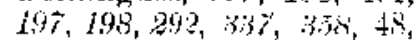
$91,123,136,154,22 \%, 234$, $250,273,285,287,292,305$, $316,321,336,343,312,456$, $57 \tilde{5}, 578,6.34,640,648,673$, $686,715,725,802,817,863$, $867,909,948,945,950,964$, 1.060 .

- Domingruez, alcalde, 2:2.

- Domingue, canonigo, 180, 600,674 .

- Domfngues, racionero, 180.

- Dominguez ¿Alblas?, 265.

- Dominguez do dAlwatrán? 578.

- Dominguez de Arcicolla, $364,1.131$.

- Domingucz Azzabar, hijas de, 1.030 .

- Dominguez el Cojo, 16\%, 210, 739.

Dominguez de itsati cha?, 398.

- bominguez, hijo de Garcla de $\Delta y$ ylon, 1.090.

- Domínguez, hijo de IJanis, 497.

-- Dominguez el Herrero, liijo de Maliha, 303, 375 .

- Domíngez el Medidor, 952.

-- Dominguez of 'Tintor $\mathrm{R}^{\circ}$, 358.

- Dominguez, hijo de Servando, 81 .

-- de Cispana, ti, $65,290,155$, 820 .

-- Esteban, 76, 208, 541, 1.102.

- Esteban de dibacal, 1.029.

- Fsteban el Ammar, 167.

- Esteban el Carmadi, 1.009.

- Esteban, hijo del alguacil D. Esteban Illanes, 770,771 , 772 .

-- Listébanez, alguacil y alcalde, 220, 267, 270, 367, 489, $558,564,590,1.028$.

Estébanez ol Zapatero, 978.

- Estebanez, 391.

- Estéfanez, hijos de, 384 .

-..- Facundo, 126.
Juan Freundo el P'escador, 743. - Falosor, j3.

- ben Farach, 123.

- ben Fárach ben Sidani, 235.

$\rightarrow$ ben Farhun, 280.

- Fernán, 689.

- Fernández, $121,529,619$, $843,845,928,930,991$.

- l'erninde\%, alguacil y alcalde, $221,624,672,829,1.034$, 1,045.

...- Fernandez Micanl, alcalde, 221.

- hijo de Fernando Micael, alguacil y alealde, 1.050 .

- Fidalgo el Molinero, 5i4, $545,3,22,913$.

-. Fidalgo el Sastre, $s t, 534$, 572,841 .

¿Wlors? 111.

- the Fontes, 506.

- Fornero, $2: 5,246$.

- de Forteda, $72,673$.

- el liraile, 955.

- el Francés, 7o.

-- Franco, 148, 421.

- Gades, 245.

- Callego, 600, 983.

- Garcit, $\%, 657,598,601$, $830,1.040$.

- Garcia, alguacil, 355, 357, 702.

- Garcia Cortes, alguacil y alealde, g2t, 965 .

- Garcia de Selay, 72, 678 . tharnara?, 226.

- hijo de Gesion, 84 .

- Gil, 624 .

- Gonzálbez, 457, 527, 692, $711,962$.

--- Gonzállez el Calero, $7 \theta^{\circ}$ 1.119 .

- Gonzálbez do ¿Yeana?, 724. Gordo, 95.

- Grande, 157.

- de Grios?, 827 .

- . Gutierrez, 672, 1.045.

- el $s$ Hacr? 645 .

- el Hadri ben Said, 448 .

- ben Hamili, presbitero, 200.

- de Hanac, 978.

- el Hariri, 984.

- de Hedido, 305.

- el ILortelano, $77,170,918$.

- ben Hosain, 221.

-.- Illán cl Carpintero, 870.

- Illán ben Ililel, 821 .

- de Tllán, de Sicla, 3.

ben Jálaf el Arráez, 228, 972,976 .

- Jimeno, 689 . 
Juan, hijo cle Juan Dominguez, 193.

- hijo de Juan Martin, i1?.

- hijo de Juan de Yalencia, xit.

- Juanes, $64,48,104,209$, $219,239,354,492,1.049$.

- Juaves Cubito, 111.

- Juanes, conocido por Juan Cobisa, 1.070.

- hijo do Juanes de Segovia, 60.

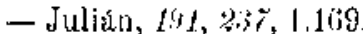

Julián el Carpintero, 68\%t, $709,1.09 \%$.

- ben Julián ben Filsel, I.160.

- Julián, hijo dei Siciliano. 762.

- Julianis ben Bahlul, 1.161.

.... Justis, $19 \%$.

- Jaurens, $19 \%$.

- Läzaro, 33j, 1.040.

- de Icón el sastre, 1.025.

- Leonardo el Carretero, 503.

- López, 625 .

- Lope de Albequd, 1.166.

- López el seedero, 1.04t3.

- Lorenzo, 268, 430.

- Iducena, 101, 358.

- de Madrid, 675.

- hijo de Malilia, 94\%, 96\%, 052.

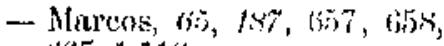
6iti5, 1.116.

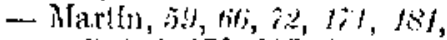

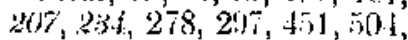
$521,561,647,653,1596,689$, $6 ! 6,709,71: 3,952,1.113$, 1.166 .

- Martin, canónigo, $L i t$.

- Martin de Benquerencia. 718.

- Martín el Carretero, iso.

- hijo de Marlín Listeban, 857.

- Martín gdo Garatelo?, 182. Martin, maestro de los al. baniles, $66 \%$ \% 670.

- ben Martín ben Salih, aI. calde, 290,807 .

- bijo de Mirtin bulvatores, 597.

-.. Mlartin el Sastre, tBo, 44\%.

- Martín, hijo de Sebasiann, 1.164.

- Martín Gbendino", 602.

- Martmez, $97,191,29 \%, 28 \%$ $65,134,321,470,627,692$, $947,1.169$.

- Martinez el Herrero, 898.

- Martínez Galvatores, al guracil y alcalde, 221,851 .
Juan el Marxeni, obispo, 181 , 1.114.

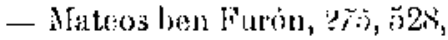
(161. $98 \mathrm{~s}, 1.080,1.0 \% 2$.

-..- Mateos de Ulías, $5: 39$.

-.- el ifayordomo, $363,99 \%$.

- Molende $, 19 \%, 172,17 \%, 208$.

- Melero, $73,415,47,182$.

- Meruanis, 22i, 43i.

- Mieas], 23.t, 6\%, 696. $8 \%$, \$si.

- Nicacl el Allanil, Sfin.

- hijo de Mlicael Cebrianis, $2-6$.

- hijo do Mieapl lisquerelo, sis!.

-... Mical el Garbí, jija.

hijo de Micael Jlianes ben Mlastiar, 1.026.

... ber Mienel Petron $23 \%$.

Hicael safuro, 314.751.

-. Micat, hijo de Juan Snerel, 513 .

- Miczel, bijo do Domingo Micael, s:\%.

- hijo de Alica ol Petrez el Carpintero, 1.046.

- Micaelis, alguacil y alcal. de. $290,10,18 \overline{1}, 564,955$, $1.024,1.0 \div 2$.

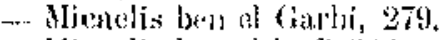
Mlicaclis ben el Iraft,

.. Migael, Jiti.

-- el GHodizllani': al Arriero, $53 i$.

al Innehel, 1.nis?.

... de gororlenes? 702 .

Momarabe, ly.s.

de N!miz ol Vinatero, 176.

- de Hurcia, 1.163

- Naval'ro, 1.1.8s.

Navaro el Conejoro, 19:3, 520.

Nientas 401, 591, 1.17.

- ¿tjos vultos?, $30 \%$. te Olins, $196,292,238$.

de otihuelas, isto.

ben omar, $12: 2$.

-- Ojthince osis.

-. de Osma, thispo, fsi, 259, gits.

- ben (Itmán, i1, 191, 1.039.

- ()ores, 26.

Pasenal, $571,615,705,983$.

- Pistro,

- hijo de Pedro, preslitero, $41 \%$.

- bijo de Pedro Holats, r, 506 .

lijo do lestro ben Abualá ben Mesilud, 233.
Juan Pelec ci Cabledi, 1.049.

- hijo i: [ [mlon de Castro, 1 fo, ) 34 .

-... hijo de P'illo Giafúm, gos. l'eclro al M : redeni, $199,486$.

-.. hijo de Jeelto l, ju Meruán Abelibar, on asmlat to $M$ ben. algariba, tijt.

- - hijo de P'utro el t'oijehoni, diacono, Bist.

-- hijo de Pedro, hijo die Lllkin, $70 \%$

hijo ke Yedro, hijo de Juan a Policheni, $8 ; 9$.

- hijo de Pedro Jaanes el P'olictleni, , $8: 29,418$.

hijo de Pcelro Jaanes el gGalingo?, 75ti.

- hijo de Palro Julian, hijo alel alguacil Julián, 607 ;

-.. I'odro ei Liwdaqui, ij, 111.

-- Poldez, 211, 221, 331, 954, $1.006,1.044$.

-- hijo de Pelayo Véle\%, 453.

- Péresz, triti.

P'ere, lijo del Crespo, 089.

- Petrez, $63,66,72,90,188$,

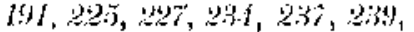
$62,46,118,145,171,176$, 180, 214, 2.10, 250, 266, 380 bis (b), 47.4, 489, 506, 511, $513,524,715,804,818,890$, $881,882,883,412,484,941$, $1.083,1.049,1.162$.

- Petrez Abenlachicas, 9\% 296.

- Telpez diatil, 181.

- Petrez el $A l$ luninil, 81,905 . Petrez, hijo del Albañil, $14 \%$.

- I'etre $z$, alguncil y alcalde, 2.20, 2.21, 325,712 .

- Petrez, eonocialo por Benal. becia, 1.103 .

- Petfez el de Camarena, 474.

- Petrez el Carfali, $89 \%$. Jetrez el Carpintero, 229.

- Peter el Gallego, 591.

-.. Petrez el Gasco, 84t.

-.... I'etı cz ben Llafsún, 540 .

- Petrez ben Hatim, $48 \overrightarrow{.}$

- Petrez Illán, bíb.

Petrez, hijo de Jilan el Gallego, $100 \%$.

-- P'irez, hijo de Juan Lázaro, 720,826 .

- Petre\% el Nalah, 345.

- l'etrez ben Meldion, 340, 400 .

- T'etrez Mocarram, $2(N, 228$, $736,1.010$.

-- H'etrez, nadil, 502, 615,820.

- Petrez, hijo del nảdir, 807 . 
Jutu Petre\% el Polichoni, ra. cioncro, $180,190.756$.

- Petrez, ¿hijo dol Purteñ?, (fos.

-.- Petrez, dancara?, 266

- I'etrez del ippodado Sotapuedo?, 322 .

- Pelrez, lianado Teutejuanes, alguacil y alcalde, $2 \% 1$,

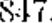

-- Petrez el Tumcro, 1.130.

- Petrez /ancudo, 20 a

- Petrez el \%aprater@ 477,501, 507,570 .

- Petrit, $73,182$.

- el Patero, lys

-.- Jodadur, 82, 400.

- el Policheni, 16: 30is

- Ponce, $71,72,810,812,830$ $008,1.04 \%, 1.083$

- Ponec, alguacil y alcalde $220,252,45.554,555,639$ $847,848,856$.

- Ruja, hijo de Julian Ruiz, 1158

- Ponz, 748, 506.947 del Pozo, 1.120.

- el Pregonero, 1.119

- el Racionero, 801. ben Raimund 3,$3 ; 4$.

- hijo do Raimundo el Alba. nil, 746 .

... Ramiles, 62, 292

- Ramilo, xacioncro, $180,577$. $578,598,601$.

- Rey de Alibat?, 1.022.

- Rodmirez aicalde, $215,3 \%$ 354,940 .

- le Roma, 19.3.

- de Romani?, ‘21.

- Ruiz, 44t, 188

Subater, 580

- Safuro, 548.

- ben Sahel, 1.15\%

- ide Sales, 946

- cle Salaya, $10 \mathrm{~S} 2$

- Salut, 76 .

- Salvatierra el Carretero 1.157.

- de Sambrán, 645.

- desimrano, 42. de San Facinido (Siharión), $425,645,964$

-- Sincher, 48, 1.029.

- Sanchez el Pescador, 720.

- sisargat, $1.0 \% 4$

- el Sistre, 181

- Sebastiáli, 508, 1501.

- le Segovia, arectiano, 89. $1 \%(5,60,2) 2$

$\cdots$ de Bulaya, St, 792.

- Selma, 130
Juan ifectuedo?, 288.

- Serrán, 21.

- de la szrilucla, 1.02f

- de Reseitia, 713.

- de Sctfila, canónign, 16j4, t70, $340,380,387,380,300$, $580,606,758$

- el Sevillatier, 1.107. L.110.

- el Sical, $3 \mathbf{t} 5$.

- Sobrino, 858

- sobrino dis] \&anterraton?, iri.

- Sintrez mis

- el Suldiácono, hijo do Mfartin Seco, 1.102.

- ben Suleimán, 894

- Tubernero, 502 .

- de Talayera, camónigo, $17 \%$ 1 i 1

- el ' Tejero, 1.02s

- el T'intorcro, 219, 296.

- Tomé, 159, 227, 257, 262 $294,368,300$.

- Tomé ben Jahya ben Pela. yo, 381 .

- de 'J'oro, 152.

- Velázutez, 114.

- Vicente, $460,611,6: 37,670$, 1.109 .

- Vicente el Herrero, 805.

-... Viconte de Bareas, 56,463 , $466,469,603,653,997$.

- hijo de Viente de l3argas, 748.

- Yesco, 256

- hijo de Zacuria, 898

- Zanumano, 964.

- el Zapatero, 68, $284,311$.

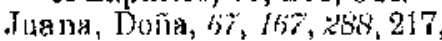
$220,474,611,641,637.662$, $607,1.109$

- hija de Domingo Juanes, $568,(6) 0$.

- Domingucz, 195, 5 bاo.

- Guiralio, subpriora, 195. 1.173.

- Juanes, $591,818$.

- Julian, 5ivi.

-- Lojuez, 1.109.

Jannos, Don, $l w r, 22 \%, 120,247$, $362,410,509,636,640,64 i)$ 942.

- ben Abdulmolic, 95 .

- nieto de Abuishac, 42.

- Albahón, 652.

- ben Albantaizo, 214.

- Albromel, 199,710

- Aljodor, 135.

- Almahroe, 186.

- alguacil y alotide, $221,679$.

- el Aneuri, 5 s.

- ben Atar ben 1 ampader, $4 \vec{F}$.
Juanes ben Ayub, alguacil y alcalde, $201,219,5(6,942$, (H)

- Don, capiscol, 314, 535,548, 7i)1.

- del Cimanecro?, 729.

- Domingo el Crespo, 862

- lijo do Estoban Iulianis, 323.

- Guilen, 7 .

- de Habia, canónigo, $17 \%$, 902.

- ben Llamili, 291

- ben Hosin, 569.

- ben Pelia ben Petro P'lúez. $1.155,1.150$

- lycol Fionent, $k(15$.

- ben Isa, 1.010́

- hijo de Juan Domíngaez, 3332.

- bijo de Lázaro ben Habib, 325.

- dde Macuchor, 333 .

- hijo de Micael, 127.

- hijo do Mica ol Cebrián, 314.

- Mirgujión, 689

- ben Molue, 19.

- hijo de 7tacaria el apolado el Yorje, $: 14$

- hijo de Ora, 814 .

- Lijo do Podro Holuatis, 428.

- hijo de Pudro Martín, 643 .

- presbitero, 99, 103,378 , 1.014 .

- sacristán, 1.058

- ber Tacaria el apodado el Monie, 548.

-- hijo de 'Tomé ben Yabya Jen Pclayo, 24:3.

Juanet ol Ricionero; 1.02!

Jucelin, Pedro, 867 .

Juliăn, Don, $28 / 1,20,628,1.175$.

- ben Abichadal, $56,171,228$

-. Inen Alithusan ben Albazo alguacil v alcalde, $8 \%$, $2 \%$, $42,68,232,349,797,1.052$.

- ben Abdelaziz el Esterero, $3\lfloor 4$.

- alcalde, 3j2, 472, 1.141.

- alculde de Canales, t3j.

- Neazár, 328

- ben Azlón, 233.

- ben Bahlul, 333. alguacil y alcalde, $\{13,819$, 821 .

- Bicent, 80 .

- de Casa Chica, 135, 993.

- ben Catruf el Droguroro, $2 t_{1}$ 498.

- Doningo ben Abdelaziz ben Cosucli, 506,518 
Julian, hijo cho Domingo ] a. J Junien, mastro, arecaliano, nardo el Sastre, 691.

- hijo de Doriliugo Lamos, $661,6063$.

- Dowinguez, 10, isfo, 26, 640.

- Domingucz, hijo del Platero. 927 .

- Wominiej, 969 .

- Ven Estebar Tuljanis, f\%.

- Estélanez, alguacil y alcaltir, 221, 205, 358,405 $470,4 s t, 950$.

- ben tation, otsi, 1,s

- el Godial, list, Tos.

- el Herrerro, 58 .

- bon Ificl, :MS, 1.16\%.

- el Hortelano, 230 .

_.. bern Iswail, 5015.512

- ben .latab, alguacil albaquim, $202,596,1.664$

- hijo de Lázaro, 173.

- Longra, 10.

- lijo de Nicatl hivareadón, si7.

- ben Micael ben Baqui, 24.

- Micaelis, 78, 216, 252, 208. Mictiplis, hijo det aluacil sid, $2 ! 14$

- San, obispo de Cuenca, for. ben 'lauro, areediano, (o), 176, 280,274

- hijo de Pedro Ferro, 251. 4.49 .

hijo de Pedro I landes, 7 gs. l'erez, escribano, 628.

- Petrez, alcalde $85,21,52 \pi$, $560,594,652,545,1,021$, $1.15 \%$

- Petrez de Bargas, 1.032, 1.115 .

- Petrez ben Asomail, 1.123. F'etrez ben Ismael, 407.

- Petriz, $1.00 \%$.

- hijo de Petro Juanes, 285.

- proboste, jo, 180 .

- ben Salmun, 411.

- de San Lotenco, 191 .

- bon sid, $\% \pi$

- Asuicop, 1.025.

- ben Jahya, $25 \%$.

Juliana, Doña, $79,3+6,405$, $565,435,628,765,820$, 1.035 .

- hija del conde, 48

- la Galinera, 79.

-.. de Guadalajara, 1.04(i.

- Mtrmán, !yb.

- Povjra, 689.

Julianis, prestitite, 974

Julianus, Sancti Laurencis, g(tej.

- Uincencii, $1.09 \%$. lit.

domilln?, Nartín tel Grmach, de, $6 \cup 2$.

Juset lyon ixer, 1.1;.

- Cachich 16.5.

- el Muśsí, 11 .

Juscpe ben Mansur, (ais, :i6io.

Justa, 6\%, 4, 65. 158, $291,314,314,322,823,852$, 424. 43. 106, $15,520,512$ $57 \overline{7}, 579,398,60 \%, 620,642$, $651,657,468,074,701,720$ $751,804,890,950,978$,

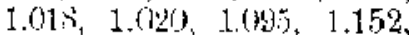
1.135

- lijja de Juan al Aarie ben listeluan, 281

- hija de Sincho Juates de iLospital?, 4t.

- Domingues, 510

- lija de Givillermo, 128.

- hija de duan el tzrac, 892

- hija de Juan Cebrian, 1.108.

- hija de Juan el Corsani, 143.

- hija de Juan de Villascca, 881.

- Junes, 608.

.. hija do Juanes MLuñon, 177.

- hija de Martín heposte ro, 66. 548, $89 \mathrm{~s}$.

- hija do Mictel dranes, 101.

- hija de Micael ben sulei man, 1

- la Alorena, 1.014.

- bijar de Ptdro, 48

-.- hijade Pedro ;Crueia to?, so

- Petrez, 201.

- madre de liajuindo Men$\mathrm{go}_{1} 44$

-. liodriguez, 1.010).

- hija de Sebastián lon klil jair, $40 \overline{7}, 1.123$.

- Lija de Sirl loen Harha mi, 24.

- Velasco, 5 ts

Justo, prestitero. 195,699

- Ablelmelic, 1ts. 165.

- hijo de... el Aklalid, 475.

- hijo de Crispist, 5i7, 5i8. 593 .

-. Wohamnes, 88.

- Iijo de Jilstio, T00.

- cl Molincro, 179

- Petrez, 3

- hija ile Temár el Adaja, 447 .

Justris lien Abrelenélín, 300 .

Kartata?. 101.

Karjinski, fo.
- e] Garí de Gaza? grit.
L., arcetiono de Alearaz, tht.

L., arehidiacous, thearacis Niglgister, birm.

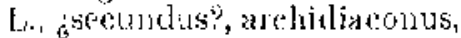
Magistind, 821

la Adruta, Nicael de, 507.

Latila, thotia, 181.

Ladif, Lorenzo lien Molarect] el, $124,92 \%$.

Jambert, $1.01 t$

fanberton es liances, 3.55, (x) $1,441$.

Lanpater, tof, 9 th.

- jostelats ban, 320\%.

- I'taro Esteltan, ijo

tamiti, El, /s:i.

Larfelos. /it.

Latuenci Petria, 18.

Iaurencja Micat-i, 701.

Laurencius, diaconus, 750, 923.

- Dominicis, at.

Laurens, hijo $46,169$.

-. Dominguez, Bis.

- Iohannes, 925

laturent, 650,719 , s64.

- de dos Barrios, 1?2.

- lijo de lsidro, 647,650, 6iol, 6.57 .

- hijo At Mingnijön, 719,720 . $862,884$.

Lazarena, Doùa, 492

- ben Adalí lodicheni, 335.

- Martin, 430.

bataceno ken Algaz, 1.04t)

Tázaro, $1001, k 15 !,(6), 81,155$ $382,489,58 \%, 629,1.025$.

- IJijo le, 61.

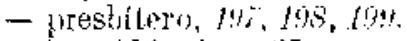
ben Abivahya, 35.

-. Aloulretsa, sil.

- ben Ali, 61, 2:is, $50,52,71$, 89, 924, 925, 926, 92i, 929, 1.039 .

- el Barbero, 1.162

- de Cobisa, 65́7.

- Flias wi Kapaltror, 520.

- hijo de Estedra, fit $1,63$.

... (x)lillolno, 1.104. ben Jálaf", 62, rab.

- de Maria Cotres, jat.

- Petri, 1.121.

- Rodriguez, 945

- Sincliez, 60

- Baneho ol 'Tabernero, 116, $1: 3 x$

- de San Toread, presibitco, $4)^{2}(1,490,997$.

- best Suleimán, 89!.

- el Zapatero, bijo tle Jilias. 5.4, 01,858 . 
[uzarus, presbiter, 262, 2\$1, $381,389$.

Lazdrada, Hicacl do, 5f!?

Gedribdo? Pedro cle, 34!y.

i,ebli, el, Ilorahim ben Atibrahim, 148 .

Ledesma, Gregorio, 10 .

I,eocadia, $\%, 64,72,73,4 ;, 123$, Ifo, 134, 246, 291, 310. 330 , $357,260,: 30,422,430,403$, $466,464,526,537,515,570$, $608,67 \%, 708,725,816,819$, $827,828,829,986,999$, $1.010,1.012,1.020,1.024$, $1.025,1.046,1.064,1.114$.

- monja, $49.6,920$.

-.. hija de Abdelaxis, 9012

- hija do dbdelmbic al Arrees, 1.015 .

- hija de $A$ dam, $72,7 i, 685$ 726,826 .

- Alvarez, 647, 650, 657, 658, $605,1.116$

- Astur, 1.045, 1.117.

- la Cirujana, $235,1.105$.

- Lija de Douninga, hija de Teman, 38, 39 .

- hija de Domingo ben Yaix ben Harrash, 236, 1.114.

- Domínguez, monja, $62 \%, 194$, $195,818,740,1.016$.

- hija de desteban Autres ben Aldelkerim, 985 .

- hija de Esteban Julianis, $537,570,573$.

- Estébanea, $7 l, 902,51 \%, 710$.

- Foliz, 653.

- Feruández, abaleza, $20 h$, $202,633,772,775,780,789$, $790,815,817,825,845,915$, 915 bis, 916, 917, 930,931 , $933,995,996$.

- Garcia, 1.030.

- Gomez, j2s.

- Juan, 578.

- hija de Juan de Cuturida, $318,740,1.100$.

- hija de Juan Dominguez, 653.

-- hija de Juan Petre\% ul Malab, $2 \% 0$.

-- hija de Juan Ponec, 111.

- Juanes, 197, 210, 213,228, $305,245,381,453$.

- hija die Juanes, 192, 1.018.

- hija de Julisn, 560, 799 .

- hija de Julián, hijo de glve. siderio?, 550 .

- Jija de Julián de IRetia, 233.

- hija de Julián, hijo de Rodrigo, 420 .

- Julianis, 377.
Leocallia Julianis, hija de dbu liserin, 500.

- J, repez, inom.

- hijar de Jarla Potrez, 1.033.

- Martine\% 2ys

- Iijer de Micatel, 738.

-- hija de Micael \&Síiz?, 77.

- hija de Micacl Sabes, 323.

- Milis, 29.

- hijar re: Otmán ben Otmán, 1 (6).

-- bijal de l'edro Fornandes, 1.014 .

-...- hija de l'edro el I'oljeheni. !1s,

- Lijil do l'edro solvos, 158

- Petre\%, $71, M 1,195,202,223$, $240,285,584,586,596,054$, (991 $962,1.033$.

-- l'etre\%, monja, : $320,644,712$, i5t2.

-n esposa de lirimundo, 1.015 .

- hija de Sancho, 83.

- hija le Subastian, 073.

- lije de Suleimán, 1.015.

- bija de Yahya el de liaeza, 108.

- hije da \%acaria el Laiti, Bo.

lebla, obispo (le, 941 .

Leôn ben Jomingo Cliteo, 472.

Leconor, Reina, tof, 204, 218 .

Leonardo Román, 096.

Loriane?, 79.

Lerma, Jedro Garces de, 274.

Jia Sabib, 5.5, 269.

Librada, 54:

Loba, $17 t, 109,248,260,350$ $392,447,462,527,566,590$, $613.837,856,081,1.002$, $1 .(124,1.032,1.035,1.045$, 1.104.

- Dominguez, 50, f71.

- Esteban Julianes, 76, 834.

- lija de Esteban. 81.

- Lija de Esteban l'etrez, 488.

- Estß]ranez, 391, 414

- hija de Juan, 1.163.

‥ Juanes, 381 .

- hija de Julian Pelrez ben Daud, 1.150.

- hija de Julián, hijo rle Pedro Jutanes, 390.

- hijn do Micael el..., 332.

- hija de Micael Algar, 1.108, 1.110.

- hija de Pedro Alionso, 557.

- Sabjb, 55, 354, 748.

- hija do Douningo ben $\mathrm{Ab}$. cle] mulic, 281 .

dioluato...?, 732 .

Loja, Abdalá de, 934.

- Martín de, 723 .
Jombarda, esposo de la, 141.

Longo, Salyl ben Daví ben el, 1.48.

Lop, thur?, $392,984$.

- J)laz, 422.

- Tome, 232.

Lope, presbilero, 191, 275, 312, $316,324,1.078$.

- ben Alodale, 74 .

- ben Audala ben Temam ven Jachit, 438.

- Abentiema. 264 .

- alfarero, 23:5.

- Maestro. 63, 558, 1.114.

- Alfizatl, I69.

- Alvalez fits, 1.020.

- hijo du Alyaro el Zapatero, 953, 1.077

- de Mrenas, $586,610,1.078$.

- el Barbero, 130.

- bijo del Brzero, 445.

- de Calatrava, 628, 1.164.

- el Carnicero, 801.

- Cristóbal de Bargis, 591, 594.

- el Cucharcro, 166.

- bes Domingo ben Salvatores, 1.175 .

- Dominguar, canónigo, 77, $166,168,180,577,578,826$.

- ben Fstelua el Carnicero, 1.153.

- listebarez, 78, 225, 833,750.

- el 15sterorn, 1.163.

- ben Farach, 224.

- Femandez, 59, 63, 70, 179 , $261,441,411,470,560,816$, $845,1.053$.

- hijo de Fernando López, 880 .

- hijo de I'rernando Micael, 1.034 .

- le Fitero, maestro, 164, 168.

- nen Gastón, 269, 542 .

- hijo de (iil de Morurelia, 403.

- Gutierrez, 627.

- ben Jair, 310.

- ben Jális, 315, 1.130 .

-.. hijo de Juan Podador, 264.

-. Juance, $62,30,400,675$.

- Lopez, 59, 394, 441, 461. $462,558$.

- Ma: tíne\%, 558.

- bijo de Micael de Algar, $18 \%$.

- Nuñc\%, 455, 1.030

- hijo de Pedro, hijo de Juan el $\Lambda$ iguacil, 618,621 .

- Lijo de I'edro Martín, 1.001.

- e] Pescador, $169,608$. 


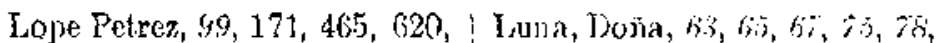
$621,693,824,1.047$.

- el Rageón, 465.

- Ruiz, 211, 1.023.

- Ruiz, arcediano, $17 \%, 638$.

- ben D. Saad, 124.

- hijo de Self, 1.020, J.021.

- ben T'emam ben liahit, presbitero, 302 .

- hijo de Teresa Juanes, $27 t$.

- de T'orrijos, 982.

- ben Yahyo, 216, 309, 1.114

- ben Yishya ben Hixen, 184.

Louetón, Martín Lúpez, hijo de, 846 .

Lopez de Haro, Diego, No, 10\%.

I,orente, Maria, 608.

Lorenz, Don, 168.

Lorenza, Doña, 504, 605 .

$\rightarrow$ Pelreg, 611.

Lorenzo, Don, 164, $169,23 \%$, $234,26,247,345,685,826$, 1.020 .

- ben Amrel, 5136

- Axefa, 376.

- Baneyas, 702.

- el Bolitir, 602,667.

- el Bellutero, 963.

- el Carpintero, 64, 76,204 , 301.

- hijo de Domenedes, 473.

- lijo de Dominero ben Suleimán isen Asún hen Servam kno, 281 .

- hijo de Esteluan, 88, 933.

-. cl listerero, 530 .

-.. ben Galib, 2:i 6 , 17s.

- hija tio Gálib, 275.

- hijo de Isidro, 641.

- hijo de Julian, âlo.

- Mofarech el Jait, $19 t_{1}, 924$ 925.

- hijo de Nicolás, 404.

- hijo de Pedro Cebrian, 62.

..- hijo de Pedro Forlunio, 352.

- el Pelctero, 20. el Sillero, 715

I.uba, Dona, 1.16:

- Micall, 69 .

Lucas el Herrero, $308,305,312$, $375,698,949,950,952$

- hijo de Junn Petre\%, tofo. el (Jrcbzo, $16 \%$.

lucia, Doña, $73,608,694$.

- bija de Luope, 224 .

- lija do Micacl Firnande\%, !)

- Miger Sutárez, $t i$.

- I'etrc $\%, 962$

Iucio, paps, 208 .

Jufalión, 312 . 20\%, 201, 211, $820,32 \%, 339$ $428,149,519,559,561,5 i 7$ $5199,605,420,981,1.114$, 1.168.

- Alvaro de, 2:36.

- Mirguel de, $213,250$.

- hija de Bartolomé de Mlixequí, 6 is.

- le Camarema A!ta, 694.

- bija de Cristoilal, 1.114

- hija de Dolniligo, 559 , 615.

-.- Domingue\%, 544.

- hija de Fsteban Julianes. 746

- hija de lemando el liane qui, 1.026 .

- Garcia, 323.

- hija de Ciarcia Juanes, 707.

- hija de illán, 819.

- Juan, 978.

- hija de Juan Sajd, 1.079.

- Juanes, subpriota, 20,760 , $763,772,808,810,813,911$, 985.

- Montel, 177.

- Iascual, 571

... hijo de Pedro, hijo de Domingo Martín el Crespo, 954.

-- htjo de Pedro Dominguez, 701.

- Pebre, coleraria, zil. 825, $\$ 28$,

- Sularez, I.0)24.

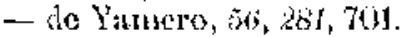

-..- do ¿Yarricró, hija de Pedro boinging el Crospo, 950 , 1.043 .

Lupa, Dopa, Rion, J75, 833.

- hija de A uairo, 199.

- Doña, viuda de Diego Gon. zalcz, 958

- hija de Sabib, 542.

Lupus, diaconus, 142 .

-- Fermandi, canonicus, 364.

- Tundisalvus, 467, 472, 757, $762,763,764,764,1.02 \%$

-- Habiber, $t \geqslant i$.

- Hartini, subdiaconus, 274 .

- I'etri, 4ti.

- Roderici, 909, 948.

- Banz, 10 í.

Juque, $A$ bmed de, 789

Llusi, Salomón ben Salomón e), 1.18 .

M., calatravensis arehicliacomes, $177,457,181$

M., decanus toldamu, 770 , i11.
M. Gaufecii, canonicus, 518, i) 45 .

M. Cinllidnis tolutane cocle sie socine, $7 \%$

M., tolttane redis archiepiscoins lispaniarumb primas, $274,1.126$.

TMarabie, Alfonso el, 765 .

Mass, Mair ben Ishace ben, 118 .

dNencanet?, hijo de l'ascual, 247.

GMacbulali?, 23.

Hacbulanip el Allunit, 319

Madero, $3 \%$. 11\%.

Watlid, Cornelio de, 211.

-- Maria Viconte dic 658.

-... P’ascuala, hija de .J uar de, (17is.

hladridera, tiraca Ja? 61.1.

Magarfi, Alfonso ol. $51 \%$

Magdalena, hija de Gracia, hi. ja de Luma, $1.0 \mathrm{~J}^{\mathrm{a}}$.

Magán, Pedro Esquerilo, llamado de, 479 .

Magaz, Dominge, 1.045.

Maharis, $A$ ben, presbitcro, $10 \%$, 379.

Malutí, viñu dèel, 12 .

Majcolas el Esculero, 6\%, 000.

- hijo de María Sartin, 619.

Mair, 284.

-.- Nubañil, 802.

- Martine\% 1.150

Hor Alvari, 1.175. Nuniz, 18 .

Malagueño, nieto del, 623.

- hursto del, 1.17.).

Malbib, hermano de, sso bis, 407 .

Málie, hijos de, $11 \pi$.

Walit?, Ben, 1fs.

Mamés, Don, 1to.

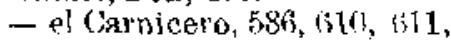
$637,070,1.109$

Manso?, 202

IItusur Sajd, 193.

Manuel, infinte Don, 216, 220\%, 630.

- ke Illain, ir.

Maqueda, Benayas ale, 1.080.

- Garcla Martín de, 647, 692, 693.

- Don Yago de, 658, 665.

- Maria Illán de, 895 .

- Martín Micalel „1, 824.

-. l'edro de, 312

Mar... Cardo, 704.

dMarasah?, Don, prestutero. 19t, 463 .

Narecto, 1.024

Marco, canósizo, $7 / 7,1.074$.

Mareolin, 362. 
Mincos, Dom, titti, 95ti, l.liss.

- Don, nireto de', 665 .

- presbitero, $188,19 \%$

-. el Areipreste, $16 \%$.

- al Conejero, 16\%.

- hijo de Dowingo Masehtín, 640

ben feliz ben Garm, 1.158 .

- Gareia, alcalde, 221, 704.

- el de Don Ciuilen, 170 . Micael 2.24.

- Micael el Fscribano, 827

Marcus, canonicus, $289,395^{\circ}$ $729,1.011 .1 .126$.

- Garsias, $646^{\circ}$.

Mareluus, diaconus, 253

Margalita, Dotna, priora, gev, $825,828$.

Maria, 3, 59, $19,20 \%, 206,210$, $2 \%, 285,118,151,172,182$, $18 \%, 20 \mathrm{~K}, 211,217,224,247$, $291,292,29 \%, 294,297,310$.

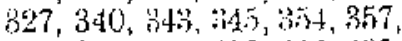
$350,364,368,599,412,435$ $437,461,467,470,471,172$, $499,516,529,5,99,558,559$, $592,596,612,625,628,640$, $645,653,661,681,688,691$, $728,733,739,777,810,800$, $819,89 \%, 960,964,978$, $1.014,1.016,1.020,1.029$, $1.032,1.035,1.073,1.080$, $1.097,1.111,1.118,1.162$ 1.169.

- híja de Aludalá, 430 .

- hija de Abdalá ben Mesaud el Midrís, 283.

- hija do Abdeluziz el Malagueño, 130 .

- abbatisa, 299.

- hija de lliharb, 88.

- Abril, 399, 717, 931.

- hija de Abnláas, 484, 485

- hija rle Abulcadí, 319.

- idam, iou.

- de dAdaquiel?, 1.046.

- Agustín, i\$89.

- Alfonso, 80, 207, 340, 505 $512,628,846,920,1.164$.

- hija de Alforso el ..., 866.

- Hija le Nhanás, 88 .

- Nlvare 1.026.

- hija de Andrés, 74.

- Aparicio, 333.

- hija de Aparicio, 919.

- Arias, 595 .

- Armildez, 2:31, 493

-- Arnaldo, 62: 462, 559, 644

-- Astur, $212,672,1.045,1.060$.

- de Benquerencia, 124, 1.087 , 1.088.

- la Bisutera, $235,863,867$.
Maria Cebriáu, 73?

- hijer de Chádar, bif.

- lija de Glomente, 1.107 , 1.110 .

- Collo slba, 36, 217, 220.

- la Conejera, $19: 3,520$. tCordel's, 420 .

- hija de Gristobal, 233.

- Diaz, $7,69.1 .044$.

-.. Domingo, (1) 24, 24, 229, 27, $81,254,262,366,368,370$, $450,572,589,620,628,652$, $681,701,726,820,857,869$ $1.018,1.022,1.027,1.044$, $1.1(1,1.1 \% 0$.

- hija de Domingo Abulías, 222.

- hija de Domingo el Almotacen, $68 \mathrm{si}$.

- hija de Domingo ben Esteban lon Solma, 982 .

- hija de Douningo ferrero, 600 .

... hija de Domingra, lija de Tcman, 38, 39. 1) ominguez, $5: 3, \quad 90 \%, 111$, $536,645,662,(667,710,983$, 1.027, $1.035,1.070$.

- entenada do Martin Moro, 646.

- Esteban, $20 \%$.

- Listeban, priora, 195, 506, $701,915,959,1.043,1.173$.

- Esteban, hija de Domingo Gonzalbo, 645, 697.

- hija de Esteban ben Chábir, 715.

- Felices, 326.

- Fernánde $2,65,73,465,580$ $606,616,641,647,650,651$, $655,65 \%, 658,665,671,715$, $783,1.116$, J.117, 1.119.

- Fernánde 2 Maleos, 694.

- liervández, monja, $195,1574$.

- Fernando, 622.

- Cudel, 607 .

- Garcia, $4,79,5 \pi 1,202,702$, $710,1.030$.

- Gareia, monja, 191,584,772, $911,985$.

- García, bija de Juan el l’re. gonero, 1.119.

- Garciez, cantora, 760, 772, 985 .

-Gil, 649, 696, 719, 828, 862 .

- Gonzilbez, $73,210,280,285$, $286,482,564,750,829,906$, $463,980,1.04\}, 1.125,1.126$, $1.127,1.163$.

- Gonzalbo, 549, 587, 6i3, 1.119.
Maria, Lija to Gomzabo Diaz. 1.056 .

- hija de Gonzalbo Domin. guez de gileantarer?, 1.165.

- hija fle Gonzalbo Pelácz, 1.041.

- Guillen, $169,211,267,519$. 346.

- Guliérez, :510, 684

- hija du Horabona, 135.

- lijia de Hosain ben Furón, 389.

- Illán de Naqued

- Illanes, 483.

- Yacob, 422.

- hija de Isa ben Abuless, $4 \$ 5$. hija de Jatim, 734 .

-. hijar de Jázim, 153

-- hija de... el Jodri, 694. Juan, 65, 166, 288, 3:17, 645, $649,689,721,829,832,871$, $872,874,874$ bis, 875,875 bis, $876,877,878,879,890$, $881,882,883,885,889,978$, 998 .

- hlja de Juan, 152, 681.

- Juan, hija de Juan Julizin el Carpinlero, 684,709 .

- esposa de Juan, 498.

- esposa de Juan el Asfar. 1.016 .

- esposa de Juan Alhasán, 303.

- hija de Juan Crespo, 460.

- hija de Juan Dominguez, hijo de Domingo Martín, 259.

-- mujer de Juan Perdiguero, till.

- hija de Juan Petrez, 358.

- hija de Juan Salama, 219, $269,354,342$.

- hija de Juan I'etrez el J3eJutir, 1.085.

- Jugnes, ñ, 160, 203, 256, $269,292,533,581,389,421$, $478,192,587,603,726,748$, $818,826,79,988,1.064$.

-- hija do Juanes Alchad, 171.

- hija de Juanes ben (ianitr, 190.

-- hija de Juanes l'aris, 377.

- Inlianes, 7S5.

- hija de Jusla, 1.(185, 1.11\%.

- Lambert, 462, 836, 1.104.

- Laurent, 121, 657, 720 .

- Iaurent, hija cle Pedro Min. guijon, 869 .

- La Iavanilera, $t 72$.

- Topez, 304, 638, 1.085.

- Lorente, 008.

- Lorenzo, 549, 598, 601, 627. 
Maria Lucas, 312

- la Matstra, $928,1.16$.

- hija de Mair Teman, ro 264 .

- Martin, Doña, $20 \%, 487,513$, $521,543,591,622,612,646$, $649,651,657,678,681,696$ $765,769,815,829,855,864$, (90), $1.027,1.124$.

- hija do Martin el laiti. 63. 167.

- Martín, monja, 1.56.

- Martín, vortera de San Clemonte, 814 .

- Martinez, 202, $81 \%$

- la Masudia, 893 .

- Mateos, 212, 1.030.

- Meléndez, 280,712,723,943, 1.173 .

- Meléndez, monja, tho.

- Maria, hija de Melendo, 947 , 965.

- Mengo, 680, 697, 719, 720, 862.

- hija de Meruál, 1.016.

- Micael, 323, 326.

- Mierel, abailesa, 186,487. $680,701,719,720,865,1.158$.

- hija de Micuel, 77,581.

- hija de Micael bos Allazo, $107,280$.

- hija de Micuel el Darrás. $382,1.076$.

- hija de Micael Juanes el Asfar, 379

- Miguélez, 20.

- hija de Milia, 125

- Mingo, 226.

- Mozola, 55, 62, 174, 198, $407,411,513,765$.

- ]a. Muda, 191.

Muñoz, 105, 495, 63\}, 1.085

- Ja Negra, 696.

- Nicoläs, 101, 977 .

- hija de Nicolás de lorres, 473.

- Nuñez, 525 .

- hija de Obaidalá, 734.

- Obiequez, 614 .

- dhijw de Ogier? Rodrfguez, 973 .

- la Ollera, Jfts.

- hija do Omar ben Alasiud, 322.

- hija de Orabona, 964

-- Maria Paris, abadeka, 186, 299.

- jde La Parra?, 188.

- Pascual, celeraria, 195, 196, $340,359,669,699,700,713$, 1.17\%.

- hija de Paulo, 921.
Harfa Pedrez monja, th.

- bija de Pedro, 208, 223, 578 .

- hija de Pedro Alcarmán, $302,-38$.

- hija de Pedro el Barbero, 708 .

- hija de Pedro de Jllescas. 1.026 .

- esposa de Pedro Junes, 151 .

hija de Pedro Moro el Adalji, 115 .

- Peláe, 57, 70, 204, 358, $255 \%$ $112,119,183,347,855,380$ lois (e), 40 $\bar{\tau}, 440,483,490$, $735,444,446,951,1.013$, 1.075.

- bija de Pelayo I'ascual, 855.

- hija de Pelayo Petre\%, 760, 904.

- la Perdiguera, 170.

- Pérez, $79,166,196,1.173$.

- Peris, 592.

- la Pescadera, 6 .

- I'ctrez, 66, 69, 85, 202, 805, $307,282,176,255,276,277$, $315,320,336,34,373,436$, $526,579,580,604,652,684$, $691,693,740,791,824,525$, $828,857,894,1.022,1.029$, $1.030,1.037,1.038,1.118$, 1,162 .

- Petrez la Maestra, 2299, 634.

- Pelrez, monja, 19.

- Petrez, subpriora. 186 .

- Petrez, porticra, 191.

- hija de doña Quebira (MIayor), 498 .

- Ralo, monia, 202,80\%

- Rodrigo, 632, 641, 651, 65i.

- Rodrigo, val de, 692.

- Roman. 70, 563, 579, 791, $849,852,853,996$.

- hija de dỗa Ramona, 6:7, 670.

- Ruiz, priora, $145,487,770$.

- Shlvudor, 221, 673, 1.085.

- Sánchè, 124, 328.

- Sancho, nonja, $52,202,689$, $796,996$.

- Sancho, hija de Pascual Juanes, 682, 1.0000.

- hija de Saucho iEscalabrado? 1.160 .

- bija de Sazcho Eqquicrdo, 1.161 .

- Stefani, ronja, 80 s.

- de Santo Domingo, 170

- hija del sastre \&Almoticali?, 1.015 .

- Setjel, 799

- Silvestre, monja, 195, 318 .
Maria simon, $7 z$.

- Simona, hija de Icortmzo, 725.

- hermana de soif, 89.

- hija de Suero Diam 154.

- 'illo, 260.

- Toniam, 35\%, 68, 727, 967, $969,1.050$

- llamada la Terecra, 762, 763 .

- 'Yeresa, 268.

- hija de Tomé, 86.

- Uelat, 807 .

- Velaseo, 211, 489, 548,608.

- Vélez monja, 20, 752, 812

- Vicente, 124, $584,700,715$. $983,1.046$.

Vieente, de Madria, 653 659 .

- hija de Vicente el Zabate. г0, 611, 687, 670, 1.109.

- la Vieja, 1.080 .

- lifa do Urraca línia i12, 975.

- Yagur, 882.

- Yahya, 34.

- bija de Yahya ben Sidabihi, 257 .

- hija de Jái $x_{16}$ 16, 830 .

Nariam, $1.008,1.020,1.030$, 1.043.

- bija de Moháned, 935.

- la Musulmana, 82.

Marin, Don, 778, 781.

Marina. Dona, 122, 282, 42 $\vec{i}$ $641,688,720,722,726,861$, $863,867,964,1.035,1.088$.

-. esposa de $A$ ndres Hetrez, 76.

- la. Bisutera, $2369,961$.

- hija de Esteban, 119.

- Felmánde $z_{1}$ priora, $195,463$.

- hija de Garcia, bija de Luna, 1.043 .

- esposa de D. Guijlen, 77 .

- hija de .Juan Gallego, 586, 610. hija de Juan Gonzálbs\%, 1.035.

- Jranes, 963

- Martín, 568

- hija de Martin, 713 .

- la Negra, de Marraqx, 692.

- hija de I'elayo, 84 .

- hija de Pedro jalabatero?, 1.165.

- Petrez, $196,204,810,1.173$.

- hija de Urraca la Madudena, $611,637,670$.

- la Vieja, 100.

Mariola, hija de ledro, 1.016

Marjota, hija de Cásim, 245.

Marquesa, Doña, $66,9 \overline{0}, 185$, 
15. 654 , $6658,179,691,1962$, $693,64,702,707,715,961$ $1.026,1.066,1.105,1.115$. Marquesa, Doña, hijos die, \{ito. - Alforso, 628.

- hija de Domingo, 69s, 701.

- Raimóndez, 6io.

Miata, Doña, 478 .

Nartila, 49, is, 62, $16 \%, 85,15 \%$ $2013,347,363,591,603,858$, !he3.

- Maeslro, 518.

- Maestro, hijo de Maria boningo, 61.1.

-. Abad, 20\%, 344, 689.

- Abenbautar, 170 .

- ben Abiestlam, 1.021.

- ben Nibloca, 54, 540, 519 .

- Abulaix, esposa de, 45 .

- el Mdui, 2:3, 302

- ol Albañil, 960 .

-- Albarez, 83̀, 124.

- b.Alchiact, 96.

- de Alcomle, 290.

- Cilio de sheomquit?, T4.

- Altomso, 192.

- Alfonso, racionera, $f \delta(\%, 915$

- ber Nfonso ben Marlin ben Pedro, 1.175.

- Alfonso, hijo de Pedro Ruiz, 723 .

- hijo dol alguacil Martín Mieacel, 1.128

- Allafí el Hortelano, $\%, 170$.

- ber Ali, 985.

- Alnáiz 96.

- Nlvarea, 265, 270, 425, 645, 964.

- Auculn, 6r, 124.

- Andirés, 1.154.

- Alldrés leen Mbulharzano 710 .

- de Andiujar, 554,945 .

- Antolin t Bruñidur, 1.113.

- el Arcediano, 14t2, 183, 6

- Armflder, raciollero, 180 , 486.

- artobispo, $111,462,183$.

- de Astorra? el Tintorero, 383,397 .

- Aslur, 1.045

- Azzabar, 569.

- hijo de Blanca, 1.009

- Martín Bono, 622,678, 864. 1.124 .

- Cabezo, 649.

- caid, 227, t52.

- el Calero, 185.

- Calvo, 78.

- de Canales, 253.

- el Carmadf de \&umilla?, 692 .
Wartion ki" ;"ystella?, 652.

- Caslel]ano, ist).

Chofes, atciproste, is, pio, tof, $176,503,534,515,572$ $603,(117,716,913,960$ $1.105,1.100,1.115$.

- Clenente, 922.

- de Grabisa, fid1.

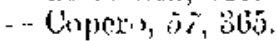

- Corde!, 1.011

- Comejo, 244.

- Corral, for

- Crespo, 284, 1.030.

- Cubero, 12f, 31 $\vec{\imath}, 347,944$.

- diácono, $730,35 \%, 040$.

- Dlaz, 17.,65i3.

- Dida\%, 1.012.

- Domiago, if.t, 79, IDI, $16 !$ $2 \% 2$, 4 ถิ?

- Domingo de AAldofoyo?, 540 .

-. ben Domingo Juanes ben Alurogivire, 1.064 .

- Dowingo el J'astor. 641,651, 6357.

- Domiugo rel P'escador, 711 .

- lijo de Domingo Lscude ro, $6002,66 \vec{i}$.

- Marten, lijo de Jumingo, hi jo de Romún, híjo de Juan Muchacho, 1.065 .

- lijo de Domingo Rubio, 490,789 .

-- Domingo el 7apatero, 843.

- Dominguez, 62, 195, 212, 117, 278, 321, 559, 594, 653, $765,1.17 \%$.

- Dominguez, presbitero, 185 , 675.

- Dotriniquiz, Durge], $6(6 \%$

- Nisquerdo, 103,230 .

Esteban, 218, 350,504

- Estelarn el Horlelano, 584, 013.

-- hijo de Listelian Julianes, $1.05 !$

- Eslétuanez, 170.

- el Fahaqui, 428.

- lielices, 199,326 .

- Félix, 161, 1.008.

-- Ferminde\%, 60, 622, 630, 716,861 .

- Fernández el Carmadl, 934 .

- Feruóndez Pantoja, 716.

- ben Fernando Gonzálbez, 1.117.

- hijo de Fernando Gonzálbez, drle Escarchir?, 1.065.

- hijo de Fermando Petrez el Portugales, 783, 922, 960 . - Filiz, 44, 54
Martia lixines, comes, $t i j$.

- linrón, canónigo, fzo, 179 , 503 .

- Gálib, 358 .

- Lialib el Dirhem y madio, (i) 49 .

- Gareés, 222), 353, 121, 940.

- Garcia, 99, 1.13, 167, 622, 636,682 .

- Ciarcia de Nbra, 634.

- Gaufradi o Cholie, canoni. go, 179

- Gil, b49.

- de Grandede, 722.

- Granndixij, 88

- Gómer, 267, 7u1.

- Gonzalbez, 12 !.

- ben Gonzalbo, 688.

- hijo de Gonzalbo el liubio, 824.

-- Guillén, clerigo, 180, 505 , $6174,642,781$

- Harube, 64, 192.

- Hastie], 818.

- de ias Heras, 689.

- cl Herrero, 480.

- de IIuescr, 654, 715 .

- Illán el Pescador, 66, 953.

- Ionjunes, 25.

- fili Ioani6, 42.

- Iohannfs, 82.

- Jaquina, 55 .

- hijo tle Juan FidaJgo, 776.

- ben Juan Martinez, 1,155.

- ben Juan Petrez, afo.

- Juanes, 64, 94, B40, 188, $239,689,917,1.061,1.062$.

- Juanes, alguacil, 222.

- Junes Aljanac, 960.

- Juanes ben Assidai, 913.

- Juanes ol Molinero, 572 , 913.

- Juanes, hijo del sidani, 572.

- ben Yúnus bon Tamí, 344.

- hijo de Justa, hija de Temam, 38,39

- el Laíti, 143.

- de Lrón, 521; 769, 1.027.

- cle Loja, canónigo, 180, 723.

- hijo de Lope, 224.

- Iopez, arzobispo, 55, 59, 61, $161,175,179,180,194,286$, $318,322,329,384,335,344$, $349,628,1.127$.

- Lopez, hijo de Lopatón, 846.

- de Madrid, arcediano, 164 .

- maestro, $170,181,184,234$. 2.39.

- Nartín, 169.

- hijo de Martin el Lencero, 593 . 
Miartín, hija cle Martio Pas cual, 1.088

- Martinez, 79, 288, 322, 596, 964

- Martinez Andrés, 821.

- Maliro, 646.

- el Medidor, $6 r$.

- Meléndez, 1.054.

- hijo de Melenilo sabico 72\%, 1.096 .

- Micall, 60, 225, 25/, 120, 204,380 bis, 47., 1.123 1.168.

- Vical, alcalde, 220, 5\%6, 610.

- Micael ben Aljarraz, 894.

- Micael, 789.

- hijo de Micacl el Cabezudo, 612,691 .

-- Micael de Maqueda ben Al bazo, 824.

- hijo do Micael ben otmán. 407 .

- Aben Moauia, 14

- de Mosquera, 587, 988.

- Muniz el Adalil, 9 i

- Navitro, 689.

- de cllias, abogado, 109, 840 .

- ben Otwán, $79,941$.

- ben Otman ben Uazlan, 33.

- Pardo, 524, 583, 556 .

- hijo de P'ezro do Castro 291,323

- hijo de Pedro Domingo 526 .

- hijo de Pedro Nartin, 696 705.

Perez Abentorel, $16 \%$,

- Pérez el Alfayath, lis

- el Peón, 171 .

el Pescador, 64

- Petrez, 222, 3i, 112, 154 $440,452,529,5566,578,617$, $643,655,671,728,042$ $1.030,1.174$.

- Petrez, alguacil alhaquim. 920

- Petrez de flidsiljsa?, 389.

- I'ctrez, liray, :20f, 339, 1.127.

- l'etriz, 165, 1.097, 1.152.

- el Podador, 70,522 .

- Polent?, 256, 984.

- presbitero, 189, 19:3, 190 $195,73,378,508,627,402$, 1.152 .

- Raimondez, 22\%, 21, 157 964.

Ropostero, 226 .

- Romanis, 121.

- Rubio, 239, 288, 500 .

- Rubio al l3elutir, 670.

- Rujz de Bargas, 1.106
Martiu laus el: lortis, 1 (0) hijo de lity le lunes, 675.

- Salama hei Nuhoeba. 12:3.

- Sâlib, 224.

- Salvatores, $170,1.169$

- Salvatores, alguacil y alcalde, $22 y, 624$ Sardina, $1 \%$

- Sinco, \$43.

- Selma ben Alihucha, 37. sinches, 701.

- el Sirafi, tis, Bog, 1.114.

- Afirfos? el Carnicero, 820

- Tomé, 228.

- el Tuerto, sacristán, 1.026.

- (1) Ufaruf, 85:

- de Valencia, io, 35t, 4to. 951

‥ Yénequก, 63), 660.

-. Tapatero, 74 - Znleima, 1.097 .

Martins, 128, 166, 1.044.

- Guillén, 484, 455, $1.08 \%$ monja, 577,57k.

- hija de P'elayo, 601.

- hija de lamilo el Zajatero, 101 .

Martino, ar

Martinus, diaconus, 226, 425, $781,92 \%, 1.006$.

- Iohannis, 572.

- Micael, 984.

- Micaelis, 75s.

- preshiter, 47, 482,487, $1.012,1.09 \mathrm{~A}$.

Natea, $60,142,16 \%, 215,187$, 9) $6: 3,1.005$

Mateo, $l 84,107,1.076$.

- hijo do Estebar el Siquili. 50 li.

--. ben Jálid, 1.049

- maestro, 184, 212, 70\%, 1.084, 1.118.

-... Micacl, $1.12 \mathrm{~s}$

- hijo de Micael ben liurón. 503 .

- presbitero, 251.

Matens, 199, 200,222,333.

- abad, $189,4 \% 2,628,544$.

- ben dAlchreramen?, 805.

- el Areipresto, J65, 776,512 .

- ben Assiguili, 775 .

-- ben Cobrián, $515,1.022$.

- ben pirón, 80, 1.141 bis.

- el Hortelano, $\$ 0,915$.

.... hijo, de Illán Srzlema, 273.

- hijo de Iuan 'Tabernero. 682 .

-- hijo de Julián ben Bablul, 411 .

- hijo de Julińn ben Selma, 305.
Yaltecs fulianis, 411 .

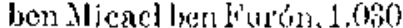

- hijo de Mieacl bon Furón 989.

de Oligs, 7iz.

- hijo de Pedro Vieente, 954.

$\rightarrow$ Potrez, 46.5 ,

Mateus, 411.

- diaconus, isis.

- J.azmri, $85.7 .76,94$.

- Iazarm, 397.

-- l'intor, 1.1138.

Mathe?, ]s

Matheus, prestitur, 417

Natias canójigo, $170,180$.

Maliner, Alarve de ben, 18

Matri, Doria, shtadesa, 2ot, 12 $114,124,149,170,188,193$ $802,803,923,1.038,1.042$ 1.068

Alfonco, $20 \%$

- hija de Alfonso, monja, 66:

Maura, Dona, 7$), 410$.

Mauricio, maeslro, 66,373 .

Maya, Dolin, 1.025.

Aayous? Jomingo, 515

Alayor, Doin, (7), 2(1), sid,

- Aifonso, 1si, 1.173.

- Alvare\%, $27 \%$

- Arias, $; 1$.

- Estcban, $19 \%, 1.173$

- Estélbancz, 28\%.

- Garcha, 608, 710.

- hija de Juan Mlicael, 713

- Jumes, 278

-- de Marín Pardo, 165

- hija de Pedro Illán, 726 .

- Petrez, 196, 320, 669, 795.

Mayor, Dona, $5: 3,193,359$ $458,460,524,533,550,754$ $783,832,850,859,932$, $1.003,1.022,1,0.30,1.104$

- hija de Abdelmélic, 111.

- Esteban, 985. hija de Esteban Amráu, 9:

- hija de lesteban llisn, 988.

- Esteban, monja, 19:5, 1.080.

- ben Gálib, 281.

- Conzalbo, 1.119.

- hija de Jun Domingurz, 888 .

- hija de Juan Micael, 718.

- Juanes, 1.030

- Micael, 71l.

- hija de Micanl, 618, 621

- Micaclis, 353.

- hija de Munio Petrez, 500.

- hija de Pedro Martín ben Abad, 664 .

- Petrez, 293.

Meana, Juan Gonzálbez, 724. Nedar, Don, $92,592,622,708$. 
Medar, hijo de Mengo, (i.t.j.

Medina, Dormingo de, 55 . .

Medinés, Pedro ben Sulcimin Masriquí, conocido por e] $1,115$.

Meir Jlahevi ben li. Isuae, /Ḧ, 1.135.

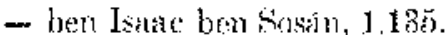

- ben Josel' ben Iravid ben Isaac ben Nelmmias, 1.131.

- ben Samuel, 50 o.

Meldom, $A$ ben, 2os., 9yt.

Melén Pérez, Jis.

Melendo, Don, alguacil $y$ aleatte, 32, $55,420,90\}$, $944,947,97,1.025$.

- hen Abdelaziz ben Lampa der, alcalile, $216,355,: 46$, 1.075 .

- el Adalid, 29\%, $18,154,171$.

- Arias, 13, 15

- Esteban, 326,395 .

- Irelices, 250, 326, 543

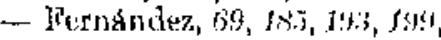
$205,206,211,216,229$.

- Pernández, hijo de Melendo, 1.025.

- Junnes, 619, 9.7.

- ben Lampader, 66, $70,1.154$, 1.158.

- - ben Iampader, algucueil y alcalde, $458,459,460,468$

- hijo de Pedro, hijo cle Fer. nando Nicaclis, 520 .

- hijo de l'edro, hijo do Juan Cebrián ben lfafs, 821 .

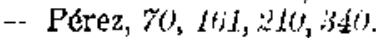

- Petrez, $27 i$ aris

- Suárez, 965.

Meigar, 1.107.

Meliana?, tul

Menahern bar Henyamin, 143 .

Mencia, Dona, 932

- Alfonso, 207 .

- hija de Alfonso el Arquero, 1.165 .

- hija de fernando Vicente, 1.173 .

Mencia Juanes, 921 .

- López, 196, 1.173.

- Petrez, 1.033.

Mendoza, Diego López de, 831.

Menéndez Pidal, Juan, 7.

Menendus Petriz, 157

Menga, Dona, 559.

- Gareia, 640, 661, 666.

- Juanes, 909.

- Martin, 190, 700.

- Petrez, 427.

- Sancho, 611, 637,670,1.109.

- 'Jomé, 385.

Mengo, 646 .
Mengo Mardin, 81٪.

- Nerguiz, 100.

- Periliguero, 690.

Herendo Bolini, 15s.

Mfcriti, $A$ li el, $2 ! 12$.

Meruim, dA dabal?, 1.016.

duetaucha?, 1.020

iccand, 131.

Mic sel, $5,: 34,644,824,1.018$, 1.098.

- Maestro, (338.

- el Abar 91.

- ben 1 bdalá ben Yahja, 805 .

-- Jen Abdelaziz, 84

- ben Abterrahmen, 815 .

- ben Abderrilimen ben Gasan, llamado Micaol $\Delta$ bazeid, 421 .

- ben Alultrráhmen, hijos de Pedro y lomingo, 142 .

- ben Abilhasán ben $\Lambda$ batzo, 800 .

- ben Mbixaber de San Gristóbat, 50 .

- Alirasto?, 62, 796.

- ben Alastiar, 1.016 .

- de Alba, 31, 298, 347, 362, 1.122.

ben Albazo, 10\%, 40, 280, 282.

- hen Alcarmán, $6 \%, 247$.

- Aleharut, 505, 512.

- A Alchel\%, 305.

- Alfonso, 2 .

- Alfuranję, 20.

- Algur, t.108, 1.110

-- Alguacil, 22:4.

- hijo del alguacil D. Julián Petren, 49, 50, 216

- hijo del alguacil Sir, 293.

- Jen Almocábar el Albañil. $2 \%, 4,5199$.

- ben Amir el Sirafi, 1.152.

- Amor, hijos de, 1.(28

- Angel, 279.

- Antolín, 432.

- arcediano, $18 \%$.

- Arnaldo, 252.

- Arnando, 77.

- ben Aron, 562 .

- ben Assal, 974.

- Asirach, 1.114.

- ben Assid, 1.156.

- Avernarar, 88.

- ben Azlón, 233.

- ben l3aqu, 7, 24.

- el Barbero, 997

- de Bargas, 142.

- Bellde\%, 3.52.

- Bellitis, 940.

- Benalsarqui, 943

- Bermóndez, 807.
Vicael, canonigo, 179

- Cansino, 7l,47\%, 501 .

$\rightarrow$ Cardend 235 .

- el Carpintero, presbitero, 90 , 1.049 .

- al Carpintero, hijo de Alcarmin, 561

- Cebrian, bi2, 63, lo3, ass.

- hijo do Cobrian el Alfarero, 266.

- hijo de Cebrian, hijo de Martín, nieto del Berniti, 249.

- Celirianez, 578.

- ben Chatur, $713,71 \%$.

- ben Uharah, 50.

- Chofre, 617 .

- Gidiz, $L()$.

-- el Comendador, liray, :202, $491,789,790$.

- cl Cormobés, 181.

- de Cuellar, 1.050.

- el de Denia, 127.

- diaconus, $6,15 \%, 266,456$, $459,1.15 \%$.

- Domingo, 223, 645, 909.

- hijo de Domingo $\Lambda$ bad, 72

- Domingo licn Altosell, 599.

- Domingo Asammar, 777.

- Domingo el Carnicero, 820 .

- hijo de Domingo ben Chá. biv, 777 .

- y Dowingo Juanes, hermanos, 74 .

- ben Domingo ben Otruán bou Guazlén, alguacil y at. cakle, $2201113,380 \mathrm{lis}, 798$.

- hijo de Domingo ben (otmán, a]guacil, 7j5.

- hen Jomingo ben Otmán, jot 2669 .

- Jomingo el ¿Sumsar?, 715.

- hijo de Jomingo ben Ja. xim, 246.

- Domingo, 1.030.

- Dominicis, 35

- Domingue, 67, 8\%, 99, 84, $89,250,341,408$.

- Dominguez, alguacil y al. calde, 291, 574, 604, 717, $806,948,1.118,1.123$.

- Domingues ben Abat, 117.

- Dominico, flio de Dominico Petriz de Pedro Acem, 124.

- Dominiquiz, tizs

- hijo del amin Jáir, 898.

- Esquerdo, 412

- Esquerdo, apodado el Bacrl, 747 .

- Esteban, 73, 74, 378, 395, $423,437,675,659,1,164$. 
Micael Esieban, canónigo, 4:36, 551.

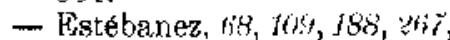
504

- Estébanea, dean, l6s, 175. $174,523,540,54,550,500$ $597,770,911$.

- el listerero ben Abiliátr, 1.161 .

- Feliz, 653.

- Jernandez, 701, 743, 959.

- de la skiguera?, Tdi.

-- Brtuctuosu, 8s.

- ben Gaiter 76,560

- ben Cidib, 1.1.2.

- Garar, 993.

-.. el Garbi, 701

- ben Garcia, j6i, 1.078

- ben stigrin?, 1.043.

. de (olpejares, $78,608,673$, 676.

- el Gomad, 663.

- cionzalbo, 237, 673.

- el Gordeli, 1.049.

- ben Hicam, 754

-- Haribas, 934.

- ben Meza Azajar, 136, 139

- ben Jalid, $73,1.129$.

- Jaques, 6.

- hijo de suan, 192.

- hijo de Juan AImahroc, 177 .

- hijo de Juan Meléndez, 514

- Hicael, hijo de Juan Joda dor, 748 ,

-- ben Juan Socrel, 242, 401, 591.

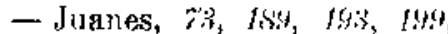
$326,3333,460,486,656,686$, 1.068 .

- Juanes ben Abiljáir, racionero, 5. $180,498,603,1.111$.

- Juanes ben Alasiar, 123.

- Juanes A safar, 208, 1.166.

-.. Juanes el Asfar, 943 .

- Juanes el Asgar, 581 .

- Juanes al Cantero, 82 $\bar{i}, 828$. - ben Juanes el Iisterero, 1.160 .

- Juanes ben Jáir, 581.

-- Juanes, presbitero, 741 .

- Juanes, racionero, 180, 117.

- Julian, $580,606$.

- Julión ben Cosuch, 585 .

- Julián ben Dasidel, 618,621

- hijo de Juliana Rovira, 689.

- Julianis, 87, 20\%, 1.014, 1.164 .

- Micael de Jadrada, 587, 789.

- Lazaro, 3ŏ3, 196, 205, 247, 905,943 .
Hicael, bijo de Jázaro, 180.

- de diandrada?, 54.

-.. hijo rle I,ope el Juabero, 1.106.

- Jopez capellán, fox. 1.085.

- Torenzo, if3.

- Lorenzo isen Mofárech, 351. Madías, $5.3,1.048$.

- minetro, racionero, 180 .

- Martin, 101, 333 . ben Nartinus, 986 .

- apodado Natamoros, 1.054

- ben Mateo ben Jálid ben Sabah. 600.

-.- mayordomo del obispo, 944.

- Milles, 64, 384 Mjdis, $87,26,198,1.005$, 1.007 .

- Midis, caid, $210,1.042$

- Mitís, $22 \pi, 29$.

- Mitis, alguacil, 28, 970 .

- el Mobchib, 1.009.

- el ¿Alogrebf?, 959.

- Muñoz 631.

- Navarro, $223,700,1.057$.

- Navero, 321.

-- de Oliolas, 415.

- Oreja, 743 .

- hijo de Pedro de ..., 683. hijo do Pedro Alcarman, 581,738

-- hijo de Pedro de Dios, li81.

- hijo de l'edro t'errero, 762, 763

- hijo de Pelácz, 62, 292.

- el Poscador, 179.

- Petrez, 6ij, $7150,155,192$, $263,300,332,383,360,437$, $573,630,942,1.15 \%, 1.158$, 1.165.

- Petre\% ben Mcarmán, 302.

- Petrez dintalejo?, 7 di.

- I'etrez, apodado Arillo, 1.007 .

Pelrez, canónigo, $17 \%, 200$.

- Petrez el Carnán, 471.

- Petrez el Fapatero, 958. Petri, 215, 976.

- ben I'etro, 23\%.

- Portagira, 44.

- presbitero, 187, 189, 150,196, 197, $199,237,33,76,360$. $380,467,472,544,810$, 1.012 .

- el Quibbal, 252.

- el Ray, 449.

- Kepti?, 1.167:

-- de Rinales, 790 .

- Sabib, $7,350,140,496,550$, 560 .

- Safuro, 63, 898.
Micael, hijo do salvator Jtanes, 71 .

el Sarafi, $69,1.152$.

- Selma, 80

- Serhario, 492.

-.. hijo de Serviti, 19:

- el birtati, :370, 4.5.

- Stepinani, isto.

- Eubdicono, 1\%, 19: 121

- ben suero Peter, 1.19?.

.... ben snloimán, gy.

- Tarín, tir, $126,136$.

Tizon, 125, 338, 798, 806 , 971.

- ben Tomé Jũigue\%, 24.

- Dorningo ben el Toseli, 566.

- Elianiz, 968

- el Vainero, fis, 1.115.

-- Zacarid, Jiz

*lajaris" $: 32 \pi$.

- Tambrano, 1.101.

-...- Zamerano, 222

Yaques, 272

- Zalcma, 88.

Miclatel, dlaconus, 389), 1.012.

- Iohanis, presbiter, 277 . $400,4 ! 10, \because 11,1.011$.

- Radge, 832.

Midis, Rama, hija do Mieael, $92 \%$.

Mido, Don, w, 1.005 .

- hijo de Mrias, 197, 288

¿Nielsima?, 75 .

Niguel, Fray, $2(15,2 \%$,

- I dizuro, 2ft.

Miguelez, zbis, 983 .

- hijo de I'edro '/aragoza el Escudero, 975 .

Mihraz, Mben, 302.

Mikael iben Hartín, 21.

Milia, Dona, $58 \overrightarrow{\text {. }}$.

- de Olias, Donta, 549

Millás Vallicrosa, José María, iv).

Minguez, Domingo, 641, 933.

Minguijon, Juan, 689 .

- Isurent ben, 710,720 .

- Maria Lorente, hija de Pedro, 869, 854

Miraglo, diil te, 488 .

Miriam, 1.029 .

Misan Suárez, Doña, 1.024

Misia, Doñ., $166,205,350,144$ 995.

- hija de ['edro Micael, 132. Mito, Jon, 797 .

- Arias, 27.

Mocacaxa la Judia, $148,186$. Mocam, Pedro Esquerdo, hijo de, 372 .

Mocátil, Aben, 42 .

Mocarrem, 1.016 . 
Mochares, Esteban de, 1.128. Mosé ben Pratal, 75.

Mochel, Don, 154.

Mochicl, Don, 316,902 .

- el Carnicero del Arrabal. $312,375,376,378$.

- e] Carnicero, hijo de Peclro, 302.

Modartani, Juan el, ij:30).

Mofarech ben Abdelterc, 12.

- el Cazador, 731 .

- ben Járir, S.

..-- Jèn Otmán, 3 .'.

Mofomath, $/ \mathrm{il}$.

Mohachir, tmima, hija de Dbraham ben, its.

Mohalto, Joina, 689

Mohámed Almograc, (jis, 898.

- Almenari ben Alquinán. 790.

- ben Mohámed el Ansurí, apodado $\Lambda$ lintim, 2:2.f, 168 .

- ben Ibrahim el Cazloni, 634.

Moharech, Aben, 495.

Moharis, hijos de, 582 .

Mohariz, adarve de $A$ ben, .39.

Mohib, Aben, 710

* Mohic el... el jeque, 517.

Mohiel el Carticero, Don, 185 , $197,950,1.022$

Momachama?, 242.

Montalban, arcipresto de, 1.164 .

Monte Pesular, Montyellier, Borgoñon de, $t f 1$.

Montreal, Domingo Petrez de 593.

Monudias, $116,25 \%$

Morarelia, Moraleja, Gil de, 103.

¿Moranxi?, I'edro el, 1.049.

Moratón, ;is.

Morcheni, Juan Pedro ak, 62, 486 .

Morechón el Caruicero, 1.109.

Morisquita, Doña, 75 .

Morlenas?, Juan de, 702.

Mosé, 148.

- ben Mbralian ben Alazara, 144 .

- ben Caparela, 75, 1.135.

- ben David ben Abu Dar ham, 146 .

- Halevi ben Haim Halevi ben Jarada, 1.139.

- ben Hiya Aben Sahalón. 150.

- ben Isaac ben Alurabam ben Sosán, 150 .

- Iren Isaac ber Nalımias, 149.

- ben Yahia Partal, 1.197.

- ben Maquir, 148.
- ben Salomón \&Natán? ver Falcon, 1:ab.

- Hacoher ben Josef ben Mojalnum ben Jloohen, tho.

- Halazan ben Josef Hahazán, $l . j 1$.

Mosquerm, Martio de, 587, 988.

- Rily Murtinez de, 610,615 , $61-61 s, 0 i 20,621$.

Motajrif, Román ben jestelan ber, 505 .

Motilla, Pedro Domingo, $6 \$ 9$.

Mozah, I laud ben suleimán ben, $1: 68$.

- hijo de, 1.045

Morárabes, 117 .

Hozimodi, $\mathrm{l} / \mathrm{l}$.

Munia, Doña, 6\%, 675, 7หg.

- Armilde\%, monja, $20 \%, 817$, 911.

- hija de Garcia ben Forcacho, 4is.j.

Munina, $14.1,20,27$.

Munio, Don, candnigo, $16 \%$, $17 \%$

- Abad, 370.

- alguacil y alcalde, 355,157 , 544,944 .

- Amucho, 335, 946

- Armllez, 274, 1.019, 1.073 .

- Botato, 1.153.

- el Bruñidor, 589, 631, 1.118.

-. el Cadí, 226 .

- Cobo, 248 .

- el Cojo, 348 .

-.. el Curtidor, 6i), 607, 820, 1.109 .

- Diaz, 1.10j.

-.- Domingo, 226, 235.

- Dominguez, 647

- Fermáadez, 7, 9. - Garclez, s9.

- hijos de, 7238 .

- Juanes, capellan, 178, 1.084 .

- Micael, $10 t$.

- hijo de Micael ben Abilhasáu ben Altazo, 164.

- Petrez 93

- Petrez, alguacil y alcalde $219,79,305,346,377,463$, $466,469,500$.

Munius, Alfons, 968.

- canonicus, 608 .

Munno, 171.

Muñoz Romero, 118, 121, 192, - Soliva, $J 81$

Murcheni, $\mathbf{E l}, 337,398$.

Mrursil el Judion, 76 .

Murs!, Y'isef el, I4s.

Murciano, El, 391.

Musa, Abubarún, 148.
Musa ben Mbaruhi, 145 .

- ben Alberuchi, 834 .

- Alcohen, 74

-. el Barluehí el Badin, apo. darto el belal, ifis.

- ben Bartel, T14

-. el Cohen, 119

-- ben Ibrabim ben IIabib, 147 .

- bern Islade Carballo el Sastro, 1.55 .

ben Ismael ben finalid, 117 .

- hem Nuel, R., 1.15.

- ben Sosín, $1 \%$

- e lsrael ben Suleimán, 14t.

Nugrela, Domingo, : 32 .

Nahmias, 1.14, Jig

- Meir y Abraham ben Josef ben David ben Isane, L.9.

Narbona, $\mathrm{B}, \pi \%, 60$.

- Doña, 69, 131 .

Navarro, Abraham, $t 49$

Nazarena, hija de Abdalí el Polichent, $29 \%$

- hija de Juan Juanes, 240.

- Doña, 1.117.

Nazar l'etriz, 308

Nechma, hija de said ben slli, 380.

Nechima, 1.003

Nehemias, 1 \%?

- Mair ben Daud, 149.

- Mair ben Ibrahim ben, 149.

- Tbrahim Len don Musa ben Yusuf, 149.

- Mair ben Ishac ben, $14 \%$.

Nicolas, Don, 5\%, is $9,247,255$, $290,322,1.152$

-non, arcipreste, 5\%, 15\%, $f 76,91,92,141,295$.

- el Alfagem. 168.

- el Carpintero, 431, 485.

- dle Dueña? 478.

- escribano, 78,359 .

- Estébanez, presbitero, 225.

- Guillén, vicario, $17 \%$.

- ben Mesaud, 208.

- Micaelis, 310.

- apodado Mozolo, 1.123.

- hijo do Pedro Domingo el Adalid, 242, 401, 591.

- el Portero, 854

- presbitero, $198,200,198$, $378,1.053$

- el Tejero, $166^{\circ}$

- de Torres, 75.

-... vicario, $52,78,211,505,512$, 519,768, 1.106 .

Nicolaus, $103,114,149,359$ $375,101,417,1.053,1.099$.

Nicholaus, capellanus, 378 , 487. 
Nicholaus Rajmundi, filius, 65 .

Noaim, 71 .

Nozha, hija de Sald de Orihue. la, el Albañil, 938.

Nuar, Fernando Juanes ber Abi, 5.jtj.

Nudi, hija, del, 41 ?

Nunio, Don, $t 6 \% ;, 168, f 9 \pi$.

Nunnos Dominiei, 352 .

Nuño, hijo del alguacil Don Paris, 906.

- conde, $69,218,738$.

- ben Fortis, 978.

- Gonzalljez, 5(k)

- hijo de Juan Nuñez, 973.

- Juanes, 525 .

- Suárez, 112, 500 .

- el Tendero, Lifi.

COba?, hijos de Don, 992.

Obaid ben Asad, 2.

Obieco (jar'cia, 614 .

Ocaña, Domingo de, 543 .

Oelera, Doña, I49.

¿gier' 1.11,973.

Oliate, Domingo Petrez de, 678,688

Oliolas, Micael de, 415.

Oliva, Joña, 416 .

Omalhada, 24i.

- hija de Hasán el Ausarl. 152, 793.

Oman, Ishac ben Yasuf ben, 1.19.

Omar, 123

- apodado Becero, hijo de Ahmed ben Chámia el Sinhechi, 790 .

- ben Colombo, 732 .

- ben Selma, 6\%.

- ben Selma el JIiremi?, 796.

- fil de Yahie, 1.05t.

- bon Yahya ben Gaudius, 124.

Outalecha, El Haquim, $14 \%$.

Onquira, hijos de Abulrebia el, $1 . i 9$.

Orabona, Doña, 62, 63, 6f, 65, $69,7 t, \pi l, 202,212,253,271$ $355,182,202,315,209,832$, $360,430,443,488,514,533$, $534,537,515,570,572,576$, $579,608,627,668,776,801$, $815,832,841,913,1.024$, $1.026,1.113,1.114,1.175$.

- Doña, abadesa, $73,204,270$, $429,437,464,483,487,521$, $754,757,760,761,763,772$ $775,787,789,790,848,911$, $955,984,985,996$.

- hija de Abdelmélic ben Far. 8 绝 $n, 249$.
Orahona, hija de ciben Yamar?, 701

- hija de Aber sLayamoro? yoy.

- Alfonso, $75,26 \%, 604$

- Audrés, monja, $20 \%, 752$

- hija de Arnaldo Muñoz. monja 911 .

- Mrmildez, vis.

- Cobrianez, 633,577,578.

- Dia $4,124,675,1.028$.

- Diaz, hija de Yago Petrez, 694.

- hija de Diego Cionzalliez 590 .

- hija de Domiuga la Gallega, 530 .

- Pija de Douingo Poláez, $645,964$.

- Dominguez, 392.

- Esteban, 584, 770, 985 .

- Estébanez, 750 .

- Feliz, 653.

- esposa de Fidalgo, 934.

- Garcia, 698, 1.0\$0, 1.169.

- Gonzábez, 2012, 710.

- Guliérrez, 684.

- hija de Juan el Axiç, 56, 953.

- hija de Juan ben Ayub, abadesa, 463 .

- hija de Juan Chico, 738.

- Juanes, abadesa, 19\%, 201 .

- abadesa, hija do Juanes bon Ayub, 496.

- hija de Julín, 618

- hija de Lorenzo, 1.020.

- hija de Maria Domingo, 1.030 .

- Martinez, 195, 1.173.

- Micael, 700, 950.

- hija del Nudi, 413 .

- hija de Pedro, 233.

- Petrez, 73, 99, 202, 286, 276 $344,574,604,620,691,735$, $812,1.056,1.118,1.127$, 1.162

- Petri, monja, 808 .

- Ponce, hija de Pedra Ruiz, hijo del alguacil D. Ruy Ponce, 703.

- priora, abadesa, 812, 813, $814,815,817$

- Remond, 583

- ben Rinaldo, 1.154.

- Salvador, 214, 229

- hija de Salvador, 542.

- Salvador ben Fadel, 210. $269,1.021$.

- subpriora, 752 .

- Vicente, 715, 1.046.

Orabuena, Don̄a, 169, 171
Orchonio Alvarez, 5it

Ordoño Petrez, 744.

Oreja, Micael, $74 \%$.

Orgaz, 79.

- Salomón de, 1 iis

Oria, sacristana, fisti.

Oribuela, Nozha, hija tie Salal de. 938 .

Orgui, Ei, $22 \%$.

Osma, Juan obisno de, 974.

- Sancha, hija do l'erlro cion. zálbez de, 1.115.

Osmundus, episcopus, $1: 3$.

Osuna, Juar listeban di de, 465.

Oxemeior, $17 \%$.

P. Garsie, prepositus, 1.126 .

P. Garsie, prestitrer, 1.i41.

p. Gutierre\%, canónigo, tro.

P. (aterii, disconus, 1.0.t.

P. Iuliani, 1.106i.

P. Magister?, archipresbiter, 837 .

P. Magister scolarum, 978.

P., presbiter, 868.

P. Ronan, canonicus, 821. .

$P$, arehidjaconus, 968 .

P., tesaurarius, 801 .

Pacuda, R. Isirac ben, lits.

dPalat?, Jacob Jahazan ben Istare, $1.1 \%$.

¿Palomba?, Dona, t.j.

Palombino?, 96, 115

Jalumbin, Nicate, 998 .

Papin, 141.

Pantoja, Alfonso, hijo de Martin Fernadez, 878, 896.

- Pedro de, 536.

- Pedro Domingo Assacaz, liamado de, 600 .

Pardesal, 20\%?.

Pardo, Don, 456

- Isaac..., conocido por Haluzo, Jacob ben Salomón, $1: \pm 9$.

Paredes, Juan Andrés de, 4 .

Paricio, 200

Paricius, presbiter, 362 .

Paris, Don, 67, 198, 294, 111, $128,166,1.008,1.098$.

- klguacil y alcalde, $2 \% 0,006$.

- Martín, $650,185$.

- Pelrez, 735.

- Petri, 114, 735.

- Don, presbitero, 197,375 , $376,401,406,950,1.022$.

Parisius, 98.

- Petri, 733.

- presbiler, 378.

Partal, Mosé ben Yahì, 149.

Partel, $A$ ben, 1.

Pascual, Don, 62, 165, 14, 130 , 
$165,169,435,506,518,559$, $563,501,722,1.160$.

Pascual de ddjunio? 689.

- de la Alameda, 705.

- nieto de ¿Collo ilbillo? $22 k$.

- el Carmadi, 571, fis.

- Domingo, s7, 1.16t.

- Domingo ol Carricero, 567 , 615,820 .

- de Estibel, 151.

- hijo de D. GFoletrero? 60.

- do Jospital, wit.

-. hijo de Juan Petrez, 217, 22i).

- Juines, 256, 702.

.. Martin, 522

- Nuño, 263.

- Jotrez l Carnicero, $6 \%, 817$. dRileno?, 700

- Sincher, escrihano, 224t, 673.

- Vicente, 460).

Fascrala, Dona, $245,290,402$, $422,477,501,537,570,632$, $641,65 \%, 668$.

- hija de Pomingo de lsurgos, 652 .

- hija de Iomingo Janes, 1.018

- hija de Gonzalbo, 713.

- hija de Juan Allonso el Cur. tikitor, $1.0 \mathrm{~m}$.

- hija rle fltan de Hadrid, 60 , 900,015 .

- hija de Tope, 224.

- Jópe\%, 1.1130

-- Sinchez, 58.

- Sanche\%, cujiscoly, 1\%.

Pasqual, 201.

Paula, Doña, 64 .

- hija re Lope el Pescador, $60 \%$.

Paulo, Jon, 424.

- lon Aberribinen al Corti. dor, 318

- canonigo, $1 \%, 1,8$.

- el Racionero, 439

- cl T'uscli, 282.

- ben Yahya el Hertero, 812, 316.

Paulus, canoricus, 461, 1.053.

- Copeanus, 317, 944,

- filiug Iolianni, 88 .

- Ioannis, 136,336 .

-... presbiter, 142.

Pedrero, Fl, 289.

Pedro, Don, 55, 169, 180, 217. $306,368,37 \mathrm{i}, 559,641,713$, $786,1.013,1.026,1.069$, 1.174 .
Pedro Abad, 54, 61, 188, 160, $362,480,960$.

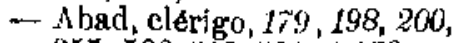
$355,506,523,520,1.122$.

- Abat, prestitero, 142.

- ben Abdala el Policheni. $209,240$.

- ben Abderrahmen, 80,282 , 942.

- ben dhderrahmen ben Yahya, 46 .

- ben Abderrihmen ben Yahya ben Harits, ajcalde, $203,219,1.038$.

Aben Omar Nbengaleb, 3 .

- ben Atisaid, 5 ti.

- Abril, canónigo, 71, 180, 644,712

- hijo de $\wedge$ btal, 238.

- Abusrmaj, 378. do Acramonte, 308.

- ben el Achami, 183.

- Achembert, canonigo, 17\%, 751 .

- Achol, 1.104.

- Agramonte, 1.101.

- de Agleda, 459, 494.

- ben $\mathrm{Nj \textrm {j }}$ tal, 197.

- Alazxar el hlfarero, 2as. 170 .

- el Alagïafi, 1.007.

- Alajame, $\therefore$.

- Alluacal, 184.

- Altañil, hijo de Bahjul, 23.

- ben Aleallas, eseribano, 1.016.

- Alcandari, 600.

- de $\Lambda$ leardete, 820 .

- Alcurmén, 69, 89.

- Aleocer, $161,182$.

- Aldozano. 179 .

- Alfonso, $283,4,729,890$ $801,892,955,1.025,1.046$

- Alfonso, alcalde, $22(1), 557$, $y 49,1.118$.

- Alfonso, canónigo, 180, 660.

- Alfonso, criado, 538, 715 1.111.

- Alfonso ben Omar ben A]. callés, 304 .

- Alfonso, teniente de alcal. $\mathrm{de}, 954,955$.

- Alforeena, 99.

-. Alguacil, alcalde, 119,120 , 220,741 .

- Albasín, 63, 192.

- ben Ali ben Mobarex, presbitero, 469 .

- ben Ali ben Maharix, 189. 311.
Pedro Almorávid, 152, 353, 905, 943 .

- Alvarez, 15\%, 198, 261, 900.

- ben $\Lambda$ mir, 61, 69.

- ben Amir, de Goadelajara, arcediano, 126,818 .

- Aodrés, 283.

- ben Andrés, presbftero, 191.

- Aramonés, 01.

- arcediano, 106, 203,345 , $126,130,133,139,162,968$, 1.057 .

- arcipreste do Jlloseas, 176, 810.

- areipreste de Segovin, 176

- Armililez, 4ri.

- el tryuero, 956.

- el Arriero, conocido por Abenmayori, 412 .

- Asacar, 152.

- Asayab, 235 .

- Aftur, 1.045

- el Bacal, 216, 974.

- ben lahilul, 2.44.

- el Balostero, Itio.

- Ballestero, 340.

-.- el J3arcanti, 853.

- hijo de Bartolomé, 020.

- Bayán, 16t.

-. Bayan el Ciego, 7is, 236.

- Benedjeto, 74, 830 .

- Jenián, 79.

- Bereto?, 328.

- Jernaldo, 2fo.

- Berraldo el Platero, 113.

- Bortiquel?, 724.

- hjlo de Bruneta, 1.013.

- caid, 227.

- de Calatraya, Don, 559.

- el de Camarena, 467.

- Camsino, 288, 528, 539 .

- de Cardona, $210,160$.

- de dCarmona?, 252.

- el Carnicero, li, 346 .

- Caro de Huecas, 917.

- Castajo, $\check{77}, 170$.

- Castellano, gí.

- de Castro, 70,317 .

- Celbriá3, j84, 164, 276, 344, :363.

- de Cuenca, $6 \pi$.

- ben Cluarah, 1.099

- Chasolin, 57, 291

- Chelahert o Gilbert, capiscol, $178,57$.

-Chelabert el Imam, 73.

- Cidiz, 1.167.

- Cobisa, 1.098 .

- el Comerciante, 111.

- Conde, is, 4.

- Concjero, 61, 355.

- el Cordobes, 218,357 . 
Pedro el Golvo, 526.

- Cosa, 817, 899.

- Criado, 75.

- Criador, $\% 0,2 \pi \%$.

- Cruzado, $113,218$.

- Cubo, 550

- de Cutrner, 44.

- diúcono, $19 \%$.

- Dlaz, 69, 206, 227, 75, 100, $104,120,293,1.030$

- Dar el Caid, $360,267,818$, 740, 1.100

- Didaz 120

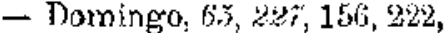
$287,289,284,412,474,506$, $607,726,801,824,820$, $1.018,1.020,1.049,1.101$.

- hijo de Domingo el rdalid, $407,1.174$.

- Domingo ben Alfelus 107.

- Domingo ben Almatrón, 345 .

- hijo de Domingo el Bordador, 236,312 .

- Domingo ben Asizfa, 480.

-- Domingo Assacar, llamado de Pantoja, 600 .

- Domingo, hijo del Tunniti, 333.

- Domingo el Chanceller, 164.

- Domingo ben Charrah, 66 , 586,953 .

- Domingo ben Domingo Crespo, 81 .

- hijo de Domingo Juanes el Crespo, 912

- ¿Domingo el Cubo?, 556

- hijo de Domingo Julián, 682.

- Domingo el Hortelano, 1.049 .

- Domingues ben Hosain, 296.

- hijo de Domingo Martín el Crespo, 701.

- Domingo el Mocadem, 702.

- Domingo, hijo de Maran, $383,397$.

- Domingo de Motilia, 689.

- * Domingo el Ortelano* 5.47 .

- Domingo el Pedrero, if

- ben Domirigo ben Pedro Esteban, 1.172.

- Domingo, hijo do Pedro Juanes, 861 .

- Domingo Sahual, 214.

- Domingo, hijo de Servando, 489 .

- Domingo ben Servando, 1.030 .

- Domingo el Socán, 536.
Pedro Dom ingue\%, 200, 178, $174,206,830,892,1.016$ 1.105 .

- Dominguezben Alitas, 808.

- Duro, 549, 587, 762.

lindura, 169.

- dde Ensenes?, 85.

- EEscarjir?, alyuacil y al. calde, 2200,435 .

- Escudero, 957 .

- Eaforzat, fit.

- despiga? $60 t$.

- Fsquerdo, 216, 73, 47!, 497 762 .

- Fsquerdo, dbijo de Mocam?, 372.

Esteban, 73, $7 \%, 180,20 \%$ $237,88,139,318,339,403$, $565,623,689,701,740,783$ $959,1.036,1.043,1.100$, 1.102

- Esteluan de Aleardete, 915. 820 .

- Esteban ben Anurún, 807.

- Fistebar el (arpintero, 480.

- Esteban cl Gallego, 754 .

- Jisteban ben Mayín, 68 , 292.

- Esteban el Molimero, 206, 1.162 .

- Esteban ben Molue, 171

- Istébanes ben Iampader. 537.

- Estebanez, 798.

- Fstebert? 486.

-- Bstéfano, 69.

- Facundo de Borox, 894.

- Fanega, 974.

- Felices, $141,206,252,654$, 1.162.

- Felices, presultero, 108,679 , 962.

- Heliz el Díacono, 5jo.

- Ferninde $z, 166,200,172$, $550,586,816$.

- Fermandez, alguacil y alcalde, z2t, 1.064 .

- Termélidez, hijo de Cristo. bal de Bargas, $j 663,1.115$.

- Fernámelez, frajle de la Orden le Predicadores, $8 \overline{5}$.

- liemández Iópoz, 702, 1.0034

- Fernando ben Hicach, 1.020

- Fernámdez de Pantoja, 19,3 199.

- hijo de Fernando Micaclis, 421.

- Ferragut 2\$6, 1.014. ferro, 269,194 .

- Ferro de Rielves, 427.

- Fortusio, 743.

...- ben Fotuh, 64.
Petlu, fray, 203, 204, 123, 388.

-- Furón, 980.

- Gallego, 104, 204.

- Garcés de Lerma, 18k, 183, 274.

- Garcia, 301, $318,401,474$, $557,575,689,649,710$, 1.100 .

Garcia cl Abad, 689.

- Garcie, hijo de Andrés de Chlataynd, 826.

- Gareith, (untimigo, $17 \%, 309$, $337,396,451$.

- Gareia, preboste, 175.

- Carcla Petrez, 723.

- de la Caseá, 1.045.

- Gasco el Carnicero, 112.

- Gebert, canónigo, $179,535$.

- Crelabert, 1.154.

- Giralilo, 198.

- Godino, 107.

- Gotino, hijo de Pelayo Go. dinez, 380 bis (d).

- dTonzálbez?, 343, 687,951.

- Cionzúlbez, alguacil y alcalde, $221,959$.

-... Gouzalbo el Deni, 1.17\%.

- hijo de Gonzalbo Juanes, 1.000 .

- gramático de la Catedral, I2:3.

- Guillelmo, 3i0.

- Guillem, 416, 576 .

-- Guillen, $16,7 \pi, 291,981$, 1. $048,1.16 \%$.

- Guillén, arciprestc, 176,837 .

- Guillén de Barcelona, 171.

- Guillen el Curtidor, 323.

- Guillén el Socán, 456.

-. Guter, 689.

- Guteris, 1.043.

- Gutierrez, 1.045, 1.118.

- Guticrrez ol Sastre, 645, 1.109 .

- el Facham, 509

- Hafsún, 477, 501, 537, 570.

- ben IItquem, 92, 141.

-- Hobais, $\%, 524,533$.

- Homán, 526.

- el Hortelano, 380 bis (e), 407.

- ben Hosain, 221.

- Illán, 45, J6h, 172, 179, 199, 2018, 544, 710, 714, 1.045.

- Illán bon Abdelhamid, 540 .

- Illán Barraśnan, $1 \%$.

- Iñiguez, 970.

- hijo del alcalde D. Illan, 882.

- hijo de Illán, hijo de Ismael, 764 .

- Illán, presbílero, 559 .

- ben Isa, alguacil, 220, 305. 
Pedro len Jàne $32,42,42$.

- bete Jala el zapatero, (i).

- Jilil, 136.

- 3itim, 75ti.

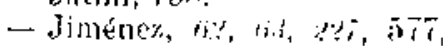
(32), ti: $1,721,1 . \mathrm{i} 13,1.114$.

- Johan d (Jlero, /tit).

- Jolamis it.

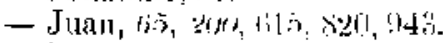

- hijo do Juan el Aluracil. hijo the l'entro Alguneil, for.

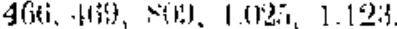

- hijo de Juan ébrián, S15.

- Junnes lijo le Esleban e.

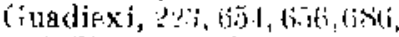
$6 ! 18,701,404,062$

- hijo the duan lermindez. 6is8, 70

- ben Inan ten filladid imen Casim, 1:2\%

- hijo de ollian Putro, alyuacil y aleatale, ses.

- hijo de Juari el lolicheni, 25?, 262

- Juanes, sis is iti is ets

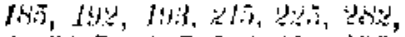
$4(6,59,76,157,211,306,325$, $333,281,10 \times, 316,(630), 675$ $944,1.153$

- Juanes, alculde, ?:3): (558, $692,693$.

- alguactl, 13., 151,5-4i, 55\%, $609,639,644,712,716,782$, $839,847,448,851,008,957$, $95 \%, 990,1$. (K) 2, 1.047, 1.083.

- Juanes, hijo do id djarofi seco?, 413

- Juaners her Almajiric, 186.

- Juance, hijo del aunfi Jair, 80i).

- Juanes Andabis:, 1.51,

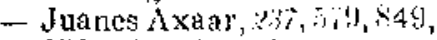
$850,852,8,3,454$.

- Juanes cl bulsile, ti:

- Juanes el Citib, 50is

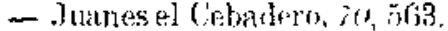

- Juaves el biscrjbano, ix.

- Juanes ben duan Jomín. guen, alcalule, $x: t$.

- Juanes, hijo de Juan Dominguez, hijo del Comerciante, alguacil $\mathrm{y}$ alcalcle, 676.

— Juanes, hijo de Maria, 573.

- Juanes el Nádir, 415.

- Juares el Poluquero, 791.

- Juanes al Polichení, 368, 513 .

- Juanes, presbítero, 685, 726

- Juanes el Secretario, 698.

- Juanes, hijo de Servo, 501.

- Jucelin, $36 t$.
Pedro Julian, 100, 102, 262 $204,308,470,556,696$, 1.076 .

- Julián ben Abdelhamid, 560,506

- hijo de Julián ben Albazo, 302.

- dulizin de Asomail?, 604 1.118.

- Juliźn lien Temail, 835.

- hijo de Julian Peljt, 162.

- Julicini 41

- Lamberto, bs, 263.

- ade latrado?, 1.044

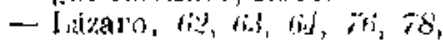

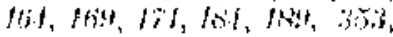
\%3, 189, 204, 227, 325, 333, 到 372

- Lazara ben Alulelcuj, 490.

- hijo de I akaro ben All, 249.

- Inkaro presbitero, 24i, 2is $311,342,375,376,379,380$, $388,394,411,439,1.078$.

- Inzaro, presbitero, imán, 301,952 .

- Iron, $121,205,325,747$, $355,9305,1.025$.

- hijo de Lope fernández, 1.034 .

- I,6per, fici, it58, 381, 1.028, $1.030,1.164$.

- Loper, diácono, 45i, 543 .

- Jorenzo, ti2, 2\%6, 852, 986, 1.114 .

- lien Maaruf, 65, 1.049.

- maestro, canónigo, 180,608, $617,644,712$

- Maharis, 76 .

- ben Mahares, presbitero, $1.09 \vec{i}$.

- Mumés, 586, 610, 637, 670.

- Namés el Carnicuro, 611.

- de Maqueda el Ticah?, 962

- hijo ale Maria Andrés, 125 , Iisi..

- del Marini?, 976.

- Marlin, H, His, tots, $21 \%$ 87, 10f, J15, 121, 191\%, 216, $24,873,898,612,691,943$, 05) 1 .

- hijo de Martin, \$12, 320 , 644, 712.

- Marlin Abengurrón, Nog.

- Marlín de Asanuga?, 385.

- ben Marín lien Bahlul, 23.

- hijo do Martín dCabello? 97.

- Martinez el Gallogo, 54,498.

- Martin Garcla, 695, 696 697,705 .

- hijo de Martin Gonzálbez, 121.
Pectro Martin el Zapaicro, 691.

- Martínez, f.l, fin, 22, 115 165, 178, 624, $928,1,173$.

- Martine\%, canóniga, 150 6it,

- Matens, 270, 166, 452, 469

- Mateos, hijo de Micael ben Jálid, $4 \$ 9$.

- Mauro, lir

- mayordomo, 262.

- hijo de Mayori, ayodaclo el Asion, 747 .

- Mazh, Mi.i.

- hijo cle Neldom, 241

- Meléndera, 615, 62\%.

- hijo de Mlelendo, 511.

- hijo de Melendo Suárez, (12)

- Melero, 587.

Mind, fsti, Jit: 52, 121. $194,239,246,324,574$.

- hijo de Micrel ben Alderwhthen, 211

- Micael djazio, Bio.

- Micaol ben Nlmocades, 502 $566,576,590$.

- Iner Micacl bei Amor ap. cediano, 80

- hijo de Micael ben Anir, 221

- hijo de Michel Angel, 578.

- Micael, arcipreste, Ma, 141.

- ben Micacl bon Bagul, 24.

- Micuel el iselian, 485.

- Micael el Belili, 434.

- Micacl ben Domingo Jua IIes, 722 .

- hijo de Micael Dominguez, 604

- hen Micacl Jominguez, 1.1.18.

- Micuol, bijo de Alartín Domingo, $711,888$.

-- Mineuijón, 720 .

- Micalel el Yebli?, 319.

- Micael el Zapatero, 998

- Mochir, 1.024.

-.- ben Mofarech, el presbitero, el xeyue, $18 \%, 466$.

- el sMoranxi?, 1.049

- el Moreno, 1.013.

-- Mrro, y2\%, 48, 126, 527.

- Muro, alcalde, 2\%1, 802

- Moro, hijo de Juan Petrez, 177.

- Morón, 994.

- Mozarabe, 1:3.

- Muchacho, 415, 1.061.

- Munio, 500.

- Maño, ₹(k), 11, 427, 559 . $584,708$. 
Pedro Munoz, arcediano, $t 7 \%$, $466,495,718$.

- nadir, $223,8 \%$

- Navario, 69, 265.

- Nicola, 234.

- hjo de Nicolás, 101, 407, $591,1.128$.

- Soel, 499.

- Noño, 201.

- obispo de Segovia, Iòt.

- ben Omar ben (xúlib ben Alcallás, 2\$: $360,941$.

- Ortiz, 1.024.

- Otmán, 515.

- Ovequiez, 2 2di.

- Paris, 6ir.

- Parisii el 7apatero, 207, 1.171.

- Pascual, 154, 705.

- Pedreg, $370,985$.

- Pedriz 4 .

- hijo de Pedro Wicael ben Aljamar, 985.

- Pelacz, 15, 110, 223, 527, $585,976,1,008,1.072$.

- hijo de Pelayo Cores, 596.

- Peláer, alguacil, 292.

- Pórez, deán, 165.

- Pérez el Rubio, gis.

- Petrez, 62, $t 33,226,227,239$ $192,293,336,370,608,735$ $956,1.056$.

- Petrez, caid, 277, 796.

- Petrez, canónigo, 180, 782.

- Petrez el Conejo, 1.174.

- Petrez el Negro, 385.

- el Polichenf, 287, 386, 387, 449.

- cl Polichent, hijos de, 273, 396.

- Ponce, presbitero, 134, 187 18.5, 200, 26: 114.

- Rajmundo, 59, 72, 117, 230, $329,386$.

- de Rivas, 449 .

- Rodriguez, 303.

- Rodriguez de Azagra, 104.

- Roldán, lesorero, i7, I7t4, 178, 212, 660, 918.

- Román, 17ti, 628 .

- Romá, canónigo, 180,544 , $585,608,821,912,1.049$.

- bijo de Romero, 990.

- el Royo, 1.012 .

- Rubio, 121.

- Rubio, apodado al Pardo sal, 805 .

- Rufo, 106.

- Ruiz, 227, 439, 538, 1.028

- Ruiz, arcediano, $176,17 \%$ $179,180,452,548,599,600$, 1.156.
Pedro Puiz de Ferrerolo, 400.

- Puiz de Ferreruela, 608.

- Ruiz a.Musid?, 744, 767.

- Ruiz, bijo de Lodrigo Jaanes, 723 .

- Ruiz de Talavera, 1.024 .

- Ruir de Val de Abixa, 582 .

- el Sacristán, 721.

- bon Said, $6 \%, 238,330$.

- Sala, 743

- Salbat, Lir.

- Salema, 350

- Sales, 160 .

- Salvador, $\$ 17$

- Salvador ben Paz, 431.

- Salvat, 382.

- de San Cebrián, $1.085 \overline{\text {. }}$

- Sanchen, 681, 682, 835. 1.029 .

- Sánchez de Funes, 678, 688.

- Sancho, $70,18 \%, 18 \%, 192$, $193,107,199,20 \%, 20 \%, 214$, $229,1.028$.

- de Santo Domingo, Fray, $18 \%$

- el Sastre, de Segovia, 20.

- Sebastian, 237.

- ade Sedet?, 560, 563

- Segura, 800 .

- Sclma, $20 \%$.

- Serrano, $15 \%$.

- Serrano el Herrero, 19

- Sobrino, 195, 251, 298.

- Sobrino, canónigo, tra, 142, 241.

- Solis, $S 9,218,1.000$.

- Sordo, 1.006. 1.051. Soriano, hijo de l'ascual, 713.

- Suárez, 6at, 906.

- Suárcz alguacil y alcalde, $2 \% 0,572,506$.

- hen Suleimán, 163, 27:3.

- Len suleiman el Mrsriquí, conocido por el Medines. 1.015 .

-- Taaliquis, 20.

- de Talavera, arcipreste, 52, $776,295$.

- tesorero, trs.

- de Tolosa, caid, $\% 9,80,12 \%$, $203,227,53,166,466,733$, 799.

- Tolosa, hijos de, 735.

- Tomas el Triguero, 72, 668, 676.

- hijo de Tama, 58.

- de la 'Torrceilla, 842.

- Valterra, $7 \%, 428,533$

- Velasco, 181.

-- el Vendedor, 1.099.
Pedro Vicente, 2223, 248,327 , 1.049.

- hijo de Vicente de Murgas, 71 .

- Vicente, ciid, 628.

- Vicante al Eserilano, 827. 962.

- ben Tisente ben Ricaet ben Yaix, 1.164

- Silla?, 1.11?

- Vinal, 37).

- Ximónez, presbitero, 896.

- ben Yahya ben Abilharits, 1 ials.

- hijo de Yahya ben $\Delta$ billarits, $212,22 \%$.

- ben Yaix ben Charah, 55, 1.095.

- Yobaco, 249

-- Yofac, 236.

- Zamorano, 22?.

- Zapatero, 95, 819, 1.07.

- 7arco, 1.15\%.

Pexiroche, 75 .

- el Arquero, t5, 195.

Pedrueho, hijo de Fugenia, 1.018.

¿̨Peláez?, 131.

Pelagio Dominiciz, 26.

- Gudesteiz, 120.

- Petriz, Jizo.

Pelagius, $15 \%$.

- Hellidiz, tist.

- diaconus, 357, 974 .

- Erigis, 120 .

I'elai Dom iniciz, 18.

Pelay Golinez, 99.

- Gutiérres, $1 \%$.

Pelayo, Jon, J69, 186, 199, 253, $2133,344,1.018$.

- Andrés, 112.

- Boro, $1 . n 67$.

- Calvo, 30 .

- al Carticero, 341.

- Crespo, 112

- sChucho? 45 i.

- Dominguez, 773.

- de Girrganda, 3.

- Garganta, 52, $18 \%$

-. (rodine\% 407.

- Gonzalbey, s8o lis (e), 407 .

- Juanes, 46, 557, 576, 1.049.

- de Jagarda, 815.

- Murtinez. 94. 260.

- Nazareno, 123.

- I'ascual de Almonacir, 855.

- Pastor, 1.049.

- Peláez, 114.

- Pelàez, ¿Veles?, 85.

- Pérez de Frómista, 57.

- el Pedrero, $16^{2} 4$. 
Pelayo Petrez, 2?; 11, 331, $373,1.107,1.110$

- Petre\%, cuid, 109, 50\%, 1.098

- Petrez de lirómisla, caid, $297,112,734,1.027,1075$.

-. pregonero, $3 \pi, 1.044$.

- prestitero, for, $401,513,501,76,5,4 ; 5$.

- el Rahajui, ii, 4lit, 419, 140 .

Rodriguer, 805 .

- Salvatoris 11.

- Sidahihi, s15.

- el Tormero, 1.1!it.

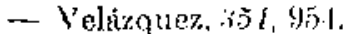

- Velez, 527, 520, 5\%5.

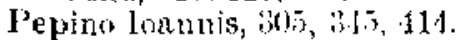

Pepion, 145.

Pórez do ollola, J., pit.

Pero loppez. ?:5.

- Iornuz, 1.17\%

- deT'alamanen, bijodejoña Jimena, !(6).

I'etro, 117, 344.

- abbate, 438.

- Allaeen, 84, 98

- Arbarez, 59, 1.069, 1 . 1 s.

- Auriensis roiscopns, lir.

- Bellitiz, 1.012.

- ben Didaco ben Jillo ben Jesteban, 1.1 $\vec{i} 1$.

- Dominico, 100.

- ben Feliz ben (rartia, 1.1.58.

- filis Iontris, fer.

- Ioanes, 1id, itti

- loamnes, 1 sí.

- Iuanes, $211 . . .1$ 1.., 211.

- Iullami, sis.

- ben Juan ben Estalan ben el (inadiexi, 1.152, 1.163, 1.17 .

- ben Juan ben Tones ben Yaliya ben Polatyi, 1.1.56,

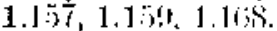

- ben. Juanes ben cimalill ben Cásim, 1.15\%, $1.1[3]$

- maior, lis.

- Nauro, 1.152.

- ben Micasel bro Juanes bron Otman, 1.170 .

- Nigro, 94(0).

- ${ }^{2}$ Pelagiz», 940.

- ben Omar ben (xálib ben Alcallás, 1.154, 1.158, 1.174.

- ben liomán, 1.156.

- Sonnrz, 120 .

- Stephaniz, 88.

- Talama, 105.

- Vicente, 1.157.

petrolo, 331 .

Petrona, Doña, 330, 384.

Petru Abon Garah, 1.099.
Petra Hbib, 170 .

- Iohannos, 49.

Petrus, Ilon, 1\%3, 1\%\%, 47, 149, 152. 393,060

- sbbas, canotices, 323,368 , 369,523 ;

- Albari\%, dijaconus, 108.

- Amnaya, lsi.

- Ansuriz, romes, for, Ar.

- Aprilis, cononicus, stit.

- Belongarii, stif.

- Clelaliert, uresbitero, 47.

- Comes s?

- coromatus gio

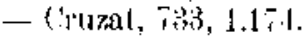

- diacomus. 111.1.11, 1.22, 149, $735,9123,1,(k 11,10.191,1.129$

- Dominies, 12\%, 1.121.

- Dominiens. 280.

- Nstevam, 38 s

- Felice, 88.

- Fernamdi, prestiter, $\$ 37$, $3(5 x, 190)$

- liater, 2(19).

- Carsia, presbiler, 2lir.

- cindisalvi, 176.

- Inhammis, 157, 775.

- filio I canis, 8i, 62, Lit.

- lulian, 1.y2.

- Iulinuiz, 1.012.

- Latmeneij, diacomus, $4 \$ 2$.

- Iazari, 375.

- Ifgionensis opiscopus, $16 \%$.

- maestrescuela, fir.

- migrister, tht, gits.

- nazarentis f piseopus, fort.

- iben Martim, glig.

- Mideus, 73 is.

- Micnel, 113, I.11, 92:3.

- Micanelis, 78

- Ortnlanus, Fil.

- Metri, ISI.

- I'stri, filius, presliter, 17

- Pejtriz, 327.

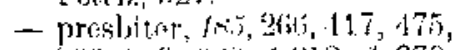

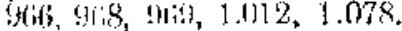

- Rodruci, dis, 142.

- Romenn, ramonicus, 821 , S283.

- Sebratiani, filius, gom.

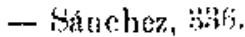

- Sancii, $378,401$.

- de Sanefi Iusti, 1012.

-- scriptor, $2: 3$.

- Secura, 780.

- Stefuni, 750.

- Stefanus, subdiaconus, 302.

- tintor, 513 .

- Tome, 837, 955, 1.154

- W. sulydiaconus, 1.122.

- Willclmi, $1.16 \vec{i}$.

Pihan, 19.
I’jpión, $7 j$.

- Sandia el Tintorero, bijo del Sacanera, 140 .

l'iterin, Guillen, 141 .

Placencia, Donth, 52, 89, 183, 292,970

P'asencia, Joña, 3

joledat?, Martin, 301

Podonco, deate bon, 1.19.

Poequilon, 17!).

Pola la Verecera, ist.

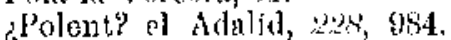

Polichent, 1,0 , $151,121,120,126$, $1.17,157,162,168,176,183$, 201,226, 230, 234, 2:5, 240, $273,25,202,2042,272,273$,

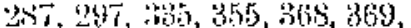
$386,387,390,396,418,449$, $518,591,749,756,972,985$.

- El, areodiano, 215, Binti.

... Domingo, 134.

- Domiligo Len $A$ bdali, 103.

Polo, Dori, itt.

- Juanes, :05, 512.

- solrino (e I). Tome el $A$ bad, i) 6 .

I'oloen Pexu, 1.100.

*ollow, lid, Mar Yahia ben E'esent, lis.

l'once, Iton, $67,24,128,166$.

- ale Berroú el linuncés, 323.

- do cabrcra, 87 .

- de Minerva, conde, $\%, 18 \%$, $15: 3,218,274$.

- Nabat de Balaguer, H.

-.. Potrez, $31,72,121,982,356$, O(H), 755, $856,908,958$; $1.002,1.017$.

- el Zapatero 978. de Verdú. 323.

Poncin, conde, fits.

Poncias I'otric; 7323.

Pons, is.

-moigues, linucisen, 6 .

Populin, Ifl.

Poreiand, hija (o Miral, 273.

Porto, prestiler, 1t2.

Portocarreco, carclenol, 83.

I'oringales, ! 158.

Frerranclo Petrez el, 716 , $8543,861,452$.

- Martin, hijo le Ferrando I'etrez el, 783, 922.

Pozo, Juan del, 1.120.

l'redicador?, Asensio el, 615.

Predicadores, Orden de los, 193.

Presbíteros de 'lolcdo, Cofradla de, 206 .

Quebira, Mayor, Doña, 498.

¿Quematero?, Don, el Carnicero, 66,210 . 
Quiralda, Dona, 252, 305.

Quitumi, Estebar, hijo de Domingo Fstelunt el 886,887 . Quadrado, 60 .

R., archid iaconlis, $809,801$.

R., archiepiscopus, $\overrightarrow{i 2} i, 060$, 968.

R. Pernardi, tanonicus, $1 S 0$, 823.

$R$, capelianns, 30y, 333, 801.

h., diaconus 309

R. Martini de Nosquera, ar. chidiaconts, 618, 821,828 .

R. Roderici, $9 \%$.

R. Stefani, presbiter, 468 .

R. de Talarera, arediano, 176 , 30s.

Rabadi, El, 15is.

Rabahi el Musulmán, 58, 15\%, 138.

Rabia Flakm, 557 .

Racrin, Aben, $466,469,500$.

hafaqul, Benedicto of, 701 .

Raimunda, hija de Pedro, (j11.

Raimuindo, Lron, $58,125,79$, 210,263

- arcediano, 176

- Domno. arzolisjo, sis, 95, 15\%, $174260,190,340,727$, 968.

- Asacaz? Mis.

- Boldi, 75 .

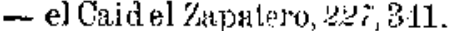

- capel]an, $16 \%, 178,138,161$, $165,191,199,574,785$

- capiscol, 17s, 1.069, 1.098, 1.049.

- de Coca, 65, 156.

- Crespo, 110.

- Grespo el Calonche, $17 \%, 60$.

- dean, $175,892$.

-. hijo de Esteban, 139.

- Guillén el Gaseo, $65,846$.

- hen ¿Hansar?, 11\%.

- hijo de Juan Amar, 4 i!

- Mengo, 67.

- obispo de Osua, 102.

- sobrino de I'edru Toloss, 44.

- preboste, $1 t i l, 195$

- el Sastre, $41,430,443$.

- ben Sons, 281. de T'olosa, 1.01:

Iaimundus, 966 .

- capellanus, 106, 141, 161 . $267,978$.

Rainalto Portogneira, 94.

hama, hija de Micael Midis, 923.

Ramilo, hijos de Don, 689 .

- hijo de Domingo Benedicto, 701 .
Ramilo, hijo de Juslo, 593.

- ijo de Justo, hijo de Cris. pin, 508, 101 .

hijo de Pedro ben Fotuh. 380 .

-.- Petrez, 6d.

- el \%apatero, $63,577,578$.

Ramirez de Artllano, TR, 184

Ramiro el Sastre, lijin tie Pedro Domingo, 1.10

Ramona, 79.

lija de Pedro Maneés, 657 , 670 .

Ramos, Domingo, 636

¿Rambocho?, hijo de Ifical loulibal, 252 .

Ratahi Almuace il Musuimán, 116

Raues, Iona, $t h$.

Raymundus, cpiscoplis, $10 \pi$.

Iaazat el Fescador, 152.

Rema, hija de Micael Martin det drrabal, 353 .

Remo, hijo de Iuan Poláez, 361 .

Romón Balaguer, 582.

Remondo, Don, $1 \%$.

Renalilo, 728 .

Renaldus, 174.

Reymuntlus, Gallecit comes, $H \%$

Ribucro, 83 is

Rica, reina, $88,10 \%$

lichard, 168 .

Richol, "Ladie de l'cdro Guilléns, 111

$-D+n, 576$.

Ritao, $2 \% \pi, 1.164$.

- ben Yahya eicanlarí, 1.152.

Iinal Bonomon?, 141

ininaldo, 1.154

Rinates, Micaej de, 790 .

Pobert, Don, alguacil, 7.48 .

Rolprtus, presbiter, 23 .

Roberto, Don, a'caldt, 20,141 $210,290,39,48$

- capellan, $161,178,338$

- el Pejetero, sisi 490.

- presbitero, $14 i, 277$.

Robredillo. Fermando de 1.113.

Rocalt, Aparicio el, 1338.

lioutelas, 630 .

Rolericus, diacontus, 73,142 , $27,376,425,976,1.126$

- ciérigo, 379, 817,909.

- Iohannis, magister schola. raw eonchensis, 768 .

- Munjz, $26 \%$

-.. Hetri, alcaide, 909. Petri, eanonicus, 274

- Petris, 581.

- Poncii, 1.175.
Roclericus, sfguntinus episco 212,483

Roderigo Ordóniz, LEO.

Rode1, is.

Rodrigo, Don, $169,1 \%, 33 \%, 407$, $6+7,651$

- Achén, as, 597.

- Alfonso, 1.168.

- ben sAlzeidr, $22 \%$

-- el Arricz, $\%, 2+88,561$.

-- Azzabar, 560.

- Jermondis, parlre de Fernanclo Alyil, 105.

- eanónigo, 179 .

- eapellin, Ms, 2.

- el Carnicero, dr Burgos, 901 .

- dikcono, tsi, 189 .

- Diaz, 16., 210, 2850, 366,488 , $742,1.0 .11,1.05 \mathrm{~s}$ hijo de Domingo, 240.

- hijo ctel amin I. Doningo, hijo de Juan T'etrez el Platero, 582 .

- hijode Dowingo Rubio, 658 .

- Domingle $\%, 29 \%, 59 \%$.

- Dominguez, alguacil y al. calde, $210,3$.

- Esteban, 725.

- el Esterero, 1.103.

- Hernandez, 53\%, 5.j8, 751 816 .

- de funes, 59,471

- Guteriz $3(i j)$

.. Jimérez, arzobispo, $\pm_{1} 8 \tilde{u}$ $03,94,06,101,103,109,114$, $115,160,162,163,1 \%, 178$ $17 \%, 180,151,2(5,227,373$, $386,887,384,390,407,408$, $420,424,449,470,476,481$, $498,508,508,510,512,525$, $526,529,528,542,558,748$ $749,750,753,997,1.063$, $1.110,1.111,1.155, \quad 1.156$ $1.159,1.16 \%, 1.36 \%, 1.173$ $1.1 \div 5$

- hijo de Juan, 762

-o Iunnes, $3,170,2 k i, 26 t$ $901,902$.

- Juares, escribano, 960 ,

- Juanes, maestresevola, 181.

- Juanos obispo, 181,825.

- hijo ie duliana? 1.014

- bijo de Justo, 415.

- el Maderero, 164.

- maestro de Calatrava, 185 , $212,710,711$.

- Martinez, 246 .

- Melénder. 584

- hermano de Nalloib, 380 bis.

- Den Moamar, 123.

- More, $58,138$. 
Rodrigo Hunoz, t\%, 36, 39, Romanus Dominicue, 419 . $53 \bar{i}, 1$.

- de Murcia, 1010

- e] de la Navirra, 12;, 161 , 16i), liti.

- Ordótioz 40.

- Ordónes ol IEsterem, 25.

- Lijo do I’asemal, I5xi

- hijo ile pedro ben lyul, 21.1.

-.- hijo de Jeclro de Cistro, $416,94$.

- hijo de Perleo viallega, rit.

- hijo de Pedro Jeén, 211

- Petrez, 227, 292 317. 45.

- Petroz calil, 314.

- Petrez, ennonigo, Ho di, 1.111.

- ben Petron bon cinillen. 1.162.

- Ponce, zill.

- Pons, 904.

-.. Pons, $74.9,9.4$.

- Rodriguez, :398.

- Rodriguez, leitn, $V_{i}, 455$. Ruiz, 446.

- Salvatores, sis, for tris, $t o()$ $193,211,21 ., 215,1.0 \% 4$.

... de San Nicolis.

- de San 7ool, :45.

- de Sunta líulatia, (it).

- de Santa Eulalia, hijo d" Micael Felices, 6 i.

- escribano, tys.

Rodriguez Mazis, Francisco, 5\%.

Rael al Judio, Is!

Rohes, Donta, I.1.

Roi, I Haim ben Sasón le? el, 1.45.

¿Roinery?, Don, $16 \%$.

Roldán, Dou, canónigo, frg, 608.

Román, Don, 6\%, 16\%, /68, 996.

- hijo do Audres, T4.

- Celsezalbo, 345.

- canónigo, $179,1.112$.

-. Dumineus, 401.

- ben Estelpan ben Motarrif, racionero, $180,59 \%$

- el Harioero, 1.130.

- Martín, $22 \%, 45 \%, 815$.

- Mrartín el Adalid, $97,278$.

- Micacl, 135, 1.020, 1.072 .

- ben Moxarrif 484.

-. hijo de Peilro el Cebrero, 315.

- ben Selma, 216,785 .

- Vicente, 491 .

Romana, Doña, 346,410.

Romani, Juan de, 921. lonero, Don, $\%, 604,821$

sRosa?, I) oña, dì

Ros Diaz, lijos de, 5 is.

Royucho, $\%, f i s$.

dRutiona?, hija ste Cobrian isoliee, $1: 3: 2$.

liubert, IJon, fit.

- Domingo, 129, 196.

Ruclericus (Ortome, n.runiger regris, f.3:.

tromzlyiz, fir.

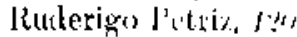

Rufint, nibalesa, $t \leq t, 217$.

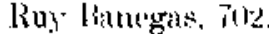

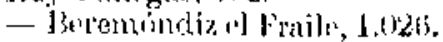

- Cristelmal, 5il.

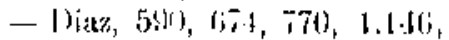
1.].16, 1.151.

- Diaz, hijo de liommir: Detatez. it).

-. hijo de: Dnmingo serrano, 1.(1) 2.1 .

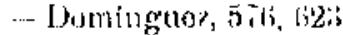

- Fermánios, anestro, Nij, $+15$.

- Giareia, sis.

- Ciarcja de (inllorujl)os, 1.119.

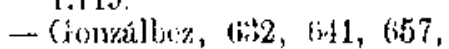
692.

- Gorqalbo (j50, 6ij

- Guteriz, $\$ 85$.

- Jimunez, armobisjo, 273. Véase IRomrjgrs Jinunez.

- Jiaurens, $26 \%$.

- J 6 pon, 5,1$], 54.1$

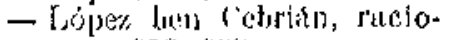
nero, 659,600 (i).

- Tojor, hijo de Ciristobal de J3argas, 632.

- lópez, raciomero, $t s($.

- Martinf\%, areodiano, $\gamma /$, 57x, 138

- Martines, sancinifo, tro, [i?i!

- Martinez ar Mosquera, camoniro, $17,174,587,1 ; 10$, (i) $5,1,17,618,620,621$

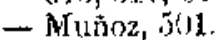

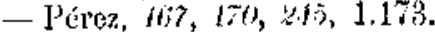

- Pírez el Ganonigo, Jijá.

- Petrez, 214, 24;, 693, 824.

- Petrez el Ćastellano,

1.119.

- Petrez de rioruillos, canónior $17 \%, 430$.

- Petrez Quemado, 614

- Ponce, 674, 1.169.

- Ponce, alguacil y alcalie, 2.81, 558,703 .
Rubio, hijo re ['edeo, it.
Ruy Sinchor, 7,702 .

sunche\%, hijo da Bstoban lielices, bing.

S. Actor, tid.

S. de Bertura, canonicus, 174, 34 .

8., camoniens, 140

S., mudridonsisurehidiacoutes,

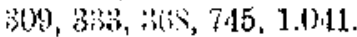

S..... helas, $7 \cdot 1$.

S. foletane eccicsio lesatura. rius, $274,1.126$

s., toletanus archipresbiter, y. $8,1.126$

Shat Alfiir, 1!li.

Saadlan, Iben, 729.

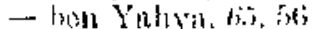

Snulin, $7 \%$.

- Jlabezán ben Jisue: $1 f i$

-2 el 'Tintorero ban el sacnme. ra, apodado d ipifint? 1.137.

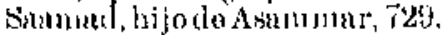

Sal ta, hija de Fareeth, 185.

... hija de fincteh bou Ishac Arriw\%, lis4.

Subih, Mbas, 1.09\%.

Subnj, Musa ben Yaliya ben, i.l.

Sabes, Sol, hija de Mical, Tis.

Sabib, Don, el Cald, 3.i, tik, 67 , (ix, $1.11,214,214,417,466$, $166,548,512,560,500,581$. $751,748,810,815,1.125$.

- ben Aledermitimes el Caid. $2 \% \%, 63,518,1.013$.

- Micati, J40.

Sitbina, hijal de ['udto duanes, ;ini().

Sitbil, Andrés loi, tos.

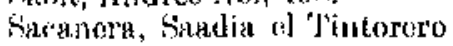
ben el, tis)

Sat Aljair, 10 H

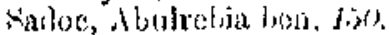

sialtiti, tist.

Saluro, Micaled, sts.

Sall], 2N1.

hen $A$ bilerráhmen, $211,3 \%$.

Siaicl, 615

-... de Oribusla, 23t.

-.. ben Yahya al Ilamado el linhsi, 315.

Sala, Iedro, 7d 3 .

Salbaticd, Aacols ben Isaac ben, tot).

Sillih, fin, disk.

-. hijo de, 561 .

Salman, Aben, 401.

Salomón ben Abraham ben Yaich, 151.

al Alealde, 65, 645. 
Salomón ben Ali, alguacil y alealde, 943 .

- ben Ali ben Guaid, alculde, $44,46,47,54,220,293,360$, $216,256,281,941,1.014$.

- ben $\mathrm{Ali}$, hermano de Sol, hija de Micael Sabes, 738. ben Albarcheloni, 1t5.

- el Bareeloness, $7 \delta$.

- ben Javid, 166 .

- ben David ben Flsigiinesi, 1.185 .

- ben Domingo ben Almarsí ben Galib ben slsilelmèlic, $45,1.154,1.160,1.161,1.174$.

- ben Domingo el Mursi escribano, 1.114

- Domíngue\%, rétit., 22: 558.

- ben Fstekan, fit.

- Hacoher ben Josel, 1 t. ben Hahazáu ben Haim Alpatal, 149

- ben Jacob ben Alamal, apo dado bes a Malut?, 14 .

- ben Isaac, 147.

- ben Iraac ben Isace ben Gato, 1.144 .

- ben lsaac ber jMeir?, 148 .

- ben lsaac Mesiua, $t .10$

- ben Josef ben Guiat, $14 \%$

- el Thlusí, 7.j.

- de Orgaz, 1.140 .

... ben Poderaco? t1t

-- ben Salomón el Llusi, 1.137.

- ben Sagon, Joo.

Saltillo, marqués dil, idj's.

Salut, 6, S14.

- hijo de Estelian Salat, 186.

Salvadar, 3 .

Salvador, Don, 23, 23:4, 63, 479.

- cl ...,995.

-. hijo de Abutata 1015

- ben Abdelmélic bon slarif, 323 .

- hijo de Alvaro Pominguez, 1.099 .

- arcediamo, $15,47$.

- ben Itliun, $25 \%$.

-- hijo de Cebrian el Altarero, 20 , 266

- diacono, 187, t5, 1, 1000

-.. Domingers, 1. (182.2.

- ben Fádel, Yd2.

- hijo de keliz A ticac, 950 .

- Guter, 54, 256.

- el Herreto, 400.

- ben Hilel, 28s, 2s9.

-. hijo de Juan Micaelis, 1.024

- Julimis, 41.

- clero del, 20

- hijo de Martín Sálìh, 807.
Salvador Muñiz, 45.

- hijo de Pedro Aragonés, 328.

- Petroz, 153, 213, 265, $1.07 \%$

- presbitero, $189,198,198$ $383,381,397,506,769,955$.

- sel Tabernelo? 653, 650.

- ben Yahy", presbitcro, 184, 371.

Salvat, Don, presbitero, 189 , $103,182,287,847,862$.

Salvator, 328.

- Iulianiz, 41.

-- ben Jálid, 250. Stephanis, 124

Samal, $1 \%$.

Samrano, Juan de, 425.

Sams, S. Sol, 1.04 H.

Simsi, Doña, 40, 127, 281, 284, $344,381,449,942$.

- lija de ibdolmesiah, 1St.

- hija de Chafar, 64, 89, 969.

- Estébanez, 225.

- hija <le Juan, 90, 195.

- esposa de Juan Juanes, 48.

- hjja de Tame ol Alfarero, a podado Algazil, 989.

- hija de Martín Juanes, 1.099.

- hija do Mofárech ben Bah luil, 109,972 .

- hija de Palro Juanes, 330 .

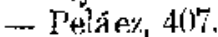

- Petreza, 171

- hija di Servando th Acrb. sise.

hija de Yaix, tid, 272.

- hija de Yahva ben Molkom, 1.036.

Sammel ben Hiya hatn Alrajal, $1.136,1.144,1.145,1.146$.

- bon Josef, 101. ben Salomon Cackich, 1.141 bis.

ben Yehuth ly Gasi, 114, 1 sts.

San Andres, iglesia de, $5 \%, 1 \%$, $150,184,212$

Sar Antolín, iglesia de, 168 $171,189,186$.

San Cipriano, iglesia de, 180 . San Cebrián, julesin de, 34

- Polro de, 1.085.

San Clemente, $70,73,78$, \&n, $87,85,109,135,143,185$, $186,187,1 \% 5,200,201,2 \mathrm{J6}$, $218,224,225,233,234,244$, $253,261,262,264,268,264$, $271,28 \%, 284,986,280,290$, $991,292,337,309,51,504$, $355,350,215,1.168$.

San Cosme, convento o igle sia dle, $180 \hat{0}$.
San Cosne y Drmián, jylesia de, 190 .

San Cristóbal, iglesia de, 186 $207,247,1.164$

San Esteloan, convento de, 187 , 215.

San Fngenio, convento de, 157.

San Facnondo, Sahaglin, Juan de, $425,645,364,1.11 \%$.

San Felix, convento de, 185.

San Gill, colación ike, 628.

San Ginés, iglesia de, 158,189 , 228.

San Ildefonso, iglesia do, 138 , b/Nos.

San Tsidro, iglesia de, 907 , $122,1.168$.

San Juan, 17 .

- del Hosprital, frailes de, 68 , 188.

- iglesia de, $198,211,229$.

San J uliñn,

San Justo, 17:\%, $899,2(t), 20 \%$, $210,1.169$.

San Lorenzo, 125, 1ht, 207, 1.165, 1.172 .

San Jucus, jol tesia de, 101,20\%.

San Marcos, iglesia de, $f 92$.

San Martín, 171; 184, 192.

- Cristóbal de, 1.012 .

San Mateo, folesiz de, 192 .

San Mignel, 1.16s.

- iglesia de, 1912

San Nieolits, 2(14, 203.

- aljame, 218.

- concejo de 114 .

- iglcsia de, $24 \%, 21 \%, 211,214$, $215,1.164$.

San Pablo, convento de, $18 \%$, 195,215 .

- iglesia de, 1.t.

Saz Pedro, convento de, 71 . I9t; , 202.

- en Ahicem, ensuvento, 70 $78,175,186,194,201,210$ $215,23 \%, 26 s, 35 \%, 1.016$, $1,178$.

San lioman, 185, 19ti, 211, 1.169 .

- Converto de, 196.

San Salvator, iglesia do, $\int 97$, $210,21 \%$.

San Seloastian, iglesia de, 198, $206,1.162$

San Scrvando, convento, 25̃3.

Santo T'omé, 173 .

San Torevato, irlesia de, 199

San Vicente, $165,1 \% 1,199$, $207,1.152,1.161,1.160$, $1.166,1.168,1.172$

- de la Sierra, fruiles de, 78 .

San Zoel, iglesia de, 228, 1.016. 
Sancha, 1)onk, $29,362,435$, $480,575,682,748,790$, $1.010,1.030,1.071,1.073$, 1.099 .

abadesa, $14 j, 241,818,323$, 740 .

- Armilile. 403.

- Barbola, 3 .

- Gobricin, $65 \%$.

- Dinz, 725 .

- Diam, aloudesa, $186,580,606$.

- Guteriz, 5\%.

- Ciutierrez, $3 ; \%, 82 \%, 919$.

- infanta Doña, 0 .

- Iñiguzz, $9 l$.

... hija cle Juan, 653, 659

- hija de Jumn Navarro, 711.

- Juanes, 1Bis, 1.001.

-.. hija de Hicarel f. Itrarcadón? 3 i.

- Prtiez, 100, $1 \mathrm{l6}, 756$. hija de l'once de Ninerva, 274.

- Dona, reina, tisf, zkis.

- Ruiz, 540.

- hija de liny Jiaz, 476.

Sancho, Don, 8 i, 786,981 $1.022,1.030$.

- III, roy, $(1), 100,101,161$, $218,29 \%, 1.008$.

- IV, rey, 21: 218, 225, 268, $679,702,715,784,1.066$.

- alolde, 22\%, !k2.

- Almocín, Val de, 689.

- arcediano, Don, $368,745$.

- hijo del rey D. lernando, arzotsispo, 17.5,599, 600,988, 1.08 t.

- Beteta, 817.

- ben Bezais, alcalde, 2li, 734.

- Bonet, 673

- hijo de doña Jruna, 316.

- cansnigo, $17 \%$.

- Carlon, 35: 940.

- Chico, 244 .

- díácono, 47.

- hijo de fistelran Socrán. 350

- Hernández 1.067.

- Gareia, 192, 694.

- Gonzilbez, 289.

- Infante Don, 107.

- Juanes, 151, 245.

- hijo de I áazaro ben Abdelcui, 261

- Lopez, 1.128.

- de Madrid, arcediano, 176.

- Marcos, 858 .

- Marbin, escribano, 218, 663 .

- Martinez, 63, 66, 95, 173, 223.
Sancho Martine candutgo, (N)(1), 1.11.

- Martinez, deán, 175, 660. $674,622,657,1.0(k)$.

- Mtartinez, racioncro, escriloano, 67\%, 686, 651, 6\%2,

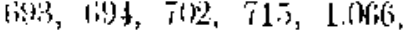
$1.71 \%$

- ber Mican ben linqui, 24.

- Mordo, tiso.

- hijo le Alumo lidtalo, 765, !hit.

- M!ñ $0 \%, 4105$.

-- hijo de Pedro Gourálbos do () Sima, 1.115 .

- Pofrez, 3.61, 610, s[s.

- Ponce, 18? 183.

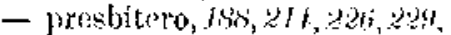
$155,435,516,741,1.024$.

- rey. si, sis.

- cl rac ristin, $M B$.

- Salyatores, tiss.

- Sogura, alguncil y atcalde,

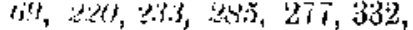
$35,798,806,482,1.125$, 1.126

- hijo de Sorvando, isi.

- tesorero, 22ki. 23.4.

- Vicente, 124, 551, 514, 531, 546.

- de: Yegros, $5+6$.

- el Zryatero, hijo de doña Bruna, 341, 1.16\%.

Sancia Ablitissa, 291, 318, 740.

Sancio lanariz, $f: 0$.

Gancius, presbiter, 741,948 , $1.05 \pi$.

- seriba, 2\$s, $960,1.094$.

Sancti Spiritus, convento de, $18 \%, 21: 5$.

Sanem ben Baldi, 815

Sangiesa, subpriola, $18 t^{4}, 487$.

tSiansa?, Sondino, 453 .

Santa Colemla, Convento de, 185.

Santa Cruz, iglesia de, 199

Santa Julalia, iglesia de, 187 , $207,2(18,1.040,1.157,1.158$. 1.164.

- Rodrigo de, 677.

Santa Justa, iglesia de, 183 , 269.

Santa Leocadia, 165, 228.

-n do junto al Alcuzar, 79, 190 .

- de Afuera, 188.

- iglesia, 210, 212, 213, 233. $251,294,1.57$

- Ia Vieja, 190.

Santa Maria de Abenrazín, obispo de, 812 .

- oil Alicem, 215, 289 .
Santa Maria Magdalena, igle. sia de, $198,19 \%, 1.168$.

šmonta Trindad, iglesia do la, I)

- orden de la, 194, 199.

Sunturonf, islise et, $t: \%$.

Santiazo, $2 a t$.

-.. iglesia de, $19 \%, 20 t, 210$,

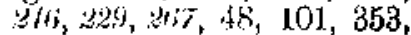
$705,1.165,1.108$.

- oridea de, 14s, 2266, 261.

Santo Domingro, convento de monjus de, $l i s i$

-. frailes de, $k 8 \%$.

- convonto de, $137,196,203$, :

- eu l'alaverk, convento de, 201.

Sunto 'Jomé, iglesia do, 199 , $20 \%$

¿Sari?, Doña, 712.

Sarra, monja, y2is.

Sarsij, Sid bon, 21.

Sarur, Abuishac ben Abiomar ol, $\mathrm{BO}$.

Sasón, ben R. Sem Job ben liarah, 150 .

Saturnino, 362 .

- ben Jáir, 30 .

- ben Julaf, 972

Satil bon Josef, 15l.

Sebretian, Don, $160,243,922$, 949.

- Dominguez del Verulugo?; 653.

- ben Furón, 973, 1.067.

- el Horteluno, 598,601

- Hulez, 94

- el Ollero, 166 .

- Pejác 381.

Sectanl, W1, 76, 452 .

Sedillot, 49 .

Segovia, Domingo de, 431

- Guillén Petrez de, 267.

Seguin, Don, 62, 161 .

.-- hijo do Bernaldo, canónigo, $180,236,809,1.114$, 1.126.

Selay, fuan Garela de, 673 .

Belaya, Juan do, 792, 1.082. .

Selma, Aben, 4.

- Don, 1.010 .

- Axxat, 12

- ben Hasán, 28.

- ben Isa el Safar, Don, 1.01.5.

- Aben, 513.

dSemcio?, 638

Senaa el Char, Ibrahim ben Ishac bes, 130

Sendino, Don, 743.

- Gonzalbez 980 .

Serbl, hijos del, 25 . 
Serhán, Mieael, 432, 433. Serrano, Ruy, hijo de Domingo Serrano, 1.024. hijo cte Clemente, 916 .

Serván Soriano, (88:).

Servanda, hija lic Alastar, 1.016.

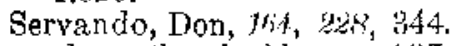

- alguacil y alcalele, areipreste, $1 \%$.

- Aseammar, $17 \%$.

- Bt Jecastos, $28 \%$.

- capellán, 77s, 1.030.

- ben Domingo Petrez de Atlu, 1.166 .

-... ben Domingo ten Servando, alcalde, 221, 1.163.

- hijo de Domingo ben Servando, alcalde, 627 .

- Domingues, 392,

- Estelmin, 378.

- el Esterero, 612.

- el Estercro, ben Gálib, 1.160.

- ben Hazán ben Servando, $276,1.164$.

- Juanes, $195,256$.

- hijo de Micael, 383, 397.

- hijo de Micacl el Acal, 130.

- ben ledro Garcla, 61, 68.

- hijo de Pedro Pe]dez, 804.

- Petro, 22\%, $382 \%$.

- presiltero, $164,2 \% 9,54$, 608, 1.029 .

- ben Said ben Arib, 16

- Sebastian, 169.

- bes Tami, $100^{\circ}$

- ben Yunus ben 'Tami, 280 , 282,800 .

Sorvandus, 22\%, 382, 768 .

- Iohammis, coronatus, 277 .

Servatus 139 .

- Alfonso Petrez, 725, 830 , $831,832$.

- Alfonso 'ealrez, hijo de, 690 .

Seseña, Juan de, 713.

dSetaquero?, Jomingo, 340 .

Setbona, 100,010 .

- hija de Odra, Is.".

Selfila, Juan de, 580

Set Filiola, Doña, 146 .

- Mayori, hija de Bernaldim. 114.

- Mayori, hija de Ali ben MeIdom, 149

Seti, Doña, 85, 115, 165, 195 . $109,256,287,344,845,355$, $356,537,698,801,818$, $1.014,1.021,1.021,1.030$, $1.123,1.157$.

- esposa de Arnaldo, 113.
Sets, hija de bomingo al covierciante, $47, ; 01, \overrightarrow{3} 40$, $5 \pi 0,668$.

- Donsingue\%, Jos, 578.

- hijar de lostcuan, 1.0iti. Jijat de Carcia el Aryustro, 72 .

- hija de Gudel, 407. Juanes, Jonis, 480 .

- hija de Michal, 754.

- hija de Mlicacl ben Suleimán, 91 .

- Horel, 739 .

- esposa de l'ascual Domingo, sis.

- hija de I'edro Crespo, 269.

- hija te P'edro el Polichenl, 4.69.

- P'etrez, 2410.

- hija tle Santón del Rubes?, 683 .

- hija del Suti, l:so.

- ben Yahya, 1.152.

- ben Ficente, 1.020 .

Setila, 150 .

- hija de Abulhasín Bono el Jelâs, 140.

Severo Diaz, 508.

Sevillano, (ionzallo ben $\mathrm{J})$. mingo Juanes el, $1.10^{-}$.

-- Ibrahim ben Omar el, 150 .

Sibib iben Micael, ñtr.

Sical, Juan el, $\ddot{o}+5$.

Síciliano, Juan Julián el, 7ís.

sisico? Tshac ben, tow.

Sid, Don, 76,560 .

- Alinachar, fit. 272.

- alguacil, 4t, 249, 89, 371

- Mayor, $169,247,735,902$.

- ben dSarsij?, 21.

Sidabihi, Aben, 294, 369,434 , 485.

Sidani el Alfarero, $1 \geqslant 3$.

Sill Nayor, Ion, 1.014.

Sidrey, $A$ ben, $319,856$.

- ben Selma ..., 11

Sierra Corella, Antonio, (o), tos.

-- San Vicente de la, Or.lon ro. ligioga de, 704.

Sigilmesi, Salomón ben lavid ben el, 150 .

Silvestre, $21 \overline{7}$.

$\mathrm{S}[$ imeno], Cayetano, arcipreste, $176,298$.

Simeón ben Isaac, 147 .

Simhá, hija de Jacob ben Cemah, 146 .

- ben Yacub ben Cag, 648.

- bija de Isaac Habib, 147 .

-. hija de José ben ¿Y amin?, 151.
Simaba, lija do Mosé ben Arroyo, 1.138

- hija de R. Jacob ben Gayat, $l+\vec{i}$.

- hija de lúsuf les (ng, to

Simin, Don, $434,485,517$, $57 x$

-... acolito, 2ist, 786.

- ben Gomez Navarro 99

- SEhat ben Mratim ben, 150 . Wartini, $489,450,482$.

- Micael, 60j8.

- hijo de Nieacl do srehel, 358

- hijo do Nlicrel de Richol, 1.115 .

- Petrez, 526 .

Simona, $217,220$.

Simonet, tianciseo, $i ;$ is.

dSincersa? 382 .

Siquili, Mateo ber. Esteban, $506,7 i \pi$.

Sirafl, Aicacl ol, 370

Sisuandus, $15 \%$.

Sitbona, hija de Isaae bon Abraham ben Sosán, 150.

- hija de Mosé el Maestro ber ditlás?, 1.5.

- hija de R. Guedalia ben $\mathrm{Me}$ nályem, $11 \pi$

Sitmayor, 98.

Smith, 4y.

Sodala, Aben, 15 .

Socala, $\Delta$ luen, $244,731$.

Socan. Pedro Domingo el, 456 , 536.

Soeni, esposa de Bartulomé, 113.

- hijo de Martin Dominguez, 1.620 .

- Hija de Mlunio temandez, 1.152.

- Rairaúndiz, 281.

-- hija de Suleimán, 79 .

- hija te Suleimán ben Ga lib, 33 .

Socrán, Istetsan, 350.

Socrel, Juan, 513,591 .

- Micael, hijo de Juan, 242, 101.

Soffa la Mora, 15te.

- la Musulmana, 65, 820 .

Sofo, Salomón ben Yehudá ben, 150 .

- Samucl beri, 200

Sol, Doña, 63, 65, 170, 226, 668, $676,746,826,870,1.018$ 1,022 .

- hija de Abucasah, 53

- López, monja, 194, 291, 740.

- Martín, 053.

- Martínez, 1.173. 
Sol, lija tle Micanl bon Sabos, ! Soli, hija de Micael el Herre$69,738$.

- Micaelis, $1 \% \%, ? 0,21 \%$

- Inonja, 24: 423,1068

- Peláez, sco bis (e).

- hija do sulvidur, ip, 82 , 92.

- hija dis suncho, liji, 2jt

- Sillis, 169, 2+7.

Soli, $59,40,8 \%, H i, 20,38$, 39. $72,126,249,261,297$, $299,370,4(7,41 \%, 45,527$ $562,581,622,673,762,820$, $823,844,857,91 \leq, 45 i, 963$, $985,985,1.014,1.024,1.030$, $1.016,1.053,1.161,1.166$.

- abadesa, 886,2 .

- hija de Abenjatals, i383.

- hija de Domingo, 600 , 1.020 .

- Jija de l)omingo Felices el Curidor, 1.6is.

- hija de Domingo Detrea, 28 i).

- hija de Domingo Petrex, litjo tlel Cantari, $552,533$.

- hija de Domingo ben Jaxim?, 246 .

- Domatnguez, ASS, 392,578 , 615 .

- hija de Félix Assammar, 67 : 685 .

- Fornandez, $7,9$.

- Garcia, 622, 636.

- Gonzalbo, 1.119.

- hija de Horabona, 135

- hija de Jimmo, 573.

- Juan, 622 .

- Juanes, S1: 9is.

- hija de Juanes ben Ayub. $496^{2}$.

- hija de Juanes el Sillero, 507.

-..- hija do Julian ben sidd, 771 .

- Julianis, 411.

- hija de Lorenzo ben Cha. $\mathrm{rah}, 441$

- hija de Lorenzo bin Hidrruch, 558

- hija de Martín Alchabar, 645 .

- hija de Martín Alchiar, 425, 964.

- hija de Martín el Pescador, apodado Dirhem y medio, 430.

- hija de Martin Petrez, 214.

- Martinez, 196.669.

- hija de Mclendo, 235.

- hija de Micael Chaves, 302.

- esposa de Micael Domin. guez, 89. ro, 67,68 .

- hija de Micau Polatez, 292.

- hija de manio Fetrez, onoo.

- Muñoz, 4)5.

--- hija de Omar ben Lixema, 94.

- hija de Oriboma, 964 .

- hija de L'edro, 2833

- hija di I'edio dContenela?. 589 !.

- hija de perlio lllain, $k$ sid.

- bija de l'edro Hicael. 134.

- hija de Pedro Potrez de Sihrolay, $\$ 24$

- I'etrez, $62,541_{1}$ 5H

- Ruiz, abidesa, $145,457$.

- bija de Salvador, $5+2$.

- bija de salvador ben liad, 260\%.

- hija de Sebasilián, monja, $20,1.068$.

- bija de Servando el $A$ eab, $1,(20)$.

- Sidis, 10 .

- la Vieja, Dona, dexa, 957.

Sompuia, diaconus, 374 .

Soriano, $A$ dán el, t8:1.

- Velasco ben, isis\%.

.... Pedro, 713 .

Sosán, $\%, 14: 3,15$

- David ben Jacob ben, 150

- Meir ben Isaac ben, 150.

- Snleimár bon Y'sof ben, tist).

Sotillo, Fernanto cómez, 698.

Sotomayor, Allonso Garcia de, 710 .

Ssecura?, $321 \%$

Stefan dijbrat, 973.

Stefarus, capollanus, $7+\ddot{i}, 757$, $762,7173,769,793,607,808$, $813,814,960,984,985$, $1.05 \%$.

Dominici. 768 .

- Iohannis, 1.1.12.

- Iohanni, filius, 75, 1.152. presbiter, $198,1.012$.

- thesaurarius, 407 .

Soaib el Molinero, bijo de Mohámed el ¿Malaires?, 939.

Suero, Don, 87'1, 1.024.

- Domlnguez, 594.

- Gonzalbez, 71, 702, 339, 908, 958.

- Meléndez, 904.

- Menéndez, 64.

- hijo de Micael Micaelis, 995.

- Micaelis, 175, 186, 550 .

- Petrez, 1.128.
Sufian, timin, 87.

...- ben dbilluce, 8 .

Saleimán, 934.

- Abrn 1.032.

- ben Abrtolbatr, 12.

(1 Amín, 380.

- Arraxah, $61,13,15$.

- el Jimir, 94.

- cl Hormant, $6 \%, 790$.

- el Martr, $\mathrm{k} 90$.

-- el Hasriqui. $\$ \pi, 1.015$.

-.- ben Mfertán, 13.

- ben Sabsan, $25 \%$

- ben Selma, gy.

Suquí, lit, 7.s.

Susana, Join, 155, 219, 302, $310,354,910,1.119$.

- Domingue\%, 558, 600 .

.. Poláe zis1.

-.. hija de Saturnino, 728.

Taabar, MI usa ben Obadia ben, Lj(i).

Tabali, Jomingo Juanes, 174.

T'adrubis, $\Lambda$ bulhastin, 710 .

'Tago, Urraca, hija de Pedro, 75 ).

Tahir, Aben, 302.

Talatí, Al, 193, 5663 .

- Pernando Dominguez el, canonigo, 400 .

Talavera, cazadores de, 291 .

Tama, Doña, 4\$0.

- hija de sajd ben Baslo, 5 s.

taml, Servando ben Juanes ben, 280, 282.

Tannery, 19 .

Tarasia, regis filia, 11\%.

Tal'azona, Garcia Sánchez Petrez de, 751.

Trrita, tion.

- La Judia, 76.

¿Tarin?, casa de Don, 293.

Traurino, Aben, el Musulmán, 23.

Tello, alcalde, $22 \%$, 724,

- Diaz, 194.

- Didaz, 38, 39,971 .

Temam, $23 \%, 967$.

- adalid, 228, 727, 969, 1.050.

- el Car'pintero, 116.

- Mair, l6i2.

- Maior, alealde, 219.

- cl Rotlcatú, 971.

-.. ben Selam, 1.130.

Tenorio, Peallo, i), 60 .

Teresa, Dona, 62, 69, 72, 170, 215, 380 bis, $407,445,451$, $479,507,559,566,576,599$, $609,638,701,724,757,821$, $991,1.083,1.105$. 
Teresa Alfon6o, 196, 660, 1.173. | Tomé Juanes, $19 \%$.

- Alfonso, sacristana, 19.5.

- hija de Audrés Abisabit, 198.

- Thaz, 6.5 $6371,684,829$.

- lija de Jirgo (ionsálbe\%, $724,850,958$.

- hija de Dominga Mican ben el Acham, I2:; 7)2. froliz, 1.113.

- hija de lemando l'etrez, 780.

-n lernàndes, $70 \%$.

- García, $73,655,671,693$, $710,824,825,829,1.169$.

- hija de Garcia Diaz, 1.1930 .

- Gii], 1.028 .

- Gonzálbez, 60: 96\%, 1.118, 1.173 .

- hija de cronzalbo I'etrea ben Abdelmélic, 1.112.

- Gonzálbez, portera, 195.

- Dofia, esposa del Ciuadiexí, 962.

- Juliancs, 599.

- hija de Juan ponce, 505, 847,848 .

- Juanes, 74, 276, 624, 639, $702,829,1.030$

- Loper, 1.173.

- Lopez, camarera, 195.

-. hija de luna, 1.081.

- hija de Marla, 1.026

- hija de Pedro Kartín, 705.

- Petres, 6\%, 此, 589, 620, $791,876,1.04 \%$

- de Santo Domingo, fro.

'J'eresucla, 792.

Tibaldo, 141.

Tirso, presbitero, 20\%, 18, 969 , 1.012 .

Tobi, 674

'Toda, hija de Lope de Cotarel, ifl, 1.122

Tadros, Iratevi, 1.145

Toledana, hija de cruillen de jarcelona, 365.

Toledano, Don, 409

- Domingo el, $55 \%, 594$.

Toledo, Dicgo de, 116.

- Sancho de, 116.

Tolosa, Pedro, 277, 466.

- Raimundo de, 1.013.

Tomá, presbitero, 184, 313, 375.

Iome, presultero, $193,275$.

- Don, 202, 424, 1.166.

- el Bebi, 91.

- hijo de Domingo Micael, 1.001 .

- flius Ganem, 491.

-ol Herrero, 436,905.
- de ilorbigot, 885

- hijo de Pedro el Ferrero 180.

-. Pelayo, 294

- el Pescalor, 698?. Saturmino, 118, las, 150 171, 217,228,724.

- ben 'jama, 58.

- ilscn Yahia, 1.152.

'lorcunto. Don, $235,451$.

-. el Allarero, $73,233$.

-. e] Esterero, $5 i$ íti.

Torquemada, Gonzalbe I'tercy de, $49 \%$.

Tol'ros, Niculas de, it:

Torrecilla, 1.475

- I'edro de ia, ôd'2

Tortosk, boninga, hija dr. I'edro de bis.

- Dominga l'etrez de!, 96 .

'osoli, Micael Domingo, th4, 566 .

Paulo el, 2N2.

'l'ota, hija de Lope d' Cotaral, 362.

- Petrez, So

Totanes, 1.175

Trinidad, convento de lik, its

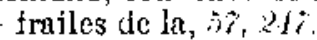

-.- iglesia de la, pur.

Turrel, Ben, +192

T'usi, hija do Salomón ben fral con, $1.1,1,1 i$

¿Uagmarech?, Hrim lwa Isaac ben, $15 \mathrm{~L}$.

Udaia, Gonsábey, b19.

Udaya, hija de Armaldo Munoz, 457 .

- hija de Domingo Martín. 1.106 .

Udeba, Dona, 559, 700, 716 .

Ueld el Helá, 75: 581

Uermudo Pelagiz, 940 .

Uotux, hija de $A$ buzeid Benatia, de Lorea, 703 .

Uraca, 733 .

Urbano II, $15 \%$

Urraca, Donta, 3, 67, 699,70 170, $123,198,273,287,305$, $364,457,579,623,677,738$, $801,810,812,813,909$, 948.

- Alfonso, 14t6.

- Alfonso, hija de Alronso Esteban, monja, 672.

- Alvarez, 1.02

- Diez, 269 .

- hija de Diaz Petrez, 752.

- hija de Domingo Esteban

el Guadiexi, 591.
Urraca, Esstébanez, 10\%, 327, $395,446,750$.

- Fornández, 78, 1.090.

- hija de Fermando el Camicero, 704 .

- I'redenandi, infanta, $l \hat{o} \dot{\prime}$

- Cimpria, 1.169

- Gomzilbe $, 19 \%, 202,285$, Jii, $701,1.125,1.126$.

-- (somzallser, sulspriora, 760 , $\$ 13$.

- hija de Cronzalto el Alguacif, 384.

- hija de Ciuter Dominguez, 684,709 .

- Gutierre, fiti, 510 .

... imperateris filia, $M$ s. Juisues, \$21, 973.

- hija de 1 dazro, 4hl.

- la Madridena, 61]. hermanr de Majwolas, 900.

- Hartínez, 16\%, 1.173.

- Micmel, 201, 201, 270, 252, $488,496,760,761,763,772$, $810,813,911,985$

- dhija de Wicael do Zuazo?, $1.03 \%$.

- Mliguel, $1 \%$

- Mluioz, monja, 195, 487.

- Hermana del obispo, 752

-.. hija do l'edro, 166.

- hija de l'edro Garcia, 1.029.

- hija de Pedro Petrez, 161.

- hja de Pedro Tago, 759.

- hija de l'edro de 'lolosa, ift, tot, $211,149,241,277$, 1.058 .

- Pelán, 183.

- Petrex, 2(1\%, 44, 210, 336. 474,735 .

- l'etrez abadesa, 20, 710, $714,825,828,1.085$

- Petrea de Tolosa, 289.

- reina, 155 .

- h!yad de liodrigo de Alcalá, i. (1) 41 .

- Rodrigue\%, 2\$\%.

- Ruiz, 712.

- Safuro, 608.

- hija de Vicente ben Balj, 1.037.

Val de Abixa, Pedro Ruiz de, 582.

Valencia, Murtin de, 410, 954.

- de Don Juan, inslituto de, iff.).

Valenciano, Ibrahim ben Ismael el, 1.51 .

Valterra, Pedro, 428.

Valverde, Fernando Juanes de, 712 . 
Vargas, Flvira Martinez Ruiz dc, 768 .

- Juan Vicente de, 603

- Pedro Fernández, hijo de Cristábal de, b6\%.

- l'edro, hijo do Vicente de, 771.

Varón, Eudosio, 7 .

Vela, Don, 144.

- el Adalid, ist, 953.

- Armlldez, uionja, 911.

Velasco, Don, 250, 640 , 700 .

- Andrés, 434.

- hijo de Doña Aura, 689.

- Muñiz, 310, 909, 918.

- Petro, 908.

Velasquita, 280.

Velilla, Dícgo I'etrez el de, 529.

Vicente, Don, :314, 393, 50\%, $535,548,689$.

- el Albañil, hijo de Pedro Mochebo?, 960 .

- Alcataa, 1.020.

- el Arquero, 417, $5 \% 1,1.111$.

- ben Arxim, 800 .

- ben ¿bacbicos?, 251, 751 .

- ben Bálech, 80 .

- de Bargas, 466, 527.

- el Cojo el Tabernero, 051 .

- de Daralmazán, 1.059.

-- ben Domingo lren Arrizq, 1.046.

- Domingo el J3izco, 101, 353 .

.. ben Domingo ben Martin Cubero, 1.1.58, 1.159, 1.107.

- hijo de Domingo dikazac? 715 .

- ben Farach ben Ganim, 994.

- hijo de Juan, 160).

- hijo de Juan de Mariina, 915 bis.

- Juanes, 486, 551. ¿Juliân?, 384.

- Martin, 87.

- hijo de Marlin dCatejlo?, 97.

- Martinez, 165

- Mateo, 1.019

- hijo de Pedro Martinez, 165.

- ben Meruáta, 1.016.

- ben Pedro ¿Mocheho?, 234.

- Peláez, 14.

- Petrez, 299

- Petrez ¿Aljasim?, 826.

- el Procurador, 645.

- ben Srad, $205,994$.

- ben Sabib, 160 .

- ben Suid, zys.

- el Sevillano, 177 .

- Stefanus, 773 .
Vicente ben Yahya of Scvillano, alguicil y alealde, 222 , $132,244$.

- el Zapatero, $800,800,801$, 852

- el Zapatero len Razac, (ii), 82:.

- Viguau, 7

Vidal, presbltero, 210,1 (b).

Villarroel, Cristúlal de, $:$.

Villaseca, lon, 2 .

- Jusla, hija de Juan de, 831.

Vinecneio, vresbitero, 191,291 , 389 .

Vincent, 49.

- ¿Aleulipán?, $6 \pi$.

Vila, portera, $186 \%$

- Dona, 580, bi.7.

- Sidis, Jo.

Vital de Uibdad el 7apatero, 323.

- de Tolosa, 21, 22

- el Zapatero, 2y1.

Vitalis, diaconus, 142, 30 ?.

Vito ben Lahya ben Suaba. $14 \%$.

Viva, Abraham ben Mosé ben, 151.

W., canonicus, $781,1.053$ :

W., canonicus, diaconus, 274 .

W., diaconus, 73 .

W., prior, $96,103,141,142$.

W., testis, 142,966 .

Wilelmus, canonicus, tra

Woepcke, 49.

Xemenus Fortuniones, $15 \%$.

Ximena, Doña, 1.084 .

- hija de Pernando ol Carnadi, 572 .

- Juanes, 2012

Ximeno Gialcta, 507.

Xristoforus, presliter, $9 i^{4}$.

Yaco Petris, $I \geqslant i$

Yacob ben dicol el Subilisicono, $1: 30$.

- ben Axor al Barcelones, 1.44.

- Yehudá Ljol.

Yacul ben \$abi, 150.

Yago, Don, 416.

- el Barhero, 502.

- el Cano, de Balaguer, 680, 719 .

- el Crespo, 402.

- de Maqueda, Don, 658, 665.

- presbitero, 961.

- el r'abernero, Don, 168 .

Yaguic, Don, 550 .

¿Yagur?, Maria, 832 .
Yaques Gómex, 940.

Yahine, Yejuuda ben Ishac ben, $t 5 t$.

Sahya ben Audelquerim. 1.012 .

- ben $A$ bderráhmem ben Zeid, 1.15B.

- ben Abresselana, 3.

- Abuzacaria, 6.5.

- el Altarero, 235.

- ben Coraix 4.

- ben Gálib, 54, 90, 110, 1.072 .

- ben Guálid ben Cásim, 46, $1 \% 3,323$.

- ben Ilixcm, 216.

- el Malagueño, 103.

- ben Molurech, 2.:k).

- ben Alafárcch el Platero, $195,155$.

- ben Molnimed el Ansari, 1.094 .

- ben Mlahares, 1.097.

- ben Onur ben'Aream, 21. 22.

- ben Pesat, apudado Fulo, 14\%.

- bon I'esat del Pollo?, 149.

- ben Sudafí, 162 .

... ben Sehamín T'azaret, 150

- ben Selna, 222, 224.

- ben Serir, 8.

- ben Sidabihi, 123, 243.

- ben Sidatihi, 184, 216.

- Tazaret, 75 .

- ben 'Temam, 140.

-- el 'Tintorero, 1.067.

- ben Yaix. 151.

- ben Jalaf, 4.

Ýaix, 68, 974.

- ben Abdafí, $19 \%$

-- ben Abiljair, I0n, 1.ti, 302. - el Sastre, 244.

-.- el Sastre ben Ahmed el Ciranadiıo, 793 .

-. ben Suleimen, 18, 15.

- ben Yohudi ben Kìa,

Gajuns? Lfrum ben R. Isale ben, 151

Yaques, 137, $8(11$.

Yardib, Aben, 12

Yebli, I'edro Micael al, 319.

Yefuda, $t r 1$.

Ychosef Halevi, 7 .

Yehuda ben Abraham, 144.

- ben Abraham Aben Noah, 1.19.

- ben $\Lambda$ braham dben Yehu. dis?, 151 .

- ben Albanat, 7.t.7.

- ben Als ben lias..., tid.

- ben Am-1)and, 116 . 
Yehudá ben el Barrac, 145 .

- ben David fben Malul?, 148 .

- Hahazán ben José Hahazán ben Mesé Hahazán Albansoli, 146

- Halevi ben Daniel IIaluvf, 146 .

- ben Isaac, 117 .

- ben Isaac dben Absil?, 14t.

- ben Josef, Jól.

- ben Josef dhen Bartel?, 145.

- Samuel bar, 15l.

Yepes, Bartolonté de, 636 , 696.

- Gonzalbo ben Domirgo Juan de, 680.

- Tuan Domingo el Cubo? de, 541 .

Yesaia ben Rabi Ishace, 48.

Yesco, Juarı, 256.

Yobeco, Dona, hija de, 1.067.

Yosef ben Jacob, 151.

- ben Josef ben lilrofe, 149.

- ben Saadia, 1.49.

Yudá ben Ibrahím el Herrero, 151.

Yunien, maestro, $36,604$.

Yunus ben Coriat, 74,146 .

- ben Ishac leen Hayton, 147 .
Yuçaf, \%4.

Túsef el Fasal, $7 d$.

- ben 1shac, 14s.

- ben Mohamed Asaquiq. 935.

Yusepe el Arcipreste ben Mansur, 911.

Y'usul' ben $A$ bdelaziz ol chábir $12: 3,14$.

-- ber Assahats, be.

-- ben Benyamín el Barcelones, lfs.

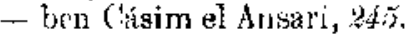

- Naamín, 148. - bon Ibrahim ben Iani, 147.

- ben dacob ben el, 1.5.5.

- ben R. Mair, 11.

- ben Jaix ttist.

- Zizá ben Isbac lyen d bi, 151 .

Zacaría, 218.

- rieto del Cordoliess, 373. 1.055

- ben Otruán, 9, 17.

\%acarias, nieto de Pedro el Cordobés, 357.

- ben Selam, 315 .

- el Tintorero, 21

Cafadola, 5:5, $75,2,130$
Zag, Simhá, hija de Jacub ben, 1 I. 1 .

Zahragüi, Abuzacaría Yahya el, 200.

Zaid, 84 .

Zambrano, Micrel, 1.101.

Zamuchi, hijo del, 456 .

7aragoza, Abulhasán Haquim Jen Omar el de, 852 .

- liernando de, 380 bis.

- Miguélez, hijo de Pedro \%a. I'agoza, 975 .

Zardel, Aben, (isl.

Zarueo, Domingo Illán de, 1.030 .

7aruti, hijos de], 492.

toinab, 1.042

Terual, 955 .

Zeyaha, hijo de Zac, 169.

rit Naimón, 148 .

\&inclo?, adalid, 227 .

thas, 151

- ben Abraham, 144

Zohara, hija de Ahmed ben Zaifar, 664.

\%uhra, 1.025 .

\%oilo Alviella, 217 .

Zuazo, Urraca, hija de Micael des, 1.087.

Zuleximán, $(7 / 2)$. 


\title{
ERRATAS ADVERTIDAS EN LOS CUATRO VOLÚMENES
}

\author{
VOLUMEN PRELIMINAR
}

\begin{tabular}{|c|c|}
\hline l'ilyinin. & $L_{1}$ motit \\
\hline 61 & 24 \\
\hline 65 & 2 \\
\hline 103 & 20 \\
\hline 147 & $3(a)$ \\
\hline 151 & $16(\mathrm{~B})$ \\
\hline 162 & 1 \\
\hline 189 & 5 \\
\hline
\end{tabular}

vis..
Lazarena ben
IIamán
Allyerguilla
hijo
Yabium
Sabid
Aldelaziz

Thetro Borie.

Lazarena, hija de

IIamam

Alberquilla

(a)

(b)

Aldelaziz

hija
Yahiun
Sabil
Abdelaziz

VOL.UMEN PRIMERO

3
10
11
12
2
17
23
17
19
2
23
24
24
12
13
5
4
22
7
29
5
31
15
9
5
13
19
26
18

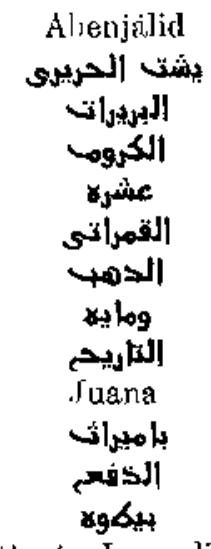

ivanta Jeocadia

$$
\text { كنب }
$$

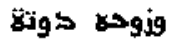

hacia la entrada por sus costados

$$
\text { والى casar }
$$

hermana de

$$
\text { الجراحة }
$$

حفيذئما

¿Kabibo?

Venta de San Pablo

cosecha

Baeza Saadí

ولعذانت

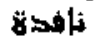

acaso on las 'lenerias de hoy

Cuxtidores
Abujalid

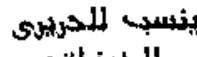

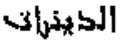

الكرهـ

عشرية

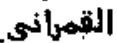

4ه।

وائو

الذاريحم

Juanes

بالميراث

|

بئره

San Lucas

$$
\text { كنبي }
$$

وزيوجة לونة

$\mathrm{y}$ otros sitios

وألى غيره

y por su her'mano

$$
\text { إلجراحم }
$$

حفيدكا

hijastro del vendedor

Barranco de San Pablo

barbecho

Baeza y Saadí

ولفs|s

زاغذية

(borrese)

Correeros 


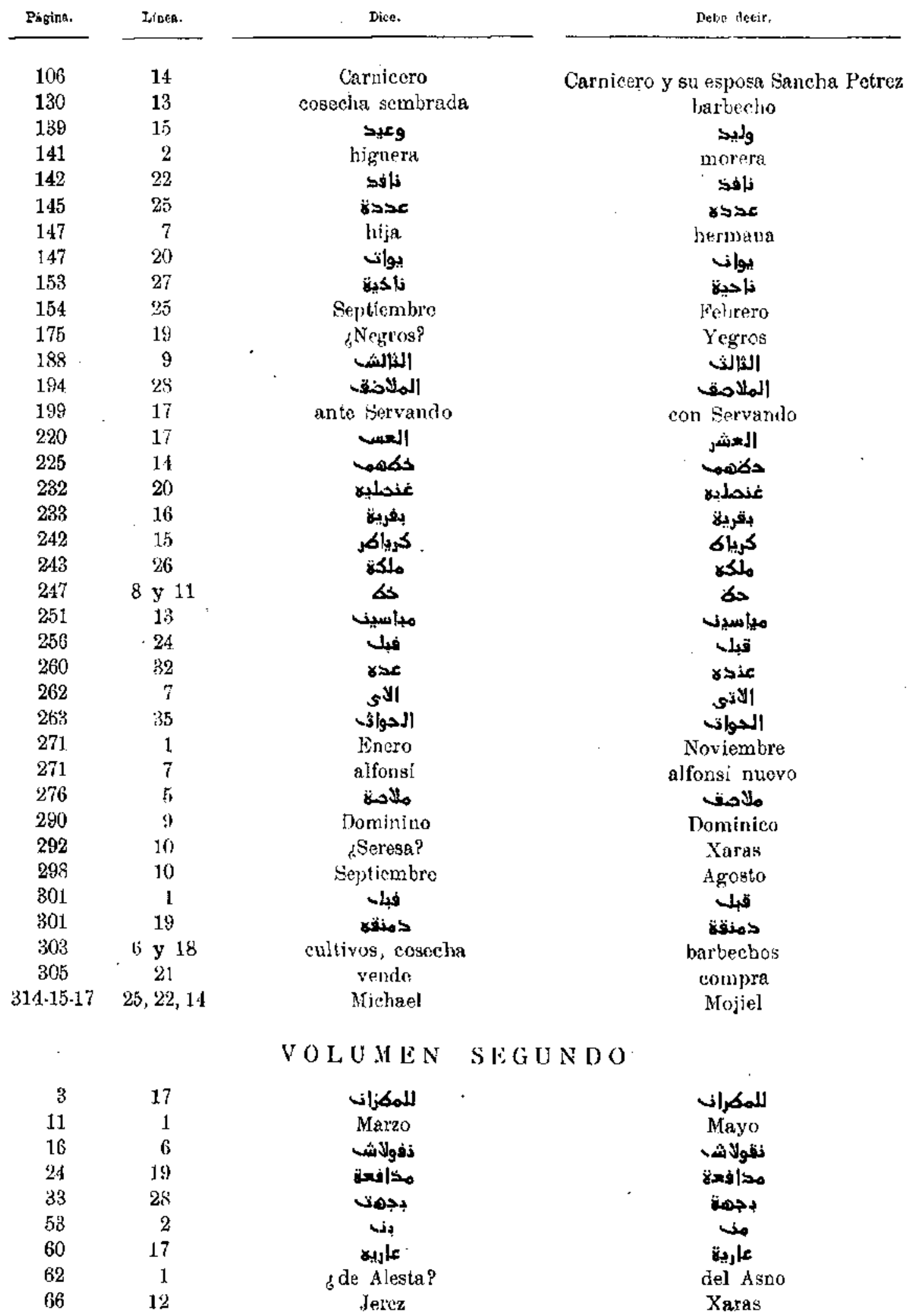




\begin{tabular}{|c|c|c|c|}
\hline Pagina. & Linca. & Irice. & Delee dccir. \\
\hline 87 & 15 & | & ارهلذس \\
\hline 90 & 17 & غراستة & غمريشية \\
\hline 101 & 27 & num. 484 & núum. 477 \\
\hline 110 & 15 & con picdra & - con alhachra \\
\hline 127 & 20 & ¿quo es de ... Eliezer? & a la mano izquierda \\
\hline 141 & 11 & comprador & yendedor \\
\hline 164 & 2 & Alhondiga & Alhandac \\
\hline 168 & 22 & s. & |עتى \\
\hline 185 & 30 & acequjas & aceñas \\
\hline 195 & 26 & 1250 & 1236 \\
\hline 201 & 16 & Abilhair & Abiljáir \\
\hline 205 & 28 & |لفشق & 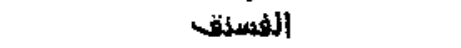 \\
\hline 212 & 27 & Bernal & Portal \\
\hline 230 & 13 & |المنغي & العقد \\
\hline 238 & 21 & num. 622 & num. 619 \\
\hline $242 \cdot 51-66$ & $15,10,10$ & Barguellas & Burguillos \\
\hline 274 & 3 & llDarcanadre, Aragón? & Daroca, provincia de $\Lambda$ ragón \\
\hline 283 & 25 & Junio & Mayo \\
\hline 804 & 27 & Noviembre & Octubre \\
\hline
\end{tabular}

YOLUMEN TERCERO

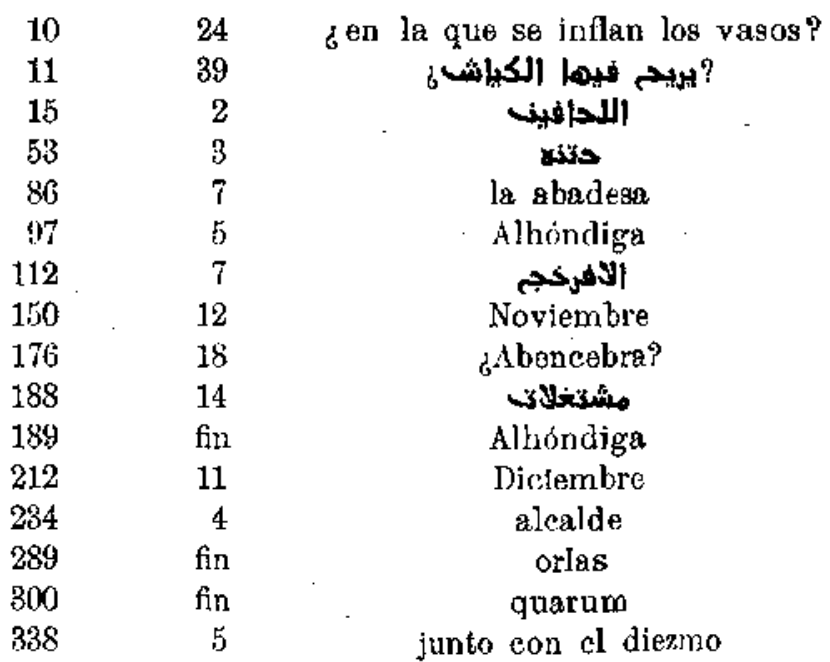

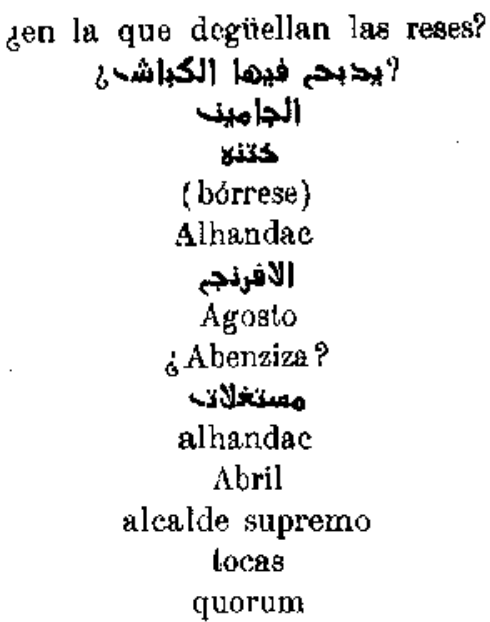

den la que degiuellan las reses?

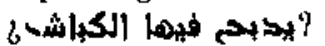
الجاهين riss

(bórrese)

Alhandac الإفرنجي Agosto

¿Abenziza?

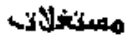

alhandac

Abril

alcalde supremo

tocas

quorum

Si el arrendatario trabaja más tierra de la citada, en dicha alqueria, pagará una décima parte por las ntilidades.<smiles>O[AsH2]</smiles>

las monjas descalzas viudas

1229

1267

hijastra

شارى

1201 los monjes descalzos

hućrfanos

1227

1265

madrastra

شارع

1199 


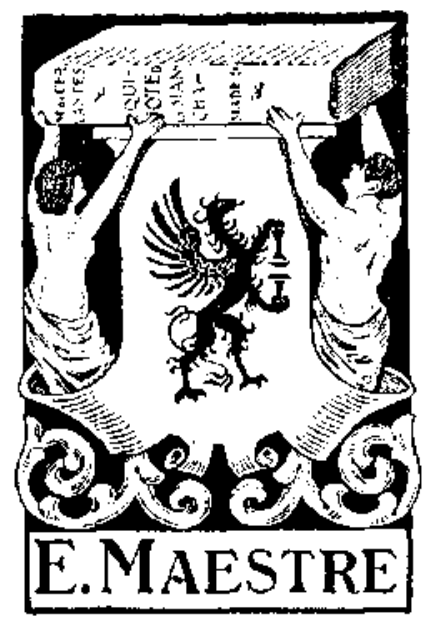

LOS MOZÁRABES DE TOLEDO EN LOS SIGLOS XII Y XIII, CUYO AUTOR ES LON RIUEL GON/ALE\% P'ALENCA, CONETA DE OUATRO VOLLBMETS, IMPRESOS EN LOS TALLEKLS DE I) EFTANISLAO MAESTRE, (SALLE DN LAS POZAS, N. 12, MADRID, DURANTE hOS AÑOS 1926 al 1930;

ILABLVDUSE TERMINADO LA

DE FSTE VOYUMEN PREIJMINAR A LOS TREINTA DÍAS

DEL YISS DE

$\mathrm{MAl}$ [O $\mathrm{DE}$ MCAXx:<smiles>c1ccc2ccccc2c1</smiles> 


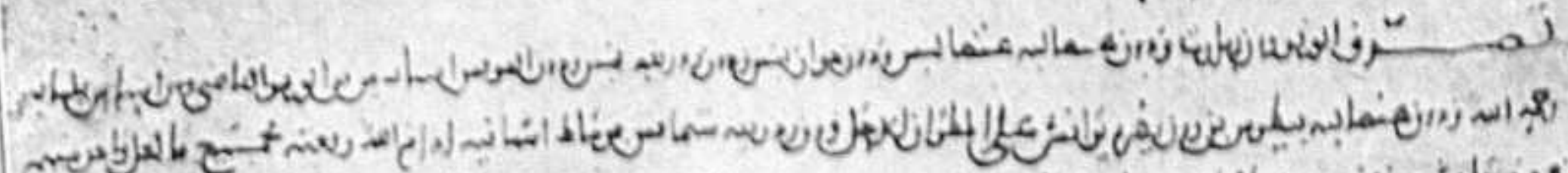

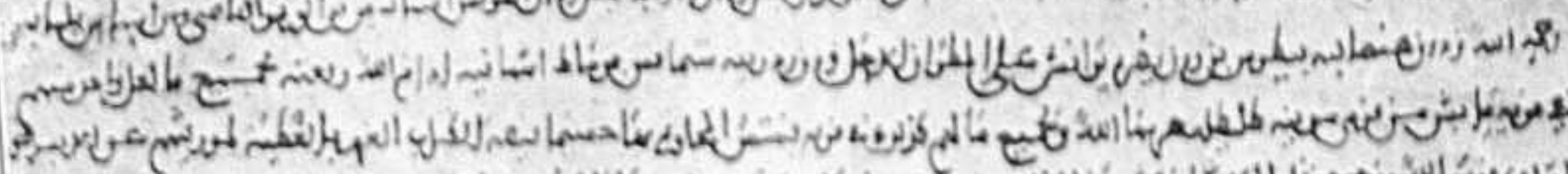

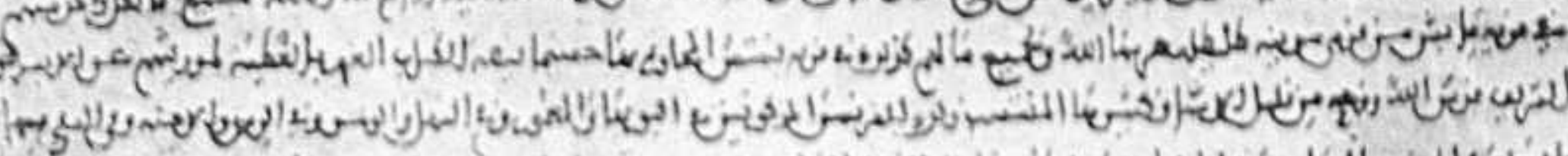

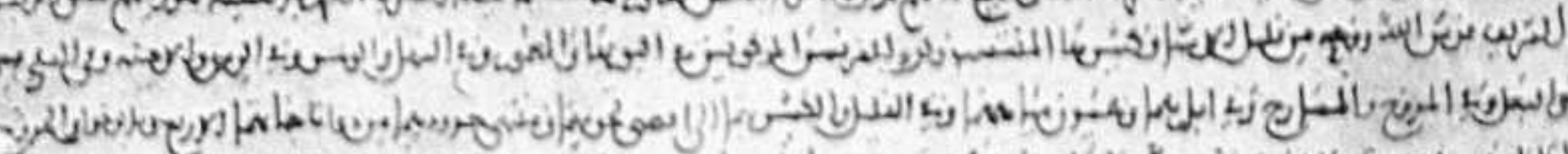

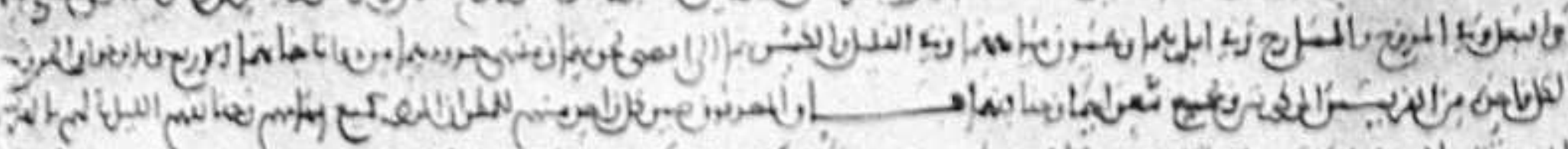

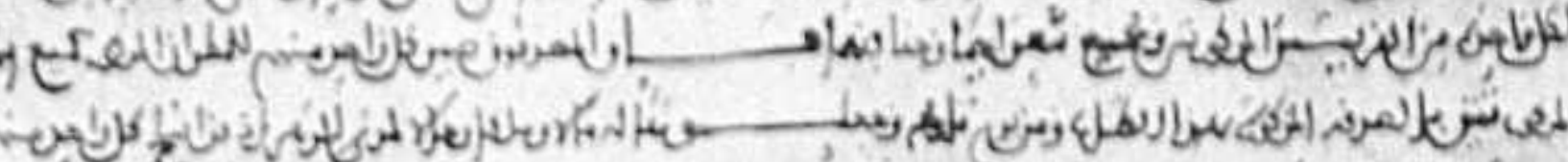

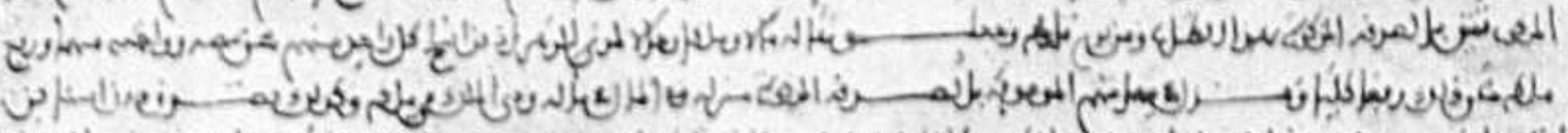

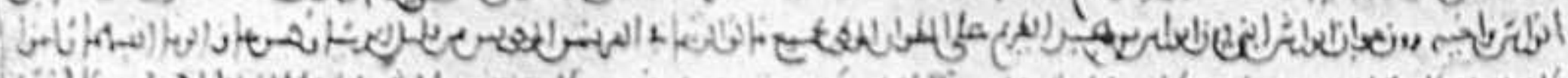

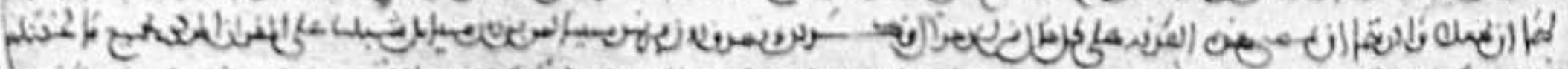

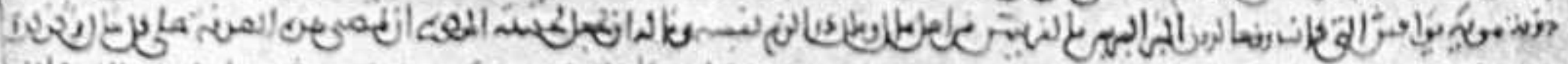

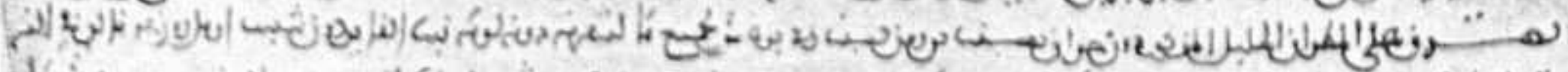

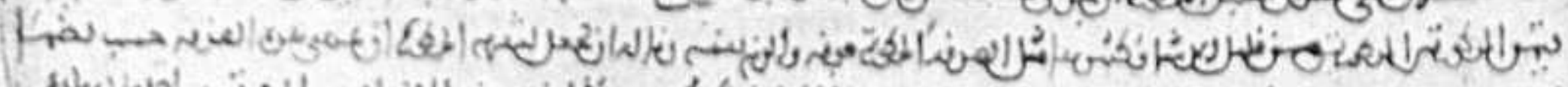

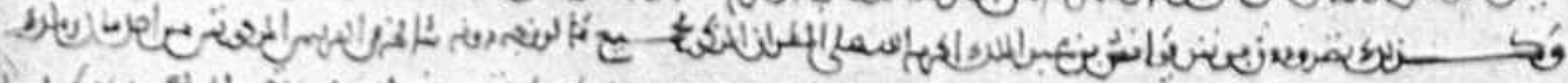

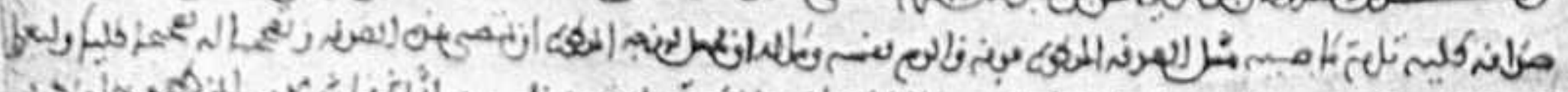

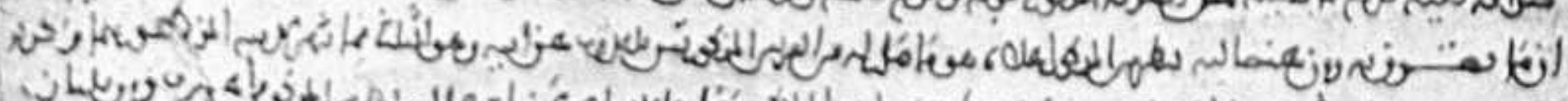

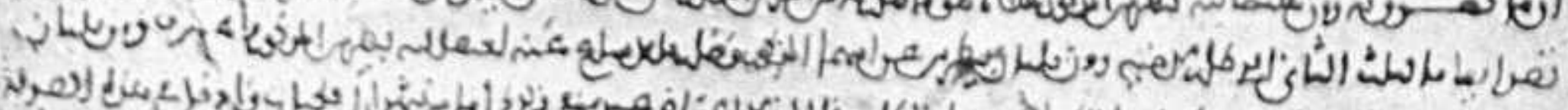

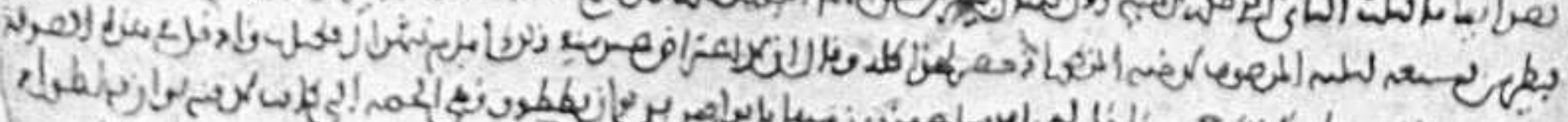

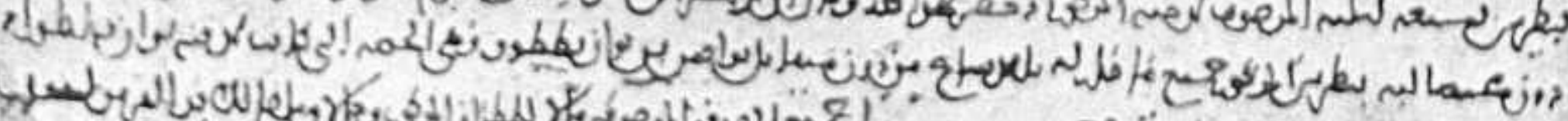

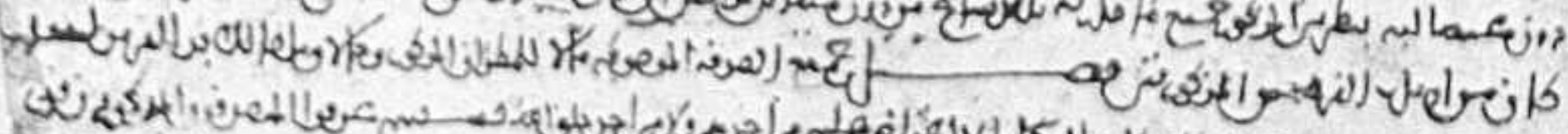

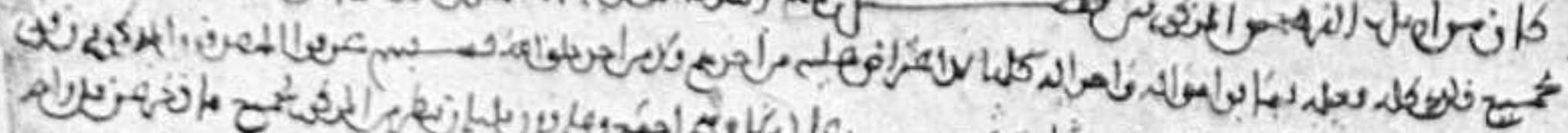

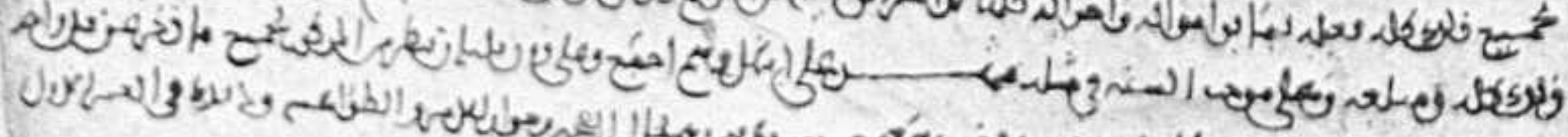

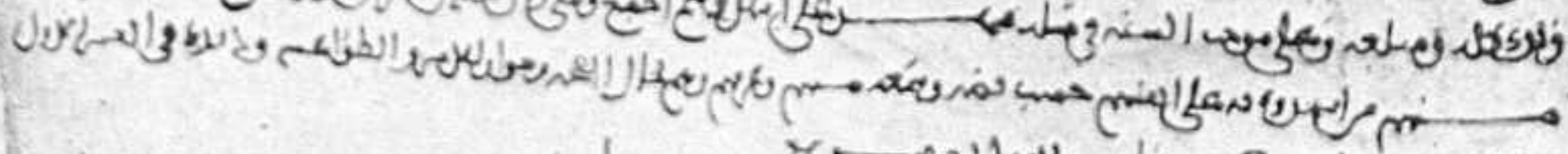
(obanponf

Donación al arzobispo D. Rodrigo: $1 .^{a}$ decena de Abril de 1213 (núm. 748) 


\section{$\underline{4}=\underline{\varepsilon}$,}

P.

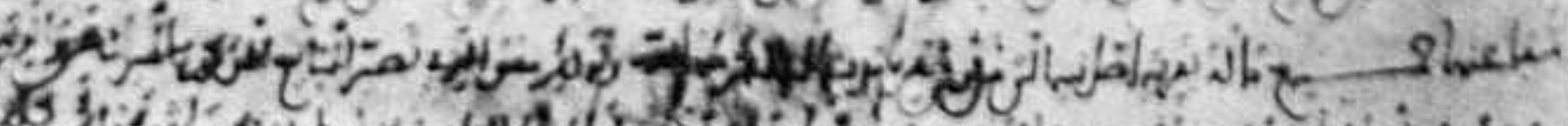

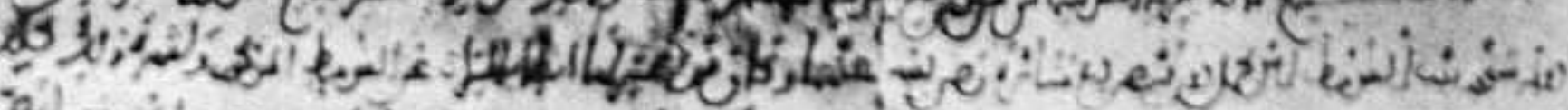

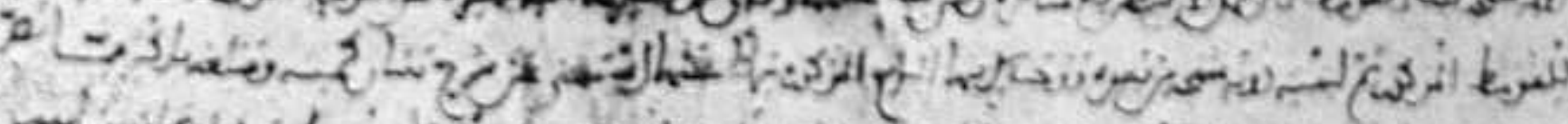

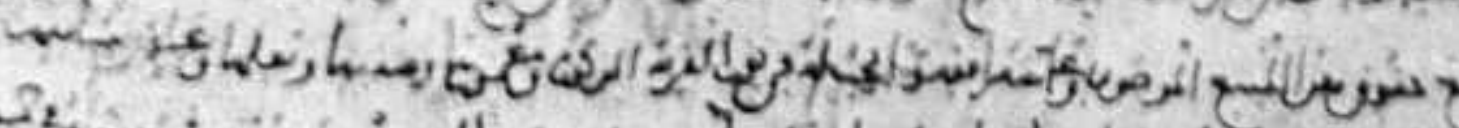

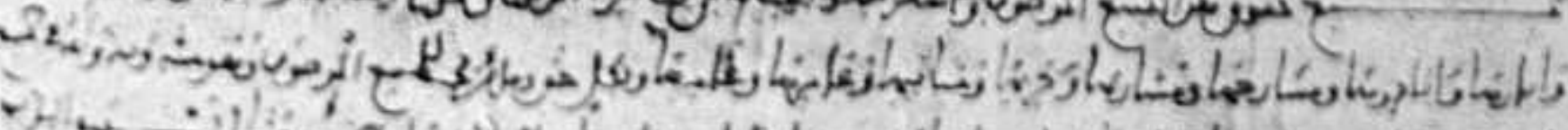

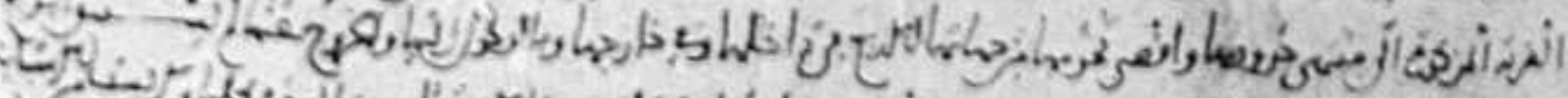

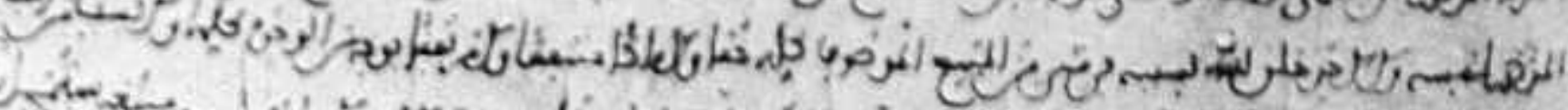

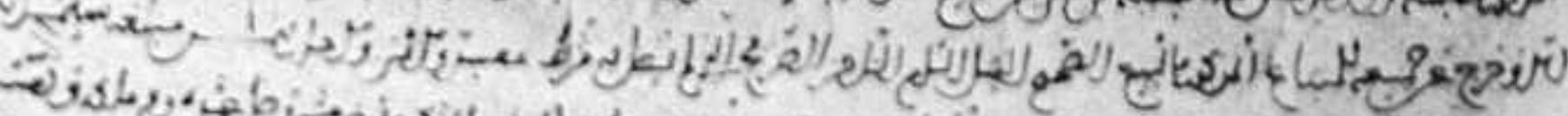

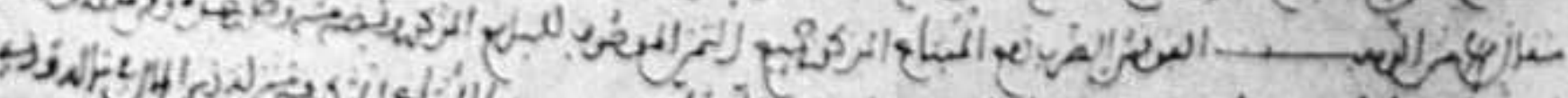

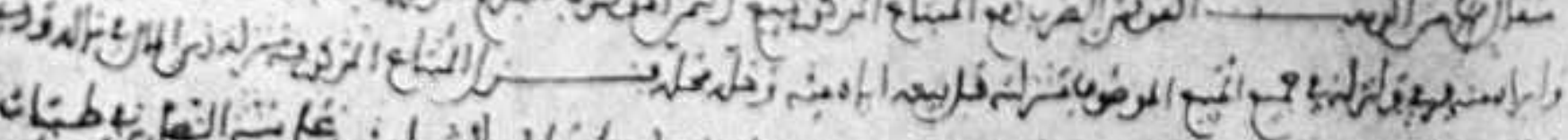
-

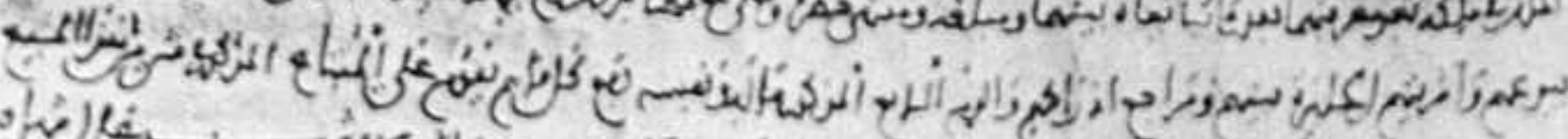

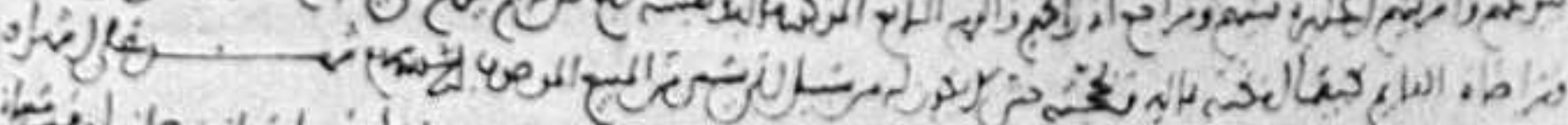

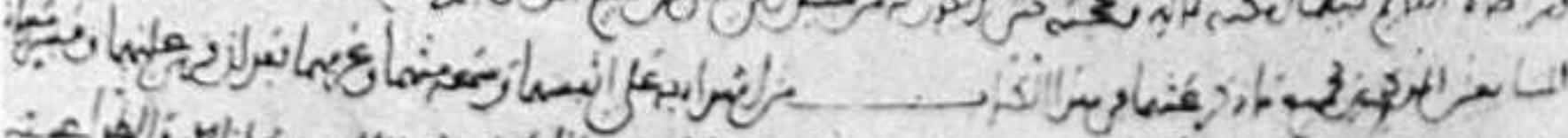

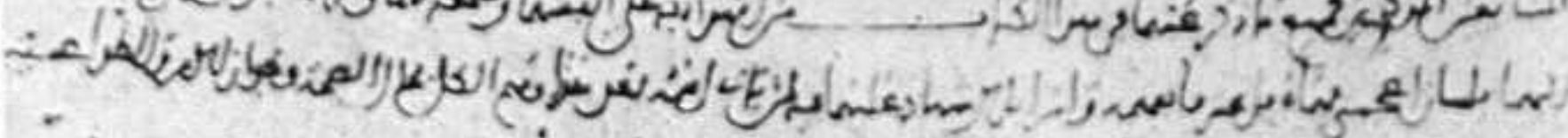

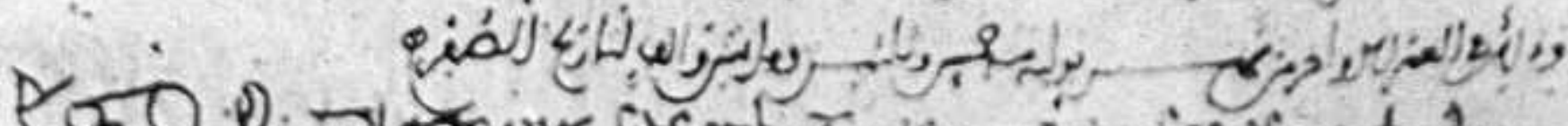

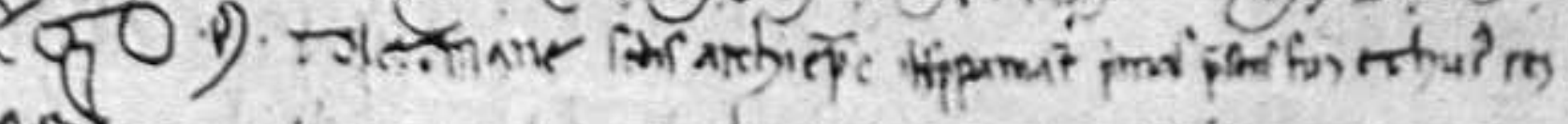

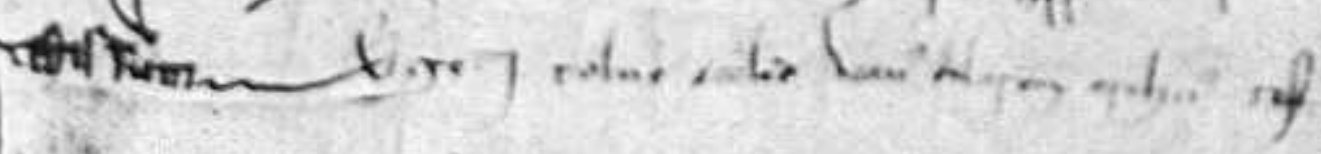

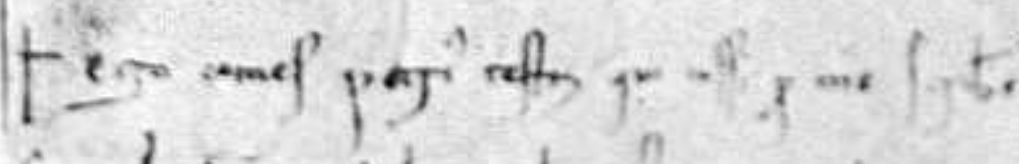

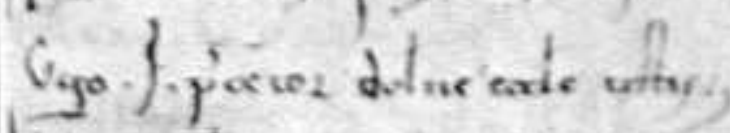

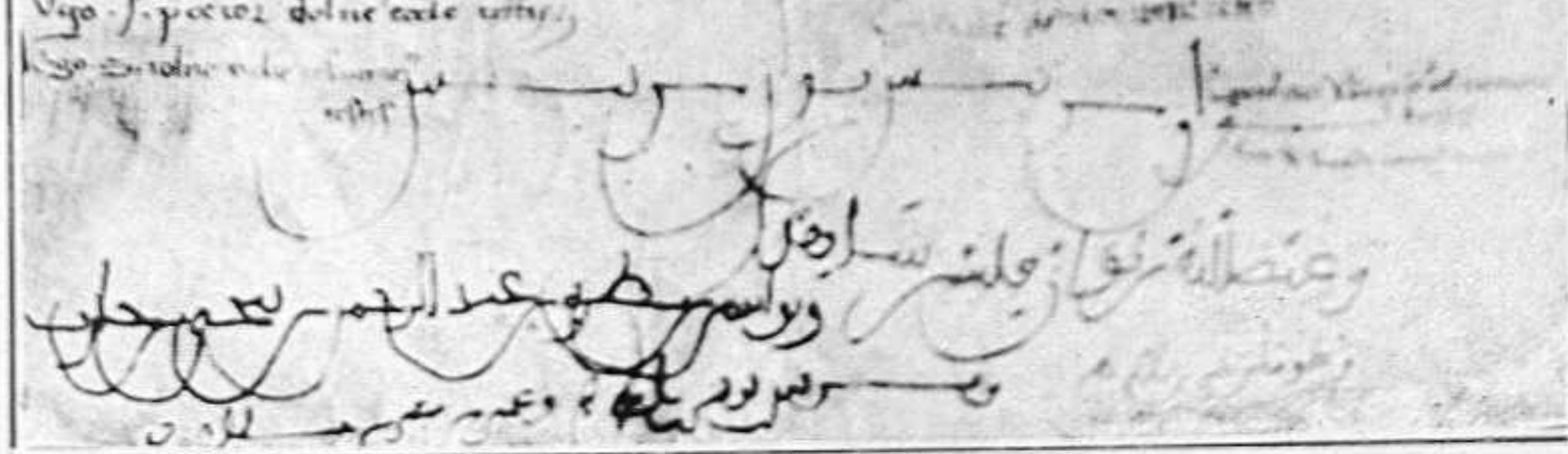

Compra de finca en Azaña, por S. Julián, obispo de Cuenca: $3 .^{a}$ decena de Julio de 1197 (núm. 274). 


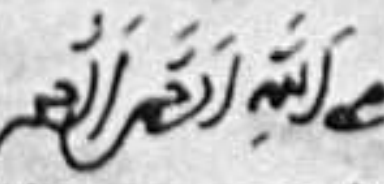

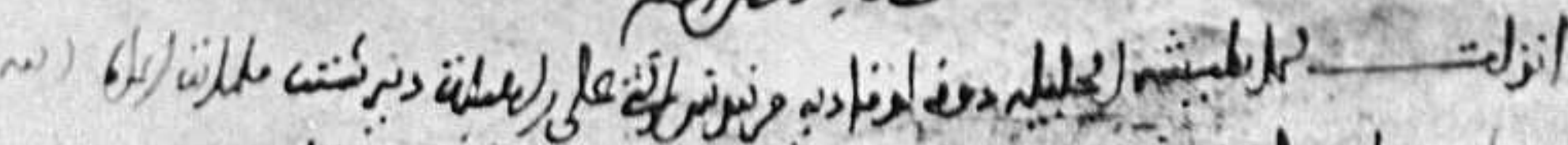

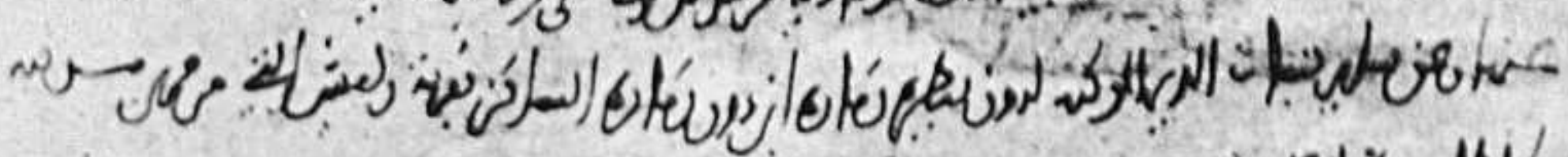

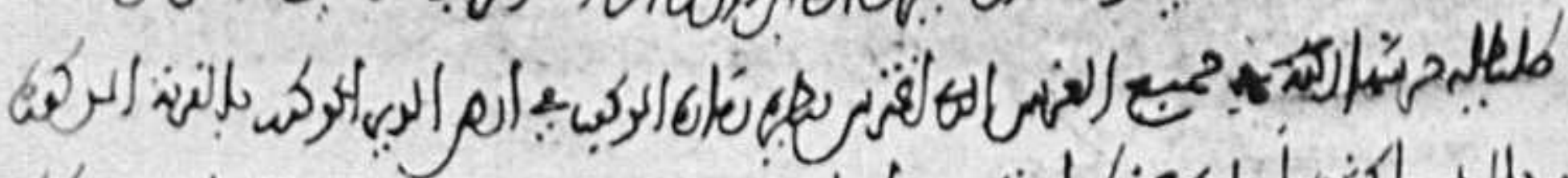

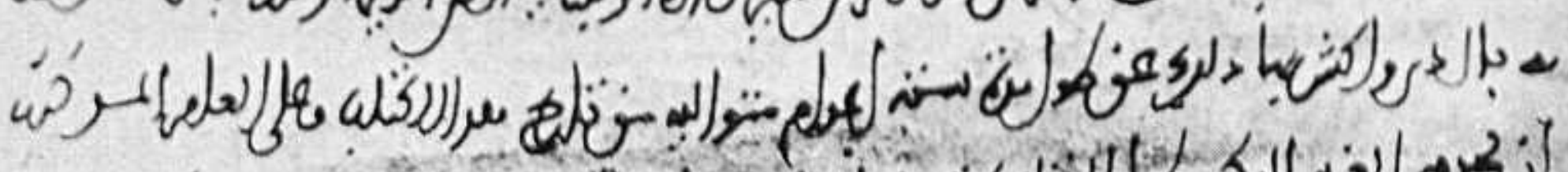

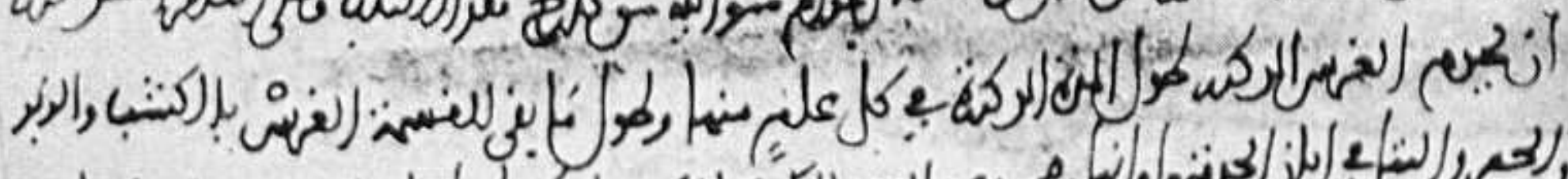

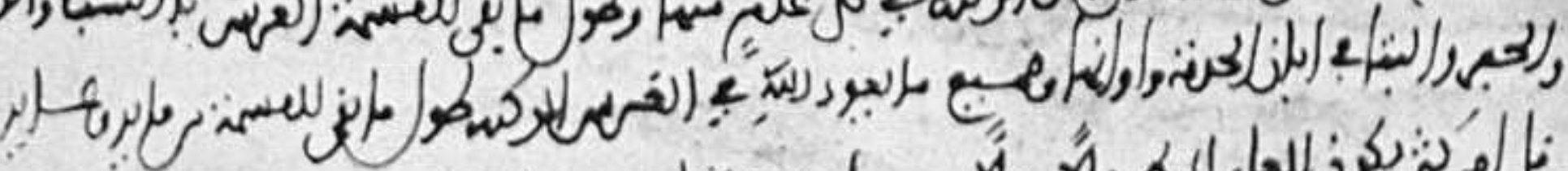

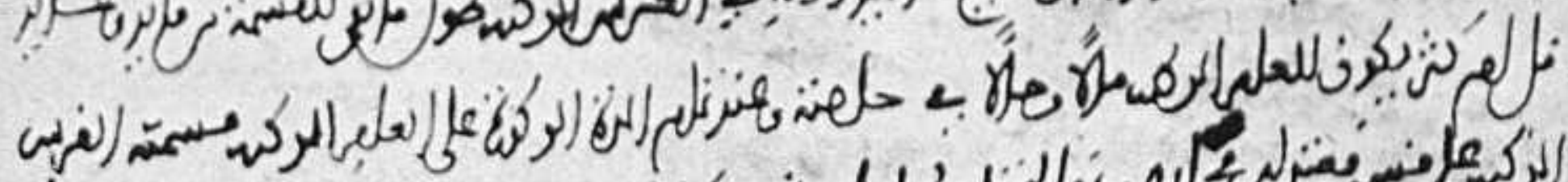
Lل́

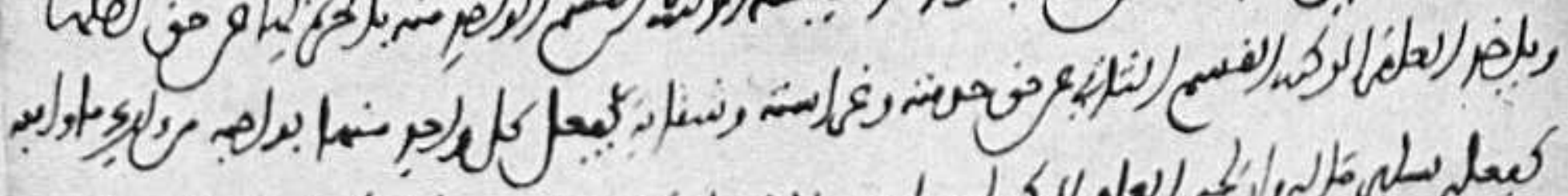

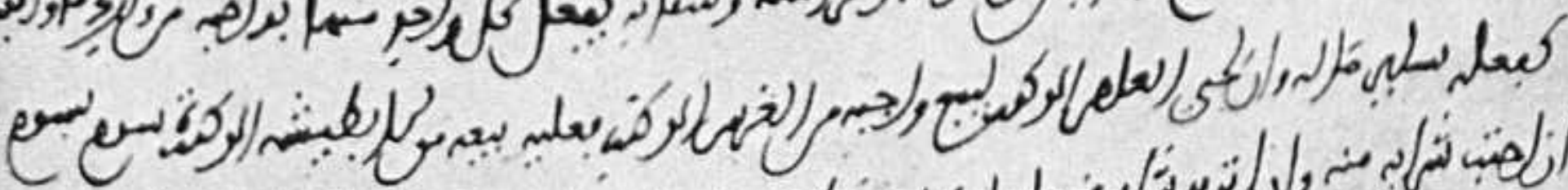

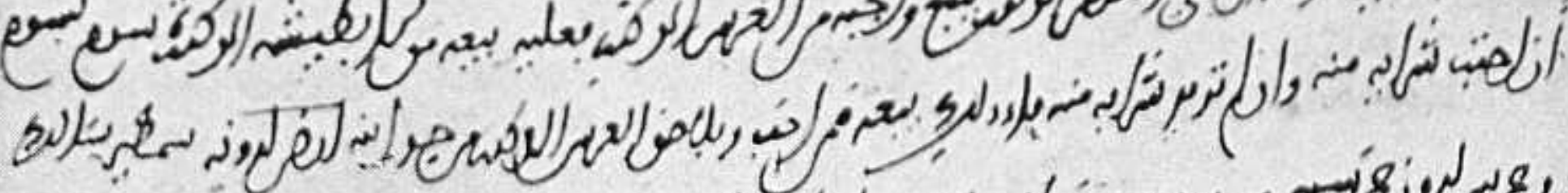

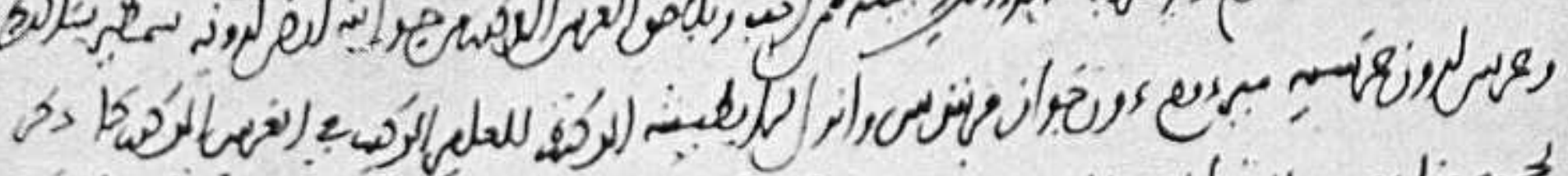

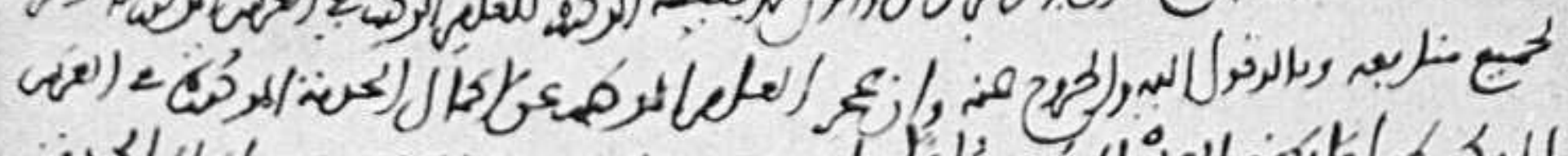

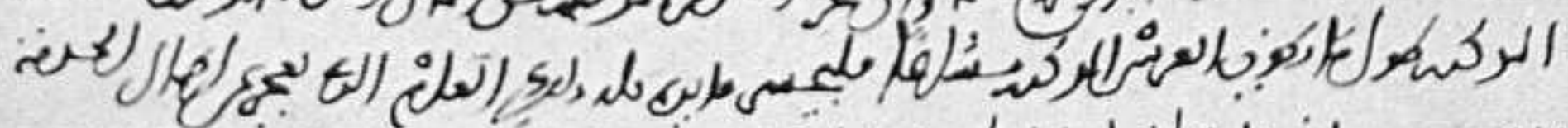

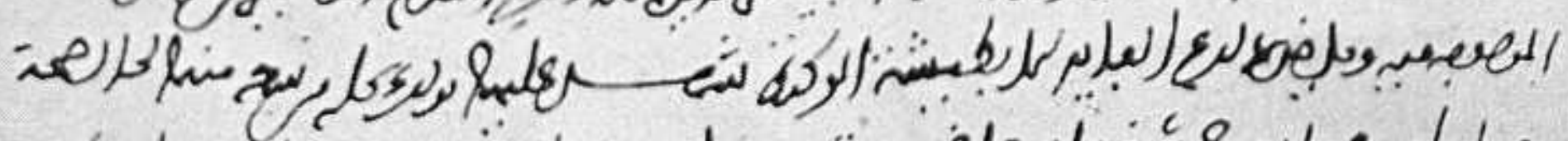

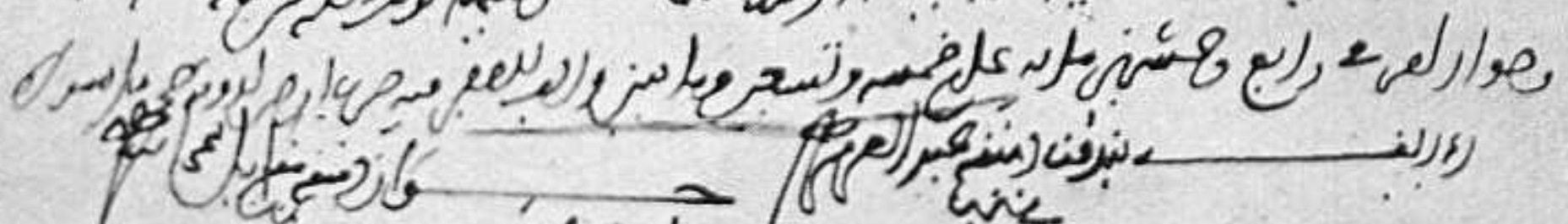
6

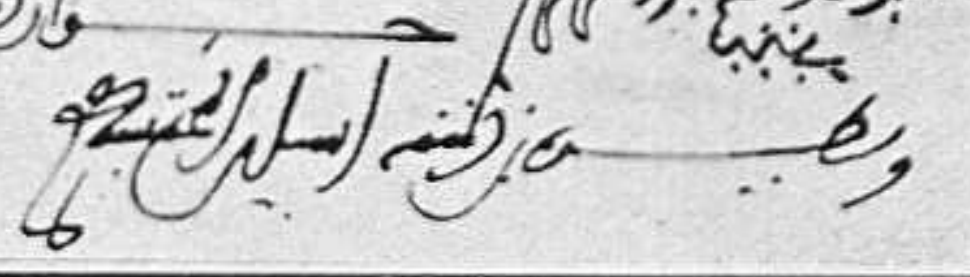

Contrato de plantación: 24 de Mayo de 1257 (núm. 930). 


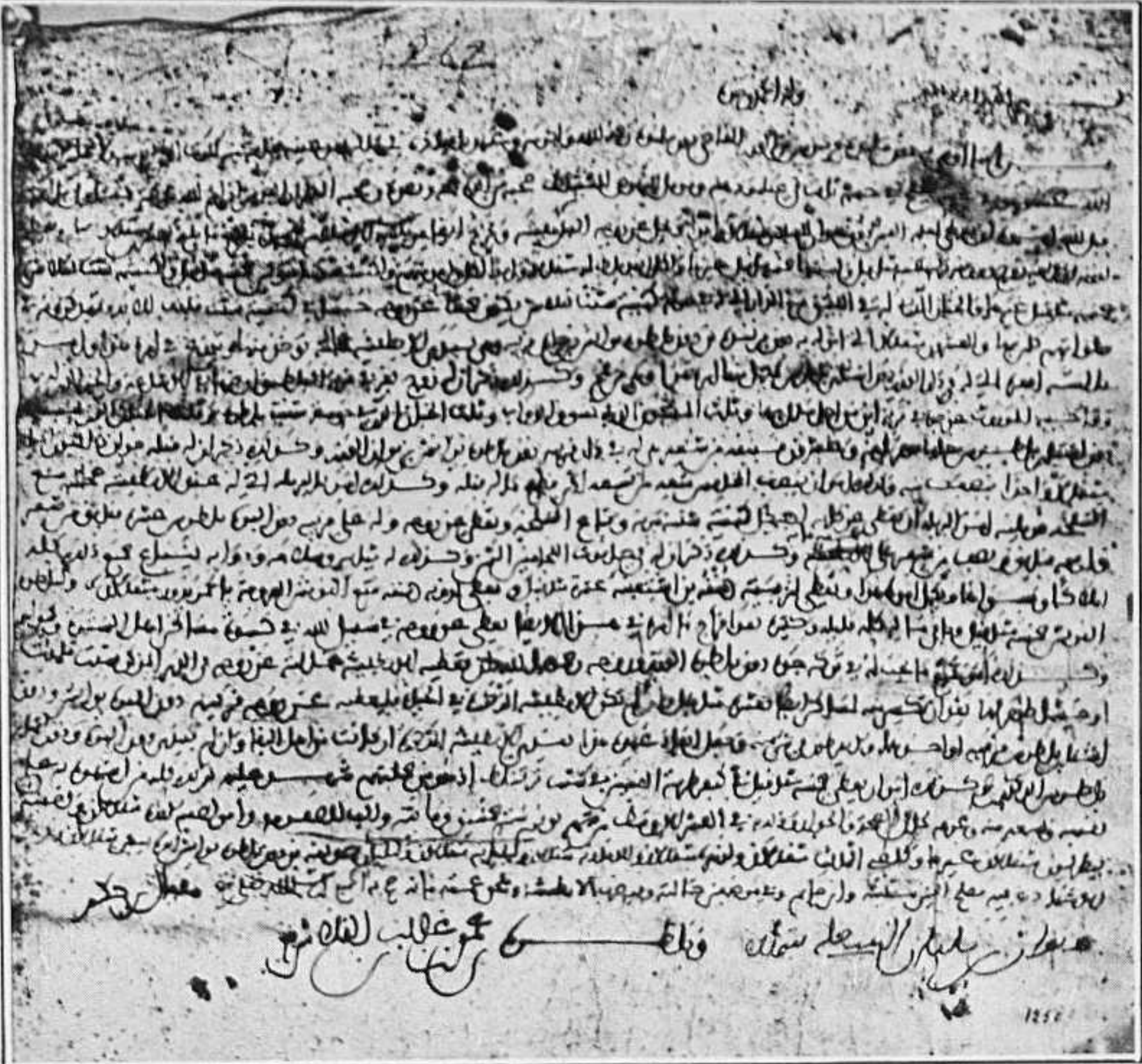

Testamento de D. Melendo Fernández: $2{ }^{a}$ decena de Noviembre de 1212 (núm. 1.025).

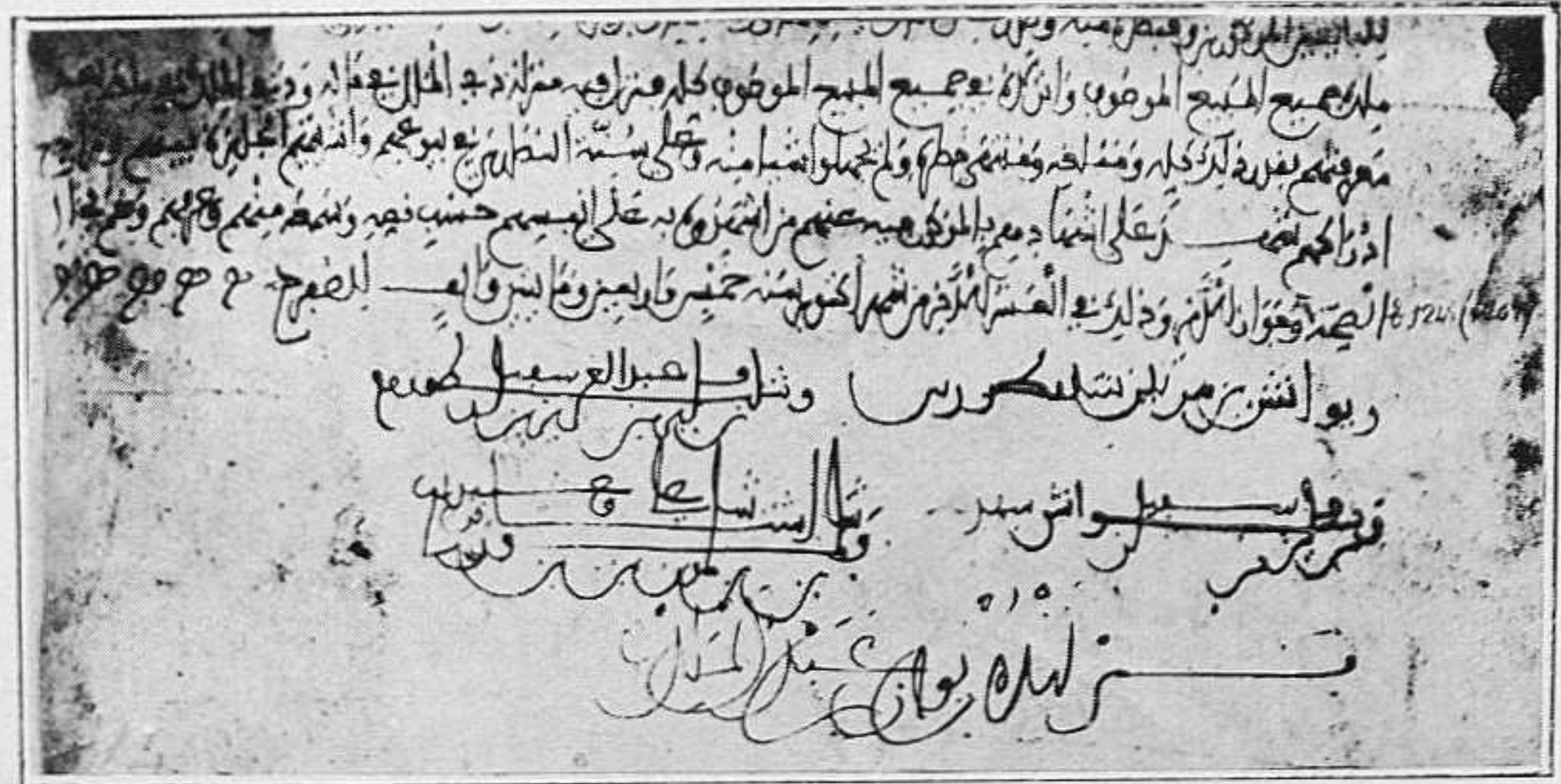

Firmas del documento núm. 358, 3. ${ }^{a}$ decena de Octubre de 1207. 


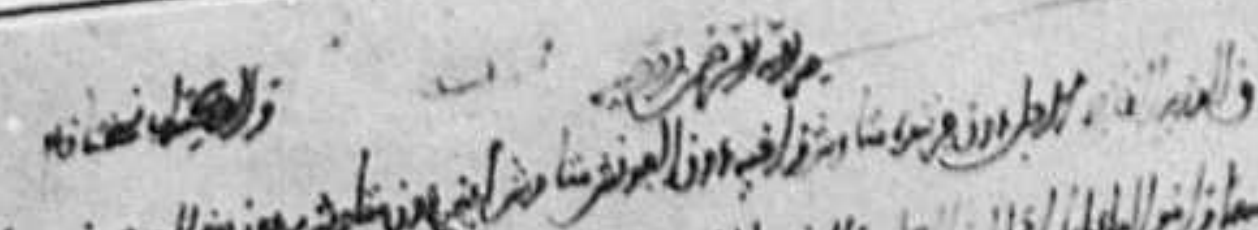

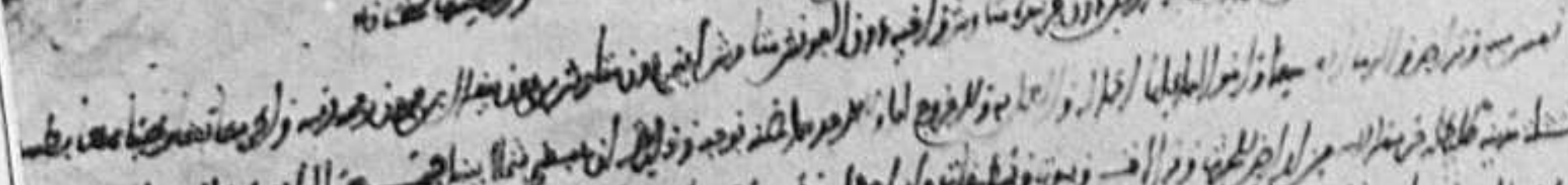

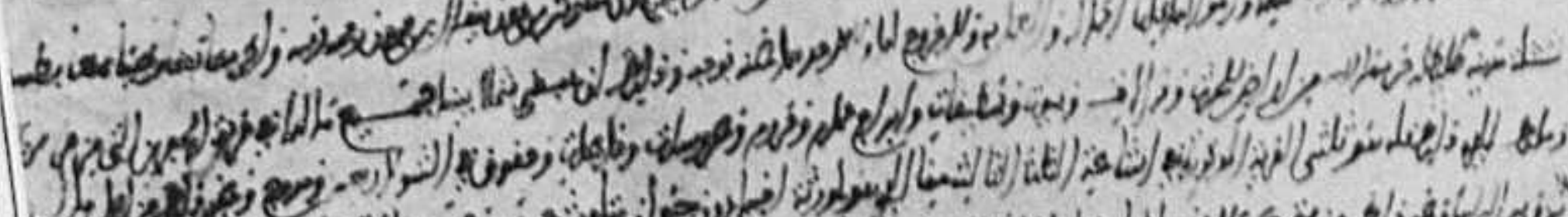

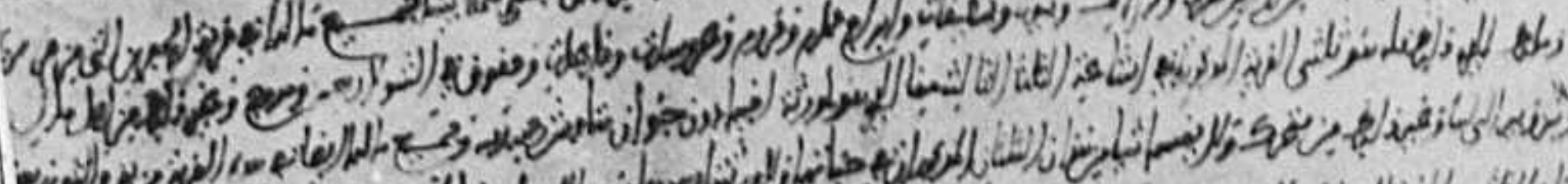

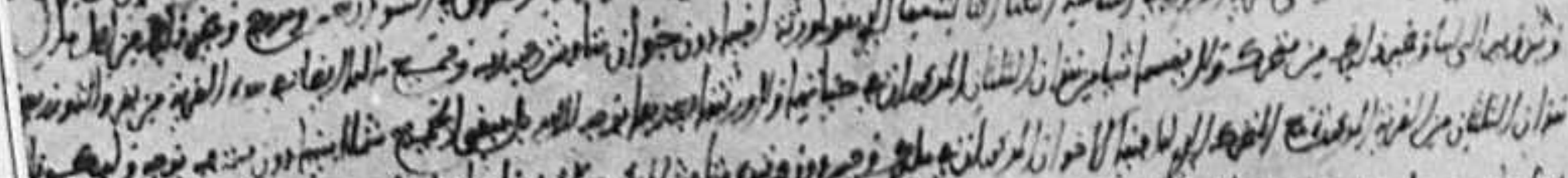
ba

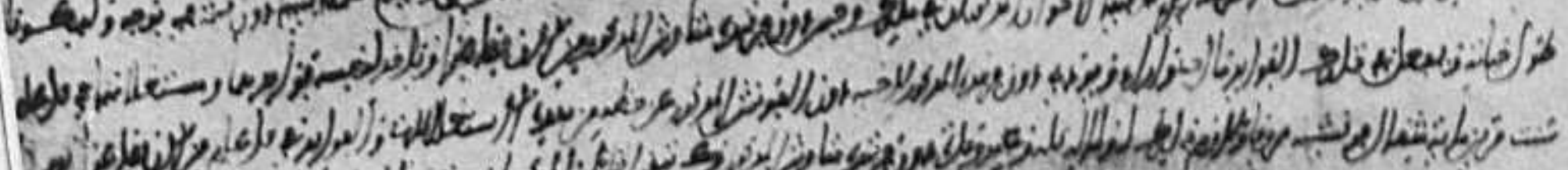

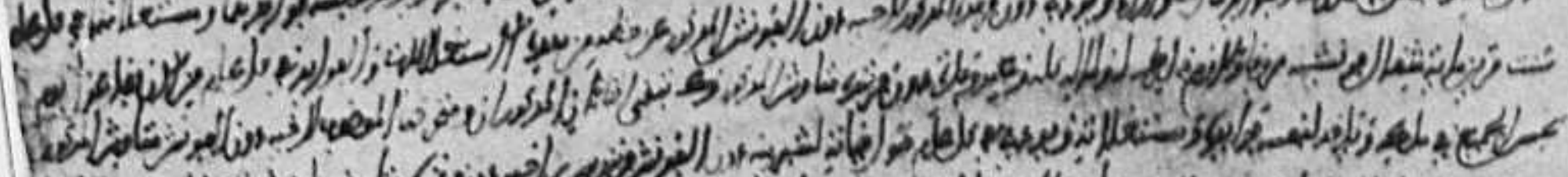

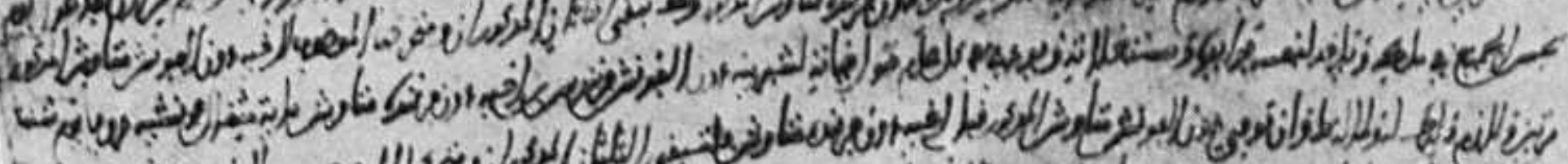

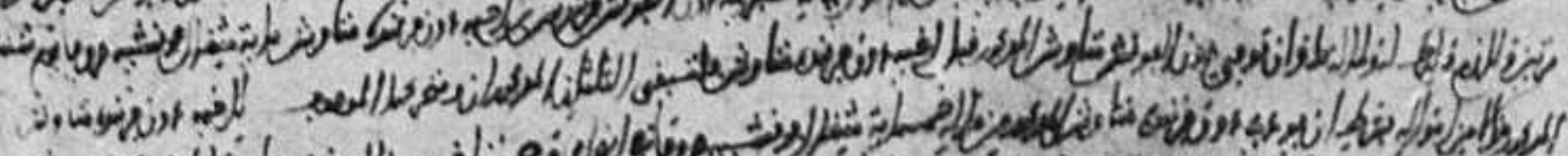

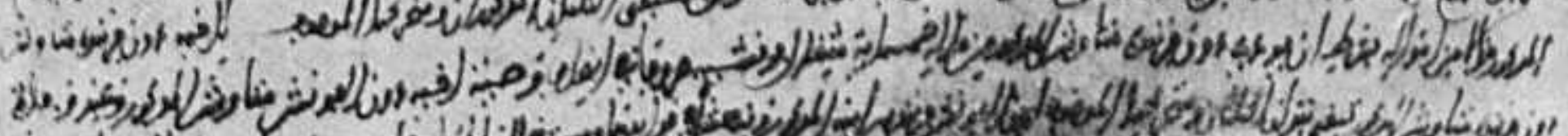

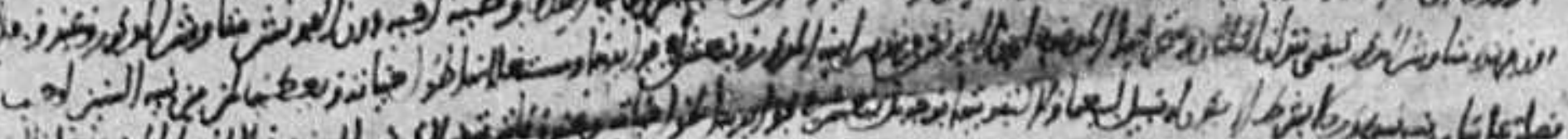
Dis

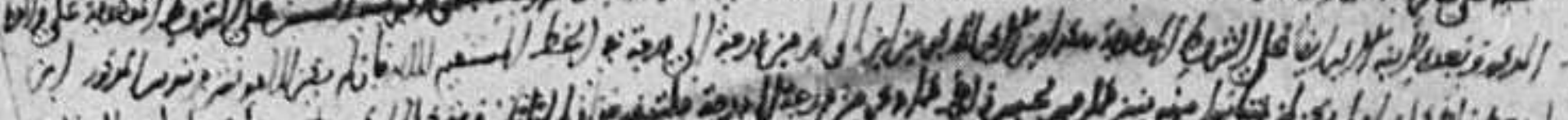

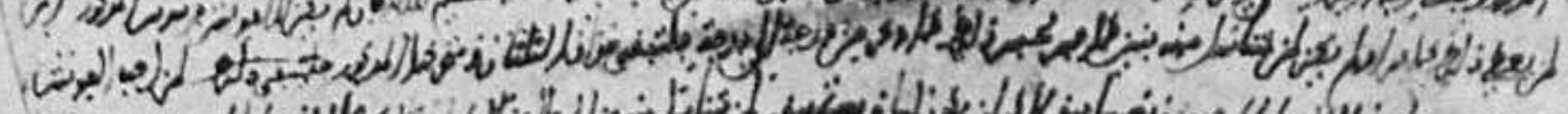

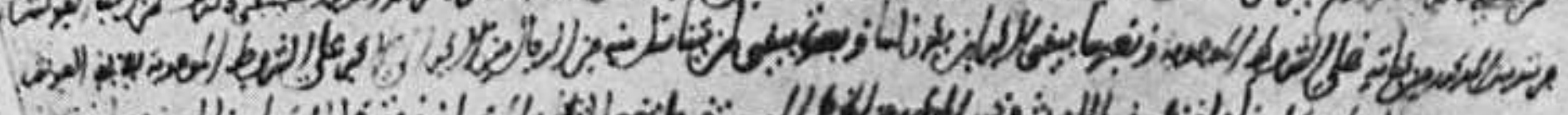

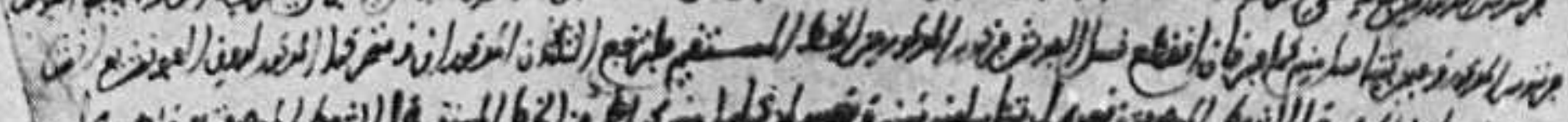

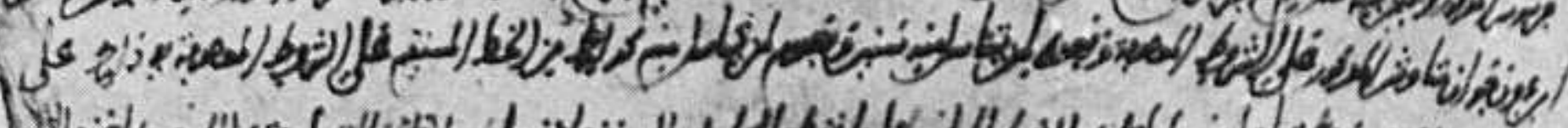

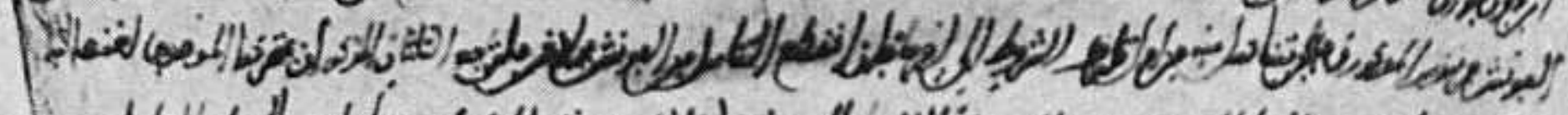

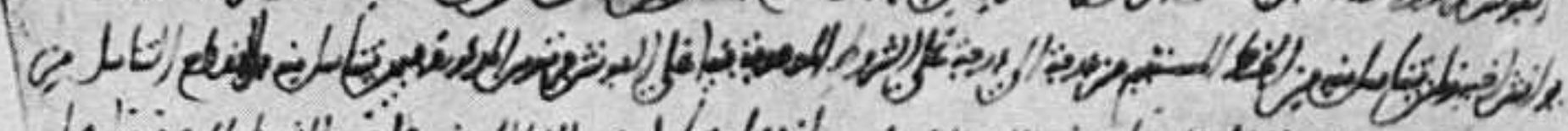
jo id

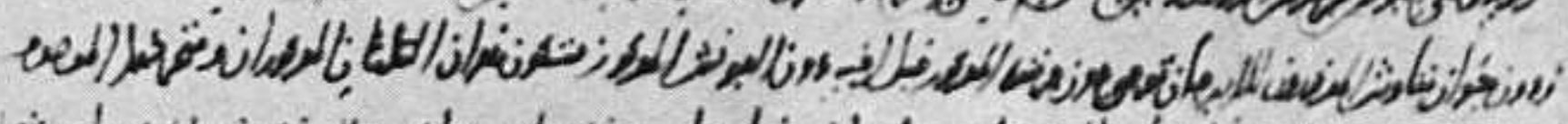
-

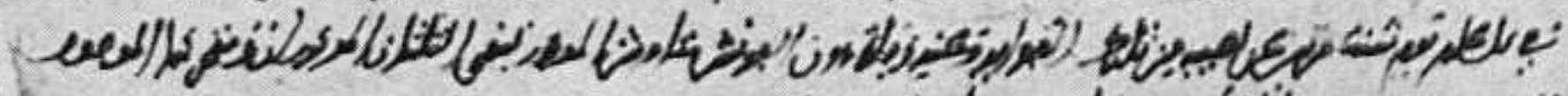

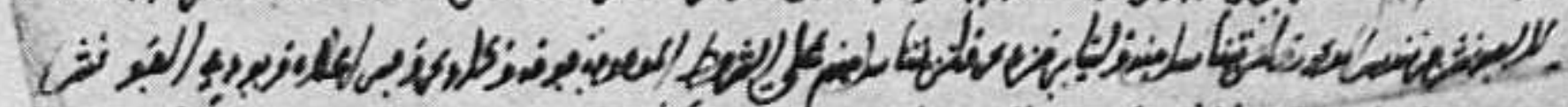
is

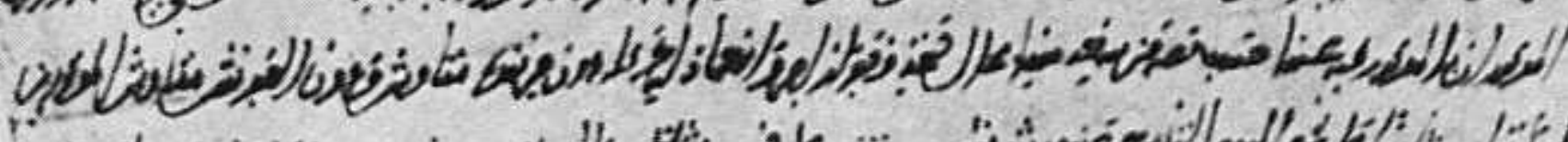

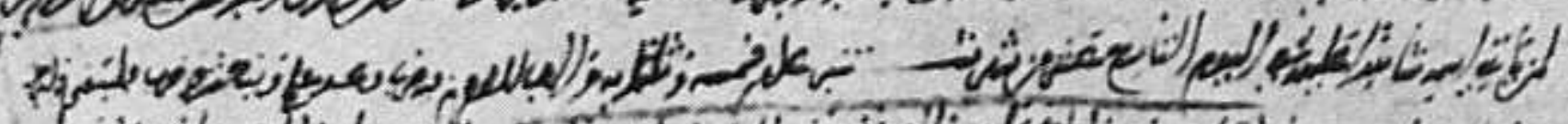

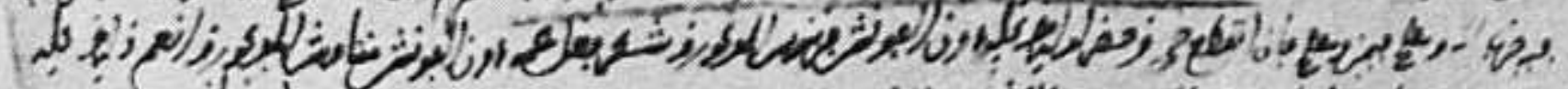

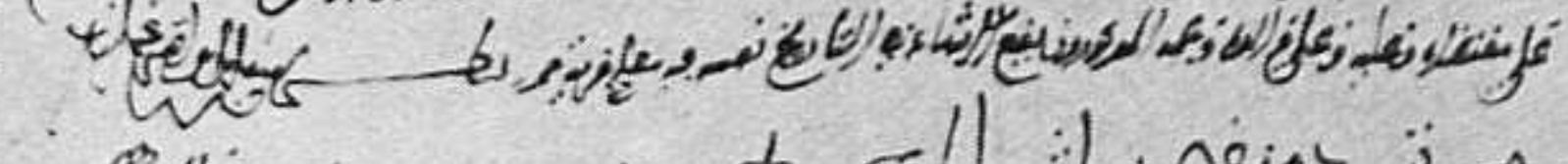

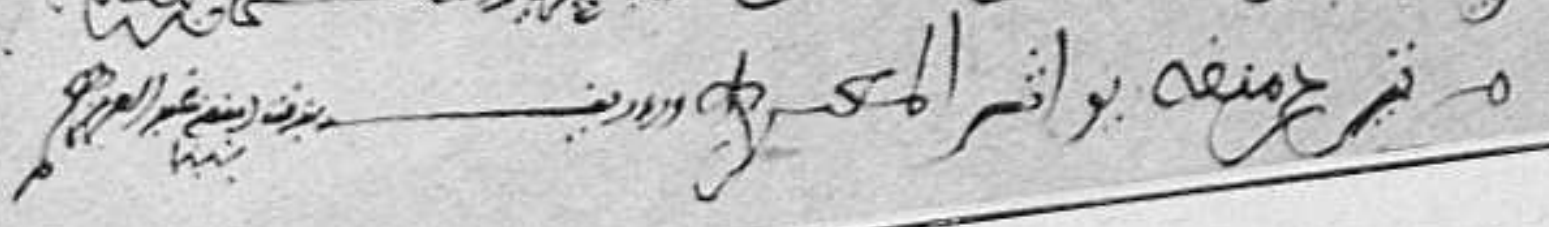




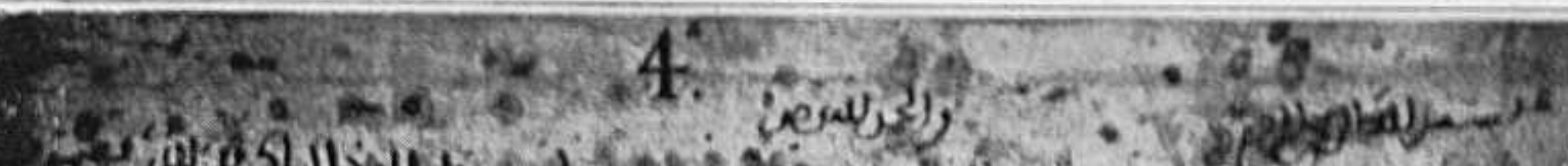
7. tats

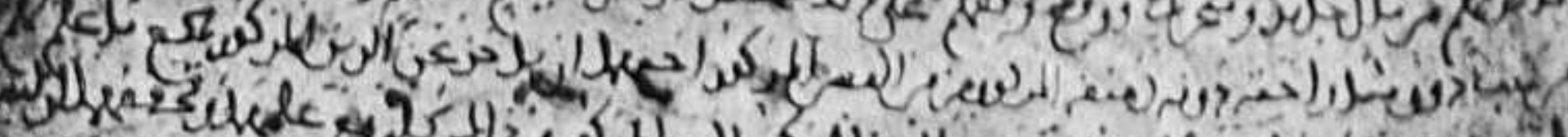

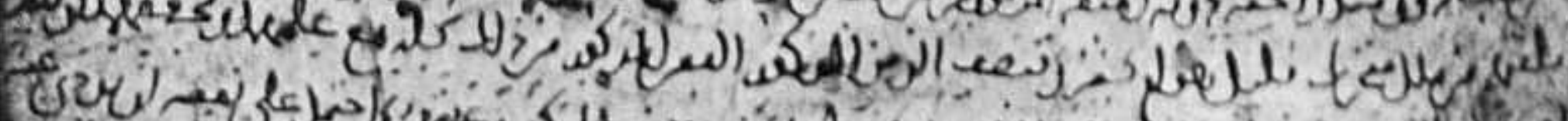
(us

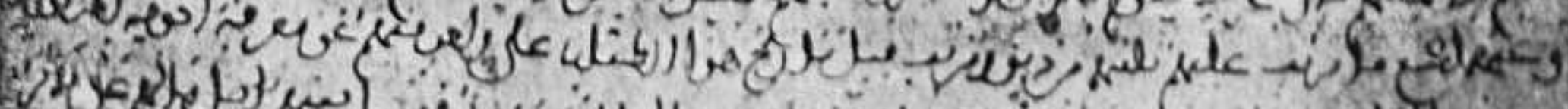

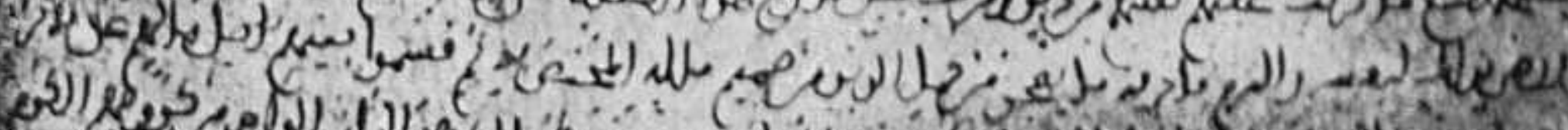

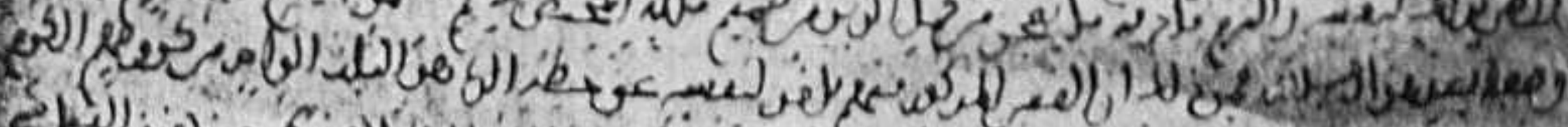
F ev?

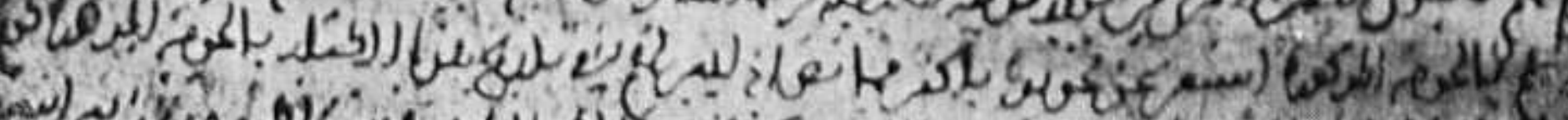

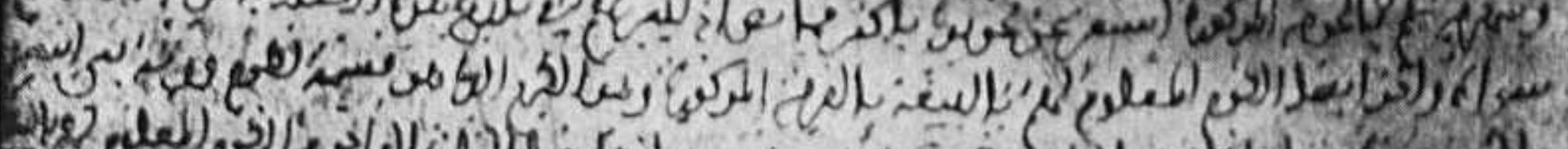

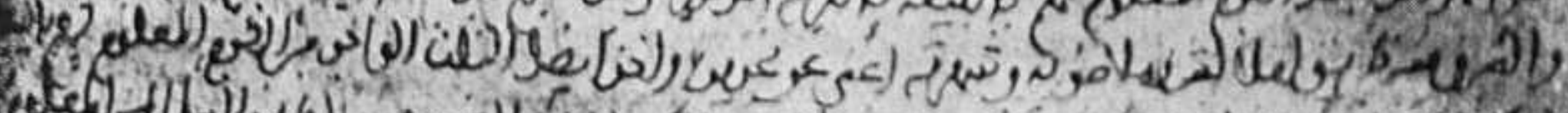

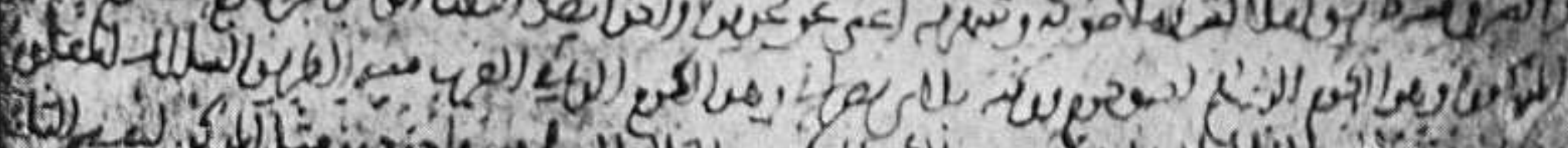
(iv) (vis)

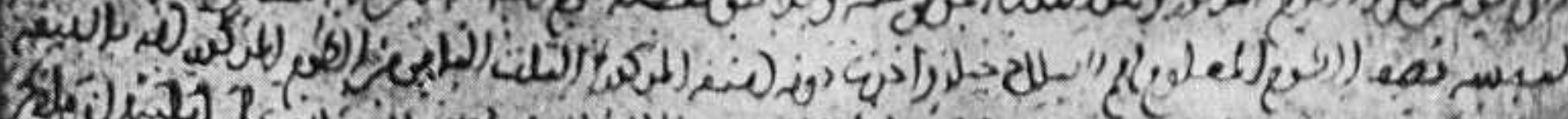

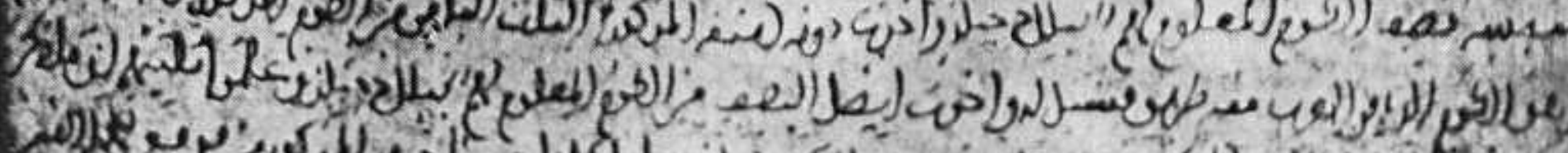

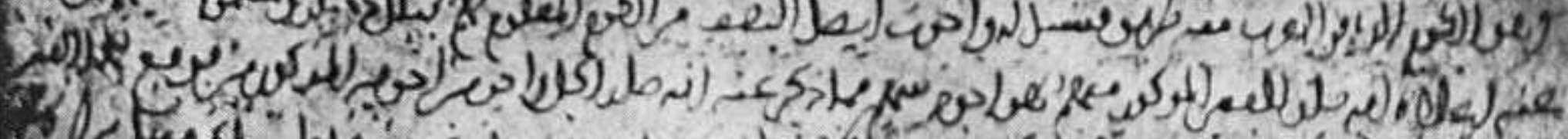

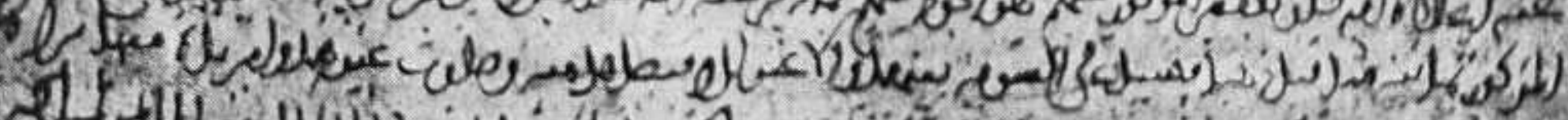

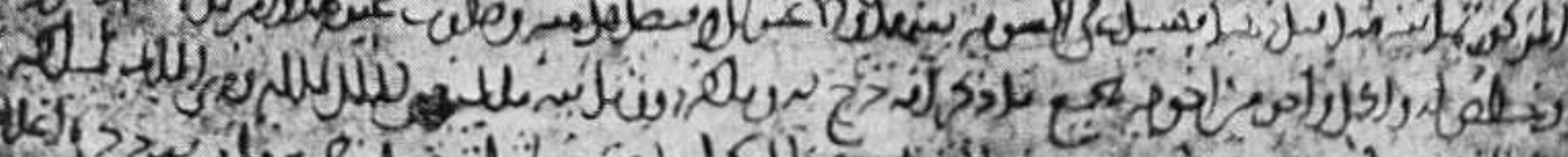

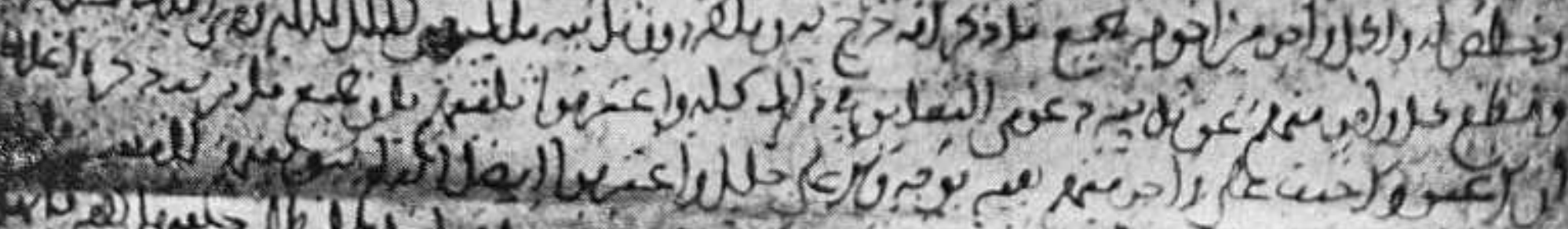

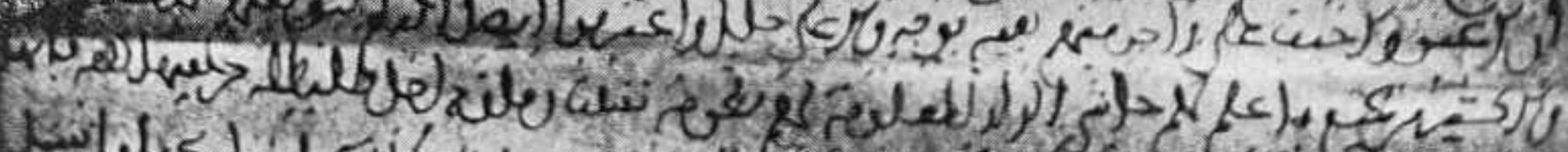

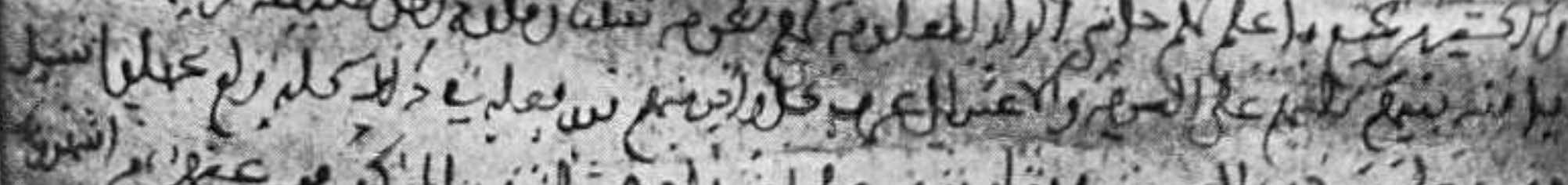

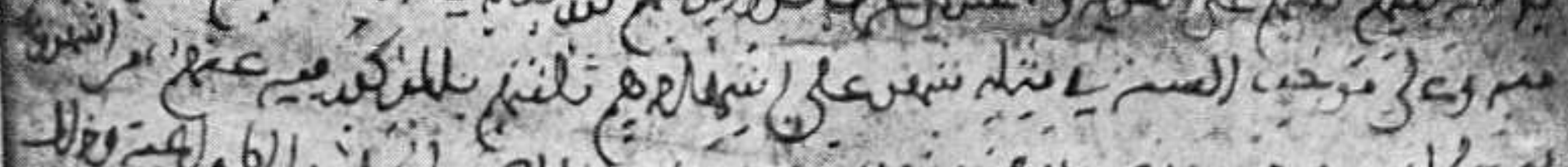

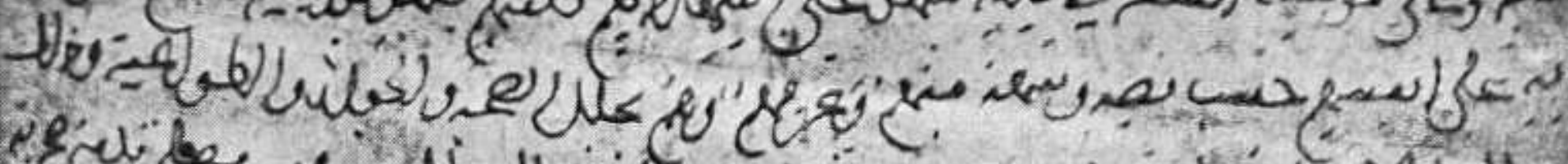

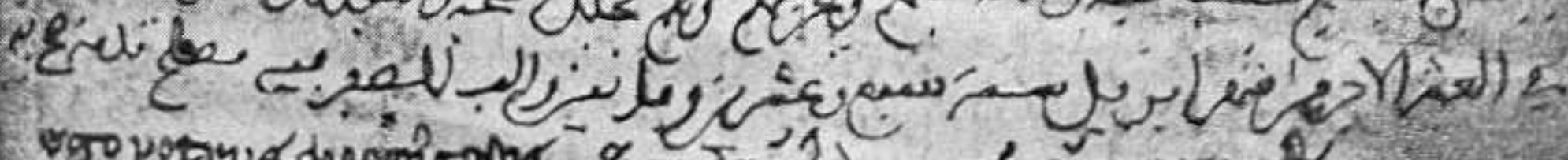

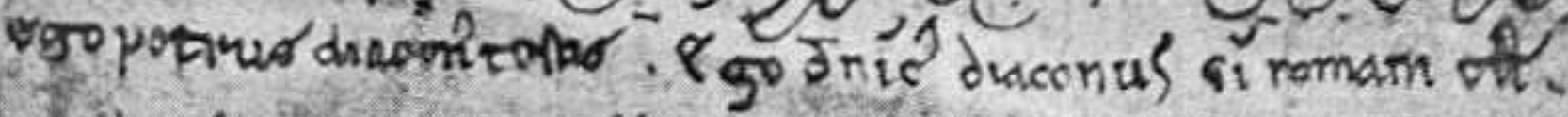

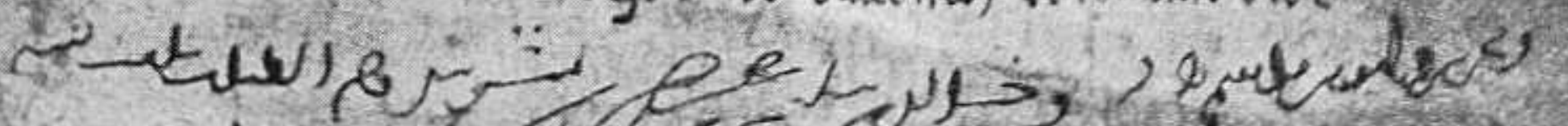

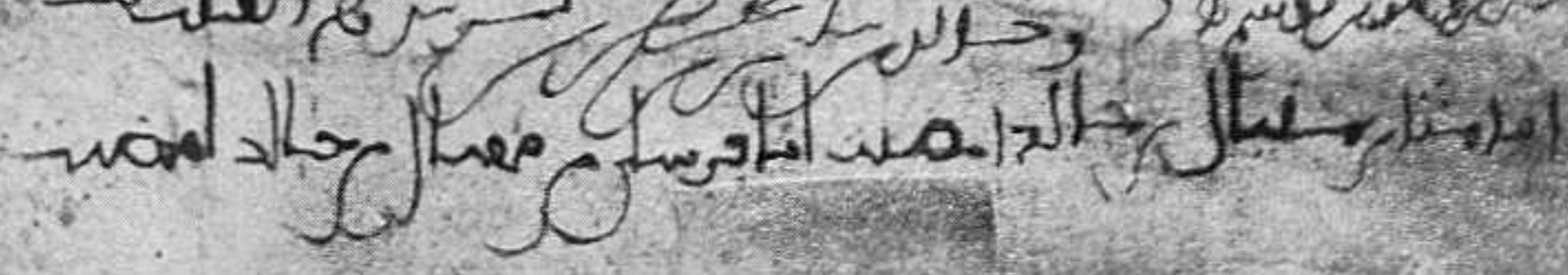


8. Corred

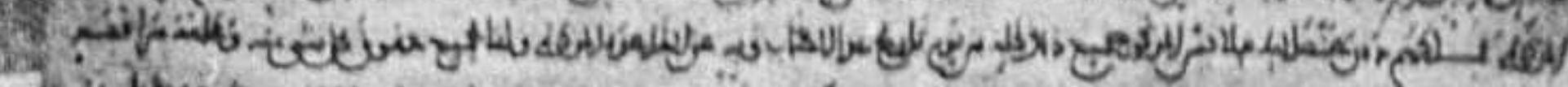

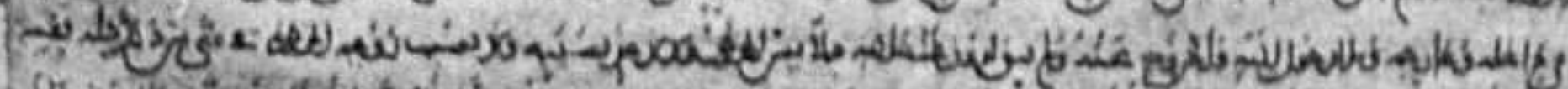

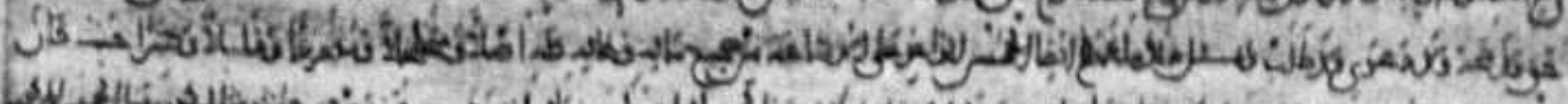

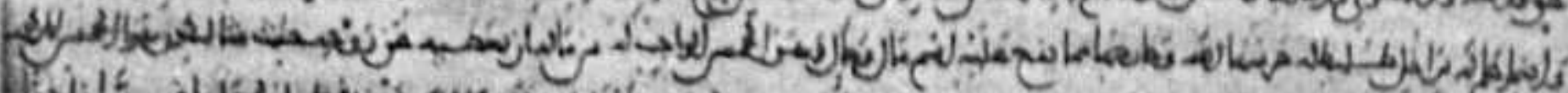

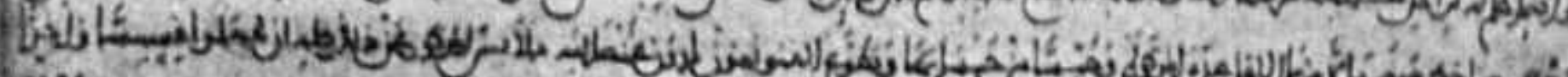
Qit)

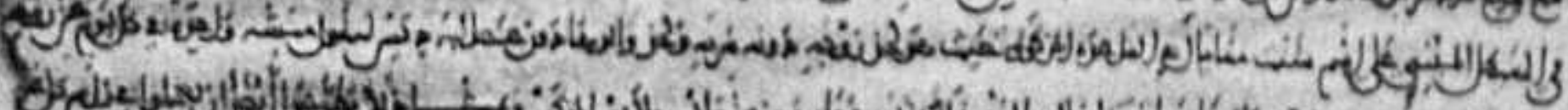

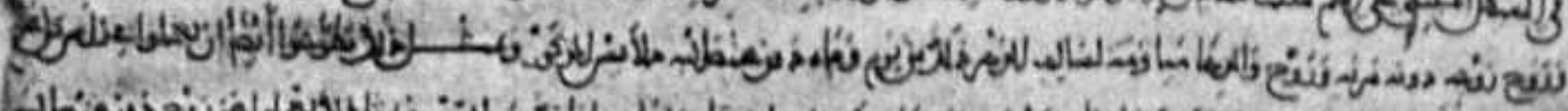

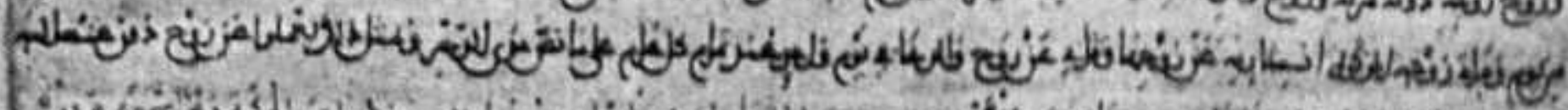

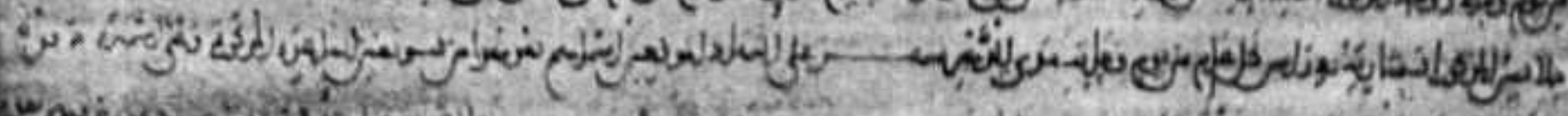

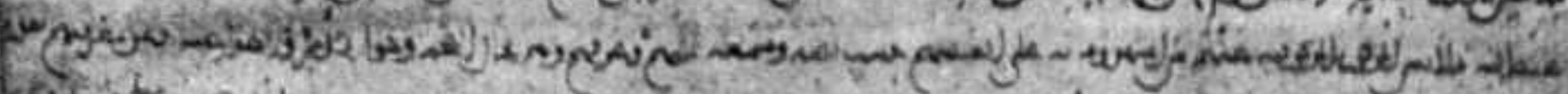

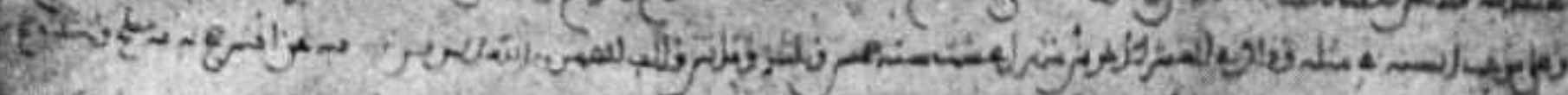

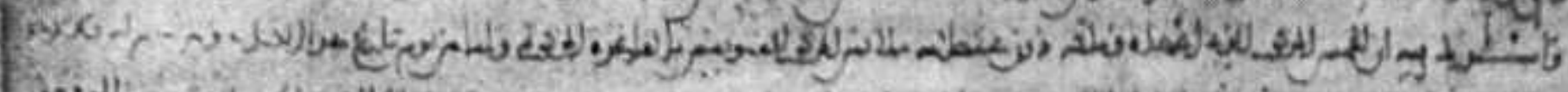

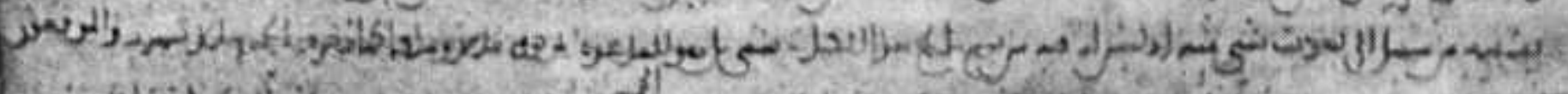

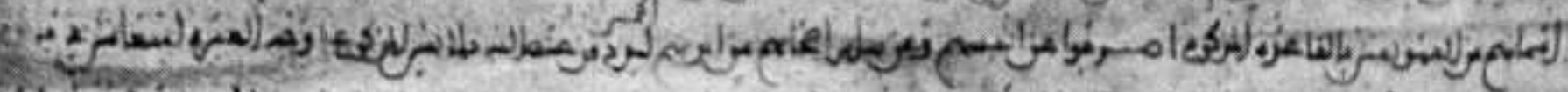

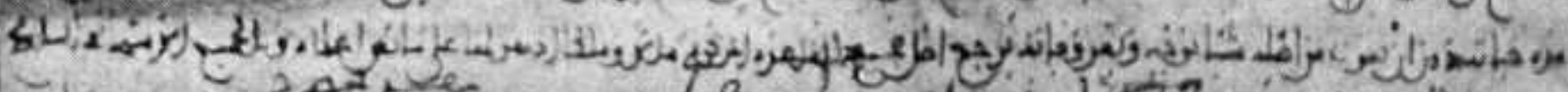

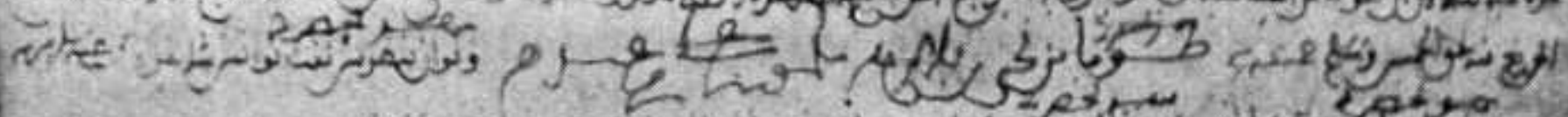

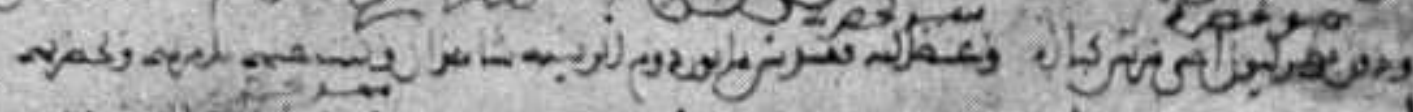

Fiva 0 is

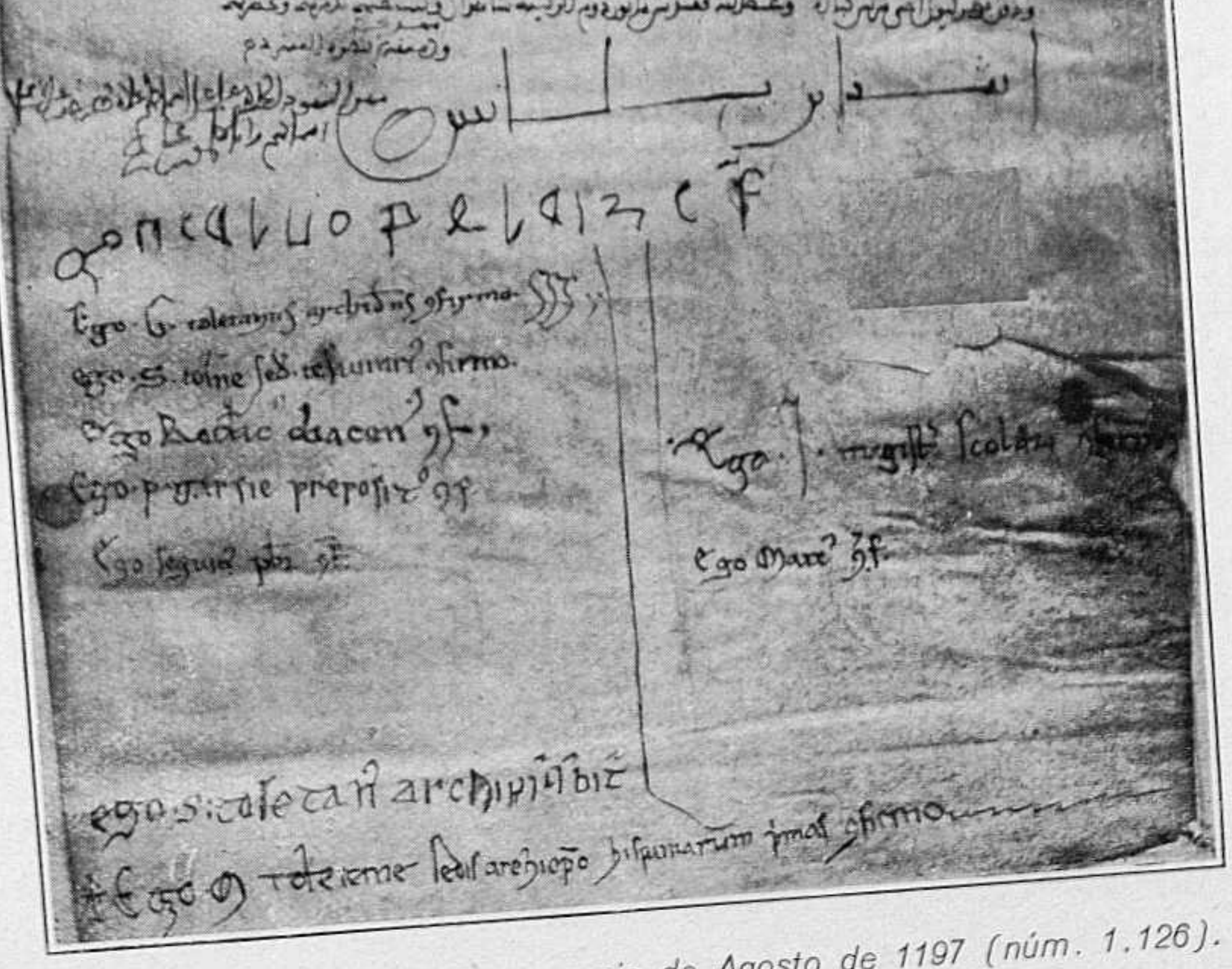

Firmas de la escritura de convenio de Agosto de 1197 (núm. 1.126). 